JAAKKO OLAVI ANTILA

Kansankirkko ristipaineessa

Suomen luterilainen kirkolliskokous 1974-2011 
Jaakko Olavi Antila

\section{Kansankirkko ristipaineessa}

Suomen

luterilainen

kirkolliskokous

1974-2011 


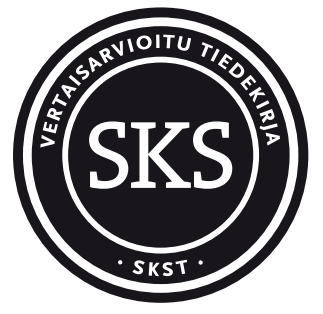

Suomalaisen Kirjallisuuden Seuran Toimituksia 1407

Teos on Suomalaisen Kirjallisuuden Seuran nimeämien asiantuntijoiden tarkastama.

VERTAISARVIOITU

KOLLEGIALT GRANSKAD

PEER-REVIEWED

www.tsv.fi/tunnus

Kirjastokonsortio Aleksandria on tukenut teoksen avointa saatavuutta.

(C) 2014 Kirkkohallitus ja SKS

Lisenssi CC BY-NC-ND 4.0 International

Digitaalinen versio perustuu Suomalaisen Kirjallisuuden Seuran kustantamaan painettuun teokseen, joka on julkaistu vuonna 2014.

Kannen ulkoasu: Timo Numminen

Taitto: Pekka Krankka

EPUB: Tero Salmén

ISBN 978-952-222-544-3 (sid.)

ISBN 978-952-222-986-1 (PDF)

ISBN 978-952-222-874-1 (EPUB)

ISSN 0355-1768 (Suomalaisen Kirjallisuuden Seuran Toimituksia)

DOI: http://dx.doi.org/10.21435/skst.1407

Teos on lisensoitu Creative Commons CC BY-NC-ND 4.0 International -lisenssillä. Tutustu lisenssiin englanniksi osoitteessa http://creativecommons.org/licenses/by-nc-nd/4.0/ tai suomeksi osoitteessa https://creativecommons.org/licenses/by-nc-nd/4.0/deed.fi.

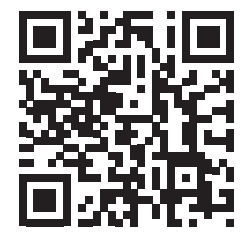

Teos on avoimesti saatavissa osoitteessa http://dx.doi.org/10.21435/skst.1407 tai lukemalla tämä QR-koodi mobiililaitteella. 


\section{Sisällys}

\section{ESIPUHE 10}

\section{UUTTA KANSANKIRKKOA ETSIMÄSSÄ 1974-1981}

Tumma joukko - värikäs edustajakunta 16

Kirkolliskokous lähi-ja maisemakuvassa 16

Herätysliike- ja puolueväki vaalityössä 18

Edustajiksi kokeneita virkamiehiä 23

Synodin tehtävät, parlamentin työtavat 27

Vastuu opista, toiminnasta ja taloudesta kasvaa 27

口 Perheenä ehtoollispöytään 29

Vaikutteita valtiopäiväjärjestyksestä 32

口 "Lex Linkola" 33

Äänestysmaljan äärellä 37

Hiippakuntarajat hallitsevat täysistunnon vaaleja 37

Valitsijamiehet tasapainoilevat 41

Tehokkaat toiminnan ja talouden rakenteet vai hengellinen erityislaatuisuus? 44

Toimikunnat hallinnonuudistuksen kompastuskivenä 44

口 Lähetystyölle oma keskus 46

Kokonaiskirkon talous paisuu 49

Sopimusjärjestelmän vaikea alku 52

Keskustelu virasta, Raamatusta ja oikeasta luterilaisuudesta julkisuuden paineessa 55

Kirkolliskokous Rooman ja Geneven välissä: virkakomitean välimietinnöt 55

Pappisvirka ei avaudu naisille 60

Jälkinäytös uskosta, opista ja lehtorinvirasta 65

Leuenbergin konkordia herättää huolen "luterilais-suomalaisesta" kristillisyydestä 6

Uusi kansankirkollinen ohjelma 71

"Routavuosien" puolustustaistelusta kansan omaksitunnoksi 71

口 Liian tasokas kasvatusohjelma? 74

Kohti missionaarista kansankirkkoa 78

Nopeatempoiseen päätöksentekoon 83

"Tuskin jälkipolvet syyttävät meitä uudistusinnon puutteesta" 83

Valiokunnissa voimat "työhön ja yöhön” 86

口Edustajat retkellä 87

Istuntosalin demokratiaa virallisten edustajien johdolla 
Vaaliuudistusten kautta päättämään kirkon perusteista 100 Yhden aikakauden saatto 100 Julkisesta arvostelusta kohti avoimempia kirkolliskokousvaaleja 101 "Naispappeusvaalit" muuttavat kokoonpanoa 103 Vaalitavan tarkistukset ja vastavihityt pappisedustajat 105 $\square$ Teologisten tiedekuntien valitsema edustaja takaisin? 108

"Rouva Puheenjohtaja" ja muut henkilövalinnat valmistellusti ja vähin keskusteluin 109

Luottavainen kirkolliskokous epävakaassa maailmassa 111 Arkipyhien palautus ja uudistuva verotus koettelevat suhteita valtiovaltaan 111

Rauhankysymyksestä ja siviilipalveluksesta paljon keskustelua, vähän päätöksiä 116 口 Rukoileva kokous 119

Talouden kasvukauden kiireet ja hiljentymisen tarve 120

Kirkkolain ja hallinnon suuret uudistukset 124

Pitkä keskustelu vaalitunnuksista johtaa päätökseen 124

Seurakunnan jäsenyys ja kieli kirkkolain kokonaisuudistuksen ongelmina 126

口 Kirkolliskokous herää saamelaisten asiaan 130

Aiempaa vahvempi kirkkohallitus 132

Naisen pääsy papiksi ja piispaksi puhuttaa kirkolliskokousta ja mediaa 134

Naispappeusaloitteet kariutuvat, paine kasvaa 134

Vuoden 1986 ennakoitu hyväksymispäätös ja arvaamaton omantunnonsuoja 138

Hapuilevaa virkateologiaa yhden äänen enemmistöllä 143

口"...ja Pojasta" 145

Toimitusten ja virsien rohkeista uudistusesityksistä kirkolliskokouksen kompromisseihin 147

Korkeakirkollinen liturgia, kastekaava ja sairaan voitelu kansankirkon kipukohtina 147

口 Viivytystaistelu avioliittokuulutuksesta 150

Valiokunta perääntyy virsipalautteen edessä 151

"On isät täällä taistelleet" - perinteen ja muutoksen jännite uudessa virsikirjassa 157

Asiantuntijamietinnöstä kohti herätysliikkeiden ja kirkon Raamattua 163

Eheä kirja vai kaksi sujuvasti käännettyä testamenttia? 163

$\begin{array}{ll}\text { Yhteisymmärrys vahvistuu kiireisessä kokouksessa } & 167\end{array}$

Vakiintuneeseen päätöksentekoon 174

Sisäisiä uudistuksia julkisuuden valokeilassa 174

"Hylätään valiokuntaan lähettämättä" 175

口 Yhteiselämää opistolla 177

Täysistunto tasa-arvoistuu $\quad 178$

\section{KIRKON HALLINTO ITSENÄISTYY 1992-200O 183}

Monipuolistuva edustajisto pyrkii jatkuvaan uudistukseen 184

Murrosvuodet vauhdittavat kansankirkollista ohjelmaa 184

Kokonaan suhteellisiin kirkolliskokousvaaleihin 186

Tuomarien riippumattomuus ja saamelaisten oikeudet kokoonpanomuutosten taustalla 190 Pyrkimys tehokkaaseen työskentelyyn ja monipuolisiin henkilövalintoihin 194

口 Sukupuolikiintiöt kirkon keskushallintoon 196 
Leikkausten, rahastoinnin ja ihmisten hädän aika

"Kirves on pantu puun juurelle" 197

"Rajaseutupiirien tapposuunnitelmasta" lomautuksiin ja uudenlaiseen virka-ajatteluun 201

Pienestä alusta kahden miljardin markan eläkerahastoksi 203

"Kirkon aika" auttamistyössä ja tiedonvälityksessä 204

$\square$ Huoli ympäristöstä 205

Valtion kyljestä kohti kansalaisyhteiskuntaa 207

Tuomiokapitulien ylläpito ja piispojen nimittäminen kirkon vastuulle 207

口Kirkkomuseo väärään aikaan ja väärään paikkaan 209

Valtio uhkaa viedä "kerman" väestökirjanpidon tehtävänjaossa 213

Uskonnonopetuksen puolustamisen vuosi 1992214

Positivisen uskonnonvapauden puolesta 216

Kasvava paine tehokkaaseen hallintoon 219

Byrokratian ja demokratian liitto estää hallinnon keventämistä 219

Kirkkoherra-paimen ja toimitusjohtaja 223

Turkuun toinen piispa 225

Ulkomaille ja ykseyteen tähyävä kirkko 228

Bryssel, Porvoo ja Euroopan yhdentyvät kirkot 228

Yhteinen julistus maailmalle vai portti ulos aidosta luterilaisuudesta? 231

Kysymys työntekijöiden tasa-arvosta sekoittuu ekumeeniseen virkateologiaan 234

Opillisesta pohdinnasta kohti käytännön jumalanpalvelusta ja kristinoppia 237

Jumalan kansan juhla ja arki 237

Jumalanpalveluselämä moninaisuuden ja hajanaisuuden jännitteessä 240

$\square$ Kirkollisia kirjoja saameksi ja viittomakielellä 246

Vuorisaarnan etiikkaa aktiivikristityille vai elämänläheistä pohdintaa joka kotiin? 247

$\square$ Arkkipiispa, apupapit ja seksuaalietiikka 249

Vahvan valmistelukoneiston aikaan 251

Uuden keskushallinnon elimet etsivät valtansa rajoja 251

Huomiota kirkon toimintaan 253

Tiedostettuja taustaryhmiä 254

\section{KIRKOLLISKOKOUS POLARISOITUU 2000-2011 259}

Vaalikampanjointi vilkastuu, vastakkainasettelut voimistuvat 260

Hiljainen kirkkotie kuohuvassa maailmassa 260

Valtakunnallinen vaalikampanjointi alkaa 262

Aktiiviseurakuntalaisten näköinen kokous? 266

Pyrkimys avoimeen keskusteluun päätöksenteossa ja henkilövalinnoissa 272

Huoli nuorista aikuisista ja kirkon jäsenyydestä uudistusten pontimena 275

Strategiatyöskentely epävarman tulevaisuuden edessä 275

口 Helppo ero, edullinen hautapaikka 276

Kummius kirkon jäsenyyden ilmapuntarina 278

Kuuntelemaan nuorten ääntä vaaleissa ja verkossa 280

口 Edustajan päiväkirja verkossa 283

Muuttoliike ja kirkosta eroaminen synkentävät talousnäkymiä 284

Puhetta pienistä yhteisöistä, päätöksiä vahvoista talousyksiköistä 284 
Kehysbudjetointiin ja strategisiin hankkeisiin

口 Kolmen viikon tulevaisuusselonteko 289

Kasvava eläkelaitos ja kirkon eettinen vastuu 292

Vapautta alueelliseen päätöksentekoon 295

Teknologiakeskuksen vai maaseutuidyllin hiippakunta läntiselle Uudellemaalle?

口 Kirkolliskokouksen paras ystävä 296

Hiippakuntahallinto itsenäistyy ja paisuu 298

Lisää liikkumavaraa seurakuntayhtymiin 301

Vaativa seurakuntahallinto ja kiista kirkkoherranvaalista 302

Jumalanpalveluselämän kiivaan uudistusvaiheen loppusuora 305

Viran ykseydestä uuteen erotteluun 305

Jumalanpalveluksen kaavasta kohti joustavia toimituksia 309

”...och på den heliga Anden" - helpoista päätöksistä vaikeaan keskusteluun 312

口 Päättäjäisten naurua 312

口 Apokryfikirjojen epäselvä asema 315

Valtiollinen ja kirkollinen lainsäädäntö hankauksessa 316

Hallinnon kieli, rakennusten suojelu ja kirkon perustehtävä 316

Tasa-arvolaki, parisuhdelaki ja vapaus valita työntekijät 319

口 Spongin ja Obaren välissä 323

Syrjinnän kielto vai vakaumuksen oikeus? 324

Eroaallon harjalla $2010 \quad 326$

Konsensus hiipuu ja auktoriteetit murtuvat 330

Paljon valmisteltavaa, vähän päätöksiä 330

口 Julkilausuma juutalaisista ja kannan ottamisen vaikeus 332

Täysistunnon merkitys vähenee, piispat vaikenevat 334

\section{KOROISTEN KOKOUS 340}

VittTeET 349

Liıte: Kirkolliskokousedustajat 1974-2011 379

LYHENTEET 392

LÄHTEET JA KIRJALLISUUS 392

Painamattomat lähteet 392

Kirkolliskokouksen pöytäkirjat ja käsitellyt mietinnöt 393

Muut painetut lähteet 394

Sanoma- ja aikakauslehdet 396

Verkkopäiväkirjat 396

Muut Internet-lähteet 396

Haastattelut ja tiedonannot 396

Kirjallisuus 397

SAmmanfattning: Kyrkomötet i den evangelisk-lutherska kyrkan i Finland 1974-2011 402

HENKILÖHAKEMISTO 411

KESKEISIÄ VUOSILUKUJA 1974-2011 
Verkkojulkaisu on omistettu Toivolle, Laurille, Maijulle, Arvolle ja Saimille 


\section{Esipuhe}

Arkkipiispa Martti Simojoki avasi 1968 virkakautensa ensimmäisen varsinaisen kirkolliskokouksen. Vuosi oli hänen mukaansa "jäävä aikakirjoihin eräänä niistä historian merkkipaaluista, joiden kohdalla tullaan pysähtymään tarkasteltaessa ihmissuvun vaiheissa vaikuttavien voimien esiinpurkautumista”. Kirkko oli kohdannut muutoksia enteilevää levottomuutta, eikä sen tullut arkkipiispan mukaan ummistaa silmiään. Vuoden 1968 kirkolliskokous katsoikin tulevaisuuteen ja aloitti laajan hankkeen kirkon keskushallinnon uudistamiseksi.

Kirkolliskokous oli kokoontunut Turussa vuodesta 1876 lähtien aluksi kymmenen, sitten viiden vuoden välein. Varsinaisten kirkolliskokousten ohella oli kuitenkin tihenevään tahtiin jouduttu kutsumaan koolle ylimääräisiä kirkolliskokouksia. Kirkon oma keskushallinto oli vahvistunut huomattavasti 1944, jolloin olivat aloittaneet toimintansa kirkkohallitus ja laajennettu piispainkokous. Viimeksi mainittuun kuuluivat piispat, kenttäpiispa, kirkkohallituksen jäsenet, yksi asessori jokaisesta tuomiokapitulista sekä kaksi maallikkoedustajaa jokaisesta hiippakunnasta. Laajennettu piispainkokous hoiti kirkolliskokousten väliaikoina joitakin kirkolliskokouksen tehtäviä. Tällainen päätöksentekojärjestelmä ei enää tyydyttänyt 1960-luvun Suomessa. Yhä useamman mielestä kirkkoa koskevat päätökset syntyivät liian hitaasti, kun samaan aikaan valtiollinen päätöksenteko nopeutui jatkuvasti. Kirkolliskokouksen jäsenmäärä liikkui 1960-luvun lopulla ja seuraavan vuosikymmenen alussa jo 140:n tienoilla. Kokous oli paisunut liian suureksi, eikä edustuksellisuuden periaate toteutunut riittävässä määrin rovastikunnittain enemmistövaalilla toimitetussa maallikkoedustajien valinnassa. 
Vuonna 1974 aloitti toimintansa uudistettu kirkolliskokous, joka kokoontui kaksi kertaa vuodessa. Se oli aiempaa pienempi, 108-jäseninen maallikkoedustajien, pappien ja piispojen kokous. Edustuksellisuus oli otettu aikakauden periaatteiden mukaisesti huomioon sen kokoonpanossa. Laajennettu piispainkokous lakkautettiin. Vastaavasti kirkolliskokouksen tehtävät lisääntyivät ja päätösvalta kasvoi. Uudistettu kirkolliskokous oli selvästi kirkon ylin päättävä elin, jonka oli määrä pystyä tekemään nopeita ratkaisuja ja ottamaan kantaa ajankohtaisiin asioihin. Se hyväksyi kirkolliset kirjat, ehdotti kirkkolakia, ohjasi kirkon toimintaa ja kantoi ylintä vastuuta opista, ekumeniasta ja kokonaiskirkon taloudesta. Muina keskushallinnon tärkeimpinä eliminä toimivat aiempaa laajempi kirkkohallitus sekä piispainkokous, johon kuuluivat piispat, kenttäpiispa ja yksi asessori jokaisesta tuomiokapitulista.

Kirkolliskokous vietti satavuotisjuhliaan 1976. Tuolloin ilmestyi Helsingin yliopiston kanslerin Mikko Juvan kirjoittama teos Kirkon parlamentti. Suomen kirkolliskokousten historia 1876-1976. Juva keskittyi kirjassaan niin sanottujen vanhamuotoisten kirkolliskokousten toimintaan vuoteen 1973 asti. Kirkolliskokousuudistuksen jälkeistä aikaa koskevan tutkimushankkeen suunnittelu alkoi puolestaan 2003. Kirkkohallitus asetti professori Seikko Eskolan johtaman työryhmän tutkimaan mahdollisuuksia vuosia 1974-200o koskevan historiateoksen kirjoittamiseksi. Kirkkohallitus esitti 2004 viisivuotisen tutkimushankkeen toteuttamista. Enemmistö kirkolliskokouksen talousvaliokunnan jäsenistä piti hanketta kuitenkin liian kalliina ja ylimitoitettuna. Hanke siirtyi myöhempään ajankohtaan, mutta sitä koskevat suunnitelmat jäivät elämään Helsingin yliopiston teologisessa tiedekunnassa.

Vuonna 2009 kirkolliskokousedustaja, Helsingin yliopiston käytännöllisen teologian professori Heikki Kotila kokosi uudelleen kirkolliskokousedustajia hankkeen taakse. Suunnitteilla oli aiempaa pienimuotoisempi, nelivuotinen hanke, jonka lopputuloksena olisi kuitenkin tieteellisen tutkimuksen kriteerit täyttävä teos. Tutkittavan ajanjakson oli määrä olla pidempi kuin aiemmassa suunnitelmassa ja ulottua aivan lähimpään historiaan. Kirkolliskokous hyväksyi hankkeen mutta rajasi sen toteuttamisen kolmeen vuoteen.

Kirkkohallitus asetti toimikunnan valmistelemaan ja ohjaamaan tutkimushanketta ja nimesi toimikunnan johtoon professori Kotilan. Hänen työnsä hankkeen parissa päättyi kuitenkin jo alkuvaiheessa. Professori Kotilan kuolema toukokuussa 2010 jätti jälkeensä suuren aukon teologisessa tutkimustyössä ja kirkon päätöksenteossa. On toivottavaa, että valmistunut historiateos voisi omalta osaltaan säilyttää hankkeen alkuvaiheen taustavoiman, professori Kotilan, muistoa.

Professori Kotilan jälkeen historiatoimikuntaa on johtanut Helsingin yliopiston käytännöllisen teologian professori Markku Heikkilä. Muina jäseninä ovat olleet piispa (emeritus), professori Gustav Björkstrand, professori Simo Heininen, filosofian maisteri Leena Huima, kirkolliskokouksen pääsihteeri, varatuomari Katri Kuuskoski, teologian tohtori Jaakko Ripatti ja professori Kyllikki Tiensuu. Sihteerinä on toiminut hallintosihteeri, filosofian maisteri Liisa Aarnio-Jääskeläinen. Toimikunta valitsi historiateokselle kirjoittajan keväällä 2010. Varsinainen kirjoitustyö kesti syksystä 2010 syksyyn 2013, ja tänä 
aikana historiatoimikunta kommentoi säännöllisesti alustavaa käsikirjoitusta. Asiantuntevan toimikunnan antama ohjaus ja tuki ovat olleet ensiarvoisen tärkeitä läpi koko hankkeen. Toimikunnan omistautuminen ja vaivannäkö ansaitsevat suuren kiitoksen.

Työtä hankkeen hyväksi ovat tehneet myös lukuisat muut henkilöt, joista on mahdollista mainita tässä yhteydessä vain muutamia. Kirkkohallituksen työyhteisö, erityisesti kirkkoneuvos Pirjo Pihlajan johtama hallintoosasto, on ollut tärkeä tuki etätyötä tehdessä. Tietoja kirkolliskokousedustajien herätysliiketaustoista 1970-luvulta 1990-luvulle ovat antaneet asessori, teologian tohtori Ossi Haaramäki, professori Kyllikki Tiensuu sekä seurakuntaneuvokset Alma Saari, Heimo Karhapää ja Leo L. Norja. Piispa (emeritus) Jorma Laulaja, ministeri Jaakko Numminen, seurakuntaneuvos Saari, filosofian lisensiaatti Esko Tokola ja rovasti Jussi Mäntymaan jälkeläiset ovat antaneet käyttööni tärkeitä lähdeaineistoja.

Kiitoksen ansaitsevat erikseen kaikki haastatellut, jotka on mainittu lähde- ja kirjallisuusluettelossa kirjan loppuosassa. Samassa luettelossa mainittujen arkistojen henkilökunta on puolestaan avuliaasti ja asiantuntevasti johdattanut lähdeaineistojen ääreen. Muiden aineistokokoelmien osalta erityisesti toimittaja Matti Karppinen Kotimaan kuva-arkistosta sekä koulutussuunnittelija Jaana Rantala ja lehtori Eeva-Kaija Lemmetyinen Turun kristilliseltä opistolta ovat nähneet paljon vaivaa hankkeen hyväksi. Työn loppuvaiheessa professori Hannu Mustakallio on lukenut käsikirjoituksen tarkasti läpi ja antanut runsaasti arvokasta palautetta.

Suuri kiitos kuuluu Suomalaisen Kirjallisuuden Seuralle, joka on ottanut teoksen julkaistavakseen Suomalaisen Kirjallisuuden Seuran Toimituksia -sarjassa, sekä seuran nimeämille vertaisarvioijille ja kustantamon henkilökunnalle. Erityisesti on syytä mainita teoksen kustannustoimittaja, kustannuspäällikkö Rauno Endén sekä teoksen graafisesta asusta ja taitosta vastannut Pekka Krankka. Lopuksi kiitän perhettäni, joka on kuluneina vuosina ollut kaikkein lähimmin mukana hankkeessa ja jolta on riittänyt ymmärtämystä ja tukea.

Käsillä olevan kirjan tarkastelujakso alkaa kirkolliskokousuudistuksen voimaantulosta 1974 ja päättyy vuoteen 2011. Kyseessä on itsenäinen jatko Mikko Juvan kirjoittamalle kirkolliskokouksen historiateokselle. Juva laati kirjansa virkatöidensä ohella toimiessaan Helsingin yliopiston johdossa, minkä vuoksi hän kertoi joutuneensa supistamaan tutkimuksensa tavoitteita. Tätä kirjaa laadittaessa lähtökohdat ovat olleet erilaiset: on ollut mahdollisuus perehtyä kolmen vuoden ajan päätoimisesti kirkolliskokousta koskevaan lähdeaineistoon ja tutkimuskirjallisuuteen sekä tarkastella niiden avulla kirkolliskokousta niin lähi- kuin maisemakuvassa. Päämääränä on ollut historiantutkimuksen kriteerit täyttävä teos, josta olisi apua historiantutkijoille sekä seurakuntien ja kokonaiskirkon päättäjille mutta johon olisi helppo tarttua, vaikka ei ennestään tuntisikaan syvällisesti kirkollista päätöksentekoa. Alkuperäisiin, 2004 esitettyihin suunnitelmiin verrattuna tutkimukseen käytettävissä ollut aika on lyhentynyt ja vastaavasti tutkittava ajanjakso pidentynyt, mikä on edellyttänyt rajauksia erityisesti erilaisten lähdeaineistojen käytössä. Esimerkiksi haastattelujen määrää on täytynyt rajoittaa.

Käsiteltävien aihealueiden valikointi on ollut luonnollisesti vaikea tehtävä. Suurten uudistushankkeiden ohella olen tarkastellut suppeampia asiakokonaisuuksia, jotka kuvastavat oman aikansa keskustelua kirkollis- 
kokouksessa tai ovat myöhemmän vaikutushistoriansa näkökulmasta merkittäviä. Olen pyrkinyt keskittymään kirkolliskokouksen kädenjälkeen kussakin päätöksentekoprosessissa. Jotkin uudistushankkeiden sinänsä tärkeät osa-alueet, joihin kirkolliskokous ei ole puuttunut, jäävät vähälle huomiolle. Vastaavasti olen nostanut esiin sellaisiakin aloitteita, jotka eivät ole johtaneet varsinaisiin päätöksiin mutta ovat herättäneet kirkolliskokouksessa huomionarvoista keskustelua. Muutamat itsenäiset asiakokonaisuudet ja täysistuntojen ulkopuolisen yhteiselämän kuvaukset on taitettu muusta tekstistä erilleen.

Päälähteinä ovat kirkolliskokouksen painetut pöytäkirjat liitteineen. Lisäksi olen käynyt läpi kirkolliskokouksen painamattomat asiakirjat, kuten valiokuntien pöytäkirjat, sekä valikoiden komiteoiden painamattomia pöytäkirjoja. Näissä kokoelmissa on jonkin verran puutteita. Esimerkiksi tutkimuskauden alkupuolen täysistunnoista ei ole säilynyt läheskään aina nimenhuutoäänestysten äänestyslistoja. Tällöin on pitänyt turvautua lehdistössä annettuihin tietoihin edustajien äänestyskäyttäytymisestä. Toisaalta se, että painettujen keskustelupöytäkirjojen pohjana ovat koko tutkimuskauden ajan olleet nauhoitukset, on lisännyt keskustelupöytäkirjojen tarkkuutta ja tasalaatuisuutta. Kirkon keskushallinnon asiakirjojen ohella olen käyttänyt arkkipiispojen arkistoja, kirkolliskokousvaaleja koskevia asiakirjoja Lapuan ja Helsingin tuomiokapitulien arkistoissa sekä kirkolliskokousta sivuavia asiakirjoja puoluearkistoissa.

Lehdistön osalta olen käynyt läpi kirkon tiedotuskeskuksen lehdistökatsaukset. Lisäksi olen katsonut Kotimaa-lehden vuosikerroista kirkolliskokouksen istuntokausia ympäröivät numerot. Muuten olen tarkastellut lehden vuosikertoja tarpeen mukaan, esimerkiksi kirkolliskokouksen vaalitalvina säännöllisesti syksystä kevääseen. Lehdistön merkitys korostuu varsinkin siksi, että kyse on lähimmästä historiasta, josta voi yrittää hahmottaa kokonaiskuvaa juuri median avulla. Viime vuosina on kuitenkin ilmestynyt myös uusia lähihistoriaa koskevia tutkimuksia, muun muassa teologisia opinnäytetöitä. Ne ovat omalta tärkeältä osaltaan tukeneet tämän teoksen valmistumista ja tarkentaneet kokonaiskuvaa niistä vuosikymmenistä, joita aikoinaan vuoden 1968 kirkolliskokouksen jäsenet odottivat jännittyneinä mutta valmiina uudistuksiin.

Nurmossa toukokuussa 2014, kun uusimuotoisen kirkolliskokouksen alkamisesta on kulunut 40 vuotta

Jaakko Olavi Antila 


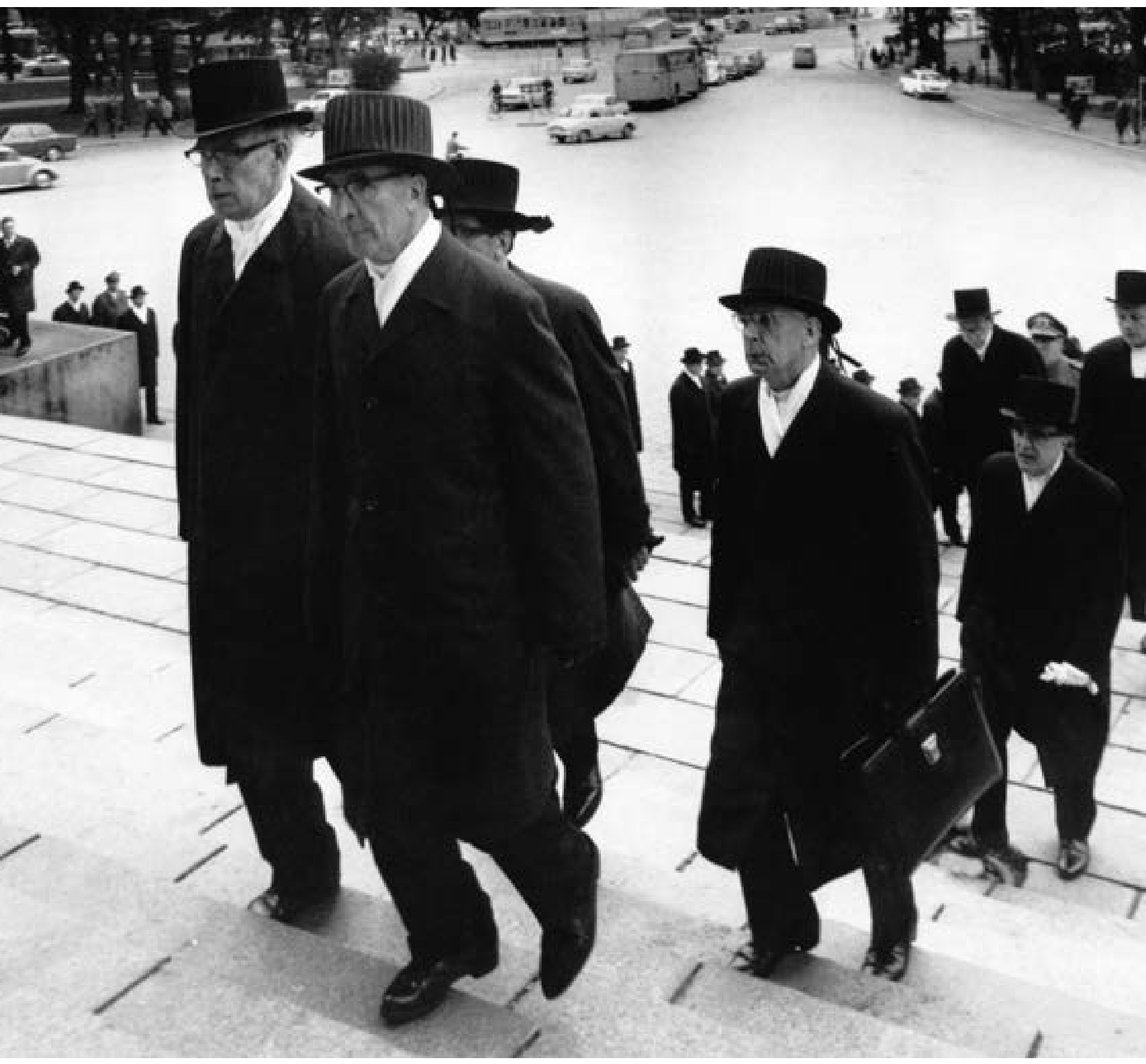




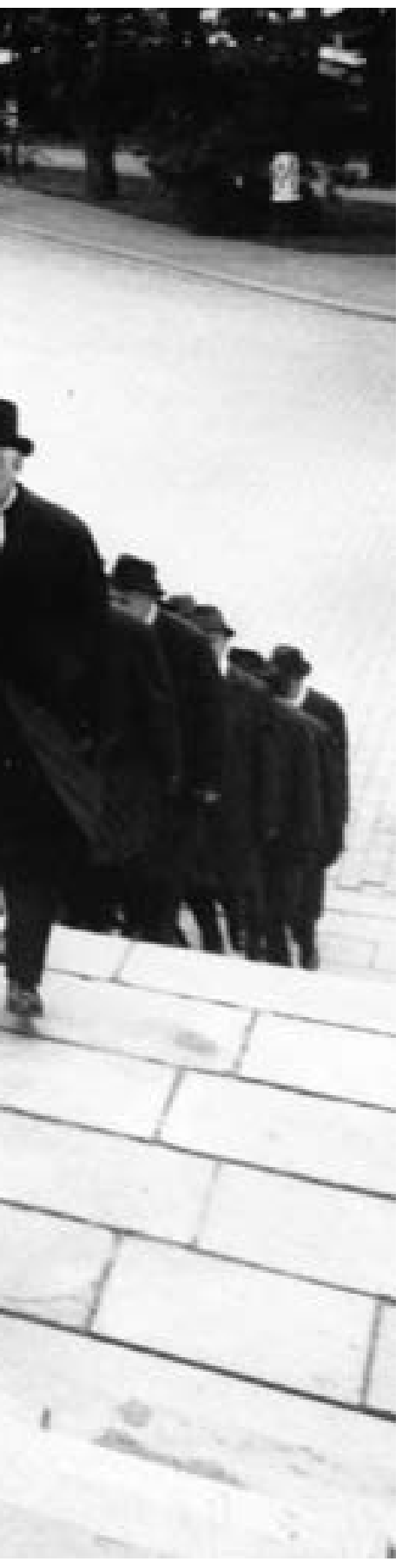

\section{UUTTA KANS ANKIRKKOA ETSIMÄSS ̈̈ $1974-1981$}

Monia uudistushankkeita käsitelleen vuoden 1968 kirkolliskokouksen kulkue. Arkkipiispa Martti Simojoen (vas.) rinnalla Lapuan hiippakunnan piispa Eero Lehtinen. Heidän takanaan toisessa rivissä Mikkelin piispa Osmo Alaja ja Porvoon piispa Karl-Erik Forssell. Kuva: Kirkon kuvapankki. 


\section{TUMMA JOUKKO}

\section{- VÄRIKÄS EDUSTAJAKUNTA}

\section{KIRKOLLISKOKOUS}

\section{L $\ddot{H} I$ - JA MAISEMAKUVASSA}

Vuoden 1974 Suomessa useimmat tunsivat Turun tuomiokirkon kellojen puolenpäivän lyönnit, sen verran yhtenäisessä sähköisen tiedonvälityksen maailmassa elettiin. Oltiin siis keskellä suomalaista ääni- ja kulttuurimaisemaa, kun toukokuun kuudentena - hieman ennen puoltapäivää - juhlava kulkue lipui kellojen soidessa Turun vanhalta akatemiatalolta kohti tuomiokirkkoa. Uudistetun kirkolliskokouksen edustajat olivat aloittamassa työtään. Kaukaa katsoen he olivat yhtenäisen näköinen, tumma joukko, joka liikkui hitaasti tuomiokirkon, vanhan suurtorin, yliopiston ja hovioikeuden välimaastossa.

Tarkemmin katsoessa erottui varsinkin kulkueen etuosassa violetteja tohtorinhattuja ja yksi harmaa sotilasunivormu. Parijonon kärjessä kulkivat piispat, ensimmäisenä arkkipiispa Martti Simojoki, joka toimi virkansa puolesta kirkolliskokouksen puheenjohtajana. Yksi oli joukosta poissa. Kuopion piispa Olavi Kares osallistui samaan aikaan Moskovan patriarkan Pimenin Suomen-vierailun ohjelmaan. Ekumeenisesta yhteydenpidosta oli tullut arkipäivää.

Piispojen jälkeen tulivat kenttäpiispa Yrjö Massa sekä korkeimman oikeuden ja korkeimman hallinto-oikeuden valitsemat edustajat. Myös tämän kolmikon kohdalla parijonossa oli yhden edustajan aukko: valtioneuvoston määräämä edustaja, opetusministeri Ulf Sundqvist oli sairastuneena poissa. Tosin muutenkin ministerit yleensä vain pikaisesti poikkesivat kirkolliskokouksessa tuomassa terveisensä. Käytäntöön vaikutti paitsi kirkolliskokouksen tiivistynyt kokoontumistahti myös periaatteellinen kirkon itsenäisyyden korostus. Ajatus kirkon ja valtion sidosten löyhdyttämisestä oli ollut poliittisessa keskustelussa vahvasti esillä varsinkin 1960luvun loppupuolella ja 1970-luvun alussa ${ }^{1}$.

Ruotsissa kirkon ja valtion suhteita käsitellyt komitea oli 1972 ehdottanut merkittäviä muutoksia kirkon ja valtion suhteisiin. ${ }^{2}$ Samaan aikaan Suomen luterilaisessa kirkossa oli selvitetty monipuolisesti suhdetta valtioon. Kirkolliskokousuudistuksen yhteydessä sekä korkeimpien oikeusistuinten valitsemat edustajat että valtioneuvoston määräämä edustaja olivat olleet vähällä pudota pois kokoonpanosta. ${ }^{3}$ Tapahtumat olivat osoittaneet, ettei kirkon johdossa toivottu valtiovallan puuttuvan voimakkaasti kirkon päätöksentekoon. Valtioneuvostossa kunnioitettiin tätä linjaa. Keväällä 1974 oli meneillään valtion aloittama selvitystyö kirkon ja valtion suhteista, mutta yhteyksien katkaisemista ei enää vaadittu yhtä voimakkaasti kuin muutamia vuosia aiemmin ${ }^{4}$. Ruotsin hallitus oli jo ilmoittanut, ettei se esittäisi syvällekäyviä muutoksia kirkon ja valtion suhteisiin. ${ }^{5}$

Vaikka opetusministeri oli poissa paitsi avajaiskulkueesta myös kirkolliskokouksen käytännön työskentelystä, hänen ministeriönsä oli kirkolliskokouksen näkökulmasta erittäin tärkeä seurannan ja vaikuttamisen kohde. Meneillään oli laaja koulujärjestelmän uudistus. Uudessa peruskoulussa uskonnonopetuksen määrä oli selvästi aiempaa vähäisempi, ja myös valmisteilla olleessa keskiasteen koulunuudistuksessa uskonnonopetuksen määrä ja sisältö olivat arvioitavina. Edellisvuonna oli keskusteltu kiivaasti uskonnonopetuksesta, ja kirkko oli monella tasolla - kirkolliskokouksesta lähtien pyrkinyt vaikuttamaan valmistelijoihin ja päättäjiin. ${ }^{6}$ Vasemmistoradikalismi oli voimissaan. Opetusministeriön sisällä oli ideologista taistelua, eivätkä kirkon asiat yleisesti näyttäneet ajan ilmapiirissä tärkeiltä. Ministerinsalkku, johon kuuluivat kirkon kannalta kaikkein keskeisimmät teemat, oli sosiaalidemokraateilla.? Puolueen piirissä oli aiempina vuosina vaadittu muutoksia kirkon asemaan. ${ }^{8}$ Lisäksi julkisessa keskustelussa oli edelleen havaittavissa jyrkkää kirkonvastaisuutta. ${ }^{9}$

Suurimman osan kulkueesta muodostivat ne 32 pappis- ja 64 maallikkoedustajaa, jotka oli valittu vaaleilla kirkon kahdeksasta hiippakunnasta. Katukiveykseltä kaikui korkokenkien ääni voimakkaammin kuin koskaan aiemmin. Pappisvirka oli edelleen miehen virka, 
mutta maallikkoedustajista naisia oli jo 20 eli lähes kolmannes. Sitä paitsi pappisviran avaaminen naisille oli valmisteilla, ja tiedossa oli, että kirkolliskokous saisi asian käsiteltäväkseen vielä samalla vaalikaudella. Tämä tietoisuus oli puolestaan näkynyt kirkolliskokousvaaleissa muun muassa siten, että naisehdokkaat olivat menestyneet huomattavasti aiempaa paremmin.

Kokoonpanoon kuuluivat vielä määräämättömäksi ajaksi valitut kirkkoneuvokset, kirkkohallituksen korkeimmat viranhaltijat, joilla oli kirkolliskokouksessa läsnäolo- ja puheoikeus. Toukokuussa 1974 heitä oli kolme, varatuomari Mauno Saloheimo, teologian tohtori Ahti Auranen sekä varatuomari Kai Sarsa. Kesäkuun alussa mukaan liittyi rovasti Olavi Vuorela, joka työskenteli kirkon toimikuntien pääsihteerinä. Kirkolle oli perustettu toimikuntia erityisesti 1940-luvun loppupuolelta lähtien suunnittelemaan jotakin työmuotoa tai vastaamaan tietystä työalasta ${ }^{10}$. Vuorelan nimitys kirkkoneuvokseksi kuvasti kirkkohallituksen kasvavaa vastuuta ja kokonaiskirkon laajenevaa toimintaa: toimikunnat hoitivat uusia tehtäviä, ja niihin oli perustettu ja oltiin edelleen perustamassa useita virkoja. ${ }^{11}$

Uudistetun kirkolliskokouksen ensimmäisellä vaalikaudella 1974-1977 kirkon keskushallinnon työntekijämäärä kasvoi 40 prosenttia. ${ }^{12}$ Muutoksen keskipisteessä oli kirkon keskusrahaston johtaja Kai Sarsa. Talousasiat olivat hyvin ajankohtaisia niin maailmanlaajuisesti kuin Suomen luterilaisessa kirkossa. Maailmantalouden pitkä korkeasuhdanne oli vaihtunut jyrkkään laskuun muun muassa energian hinnan noustessa, inflaation nopeutuessa ja työttömyyden kasvaessa ${ }^{13}$. Samaan aikaan kirkon eläkevastuu ja kokonaiskirkon työntekijämäärä kasvoivat voimakkaasti, mikä laajensi kirkon keskusrahaston taloutta nopeasti.

Läheltä näki, etteivät kirkolliskokousedustajat olleet sellainen tasaisen tumma joukko kuin kaukaa olisi saattanut luulla. Tätä lähikuvaa on katsottava ja selvitettävä, keitä kirkolliskokouksen jäsenet olivat, miten heidät oli valittu ja ennen kaikkea mitä he tekivät. Keillä heistä oli eniten valtaa? Millaisia ryhmittymiä kirkolliskokouksen työssä erottui? Mitkä piirteet leimasivat asioiden käsittelyä tai henkilövalintoja eri aikoina? Näitä asioita selvitettäessä päälähteitä ovat kirkolliskokouksen painetut pöytäkirjat liitteineen, jossain määrin myös komiteoiden ja valiokuntien painamattomat asiakirjat. Kirkollis- kokouksen koostumuksen ja edustajien vaikutusvallan selvittämiseksi olen tilastoinut näitä seikkoja mittaavia tekijöitä neljältä vaalikaudelta, vuosina 1974, 1986, 1996 ja 2008 alkaneilta kausilta.

Ei voi kuitenkaan unohtaa "maisemakuvaakaan". On hyvä siirtyä välillä kauemmas ja nähdä kirkolliskokous kulkemassa milloin vanhan, suuren kirkon taustaa vasten, milloin torin laidalla. Välillä taustalla näkyy hovioikeus, välillä yliopisto. Joen toisella puolella siintävät Turun Sanomien ja Åbo Underrättelserin toimitusten korttelit. Silloin kirkolliskokous näkyy suhteessa kirkkoon, talous- ja yhteiskuntaelämään, lainsäädännön kokonaisuuteen, teologiseen keskusteluun ja tiedotusvälineisiin. On myös kysyttävä, kulkiko kirkolliskokous tässä maisemassa niin hitaasti tai rivakasti kuin eri havainnoitsijat ovat kulloinkin nähneet. Miten kirkolliskokousuudistukseen ladatut toiveet aiempaa nopeammasta päätöksenteosta toteutuivat, ja mitkä seikat vaikuttivat uudistustahtiin? Joka suunnasta ei kuitenkaan pysty katsomaan ainakaan yhtä aikaa. Monet näkökulmat on ollut pakko sivuuttaa.

Vuosina 1876-1973 kirkolliskokous oli kokoontunut Turun keskustassa: kirkko oli näkynyt kaupunkikuvassa. Keväällä 1974 edustajat siirtyivät heti avajaisten jälkeen kaupungin laidalle, Linnasmäellä sijaitsevalle Turun kristilliselle opistolle, keskelle rauhallista asuinaluetta. Ulospäin ei enää välttämättä tiennyt, että kirkolliskokous kokoontui kaupungissa. Siirtymä oli kuva kirkon paikan muuttumisesta 1900-luvun jälkipuoliskolla. Voimakkaan muuttoliikkeen myötä kirkon työn painopiste alkoi siirtyä kasvaville lähiöalueille. Vastaavasti monissa maalaisseurakunnissa kärsittiin muuttotappiosta.

Kokouspaikan vaihdos kuvasti myös toisenlaista uskonnollisuuden muutosta. Luterilaiseen kirkkoon kuului peräti 92 prosenttia maan väestöstä, mutta osuus oli laskusuunnassa. Kirkosta eroaminen oli helpottunut 1969, ja seuraavan vuosikymmenen alkupuolella liike ulos kirkosta oli selvästi aiempaa vilkkaampaa. Erityisen korkea lukema, 17438 eronnutta, oli laskettu juuri uudistetun kirkolliskokouksen kokoontumisen alla vuonna $1973 \cdot{ }^{14}$ Monet tunnusluvut, jotka mittasivat osallistumista kirkon toimintaan, osoittivat alaspäin. Vuonna 1974 saavutettiin yksi rajapyykki, kun luterilaisen kirkon jäseniksi kastettavien osuus syntyneistä alitti 95 prosentin rajan. ${ }^{15}$ Osuus oli laskusta huolimatta todella 
suuri, selvästi suurempi kuin kirkkoon kuuluvien osuus väestöstä. Sen sijaan toisaalla näkyi merkkejä perinteisten rakenteiden murtumisesta. Avosuhteet yleistyivät, ja 1974 lähes joka kymmenes lapsi syntyi avioliiton ulkopuolella. ${ }^{16}$ Julkinen instituutio oli yhä useammin vaihtumassa yksityisiin elämänratkaisuihin, ja sama privatisoituminen kosketti uskonasioita. ${ }^{17}$ Kirkolliskokous oli tällaisesta muutoksesta huolissaan, mutta samalla sekin siirtyi - ainakin symbolisesti - julkiselta areenalta esikaupungin suojaan.

Keväällä 1974 alkamassa ollut istuntokausi oli viikon mittainen, kun edellisvuoteen saakka Turussa oli oltu koolla yleensä kuukauden ajan. Toisaalta istuntokausia olisi vastedes huomattavasti aiempaa useammin, kahdesti vuodessa: toukokuussa äitienpäivän alla ja marraskuussa juuri ennen almanakkoihin ilmestynyttä uutta juhlaa, isänpäivää. Vuosina 1974-2011 kirkolliskokous oli koolla yhteensä 376 istuntopäivää. Päiviä kertyi lähinnä lakimääräisiltä kevät- ja syysistuntokausilta mutta myös muutamista ylimääräisistä istunnoista. Vuosittaisten istuntopäivien määrä vaihteli kahdeksasta 16:een, mutta keskimäärin niitä oli kymmenen. Lisäksi varsinaisten istuntokausien välillä edustajat istuivat usein valiokunnissa. Tänä 38 vuoden aikana kirkolliskokous kulki pitkän matkan siitä maailmasta, jossa kuunneltiin radion yleisohjelmaa ja aloiteltiin isien uuden juhlapäivän viettoa.

\section{HERÄTYSLIIKE- JA PUOLUEVÄKI VAALITYÖSS $\ddot{A}$}

Juhlavaa avajaiskulkuetta edelsivät sadat vaalit eri puolilla Suomea. Ensin jokaisen seurakunnan kirkkoneuvosto nimesi valitsijamiehet, joiden määrä oli suhteutettu seurakunnan väkilukuun. Valitsijamiehet puolestaan kokoontuivat hiippakunnittain valitsemaan kirkolliskokouksen maallikkoedustajat. Papit kokoontuivat samaan aikaan rovastikunnittain äänestämään omista edustajistaan. Valtioneuvosto, korkein oikeus ja korkein hallinto-oikeus valitsivat kukin yhden kirkolliskokousedustajan. Kirkkolain mukaan nämä kolme edustajaa eivät olleet kyseisten valtiollisten elinten edustajia, jotka olisivat vastanneet toiminnastaan taustainstituutiolleen. Muiden kirkolliskokousedustajien tavoin he olivat riippumattomia koko kirkon edustajia. ${ }^{18}$ Piispat ja kenttäpiispa osallistuivat kokoukseen itseoikeutettuina, mutta jos joku piispoista oli estynyt, tuomiokapitulin oli valittava keskuudestaan hänen tilalleen edustaja.

Kirkon hallinnonuudistuksessa kirkolliskokouksen jäsenmäärä oli pudonnut kolmanneksella 108:aan ja tullut siten lähelle Ruotsin satajäsenistä kirkolliskokousta. Niin sanotussa uusimuotoisessa kirkolliskokouksessa maallikkoedustajien osuus oli 62 prosenttia, hieman suurempi kuin Ruotsissa. Muutenkin Suomessa maallikoilla oli ollut enemmistö kirkolliskokousjärjestelmän alusta asti, Ruotsissa taas vuodesta $1949 .{ }^{19}$ Vanhamuotoiseen kirkolliskokoukseen edustajat oli valittu rovastikunnittain, jolloin väkimäärältään pienten hiippakuntien edustus oli ollut suhteellisesti huomattavan suuri. Porvoon hiippakunnasta oli valittu väkilukuun suhteutettuna selvästi yli kaksi kertaa niin paljon edustajia kuin Helsingin hiippakunnasta. Sen sijaan vuodesta 1974 lähtien kunkin hiippakunnan väkiluku määritti edustajien lukumäärän. Pienten hiippakuntien edustus turvattiin siten, että jokaisesta hiippakunnasta oli valittava vähintään kaksi pappia ja neljä maallikkoa.

Uudistetun kirkkolain mukaan pappis- ja maallikkoedustajien vaalit toimitettiin joka neljäs vuosi helmikuun ensimmäisenä maanantaina. Edustajan toimivalta alkoi valinnasta ja ulottui seuraaviin vaaleihin. Määritelmä oli sama kuin kansanedustajien osalta valtiopäiväjärjestyksessä: maassa olisi poikkeusoloissakin aina paitsi toimivaltainen eduskunta myös toimivaltainen kirkolliskokous. ${ }^{20}$ Myös neljän vuoden vaalikausi oli sama kuin eduskunnalla, samoin vaalien ajankohta kevättalvella. Kirkolliskokousuudistusta koskeneen päätöksenteon aikaan syksyllä 1971 eduskunnan hajottaminen oli vielä muuttanut eduskuntavaalien rytmiä. Myöhemmin tutkimuskaudella valtiollinen päätöksenteko kuitenkin vakiintui, ja kirkolliskokousvaalit säilyivät erillään eduskuntavaalikeväästä.

Niin pappis- kuin maallikkoedustajat valittiin lähtökohtaisesti enemmistövaalilla, mutta maallikkoedustajien vaalissa otettiin käyttöön suhteellinen vaalitapa, mikäli neljäsosa vaalikokouksen osanottajista sitä vaati. ${ }^{21}$ Näin pienemmilläkin valitsijamiesryhmillä oli periaatteessa mahdollisuus saada ehdokkaitaan valituksi. Suhteellisessa vaalissa ehdokasnimien järjestys vaalilipussa määräsi kunkin ehdokkaan saaman äänimäärän. ${ }^{22} \mathrm{Va}$ litsijayhdistyksiä tai ehdokaslistoja ei ollut, minkä oli tarkoitus nopeuttaa vaalitoimitusta ja estää rajalinjojen 
60

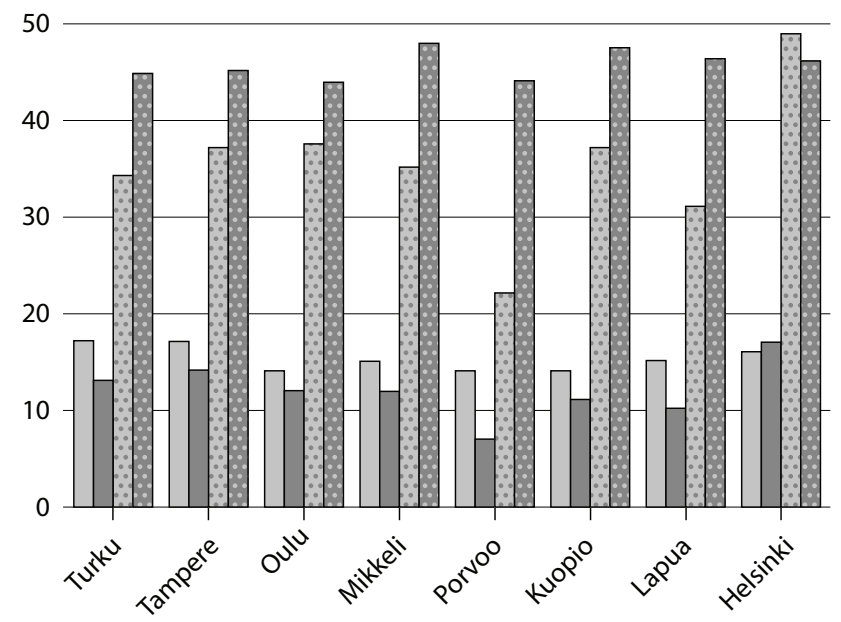

muodostumista. ${ }^{23}$ Käytännössä vaalitapa johti taktikointiin, koska vain siten ryhmän oma ääniosuus pystyttiin hyödyntämään täysipainoisesti. Valmistelu jäi kulissien taakse pienille piireille. Moni valitsijamies sai vaalipaikalla käteensä lapun, johon oli merkitty, mitkä nimet hänen oli kirjoitettava vaalilippuun ja missäjärjestyksessä. ${ }^{24}$

Koska kirkolliskokouksen valintaprosessi sisälsi satoja erillisiä vaaleja, siitä on mahdotonta muodostaa kattavaa kuvaa. Siksi esimerkkinä toimii kaksi erilaista hiippakuntaa, ensinnäkin vanhojen herätysliikkeiden ja maaseutuseurakuntien hallitsema Lapuan hiippakunta ja toiseksi kaupunkivaltainen, herätysliikeprofiililtaan heikompi mutta samalla monimuotoisempi Helsingin hiippakunta. Uusimuotoisen kirkolliskokouksen ensimmäisinä istuntokausina myös poliittisten puolueiden kiinnostus kirkolliskokousta kohtaan kasvoi huomattavasti. Aktiivisimpia olivat Keskustapuolue (jäljempänä myös keskusta) ja Kansallinen Kokoomus (kokoomus), joiden toimintaa lähinnä tarkastelen. Virallisen ehdokasasettelun puuttuessa poliittiset puolueet ovat harvoja taustaryhmiä, joiden toiminnasta kirkolliskokousvaalien alla on säilynyt asiakirja-aineistoa. Vaikka herätysliikkeillä oli erityisesti tietyissä hiippakunnissa merkittävä vaikutus vaaliasetelmiin, ilman ehdokaslistoja toimitetuissa vaaleissa tätä vaikutusta on usein vaikea mitata.

Helsingin hiippakunnan maallikkoedustajien valintakokoukseen saapui helmikuun neljäntenä 1974 yhteensä
Kuvio 1: Kirkolliskokousedustajien määrä ja sen suhde hiippakunnan väkilukuun

Hiippakuntien väkilukutiedot

Kirkon kalenteri 1975, 155.

Edustajia v. 1973, henkilöä

Edustajia v. 1974, henkilöä

…… Tuhatta henkeä / yksi edustaja v. 1973

…ํ.. Tuhatta henkeä / yksi edustaja v. 1974

240 valitsijamiestä, joista huomattava osa toimi opetusalalla. ${ }^{25}$ Runsaan kuudenneksen ammattinimike osoitti asian suoraan, ja lisäksi esimerkiksi moni filosofian maisterin tittelillä merkityistä toimi todennäköisesti opettajana. Seuraavaksi eniten työllistivät tekninen ala ja maatalousala, jolla työskenteleviä valitsijamiehiä oli pääkaupungin hiippakunnassakin huomattavasti enemmän kuin vaikkapa työväestöä. Viimeksi mainittuja oli valitsijoista vain kolmisen prosenttia, saman verran kuin esimerkiksi upseereja. Helsingin hiippakunnan valitsijakunta oli huomattavan koulutettua ja työskenteli suurelta osin johtavassa asemassa. ${ }^{26}$

Suhteellisen vaalitavan ja enemmistövaalin erot näkyivät selvästi Helsingin hiippakunnassa. Maallikkoedustajien suhteellisessa vaalissa pääkaupungin ulkopuoliset rovastikunnat saivat omia ehdokkaitaan hyvin läpi - varsinkin kun alueen valitsijat olivat ensimmäisellä kerralla vuonna 1974 valmistautuneet paremmin kuin helsinkiläiset ${ }^{27}$. Myös pappisedustajien vaalissa nämä rovastikunnat antoivat eniten ääniä oman alueensa ehdokkaille. Muualta ei ääniä kuitenkaan kertynyt, joten kirkolliskokoukseen valittiin sellaisia Helsingin ja Espoon pappeja, jotka nauttivat luottamusta ympäri hiippakuntaa. Vuonna 1974 kaikki hiippakunnan pappisedustajat tulivat hiippakunnan keskusalueen rovastikunnista, joihin kuitenkin kuului vain kolmasosa hiippakunnan väkiluvusta. Papistolle oli pääkaupunkiseudulla tarjolla monia kirkollisia erityistehtäviä, mikä näkyi vaalituloksessa: edustajien joukossa oli seurakuntapappien ohella muihin tehtäviin sijoittuneita pappeja. ${ }^{28}$

Alueellisen edustavuuden näkökulmasta maallikkoedustajien suhteellinen vaalitapa osoittautui Helsingin hiippakunnassa toimivammaksi kuin pappisedustajien enemmistövaali. Sen sijaan teologisesti enemmistövaali puolusti paikkaansa pappisedustajien vaalissa, jossa äänestäjät tunsivat toisensa ja ehdokkaansa. 
Teologisesti katsottuna kirkolliskokoukseen ei valittu edustajia eri rovastikunnille eikä edes eri hiippakunnille vaan mahdollisimman laajaa luottamusta nauttivia edustajia koko kirkolle. ${ }^{29}$ Selvimmin tämän vanhan yksimielisyysperiaatteen ilmaisi kirkkolakiin kirjattu, papiston vaalikokouksen puheenjohtajalle suunnattu määräys, joka oli sama kuin piispanvaalissa:

Ennen kuin ryhdytään äänestämään, pitäköön vaalintoimittaja rukouksen ja muistuttakoon valitsijoita vaalin tärkeydestä ja arvosta sekä kehottakoon heitä, muuta tarkoittamatta kuin Jumalan kunniaa ja kirkon hyödyn edistämistä, ehdottamaan ne papit, jotka he parhaan ymmärryksensä ja omantuntonsa mukaan katsovat jumalanpelon, opin ja kyvyn puolesta kelvollisimmiksi -.$-^{30}$

Lapuan hiippakunnassa, josta valittiin kolme pappisedustajaa, alueellinen tasapaino toteutui vuoden 1974 vaalissa paremmin ja tietoisemmin kuin Helsingin vaalissa. Lähes kaikissa rovastikunnissa pidettiin huolta siitä, että eniten ääniä saaneiden joukossa oli pappeja niin Etelä-Pohjanmaalta kuin Keski-Suomesta. Sen sijaan näiden kärkiehdokkaiden nimiin vaikuttivat kunkin rovastikunnan herätysliikeasetelmat ja paikalliset tekijät. ${ }^{31}$ Oulun hiippakunnassa taas kirjoittamattoman säännön mukaan pyrittiin neljän pappisedustajan joukkoon saamaan niin herännäisyyden, evankelisuuden, vanhoillislestadiolaisuuden kuin Elämän Sanan lestadiolaisuuden eli niin sanotun pappislinjan edustaja. ${ }^{32}$

Kaikkein selvimmin suhteellisen vaalitavan ja enemmistövaalin väliset erot näkyvät, kun vertaillaan maallikkoedustajien vaalia Lapualla ja Helsingissä. Siinä missä Helsingissä sovellettiin niin 1974 kuin neljä vuotta myöhemmin suhteellista vaalitapaa, Lapualla oli molemmilla kerroilla käytössä enemmistövaali. Vuonna 1974 Lapuan hiippakunnasta valittujen maallikkoedustajien joukkoa hallitsi suvereenisti yksi alueen vahvoista herätysliikkeistä - evankelisuus. Neljä vuotta myöhemmin herätysliikepohja oli monipuolisempi, mutta tuolloin lähes koko edustajajoukko tuli hiippakunnan länsiosasta Etelä-Pohjanmaalta. Ehdokkaista keskusteltaessa vaalikokouksessa nousi esiin yhtä monta nimeä EteläPohjanmaalta kuin Keski-Suomesta, mutta enemmistövaalista tuli itä-länsi-ottelu, jossa voiton vei länsi, tarkemmin sanottuna Etelä-Pohjanmaan keskustalaisten lista. ${ }^{33}$ Vaalitulokseen pettynyt Jyväskylän rovastikunta jätti vielä samana keväänä hiippakuntakokoukselle aloitteen Jyväskylän hiippakunnan perustamisesta. ${ }^{34}$

Ehdokasasettelun puute aiheutti ongelmia maallikkoedustajien vaalissa. Lapuan hiippakunnan maallikkoedustajien valintakokous esittikin 1974 tuomiokapitulille toivomuksen, että kokouskutsu lähetettäisiin vastaisuudessa aiemmin ja että siihen liitettäisiin osanottajaluettelo..$^{35}$ Toiveena oli saada lisäaikaa yhteydenottoihin ja vaalitaktiikasta sopimiseen. Helsingin hiippakunnassakin oli huomattavissa nopean valmistautumisen jälkiä, kuten se, etteivät valitsijamiehet läheskään aina tunteneet ehdokkaita, joita he äänestivät. Vuonna 1974 tämä seikka näyttää vaikuttaneen tulokseenkin: yksi edustaja olisi parantanut varamiessijaansa, jos kaikki häntä äänestäneet olisivat osanneet kirjoittaa hänen nimensä oikein ${ }^{36}$.

Maallikkoedustajien vaalissa oli äänestysohjeita laatimassa myös puolueorganisaatioiden edustajia. Poliittiset puolueet olivat kiinnostuneet uudella tavalla kirkollisista vaaleista, kun seurakuntavaalit oli syksyllä 1970 toimitettu ensi kertaa suhteellisella vaalitavalla. Sen jälkeen puolueiden keskinäinen kilpailu valta-asemasta yhteiskunnan eri alueilla heijastui entistä näkyvämmin kirkkoonkin. ${ }^{37}$ Esimerkiksi Keskustapuolueessa lähestyvät kirkolliskokousvaalit olivat tammikuussa 1974 esillä niin puoluehallituksessa kuin piirijärjestöittäin pidetyissä seurakuntavaaliseminaareissa. ${ }^{38}$ Keskustalaisia maallikkovalitsijoita pyrittiin saamaan puhelimitse tai neuvottelukokousten avulla kosketuksiin yhteisten ehdokkaiden nimeämiseksi. ${ }^{39}$ Suomen Sosialidemokraattisen Puolueen (SDP) piirissä vastaava yhteydenpito ei onnistunut, koska valitsijamiesten joukosta ei juuri löytynyt työväestön edustajia. Kristillisten Sosialidemokraattien Liiton liittosihteerin Pekka Lampisen sanat olivat kuvaavia: "Mutta kyllä se on työväen kannalta murheellinen tämä kirkolliskokous. - - Mutta nyt on tätä surkeutta vain siedettävä." ${ }^{\circ}$ Helsingin hiippakunnan valitsijamiesten ammattijakauma tuki synkkää tilanneanalyysia: hiippakunnassa, jonka alueella työväestöä oli paljon ja SDP vahva puolue, valitsijoiden joukossa oli työväestön edustajia vain muutama prosentti.

Seitsenkymmenluvun kirkolliskokousvaaleissa toimivatkin lähinnä keskustan ja kokoomuksen puolueorganisaation edustajat. He puolestaan yrittivät saada läpi vanhoihin herätysliikkeisiin eli rukoilevaisuuteen, 
herännäisyyteen, evankelisuuteen ja lestadiolaisuuteen lukeutuvia henkilöitä. Kummankin puolueen kirkkopolitiikassa pyrittiin säilyttämään näihin herätysliikkeisiin kuuluvien äänestäjien luottamus. Keskustassa puolueen naisjärjestö oli erityisen aktiivinen. Sen vaalityössä oli myös selvä sisällöllinen tavoite: kirkolliskokoukseen tuli saada mahdollisimman paljon edustajia, jotka kannattivat pappisviran avaamista naisille. Naisjärjestön aktiivisuus tuotti tulosta, ja kirkolliskokoukseen valittiin useita puolueessa toimineita naisia. ${ }^{41}$ Kokoomuksen naisjärjestön piirissä esitettiin kirkolliskokousuudistuksen jälkeisinä vuosina aivan samanlaisia tavoitteita. ${ }^{42}$ Naispappeuskysymys olikin keskeisimpiä teemoja 1970-luvun kirkolliskokousvaaleissa.

Kirkolliskokousedustajilta kysyttiin puoluekantaa vuonna 1976. Kaikkiaan 60 prosenttia heistä ilmoittautui puoluepoliittisesti sitoutumattomiksi. Sitoutuneiden joukossa keskusta ja kokoomus pitivät selvää kärkipaikkaa: molempien kannattajakuntaan luki itsensä 15 edustajaa eli noin 14 prosenttia edustajista. Eduskunnan suurimman puolueen, SDP:n, kannattajana piti itseään vain kolme edustajaa. Toiseksi suurimman puolueen, Suomen Kansan Demokraattisen Liiton, kannattajat puuttuivat tyystin. ${ }^{43}$ Vuoteen 1973 verrattuna tilanne oli muuttunut todella selvästi. Tuolloin lähes puolet, 45 prosenttia, edustajista oli lukeutunut kokoomukseen. Keskustalaisia oli ollut 12 prosenttia ja sosiaalidemokraatteja 10 prosenttia. ${ }^{44}$ Todennäköisesti monet kokoomuksen äänestäjät eivät enää halunneet ilmoittaa puoluekantaansa 1976, jolloin kirkon ja kirkolliskokouksen puoluepolitisoituminen oli ajankohtaisempi ja arempi kysymys kuin viimeisen vanhamuotoisen kirkolliskokouksen aikaan.

Joka tapauksessa kyselyn valossa keskustan ja kokoomuksen keskinäiset voimasuhteet olivat tasapainottuneet, kun taas vasemmistoon lukeutuvien osuus oli supistunut entisestään. Kirkolliskokousuudistuksen suunnittelun yhteydessä esillä ollut edustuksellisuuden periaate ei vasemmiston osalta toteutunut. Syyt olivat paljolti seurakuntatason tapahtumissa. Sosialististen puolueiden kannattajat osallistuivat seurakunnan toimintaan ja päätöksentekoon keskimääräistä harvemmin, ja myös vuoden 1970 seurakuntavaaleissa vasemmistolaisiksi luettujen valitsijayhdistysten menestys oli ollut selvästi heikompaa kuin vuoden 1968 kunnallisvaaleissa ${ }^{45}$.
Seuraavaksi karsintaa oli tapahtunut, kun kustakin seurakunnasta oli valittu kirkolliskokousvaaleja varten muutamia valitsijamiehiä. Vähemmistönä olleiden vasemmistolaisten seurakuntapäättäjien oli ollut vaikea saada edustajiaan valitsijamiesten joukkoon. Maallikkoedustajien vaalin moninkertainen välillisyys yksipuolisti kirkolliskokouksen jäsenten puoluejakaumaa. Mahdollisuus suhteelliseen vaaliin hiippakunnallisessa vaalikokouksessa ei korjannut tilannetta, koska valitsijajoukko oli jo ehtinyt yksipuolistua aiemmissa seurakuntatason vaaleissa.

Helmikuun 1974 jälkeen puolueet kiinnostuivat entistä enemmän omasta suhteellisesta osuudestaan kirkon johtopaikoilla. Kiinnostus näkyi seuraavan syksyn piispanvaaleissa ja seurakuntavaaleissa. Poliittista jännitystä osoitti, että arkkipiispa Martti Simojoen päätöspuhe syksyn kirkolliskokouksessa seurakuntavaalien alla sai aikaan kitkerän sananvaihdon. Asevelipappien kärkinimiin kuulunut Simojoki oli sodanjälkeisinä vuosikymmeninä pyrkinyt määrätietoisesti rakentamaan yhteyksiä työväestöön. Tälläkin kertaa hän painotti, että myös työväenliikkeen edustajia tuli saada mukaan seurakunnan luottamustehtäviin. Simojoki halusi toiminnallaan varjella eri kansalaisryhmien keskinäistä yhteyttä, mutta ei-sosialististen puolueiden lehdistössä hänen sanansa tulkittiin - kuten joskus aiemminkin - suoraksi kannatukseksi SDP:lle. ${ }^{46}$ Edelleen vuoden 1978 seurakuntavaaleissa poliittisen puolueen pohjalle muodostettujen valitsijayhdistysten määrä kasvoi voimakkaasti. Jos sopuvaaleja ei lasketa mukaan, kahdessa kolmesta seurakunnasta oli tuolloin pelkästään puoluelistoja. ${ }^{47}$

Puoluepoliittisten vaaliasetelmien voimistuminen näkyi siinäkin, että puolueiden kirkkopoliittisissa organisaatioissa alettiin valmistautua vuoden 1978 kirkolliskokousvaaleihin jo pari vuotta etukäteen. ${ }^{48}$ Kirkolliskokousvaaleja edelsivät tasavallan presidentin valitsijamiesvaalit. Toisiaan lähentyneet keskusta ja kokoomus olivat yhteisrintamassa Urho Kekkosen takana, ja yhteistyö jatkui kirkolliskokousvaaleissa. Puolueiden kirkkopoliittiset valmisteluelimet asettivat tavoitteekseen vaikuttaa jo maallikkoedustajien valitsijamiesten valintaan seurakunnissa. Omaan puolueeseen lukeutuvat maallikkovalitsijat kutsuttiin ennen vaalia kokouksiin, joissa sovittiin vaalitaktiikasta ja jaettiin äänestysohjeet. $^{49}$

T U M M A J U K K O - V ÄRIK ÄS EDUSTAJAKU N T A 21 
Kirjeissään valitsijamiehille niin keskustan kuin kokoomuksen kirkkopoliittisten elinten edustajat kehottivat pitämään huolta oman puolueen suhteellisesta osuudesta. Kun puolueissa tiedettiin, että moni valitsijamies vastusti kirkollisten henkilövalintojen puoluepolitisoitumista, vaalityötä oli perusteltava toisten puolueiden uhalla. Keskustassa muistutettiin - aiemman kyselytutkimuksen valossa tosin vailla selviä perusteita - puolueen heikosta edustuksesta kirkon ylimmissä hallintoelimissä. Kokoomuksessa taas oli esillä vasemmiston vaara, jolle sosiaalidemokraattien kolmen edustajan osuus edellisessä kirkolliskokouksessa antoi yhtä lailla varsin rajallisesti tukea. ${ }^{50}$ SDP:n piirissä esitetyt vaatimukset kirkon aseman voimakkaasta muuttamisesta olivat 1970-luvun loppupuolella laantuneet, ja puolueessa oli alettu etsiä uusia yhteyksiä kirkkoon. ${ }^{51}$ Alkanut suunnanmuutos ei kuitenkaan estänyt keskustaa ja kokoomusta vetoamasta vasemmistoradikalismin vuosien aikaisiin uhkakuviin.

Kokoomuksen kirkkopoliittisen työryhmän puheenjohtaja oli kirkon sopimusvaltuuskunnan toimistonjohtaja Jouni Veinio. Lisäksi työryhmään kuului toinen sopimusvaltuuskunnan virkamies Sakari Karjalainen, jonka vastuualueena työryhmässä oli erityisesti vaalityö kirkolliskokousvaaleissa..$^{52}$ Kirkon sopimusvaltuuskunnan tehtävänä oli edustaa kirkkoa työnantajana. Se oli kirkolliskokouksen valitsema elin, jonka tuli vastata toiminnastaan kirkolliskokoukselle ja jättää toimintakertomuksensa sen hyväksyttäväksi. Osallistuessaan kokoomuksen nimissä ehdokkaiden etsimiseen ja vaalityöhön kirkolliskokousvaaleissa sopimusvaltuuskunnan virkamiehet olivat siis välillisesti vaikuttamassa omien esimiestensä valintaan.

Kokoomuksen kirkkopoliittisen työryhmän päähuomio kohdistui vuoden 1978 vaalityössä Helsingin hiippakuntaan. ${ }^{53}$ Maallikkoedustajien vaalissa hiippakunta olikin Tampereen ja Turun ohella puolueen vahvoja alueita. Keskustan tärkeimpiä tukialueita olivat Lapuan, Oulun ja Turun hiippakunnat eli vahvat herätysliikealueet. ${ }^{54}$ Kaikkiaan keskusta ja kokoomus menestyivät maallikkoedustajien vaalissa erittäin hyvin. Valituista maallikkoedustajista tunnistettiin keskustalaisiksi 26 henkilöä eli 40 prosenttia. ${ }^{55}$ Vastaavasti kokoomuksessa luettiin oman puolueen kannattajiksi 24 maallikkoedustajaa. Kokoomukseen tai keskustaan laskettiin näin ollen kuuluvaksi lähes neljä viidestä maallikkoedustajasta. Ruotsalaiselle kansanpuolueelle (RKP) laskettiin Porvoon hiippakunnan viisi maallikkoedustajapaikkaa, Suomen Kristilliselle Liitolle samaten viisi paikkaa ja SDP:lle kolme edustajaa. Porvarillisella puolella esitetyt uhkakuvat vasemmiston noususta olivat jälleen osoittautuneet perusteettomiksi. Lopulta 64 maallikkoedustajasta jäi jäljelle yksi, jolle keskustassa ja kokoomuksessa ei onnistuttu löytämään kotipuoluetta ja jonka nimen kohdalle merkittiin "sitoutumaton".56

Tällä kertaa tiedot poliittisesta taustatyöstä levisivät myös julkisuuteen..$^{57}$ Kotimaa vertasi pääkirjoituksessaan tilannetta happamasti ja osuvasti poroerotukseen, "jossa puoluepaliskunnat merkitsevät omiaan ja kaikki yhdessä huolehtivat siitä, ettei kukaan jää erottelun ulkopuolelle". ${ }^{8}$ Kun edellisellä nelivuotiskaudella 60 prosenttia kirkolliskokousedustajista oli määritellyt itsensä sitoutumattomiksi, nyt niillekin, jotka ehkä itse olisivat pitäneet itseään sitoutumattomina, löydettiin puoluetoimistoissa puoluekanta. Kirkon puoluepolitisoitumisesta puhuttiin vaalien jälkeen runsaasti, ja piispakunnastakin kuului puheenvuoroja sitä vastaan. ${ }^{59}$

Puolueiden kiinnostus uusimuotoisen kirkolliskokouksen edustajavaaleja kohtaan oli ollut selvää jo 1974, mutta 1978 se kohosi huippuunsa - vuosia myöhemmin kuin esimerkiksi kouluneuvostoissa tai korkeakoulupolitiikassa. Puolueiden osallistuminen kirkollisiin vaaleihin olikin osa jonkinlaista politisoitumisen toista aaltoa, joka näkyi myös ammattiyhdistysliikkeessä. Vuonna 1978 tuo aalto oli korkeimmillaan mutta samalla jo kääntymässä laskuun. ${ }^{60}$ Lisäksi on huomattava, että pappisedustajien vaalissa poliittiset puolueet eivät saaneet lainkaan sellaista asemaa kuin maallikkoedustajia valittaessa. Puolueiden vaikutus ei myöskään juuri näkynyt vaalien jälkeisessä kirkolliskokoustyöskentelyssä: vaikka puolueiden kirkkopoliittiset elimet kutsuivat kirkolliskokousedustajia koolle, nimesivät yhdyshenkilöitä tai kaavailivat kirkolliskokousaloitteita, kirkolliskokoukseen ei syntynyt kiinteitä, selvärajaisia tai vaikutusvaltaisia - saati ryhmäkuria käyttäviä - puolueryhmiä. ${ }^{61}$ Siten työskentely erosi olennaisesti eduskunnasta. ${ }^{62}$

Kirkolliskokousedustajien poliittinen jakauma poikkesi valtakunnanpoliittisista asetelmista ja siten myös kirkon koko jäsenistön puoluejakaumasta. Tilanne vaikutti kirkolliskokouksen sisäiseen ryhmätoimintaan. 
Esimerkiksi kokoomuksen paitsioasema valtakunnanpolitiikassa oli omiaan hillitsemään kokoomuslaisten yhteistyötä kirkolliskokouksessa, vaikka puolueen kannattajia oli kirkon päättäjien joukossa suhteellisesti paljon ${ }^{63}$. Sosiaalidemokraattisessa työväenliikkeessä toimivat kirkolliskokousedustajat puolestaan kokivat edustavansa monissa asioissa pientä vähemmistöä, vaikka kirkon jäsenistössä olikin huomattava joukko samaan aatteelliseen perintöön nojaavia. ${ }^{64}$

Uusimuotoisen kirkolliskokouksen vaalitapa herätti tuoreeltaan arvostelua epädemokraattisuudesta ja avoimuuden puutteesta. ${ }^{65}$ Tampereen hiippakuntakokous ehdotti keväällä 1978, että kirkolliskokouksen edustajaehdokkaat nimettäisiin ennalta. Samassa yhteydessä Helsingin hiippakunnan uusi maallikkoedustaja, apulaisprofessori Seikko Eskola jätti aloitteen, että luovuttaisiin myös valitsijamiesjärjestelmästä. Sen sijaan seurakunta- ja kirkkoneuvostojen jäsenet voisivat valita hiippakuntansa maallikkoedustajat suoraan - mieluiten postiäänestyksenä. ${ }^{66}$ Maarian kirkkoherra, evankelisuuteen lukeutunut Eero Parvio vastusti aloitetta muun muassa siitä syystä, että hänen mielestään kirkollinen vaali ei koskaan ollut vain pelkkä tekninen vaalitoimitus vaan hengellinen tapahtuma: "On arvokasta se, että yleisillä kansanvaaleilla valitut paikallisseurakuntien hallintoelimet vastuullisesti valtuuttavat keskuudestaan määrätyt henkilöt keskustelemaan ehdokkaista ja suorittamaan valinnan." ${ }^{67}$ Puolustaessaan näillä sanoilla vaalitapaa Parvio tosin tuli tahtomattaan osoittaneeksi sen monimutkaisuuden.

Seuraavan kerran ehdokasasetteluun ja vaaliliittoihin palattiin 1981 Eskolan ja toisen Helsingin hiippakunnan edustajan, Helsingin kauppakorkeakoulun julkisoikeuden professorin Jaakko Voipion aloitteiden pohjalta. ${ }^{68}$ Kirkolliskokous ei lähtenyt tuossa vaiheessa toteuttamaan vaaliliittoja vaan siirsi asian osaksi laajempaa vaaliuudistusta. Marraskuussa 1981 - vaalivalmistelujen ollessa hiippakunnissa jo käynnissä - kirkolliskokoukselta lähti kuitenkin ohjeistus, joka mahdollisti ehdokkaiden esittämisen etukäteen maallikkoedustajien vaalissa. Samalla jokainen maallikkovalitsija saisi luettelon kaikista hiippakuntansa valitsijamiehistä. ${ }^{69}$ Toiveet avoimuuden ja ennakkovalmistelujen lisäämisestä toteutuivat osittain.

\section{EDUSTAJIKSI KOKENEITA VIRKAMIEHIÄ}

Viralliset edustajat toivat kirkolliskokoukseen pysyvyyttä. Erityisesti virkansa puolesta edustajina olleet piispat ja kenttäpiispa olivat kokeneita kirkolliskokousedustajia. Vuonna 1974 seitsemällä piispalla kahdeksasta oli meneillään neljäs tai useampi edustajakausi. Myöhemmin valituilla uusilla piispoilla oli niin ikään yleensä vankka kokemus kirkolliskokoustyöskentelystä. Kokemus näkyi myös piispojen keski-iässä, joka keväällä 1974 oli 60 vuotta. Pian sen jälkeen kaksi piispaa jäi kuitenkin eläkkeelle ja sai 1930-luvun alussa syntyneet seuraajat. Pappisedustajien keski-ikä oli uusimuotoisen kirkolliskokouksen alkaessa huomattavasti alhaisempi, 48 vuotta. Nuorin oli 33-vuotias Uudenkaarlepyyn Kristliga Folkhögskolanin rehtori Gustav Björkstrand, vanhin taas 6o-vuotias Kuopion tuomiorovasti Samuli Aaltonen, joka kuoli vielä saman nelivuotiskauden aikana.

Maallikkoedustajien keski-ikä oli vaalikauden alkaessa hieman yli 50 vuotta. $^{70}$ Seurakuntien luottamushenkilöiden keski-ikä oli kirkolliskokousvaalien aikaan suunnilleen samaa tasoa, joten valittujen edustajien ja valitsijoiden välillä ei ollut tältä osin havaittavissa eroa. ${ }^{71}$ Oulun hiippakunnan maallikkoedustajien joukosta löytyivät niin 29-vuotias vanhoillislestadiolainen opettaja Erkki Piri kuin evankelisuuteen lukeutunut 80-vuotias maanviljelysneuvos Viljami Kalliokoski. Uusia edustajia oli kolmannes, ja myös edustajien keski-ikä laski hieman edellisvuoden kirkolliskokoukseen verrattuna ${ }^{72}$. Vuoden 1974 kirkolliskokousvaaleissa ei kuitenkaan nähty samanlaista nuorennusleikkausta ja suurten ikäluokkien nousua kuin 1970-luvun alussa oli koettu eduskuntavaaleissa. Tähän seikkaan vaikutti osaltaan maallikkoedustajien vaalin välillisyys: vielä vuoden 1970 seurakuntavaaleissa valituilta päättäjiltä oli edellytetty vähintään 25 vuoden ikää, joten 1974 nuorimmatkin maallikkoedustajien valitsijamiehet olivat jo lähes 30-vuotiaita.

Piispojen tavoin myös korkeimpien oikeusistuinten valitsemat edustajat toivat kokoukseen pysyvyyttä. Korkeimman oikeuden valitsemana edustajana oli oikeusneuvos Johannes Leivonen. Häntä kohtaan tunnettua luottamusta osoitti, että hän olisi päässyt kirkolliskokoukseen myös toista reittiä: Helsingin hiippakunnan valitsijamiehet antoivat hänelle maallikkoedustajien

T U M M A J O UKO - V ÄRIK ̈̈S E D US TA JAKU N T 23 
vaalissa kaikkein suurimman äänimäärän. Korkeimman hallinto-oikeuden valitsemina edustajina toimivat puolestaan hallintoneuvos Seppo Ojala ja hänen jälkeensä hallintoneuvos Pekka Kurvinen.

Kirkon keskushallinnon uudistuksessa hovioikeuksien ja oikeustieteellisen tiedekunnan valitsemat edustajat oli jätetty pois kirkolliskokouksen kokoonpanosta. ${ }^{73}$ Vaikka vuoden 1971 ylimääräinen kirkolliskokous oli päättänyt säilyttää korkeimpien oikeusistuinten valitsemat edustajat, kirkkolain takaama oikeusoppineiden edustus kapeni uudistuksen myötä huomattavasti. Siten uudistus korosti kahden jäljelle jääneen edustajan asemaa ja vastuuta. Toisaalta kirkolliskokouksen maallikkovalitsijat halusivat uudessakin tilanteessa 1974 turvata oikeudellisen asiantuntemuksen, mitä kuvasti Helsingin hiippakunnan vaalitulos. Oikeustieteellisen tiedekunnan edustajan puuttumisen korvasi se, että Porvoon hiippakunnasta valittiin maallikkoedustajaksi Åbo Akademin yksityisoikeuden professori Lars Erik Taxell. Saman hiippakunnan toinen maallikkoedustaja, tuomiokapitulin lainoppinut asessori Gunnar Träskman taas toi kirkolliskokoukseen kirkon hallinnon ja lainsäädännön tuntemusta. Myös pappisedustajaksi valittu Hämeenlinnan kirkkoherra Olli Heilimo oli arvostettu kirkkolain tuntija. Kun vielä kirkolliskokoukseen tuli muutamia lakimiehiä eri hiippakunnista, oikeudellinen asiantuntemus ei päässyt romahtamaan sillä tavalla kuin etukäteen oli pelätty. Vuonna 1978 alkaneella nelivuotiskaudella tätä asiantuntemusta edusti Taxellin, Träskmanin ja Heilimon ohella näkyvästi Jaakko Voipio.

Kokeneiden virallisten edustajien joukossa valtioneuvoston määrämät edustajat muodostivat poikkeuksen ja vaihtuivat tiuhaan vuosina 1974-1981 - istuihan tuona aikana monia lyhytikäisiä hallituksia. Edustajana oli poikkeuksetta ministeri opetusministeriöstä. Hän oli paikalla istuntokauden aikana yleensä vain yhtenä päivänä, jolloin hän järjesti kirkolliskokousedustajille kahvitilaisuuden. Monilla istuntokausilla ministerille ei ollut määrätty lainkaan varamiestä tai jos olikin, varaedustajakaan ei ollut läsnä kuin erityistapauksissa. Uusimuotoisen kirkolliskokouksen alkuvaiheessa opetusministeri Ulf Sundqvist linjasi, ettei valtiovalta halunnut puuttua kirkon sisäisiin asioihin ${ }^{74}$. Vaikka valtioneuvoston määräämät edustajat eivät käytännössä juuri osallistuneet kirkolliskokouksen työskentelyyn, epäviralliset tapaamiset tuon yhdenkin päivän aikana tarjosivat kirkon edustajille tärkeän kanavan valtiovallan suuntaan. Joskus jonkin opetusministeriötä olennaisesti koskettavan asian käsittely oli myös mahdollista ajoittaa niihin tunteihin, jolloin ministeri oli paikalla.

Vuonna 1974 hiippakunnittain valituista pappisedustajista peräti runsaalla viidenneksellä oli meneillään vähintään neljäs edustajakausi. ${ }^{75}$ Suurin osa pappisedustajista oli toista tai kolmatta kauttaan kirkolliskokouksessa, eikä puolet hiippakunnista lähettänyt Turkuun yhtään uutta pappisedustajaa. Hiippakunnista valitut maallikkoedustajat sen sijaan olivat selvästi pappisedustajia kokemattomampia. Maallikkoedustajat, joilla oli yleisesti tunnettu herätysliiketausta, olivat keskimääräistä kokeneempia. Herätysliikkeeseen lukeutuvat äänestäjät tarjosivat oman liikkeensä edustajille tavallista vakaamman kannatuspohjan.

Vielä herätysliiketaustaakin selvemmin sukupuoli erotteli kokeneita ja uusia edustajia. Vuoden 1970 eduskuntavaaleissa naisten osuus valituista oli ensi kertaa ylittänyt 20 prosentin rajan. ${ }^{76}$ Naisedustajien määrä kasvoi 1970-luvun alkupuolella myös kirkolliskokouksessa, mikä tarkoitti samalla, että mukana oli paljon ensimmäisen kauden edustajia. Itse asiassa 1974 valitut maallikkomiehet eivät kokemukseltaan eronneet kovin merkittävästi papistosta. Sen sijaan naisedustajista lähes kaksi kolmannesta oli kirkolliskokouksessa ensimmäistä kauttaan. Kirkolliskokouksen jäsenten vaihtuvuus oli 1974 pitkälti uusien naisedustajien varassa. Viimeisen vanhamuotoisen ja ensimmäisen uusimuotoisen kirkolliskokouksen vaalit olivat ajallisesti lähellä toisiaan, mikä osaltaan selittää vähäistä vaihtuvuutta. Sen sijaan neljä vuotta myöhemmin hiippakunnittain valittujen pappis- ja maallikkoedustajien joukossa jo hieman yli puolet oli uusia.

Vuonna 1974 kirkolliskokoukseen valittiin 20 naista. Heidän osuutensa maallikkoedustajista oli yli kaksinkertainen verrattuna edellisen vuoden kirkolliskokoukseen ja kymmenen prosenttiyksikköä korkeampi kuin naisten osuus 1972 valitussa eduskunnassa. Tämä huima nousu ei enää jatkunut vuoden 1978 kirkolliskokousvaaleissa, joissa naisedustajien määrä kasvoi vain yhdellä. Vaalitulokseen heijastui se, etteivät naispappeuskysymys ja lehtorinviran kehittäminen olleet tuolloin kirkolliskokouksen asialistalla. Naisedustajien määrän vaihteluil- 


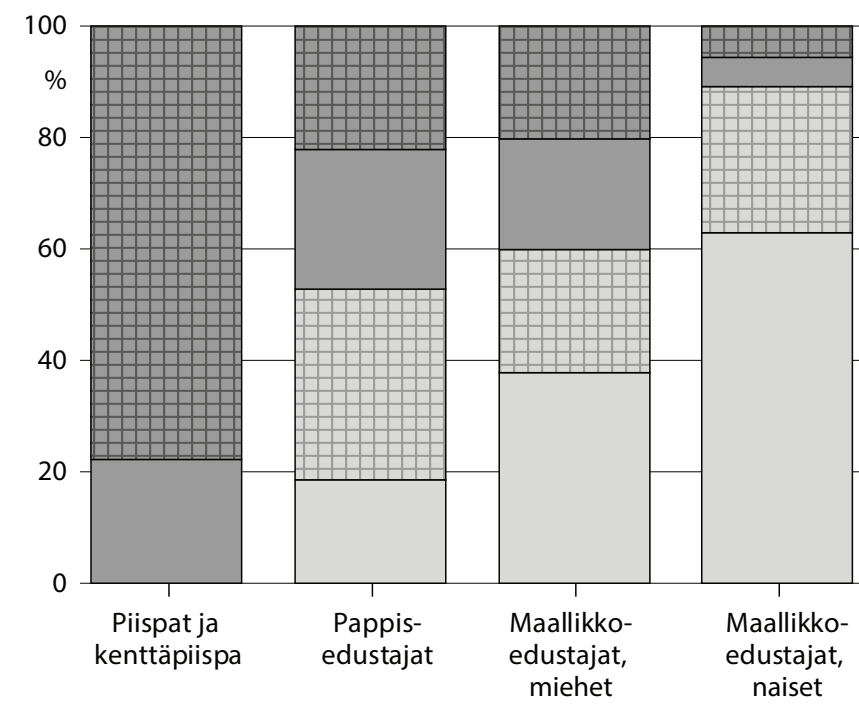

le hiippakuntien kesken ei löydy yksiselitteisiä syitä, ja esimerkiksi herätysliikkeiden vahvoilta alueilta valittiin kirkolliskokoukseen naisia siinä missä muualtakin. Sen sijaan herätysliikkeiden kesken oli eroja. Vuonna 1974 kirkolliskokoukseen valittiin naisedustajia, joilla oli yleisesti tunnettu tausta herännäisyydessä tai evankelisuudessa. Naisten osuus herännäismaallikoista oli sama kuin naisten osuus maallikkoedustajista muutenkin. Myös evankelisilla naisedustajilla oli näkyviä tehtäviä herätysliikkeessään: Alma Saari oli Karstulan evankelisen kansanopiston apulaisrehtori, ja laihialainen kansakoulunopettaja Aili Rajamäki toimi maallikkopuhuja$\mathrm{na}^{77}$. Vanhoillislestadiolaiset valitsijat antoivat äänensä liikkeen johtohenkilöille ja saarnaajille. Näissä tehtävissä oli pelkästään miehiä.

Vuonna 1974 valituille kirkolliskokousedustajille tehdyn kyselytutkimuksen mukaan hieman alle puolella, 48 edustajalla, oli herätysliiketausta. Osuudeltaan suurin oli herännäisyys, johon kertoi kuuluvansa 20 edustajaa. Evankelisuuteen lukeutui 14 ja lestadiolaisuuden eri suuntauksiin yhdeksän edustajaa. ${ }^{78}$ Herätysliikkeiden alueellinen jakauma näkyi kirkolliskokouksen kokoonpanossa selvästi. Lapuan hiippakunnassa herätysliiketausta oli lähes jokaisella edustajalla, ja enemmistö lukeutui evankelisuuteen. Kuopion hiippakunnan maallikkoedustajissa taas herännäisyydellä oli erittäin vahva edustus. Oulun edustajistossa lestadiolaisuuden suuntaukset olivat vahvimpia herätysliikkeitä, ja Mikkelissä näkyi viidennen herätysliikkeen vaikutus.
Kuvio 2: Kirkolliskokouksen jäsenten edustajakokemus 1974: Kuinka mones kausi kirkolliskokousedustajilla oli meneillään eri ryhmissä?
4. tai useampi 3.

2.

1.
Ylimääräisiä kirkolliskokouksia, joissa istuivat edelliseen varsinaiseen kirkolliskokoukseen valitut edustajat, ei ole kuviossa laskettu erillisiksi edustajakausiksi.
Kirkolliskokouksen pappisedustajat olivat valtaosin johtavaa seurakuntapapistoa. Vuonna 1974 valituista pappisedustajista selvä enemmistö, kolme neljäsosaa, oli kirkkoherroja - joukossa useita tuomio- ja lääninrovasteja. Kirkkoherrojen joukon ulkopuolelta valittuihin harvoihin pappisedustajiin kuului arkkihiippakunnan pappisedustaja, Helsingin yliopiston kansleri Mikko Juva. Hänestä tuli arkkipiispa 1978 Martti Simojoen jäätyä eläkkeelle. Turun arkkihiippakunnan tuomiokapitulin asessorit olivat kirkolliskokousvaalien alla pyytäneet, ettei heitä äänestettäisi ${ }^{79}$. He jäivät kuitenkin poikkeuksiksi, ja muuten kirkolliskokoukseen tuli huomattavan paljon tuomiokapitulien jäseniä. Keväällä 1974 neljännes pappisedustajista ja noin kuudesosa kaikista kirkolliskokouksen jäsenistä kuului johonkin tuomiokapituliin. Hiippakuntatason näkökulmalla oli siten hyvät mahdollisuudet päästä esille kirkolliskokouksessa. Toisaalta kirkolliskokouksesta tuli tällä tavoin pitkälti päällekkäinen piispainkokouksen kanssa, eräänlainen laajennettu piispainkokous, jonka vallan ytimessä olivat piispat ja tuomiokapituleihin kuuluva johtava papisto.

Piispojen ja pappisedustajien ohella 1974 maallikkoedustajissa oli kolme teologia, joten teologien osuus kirkolliskokousedustajista oli hieman yli 40 prosenttia. Tämä joukko oli myös kouluttautunut tavallista pidemmälle. Pappisedustajista 41 prosentilla oli yliopistollinen jatkotutkinto. Erityisen koulutettuja olivat Helsingin "yliopistohiippakunnan" pappisedustajat. Kokonaisuudessaan hieman yli puolella kirkolliskokouksen teologeista ja yli viidenneksellä kaikista kirkolliskokousedustajista oli teologinen jatkotutkinto. Lisäksi kirkolliskokouksessa istui neljä teologian kunniatohtoria.

Uusimuotoisen kirkolliskokouksen alkaessa teologisen tiedekunnan edustaja oli jätetty pois virallisten edustajien joukosta, mutta kirkolliskokouksessa oli edelleen neljä entistä teologian professoria tai apulaisprofessoria.

T UMMA JOUKKO-V ̈ RIK ̈̈S E D S TA JAKUN T A 
Toisen nelivuotiskauden alkaessa yliopistoteologien osuus vahvistui entisestään Porvoon hiippakunnan pappisedustajien myötä: edustajana aloittanut Fredric Cleve oli Åbo Akademin systemaattisen teologian apulaisprofessori, kun taas Gustav Björkstrand oli siirtynyt hoitamaan kirkkohistorian professuuria. Kun vielä Helsingin yliopiston ekumeniikan professori Kalevi Toiviainen siirtyi samanaikaisesti Mikkelin hiippakunnan piispaksi, oli teologisen tiedekunnan edustajan jättämä aukko korvautunut muilla henkilövalinnoilla, kuten oli käynyt pitkälti myös oikeusoppineiden edustuksen osalta.

Vuosina 1974 ja 1978 hiippakunnittain valituista maallikkoedustajista selvästi yli neljännes työskenteli tittelinsä perusteella opetusalalla. Vuonna 1978 työnsä aloittaneessa kirkolliskokouksessa oli myös kahdeksan insinööriä tai diplomi-insinööriä, kun taas kymmenen edustajaa työskenteli maa- ja metsätalouteen liittyvissä tehtävissä. Yhteensä nämä kolme alaa kattoivat yli puolet maallikkoedustajista. Julkisen sektorin korkea osuus sekä suhteessa suuri ylempien toimihenkilöiden ja maanviljelijöiden edustus olivat samaan aikaan tyypillisiä piirteitä myös eduskunnassa ${ }^{80}$. Opettajien ja maanviljelijöiden osuus oli varsinkin aiempina vuosikymmeninä ollut kansanedustajien keskuudessa korkea. ${ }^{81}$ Kirkolliskokouksen maallikkoedustajissa näkyivät edelleen erityisen selvästi nämä kaksi ammattiryhmää, joiden edustajia oli runsaasti mukana paikallistasolla niin seurakuntien kuin kuntien päätöksenteossa. Opetusala korostui erityisesti naisedustajien ammattinimikkeissä, kuten oli näkynyt aiemmissakin kirkolliskokouksissa ${ }^{82}$.

Ensimmäisissä uusimuotoisissa kirkolliskokouksissa oli pappien ja kirkon lakimiesten ohella jonkin verran muitakin kokonaiskirkon, seurakuntien ja kristillisten järjestöjen työntekijöitä. Vuonna 1974 maallikkoedustajien joukosta löytyivät diakoniatyöntekijä, kanttori ja suntio. Kirkolliskokouksessa oli myös kuntien johtavia viranhaltijoita: 1974 alkaneella nelivuotiskaudella kaksi edustajaa toimi kunnan tai kauppalan johtajana, seuraavalla vaalikaudella kolme. Vuonna 1978 kirkolliskokoukseen valittu valtakunnansovittelija Matti Pekkanen taas edusti maan korkeinta työmarkkinapolitiikan tuntemusta.

Maallikkoedustajien työalat ja -tehtävät vastasivat pitkälti heidät valinneiden valitsijamiesten ammattijakaumaa mutta eivät seurakuntien luottamuselinten sosio- ekonomista rakennetta. Johtavassa asemassa toimivien ja viranhaltijoiden asema korostui kirkolliskokouksessa, kun taas työväestö, johon kuului lähes viidennes seurakuntien luottamuselinten jäsenistä, jäi 1974 kirkolliskokouksen ulkopuolelle ${ }^{8_{3}}$. Myös yksityisten palvelualojen toimihenkilöitä oli kirkolliskokouksessa vain vähän, vaikka nämä alat olivat kasvaneet voimakkaasti sodanjälkeisinä vuosikymmeninä. ${ }^{84}$ Helsingin hiippakunnan valitsijamiesten ammattijakauma osoittaa, että sosioekonominen kapeutuminen tapahtui suurimmaksi osaksi jo seurakunnissa valittaessa maallikkoedustajien valitsijamiehiä: kunkin seurakunnan harvat valitsijamiespaikat päätyivät hyvin usein johtavassa asemassa oleville ja virkamiehille. Työväestön puuttuminen ja osin siihen liittyvä poliittisen vasemmiston kannattajien harvalukuisuus osoittivat, ettei edustuksellisuuden periaate kaikilta osin toteutunut.

Kirkolliskokouksen satavuotisen historian aikana kirkolliskokousuudistukseen mennessä kirkollinen ja valtiollinen päätöksenteko olivat eriytyneet toisistaan. Vuonna 1898 peräti kolme neljästä kirkolliskokousedustajasta oli istunut säätyvaltiopäivillä, mutta eduskuntauudistuksen myötä kirkolliskokouksen yhteys valtiopäiviin oli heikentynyt ratkaisevasti. Vielä toisen maailmansodan jälkeen kymmenesosalla kirkolliskokousedustajista oli kansanedustajakokemusta, mutta 1970-luvun alussa tällaiset kytkökset eduskuntatyöhön hävisivät lähes täysin. ${ }^{85}$ Myöskään vuonna 1974 kirkolliskokoukseen ei valittu yhtään istuvaa kansanedustajaa. Sen sijaan kirkolliskokoukseen tuli neljä entistä kansanedustajaa, jotka olivat edustaneet politiikassa keskiryhmiä. Poliittisten puolueiden aktivoituminen kirkolliskokousvaaleissa edisti todennäköisesti tämän joukon kasvua. Kokenein entisistä kansanedustajista oli maanviljelysneuvos Viljami Kalliokoski Halsualta. Maalaisliiton entinen puheenjohtaja ja moninkertainen maatalousministeri oli istunut 41 valtiopäivillä 1920-luvulta 1960-luvulle.

Yksi istuva kirkolliskokousedustaja, pankinjohtaja Matti Maijala Virroilta, valittiin kansanedustajaksi vuoden 1975 vaaleissa. Keskustapuolueen listalta valittu Maijala vei Lapuan tuomiokapitulin tutkittavaksi, oliko eduskunnan jäsenyys lain mukaan este kirkolliskokousedustajan tehtävälle ${ }^{86}$. Maijala sai jatkaa kirkolliskokouksessa. Hänen kysymyksensä osoitti kuitenkin, 
On huomattava, että samaan tapaan eduskunnan työskentely arkipäiväistyi $1970-l u v u l l a .{ }^{87}$ Muutos ilmeni kirkolliskokouksessa myös siten, että kulkueessa nähty piispojen yhteinen rintama hajosi istuntosaliin tultaessa. Piispat olivat aiemmin istuneet eturivissä, mutta kirkkohallituksen esittämän uuden työjärjestyksen mukaan he kuuluivat oman hiippakuntansa edustajien joukkoon. ${ }^{88}$ Ratkaisussa voi havaita aikakaudelle tyypillisiä demokratisoimispyrkimyksiä. Vaikka apostolien aikaan ulottuvassa kirkolliskokousten historiassa oli Pohjolassa alkanut uusi vaihe, yhdessä suhteessa kirkolliskokous palasi Jeesuksen ensimmäisten seuraajien kiistakysymyksiin: piispojen siirron johdosta uusimuotoinen kirkolliskokous alkoi keskustelulla istumajärjestyksestä.

Mikkelin piispa Osmo Alaja lähetti "kaipaavan tervehdyksensä" piispaystävilleen Lapuan Eero Lehtiselle ja Kuopion Olavi Karekselle, joista oli joutunut eroon. Alaja piti aiheettomana pelkona, että piispojen eturivi olisi äänestyksissä - jotka toimitettiin useimmiten seisomaan nousten - mallina muille edustajille: "Äänestyksessä en ole koskaan katsellut taakseni eikä minulla ole mitään taustapeiliä käytössäni.” Päinvastoin hän arveli hiippakuntansa edustajien olevan kiusaantuneempia nyt, kun piispa oli heidän joukossaan "kaitsijana". Alajan kysymys ei kuitenkaan liittynyt ainoastaan piispojen ulkoiseen vaikutusvaltaan äänestyksissä. Hänen mukaansa istumajärjestyskin saattoi heijastaa kirkkonäkemystä. ${ }^{89}$ Pohjimmiltaan oli kyse siitä, miten kirkolliskokouksen tehtävä ymmärrettiin.

Kirkkolakia muutettaessa uusimuotoisesta kirkolliskokouksesta oli pyritty tekemään elin, joka itse saisi päättää kaikista tärkeistä kirkkoa koskevista asioista. ${ }^{\circ}$ Taustalla vaikuttivat demokratisoimista ja hallinnon tehostamista koskeneet paineet, jotka olivat näkyneet laajalti yhteiskunnassa ja johtaneet valtiossa esimerkiksi pyrkimyksiin vahvistaa eduskunnan asemaa. ${ }^{91}$ Uudistuksessa kirkolliskokous oli saanut vanhojen tehtäviensä ohelle lähinnä laajennetun piispainkokouksen aiemmin hoitamia tehtäviä. Kirkolliskokouksen perinteisenä tehtävänä oli hyväksyä ja määrätä otettavaksi käyttöön kirkolliset kirjat: raamatunkäännös, katekismus, virsikirja sävelmistöineen, kirkkokäsikirja sekä messusävelmistö..$^{92}$ Näitä asioita valmisteli kirkolliskokouksessa käsikirjavaliokunta. Vuoden 1973 kirkolliskokous oli aloittanut monia merkittäviä kirkollisten kirjojen uudis- tushankkeita, kuten raamatunkäännöstyön, suomenkielisen virsikirjan uudistamisen ja kirkollisten toimitusten kirjan valmistelun. Alkanut mittava liturginen uudistustyö nojautui jumalanpalveluskeskeisyyden periaatteeseen. ${ }^{93}$ Vuosina 1974-1981 suuret uudistukset olivat komiteoiden käsissä, ja kirkolliskokouksen tehtävänä oli lähinnä ottaa kantaa komiteoiden välimietintöihin. Turkuun kokoontuneiden edustajien päähuomio oli yhteiskunnallisissa ja hallinnollisissa kysymyksissä.

Käsikirjavaliokunta kärsi tänä aikana välillä suorastaan asiapulasta. Sen puheenjohtaja, piispa Alaja mietti jopa, kuuluiko hänen valiokuntansa ollenkaan pysyvien valiokuntien joukkoon. Pohdiskelun johdosta valiokunnan tehtävää laajennettiin, jotta sinne saatiin lähetetyksi myös sellaisia asioita, jotka jollakin tavalla sivusivat kirkollisia kirjoja. ${ }^{94}$ Hyvällä tahdolla tällaiseksi asiakokonaisuudeksi tulkittiin esimerkiksi kirkkomuusikon virkojen uudelleenjärjestely; olivathan nämä viranhaltijat työssään tiiviisti tekemisissä kirkkokäsikirjan ja virsikirjan kanssa. Valiokunta sai kyllä jonkin verran suoraan omaakin alaansa koskevia tehtäviä - esimerkiksi, kun kirkolliskokous aloitti ruotsinkielisen virsikirjan uudistustyön ja hyväksyi uskontunnustusten uudet sanamuodot.

Toinen kirkolliskokoukselle perinteisesti kuulunut tehtävä oli tehdä ehdotuksia kirkkolain säätämisestä, muuttamisesta, selittämisestä tai kumoamisesta. ${ }^{95}$ Kirkollisten kirjojen hyväksymisen tavoin kirkkolakiehdotusten tekeminen edellytti erityistä käsittelyjärjestystä ja kolmen neljäsosan määräenemmistöä annetuista äänistä. ${ }^{96}$ Kirkkolain muutosehdotukset annettiin hallituksen esityksinä eduskunnalle, jolla oli oikeus joko hyväksyä tai hylätä ne. Asian käsittelyyn saivat osallistua vain Suomen evankelis-luterilaiseen kirkkoon kuuluvat kansanedustajat. Osana kirkon ja valtion keskinäisten suhteiden muokkaamista oli vuosina 1974-1981 suunnitteilla laajamittainen uudistushanke, jossa kirkkolaki oli tarkoitus jakaa lakiosaan ja kirkon itsensä säätämään kirkkojärjestykseen. Uudistuksen myötä myös kirkkoon kuulumattomien kansanedustajien oli määrä päästä mukaan kirkkolain käsittelyyn. Vastaavasti kirkolliskokous voisi aiempaa itsenäisemmin päättää kirkon sisäisistä asioista.

Kirkkolain muutoksia valmisteli useimmiten lakivaliokunta, uskoon ja oppiin kiinteästi liittyvissä asioissa 
taas siviili- eli sittemmin perustevaliokunta. Vuosien 1968, 1971 ja 1973 kirkolliskokoukset olivat uudistaneet voimakkaasti kokonaiskirkon ja seurakuntien hallintoa. Siitä huolimatta ja myös sen vuoksi kirkolliskokous sai vuosina 1974-1981 asialistalleen lukuisia hallintoa koskevia kirkkolain muutosehdotuksia. Erityisesti hiippakuntakokousten aloitteista näkyi, että paikallistasolla löydettiin uudistetuista säännöksistä paljon parannettavaa. Oppia koskevista kirkkolain muutospyrkimyksistä sai ehdottomasti eniten huomiota kysymys pappisviran avaamisesta naisille. Uudistus ei toteutunut 1970-luvulla, mutta sen sijaan toinen merkittävä oppia koskeva kirkkolain muutosehdotus hyväksyttiin 1977. Kirkolliskokous esitti pitkän valmistelun jälkeen, että lapsi voisi osallistua ehtoolliselle, kun mukana olisi hänen kristillisestä kasvatuksestaan vastaava, konfirmoitu kirkon jäsen. ${ }^{97}$
Kirkolliskokouksen tehtävänä säilyi tehdä ehdotuksia hiippakuntien perustamisesta tai muuttamisesta, jolloin lopullinen päätösvalta oli tasavallan presidentillä. ${ }^{8}$ Ensimmäisissä uusimuotoisissa kirkolliskokouksissa nousivat esille paitsi uuden hiippakunnan perustaminen Keski-Suomeen myös Turun arkkihiippakunnan ja Helsingin hiippakunnan jakaminen. Merkittäviä muutoksia hiippakuntakarttaan ei noina vuosina kuitenkaan piirretty.

Keskustelu hiippakuntarajoista sai huomattavasti vähemmän julkisuutta kuin toinen kirkolliskokouksen perinteinen tehtävä suhteessa valtiovaltaan: toimittaa hallitukselle lausuntoja, esityksiä ja toivomuksia, jotka koskivat kirkon suhdetta valtioon tai toisiin uskonnollisiin yhdyskuntiin. Samaan kokonaisuuteen sisältyivät myös kirkollisverotus, kirkon palvelusehdot ja niin

\section{Perheenä ehtoollispöytään}

Lapsia alettiin päästää ehtoolliselle Euroopan luterilaisissa kirkoissa varsinkin 1950-luvulta lähtien. Suomessakin virisi tuolloin keskustelu lapsikommuuniosta, ja uukuniemeläinen maanviljelijä Ensio Vanhanen teki asiasta aloitteen vuoden 1958 kirkolliskokoukselle. I Asian käsittely eteni hitaasti, mikä johtui paljolti aloitteen pietistisväritteisestä teologiasta ja toisaalta rippikoulun asemaa koskeneesta huolesta. ${ }^{\text {II Lo- }}$ pulta vuoden 1973 kirkolliskokous antoi kirkkolakikomitealle tehtäväksi laatia lakitekstin, jonka mukaan kastetut lapset saisivat osallistua ehtoolliselle vanhempiensa tai muiden heidän kristillisestä kasvatuksestaan huolehtivien kanssa. Ehtoolliselle pääsisivät myös ne seurakunnan nuoret, jotka olivat rippikoulussa saaneet opetusta ehtoollisen merkityksestä. ${ }^{\text {II }}$

Kirkkolakikomitea oli hyvin kriittinen uudistusta kohtaan mutta laati tehtävänsä mukaisesti esityksen lakimuutoksiksi. Komitea edellytti, että lasten tuli saada opetusta ennen ehtoolliselle osallistumista, ja rajasi siten käytännössä alle päiväkerhoikäiset lapset pois ehtoollispöydästä. Ehtoolliselle osallistuminen vasta konfirmaation jälkeen säilyi pääsääntönä. ${ }^{\text {Iv }}$ Piispainkokous taas korosti lausunnossaan vielä entisestään konfirmaatiota ja esitti, ettei nuorelle annettaisi mahdollisuutta osallistua rippikoulun aikana itsenäisesti ehtoolliselle. ${ }^{v}$ Teologiset epäilykset ja huoli rippikoulun tulevaisuudesta olivat edelleen suuria. ${ }^{\mathrm{vI}}$

Kirkolliskokouksen perustevaliokunta oli piispainkokousta valmiimpi uudistuksiin. ${ }^{\mathrm{VII}}$ Erityisesti vanhoillislestadiolaiset edustajat, joiden käsityksen mukaan lapset olivat luonnostaan uskovia ja kelvollisia ehtoolliselle, puolustivat lapsikommuuniota. Toisaalta myös uudistuksen epäilijät tiivistivät rivejään täysistunnossa. Lopulta kirkolliskokous seurasi pitkälti piispainkokouksen linjaa ja poisti rippikouluehtoollisen. ${ }^{\text {vII }}$ Kirkolliskokouksen perääntymisessä saattoi näkyä yleisempi ilmapiirin muutos: jotkin kirkolliskokouksen 1970-luvun alun yleisessä uudistusmielisyydessä tekemät linjaukset alkoivat epäilyttää jo muutamaa vuotta myöhemmin.

Kirkolliskokouksen päätöksen jälkeen piispainkokous perääntyi edelleen antaessaan toimintaohjeita. Se asetti käytännössä lasten ehtoolliselle viiden vuoden alaikärajan. Lapsen saattajat taas rajattiin pelkästään konfirmoituihin perheenjäseniin - kummeja tai isovanhempia ei mainittu. Lopputuloksena oli lapsikommuunion sijasta perhe-ehtoollinen. ${ }^{\mathrm{Ix}}$ Silti päätös oli osa teologista siirtymää, jonka myötä ehtoollinen oli muuttumassa itsetutkiskelun paikasta yhä korostetummin yhteyden ateriaksi. ${ }^{1 x}$

I Björkstrand 1980, 43-44; Hiltunen 1998, 35, 51, 57, 60.

II Björkstrand 1980, 45 .

III Hiltunen 1998, 65, 75-76.

IV Kirk.kok.ptk-s. 1976, liite VI 2, 8-10; Hiltunen 1998, 78.

V Kirk.kok. ptk-k. 1977, liite II 1; Hiltunen 1998, 81.

VI Björkstrand 1980, 57.

VII Kirk.kok. ptk-s. 1977, liite VII-B 5; Björkstrand 1980, 58-59; Hiltunen 1998, 83-84.

VIII Kirk.kok. kptk-s. 1977, 29 \$, 33 §; Björkstrand 1980, 61; Hiltunen 1998, 82-83, $85,112$.

IX Björkstrand 1980, 57, 61; Hiltunen 1998, 87.

X SEK 1976-79, 148-149. 
sanotut sekalaisasiat. ${ }^{99}$ Viimeksi mainittuun ryhmään kuuluivat avioliittoa, valaa ja huoltoapua koskevat asiat sekä kysymykset uskonnonopetuksesta ja koulukasvatuksesta. ${ }^{100}$ Kirkolliskokouksen tehtävänä oli aiemminkin ollut ottaa kantaa kaikkiin näihin asiaryhmiin, mutta tehtävää oli kirkolliskokouksen väliaikoina hoitanut kiireellisten ja vähemmän tärkeiksi katsottujen kysymysten osalta laajennettu piispainkokous. ${ }^{101}$

Kahdeksan vuoden aikana kirkolliskokous käsitteli tavalla tai toisella kaikkia tässä lainkohdassa mainittuja, valtiota koskettavia asioita. Aivan erityisessä asemassa oli koulujen uskonnonopetus, joka oli vuosina 1974-1981 käytännössä yhtäjaksoisesti kirkolliskokouksen asialistalla. Uskonnonopetuksen kysymyksiä pohti varsinkin erikseen asetettu kasvatusasiain valiokunta, kun taas muuten lähinnä perustevaliokunta vastasi kirkolliskokouksen periaatteellisten kannanottojen valmistelusta. Kasvatusasiain valiokunta laati myös mietinnön kirkon kasvatustoiminnan kokonaisohjelmasta, merkittävästä kasvatusasiakirjasta, jonka tarkoituksena oli tarjota ohjeet seurakunnille kaikkien eri ikäryhmien opetustyön suunnitteluun ja organisointiin. Talousvaliokunnan alaan kuuluneet kirkon palvelusehdot taas korostuivat uusimuotoisen kirkolliskokouksen ensimmäisillä vaalikausilla siksi, että kirkossa siirryttiin vuoden 1975 alussa virka- ja työehtosopimusjärjestelmään.

Uudistunut kirkolliskokous sai hoitaakseen monia aiemmin laajennetulle piispainkokoukselle kuuluneita tehtäviä. Kirkolliskokouksen tehtäväksi tuli valita määräaikaiset, luottamustoimiset kirkkoneuvokset. Näiden kahdeksan henkilön lisäksi kirkkohallituksen täysistunnon jäseninä olivat arkkipiispa puheenjohtajana, kaksi piispainkokouksen nimeämää jäsentä sekä määräämättömäksi ajaksi valitut, virassa olevat kirkkoneuvokset. Kirkkohallitus oli saanut keskushallinnon uudistuksen yhteydessä kirkolliskokouksen tavoin lisää valtaa, ja vastapainoksi sen täysistuntoa oli laajennettu. Kirkolliskokous vahvisti kirkkohallituksen hallinnoiman kirkon keskusrahaston talousarvion ja päätti, kuinka paljon seurakuntien oli kirkollisveron perusteella vuosittain maksettava kirkon keskusrahastoon. Jälkikäteen kirkolliskokous tarkastutti keskusrahaston ja muiden kirkkohallituksen hoitamien rahastojen tilit ja hallinnon, vahvisti tilinpäätöksen ja päätti vastuuvapauden myöntämisestä. Lisäksi kirkolliskokouksen tehtäväksi siirtyi antaa määräyksiä kirkkolain täytäntöönpanosta. ${ }^{102}$

Laajennetulta piispainkokoukselta siirtyi kirkolliskokouksen tehtäväksi myös kirkon toimintaa tukevien toimikuntien asettaminen ja ohjeistaminen. ${ }^{103}$ Toimikunnat olivat syntyneet erityisesti suunnittelemaan ja toteuttamaan uusia työmuotoja. Uudistetussa kirkkolaissa vastuu toimikuntien ohjaamisesta jakautui lähinnä kirkolliskokouksen ja kirkkohallituksen kesken. Kirkolliskokous määräsi toimikuntien valtuudet ja antoi ohjeita, kun taas kirkkohallitus valvoi toimikuntien työtä näiden ohjeiden mukaan. Samaten kirkkohallitus valvoi toimikuntien rahankäyttöä ja hallintoa. ${ }^{104}$ Piispainkokous saattoi tehdä esityksiä ja antaa suosituksia toimikunnille. ${ }^{105}$ Toimikuntien suhde kirkon eri keskuselimiin herätti kuitenkin jatkuvaa keskustelua, ja uusimuotoinen kirkolliskokous asetti lähes ensi töikseen komitean valmistelemaan toimikuntalaitoksen uudistamista. Toimikuntia koskevia asioita kirkolliskokouksessa valmisteli toimikuntavaliokunta.

Laajennetun piispainkokouksen tehtävänä oli vielä ollut päättää kirkon suhteista muihin kirkkoyhdyskuntiin ja kirkkojenvälisiin järjestöihin. Tehtäväalue oli ekumenian voimistumisen myötä muuttunut koko ajan keskeisemmäksi. Hallinnonuudistuksessa se siirtyi kirkolliskokoukselle. Kirkolliskokouksen tehtävänä oli lisäksi asettaa näiden asioiden valmistelua ja käytännön hoitamista varten kirkon ulkomaanasiain toimikunta, jonka puheenjohtajana toimi arkkipiispa. ${ }^{106}$ Ekumenian vahvistumisen myötä kirkolliskokous sai myös tehtävän, joka ei sellaisenaan ollut aiemmin kuulunut millekään kirkolliselle elimelle. Tuo tehtävä oli yhtenä syynä piispa Alajan huoleen kirkkokäsityksen ja sitä ilmentävän istumajärjestyksen muuttumisesta. Tehtäväkohdan mukaan kirkolliskokouksen tuli "käsitellä kysymyksiä, jotka edellyttävät kirkon uskoa ja oppia koskevia tai niihin pohjautuvia periaatteellisia kannanottoja, sekä ryhtyä toimenpiteisiin niiden johdosta". ${ }^{107}$

Avatessaan kirkolliskokouksen keväällä 1974 arkkipiispa Simojoki kertoi, että hän oli saanut ulkomailta tätä lainkohtaa koskevia tiedusteluja. Niissä kysyttiin, oliko Suomen luterilaisessa kirkossa alettu korostaa synodaalista hallintomallia piispallisen järjestyksen kustannuksella. Kysyjien mukaan kirkon uskoa ja oppia koskevat linjaukset kuuluivat piispoille. Simojoki kertoi vakuut- 
taneensa kyselijöille, ettei kirkossa ollut ollut tarkoitus luopua perinteisestä synodaalis-episkopaalisesta järjestyksestä eli piispojen itsenäisestä asemasta kirkolliskokouksen rinnalla. Hän lisäsi kuitenkin: "Tulevaisuudessa nähdään, millaiseksi käytäntö muodostuu ja millaisia eteenpäin viittaavia, toistaiseksi kenties vielä piileviä seikkoja suoritettuun lainmuutokseen saattaa kätkeytyä." ${ }^{108}$ Piispojen vallan suhde pappien ja maallikkojen vaikutusmahdollisuuksiin oli vanha keskustelunaihe, joka oli aiheuttanut kiistoja jo esimerkiksi 160o-luvun Ruotsissa. ${ }^{109}$ Oli kuitenkin oireellista, että uskoa ja oppia koskeva päätösvalta nousi esille heti uusimuotoisen kirkolliskokouksen aluksi ja vieläpä matalakirkollisten piispojen puheenvuoroissa. Sittemmin tuo lainkohta puhutti kirkolliskokousta useaan otteeseen.

Lainkohta oli peräisin kirkon keskushallinnon uudistusta luotsanneen Tampereen piispan Erkki Kansanahon puheenvuorosta vuoden 1971 ylimääräisessä kirkolliskokouksessa. Kansanahon mukaan kirkon oppia koskevien asioiden käsittely oli jäänyt kirkolliskokouksen tehtäväluettelossa puutteelliseksi. Ekumeeninen keskustelu saattoi kuitenkin tuoda tällaisia asioita kirkolliskokouksen päätettäväksi muutenkin kuin vain kirkollisten kirjojen käsittelyn yhteydessä. ${ }^{10}$ Mitä ilmeisimmin Kansanaho viittasi Euroopan luterilaisten ja reformoitujen kesken käytyihin neuvotteluihin, joiden alkuvaiheessa hän oli ollut Suomen luterilaisen kirkon edustajana. ${ }^{111}$ Hän ehdottikin kirkolliskokouksen tehtäväluetteloon uutta lainkohtaa: "- - käsitellä kysymyksiä, jotka edellyttävät kirkon uskoa ja oppia koskevia periaatteellisia kannanottoja, sekä ryhtyä toimenpiteisiin niiden johdosta". ${ }^{12}$ Arkkipiispa Simojoki ilmaisi olevansa varauksettoman iloinen Kansanahon ehdotuksesta. Hän puolusti sitä niin vakuuttavasti, että äänestyksessä Kansanahon ehdotus sai yksimielisen tuen. ${ }^{113}$

Vuoden 1971 ylimääräisessä kirkolliskokouksessa oli laajojen hallinnon uudistushankkeiden käsittelyä varten peräti kaksi valiokuntaa, kirkon hallintovaliokunta ja seurakunnan hallintovaliokunta. Ensin mainittu valmisteli loppuun keskushallinnon uudistuksen. Valiokunta teki Kansanahon ehdottamaan lainkohtaan vain pienen lisäyksen: tarkoitettiin kysymyksiä, jotka edellyttivät "kirkon uskoa ja oppia koskevia tai niihin pohjautuvia periaatteellisia kannanottoja" ${ }^{114}$ Kolmen sanan lisäystään valiokunta perusteli sillä, että näin lainkohta

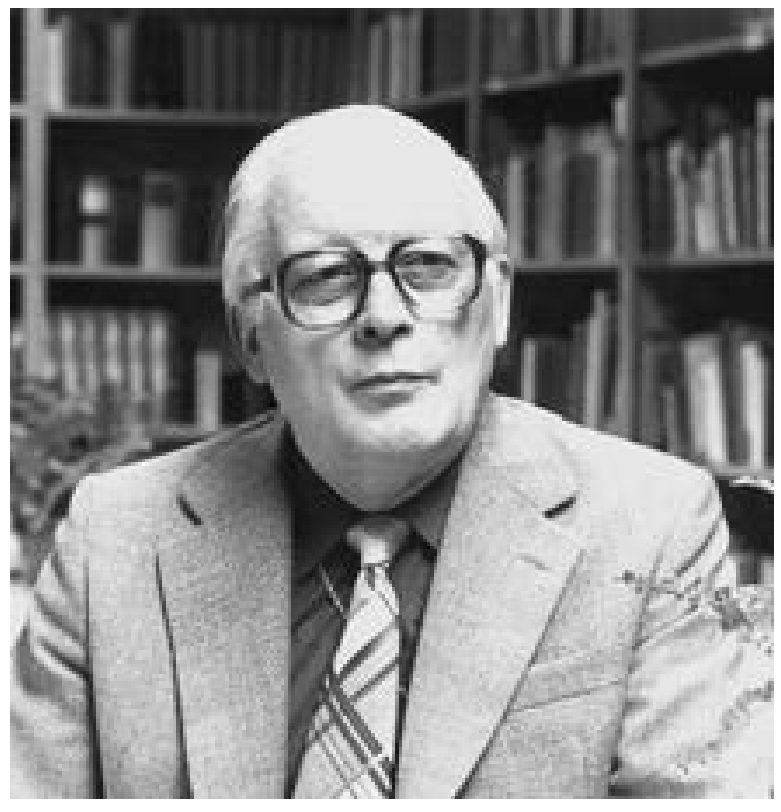

Tampereen piispa Erkki Kansanaho johti 1960- ja 1970-luvun vaihteessa kirkon keskushallintoa uudistanutta komiteaa. Hänen ehdotuksestaan kirkkolakiin lisättiin erillinen kohta, jonka mukaan kirkolliskokouksen tehtävänä oli käsitellä uskoa ja oppia koskevia periaatteellisia kysymyksiä. Kuva: Kirkkohallitus.

kattaisi myös sellaiset sosiaalieettiset kannanotot, jotka eivät suoraan koskeneet uskoa ja oppia mutta pohjautuivat niihin. ${ }^{115}$ Uusimuotoisen kirkolliskokouksen alkuun mennessä oli kuitenkin herännyt epäilyksiä. Lainkohdan hyväksymiseen ratkaisevasti vaikuttanut arkkipiispakin tunnusti, että lakitekstiin saattoi kätkeytyä "piileviä seikkoja". Esillä oli ennen kaikkea kysymys kirkolliskokouksen ja piispainkokouksen keskinäisestä tehtävänjaosta, mutta lainkohtaan liittyi muitakin ongelmia.

Kaikissa vaiheissa lainkohdan nopean valmistelun aikana säännöksestä oli pyritty saamaan mahdollisimman lavea, jotta kirkolliskokouksella olisi sen myötä lain takaama selkänoja ottaa kantaa kattavasti uskoa ja oppia koskeviin asioihin. ${ }^{116}$ Ongelmana oli, että samalla tämä kohta määrättiin kolmen neljäsosan määräenemmistösäännöksen piiriin. ${ }^{117}$ Näin määräenemmistösäännöksen soveltamisalasta tuli laaja ja epämääräinen. ${ }^{118}$ Vuoden 1971 ylimääräisessä kirkolliskokouksessa toiminut kirkon hallintovaliokunta kirjasi tahtomattaan jo mietintöönsä ensimmäisen soveltamisongelman: valiokunnan 
mukaan tämän lainkohdan nojalla kirkolliskokous saattoi lausua sosiaalieettisiä kannanottoja, jotka pohjautuivat kirkon uskoon ja oppiin. Kirkkolaissa oli kuitenkin myös erillinen kohta, jonka mukaan kirkolliskokouksen tehtävänä oli - yksinkertaisella enemmistöllä - ottaa kantaa tällaisiin yhteiskunnallisiin kysymyksiin. Kirkon hallintovaliokunnan perusteluja seuraten olisi ollut johdonmukaista tulkita, että vain määräenemmistöä sovellettaessa tällainen kannanotto perustui kirkon uskoon ja oppiin. Määräenemmistösäännöksen ahkera soveltaminen saattoi vaikeuttaa kirkolliskokouksen työskentelyä. Vastaavasti yksinkertaisella ääntenenemmistöllä tehty päätös saattoi herättää kysymyksen, miksi kirkolta ylipäätään pyydettiin lausuntoja, jos kirkolliskokous ei katsonut niiden pohjautuvan uskoon ja oppiin.

\section{VAIKUTTEITA VALTIOPÄIVÄJÄRJESTYKSESTÄ}

Piispat ehtivät istua hajallaan kokoussalissa vain vuoden: hyväksyessään varsinaisen työjärjestyksensä kirkolliskokous palautti heidät eturiviin muiden virallisten edustajien luokse. Lakivaliokunnan mukaan piispat erottuivat asemaltaan hiippakunnittain valituista edustajista siinä määrin, että tämän seikan oli syytä näkyä myös istumajärjestyksessä. ${ }^{119}$ Alajan kaipaamat kollegat Lehtinen ja Kares ehtivät tosin eläkkeelle ennen uuden työjärjestyksen voimaantuloa. Piispat olivat eturivissä myös sikäli, että kirkkolain mukaan yksi heistä, arkkipiispa, toimi kokouksen puheenjohtajana. Hänellä oli rinnallaan kaksi kirkolliskokouksen valitsemaa varapuheenjohtajaa. ${ }^{120}$ Kirkolliskokouksen työjärjestyksen mukaan nämä kolme sekä valiokuntien puheenjohtajat muodostivat yhdessä puhemiesneuvoston, jonka tärkeimpinä tehtävinä oli toimia puheenjohtajan neuvottelukuntana kirkolliskokousta koskevissa asioissa sekä ehdottaa, mille kirkolliskokouksen valmisteluelimelle käsittelyyn tullut asia lähetettiin. Neuvoston mallina oli eduskunnan puhemiesneuvosto, joka oli koottu aivan samoin perustein. ${ }^{121}$

Eduskunnan työskentelystä muistuttivat myös valitsijamiehet, jotka kirkolliskokous valitsi keskuudestaan. Näiden 25 henkilön osuus kaikista edustajista oli suunnilleen yhtä suuri kuin eduskunnassa. ${ }^{122}$ Valitsijamiesten vaali toimitettiin ryhmittäin siten, että pappisja maallikkoedustajat muodostivat vaalissa hiippakunnittain omat ryhmänsä ja vielä viralliset edustajat oman ryhmänsä. Kullakin ryhmällä oli valitsijamiespaikkoja ryhmän koon mukaisessa suhteessa, kuitenkin vähintään kaksi. ${ }^{123}$ Valitsijamiehet saivat kirkolliskokouksessa merkittävän aseman. ${ }^{124} \mathrm{He}$ valitsivat jäsenet paitsi kirkolliskokouksen valiokuntiin myös kirkon toimikuntiin. Niin ikään kirkolliskokous saattoi valtuuttaa heidät valitsemaan jäsenet kirkolliskokouksen asettamiin komiteoihin. Lisäksi valitsijamiehet valmistelivat kirkolliskokoukselle ehdotuksen useista muista henkilövalinnoista. ${ }^{125}$ Pian kirkolliskokous katsoi kuitenkin valitsijamiesten saaneen jo liian paljon valtaa. Se päätti, että toimikuntien jäsenten vaali voitiin tarvittaessa siirtää täysistuntoon. ${ }^{126}$

Avatessaan ensimmäisen uusimuotoisen kirkolliskokouksen arkkipiispa Simojoki painotti, että asioiden valmistelu kirkolliskokouksen valiokunnissa oli saatava toimivaksi. Ellei se onnistuisi, virkamiehet tekisivät entistä suuremmassa määrin ratkaisuja ja ohjaisivat kirkon toimintaa. ${ }^{127}$ Uhat tällä kohden olivat selviä, koska kirkolliskokouksen kokoontumisrytmin muutos vaati valiokunnilta nopeaa ja tehokasta työskentelyä lyhyiden, viikon kestävien istuntokausien aikana. Niinpä kirkolliskokouksen uutta työjärjestystä valmisteltaessa valiokuntia koskevat määräykset olivat erityisen tarkassa harkinnassa. ${ }^{128}$

Kirkolliskokoukselle määrättiin työjärjestyksessä kahdeksan pysyvää valiokuntaa, joista useimmissa oli 11 jäsentä ja neljä varajäsentä. ${ }^{129}$ Valtiopäiväjärjestyksen mukaan 11 jäsentä oli myös eduskunnassa eräänlainen valiokuntien jäsenmäärän rajapyykki: vähintään sen kokoiselle ylimääräiselle valiokunnalle saattoi osoittaa pysyvien valiokuntien tehtäviä. ${ }^{130}$ Toimitusvaliokuntaan, joka viimeisteli lopulliseen muotoonsa kokouksen päätökset ja kirjelmät, kuului kolme varsinaista jäsentä. Kansliavaliokunta huolehti kirkolliskokouksen taloudesta ja antoi ohjeet, joiden perusteella kirkkohallitus hoiti kirkolliskokouksen käytännön järjestelyjä. Yleinen valmistusvaliokunta taas käsitteli asiat, jotka eivät kuuluneet muiden valiokuntien tehtäväalueelle - yleensä hiippakuntakokousten ja edustajien jättämät aloitteet. ${ }^{131}$

Siviilivaliokunnan nimellä oli pitkä historia. Toinen lakivaliokunta oli nimetty siviilivaliokunnaksi 1898 , koska valiokunta oli käsitellyt siviiliavioliittoa ja siviilirekisteriä. ${ }^{132}$ Uusimuotoisen kirkolliskokouksen alkaessa todettiin, että nimi oli epäselvä ja herätti enintään 
"mielikuvan, että kenttäpiispaa ja muuta sotilashenkilöä ei voida sinne valita". Osmo Alaja ja Viljami Kalliokoski muotoilivat täysistunnossa uudeksi nimeksi perustevaliokunnan, koska valiokunnan tehtävänä oli lausua asioita kirkon perusteista käsin. ${ }^{133}$ Sen ruotsinkielisenä nimenä oli konstitutionsutskottet aivan samoin kuin Ruotsin parlamentin perustuslakivaliokunnalla. Nimi sopikin valiokunnan luonteeseen - muodostivathan uskoa, oppia ja tunnustusta koskevat kysymykset kirkon "perustuslain".

Sekä valitsijamiehet että valiokuntien jäsenet valittiin kahden vuoden välein, ellei kirkolliskokous päättänyt toisin. ${ }^{134}$ Lisäksi oli mahdollista asettaa ylimääräisiä valiokuntia. Kahdella ensimmäisellä vaalikaudella asetettiin kasvatusasiain valiokunta. Eduskunnan valiokuntien tavoin kirkolliskokouksen valiokuntien oli mahdollista jakautua kahdeksi osastoksi, jotka antoivat valiokunnan nimissä mietintöjä. ${ }^{135}$ Valiokunta oli pää-

\section{"Lex Linkola"}

Satakunnan piirimetsänhoitaja Juhani Linkola Porista oli ollut vuodesta 1958 arkkihiippakunnan kirkolliskokousedustaja, ja vuodesta 1974 hän oli myös kirkkohallituksen jäsen. Vuosien 1968 ja 1973 kirkolliskokouksissa hän oli ajanut voimakkaasti työjärjestykseen lisäystä, jonka nojalla toisarvoiset tai epäselvät aloitteet voitaisiin hylätä valiokuntaan lähettämättä. Linkolan aloite oli kuitenkin kaatunut ensin kirkkohallituksen ja lopulta kirkolliskokouksen enemmistön vastustukseen. Vastustajien mielestä epäkelvot aloitteet olivat niin harvinaisia, ettei työjärjestyksen muutokseen ollut tarvetta. ${ }^{\mathrm{I}}$

Sen sijaan uusimuotoisen kirkolliskokouksen työjärjestykseen oli jo kirkkohallituksen esityksessä merkitty mahdollisuus hylätä hiippakuntakokousten ja edustajien aloitteet

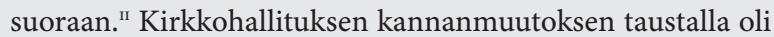
todennäköisesti halu suojella kirkollista päätöksentekojärjestelmää sellaiselta aloitetulvalta, jonka kanssa eduskunta samaan aikaan taisteli. Kirkolliskokous laajensi säännöksen koskemaan myös piispainkokouksen ja kirkkohallituksen esityksiä" ${ }^{\text {II }}$. Ensimmäisen kerran kirkolliskokousuudistuksen jälkeen suoraa hylkäämismahdollisuutta sovellettiin edustajaaloitteeseen keväällä 1977 . $^{\text {v }}$

Keväällä 1978 Linkola teki aloitteen urkujen paikasta kirkossa. Useimpien edustajien mielestä asia voitiin hoitaa seurakunnissa ilman kirkolliskokouksen toimia, eikä asia edennyt valiokuntaan asti. Linkola ilmoitti joutuneensa tösvaltainen, kun vähintään kaksi kolmasosaa sen jäsenistä oli saapuvilla. Kirkolliskokouksen istuntokausien aikana myös varajäsenillä oli läsnäolo- ja puheoikeus valiokunnassa, vaikka varsinaiset jäsenet olisivatkin olleet paikalla. Asiat pyrittiin valmistelemaan valiokunnissa mahdollisimman pitkälti istuntokausien aikana, ja kausien väliseen työskentelyyn tarvittiin puhemiesneuvoston lupa. ${ }^{136}$

Varajäsenten nimeäminen tuotti valitsijamiehille toistuvia vaikeuksia. Lisäksi jotkut varajäsenet pahoittivat mielensä, koska he eivät kokeneet pääsevänsä tasavertaiseen asemaan muiden edustajien kanssa. Jo 1978 uuden vaalikauden alkaessa kirkolliskokous päättikin luopua varajäsenjärjestelmästä. Käytännössä jäsenmäärä nousi useimmilla valiokunnilla 15:een ja yleisellä valmistusvaliokunnalla, joka työskenteli paljolti kahtena erillisenä osastona, 17:ään. Samalla päätösvaltaisuuden ehtoja lievennettiin: vastaisuudessa riitti, että enemmän kuin

oman aloitteensa uhriksi, mikä herätti kirkolliskokouksessa hilpeyttä. ${ }^{v}$ Aloitteen kaatuminen oli hänelle kuitenkin pohjimmiltaan kova vastoinkäyminen. Kun vuoden kuluttua keväällä 1979 erästä hiippakuntakokousaloitetta ehdotettiin hylättäväksi valiokuntaan lähettämättä, Linkola totesi: ”Olen kerran kokenut, kun hyvä aloite pannaan paperikoriin suoraan, ja se on niin masentavaa, etten halua sitä kenellekään muulle." Aloite lähetettiin valiokuntaan. ${ }^{\mathrm{vI}}$

Miehestä, joka kerran oli ollut esitaistelija aloitteiden karsimisessa, oli omien kokemustensa myötä tullut aloitteiden valiokuntavalmistelun ehdoton puolustaja. Yhteistä kaikille kolmelle lähetekeskustelulle oli, että Kokkolan suomalaisen seurakunnan kirkkoherra Heikki Vaahtoniemi vaati aloitteiden jättämistä suoraan raukeamaan. Linkolan täydellisen kannanmuutoksen jälkeen Vaahtoniemi profiloitui henkilönä, joka halusi säästää kirkolliskokouksen valiokuntia vähämerkityksisiksi katsomiltaan aloitteilta. ${ }^{\mathrm{VII}}$

I Kirk.kok.ptk-l. 1968, liite V 23; Kirk.kok. ptk. 1973, 9-12. Suora hylkäysmahdollisuus oli ollut käytössä kirkolliskokouksen alkuaikoina. Juva 1976, 21.

II Kirk.kok. ptk-k. 1974, liite III 1.

III Kirk.kok. ptk-s. 1974, $20 \$, 44 \$$, liite VI-A 3, 4, 15.

IV Kirk.kok. kptk-k. 1977,49\$.

V Kirk.kok. kptk-k. 1978, 49 \$.

VI Kirk.kok. kptk-k. 1979, 41 §.

VII Näin myös Kirk.kok. kptk-k. 1980,35§. 
puolet valiokunnan jäsenistä oli saapuvilla. Siten puhemiesneuvoston ja valitsijamiesten kokousten aiheuttamat poissaolot eivät enää estäneet valiokunnan työtä. ${ }^{137}$

Oikeus esittää asioita kirkolliskokoukselle oli piispainkokouksella, kirkkohallituksella, yksittäisillä kirkolliskokousedustajilla sekä hiippakuntakokouksilla. Viimeksi mainitut koostuivat maallikoista ja papeista ja kokoontuivat hiippakunnissa vuosittain. Kirkolliskokousuudistuksen yhteydessä hiippakunnallisten pappeinkokousten aloiteoikeus poistui, mikä tasapainotti maallikkojen ja pappien mahdollisuuksia saada asioita kirkolliskokouksen käsittelyyn. Aloiteoikeus oli korostetusti kirkon sisäinen, ja yhdistettynä kirkkolain erityiseen säätämisjärjestykseen se alleviivasi kirkon itsenäisyyttä. Käytännössä valtioneuvoston ainoa keino saada asiansa kirkolliskokouksen käsiteltäväksi oli valtioneuvoston määräämän edustajan edustaja-aloite. Tämä keino oli sikäli ongelmallinen, että kirkkolain mukaan valtioneuvoston määräämä edustajakin oli taustayhteisöstään riippumaton kirkon edustaja. Kirkolliskokous totesikin 1979 periaatteellisesti, että valtioneuvostolle olisi syytä antaa oikeus tehdä esityksiä suoraan kirkolliskokoukselle. ${ }^{138}$

Eduskunta oli esikuvana kirkolliskokouksen työskentelytavoille hyvin monessa kohden, mutta eräissä suhteissa se oli varoittavana esimerkkinä: edustaja-aloitteiden määrä oli eduskunnassa kasvanut voimakkaasti, ja vain pieni osa niistä ehdittiin ottaa käsittelyyn. Aloitteet olivat pitkälti menettäneet merkityksensä. Myös eduskunnan täysistunnosta oli tullut puheenvuorotulvan myötä lähinnä ulkoinen näyttämö, jolla oli hyvin vähän todellista merkitystä asioiden käsittelylle. ${ }^{139}$ Kirkolliskokouksessa pyrittiin varmistamaan, että kokouksen toimintakyky säilyisi vastaisuudessakin. Työjärjestystä laadittaessa yritettiin välttää aloitetulvaa mutta samalla varjella aloiteoikeutta. ${ }^{140}$ Edustaja-aloitteen sai jättää tiettyinä päivinä kevätistuntokauden aikana tai muulloin, mikäli jokin kirkolliskokouksen päätös antoi suoraan siihen aiheen. Raha-asia-aloitteet tuli jättää syksyllä tiettyyn päivään mennessä. Työjärjestyksen muuttaminen haluttiin helpoksi: sitä koskevan aloitteen saattoi jättää milloin vain, kuten eduskunnassakin. ${ }^{141}$ Kirkolliskokouksessa käsiteltävät asiat tulivat pöydällepanon jälkeen täysistunnossa ensin lähetekeskusteluun. Kirkolliskokousuudistuksen myötä tuli mahdolliseksi

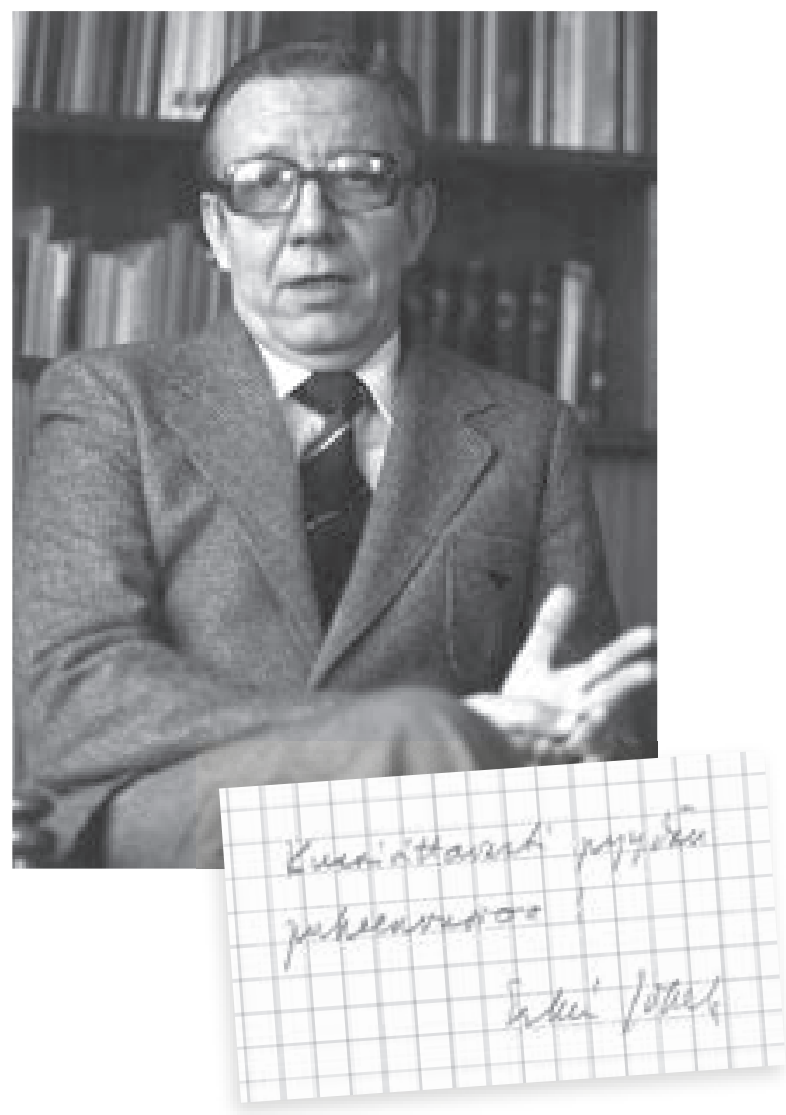

Vuoden 1979 kevätistuntokaudella Oulun diakonissalaitoksen johtaja Erkki Jokela pyysi työjärjestyksen mukaisesti puheenvuoroa paperilappusella. Kuvat: Kirkkohallitus.

hylätä asia jo lähetekeskustelussa lähettämättä sitä lainkaan valiokuntaan. ${ }^{142}$

Puheenvuoroa pyydettiin nousemalla seisomaan tai toimittamalla puheenjohtajalle kirjallinen pyyntö. Puheet pidettiin puhujakorokkeelta, joskin lyhyen puheenvuoron, jossa edustaja ilmaisi kantansa ilman perusteluja, saattoi käyttää paikaltaan. Yleensä tällaiset puheenvuorot olivat kannatuspuheenvuoroja jollekin täysistunnossa tehdylle muutosehdotukselle. Edustajan oli mahdollista käyttää myös enintään kahden minuutin vastauspuheenvuoro välittömästi jonkin puheenvuoron jälkeen. ${ }^{143}$ Jos edustaja puhui ruotsiksi eikä itse esittänyt puheensa pääsisältöä suomeksi, kirkolliskokouksen tulkki käänsi pääkohdat. ${ }^{144}$ Tulkkina toimi kirkolliskokouksen notaari, käytännössä arkkipiispan sihteeri. 
Työskentelyn sujuvoittamiseksi Porvoon hiippakunnan edustajat tosin käänsivät useimmiten itse puheensa pääkohdat tai koko puheensa suomeksi - tai sitten puhuivat alusta lähtien suomea.

Keskustelussa tehty muutosehdotus otettiin äänestykseen vain, jos joku kannatti sitä. ${ }^{145}$ Yleensä äänestäminen tapahtui seisomaan nousten, ja puheenjohtaja totesi, oliko kyseessä enemmistö vai vähemmistö. Jos tämä äänestystapa ei tuonut selvää vastausta, puheenjohtaja määräsi nimenhuutoäänestyksen. Aluksi nimenhuutoäänestyksen toimittamiseksi riitti myös, että yksittäinen edustaja vaati sitä. Kielteiset kokemukset heti työskentelyn alkumetreillä saivat kuitenkin kirkolliskokouksen tiukentamaan säännöstä: vaadittiin, että lisäksi joku toinen edustaja kannatti nimenhuutoäänestystä. ${ }^{146}$ Keskinäisen luottamuksen lisääntyessä nimenhuutoäänestyksen ehdottaminen kävi harvinaiseksi. Säännökset edellyttivät, että määräenemmistön vaativat asiat otettiin aina kahteen käsittelyyn. Niistä jälkimmäisessä päätettiin nimenhuutoäänestyksellä esityksen hyväksymisestä tai hylkäämisestä.

Kirkon keskusrahaston talousarvion käsittelyssä korostui talousvaliokunnan vastuu, koska valiokunta valmisteli syksyisin ehdotuksensa talousarvioksi ilman edeltävää kirkolliskokouksen lähetekeskustelua. Lähetekeskustelun puute korvattiin tosin alusta lähtien siten, että talousarviokäsittelyn päätyttyä kirkolliskokousedustajille annettiin mahdollisuus esittää taloudenpitoa koskevia toivomusponsia. Perusteluna oli tässäkin kohden, että eduskunnassa oli talousarvion lähetekeskustelussa mahdollista lausua tällaisia toivomuksia. Talousvaliokunnan osuutta korosti myös se, että täysistunnossa hyväksytyt määrärahamuutokset piti pääsäännön mukaan palauttaa vielä valiokuntaan. ${ }^{147}$ Lehdistössä huomautettiin ajoittain, ettei kirkon keskusrahaston talousarviosta ollut mahdollista käydä tarpeeksi laajaa ja avointa julkista keskustelua. ${ }^{148}$

Kirkolliskokouksen työskentelyrytmiin vaikutti olennaisesti säännös, jonka mukaan asia raukesi, mikäli sitä ei ennen vaalikauden loppua ehditty käsitellä loppuun tai antaa muun elimen kuin kokouksen oman valiokunnan valmisteltavaksi. Aivan vastaava säännös oli eduskunnan osalta valtiopäiväjärjestyksessä. ${ }^{149}$ Asioiden käsittelyä nopeutti se, että kirkolliskokousuudistuksen jälkeen kirkollisten kirjojen uudistuksista ja kirkkolain muutosehdotuksista ei enää tarvinnut pyytää hiippakuntien pappeinkokousten, hiippakuntakokousten tai seurakuntien kirkkoneuvostojen lausuntoja. Sen sijaan kirkkohallituksen tuli antaa lausuntonsa kirkkolakia koskevista esityksistä. Piispainkokoukselta edellytettiin samanlainen lausunto kirkollisia kirjoja tai uskoa ja oppia koskevissa kysymyksissä.. ${ }^{150}$

Äänestäminen tapahtui kirkolliskokouksessa yleensä seisomaan nousten. Määräenemmistöä edellyttävien päätösten kohtalo ratkaistiin kuitenkin nimenhuutoäänestyksellä. Kuva: Kotimaan kuva-arkisto / Matti Kivekäs.

\section{Picture removed from the open access version of this book.}




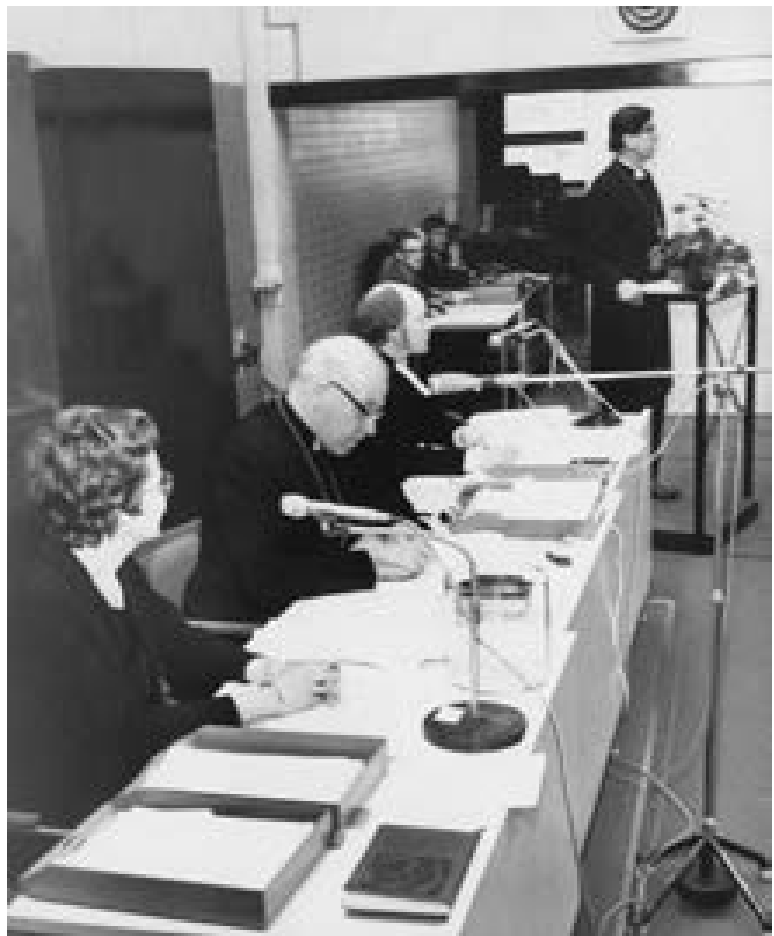

Kirkkolain hallintosäännöksissä näkyi monia kirkon tunnustukseen liittyviä erityispiirteitä. Maallikkoedustajien enemmistöasema nojasi teologisesti yhteisen pappeuden periaatteeseen, kun taas kirkon erityisen viran edustajien huomattava osuus perustui heidän vastuuseensa oikeasta Jumalan sanan saarnasta ja sakramenttien hoitamisesta. ${ }^{151}$ Kirkolliskokouksen työskentelytapojen ja varsinkin sen sisäisen työjärjestyksen suuntaviitat löytyivät sen sijaan yleensä Arkadianmäeltä. Kirkkohallitus käyttikin kirkolliskokouksen työjärjestystä valmistellessaan apuna eduskunnan virkamiehiä ja pyrki seuraamaan valtiopäiväjärjestystä sekä eduskunnan työjärjestystä ${ }^{152}$. Kirkolliskokouksen lakivaliokunta otti omassa valmistelussaan vielä lisää vaikutteita eduskunnan toimintamuodoista. ${ }^{153}$ Kirkolliskokouksessa oli aiempaa vähemmän kansanedustajia, ja kirkon johto karttoi kirkon puoluepolitisoitumista, mutta työnsä puitteita rakentaessaan kirkolliskokous seurasi tarkasti eduskuntaa.

Kirkolliskokouksella oli ajoittain vaikeuksia seurata uutta työjärjestystä. Viljami Kalliokoskella oli keskeinen tehtävä selviteltäessä, miten työjärjestyksen määräyksiä tulkittiin eduskunnassa. Erityisen pitkään hän
Kirkolliskokouksen puheenjohtaja, arkkipiispa Martti Simojoki ja puhujakorokkeella oleva Mikkelin piispa Osmo Alaja kantoivat kirkolliskokousuudistuksen jälkeisinä vuosina huolta kirkon episkopaalisesta luonteesta. Simojoen vierellä kirkolliskokouksen sihteeri Sinikka Pylkkänen ja notaari, arkkipiispan sihteeri Jouko Martikainen. Kuva: Kirkolliskokouksen kuvakokoelma / Arvo Salminen.

sai seisoa puhujakorokkeella arkkipiispan kutsumana, kun puheenjohtajat pohtivat kirkon keskusrahaston tilintarkastajien vaalin toimittamista. Keskustelu vaalin menettelytavoista tuotti yli viisi sivua keskustelupöytäkirjaa ennen kuin päästiin täyttämään vaalilippuja. ${ }^{154}$ Uuden kirkolliskokouksen järjestäytyminen aiheutti vielä 1978 lähes yhtä paljon työjärjestystä koskevia epäselvyyksiä kuin neljä vuotta aiemmin. ${ }^{155}$

Työskentelytapojen perusteella kirkolliskokous oli kirkon parlamentti, niin selvästi sen työjärjestys kytkeytyi eduskunnan toimintatapoihin. Uusimuotoisen kirkolliskokouksen alkumetreillä näytti kuitenkin mahdolliselta, että kirkolliskokouksesta oli tulossa korostetusti kirkon parlamentti myös siten, että se saisi selvästi näkyvimmän valta-aseman kirkon päätöksenteossa. Vaikka kirkolliskokouksen valtaa oli perinteisestikin perusteltu kristittyjen yhteisellä pappeudella, yhteiskunnassa 1960-luvun lopulla ja seuraavan vuosikymmenen alussa vallalla ollut demokratian korostus oli omiaan vahvistamaan entisestään kirkolliskokouksen asemaa hallinnonuudistuksessa ja sen tulkinnoissa.

Tulkintojen vaihtelua kuvastaa se, että kirkkohallituksen ohella myös piispainkokous pyysi työjärjestykselleen kirkolliskokouksen vahvistusta. Kirkolliskokouksen itsensä oli asessori Gunnar Träskmanin ja lakivaliokunnan johdolla todettava, ettei sillä ollut valtaa puuttua piispainkokouksen työskentelytapoihin. ${ }^{156}$ Laajennetun piispainkokouksen lakkauttamisen yhteydessä piispainkokouksen asemaa oli vahvistettu ja sen tehtäviä lisätty. Jo ensimmäisessä uusimuotoiselle kirkolliskokoukselle lähettämässään esityksessä piispainkokouksella oli kuitenkin halua asettua kirkolliskokouksen rinnalta kirkolliskokouksen alaiseksi, lähinnä kirkkohallituksen kaltaiseksi elimeksi. Kirkolliskokouksen oli puolustettava piispainkokouksen riippumattomuutta.

Piispainkokouksen ja kirkolliskokouksen keskinäinen suhde ei ollut käytännössä selvä, kuten ei ylipäätään piispainkokouksen asema kirkon keskushallinnossa. Piispa Alajan puheenvuoro ja piispainkokouksen työjärjestys- 
tä koskeneet epäselvyydet osoittivat sen kouriintuntuvasti. Kirkolliskokous antoi syksyllä 1974 kirkkolain täytäntöönpanomääräyksen piispainkokouksen ja kirkon muiden viranomaisten yhteyksistä, mikä selvensi tilannetta ${ }^{157}$. Samalla kun kirkolliskokous palautti piispat kirjaimellisesti eturiviinsä, se siirsi piispainkokouksen itsenäiselle paikalleen. Kirkolliskokous osoitti, ettei aikakauden yleinen demokratian korostus saanut viedä piispojen valtaa ja vastuuta kirkon opin valvonnasta. Tulkintaongelmat kirkolliskokouksen ja piispainkokouksen toimivaltasuhteesta olivat kuitenkin oireellisia.

\section{ÄÄNESTYSMALJAN ÄÄRELL $\ddot{A}$}

\section{HIIPPAKUNTARAJAT HALLITSEVAT TÄYSISTUNNON VAALEJA}

Hallinnonuudistuksen myötä kirkolliskokous sai päävastuun kirkon keskushallinnon luottamushenkilövalinnoista. Niitä koskevia ratkaisuja edelsivät monet epäviralliset kokoontumiset. Tärkeimpiä olivat hiippakunnittain pidetyt kokoukset, jotka ajoittuivat yleensä kirkolliskokouksen alkua edeltävään sunnuntai-iltaan. Vaalikauden alkaessa selvitettiin esimerkiksi, mihin valiokuntaan kukin hiippakunnan edustajista halusi. ${ }^{158}$ Puolueiden aktivoituminen vuosien 1974 ja 1978 kirkolliskokousvaaleissa näkyi myös uudenlaisina ryhmäkokouksina. Puolueiden kirkkopoliittiset elimet kutsuivat koolle omaa puoluettaan lähellä olevia edustajia ja pyrkivät saamaan nämä yhteistyöhön nimenomaan kirkolliskokouksen henkilövalinnoissa. ${ }^{59}$

Ainakin keskustan osalta ryhmäkokoukseen saapui erityisesti naisedustajia. ${ }^{160}$ Taustalla voi nähdä kaksi syytä. Ensinnäkin puolueen naisjärjestön vaalityö oli tuonut kirkolliskokoukseen puolueessa aktiivisesti toimineita naisia. Toiseksi kirkolliskokouksen naisjäsenet olivat lähes järjestään aloittelevia edustajia, joilla ei ollut valmiina samanlaisia vaikuttamiskanavia kuin jo aiemmin kirkolliskokouksessa istuneilla miesedustajilla. Mahdollisuus tulla mukaan puoluepoliittiseen ryhmäkokoukseen oli siten naisille tärkeä tilaisuus verkostoitumiseen.

Vuonna 1974 kirkolliskokousedustajat olivat hyvin yksimielisiä siitä, että toinen varapuheenjohtajan paikoista kuului Porvoon hiippakunnan edustajalle Lars Erik
Taxellille. Erimielisyys koski sitä, kuka olisi hänen rinnallaan varapuheenjohtajana. ${ }^{161}$ Aiemmin toinen varapuheenjohtajista oli ollut piispa, mutta nyt piispat ilmoittivat haluavansa jättää tehtävän muille. Heidän ehdokkaansa oli tosin edelleen virallinen edustaja, oikeusneuvos Johannes Leivonen. Kirkon hallintoa oli juuri pyritty kansanvaltaistamaan, ja ilmeisesti ajatus vaaleilla valittujen edustajien sivuuttamisesta kohtasi kokouksen väliajalla vastustusta - niin pitkästi Olavi Kares joutui myöhemmin perustelemaan Leivosen ehdokkuutta. ${ }^{162}$

Lopulta Taxellin rinnalle toiseksi varapuheenjohtajaksi valittiin pitkäaikainen varapuheenjohtaja Viljami Kalliokoski. Mikko Juva hävisi Kalliokoskelle vain niukasti, ja vaalissa näyttävät olleen vastakkain pohjoiset ja eteläiset hiippakunnat. Leivonen jäi kolmanneksi virallisten edustajien äänillä. Vaali käytiin täysistunnon tauolla hiippakuntaryhmittäin sovittujen linjojen mukaisesti. Puoluepolitiikka ei noussut hallitsevaksi, vaikka ainakin keskustan puolueorganisaatiossa oli valmisteltu Kalliokosken valintaa. ${ }^{163}$

Kirkolliskokouksen täysistunnon uutena tehtävänä oli valita nelivuotiskaudeksi kahdeksan määräaikaista, luottamustoimista kirkkoneuvosta, yksi jokaisesta hiippakunnasta. Vaali herätti ennakolta erityisen paljon mielenkiintoa. Kunkin hiippakunnan hiippakuntakokous oli pannut järjestykseen kolme ehdokasta, ja näiden ehdotusten pohjalta valitsijamiehet laativat esityksen kirkolliskokoukselle. Valitsijamiehet joutuivat joidenkin hiippakuntien osalta tiukkoihin äänestyksiin, mikä johti siihen, että heidän rivinsä olivat hajallaan täysistuntoon tultaessa. Valmisteluelimen puheenjohtaja Erkki Kansanaho joutui puuttumaan keskusteluun, jossa oli "käytetty propagandistisia puheenvuoroja". ${ }^{164}$

Määräaikaisten kirkkoneuvosten valinta nostatti kirkolliskokouksessa myös periaatteellisia kysymyksiä. Ensimmäinen koski sitä, missä määrin kirkolliskokouksen tuli kunnioittaa hiippakuntien ehdokasasettelua ja missä määrin taas sillä oli oikeus katsoa asiaa kokonaisuuden kannalta. Kyse oli lähinnä siitä, että lainopin, seurakuntaelämän ja talouden asiantuntemus olisi edustettuna tarpeeksi laajasti ja että kirkkoneuvosten joukosta löytyisi myös jonkin pienen seurakunnan jäsen. ${ }^{165}$ Valitsijamiesten esitys oli kompromissi, joka sisälsi vähäisiä muutoksia hiippakuntien ehdotukseen. Jäljellä 
oli kuitenkin kysymys, kykenikö yli sadan edustajan joukko täysistunnossa tekemään hallittuja ja punnittuja muutoksia valitsijamiesten esittämään nimilistaan. ${ }^{166}$ Kansanahon voimakkaassa puheenvuorossa voikin nähdä huolen siitä, millaisen arvovallan valitsijamiehet uusimuotoisessa kirkolliskokouksessa saisivat. Alku ei näyttänyt lupaavalta: moni valitsijamieskin luopui täysistunnossa julkisesti yhteisestä esityksestä.

Toinen erimielisyys koski sitä, oliko jäsenyys kirkon muissa elimissä kirkkoneuvokselle eduksi vai haitaksi. Yhtäältä oli epäselvää, oliko hallinnollisesti oikein valita kirkkohallitukseen valitsijamiesten ehdottama Oulun tuomiokapitulin lainoppinut asessori Eero Heinonen. Kulkivathan jotkin asiat tuomiokapitulista kirkkohallituksen käsittelyyn. Toisaalta keskusteltiin siitä, missä määrin kirkkohallituksessa tuli olla kirkolliskokouksen jäseniä. Joidenkuiden mielestä tehtäviä ei tullut kasata samoille henkilöille, kun taas toisten mielestä kokemus kirkolliskokouksesta oli selvä etu. Valitsijamiesten esityksen mukaisesti kahdeksan kirkkoneuvoksen joukkoon valittiin lopulta kolme kirkolliskokouksen jäsentä. ${ }^{167}$ Yksi heistä oli kokenut kirkkohallituksen jäsen, helsinkiläinen kirkkoherra John Forsberg. Hänen valintansa ei herättänyt vastalauseita, vaikka kirkon viralla oli kirkkohallituksessa muutenkin edustus piispainkokouksen valitsemien edustajien sekä arkkipiispan välityksellä. Sen sijaan täysistunnossa julkilausumaton tehtäväjako näkyi siten, että vain harvat pappisedustajat puuttuivat asian käsittelyyn. Valitsijamiesten puheenjohtajaa lukuun ottamatta piispat vaikenivat täysin. ${ }^{168}$

Kirkkoneuvosten valinta johti myös keskusteluun naisten edustuksesta. Valitsijamiehet esittivät kirkkoneuvokseksi yhtä naista, varatuomari Anna Maija Silvolaa Helsingin hiippakunnasta. Sen sijaan asessori Eero Heinonen ohitti heidän esityksessään Oulun hiippakunnan ensimmäisen ehdokkaan, kouluneuvos Sanni Karjalaisen. ${ }^{169}$ Naisedustajat kävivät täysistunnossa työhön Karjalaisen puolesta, ja lopulta saman hiippakunnan edustaja, koulutoimentarkastaja Meeri Päivänsalo nosti avoimesti esiin naisten suhteellisen osuuden: miten kirkkokansa kokisi sen, että kirkolliskokous syrjäyttäisi hiippakunnan naisehdokkaan? Hallintoasiainsihteeri Tapani Heinämäki Hyvinkäältä piti myös naisedustusta sinänsä tarpeellisena mutta yhtä naisedustajaa riittävänä: Silvola voisi "olla terveisten viejänä, ja jos hänellä tarmoa ja kykyä on, hän voi tehdä työtäkin, ja seuraavalla kerralla katsotaan, onko syytä lisätä tätä naisedustusta”. ${ }^{170}$ Ainakin jotkut siis näkivät Silvolan tulevan kirkkohallitukseen ikään kuin koeajalle naisten puolesta. Lopulta asessori Heinonen voitti Oulun hiippakunnassa niukasti kouluneuvos Karjalaisen, ja ainoaksi naiseksi kirkkohallituksessa jäi varatuomari Silvola. ${ }^{171}$

Puoluepolitiikka pääsi keskusteluun mukaan siten, että kolme keskustalaisten edustajien listalla ollutta henkilöä eri hiippakunnista otti kantaa Lapuan hiippakunnasta valittavan kirkkoneuvoksen vaaliin. Puheenvuoroissa ei mainittu mitään puoluekannoista, mutta kansakoulunopettaja Väinö Vähäsarja Vaalasta saattoi tunnistaa puoluepoliittisen pohjavireen: hän paheksui voimakkaasti, että muiden hiippakuntien edustajat puuttuivat "naapurin asioihin". ${ }^{172}$ Kirkolliskokousedustajat olivat virallisesti koko kirkon edustajia, mutta käytännössä keskustelussa ilmeni hiippakuntien itsenäisyyteen liittyneitä pidäkkeitä, jotka nostivat kynnystä puuttua muihin kuin edustajan omaa hiippakuntaa koskeviin henkilövalintoihin. ${ }^{173}$

Keskustalaisten ehdotus jäi lopulta vaalissa tappiolle, mikä antoi realistisen kuvan puoluepoliittisen taustatyön mahdollisuuksista kirkolliskokouksessa. ${ }^{174}$ Puoluepoliittisiksi arvioidut motiivit kääntyivät lähinnä ehdokasta vastaan. ${ }^{175}$ Joka tapauksessa julkisuudessa esiintyi vaalin jälkeen keskustelua puoluepolitiikan vaikutuksesta määräaikaisten kirkkoneuvosten valintaan. ${ }^{176}$ Myöhemmin nelivuotiskauden aikana puoluepoliittiset asetelmat nousivat esiin vielä valittaessa komiteaa, jonka oli määrä valmistella kirkolliskokoukselle ehdotus lausunnoksi parlamentaarisen Kirkko ja valtio -komitean mietinnöstä. ${ }^{177}$

Seuraavan nelivuotiskauden alkaessa puoluepoliittiset asetelmat vahvistuivat, mitä jo helmikuun 1978 kirkolliskokousvaalit ennakoivat. ${ }^{178}$ Niin keskustassa kuin kokoomuksessa koottiin edustajia kirkolliskokouksen aattoiltana pidettävään ryhmäkokoukseen. ${ }^{179}$ Kokoomuksen ryhmäkokouskutsussa puolue tosin pyrittiin häivyttämään joka suhteessa mahdollisimman kauas taustalle. ${ }^{180}$ Pysyvää ryhmätoimintaa ei tälläkään kertaa syntynyt. ${ }^{181}$ Sen sijaan kirkolliskokouksen aaton ryhmäkokoukset saivat ensimmäistä kertaa julkisuutta. ${ }^{82}$

Yksi ryhmäkokousten asia oli toisen varapuheenjohtajan vaali. ${ }^{183}$ Vuoden alussa kuolleelle Viljami Kalliokos- 


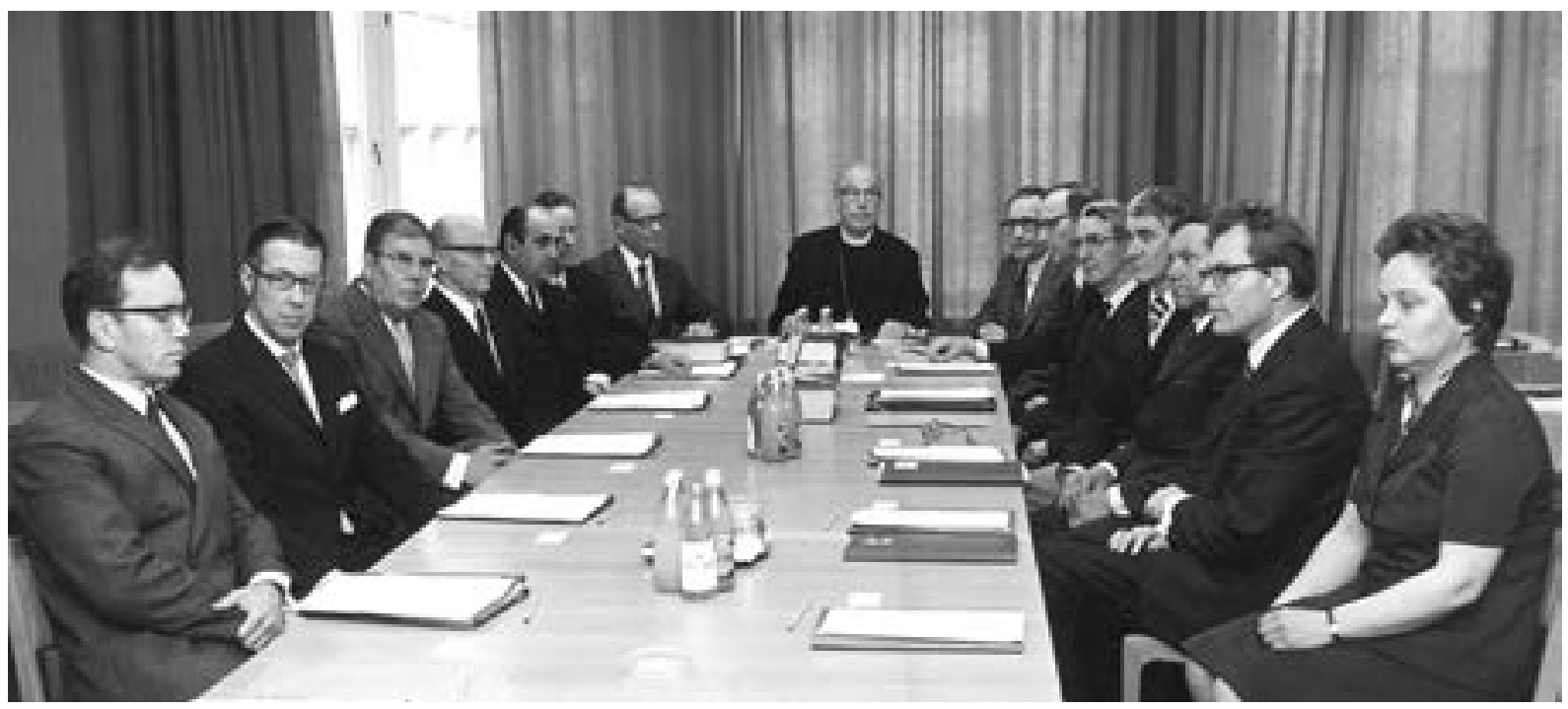

kelle oli valittava seuraaja. Täysistunnossa naiskysymys ohitti kuitenkin puolueasetelmat. Insinööri Rafael Nyqvist Kemijärveltä ehdotti, että toiseksi varapuheenjohtajaksi valittaisiin nainen, Meeri Päivänsalo Oulun hiippakunnasta. "Tämä voi tuntua monesta teistä - - aika uskalletulta ja uudelta näkökulmalta", Nyqvist totesi sanoittaen sen, ettei naisten tie kirkon johtopaikoille ollut neljässä vuodessa juuri ehtinyt silottua. Nyt asiaa oli ajamassa aiempaa selväpiirteisempi naisrintama, jota virkakysymyksen käsittely vuosina 1975 ja 1976 oli vahvistanut. ${ }^{184}$

Ehdokkaaksi nousi jälleen myös Johannes Leivonen, joka kuitenkin itse toivoi, ettei häntä äänestettäisi. Hänen mukaansa puheenjohtajavalinnat loivat ulospäin kuvaa kirkolliskokouksesta. Siksi molempien varapuheenjohtajien oli tärkeää olla vaaleilla valittuja maallikkoedustajia, joita oli enemmistö kirkolliskokouksessa. ${ }^{185}$ Oulun piispa Hannes Leinonen taivutteli Leivosta ehdokkaaksi teologisoimalla asian vahvasti: "- - jos Jumalan seurakunta hänen tahtonsa mukaan seurakunnan jäsentä kutsuu johonkin tehtävään, niin seurakunnan jäsenen ei tule siitä kieltäytyä." ${ }^{186}$ Samalla Leinonen asettui käytännössä oman hiippakuntansa ehdokasta vastaan, ilmeisesti ainakin osittain teologisista syistä. Leinonen oli näet edellisellä nelivuotiskaudella kuulunut siihen pieneen joukkoon, joka oli voimakkaasti vastustanut paitsi naispappeutta myös kaikkia lehtorin oikeuksien laajentamispyrkimyksiä. Hänen ystävällistä
Toukokuussa 1974 valittu kirkkohallitus ensimmäisessä täysistunnossaan 7 . kesäkuuta samana vuonna. Kuvassa vasemmalta John Vikström, Aulis Nurmisto, Juhani Linkola, Pentti Niemelä, John Forsberg, Kai Sarsa, Mauno Saloheimo, Martti Simojoki, Ahti Auranen, Olavi Vuorela, Eero Lehtinen, Eero Heinonen, Heikki Kokko, Aarre Huuskonen ja Anna Maija Silvola. Silvola jäi ainoaksi naisedustajaksi, vaikka jotkut edustajat yrittivät lisätä naisten määrää kirkkohallituksessa. Kuva: Kirkkohallitus.

mutta samalla isällistä suhtautumistaan oman hiippakuntansa ainoaan naisedustajaan oli puolestaan samaan aikaan kuvastanut se, että hän oli puhunut Päivänsalosta "tyttärenä". ${ }^{87}$ Sama suhtautumistapa näkyi varapuheenjohtajan vaalissa.

Toisen varapuheenjohtajan vaalista tuli hyvin tasainen. ${ }^{188}$ Leivonen valittiin tehtävään lopulta neljän äänen erolla, vaikka naisten kerrottiin olleen yhtenä rintamana Päivänsalon takana ja vaikka Leivonen itsekin kehotti olemaan äänestämättä itseään. Lopputuloksessa oli ennen kaikkea kyse siitä, että edustajien enemmistö halusi puheenjohtajistoon ensisijaisesti Taxellin, Kalliokosken ja Leivosen kaltaisia arvostettuja lain ja kokoustyöskentelyn tuntijoita. Joistakin puheenvuoroista saattoi kuitenkin myös päätellä, että naisedustajat olivat vielä sillä "koeajalla", josta edellisen nelivuotiskauden alkaessa oli vihjattu.

Määräaikaisia, luottamustoimisia kirkkoneuvoksia valittaessa puhuttivat keväällä 1978 paljolti samat asiat kuin neljä vuotta aiemmin, mutta tällä kertaa entistä 
voimakkaammin. Edellisellä kerralla kirkkohallitukseen oli valittu yksi kirkkoherra ja yksi tuomiokapitulin lainoppinut asessori, mutta nyt hiippakuntien ensisijaisten ehdokkaiden joukossa oli yhden kirkkoherran lisäksi peräti kaksi lainoppinutta asessoria. ${ }^{189}$ Valitsijamiesten puheenjohtaja Kansanaho myönsi, että hänen johtamassaan hallinnonuudistuksessa määräaikaisiksi kirkkoneuvoksiksi oli nimenomaan kaavailtu muita kuin seurakuntien tai tuomiokapitulien viranhaltijoita. Näiden edustus kirkkohallituksessa oli turvattu muuta kautta. Valitsijamiehet halusivat kuitenkin kunnioittaa hiippakunnan ehdotusta, mikäli hiippakunnan äänestystulos oli ollut selvä. Sen sijaan varsinaisessa vaalissa täysistunnossa arkkihiippakunnan aiempi kirkkoneuvos, metsänhoitaja Juhani Linkola korvasi selvin äänin valitsijamiesten esittämän Tyrvään kirkkoherran Timo Kökön. Anna Maija Silvola taas jatkoi edelleen ainoana naisena kirkkohallituksessa. ${ }^{190}$

Lopputuloksesta huolimatta valitsijamiesten esitys Timo Kökön valitsemiseksi oli omiaan hämärtämään entisestään eri elinten välisiä tehtävärajoja kirkon sopimuspolitiikassa keväällä 1978: sen lisäksi, että kaksi kirkon sopimusvaltuuskunnan keskeistä virkamiestä osallistui aktiivisesti kirkolliskokousedustajien vaalityöhön, Suomen kirkon pappisliiton puheenjohtaja Kökkö oli ehdolla kirkkohallitukseen. Sopimusvaltuuskunnan toimisto liittyi läheisesti kirkkohallitukseen, ja keskustelussa muistutettiin, että kirkkohallitus myös valitsi edustajansa sopimusvaltuuskuntaan. Valitsijamiesten esityksen pohjalta tämä kirkkohallituksen edustaja olisi voinut teoriassa olla sopimusneuvottelujen vastapuolen puheenjohtaja. ${ }^{191}$ Työmarkkinapoliittisesti sekavaa tilannetta täydensi, että samana vuonna kirkolliskokoukseen oli valittu valtakunnansovittelija käyttämään kirkon työnantajapuolen ääntä.

Niin 1974 kuin 1978 luottamustoimisia kirkkoneuvoksia valittaessa osoittautui hankalaksi turvata pienten seurakuntien edustus ja naisten osuus. Aivan samat ongelmat olivat edessä, kun kirkolliskokous valitsi hiippakunnittain jäsenet ja varajäsenet kirkon sopimusvaltuuskuntaan. Syksyllä 1974 kirkolliskokousedustajat ilmoittivat sopimusvaltuuskunnan jäsenten vaaliin yhteensä 32 ehdokasta. Nämä olivat kaikki miehiä, ja talousvaliokunta sai turhaan hakea joukosta pienen seurakunnan edustajaa. Valiokunta joutui itse etsimään ehdokkaiden ulkopuolelta henkilön, joka olisi sekä nainen että pienen seurakunnan jäsen. Tehtävän vaikeutta osoittaa, että ehdokkaita etsittäessä 11000 jäsenen Hamina jouduttiin tulkitsemaan pieneksi seurakunnaksi. ${ }^{192}$ Kirkolliskokouksen luottamushenkilövaalit olivat suurista kaupunkiseurakunnista tulevien miesten vaaleja.

Sopimusvaltuuskunnan vaaliin saivat osallistua vain ne edustajat, joiden työsuhteen ehtoja kirkon virkaehtosopimus ei koskenut, toisin sanoen suurin osa maallikkoedustajista, piispat ja muutamat kirkon ulkopuolella työskentelevät papit. Muut joutuivat poistumaan kokoussalista. Tosin asian lähetekeskustelussa kaikki edustajat olivat läsnä, ja kerran myös Tampereen tuomiorovasti Pertti Ranta otti kantaa valintaperiaatteisiin. ${ }^{193}$ Lain hengen kannalta oli ongelmallista, että Suomen kirkon pappisliiton johtokunnan aiempi varapuheenjohtaja, joka vaalia toimitettaessa joutui poistumaan kokoussalista, antoi lähetekeskustelussa evästystä talousvaliokunnan maallikkojäsenille. Kyseessä ei ollut ainoa kerta, jolloin jääviyden rajat osoittautuivat häilyviksi kirkolliskokouksen vaaleissa tai kirkon palvelussuhdepolitiikasta keskusteltaessa.

Täysistunnossa toimitettaviin vaaleihin kuuluivat vielä määräämättömäksi ajaksi valittavien kirkkoneuvosten, kirkkohallituksen korkeimpien virkamiesten, vaalit. Valittaessa lainoppinutta kirkkoneuvosta vuonna 1975 kirkolliskokousedustajat arvostelivat erityisesti saamiensa taustatietojen vähäisyyttä. Kirkkoneuvokseksi valittiin varatuomari Matti Halttunen, joka toimi sittemmin virassaan aina vuoteen 2008 asti. Kirkolliskokouksen sihteeri, varatuomari Sinikka Pylkkänen, joka näyttäytyi erityisesti naisedustajien ehdokkaana, jäi vaalissa selvästi taakse. ${ }^{194}$

Menettelytapakysymykset nousivat seuraavan kerran esille, kun eläkkeelle jääneen Ahti Aurasen tilalle valittiin syksyllä 1978 jumaluusoppinut kirkkoneuvos. Aiemmilla kerroilla kuullun arvostelun vuoksi uusi arkkipiispa Mikko Juva muutti käsittelyjärjestystä ja antoi niin virallisille kuin epävirallisille keskusteluille tilaa eri vaiheissa. ${ }^{195}$ Viimeksi mainittuja oli tosin käyty jo hyvissä ajoin keväästä lähtien kokoomuksen ja keskustan kirkkopoliittisissa elimissä. Kirkolliskokouksessa sen sijaan näkyivät ainakin päällepäin vain herätysliike- ja hiippakunta-asetelmat. Virkaan valittiin Kiuruveden kirkkoherra Jukka Malmivaara. ${ }^{196}$ 


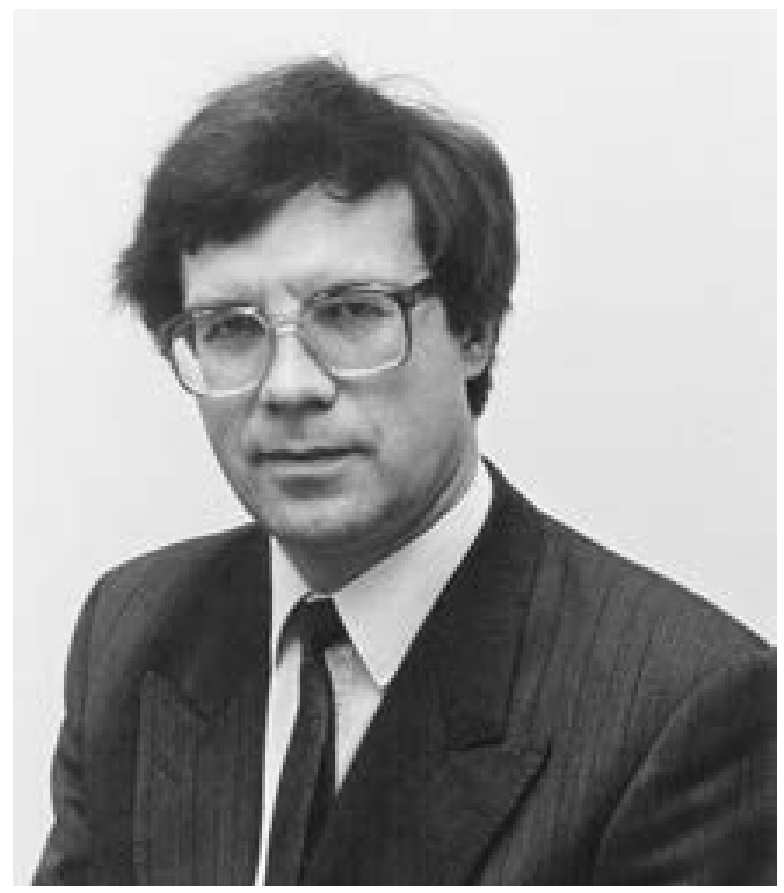

Kirkolliskokous valitsi 1975 lainoppineeksi kirkkoneuvokseksi varatuomari Matti Halttusen, joka sittemmin toimi tässä virassa aina vuoteen 2008 asti. Kuva: Kirkkohallitus / Ritva Neuvonen.

Kirkkoneuvosehdokkaiden joukossa oli monia kirkolliskokouksen pappisjäseniä, mutta vain kaksi valitsijamiesten nimeämää kärkiehdokasta pidättäytyi antamasta ääntään. Kirkkolain mukaan kirkolliskokouksen jäsen oli esteellinen ottamaan osaa häntä henkilökohtaisesti koskevan päätöksen tekemiseen, ja Jaakko Voipio paheksuikin voimakkaasti edustajien toimintaa. ${ }^{197}$ Julkisoikeuden professori sai 1978 olla muutenkin ahkerasti muistuttamassa kirkolliskokousta hyvän hallinnon periaatteista. ${ }^{198}$

Hiippakunta- ja herätysliikerajat loivat puitteet täysistuntokeskusteluille kirkolliskokouksen toimittamissa vaaleissa. Toinen yleispiirre oli, että naisten yhteisrintama ja puhe naisten edustuksesta voimistuivat uusimuotoisen kirkolliskokouksen ensimmäisinä vuosina. Keskustelun vaikutus ei kuitenkaan ulottunut vaalien tuloksiin. Vaikka naisten määrä kirkolliskokouksessa oli kasvanut voimakkaasti, heidän oli edelleen hyvin vaikea päästä kirkollisen päätöksenteon ydintehtäviin. Naisedustajat eivät saaneet moneltakaan mieheltä tukea esittämilleen naisehdokkaille.
Erityisesti niihin vaaleihin, jotka oli työjärjestyksen mukaan toimitettava aina umpilipuin täysistunnossa, sisältyi myös yllätyksiä. Mahdollisuus äänestää täysin esillä olleista ehdokasnimistä riippumatta tarjosi tilaa pienille protesteille, jonkun keskustelussa unohdetun henkilön esille nostamiselle ja yksinkertaisesti lipsahduksille. Vuonna 1976 kirkolliskokous valitsi kirkon keskusrahaston varatilintarkastajaksi varatuomari Juha Linnan, mutta yhden äänen sai myös Väinö Linna. ${ }^{199}$ On mahdotonta tietää, oliko kyseessä vahinko vai hiljainen vastalause pelkäksi muodollisuudeksi tullutta mutta aikaa vienyttä vaalia kohtaan. Joka tapauksessa kirkolliskokous muutti seuraavalla istuntokaudella työjärjestystään siten, että se saattoi suoraan hyväksyä täysistunnossaan valitsijamiesten ehdotuksen tilintarkastajiksi. ${ }^{200}$ Vaali siirtyi käytännössä valitsijamiehille.

\section{VALITSIJAMIEHET TASA PAINOILEVAT}

Uusimuotoisen kirkolliskokouksen ensimmäisiä tehtäviä oli valitsijamiesten nimeäminen. Valmisteluelimen kokoonpanoa punnittiin hiippakunnittain ilmeisen tarkkaan, ja valitsijamiehet olivatkin kuin pienoiskuva kirkolliskokouksesta. Esimerkiksi pappis- ja maallikkoedustajia tuli valitsijamiehiin suunnilleen samassa suhteessa kuin heitä oli kirkolliskokouksessa. Myös naisedustajien osuus otettiin huomioon: maallikkovalitsijamiehistä heitä oli suurempi osuus kuin kokonaisuudessaan maallikkoedustajista. Sen sijaan valitsijamiehet erosivat kokemukseltaan edustajien keskiarvosta. Varsinkin pappisedustajien valinnassa kirkolliskokouskokemus näyttää olleen määräävä tekijä: ensimmäisen kauden edustajia ei ollut pappisvalitsijamiehissä lainkaan, ja kolme neljäsosaa istui vähintään kolmatta kauttaan kirkolliskokouksessa. Maallikkovalitsijamiehistäkin vain viidennes oli ensimmäisen kauden edustajia. Edelleen 1978 valitsijamiehiin pyrittiin saamaan kokeneita edustajia mutta samalla riittävästi vaihtuvuutta näiden kokeneiden edustajien kesken.

Valitsijamiesten ensimmäinen velvollisuus oli valita jäsenet valiokuntiin. Tässä vaikeassa tehtävässä valitsijamiehet joutuivat ottamaan huomioon edustajien omat toiveet sekä erikoisalan ja edustajakokemuksen, hiippakuntien keskinäisen tasapainon sekä pappis- ja maallikkoedustajien osuudet. Kaikkia toiveita ei mitenkään voitu toteuttaa. Valitsijamiesten jäseneen kohdistui 
odotuksia ja vaikuttamispyrkimyksiä, ja hän saattoi joskus saada silmilleen rajunkin purkauksen oman hiippakuntansa edustajalta, jota ei ollut voitu sijoittaa haluamaansa valiokuntaan ${ }^{201}$.

Valiokuntien kokoonpanot lähtivät nopeasti urautumaan, mikä näkyi erityisesti niiden sisällä puheenjohtajan valinnassa. Mikäli valiokunnassa oli piispa, valitsijamiehet merkitsivät hänet kokoonkutsujaksi. Niin 1974 kuin neljä vuotta myöhemmin puheenjohtaja Kansanaho korosti kirkolliskokoukselle, ettei kyseessä ollut esitys valiokunnan puheenjohtajaksi ${ }^{202}$. Käytännössä lopputulos oli kuitenkin molemmilla kerroilla juuri tällainen. ${ }^{203}$ Vain harvat piispat kyseenalaistivat perinteen, että piispa oli valiokunnan puheenjohtajana. ${ }^{204}$

Käytännöksi muodostui ensimmäisillä nelivuotiskausilla, että laki-, peruste-, käsikirja- ja toimikuntavaliokuntaa sekä yleistä valmistusvaliokuntaa johti virallinen edustaja, ensin mainittua nimenomaan juristi. Talousja kansliavaliokuntaa sen sijaan johtivat maallikkoedustajista valitut talouden asiantuntijat. Näistäkin kahdesta valiokunnasta vain ensin mainittu valmisteli tärkeitä päätöksiä kirkolliskokoukselle. Asetelma johti siihen, että esimerkiksi 1978 kirkolliskokouksen puhemiesneuvostossa istui seitsemän virallista edustajaa ja vain kolme hiippakunnittain vaaleilla valittua edustajaa. Itse asiassa kirkolliskokouksen puhemiesneuvosto oli koko kirkon episkopaalisin elin, jossa piispoilla oli suurempi osuus jäsenpaikoista kuin piispainkokouksessa.

Valiokuntien kokoonpanoissa oli suuria eroja, jotka selittyivät paitsi valiokunnan tehtävästä myös tuon tehtävän painoarvosta käsin. Jo keväällä 1974 seitsemästä suuresta valiokunnasta erottui neljä "pappisvaliokuntaa”, joiden jäsenistössä papeilla oli huomattavasti suurempi osuus kuin kirkolliskokouksessa muuten. Keväällä 1978 pappien osuus näissä valiokunnissa vain kasvoi neljän vuoden takaiseen verrattuna. Lakivaliokuntaa saattoi kutsua myös kirkkoherravaliokunnaksi. Vuonna 1974 siihen valittiin peräti kuusi kirkkoherraa rinnallaan kolme kirkolliskokouksen korkeinta juristia - oikeusneuvos Leivonen, hallintoneuvos Ojala ja professori Taxell - sekä piispa Leinonen ja koulutoimentarkastaja Päivänsalo.

Myös käsikirjavaliokunta oli pappien hallitsema, joskin niin 1974 kuin neljä vuotta myöhemminkin valiokunnan maallikkoedustajien joukkoon saatiin kanttori.
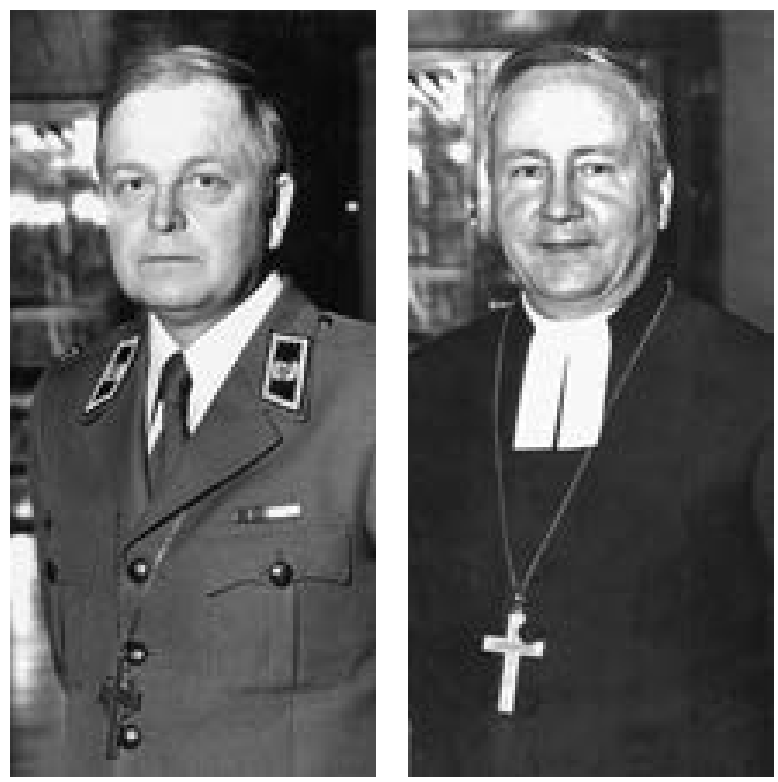

Yleisen valmistusvaliokunnan kahta osastoa johtivat kenttäpiispa ja virassa nuorin piispa. Vaalikaudella 1978-1981 valiokunnan johdossa olivat kenttäpiispa Viljo Remes ja Mikkelin piispa Kalevi Toiviainen. Heidän lisäkseen valiokunnassa ei ollutkaan muita pappeja vaan lähinnä kirkolliskokoustyötään aloittelevia maallikkoedustajia. Kuvat: Kirkkohallitus / Arvo Salminen.

Siviili- eli perustevaliokunnassa sekä toimikuntavaliokunnassa pappeja oli ensimmäisillä nelivuotiskausilla suunnilleen yhtä paljon kuin maallikkoja, ja erityisesti ensin mainittuun pyrittiin saamaan monipuolisesti eri mielipidesuuntia edustavia jäseniä. Ylimääräisenä perustettuun kasvatusasiain valiokuntaan tuli varsinkin opetusalalla toimineita maallikkoedustajia, mikä selitti naisten poikkeuksellisen suurta määrää valiokunnassa. Samasta syystä myös eduskunnassa oli 1900-luvun loppupuolella kaikkein eniten naisedustajia sivistysvaliokunnassa, lähes kaksi kolmasosaa jäsenistä205.

Talousvaliokunta oli maallikkoedustajien hallussa: 1974 siihen valittiin kymmenen maallikkoa ja yksi pappi. Kirkolliskokous halusi turvata kehitysalueiden edustuksen valiokunnassa, mitä osoittaa se, että valiokunnan harvat pappisjäsenet valittiin kirkon köyhimpien alueiden edustajista. Talousvaliokunnan tavoin kansliavaliokunta oli täysin maallikkoedustajien hallitsema, ja myös yleisessä valmistusvaliokunnassa oli maallikkoenemmistö. Valiokunnassa oli 1980-luvun alussa 17 jäsentä, joiden joukossa oli piispa, kenttäpiispa ja 15 maallikko- 
edustajaa. Hiippakunnittain valittuja pappisedustajia tai juristeja ei kuulunut valiokuntaan. Lähtökohdat kirkkolakia tai kirkon oppia koskevien aloitteiden käsittelyyn eivät olleet ihanteelliset.

Keväällä 1974 kolmelle neljäsosalle kirkolliskokousedustajista oli tarjolla varsinainen valiokuntapaikka. Suurelle osalle jäi vain varajäsenyys, kaikille ei sitäkään. Kolmannen tai useamman kauden edustaja sai helposti varsinaisen valiokuntapaikan. Toisen kauden edustajistakin vielä selvästi keskimääräistä useampi pääsi varsinaiseksi jäseneksi valiokuntaan, mutta kirkolliskokouksen tulokkaista vain hieman yli puolet sai tämän luottamuksen. Näissä valiokuntapaikatta jääneissä ensikertalaisissa oli kuitenkin valitsijamiehiä, ja pääsipä joku tuosta joukosta kirkkohallitukseenkin.

Valiokunnan valmistelemien asioiden painoarvo vaikutti siihen, kuinka kokeneita edustajia valiokuntaan sijoitettiin. Kolmella neljästä lakivaliokunnan jäsenestä oli menossa vähintään kolmas edustajakausi, eikä joukossa ollut lainkaan ensikertalaisia. "Kirkkoherravaliokunta" oli samalla kaikkein kokeneimpien kirkolliskokousedustajien valmisteluelin. Vastaavasti enemmistö yleisen valmistusvaliokunnan ja kansliavaliokunnan jäsenistä oli kirkolliskokouksen tulokkaita. Muut valiokunnat sijoittuivat näiden ääripäiden väliin.

Vuonna 1974 suurin osa naisedustajista oli ensikertalaisia, joten heidän sijoittumistaan eri valiokuntiin selittivät samat tekijät kuin muidenkin tulokkaiden osalta. Sen sijaan vuoden 1978 kirkolliskokousvaaleissa naisedustajien vaihtuvuus oli pientä, ja kirkolliskokoukseen valitut naiset olivat siten kokenutta joukkoa. Siitä huolimatta he sijoittuivat valiokuntiin hyvin epätasaisesti: heitä oli paljon yleisessä valmistusvaliokunnassa ja kansliavaliokunnassa, mutta heitä ei valittu tärkeisiin valmistelutehtäviin laki- tai talousvaliokuntaan - lakivaliokuntaan ei edes varajäseniksi. Myös opillisten asioiden valmistelusta naiset olivat paljolti ulkona, koska heitä ei ollut peruste- tai käsikirjavaliokunnassa. Maallikkomiehiä näissä neljässä valiokunnassa oli yhteensä 21. Kokeneenkin naisedustajan oli siten selvästi vaikeampi saada paikka tärkeästä valiokunnasta kuin miespuolisen maallikkoedustajan. Naisedustajien henkireikä oli kasvatusasiain valiokunta, jossa opetusalalla toimineet naiset pääsivät valmistelemaan tärkeitä ja ajankohtaisia kannanottoja.
Ensimmäisissä valiokuntavaaleissa vähintään yksi valiokuntapaikka oli viralliselle edustajalle käytännössä itsestäänselvyys. Tosin puheenjohtajana toimiva arkkipiispa ja työskentelyyn muutenkin harvoin osallistuva valtioneuvoston määräämä edustaja jäivät valiokuntien ulkopuolelle. Pappisedustajillekin valiokunnan ovet aukesivat selvästi helpommin kuin maallikkoedustajille: vain kuudennes papeista jäi ilman varsinaista valiokuntapaikkaa, kun maallikkoedustajista kohtalon koki kolmasosa. Pienissä hiippakunnissa valiokuntapaikkojen osuus oli suhteellisesti hieman korkeampi kuin suurissa.

Valiokuntapaikkojen osalta poikkeuksena oli Porvoon hiippakunta, jonka kaikki vaaleilla valitut edustajat sijoitettiin johonkin valiokuntaan. Kirkolliskokouksen kaksikielinen työskentely edellytti sitä, että jokaisessa valiokunnassa oli Porvoon hiippakunnan edustaja. Kirkolliskokousuudistuksen jälkeen käännöspalvelut olivat aluksi hyvin puutteellisia, ja valiokuntien ruotsinkieliset jäsenet joutuivat tekemään käännöstyötä - usein yömyöhään. Laajaa edustusta edellytti myös se, että Porvoon hiippakunnan olosuhteet ja toiminnalliset rakenteet poikkesivat muista hiippakunnista. Hiippakunnan viidestä maallikkoedustajasta enemmistö, kolme, istui kirkolliskokouksen johdossa puhemiesneuvostossa, kun muista hiippakunnista siellä oli yhteensä kaksi maallikkoedustajaa. Nämä vertailut kertovat paitsi Porvoon hiippakunnan edustajien poikkeuksellisen mittavasta asiantuntemuksesta kaudella 1974-1977 myös siitä, että uudistettu kirkolliskokous halusi työnsä alkuvaiheessa kiinnittää huomiota kaksikielisyyteen.

Valitsijamiesten tehtävänä oli vuosittain toimittaa kirkon toimikuntien täydennysvaalit. Puheenjohtaja Kansanahon sanoin tehtävä oli epäkiitollinen. ${ }^{206}$ Toimikuntien johtosäännöt olivat moninaisia, eikä sekaannuksilta vältytty. ${ }^{207}$ Lisäksi toimikuntien vaaleissa valitsijamiehet joutuivat vielä valiokuntavaalejakin monimutkaisempaan puntarointiin. Toimikuntien johtokunnat oli alun perin perustettu asiantuntijaelimiksi, mutta niiden valinnan siirryttyä kirkolliskokoukselle paineet edustuksellisuuden lisäämiseksi kasvoivat ${ }^{208}$. Oulun, Kuopion ja Lapuan hiippakuntien kirkolliskokousedustajat tekivät yhteistyötä saadakseen toimikuntiin pohjoisen Suomen edustajia. ${ }^{209}$ Valitsijamiehetkin pyrkivät mahdollisuuksien mukaan alueelliseen tasapainoon. Samalla oli yritettävä löytää monipuolisesti eri ammattiryhmiä 
edustavia, mahdollisimman päteviä henkilöitä. Ensimmäisen nelivuotiskauden aikana alueellinen tasapaino ei toteutunut kaikkia tyydyttävällä tavalla. Pohjoisessa ihmeteltiin, että toimikuntien yli sadasta jäsenestä kukaan ei ollut Oulun ja Nurmeksen välisen linjan pohjoispuolelta. ${ }^{210}$ Valitsijamiesten tehtävä toimikuntien jäsenten valinnassa helpottui vuodesta 1980 lähtien, kun toimikuntavaliokunta tuli mukaan vaalien valmisteluun.

Ensimmäisissä täydennysvaaleissa valitsijamiehet valitsivat toimikuntiin useita kirkolliskokouksen jäseniä. ${ }^{211}$ He halusivat taata, että yhteys toimikuntien ja kirkolliskokouksen välillä toimisi. Tätä yhteyttä korosti vielä se, että piispa Kansanaho oli puheenjohtajana niin toimikuntavaliokunnassa kuin valitsijamiehissä. Seuraavissa täydennysvaaleissa kirkolliskokousedustajien osuus säilyi suunnilleen entisellään: noin viidennes toimikuntien jäsenistä oli kirkolliskokousedustajia, ja sama osuus kirkolliskokousedustajista istui jossakin toimikunnassa. Tiettyihin tärkeisiin toimikuntiin, kuten kirkon diakoniatyön keskukseen ja kirkon kasvatusasiain keskukseen (KKK) valittiin erityisen paljon kirkolliskokouksen jäseniä. ${ }^{212}$ Kun ottaa huomioon, että kirkolliskokouksen jäseniä oli mukana myös monien toimikuntien alaisten elinten työssä, kirkolliskokousedustajien yhteys toimikuntalaitokseen oli vahva ja voimistui jatkuvasti nelivuotiskauden edetessä.

Välillä toimikuntien täydennysvaaleihin liittyi dramatiikkaa. Vuonna 1980 epävirallisissa keskusteluissa ilmeni, että jotkut valitsijamiehet halusivat valita toimikuntiin jäseniä poliittisten mielipiteiden mukaan. Tilanne johti täysistunnossa kuultuun vetoomukseen, ettei politiikan annettaisi "mennä sisälle valitsijamiesten kokoushuoneen ovesta". ${ }^{213}$ Valitsijamiesten olikin mietittävä valinnoissaan niin monia eri tekijöitä, etteivät puoluepoliittiset ryhmäjaot lopulta juuri päässeet vaikuttamaan heidän ratkaisuihinsa. ${ }^{214}$

Tunteet saattoivat kuumentua muista syistä. Asessori Ossi Haaramäen mukaan Pielisensuun kappalainen Matti Sihvonen ehdotti valitsijamiesten kokouksessa 1977, että vaihtuvuuden lisäämiseksi Helsingin piispaa Aimo T. Nikolaista ei enää valittaisi kirkon ulkomaanasiain toimikuntaan. Haaramäki kannatti opiskelutoverinsa ehdotusta. Nikolainen oli toimikunnan varapuheenjohtaja, ja hän oli ollut elimen jäsenenä vuodesta 1953 asti. Kuullessaan ehdotuksesta kokouksen väliajalla hän kiihtyi ja uhkasi Haaramäen mukaan lopettaa kokonaan ulkomaisten vieraiden kutsumisen. Tapahtumista huolimatta valitsijamiehet valitsivat piispojen keskuudesta toimikuntaan Tampereen piispan Paavo Kortekankaan. ${ }^{215}$

\section{TEHOKKAAT TOIMINNAN JA}

\section{TALOUDEN RAKENTEET VAI}

\section{HENGELLINEN ERITYISLAATUISUUS?}

\section{TOIMIKUNNAT HALLINNONUUDISTUKSEN KOMPASTUSKIVENÄ}

Eri työaloihin erikoistuneet toimikunnat olivat syntyneet sodanjälkeisinä vuosikymmeninä ajankohtaiseen tarpeeseen ilman selvää suunnitelmallisuutta. Kirkon keskushallintoa uudistettaessa 1970 -luvun alussa niitä oli jo 14. Osoittautui vaikeaksi päättää, mikä elin ohjaisi toimikuntien työtä laajennetun piispainkokouksen lakkauttamisen jälkeen. Asiaa valmistellut kirkon hallintokomitea ehdotti, että kirkolliskokoukseen perustettaisiin erityinen kirkollisen työn valiokunta, joka valmistelisi kaikki toimikuntien valvontaa koskevat asiat. Vuoden 1971 ylimääräisessä kirkolliskokouksessa toiminut kirkon hallintovaliokunta taas ehdotti toimikuntien valvonnan keskittämistä kirkkohallitukselle, jonka kokoonpanoa vastapainoksi laajennettaisiin. Kirkolliskokouksen täysistunto ei kuitenkaan kaikissa kohdin hyväksynyt esitystä kirkkohallituksen vallan lisäämisestä. ${ }^{216}$ Lopputuloksena oli edustuspohjaltaan laaja kirkkohallitus, jonka toimivalta suhteessa toimikuntiin oli rajattu mutta ilmeisen epäselvä.

Piispa Kansanaho tulkitsi kirkolliskokouksen tahdon kirkkohallituksen kannalta hyvin tiukasti: kirkkohallitus saattoi vain valvoa, että toimikunnissa noudatettiin kirkolliskokouksen antamia ohjeita. Kansanaho vei siten tulkintaa takaisin kohti johtamansa kirkon hallintokomitean alkuperäistä esitystä ja painotti kirkolliskokouksen sekä sen toimikuntavaliokunnan valtaa. ${ }^{217}$ Kokonaisuuteen sopi, että Kansanaho valittiin uuden toimikuntavaliokunnan puheenjohtajaksi. ${ }^{218}$ Laajennettu piispainkokous oli viime töikseen teettänyt toimikuntien asemasta selvityksen, jossa ehdotettiin toimikuntien karsimista ja jäljelle jäävien muuttamista kirkkohallituksen osastoiksi. ${ }^{219}$ Uusimuotoinen kirkol- 
liskokous asetti puolestaan heti ensimmäisellä istuntokaudellaan Vanhankirkon seurakunnan kirkkoherran, sittemmin Helsingin tuomiorovastin Mauri Larkion johtaman komitean selvittämään toimikuntien asemaa ja organisaatiota. ${ }^{220}$

Toimikuntauudistuksen suuntaan vaikuttivat 1974 uuden kirkolliskokouksen alkuinnostus ja -kriittisyys. Pohdittiin jopa erillisen komitean asettamista selvittämään kirkon korkeakoulutoimikunnan työtä, jonka toimikuntavaliokunta katsoi jäävän otteensa ulkopuolelle. ${ }^{21}$ Myös kirkon tiedotuskeskus sai osakseen arvostelua. Epäluottamus tuli esiin erityisen selvästi, kun kirkolliskokous päätti perustaa kirkon kirjallisuuspalkinnon. Kirkollisia kulttuuripalkintoja perustamalla kirkolliskokous osallistui 1970-luvun puolivälin kamppailuun suomalaisen kulttuurin suunnasta. Siksi ei ollut yhdentekevää, kuka pääsi kirkon nimissä arvottamaan kulttuuria. Monet edustajat epäilivät, uskalsiko tiedotuskeskukselle antaa avoimen valtakirjan päättää palkinnon saajasta ${ }^{222}$. Jännittynyttä ilmapiiriä kuvasti edelleen se, että Munkkivuoren kirkkoherra Eero Saarinen ja kirkkoneuvos Olavi Vuorela ajautuivat toimikuntia käsiteltäessä sanailuihin, joihin arkkipiispa Simojokikin puuttui puheenjohtajan paikaltaan. ${ }^{223}$ Jos kirkolliskokousta verrattiin parlamenttiin, se oli työnsä alussa lähinnä suuri oppositio ruotimassa kirkkohallituksen ja erityisesti toimikuntien työtä.

Tähän 1974 vallinneeseen oppositiomielialaan sopi hyvin se, että toimikuntakomitea pyrki seuraavana vuonna välimietinnössään rajaamaan kirkkohallituksen tehtävät suhteessa toimikuntiin mahdollisimman vähäisiksi. Kirkon työn korkein johto kuului komitean mukaan kirkolliskokoukselle ja sen toimikuntavaliokunnalle. Komitean kanta tiivistyi toteamukseen, että kirkolliskokous oli kirkon yhteisen työn "ylin hallintoelin". ${ }^{224}$ Komitea oli jopa "kansanaholaisempi" kuin Tampereen piispa itse. Se edusti puhtaaksi viljeltyä tulkintaa kirkolliskokouksen vallasta ja palasi pitkälti kirkon hallintokomitean alkuperäisiin ajatuksiin. Organisaation osalta komitea ehdotti toimikuntien keskittämistä viideksi toimintakeskukseksi. ${ }^{225}$ Kumpikin ehdotus sai kirkolliskokouksessa vastaansa ankaraa arvostelua. Mieliala ei ollut enää samanlainen kuin vuotta aiemmin.

Joissakin valtiollisissa parlamenteissa valiokunnille oli määrätty myös hallinnollisia tehtäviä. ${ }^{226}$ Siitä huo- limatta kansleri Mikko Juva hyökkäsi kirkolliskokoukselle suunniteltua roolia vastaan: "synodit eivät missään kirkon perinteessä ole hoitaneet eivätkä hoida hallintoa". Hän piti "epäsuotavana ja epäterveenä" komitean ajatusta tehdä toimikuntavaliokunnasta eräänlainen toimikuntahallitus eli yhdistää "parlamentaarinen valmisteluelin ja hallintoelin". Kirkkoneuvos Vuorela huomautti myös, ettei kirkkohallitus ollut vain konsistori vaan että siinä olivat kirkolliskokouksen ja piispainkokouksen valitsemien edustajien välityksellä mukana synodaalinen ja episkopaalinen elementti. ${ }^{227}$ Juvan perusteet tulivat pitkälti valtiollisesta vallanjako-opista, kun taas Vuorelan argumentit olivat teologisia. Miehet päätyivät joka tapauksessa samaan johtopäätökseen: kirkkohallituksen tehtäviä suhteessa toimikuntiin olisi mahdollista ja järkevää lisätä. Rintamalinja kirkolliskokouksen ja kirkkohallituksen puolustajien välillä oli piirtymässä.

Vieläkin jäätävämmän vastaanoton sai komitean ehdotus toimikuntien yhdistämisestä toimintakeskuksiksi. Piispa John Vikström otti lähtökohdakseen sanonnan: "Hullut vievät tätä maailmaa eteenpäin, viisaat pitävät sitä pystyssä." Mietintö oli vaarassa muuttaa toimikunnat kirkon "hulluista" työntekijöistä "viisaiksi" hallinnoijiksi: "Yhä useammin tuntuu siltä, että yhä suurempi osa kirkon työntekijöistä istuu pohtimassa, mitä pitäisi tehdä, sen sijaan että tehtäisiin jotakin." Vikströmin mielestä toimikuntien paikka oli etulinjassa, eikä niitä tullut tuoda sieltä rakenneuudistuksilla pois. ${ }^{228}$ Taisteluretoriikka toistui muulloinkin toimikunnista puhuttaessa - erityisesti niillä, jotka puolustivat pienten toimikuntien itsenäisyyttä. ${ }^{229}$

Kädenvääntö keskitetyn ja hajautetun hallinnon välillä ei ollut kirkossa uutta, mutta 1970-luvulla sen voi nähdä liittyneen vastaavaan keskusteluun valtionhallinnon suunnasta. Tuohon aikaan ministeriöissä oli alettu siirtyä laajapohjaisista komiteoista ja toimikunnista aiempaa kevyempiin ja ministerijohtoisempiin työryhmiin $^{230}$. Samaten rinnakkaisuutta kirkolliskokouksen sananvaihdolle voi nähdä siinä, että valtionhallinnossa keskusteltiin asiantuntijavaltaa painottaneiden keskusvirastojen ja poliittiseen ohjaukseen nojautuneen ministeriöjärjestelmän välisestä vallanjaosta. ${ }^{231}$

Kirkolliskokouksen keskustelussa tuli näkyviin myös se, että toimikuntiin oli edellisenä vuonna valittu paljon kirkolliskokousedustajia. Tuolla hetkellä kirkon 14 
toimikunnasta 11:ssä oli puheenjohtajana kirkolliskokouksen varsinainen jäsen. Kirkolliskokousedustajien korkea osuus ei merkinnyt kirkolliskokouksen otteen tiukentumista, jota esimerkiksi piispa Kansanaho oli koko ajan toivonut. Kun toimikunnissa istuneet kirkolliskokousedustajat saivat eteensä toimikuntakomitean ehdotuksen, heistä tuli hetkessä toimikuntiensa edunvalvojia kirkolliskokouksessa. Oppositiohenkiset puheenvuorot vaihtuivat toimikuntien puolustuspuheisiin. Muutosta selitti myös kirkolliskokouksen uusi kokoontumispaikka ja sen mukanaan tuoma tiivis yhteiselämä. Epäluulot toimikuntia kohtaan hälvenivät, kun kirkolliskokousedustajat tutustuivat toimikunnissa istuviin kollegoihinsa ja kirkkohallituksen virkamiehiin.

Toimikuntakomitean mietinnön tullessa kirkolliskokouksen käsittelyyn toimikuntalaitoksen ongelmat eivät näyttäneet enää niin suurilta kuin 1974. Ensinnäkin suuri osa epäkohdista oli ehditty korjata jo ennen komitean asettamista, mutta toteutetut uudistukset ehtivät kantaa hedelmää vasta vuoteen 1975 mennessä. Kirkolliskokous oli itsekin ehtinyt kehittää toimikuntalaitosta. Keväällä 1975 se oli vahvistanut lähetystyön asemaa toimikuntalaitoksessa perustaessaan kirkon lähetystyön keskuksen. ${ }^{232}$ Muuttuneiden asenteiden taustalla näyttää olleen myös se, että oli helppoa puhua yleisesti toimikuntalaitoksen uudistamistarpeesta. Konkreettinen ehdotus toimikuntien yhdistämisestä oli sen sijaan paljon vaikeampi hyväksyä.. ${ }^{233}$

Vuoden 1975 asennemuutos näkyi myös käsiteltäessä toimikuntien toimintakertomuksia. Edelliselle vuodelle ominaiset kiireelliset parannusvaatimukset puuttuivat toimikuntavaliokunnan mietinnöstä, joka oli yleissävyltään toimikunnille myönteinen. Vuonna 1974 toimintakertomusten käsittely oli virittänyt vilkkaan täysistuntokeskustelun, mutta seuraavana vuonna keskustelu käsitti kaksi puheenvuoroa, joista seikkaperäisempi koski Itäja Länsi-Saksan nimien oikeaa kirjoitusasua. ${ }^{234}$ Edellisenä vuonna toimikuntalaitoksen hajanaisuus oli ollut

\section{Lähetystyölle oma keskus}

Vuoden 1971 ylimääräinen kirkolliskokous asetti komitean tutkimaan lähetystyön asemaa kirkon lainsäädännössä ja hallinnossa. Suomen poliittisen aseman vakiintuminen ja yleinen kansainvälistyminen johdattivat kirkossakin kiinnittämään entistä enemmän huomiota kansainväliseen toimintaan.' Teologian tohtori Toivo Saarilahden johtaman komitean päämääränä oli jäsentää lähetystyö aiempaa kiinteämmin kirkon ja seurakuntien toimintaan. Komitea esittikin 1974 lähetystyön kehittämistä moninaisin tavoin kirkon eri tasoilla. Meneillään olleen toimikuntauudistuksen kannalta mietinnön keskeisintä ainesta oli esitys, että kirkon lähetystyön neuvottelukunnan pohjalta perustettaisiin uusi kirkon lähetystyön keskus. Sen oli tarkoitus toimia aiempaa tehokkaampana yhteistyöelimenä lähetysjärjestöjen kesken ja koordinoida laajentunutta kotimaantyötä."

Kirkolliskokouksen siviilivaliokunta ja kokouksen asettama toimikuntakomitea löysivät yhteisen linjan ja maltillisen ratkaisun. Uusissa suunnitelmissa keskus oli alkuperäisiä kaavailuja suppeampi. Samalla pidättäydyttiin sellaisista organisaatiomuutoksista, jotka olisivat vaikuttaneet olennai-

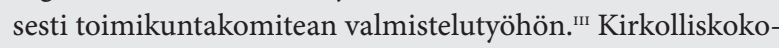
us päätti jo keväällä 1975 perustaa kirkon lähetystyön keskuksen..$^{\text {v }}$ Päätös oli yksi niistä ensiaputoimista, joilla kirkolliskokous pyrki selkeyttämään toimikuntalaitosta toimikunta-

komitean työn ollessa vielä kesken. Tällaiset osauudistukset vaimensivat kirkolliskokousedustajien keskuudessa vaatimuksia toimikuntalaitoksen nopeasta kokonaisuudistuksesta.

Kirkolliskokous kantoi vastuuta lähetystyöstä myös hyväksymällä Evankelisluterilaisen Lähetysyhdistys Kylväjän kirkon viralliseksi lähetysjärjestöksi 1979. ${ }^{v}$ Päätöstä tehtäessä piispa John Vikström ehdotti lisäpontta, jonka mukaan kirkon lähetystyön keskus velvoitettaisiin antamaan joka neljäs vuosi kirkolliskokoukselle selonteko siitä, miten kirkon lähetysjärjestöiksi hyväksytyt yhdistykset täyttivät niille asetetut ehdot. Ponsiehdotus hävisi kuitenkin äänin $65-31{ }^{\mathrm{VI}}$ Keskushallinnon uudistamisen jälkeisinä vuosina kirkolliskokous pyrki vahvistamaan lähetystyön asemaa kirkon organisaatiossa, mutta toisaalta sen enemmistö halusi antaa lähetysjärjestöille laajan itsenäisyyden. Tätä linjaa noudatettaessa lähetystyön ajankohtaiset kysymykset siirtyivät vähitellen kirkolliskokouksen keskusteluista muiden kirkon elinten huoleksi.

I Haapanen 1978, 45, 47-50; Murtorinne 1995, 422; Helander 2002, 129.

II Kirk.kok. ptk-s. 1974, liite IV.

III KKHA KKA Hh 1 ptk. 6.2.1975 $\$ 120$, ptk. 14.5.1975 $\$ 174$, kirkon lähetysasiain neuvottelukunnan lausunto välimietinnöstä; Kirk.kok.ptk-k. 1975, liite V-B 10.

IV Kirk.kok.ptk-k. 1975, 89 \$.

V Kirk.kok. ptk-s. 1979, 39 \$; SEK 1976-79, 213-214.

VI Kirk.kok. kptk-s. 1979, 39 \$. 
kirkolliskokoukselle paha ongelma. Nyt hajanaisuus oli muuttunut luovaksi yksilöllisyydeksi, jota ei saanut tukahduttaa hallinnollisilla yhtenäistämistoimilla.

Kirkolliskokouksessa kaikki olivat yksimielisiä siitä, että piispainkokouksen yhteyttä toimikuntalaitokseen tuli kehittää. Toimikuntavaliokunta päätyi myös ehdottamaan, että kirkkohallituksen valtuuksia lisättäisiin. Kiperin kysymys oli, tuliko toimikuntia yhdistää laajemmiksi kokonaisuuksiksi: olisiko seurauksena toiminnan tehostuminen vai vapauden kaventuminen? ${ }^{235}$ Mielipiteet jakautuivat voimakkaasti. Lopulta kirkolliskokous hyväksyi Timo Kökön ehdotuksesta niukasti kolmen äänen enemmistöllä monitulkintaisen kompromissin: toimikuntia yhdistettäisiin vain silloin, kun se toiminnan kannalta oli perusteltua. ${ }^{236}$ Komitea sai kirkolliskokoukselta kaikkea muuta kuin selvän ohjeistuksen jatkotyöskentelylleen.

Komitea joutui työtään jatkaessaan miettimään pitkään, mitä kirkolliskokous oli lopulta halunnut sanoa. Lopputuloksena oli, että komitea selitti kirkolliskokouksen lausumia katekismuksen ohjeen mukaisesti parhain päin - tosin omalta kannaltaan - ja päätti jatkaa aiemmin omaksumallaan linjalla. ${ }^{237}$ Kieltämättä tuo linja olikin kirkolliskokouksen alkuperäisen toimeksiannon mukainen. Jonkin verran komitea tuli vastaan niitä, jotka vastustivat toimikuntien yhdistämistä suuremmiksi yksiköiksi: komitean enemmistö ehdotti loppumietinnössään viiden sijasta seitsemää toimintakeskusta. ${ }^{238}$

Toimikuntakomitean eräs ongelma oli kiire. Komitea yritti saada loppumietintönsä valmiiksi niin, että se ehdittäisiin käsitellä vielä samalla nelivuotiskaudella. Välimietintöä valmisteltaessa kiire johti siihen, että toimikuntien antamia lausuntoja ei ehditty ottaa juuri huomioon. ${ }^{239}$ Vastaavasti loppumietintöä kirjoitettaessa komitean sihteeri Esa Siljamäki valitteli komitean jäsenille, että kireä aikataulu näkyi työn laadussa. ${ }^{240}$ Loppuvaiheen kiirettä kuvasti sekin, että lupa mietinnön painattamiseen ehdittiin pyytää kirkkohallitukselta vasta, kun mietinnöt olivat jo painotuoreina odottamassa jakelua. $^{241}$

Pyrkiessään nopeaan työskentelyyn komitea teki karhunpalveluksen paitsi itselleen myös kirkolliskokoukselle: mietintö ehti kyllä komitean tavoitteen mukaisesti saman kirkolliskokouksen käsittelyyn mutta vasta vaalikauden viimeisellä istuntokaudella syksyllä 1977. Kirkol- liskokous ei enää ehtinyt valmistella asiaa, joten ainoa mahdollisuus pelastaa asia raukeamiselta oli lähettää se kirkkohallitukselle jatkovalmisteluun nopeasti ilman periaatteellisia keskusteluja. Täysistunnossa kuultiin moitteita, että komitea oli sivuuttanut kirkolliskokouksen aiemmat evästykset. Uusimuotoisen kirkolliskokouksen ensimmäisen nelivuotiskauden aikana oli toimikuntalaitosta pyritty uudistamaan voimakkaasti, mutta syksyllä 1977 lopputulos näytti laihalta. ${ }^{242}$

Vuonna 1978 uuden vaalikauden alkaessa kirkolliskokouksella oli taas uutta innostusta ottaa toimikuntalaitos aiempaa tiukemmin ohjaukseensa. Toimikuntavaliokunnan puheenjohtaja Erkki Kansanaho tähdensi toimikunnille ja kirkkohallitukselle, että ohjeet, joita valiokunta esitti mietinnöissään, oli tarkoitettu noudatettavaksi siinä missä ponnetkin: kirkkohallituksen saati toimikuntien ei tullut ryhtyä pohtimaan ohjeiden tarkoituksenmukaisuutta vaan keskittyä siihen, miten niitä voitiin soveltaa käytäntöön. ${ }^{243}$ Ajatuksesta, että toimikuntien johto keskittyisi kirkolliskokouksen toimikuntavaliokunnalle, oli hallinnonuudistuksen aikana jo moneen kertaan luovuttu, mutta käytännössä toimikuntavaliokunta ei näyttänyt tilanteeseen tyytyvän.

Piispa Aimo T. Nikolainen arvosteli Kansanahon näkemystä. Nikolaisen mukaan vain ponnet olivat kirkkohallitusta velvoittavia. Kirkkoneuvos Ahti Auranen puolestaan viittasi myöhemmin katkeran oloisena Kansanahon vaatimuksiin: "- - täällä nimenomaan on sanottu, että kirkkohallitus ei saa käyttää omaa järkeään, vaan totella sokeasti mitä käsketään.” ${ }^{244}$ Pian näiden sananvaihtojen jälkeen toimikuntavaliokunnan yhteys toimikuntiin parani, kun se aloitti tutustumisen kaikkiin toimikuntiin ja keskustelut niiden edustajien kanssa. ${ }^{245}$

Uuden nelivuotiskauden aloitus 1978 muistutti sikälikin edellistä, että kirkolliskokous ryhtyi jälleen vauhdittamaan toimikuntalaitoksen uudistamista. Edellinen kirkolliskokous oli valinnut toimikuntien pääsihteerinä toimivaksi kirkkoneuvokseksi Vaasan suomalaisen seurakunnan kirkkoherran Timo Rusaman, joka oli ollut ankarimpia toimikuntakomitean välimietinnön arvostelijoita ja toimikuntien itsenäisyyden puolustajia. Rusama jätti keväällä 1978 uudelle kirkolliskokoukselle työstään kertomuksen, jonka tietyt kohdat saattoi tulkita muistosanoiksi toimikuntakomitean työlle. Kirkolliskokous nousi kuitenkin vaatimaan, ettei asiaa saanut 
Arkkipiispa Mikko Juva ajoi kirkolliskokouksen peräsimessä voimakkaasti kirkon keskushallinnon uudistamista ja kirkkohallituksen vallan lisäämistä. Uudistusesityksen päälinjat eivät kuitenkaan toteutuneet Juvan kaudella. Kuva: Kirkkohallitus / Arvo Salminen.

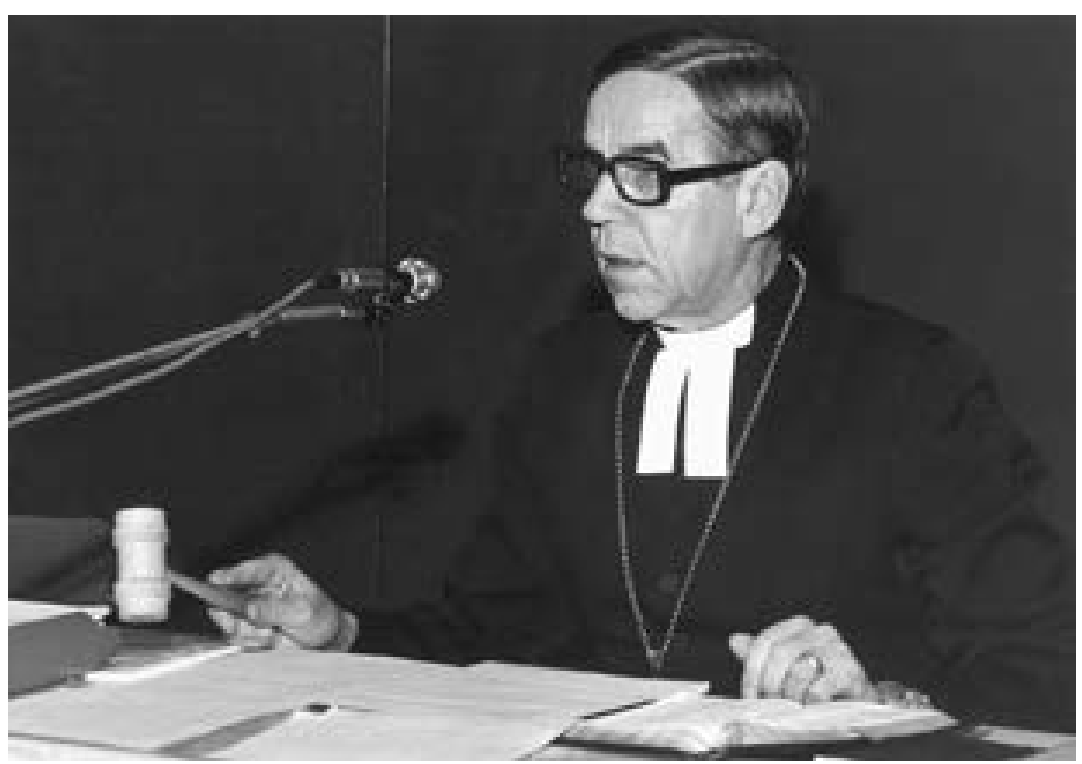

haudata ja ettei kiista toimikuntien yhdistämisestä saanut peittää alleen muita tarpeellisia uudistuksia. ${ }^{246}$

Kirkkohallitus palasikin asiaan 1979, mutta tavalla, jota kirkolliskokouksessa harva osasi ennakoida. Uusi arkkipiispa Mikko Juva oli tyytymätön kirkon keskushallinnon uudistuksen tuloksiin sekä arkkipiispan työmäärään ja hajanaiseen tehtäväkenttään. Juvan aloitteesta kirkkohallituksen esitys laajeni toimikuntien rakenteen ulkopuolelle periaatteellisiin kysymyksiin siitä, mikä oli kirkolliskokouksen, kirkkohallituksen ja piispainkokouksen valta sekä tehtävä suhteessa toimikuntiin. Toimikunnat säilyisivät asiantuntijaeliminä, mutta kirkkohallitus pääsisi koordinoimaan ja ohjaamaan yleiskirkollista toimintaa. Samalla kirkkohallituksen ja piispainkokouksen välistä vallan kahtiajakoa oli määrä purkaa ja asioita keskittää arkkipiispan johtamalle kirkkohallitukselle. Toimikuntien sihteeristöt ja toimistot sekä kirkon sopimusvaltuuskunta liitettäisiin kirkkohallitukseen. ${ }^{247}$ Kirkkohallituksen asemaa korostanut esitys seurasi linjaa, jota Mikko Juva oli kirkolliskokouksessakin edustanut. Toimikuntakomitean loppumietinnön kohtalo ei edelleenkään näyttänyt järin loistokkaalta: ensin mietintö oli ollut vaarassa hautautua kirkkohallitukseen, ja lopulta kirkkohallitus päätyi ehdottamaan toimikuntien aseman järjestämistä aivan päinvastoin kuin kirkkohallituksen vallanlisäystä vierastanut komitea oli esittänyt.
Loistokkaaksi ei voi kuvailla kirkkohallituksenkaan esityksen tietä. Useat lausunnonantajat arvostelivat sen linjaa. Edellisen hallinnonuudistuksen johtava hahmo Erkki Kansanaho ja kirkkojärjestyskomitean puheenjohtaja John Vikström totesivat, että esitys oli muuttamassa kirkon järjestysmuodon perusteita ja viemässä piispoilta ja kirkolliskokoukselta valtaa kirkkohallitukselle. Esitykseen kaivattiin myös perusteluja. Lisäksi kokoussalissa kuului toimikuntien itsenäisyyttä puolustavia ääniä aivan samoin kuin silloin, kun toimikuntakomitea oli ehdottanut toimikuntien saattamista entistä tiukemmin kirkolliskokouksen valtaan. Taustalla vaikutti edelleen myös Juvan edeltäjän Martti Simojoen varauksellisuus kirkkohallituksen vallan lisäämistä kohtaan. Juva jäi piispojen keskuudessa melko yksin perustellessaan seikkaperäisesti, että uudistus vähentäisi hajanaisuutta, yhdistäisi taloudellishallinnollisen ja toiminnallisen puolen kirkon keskushallinnossa, toisi arkkipiispalle tukea ja vahvistaisi kirkon ulkomaanasioiden hoitoa. ${ }^{248}$ Kirkkohallituksen esitys johti lopulta vain joihinkin pieniin kirkkolain tarkistusesityksiin syksyllä 1981, ja erotessaan seuraavana keväänä Juva ilmaisi tyytymättömyytensä kirkon keskushallintoon. ${ }^{249}$ Uusimuotoisen kirkolliskokouksen ensimmäiset kahdeksan vuotta olivat täynnä pyrkimyksiä kehittää toimikuntajärjestelmää, mutta tulokset jäivät melko laihoiksi. 


\section{KOKONAISKIRKON TALOUS PAISUU}

Kirkolliskokouksen uusi jokasyksyinen tehtävä oli hyväksyä kirkon keskusrahaston talousarvio seuraavalle vuodelle. Samalla kirkolliskokous päätti penniverosta eli siitä, kuinka monta penniä seurakuntien oli tilitettävä keskusrahastolle jokaista saamaansa veroäyriä kohden. Tähän päätökseen tiivistyi kysymys, missä määrin rikkaiden seurakuntien tuli avustaa penniverolla pieniä ja köyhiä seurakuntia. Talousarvion käsittely hallitsi usein nimenomaan syysistuntokauden viimeisiä päiviä, ja erottaessa mielet saattoivat olla vielä kiihtyneitä. Näin oli kerran Pohjanmaalle palaavien edustajien henkilöautossa, jossa talousarvion käsittely jatkui kiivaana. Kun kuljettajalla viimein oli aikaa omistaa huomiotaan myös ympäröivälle liikenteelle, hän havaitsi seurueen edenneen jo kauas Turun ulkopuolelle, joskin väärään suuntaan. ${ }^{250}$

Kirkon keskusrahasto oli perustettu 1941 nimenomaan heikossa taloudellisessa tilanteessa olevien seurakuntien avustamiseksi. Vuoteen 1974 tultaessa keskusrahaston vastuu oli kuitenkin laajentunut monille muillekin alueille, kuten kirkon yhteiseen toiminaan ja hallintoon. Alkuperäinen avustustoiminta kattoi enää noin viidenneksen kaikista rahaston menoista. ${ }^{251}$ Keskusrahaston talousarviossa oli myös vain rajallisesti asioita, joihin kirkolliskokous saattoi vaikuttaa. Vielä vähemmän oli asioita, joihin pystyi puuttumaan talousarvion käsittelyssä. Esimerkiksi kirkon yhteisten virkojen tuomiin menoihin kirkolliskokous pääsi sanomaan sanansa keväisin perustaessaan uusia virkoja.

Syksyisin käsittelyssä ollut pennivero jakautui perusmaksuun ja eläkemaksuun. Viimeksi mainittu oli kasvanut nopeasti 1970-luvun alussa eläkkeensaajien määrän lisääntyessä ja eläkkeiden noustessa. Jo selvästi suurin osa keskusrahaston saamista tuloista kului kirkon työntekijöiden eläkkeiden maksamiseen. ${ }^{252}$ Kirkolliskokous ei käytännössä voinut juuri vaikuttaa eläkebudjettiin, vaan kokouksen valta keskittyi keskusrahaston perusmaksuun. Sitä korottamalla oli mahdollista lisätä köyhien seurakuntien avustuksia. Penniveroa koskevaan kädenvääntöön ajauduttiin erityisesti syksyllä 1974. Öljykriisin synnyttämä taantuma sekä huono sato synkensivät näkymiä monissa maaseudun seurakunnissa, joiden taloutta voimakas maaltamuutto oli jo ennestään koetellut. Aineksia jännitteille loi myös vuoden 1973 kirkolliskokouksen periaatepäätös korottaa perusmaksu 0,054 pennistä suoraan enimmäismäärään eli o,07 penniin veroäyriltä. ${ }^{253}$

Kirkkohallitus ja talousvaliokunnan enemmistö esittivät maksun korottamista vain 0,058 penniin, kun taas talousvaliokunnan vähemmistö Raahen rovastikunnan lääninrovastin Jussi Mäntymaan ja valiokunnan puheenjohtajan, ylitarkastaja Pentti Reinilän johdolla kannatti korotusta 0,062 penniin veroäyriltä. ${ }^{254}$ Toinen miehistä tuli yhdestä kirkon köyhimmistä rovastikunnista, toinen varakkaasta Töölön rovastikunnasta, mutta he löysivät toisensa. Reinilä oli kuitenkin selvä poikkeus eteläisen Suomen hiippakuntien edustajissa, jotka asettuivat laajalla rintamalla lisäkorotusta vastaan. Vastaavasti korotettu pennivero sai tukea Oulun, Kuopion ja Lapuan hiippakunnista. Toisaalta pohjoisenkaan Suomen rintama ei ollut yhtenäinen. Piispat vaikenivat lähes täysin penniverokeskusteluissa. He eivät halunneet olla syventämässä vastakkainasettelua hiippakuntien välillä. ${ }^{255}$

Etelän ja pohjoisen välille syntyi ajoittain kovasanainen kädenvääntö, joka päättyi talousvaliokunnan enemmistön kannan voittoon äänin $72-34 .{ }^{256}$ Seuraavina vuosina perusmaksun korotusvaatimukset laimenivat samalla, kun kirkolliskokousedustajien luottamus niin toisiinsa kuin kirkkohallitukseen vahvistui. Vuodeksi 1976 perusmaksu nousi o,062 penniin veroäyriltä, ja se jäi pitkäksi ajaksi tuolle tasolle. Työskentelyn vakiintuessa kirkolliskokous saattoi etukäteen esittää kirkkohallitukselle toivomuksiaan, joita tämä pyrki valmistelussaan mahdollisuuksien mukaan toteuttamaan. Erityisen tärkeä syy korotusvaatimusten vaimenemiseen oli keskusrahaston eläkemaksujen nopea nousu, joka teki mahdottomaksi korottaa samaan aikaan voimakkaasti keskusrahaston perusmaksua. Kirkkohallitus ja talousvaliokunta löysivät myös yhteisymmärryksen varoittaessaan kirkolliskokousta menolisäyksistä. ${ }^{257}$

Kirkon keskusrahaston eläkemaksujen nopea kasvu johtui suureksi osaksi valtion eläkelainsäädännön ongelmallisesta eläkeindeksistä. Vuonna 1974 kirkkohallitus esitti seuraavan vuoden talousarvioon eläkemaksun suuruudeksi o,114 penniä veroäyriltä, mihin sisältyi vajaan kolmen prosentin korotus edellisvuodesta. ${ }^{258}$ Seuraavana vuonna eläkemaksun osuus seurakuntien 


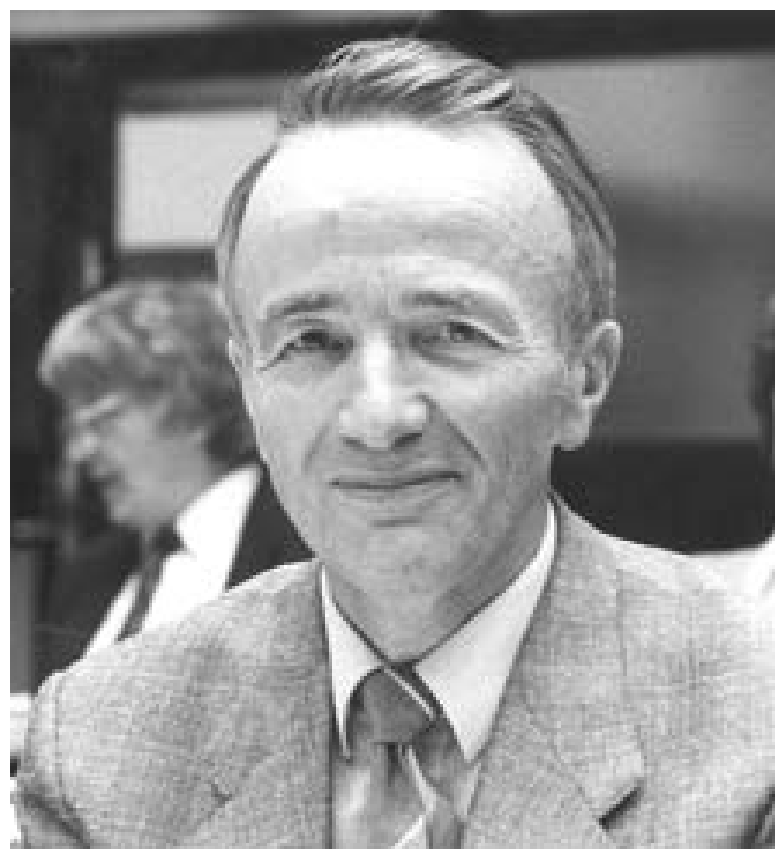

Lapuan kaupunginsihteeri Väinö Takala toimi kirkolliskokouksen talousvaliokunnan puheenjohtajana täyden vuosikymmenen 19781987. Tuona aikana talouskasvu alkoi tuoda lisää liikkumatilaa budjetin valmisteluun. Talousvaliokunta joutuikin käyttämään tuota tilaa, kun Takalan kotiseurakunnassa tuhopoltossa palanut kyläkirkko oli rakennettava uudelleen. Kuva: Kirkkohallitus / Erkki Talvila.

verotuloista nousi jopa yli kymmenen prosenttia, minkä jälkeen kasvu tasaantui valtiovallan muutettua eläkeindeksiä. Syksyllä 1981 talousvaliokunta saattoi lopulta pienentää eläkemaksua kirkkohallituksen esitykseen verrattuna, jolloin talousarvion loppusumma supistui noin kaksi miljoonaa markkaa. Pienentäessään tuloja valiokunta lisäsi menoja yhteensä lähes puoli miljoonaa markkaa palaneen Lapuan Kauhajärven kirkon rakentamiseksi ja Tampereen tuomiokapitulin uusia tiloja varten. Kyseessä oli ensimmäinen kerta, kun talousvaliokunta ja kirkolliskokous tekivät talousarvioesitykseen todella merkittäviä muutoksia pelkän hienosäädön sijaan. Muutoksiin oli varaa, koska korkeasuhdanne oli saavuttanut kirkon talouden. ${ }^{259}$

Kirkolliskokous ei ollut yhtä innokas kasvattamaan kirkon eläkerahastoa ja lisäämään seurakuntien eläkerahastomaksuja kuin vaikkapa taloudesta vastannut kirkkoneuvos Kai Sarsa olisi ollut. Jo syysistuntokaudella 1978 hän huolehti 40 vuoden kuluttua vuonna 2018 odotettavissa olleista suurista eläkevastuista. ${ }^{260}$ Vuonna 1979 kirkon eläkerahaston varat vastasivat vain puolen vuoden eläkemenoja. Tässä tilanteessa kirkkohallituksen asettama toimikunta esitti siirtymistä eläkerahastointiin. Asia ei kuitenkaan lähtenyt etenemään nopeasti. ${ }^{261}$ Penniveroa oli jouduttu jo ilman rahastointiakin korottamaan todella voimakkaasti, mikä loi osaltaan painetta kirkollisveron nostamiselle ja herätti arvostelua erityisesti Etelä-Suomen kaupunkiseurakuntien edustajien keskuudessa. ${ }^{262}$ Sitä paitsi kirkon jäsenmäärä ja tulopohja näyttivät 1970-luvun lopulla melko vakailta, ja sodanjälkeisen ajan poikkeuksellinen talouskasvu oli totuttanut toiminnan jatkuvaan laajentamiseen. Kiinteistöjä rakentavassa ja uusia virkoja tiuhaan perustavassa kirkossa kirkolliskokousedustajien oli vaikea asennoitua vuosikymmenten päässä odottaviin ongelmiin.

Uusimuotoisen kirkolliskokouksen kahden ensimmäisen vaalikauden aikana, vuoden 1975 budjetista vuoden 1982 budjettiin, talousarvion loppusumma yli kolminkertaistui. Keskeisenä syynä oli aikakauden korkea inflaatio, joka 1975 lähenteli öljyn hinnannousun perässä jopa 18:aa prosenttia. Talousarvio kasvoi kuitenkin myös reaaliarvoltaan erittäin nopeasti ensimmäisen nelivuotiskauden aikana. Syksyllä 1977 kirkolliskokous hyväksyi talousarvion, jonka loppusumma oli nimellisarvoltaan kaksinkertainen ja reaaliarvoltaankin lähes puolet suurempi kuin kolme vuotta aiemmin hyväksytty talousarvio. Suuri ja toimintatavaltaan usein vaikeasti ennakoitava päätöksentekoelin sai budjettivastuun aikana, jolloin muutokset olivat sekä suuria että nopeita. Vuodesta 1975 eteenpäin kirkolliskokous jättäytyi kuitenkin paljolti talousarvioesityksen valmistelleen kirkkohallituksen ja sen virkamiesten varaan.

Verotilitysten kulku seurakuntalaisilta kirkon keskusrahastoon vei aikansa, minkä vuoksi keskusrahaston talousarviot seurasivat kansantalouden muutoksia muutaman vuoden viiveellä. Sen sijaan 1970-luvun puolivälin taantuma näkyi välittömästi talousarvion menoluokkien keskinäisissä osuuksissa. Kirkolliskokouksen evästämänä kirkkohallitus kasvatti talousarvioesityksissään voimakkaasti seurakunnallisen toiminnan tukea. Samaten kasvoi hiippakunnallisen toiminnan rahoitus, joka oli ollut pitkään jälkeenjäänyttä. Erityisesti piispat ja seurakuntapapit vaativat painopisteen siirtämistä kirkon toimikunnista hiippakuntiin ja siten lähem- 

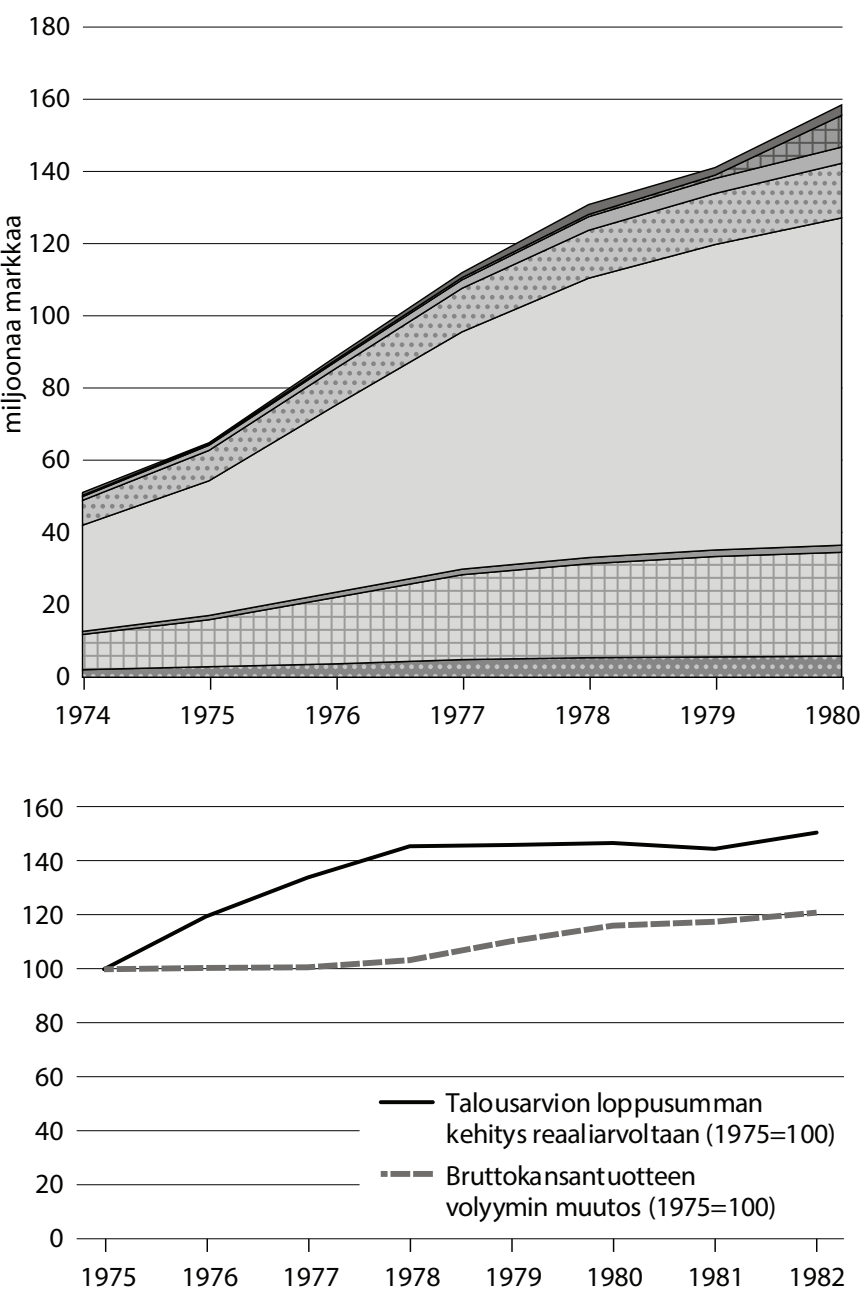

mäs seurakuntia ${ }^{263}$. Kirkolliskokous päättikin perustaa pääsihteerin viran jokaiseen tuomiokapituliin ja lisäksi muita toiminnallisia virkoja. ${ }^{264}$ Tuomiokapitulien jäsenten vahva edustus kirkolliskokouksessa ei siten jäänyt vaille tulosta.

Kirkkohallitus ja varsinkin kirkolliskokouksen talousvaliokunta suhtautuivat pidättyvästi kaikkinaiseen virkojen lisäämiseen, mutta monet lisäykset olivat välttämättömiä - kuten kirkon sopimusvaltuuskunnan asettamisen myötä perustetut virat. ${ }^{265}$ Sen sijaan täysistunnossa enemmistö edustajista lähti monta kertaa tukemaan jotakin talousvaliokunnan esityksestä puuttunutta virkaa. Ratkaisuja ongelmiin haettiin virkoja perustamalla, eivätkä useimmat edustajat kantaneet kovin suurta huolta kirkon talouden kantokyvystä.
Kuvio 3: Menoluokkien kehitys ja loppusumman muutos nimellisarvoltaan kirkon keskusrahaston talousarvioissa vuosille 1974-1980

Talousarviovuonna 1981 budjetin rakenne muuttui, minkä vuoksi 1980-luvun talousarvioita vertaillaan myöhemmin omana kokonaisuutenaan.

Siirrot rahastoihin

Muut pääluokat

Hiippakunnallinen toiminta

K.... Kirkon muut yhteiset tarpeet (mm. toimikunnat)

$\square$ Eläkkeet

$\square$ Rajaseututoiminnan avustaminen

世 Seurakunnallinen toiminta

Hallintomenot

Kuvio 4: Loppusumman reaaliarvon mukainen kehitys kirkon keskusrahaston talousarvioissa vuosille 1975-1982

Kuviossa sovellettu tilastoaineisto: Kansantalouden tilinpito 2006; Kuluttajahintaindeksi.

Kuviossa 3 kohtaan "muut pääluokat" kuuluneet kiinteistömenot kasvoivat vuonna 1980, kun kirkon keskushallinnolle hankittiin toimitalo Katajanokalta. Hallintomenojen osuutta keskusrahaston taloudesta taas kasvatti 1970-luvun puolivälistä lähtien paitsi kirkon sopimusvaltuuskunnan perustaminen myös siirtyminen uusimuotoiseen kirkolliskokoukseen. Avatessaan viimeistä kertaa kirkolliskokouksen keväällä 1978 arkkipiispa Simojoki kiinnitti huomion hallintomenoihin. Samaan aikaan kun työttömyysluvut olivat huipussaan, kirkon ja seurakuntien taloudessa ei ollut mainittavia vaikeuksia: "Kristillinen omatunto tuskin voi olla aivan rauhallinen näissä olosuhteissa." Vaikka kirkko ei sanottavasti vaikuttanut koko maan taloudenhoitoon, senkin oli arkkipiispan mukaan järjestettävä taloutensa niin, että se kantoi ihmisten kuormia ja auttoi työttömiä. ${ }^{266}$ Kun Liberaalista Kansanpuoluetta edustanut opetusministeri Jaakko Itälä saapui myöhemmin kirkolliskokoukseen, hän sai tuoda arkkipiispalle Suomen Kansan Demokraattisen Liiton edustajan, työministeri Arvo Aallon kiitokset suoraan hallituksen iltakoulusta. ${ }^{267}$ Simojoen puhe sai myös lehdistössä osakseen paljon huomiota. ${ }^{268}$ 
Yleensä talousvaliokunta teki talousarvion menoihin pieniä leikkauksia, jotka istuntosalissa kääntyivät pieniksi lisäyksiksi. Talousvaliokunta korosti luonnollisesti puheenjohtajiensa suulla toistuvasti sitä, miten tärkeää oli välttää kirkon yhteisten menojen lisäämistä "kun ei ole rahaa niin ei ole rahaa, vaikka olisi kuinka rikkaan talon poika". ${ }^{269}$ Erityisesti uusimuotoisen kirkolliskokouksen alkuvuosina valiokunta halusi alleviivata tätä pyrkimystään tekemällä periaatteellisia, talousarvion kokonaisuuden kannalta merkityksettömiä nipistyksiä eri puolilta talousarviota. Näiden leikkausten ongelmana oli, että pieni supistus saattoi haitata huomattavasti käytännön työtä. Syksyllä 1974 esille nousivat kirkon perheasiaintoimikunnan sanelukonehankinnat, joihin varattua määrärahaa talousvaliokunta pienensi vajaat 5000 markkaa. Toimikunnan sihteeri Matti Joensuu istui kirkolliskokouksessa ja pystyi puolustamaan toimikuntaansa. ${ }^{270}$

Asiaan liittyi periaatteellisia puolia. Talousvaliokunta halusi painottaa menokuria, kun taas Joensuu pelkäsi pienten leikkausten luovan epäluuloa talousarvion laatijoiden keskuudessa: menot kirjattaisiin varmuuden vuoksi yläkanttiin, eikä määrärahoja uskallettaisi jättää käyttämättä supistusten pelossa. Periaatekeskustelun välineenä toimi määräraha, joka ei ollut edes promillen kymmenesosaa talousarvion loppusummasta. Tilanne sai jotkut ehdottamaan siirtymistä joustavampaan kehysbudjetointiin: "Silloin meidän ei tarvitsisi takertua joihinkin sanelukoneisiin tällä foorumilla." ${ }^{271}$ Leikkauksillaan talousvaliokunta pakotti joka tapauksessa talousarvioehdotuksen tekijät perustelemaan tarkasti ehdottamansa menolisäykset. Työ tuotti tulosta, ja talousvaliokunnan yhteistyö kirkkohallituksen kanssa parani. ${ }^{272}$ Suunnitelmallisuutta lisäsi sekin, että kirkkohallitus ryhtyi talousvaliokunnan vaatimuksesta laatimaan talousarvion rinnalle pitkän tähtäimen toimintasuunnitelman. ${ }^{273}$

Kahdella alueella luottamuksen saavuttaminen oli vaikeaa. Ensinnäkin epäilykset, joita ilmeisen moni talousvaliokunnan ja kirkolliskokouksen jäsen tunsi kirkon tiedotuskeskusta kohtaan, näkyivät tiedotuskeskuksen ehdottamien lisämäärärahojen kohtalossa. ${ }^{274}$ Toiseksi kirkon ulkomaanasiain toimikunnan ehdottamat määrärahat pienenivät toistuvasti talousvaliokunnassa. Varsinkin maallikkojen keskuudessa ilmeni varaukselli- suutta kansainvälisiä yhteyspyrkimyksiä kohtaan, mikä näkyi talousvaliokunnan mietinnöissä. Täysistunnossa sitten piispat, Luterilaisen maailmanliiton presidentti Mikko Juva ja muutamat ekumeenisesti valveutuneet kirkkoherrat nousivat vaatimaan määrärahojen palauttamista. Vaikka kirkolliskokouksen oli organisaationa - Suomen valtion tavoin - helpompi puuttua ihmisoikeusrikkomuksiin Namibiassa kuin Neuvostoliitossa, itäblokin kristittyjen ongelmien silottelusta ei ollut tietoa ainakaan silloin, kun Juva vaati selväsanaisesti rahoitusta sosialististen maiden kirkonmiesten koulutustilaisuuksille. Piispojen ja näkyvimpien pappien vetoavat puheenvuorot tuottivat yleensä tulosta täysistunnossa, ja talousvaliokunnan poistamat määrärahat palautettiin. 275

Talousarvion käsittelystä tuli kirkolliskokouksessa samantapainen laaja yleiskeskustelu kirkon tilasta ja suunnasta kuin eduskunnan budjettikeskustelut olivat valtion osalta. Samaten talousarviokeskustelut korvasivat kyselytuntien puutetta kirkolliskokouksessa. Kirkkoneuvokset saivat vierailla ahkerasti puhujakorokkeella vastaamassa mitä moninaisimpiin kirkolliskokousedustajien kysymyksiin.

\section{SOPIMUSJÄRJESTELMÄN VAIKEA ALKU}

Uusimuotoisen kirkolliskokouksen alkaessa elettiin siirtymävaihetta kirkon palvelussuhdepolitiikassa. Kirkon virka- ja työehtosopimusjärjestelmää koskevat lait odottivat eduskunnan hyväksymistä. Lait pohjautuivat valtion ja kuntien esimerkkiin, ja kaavailtu kirkon sopimusvaltuuskunta muistutti kunnallista sopimusvaltuuskuntaa. Kirkkoa koskevien lakien erityispiirteenä ja niiden eduskuntakäsittelyn suurimpana ongelmana oli supistettu lakko-oikeus, jonka mukaan viranhaltijan oli työtaistelunkin aikana hoidettava kirkon pyhiin toimituksiin kuuluvat tehtävät. ${ }^{276}$ Lait eivät olleet sisältyneet kirkon keskushallinnon uudistukseen, mutta niiden oli määrä tulla voimaan jo vuoden 1975 alussa. Siten kirkon keskushallinto ehti toimia Kansanahon komitean valmistelemassa muodossa käytännössä vain vuoden $1974 .^{277}$

Keväällä 1974 uudistettu kirkolliskokous päätti paitsi ensimmäistä myös viimeistä kertaa kokonaiskirkon työntekijöiden palkoista. Kirkkohallitus esitti palkkoihin kuoppakorotuksia, mutta kirkolliskokouksen 
talousvaliokunta veti ehdotukset suurimmaksi osaksi takaisin. Talousvaliokunta perusteli ratkaisuaan sillä, että oli parempi odottaa uutta palkkausjärjestelmää ja kirkon sopimusvaltuuskunnan asettamista. ${ }^{27}$ Samalla valiokunnan ratkaisu vahvisti kuitenkin kuvaa aloittavan kirkolliskokouksen innosta ja itseluottamuksesta sekä kriittisyydestä kirkkohallitusta kohtaan: vaikka valmisteluaikaa oli viikon aikana äärimmäisen vähän ja valiokunnan pohjatiedot asian taustoista vajavaiset, kirkkohallituksen esitys monimutkaisessa asiassa pantiin uusiksi. Valmistelun kiirettä kuvastaa, että tätä ja muita asioita käsitellessään talousvaliokunta piti istuntoviikon aikana 14 kokousta, enimmillään kuusi päivässä.

Ongelmat alkoivat, kun täysistunnossa ryhdyttiin äänestämään palkoista toimikunta kerrallaan. Kirkolliskokousedustajille tuli mahdollisuus lausua henkilökohtainen, toimikuntien sihteerien rahapussissa tuntuva mielipiteensä kustakin toimikunnasta. Kirkon diakoniatyön keskus sai palkankorotukset, kasvatusasiain keskus ei. ${ }^{279}$ Pidemmälle ei päästy. Menettelytapaa oli muutettava kesken äänestyksen ja päätettävä muiden toimikuntien palkoista yhtenä kokonaisuutena. Loppujen toimikuntien osalta päätökseksi tuli talousvaliokunnan linja. ${ }^{280}$ Näytelmän viimeinen episodi oli syysistuntokaudella, kun kirkolliskokous käytännössä pyörsi päätöksensä ja myönsi toimikuntien viranhaltijoille takautuvasti kirkkohallituksen ehdottamat palkankorotukset. $^{281}$

Uudistuksen tavoitteena oli siirtyä vallinneesta hajanaisuudesta keskitettyyn, kaikkia työntekijäryhmiä yhtenäisesti koskevaan neuvottelujärjestelmään. ${ }^{282}$ Järjestelmän oli määrä pystyä hoitamaan kokonaiskirkonkin viranhaltijoiden palkkausasiat paremmin kuin kirkolliskokous saattoi tehdä. Kovin korkealle kirkolliskokous ei omalla esimerkillään rimaa asettanutkaan. Odotukset sopimusjärjestelmää kohtaan olivat kirkolliskokouksessa kuitenkin suuret. Sopimusvaltuuskunnan edellytettiin korjaavan aiempina vuosina kertyneet epäkohdat nopeasti ja laadukkaasti. Toimikuntakomitean ja sopimusvaltuuskunnan työtä yhdisti se, että kirkolliskokouksessa kohdistettiin työhön suuria mutta usein tarkasti yksilöimättömiä odotuksia. Sellaisissa odotuksissa oli helppo pettyä.

Kirkon uutta sopimusjärjestelmää koskevat lait etenivät tasavallan presidentin esittelyyn vasta joulun alla
1974. Niinpä kirkolliskokousedustajat kokoontuivat vielä vuoden viimeisinä hetkinä ylimääräiseen istuntoon Helsinkiin toimittamaan sopimusvaltuuskunnan vaalin. Talousvaliokunta pyysi kirkolliskokousedustajilta ehdokkaita, joilla olisi työmarkkinakentän eri sektorien tuntemusta sekä seurakunnan hallinnon ja talouden tietämystä. Joukossa tuli olla riittävä määrä juristeja. ${ }^{283}$ Huomiota herättää, että seurakunnan perustyön tuntemuksesta ei puhuttu mitään. Ehdokasasettelu alleviivasi sopimusjärjestelmän sisällä sellaista talouden ja toiminnan välistä erottelua, josta samaan aikaan oli pyritty pois seurakuntien hallinnonuudistuksessa. Pahimmillaan seurakuntien perustyön näkökulman esillä pitäminen uhkasi jäädä toisen neuvotteluosapuolen, työntekijäjärjestöjen, huoleksi. Vielä 1974 kirkolliskokous haki kuitenkin vuosikymmenen alun tavoin esimerkkiä muualta yhteiskunnasta, oli sitten kyse toimikuntalaitoksen järjestämisestä tai työmarkkinajärjestelmästä.

Tyytymättömyys sopimusvaltuuskuntaa kohtaan purkautui jo sen ensimmäisenä toimintavuonna. Arvostelussa näkyivät ylimitoitetut odotukset, kiire uuden järjestelmän toteutuksessa, uudistusten siirtäminen sopimusvaltuuskunnalle ja se, että joitakin työmarkkinapolitiikasta omaksuttuja periaatteita oli sovellettu valikoiden kirkon sopimusjärjestelmään. Kirkolliskokouksessa seurakuntapapit ja muut kirkon työntekijät joutuivat poistumaan sopimusvaltuuskunnan jäseniä valittaessa ja sen ohjesäännöstä päätettäessä, mutta muissa yhteyksissä he nostivat esiin sopimusvaltuuskunnan asioita. Keskustelu kirkon keskusrahaston talousarviosta oli syksyllä 1975 paljolti keskustelua kirkon sopimusvaltuuskunnasta. Osa pappien esittämästä kritiikistä, kuten epäonnistuneiden sopimusten arvostelu, olisi sopinut paremmin Suomen kirkon pappisliiton elimiin. Osa kosketti järjestelmän keskusjohtoisuutta sekä sitä, että kirkon virka - erityisesti piispat - ei ollut edustettuna valtuuskunnassa vahvistamassa teologista ja toiminnallista näkökulmaa. ${ }^{284}$

Papit nousivat kirkkolain hengen mukaisesti puolustamaan kirkon erityislaatuisuutta ja viran edustusta kaikkialla kirkon hallinnossa. He tekivät sen kuitenkin virkaehtosopimuslain hengen näkökulmasta kyseenalaisesti - eihän heillä ollut lain mukaan oikeutta osallistua kirkon sopimusvaltuuskuntaa koskevaan päätöksentekoon. Augsburgin valtiopäiville laaditun tunnustuksen 
Varsinkin kirkon sopimusjärjestelmän toiminnan alkuvaiheessa kirkolliskokouksessa käytiin tiukkoja keskusteluja järjestelmästä. Erityisesti pappisjäsenet arvostelivat kirkon sopimusvaltuuskunnan toimintaa. Sopimusvaltuuskunnan toimistonjohtaja Jouni Veinio (vas.) keskustelemassa talousvaliokunnan pitkäaikaisen pappisjäsenen, kirkkoherra Jussi Mäntymaan kanssa täysistunnon väliajalla.

Kuva: Kotimaan kuva-arkisto / Jukka Granström.

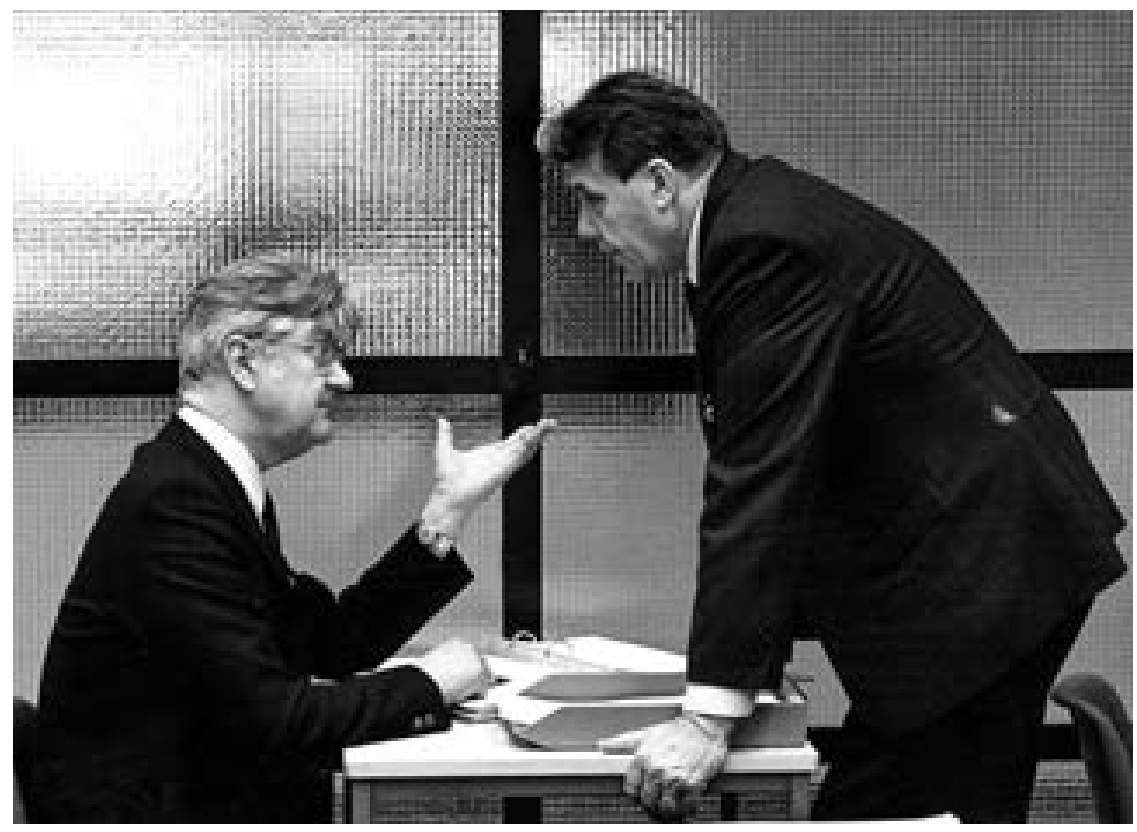

ja Suomen valtiopäivien säädösten välisessä jännitteessä eri lakien henkiä ei ollut aina helppo koetella.

Epäkohtia osoitti, että kirkolliskokous sai keväällä 1976 piispainkokoukselta, kirkkohallitukselta ja hiippakuntakokouksilta yhteensä seitsemän sopimusvaltuuskuntaa suoraan käsittelevää esitystä tai aloitetta. ${ }^{285}$ Piispainkokous toivoi, että sopimusvaltuuskuntaan saataisiin teologista ja toiminnallista asiantuntemusta ja että valtuuskunta asetettaisiin aiempaa selvemmin vastuuseen kirkolliskokoukselle. ${ }^{286}$ Keväällä 1976 kirkolliskokous hyväksyikin sopimusvaltuuskunnan ohjesäännön, jonka mukaan valtuuskunnan tuli vuosittain antaa toimintakertomus kirkolliskokoukselle. ${ }^{287}$ Valvonnan tarve tuli näkyviin erityisen selvästi seuraavana vuonna, kun kirkolliskokouksessa istuneet korkeimpien oikeusistuinten valitsemat edustajat huomasivat valmisteluasiakirjoista, että sopimusvaltuuskunta oli saanut kirkon virkaehtosopimuksessa virkaehtosopimuslain vastaisia valtuuksia. ${ }^{288}$

Kirkkohallitus esitti piispainkokouksen pyynnöstä - sopimusvaltuuskunnan voimakkaasta vastustuksesta huolimatta - valtuuskunnan täydentämistä piispajäsenellä. Sopimusvaltuuskunnan mielestä tällainen jäsen voitiin tulkita papiston edustajaksi, vaikka tuomiokapitulit olivatkin valtion virastoja ja piispat siten kirkon virkaehtosopimuksen ulkopuolella. ${ }^{289}$ Valtuuskunnan perustelut nojautuivat yleisiin sopimusjärjestelmän vaatimuksiin, ja niiden avulla olisi ollut vaikea puolustaa monia kirkon hallinnon erityispiirteitä, kuten pappien jäsenyyttä kirkolliskokouksessa. Kirkolliskokous päätyi ratkaisuun, jonka mukaan sopimusvaltuuskunnassa oli läsnäolo- ja puheoikeus paitsi kirkkohallituksen edustajalla myös piispainkokouksen määräämällä piispalla ${ }^{290}$. Piispan osalta ratkaisu oli mahdollinen nimenomaan tuomiokapitulien valtiollisen aseman vuoksi. Paradoksaalisesti kirkon ja valtion välinen vanha sidoskohta, jota monet olivat kirkossakin arvostelleet, tuli edellytykseksi sille, että kirkon omalakinen perustehtävä pääsi aiempaa paremmin esiin sopimusneuvotteluissa.

Kirkon sopimusvaltuuskunnan arvostelu kirkolliskokouksessa osoitti saman muutoksen, joka nousi esiin toimikuntakomitean mietintöä käsiteltäessä. Uudistetun kirkolliskokouksen aloittaessa työtään elettiin keskellä organisaatiokeskeistä suunnittelu- ja tehostamisvirtausta. Tämä ajattelutapa näkyi taustalla paitsi arvosteltaessa toimikuntalaitoksen hajanaisuutta myös linjattaessa kirkon sopimusvaltuuskunnan kokoonpanoa. Nopeasti vuosikymmenen puolivälistä lähtien - yleisen ilmapiirin muuttuessa uskonnolliselle toiminnalle suosiollisemmaksi - voimistuivat kuitenkin äänet, 
jotka vastustivat tällaisten virtausten kopioimista jälkikäteen kirkkoon ja painottivat päinvastoin kirkon erityisluonnetta ja perustehtävää.

Samaan aikaan kirkon palkkausjärjestelmä oli yleensäkin murroksessa. Vuosina 1976-1977 kirkolliskokous pohti, mahdollistettaisiinko siirtyminen luontoisetupalkkauksesta kokonaispalkkaukseen. Luontoisetujen verotuksen kiristyttyä monet viranhaltijat olivat halunneet luopua asuntoedustaan. ${ }^{291}$ Keskustelu tiivistyi jälleen kysymykseen, oliko kirkon seurattava muun yhteiskunnan esimerkkiä vai pidettävä kiinni erityislaadustaan. Erityisesti talouden asiantuntijat kannattivat siirtymistä kokonaispalkkaukseen, koska näin oli tehty muuallakin julkisen hallinnon piirissä. Papiston ja maallikkojen keskuudesta astui kuitenkin esiin pappiloiden puolustajia, joiden mukaan papin tuli elää seurakuntansa keskellä. Lisäksi moni epäili, että siirtyminen kokonaispalkkaukseen riippuisi liiaksi yksittäisen viranhaltijan henkilökohtaisista tarpeista. ${ }^{292}$ Asia siirtyi lopulta kolmen vuoden päähän vuoteen $1980 .{ }^{293}$ Noina vuosina asenteet muuttuivat kokonaispalkkaukselle myönteisemmiksi. Useiden mielestä aika oli ajanut ohi ympäristöstä erottuvasta, viranhaltijoille usein kalliista ja puolisoilta paljon työtä vaativasta pappila-asumisesta. Jotkut peräsivät kirkolta edelleen omaleimaisuutta ja pappiloiden vaalimista, mutta tällä kertaa kirkolliskokous hyväksyi uudistuksen selvällä enemmistöllä. ${ }^{294}$

Kirkon sopimusjärjestelmässä ei sen sijaan näkynyt selkiintymisen merkkejä. Edustajien kokoontuessa Turkuun keväällä 1980 kirkossa oli juuri ohitettu lakonuhka, joka oli tuonut paljon kielteistä huomiota. ${ }^{295}$ Kirkolliskokouksessa oltiin yhtä mieltä siitä, että sopimusjärjestelmässä kaikki ei ollut kunnossa, mutta toisaalta ehdotukset toimenpiteiksi johtivat vain verkkaisesti tuloksiin. Kirkkohallituksen esitys sopimusvaltuuskunnan liittämisestä kirkkohallitukseen ei toteutunut, vaan valtuuskunta jatkoi itsenäisenä yksikkönä. ${ }^{296}$ Moni näki kirkolliskokouksen ja sopimusvaltuuskunnan yhteyksissä edelleen parantamisen varaa. Valtiotieteiden maisteri Sinikka Isotalo totesi syksyllä 1981, kun sopimusvaltuuskunnasta oli keskusteltu kahdeksan vuotta: "Minusta tuntuu, että kaikilla meillä ei ole oikein käsitystä siitä, miten tämä sopimusjärjestelmä toimii."297

Joka tapauksessa kirkon erityislaatuisuus ja perustehtävä korostuivat kirkolliskokoustyöskentelyssä 1970- ja 1980-luvun vaihdetta kohden. Muutos näkyi siinäkin, että viroista keskusteltaessa jumalanpalveluselämä alkoi vähitellen saada osakseen yhä enemmän huomiota. Kirkon jumalanpalvelus- ja musiikkitoimikunnan resurssit olivat kauan olleet selvästi vähäisemmät kuin useimmilla muilla toimikunnilla, mutta kirkolliskokous perusti viimein 1978 toimikunnalle päätoimisen sihteerin viran. ${ }^{298}$ Samaten kanttoriurkurien asemaan saatiin helpotusta, kun vuodesta 1958 valmisteltu uudistus tuotti tuloksen kirkolliskokouksessa keväällä 1979. ${ }^{299}$ Perusratkaisuna oli viran porrastaminen kolmeen tyyppiin, joista keskimmäinen vastasi voimassa ollutta kanttorinvirkaa. ${ }^{300}$ Uudistuksen valmistelun aikana paljon kanttoriurkureita oli lähtenyt kirkon palveluksesta, ja kirkolliskokouksessakin oli usein kannettu huolta kirkkomusiikin tulevaisuudesta.

Kirkkomuusikon virkoja koskevan uudistuksen hyväksyminen ei ollut itsestään selvää. Käsikirjavaliokunnan mietintöä käsiteltäessä valiokunnan puheenjohtaja, Lapuan piispa Yrjö Sariola painotti uudistuksen tärkeyttä, minkä jälkeen kirkkoneuvos Kai Sarsa ehdotti valiokunnan mietinnön jättämistä raukeamaan taloudellisista syistä. Tällainen kirkkoneuvoksen mielipide kirkolliskokouksen valiokunnan laajasta mietinnöstä oli varsin ainutlaatuinen. Täysistunnossa jouduttiin muokkaamaan lakipykäliä ja palauttamaan asia pariin kertaan käsikirjavaliokuntaan, mutta lopullisessa äänestyksessä kukaan ei vastustanut esitystä. ${ }^{301}$ Kirkolliskokous oli jälleen enemmän huolissaan kirkkomusiikista ja köyhien seurakuntien kanttoritilanteesta kuin kirkon talouden kantokyvystä.

\section{KESKUSTELU VIRASTA, RAAMATUSTA JA OIKEASTA LUTERILAISUUDESTA JULKISUUDEN PAINEESSA}

\section{KIRKOLLISKOKOUS}

ROOMAN JA GENEVEN VÄLISS $\ddot{\text { A }}$

VIRKAKOMITEAN VÄLIMIETINNÖT

Tutkimuksessaan Luterilaisuus Rooman ja Geneven välissä professori Pentti Laasonen selvittää, miten reformaatiokauden jälkeen erityisesti Keski-Euroopan luterilaiset hakivat identiteettiään roomalaiskatolisuuden ja kalvinilaisuuden, Rooman ja Geneven, välissä. Tämä 
160o-luvun rajanveto kosketti Ruotsia verrattain kaukaisesti ja lyhytaikaisesti. ${ }^{302}$ Myös myöhempinä vuosisatoina molempiin tunnustuskuntiin voitiin pitää Pohjolassa etäisyyttä. Tunnustuksellisuuden eräänlaisen toisen aallon myötä kielteiset käsitykset erityisesti katolisesta kirkosta elivät vahvoina vielä 19oo-luvulla. Ruotsissa antikatolisuus näkyi julkisessa keskustelussa selvästi 1960-luvun alussa, ja samanlaisia asenteita esiintyi jonkin verran Suomen luterilaisessa kirkolliskokouksessa keskusteltaessa 1968 siitä, tuliko luostarien perustamiskielto poistaa laista. ${ }^{303}$

Ekumenian edistyminen muutti tilannetta. Vatikaanin toinen kirkolliskokous avarsi katolisen kirkon suhdetta muihin kirkkokuntiin 1960-luvulla, ja toiveet kirkkojen nopeasta lähentymisestä elivät vahvoina. ${ }^{304}$ Helsingin yliopiston dogmatiikan professori Seppo A. Teinonen ehdotti 1973 Suomen ekumeenisen neuvoston vuosikokouksessa voimakkaita toimia, jotta kirkollinen yhteys voisi toteutua maassa vuoteen 1985 mennessä. ${ }^{305}$ Toisaalta ekumeenisen innostuksen rinnalla kärjistyi ekumenian vastustus. ${ }^{306}$ Ekumenian edistyessä Suomi ei ollut irrallaan Keski- ja Etelä-Euroopan kirkollisista tapahtumista, vaan ne heijastuivat suoraan Suomen luterilaisen kirkon kirkolliskokouksen asialistalle. Erityisesti Leuenbergin konkordia ja kysymys kirkon virasta nostivat
Pohjolan perillä 1970-luvulla kerralla pintaan sen rajanvedon, jota Pfalzissa, Saksissa tai Brandenburg-Preussissa oli käyty jo 160o-luvulla: oliko luterilaisuus lähempänä Roomaa vai Geneveä? Ja ennen kaikkea: mikä oli oikeaa luterilaisuutta näiden kahden välissä?

Vuoden 1968 kirkolliskokous oli asettanut virkakomitean tutkimaan pappisvirkaa ja 1963 perustetun lehtorinviran kehittämistä. Lisäksi komitean tehtävänä oli harkita kirkkolakiin sellaisia muutosehdotuksia, jotka mahdollistaisivat naisten osallistumisen pappisviran eri tehtävien hoitamiseen. Komitean puheenjohtajana oli professori Seppo A. Teinonen, varapuheenjohtajana asessori Thure Eriksson sekä muina varsinaisina jäseninä Raamatun alkukielten apulaisprofessori Esko Haapa, hovioikeudenneuvos, sittemmin Vaasan hovioikeuden presidentti Ritva Hyöky ja pitkään lehtorina toiminut varhaiskasvatussihteeri Pirkko Lehtiö. Komitean kutsumana sihteerinä toimi Teinosen assistentti, teologian

Toukokuussa 1975 istuntosalia valaisivat kevätauringon ohella tiedotusvälineiden valonheittimet ja salamavalot. Mielenkiinto kohdistui erityisesti virkakomitean osamietintöihin. Eturivissä vasemmalta hallintoneuvos Pekka Kurvinen, oikeusneuvos Johannes Leivonen, kansliapäällikkö Jaakko Numminen, kenttäpiispa Yrjö Massa sekä piispat Paavo Kortekangas ja Yrjö Sariola. Kuva: Kirkolliskokouksen kuvakokoelma / Arvo Salminen.

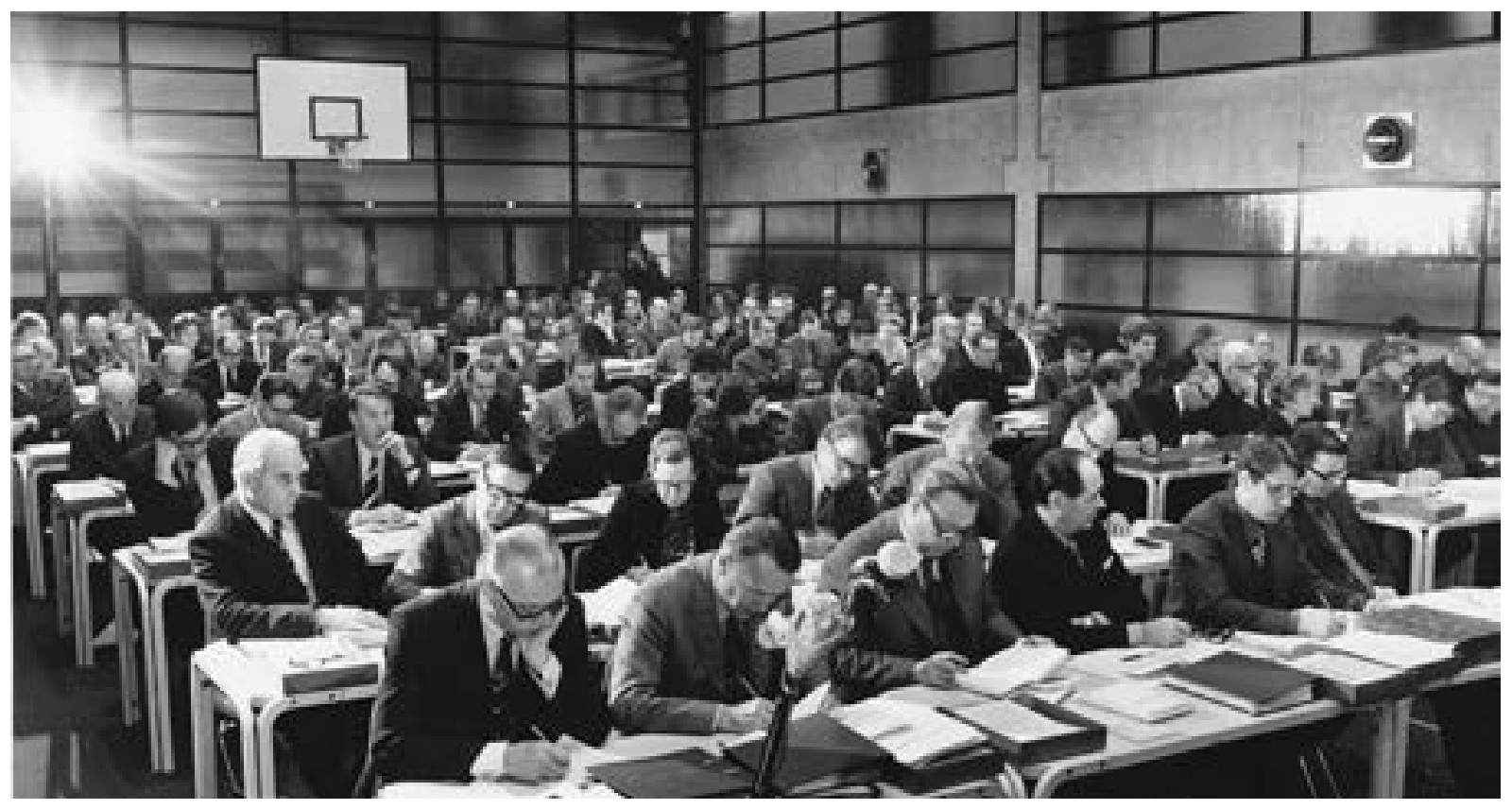


lisensiaatti Simo Kiviranta. Komitealta, jolle kirkolliskokous oli jo kertaalleen antanut lisäaikaa, odotettiin loppumietintöä keväällä 1975. Loppumietinnön sijaan komitea julkaisi kaksi osamietintöä, jotka koskivat kahta komitean kolmesta teemasta, nimittäin kirkon virkaa kokonaisuutena ja lehtorinviran kehittämistä. Samalla komitea pyysi työlleen vielä lisäaikaa vuoden loppuun asti. ${ }^{307}$

Kevään 1975 kirkolliskokouksen alkaessa julkinen mielenkiinto kohdistui komitean mietintöihin mutta ei niinkään niihin kahteen aihepiiriin, joista mietinnöt oli jätetty, vaan kolmanteen teemaan eli naispappeuteen, johon ei ollut puututtu. Naisjärjestöjen Keskusliitto jätti huhtikuussa arkkipiispalle vetoomuksen pappisviran avaamisesta naisille ja sai tukea lehdistöltä. ${ }^{308}$ Naisasialiike oli noussut 1960-luvulta lähtien esille kaikissa Pohjoismaissa, eikä sen ääntä voitu jättää huomiotta kirkossakaan, joskin naisjärjestöjen kiinnikkeet puoluepolitiikkaan herättivät epäluuloja. ${ }^{309}$ Vetoomuksen perusteluina olivat ennen kaikkea tasa-arvo ja se, että Suomi oli viimeinen Pohjoismaa, jonka luterilaisessa valtakirkossa naisia ei voitu vihkiä papiksi. ${ }^{310}$ Samoihin perusteisiin oli edellisenä syksynä viitannut opetusministeri Sundqvist tuodessaan valtioneuvoston tervehdyksen kirkolliskokoukselle. ${ }^{311}$ Myös vuoden 1975 julistaminen Yhdistyneitten kansakuntien naisten vuodeksi vauhditti vaatimuksia pappisviran avaamisesta naisille. ${ }^{312}$ Vastaavasti kirkolliskokous sai muutamien herätysliikkeiden elimiltä kirjelmiä, joissa vaadittiin pidättymistä uudistuksesta. ${ }^{313}$ Kirkolliskokoukseen suuntautui puolelta ja toiselta vaikuttamispyrkimyksiä asiassa, joka varsinaisesti ei tuolla hetkellä ollut sen esityslistalla.

Myöskään kirkolliskokouksessa ei ollut virkakomitean kahta teemaa ilman kolmatta, ja naispappeuskysymys heijastui kaikkeen, mitä virasta sanottiin. Se oli päällimmäisenä mielessä myös kuunneltaessa arkkipiispa Simojoen avaussanoja - puhetta, jossa hän varoi mainitsemasta kertaakaan kirkon virkaa saati naispappeutta. Arassa tilanteessa arkkipiispa ei halunnut esittäytyä kirkolliskokouksen johdattelijana. Tosiasiassa hän puhui juuri näistä asioista. Simojoki käsitteli luterilaisen raamatuntulkinnan perusteita, jotka olivat välittömästi sidoksissa naispappeuskysymykseen. Hän painotti, että oppiin kuuluvissa asioissa kirkolliskokouksella ei voinut olla harkintavaltaa ohi Raamatun. Samaan hengen- vetoon hän kuitenkin jatkoi, että muuttuvat ajat asettivat kirkolle uusia kysymyksiä ja tehtäviä, joiden vuoksi oli kyettävä esittämään uusia kannanottoja Raamatun pohjalta. Lutheriin viitaten Simojoki totesi, että kirkon järjestysmuotoa ja jumalanpalvelusta tuli ajatella uudelleen pitäen silmällä, mitä kristillinen rakkaus kussakin asiassa edellytti. ${ }^{314}$ Myöhemmin Eero Huovisen tutkimus osoitti, että naispappeuden torjujien näkemyksissä kirkon järjestysmuoto - virka mukaan lukien - kuului uskon keskukseen ja oli pysyvä. ${ }^{15}$ Simojoki liittyi hienovaraisin teologisin sanakääntein mutta selvästi niihin, joiden mukaan kirkon järjestysmuotoa voitiin tulkita uudelleen eri historiallisissa tilanteissa. Tämä ajattelutapa taas sopi luontevasti yhteen myönteisen naispappeuskannan kanssa.

Komitean välimietinnöissä korostui kauttaaltaan kuluneina vuosina virasta käyty ekumeeninen keskustelu. Komitea nojasi Uuden testamentin myöhäisissä osissa erottuvaan kolmisäikeiseen, piispoista, papeista sekä diakoneista muodostuvaan virkaan ja esitti lehtorinvirkaa sijoitettavaksi diakonaattiin. Tällöin lehtori saisi pysyvän vihkimyksen ja voisi saarnata jumalanpalveluksessa sekä jakaa mutta ei toimittaa ehtoollista. Korostaessaan kolmisäikeistä virkakäsitystään komitea oli jyrkkäsanainen: Raamatun kaanonin sisällä nähtävän viran ja sen kehityksen hylkääminen johtaisi luterilaisen raamattuperiaatteen hylkäämiseen. ${ }^{316}$

Komitean kannanotot herättivät kirkolliskokouksessa arvostelua. Rehtori Gustav Björkstrandin mielestä oli keskusteltava, halusiko kirkolliskokous todella ottaa askelen aitoluterilaisesta traditiosta katolisen, anglikaanisen ja ortodoksisen virkakäsityksen suuntaan. Björkstrandin mielestä poikkeukset vanhasta luterilaisesta teologiasta tulivat selvästi näkyviin piispanviran uudessa korostuksessa, diakonaatin uudistuksessa ja ehdotuksessa, että lehtori saisi jakaa ainoastaan siunattua leipää ja viiniä. Arkkipiispa Simojoki yhtyi kritiikkiin ja totesi, että puheessa sakramentin jakamisesta ja virasta liikuttiin huomaamatta pois luterilaisen uskon tärkeimmistä asioista: "Pidän tätä tunnustuskirjojen vastaisena ja luterilaisen opin kannalta harhaan vievänä." ${ }^{117}$ Oli hyvin poikkeuksellista, että arkkipiispa syytti dogmatiikan professorin johtaman kirkon komitean tuotoksia käytännössä harhaoppisiksi. Jo Teinosen edeltäjän Osmo Tiililän kaudella oli totuttu siihen, että dogmatiikan 
professori tuomitsi kirkon johdon toiminnan, mutta keväällä 1975 Turusta kaikui takaisin terävä vastaus.

Myös Johannes Leivonen piti komitean mietintöjen perusteluja yksipuolisina. Puheessaan, josta hän sai kirkolliskokouksessa harvinaiset aplodit, hän puuttui myös mietintöjen yliopistoteologiseen kieleen:

Komitean mietinnössä parilla sivulla käsitellään mm. sakramenttien funktiota, partikulariteetin skandaalia, yhteisön saaman Jumalan auktoriteetin demonstroimista sekä eräiden tosiasioiden ratifioimista ja manifestoitumista. - - Raamatun suomennosta on ymmärrettävä Raamatun lukijoitten, komitean mietintöä olisi ymmärrettävä meidän kaikkien kirkolliskokoukseen osallistuvien ilman suurempia vaikeuksia. ${ }^{318}$

Kirkolliskokous käsitteli samaan aikaan raamatunkäännöskomitean ensimmäistä osamietintöä, ja vertailtaessa mietintöjä virkakomitea joutui jatkuvasti alakynteen. Perustevaliokunta moitti virkakomiteaa työn viivästymisestä, mutta käsikirjavaliokunta antoi raamatunkäännöskomitealle tunnustusta "määräajassa valmistuneesta, selkeästä ja seikkaperäisestä mietinnöstä". ${ }^{319}$ Raamatunkäännöstyön käsittely sujui yksimielisessä hengessä.. ${ }^{20}$ Samaa ei voinut sanoa virkakomitean tulosten ruotimisesta, vaikka jotkut pyrkivätkin sovittelemaan.

Yksi viimeksi mainituista oli Alma Saari, joka ennätti varaamaan puheenvuoron heti keväisen lähetekeskustelun aluksi. Kirkolliskokouksen naisedustajat olivat keskenään sopineet tästä puheenvuorosta. Ensimmäisen kauden edustaja Saari, joka ei ollut esiintynyt kirkolliskokouksessa vielä kertaakaan, oli valittu puheenvuoron käyttäjäksi, koska hänellä ei ollut rasitteenaan samaa naisasianaisen leimaa kuin joillakuilla muilla edustajilla. Naisedustajien ryhmäkokouksessa oli myös annettu evästykseksi, ettei puheenvuoro saanut ärsyttää miehiä. Ryhmäkokouksen pohjalta Saari oli yhdessä Oriveden yhteiskoulun rehtorin, teologian tohtori Eeva Ojasen kanssa valmistanut puheenvuoron. ${ }^{321}$ Tavoitteensa puhe täyttikin ja jäi samalla pöytäkirjaan todistukseksi naisedustajien huterasta arvovallasta ja heidän enemmistönsä arkuudesta uusimuotoisen kirkolliskokouksen alkuvaiheessa. Saari ilmaisi tyytyväisyytensä lehtorinvirkaa koskeviin komitean esityksiin ja ehdotti osamietintöjen hyväksymistä sekä lisäajan myöntämistä. Hän ei sanonut yhtään poikkipuolista sanaa komitean mietinnöistä tai puuttunut naispappeuskysymykseen. ${ }^{322}$
Maltillinen linja ei kuitenkaan riittänyt kaikille naisedustajille. Heistä seitsemän jätti yhdessä neljän maallikkomiehen kanssa aloitteen, jonka mukaan kirkolliskokouksen tuli antaa kirkkolakikomitean tai erikseen asetettavan komitean tehtäväksi valmistella kiireellisesti kirkkolain muutos, jonka nojalla myös nainen voitaisiin vihkiä papiksi. ${ }^{23}$ Aloitetta voimakkaasti ajanut Meeri Päivänsalo kertoi teologien kiistellessä menettäneensä uskonsa teologisiin perusteluihin ja vetosi kirkon jäsenten enemmistön kantaan. ${ }^{324}$ Aloite merkitsi käytännössä epäluottamuslausetta virkakomitealle. Samalla se oli hätähuuto asian saamiseksi ratkaisuun mahdollisimman nopeasti.

Virkakomitean osamietinnöt olivat omiaan luomaan teologien keskuudessa vastakohta-asetelmaa niin sukupolvien kuin teologisten oppiaineiden välille. Ensinnäkin monien piispojen julkaisut kuuluivat siihen 1940- ja 1950-luvun aikakauteen, jolloin ilmestyneet virkaa koskevat teokset olivat mietinnön mukaan osittain vanhentuneita ja ratkaisevissa kohdissa puutteellisia. ${ }^{325}$ Esimerkiksi Martti Simojoki oli paimenkirjeessään Mikkelin uutena piispana 1952 asettunut korkeakirkollista virkakäsitystä vastaan, ja kevään 1975 lähetekeskustelussa Osmo Alaja vetosi edeltäjänsä sanoihin. ${ }^{326}$ Nämä kaksi piispaa tunnustivat kyllä, että he olivat eri mieltä kuin komitea ja erityisesti sen puheenjohtaja Teinonen, jonka kartalla luterilaisuus sijoittui selvästi lähemmäksi Roomaa kuin Geneveä. Sen sijaan he eivät suinkaan suostuneet myöntämään käsityksiään vanhentuneiksi.

Komitea totesi lisäksi, miten vielä 1940- ja 1950-luvun eksegeettiset traditiot ja varsinkin johtava saksalainen koulukunta olivat esittäneet viran kehittymisestä Uudessa testamentissa käsityksiä, jotka eivät perustuneet tieteellisiin tuloksiin vaan "kontroverssiteologisiin asenteisiin". ${ }^{27}$ Perustevaliokunnan puheenjohtajan, Uuden testamentin eksegetiikan entisen professorin Aimo T. Nikolaisen saattoi lukea komitealta tylyn tuomion saaneiden eksegeettisten traditioiden edustajiin. Näistä lähtökohdista perustevaliokunta lähti kirjoittamaan historiansa ensimmäistä mietintöä.

Työstä ei tullut helppoa, vaikka synnytettävä mietintö oli vain melko lyhyt ehdotus asian jatkokäsittelystä. Valiokunnan sihteeri, teologian lisensiaatti Tapio Saraneva sai tehdä useita mietintöluonnoksia. ${ }^{328}$ Ratkaisevaa käsittelyä valiokunnan pöytäkirja kuvasi: "Pitkäksi 


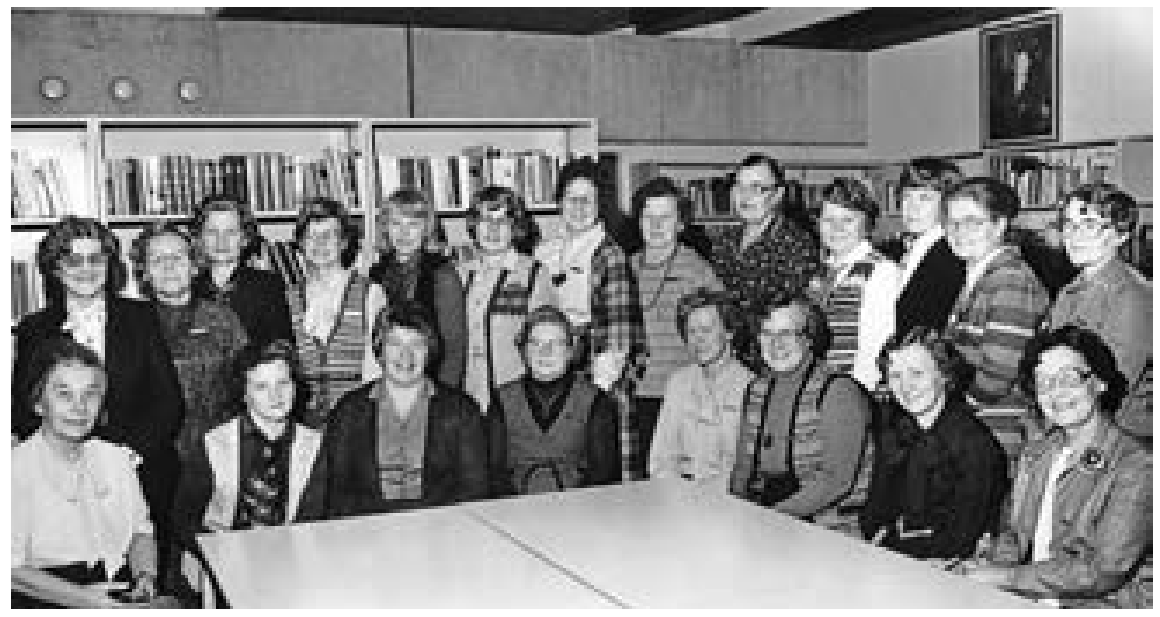

Kirkolliskokouksen naisedustajat kokoontuivat 1980-luvulle asti säännöllisesti omiin kokouksiinsa, muun muassa sopimaan omista "ryhmäpuheenvuoroistaan". Yhteistyö korostui käsiteltäessä pappisviran avaamista naisille. Kuvassa naisedustajat syksyllä 1981. Kuva: Kirkolliskokouksen kuvakokoelma / Arvo Salminen. venyneen keskustelun jälkeen päätettiin vielä tehdä eräitä korjauksia viime kokouksessa korjattuun mietintöluonnokseen." Samalla viisi edustajaa eli lähes puolet valiokunnan jäsenistä jätti eriävän mielipiteen. ${ }^{329}$ Sen allekirjoittajat eivät hyväksyneet valiokunnan enemmistön esittämää pontta, jonka mukaan kirkolliskokous antaisi virkakomitealle tehtäväksi valmistella lopullisesta kannastaan riippumatta naispappeuden edellyttämät kirkkolain muutokset. $\mathrm{Ne}$, jotka vastustivat tai epäröivät pappisviran avaamista naisille, kokivat ponnen ennakoivan komiteatyön lopputulosta. Puheenjohtaja Nikolainen kiisti nämä epäilyt: valiokunnan enemmistö halusi ainoastaan varmistaa, että asia ehdittiin käsitellä vaalikauden aikana. Lopulta piispa Vikströmin ehdottama lievennetty ponsimuoto, jonka mukaan kirkolliskokous vain "pyysi" komiteaa valmistelemaan lakimuutokset, voitti eriävän mielipiteen kannan äänin 60-40..$^{330}$

Voimakkaimmat naispappeuden kannattajat pitivät eriävää mielipidettä tahallisena jarrutuksena. ${ }^{331}$ Pohjimmiltaan oli kuitenkin kyse kahdesta asiasta: ohjasiko ponsi komitean työskentelyä tiettyyn suuntaan ja oliko kiirehtiminen asiassa eduksi vai haitaksi? Joidenkuiden naispappeutta periaatteessa kannattavien mielestä kirkko oli vaarassa hajota, mikäli pappisvirka avattaisiin nopeasti naisille. Useimmat naispappeuden kannattajat olivat kuitenkin päinvastoin sitä mieltä, että tilanne tulehtui jatkuvasti sitä enemmän, mitä pidemmälle päätöstä lykättiin. Perustevaliokunnan mietinnöstä keskusteltaessa väännettiin kättä nimenomaan naispappeudesta. Komitean ajatukset lehtorinvirasta ja diakonaatin uudistamisesta painuivat täysin unholaan. Kirkolliskokous antoi komitealle lisäajan. Vanhoillislestadiolainen saarnaaja Lauri Taskila Raahesta puki asian raamatunlauseeseen: "Anna hänen vielä tämä vuosi olla, jos se sittenkin hedelmän tekisi, ellei, hakkaa se sitten pois." ${ }^{32}$

Virkakomitea oli sikäli harvinainen kirkon komitea, että kukaan sen jäsenistä ei istunut kirkolliskokouksessa. Tämä seikka saattoi näkyä myös komitean mietintöjen kriittisessä vastaanotossa. Komitean puolustaminen jäi 1975 paljolti kahden kirkkoherran varaan. Nurmon kirkkoherra Ossi Haaramäki, jonka väitöskirjatyötä professori Teinonen parastaikaa ohjasi, nousi puolustamaan komitean teologista kokonaislinjaa, Helsingin yliopiston systemaattisen teologian tutkimusta ja komitean ekumeenista lähestymistapaa. Tilanteen jännittyneisyyttä kuvasti, että Aimo T. Nikolainen koki Haaramäen kyseenalaistavan hänen ekumeenisen kokemuksensa. ${ }^{333}$ Muutenkin asian käsittelyyn kirkolliskokouksessa heijastui, että perustevaliokunnan puheenjohtaja oli avoimessa oppositiossa virkakomiteaan nähden. Maarian kirkkoherra Eero Parvio asettui puheenjohtaja Teinosen ja naispappeutta vastustavien virkakomitean jäsenten edusmieheksi ja viestinviejäksi. Hän kertoi tietoja Teinosen "todellisista" mielipiteistä, joita tämä ei kuitenkaan yksimielisyyden saavuttamiseksi ollut Parvion mukaan vaatinut osamietintöihin. ${ }^{334}$

Tosiasiassa Teinonen oli jo kevääseen 1975 mennessä menettänyt toivonsa oman komiteansa suhteen. Kirkolliskokouksen kevätistuntokaudelle ennättäneessä kirja- 
sessaan Kirkon uudistus ja naispappeus Teinonen julkisti kielteisen naispappeuskantansa ja samalla eräänlaisen oman mietintönsä. Hieman istuntokauden jälkeen hän pyysi eroa komiteasta perustellen ratkaisua uusilla virkatehtävillään. Teologinen tiedekunta oli valinnut hänet dekaaniksi. Teinonen pyrki kirjeessään arkkipiispalle - vastoin koko totuutta - alleviivaamaan sitä, että hän ei eronnut omasta tahdostaan: "- - en mahda mitään sille, että minut vyöttää toinen ja vie, minne en tahdo."335 Simojoen kirkolliskokouksessa lausumat sanat siitä, että komitean mietintö vei harhaan luterilaisesta opista, olivat omiaan kiristämään tuota vyötä.

Teinosen erottua varapuheenjohtaja Thure Eriksson nousi komitean johtoon. Syksyn 1975 kirkolliskokous valitsi yksimielisesti varajäsen Timo Holman uudeksi komitean jäseneksi, ja uudeksi varajäseneksi tuli teologian tohtori Olavi Rimpiläinen. ${ }^{336}$ Kirkolliskokous ei komiteatyön loppumetreillä halunnut muuttaa naispappeuden kannattajien ja vastustajien voimasuhteita komiteassa.

\section{PAPPISVIRKA EI AVAUDU NAISILLE}

Virkakomitean loppumietintö saapui kevään 1976 kirkolliskokoukselle, ja sen käsittely leimasi vuoden molempia istuntokausia. Loppumietinnössä oli otettu huomioon kirkolliskokouksessa kuultu arvostelu. Mietinnön mukaan viran kolmijako ei ollut jumalallisesti säädetty hierarkia vaan varhaisesta kirkosta periytynyt, periaatteessa hyväksyttävä ja arvokas kirkollinen asetus. ${ }^{337}$ Loppumietinnössä lähdettiin myös liikkeelle Raamatusta ja tunnustuskirjoista eikä ekumeenisesta keskustelusta ja uusimmasta tutkimuksesta, kuten paljon arvostellussa toisessa välimietinnössä. Seikkaperäinen mietintö sisälsi suunnitelmia myös laajemmaksi virkareformiksi kolmisäikeisen virkarakenteen pohjalta. ${ }^{338}$

Loppumietintö oli siitä poikkeuksellinen, että se ei päättynyt selviin ponsiin. Sen sijaan niin naispappeutta kannattanut enemmistö kuin sitä vastustanut vähemmistö kirjoitti omat johtopäätöksensä yhteisesti hyväksytyn mietintötekstin pohjalta. ${ }^{339}$ Komitean erimielisyys herätti julkisuudessa hämmästystä ja hämmennystä. ${ }^{340}$ Mietintöön liittyi kirkolliskokouksen pyytämä tekninen kirkkolain muutosehdotus. Se näyttäytyi julkisuudessa tuoreeltaan komitean enemmistön kannan tukena, joten pyyntöä vastustaneiden kirkolliskokousedustajien epäi- lykset kävivät toteen. ${ }^{341}$ Vähemmistön, Esko Haavan ja Timo Holman, mielestä pappisviran avaaminen naisille vaati "ratkaisevaa muutosta asenteissamme virkateologian perusteisiin". Enemmistö, Thure Eriksson, Pirkko Lehtiö ja Ritva Hyöky, perääntyi johtopäätöksissään mietinnön peruskorostuksesta, jonka mukaan paitsi viran tehtävä myös tietyt viran sisällölliset piirteet kuuluivat kirkon pysyvään konstituutioon eli olennaisrakenteeseen. ${ }^{342}$

Mietinnön tekstin ja enemmistön johtopäätösten lievät ristiriidat huomattiin kirkolliskokouksessakin. Vaikka mietintö sai kiitosta myös niiltä, jotka olivat edellisenä vuonna arvostelleet voimakkaasti välimietintöjä, Mikko Juva ei säästellyt sanojaan. Hänen mielestään mietintö edusti katolisen kirkon virkakäsitystä, johon luterilaiset tunnustuskirjat oli pakotettu sopimaan: "Tietysti komitean maallikkojäsenet eivät ole tätä tajunneet, vaan ovat allekirjoittaneet mietinnön."343 Oli kova väite, että jotkut kirkolliskokouksen komiteaan valitsemista jäsenistä eivät tajunneet mietintönsä sisältöä eivätkä siten olleet kykeneviä tehtäväänsä - varsinkin, kun "maallikkojäsenistä" hovioikeuden presidentti Hyöky oli ainoa, jolla ei ollut teologin koulutusta. Pappisjäsenet taas olivat Juvan mukaan tietoisesti johdattaneet komiteatyötä harhaan.

Komitean enemmistö edusti johtopäätöksissään niin sanottua funktionalistista virkakäsitystä, jonka mukaan viran jumalallinen säätämys kohdistui vain viran tehtävään eli funktioon. Virka samastui saarnattuun sanaan. Sen sijaan varsinaisen mietintötekstin konstitutiivisessa virkakäsityksessä näkyi ajatus, että pappi oli virassaan Kristuksen edustaja. Juva itse edusti kirkolliskokouksessa puhuessaan lähinnä välittävää mallia: pappisvirka - ei siis ainoastaan viran funktio - oli kyllä jumalallinen säätämys, mutta tämän säätämyksen piiriin ei liittynyt olemuksellisia, viranhaltijan persoonaa ja esimerkiksi sukupuolta koskevia seikkoja. ${ }^{344}$

Loppumietinnön pohjatekstin kirjoittajina olivat Simo Kiviranta, Esko Haapa ja Timo Holma, jotka kaikki vastustivat pappisviran avaamista naisille. ${ }^{345}$ Naispappeuden kannattajilla eli komitean enemmistöllä oli lähinnä mietintötekstiä kommentoiva ja korjaava rooli, ja kiire mietinnön valmistamisessa syksyllä 1975 heikensi entisestään tämän joukon mahdollisuuksia paneutua tekstiin. Kirjoittajat pystyivät perustelemaan mietinnön käsitteiden takana olevaa ajattelua aivan toisella tavalla 
kuin muut komitean jäsenet, mistä tuli etua naispappeuden vastustajien ydinjoukolle. Komitean vähemmistön kirjoittamat johtopäätökset seurasivatkin hyvin tarkasti varsinaisen mietintötekstin teologista linjaa.

Naispappeutta vastustavien kiinteä yhteistyö tuli esiin myös, kun piispainkokous käsitteli huhtikuussa 1976 omaa lausuntoaan komitean mietinnöstä. Piispa Nikolaisen johtama työryhmä oli valmistellut lausuntoehdotuksen. Piispainkokouksessa asessori Timo Holma jätti kuitenkin lausuntoehdotukseen laajan vastineen, jonka olivat tosiasiassa kirjoittaneet virkakomitean sihteeri Simo Kiviranta ja Lapin (Tl) kirkkoherra Anssi Simojoki. ${ }^{346}$ Ei ollut ennenkuulumatonta, että komiteoiden jäsenet arvostelivat mietintöjensä jatkokäsittelyä kirkon elimissä, mutta Holman hyökkäys oli jännittyneessä tilanteessa erityisen dramaattinen. Nopeassa kokoustilanteessa piispainkokous ei kyennyt pureutumaan Holman puheenvuoroon $^{347}$.

Lopputuloksena oli, että piispainkokous ei antanut hyväksyntäänsä lausuntoehdotukselle vaan lähetti sen ainoastaan tiedoksi kirkolliskokoukselle. Varsinaiseksi piispainkokouksen lausunnoksi jäi toteamus, että naispappeuden toteuttaminen oli mahdollista, joskaan ei välttämätöntä. ${ }^{348}$ Lehdistössä lausuntoa tulkittiin monella tavalla, ja jotkut arvostelivat sen ympäripyöreyttä. ${ }^{349}$ Kun sen enempää virkakomitea kuin piispainkokouskaan ei ollut päätynyt selvään lopputulokseen, vastuu jäi kirkolliskokouksen harteille. Kärkölän kirkkoherra Martti Lepola kysyi kirkolliskokouksessa: "Eivätkö piispat todella tahdo kantaa hengellistä vastuuta sillä tavoin, että olisivat meitä tässä asiassa johdattaneet ja yksityiskohtaisesti ottaneet kantaa virkakomitean mietintöön?" 350

Holman puheenvuoro jaettiin kirkolliskokousedustajien pöydille, ja se päätyi reunamerkinnöillä varustettuna myös perustevaliokunnan arkistoon. ${ }^{351}$ Ilmeisesti sillä oli ainakin jonkinlainen vaikutus, kun valiokunta valmisti mietintöään syksyn 1976 kirkolliskokoukselle. Aimo T. Nikolaisen valmistelemaan mietintöluonnokseen ei näet tullut joitakin sellaisia hänen johtamansa piispainkokouksen työryhmän lausumia, jotka Holma oli tuominnut epäjohdonmukaisiksi. ${ }^{352}$ Vaikka valiokunnan enemmistö otti huomioon naispappeuden vastustajien kommentteja, alusta asti oli selvää, ettei yksimieliseen mietintöön päästäisi. Asiat voitiin siis sanoa suoraan. Lopullisesta mietinnöstä löytyneet puolenkymmentä huutomerkkiä jo sinänsä osoittivat, ettei kyse ollut kuivasta mietintökielestä vaan kahden näkemyksen räiskyvästäkin törmäämisestä. Vasta perustevaliokunnan mietinnössä ja eriävässä mielipiteessä kirjoitettiin auki se jännite, joka komiteatyössä oli piilotettu yhteisen mietinnön ja eriävien johtopäätösten taakse.

Vastakkaisten kantojen esittäminen selvensi asetelmia. Kun lisäksi ratkaisevan käsittelyn alkaessa oli varmaa, ettei uudistus saisi taakseen määräenemmistöä, täysistuntokeskustelut olivat 1976 kokonaisuudessaan maltillisempia kuin vuotta aiemmin. Myös perustevaliokunnan jäsenet kehuivat valiokuntansa henkeä. ${ }^{353}$ Matkalla virkakomiteasta perustevaliokunnan mietintöön vastakkaiset kannat vakiintuivat jo siksikin, että paljolti samat henkilöt vastasivat puolin ja toisin tärkeimmistä kannanotoista eri vaiheissa. Kirkolliskokouksessa tämä seikka tarkoitti sitä, että neljä viidestä keväällä lähetekeskustelussa puhuneesta ruoti valiokunnan mietintöä edelleen syksyllä. Kaiken lisäksi useat näistä puhujista olivat perustevaliokunnan jäseniä. Paljon ei puuttunut asetelmasta, että valiokunta kävi täysistunnossa ensin itseään varten lähetekeskustelun ja lopuksi mietintönsä pohjalta palautekeskustelun. Kannastaan epävarmoille ja rintamalinjojen väliin sijoittuville jäi helposti sivustaseuraajan osa, ja he alkoivat nousta esiin vasta täysistuntokeskustelujen loppupuolella.

Kirkolliskokoukselle lähetettiin edellisvuoden tavoin kirjelmiä. ${ }^{354}$ Lehdistö taas seurasi tiiviisti virkakysymyksen käsittelyä. ${ }^{35}$ Kevään istuntokauden avajaispäivänä Turun Sanomien pääkirjoitus ei kuitenkaan koskenut naispappeuskysymystä vaan naisten asepalvelusta..$^{356}$ Naisten työmahdollisuudet olivat kauttaaltaan yleisen mielenkiinnon kohteena, ja virkakysymyksen käsittely kirkolliskokouksessa voimisti entisestään keskustelua heidän toimintamahdollisuuksistaan yhteiskunnassa.

Kirkolliskokouksen täysistuntoihin heijastui voimakkaasti julkinen keskustelu naispappeudesta. Satojen aihetta koskevien lehtikirjoitusten joukosta eniten huomiota sai osakseen pieni, lähes huomaamaton $\mathrm{Ko}$ timaa-lehden mielipidesivun alalaidassa julkaistu teksti. Seppo A. Teinosen aloitteesta syntyneessä kirjoituksessa Helsingin yliopiston systemaattisen teologian professorit ja apulaisprofessorit totesivat, että piispainkokouksen esittämät perustelut naispappeuden toteut- 
tamiseksi merkitsivät Raamattuun ja tunnustuskirjoihin nähden olennaisesti uutta virkakäsitystä. ${ }^{357}$ Lausuma merkitsi terävöitystä virkakomitean vähemmistön kirjoittamiin johtopäätöksiin, ja se vastasi apulaisprofessori Tuomo Mannermaan Oulun hiippakuntakuntakokouksessa esittämää ja kokouksen hyväksymää muotoilua: naispappeuskeskustelussa ei ollut kyse vain kirkon virkaa koskevista asenteista vaan opista. ${ }^{35^{8}}$ Kansleri Mikko Juva puuttui kirkolliskokouksessa siihen, että "eräät minun yliopistoni teologit" olivat kiirehtineet "ex cathedra eli oppituoleistaan tieteellisellä arvovallalla arvostelemaan piispainkokouksen lausuntoa":

Nyt tietysti yliopistossa saa väittää aivan mitä tahansa. (Hilpeyttä) Se on yliopiston vapauteen kuuluva asia. Mutta tähän vapauteen kuuluu se, että kaikki väitteet on perusteltava, eivätkä ystäväni viisi systemaatikkoa perustele väitettään millään tavalla. Tällaisenaan eräässä kirkkomme äänenkannattajaksi itseään nimittävässä lehdessä julkaistu lausuma on tyypillinen auktoriteettiuskon vaatimus, joka ei sovellu yliopistoon eikä myöskään kirkolliskokoukseen. Tämän takia tätä lausuntoa ei kukaan luterilainen kristitty voi ottaa vakavasti. (Hilpeyttä) $)^{359}$

Istuntokauden jälkeen Juva kertoi arkkipiispa Simojoelle jättäneensä "Teinosen tallin" rauhaan ja puuttuneensa tilanteeseen vasta, kun "heidän arroganssinsa Kotimaan julkilausumassa ylitti kaikki rajat": "Mutta kun nämä pojat nyt ovat aloittaneet hyökkäyksensä, osaan kyllä puolustautua." ${ }^{360}$ Puolustautuessaan Juva tuli tosin vedonneeksi melko voimakkaasti omaan auktoriteettiinsa kanslerina, samoin kuin piispainkokouksen auktoriteettiin - eihän piispainkokouskaan ollut virallisesti perustellut kantaansa, jonka mukaan naispappeus oli mahdollinen mutta ei välttämätön. Kirkolliskokouksen eri mielipidelaidoilla tekstit tulkittiin keskenään vastakkaisilla tavoilla. Pohjoisen piispan Hannes Leinosen mielestä oli "kaunis se nöyrä ja vaatimaton tapa", jolla systemaatikot olivat lausuneet käsityksensä ${ }^{361}$.

Keskenään päinvastaiset tulkinnat näkyivät lähes kaikissa argumenteissa kirkolliskokouksen keskustelussa. Joidenkuiden mielestä kirkolliskokous ei saanut alistua ulkopuoliseen painostukseen, kun taas toisten mukaan tällaiset vaatimukset naispappeuden puolesta oli otettava vakavasti. ${ }^{362}$ Kummankin osapuolen edustajat valittivat joutuneensa leimatuiksi julkisessa keskustelussa. ${ }^{363}$
Myös näkemykset todistusvelvollisuudesta olivat keskenään päinvastaiset. Naispappeuden kannattajien mielestä oli erikseen todistettava, että naispappeus oli vastoin Raamatun sanaa, kun taas vastustajien mielestä todistusvastuu oli uudistuksen ajajilla. ${ }^{364}$ Sama toistui käsiteltäessä Lutherin naispappeuden vastaisia kirjoituksia. Naispappeuden kannattajien mielestä ei voinut lähteä siitä, että kaikki Lutherin kirjoittama olisi yhtäpitävää tunnustuskirjojen kanssa. Vastustajien mielestä taas tämä yhtäpitävyys oli lähtökohta, koska Lutherilla oli samanlainen konstitutiivinen virkakäsitys kuin tunnustuskirjoilla. ${ }^{365}$ Oli selvää, että tällaisessa tilanteessa keskustelu ei juuri edistynyt.

Keskusteluun osallistuneet miehet, niin papit kuin maallikot, puhuivat ennen kaikkea Raamatusta ja tunnustuksesta. Naiset taas puolustivat pappisviran avaamista naisille ennen kaikkea kirkon tehtävällä ja evankeliumin levittämisellä. Viimeksi mainitut perusteet olivat Ruotsissakin osoittautuneet tärkeiksi argumenteiksi naispappeuden puolesta. ${ }^{366}$ Virkakomitean loppumietinnön liitteenä ollut teologian tohtori Heikki Mäkeläisen selvitys osoitti, ettei kirkkoon ollut tulossa pappispulaa vaan että ennemminkin oli uhkana pappien ylitarjonta. ${ }^{367}$ Tutkimustulos vei pohjaa kirkon tehtävää painottavilta naispappeuden perusteluilta ja oli omiaan ohjaamaan keskustelua raamatulliseen ja virkateologiseen suuntaan. Toisaalta piispainkokouksen lausunto, jonka mukaan uskon ja opin pohjalta naispappeuskysymys oli mahdollista ratkaista kumpaankin suuntaan, antoi tukea niille, jotka hakivat perusteluja nimenomaan käytännön seurakuntatyöstä.

Virkakomitea oli yksimielisesti valmis antamaan lehtorille saarnaoikeuden. Koska naisen ei tarvinnut komitean mielestä vaieta edes seurakunnan pääjumalanpalveluksessa, piispat Nikolainen ja Vikström näkivät ainoana kysymyksenä naispappeuden tiellä enää sen, saiko nainen olla johtamassa kristillistä seurakuntaa. Mikäli kysymykseen naispappeudesta vastattiin kielteisesti, heidän mielestään johdonmukaisuus edellytti siinä tapauksessa naisten sulkemista myös kirkon luottamustehtävistä. Eero Parvion mukaan pappisvirkaa ja seurakunnan luottamustehtäviä ei voinut verrata toisiinsa: naisten pääsy vaalikelpoisiksi kirkon luottamuselimiin oli ollut "tyypillinen yhteiskunnallinen asia, joka liittyi yhteiskunnassa muutenkin tapahtuvaan kehityk- 


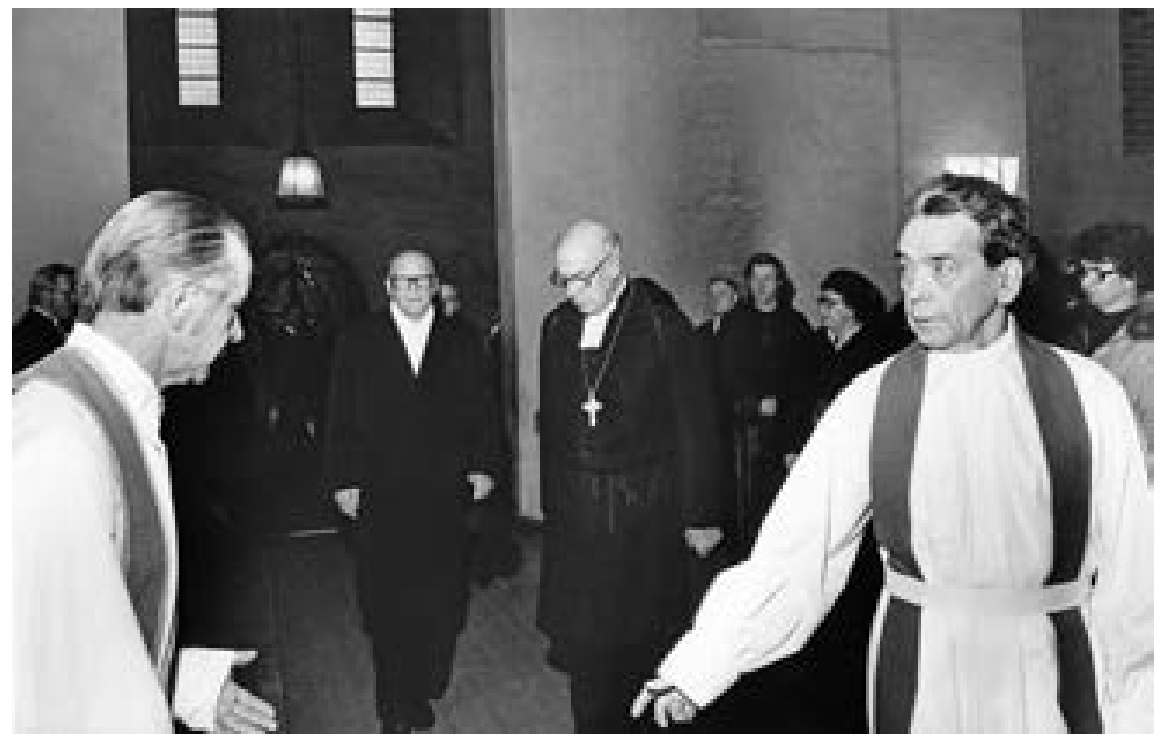

Pappisviran avaaminen naisille tuli ratkaisevaan käsittelyyn syysistuntokaudella 1976. Edeltävänä viikonloppuna kirkolliskokous ja valtiojohto kokoontuivat kirkolliskokouksen satavuotis- ja Turun tuomiokapitulin 7oo-vuotisjuhlaan. Tasavallan presidentti Urho Kekkosen ottivat Turun tuomiokirkossa vastaan tuomiorovasti Lauri Huovinen (vas.), arkkipiispa Martti Simojoki ja lääninrovasti Alvar Kurtén. Kuva: Kirkolliskokouksen kuvakokoelma / Arvo Salminen. seen”. ${ }^{68}$ Äänestäminen, jonka Parvio toisissa yhteyksissä kirkolliskokouksessa korosti olevan syvästi kristillinen toimenpide, "hengellinen jumalanpalvelustoimi", muuttui naispappeuskeskustelussa "tyypilliseksi yhteiskunnalliseksi asiaksi". ${ }^{69}$ Tosin myöskään Nikolaisen ja Vikströmin perustelut eivät vastanneet niitä argumentteja, joita naisten vaalikelpoisuuden puolustajat olivat vuosisadan alkuvuosikymmenten kirkolliskokouksissa esittäneet. Vaikka naisten vaalikelpoisuuden vastustajat olivat tuolloin epäilleet uudistuksen johtavan vähitellen naispappeuteen, vaalikelpoisuuden puolustajat olivat nähneet nämä kaksi asiaa yleensä toisistaan erillisinä. ${ }^{370}$

Täysistuntokeskusteluissa Lapuan piispa Yrjö Sariola ja Kuopion piispa Paavo Kortekangas korostivat kirkon yhteyttä, ja arkkipiispa Simojoki pyrki samaan päämäärään jättäytymällä kokonaan keskustelun ulkopuolelle. ${ }^{371}$ Voimakkaimmat kannanottajat löytyivät perustevaliokunnan sisältä, ja papiston kaksi ääripäätä, Mikko Juva ja Eero Parvio, tulivat samasta hiippakunnasta. Perustevaliokunnan varapuheenjohtajana toimineen Juvan rinnalla valiokunnan puheenjohtaja Nikolainen otti voimakkaasti kantaa naispappeuden puolesta. ${ }^{372}$

Yksi naispappeuskeskusteluun aktiivisimmin osallistuneista maallikoista, insinööri Rafael Nyqvist - eräänlainen kirkolliskokouksen tuomiopäivän pasuuna - oli tässäkin kysymyksessä persoonallisella linjallaan. Hän käänsi kirkolliskokouksen katseita kohti Roomaa, mut- ta ei Pyhää istuinta vaan ennemminkin Rooman klubia. Ennustaessaan maailmalle ja erityisesti länsimaille syvenevää kriisiä hän näki ainoan jäljellä olevan voimavaran naisissa. ${ }^{373}$ Kysymys luonnonvarojen rajallisuudesta ja jakamisesta oli julkisessa keskustelussa ja myös ekumeenisessa liikkeessä ajankohtainen aihe 1970-luvun jälkipuoliskolla. ${ }^{374}$ Kirkolliskokoukseen tämä keskustelu heijastui vain lähinnä Nyqvistin puheenvuoroissa, mutta niissä mitä moninaisimmissa yhteyksissä. ${ }^{375}$

Seuratuimman puheenvuoron käytti keskustalainen opetusministeri Marjatta Väänänen. Naisjärjestöjen Keskusliiton puheenjohtajana hän oli ollut yhdessä saman puolueen vaikuttajan, kirkolliskokousedustaja Katri Kaarlosen kanssa myös kirkolliskokoukselle suunnatun vetoomuksen takana. ${ }^{376}$ Väänänen oli saanut hallituksen iltakoulussa tehtäväkseen esittää kirkolliskokoukselle hallituksen myönteisen naispappeuskannan. ${ }^{377}$ Sen hän teki korostaen asemaansa yksittäisenä kirkolliskokouksen jäsenenä ja painottaen, ettei valtiovallalla ollut syytä puuttua kirkon asioihin. ${ }^{378}$ Naispappeuskysymys katsottiin kuitenkin hallituksessa niin tärkeäksi, että varaedustaja, kansliapäällikkö Jaakko Numminen joutui keskeyttämään Leningradin-virkamatkansa ja lähtemään Turkuun antamaan äänensä naispappeuden puolesta. ${ }^{379}$ Asian yleinen yhteiskunnallinen painoarvo ja toisaalta sen kirkollinen herkkyys aiheuttivat mielenkiintoisen kontrastin: kyseessä oli kirkollis- 
kokouksen nelivuotiskauden ainoa asia, jonka käsittelyyn valtioneuvoston määräämät edustajat ottivat selvästi osaa, mutta samaan aikaan kirkon opista suurinta vastuuta kantanut yksittäinen henkilö, arkkipiispa, pidättäytyi puhumasta ja lopulta jopa äänestämästä.

Äänestykseen lähdettäessä kirkolliskokousedustajilla olivat tukenaan lausunnot, jotka kirkolliskokous oli keväällä pyytänyt seurakuntien kirkkoneuvostoilta. Vastaukset siihen, tuliko naispappeus toteuttaa tuossa vaiheessa, jakautuivat lähes tasan kahtia. Sen sijaan kaksi kolmesta seurakunnasta piti naispappeutta kirkon uskon ja opin pohjalta mahdollisena. Seurakunnat, jotka olivat heti valmiita lakimuutokseen, kattoivat lähes 60 prosenttia kirkon väkiluvusta. ${ }^{380}$ Osuus ei poikennut paljon kirkolliskokouksesta, jossa naispappeuden puolesta äänesti lopulta 66 ja vastaan 37 edustajaa. ${ }^{381}$ Naispappeutta kannatti selvästi suurempi osuus kuin vuonna 1963 edellisen kerran asiasta äänestettäessä, mutta kolmen neljäsosan määräenemmistö ei toteutunut. Niin hiippakunnittain valittujen pappisedustajien kuin maallikkomiesten keskuudessa puolesta ja vastaan äänestäneiden määrässä ei ollut suurta eroa. Ero tuli siitä, että kaikki naisedustajat äänestivät naispappeuden puolesta. ${ }^{32}$ Äänensä antaneista seitsemästä piispasta kaksi, Yrjö Sariola ja Hannes Leinonen, äänesti naispappeuden toteuttamista vastaan - ensin mainittu siksi, ettei hänen mielestään ollut vielä oikea aika muutokselle. ${ }^{383}$

Niin lausunnot kuin kirkolliskokouksen äänestystulos osoittivat, että lounaisen, läntisen ja pohjoisen Suomen vahvat herätysliikealueet asennoituivat uudistuksen toteuttamiseen kielteisimmin. ${ }^{384}$ Herätysliikkeiden tunnetuista jäsenistä valtaosa antoikin ei-äänen, mutta äänestystulos oli monisyinen. Ensinnäkin uudistusta puoltaneiden naisedustajien joukossa oli paljon herätysliikkeisiin kuuluvia. Herännäisyyteen lukeutuvista edustajista lähes puolet äänesti naispappeuden puolesta, missä näkyi herätysliikkeen kansankirkollistuminen. Myös evankelisuuden, Kansan Raamattuseuran ja lestadiolaisuuden pappislinjan piirissä oli naispappeuden kannattajia. Evankelisen liikkeen kahden vahvan hiippakunnan, Turun ja Lapuan, edustajien välillä oli havaittavissa herätysliikkeen sisäisiä alueellisia eroja: arkkihiippakunnan evankeliset edustajat suhtautuivat naispappeuteen kielteisemmin kuin Lapuan hiippakunnan evankeliset. Ainoastaan vanhoillislestadiolaiset ja rukoilevaisedustajat olivat yhtenäisesti naispappeutta vastaan.

Naispappeuden toteuttaminen raukesi määräenemmistön puutteeseen, mutta kirkolliskokous hyväksyi John Vikströmin ehdottaman ponnen, jolla asian valmistelemista jatkettiin. Ponnen tarkoituksena oli Vikströmin mukaan ehkäistä tilanteen tulehtumista ja osoittaa, ettei asia ollut poissa päiväjärjestyksestä. Kirkolliskokous antoi piispainkokoukselle tehtäväksi valmistella asiaa edelleen ja tehdä siitä esityksen sopivana ajankohtana. ${ }^{385}$ Päätös jatkaa asian valmistelua saikin lehdistössä myönteistä huomiota. Vaikka useimmat lehdet valittelivat naispappeuden kaatumista, ne tulkitsivat lopputuloksen lähinnä päätöksen lykkääntymiseksi. ${ }^{386}$

Naispappeusasian käsittelyyn liittyi tärkeänä juonteena kysymys siitä, saattoivatko uudistuksen vastustajat sen toteutuessa kieltäytyä yhteistyöstä naispappien kanssa. Piispainkokous hyväksyi keväällä 1976 arkkipiispa Simojoen muotoileman ponnen: mikäli pappisvirka avattaisiin naisille, niille, jotka eivät voineet päätöstä hyväksyä, oli taattava mahdollisuus toimia kirkossa vakaumuksensa mukaisesti. ${ }^{387}$ Kokenut juristi Lars Erik Taxell näki heti ehdotuksen ongelmat ja asian valmistelun vaativuuden, mutta ajanpuutteen vuoksi kirkolliskokouksen perustevaliokunta joutui ottamaan tämänkin asian valmisteltavakseen. ${ }^{388}$

Valiokunnassa Mikko Juva valmisteli omantunnonklausuulia koskevat kohdat. Teologi Juva sai valmistelutehtävän yksin, vaikka nimenomaan asian oikeusopilliset ongelmat olivat nousseet esiin täysistunnossa ja vaikka valiokuntaan kuului Porvoon hiippakunnan lainoppinut asessori Gunnar Träskman. Tämä oli työssään joutunut perehtymään täysin vastaavanlaiseen kysymykseen selvitellessään tapauksia, joissa jotkut hiippakunnan papit olivat kieltäytyneet vihkimästä eronneita. ${ }^{389}$ Kun vielä puheenjohtaja Nikolainen valmisteli mietinnön muut osat, prosessi kuvasti perustevaliokunnan puheenjohtaja- ja varapuheenjohtajakeskeistä työskentelytapaa.

Juvan luonnos oli sävyltään hyvin sovitteleva mutta johtopäätöksiltään yksiselitteinen: pappien osalta ei voinut ajatella säännöstöä, jonka nojalla voisi kieltäytyä yhteistyöstä pappisvirkaan vihityn työtoverin kanssa. ${ }^{390}$ Valiokunnan enemmistö liittyi tähän kantaan mutta halusi lisätä seurakuntalaisten oikeuksia: naista ei saanut 
asettaa ehdolle seurakunnan ainoaan papinvirkaan, mikäli kirkkoneuvosto ei sitä yksimielisesti hyväksynyt tai mikäli ehdolle ei pantu myös mieshakijaa. ${ }^{391}$ Erityisesti omantunnonklausuulin käsittelyssä näkyi se kiire, joka leimasi kahdeksan vuotta kestäneen valmistelun loppuvaihetta. Jättäessään mietintönsä valiokunta ei ollut ehtinyt vielä saada kirkkohallituksen lausuntoa eikä kirkolliskokouksen pyytämää selvitystä naispappeuden vaikutuksista muissa kirkoissa. ${ }^{392}$ Selvitys olisi osoittanut, että joissakin kirkoissa omantunnonklausuulista oli myönteisiäkin kokemuksia. ${ }^{393}$ Tuossa tilanteessa valiokunnan kantaan heijastuivat läheisimmän kumppanin, Ruotsin kirkon, kohtaamat vaikeudet. Valiokunnan linjaus menetti kuitenkin merkityksensä, kun koko esitys kaatui määräenemmistön puutteeseen. ${ }^{394}$

Näkemyserot ja asiakokonaisuuden laajuus olivat pitkittäneet virkakomitean työtä, mutta pitkällisen pohdinnan tulokset eivät kaikilta osin päässeet näkyville päätöksentekotilanteessa. Työn pitkittyessä odotukset kasvoivat, ja lopulta sekä komitea että kirkolliskokous joutuivat laatimaan mietintönsä kiireessä. Nopeatahtisessa valmistelutyössä yksittäisten henkilöiden rooli kasvoi kirkolliskokouksessakin lähes yhtä suureksi kuin suppeassa komiteassa.

\section{JÄLKINÄYTÖS USKOSTA, OPISTA JA LEHTORINVIRASTA}

Vuonna 1976 kirkolliskokouksen käsittelyyn tulivat niin virkakysymys kuin Leuenbergin konkordia. Arkkipiispa Simojoki totesi kevätistuntokautta avatessaan enteellisesti, että näiden päätösten myötä jouduttaisiin ensimmäistä kertaa harkitsemaan, millaisen ja miten pitkälle ulottuvan päätösvallan kirkolliskokous oli saanut uskoa ja oppia koskevissa asioissa. Kyse oli ennen kaikkea siitä, miten oli tulkittava Erkki Kansanahon ehdotuksesta 1971 lisättyä kirkkolain kohtaa, joka kosketteli kirkolliskokouksen tehtävää uskon ja opin asioissa. ${ }^{395}$

Tiukimpaan testiin tuo lainkohta joutui vasta varsinaisen naispappeusäänestyksen jälkeen. Hallintoneuvos Pekka Kurvinen kiinnitti huomiota siihen, että seurakunnat olivat naispappeuskyselyn osana vastanneet kysymykseen, oliko naispappeus kirkon uskon ja opin pohjalta mahdollinen. Kurvisen mielestä myös kirkolliskokouksen tuli erikseen ottaa kantaa tähän kysymykseen, mikäli pappisviran avaaminen naisille ei saisi taakseen määräenemmistöä. Keskustelussa Kurvisen ehdotukselle löydettiin tukea myös Englannin kirkosta, jossa naispappeuden periaatteellista puolta ja käytännön toteuttamista oli käsitelty erikseen. ${ }^{396}$ Kurvinen itse kuului piispa Sariolan ohella niihin harvoihin kirkolliskokousedustajiin, jotka periaatteessa kannattivat naispappeutta mutta äänestivät tuossa vaiheessa sen toteuttamista vastaan. He olisivat lisä-äänestyksen myötä saaneet äänensä kuuluviin.

Johannes Leivonen teki varsinaisen ehdotuksen äänestyksestä: mikäli perustevaliokunnan esittämät lakimuutokset hylättäisiin, "kirkolliskokous antaisi KL 529 §:n 2 mom. 2 kohdassa tarkoitetun uskoon ja oppiin pohjautuvan periaatteellisen kannanoton" asiasta. ${ }^{397}$ Leivonen mainitsi erikseen Kansanahon ehdotuksesta syntyneen kirkkolain kohdan. Oli selvästi kyse kannanotosta, joka edellyttäisi kolmen neljäsosan määräenemmistöä. Seuranneen, suunniteltua pidemmäksi venähtäneen ruokatauon tapahtumista ei ole enää mahdollista saada tarkkaa tietoa. Joka tapauksessa ne johtivat Kotimaa-lehdessä pitkälliseen keskusteluun, johon osallistui aktiivisesti myös naispappeuden vastustajien yhteistyöverkostoksi perustettu Paavalin synodi ${ }^{398}$. On ilmeistä, että ruokailun ohessa kokouksen puheenjohtajat ja oikeusneuvos Leivonen pohtivat kysymystä määräenemmistöstä.

Heti tauon päätyttyä varapuheenjohtaja Lars Erik Taxell ehdotti, että viittaukset määräenemmistösäännöksiin jätettäisiin ponnesta pois, jolloin kirkolliskokous voisi päättää asiasta yksinkertaisella enemmistöllä. Taxellin mukaan kirkolliskokous "määrittelisi kantansa periaatteelliseen kysymykseen, onko naispappeus kirkkomme uskon ja opin pohjalta mahdollinen". ${ }^{399}$ Taxellin sanat periaatteellisesta kannasta uskon ja opin pohjalta olivat kuitenkin kuin suoraan siitä määräenemmistöä edellyttäneestä kirkkolain kohdasta, jota koskevan maininnan hän oli ehdottanut poistettavaksi.

Taxellin ehdottamassa äänestyksessä enemmistö edustajista ilmoitti äänin 70-33 kannattavansa periaatteessa naispappeutta. Jaa-äänen antoi muutama edustaja enemmän kuin varsinaisessa kirkkolakia koskeneessa äänestyksessä, mutta määräenemmistöön numerot eivät olisi riittäneet. Arkkipiispa Simojoki ilmoitti kirkolliskokouksen ilmaisseen "kantanaan, että naispappeus on kirkkomme uskon ja opin pohjalta mahdollinen".400 
Simojoki ei maininnut "periaatteellisesta" kannasta, mutta muuten toistuivat samat sanat kuin ponnesta poistetussa lainkohdassa. Myöhemmin Simojoki totesi äänestysmenettelyä arvostelleille, että kyseessä ei ollut kirkkolain määräenemmistösäännöksissä tarkoitettu kirkon uskoa ja oppia koskeva periaatteellinen kannanotto. ${ }^{401}$

Tulkitsijasta riippuu, mistä kirkolliskokouksen katsotaan päättäneen, kun se äänesti Taxellin ponnesta. Asiallisesti ponsi ei tuonut mitään lisää kirkolliskokouksen päätökseen: jo se, että yksinkertainen enemmistö oli ollut valiokunnan mietinnön takana ja puolustanut naispappeuden välitöntä toteuttamista, olisi riittänyt osoittamaan, että enemmistö edustajista piti naispappeutta kirkon uskon ja opin kannalta mahdollisena. Äänestys Taxellin ponnesta osoittikin lähinnä vain kirkkolain määräenemmistösäännösten tulkinnanvaraisuuden. Vuonna 1976 kirkolliskokouksen johdon tulkinta oli, että kirkolliskokous saattoi itse päättää, milloin se sovelsi määräenemmistösäännöksiä ja katsoi jonkin uskoa sekä oppia koskevan kannanoton erityiseksi kirkon periaatteelliseksi kannanotoksi ${ }^{402}$. Ongelmana oli, että kirkkolaki ei sisältänyt mainintaa tällaisesta kirkolliskokouksen omasta harkintavallasta.

Teologian tohtori Olavi Tarvainen kyseenalaisti ensimmäisenä yksinkertaisella enemmistöllä toimitetun äänestyksen Kotimaa-lehdessä. Tarvainen oli ollut vuoden 1971 ylimääräisessä kirkolliskokouksessa toimineessa kirkon hallintovaliokunnassa sorvaamassa puheena ollutta kirkkolain kohtaa. Oikeusneuvos Leivonen selitti vastauksessaan, ettei kirkolliskokous ollut ratkaissut kirkon kantaa asiassa. Sen sijaan kokouksen jäsenet olivat vain ilmaisseet oman käsityksensä. Samasta asiasta oli Leivosen mukaan ollut kyse silloin, kun uusimuotoinen kirkolliskokous oli yksinkertaisella enemmistöllä antanut valtioneuvostolle uskoon ja oppiin pohjautuvia lausuntoja lakiuudistuksista. ${ }^{403}$ Kaikkiaan uusimuotoinen kirkolliskokous näyttääkin tulkinneen lainkohdan huomattavasti suppeammaksi kuin asiaa aikoinaan valmistellut valiokunta, jonka mukaan lainkohdan alle kuuluivat esimerkiksi kirkon uskoon pohjautuvat sosiaalieettiset kannanotot. ${ }^{404}$

Leivonen perusteli myöhemmin, että määräenemmistösäännöksen käytöstä oli haluttu luopua, koska niin myönteisen kuin kielteisen kannanoton oli havaittu jäävän ilman määräenemmistöä. ${ }^{05}$ Päivällistauon keskus- teluissa haluttiin siis saada aikaan jokin selvä kannanotto. Kyse ei sittenkään ollut vain siitä, että kirkolliskokous olisi omassa keskuudessaan selvitellyt kantaansa asiaan. Se olisi onnistunut, vaikka määräenemmistösäännöstä olisikin sovellettu. Kirkolliskokouksen päätöksen alla uhkaukset erota kirkosta, mikäli pappisvirkaa ei avattaisi naisille, olivat saaneet paljon julkisuutta ${ }^{406}$. Leivosen perustelut osoittavat, että kirkolliskokouksen johtohenkilöt halusivat jo ennakolta tyynnyttää kielteisen naispappeuspäätöksen saamaa julkisuutta tiedolla siitä, että kirkolliskokous oli periaatteessa naispappeuden kannalla. Toisaalta tällainenkin periaatepäätös oli kirkolle ongelmallinen: jos kerran opillisia esteitä naisten pappeudelle ei ollut, kirkolliskokouksen päätöksen perusteluja oli helppo etsiä julkisuudessa epätasa-arvoisesta ja patriarkaalisesta ajattelutavasta ${ }^{407}$.

Kirkolliskokouksen äänestys oli tavallaan myös osa paikan määrittämistä Rooman ja Geneven välissä. Jo perustevaliokunnan mietintöä esitellessään piispa Nikolainen oli todennut voimakkaasti, että kirkko uhkasi eristäytyä muista luterilaisista kirkoista, jos se liiaksi kallistui joko katolisen oppitradition tai reformoidun kristikunnan konservatiivisten ryhmien suuntaan ${ }^{408}$. Tästä näkökulmasta naispappeuden toteaminen luterilaisen opin mukaiseksi erillisellä äänestyksellä oli rajanvetoa sekä Roomaan että Geneveen. Vaikka ekumenia ei ollut näkyvin teema kirkolliskokouksen virkakeskustelussa, Teinosen johtaman virkakomitean vahvasti teologinen lähestymistapa johti siihen, että naispappeuskeskustelu oli 1970-luvun puolivälissä hyvin teologisesti painottuneessa vaiheessa.

Naispappeutta koskeneiden äänestysten jälkeen käsittelyyn tuli perustevaliokunnan mietintö lehtorinviran kehittämisestä. Monet edustajat näkivät siinäkin pyrkimyksiä edistää naispappeutta. Erityisesti lehtoreille ehdotetut uudet jumalanpalvelustehtävät jakoivat mielipiteitä. Mietinnön mukaan lehtorinvirkaa oli määrä kehittää "saarnaviran puitteissa" erityisvirkana. ${ }^{409}$ Eero Parvio vertasi sanoja Troijan puuhevoseen, jonka avulla lehtorit oli naispappeuden kaaduttua tarkoitus kuljettaa vaivihkaa pappisviran, saarnaviran, piiriin. Mikko Juva myönsi avoimesti, että naiset oli tarkoitus kuljettaa mietinnön avulla pappisviran sisälle mutta ei salaa vaan hevosen päällä. Keskustelussa Juvan ja Parvion välille syntyi osittain henkilöönkin käyvää piikittelyä, ja 
samalla paljastui, ettei valiokunnassa ollut naispappeuttakaan käsiteltäessä ollut niin hyvä henki kuin sen jäsenet olivat antaneet ymmärtää. ${ }^{40}$ Onkin luultavaa, että tiedotusvälineiden tiivis mielenkiinto naispappeuskeskustelua kohtaan sai pitämään piilossa ne jännitteet, jotka sitten lehtorinvirkaa ruodittaessa purkautuivat esiin. Lehtorinviran käsittely poikkesi naispappeusäänestyksestä myös sikäli, ettei lopputulos ollut ennalta tiedossa. Epävarmuus oli omiaan kiristämään ilmapiiriä.

Myös lehtorinviran käsittelyn loppuvaiheita leimasi kiire. Tyytymättömänä virkakomitean ehdotuksiin perustevaliokunta laati lakimuutosehdotuksensa lähes puhtaalta pöydältä. Jälleen kirkolliskokous oli paineen alla, ja monet - eivät vähiten lukuisat teologisen koulutuksen saaneet naiset - odottivat siltä selvää vastausta. Virkakomitean teologiset pohdinnat joutuivat monissa kohdin antamaan tietä käytännön odotuksille. ${ }^{411}$ Kiireessä valiokunta joutui tuomaan täysistuntoon ensin keskeneräisen tekstin ja sitten viimeistelemään seuraavaksi päiväksi - piispa Nikolaisen sanoin "kaikki voimat työhön ja yöhön heittäen" - lopullisen mietintönsä. ${ }^{412}$

Lopullisessa mietinnössään valiokunta tuli naispappeuden vastustajia vastaan. Valiokunta esimerkiksi määräsi kirkkoherra Olli Heilimon ehdotuksesta rajoituksen, että lehtorin saarnaaminen jumalanpalveluksessa edellytti kirkkoherran lupaa. Samalla kiistaa aiheuttaneet sanat "saarnaviran puitteissa" poistettiin mietinnöstä. ${ }^{413}$ Kaikki eivät olleet valmiita hyväksymään rajoitettuakaan saarnaoikeutta. Tiukinta linjaa edusti piispa Leinonen, joka ei halunnut antaa lehtorille lupaa osallistua myöskään konfirmaation toimittamiseen. Pappislinjan lestadiolaisuuteen lukeutunut piispa sai tuekseen vanhoillislestadiolaiset edustajat. ${ }^{414}$ Lopullisessa äänestyksessä valiokunnan esitys sai taakseen määräenemmistön selvin numeroin 97-7.415 Samalla syntyi käytännössä pappisviran tapainen pysyvä lehtorinvirka, vaikka virallisesti lehtorinvirka määriteltiinkin kirkkolaissa yksittäiseen seurakuntaan sidotuksi maallikkoviraksi. ${ }^{416}$

Virkakomitean työn ja kirkolliskokouksen vuosien 1975-1976 istuntokausien suurimman merkityksen voi nähdä siinä, että keskustelu virkateologiasta selkiintyi tietyin osin: funktionalistisen ja konstitutiivisen virkakäsityksen välinen vastakkainasettelu, joka kevään 1975 istuntokaudella oli näkynyt selvästi, lieventyi. Konstitutiivista käsitystä mietinnöissään edustanut virkakomitea oli valmis pehmentämään käsitystään siitä, mitä seikkoja Raamattu määräsi kuuluvaksi viran pysyvään säätämykseen. Näin matalakirkollista virkateologiaa edustaville tuli aiempaa helpommaksi hyväksyä komitean virkakäsityksen lähtökohdat ja ajatus pappisviran jumalallisesta säätämyksestä.

Perusjännitteenä säilyi kuitenkin se, että naispappeuden vastustajien mielestä konstitutiivinen virkakäsitys edellytti pappisviran säilyttämistä miehen virkana. Konstitutiivisen virkakäsityksen osakseen saama lisääntyvä hyväksyntä toi siten uusia ongelmia naispappeuden puolustajille tilanteessa, jossa paine uudistuksen aikaansaamiseksi oli kova. Virkateologisten seikkojen pitkälliselle ja laaja-alaiselle pohdinnalle ei yksinkertaisesti jäänyt aikaa eikä tilaa. Esimerkiksi 1975 kiistaa herättänyt kysymys viran kolmisäikeisyydestä jäi nopeasti syrjään. Naispappeudesta tuli käytännössä se ikkuna, jonka kautta virkakomitean loppumietintöä katsottiin. Komitean ajatus uudesta diakonaatista ja lehtorin sijoittamisesta siihen hylättiin vähin äänin, minkä myötä myös keskustelu diakonian viran uudistamisesta lakkasi kirkossa lähes kokonaan ${ }^{417}$.

\section{LEUENBERGIN KONKORDIA HERÄTTÄ̈̈ HUOLEN "LUTERILAIS-SUOMALAISESTA" KRISTILLISYYDESTÄ}

Toisen maailmansodan jälkeen Saksan reformatoriset kirkot olivat perustaneet kirkkoliiton ja vähitellen pyrkineet myös saarnatuoli- ja ehtoollisyhteyteen jäsenkirkkojen kesken. ${ }^{418}$ Yhteyspyrkimykset voimistuivat 1960-luvulta lähtien. Tuolloin kahdenväliset oppikeskustelut saivat ylipäätään painoa ja kirkkoliitot alkoivat enenevästi omaksua ekumeenisia tehtäviä. ${ }^{419}$ Prosessi huipentui maaliskuussa 1973. Euroopan luterilaisten, reformoitujen ja unioitujen kirkkojen edustajat hyväksyivät silloin ehdotuksen kirkolliseen yhteyteen johtavaksi asiakirjaksi. Tämän Leuenbergin konkordian päämääränä oli muodostaa opillinen perusta kirkolliselle yhteydelle niin, että konkordian hyväksyneet kirkot pysyivät itsenäisinä ja säilyttivät oman tunnustuksensa muuttumattomana. Aiemmin lausutut molemminpuoliset oppituomiot eivät kuitenkaan konkordian mukaan koskeneet kirkkojen vallinnutta opillista kantaa. ${ }^{420}$

Pohjolan luterilaiset kirkot eivät kiirehtineet mukaan konkordiaan. Vuonna 1976 kirkolliskokous sai asiaa 
pitkään harkinneelta piispainkokoukselta esityksen, jonka mukaan Suomen luterilainen kirkko jättäytyisi konkordian ulkopuolelle. Valmisteluissa, joissa erityisesti dosentti Tuomo Mannermaan rooli oli ollut keskeinen, oli todettu epäselvyyksiä kirkollisen yhteyden käsitteessä sekä konkordian suhteessa tunnustukseen. Niin ikään konkordian metodiin sisältyi ongelmia. Piispainkokous perusteli esitystään myös sillä, ettei konkordialla ollut merkitystä kirkollisille oloille Suomen kaltaisessa maassa, jossa ei ollut vanhastaan juurikaan reformoitua kristillisyyttä. ${ }^{221}$ Vaikka piispainkokous ei puoltanut konkordian hyväksymistä, se ehdotti pyrkimistä ehtoollisyhteyteen asiakirjan hyväksyneiden ei-luterilaisten kirkkojen kanssa ja osallistumista konkordiaan liittyviin opillisiin keskusteluihin. ${ }^{422}$ Keskeisin osa piispainkokouksen esitystä oli ehdotus Kirkkojen maailmanneuvoston Faith and Order -komissiolle osoitettavaksi kirjeeksi, jolla Suomen luterilainen kirkko perustelisi kantansa konkordiaan. ${ }^{423}$

Arkkipiispa Simojoki oli osoittautunut piispoista kriittisimmäksi konkordiaa kohtaan. Hän pelkäsi sen vievän tielle, joka johtaisi lopulta luterilaisuuden häviämiseen. ${ }^{224}$ Simojoki seurasi virkakysymyksestä käytyä keskustelua lähinnä sivusta ja kapusi kirkolliskokouksessa muutenkin harvoin puhujakorokkeelle, mutta tällä kertaa hän otti ohjat käsiinsä ja varasi ensimmäisen puheenvuoron. Hänen mukaansa asiassa ei ollut kyse vähemmästä kuin "luterilaisuuden olemuksesta ja sen säilymisestä meidän kirkossamme, luterilaisesta identiteetistä Suomen evankelis-luterilaisessa kirkossa". Simojoki arvosteli voimakkaasti sitä, ettei suomalaisten huomautuksia ollut otettu huomioon konkordiatekstiä valmisteltaessa. Hän esitti lukuisia terävöityksiä Faith and Order -komissiolle tarkoitettuun kirjeluonnokseen. ${ }^{425}$

Piispat Nikolainen ja Kansanaho, jotka olivat aiemmin olleet konkordian puolella, antoivat tunnustusta konkordialle mutta katsoivat, ettei sitä voinut hyväksyä. Aiemmin eri suuntiin vetäneet piispat vastustivat nyt yhtenäisesti konkordian hyväksymistä. Yhteisymmärrys oli saavutettu, kun piispainkokouksen esitykseen oli sisällytetty myös konkordian kannalta myönteistä ainesta. Epäilemättä nähtävissä oli vahvasti myös arkkipiispa Simojoen auktoriteetti. Teologeista vain Mikko Juva, joka katsoi asiaa Luterilaisen maailmanliiton presidentin teh- tävistä käsin, asettui puolustamaan konkordian hyväksymistä. ${ }^{226}$ Käytännöllisiä seikkoja painottanut Juva oli jälleen vastakkain teologisia erityisvaatimuksia korostavien kanssa - aivan samoin kuin keskusteltaessa toimikuntauudistuksesta ja virkakysymyksestä.

Lähetekeskustelusta tuli piispojen ja ekumeenikkojen keskustelu- ja osin esitelmätilaisuus, jonka lopuksi kolme pohjoisen persoonallista maallikkoa avasi suunsa. He olivat niitä, jotka uskalsivat puhua vaikeistakin opillisista kysymyksistä. Myyntijohtaja Erkki Reinikainen esitti vanhoillislestadiolaisten kannan, jonka mukaan kirjelmäehdotus oli liian myönteinen jatkokäsittelylle. Rafael Nyqvist taas vei jälleen huomion maapallon energiasektorin rajallisuuteen ja totesi sen edellyttävän myös kristittyjen keskinäistä vuoropuhelua. Lopuksi Väinö Vähäsarja toi terveiset kotiseudultaan, missä Leuenbergin konkordiasta ei hänen mukaansa tiedetty mitään: "Siinä on vain kaksi sanaa, joita kainuun murretta puhuva ei osaa edes oikein lausua, kun vieraskielisiä kirjaimiakin on monta. Ja joidenkin mieleen tulee jopa lentokone, joka on ääntä nopeampi.” ${ }^{427}$ Näiden puheenvuorojen myötä keskustelu konkordiasta asettui suunnilleen sille paikalle, joka sillä oli seurakuntalaisten näkökulmasta.

Perustevaliokunnan jäsenet jakautuivat mielipiteiltään kahteen yhtä suureen ryhmään. Kummallakin oli eri selitykset sille, miksi Suomen luterilainen kirkko ei voinut hyväksyä konkordiaa. Puheenjohtaja Nikolaisen ympärille muodostui ryhmä, joka oli piispainkokouksen esityksen kannalla ja jonka mukaan ongelmat löytyivät konkordian sisällöstä. Varapuheenjohtaja Juvan ympärille taas kerääntyivät ne, joiden mielestä konkordian hyväksymisen esteenä olivat Suomen luterilaisen kirkon hajanaisuus ja ennakkoluulot. Sihteeri Heikki Mäkeläinen sai tehtäväkseen laatia ensin mainitulta kannalta mietinnön pohjatekstin, kun taas Juva laati pohjatekstin jälkimmäisestä näkökulmasta. Konkordiaa kohtaan kriittisintä kantaa edustanut Eero Parvio laati vielä konkordian ongelmista muistion, jossa hän vetosi erityisesti niin sanotuissa Ratzeburgin teeseissä lausuttuun kritiikkiin. ${ }^{428}$ Tässä kohtaa Suomen Luterilaisen Evankeliumiyhdistyksen (SLEY) kädenjälki tuli näkyviin asian kirkolliskokouskäsittelyssä. Teologian lisensiaatti Simo Kiviranta oli 1972 osallistunut SLEY:n lähettämänä Ratzeburgissa alkaneeseen Leuenbergin konkordialuon- 
noksen vastaiseen prosessiin. ${ }^{429}$ Samaan herätysliikkeeseen lukeutunut Parvio piti puolestaan huolen siitä, että tämän työskentelyn tulokset pääsivät esille perustevaliokunnan valmistelussa.

Virkakysymyksen ja Leuenbergin konkordian valmisteluvaiheet osoittavat, miten voimakkaasti opillisten asioiden valmistelu perustevaliokunnassa keskittyi Nikolaisen, Juvan ja Parvion henkilöihin. Kun valiokunnan lainoppineet jäsenet olivat olleet syrjässä omantunnonklausuulia koskeneesta valmistelutyöstä, Leuenbergin konkordiaa käsiteltäessä saman osan sai valiokunnassa istunut systemaattisen teologian asiantuntija, teologian tohtori Yrjö Salakka. Näin oli siitäkin huolimatta, että oppialan tuntemus oli aihepiirin kannalta hyvin tärkeää. Eri kannoilla olleiden edustajien laatimista valmisteluasiakirjoista valiokunta muodosti mietintönsä siten, että asiakirjat käytännössä liitettiin yhteen.

Mietinnön sanat opillisesta yksimielisyydestä kuvastivat tällä menetelmällä saavutettua lopputulosta. Valiokunnan mukaan opillinen yksimielisyys ei tarkoittanut koko "dogmatiikkaa" vaan sitä, että kirkoissa yksimielisesti saarnattiin puhtaasti käsitettyä evankeliumia ja sakramentit jaettiin Jumalan sanan mukaisesti. Lausumaa seurasi Parvion vaatima lisäys: "Tietenkin tähän liittyvät kaikki Augsburgin tunnustuksen artikloissa mainitut opetukset, koska evankelinen oppi muodostaa eheän kokonaisuuden." ${ }^{330}$ Parvion lisäys vei mietintöä takaisin sille linjalle, jota Saksan luterilaiset olivat edustaneet 1950-luvulla luterilaisten ja reformoitujen keskusteluissa. ${ }^{431}$ Samalla syntyi jännite edellä lausuttuun: piispainkokouksen asettama työryhmä, jonka lausumaa tästä asiasta valiokunta oli juuri aiemmin moittinut sanonnaltaan epäonnistuneeksi, oli edustanut pitkälti Parvion mainitsemaa käsitystä. ${ }^{432}$

Valiokunta jatkoi toteamalla, ettei Leuenbergin konkordia ollut "täysin tyydyttävästi selvittänyt evankeliumin yhteisen käsittämisen sisällystä" ${ }^{333}$ Samaa tosin saattoi sanoa siitä, miten valiokunta itse oli tiivistänyt opetuksensa tästä asiasta pari virkettä aiemmin. Avatessaan kevään 1976 kirkolliskokouksen, jossa Leuenbergin konkordia tuli lähetekeskusteluun, arkkipiispa Simojoki oli johdattanut edustajia opillisten kysymysten käsittelyyn: "Kirkolliskokous ei voi toimia samalla tavalla kuin jonkin puolueen puoluekokous, jossa - - saadaan aikaan kompromissi, johon kukaan ei lopulta ole tyytyväinen ja joka on aiheena jatkuviin riitoihin." ${ }^{434}$ Perustevaliokunta kykeni saamaan aikaan juuri tällaisen kompromissin. Voimasuhteet eri näkökantojen kesken olivat valiokunnassa melko lailla tasapainossa, joten kaikesta päätellen valiokunta pyrki puheenjohtajansa johdolla kaikin keinoin välttämään eriäviä mielipiteitä. Muodollisesta yksimielisyydestä huolimatta mietinnön ristiriitainen sisältö kyseenalaisti arkkipiispa Simojoen korostuksen, jonka mukaan konkordian ulkopuolelle jättäytyminen ei johtunut Suomen luterilaisen kirkon sisäisistä erimielisyyksistä vaan konkordian ongelmista.

Mietinnön sisäiset jännitteet heijastuivat myös Faith and Order -komissiota varten laadittuun kirjeluonnokseen. Simojoen lähetekeskustelussa ehdottamat muutokset päätyivät hyvin suurelta osin kirjeluonnokseen, mutta myös Juva sai siihen kädenjälkensä. ${ }^{435}$ Simojoen asemaa asian käsittelyssä kuvasti, että esitellessään perustevaliokunnan mietintöä suuressa salissa piispa Nikolainen joutui jo etukäteen perustelemaan ja puolustelemaan sitä, että valiokunta ei ollut sellaisenaan toteuttanut kaikkia Simojoen vaatimia muutoksia. Sen sijaan niitä kohtia, joissa valiokunta oli muuttanut omaaloitteisesti piispainkokouksen ehdotusta, hänen ei tarvinnut samalla tavalla perustella. ${ }^{436}$

Vastakohdiksi nousivat Simojoen laajaa tukea saanut tulkinta, jonka mukaan Leuenbergin konkordiaa oli arvioitava nimenomaan opillisesti, ja Juvan kanta, että kyseessä oli puhtaasti kirkko-oikeudellinen asiakirja. Täysistunnossa Juva kutsui konkordiaa ystävyys-, yhteistyö- ja avunantosopimukseksi, kuten konkordian puolustajat olivat muissakin yhteyksissä tehneet. ${ }^{437}$ Vertaus oli ovela: harva 1970-luvun Suomessa halusi väittää, että YYA-sopimuksen myötä kotimaa olisi luopunut oikeudestaan määrätä sisäisistä asioistaan. Toisaalta vertaus oli riskialtis, saattoihan se luoda mielikuvan sopimuksesta, jonka sopijaosapuolet olivat voimasuhteiltaan ja vaikutusmahdollisuuksiltaan kaikkea muuta kuin tasaväkisiä.

Simojoki oli tyytymätön valiokunnan ehdottamaan kirjeluonnokseen ja vihjasi sivulauseessa, että asia oli syytä palauttaa perustevaliokuntaan. Valiokunnan puheenjohtaja Nikolainen teki omat johtopäätöksensä ja pyysi asian takaisin valmisteluun. ${ }^{438}$ Jatkokäsittelyssä valiokunnan oli valittava puolensa, ja enemmistö päätyi arkkipiispan ja John Vikströmin edustamalle kannalle. 
Vähemmistö jätti nyt Juvan johdolla eriävän mielipiteen ja ehdotti lisäpontta, jonka mukaan piispainkokous tekisi konkordiaan liittymisestä esityksen kirkolliskokoukselle soveliaana ajankohtana. ${ }^{439}$

Lopullisessa äänestyksessä perustevaliokunnan toinen mietintö hyväksyttiin äänin 94-5. Kirkolliskokous ei hyväksynyt konkordiaa mutta kehotti kirkon ulkomaanasiain toimikuntaa huolehtimaan osallistumisesta konkordiaan liittyviin jatkokeskusteluihin ja valmistelemaan kysymystä ehtoollisyhteydestä konkordian hyväksyneiden ei-luterilaisten kirkkojen kanssa. Juvan ehdottama, eriävän mielipiteen sanamuodosta hieman lievennetty lisäponsi hävisi melko niukasti kymmenellä äänellä. ${ }^{440}$ Keskusteluissa puhujakorokkeelle nousivat piispojen lisäksi lähinnä vain vastakkaisia kantoja edustaneet valiokunnan papit Juva ja Parvio sekä muutama vanhoillislestadiolainen maallikkoedustaja.

Leuenbergin konkordia ei ollut seurakuntien tasolla oleellinen tai jännittynyt kysymys. Asiaa kuvasi hyvin arkkipiispa Simojoen toiminta kirkolliskokouksessa. Herkkää naispappeuskysymystä käsiteltäessä hän vetäytyi taustalle ja yritti pysyä hajottavan keskustelun ulkopuolella. Sen sijaan hän johti suvereenisti Leuenbergin konkordian käsittelyä sen kaikissa vaiheissa kirkollis-

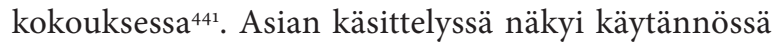
se kirkkolakiin kirjattu periaate, jonka mukaan arkkipiispalla oli suuri vastuu kirkon ekumeenisista suhteista. Kirkolliskokouksen panos asiassa jäi melko vähäisek$\mathrm{si}^{442}$. Konkordiaa käsitellessään se oli kuin eräänlainen laajennettu piispainkokous, joka lähinnä seurasi yleisönä arkkipiispan ja Luterilaisen maailmanliiton presidentin välistä kädenvääntöä sekä muiden piispojen puheenvuoroja. Lars Erik Taxell kyseenalaistikin sen, että kirkolliskokous joutui päättämään yksin näin vaikeista opillisista kysymyksistä443. Perustevaliokunta yritti pientä irtiottoa arkkipiispan ja myös piispainkokouksen ehdotuksista, mutta valiokunnan ehdotukset saivat tylyn tuomion heti täysistunnossa. ${ }^{444}$

Asian kirkolliskokouskäsittely ei kuitenkaan jäänyt sisällöltään täysin merkityksettömäksi. Juuri perustevaliokunnan valmistelussa ja täysistunnon puheenvuoroissa nousi erityisen selvästi esiin kysymys kirkon luterilaisesta identiteetistä ja paikasta ekumeenisessa kentässä. ${ }^{445}$ Kirkolliskokousedustajista Mikko Juva oli erityisen selvästi lähellä Geneveä niin virkakeskustelussa kuin
Leuenbergin konkordiaa käsiteltäessä. Hänen asenteensa luterilaisuuden katolisia juuria painottaneeseen systemaattisen teologian tutkimukseen oli hyvin kriittinen. Tuomo Mannermaan johtamassa Leuenbergin konkordian analyysissa ei Juvan mukaan ollut kyse muusta kuin siitä, että "systemaattisen teologian parhaat aivot haaskaavat aikaansa". "Minä en suoraan sanoen jaksa olla kiinnostunut herrojen merkityksettömistä puuhailuista”, hän parahti kirjoittaessaan Simojoelle. ${ }^{446}$

Eero Parvio taas oli voimakkain yksittäinen Rooman "äitikirkon" perintöä puolustanut reformaation oikean laidan edustaja. Näiden kahden ääripään välillä valtaenemmistö kirkolliskokousedustajista oli niitä, jotka halusivat pysytellä tarpeeksi etäällä niin Roomasta kuin Genevestä. Jotkut tästä joukosta halusivat avata pappisviran naisille eivätkä tunteneet vetoa virkakomitean esittelemiin teologisiin yksityiskohtiin. Heistä nekin, jotka ehkä olisivat olleet valmiita liittymään konkordiaan, tyytyivät mukisematta piispojen yksimieliseen kantaan, joka sitä paitsi merkitsi pitäytymistä tässä asiassa Pohjoismaiden kirkkoperheen näkemykseen. Pohjolan kirkkojen keskinäisellä yhteydellä oli luontevaa samaan aikaan puolustaa naispappeutta ja vastustaa Leuenbergin konkordiaa.

Toiset Roomaan ja Geneveen etäisyyttä pitäneet taas lukeutuivat naispappeutta vastustavaan herätysliikeväkeen, jonka raamatuntulkinnassa saattoi nähdä pietismin kautta siivilöityneitä reformoidun raamattukäsityksen piirteitä. Se ei kuitenkaan tarkoittanut, että nämä edustajat olisivat tunteneet minkäänlaista yhteyttä reformoituihin. Erityisen selvän pesäeron kaikenlaiseen ekumeniaan halusivat tehdä vanhoillislestadiolaiset edustajat ${ }^{447}$. Heidän lisäkseen jotkut viidenteen herätysliikkeeseen lukeutuvat kirkolliskokouksen jäsenet edustivat teologista, ehdotonta ekumeniakritiikkiä. Näitä edustajia oli eniten Mikkelin hiippakunnan penkkirivillä - olihan hiippakunta viidesläisyyden vahvaa tukialuetta ${ }^{448}$. Yksi julistukseltaan selväsanainen ja mielipiteitäkin jakanut hiippakunnan maallikkoedustaja oli vuosina 1974-1977 Mikkelin lääninvankilan johtaja Sulo Laine, joka seuraavalla vuosikymmenellä toimi helluntaiseurakunnan saarnaajana. ${ }^{449}$ Vaikka varsinkin maallikkoedustajien keskuudessa oli tiettyä penseyttä kirkon johdon kansainvälistä osallistumista ja siihen ehdotettuja määrärahoja kohtaan, useimmat kokousedus- 
tajat lähestyivät ekumeniaa käytännöllisesti ja ilman voimakkaita mielipiteitä. Heidän mielestään kaukaisessa Pohjolassa ei tarvinnut sekaantua Keski-Euroopan kiistoihin ja ruveta määrittelemään aiempaa tarkemmin omaa paikkaa Rooman ja Geneven välissä.

Kirkon suomalaiskansallinen identiteetti nousi esiin kirkolliskokouksen käsitellessä Leuenbergin konkordiaa ja yllättäen erityisen selvästi Aimo T. Nikolaisen puheissa. Hänen mukaansa kirkolliskokousedustajat eivät voineet hyväksyä "oman luterilais-suomalaisen kirkkomme identiteetin alttiiksi antamista vähäisessäkään määrin" 450 . Vielä toisen kerran hän painotti, että kirkon tuli säilyttää "luterilainen ja suomalainen" identiteetti. ${ }^{451}$ Evankelis-luterilainen kirkko muuttui hänen sanastossaan "luterilais-suomalaiseksi" kirkoksi. Evankelisuus - mikäli sillä tarkoitettiin Keski-Euroopan kirkkojen yleisevankelisen ajattelutavan leimaamia yhteyspyrkimyksiä - sai antaa tilaa suomalaisuudelle. Sen enempää luterilaisuutta kuin suomalaisuuttakaan ei saanut asettaa uhanalaiseksi. Naispappeuskeskustelussa Nikolainen oli painottanut, että kyse oli kirkon paikasta evankelisessa kristikunnassa eikä vain siitä, "miten me tällä omalla niemellämme omat sisäiset kysymyksemme hoidamme" ${ }^{\prime 52}$. Leuenbergin konkordiaa käsiteltäessä hän heräsi korostamaan myös suomalaisen kristillisyyden säilyttämistä "tällä omalla niemellämme".

Helsingin yliopiston systemaattisen teologian tutkijat olivat avainpaikalla keskusteltaessa niin virkakysymyksestä kuin Leuenbergin konkordiasta, mutta kirkolliskokouksessa heitä ei ollut. Dogmatiikan professori Osmo Tiililä oli aikoinaan polttanut sillat kirkon johtoon, eikä hänen seuraajansa Seppo A. Teinosen suorasukainen tyyli helpottanut niiden rakentamista uudelleen. Arkkipiispa Simojoki kyllä kuunteli systemaatikkoja erityisesti Leuenbergin konkordian osalta, mutta kirkon johdossa oli myös sellaisia muiden teologisten oppiaineiden edustajia kuten Erkki Kansanaho, Aimo T. Nikolainen ja Mikko Juva, jotka puhuivat sangen erilaista kieltä kuin Teinonen ja hänen koulukuntansa. Systemaattisen teologian tutkijoiden ja kirkolliskokouksen välisestä rajaaidasta ei voinut syyttää kirkon keskushallinnon uudistusta ja teologisen tiedekunnan edustajan poistumista. Tiedekunnan edustajat oli valittu viimeisiin vanhamuotoisiin kirkolliskokouksiin muista oppiaineista kuin systemaattisesta teologiasta ${ }^{453}$.
Myös Leuenbergin konkordia nosti esiin kirkkolain määräenemmistösäännösten tulkinnan. Täysistuntokäsittelyä johtanut varapuheenjohtaja Taxell katsoi, että perustevaliokunnan mietinnön hyväksyminen edellytti kolmen neljäsosan määräenemmistöä. ${ }^{454}$ Hänen mielestään kyse oli kirkkolain tarkoittamasta uskoa ja oppia koskevasta periaatteellisesta kannanotosta. ${ }^{455}$ Tulkinta oli sikäli luonteva, että piispa Kansanaho oli jo 1971 perustellut kyseistä kirkkolain säännöstä juuri ekumeenisten asiakirjojen synnyttämällä tarpeella. Myös piispainkokous viittasi esityksessään kyseiseen lainkohtaan perusteluna sille, että se siirsi asian kirkolliskokouksen ratkaistavaksi ${ }^{456}$.

Aimo T. Nikolainen puolestaan korosti, että valiokunta "ei todellakaan" ollut ehdottanut mietintöä määräenemmistön vaativaksi asiaksi. Hän antoi ymmärtää, että vain konkordian hyväksyminen olisi edellyttänyt kolmea neljäsosaa äänistä. ${ }^{457}$ Uusimuotoisen kirkolliskokouksen alkuvuosina ei päästy täyteen selvyyteen siitä, miten uutta kirkkolain kohtaa ja määräenemmistösäännöksiä oli tulkittava. Avauspuheessaan keväällä 1974 arkkipiispa Simojoki oli viitannut tuohon lainkohtaan todeten, että siinä mainittua tehtävää toteuttamalla kirkolliskokouksen oli otettava kantaa kansakunnan elinkysymyksiin ${ }^{48}$. Ainoa päätös, jossa tuota lainkohtaa sitten sovellettiin, koski sanamuotoa, jolla kirkolliskokous perusteli jättäytymistä Leuenbergin konkordian ulkopuolelle. Päätös ei varsinaisesti kuulunut "kansakunnan elinkysymyksiin". Niihin kirkolliskokous otti kantaa yksinkertaisella enemmistöllä.

\section{UUSI KANSANKIRKOLLINEN OHJELMA}

\section{"ROUTAVUOSIEN" PUOLUSTUSTAISTELUSTA KANSAN OMAKSITUNNOKSI}

Uudistetun kirkolliskokouksen aloittaessa työnsä elettiin vielä vasemmistoradikalismin vuosia. Samaan tapaan kuin yli kuuden vuosikymmenen takaisina "routavuosina" nytkin kirkossa oli jouduttu soveltamaan myöntyvyyspolitiikkaa suhteessa valtiovaltaan ja sopeutumaan lukuisiin epämieluisiin uudistuksiin. ${ }^{459}$ Kirkkovuoden kulkua oli suostuttu muuttamaan: kolme arkipyhää, loppiainen, helatorstai ja toinen helluntaipäivä, oli työmarkkinasovun saavuttamiseksi siirretty 
lauantaipäivään. Kirkossa oli pohdittu oman valtiollisen aseman osittaista purkamista, jottei asian ajaminen olisi jäänyt niille, jotka kirkon ulkopuolella vaativat rajuja muutoksia sen asemaan. Peruskoulu-uudistuksen ja viisipäiväiseen työviikkoon siirtymisen yhteydessä uskonnonopetuksen tuntimäärä uudessa peruskoulussa oli vähentynyt huomattavasti aiempaan verrattuna ${ }^{460}$. Vuonna 1969 valtio oli sallinut keskioluen myynnin ruokakaupoissa, ja alkoholin kulutus oli lähtenyt kasvuun. ${ }^{461}$

Uudistusmieli oli leimannut varsinkin vuoden 1968 kirkolliskokousta, mutta 1970-luvun edetessä muutosten vastaiset äänet voimistuivat. ${ }^{462}$ Yhteiskunnallinen aktiivisuus säilyi, mutta sen painopiste alkoi siirtyä maailmanlaajuisista eettisistä kysymyksistä suomalaisen yhteiskunnan ongelmiin ja asemien puolustamiseen. Esimerkiksi vuoden 1973 kirkolliskokous lähetti uskonnonopetuksen tilanteesta kirjelmän valtiovallalle ${ }^{463}$. Samaten kirkolliskokous puuttui abortteihin, joiden määrä oli 1973 huipussaan. Vuoden 1970 aborttilain myötä lailliset abortit olivat lisääntyneet voimakkaasti, vaikkakaan niiden määrä ei ollut kansainvälisesti vertailtuna poikkeuksellinen. ${ }^{464}$ Yleinen epävarmuus tulevaisuudesta näkyi kirkolliskokouksen työssä myös keväällä 1974. Arkkipiispa Simojoki julisti avauspuheessaan:

Kuta vähemmän kristilliset perusteet pääsevät vaikuttamaan maamme lainsäädäntöön, opetustoimeen ja muuhun kulttuurielämään, sitä tärkeämpää on, että kirkkomme piirissä - ja myös kirkolliskokouksen vastuulla - selvästi, aidosti ja asiantuntemuksella riittävän konkreettisesti tuodaan esiin kristillisen uskon pohjalta nousevat terveen elämän perusteet. Tämä on Jumalan sanan julistamista ja se kuuluu kirkolle. ${ }^{465}$

Näkemys, että asiat eivät olleet menossa ainakaan parempaan päin ja että kirkolliskokouksen oli toimittava määrätietoisesti, toistui kirkolliskokousedustajien puheissa. Piispa John Vikström totesi kohtalokkaaseen sävyyn: "Voi tulla aika, ja se voi olla lähellä, kun meidän on todella sanottava jotain vakavasti Suomen kansalle." ${ }^{466}$

Kirkolliskokouksessa kuultiinkin vahvoja kannanottoja. Kevään voimakkain taistelu- ja samalla hätähuuto kuului Vikströmin omasta tuomiokapitulista, joka puuttui uuden väestökirjalain seurauksiin. Väestörekisterikeskus vaati kirkkoherroilta ja seurakunnilta huomattavasti enemmän työtä kuin laki edellytti. Tehtävät veivät aikaa seurakunnan perustyöltä. ${ }^{467}$ Istuntosalissa valiteltiin, ettei kirkko ollut puolustautunut tarpeeksi ponnekkaasti. Kirkkoneuvos Ahti Auranen vakuutti kirkkohallituksen pitäneen tiukasti kirkon puolia mutta kohdanneen mahdollisuuksiensa rajat: "ministeriöllä näyttää olevan enemmän valtaa”. Keskustelun sanasto kuvasti ilmapiiriä: neuvottelut väestörekisterikeskuksen kanssa olivat olleet "hankalia", ja valtiovallan "hallitusherrojen" käytös oli ollut "töykeää" tai suorastaan "ihmisvastaista". ${ }^{468}$

Kevään 1974 keskustelujen perusteella ei välttämättä voinut uskoa, että kyse oli samasta kirkosta, joka usein oli kielteiseen sävyyn leimattu valtion liittolaiseksi. Turun yliopiston eläintieteen apulaisprofessori Hannu Suomalainen kehotti seurakuntia jättämään väestökirjanpitoasiat ruuhkautumaan. Ruotsinkielisillä oli vanhastaan ollut maine perustuslaillisen vastarinnan kannattajina, ja Ahvenanmaan kirkkoherrat olivat jo ryhtyneet lakkoon ylimääräisiksi katsottujen tehtävien osalta. ${ }^{669}$ Enemmistö maan papeista pysyi kuitenkin myöntyvyyslinjalla, kuten aikoinaan kutsuntalakkojenkin yhteydessä. Sen sai kokea myös edustaja Suomalainen, joka kertoi saaneensa moitteet "nykyisen hallitusvallan liian terävästä arvostelusta". ${ }^{470}$ Syysistuntokaudelle tultaessa keskustelu väestökirjanpidosta rauhoittui. Perustevaliokunta laati asiasta punnitun ja kiihkottoman mietinnön, ja täysistunnossa John Forsberg paheksui omassa hiippakunnassaan vallinneita asenteita. ${ }^{471}$ Muutos oli osittain samanlainen kuin kirkolliskokouksen suhteessa kirkkohallitukseen ja toimikuntiin: alkukriittisyys muuttui vähitellen luottamukseksi keskinäisen tutustumisen ja tarkemman asioihin perehtymisen myötä.

Porvoon ohella muistakin hiippakunnista tuli kirkolliskokoukselle ajankohtaisia ongelmia koskevia aloitteita. Uusimuotoisen kirkolliskokouksen alkuvaiheessa varsinkin puolen Suomen hiippakunta Oulu lähetti niitä pinta-alansa mukaisessa suhteessa ${ }^{472}$. Aloitteista näkyi, että hiippakunta oli perinteisesti poliittisesti aktiivista seutua ja samalla kantaa ottavan herätysliikkeen, vanhoillislestadiolaisuuden, vahvaa tukialuetta. Yhtään Oulun hiippakuntakokouksen neljästä yhteiskunnallisesta aloitteesta ei jätetty raukeamaan. Se oli huomattava ele, koska kirkolliskokous ei tuntenut erityistä sääliä hiippakuntakokousten aloitteita kohtaan. Kirkolliskokous oli 
huolissaan yhteiskunnan suunnasta, ja tässä tilanteessa se halusi tuoda julki arkkipiispan avajaispuheessaan mainitsemat "kristillisen uskon pohjalta nousevat terveen elämän perusteet".

Opetusministeri Ulf Sundqvist ei päässyt kevään 1974 istuntokaudelle sairastumisen vuoksi, mikä saattoi osaltaan ruokkia epäluuloja ja kirkolliskokouksessa kuultuja kovia puheenvuoroja. Opetusministeri ja kirkolliskokous joutuivat puhumaan toisilleen etäisesti sähkeiden välityksellä. Sundqvistin sähkeestä piirtyi myönteinen kuva koulujen uskonnonopetuksen tilanteen kehityksestä sekä kirkon ja opetusviranomaisten välisestä yhteistyöstä. ${ }^{473}$ Kouluhallitukseen oli perustettu uskonnonopetuksen ylitarkastajan virka, ja kouluhallituksen asettaman työryhmän mielestä uskonnonopetuksen tuntimäärää peruskoulussa oli välttämätöntä lisätä. ${ }^{474}$

Kirkolliskokouksen vastaus ei ollut sellainen muodollinen tervehdys kuin kokouksen tervehdyssähke tasavallan presidentille. ${ }^{475}$ Asian tärkeydestä kertoo se, miten tarkkaan vastaussähkettä hiottiin. Yleisen valmistusvaliokunnan laatima sähke-ehdotus sai täysistunnossa uuden muodon, kun tyylin taitajana tunnettu helsinkiläinen filosofian maisteri Tauno Väinölä saneli oman ehdotuksensa sähkeen tekstiksi. Samalla saatiin yksi esimerkki täysistuntojen merkityksestä kirkolliskokouksen työskentelyssä. Valiokunta teki Väinölän versioon kuitenkin yhden hyvin kuvaavan muutoksen: koulujen uskonnonopetuksen osalta kehityksen ei toivottu "jatkuvan suotuisasti" vaan "muodostuvan suotuisaksi". ${ }^{476}$ Kirkolliskokous halusi välttää kuvaa, että ensimmäiset, vielä melko epävarmat merkit uskonnonopetuksen aseman parantumisesta riittäisivät kirkolle. Siten vastaus poikkesi opetusministerin lähettämästä sähkeestä olennaisessa kohdassa.

Myös siviilivaliokunta oli sitä mieltä, ettei kirkolliskokouksen tullut hiljaa seurata uskonnonopetuksen tilannetta. ${ }^{477}$ Valiokunnan mietintöä valmistelivat teologian tohtori Eeva Ojanen ja Savonlinnan seminaarin rehtorina toiminut kouluneuvos Anna Kekkonen, joka menehtyi sittemmin jo keväällä 1975. Täysistunnossa ponsien muokkaamiseen vaikutti olennaisesti koulutoimentarkastaja Meeri Päivänsalo. ${ }^{478}$ Runnin emäntäkoulun rehtorina Iisalmessa toimineesta agronomi Mirja Ronnista taas tuli vuodesta 1974 lähtien väsymätön puolestapuhuja ammatillisten oppilaitosten elämänkatsomukselli- selle opetukselle. ${ }^{479}$ Opetusalalla toimineet naisedustajat kantoivat suurta huolta uskonnonopetusta koskevista asioista.

Oulun hiippakuntakokoukselta tuli jälleen keväällä 1975 uskonnonopetusta koskeva aloite. Tuolloin keskustelu uskonnonopetuksesta oli kirkolliskokouksessa jo urautumassa: paljolti samat edustajat puhuivat kukin samoista tärkeiksi katsomistaan teemoista kuin aiemmin. ${ }^{480}$ Kirkon kasvatusasiain toimikunnan puheenjohtaja, Kuopion piispa Paavo Kortekangas toivotti perustevaliokunnalle menestystä, "kun se yrittää löytää leikillisesti sanoen viidennenkymmenennenviidennen uuden puolen uskonnonopetuksesta". ${ }^{881}$ Näitä puolia - tosin tuskin täysin uusia - valiokunta löysikin useita: se antoi Kortekankaan keskukselle pitkän tehtävälistan, jota reunustivat kiitokset keskuksen työstä. ${ }^{82}$ Tilanteeseen oli saatu selvää parannusta, kun keväällä valtioneuvoston määräyksestä oli lisätty yläasteen uskonnonopetusta. ${ }^{483}$ Uskonnonopetuksen asemaa puolustettaessa kirkolliskokouksen ja kasvatusasiain keskuksen välinen yhteistyö toimi hyvin. Kirkolliskokouksen ja toimikuntien keskinäisessä suhteessa oli kuitenkin myös toisenlaisia esimerkkejä: kirkon yhteiskunnallinen toimikunta ja kirkolliskokous valmistelivat samanaikaisesti toisistaan tietämättä kannanottoja alkoholipolitiikkaan ${ }^{484}$.

Perustevaliokunta päätyi jykevään kannanilmaisuun, "ettei kirkolliskokous tule vaieten hyväksymään uskonnonopetuksen aseman heikentämistä". ${ }^{485}$ Kirkolliskokouksessa kuultiin uskonnonopetuksesta puhuttaessa paljon taisteluretoriikkaa. ${ }^{486}$ Suoraa sanankäyttöä osoitti perustevaliokunnan puheenjohtajan, piispa Nikolaisen toteamus, ettei kommunismi edustanut Itä-Euroopassa kansan enemmistön henkisiä arvostuksia. Piispa valitteli, että Suomessa kasvatus- ja koulutusohjelman ulkomaiset esikuvat otettiin usein "sellaisesta ahdashenkisestä yhteiskunnasta". ${ }^{487}$ Ekumeenisesti kokeneilla kirkolliskokousedustajilla oli uskallusta ja tietoa arvostella itäblokin yhteiskunnallista tilannetta.

Jykevää kieltä kirkolliskokous käytti samaisena syksynä 1975 myös lähettäessään alkoholilainsäädäntöä koskevan kirjelmän valtioneuvostolle ja eduskuntaryhmille. Kirkolliskokous vaati keskioluen myyntiä pois elintarvikeliikkeistä ja sen anniskelun rajoittamista todeten, "että kansakunnan siveellinen ryhti on keskiolutlain voimaantulon jälkeen monin tavoin veltostunut". ${ }^{488}$ Heti 
keväästä 1974 lähtien kirkolliskokouksen keskustelut ja kannanotot osoittivat uuden vaiheen alkaneen. Vaikka tulevaisuus näytti epävarmalta, kirkolliskokous ei ollut enää valmis antamaan periksi samalla tavalla kuin vielä muutama vuosi aiemmin. "Routavuosiin" kuului myös vetoaminen annettuihin lupauksiin. Hieman samaan tapaan kuin autonomian kauden suomalaiset olivat vedonneet suuriruhtinaan hallitsijanvakuutukseen, kirkolliskokousedustajat pyrkivät toistamaan opetusministerien kahvitilaisuuksissa lausumia, kirkolle myönteisiä sanoja, jotta niitä muistettaisiin vastaisuudessakin - erityisesti kun hallitukset ja lupausten antajat vaihtuivat taajaan.

Uudistetun kirkolliskokouksen aloittaessa työtään kirkon "routavuodet" olivat jo kääntymässä loppuaan

\section{Liian tasokas kasvatusohjelma?}

Koko 1970-luku oli Suomessa kasvatususkon aikaa. Koulutusjärjestelmää ja varhaiskasvatusta uudistettiin ja laajennettiin voimakkaasti. Kirkko oli mukana murroksessa paitsi lausunnonantajana myös suurena kasvatusorganisaationa. Sen kasvatustyön toimintamuodot kukoistivat, vaikka toisaalta yhteiskunnassa käytiin kamppailua kristillisen uskon asemasta kasvatuksen arvopohjana. Kirkon kasvatusasiain keskus ryhtyi 1971 laatimaan kirkolliskokouksen toimeksiannosta laajaa kasvatustoiminnan kokonaisohjelmaa. Ohjelman voi nähdä samantapaisena poikkeuksellisen laajana uudistushankkeena kuin valtion tasolla samaan aikaan toteutetut koulutusuudistukset. Kirkon taloudellinen asema näytti turvatulta, joten suurimuotoiset suunnitelmat olivat mahdollisia. Ohjelman yhtenä päätarkoituksena oli turvata kirkon oma kasteopetus ja kasvatustoiminta kaikissa oloissa ja vahvistaa siten kirkkoa. Asiakirja pyrki vaalimaan kirkon omaleimaisuutta, jonka puolesta myös kirkkojärjestyskomitea työskenteli. ${ }^{I}$

Ohjelman perusteet tulivat kirkolliskokouksen käsittelyyn 1976. Niiden mukaan kasvatustyötä tuli suunnitella ikäryhmittäin ja seurakuntakohtaisesti ylittäen samalla työalojen väliset raja-aidat. Lähtökohtana oli kasvatettavan elämäntilanne. Ratkaisu herätti jonkin verran tyytymättömyyttä niissä, jotka toivoivat ohjelmalta opillista otetta. ${ }^{\text {II }}$ Kirkolliskokouksessa kannettiin lisäksi huolta siitä, ettei kasteopetusta ja koulujen uskonnonopetusta erotettaisi liian voimakkaasti toisistaan. ${ }^{\text {III }}$ Valtioneuvoston tervehdyksen tuonut opetusministeri Marjatta Väänänen sen sijaan kiitteli, että kirkon piirissä oli huolella valmisteltu ajankohdan tarpeet huomioon ottava kasvatusohjelma. ${ }^{\text {IV }}$ kohti, mitä osoitti myös kirkolliskokouksen rohkeus puhua suoraan valtiovallalle. Toisen vaalikautensa aluksi keväällä 1978 kirkolliskokous sai tehtäväkseen antaa lausunnon keskiasteen koulunuudistuksen opetussuunnitelmatoimikuntien mietintöjen yhteenvedosta eli asiakirjasta, joka jo nimellään osoitti koulunuudistuksen monivaiheisuuden ja laajuuden. Yhteensä 14 opetussuunnitelmatoimikuntaa oli linjannut uudenlaista keskiastetta - erityisesti ammatillista koulutusta ${ }^{489}$. Aiemmin lukiossa oli ollut viittä kurssia vastaava määrä uskonnonopetusta. Lukion opetussuunnitelmatoimikunnan enemmistö ehdotti vastaisuudessa kolmea kaikille yhteistä ja kahta valinnaista kurssia. Ehdotus merkitsi vähennystä kaikille yhteiseen opetukseen,

Myös kasvatusasiain valiokunnan mietintö ohjelmasta oli laaja ja seikkaperäinen. ${ }^{\mathrm{V}}$ Asian laajakantoisuuteen nähden keskustelu jäi kirkolliskokouksessa vähäiseksi. ${ }^{\text {VI }}$ Osin kyse oli luultavasti siitä, että periaatteellinen asiakirja jäi edustajille hieman etäiseksi, osin taas siitä, että ohjelman korkeatasoisuudesta oltiin yhtä mieltä. Kasvatusasiain valiokunnan puheenjohtaja, piispa John Vikström ihasteli asiakirjan tasoa mutta kysyi monen muun edustajan tavoin, miten ohjelma pystyttiin toteuttamaan käytännössä. Helsingin tuomiorovasti Mauri Larkio pelkäsi, että muodikkaan suunnittelun, symposiumien ja konferenssien keskellä varsinainen seurakuntatyö uhkasi jäädä tekemättä. ${ }^{\text {VII }}$

Hyväksyessään ohjelman kirkolliskokous halusi antaa seurakunnille mahdollisuuden joustaa omissa ratkaisuissaan. ${ }^{\text {VIII }}$ Päätöksen jälkeen alkoi laaja koulutustoiminta. Paikoittain ohjelmatyöskentely oli hedelmällistä ja lähensi työntekijäryhmiä toisiinsa. Ohjelmaa lähdettiin kuitenkin toteuttamaan hyvin eri tahtiin eri puolilla, ja useimmissa seurakunnissa into tähän vaativaan työhön hiipui nopeasti 1980-luvun kuluessa. ${ }^{\mathrm{IX}}$ Tasokas ohjelma osoittautui tietyllä tavalla liiankin tasokkaaksi.

I Kirk.kok. ptk-s. 1976, liite II 9; SEK 1976-79, 32-33, 35-36; Malkavaara 200o, 241; S. Häkkinen 2010, 125.

II Kirk.kok. ptk-s. 1976, liite II 9; SEK 1976-79, 33, 165-166; S. Häkkinen 2010, 125.

III Kirk.kok. kptk-k. 1977, 46 \$, 48 §.

IV Kmaa 12.11.1976 Opetusministeri: Naisen asema kirkossa ja kirkon kasvatustoiminnan kokonaisohjelma kiinnostavat.

V Kirk.kok. ptk-k. 1977, liite X-G 1.

VI Kirk.kok. kptk-s. 1976, 35 \$; Kirk.kok. kptk-k. 1977, 46 \$, 48 \$.

VII Kirk.kok. kptk-k. 1977, $46 \$$.

VIII Kirk.kok. kptk-k. 1977, 48 \$.

IX SEK 1976-79, 166, 191-192; SEK 1984-87, 229; SEK 1988-91, 89; Rissanen 1989, 85-87; Ripatti 2004, 169; Malkavaara \& Mustakallio 2012a, 507. 
mutta toisaalta pelot uskonnonopetuksen poistamisesta kokonaan kaikille yhteisten aineiden listalta eivät toteutuneet. ${ }^{490}$

Poliittisen ilmapiirin muuttuessa kirkolliskokous saattoi puolustaa uskonnonopetusta aiempaa vahvemmista asemista. Luottamus vuosina 1975-1977 istuneita Martti Miettusen hallituksia ja erityisesti vuosina 1976-1977 opetusministerinä toiminutta Marjatta Väänästä kohtaan oli kirkon piirissä vahva. Myös opetusministeriön virkamiesten keskuudessa kirkon tavoitteilla oli 1970-luvun puolivälistä lähtien uusia tukijoita, kuten kansliapäällikkö Jaakko Numminen. ${ }^{491}$ Kirkolliskokous vaati uskonnonopetuksen aseman säilyttämistä ennallaan sekä uskonnollisen, eettisen ja elämänkatsomuksellisen opetusaineksen lisäämistä ammatillisessa koulutuksessa. ${ }^{492}$ Ammatillisen opetuksen osalta tulokset jäivät vähäisiksi, mutta lukion suhteen tavoitteet toteutuivat lopulta erinomaisesti, kun uskonnonopetukseen tuli viisi kaikille oppilaille yhteistä kurssia. Lisäksi uusi lukiolaki vuodelta 1983 vahvisti lukion uskonnonopetuksen lainsäädännöllistä asemaa aiempaan tilanteeseen verrattuna. ${ }^{493}$

Valtioneuvoston kahvitilaisuudessa opetusministeri Jaakko Itälä vakuutti kirkolliskokoukselle, että opetusministeriössä kiinnitettäisiin vakavaa huomiota keskiasteen uudistuksesta annettaviin lausuntoihin, joista kirkolliskokouksen lausunto olisi "varmasti kaikkein tärkeimpiä". ${ }^{494}$ Kysymykseksi nousi kuitenkin, joutuiko kirkko lausumaan sanottavansa liian myöhäisessä vaiheessa. Tällöin kirkkoa ei ehdittäisi käytännössä kuunnella, vaikka siihen olisikin halua. Arkkipiispa Simojoki nosti ongelman esiin vastatessaan Itälälle. Hän oli tuolloin viimeistä istuntokauttaan kirkolliskokouksen puheenjohtajana. Simojoen mukaan kirkolla ei ollut juuri kanavia, joiden kautta se voisi tärkeissä ratkaisuissa välittää valtiovallalle uskon näkökulman. Mahdollisuudet olivat oleellisesti huonommat kuin aikana, jolloin valtiopäivillä ja poliittisen elämän johtopaikoilla oli ollut paljon papistoa. Ikään kuin testamenttinaan Simojoki kehotti nuorempia piispoja kantamaan huolta näistä yhteyksistä. ${ }^{495}$

Vastatessaan Simojoelle Itälä vei huomion kanavista henkilöihin: "Mutta sanoisin, että jos kirkon päämies on sellainen kuin arkkipiispa Simojoki ja hänen edeltäjänsä ovat olleet, niin tavalla tai toisella se ääni sitten kui- tenkin tulee kuuluviin." ${ }^{496}$ Sillä tavalla opetusministerin ja kirkolliskokouksen yhteydenpito oli jo tuolloin tiivistynyt, että opetusministeri Itälä oli ollut samana aamuna kasvatusasiain valiokunnan kuultavana keskiasteen koulunuudistuksesta. ${ }^{497}$ Valiokunta taas seurasi arkkipiispan viitoittamaa tietä ja vaati luterilaisen kirkon edustusta keskiasteen koulunuudistuksen neuvottelukuntaan. ${ }^{498}$

Itälän vastaus Simojoelle jäi varovaiseksi, mutta hänen seuraajansa, RKP:n Pär Stenbäck, toisti kahvitilaisuuksissa vuosina 1979 ja 1980 juuri Simojoen esiin nostamia asioita. Stenbäck ehdotti kirkon ja opetusministeriön välisen henkilökohtaisen kanssakäymisen tiivistämistä sekä muutenkin valtion ja kirkon keskinäisen vuorovaikutuksen lisäämistä. ${ }^{499}$ Hänkään ei pystynyt osallistumaan kirkolliskokouksen työskentelyyn pidempää aikaa kuin muut ministerit, mutta ei ollut opetusministerille aivan tavanomaista anoa erikseen vapautusta kirkolliskokouksen työstä, kuten Stenbäck teki..$^{500}$

Tästä tilanteesta oli vain lyhyt matka siihen, että syksyllä 1981 opetusministeriön kansliapäällikkö Jaakko Numminen osallistui valtioneuvoston määräämänä edustajana pitkähkön aikaa kirkolliskokouksen työhön ja myös keskusteluun. Sen hän teki enemmän asiantuntijana kuin kirkolliskokouksen päätöksentekijänä. Nummisen myöhemmän arvion mukaan ainakin hän itse korosti kahvitilaisuuksissa pitämissään puheissa kirkolliskokouksen roolia tavalla, joka antoi helposti liioitellun kuvan kirkollisten asioiden merkityksestä opetusministeriön asiapaljouden keskellä ${ }^{501}$. Kahvitilaisuuden kohteliaat sanakäänteet, joita oli vanhamuotoisen kirkolliskokouksen aikaan kuultu muutaman vuoden välein mutta jotka uudistuksen jälkeen lausuttiin kaksi kertaa vuodessa, saattoivatkin luoda kirkolliskokousedustajien keskuudessa ajoittain liiallisia odotuksia valtiovaltaa kohtaan.

Parantuneet henkilökohtaiset yhteydet opetusministeriöön eivät suoraan merkinneet sitä, että kirkolliskokous olisi luopunut kirjelmistä. Viimeisinä virkavuosinaan arkkipiispa Simojoki oli valitellut kirkon kääntyneen sisäänpäin. Arkkipiispan kehotuspuhe tuotti tulosta, ja 1970-luvun lopulla kirkko alkoi osallistua yhä enemmän yhteiskunnassa virinneeseen katsomukselliseen keskusteluun. ${ }^{502}$ Muutos näkyi myös kirkolliskokouksen työssä. Turun kristilliseltä opistolta lähti 
1980-luvun alussa valtioneuvostolle lukuisia kirjelmiä - pelkästään vuonna 1980 neljä. Kirkolliskokous esimerkiksi ehdotti kehitysyhteistyöhön tarkoitettujen lahjoitusten muuttamista valtionverotuksessa verovapaiksi ${ }^{503}$. Samaten se ehdotti aborttilakia muutettavaksi niin, että raskauden keskeyttäminen sallittaisiin lähinnä vain naisen tai lapsen terveyttä koskevien syiden perusteella tai muuten pakottavissa poikkeustapauksissa. Samassa kirjelmässä kirkolliskokous painotti yhteiskunnan tukea lapsiperheille ja yksinhuoltajille sekä toivoi terveydenhoitohenkilöstölle oikeutta kieltäytyä vakaumuksellisista syistä osallistumasta raskauden keskeyttämiseen..$^{504}$

Yksi kirjelmistä koski uutta sukunimilakiehdotusta. Perustevaliokunnan enemmistö painotti aviopuolisoiden yhteisen sukunimen merkitystä, koska sen katsottiin yhdistävän perhettä. Mietintöön liittyi kuitenkin Lars Erik Taxellin eriävä mielipide. Professori Taxell puolusti poikansa Christoffer Taxellin johtaman oikeusministeriön valmistelemaa lakiesitystä ja halusi turvata lainsäädännössä perheen yhteyden ohella myös vaimon tasapuolisen oikeuden päättää sukunimestään. Taxell ja muut Porvoon hiippakunnan edustajat jäivät kirkolliskokouksessa käytännössä yksin. ${ }^{505}$ Åbo Underrättelser ihmetteli, ettei edes muiden hiippakuntien naisedustajilta juuri liiennyt tukea naisen oikeudelle omaan sukunimeensä..$^{506}$

Kirjelmän vaiheissa näkyi, ettei kirkon johdolla ollut juuri epävirallisia kanavia muihin ministeriöihin kuin opetusministeriöön. Kirjelmän johdosta oikeusministeri Christoffer Taxell arvosteli kirkolliskokousta siitä, että se oli ottanut kantaa valmisteilla olevaan asiaan olematta ensin yhteydessä ministeriöön ja tiedustelematta siltä lisätietoja. Juristiprofessori Jaakko Voipio puolusti kirkolliskokousta toteamalla, että lakiehdotus oli jo julkistettu ja että siitä oli riittävästi tietoa saatavissa: ”Jos kirkolliskokous noudattaisi ministeri Taxellin varmaan hyvässä tarkoituksessa esittämään kritiikkiä, se myöhästyisi jatkuvasti.” ${ }^{507}$ Tosin nytkään kirkolliskokous ei ennättänyt lausua mielipidettään tarpeeksi ajoissa vaikuttaakseen valmistelun lopputulokseen. ${ }^{508}$

Oikeusministeri Taxellin esittämä kritiikki näyttää olleen osasyynä siihen, että vuosina 1980 ja 1981 kirkolliskokous punnitsi kannanottojaan pitkään. Toinen syy perusteelliseen harkintaan oli yhteiskunnallisen ilmapiirin muutos. Kirkolliskokousedustajat totesivat, että

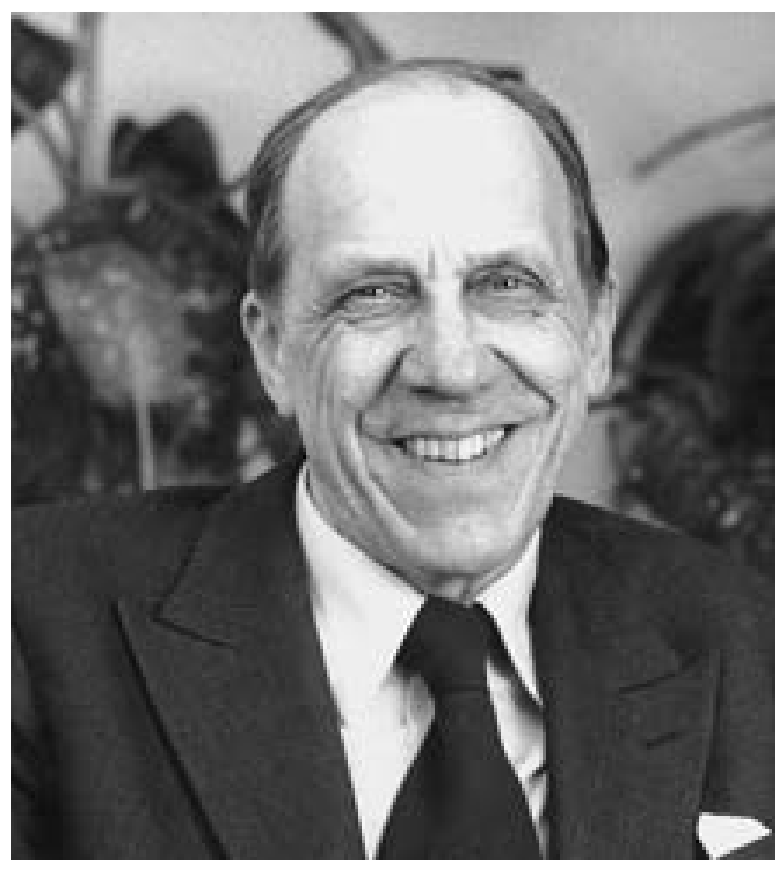

Professori Lars Erik Taxell puolusti yhdessä muun Porvoon hiippakuntaryhmän kanssa naisen oikeutta päättää sukunimestään myös avioituessaan. Taxell oli vaikutusvaltainen ja luotettu edustaja, mitä osoitti hänen valintansa varapuheenjohtajaksi vaalikausille 19741977 ja 1978-1981. Tässä kysymyksessä hän jäi kuitenkin pieneen vähemmistöön. Kuva: Kirkkohallitus.

hallitukset olivat kirkolle aiempaa myötämielisempiä. Edustajat halusivat lausua kantansa tässä tilanteessa mahdollisimman harkitusti ja vastuullisesti. Samalla asiat näyttäytyivät entistä monisyisempinä. Avosuhteiden osalta kirkolliskokousedustajilla oli suuria vaikeuksia löytää yhteinen näkemys siitä, mistä valtiovallalle tuli kirjoittaa: kirjelmä kävi vuoden aikana ennätyksellisesti neljä kertaa yleisessä valmistusvaliokunnassa, minkä jälkeen lopputulos herätti edelleen arvostelua ${ }^{509}$. Muun muassa näiden kokemusten myötä arkkipiispa Juva totesi, että kirkolliskokouksen mahdollisuudet laatia kirjelmiä eivät olleet erityisen hyvät "ja että meidän tulee perusteellisesti harkita, milloin me otamme tällaisen tehtävän suorittaaksemme". ${ }^{110}$

Päätöksentekoa vaikeutti, että julkisuuden valokeila oli pitkin kokousviikkoa juuri kirkolliskokouksen kannanotoissa. Varsinkin täysistuntokeskustelut, jotka usein muuttuivat sangen tunnepitoisiksi, jakoivat lehdistössä mielipiteitä ja synnyttivät kärkevää kirjoittelua. ${ }^{511}$ Seuraavana vuonna pölyn laskeuduttua Juva pystyi jo iloit- 
semaan vaikeuksien kautta synnytetyistä kirjelmistä: ne olivat tuoneet päättäjien tietoon kirkon selkeän mielipiteen ja välittäneet julkiseen keskusteluun viestin, "että kirkko ottaa vakavasti kantaa Suomen yhteiskunnan olennaisiin eettisiin ongelmiin". ${ }^{12}$ Kirkolliskokous oli uskaltautunut puhumaan suoraan - pelkäämättä julkisuudessa jakautuvia mielipiteitä.

Kannanottoja laatiessaan kirkolliskokous joutui lähes joka kerta pohtimaan vaikeita periaatteellisia kysymyksiä. Monet edustajat olivat sitä mieltä, että kirkolliskokouksen tuli keskittyä kirkon omiin toimenpiteisiin epäkohtien lievittämiseksi sen sijaan, että kokous neuvoisi valtiollisia päättäjiä. Jotkut myös pelkäsivät, että liiallisen kirjelmien lähettämisen myötä kirkolliskokouksen ääni kärsisi inflaation. Edelleen pohdittiin, miten kirkolliskokouksen oli ilmaistava asiansa: tuliko puhua periaatteiden ja ihanteiden tasolla vai ehdottaa konkreettisia mutta samalla kompromissinomaisia lainmuutoksia - puhua kuin Jeesus vai kuin Mooses, kuten Espoonlahden kirkkoherra Jussi Talasniemi kiteytti ongelman keskusteltaessa aborttia koskevasta kannanotosta. Tuolla kerralla kirkolliskokous päätyi ensin mainittuun periaatteeseen ja katsoi, ettei poliittiselle kompromissille ollut syytä antaa kristillistä auktoriteettia ja samalla suhteellistaa absoluuttisia arvoja. ${ }^{513}$

Samaan kokonaisuuteen liittyi kysymys, tuliko kirkolliskokouksen perustella kantansa Raamatulla ja tunnustuksella vai vakaumuksesta riippumattomilla argumenteilla. Ymmärsikö ja ottiko valtiovalta vakavasti raamatullisia perusteluja - tai oliko kirkolla ylipäätään oikeutta vaatia uskostaan käsin muutoksia lainsäädäntöön, joka kosketti kaikkia ihmisiä vakaumukseen katsomatta? Toisaalta raamatullisista perusteista luopuminen näytti vähintään yhtä ongelmalliselta vaihtoehdolta: jos kirkolliskokous perusteli kantaansa vain kaikkien hyväksymillä "järkisyillä", miksi valtioneuvosto pyytäisi lausuntoja kirkolliskokoukselta? Mihinkään yksiselitteiseen lopputulokseen ei näissä pohdinnoissa päästy.

Keskusteltaessa kannanotosta alkoholilainsäädäntöön kirkolliskokouksessa nousi 1975 esille vielä kolmas periaatteellinen kysymys. Joidenkuiden mielestä asia oli hoidettavissa tehokkaimmin ilman kirkolliskokouksen kirjelmää valtioneuvostolle. Toisten ajatuksissa taas oli huoli, millaisen kuvan kirkolliskokous antaisi itsestään ja kirkosta, jos se ei ottaisi kantaa. Näiden edustajien mielestä keskiolutlaki saatettiin uudistaa ilman kirkolliskokouksen kannanottoakin, mutta tätä kannanottoa tarvittiin kirkkoa kohtaan tunnetun luottamuksen säilyttämiseksi. ${ }^{514}$ Tällainen ajattelutapa tuli jo lähelle etujärjestön toimintamallia: vaikka kannanotto alkoholilainsäädäntöön tähtäsikin koko kansan hyvinvointiin, sitä punnittiin oman instituution edun näkökulmasta. Kaikkiaan kirkolliskokouksen ääni osoittautui vaikuttavimmaksi silloin, kun valtiovalta nimenomaan pyysi siltä lausuntoa. Sen sijaan niissä tapauksissa, joissa kirkolliskokous ryhtyi oma-aloitteisesti käyttämään "kansan omantunnon" ääntä, sen laatimat kirjelmät eivät sanottavasti vaikuttaneet alkoholi-, abortti- tai sukunimilainsäädäntöön.

Vaikka kirkolliskokous kääntyi valtioneuvoston puoleen virallisia kanavia pitkin useita kertoja 1970- ja 1980-luvun vaihteessa, arkkipiispa Simojoen ja ministeri Stenbäckin korostamat epävirallisen tason yhteydet eivät jääneet vaille merkitystä. Kirkolliskokouksessa kuului ääniä, joiden mukaan tehokkaimmin hyvään lopputulokseen päästäisiin, mikäli ensisijaisesti toimikunnat pyrkisivät vaikuttamaan päätöksiin niiden valmisteluvaiheessa. ${ }^{515}$ Henkilökohtaiset yhteydet opetusministeriöön taas näkyivät siinä, että kirkolliskokous ei ryhtynyt keväällä 1981 toimenpiteisiin, vaikka opetusministeriön työryhmä oli ehdottanut koulujen päivänavauksen ja uskonnonopetuksen välisen yhteyden katkaisemista. Keskeisenä perusteluna tälle pidättäytymiselle oli, että opetusministeri Stenbäck oli kirkolliskokouksen kahvitilaisuudessa kertonut vastustavansa työryhmän suunnitelmia. ${ }^{516}$ Henkilökohtaiset yhteydet ja luottamus ministeriin riittivät korvaamaan kirjelmän.

Erityisen kovaan testiin neuvotteluyhteydet valtiovaltaan joutuivat aina, kun oli kyse raamatunkäännöstyön rahoittamisesta. Raamatunkäännöskomitea lähti työssään liikkeelle periaatteesta, että valtion tuli kustantaa koko käännöstyö. Vuosina 1974 ja 1975 komitea sai myös kahteen kertaan lupauksen rahoituksesta opetusministeriön ministereiltä Ulf Sundqvistilta ja Marjatta Väänäseltä. Komitean puheenjohtajan Aimo T. Nikolaisen kelpasi esitellä sitä kirkolliskokoukselle. Nikolainen valmisteli kirkolliskokousta kuitenkin varautumaan siihen, että valtio kustantaisi vain pääosan suunnitellusta summasta. Silloin kirkolliskokous voisi joutua täyttämään marginaalin, "joka toivottavasti on vähäinen".517 
Valtion tulo- ja menoarvioon ei tullut koko summaa eikä edes pääosaa vaan vain murto-osa suunnitellusta. Sundqvistin ja Väänäsen lupaukset eivät valtiovarainministeriön edessä osoittautuneet taantuman aikana kovin painaviksi. Kirkolliskokouksessa alkoi vuosien taistelu, jossa piispa Nikolainen oli ahtaalla talousvaliokunnan ja valtiovallan välissä. Talousvaliokunta oli haluton kasvattamaan kirkon taloudellista panosta käännöstyössä ennen kuin valtio tekisi kirkon kanssa sopimuksen hankkeen läpiviemisestä. Nikolainen taas halusi turvata käännöstyön jatkumisen kirkon rahoituksella edes jollakin tavalla. Näin oli hänen mukaansa helpompi saada myös valtiovalta myöhemmin lisäämään osuuttaan. Nikolainen ajoi asiaa sinnikkäästi ja sai täysistunnoissa toistuvasti korotetuksi talousvaliokunnan ehdottamia määrärahoja. ${ }^{518}$

Syksyllä 1977 kirkolliskokous hyväksyi seuraavalle vuodelle talousarvion, jonka mukaan kirkko maksoi kolmanneksen enemmän raamatunkäännöstyön kuluja kuin valtio. Valtio oli alkanut lisätä rahoitustaan, mutta edelleen oltiin kaukana niistä vuoden 1974 lupauksista, joihin luottaen käännöstyöhön oli ryhdytty. Lopulta uuden vuosikymmenen alkaessa päästiin tilanteeseen, jossa valtion osuus ylitti kirkon osuuden..$^{519}$ Kirkolliskokouksen lähettämät kirjelmät osoittautuivat usein ongelmallisiksi vaikuttamiskeinoiksi, mutta taistelu raamatunkäännöstyön rahoituksesta osoitti kirkolliskokoukselle, että myös suullisiin lupauksiin perustuneessa epävirallisessa yhteydenpidossa oli rajoitteensa.

\section{KOHTI MISSIONAARISTA KANSANKIRKKOA}

Kirkon päätöksenteossa huomio alkoi 1970-luvun edetessä kiinnittyä entistä enemmän kirkon syvimpään olemukseen ja tehtävään. Uskonnollisuudelle ja kirkolle aiempaa myönteisempi ilmapiiri mahdollisti osaltaan näkökulmanmuutoksen. ${ }^{520}$ Vuoden 1973 kirkolliskokous oli saanut käsiteltäväkseen kirkon järjestysmuodon tutkimiskomitean ensimmäisen mietinnön, jossa tarkasteltiin kirkon perusluonnetta ja tehtävää sekä linjattiin periaatteita kirkkolain uudistamiselle. Aihepiirin tärkeys oli ollut alusta alkaen tiedossa, mikä näkyi arkkipiispa Simojoen johtaman komitean kokoonpanossa. Komitea pyrki yhdistämään kirkossa vaikuttaneita erilaisia kirkkokäsityksiä ja päätyi lopputulokseen, että val- litseva kansankirkkojärjestelmä tuli säilyttää perustana uusittaessa Suomen luterilaisen kirkon rakenteita. Komitean mukaan tällainen malli ei merkinnyt tunnustuskirkolle vastakkaista järjestelmää, vaan kansankirkonkin jäseniltä edellytettiin sitoutumista kirkon uskoon ja tunnustukseen. Ajattelutapa vastasi komitean jäsenten Martti Simojoen ja Mikko Juvan näkemyksiä.. ${ }^{521}$

Erilaisten näkökulmien sulauttaminen synnytti arvostelua siitä, että teologinen ja sosiologinen tarkastelutapa olivat mietinnössä sekoittuneet. Vaikka komitean puheenjohtaja Simojoki korosti, että kirkkonäkemyksen tuli perustua uskoon ja oppiin, erityisesti viidennen herätysliikkeen ja evankelisuuden piirissä esiintyi vaatimuksia vielä tiukemmasta pitäytymisestä tunnustukseen. Tällaista arvostelua olivat esittämässä osaltaan samat Helsingin yliopiston nuoret systemaatikot, jotka myöhemmin vaativat kirkolta opillisesti tarkkaa linjaa virkakysymyksessä sekä Leuenbergin konkordiaa käsiteltäessä. Kaikki nämä aiheet liittyivätkin kiinteästi toisiinsa väljän ja matalakirkollisen kansankirkollisuuden kritiikissä 1970-luvulla: Raamatun, tradition ja kirkon viran oli saatava niille kuuluva asema. ${ }^{522}$

Vuoden 1973 kirkolliskokous hyväksyi komitean linjaukset siitä, että kirkon julkisoikeudellinen asema tuli säilyttää ja kirkkolaki jakaa lakiosaan sekä kirkon itsensä säätämään kirkkojärjestykseen. Samalla kirkolliskokous valtuutti komitean jatkamaan edelleen työtään. ${ }^{523}$ Komitean jatkotyöskentely sai dramaattisen käänteen keväällä 1974, kun sen keskeisimmät jäsenet Simojoki ja Juva jättivät eronpyyntönsä. ${ }^{524}$ Simojoen ja Juvan eroa selitettiin tuoreeltaan komitean mietinnön kohtaamalla arvostelulla, mutta luultavasti taustalla oli muutakin. Juva oli jo syksyllä 1971 pohtinut eroa ja valitellut niin komitean tehtävän suuruutta kuin pettymystään sihteerinä toimineeseen teologian tohtori Seppo Löyttyyn, joka oli joutunut hoitamaan tehtävää oman virkatyönsä ohella. ${ }^{525}$ Kirkolliskokous piti komitean nokkamiesten eroa niin merkittävänä asiana, että se katsoi komitean työn päättyneeksi. ${ }^{226}$ Tosin kokous asetti heti uuden komitean, joka sai saman tehtävän ja pitkälti samat jäsenet kuin edeltäjänsä. ${ }^{527}$ Komitean puheenjohtajaksi tuli John Vikström ja sen nimeksi kirkkojärjestyskomitea. ${ }^{528}$

Valtioneuvosto oli 1972 asettanut parlamentaarisen Kirkko ja valtio -komitean tutkimaan kirkon ja valtion suhteiden uudistamista. Kaksi vuotta myöhem- 
min uutta kirkkojärjestyskomiteaa asetettaessa kirkolliskokouksessa oli esillä ajatus, että valtion elin ei yksin saanut laatia asialistaa kirkon tulevaisuutta linjattaessa. ${ }^{529}$ Kun kirkon ja valtion erottamisvaatimukset olivat voimistuneet 1960-luvulla, laajennettu piispainkokous oli yrittänyt säilyttää aloitteen kirkolla ja asettanut piispa Kansanahon johtaman komitean selvittämään kirkon aseman uudistamista. ${ }^{530}$ Vastaavasti kun parlamentaarinen Kirkko ja valtio -komitea teki työtään seuraavalla vuosikymmenellä, kirkolliskokous ei jäänyt odottelemaan komitean työn tuloksia vaan halusi omista perusteistaan käsin tutkia kansankirkon käsitettä, kirkkolain säätämisjärjestystä ja kirkkolain jakamista.

Kirkkojärjestyskomitean teemat eivät poistuneet kirkolliskokouksen asialistalta komitean asettamisen jälkeen. Erityisesti kaksi edustaja-aloitetta nosti esiin kansankirkon kipukohtia. Ensinnäkin professori Lars Erik Taxell kyseenalaisti edustaja-aloitteessaan sen, että konfirmaatio oli kirkollisen äänioikeuden edellytys. Vanha vastakkainasettelu kansankirkko- ja tunnustuskirkkoajattelun välillä nousi jälleen pintaan, ja siihen liittyi kaikuja jo taakse jääneestä kirkollisen suunnan ja raamatullisen suunnan eli beckiläisen pietismin välisestä kamppailusta. Kirkolliskokouksissa oli 180o-luvun lopussa ja 1900-luvun alussa vuosikymmeniä pohdittu siviiliavioliittokysymystä ja keskusteltu siitä, tuliko kirkon jäseniltä odottaa julkista tunnustautumista ja ehtoollisella käyntiä. ${ }^{531}$ Taxellin aloite nostatti jälleen saman peruskysymyksen.

Taxellin mielestä kirkon jäsenen oikeuksien ja velvollisuuksien tuli olla tasapainossa: kun kastetulla kirkon jäsenellä oli velvollisuus maksaa kirkollisveroa, hänellä tuli olla myös äänioikeus. Kirkolliskokouskeskustelussa tämä juristien linja, jonka perustelut olivat aivan erilaiset kuin beckiläisessä ajattelussa mutta johtopäätökset täysin samat, sai tukea vanhoillislestadiolaisilta edustajilta. Näiden mukaan ketään ei tullut vastoin omaatuntoaan pakottaa ehtoolliselle, mikä oli perusteluna jo huomattavan lähellä perinteisiä beckiläisiä kantoja. Nämä argumentit saivat vastaansa piispojen edustaman kansankirkollisen näkemyksen, jonka mukaan kirkon tehtävä oli lähestyä jäseniään pyhien toimitusten kautta, sekä evankelisten edustajien tunnustuksellisen kannan, joka tuli vastaavasti hyvin lähelle vuosisadan alun kirkollista suuntausta. ${ }^{532}$
Asian käsittelyssä näkyi 1974 sama jännite kuin vuotta aiemmin kirkon järjestysmuodon tutkimiskomitean mietinnöstä keskusteltaessa: tuliko kirkon mukautua yhteiskuntaan vai korostaa omalakisuuttaan? Taxellin mukaan vastaisuudessa olisi yhä enemmän konfirmoimattomia kirkon jäseniä. Jos kirkko ei kiinnittäisi heidän äänioikeuteensa huomiota, asian nostaisivat ennemmin tai myöhemmin esille kirkkoon kielteisesti suhtautuvat piirit. Jälleen kerran oli pyrkimyksenä säilyttää aloite kirkolla sellaisissa kysymyksissä, jotka joka tapauksessa myöhemmin edellyttivät ratkaisua. Ja jälleen kerran vuoden 1974 aikana synkät tulevaisuudennäkymät heijastuivat kirkolliskokouksen työskentelyyn. Taxellin aloitetta vastustanut Timo Rusama taas edusti sitä 1970-luvun edetessä yhä kasvanutta joukkoa, jonka mielestä kirkon ei tullut kopioida ratkaisumalleja muualta yhteiskunnasta tai antaa periksi ympäröivässä paineessa. Aloite päätyi piispainkokouksen tutkittavaksi ilman nopeaa ratkaisua mihinkään suuntaan. ${ }^{533}$

Toinen kansankirkon peruskysymyksiin pureutuva aloite koski kirkon jäsenyyttä. Kotimaan päätoimittajan paikalta Vihdin kirkkoherraksi siirtynyt Leino Hassinen, joka oli ollut pari kautta poissa kirkolliskokouksesta, palasi kokoussaliin keväällä 1978 hyvin aktiivisena edustajana. Hän puuttui heti moniin näkemiinsä epäkohtiin ja ehdotti yhdessä aloitteessaan, että piispat selvittäisivät, mitä kirkko opetti jäsenyydestään. Hassisen mukaan kansankirkon tilanne oli muuttunut nopeasti, kun esimerkiksi Helsingissä kirkkoon kuulumattomien osuus oli noussut viidennekseen väestöstä. Kirkon sielunhoidollinen käytäntö, jossa kirkkoon kuuluvien ja kuulumattomien välillä ei juuri tehty eroa, ei enää ollut Hassisen mielestä perusteltu. Kirkon oli entistä tietoisemmin selvitettävä, mitä merkitsi kirkon jäsenyys ja siitä luopuminen. Voimakkain ilmaisuin Hassinen luonnehti, miten "sielunhoidollisuus" toteutui vallinneessa tilanteessa:

Jos kirkko pitää jäsenyyttään käytännöllisenä väestökirjanpitokysymyksenä ja ilman uskonnollista sisältöä olevana veronmaksuasiana, joka voidaan kohdata sielunhoidollisin palveluin, siitä on opetettava julkisesti. Pelkällä vaikenemisella kirkko opettaa nykyisessä tilanteessa kuuluvasti, ettei sen jäsenyys merkitse uskonnollisesti juuri sitä eikä tätä. - - Kirkko, jonka jäsenyys ei anna iloa eikä tietoisuutta uskon osallisuudesta ja elämänyhteydestä Kristukseen, itse asiassa karkottaa 
jäsenensä. Jos kansankirkko pyrkimyksessään kaikenkattavuuteen tyhjenee sisimmästä olemuksestaan, se pettää sekä Lähettäjänsä että jäsenensä. Siitä tulee jonkinlainen epämääräinen kansanuskonnollisuuden huolintalaitos. ${ }^{534}$

Aloitteen käsittelyn aikoihin julkisuudessa olivat esillä tutkimustulokset, joiden mukaan sitoutuminen kirkon uskoon oli pysynyt ennallaan ja rukouselämä hieman vähentynyt mutta sen sijaan kirkkoon sitoutuminen voimistunut. ${ }^{535}$ Jotkut tulkitsivat tyytyväisinä kirkon aseman vahvistuneen, toiset taas kysyivät Hassisen tavoin, oliko hintana kirkon erityisluonteen vaarantuminen. ${ }^{536}$ Kirkolliskokouksessa kaikki olivat yhtä mieltä asian ajankohtaisuudesta. Kansankirkollista näkemystä korostavat edustajat katsoivat kuitenkin kirkkojärjestyskomitean valmistelun riittävän, kun taas tunnustusta painottavat kaipasivat lisäksi piispojen painavaa puheenvuoroa asiasta. Ensin mainittu kanta voitti lopulta äänin 56-41. Vilkas täysistuntokeskustelu erkani osittain Hassisen aloitteen teemasta. Vanhoillislestadiolaiset edustajat ryhtyivät näet avoimesti arvostelemaan piispa Nikolaisen esittämää kaste- ja seurakuntanäkemystä, mikä johti heidän ja muiden edustajien väliseen sananvaihtoon. ${ }^{537}$

Kolmas kirkkojärjestyskomitean alaan keskeisesti liittyvä asiakokonaisuus tuli kirkolliskokouksen käsittelyyn, kun parlamentaarinen Kirkko ja valtio -komitea sai 1977 mietintönsä valmiiksi. Vuonna 1979 kirkolliskokouksen tärkeimpiä tehtäviä oli antaa lausunto komitean mietinnöstä. Kirkko ja valtio -komitean mietintö oli maltillinen, mikä heijasteli yhteiskunnallisen ilmapiirin muuttumista kirkolle aiempaa myönteisemmäksi 1970-luvun loppupuolella. Komitea pyrki uskonnonvapauslain hengessä lisäämään niin kirkon työskentelyvapautta kuin toisaalta yksilöiden valinnanvaraa erinäisissä asioissa. Se esitti kirkkolain jakamista yhtäältä kirkon omiin säännöksiin ja toisaalta lakiosaan, joka sääntelisi lähinnä kirkon asemaa ja jota voisivat käsitellä myös kirkkoon kuulumattomat kansanedustajat. Tuomiokapitulilaitoksen oli määrä muuttua kirkon sisäiseksi organisaatioksi ja piispojen nimitysoikeuden siirtyä tasavallan presidentiltä kirkon omille elimille. ${ }^{538}$ Erimielisyyksien laantumista osoitti osaltaan se, ettei lehdistö uhrannut paljon palstatilaa komitean mietinnön käsittelyyn. ${ }^{539}$

Parlamentaarisen komitean ratkaisut muistuttivat monin paikoin kirkon oman, piispa Kansanahon johtaman
Kirkko-valtio-komitean vuosikymmenen alussa esittämiä linjauksia. Siten kirkolliskokous saattoi yhtyä suurimpaan osaan laajan mietinnön ehdotuksista ja lähes kaikkiin sen keskeisiin linjaratkaisuihin. ${ }^{540}$ Yksi keskustelua herättäneistä yksityiskohdista liittyi kirkon sanoman näkyvyyteen ja kuuluvuuteen sähköisissä tiedotusvälineissä. Asian käsittelyyn vaikutti myös arkkipiispan vaihtuminen. Martti Simojoki oli pyrkinyt säilyttämään kirkon kannalta epävarmassa tilanteessa tiedotusvälineiden luottamuksen. Hän oli kirkolliskokouksessakin korostanut, että kirkon tuli saada arvostella valtiovaltaa, mutta neljännestä valtiomahdista hän oli puhunut aina arvostavasti ja kiitellyt paikalla olleita toimittajia ${ }^{541}$. Kun julkisen sanan kiinnostus kirkkoa kohtaan oli ollut 1970-luvun alkupuolella laimeaa, hän oli etsinyt rikkaa kirkon omasta silmästä. ${ }^{542}$

Sen sijaan Mikko Juva puuttui avauspuheessaan keväällä 1979 kristillisen ohjelmatarjonnan vähäisyyteen televisiossa. ${ }^{543}$ Puhe kertoi paitsi arkkipiispan vaihtumisesta myös aikojen muuttumisesta ja kirkon liikkumatilan kasvamisesta: 1970-luvun lopun ilmapiirissä oli mahdollista odottaa, että medialle kohdistettu kehotuspuhe ei enää kääntyisi itseään vastaan vaan voisi tuottaa tulosta. Juvan avauspuhe ja televisiota kohtaan esitetyt vaatimukset saivatkin lehdistössä hyvin ymmärtävän vastaanoton ${ }^{544}$. Antaessaan samana vuonna lausunnon Kirkko ja valtio -komitean mietinnöstä kirkolliskokouksen täysistunto kiinnitti huomiota uskonnollisten ohjelmien määrään televisiossa ja vaati kirkolle oikeutta omaan kaapelitelevisiotoimintaan. ${ }^{545}$ Seitsenkymmenluvun viimeisellä istuntokaudella nousivat esiin ne ongelmat ja mahdollisuudet, joita sähköisen median alkava muutosaalto oli tuomassa kirkolle. Oltiin kovaa vauhtia etääntymässä maailmasta, jossa laajat kansalaispiirit arkisin kuuntelivat yleisohjelmasta Turun tuomiokirkon kellojen lyöntejä.

Kirkko ja valtio -komitean mietinnön käsittely tiivistyi lopulta kahteen hiippakunnalliseen kysymykseen: tuliko tuomiokapitulit siirtää valtiolta kirkolle ja kuuluiko piispojen nimittäminen vastaisuudessakin tasavallan presidentille? Muutoksia vastustavien mielestä kirkon ja valtion etäännyttäminen toisistaan saattoi johtaa kirkon julkisoikeudellisen aseman menettämiseen ja heikentää kirkon taloudellista vakautta. Erityisesti monet maallikkoedustajat kuuluivat tähän joukkoon. Muutos- 


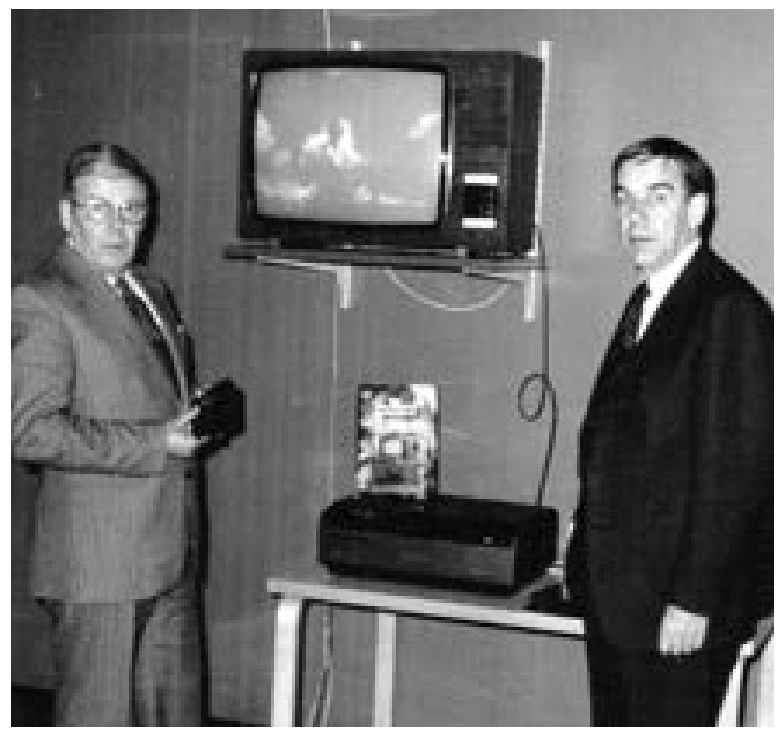

Arkkipiispa Mikko Juva (oik.) ja metsänhoitaja Juhani Linkola kiinnittivät 1979 kirkolliskokouksen huomiota kirkon näkyvyyteen televisiossa. Miehet esittelivät kirkolliskokousedustajille myös uutta videotekniikkaa. Kuva: Kirkolliskokouksen kuvakokoelma / Hemminki Haavio.

ten vastustajien mielestä kirkon itsenäisyyden ja riippumattomuuden lisääminen oli mahdollista nimenomaan läheisessä yhteydessä valtion kanssa. Muutoksia puolustavat taas katsoivat, että kirkon hallinnollisen itsenäisyyden lisääminen loisi puitteita muullekin riippumattomuudelle. ${ }^{546}$

Kirkkojärjestyskomitean puheenjohtaja John Vikström ja sen lainopillinen asiantuntija Lars Erik Taxell puolustivat pyrkimyksiä lisätä kirkon itsenäisyyttä. Heidän toiminnassaan voi nähdä suomenruotsalaisen liberaalin perinteen vaikutusta. ${ }^{547}$ Kirkkojärjestyskomitea kokonaisuudessaankin päätyi pitämään tuomiokapituleja ennen kaikkea kirkon eliminä.. ${ }^{548}$ Niin ikään arkkipiispa Juva, joka oli poliittisessa toiminnassaan edustanut näkyvästi liberaalia suuntaa, painotti kirkon hengellistä ja hallinnollista itsenäisyyttä. Hän oli valmiimpi purkamaan kirkon ja valtion keskinäisiä siteitä kuin edeltäjänsä Simojoki. Avatessaan kirkolliskokouksen keväällä 1979 Juva painotti, että voidakseen hoitaa tehtävänsä kansan omanatuntona kirkon oli oltava riippumaton niin valtiovallasta kuin yleisestä mielipiteestä. ${ }^{549}$ Liberaalisen Kansanpuolueen edustajana Kirkko ja valtio -komiteassa ollut Juva arvosteli voimakkaasti pyrkimyksiä säilyttää tuomiokapitulit valtiolla ja piispojen nimittäminen tasavallan presidentillä. ${ }^{550}$ Hänen mielestään tällaiset asenteet kirkolliskokouksessa osoittivat, että Suomessa oli tosiasiassa valtiokirkko:

Tuntuu jotenkin oudolta, etten sanoisi haikealta, että kun valtion komitea lausuu kirkolle: ettekö te pysty itse valitsemaan itsellenne piispoja, niin kirkolliskokous pyytää: suurempi objektiivisuus ja arvovalta saavutetaan, kun tämän asian hoitaa tasavallan presidentti. Ei SAK:n puheenjohtajaa mikään valtiovalta nimitä, eikä kai kukaan epäile, etteikö hänellä olisi arvovaltaa tässä yhteiskunnassa. Kirkon arvovalta ei ole kiinni siitä, kuka piispat nimittää, määrääkö piispat paavi tai keisari tai valitseeko heidät seurakunta. - - Kirkossa, joka tahtoo, että sen piispat saavat tasavallan presidentin allekirjoittaman valtakirjan, eikä luovu tästä, vaikka valtiovallan asettama komitea sitä ehdottaa, vallitsee epäilyksittä valtiokirkon henki. ${ }^{551}$

Voimakkainta linjakeskustelua kävivät piispat, joiden keskuudessa näkyivät myös sukupolvien väliset erot: Juvan ohella 1920- ja 1930-luvun vaihteessa syntyneet piispat olivat valmiita ainakin periaatteessa siirtämään tuomiokapitulit ja piispojen nimittämisen kirkolle, kun taas Aimo T. Nikolainen ja Erkki Kansanaho vastustivat.52 Nikolainen piti Juvan vertausta työntekijäpuolen keskusjärjestöön jopa vaarallisena:

Me emme saa tulla miksikään etujärjestöksi ja sellaisella tavalla sitten koettaa pakottaa valtiovaltaa, vaan meidän pitää Suomen kansan kirkkona, joka on kaikki sen kohtalot tähänkin saakka jakanut, yhdessä kulkea tämän kansan kanssa eteenkinpäin Jumalan sanaa puhtaasti julistaen. ${ }^{553}$

Vuosikymmenen lopun muuttunut asenneilmasto paljasti, että kirkossa aiempina vuosina ilmennyt valmius katkaista siteitä valtioon oli johtunut pitkälti yhteiskunnallisen tilanteen aiheuttamista paineista. Esimerkiksi Erkki Kansanaho oli kirkon asettamaa Kirkko-valtiokomiteaa johtaessaan kannattanut tuomiokapitulilaitoksen siirtämistä valtiolta kirkolle. Kun kirkolliskokous käsitteli valtion asettaman komitean ehdotusta 1979, Kansanaho puolusti tuomiokapitulien säilyttämistä valtiolla. Muuttuneessa ilmapiirissä tuomiokapitulien valtiollinen asema ei näyttäytynyt taakkana ja hidasteena vaan voimavarana sekä kirkon ja valtion keskinäisen luottamuksen osoituksena.. ${ }^{554}$ Myös kirkolliskokous oli tällä välin lisännyt voimavaroja hiippakunnalliseen 
toimintaan ja siten hillinnyt omilla päätöksillään muutoksen tarvetta.

Niin tuomiokapitulien ylläpidosta kuin piispojen nimitysoikeudesta äänestettäessä kirkolliskokous jakautui lähes tasan kahteen leiriin. Kokous päätyi lopulta 13 äänen enemmistöllä kannattamaan tuomiokapitulien säilyttämistä valtionhallinnon osana. Toisaalta piispojen nimitysoikeuden siirtäminen presidentiltä kirkon omille elimille sai viiden äänen enemmistön. Siihen, että piispojen enemmistön kanta ei voittanut ensin mainitussa äänestyksessä, olivat todennäköisesti syynä taloudelliset seikat. Moni pelkäsi tilannetta, jossa tuomiokapitulien kustannukset siirtyisivät yhtäkkiä kokonaan kirkon maksettaviksi. Äänestysten tasaisuus enteili kuitenkin muutoksen mahdollisuutta. ${ }^{55}$

Tuolle mahdollisuudelle toi lisäpontta kirkkojärjestyskomitean mietintö, joka tuli kirkolliskokouksen käsittelyyn 1980. Työssään komitea oli paneutunut teologiasta käsin paljolti samoihin kysymyksiin, joita Kirkko ja valtio -komitea oli käsitellyt valtiosuhteesta käsin. ${ }^{556} \mathrm{Ko}$ mitea yhtyi edeltäjänsä kirkon järjestysmuodon tutkimiskomitean teologisiin perusteisiin ja pitkälti myös muihin johtopäätöksiin. Mietintönsä osana se esitti merkittävän kansankirkollisen ohjelman, jossa näkyi varsinkin puheenjohtaja Vikströmin kädenjälki. Kansankirkollinen linja ei ollut vain perusteiden etsimistä vallinneelle tilanteelle vaan tietoinen valinta. Kirkkojärjestyskomitea korosti kirkon henkistä, hallinnollista ja taloudellista itsenäisyyttä. Edelleen se painotti pyrkimystä kohti entistä selvempää yhteisöluonnetta sekä kirkon vastuuta kristillisestä kasvatuksesta. Kansankirkon tuli löyhdyttää siteitään valtioon ja vahvistaa riippuvuuttaan maailmanlaajuisesta kirkosta. Näitä teologisesti motivoituja pyrkimyksiä tukivat monet Kirkko ja valtio -komitean ehdotukset. Kirkkojärjestyskomitean mietintö oli myös vastausta niille, joiden mukaan yhteiskunnallinen paine oli saanut kirkon puolustamaan liiaksi omaa asemaansa sen sijaan, että se olisi keskittynyt olemukseensa ja tehtäväänsä. Kirkkojärjestyskomitean mukaan kirkko ei saanut tyhjentyä pelkiksi toiminnoiksi ja unohtaa itsenäistä olemistaan. ${ }^{557}$

Kansankirkon olemuksen ja tulevaisuuden tutkimisen ohella komitean keskeisenä tehtävänä oli esittää periaatteet kirkkolain jakamiseksi ja uudistamiseksi. Tehtävä liittyi suoraan niihin tavoitteisiin, joita komitea oli kansankirkolle asettanut. ${ }^{558}$ Tässä selvitystyössä tuli näkyviin erityisesti komitean pysyvänä asiantuntijana toimineen Lars Erik Taxellin kädenjälki. Kirkolliskokouksen perustevaliokunta yhtyi pääosin kirkkojärjestyskomitean linjauksiin kirkkolain kokonaisuudistuksesta. Jotkin komitean teologiset lähtökohdat, kuten kirkon viran painottaminen, herättivät valiokunnassa ja täysistunnossa kuitenkin arvostelua. ${ }^{559}$ Monilta osin kirkkojärjestyskomitean esittämät ratkaisut olivat saaneet kirkolliskokoukselta tuen jo Kirkko ja valtio -komitean mietintöä käsiteltäessä, ja niinpä kirkolliskokous saattoi lähteä nopeasti toteuttamaan Vikströmin komitean linjauksia. Se asetti 14-jäsenisen komitean laatimaan ehdotusta uudeksi kirkkolaiksi ja siihen liittyväksi kirkkojärjestykseksi. ${ }^{50}$ Vallitseva ajatus oli, että erimielisyyttä aiheuttavia laajoja kysymyksiä ei tullut ratkaista kirkkolain uudistuksen yhteydessä, jotta koko uudistus ei olisi vaarassa kaatua määräenemmistön puutteeseen. Työssä lähdettiin liikkeelle keskittyen kirkkolain rakenteelliseen uudistamiseen ja jakamiseen. ${ }^{561}$

Pohdittaessa kansankirkon luonnetta 1970-luvulla keskeinen ongelma oli työntekijöiden omantunnonvapaus. Rajanveto omantunnonvapauden ja kirkon yhtenäisyyden välillä oli vaikeaa. Ongelmat tulivat esiin naispappeuspäätöksen yhteydessä keskusteltaessa mahdollisesta omantunnonklausuulista. Samaan aikaan perustevaliokunta sai käsiteltäväkseen piispainkokouksen esityksen, jonka mukaan papille annettaisiin oikeus omantunnonsyistä kieltäytyä vihkimästä eronnutta, jonka aiempi puoliso oli elossa. Kirkkohallitus oli täysin päinvastaista mieltä kuin piispainkokous ja ehdotti esityksen jättämistä raukeamaan..$^{562}$ Asetelma oli sama kuin naispappeusesitystä käsiteltäessä: piispat halusivat turvata kirkon työntekijöiden omantunnonvapauden, kun taas asiaa erityisesti lain näkökulmasta katsoneet varoittivat ongelmista.

Perustevaliokunnan enemmistö päätyi välimaastoon, tosin lähemmäs kirkkohallitusta, ja esitti samanlaisia epävirallisia menettelytapoja kuin virkakysymyksen omantunnonklausuulia käsiteltäessä. Puheenjohtaja Nikolainen iloitsi, että milloinkaan aiemmin ei eronneiden vihkimistä käsitellyt valiokunta ollut saavuttanut niin suurta yksimielisyyttä kuin tuolla kertaa. Kun tuohonkin mietintöön liittyi kaksi eriävää mielipidettä, joiden takana oli neljä valiokunnan jäsentä, kovin paljoa ei 
ennätykseen vaadittu. Lopulta kirkolliskokous kääntyi täysistunnossa selvällä enemmistöllä lähinnä piispainkokouksen linjalle: oli lähdettävä selvittämään mahdollisuuksia asian hoitamiseksi kirkkolainsäädännöllä. ${ }^{563}$ Kirkolliskokouksen periaateratkaisu poikkesi naispappeuskysymyksessä omaksutusta linjasta, mutta eronneiden vihkimisessäkin matka lainsäädännön muuttamiseen oli vielä hyvin pitkä.

Erityisen paljon keskustelua kirkon työntekijän omantunnonvapaudesta ja kirkon luonteesta syntyi 1980, kun Maarian seurakunnan pastori kieltäytyi kastetilaisuudessa hyväksymästä kummeiksi avosuhteessa eläviä kirkon jäseniä. Tapaus pysyi pitkään julkisuudessa. Arkkipiispa Juva tuomitsi tällaisen yksittäisen papin julkisen kirkkokurin käytön, kun taas 71 pappia allekirjoitti julkilausuman, jossa he antoivat tukensa pastorille ja ilmaisivat huolensa pysymisestä Raamatun, tunnustuksen ja kirkkolain perustalla. ${ }^{564}$ Juva nosti tapauksen esiin avatessaan kirkolliskokouksen keväällä 1981. Hän piti liikehdintää osoituksena virtauksesta, joka pyrki muuttamaan kirkon avarasta kansankirkosta tietoisesti uskovien kirkoksi. Juva itse puolusti puheessaan määrätietoisesti ensin mainittua kirkkoihannetta. ${ }^{565}$ Puhe sai yleisessä sanomalehdistössä osakseen myönteistä huomiota. Kirkolliset lehdet olivat sen sijaan selvästi varauksellisempia: nekin, jotka yhtyivät arkkipiispan pääsanomaan, katsoivat hänen tulkinneen julkilausuman allekirjoittajien motiiveja liian yksioikoisesti. ${ }^{566}$

Arkkipiispa Juvan näkökulmasta kirkko oli kansan omanatuntona silloin, kun se oli tarpeeksi riippumaton valtiosta kyetäkseen arvostelemaan vallanpitäjiä. Sen sijaan kirkossa oli myös niitä, joiden mielestä kirkon oli oltava kansan omanatuntona myös saarnaamalla synti synniksi yksittäisten kirkon jäsenten elämänratkaisuissa. Tätä kantaa edustavien kanssa arkkipiispa joutui ristiriitaan. Jännitteistä huolimatta kokonaiskuvaksi muodostui se, että sodanjälkeisiä vuosikymmeniä leimannut kiista yksilön pelastusta ja kirkon yhteiskunnallista tehtävää painottavien välillä laantui 1970-luvun puolivälissä ${ }^{567}$. Kirkolliskokous etsi ratkaisuja, joilla kansankirkko ja tunnustuksellisuuden ihanne voitaisiin sovittaa yhteen. Yleisen asenneilmaston muuttuminen uskonnolle aiempaa myönteisemmäksi vähensi tarvetta vetää tiukasti rajaa muuhun yhteiskuntaan ja samanaikaisesti antoi kirkolle tilaa korostaa omalakisuuttaan. Tälle pohjalle rakentui kirkkojärjestyskomitean esittämä kansankirkollinen ohjelma.

\section{NOPEATEMPOISEEN \\ PÄÄTÖKSENTEKOON}

\section{”TUSKIN JÄLKIPOLVET SYYTTÄVÄT MEITÄ UUDISTUSINNON PUUTTEESTA"}

Tuskin jälkipolvet syyttävät meitä uudistusinnon puutteesta. Kun vuosi sitten eräässä kahvipöydässä mietimme, mitä vanhaa hapatusta kirkossa vielä on, jota me emme ole viiden vuoden sisällä uudistaneet tai edes yrittäneet uudistaa, muisti Pertti Mäkeläinen: Herran siunaus, eikä sitä saada ensi jouluksi enää millään joulukirkkoon. Tämä kuvannee meidän uudistusintoamme. ${ }^{58}$

Näin totesi jyväskyläläinen opettaja Paavo Ojalainen uusimuotoisen kirkolliskokouksen ensimmäisen vaalikauden loppuhetkillä syksyllä 1977. Moninaiset uudistukset olivat olleet kirkolliskokouksessa esillä erityisen voimakkaasti vuodesta 1968, ja tämä pohjavire jatkui myös 1970-luvun puolivälissä. Uudistaminen oli kuitenkin erilaista. Siinä missä vuosien 1968, 1971 ja 1973 kirkolliskokoukset olivat toteuttaneet laajoja uudistuksia erityisesti kirkon keskushallinnossa ja seurakuntahallinnossa, uusimuotoisen kirkolliskokouksen alkuvaiheessa kyse oli ennemminkin monista pienistä muutoksista. Vuoden 1973 kirkolliskokouksen käsittelyssä oli ollut hieman alle 150 asiaa, joista monet olivat olleet suuria kokonaisuudistuksia, kun taas vuosina 1974-1977 asioita oli noin $260^{569}$.

Tiheästi kokoontuva kirkolliskokous saattoi toteuttaa uudistuksia yksitellen. Esimerkiksi hiippakuntakokouksista tuli vuosittain kirkolliskokoukselle lukuisia tarkasti rajattuja aloitteita, joiden käsittely oli omiaan johtamaan vähittäiseen ja jatkuvaan muutokseen. Edelleen uudistustahtia nopeutti huomattavasti se, ettei kirkolliskokouksen tarvinnut enää pyytää lausuntoja hiippakuntakokouksilta ja hiippakuntien pappeinkokouksilta ${ }^{570}$. Nopeutuneella työskentelyllä oli myös kääntöpuolensa: toimikuntauudistus yritettiin toteuttaa kirkolliskokouksen uuden kokoustahdin mukaisesti yhden vaalikauden aikana, mikä johti kiireeseen kaikissa valmisteluvaiheissa ja lopulta koko uudistuksen lykkääntymiseen. 
Jatkuvat mutta toisaalta alaltaan pienet uudistukset aiheuttivat muitakin ongelmia. Vuonna 1975 keskusteltiin jälleen kerran hiljattain muutetusta kirkon vaalijärjestelmästä, josta sekä hiippakuntakokoukset että kirkolliskokousedustajat löysivät useita epäkohtia. ${ }^{571}$ Uusi vaalijärjestelmä oli ollut käytössä ensimmäistä kertaa vuonna 1970. Ensimmäisten kokemusten perusteella siihen oli tehty muutoksia jo 1973. Nämä muutokset eivät olleet ehtineet vielä voimaan vuoden 1974 seurakuntavaaleihin mennessä, mutta silti kirkolliskokous lähetti näiden seurakuntavaalien kokemusten pohjalta kirkkolakikomitealle valmisteltavaksi lakiuudistuksia.

Joistakin kirkkolain pykälistä oli uusimuotoisen kirkolliskokouksen alkuvaiheessa liikkeellä kolme versiota: voimassa ollut laki, eduskunnan hyväksyntää odottanut kirkolliskokouksen ehdottama lakimuutos ja kirkolliskokouksessa käsittelyssä ollut jälleen uusi lakimuutos. Pitkäjänteistä ja korkeatasoista lainsäädäntötyötä ei helpottanut, että tällaisissa tilanteissa kirkolliskokouksen valiokuntakin oli joskus tietämätön siitä, millaisiin säännöksiin se oli valmistelemassa muutoksia. Näin kävi perustevaliokunnan laatiessa mietintöä lasten pääsystä Herran ehtoolliselle. Kokonaisuudessaan mietinnön käsittely oli poikkeuksellinen: arkkipiispa Simojoki totesi ensin kaksi valiokunnan ehdotusta ja lopulta yhden keskustelussa ehdotetun lisäponnen äänestykseen kelpaamattomiksi. ${ }^{572}$

Nopeaa tahtia kuvasi konkreettisesti sekin, että piispa Osmo Alaja teki syksyllä 1975 määrärahaehdotuksen, joka oli muodoltaan kirkolliskokouksen uuden työjärjestyksen ja sisällöltään uuden lainsäädännön vastainen. ${ }^{573}$ Käsikirjavaliokunnan puheenjohtajakaan ei ollut ehtinyt mukaan uudistustahtiin. Ongelmia pahensi eduskunnan asiaruuhka, joka hidasti myös kirkolliskokouksen jättämien kirkkolain muutosehdotusten käsittelyä. Hidasteita saattoi tulla matkaan opetusministeriössäkin, jossa kansliapäällikkö Jaakko Numminen joutui kertomansa mukaan useita kertoja kiirehtimään kirkolliskokouksen jättämien esitysten käsittelyä: kiireessä ne saattoivat jäädä virkamiesten pöydille ${ }^{574}$. Samaan aikaan toiminnaltaan nopeutunut kirkolliskokous jätti kuitenkin entistä useammin ja entistä suppeampia kirkkolain muutosesityksiä.

Pienten osauudistusten määrä ei laskenut kirkolliskokouksen seuraavankaan vaalikauden alkaessa. Keväällä
1980 Johannes Leivonen laski, että kuluneen vuoden aikana oli ollut muutettavana 147 kirkkolain pykälää eli runsas neljännes kaikista pykälistä. Hän osoitti, että kulloinkin voimassa olevista kirkkolain pykälistä oli mahdotonta pysyä selvillä, ja näki ainoana ratkaisuna kirkkolain jakamisen kahtia. ${ }^{575}$ Kirkkolain kokonaisuudistuksen valmistelu alkoikin 1980-luvun alussa näkyä kirkkolain muutosesitysten määrässä: monia muutosehdotuksia lähetettiin uudistusta valmistelevalle komitealle. Vaikeista olosuhteista huolimatta kirkolliskokouksen lainvalmistelussa selvittiin ilman suurempia virheitä, mistä kiitos kuului paljolti kokouksen juristeille. Erityisesti vuoden 1971 päätös säilyttää korkeimpien oikeuksien valitsemat edustajat kokoonpanossa vaikutti käytännön työhön. Samoin pian kirkolliskokousuudistuksen jälkeen perustettu kirkon laintarkastustoimikunta, joka tarkasti kirkolliskokouksen käsittelyyn tulevat lakiesitykset, osoittautui tarpeelliseksi.

Kirkolliskokouksen esityslistalla keskeisimmällä sijalla olivat kirkkohallituksen, piispainkokouksen ja kirkolliskokouksen asettamien komiteoiden esitykset. Ensimmäisellä nelivuotiskaudella tällaisia esityksiä tuli 96 eli keskimäärin 12 yhdelle istuntokaudelle. Selvästi eniten esityksiä tuli kirkkohallitukselta, noin kaksi kolmesta esityksestä. Kirkolliskokouksessa oli toistuvasti ongelmia ja myös horjuvuutta pohdittaessa, miten paljon kokous saattoi poiketa pohjaesityksestä ilman uutta, erillistä aloitetta.

Kirkkojen välisessä vertailussa Suomen luterilaisen kirkon kirkolliskokouksen aloiteoikeus oli monessa mielessä erityinen. Pohjoismaisittain oli poikkeuksellista ensinnäkin se, että aloiteoikeus oli korostetusti kirkon sisäinen. Toisaalta kirkon sisällä tuo aloiteoikeus oli harvinaisen laaja ja ulottui alueelliselle tasolle, hiippakuntakokouksiin. ${ }^{576}$ Kirkon sisäisen aloiteoikeuden varaan rakentuva kirkkolainsäädäntö auttoi osaltaan kirkkoa selviämään ideologisesta taistelusta ja demokratisoituvan yhteiskunnan aiheuttamasta paineesta 1960-luvun lopulla ja seuraavan vuosikymmenen alkupuolella. 577 Kaikissa tilanteissa kirkko sai ainakin periaatteessa itse määritellä kirkolliskokouksen esityslistan.

Aloiteoikeuden laajuus kirkon sisällä aiheutti kuitenkin kirkolliskokousuudistuksen yhteydessä pelkoa, että kirkolliskokous tukehtuisi aloitetulvaan. Tässä suhteessa eduskunta, joka muuten oli kirkolliskokoukselle työ- 
järjestykseltään myönteinen esikuva, näyttäytyi varoittavana esimerkkinä. Avatessaan kirkolliskokouksen keväällä 1974 arkkipiispa Simojoki kehotti hiippakuntakokouksia noudattamaan tiukkaa seulaa, kun aloitteita lähetettiin kirkolliskokoukselle578. Oman kaitsijan ääni oli kuultu jo aiemmin arkkihiippakunnassa: hiippakuntakokouksista ainoastaan Turun kokous pidättyi lähettämästä aloitteita vuoden 1974 kirkolliskokoukselle. Simojoen sanojen pontimena olivatkin todennäköisesti muista hiippakunnista tulleet 30 aloitetta. Pelkästään Oulussa oli tehty lähes kolmannes kaikista aloitteista ja Lapuallakin melkein yhtä paljon. Vastaavasti Etelä-Suomen väestökeskuksissa oli vaiettu. Aloitteista kolmannes koski kirkollisia vaaleja. Uudistetun kirkolliskokouksen alkutaipaleella hallinnolliset ja taloudelliset kysymykset hallitsivat esityslistaa niin vahvasti, että seuraavina vuosina edustajien ilo oli suuri, kun käsittelyyn tuli uskoa ja jumalanpalveluselämää koskevia asioita ${ }^{579}$.

Kirkolliskokousedustajat osasivat säännöstellä omia edustaja-aloitteitaan. He tunsivat asioiden valmistelua ja tiesivät jokaisen aloitteen kuormittavan valiokunnissa istuvia edustajatovereitaan. Toisaalta istuntosalissa läsnä olevan edustajan aloitetta ei ollut niin helppoa mitätöidä kuin persoonattomasta hiippakuntakokouksesta tullutta ehdotusta. Edustaja-aloitteilla olikin usein enemmän painoa kuin hiippakuntakokousaloitteilla, joiden tyypillisiä syntyvaiheita tuomiorovasti Mauri Larkio päivitteli täysistunnossa vuonna 1977:

Mitkä portaat ja mikä koneisto käynnistetäänkään monta kertaa vain siksi, että aloite todetaan täällä epäkelvoksi. Sitä ei lähetetä kentältä niinkään kentän todellisen tarpeen vuoksi, vaan sen tähden, että joku yksityinen työntekijä luulee keksineensä suuren valon, jonka hän esittää rovastikunnassa. Lääninrovasti on kiusallisessa tilanteessa. Hän pääsee helpoimmalla lähettämällä aloitteen eteenpäin, eikä aina hiippakuntakokouskaan tahdo torjua, ettei kaveri tulisi nolatuksi. Ja niin viime kädessä joudutaan täällä torjumaan aloitteita. ${ }^{50}$

Oli ehdotuksia, joiden hylkäämisestä ei kulunut kauaakaan, kun jokin hiippakuntakokous lähetti asian uudelleen kirkolliskokoukselle. Kirkolliskokous jätti niin vuoden 1974 hiippakuntakokous- kuin edustaja-aloitteistakin suunnilleen puolet raukeamaan. Sen jälkeen raukeamaan jätettyjen aloitteiden osuus kuitenkin pieneni, ja aloite lähetettiin yhä useammin toiselle kirkolli- selle elimelle - yleensä kirkkohallitukselle - tutkittavaksi ja mahdollisia toimenpiteitä varten. Kirkolliskokouksen oma seula väljeni, ja kansleri Mikko Juva totesi olevansa huolissaan kirkolliskokouksen innosta: "Me keksimme monia hyviä ja hyödyllisiä asioita ja toteamme, että ne pitäisi selvittää. Sitten me katsomme, että onhan meillä kirkkohallitus, joka saa tämän asian selvittää., ${ }^{581}$ Kirkkohallitusta työllistämällä kirkolliskokous loi välillisesti painetta toimikuntalaitoksen laajentamiseen ja kirkon yhteisten virkojen lisäämiseen.

Ensimmäisellä nelivuotiskaudellaan uusimuotoinen kirkolliskokous lähetti asioita toisille elimille jatkovalmisteluun tai toimenpiteitä varten noin 120 kertaa. Luku ei ole tarkka, koska rajanveto on vaikeaa. Lukuun on pyritty laskemaan vain tapaukset, joissa kirkolliskokous selvästi delegoi asian hoitamisen eteenpäin. Esimerkiksi kirkon taloutta käsitellessään kirkolliskokous lausui kirkkohallitukselle monenlaisia toivomuksia, joita ei ole laskettu mukaan. Eniten kirkolliskokous lähetti asioita Juvan mainitsemalle kirkkohallitukselle, komiteoille, kirkon toimikunnille ja lakimuutosehdotuksina hallitukselle - kullekin näistä neljästä organisaatiosta runsaan viidenneksen kaikista eteenpäin lähetetyistä asioista. Komiteoille lähetetyistä asioista selvästi suurin osa meni kirkkolakikomitealle. Käytännön ongelmia aiheutti se, että toisiinsa liittyviä lakiasioita tuli niin kirkkolakikomitean kuin kirkkohallituksen valmisteltavaksi, jolloin uudistusten johdonmukaisuus kärsi.

Valtakunnan hallitukselle suunnattujen lakimuutosehdotusten määrä oli huomattava. Jos mukaan lasketaan myös valtioneuvostolle lähetetyt lausunnot ja kirjelmät, valtiojohdolle lähti kirkolliskokouksesta enemmän asioita kuin millekään yksittäiselle kirkon elimelle. Tässä mielessä ei ollut ihme, että lakimuutokset viipyivät. Toisaalta valtioneuvosto joutui usein odottelemaan kirkon lausuntoja, ja kirkolliskokouksen uusikin kokoontumistahti osoittautui valtiovallan lausuntopyyntöjen edessä usein liian verkkaiseksi. Syntyi ehdotuksia, että kirkkohallitus voisi toimia täydentävänä lausunnonantajana kiireellisissä mutta verrattain kehällisissä asioissa.

Piispainkokoukselle lähti keskimäärin yksi asia kirkolliskokouksen istuntokautta kohden. Sekin oli paljon, kun ottaa huomioon piispainkokouksen pienen organisaation. Piispainkokous oli saanut uusia tehtäviä kirkon keskushallinnon uudistuksessa, mikä näkyi siten, 
että monet asiat tulivat kirkolliskokoukseen piispainkokoukselta tai piispainkokouksen lausunnolla varustettuina. Samaten kirkolliskokous lähetti asioita piispainkokouksen valmisteltavaksi. Piispainkokouksenkaan voimavarat eivät seuranneet nopeutuvan kirkollisen lainsäädäntötyön tahtia. Sihteerinsä ja valmistusvaliokuntansa voimin tämä kahdesti vuodessa kokoontuva elin joutui työstämään monitahoisia ja vaikeita asiakokonaisuuksia. Kunnollisen valmisteluorganisaation puuttuessa jouduttiin perustamaan tilapäisiä toimikuntia tai teettämään piispainkokouksen valmistelutöitä kirkon pysyvillä toimikunnilla ${ }^{582}$. Kun lisäksi samoja asioita käsiteltiin monissa keskushallinnon elimissä, jouduttiin asettamaan useita työryhmiä selvittelemään yksittäisiä kysymyksiä. ${ }^{583}$

Uusimuotoisen kirkolliskokouksen aloitettua työnsä piispat itsekin innostuivat ehdottamaan asioiden lähettämistä piispainkokouksen valmisteluun. Näin he halusivat taata, että opilliset seikat otettiin kunnolla huomioon ja että he itse pääsivät vaikuttamaan valmisteluun. Samalla he kuitenkin olivat mukana luomassa piispainkokouksesta eräänlaista toista kirkkohallitusta, kirkolliskokouksen valmisteluorganisaatiota. Sellaiseen piispainkokouksella ei kuitenkaan ollut resursseja. Piispainkokouksen arvovaltaa näytti rasittavan yksittäistapauksista eniten se, että keväällä 1976 kollegio ei kyennyt antamaan minkäänlaista perusteltua kannanottoa naispappeuskysymykseen.

Lisäksi piispainkokous sijoitti itsensä käytännössä herkästi kirkolliskokoukselle alisteiseksi elimeksi, mikä näkyi jo vuonna 1974 halussa alistaa piispainkokouksen työjärjestys kirkolliskokouksen hyväksyttäväksi. Kun piispainkokous tietyllä tavalla arkipäiväistyi, piispoilla oli entistä suurempi tarve hakea kirkolliskokoukselta tukea ja selkänojaa toimilleen. Matalakirkollinen Osmo Alaja oli yllättäen ensimmäisiä, joka istuessaan viimeistä kertaa kirkolliskokouksessa syksyllä 1977 kiinnitti huomiota piispainkokouksen arvovallan rapautumiseen ${ }^{584}$. Vähitellen piispat ryhtyivät sanomaan vastaan niille, jotka ehdottivat asioita piispainkokouksen tutkittavaksi. "Sehän ei ole mikään tutkimuslaitos", tiivisti Aimo T. Nikolainen opetuksensa piispainkokouksesta ${ }^{585}$. Vahinko oli kuitenkin ehtinyt jo tapahtua. Uusimuotoisen kirkolliskokouksen alkuvuosina elettiin aikaa, jolloin hiippakuntatason kehittäminen oli jäänyt monessa mielessä jälkeen ja jolloin piispainkokouksen ääni oli kärsimässä selvän inflaation.

Kirkolliskokousuudistuksen aikaan yhteiskunta näytti muuttuvan kiihtyvällä tahdilla asettaen vaatimuksia kirkolle, mutta toisaalta kirkossa oli vahvoja ryhmiä, jotka vastustivat mukautumista. ${ }^{56}$ Kirkolliskokous yritti tasapainoilla välimaastossa. Pappisvirka ei avautunut naisille, mutta ratkaisevan äänestyksen jälkeisillä toimilla kokouksen enemmistö pyrki etenemään niin pitkälle naispappeuden suuntaan kuin vain suinkin oli mahdollista. Kokous halusi ymmärtää niitä pappeja, jotka kieltäytyivät vihkimästä eronneita, ja se korosti avioliiton ensisijaisuutta avosuhteeseen nähden. Toisaalta sen puheenjohtaja ilmoitti selvästi, ettei papin tullut määrittää tällaisilla perusteilla kummin kelpoisuutta. Niin suomalaisessa keskustelussa kuin ekumenian kentässä kirkolliskokous pyrki yhdistämään avaran kansankirkollisuuden ja vahvan tunnustuksellisuuden. Mahdollisuudet viimeksi mainitun painottamiseen parantuivat 1970-luvun edetessä yleisen ilmapiirin muuttuessa uskonnolle aiempaa myönteisemmäksi.

Kirkolliskokous toteutti aktiivisesti kansankirkon perinteistä tehtävää toimia eettisenä kannanottajana, eräänlaisena kansan omanatuntona. Se puolusti perinteisiä moraalinormeja ja esimerkiksi uskonnonopetuksen asemaa. Toisaalta kirkolliskokouksen jäsenet tunnustelivat tarkkaan, mikä oli kokouksen liikkumatila kulloisessakin tilanteessa. He ottivat välillä tiukasti kantaa valtiovallan toimiin mutta arvioivat myös kriittisesti vaikuttamismahdollisuuksiaan: oma-aloitteisesti laaditut kannanotot osoittautuivat vaikutuksiltaan heikonlaisiksi, ja pyydettyjen lausuntojenkin vaihtoehtona pohdittiin siirtymistä henkilökohtaiseen vaikuttamiseen jo valmisteluvaiheessa. Yhteiskunnan asenneilmaston muuttuessa vuosikymmenen lopulla kirkolliskokous käytti liikenevän liikkumatilan ja rohkeni vedota entistä avoimemmin myös teologisiin perusteluihin.

\section{VALIOKUNNISSA VOIMAT "TYÖHÖN JA YÖHÖN"}

Eduskunnan on sanottu olevan yhtä vahva kuin sen valiokuntalaitos. Parlamenttiryhmien vahvuus ja yhtenäisyys ovat puolestaan määritelleet valiokuntien liikkumatilaa: mitä vahvempia nämä ryhmät ovat olleet, sitä heikommaksi on jäänyt valiokuntien vallankäyttöasema. ${ }^{587}$ Molemmat toteamukset sopivat kirkolliskokouk- 
seen. Sielläkin valiokunnilla oli ratkaiseva osuus siinä, missä määrin kirkolliskokous puuttui kirkkohallituksen, piispainkokouksen tai komiteoiden esityksiin. Organisoidun ryhmätoiminnan puute taas toi kirkolliskokouksessa paitsi täysistunnolle myös valiokunnille valtaa tavalla, joka oli eduskuntaan nähden hyvin poikkeuksellista. Kirkolliskokouksen valiokuntien valta perustuikin keskushallinnon uudistuksen jälkeisinä vuosina ennen kaikkea siihen, ettei kirkolliskokouksen sisällä ollut - virallisia edustajia lukuun ottamatta - vahvoja vallankäyttäjiä, jotka olisivat kilpailleet valiokuntien kanssa. Sen sijaan valiokuntien omat resurssit olivat sangen vähäisiä ja aikataulut kireitä. Kirkolliskokouk-

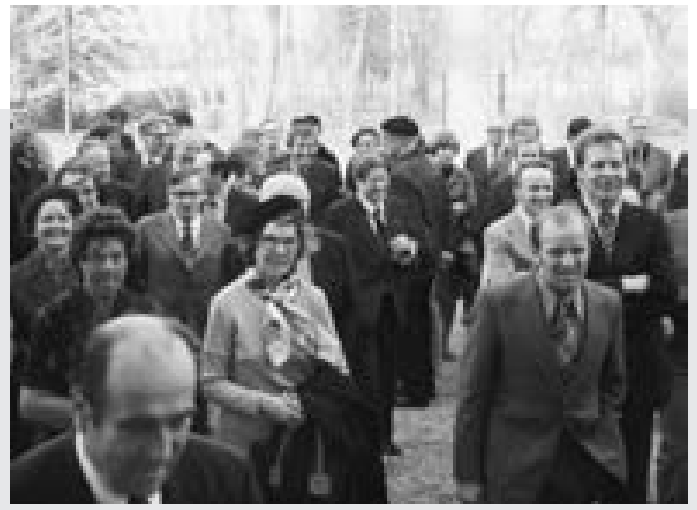

\section{Edustajat retkellä}

Kiireisen työskentelyn keskellä kirkolliskokous raivasi kerran nelivuotiskaudessa tilaa pienelle tai joskus hieman laajemmalle tutustumisretkelle. Ajatus sai alkunsa kansliavaliokunnassa, ja arkkipiispa Simojoki antoi sille tukensa. Samalla hän ehdotti ensimmäisiksi retkikohteiksi keväällä 1977 Louhisaaren kartanoa sekä Askaisten ja Merimaskun kirkkoja. ${ }^{\mathrm{I}}$ Kansliavaliokunnan nimeämä työryhmä valmisteli retken ohjelman. ${ }^{\text {II }}$

Toimittajat seurasivat tarkasti ensimmäistä retkeä. Historiallisten kohteiden ohella kirkolliskokous sai nähdä työnsä hedelmiä: pienessä, kirkon keskusrahaston avustusten turvin elävässä Merimaskun seurakunnassa edustajat otettiin vastaan odotettuina vieraina. Tunnelma oli herkistynyt. Retken päättänyt tutustuminen Kultarannan puutarhaan Naantalissa oli siinä mielessä erityinen hetki, että kuultavissa oli Kultarannan asukkaan muistoja: kirkolliskokousedustaja, emäntä Katri Kaarlonen oli asunut Kultarannassa kolme kesää, kun hänen isänsä Kyösti Kallio oli toiminut tasavallan presidenttinä. ${ }^{\text {III }}$ sen koolla ollessa valiokuntien työhön sopivat piispa Nikolaisen sanat "työhön ja yöhön" heitetyistä voimista.

Vuosina 1974-1977 sekä talous- että perustevaliokunta kirjoittivat kumpikin yli sata sivua mietintötekstiä. Yleiseltä valmistusvaliokunnalta tuli kaikkein eniten mietintöjä, yhteensä 60, mutta lähes kaikki olivat lyhyitä yhden sivun tekstejä. Vastaavasti käsikirja- ja kansliavaliokunnan mietintöjen määrä ja laajuus olivat vähäisimpiä. ${ }^{58}$ Niin valiokuntien kuin koko kirkolliskokouksen työskentelyä vaikeutti se, että käsiteltävien asioiden määrä saattoi vaihdella paljon istuntokaudesta toiseen ${ }^{589}$.

Valiokuntien suppeat pöytäkirjat luovat kuvaa niiden työskentelystä. Ahvenanmaan edustajan, insinööri

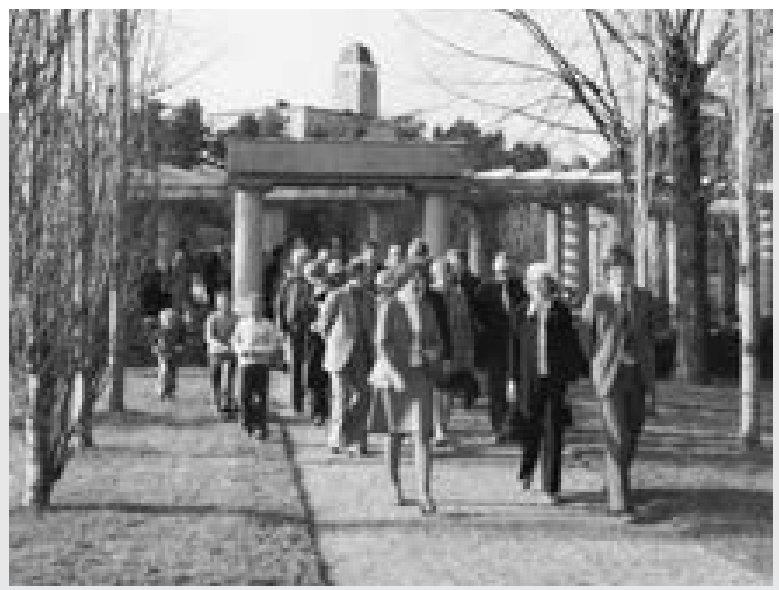

Kirkolliskokouksen ensimmäisen retken osanottajia Louhisaaren kartanon edustalla ja Kultarannan puutarhassa keväällä 1977. Kuvat: Kirkolliskokouksen kuvakokoelma / Juhani Linkola.

Kirkolliskokouksen retki huomattiin myös päättäjien ahkerana moraalinvartijana tunnetussa iltapäivälehdistössä. Ilta-Sanomien kokousselostuksessa kiinnitettiin huomiota kirkolliskokouksen kalleuteen ja arvosteltiin aikaa vienyttä retkeä: "Kirkolliskokouksen istunnoissa alkaa olla melkoista tyhjäkäyntiä.,'Iv Artikkelin kirjoittaja, toimittaja Sirkku Nyström sai tosin pari vuosikymmentä myöhemmin itsekin kirkolliskokousedustajana kutsun perinteiselle retkelle. Kansliavaliokunta puolestaan totesi saamansa palautteen perusteella retken onnistuneeksi ${ }^{\mathrm{V}}$.

I KKHA KKA Cig 1 ptk. 12.11.1976 \$67.

II KKHA KKA Cig 1 ptk. 1.5.1977 \$12, ptk. 2.5.1977 \$14.

III Kmaa 10.5.1977 RETKEILY isoisten jäljille (Kirsti Ritopeura).

IV IS 5.5.1977 Kirkolliskokouksessa tyhjäkäyntiä (Sirkku Nyström).

V KKHA KKA Cig 1 ptk. 5.5.1977 \$21. 
Knut von Schantzin johtama kansliavaliokunta kokoontui arvokkaasti pitäessään huolta kirkolliskokouksen taloudesta. Pöytäkirjat olivat huoliteltuja ja liitteineen hyvässä järjestyksessä. Samaan aikaan kokonaiskirkon taloudesta vastaava talousvaliokunta sai käsiteltäväkseen laajakantoisia kysymyksiä, joihin sen oli usein nopeasti sorvattava kannanottonsa. Talousvaliokunnan mietinnöt eivät saaneet siirtyä puolella vuodella seuraavalle istuntokaudelle, mikä oli mahdollista useimmille muille valiokunnille. Etukäteistyöskentely istuntokausien välillä oli siksi erityisen tärkeää talousvaliokunnalle. Kaikkiaan valiokunnalla oli 1974 runsaassa puolessa vuodessa yhteensä 28 kokousta. Seuraavana vuonna tahti rauhoittui: vuosina 1975-1981 valiokunnan vuosittainen kokousmäärä vaihteli 15:stä 19:ään.

Talousvaliokunnan johdossa olleet revisioneuvos Pentti Reinilä ja Lapuan kaupunginsihteeri Väinö Takala joutuivat valittelemaan kirkolliskokoukselle, että valiokunta oli ollut milloin ylivoimaisen tehtävän edessä, milloin taas joutunut kiireessä jättämään kirkolliskokoukselle heikkolaatuisia mietintöjä. Päänsilittelyjä ei tullut kokoussalistakaan, jossa talousvaliokunta oli arvostelluimpia valiokuntia. ${ }^{590}$ Kirkolliskokouksen kymmenet tuhannet markat pysyivät kansliavaliokunnassa järjestyksessä, mutta kokonaiskirkon kymmenet miljoonat jäivät talousvaliokunnassa ajoittain hyvin nopealle käsittelylle. Sikäli lopputulos ei ollut yllättävä, että molempien asioiden valmisteluun oli varattu suunnilleen yhtä paljon työvoimaa. Ero oli siinä, että talousvaliokunnalla oli ulkopuolinen sihteeri, varatuomari Reijo Lehtinen kirkkohallituksesta. Ennen pitkää kansliavaliokunnan sisältä nousi ehdotus, että valiokunnan jäsenmäärää pienennettäisiin. Kun varajäsenistä luovuttiin, valiokuntien koko kasvoi käytännössä vähintään 15 henkilöön, mutta kansliavaliokunnan jäsenmäärä väheni yhdeksään. ${ }^{591}$

Oma lukunsa oli yleinen valmistusvaliokunta, johon lähetettiin ne edustaja- ja hiippakuntakokousaloitteet, joilta ei odotettu paljoa, ja lisäksi jonkin verran niitä, jotka osoittautuivat tutkimisen arvoisiksi, monitahoisiksi ja vaativiksi kokonaisuuksiksi. Talousvaliokunnan ohella yleinen valmistusvaliokunta sai täysistunnoissa usein osakseen arvostelua. Kirkolliskokousedustajilla oli esimerkiksi erimielisyyksiä siitä, missä määrin yleisen valmistusvaliokunnan tuli tutkia saamiaan aloittei- ta $^{592}$. Muut valiokunnat käsittelivät asioita, jotka oli jo toisaalla valmisteltu pitkälle, mutta yleisen valmistusvaliokunnan saamat aloitteet vasta odottivat tutkimista. Pohdittiin, oliko valiokunnan tutkittava aloitteita, otettava niihin perusteellisesti kantaa ja laadittava selvä evästys jatkovalmistelua varten vai ainoastaan siivilöitävä joukosta tutkimisen arvoiset asiat ja lähetettävä ne eteenpäin. Käytännön paine vei jälkimmäisen vaihtoehdon suuntaan.

Yleinen valmistusvaliokunta sai uusimuotoisen kirkolliskokouksen alkuaikoina enemmän asioita käsiteltäväkseen kuin muut valiokunnat, vuosittain lähemmäs parikymmentä. Keväästä 1974 kevääseen 1975 lähetettiin valiokuntiin yhteensä 116 asiaa, joista yli kolmannes (42) yleiseen valmistusvaliokuntaan. Näistä lähtökohdista valiokunnan oli vaikea toteuttaa valmistelutehtäväänsä perusteellisesti. Valiokunnan ongelmia lisäsi vielä kirkolliskokouksen oma työjärjestys, jonka mukaan edustaja-aloitteiden tuli olla lyhyesti perusteltuja. Tarkkojen perustelujen puuttuessa valiokunnan oli lähdettävä tutkimustyössään liikkeelle usein melko puhtaalta pöydältä. Joskus valiokunnan toisarvoiseksi tulkitsema aloite huomattiin myöhemmin täysistunnossa tärkeäksi, kun aloitteen tekijä perusteli sitä laajasti.

Paljolti aloittelevista maallikkoedustajista koottu yleinen valmistusvaliokunta joutui usein käsittelemään erityisasiantuntemusta vaativia asioita. Puheenjohtajiksi "joutuivat" kenttäpiispa ja virassaan nuorin piispa. Jo valiokunnan kokoonpano teki siitä alttiin arvostelulle esimerkiksi verrattuna arvovaltaiseen lakivaliokuntaan. Yleisen valmistusvaliokunnan jäsenten itseluottamuskaan ei ollut aina vahva. Kerran valiokunta esitti kirjelmän lähettämistä valtioneuvostolle mutta arasteli itse ryhtyä sitä valmistelemaan. Kirkolliskokouksen oli määrättävä valiokunta tekemään kirjelmäehdotus. ${ }^{593}$ Joskus valiokunnan jäsen ja kerran puheenjohtajakin ehdotti, ettei asiaa palautettaisi valiokuntaan, koska lopputulos voisi olla huonompi kuin pelkällä täysistuntotyöskentelyllä. ${ }^{594}$ Näin oli silloin, kun valiokunnan toisen osaston puheenjohtaja, piispa Kalevi Toiviainen puuskahti: "Nähtävästi on hieman vaarallista tahrata nimensä yleisen valmistusvaliokunnan huonon vastaanoton saaviin papereihin." ${ }^{995}$

Jokainen valiokunta, joka valmisteli määräenemmistön vaativia päätöksiä, joutui punnitsemaan esityksen 
läpimenomahdollisuuksia. Erityisesti lakivaliokunta hajotti samaakin asiaa koskevia lakiuudistuksia osasiksi, mikäli se ei ollut varma, että kaikki muutokset saisivat taakseen määräenemmistön. ${ }^{596}$ Tiiviit, toistuvat istuntokaudet ja niiden mahdollistama tutustuminen toisiin edustajiin helpottivat kirkolliskokouksen sisäisten voimasuhteiden arviointia. Mikko Juva totesikin päättäessään syksyn 1981 kirkolliskokousta, että keskustelu valiokuntien mietinnöistä oli vähentynyt. Kun neljä vuotta oli oltu yhdessä, valiokunnat olivat oppineet kirjaamaan edustajien tunnot. ${ }^{597}$ Juvan havainto piti paikkansa, mutta asiaan vaikutti todennäköisesti myös kokouksen odottava tunnelma: monia suuria muutoksia oli siirretty seuraaville istuntokausille, ja edustajien katseet oli jo suunnattu niihin.

Talousasioiden ohella myös valtioneuvostolle annettavat lausunnot vaativat kirkolliskokoukselta nopeaa toimintaa. Keväällä 1978 kasvatusasiain valiokunta joutui yhden istuntoviikon aikana laatimaan lausuntoehdotuksen, joka koski hyvin laaja-alaista keskiasteen koulunuudistusta. Mietintöä esitellessään piispa Vikström kertoi tulkintavaikeuksista, joita hänellä oli valiokunnan puheenjohtajana edellisenä yönä ollut: aina ei voinut olla varma siitä, oliko nyökytys katsottava hyväksymisen vai nukkumisen merkiksi. ${ }^{598}$ Usein kirkolliskokousedustajat valittelivat kiivasta tahtia ja erityisesti sitä, että valiokuntien mietintöihin tutustumiselle ei jäänyt riittävästi aikaa. Pitkät päivät ja lyhyet yöunet eivät kuitenkaan yksinomaan uuvuttaneet kirkolliskokousedustajia, vaan täysistunnoissa pääsi esiin myös yötyöhön usein liitetty luovuus. Samaisella kevään 1978 istuntokaudella tuomiorovasti Pertti Ranta kirjoitti eräänä yönä puheenvuoron, jossa hän intoutui puolustamaan kirkkomuusikkojen aseman uudistamista tyylillisenä esikuvanaan itse Aleksis Kivi:

Tuoltapa taloistansa ja torpistansa kirkkopolulle käyvät vanhat ja nuoret. Vakaasti astelevat vanhemmat haastellen viikon kuulumiset, lapset kirmaten kuin laitumelle päässeinä. Moni myös autollansa kirkkotielle joutuu, ja kohtapa kaikuu temppelistä ylös korkeuteen veisuu mahtava ja voimallinen. Moni silmäkulma kostuu, kun rovasti saarnassaan Luojan töistä kertoilee ja kun kirkasääninen kuoro pian virren virittää ja siihen koko kirkkokansa yhtyy, kukin äänellänsä. Ja kunnaallansa seurakuntatalo soma, sinne joka päivä monen nuoren ja vanhan askel johtaa. Siellä soivat viulut ja klaneetit, siellä laulu kaikuu. Kuorojensa parissa siellä puuhaileepi kanttori, ei äkeänä lukkarina vaan iloisena työtään tehden. Ja kaikki, kaikki Taivaan Taaton ylistystä soi. ${ }^{599}$

\section{ISTUNTOSALIN DEMOKRATIAA}

\section{VIRALLISTEN EDUSTAJIEN JOHDOLLA}

Opettaja Erkki Piri kertoi kirkolliskokoukselle edustajantyönsä alkuvaiheista:

Kun tulin vuonna 1973 ensimmäisen kerran kirkolliskokoukseen, seurasin arkana ja vähän orjamielisenäkin Akatemiatalon eteisessä, kun eräs hyvin kokenut kirkolliskokousveteraani, joka ei ole enää täällä, neuvoi nuorempaansa. Hän sanoi, että täällä kirkolliskokouksessa on mm. kolmenlaisia edustajia: On joukko teologeja, jotka ratkovat kirkon taloudellisia kysymyksiä (hilpeyttä), on tunnollisia asioihin paneutujia, jotka tarkasti ja kriittisesti kuuntelevat, sitten on kolmanneksi joukko maallikoita, jotka pyrkivät ratkomaan teologisia kysymyksiä (hilpeyttä). ${ }^{600}$

Kirkolliskokouksessa täysistunnoissa pidetyillä puheilla oli suuri merkitys. Vaalikaudella 1974-1977 kuultiin 2400 puheenvuoroa, joista läsnäolo- ja puheoikeutetut, määräämättömäksi ajaksi valitut kirkkoneuvokset käyttivät hieman yli sata. Viralliset edustajat, joiden osuus kaikista äänivaltaisista edustajista oli 11 prosenttia, käyttivät yli neljänneksen puheenvuoroista. Osuus virallista edustajaa kohden oli vieläkin suurempi, mikäli valtioneuvoston määräämää edustajaa ei lasketa mukaan. Virallisten edustajien puheiden määrää nosti huomattavasti se, että enemmistö heistä toimi jonkin valiokunnan puheenjohtajana. Tässä tehtävässä he esittelivät ja perustelivat valiokuntansa mietintöjä. Äänivaltainen kirkolliskokousedustaja puhui nelivuotiskauden aikana keskimäärin 21 kertaa. Maallikkoedustaja puhui selvästi keskimääräistä vähemmän, 15 kertaa, kun taas hiippakunnittain valitut pappisedustajat puhuivat hieman tavallista useammin. Piispa nousi sen sijaan puhujakorokkeelle keskimäärin lähes neljä kertaa niin usein kuin tavallinen maallikkoedustaja.

Naisedustajat olivat kirkolliskokouksen vaiteliainta joukkoa: he puhuivat vain runsaan kolmanneksen siitä mitä muutenkin jo tavallista hiljaisemmat maallikkoedustajat keskimäärin. Tuohon aikaan kirkolliskokouksessa vallinnut ilmapiiri oli sellainen, että 
naisedustajan kynnys astua puhumaan oli korkeampi kuin miehillä. Maallikkoedustajissa oli viisi henkilöä, jotka eivät puhuneet kertaakaan. Sen sijaan papistossa jokainen yhdenkin kauden varaedustaja kirjautti jälkensä kirkolliskokouksen keskustelupöytäkirjaan. Kovin selviä yhtäläisyysmerkkejä puhemäärän ja vaikutusvallan välille ei sovi piirtää. Kirkolliskokouksessa oli tilaa "tunnollisille asioihin paneutujille", jotka istuivat hiljaa ja kuuntelivat tarkasti. Tällainenkin henkilö saattoi kantaa vastuuta keskeisessä valiokunnassa tai vaikuttaa asioiden kulkuun verkostojensa kautta kokouspaikan käytävillä. Vastaavasti puheenvuorojen suuri lukumäärä ei läheskään aina tarkoittanut merkittävää vaikutusvaltaa.

Keskustelupöytäkirjoissa toistuivat paljolti tietyt nimet. Eniten puhunut kymmenesosa käytti neljän vuoden aikana yli kolmanneksen kaikista puheenvuoroista, vaikka kaikki tähän joukkoon kuuluneet eivät edes istuneet koko vaalikautta. Maallikkoedustaja, jonka tunnettiin kuuluvan johonkin herätysliikkeeseen, puhui useammin kuin maallikkoedustaja keskimäärin. Juuri herätysliikeväen joukosta löytyivät ne Erkki Pirin mainitsemat maallikkoedustajat, jotka tarttuivat teologisiin kysymyksiin. Heihin kuului Piri itsekin yhdessä kahden muun Oulun hiippakunnasta saapuneen vanhoillislestadiolaisen maallikkoedustajan, Erkki Reinikaisen ja Lauri Taskilan, kanssa. Erityisesti Reinikainen saavutti voimakkaista mielipiteistään huolimatta kirkolliskokouksessa yleistä arvostusta ${ }^{601}$. Vastaavasti eteläisestä Suomesta saapui monia talouden ja hallinnon asiantuntijoita, joiden työ kirkolliskokouksessakin keskittyi näille aloille.

Piispoista eniten puhuivat Aimo T. Nikolainen ja Erkki Kansanaho, jotka tilastollisesti kapusivat puhujakorokkeelle lähemmäs kolme kertaa päivässä. Arkkipiispa Simojoki taas puhui vain harvoin, lähinnä kun syyt olivat erityisen painavat. Vielä Helsingin piispana hän oli ollut kirkolliskokouksen aktiivisin puheenjohtajiston ulkopuolinen puheenvuorojen käyttäjä ${ }^{602}$. Simojoen pidättyvä esiintyminen näyttääkin johtuneen ennen kaikkea siitä, miten hän ymmärsi arkkipiispan roolin kirkolliskokouksen puheenjohtajana. Sitä vastoin Simojoki piti puheenjohtajan tehtävän tiukasti itsellään ${ }^{603}$. Melko usein hän myös antoi kirkolliskokoukselle palautetta puheenjohtajan paikalta jälkikäteen, kun päätös oli tehty. ${ }^{604}$ Mikko Juva toimi arkkipiispana aivan toi- sin. Keskustelun kuluessa hän hakeutui mielellään tiukkaan mielipiteidenvaihtoon. Juva myös luovutti vastuuta varapuheenjohtajille, mihin ainakin joissain tilanteissa hän kertoi syyksi työuupumuksensa ${ }^{605}$. Tämä työnjako helpotti osaltaan Juvan osallistumista keskusteluun.

Arkkipiispa Simojoki oli puheenjohtajana erityisen tarkka työjärjestyksen muodollisesta noudattamisesta - usein kirkolliskokouksen korkeimpia juristejakin tiukempi. Mikko Juva taas kantoi paljon huolta aikataulusta. Eräällä kerralla hän pyysi hienovaraisesti huomauttaa, "että olemme vasta tiistaissa ja ilmeisesti istumme, mikäli edustajat haluavat puhua kaikista asioista taivaan ja maan välillä ja vähän muistakin jokaisessa keskustelussa, vielä perjantainakin”. ${ }^{606}$ Keväällä 1981 hän valitteli kirkkorukouksen taukoja käsiteltäessä: "Minä pidän liian pitkiä taukoja, niin että aina ehtii uusi puhuja nousta!"607

Kirkolliskokousedustajan vaikutusvaltaa voi tarkastella tutkimalla, miten monesti hänen täysistunnossa tekemänsä muutosehdotukset hyväksyttiin. Eduskunnassa tällaiset muutosehdotukset lyötiin tavallisesti lukkoon eduskuntaryhmissä ennen täysistuntoa, ja ne olivat siten etukäteen tiedossa. ${ }^{608}$ Sen sijaan kirkolliskokouksessa ei ollut edustajaryhmiä, jotka olisivat päättäneet muutosehdotuksista tai joiden kesken olisi voitu sopia asioista etukäteen. Täysistunnon tapahtumia oli usein vaikea ennakoida. ${ }^{609}$ Myös muutosehdotukset tulivat yleensä nopeasti ja yllättäen. Ehdotusta ei ollut aikaa ruveta analysoimaan pohjia myöten, vaan oli luotettava ehdotuksen tekijän arvostelukykyyn. Joskus kannatuspuheenvuoron käyttäjä ilmoitti julkisestikin asettuneensa muutosehdotuksen taakse, koska ehdotuksen tekijä "yleensä tekee vain viisaita esityksiä' ${ }^{\prime 10}$.

Toki edustajien äänestyskäyttäytymiseen vaikuttivat oleellisesti keskustelussa esitetyt asiaperustelut sekä se, ketkä ehdotusta kannattivat. Äänestyshetkelläkään kaikkien mielipide ei ollut vielä muotoutunut. Seisomaan noustaessa eturivin piispojen ja oikeusoppineiden selät olivat tarkkaavaisten katseiden alla, ja vastaavasti nimenhuutoäänestyksessä kuunneltiin näiden samojen henkilöiden kantaa erityisen keskittyneesti. Seikko Eskola ehdotti 1981 vaihtelua äänestysjärjestykseen. Hänen mielestään joka kerta aakkosten alusta aloitettu äänestys ei ollut tasapuolinen: "Tunnustan itse, että monissa lakiasioissa olisi mukavampaa äänestää L:n jälkeen. Monet keskustelut ovat antaneet sen vaikutelman, että piis- 


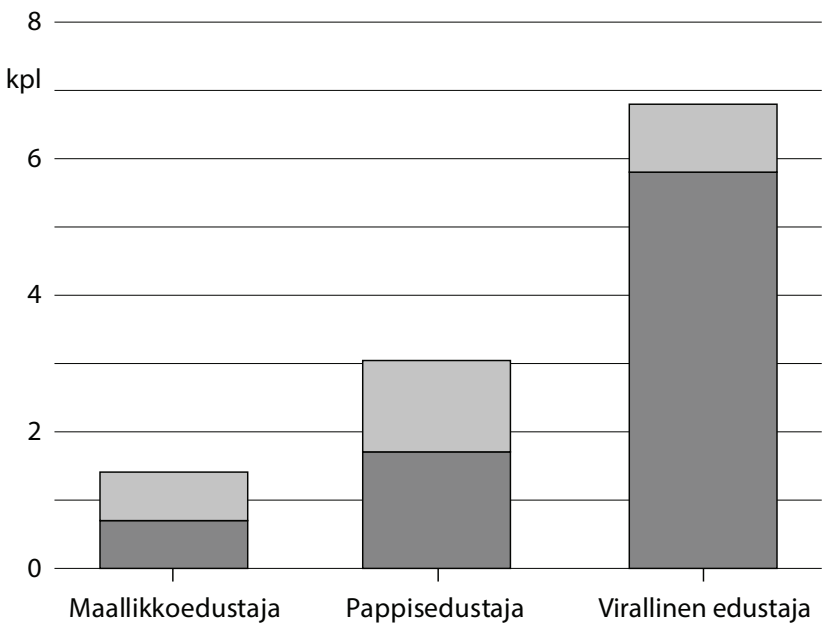

pan vaikutusvalta voi olla hiukan suurempi, jos hänen nimensä sattuu alkamaan J:lla kuin V:llä." ${ }^{111}$ Muutosta ei tullut, mutta puheenvuoro kuvasti virallisten edustajien valtaa kirkolliskokouksessa. Monenlaiset seikat vaikuttivat siis siihen, mikä ehdotus lopulta hyväksyttiin. Yhden nelivuotiskauden äänestyksistä tulee kuitenkin kokoon jo niin suuri otos, että väistämättä nousee esiin myös muutosehdotuksen tekijän henkilökohtainen vaikutusvalta.

Vaalikaudella 1974-1977 kirkolliskokouksen täysistunnoissa tehtiin käsittelyn pohjana olleeseen puhemiesneuvoston tai valiokunnan esitykseen 264 muutosehdotusta. Näistä muutosehdotuksista peräti 62 prosenttia hyväksyttiin. Todellisuudessa muutosehdotus voitti pohjaesityksen vieläkin useammin: monesti oli toisiaan vastaan kilpailemassa monta vaihtoehtoista muutosehdotusta, joista enimmillään yksi voitiin hyväksyä. Tilanne oli aivan toisenlainen kuin eduskunnassa, jossa muutosehdotuksen hylkääminen oli yleensä jo etukäteen täysin selvää. Valtiollisessa parlamentissa ehdotuksia tehtiin lähinnä julkisuutta varten ja periaatteellisen kannan osoittamiseksi, ei lopputuloksen muuttamiseksi ${ }^{612}$.

Kirkolliskokouksessa päätöksenteko oli prosessi, joka päättyi vasta puheenjohtajan nuijan kopautukseen. Naispappeuskeskustelua lukuun ottamatta julkisuus ei myöskään ollut niin suurta, että sitä varten olisi kannattanut esittää puheenvuoroja. ${ }^{613}$ Myös välillinen vaalijärjestelmä ja osittain käytössä ollut enemmistövaali vaikuttivat siihen, että kirkolliskokoukseen valittiin yleensä
Kuvio 5: Yksittäisen edustajan täysistunnoissa tekemien muutosehdotusten keskiarvo kaudella 1974-1977

Virallisten edustajien osalta kuviossa ovat mukana piispat, kenttäpiispa ja korkeimpien oikeusistuinten valitsemat edustajat. Valtioneuvoston määräämää edustajaa ei ole otettu huomioon, koska hän ei käytännössä juuri osallistunut noina vuosina kirkolliskokouksen työskentelyyn.

Hylätyt

Hyväksytyt

yhteistyökyvystään tunnettuja, mahdollisimman laajaa luottamusta nauttivia henkilöitä. Täysistunnoissa tehdyt muutosehdotukset tähtäsivät ensisijaisesti siihen, että asiassa päästäisiin mahdollisimman hyvään lopputulokseen. Siksi näitä ehdotuksia kannatettiin.

Keskimääräinen maallikkoedustaja teki nelivuotiskauden aikana 1,4 muutosehdotusta, kun taas pappisedustajalla luku oli kaksinkertainen. Virallinen edustaja taas teki yli kaksi kertaa niin monta muutosehdotusta kuin pappisedustaja ja 4,5-kertaisesti maallikkoedustajaan verrattuna. Noin puolet maallikkoedustajien tekemistä muutosehdotuksista hyväksyttiin, mikä oli jo sinänsä suuri osuus. Pappisedustajilla hieman yli puolet muutosehdotuksista meni läpi. Ero maallikkoedustajiin nähden oli lähinnä ehdotusten lukumäärässä, ei niiden hyväksymisprosentissa. Sen sijaan virallisten edustajien tekemistä ehdotuksista hylättiin vain joka seitsemäs. Maallikkoedustajien osalta edustajakokemus näkyi selvästi: neljännen tai useamman kauden maallikkoedustajan ehdotus meni läpi yli 60 prosenttia useammin kuin ensimmäisen kauden maallikkoedustajan esittämä muutos.

Lukuja voi tulkita niin, että edustajalla, joka teki useita muutosehdotuksia ja sai niistä suuren osan läpi, oli paljon vaikutusvaltaa. Sen sijaan tilastojen perusteella ei voi sanoa, että jollakulla yksittäisellä edustajalla olisi ollut tavallista vähemmän vaikutusvaltaa. Esimerkiksi arkkipiispa Simojoki, joka puhui harvoin ja teki vielä harvemmin muutosehdotuksia, oli merkittävä vallankäyttäjä. Yleensä riitti, että hän vihjaisi kantansa, jolloin muut 
tekivät muutosehdotukset hänen puolestaan. Näin arkkipiispan ei tarvinnut laittaa arvovaltaansa peliin äänestyksissä. Toisenlaisen esimerkin vallankäyttäjästä tarjoaa talousvaliokunnan puheenjohtaja Pentti Reinilä, joka kyllä teki lukuisia muutosehdotuksia mutta jäi usein ehdotuksineen vähemmistöön. Häneen kuitenkin luotettiin juuri siksi, että hänen tiedettiin edustavan harkitsevaa ja tiukkaa talouslinjaa.

Kansleri Mikko Juva erottui papiston keskuudessa: hän teki muutosehdotuksia yli viisi kertaa niin paljon kuin keskimääräinen pappisedustaja. Kolme neljästä hyväksyttiin, joten hyväksymisprosenttikin oli lähellä virallisia edustajia. Juva oli matkalla kohti Pyhän Henrikin istuinta. Vastaavasti Seikko Eskolan mainitsema "L"-kirjain, oikeusneuvos Johannes Leivonen, teki nelivuotiskauden aikana yksin 38 muutosehdotusta eli enemmän kuin muut 11 virallista edustajaa yhteensä. Yhdeksän kymmenestä hyväksyttiin. Sama läpimenoprosentti oli kymmenen muutosehdotusta tehneellä piispa Nikolaisella, kun taas piispa Kansanahon kaikki kuusi pohjaesityksestä poikkeavaa ehdotusta hyväksyttiin. Erityisen kuvaavaa oli, että Leivonen ja Nikolainen saivat kahdestaan läpi saman verran muutosehdotuksia kuin kaikki 64 maallikkoedustajaa yhteensä.

"Oikeusneuvos Leivonen on puhunut järkeä niin kuin yleensä", aloitti piispa Paavo Kortekangas erään puheenvuoronsa täysistunnossa syksyllä $1975 .{ }^{614}$ Sanat kuvastivat hyvin Johannes Leivosen kirkolliskokouksessa saavuttamaa asemaa. Olemukseltaan hillitty ja vaatimaton Leivonen vakuutti toiset edustajat asiantuntemuksellaan. ${ }^{65}$ Hän oli eräänlainen toiminnan laillisuuden valvoja, joka ehti monta kertaa väliin, kun kirkolliskokous oli ajautumassa virheelliseen menettelytapaan. Leivosen muutosehdotuksissa oli usein tarkoituksenmukaisuusseikkojen sijaan kyse siitä, toimiko kirkolliskokous ylipäätään lain mukaisesti. Ehdotuksia oli helppo kannattaa.

Kirkolliskokousuudistuksessa oikeusoppineiden edustus kaventui huomattavasti aiemmasta, mikä korosti entisestään korkeimpien oikeusistuinten valitsemien edustajien merkitystä. Lakivaliokunnan työ kiertyi näiden edustajien ja aivan erityisesti puheenjohtaja Leivosen ympärille ${ }^{616}$. Kirkkolain muutosehdotus tuskin olisi päätynyt kirkolliskokouksen kannaksi ilman heidän hyväksyntäänsä. Asetelma voi kuitenkin herättää myös kysymyksiä lainsäädäntövallan ja ylimmän tuomiovallan suhteesta. Kirkkolakia säädettäessä kirkolliskokouksella oli keskeinen asema, koska eduskunta saattoi vain hyväksyä tai hylätä kirkolliskokouksen jättämän esityksen. Kansanedustajille normaalisti kuulunut oikeus vaikuttaa lain sisältöön oli kirkkolain osalta kirkolliskokousedustajilla. Kirkolliskokouksessa tätä tehtävää olivat kuitenkin kaikkein vaikutusvaltaisimmin hoitamassa korkeimpien oikeusistuinten jäsenet, joilla ei ollut oikeutta toimia kansanedustajana.

Kirkkolain kirjaimen mukaan nämä edustajat eivät tosin olleet kirkolliskokouksessa oikeusistuinten edustajia vaan nimenomaan kirkon edustajia, jotka oikeusistuin oli vain valinnut. Käytännössä he kuitenkin toivat kokoukseen niitä tulkintoja ja periaatteita, jotka olivat kypsyneet tuomarintyössä. Voikin sanoa, että vallanjako ei kirkkolakia säädettäessä toteutunut samalla tavalla kuin muussa lainsäädännössä. Vallanjaon puuttuminen kirkosta kosketti valtiota myös tuomiokapitulien kautta - olivathan ne tuohon aikaan valtion virastoja. Useat niiden jäsenet olivat ensin kirkolliskokouksessa säätämässä kirkkolakia ja myöhemmin tutkimassa ja rankaisemassakin sen perusteella.

Hiippakuntien sisäinen yhteistoiminta näkyi kauttaaltaan kirkolliskokouksen työssä. Esimerkiksi Tampereen hiippakunnan papeista tuomiorovasti Pertti Ranta ja Pyynikin kirkkoherra Aulis Raunio tukivat toinen toistaan. ${ }^{67}$ Paikallispatrioottisuus ja hiippakuntien väliset raja-aidat kohosivat erityisesti keskusteltaessa kirkkomuusikkojen ja teologien koulutuspaikoista sekä kirkon toimitalon sijainnista. Keväällä 1975 kuusi Tampereen hiippakunnan edustajaa jätti piispa Kansanahon johdolla aloitteen kirkkomusiikkiosaston perustamisesta Pirkanmaan musiikkiopiston yhteyteen. ${ }^{618}$ Voimakasta vastustusta nousi Kuopion hiippakunnasta, jonka keskuskaupungissa jo koulutettiin kirkkomuusikkoja. ${ }^{619}$ Kansakoulunopettaja Väinö Vähäsarja intoutui kehumaan Kuopiota ja painottamaan, miten "pätevät opettajatkin viihtyvät erinomaisesti siellä Kallaveden rannalla”. Ilmeisesti Vähäsarjan puheen johdosta piispa Nikolainen ehdotti vierustovereilleen Kallavesj'-laulun laulamista. Keskustelun edetessä Kuopion piispa Kortekangas kävi vielä esittämässä toiveensa, että asia ei muodostuisi Kuopion ja Tampereen väliseksi kilpailuksi. ${ }^{620}$ Toive oli hurskas ja ilmeisen myöhässä. 


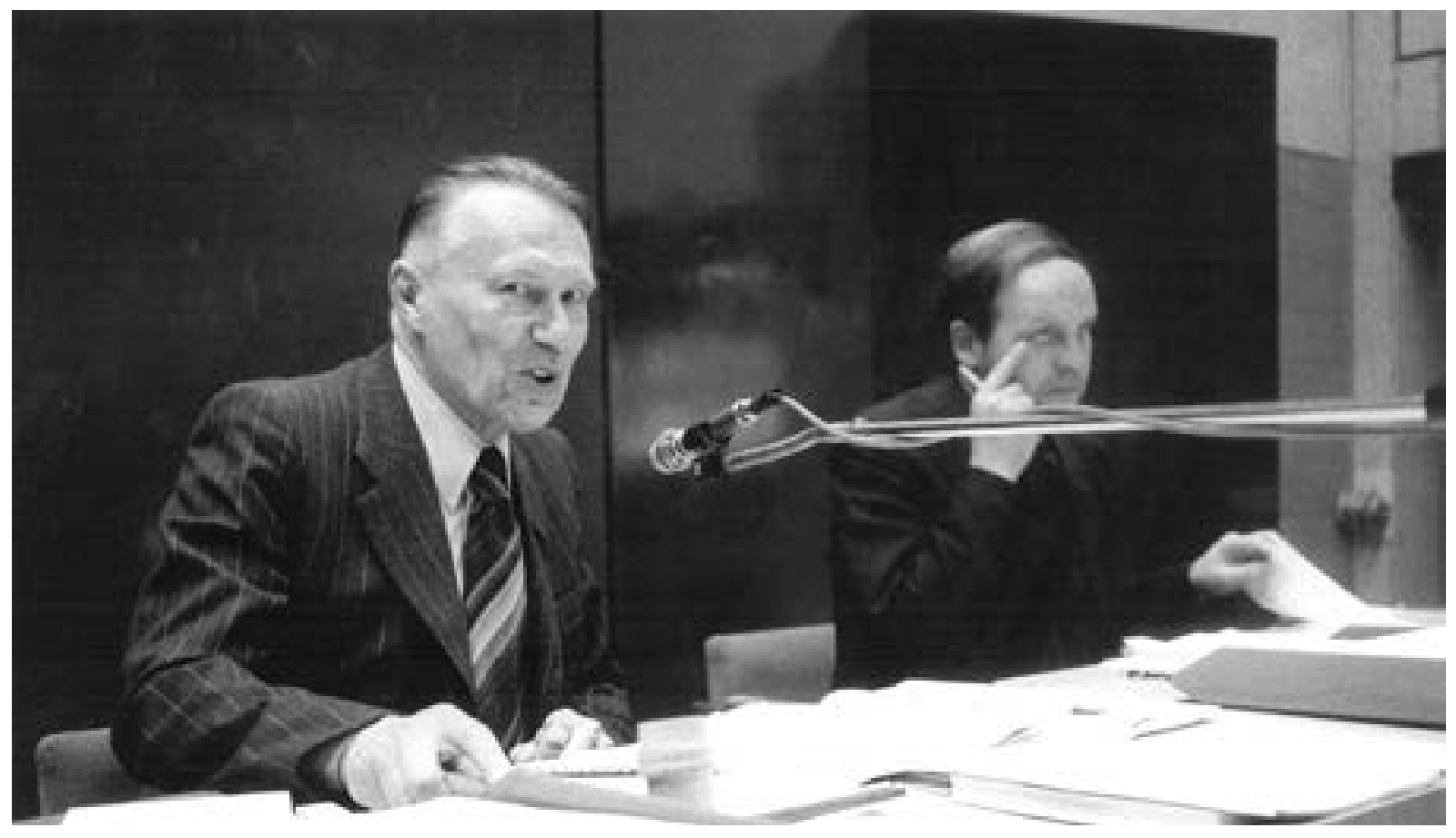

Vanhoillislestadiolaiset edustajat muodostivat kirkolliskokouksen yhtenäisimmän edustajaryhmän. Johtoasema ryhmässä oli Suomen Rauhanyhdistysten Keskusyhdistyksen (SRK) johtokuntaan kuuluneella ja vuodesta 1978 sen varapuheenjohtajana toimineella Erkki Reinikaisella. Kuvaavaa oli, että 1974 siviilivaliokunnan mietintöön yhtynyt valiokunnan jäsen Lauri Taskila vaihtoi mielipidettään täysistunnossa sen jälkeen, kun Reinikainen oli ilmoittanut äänestävänsä vastoin valiokunnan kantaa. ${ }^{621}$ Vanhoillislestadiolaiset edustajat olivat aktiivisia ja kannattivat toistensa ehdotuksia, mistä oli seurauksena, että nämä ehdotukset päätyivät aina äänestykseen. Ehdotuksille oli lisäksi tyypillistä, että ne olisivat toteutuessaan terävöittäneet valiokunnan esittämiä sanamuotoja. Ajoittain jouduttiin vaikeisiin äänestyksiin, kun erimielisyys sanamuodosta oli synnyttämässä kuvaa myös asiasisältöä koskevasta erimielisyydestä. ${ }^{622}$

Ehdottomasti vaikutusvaltaisimman, keskenään yhteyttä pitävän edustajaryhmän muodostivat piispat. Yhteydenpito ei tarkoittanut, että piispat olisivat olleet asioista keskenään välttämättä samaa mieltä. Heidän mielipiteissään tulivat näkyviin myös sukupolvien väli-
Oikeusneuvos Johannes Leivonen oli kirkolliskokouksessa voimakas auktoriteetti, jonka asema ei perustunut karismaattiseen esiintymiseen vaan syvään asiantuntemukseen. Lainkäytön professori Jyrki Virolainen on todennut, että Johannes Leivonen oli "erityisen pätevä juristi ja KKO:n huippuja, mutta luulen, että pappina hänestä olisi tullut arkkipiispa".*. Yhtä arkkipiispan tehtävää oikeusneuvos Leivonen hoitikin vuosina 1978-1986 johtaessaan puhetta kirkolliskokouksessa. Leivosen vieressä kirkolliskokouksen notaari, arkkipiispan sihteeri Tapio Saraneva. Kuva: Kirkkohallitus.

set erot erityisesti silloin, kun käsiteltiin virkateologiaa: vanhempi polvi, Nikolainen, Alaja, Kansanaho, Simojoki ja Juva, edusti pietistishenkistä, viran funktiota painottavaa näkemystä, kun taas monet 1920-luvun lopulla ja 1930-luvulla syntyneet piispat - näkyvimpinä keskustelijoina Toiviainen ja Vikström - hyväksyivät ajatuksen, että virka vähintään välillisesti kuului kirkon olennaisrakenteeseen. ${ }^{623}$

Papeilla ja piispoilla olikin kirkolliskokouksessa vahva asema paitsi käytännössä myös periaatteellisesti. Kirkkojärjestyskomitea totesi mietinnössään, että kirkko

\footnotetext{
* Jyrki Virolaisen kommentti 25.5.2009. - Kemppinen, Jukka.

<http://kemppinen.blogspot.com/2009/05/lauerma-ja-pahuus.html>. Katsottu 19.10.2011.
} 
oli läsnä silloin, kun sekä kirkon jäsenet että virka olivat saapuvilla. Ainoastaan nämä kaksi yhdessä saattoivat edustaa kirkkoa ja tehdä päätöksiä kirkon puolesta. Siten myös kirkon hallinnon kaikilla tasoilla oli turvattava niin seurakuntalaisten edustuksellisuus kuin viran läsnäolo. Tästä lähtökohdasta esimerkiksi piispojen jäsenyys ja pappien erillinen kiintiö kirkolliskokouksessa olivat luontevia ratkaisuja. ${ }^{624}$

Samaan aikaan Norjan kirkossa suunniteltiin kirkolliskokousta. Englannin anglikaanisen kirkon ohella keskeisenä esikuvana oli Suomen kirkolliskokous, jossa Norjan kirkon edustajia kävi myös vieraina. Norjan kirkolliskokous aloitti toimintansa 1984, ja se koostui lähinnä hiippakuntaneuvostojen jäsenistä - mukaan lukien piispoista. ${ }^{625}$ Ruotsissa taas oli pääsemässä vallalle ajatus, että piispojen ja pappien erilliset kiintiöt kirkolliskokouksessa olivat epädemokraattisia jäänteitä vanhasta sääty-yhteiskunnasta. Suunnitteilla olleen kirkolliskokousuudistuksen perustana oli teologia, joka keskittyi viran funktioihin eikä mieltänyt virkaa Jumalan asettamaksi. ${ }^{626}$ Kehityssuunta oli päinvastainen kuin Suomessa.

Suomalainen linja oli mahdollinen pitkälti siksi, että kirkolliskokousedustajat olivat toiminnassaan hyvin itsenäisiä. Vastaavasti Ruotsin kirkolliskokous, joka sitoutui lähemmin poliittiseen yhteiskuntaan ja jossa puolueilla oli aivan toisella tavalla näkyvä asema, oli selvästi matalakirkollisempi kuin suomalainen vastineensa. ${ }^{627}$ Tosin Suomen kirkolliskokouksessakin ilmeni kirkko- järjestyskomitean mietintöä käsiteltäessä arvostelua, että komitea oli korostanut virkaa liiaksi. Kirkon viran kiintiötä kirkolliskokouksessa ei kuitenkaan kyseenalaistettu, vaan lähinnä kysyttiin, oliko kiintiön puitteisiin lisättävä pappien ohelle muitakin työntekijäryhmiä. ${ }^{628}$ Asetelmat olivat siten hyvin toisenlaiset kuin Ruotsissa, vaikka suuri osa suomalaisista kirkolliskokousedustajista lukeutui matalakirkollisiin herätysliikkeisiin.

Monet kirkolliskokouksen tapahtumat 1970-luvun jälkipuoliskolla ja 1980-luvun alussa kertoivat tunnustuksellisuuden vahvasta asemasta kansankirkollisuuden rinnalla. Lainsäädäntö takasi kirkolliskokoukselle laajan itsenäisyyden, ja ortodoksisen kirkon vahva asema saattoi vielä vahvistaa sitä: kun maassa oli kansankirkko, jonka hallinto rakentui itsestään selvästi muusta kuin maallisesta demokratiasta käsin, luterilaiseenkaan kirkkoon ei kohdistunut yhtä voimakkaita demokratisoimispaineita kuin länsinaapurissa.

Piispat olivat kirkolliskokouksen johtohahmoja, mutta toisten kirkon korkeiden viranhaltijoiden, määräämättömäksi ajaksi valittujen kirkkoneuvosten, asema oli erilainen. Kuopion aiempi piispa Eino Sormunen oli tarinan mukaan kertonut voivansa ajatella myönteisesti kirkkohallituksesta vain saunan jälkeen takkavalkean äärellä. Turun kristillisen opiston uusista tiloista löytyivät nämä myönteisen ajattelun edellytykset, mutta kirkkoneuvoksen asema ei ollut aina helppo. Kiitosta tuli harvoin. Odotukset olivat sen sijaan jatkuvasti

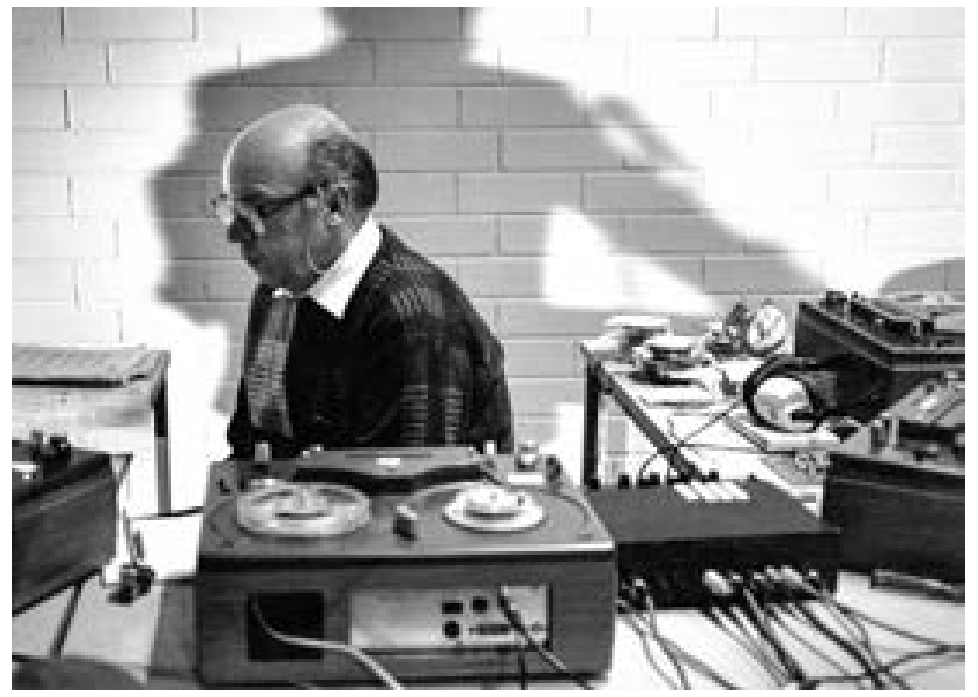

94

4 U U T T A K A N S A N K R K KOA E TS I M ÄS S Ä 1974-1981
Jokaisen täysistunnossa puhuneen edustajan varjossa toimi useita kanslian työntekijöitä, joiden tehtävänä oli muun muassa saattaa puheet osaksi painettua keskustelupöytäkirjaa. Sitä varten puheet nauhoitettiin ja tallennettiin pitkään lisäksi vielä pikakirjoituksella. Kuva: Kotimaan kuvaarkisto / Risto Krogerus.

Kirkolliskokouksen kanslian henkilökuntaa keväällä 1978. Takarivissä vasemmalta Sointu Väkevä, Kirsti Pennanen, Kaija Ryömä, Berit Nyström ja Eeva Mäntymaa. Eturivissä vasemmalta Terttu Virtanen, Tellervo Wallasvuo, Pirkko Holopainen, Tamara Schütt ja Pirkko Hirvola. Kuva: Kirkolliskokouksen kuvakokoelma / Juhani Linkola. 
kovia. Kirkkoneuvoksen tuli auttaa kirkolliskokousta ja johdattaa sitä oikeaan ratkaisuun antaen riittävät tiedot. Joskus hänen odotettiin ehdottavan konkreettisesti jotakin ratkaisua, joskus taas arvosteltiin, kun hän niin teki. Uusimuotoisen kirkolliskokouksen mukanaan tuoma tiivis kanssakäyminen näkyi kuitenkin siten, että kirkkoneuvoksia kohtaan tunnettu luottamus lisääntyi vuosien kuluessa.

Kirkolliskokousuudistuksen myötä alkoi hahmottua uudenlainen kirkolliskokouksen kanslia, jonka toiminnassa Turun kristillisen opiston henkilökunnalla oli suuri osuus. Alkuvaiheessa pöytäkirjat valmistuivat paitsi nauhoitusten myös pikakirjoittaja Pirkko Holopaisen avulla. ${ }^{629}$ Kirkolliskokouksen sihteerinä toimi kirkkohallituksen sihteeri, varatuomari Sinikka Pylkkänen. Arkkipiispa Simojoki ei luultavasti osunut väärään kiittäessään keväällä 1974 erityisesti sihteeriä, "joka on kantanut täällä raskaimman taakan". ${ }^{630}$ Sihteeri joutui hallitsemaan kirkolliskokouksen kokonaistilanteen ja johtamaan kanslian toimintaa. Täysistuntojen aikana hän oli sidottuna sihteerin tehtäväänsä ja niiden välillä vielä hyvin usein valiokuntien asiantuntijaksi. Istuntokausien väliaikanakin hänen oli pidettävä yhteyttä komiteoihin ja valiokuntiin sekä huolehdittava pöytäkirjojen valmistumisesta ja erinäisistä kirkolliskokouksen juoksevista asioista. Varatuomari Pylkkänen sai pian rinnalleen apulaissihteeri Sointu Väkevän, mikä helpotti olennaisesti hänen työtaakkaansa ${ }^{631}$.

Kun arkkipiispat Martti Simojoki ja Mikko Juva lausuivat kirkolliskokouksen nelivuotiskausien päätössanoja vuosina 1977 ja 1981, tärkein johtopäätös kirkolliskokouksen työskentelystä oli molemmilla kerroilla sama: keskinäinen luottamus oli lisääntynyt. ${ }^{632}$ Samalla kirkolliskokous oli hahmottanut kirkon olemusta ja paikkaa yhteiskunnassa sekä kirkolliskokouksen omaa, aiempaa vahvempaa asemaa kirkon keskushallinnossa. Keskinäistä luottamusta ja oman paikan hahmottamista tarvittiin, koska kirkolliskokous oli käymässä kohti suurten kokonaisuudistusten aikaa.

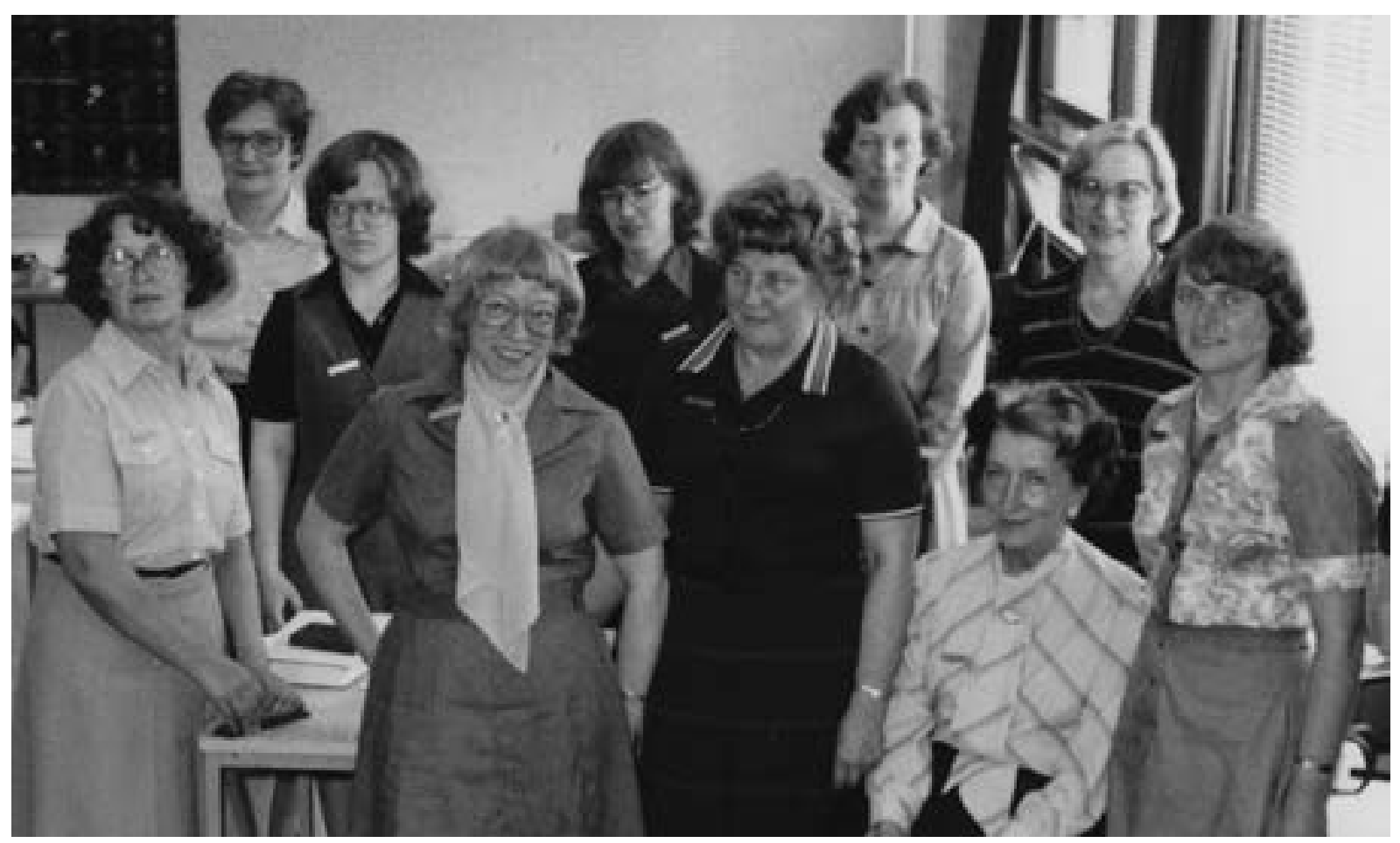


[20. ed. Jura jatk.1

timlis mesdibe we

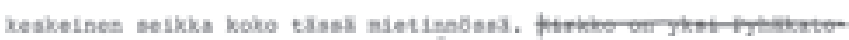

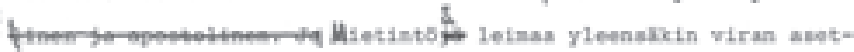

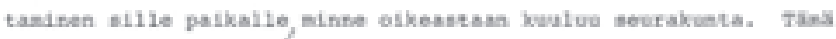
ilmenee kun puhotaan papin kutruninesta ja papin vihkininenti.

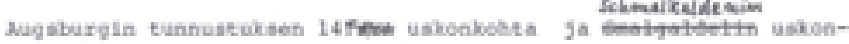

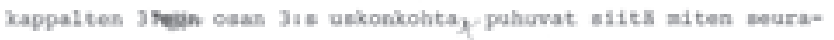

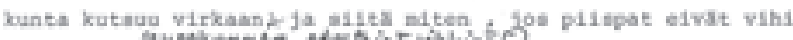

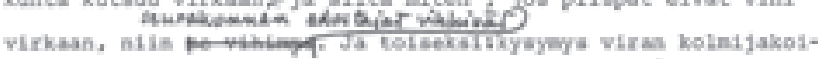

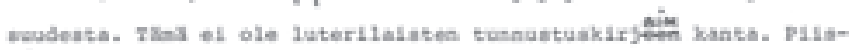
polia ei cunustuskirjojeh makash ole iore divino, sis juna-

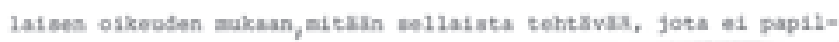
lakig gle, Gepa rirkash vikinisen bateilansa voi suoriteas papfí

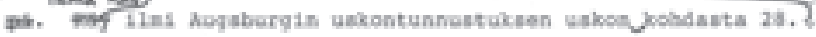
Mita diakonis virkake telee, niln meldin tuanustuskirjame mai-

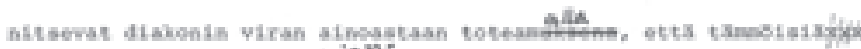

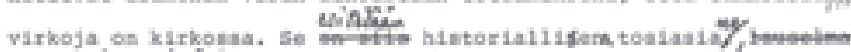
vas cimerkiv

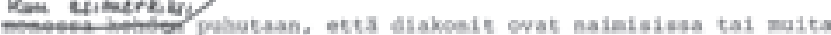

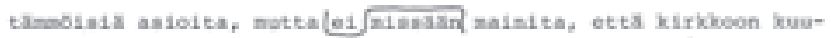

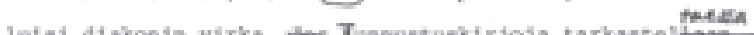

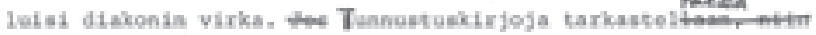

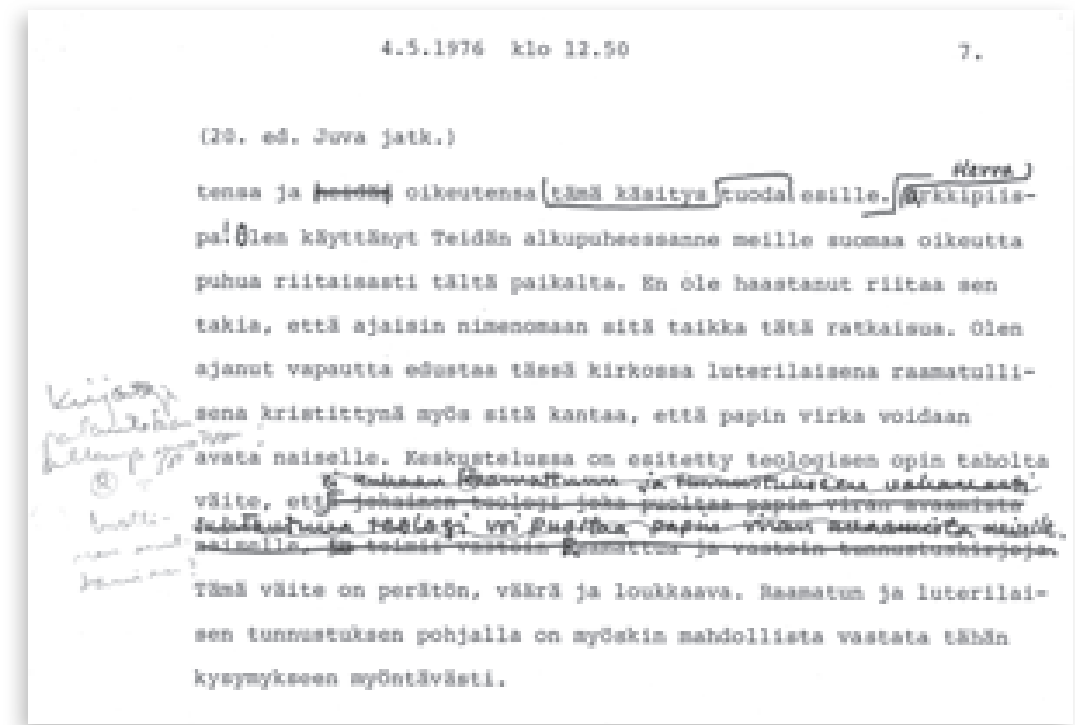

Koneella kirjoitetut puheenvuorot toimitettiin edustajille tarkastettaviksi. Kirkolliskokouksen sihteeri ja viime kädessä pöytäkirjantarkastajat päättivät, millaiset edustajien tekemät korjaukset oli katsottava puhutun kielen selvennyksiksi, mitkä taas varsinaista asiasisältöä koskeviksi muutoksiksi. Ensin mainitut muutokset hyväksyttiin, jälkimmäisiä ei. Yllä on katkelma Mikko Juvan puheesta kevään 1976 naispappeuskeskustelussa. Juva viivasi yli kuvan yläosassa olevan virkkeen, mutta poiston luvallisuus kyseenalaistettiin kirkolliskokouksen kansliassa. Sihteeri Sinikka Pylkkäsen (S.P.) ehdotuksesta pöytäkirjantarkastaja Tauno Väinölä (T.V.) hyväksyi kuitenkin Juvan tekemän poiston. Yhtä hyvin ei käynyt muutokselle, jonka Juva teki saman puheenvuoron loppuun: Sinikka Pylkkänen katsoi, että teksti tuli palauttaa alkuperäiseen muotoonsa (alla). 


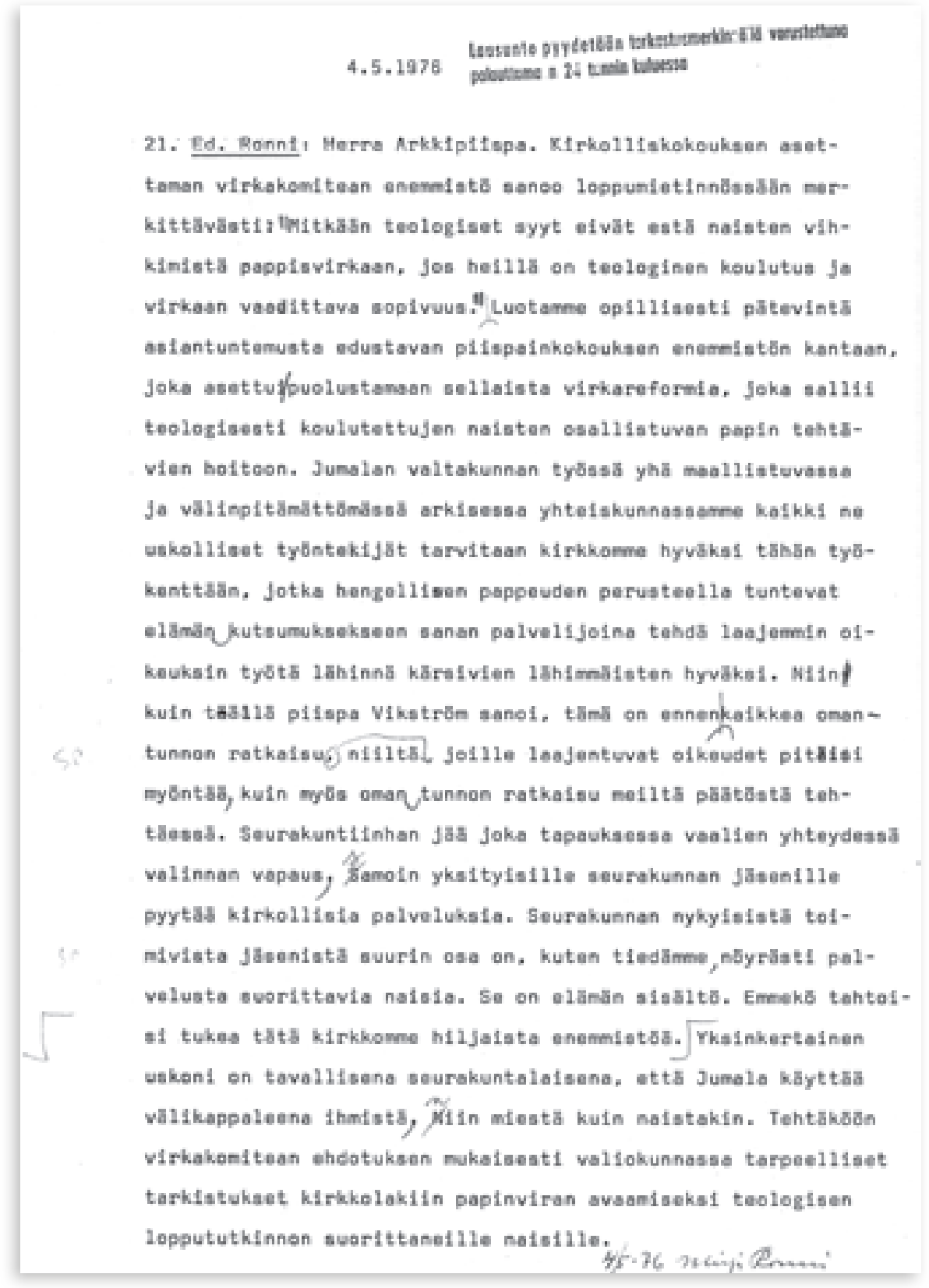

Juvan jälkeen puhuneen Mirja Ronnin teksti sisälsi huomattavasti vähemmän muutettavaa, ja muutokset olivat pelkästään konekirjoittajan nopeasti laatiman tekstin kielenhuoltoa. Edustajat, jotka puhuivat harvoin, valmistelivat puheensa huolellisesti etukäteen. Se näkyi korjausten vähäisyytenä. Paljon ja spontaanisti puhuneilla, kuten Mikko Juvalla, Erkki Kansanaholla tai Aimo T. Nikolaisella, taas oli luonnollisesti kosolti kynäiltävää puheenomaisen tekstin saamiseksi kirjallisesti moitteettomaan muotoon. Kuvat: Kirkkohallitus. 


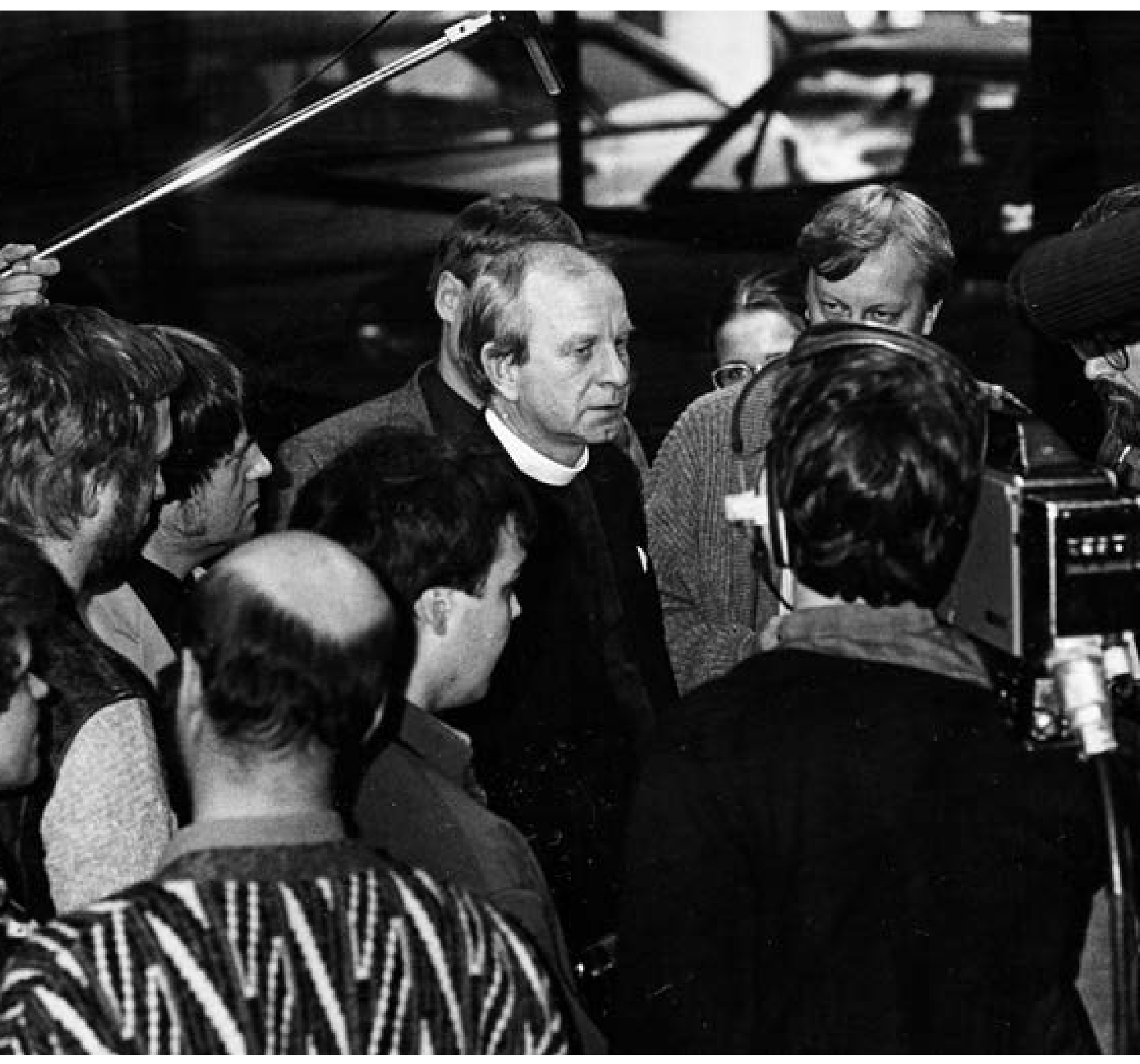




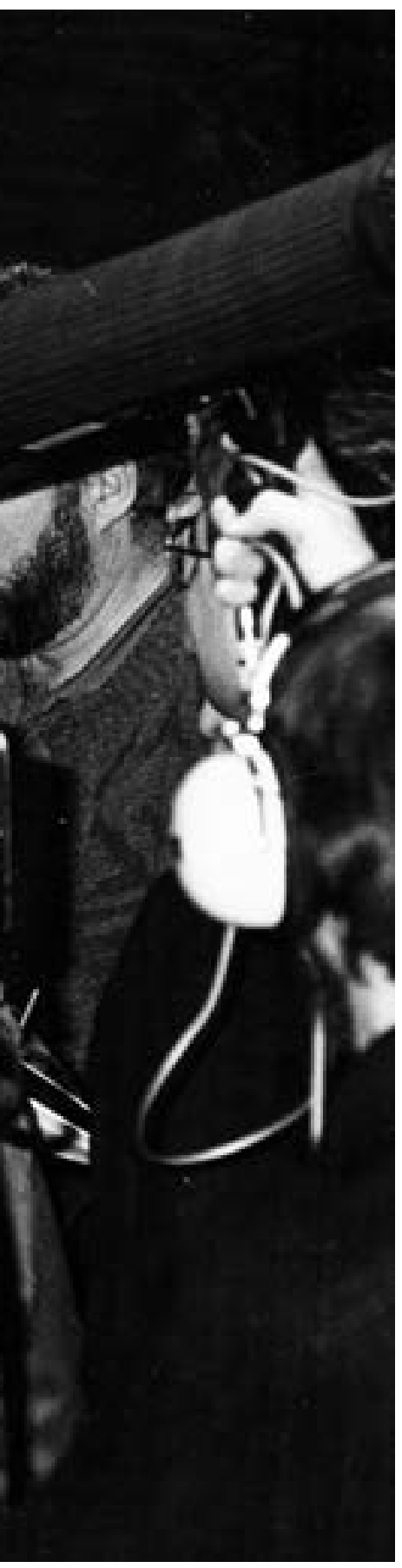

\author{
NaispapPEUS, \\ VIRSIKIRJA JA \\ RAAMATUNKÄÄNNÖS \\ 1982-1992
}

Oulun piispa Olavi Rimpiläinen poistui istuntosalista 1986 osallistuttuaan naispappeusäänestykseen. Ainoa lakimuutosta vastustanut piispa sai vastata lukuisiin toimittajien kysymyksiin. Kuva: Kotimaan kuva-arkisto / Jukka Granström. 


\section{VAALIUUDISTUSTEN KAUTTA PÄÄTTÄMÄÄN KIRKON PERUSTEISTA}

\section{YHDEN AIKAKAUDEN SAATTO}

Tumma kulkue lipui ulos Helsingin tuomiokirkosta syyskuun seitsemäntenä päivänä 1986. Presidentti Urho Kekkonen oli juuri siunattu hautaan, ja suomalaiset olivat pysähtyneet televisioidensa ääreen. Samalla he olivat ehkä huomaamattaan eläneet hetken monien kirkolliskokouksessa ja koko yhteiskunnassa ajankohtaisten muutosten keskellä.

Heti hautajaisten aluksi katsojat saivat tietää, että hautajaisjumalanpalvelus noudatteli uutta kaavaa, joka oli otettu käyttöön edellisenä adventtina osana uutta kirkollisten toimitusten kirjaa. Pian kirkkokansa yhtyi alkuvirteen "Sä sait, oi Jeesus, voiton, lunastit laumasi" vuoden 1938 virsikirjan sanoin. Tuo virsikirja eli kuitenkin viimeisiä hetkiään virallisessa käytössä. Kirkolliskokous oli puoli vuotta aiemmin hyväksynyt ylimääräisessä istunnossaan niin suomen- kuin ruotsinkielisen virsikirjan, ja nämä kirjat odottivat käyttöönottoaan. Hautajaisissa voimalla kaikunutta alkuvirttä veisattaisiin vastaisuudessa ilman "oi"-huudahduksia ja lyhennettyjä persoonapronomineja: "Sait, Jeesus, täyden voiton, lunastit laumasi”.

Virren jälkeen alttarille asteli kolme miestä: 1982 arkkipiispaksi nimitetty John Vikström, Helsingin tuomiorovasti Jouko Sihvo ja ruotsinkielisen Markuksen seurakunnan kirkkoherra Henrik Perret. Kaksi kuukautta myöhemmin kirkolliskokouksessa oli tulossa ratkaisevaan käsittelyyn aloite pappisviran avaamisesta naisille. Silloin Vikström ja Perret olisivat Turussa antamassa äänensä. Kirkollista keskustelua seuranneiden tiedossa oli, että äänet olivat menossa vastakkaisille puolille.

Tuomiorovasti Sihvo luki Raamatun sanaa Johanneksen evankeliumin 14. luvusta. Käännös oli vuodelta
1938, mutta raamatunkäännöskomiteassa uutta suomennosta oli työstetty jo pitkälle. Kesällä 1989 valmistui komitean ehdotus Uudeksi testamentiksi. Siinä Sihvon lukeman raamatunkohdan alun "Älköön teidän sydämenne olko murheellinen" korvasi kehotus "Älkää vaipuko epätoivoon". Aikaisemmalle käännökselle ominainen puhe sydämelle tai sielulle oli karsittu pois, ja muutenkin kieltä oli pyritty muuttamaan ajanmukaiseksi. Syyskuussa 1986 kaikki siunaustilaisuuden osat elivät muutoksessa.

Hienoisessa muutoksessa olivat myös kirkon ja valtion suhteet. Ministerien penkkirivillä istui kokenut kirkolliskokouksen pappisedustaja Gustav Björkstrand, jonka vastuulla opetusministeriössä oli nyt kirkolliskokouksen lakiesitysten saattaminen eduskunnalle. Tilanne oli muuttunut huomattavasti 1970-luvun puolivälistä, jolloin kirkolliskokouksessa oli suhtauduttu hyvin epäillen opetusministeriöön. Kirkon epäviralliset yhteydet valtioneuvostoon olivat aiempaa tiiviimmät: keskeinen uudistus oli kirkon ja valtion virkamiestason yhteistyöelin $^{1}$. Suunnitelmat nopeista muutoksista kirkon ja valtion keskinäisissä suhteissa olivat laantuneet 1980-luvun alkupuolella kansliapäällikkö Jaakko Nummisen johtaman työryhmän toiminnan myötä. ${ }^{2}$ Muutoksen suunta vei kuitenkin hitaasti kohti kirkon ja valtion lainsäädännöllisten siteiden höllentämistä. Valmisteilla oli kirkkolain jakaminen kahtia, ja 1980-luvulla alettiin selvitellä myös reformaatiokaudella valtion virastoiksi siirrettyjen tuomiokapitulien asemaa.

Täysin mutkaton kirkon yhteys valtiojohtoon ei ollut. Jännitteet henkilöityivät 1986 erityisesti tasavallan presidentti Mauno Koivistoon, joka käveli tuomiokirkon etuosaan pitämään edeltäjänsä muistopuheen. Suomen historian ensimmäinen sosiaalidemokraattinen presidentti oli aloittanut tehtävässään samoihin aikoihin kuin 1982 valittu kirkolliskokous. Tuo kirkolliskokous oli lähettänyt eduskunnalle arkipyhiä koskevan kirkkolain muutosesityksen, josta eduskunta oli äänestänyt syksyllä 1985. Päätös oli jälkiseurauksineen kiristänyt tasavallan presidentin ja kirkon johdon suhteita sekä voimistanut vaatimuksia kirkon ja valtion keskinäisten siteiden höllentämiseksi³.

Presidentti Koivistoon henkilöityi laajemminkin suomalaisen yhteiskunnan ja poliittisen järjestelmän muutos. Urho Kekkosen mukana oltiin saattelemassa hau- 
taan presidentin korostunutta valta-asemaa, joka oli leimannut edeltäneitä vuosikymmeniä. Kun Kekkonen oli jäänyt lopullisesti sairauslomalle tasavallan presidentin tehtävästä, monenlaiset patoutuneet muutospaineet olivat alkaneet purkautua. Vaadittiin parlamentaarista vallankäyttöä ja avoimuutta. ${ }^{4}$

Kirkolliskokousuudistuksen aikaan 1974 Turussa olivat olleet esillä tulevaisuuden uhkakuvat. Ne olivat koskeneet erityisesti suomalaista yhteiskuntaa, jonka arvojen oli katsottu jatkuvasti erkaantuvan kristillisistä ihanteista. Samaan aikaan liennytys oli kuitenkin tasapainottanut kansainvälistä tilannetta ${ }^{5}$. Kirkolliskokouksen uuden nelivuotiskauden alkaessa 1982 Suomen aatteellinen kuohunta oli monella tavalla rauhoittunut. Kirkkoon luotettiin aiempaa enemmän, ja uskonnollisuus oli kyselytutkimusten mukaan vahvistunut ${ }^{6}$. Toisaalta samaisena vuonna 1982 kirkon jäsenten osuus maan väkiluvusta laski ensi kertaa alle 90 prosentin, ja yksilöllisyyden korostus oli vahvaa kaikilla elämänalueilla: yhä harvempi liittyi esimerkiksi perhe- ja seksuaalietiikan kysymyksissä kirkon ilmaisemiin ihanteisiin, ja entistä useampi ilmoitti uskovansa Jumalaan eri tavalla kuin kirkko opetti. ${ }^{7}$ Edelleen kansainvälisessä politiikassa liennytys jäi taakse. Kylmän sodan jännitys lisääntyi, ja tulevaisuus näytti pelottavalta. ${ }^{8}$ Kun sitten syyskuussa 1986 Neuvostoliiton edustajat toivat presidentti Kekkosen arkun äärelle miehen korkuisen seppeleen, he totuttelivat parhaillaan uuteen poliittiseen ohjelmaan, joka tiivistyi kahteen sanaan: avoimuus (glasnost) ja jälleenrakennus (perestroika). ${ }^{9}$ Kirkolliskokouksen seuraavan vaalikauden päättyessä heidän valtiotaan ei enää ollut.

\section{JULKISESTA ARVOSTELUSTA KOHTI}

\section{AVOIMEMPIA KIRKOLLISKOKOUSVAALEJA}

Vuoden 1982 kirkolliskokousvaalien alla kirkolliskokous antoi ohjeet maallikkoehdokkaiden nimeämisestä ennakkoon. Lisäksi tuomiokapitulit laativat omia ohjeitaan, ja käytännöksi muodostui, että maallikkoedustajien valitsijamiehet koottiin rovastikunnittain neuvottelemaan ehdokkaista. Ehdokasasettelun pääpaino oli näissä kokouksissa, vaikka myös yksittäisillä valitsijamiehillä oli oikeus tehdä etukäteen ehdotuksia. Vaalikokouksessa valitsijamiehet eivät kuitenkaan olleet sidottuja ennakkoon ehdotettuihin nimiin. ${ }^{10}$ Lapuan tuomiokapituli korosti vuoden 1978 vaalin kokemusten pohjalta, että rovastikuntien ehdotuksissa oli oltava tasaisesti ehdokkaita hiippakunnan eri puolilta. Käytännössä kuitenkin niin Lapuan kuin Helsingin hiippakunnassa kunkin rovastikunnan valitsijamiehet keskittyivät etsimään useimmiten kaksi tai kolme ehdokasta oman rovastikuntansa alueelta. Jos joku henkilö mainittiin kahden tai useamman rovastikunnan ehdotuksessa, hänet valittiin erittäin todennäköisesti kirkolliskokoukseen. ${ }^{11}$

Ehdokkaiden nimeäminen ennalta ei tuonut toivottua parannusta. Työväestön huono vaalimenestys kirvoitti arvostelua läpi vasemmistolehdistön. ${ }^{12}$ Ehkä kaikkein synkimmän kuvauksen julkaisi Kemin seurakunnan valitsijamiehiä haastatellut Pohjolan Työ: "Se [vaalikokous] oli hämmästyttävä kokous. Erittäin valheellisesti kokoonpantu ja valheellisesti toimiva. Sekava 300 huutajan ja huiskuttajan tilaisuus. Junttaus ja lahkolaisten ja oikeistolaisten ryhmätoiminta sulki uudet ja kaikki työväenhenkiset varmasti pois - -."13

Porvarillisellakin puolella näkyi vaalimenestyksestä huolimatta suuri tyytymättömyys. Helsingin hiippakunnan valitsijamies, Kotilieden pitkäaikainen päätoimittaja Eila Jokela valitti Uudessa Suomessa, että vaalilippuun kirjoitettavat nimet oli jälleen sovittu puoluehakuisissa "junttakokouksissa", joihin läheskään kaikkia valitsijamiehiä ei ollut kutsuttu. Valitsijamiehille annettiin lupa vaikuttaa vain siihen, keitä he äänestivät varaedustajiksi: "Olin nyt toista - ja viimeistä - kertaa valitsijamiehenä. Temppeliaukion kirkossa pidetyssä vaalissa tunsin jälleen osallistuvani kirkolle arvottomiin menoihin. Ensin veisattiin virsi ja pidettiin rukous. Seuraavassa hetkessä alkoi häikäilemätön loppujunttaus. Minusta se oli omantunnonvapauden polkemista." Lisäksi Jokela päivitteli vaalitoimituksen teknisiä puutteita hiippakunnassaan. ${ }^{14}$ Sanomalehdistö oikealta vasemmalle langetti tuomionsa kirkolliskokousvaaleille, eikä kirkollisella lehdistöllä ollut myönteisempää sanottavaa. ${ }^{15}$

Helmikuun 1982 kirkolliskokousvaalien kielteisten kokemusten johdosta kirkolliskokoukseen tuli samana keväänä kaksi aloitetta, jotka tähtäsivät maallikkoedustajien vaalitavan uudistamiseen. Toisen lähetti Helsingin hiippakunnan hiippakuntakokous, ja toisen laati Eila Jokelan kehotuksesta apulaisprofessori Seikko Eskola, joka oli aiemminkin yrittänyt uudistusta. Tällä kertaa Eskola pyysi aloitteeseen mukaan varatuomari 
Pekka Leinon ja oikeusneuvos Johannes Leivosen, joista erityisesti jälkimmäisen oli määrä tuoda aloitteelle arvovaltaa. Aloitteista näkyi, että tyytymättömyys oli erityisen voimakasta Helsingin hiippakunnassa. Avoimuuden puutteen ohella vaalijärjestelmän ongelmia olivat moniportaisuus sekä se, että muutokset seurakuntien luottamuselimissä heijastuivat kirkolliskokoukseen pitkällä viiveellä: kirkolliskokousvaalien aikaan seurakuntien luottamushenkilöillä oli menossa jo nelivuotisen vaalikauden viimeinen vuosi. ${ }^{16}$

Kirkkoneuvos Matti Halttusen johtama kirkkolakikomitea ehdotti edustaja-aloitteen mukaisesti suhteellista vaalia, jonka toimittaisivat kirkkovaltuustot tai täydellisessä yhteistaloudessa olevissa seurakunnissa seurakuntaneuvostot. Komitea ei kuitenkaan puoltanut aloitteessa ehdotettua tunnusten sallimista: asiasta oli päätettävä seurakuntavaalisäännösten yhteydessä. Näin yksi kiistakysymys poistui mietinnön hyväksymisen tieltä. ${ }^{17}$

Komitea esitti myös kirkolliskokousta koskevia ajallisia muutoksia. Uusien ja vanhojen kirkolliskokousedustajien toimikauden rajana eivät olisikaan enää vastaisuudessa vaalit vaan toukokuun alku. Oli aiheutunut joitakin ongelmia siitä, ettei kirkolliskokousvaalien jälkeisinä mutta kevätistuntokautta edeltävinä kuukausina ollut olemassa toimivaltaisia valiokuntia. Lisäksi kirkolliskokousvaalit oli komiteankin mielestä saatava ajallisesti lähemmäksi seurakuntavaaleja, seurakunnan luottamuselinten toimikauden toisen vuoden alkuun. ${ }^{18}$ Lakivaliokunta ratkaisi asian esittämällä, että kirkolliskokous tuli 1986 valita poikkeuksellisesti vain kahdeksi vuodeksi. ${ }^{19}$

Ongelmallisimmaksi osoittautui komitean ehdotus, että seurakuntien äänimäärät painotettaisiin suoraan suhteessa niiden väkilukuun. Esitys olisi toteutuessaan merkinnyt suurta muutosta, koska voimassa ollut järjestelmä takasi pienimmille seurakunnille selvästi suuremman äänivallan kuin niiden väkiluku olisi edellyttänyt. ${ }^{20}$ Lakivaliokunnan enemmistö päätyi esittämään välittävää ratkaisua, joka ei kuitenkaan kelvannut pienistä seurakunnista tuleville edustajille. Oikeastaan vasta lakivaliokunnan mietintö sai aikaan tiukan kädenväännön kirkolliskokouksessa. Toinen varapuheenjohtaja joutui jopa väläyttämään harvinaista neuvottelutaukojen mahdollisuutta. Neuvottelut onnistuivat kuitenkin ilman taukoakin, ja puheenjohtaja joutui yhtä lailla harvinaislaatuisesti pyytämään hiljaisuutta: "Viralliset puheenvuorot eivät oikein kuulu." ${ }^{21}$ Äänivallan supistumisen lisäksi pienten seurakuntien edustajia huoletti se, että suurten seurakuntien luottamushenkilöiden olisi helppo sopia ehdokkaistaan ja äänten keskittämisestä. Uudistuksen kannattajien mielestä tosin suurten seurakuntien junttaus onnistui parhaiten nimenomaan käytössä olleessa järjestelmässä. Vuonna 1982 kirkolliskokoukseen oli päässyt vain kaksi edustajaa alle 2 ooo hengen seurakunnista. ${ }^{22}$

Jotkut pelkäsivät suhteellisten vaalien vievän poliittisten puolueiden ylivaltaan. Tältäkin osin toiset vakuuttivat, ettei tilanne voisi mennä ainakaan huonommaksi. Voimassa ollut vaalijärjestelmä loi hyvät mahdollisuudet poliittiselle manipulaatiolle. ${ }^{23}$ Erityisesti alueeltaan laajojen hiippakuntien edustajat kiinnittivät huomiota rovastikuntien tasaiseen edustukseen, kun taas etelän kaupunkiseurakuntien edustajien tavoitteena oli erilaisten mielipidesuuntien kattava edustus. Oulun hiippakunnan edustajat huomauttivat, että nimenomaan valitsijamiesten neuvottelut antoivat mahdollisuuden nostaa kirkolliskokoukseen edustajia sellaisistakin ryhmistä, jotka olivat liian pieniä menestyäkseen suhteellisissa vaaleissa. Siten istuvaan kirkolliskokoukseen oli kyetty valitsemaan Oulun hiippakunnasta saamelainen talollinen Ola Pieski. Samaten neuvottelujen kautta oli ollut mahdollista turvata erityisasiantuntijoiden, kuten juristien, edustus. Etelän kaupunkiseurakuntien jäsenet vastasivat, että vallinneessa järjestelmässä suhteellisuus oli valitsijamiesten hyväntahtoisuuden varassa mutta uudessa järjestelmässä taas sisäänrakennettuna. ${ }^{24}$

Jäljelle jäi sovittamaton ristiriita. Professori Jaakko Voipio teki täysistunnossa muutosehdotuksen, joka todennäköisesti toi monen epävarman edustajan lakiuudistuksen taakse. Voipio ehdotti, että vaalisalaisuuden turvaamiseksi vaaliliput avattaisiin seurakunnan sijaan tuomiokapitulissa. Monet huomauttivat tulosten julkistamisen lykkääntyvän mutta hyväksyivät ehdotuksen, jotta määräenemmistö voitaisiin saavuttaa ja vaalisalaisuus turvata. ${ }^{25}$ Ratkaisevassa äänestyksessä määräenemmistövaatimus ylittyi niukasti neljällä äänellä. ${ }^{26}$

Vaalitavan käsittely liittyi koko uusimuotoisen kirkolliskokouksen ajan kestäneeseen vaikeaan prosessiin, jossa maaseutuyhteiskuntaan suunniteltuja kirkon vaalisäännöksiä muokattiin kaupunkeihin sopiviksi. 
Etelä-Suomen suurissa kaupungeissa vaadittiin kirkolliskokousvaalien uudistamista, kun taas maaseutuvaltaisemmilla alueilla vanhalla järjestelmällä oli vahvaa kannatusta - ainakin vaaleissa menestyneiden keskuudessa eli siinä joukossa, joka istui kirkolliskokouksessa päättämässä asioista. Vuonna 1983 kirkolliskokous otti kuitenkin vaivalloisten vaiheiden jälkeen pienen askelen kohti Helsinkiä.

Eräät lehdet pitivät askelta aivan liian lyhyenä ja vaativat maallikkoedustajien vaalin muuttamista suoraksi kansanvaaliksi. Toiset lehdet taas vastustivat ajatusta: seurauksena arveltiin olevan puolueiden sekä rikkaiden ja julkisuudesta tunnettujen henkilöiden hallitsemat vaalit, joiden äänestysprosentti olisi pieni ja tulos sattumanvarainen. ${ }^{27}$ Kaikkein vähiten ymmärtämystä uudistettu vaalitapa sai osakseen sosiaalidemokraattisessa lehdistössä, jossa tyytymättömyyttä herätti paitsi välillinen vaali myös pappiskiintiö. ${ }^{28}$ Suomen Sosialidemokraatin mukaan kirkolliskokousvaalit olivat suomalaisessa kansanvallassa "merkillinen historiallinen jäänne vanhaa sääty-yhteiskuntaa. Mukana on roima annos pappisvaltaa ja kohtuullinen ripaus talonpoikaista manttaalihenkeä." ${ }^{29}$ "Manttaalihenki" eli äänten painoarvon vaihtelu tosin turvasi muiden muassa suurten kaupunkiseurakuntien sosiaalidemokraattien äänivaltaa pienten maalaisseurakuntien valtuustoja vastaan. ${ }^{30}$ Vaikka SDP:n piirissä yleisesti suhtauduttiin kirkkoon 1980-luvulla aiempaa myönteisemmin, kirkon hallintorakenteet eivät edelleenkään saaneet juuri ymmärtämystä.

\section{"NAISPAPPEUSVAALIT" MUUTTAVAT KOKOONPANOA}

Kirkolliskokouksen 1983 hyväksymät vaalisäännökset muuttivat vuoden 1986 kirkolliskokousvaalien luonnetta. Miltei yhtä paljon vaaleihin vaikutti kuitenkin lainkohta, joka jäi kirkolliskokouksessa ennalleen. Pappisviran avaaminen naisille ei saanut taakseen tarvittavaa määräenemmistöä 1984, minkä jälkeen oli selvää, että vuoden 1986 kirkolliskokousvaalit kiertyisivät yhden asian ympärille. Lehdistössä käsiteltiin vaalivalmisteluja jo yhdeksän kuukautta ennen vaaleja. ${ }^{31}$ Puolueista oli syksyllä 1985 liikkeellä erityisesti SDP, joka kehotti äänestämään naispappeuden kannattajia ja suositteli, että äänten keskittämiseksi naispappeuden kannattajat perustaisivat joka hiippakunnassa vain yhden valitsijayhdistyksen..$^{32}$ Toive ei toteutunut, mutta naispappeuden kannattajien ja vastustajien jakolinja näkyi monin paikoin ehdokasasettelussa.

Helsingin hiippakunnan maallikkoedustajien vaalissa naispappeuskysymys vaikutti selvästi ryhmänmuodostukseen. ${ }^{33}$ Muissa hiippakunnissa naispappeus ei ollut yhtä määräävä tekijä. Pohjoisempien hiippakuntien asetelmista antaa kuvan Lapuan hiippakunta, jossa puolueryhmät, alueelliset pyrkimykset, herätysliikeasetelmat sekä uuden vaalitavan heikko tuntemus johtivat siihen, että hiippakunnan alueelle perustettiin peräti kahdeksan ehdokaslistaa. Enintään kolmen nimen ehdokaslistoja oli kolme. ${ }^{34}$ Tällaisilla listoilla ei ollut menestymismahdollisuuksia.

Väestöpohjaltaan pienessä mutta alueellisesti monivivahteisessa hiippakunnassa ehdokaslistojen enimmäispituus, puolitoista kertaa valittavien määrä, osoittautui heti liian vähäiseksi. Eri rovastikunnista ei ollut mahdollista saada tasapuolista edustusta lähinnä puolueittain kootuille ehdokaslistoille. Paitsioon jääneillä alueilla perustettiin pienlistoja, joilla ei ollut mahdollisuuksia. Yhtä lailla olivat vaarassa jäädä ilman edustajaa ne alueet, joilta oli ehdokaslistoille valikoitunut paljon henkilöitä. Esimerkiksi Oulun hiippakunnassa vaara uhkasi eteläosaa, Kokkolan ja Kalajoen rovastikuntia, joista jälkimmäinen jäikin ilman maallikkoedustajaa ${ }^{35}$.

Vuoden 1986 vaalit osoittautuivat monella tavalla yllätyksellisiksi. Valitsematta jäi usea kokenut edustaja ja erityisen moni juristi. Kirkolliskokoukseen valittiin hiippakunnista vain yksi oikeusoppinut, Pekka Leino Helsingin hiippakunnasta. Kun viralliset edustajat lasketaan mukaan, kirkkolakiesityksiä oli valmistelemassa äänivaltaisena kolme juristia. Se oli ennenkuulumatonta kirkolliskokouksen historiassa. Kävi, kuten jotkut olivat pelänneet: uusi vaalitapa ei turvannut juridista asiantuntemusta kirkolliskokoukseen. Valiokuntia oli vaalituloksen takia poikkeuksellisesti suurennettava ja kukin oikeusoppinut sijoitettava kahteen valiokuntaan. Kun vielä Johannes Leivonen valittiin edelleen varapuheenjohtajaksi, kirkolliskokouksen juristien työtaakka oli todella raskas.

Myös pappisedustajien vaali toi merkittäviä muutoksia kirkolliskokouksen kokoonpanoon. Helsingin hiippakunnan pappisedustajien vaalissa 1982 Paavalin synodia lähellä olevat ehdokkaat olivat menestyneet 
Kuvio 6: Kirkolliskokouksen jäsenten edustajakokemus vuosina 1974 ja 1986: Kuinka mones kausi kirkolliskokousedustajilla oli meneillään eri ryhmissä?

$\square$ 4. tai useamp
$\square$ 3.
$\square 2$.
$\square$ 1.

hyvin. Kirkkoherra Jussi Talasniemi oli saanut suurimman äänimäärän, yli 200 ääntä, mikä kertoi laajasta luottamuksesta yli ahtaimpien mielipiderajojen: puolet Talasniemen äänimäärästä oli tuossa vaalissa vielä riittänyt pappisedustajan paikkaan. ${ }^{36}$ Yhtä kuvaava oli muutos tultaessa vuoteen 1986. Silloin Talasniemi ja muut naispappeuden vastustajat jäivät varasijoille. Enemmistövaali, jossa naispappeuden kannattajat keskittivät äänensä toisille samanmielisille, ei jättänyt sijaa vastustajille. Näin kävi muuallakin. Lapuan hiippakunnassa yleinen näky oli, että rovastikuntien vaalitulosten kärjessä oli kolme naispappeuden kannattajaa. Lappajärven rovastikunnassa, jossa voimasuhteet olivat päinvastaiset, kolmen kärjessä oli kolme vastustajaa. ${ }^{37}$

Turussa, Tampereella, Mikkelissä, Lapualla ja Helsingissä kaikki pappisedustajat olivat naispappeuden kannattajia. Oulussa, missä papiston enemmistö vastusti naispappeutta, kaikki valitut olivat uudistusta vastaan. Oulussa vastustajat keskittivät äänensä niin tarkasti tietyille ehdokkaille, että valittujen pappien äänimäärissä oli heittoa enimmilläänkin vain neljä ääntä. Ainoastaan Kuopion ja Porvoon hiippakunnista tuli kirkolliskokoukseen sekä naispappeutta vastustavia että sitä kannattavia pappeja..$^{38}$ Konsensushenkisyys oli muutenkin Porvoon hiippakunnan kirkolliskokousvaaleille ominainen piirre: edustajanvaihdoksia tapahtui lähinnä silloin, kun joku aiemmista edustajista jätti asettumatta

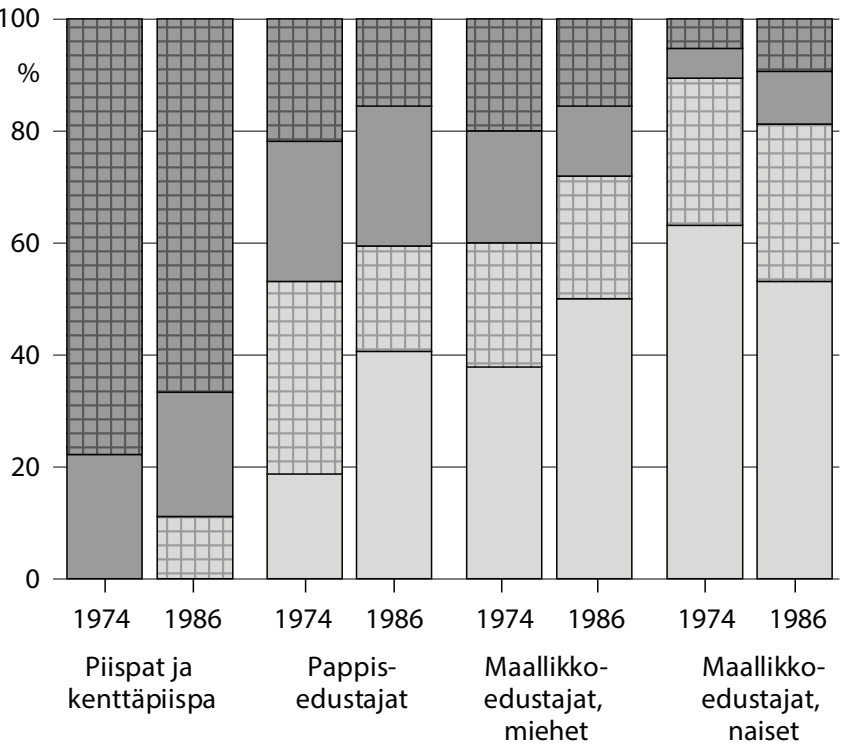

ehdolle. ${ }^{39}$ Joka tapauksessa pappisedustajien vaalin enemmistövaalitapa johti 1986 siihen, että useimmissa hiippakunnissa naispappeuden vastustajat eivät saaneet yhtään ehdokastaan läpi. Tästä syystä naispappeutta kannattavien osuus oli pappisedustajien keskuudessa suurempi kuin pari vuotta aiemmin tehdyn mielipidetutkimuksen mukaan papistossa keskimäärin..$^{\circ}$

Vuonna 1986 valittu kirkolliskokous muistutti pappisja maallikkoedustajien ikäjakauman osalta 1974 valittua edustajistoa. Vaaliasetelmien kytkeytyminen naispappeuskysymykseen johti sen sijaan huomattavaan muutokseen naisedustajien määrässä: heitä oli tasan puolet maallikkoedustajista. Osuus oli selvästi suurempi kuin samaan aikaan eduskunnassa, jossa sielläkin naisedustajien osuus oli noussut vuoden 1983 vaaleissa 31 prosenttiin $^{41}$. Muutos näkyi myös syksyn 1986 seurakuntavaaleissa, joissa valituista luottamushenkilöistä lähes puolet oli naisia. ${ }^{42}$ Kirkolliskokouksessa edellinen hyppäys naisedustajien määrässä oli tapahtunut 1974, jolloin naispappeus oli myös ollut selvästi esillä vaaleissa. Vuonna 1986 maallikkoedustajista yli puolet oli ensimmäisen kauden edustajia, pappisedustajistakin 41 prosenttia. Kirkolliskokousuudistuksen myötä edustajien vaihtuvuus oli lisääntynyt, mutta erityisen suurta se oli vuoden 1986 "naispappeusvaaleissa"43.

Vuoden 1986 vaaleissa eri edustajaryhmien väliset kokemuserot supistuivat huomattavasti kymmenen vuoden takaiseen tilanteeseen verrattuna: naisedustajat 
olivat aiempaa kokeneempia, kun taas miesmaallikot ja varsinkin pappisedustajat olivat kokemattomampia kuin 1970-luvun puolivälissä. Papisto oli jopa hieman kokemattomampaa kuin maallikkomiehet vuonna 1974. Naispappeusvaalit myllersivätkin kaikkein voimakkaimmin juuri papiston rivejä. Helsingissä, missä kiista muutti selvästi vaaliasetelmia, papiston vaihtuvuus oli suurinta: kaksi kolmasosaa oli ensimmäisen kauden edustajia. Lapuan hiippakunnassa, jossa naispappeuskysymys heijastui vaaleihin selvästi vähemmän kuin Helsingissä, peräti 40 prosenttia kaikista vaaleilla valituista edustajista oli samoja kuin uusimuotoisen kirkolliskokouksen alkaessa 1974.

Pappisedustajat olivat 1986 edelleen useimmiten johtavaa papistoa: lähes kolme neljäsosaa oli kirkkoherroja, ja tuomiokapitulissa istui neljännes. Toisaalta kirkon erityisvirassa tai kristillisen järjestön palveluksessa olevien määrä kasvoi. Maallikkoedustajissa oli edelleen paljon opettajia ja koulunjohtajia: runsaan kolmanneksen ammattinimike kertoi henkilön olevan opetusalalla. Papeista 47 prosenttia oli suorittanut yliopistollisen jatkotutkinnon, kun 1974 vastaava osuus oli ollut 41 prosenttia. Tohtoriopintojen yleistyminen yliopistoissa heijastui kirkolliskokouksen kokoonpanoon. Vuonna 1986 neljänneksellä kaikista kirkolliskokousedustajista oli teologinen jatkotutkinto.

Pappisedustajista lähes kaikilla ja maallikkoedustajistakin puolella oli yleisesti tunnettu herätysliiketausta. Pappisedustajien keskuudessa herännäisyyden näkyvyys kasvoi voimakkaasti ja oli selvintä Kuopion sekä Lapuan hiippakunnissa. Kaikista pappisedustajista selvästi yli puolet saattoi lukea herännäisyyttä lähellä oleviksi. Muiden herätysliikkeiden osuus pappisedustajien joukossa säilyi paljolti ennallaan lukuun ottamatta evankelisuutta. Poikkeukselliset vaaliasetelmat johtivat siihen, ettei näkyviä evankelisia pappeja valikoitunut kirkolliskokoukseen.

Maallikkoedustajien keskuudessa evankelisuus nousi vastaavasti suurimmaksi liikkeeksi. On huomattava, että enemmistö evankelista liikettä lähellä olevista maallikkoedustajista kuului naispappeuden kannattajiin. Viidesläisyyteen lukeutuvat kasvattivat osuuttaan voimakkaasti ja nousivat herännäisyyden rinnalle. Noin puolet kannatti ja puolet vastusti naispappeutta lähinnä sen mukaan, oliko henkilö lähellä asialle melko myön- teistä Kansan Raamattuseuraa vai kielteisen kannan ilmaissutta Suomen Evankelisluterilaista Kansanlähetystä. Viimeksi mainittuun liikkeeseen kuului kolme edustajaa, ja siihen lukeutuvien osuus olikin kirkolliskokouksessa selvässä nousussa ${ }^{44}$.

Vanhoillislestadiolaisten edustajien kokonaismäärä supistui kolmesta kahteen. Vähennys liittyi siihen, että naispappeuden kannattajat toimivat keskitetysti Oulun hiippakunnan maallikkoedustajien vaalissa ja saivat kolme neljäsosaa edustajanpaikoista. ${ }^{45}$ Tulos oli vastapainoa naispappeuden vastustajien menestykselle hiippakunnan pappisedustajien vaalissa. Herätysliikkeen lehti Päivämies ei ollut tuloksesta pahoillaan, koska "kristillisyyden terveellinen suola kuitenkin jäi kirkolliskokoukseen" ja koska "kristillisyydellä" eli vanhoillislestadiolaisuudella ei ollut lehden mukaan muutenkaan paineita valloittaa kirkkoa. ${ }^{46}$ Jumalan valtakunta oli kuin suola tai hapate, joka pienenäkin määränä - kahdenkin edustajan välityksellä - vaikuttaisi kirkolliskokouksessa. Sen sijaan muuten lestadiolaisuuden kirjo monipuolistui, kun uusina edustajina aloittivat esikoislestadiolainen kauppias Martti Drachman Lahdesta ja Rauhan Sanan lestadiolaisuuteen lukeutunut rehtori Mauno Vuollo Muoniosta.

\section{VAALITAVAN TARKISTUKSET}

\section{JA VASTAVIHITYT PAPPISEDUSTAJAT}

Vuoden 1986 kirkolliskokousvaalit paljastivat erityisesti papiston enemmistövaalin epäkohdat. Myös maallikkoedustajien uudessa vaalitavassa ilmeni alkuvaikeuksia. Niinpä samana keväänä uusi kirkolliskokous sai peräti seitsemän kirkolliskokousvaaleja koskevaa hiippakuntakokous- tai edustaja-aloitetta. Kenttäpiispa Jorma Laulajan johtama yleisen valmistusvaliokunnan toinen osasto liittyi aloitteisiin, joiden mukaan pappisedustajienkin vaalitapa tuli muuttaa suhteelliseksi. ${ }^{47}$ Epäilyksiä herätti lähinnä se, että jotkut arvelivat suhteellisen vaalitavan voimistavan erinäisiä ryhmäkuntia papiston keskuudessa. Toisaalta yleisesti kannatettiin ehdokasasettelun siirtymistä epävirallisista pienten piirien puhelinkeskusteluista julkisuuteen..$^{8}$ Kirkolliskokous hyväksyi suhteelliseen vaalitapaan siirtymisen lopulta vaivatta kirkkolain kokonaisuudistuksen yhteydessä $1991 .^{49}$

Maallikkoedustajien vaalissa polttavin ongelma oli viikkoon venähtänyt tulosten odotusaika - mikäli 
tuloksia ylipäätään saatiin viralliselta vaaliorganisaatiolta. Viivästys oli tosin ollut tiedossa jo kirkolliskokouksen päättäessä, että äänet oli laskettava hiippakuntatasolla. Lehdistöltä ei herunut ymmärtämystä hidasta tulospalvelua kohtaan..$^{50}$ "Hyvä, ettei silloin jouduttu käyttämään kärrykyytiä tai rekipeliä", luonnehti kirkolliskokousedustaja, Kainuun Sanomien toimittaja Mauno Hyyryläinen äänestyslippujen toimittamista tuomiokapituliin. ${ }^{51}$ Kirkolliskokous ei kuitenkaan ryhtynyt nopeisiin toimenpiteisiin. Vuoden 1988 kirkolliskokousvaalit käytiin pitkälti entisin säännöksin, mikä johti lehdistössä jälleen valituksiin erityisesti tulospalvelun hitaudesta ${ }^{52}$. Merkittävin muutos oli, että kirkolliskokous kaksinkertaisti ehdokaslistojen enimmäispituuden vuoden 1986 ongelmien välttämiseksi. ${ }^{53}$ Päätös auttoikin ehdokasasettelua vaaliteknisesti järkeviin uomiin. Vaikka esimerkiksi Lapuan hiippakunnassa oli yhtä monta ehdokasta (55) kuin kaksi vuotta aiemmin, nyt he mahtuivat kahdeksan sijasta neljälle listalle.

Alueelliset sekä puolue- ja herätysliikeasetelmat painottuivat maallikkoedustajien vaalissa eri tavoin eri hiippakunnissa. Lapuan hiippakunnassa sosiaalidemokraattien ja vanhoillislestadiolaisten kokoamat listat sisälsivät eniten sellaisia henkilöitä, jotka olivat olleet ehdokkaina myös aiemmin. Kyseessä olivatkin selvästi kiinteimmät taustaryhmät, kun taas porvaripuolueiden ympärille kootut ehdokaslistat olivat höllempiä, lähinnä vaaliteknisiä yhteenliittymiä. ${ }^{54}$ Huomiota herätti, että kautta maan keskustan kokoamilla ehdokaslistoilla olleet naispappeuden vastustajat menettivät paikkansa. Niin kävi myös näkyvimpiin maallikkoedustajiin kuuluneelle talousvaliokunnan puheenjohtajalle Väinö Takalalle. Naispappeuskysymys ei kuitenkaan näytä jättäneen ainakaan kaikkialle syviä haavoja, koska monin paikoin eri kannoilla olevat mahtuivat samoille ehdokaslistoille. 55

Helsingin hiippakunnassakaan ehdokkaiden naispappeuskanta ei ollut enää yhtä määräävä tekijä kuin edellisissä vaaleissa. Esimerkiksi herätyskristillisyyttä ja tunnustuksellisuutta julkisesti korostanut valitsijayhdistys oli aiempaa väljempi. ${ }^{56}$ Hiippakunnan ehdokasjoukko myös monipuolistui: opetusalalla toimivien ehdokkaiden osuus oli selvästi aiempaa pienempi, kun taas tekniikan alan edustajia oli lähes neljännes kaikista ehdokkaista. Helsinkiläisten ehdokaslistalla oli erityisen paljon lakimiehiä, selvästi yli neljännes ehdokkaista. Taustalla oli lehdistössäkin näkynyt yritys varmistaa, ettei kahden vuoden takainen onnettomuus toistuisi - olihan sitä paitsi uuden kirkolliskokouksen tarkoitus toteuttaa historiallisen laaja kirkkolain kokonaisuudistus ${ }^{57}$. Uutta oli, että tiedotuksen ja journalismin edustajia oli peräti kymmenesosa kaikista hiippakunnan ehdokkaista. Asetelma kuvasti vuosikymmenen mediamurrosta. Varsinkin suurten kaupunkiseurakuntien päättäjät kiinnittivät huomiota viestinnän merkitykseen.

\section{Picture removed from the open access version of this book.}

Kirkolliskokouksen pappisedustajien vaali käynnissä Helsingin tuomiorovastikunnassa 1988. Vaalia toimittamassa tuomiorovasti Jouko Sihvo. Kuva: Kotimaan kuva-arkisto / Seppo J. J. Sirkka. 
Ehdokasasettelun monipuolistumista kuvasti myös, että kansandemokraatit, jotka olivat aiemmin kokeneet jäävänsä lähes täysin ilman vaikutusvaltaa, saivat ehdokkaansa Oulun hiippakunnan laajapohjaisen valitsijayhdistyksen listalle..$^{58}$ Ehdokaslistojen monipuolistuminen ulottui kuitenkin vain osin maallikkoedustajien vaalin tulokseen. Juristeja tosin valittiin hiippakunnista yhteensä kuusi, mutta muuten ammattijakauma säilyi entisellään. Kirkolliskokous pysyi suurena "opettajainkokouksena". Pitkälti sama asetelma oli Ruotsin kirkolliskokouksessa ${ }^{59}$. Vastaavasti viimeinenkin työväestöön kuuluva edustaja putosi pois, kun maalari Antero Alasta ei enää valittu Helsingin hiippakunnasta. Lehdistö kautta linjan valitteli kirkolliskokouksen saamaa yksipuolista kokoonpanoa, jossa suurista seurakunnista tulevilla ja korkeasti koulutetuilla opetus- sekä sosiaali- ja terveysalan virkamiehillä oli yliedustus. ${ }^{60}$

Varsinkin Helsingin hiippakunnassa oli ongelmia maallikkoedustajien vaalin ääntenlaskussa ja tulospalvelussa. Ääntenlaskenta alkoi viimeisenä mahdollisena päivänä ja kesti silloin lähelle puoltayötä. ${ }^{61}$ Jo muutenkin vaikea toimitus seurakuntakohtaisine kertoimineen jouduttiin suorittamaan kiireessä ja paineen alla iltamyöhään. Lehtori Ritva Salmenkiven äänimäärä luettiin väärin: edustajapaikan selvin numeroin saanut Salmenkivi putosi kokouksen ulkopuolelle. ${ }^{62}$ Virhe huomattiin myöhemmin valitsijayhdistyksen asiamiehen omaaloitteisen toiminnan ansiosta. Tapaus puhutti keväällä kirkolliskokouksessa, jossa vaadittiin jälleen ääntenlaskuun sekä huolellisuutta että ripeyttä. ${ }^{63}$

Ensimmäiset naiset vihittiin papiksi kirkolliskokousvaaleja edeltävänä päivänä. Mieskollegat olivat aktiivisia, ja tiukasta aikataulusta huolimatta kirkolliskokoukseen valittiin kaksi päivän ikäistä pappia, Sisko Raitis arkkihiippakunnasta ja Pirkko Lehtiö Helsingin hiippakunnasta. Kun lisäksi naisten osuus maallikkoedustajista kasvoi selvästi yli puoleen, kaikista hiippakunnittain valituista edustajista naisia oli jo 40 prosenttia. Naisten määrä maallikkoedustajien keskuudessa kasvoi 1980-luvun aikana yli 70 prosenttia. Määrän kasvaessa myös yhteistoiminta alkoi hiipua: kokoontumiset jatkuivat vielä 1986 mutta loppuivat nopeasti tarpeettomina ${ }^{64}$. Naisedustajista, jotka kymmenen vuotta aiemmin olivat arastellen pitäneet sovittelevia puheenvuoroja, oli tullut tasavertaisia miesmaallikkojen kanssa.

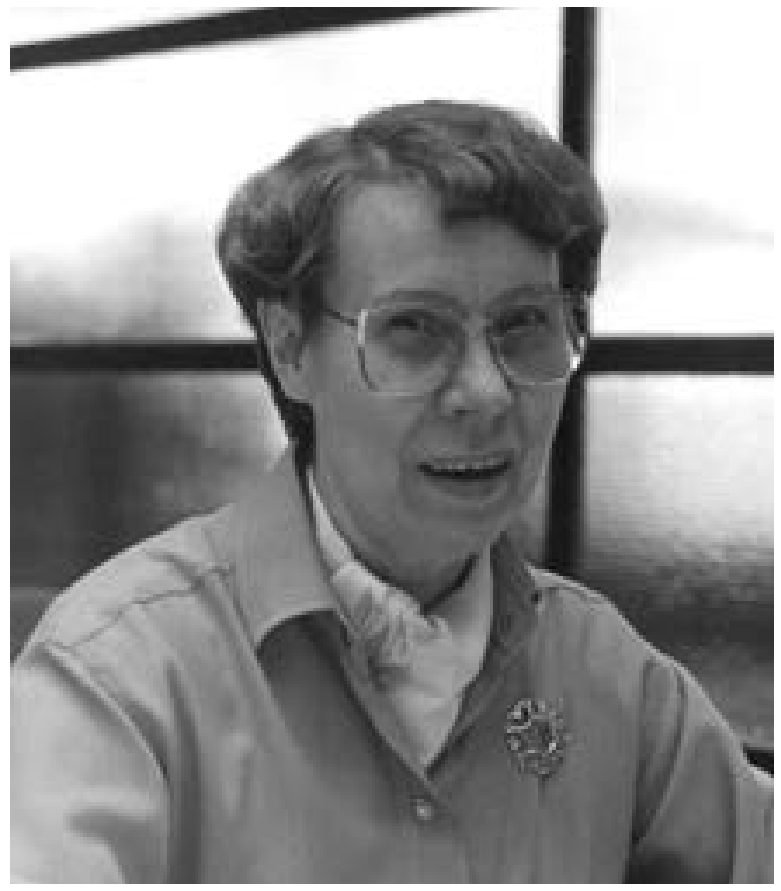

Helsingin hiippakunnan pääsihteeri, teologian tohtori Pirkko Lehtiö valittiin kirkolliskokouksen pappisedustajaksi 1988 vain päivä sen jälkeen, kun hänet oli vihitty papiksi. Lehtiö oli ollut omalta osaltaan edistämässä pappisviran avaamista naisille muun muassa virkakomitean jäsenenä 1960- ja 1970-luvulla. Kuva: Kirkkohallitus / Ritva Neuvonen.

Toinenkin muutos tapahtui 1988: naispappeustaistelun aikainen selvä kahtiajako, jossa naisedustajat olivat olleet keskenään samalla puolella, alkoi vähitellen murtua. Helsingin hiippakuntaan perustetulta, tunnustuksellisuutta painottaneelta listalta valittiin kirkolliskokoukseen kaksi naista, toimittaja Leena Huima Helsingistä ja Suomen Raamattuopiston rehtori Liisi Jokiranta Vantaalta. Sallivasta naispappeuskannastaan huolimatta Huima otti kirkolliskokousedustajana muutaman kerran osaa myös Oulun piispan Olavi Rimpiläisen johtamiin epävirallisiin kokoontumisiin, joihin kutsuttiin niin sanottuja tunnustuksellisia edustajia. ${ }^{65}$ Arkkihiippakunnasta puolestaan valittiin 1988 edustajaksi turkulainen filosofian maisteri Eeva Laato, joka oli hyvin kriittinen useita uudistushankkeita kohtaan. Sama mielipiteiden kirjo, joka oli aiemmin ollut nähtävissä miesedustajien keskuudessa, tuli jäädäkseen myös naisedustajien piiriin. Kaikkien naisedustajien 
yhtenäinen ryhmätoiminta kävi paitsi tarpeettomaksi myös mahdottomaksi.

Vuonna 1988 kirkolliskokoukseen valittujen naisten joukossa oli yhteiskuntatieteiden maisteri Lea Savolainen Hämeenlinnasta. Hän oli ensimmäinen SDP:n kansanedustaja, joka istui kirkolliskokouksessa muuten kuin valtioneuvoston määräämänä edustajana. Valinta kuvasti ensinnäkin sitä, miten uusi ehdokasasettelu ja suhteellinen vaalitapa paransivat sosiaalidemokraattien menestymismahdollisuuksia kirkolliskokousvaaleissa. Samalla valinta symboloi omalla tavallaan kirkon ja sosiaalidemokraattisen työväenliikkeen johdon lähentyneitä suhteita.

Savolaisen valinta oli myös osa muutosta, jonka myötä kirkolliskokouksen henkilöyhteydet valtiolli- sen päätöksenteon huipulle vahvistuivat 1980-luvulla. Vuosikymmenen aikana peräti kaksi istuvaa kirkolliskokousedustajaa nimitettiin ministeriksi. RKP:n Gustav Björkstrand nimitettiin 1983 ministeriksi opetusministeriöön. Kokoomuksen Ulla Puolanne taas valittiin neljä vuotta myöhemmin ministeriksi valtiovarainministeriöön. Lisäksi kirkolliskokouksessa oli useita istuvia kansanedustajia, mikä oli 1970-lukuun verrattuna uutta. Maanviljelijä Heikki Kokko edusti vuosikymmenen alkupuolella keskustaa, kun taas vuosikymmenen loppupuolella Puolanteen ohella valtiotieteiden maisteri Päivi Varpasuo kuului kokoomuksen eduskuntaryhmään.

Erityisesti naiskansanedustajien lukuisuus kirkolliskokouksessa herättää huomiota. Yhtäältä muutos liittyi siihen 1980-luvun yleiseen kehityslinjaan, että nais-

\section{Teologisten tiedekuntien valitsema edustaja takaisin?}

Vuoteen 1973 asti Helsingin yliopiston teologinen tiedekunta oli valinnut kirkolliskokoukseen yhden edustajan. Kirkolliskokousuudistuksen myötä poistunut käytäntö nousi uudelleen puheenaiheeksi 1980-luvulla. Taustalla oli ensinnäkin raamattukeskustelu, jonka polttopisteessä olivat Helsingin yliopiston eksegetiikan laitos ja aivan erityisesti professori Heikki Räisänen. ${ }^{I}$ Monien mielestä kirkon suhde tiedekuntaan ei ollut kunnossa. Myös ne Helsingin yliopiston teologisen tiedekunnan opettajat, joilla oli halua vaikuttaa kirkon päätöksentekoon, olivat tyytymättömiä tilanteeseen. Porvoon hiippakunnan pappisedustajien joukossa oli ollut Åbo Akademin teologian professori lähes koko kirkolliskokousuudistuksen jälkeisen ajan, joten ongelma koski nimenomaan Helsingin yliopistoa.

Kirkolliskokouksessa asiasta keskusteltiin 1985 edustajaaloitteen ja neljä vuotta myöhemmin Helsingin hiippakuntakokouksen aloitteen pohjalta. Aloitteiden näkyvin puolustaja oli yleisen historian apulaisprofessori Seikko Eskola. Edustuksen palauttamista pidettiin tärkeänä nimenomaan kirkolliskokouksen ja Helsingin yliopiston yhteyksien parantamiseksi. Teologista asiantuntemusta ei aloitteiden tekijöiden mielestä tarvittu lisää. Aloitteet saivat kuitenkin osakseen vastustusta juuri siksi, että kirkolliskokouksessa katsottiin olevan jo riittävästi teologeja. Maallikko- ja pappisedustajien välille syntyi jännitteitä: kysyttiin, miksi pappeja kouluttava laitos pitäisi asettaa eri asemaan muihin oppilaitoksiin nähden. ${ }^{\text {II }}$ Asetelmaa kuvasti se, että maallikkovaltainen yleinen valmistusvaliokunta oli lähes yksimielisesti aloitteita vastaan, mutta täysistunnossa tilanne oli tasaväkisempi. ${ }^{\text {III }}$ Vuonna 1989 aloite jätettiin raukeamaan äänin 64-33 eli lähes samassa suhteessa kuin kokouksessa oli maallikko- ja pappisedustajia. Aivan täysin mielipiteet eivät tosin noudattaneet näiden edustajaryhmien välisiä rajoja. ${ }^{\text {IV }}$

Ruotsissa luovuttiin 1980-luvun alkupuolella kirkolliskokouksen edustajakiintiöistä ja itseoikeutetuista edustajista. Pappisvirkaa ei tuolloin kuvattu teologisesti, vaan papit nähtiin ennemminkin virkamiehinä. ${ }^{v}$ Vuonna 1983 Ruotsin ensimmäiseen uudistettuun kirkolliskokoukseen valittiin 13 piispasta vain kolme. ${ }^{\text {VI }}$ Suomessa tällainen linja ei saanut kannatusta, mutta toisaalta ei myöskään oltu valmiita palaamaan taaksepäin ja lisäämään virallisten edustajien määrää.

Vaikka muutosta ei hyväksytty kirkkolakiin, se kirjattiin seuraavissa kirkolliskokousvaaleissa vaalilippuihin. Vuonna 1992 kirkolliskokoukseen valittiin dekaani niin Helsingin yliopiston kuin Åbo Akademin teologisesta tiedekunnasta. Hetkellisesti teologisista tiedekunnista oli kirkolliskokouksessa kattavampi edustus kuin yhdessäkään aloitteessa kirkkolain muuttamiseksi oli edellytetty.

I Kirk.kok. kptk-k. 1984, 66 \$.

II Kirk.kok. kptk-k. 1985, 37 \$; Kirk.kok. ptk-k. 1985, liite X 1; Kirk.kok. kptk-s. 1985, 39 \$; Kirk.kok. kptk-k. 1989, 22 \$, 59 \$; Kirk.kok. ptk-k. 1989, liite V 12; S. Eskola 2004, 139.

III Kirk.kok. ptk-s. 1985, liite VI-E 6; Kirk.kok. ptk-k. 1989, liite VII-C 1.

IV Kirk.kok.kptk-k.1989,59 \$.

V Bexell 1990, 164.

VI Åstrand 1994, 133 . 
ten osuus maallikkoedustajista kasvoi voimakkaasti. Toisaalta taustalla oli poliittisten naisjärjestöjen toiminta naispappeuden puolesta. Siten valtakunnanpolitiikassa aktiivisia naisia saatiin ehdokkaiksi myös kirkolliskokousvaaleihin. Kun Kotimaa nosti 1988 kirkolliskokousedustajien joukosta esiin puoluevaikuttajia, lehden mainitsemista kymmenestä henkilöstä kahdeksan oli naisia ${ }^{66}$. Artikkelissa mainitut naisedustajat olivat kirkolliskokouksessa myös hyvin aktiivisia ja toivat keskusteluun monia yhteiskunnallisia ja maailmanlaajuisia ongelmia.

\section{"ROUVA PUHEENJOHTAJA" JA MUUT HENKILÖVALINNAT VALMISTELLUSTI JA VÄHIN KESKUSTELUIN}

Kirkolliskokouksen sisäiset henkilövalinnat eivät 1980-luvulla saaneet aikaan yhtä kiivaita keskusteluja kuin edellisellä vuosikymmenellä. Hiippakunnittain järjestetyt neuvottelukokoukset olivat kehittyneet ja hiippakuntaryhmien välinen tiedonkulku parantunut, minkä vuoksi konsensus löytyi yleensä jo ennen täysistuntoa. Erityisen laaja yksimielisyys oli vuosina 1982 ja 1986 siitä, että ensimmäiseksi varapuheenjohtajaksi tuli valita Johannes Leivonen. Aiemmin kuultuja epäilyksiä virallisen edustajan valinnasta ei enää esitetty. Päinvastoin kyseltiin, miten kirkolliskokous tulisi toimeen, ellei Leivonen olisi varapuheenjohtajana. ${ }^{67}$ Leivosen jäätyä eläkkeelle hänen tilalleen valittiin vuodeksi 1987 hallintoneuvos Olli Sakki. ${ }^{68}$

Toiseksi varapuheenjohtajaksi oli sen sijaan valittava uusi henkilö Lars Erik Taxellin jäätyä pois kirkolliskokouksesta. Vuonna 1982 katkesi kaksi vaalikautta jatkunut käytäntö, että varapuheenjohtajista toinen tuli Porvoon hiippakunnasta. Asiaan saattoi vaikuttaa se, että kirkolliskokouksen kokoontuessa toukokuussa 1982 John Vikström oli jo ehtinyt nousta arkkipiispanvaalin ylivoimaiseksi ennakkosuosikiksi ${ }^{69}$. Puheenjohtajistoon oli siten tulossa joka tapauksessa yksi äidinkieleltään ruotsinkielinen. Sen sijaan yhä laajemmin oltiin sitä mieltä, että puheenjohtajistoon oli valittava nainen. Vuonna 1982 Meeri Päivänsalo saikin yli puolet kaikista äänistä toisen varapuheenjohtajan vaalissa. ${ }^{70}$ Alkoi uusi perinne varapuheenjohtajan paikkojen jaossa, ja toisaalta Viljami Kalliokosken kauden jälkeen katkennut Oulun hiippakunnan edustus puheenjohtajistossa sai jatkoa.

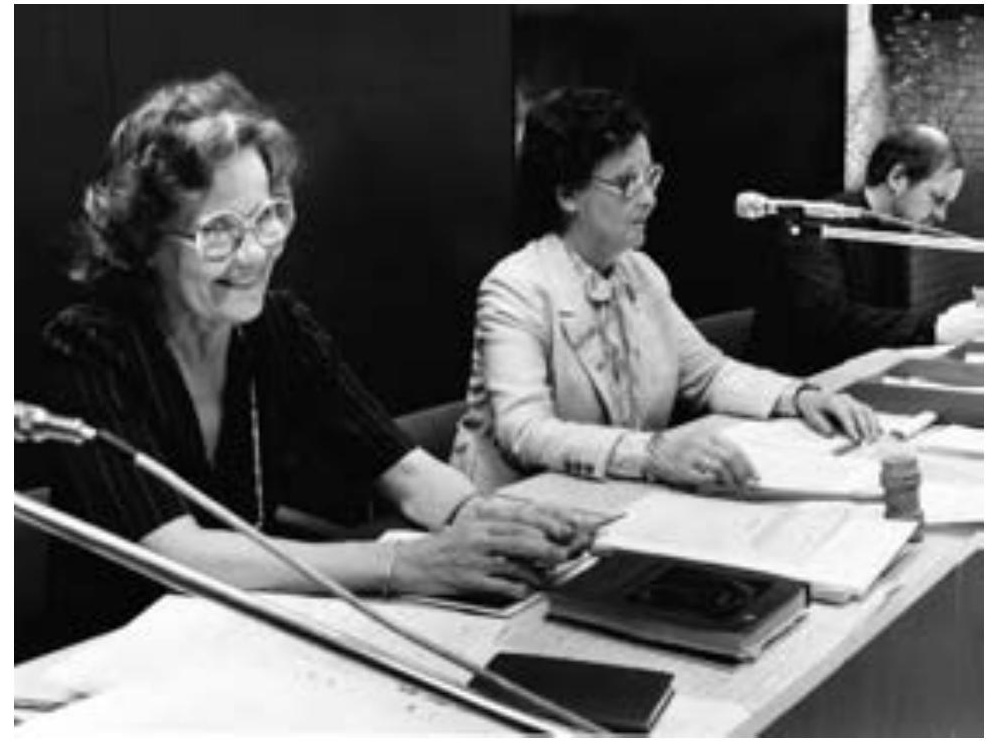

Keväällä 1982 kirkolliskokouksen johdossa siirryttiin uuteen aikaan, kun puheenjohtajistoon valittiin ensimmäistä kertaa nainen, kouluneuvos Meeri Päivänsalo (oik.). Siitä lähtien otettiin käytännök$s i$, että varapuheenjohtajista toinen oli nainen. Päivänsalon vierellä kirkolliskokouksen sihteeri Sinikka Pylkkänen. Kuva: Kirkon kuvapankki / Arvo Salminen.

Vuonna 1988 valittiin samoilla periaatteilla varapuheenjohtajaksi filosofian maisteri Raija-Liisa Mikkola Kokkolasta. Tuolloin siirryttiin myös käytäntöön, että ensimmäisenä varapuheenjohtajana oli naisedustaja. Toiseksi varapuheenjohtajaksi valittiin rehtori Kalevi Nummi Tampereelta. ${ }^{71}$ Varapuheenjohtajista Mikkola sai paljon vastuuta täysistuntojen johtamisessa. Kirkolliskokouksen johto pyrki tälläkin tavoin osoittamaan ulospäin, ettei kirkossa evätty naisilta pääsyä korkeisiin tehtäviin. ${ }^{72}$ Tällaisen kuvan vahvistaminen oli ajankohtaista jo siksi, että samaan aikaan julkisuudessa ilmeni tyytymättömyyttä, koska piispanviran avaaminen naisille näytti epävarmalta. 
Kirkolliskokoustehtävät jakautuivat edustajien kesken monelta osin samoin kuin aiemmin. Valitsijamiehet olivat edelleen kokeneita: 1986 valitsijamieheksi pääsi kirkolliskokouksen tulokkaista hieman yli neljä prosenttia mutta vähintään neljättä kauttaan kirkolliskokouksessa istuvista lähes puolet. Valitsijamiesten vaalit sujuivat hiippakunnittain hyvin yksimielisesti muuten paitsi Helsingin osalta ${ }^{73}$. Pääkaupungin hiippakunnan neuvottelukokoukset eivät olleet yhtä järjestelmällisiä kuin monissa muissa hiippakunnissa, ja myös hiippakunnan edustajat jakautuivat tavallista selvemmin eri mielipideryhmiin. Jopa valitsijamiesten varamiesten vaalista saattoi tulla tiukka ${ }^{74}$. Yleensä valitsijamiehiin pyrittiin saamaan pappeja ja maallikkoja suunnilleen samassa suhteessa kuin heitä oli kirkolliskokouksessa. Poikkeuksiakin oli. Kirkolliskokoustehtävissä kuormitetut Porvoon hiippakunnan pappisedustajat antoivat 1988 kaikki valitsijamies- ja varamiespaikat maallikkoedustajille.

Vuonna 1982 päätettiin sijoittaa jokainen edustaja johonkin pysyvistä valiokunnista, minkä vuoksi useimpien valiokuntien kokoa oli suurennettava 15-17 jäseneen. Kaikki kirkolliskokousedustajat saatiin mukaan valmistelutyöhön, mutta esimerkiksi istuntokausien välillä paljon työskentelevästä talousvaliokunnasta uhkasi tulla jo liian suuri. ${ }^{75}$ Valiokuntien koon kasvattaminen tarkoitti käytännössä maallikkoedustajien lisäämistä valiokuntiin. Neljästä pappisvaliokunnasta saattoi edelleen puhua siinä mielessä, että 1982 neljä viidestä papista oli joko laki-, peruste-, käsikirja- tai toimikuntavaliokunnassa. Kuitenkin näistä valiokunnista vain käsikirjavaliokunnassa papeilla oli enemmistö - tosin sitäkin selvempi yli kahden kolmasosan osuus. Juuri tämä valiokunta käsitteli yhtä vaalikauden suurista kirkollisista hankkeista, uutta kirkollisten toimitusten kirjaa.

Myös toiseen hyvin keskeiseen valiokuntaan, virsikirjavaliokuntaan, valittiin niukka pappisenemmistö. Samoin tapahtui seuraavalla vaalikaudella asetettaessa hallintovaliokunta, jonka tehtävänä oli valmistella kirkon keskushallinnon uudistusta. Kun vielä 1988 alkaneen vaalikauden keskeisimpiin valiokuntiin, kirkkolain uudistamisvaliokuntaan ja raamatunkäännösvaliokuntaan, tuli kahden kolmasosan pappisenemmistö, kaikki poikkeuksellisen laajaa valmistelua vaatineet uudistukset käsiteltiin muutamissa pappisenemmistöisissä valio- kunnissa. Ulospäin näkymätöntä työtä tehneeseen kansliavaliokuntaan ei koko vuosikymmenen aikana valittu yhtäkään pappia. Valiokunnan käsittelemät asiat vaikuttivat edelleen myös siihen, miten kokeneita edustajia siihen sijoitettiin. Jos yleisen valmistusvaliokunnan puheenjohtajia ei lasketa mukaan, 1986 valiokunnan jäsenistä lähes 90 prosenttia oli ensimmäisen kauden edustajia. Laajakantoista hallinnonuudistusta käsitelleessä hallintovaliokunnassa taas ei ollut yhtään kirkolliskokouksen tulokasta.

Valtioneuvoston määräämä edustaja oli osallistunut kirkolliskokouksen työskentelyyn 1970-luvulla vain harvoin. Seuraavalla vuosikymmenellä Ruotsalaisen kansanpuolueen ministerien kaudella tilanne alkoi muuttua, ja lopulta 1988 valtioneuvoston määräämä edustaja valittiin ensimmäistä kertaa valiokunnan jäseneksi. Siitä lähtien varaedustaja, opetusministeriön vanhempi hallitussihteeri Marjatta Lehtinen osallistui yhtäjaksoisesti täysistuntoihin ja lakivaliokunnan työhön. Vaikka hän olikin edustajana virallisesti yksityishenkilö, uuden käytännön myötä kirkolliskokouksen oli päätöksiä valmisteltaessa aiempaa helpompi saada selville valtiovallan näkökantoja. Vastaavasti kirkkolain muutoksia valmisteltaessa esillä olleet näkökulmat välittyivät tehokkaasti opetusministeriöön.

Naisedustajat sijoittuivat valiokuntiin 1980-luvulla paljon tasaisemmin kuin edellisellä vuosikymmenellä. Nyt heille avautui ovi myös keskeisiin valiokuntiin siinä missä maallikkomiehillekin. Vuonna 1986 esimerkiksi perustevaliokuntaan, jonka tiedettiin käsittelevän naispappeusaloitteen, valittiin seitsemän maallikkoedustajaa, joista viisi oli naisia. Perustevaliokunnan kokoonpano herätti harvinaislaatuisesti julkista arvostelua: Timo Holma moitti, että naispappeuden vastustajia oli valittu valiokuntaan vain kaksi, vaikka vastustajien suhteellinen osuus olisi edellyttänyt kolmea tai neljää edustajaa. Valitsijamiesten toiminta valiokuntapaikkojen jaossa oli hänen mukaansa "Ruotsin mallin mukaista tarkoitushakuista diskriminointia", joka uhkasi "muuttaa tämän puoluejohtoiseksi valtiokirkoksi" ${ }^{6}$

Kun 1970-luvulla naisedustajien joukossa oli ollut lähinnä opettajia, 1988 ammattien kirjo oli huomattavasti monipuolisempi. Naisedustajat saattoi asiantuntemuksensa perusteella hyvin sijoittaa eri valiokuntiin, ja heitä olikin yli puolet maallikkoedustajista kaikissa suurissa 
valiokunnissa talousvaliokuntaa lukuun ottamatta. Miesten "viimeinen linnake" kirkolliskokouksessa ei ollut oppia vaan taloutta käsittelevä elin. Naisia oli erityisen suuri osuus maallikkoedustajista toimikuntavaliokunnassa ja keskeisessä kirkkolain uudistamisvaliokunnassa. Naiset saivat kirkolliskokouksessa vastuuta kirkon toiminnan ohjaamisesta samalla, kun seurakuntien työntekijäkunta naisistui kovaa vauhtia. Sen sijaan yksittäisiä valiokunnan varapuheenjohtajuuksia pidemmälle naisedustajat eivät edenneet - olihan suurin osa valiokunnista muutenkin virallisten edustajien ja siten miesten johdossa.

Valitsijamiehet päättivät 1982 pyrkiä lisäämään naisjäsenten määrää myös kirkkohallituksessa, vaikka sukupuolta ei pidettykään ensisijaisena tai ratkaisevana tekijänä. Kahdeksan luottamustoimisen kirkkoneuvoksen joukossa naisten määrä nousi 1980-luvun ajaksi kahteen. Muuten keskustelunaiheet ja kirkolliskokouksen linja säilyivät kirkkoneuvoksia valittaessa hyvin samanlaisina kuin edellisellä vuosikymmenellä. ${ }^{77}$

Toimikuntien ja sittemmin keskusten johtokuntien vaaleissa valitsijamiehet ryhtyivät vuosikymmenen kuluessa määrätietoisesti rajoittamaan edustajakausia. Jäsenyyden enimmäispituudeksi määritettiin 12 vuotta. Vaaleissa näkyi jossain määrin entinen vastakkainasettelu: tuliko toimikunnista saada tehokkaita, melko pieneltä alueelta koottuja asiantuntijaelimiä vai alueellisesti monipuolisia edustuselimiä, joissa kuului myös pienten seurakuntien ääni? Kahdeksankymmenluvulla liikuttiin hieman jälkimmäisen näkemyksen suuntaan. ${ }^{78}$ Myös naisten määrän lisäämiseen kiinnitettiin huomiota. ${ }^{79}$

Kirkkoneuvoksen virantäytöt eivät herättäneet täysistunnoissa juuri keskustelua. Sen sijaan käytävillä kohistiin. Vuonna 1985 valittiin Kai Sarsalle seuraaja kirkon keskusrahaston johtajaksi. Lähetystöneuvos Kari Bergholm sai valitsijamiehissä yhden äänen enemmän kuin kirkkohallituksen pitkäaikainen työntekijä, ennakkokaavailuissa vahvoilla ollut palkkauslakimies Reijo Lehtinen. Valitsijamiesten ratkaisu herätti huomiota, mutta lopulta kirkolliskokous asettui äänin 63-40 Lehtisen taakse. ${ }^{80}$

Kun 1990 valittiin toimikuntien pääsihteerinä toimiva kirkkoneuvos, kaikki neljä pääehdokasta olivat perinteiseen tapaan kirkolliskokouksen pappisedustajia. Tehtävään valittiin asessori Heikki Mäkeläinen. ${ }^{81}$
Aiempina vuosina oli ollut erilaisia tulkintoja siitä, miten kirkkoneuvoksen virkaan valinta vaikutti kirkolliskokouksen jäsenyyteen. Jukka Malmivaara oli jättänyt kirkolliskokouksen siirtyessään kirkkoneuvoksen virkaan, kun taas Timo Rusama ja Pertti Mäkeläinen olivat istuneet lopuillaan olleen vaalikauden päätökseen asti. ${ }^{82}$ Heikki Mäkeläinen pysyi kirkolliskokouksessa. Vaalikausi oli tuolloin vasta puolivälissä, ja tilanne oli sikäli poikkeuksellinen, että Mäkeläisellä oli näkyvä asema sekä luottamushenkilönä kirkkolain uudistamisvaliokunnassa että kirkkohallituksen johtavana viranhaltijana.

\section{LUOTTAVAINEN KIRKOLLISKOKOUS EPÄVAKAASSA MAAILMASSA}

\section{ARKIPYHIEN PALAUTUS JA UUDISTUVA VEROTUS KOETTELEVAT SUHTEITA VALTIOVALTAAN}

Vuoden 1971 ylimääräinen kirkolliskokous oli taipunut siihen, että loppiainen, helatorstai ja toinen helluntaipäivä siirrettiin lauantaipäivään. Taustalla oli osana tulopoliittista kokonaisratkaisua tehty sopimus, jonka eteen kirkolliskokous joutui. Kirkolliskokousta moitittiin alistumisesta. Kaksoispyhät nostattivat kovaa arvostelua varsinkin, kun muissa Pohjoismaissa ei vastoin odotuksia siirrytty vastaavaan kalenteriin. Jo 1978 Oulun ja Porvoon hiippakuntakokoukset ehdottivat, että arkipyhät palautettaisiin entisille paikoilleen. Työmarkkinajärjestöjen edustajat sekä asiantuntijana kuultu kirkolliskokousedustaja, valtakunnansovittelija Matti Pekkanen pitivät palautusta hyvin vaikeana. Asia lähetettiin kuitenkin piispainkokoukselle harkittavaksi. Tälläkin kertaa tuntui ulkoinen paine, joka tosin nyt ei tullut työmarkkinajärjestöjen suunnasta vaan uudistukseen pettyneestä "kansasta". ${ }^{83}$ Sen sijaan että arkipyhien palauttamista olisi perusteltu kirkon itseymmärryksestä käsin, kirkolliskokous yritti jälleen toimia ennen kaikkea eräänlaisena valtakunnansovittelijana työmarkkinajärjestöjen ja "kansan" välillä. Sittemmin mielipidetutkimukset osoittivatkin kansalaisten toivovan yleisesti arkipyhien palauttamista, ja asia pysyi esillä lehdistössä ${ }^{84}$.

Opetusministeri Pär Stenbäck ilmoitti eduskunnassa joulukuussa 1980, ettei hänen johtamansa opetusministeriö vastustaisi loppiaisen ja helatorstain palautusta, 
mikäli kirkolliskokous tekisi asiasta ehdotuksen. ${ }^{85}$ Piispainkokous esittikin 1982 kirkolliskokoukselle, että nämä kaksi pyhää palautettaisiin entisille paikoilleen. Helluntai muutettaisiin yksipäiväiseksi, jotta työmarkkinajärjestöt saataisiin suostumaan palautukseen. Piispainkokouksen mukaan ilmapiiri oli muuttunut, ja talouden tehokkuuden tilalle oli tullut elämänlaadun korostaminen. Piispainkokous esitti lainmuutoksen ehdoksi, että siirrettävät arkipyhät säilyisivät yhteiskunnallisina vapaapäivinä. Hallituksen tuli antaa kirkkolakiesitys eduskunnalle vain siinä tapauksessa, että tämä ehto voitiin toteuttaa. ${ }^{86}$

Kirkolliskokouksen perustevaliokunta yhtyi pääosin piispainkokouksen esitykseen, mutta viimeksi mainittua ehtoa se ei hyväksynyt. Valiokunnan ja erityisesti sen lakimiesjäsenen Jaakko Voipion mielestä kirkolliskokouksen ei tullut antaa valtiovallalle ehdollisia esityksiä. Sellainen toiminta olisi hämärtänyt periaatetta, että kirkolliskokouksen tekemät esitykset voitiin vain hyväksyä tai hylätä. Kirkolliskokous olisi luovuttanut osan harkintavallastaan valtion elimille, jotka olisivat voineet vastaisuudessa ryhtyä asettamaan ennakkoehtoja kirkkolain muuttamiselle. ${ }^{87}$

Ratkaisevassa käsittelyssä perustevaliokunta ei saanut taakseen aivan yksimielistä tukea mutta kylläkin selvästi kolmen neljäsosan määräenemmistön äänin $82-6 .{ }^{88}$ Kirkolliskokous oli näin asettunut nopeasti yhden istuntoviikon aikana työmarkkinajärjestöjen kantaa vastaan. Kirkon johdon suhteet työväenliikkeeseen ja sitä edustaviin poliittisiin puolueisiin olivat parantuneet 1980-luvun alkaessa ${ }^{89}$. Samaten luottamus kirkkoon oli edelleen kasvanut 1970-luvun loppupuolelta lähtien samalla, kun yleinen ilmapiiri oli alkanut muuttua aiempaa uskontomyönteisemmäksi ja myös konservatiivisemmaksi. ${ }^{90}$ Piispainkokous ja kirkolliskokous arvioivat kirkon aseman 1980-luvun alussa sen verran vakaaksi, että ne uskalsivat ryhtyä toimiin. ${ }^{91}$ Erona 1970-luvun lopulla kirkolliskokouksessa käytyihin keskusteluihin oli, että keväällä 1982 tilannetta pohdittiin pitkälti kirkon omalta kannalta. Todettiin esimerkiksi, miten kaksoispyhät olivat rappeuttaneet pyhäpäivän viettoa ${ }^{92}$. Kokous toimi omista lähtökohdistaan ja suhtautui aiempaa luottavaisemmin kirkon asemaan.

Piispat korostivat kirkon johdonmukaista linjaa vuodesta 1971 vuoteen 1982: koko ajan oli ollut tärkeintä turvata kirkkopyhien säilyminen yhteiskunnallisina vapaapäivinä. Vuonna 1971 tuo päämäärä oli edellyttänyt kolmen pyhän siirtämistä viikonloppuun, mutta 1982 nähtiin mahdollisuuksia palata kohti aiempaa käytäntöä. Varsinkin lähetekeskustelussa esiintyi ajatuksia, että arkipyhät voitaisiin palauttaa entisille paikoilleen myös ilman, että ne säilyisivät yhteiskunnallisina vapaapäivinä. Piispojen esiintyminen vaimensi kuitenkin tällaiset puheenvuorot. ${ }^{93}$

Jatkuvuutta oli myös siinä, että kummallakin kerralla kirkolliskokous nojautui elimiin, jotka olivat vahvistaneet asemiaan poliittisessa järjestelmässä. Vuonna 1971 kirkolliskokous oli antanut periksi voimistuneiden työmarkkinajärjestöjen edessä94. Sen sijaan 1982 ei enää juurikaan välitetty työmarkkinajärjestöjen vastustuksesta vaan nojattiin hallitukseen ja eduskuntaan, joiden asema oli vahvistunut uudelleen työmarkkinajärjestöjen kustannuksella. ${ }^{95}$ Myös hieman aiemmin presidentiksi valittu Mauno Koivisto oli korostanut parlamentarismin periaatteita ja siten pyrkimystä vahvaan hallitukseen ja eduskuntaan..$^{96}$ Arkipyhien palauttaminen oli viime kädessä parlamentaarisen lainsäädäntöjärjestelmän ja työmarkkinajärjestöjen välinen voimainkoitos. Luopuessaan lakiesityksensä ehdollisuudesta kirkolliskokous saneli vuorostaan valmiin ratkaisumallin työmarkkinapolitiikan sopijapuolille.

Samaan aikaan kun kirkolliskokous oli irtautumassa 1970-luvun alun tulopoliittisen kokonaisratkaisun päätöksistä, se sai eteensä vuoden 1981 kokonaisratkaisun eli "Pekkas-sopimuksen" päätökset. Kirkon edustajat joutuivat jälleen tapahtuneiden tosiasioiden eteen, vaikka sopimus oli syntynyt kirkolliskokouksen silloisen jäsenen, valtakunnansovittelija Matti Pekkasen johdolla. Työmarkkinaosapuolet olivat sopineet, että aiemmin verottomat sosiaalietuudet muutettaisiin verollisiksi. Muutos tiesi käytännössä kirkollekin lisää verotuloja. Valtiovarainministeriö edellytti, että kirkko palauttaisi nämä niin sanotut sove-tulot valtiolle lähes täysimääräisinä. Opetusministeriön ja kirkon edustajien muodostaman, kansliapäällikkö Jaakko Nummisen johtaman työryhmän neuvotteluissa päädyttiin kuitenkin suosittelemaan, että valtion ja kirkon välisellä sopimuksella palautettaisiin vain puolet lisäverotulosta valtiolle. Vaikka valtiovarainministeriön vaatimuksesta osuutta nostettiin vielä 65 prosenttiin, uudet neuvotteluyhtey- 


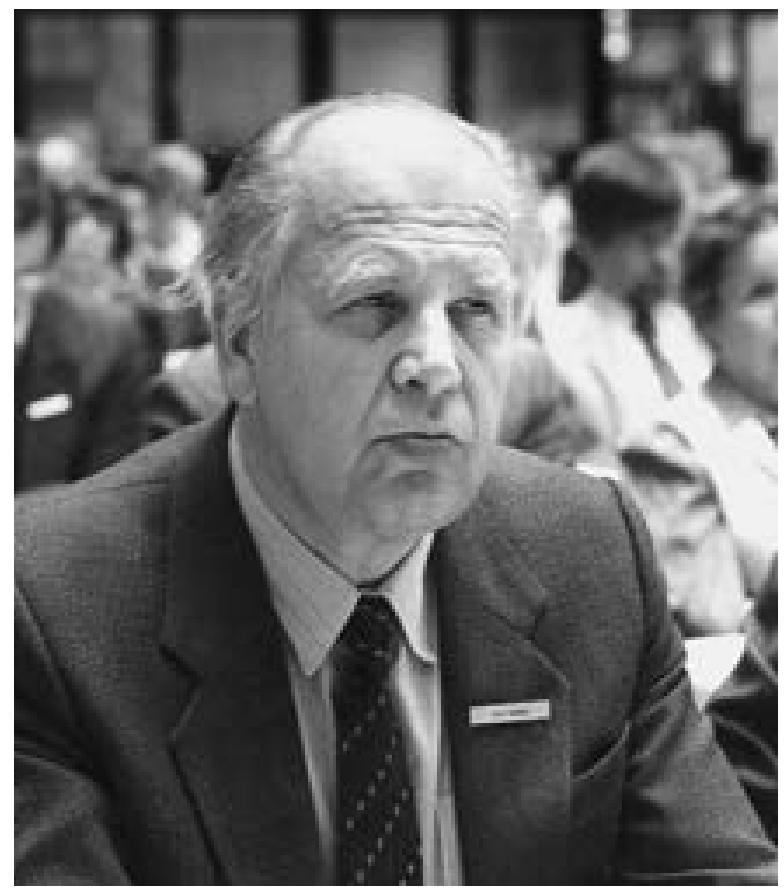

Korkeimman hallinto-oikeuden valitsema edustaja, hallintoneuvos Olli Sakki oli kirkolliskokouksessa 198o-luvulla näkyvä vaikuttaja, joka toimi vuoden myös kokouksen varapuheenjohtajana. Hänen laintulkintansa vaikutti esimerkiksi siihen, ettei kirkolliskokous 1982 korvannut valtiolle lisätuloja, joita valtiovarainministeriö oli laskenut kirkon saavan sosiaalietuuksien verotuksesta. Kuva: Kirkkohallitus / Erkki Talvila.

det kirkon ja valtioneuvoston edustajien kesken liennyttivät ilmapiiriä. Kirkkohallitus piti kuitenkin periaatteellisena ongelmana, että kirkon ja valtion suhteita ryhdyttäisiin sääntelemään muuten kuin lainsäädännöllä. Kirkkohallituksen enemmistö esitti kirkolliskokoukselle, että kirkko sitoutuisi lakimuutoksella korvaamaan tuomiokapitulilaitoksen valtiolle aiheuttamat kulut.97

Asian monimutkaisuutta ja vaikeutta kuvasti, että kansliapäällikkö Numminen puhui kirkolliskokouksen lähetekeskustelussa lähes tunnin esitellessään asian käsittelyvaiheita. Nummisen mukaan sove-kysymys näytti heittäneen varjon kirkon ja valtion suhteiden ylle. Samalla hän kuitenkin korosti, että myös opetusministeriön edustajat oli kutsuttu neuvottelupöytään varsin myöhäisessä vaiheessa. ${ }^{98}$ Nummisen puheessa kirkon ja opetusministeriön edustajat näyttäytyivät yhteisessä rintamassa. Asetelma antoi kirkolliskokoukselle liikkumatilaa.
Ehdotukset lisäverotulojen palauttamisesta eivät saaneet kirkolliskokousedustajilta varauksetonta tukea. Muiden muassa hallintoneuvos Olli Sakki näki suuria periaatteellisia ongelmia väitteessä, että kirkko saisi ylimääräisiä verotuloja. Kirkollisvero oli pääosaltaan jakovero, jota tuli koota vain sen verran kuin seurakuntien toimintaan tarvittiin. Ajatus lisäverotulosta soti tätä periaatetta vastaan. Oli muutenkin kiistanalaista, mikä oli uudistuksen kirkolle tuoma lisätulo, ja ainakin mahdollisen lisätulon suuruus vaihteli paljon eri seurakunnissa. Lähetekeskustelussa huomautettiin myös, että kirkon jäsenet joutuisivat uudistuksen myötä rahoittamaan kaikille yhteiskunnan jäsenille tarkoitettuja sosiaalietuuksia suuremmalla osuudella kuin kirkkoon kuulumattomat. Keskustelussa nousi vahvasti esille ajatus, että valtiolle ei palautettaisi mitään. Sen sijaan seurakuntia kehotettaisiin ohjaamaan mahdollinen lisätulo kirkon sosiaaliseen työhön Suomessa ja ulkomailla sekä veroäyrin hintapaineen hillitsemiseen. ${ }^{99}$ Myös talousvaliokunta asettui tälle kannalle, eikä kukaan kirkolliskokousedustajista lopulta tehnyt vastaehdotusta. ${ }^{100}$

Kirkon linja kiristyi sitä selvemmin, mitä enemmän luottamushenkilöt pääsivät vaikuttamaan asian käsittelyyn. Kirkon ja valtion virkamiesten keskinäisissä neuvotteluissa oli etsitty sopimusratkaisua valtiovarainministeriön vaatimusten pohjalta. Kirkkohallitus, jossa oli mukana luottamushenkilöitä, oli ehdottanut rajatumpaa korvausta kirkkolakiteitse. Tällöin kirkolla olisi ollut yksinoikeus määritellä palautuksen ehdot. Vaaleilla valittujen edustajien hallitsema kirkolliskokous kieltäytyi kuitenkin kaikista suorista maksuista.

Vuoden 1982 tapahtumien myötä kaikki olivat yhtä mieltä siitä, että kirkon tuli vastaisuudessa päästä mukaan neuvotteluihin jo asioiden valmisteluvaiheessa. Väistyvälle arkkipiispalle Mikko Juvalle sove-ongelmat olivat käytännön esimerkki niistä kirkon keskushallinnon ongelmista, joihin hän oli yrittänyt saada ratkaisua. Kirkolliskokouksen avauspuheessa Juva valitteli, että keskushallinnon hajanaisuus haittasi kovasti kirkon asian ajamista: "Tulokset eivät häikäise suuruudellaan varsinkaan jos vertaamme niitä toisen kansankirkon saamiin etuihin." ${ }^{101}$ Näillä sanoilla Juva korvasi puhekonseptinsa alkuperäisen muotoilun, jossa hän kuvaili luterilaisen kirkon osaa ortodoksien rinnalla "lehdellä soittelemiseksi". ${ }^{102}$ Myös kansliapäällikkö Jaakko 
Nummisen myöhemmän arvion mukaan ortodoksisen kirkon asioita hoidettiin esimerkiksi opetusministeriössä erityisen perusteellisesti. Näin oli ennen kaikkea siksi, että ortodoksiset piispat pitivät henkilökohtaisesti yhteyttä ministeriön virkamiehiin aivan toisin kuin luterilaisen kirkon edustajat. ${ }^{103}$

Juva piti suurena ongelmana, ettei luterilaisen kirkon neuvottelijoilla ollut valtuuksia edustaa muita kuin itseään. ${ }^{104}$ Tavallaan vuoden 1982 kirkolliskokous osoitti omalla toiminnallaan Juvan syytökset oikeiksi, kun se hylkäsi kirkkohallituksen edustajien neuvottelemat ratkaisut. Myös Juvan seuraaja John Vikström kyseli, oliko kirkko tyytynyt liiaksi ottamaan valtiolta vastaan vaatimuksia, arvostelua tai kiitosta sen sijaan, että se olisi keskustellut tasa-arvoisena ja täysi-ikäisenä osapuolena ${ }^{105}$.

Vuonna 1982 tapahtuneen kirkolliskokouksen rohkaistumisen myötä molemmat arkkipiispat tosin näkivät tilanteen muuttuneen. Juvan sanoin luterilainen kirkko oli ottamassa vanhan paikkansa suomalaisen yhteiskunnan neuvottelupöydässä. ${ }^{106}$ Myös lehdistössä kirkolliskokouksen toiminta herätti huomiota. Sille riitti ymmärtämystä ja kiitostakin. Toisaalta lehdet varoittelivat uhkarohkeudesta: kirkolliskokouksen itsenäinen korkean profiilin toiminta saattoi johtaa yhteiskunnallisiin kiistoihin sekä vähentää kirkon johtajien ja kirkkohallituksen uskottavuutta. ${ }^{107}$

Sove-päätös näkyikin erityisesti valtiovarainministeriön edustajien asennoitumisessa kirkkoon. ${ }^{108} \mathrm{Kir}$ kolliskokouksen päätöksen jälkeen ministeriö poisti talousarvioesityksestä määrärahat raamatunkäännöstyöhön, ja hankkeen tukeminen jäi kansanedustajien aloitteiden varaan. ${ }^{109}$ Vuonna 1984 ministeriön asettama yritysverotuksen kehittämislinjakomitea taas ehdotti, että kirkollisvero poistettaisiin yhteisöiltä. Ehdotuksessa ei otettu huomioon seurakunnille aiheutuvia seurauksia eikä kirkon yhteiskunnallisia velvollisuuksia. Kirkolliskokous vastusti voimakkaasti suunnitelmia. ${ }^{110}$ Aivan kuten arkipyhäpäätöksen jälkeen se sai kannalleen kaikkein vähiten ymmärtämystä vasemmistolehdistöltä. ${ }^{111}$

Kun uusimuotoisen kirkolliskokouksen alkuvaiheessa oli keskusteltu uskonnonopetuksen asemasta, opetusministeriö oli näyttäytynyt epävarmana kumppanina. Varsinkin Pär Stenbäckin ministerikaudesta eteenpäin, Ruotsalaiseen kansanpuolueeseen lukeutuvien minis- terien johdolla siitä tuli kuitenkin kirkolliskokoukselle merkittävä tukipilari. Kirkon ja opetusministeriön edustajien yhteistyö osoitti myös, että kirkon ja valtion läheiset suhteet saattoivat tietyissä tilanteissa lisätä kirkon itsenäisyyttä. Arkipyhien palautuksessa ja sove-päätöksessä tuo yhteistyö oli vähentämässä kirkon riippuvuutta työmarkkinajärjestöjen päätöksistä. Eduskunnan ja valtioneuvoston vahvistuminen Suomen poliittisessa järjestelmässä paransi kirkolliskokouksen toimintamahdollisuuksia. ${ }^{112}$

Vuonna 1982 kirkolliskokouksen asenne valtiovaltaan oli hyvin erilainen Pohjanlahden itä- kuin länsipuolella. Suomen luterilainen kirkolliskokous pohti järjestysmuotoaan teologisesti ja puolusti voimalla päätösvaltaansa kirkkoa koskevissa asioissa. Samaan aikaan Ruotsin kirkolliskokous hyväksyi demokratian lähtökohdista laaditun hallituksen esityksen, joka muodollisesti sitoi kirkolliskokousta vahvasti valtioon vaikkakin samalla antoi valtiovallalle mahdollisuuden delegoida päätöksentekoa kirkolliskokoukselle ${ }^{113}$. Dagens Nyheterin toimittaja kuvaili maansa kirkolliskokouksen toimintaa "itsensä kieltämisen maailmanennätykseksi" ${ }^{114}$ Svenska Dagbladetin mukaan kirkon luonne valtiokirkkona oli tuolloin korostuneempi kuin milloinkaan aiemmin. ${ }^{15}$

Keskeinen syy eroihin kahden kirkolliskokouksen toimintatapojen välillä oli siinä, että Ruotsissa kirkollinen päätöksentekojärjestelmä oli sulautunut maan poliittiseen järjestelmään. ${ }^{116}$ Suomen kirkolliskokousvaaleissa taas poliittisten puolueiden vaikutus vakiintui 1980-luvulle tultaessa vaalitekniseen ehdokasasetteluun, eikä se ulottunut enää kirkolliskokouksen päätöksentekoon edes ajoittain, kuten oli ollut 1970-luvun loppupuolella. Esimerkiksi Keskustapuolueen kirkkopoliittisen toimikunnan työryhmä kirjasi 1983, ettei puolueen tullut pyrkiä vaikuttamaan kirkolliskokouksen keskustalaisiin jäseniin mutta että näiden jäsenten oli suotavaa pitää keskenään tarvittaessa yhteyttä. ${ }^{117}$ Sitä paitsi monet valitsijayhdistykset perustettiin täysin muulta kuin puoluepoliittiselta pohjalta. Puoluepoliittisesti aktiivisetkin kirkolliskokousedustajat tunsivat itsensä kirkon edustajiksi ja tarvittaessa myös edunvalvojiksi suhteessa valtiovaltaan. Ruotsin tapahtumat nähtiin Turun kristillisellä opistolla varoittavana esimerkkinä, ja pelko niiden toistumisesta Suomessa vaikutti tiettyjen kirkolliskokouksen päätösten taustalla 1980-luvun kuluessa. 
Suomessa valtion ja kirkon lähentyminen 1980-luvun edetessä ei ollut lainsäädännöllistä, vaan se perustui epävirallisiin yhteyksiin. Uudet henkilösuhteet politiikan huipulle tulivat nopeasti myös käytännön testiin. Vuoden 1984 syysistuntokaudella ministeri Gustav Björkstrand kertoi valtioneuvoston kahvitilaisuudessa, että hän suunnitteli tuovansa hallituksen käsiteltäväksi kirkolliskokouksen esityksen arkipyhien palauttamisesta. Ilmoitus herätti paljon huomiota. ${ }^{118}$ Mielipidetiedustelut osoittivat tuossa vaiheessa, että selvä enemmistö kansasta oli arkipyhien palauttamisen takana. Sen sijaan työmarkkinajärjestöt vastustivat asiaa voimakkaasti. Björkstrand vei asiaa sinnikkäästi eteenpäin korostaen, että hallituksen oli toimitettava kirkolliskokoukselta saamansa kirkkolain muutosehdotukset eduskunnalle. Tulkinta oli sama kuin aiemmin perustevaliokunnalla, jonka mukaan kirkkolain muutosehdotukset eivät olleet ehdollisia. Erityisesti vasemmiston piirissä ilmenneestä vastustuksesta huolimatta esitys eteni eduskuntaan, ja se hyväksyttiin syksyllä 1985 lopulta selvin numeroin. ${ }^{119}$

Asian eduskuntakäsittely viritti arvostelua siitä, että vain kirkkoon kuuluvat kansanedustajat saivat osallistua kirkkolain käsittelyyn. ${ }^{120}$ Kansan Uutiset suhtautui päätökseen erityisen kielteisesti: "Suurempi kuin ratkaisu sinänsä on se ajan ilmiö, että maan hallitus on näin nöyrä kirkolliskokouksen suhteen ja asettaa sen tahdon työmarkkinajärjestöjen yhteisen tahdon yläpuolelle." ${ }^{121}$ Lehti välitti mielikuvaa, että työmarkkinajärjestöt edustivat kansan tahtoa aidommin kuin lähes 90 prosenttia väestöstä käsittäneen luterilaisen kirkon korkein päätöksentekoelin. Mielikuva vastasi 1970-luvun alun yleistä ilmapiiriä mutta ei enää 1980-luvun asenteita.

Tasavallan presidentti Koivisto oli hyvin kriittinen arkipyhien palautuspäätöstä kohtaan. Hän siirsi lakimuutoksen voimaantulon vasta vuoden 1992 alkuun, mikä puolestaan aiheutti periaatteellisen keskustelun presidentin valtaoikeuksista. ${ }^{122}$ Asetelma oli siinä mielessä yllättävä, että parlamentarismia korostanut valtionpäämies asettui käytännössä valtioneuvostoa ja eduskuntaa vastaan. Koivisto oli ollut 1970-luvun alussa vaikuttamassa arkipyhien siirtoon työntekijäpuolella, mikä osaltaan selitti hänen voimakasta reaktiotaan ${ }^{123}$. Talousajattelun lisäksi presidentin ratkaisussa näkyi hänen vapaakristillisyyden värittämä kotitaustansa ja kriit- tisyytensä luterilaisen kirkon yhteiskunnallista valtaa kohtaan. ${ }^{124}$ Tapauksen yhteydessä Koivisto ilmaisi muutenkin halunsa löyhdyttää kirkon ja valtion keskinäisiä suhteita. ${ }^{125}$ Presidentin mielipide antoi uutta pontta tuomiokapitulien asemaa ja rakennetta koskeville uudistuspyrkimyksille. Kirkolliskokous pääsi ottamaan asiaan kantaa 1986, kun sen tehtäväksi tuli antaa lausunto ministeri Björkstrandin asettaman tuomiokapitulitoimikunnan toisesta osamietinnöstä.

Toimikunta esitti erilaisia tulevaisuuden ratkaisumalleja ja päätyi itse suosittelemaan, että tuomiokapitulien jakoa hallinnolliseen ja toiminnalliseen osaan kehitettäisiin. ${ }^{126}$ Kirkolliskokouksen perustevaliokunta taas kannatti lähinnä mallia, jonka mukaan tuomiokapitulit oli määrä siirtää kirkon ylläpidettäviksi. Valiokunnan enemmistön mielestä piispojen nimittäminen tuli kuitenkin säilyttää presidentillä. Valiokunnan kanta tuomiokapitulien rahoitukseen ja piispojen nimittämiseen oli täysin päinvastainen kuin kirkolliskokouksen 1979 antama lausunto Kirkko ja valtio -komitean mietinnöstä. ${ }^{127}$ Kannat vaihtelivat, koska enemmistöt olivat pieniä.

Kirkolliskokous palasi niukan 11 äänen enemmistön turvin täysistunnossaan tuomiokapitulitoimikunnan linjoille. Valiokunnan enemmistön kanta, jonka mukaan piispojen nimittäminen säilyisi presidentillä, voitti puolestaan äänin 60-42. Kirkolliskokous ei kuitenkaan hylännyt täysin ajatusta tuomiokapitulien siirtämisestä kirkolle vaan katsoi, että sitä oli tutkittava pitkän aikavälin ratkaisumahdollisuutena. ${ }^{128}$ Varovaista linjaa selitti osaltaan se, ettei tuomiokapitulilaitosta voinut lähteä olennaisesti muuttamaan ennen kirkkolain kokonaisuudistusta ja valmisteilla ollutta kirkon keskushallinnon uudistusta. Myös kirkolle myönteinen ilmapiiri sai aikaan sen, ettei kirkon ja valtion suhteissa ollut tarvetta nopeisiin muutoksiin. ${ }^{29}$

Täysistuntokäsittelyä edeltänyt kahvitilaisuus osoittautui kirkolliskokouksen päätöksen kannalta todella merkittäväksi. Opetusministeriön tervehdyksen lausunut kansliapäällikkö Jaakko Numminen puolusti kirkon ja valtion keskinäisiä sidoksia - vastoin vastaavan ministerin käsityksiä. Numminen toivoi, ettei kirkko tarkastelisi esimerkiksi piispojen nimittämistä vain omalta kannaltaan vaan koettaisi katsoa asiaa myös valtion näkökulmasta. Nummisen mukaan kirkon oli hyvä pitää mielessä kysymys siitä, miten maallisen esivallan 
kristillisyys turvattaisiin, koska tällä seikalla oli suuri henkinen vaikutus koko yhteiskuntaan ja esimerkiksi kouluopetukseen. Kirkon tuli käyttää asemaansa aktiivisesti suomalaisen yhteiskunnan rakennukseksi. ${ }^{130}$ Nummisen sanat ja niitä seurannut keskustelu kahvitilaisuudessa saivat kirkolliskokoustyöskentelyssäkin osakseen paljon huomiota. Kirkolliskokousedustajat viittasivat toistuvasti Nummisen puheenvuoroon, ja se näyttää hillinneen pyrkimyksiä irrottaa tuomiokapitulilaitos valtiosta. ${ }^{131}$

Puheenvuoro kuvasti Nummisen myönteistä suhtautumista kirkkoon. Samalla se liittyi laajempaan 1980-luvun ilmiöön: kirkon ja valtion vahvoille keskinäisille siteille nousi näkyviä puolustajia. Tähän "uusvaltiokirkolliseen" ryhmään kuuluivat Nummisen ohella Paavo Kortekangas, Jaakko Voipio ja Gunnar Träskman. ${ }^{132}$ Silti tämäkään valtiokirkollisuus ei tähdännyt ruotsalaiseen malliin, jossa valtiovallalla oli merkittävä päätösvalta kirkon asioihin. Suomessa opetusministeriön kansliapäällikkö pyysi päinvastoin kirkolliskokoukselta, että se pyrkisi vaikuttamaan enemmän valtiolliseen päätöksentekoon. Suomalaista ja ruotsalaista keskustelua yhdisti se, että molemmissa maissa lähdettiin vuosikymmenen edetessä höllentämään kirkon ja valtion keskinäisiä siteitä vähittäisten osauudistusten avulla ${ }^{133}$.

Suomessa opetusministeriön tuomiokapitulitoimikunta sai työnsä valmiiksi 1987. Aloite hiippakuntahallinnon kehittämisestä siirtyi kirkolle, ja 1989 kirkolliskokous asetti tehtävää varten tuomiokapitulikomitean. ${ }^{134}$ Opetusministeriön toimikunta ehdotti viimeisessä mietinnössään, että osa tuomiokapitulien kustannuksista siirrettäisiin kirkolle. Kirkolliskokous hyväksyi uudistuksen, kunhan lakkautettujen seurakuntien keskusarkisto siirtyisi samalla valtion ylläpidettäväksi. ${ }^{135}$ Valtiovarainministeriö ryhtyi nopeasti jo pelkän toimikunnan mietinnön perusteella siirtämään tuomiokapitulien kustannuksia kirkolle. Rivakassa toiminnassa oli nähtävissä vielä tyytymättömyys, jonka kirkolliskokouksen sove-ratkaisu oli aiheuttanut. Vastaavasti kirkolliskokouksen vaatimus keskusarkiston siirtämisestä valtiolle ei edennyt lainkaan opetusministeriöstä valtiovarainministeriön budjettivalmisteluun. Molemmat kustannuserät olivat lankeamassa kirkon keskusrahaston vuoden 1989 talousarvioon, ja kirkolliskokous joutui asiassa vaikeuksiin. ${ }^{136}$ Arkkipiispa Vikström ilmaisi kirjeessään opetusministeri Christoffer Taxellille kirkon edustajien yleisen pettymyksen opetusministeriön virkamiesten toimiin asiassa. ${ }^{137}$ Kirkolliskokouksen täytyi perääntyä ja varata keskusrahaston talousarvioon molemmat määrärahat vuosiksi 1989 ja 1990. ${ }^{138}$ Kirkko joutui sittenkin hakemaan edelleen paikkaansa yhteiskunnan neuvottelupöydässä.

\section{RAUHANKYSYMYKSESTÄ JA SIVIILI- PALVELUKSESTA PALJON KESKUSTELUA, VÄHÄN PÄ̈̈TÖKSIÄ}

Vuonna 1982 julkaistiin päivitetty matrikkeli Suomen teologeista. Kirjasta saattoi lukea, että arkkipiispa Mikko Juva oli reservin kapteeni ja että kaikki muutkin piispat olivat reservin upseereja. Sama päti edelleen valtaosaan papistosta. Uudessa matrikkelissa oli kuitenkin useita Lauttasaaren ylimääräisen apulaisen Kari Mäkisen kaltaisia nuoria pappeja, joilla ei ollut sotilasarvon kohdassa mainintaa. ${ }^{139}$ Nämä miehet olivat läpäisseet vakaumusta koskeneet tutkimukset ja suorittaneet siviilipalveluksen. Epävakaa maailmantilanne ja suurvaltojen kilpavarustelu lisäsivät rauhanliikkeen kannatusta ja myös kirkossa rauhankysymykselle omistettua huomiota $^{140}$. Toisaalta siviilipalvelus oli vielä harvinainen ja jäi yleisessä arvostuksessa selvästi varusmiespalveluksesta jälkeen. Vasta myöhemmin tuli aika, jolloin siviilipalveluksen suorittaminen nousi teologimatrikkeleissakin maininnan arvoiseksi asiaksi - tai jolloin siviilipalvelusmies saattoi edetä suurempaa huomiota herättämättä arkkipiispaksi asti.

Kysymys sodasta nousi kirkolliskokouksen keskusteluun yllättäen marraskuussa 1980, kun keskusteltiin aborttilaista. Jo pari kuukautta aiemmin arkkipiispa Mikko Juva oli jakanut mielipiteitä pitämällä puheen Sadankomitean rauhanjuhlassa. Lisää julkisuutta oli luvassa, kun Juva vastasi - myöhemmän kertomansa mukaan kimpaantuneena - kirkolliskokouksessa puheenvuoroihin, joissa abortista oli puhuttu lastenmurhana. ${ }^{141}$ Juvan mukaan hän ja hänen ikäpolvensa, joka oli ase kädessä puolustanut maata ja tappanut ihmisiä, ei "totisesti uskalla lähteä syyttämään näitä naisia murhaamisesta ja itse vaatia, että samaa sanaa ei meistä saisi käyttää”. ${ }^{142}$

Juvalle vastasi kaksi vakinaisesta palveluksesta eronnutta everstiluutnanttia. Kirkkoneuvos Jukka Malmivaara kertoi käsittäneensä taistelun Suomen puo- 
lesta taisteluksi elämän puolesta, ja Erkki Reinikainen yhtyi "entisenä rintamamiehenä ja etulinjan jalkaväkikomppanian päällikkönä” näihin sanoihin. ${ }^{143}$ Juva täsmensi tarkoittaneensa sitä, että sodastakin oli selvä käsky "älä tapa!" mutta että käskystä ei voinut tehdä johtopäätöstä, joka kielsi isänmaan puolustamisen: ”Jos abortin tehnyt nainen tuntee itsensä syntiseksi naiseksi, niin jalkaväen joukkueenjohtaja [Juva] tuntee itsensä syntiseksi mieheksi, ja ihmettelen, ellei komppanianpäälliköllä ole samaa tuntua." Reinikainen vastasi, että mainittu komppanianpäällikkö tunsi itsensä syvästi syntiseksi mieheksi, "mutta se synnillisyys ei johdu siitä, että olen ollut taistelemassa isänmaan puolesta". ${ }^{144}$

Seurasi pitkä julkinen keskustelu. Sen aikana Juva sai kuulla ja lukea moneen kertaan, että arkkipiispa syytti rintamamiehiä murhaajiksi. ${ }^{155}$ Sota-ajan käsittely oli alkanut Suomessa vapautua 1970-luvun loppuvuosista lähtien, ja esimerkiksi Neuvostoliitosta oli ryhdytty vähitellen avoimesti puhumaan talvisodan aloittajana. ${ }^{146}$ Vapautuva keskusteluilmapiiri oli kuitenkin mustavalkoinen, mikä näkyi Juvan puheen vastaanotossa. Arkkipiispa kulki tosiasiassa keskitietä: kun piispainkokous laati 1982 suosituksia kirkon kansainvälisen vastuun toimintalinjoiksi, Juva ohjasi lopullisen asiakirjan sanamuotoja niin, ettei siviilipalvelusta enää nostettu yhtä selvästi samanarvoiseksi asevelvollisuuden kanssa kuin luonnoksessa ${ }^{147}$. Kirkon johdon oli vaikea tasapainoilla mieliä kuohuttaneessa ja usein voimakkaasti politisoituneessa rauhankysymyksessä.

Keväällä 1983 suurvaltapoliittiset jännitteet lisäsivät entisestään rauhankysymyksen ajankohtaisuutta. Yhdysvallat valmisteli keskikantaman ydinohjusten sijoittamista Länsi-Eurooppaan, ja maan presidentti Ronald Reagan lausui maaliskuussa ehdotuksen avaruuteen rakennettavasta ohjustentorjuntajärjestelmästä. Asevarustelua koskevien suunnitelmien myötä rauhanliike voimistui ennennäkemättömiin mittoihin eri puolilla Länsi-Eurooppaa. Monien mielestä myös Neuvostoliitto käyttäytyi uhkaavasti lisätessään asevoimaansa. ${ }^{148}$ Huhtikuun lopulla Uppsalassa järjestettiin kristillinen rauhankonferenssi, ja seuraavan kuun alussa Turussa kokoontunut kirkolliskokous sai käsiteltäväkseen kaksi rauhankysymystä koskettavaa asiaa.

Ensinnäkin piispainkokous antoi kirkolliskokoukselle selvityksen Kirkkojen maailmanneuvoston tilasta. ${ }^{149}$
Kirkolliskokous oli pyytänyt selvityksen 1981. Edustajien keskuudessa oli tuolloin herättänyt epäilyksiä erityisesti rasismin vastainen erityisrahasto, joka oli antanut avustuksia myös aseellista toimintaa harjoittaville järjestöille. ${ }^{150}$ Suhtautuminen tähän toimintaan jakoi länsimaisia kirkkoja poliittisesti ja teologisesti varsinkin 1980-luvun alkupuolella. ${ }^{51}$ Erimielisyydet näkyivät myös Suomessa kirkolliskokouksen keskustellessa piispainkokouksen selvityksestä. ${ }^{152}$

Kirkolliskokouksen käsittelyyn tuli keväällä 1983 niin ikään Porvoon hiippakuntakokouksen aloite, jossa ehdotettiin, että siviilipalveluksen voisi suorittaa seurakunnan työssä. ${ }^{153}$ Syntyi vilkas keskustelu, jossa kuultiin tunteisiin vetoavia puheenvuoroja omantunnonkysymysten kanssa kamppailevista nuorista. Toisaalta jotkut olivat vahvasti sitä mieltä, etteivät siviilipalveluksen sodan ajan tavoitteet sopineet yhteen seurakuntatyön kanssa. Vaikka aloitteen arvostelijoiden mukaan keskustelussa ei ollut suinkaan kyse kirkolliskokouksen rauhantahdosta, puheenvuorot kiertyivät juuri tämän teeman ympärille. Pääkysymykseksi nousi, miten kirkko suhtautui rauhantyöhön, ei se, oliko seurakunnilla mahdollisuuksia toteuttaa siviilipalvelukselle asetettuja tavoitteita. ${ }^{154}$

Yli 20 puheenvuoroa käsittänyt lähetekeskustelu sai paljon huomiota lehdistössä. Kuopion piispa Jukka Malmivaara ja Oulun piispa Olavi Rimpiläinen olivat yhdessä 16 muun edustajan kanssa valmiit hylkäämään aloitteen suoraan valiokuntaan lähettämättä, ja he saivat jälkeenpäin tukea porvarillisesta lehdistöstä. ${ }^{155}$ Yleisesti epäiltiin seurakuntien mahdollisuuksia tarjota siviilipalveluspaikkoja. ${ }^{156}$ Perustevaliokunnan johdolla kirkolliskokouskin asettui lopulta tälle kannalle: niin asekuin siviilipalveluksen järjestäminen oli valtion eikä kirkon tehtävä. Täysistuntokeskustelussa oli kuitenkin avoimuutta palata asiaan uudelleen, jos siviilipalveluksen muodot muuttuisivat tai jos valtiovalta tiedustelisi asiaa kirkolta. ${ }^{157}$

Nämä ehdot toteutuivat 1990, kun kirkolliskokouksen tehtäväksi tuli antaa lausunto siviilipalveluslaista ja -asetuksesta. Lakiehdotuksen mukaan siviilipalveluksen saattoi vastaisuudessa suorittaa myös luterilaisessa tai ortodoksisessa kirkossa tai niiden seurakunnissa. ${ }^{158}$ Perustevaliokunnan enemmistö toisti kirkolliskokouksen aiemman kannan mutta piti siviilipalveluksen 
suorittamista seurakunnassa periaatteessa mahdollisena. ${ }^{159}$ Täysistunnossa muun muassa regimenttien rajat herättivät keskustelua. Sananvaihto liukui kuitenkin jälleen kysymykseen, hyväksyikö kirkko siviilipalveluksen. Aihe oli latautunut ja mietinnön teksti sen vuoksi altis keskenään lähes päinvastaisille tulkinnoille. Kirkolliskokouksen lausunto hyväksyttiin lopulta pääkohdiltaan valiokunnan ehdottamassa muodossa. ${ }^{160}$

Moni kirkolliskokousedustaja totesi asenteensa siviilipalvelukseen muuttuneen aiempaa myönteisemmäksi. Toisaalta maailmassa, jossa rautaesirippu oli alkanut repeytyä, ei kirkolliskokouksella ollut tarvetta samanlaiseen syvään eettiseen pohdiskeluun kuin seitsemän vuotta aiemmin. Kirkolliskokouskäsittelyjen aikana oli havaittavissa, että hyvin pitkälti samat henkilöt vastustivat niin siviilipalveluksen suorittamista seurakunnassa kuin naispappeutta. Teologisesti taustalla voi nähdä tietynlaisen tarkkarajaisen regimenttiajattelun: sen enempää yhteiskunnallista tasa-arvokäsitettä kuin valtiollista siviilipalvelustakaan ei saanut tuoda osaksi seurakunnan hengellistä toimintaa. Ainakin joiltain osin taustalla erottui kuitenkin myös säilyttävä kristillisisänmaallinen ajattelutapa, joka näkyi yhtä lailla suhtautumisessa kirkon oppiin kuin maanpuolustukseen.

Ajan muuttuminen näkyi myös syksyllä 1987. Silloin kirkolliskokous myönsi Erkki Reinikaisen aloitteesta 140 ooo markan avustuksen Suomen sotien 1939-1945 sankarivainajia koskevan tiedoston ja muistojulkaisun rahoittamiseksi. Näin tapahtui siitä huolimatta, että kirkkohallituksen ja talousvaliokunnan mielestä määrärahan käyttötarkoitus oli kirkkolaissa säädetyn toimialan ulkopuolella. ${ }^{161}$ Neuvostoliiton uudistusmielisen politiikan myötä Suomessa oli alettu osoittaa aiempaa julkisemmin kunnioitusta sotaan osallistuneille, eikä kirkolliskokouskaan antanut kirkkolain estää kunnian tekemisestä sankarivainajille.

Kirkolliskokouksen oli otettava kantaa kirkkolain rajoituksiin myös käsitellessään kirkon kansainvälistä toimintaa. Kansainvälinen vastuu oli monin tavoin esillä Suomessa ja sen luterilaisessa kirkossa 1980-luvulla, ja kirkon ulkomaanavun avustustoiminta laajeni vuosikymmenen kuluessa voimakkaasti. Kirkkolain asettamat rajat puhuttivat erityisesti, kun oli kysymyksessä rahallisen avun antaminen Afrikan nälänhädästä kärsiville tai tuenilmaisu eteläisen Afrikan sorretuille. ${ }^{162}$
Etelä-Afrikan apartheid-järjestelmän aiheuttamat ristiriidat olivat kärjistyneessä vaiheessa toukokuussa 1988, kun kirkolliskokouksen jäsenet kokoontuivat Turkuun. Arkkihiippakunnan edustajana kirkolliskokoukseen juuri valittu opettaja Rauni Rautavuori jätti edustaja-aloitteen, jonka mukaan kirkkohallituksen tuli muun muassa toimia Etelä-Afrikkaa koskeneiden talouspakotteiden laajentamiseksi ja aseidenvientikiellon valvomiseksi. Aloitteen taustalla oli Norjassa järjestetty Pohjoismaiden ja eteläisen Afrikan kirkkojen konferenssi. ${ }^{163}$

Kirkolliskokous osoitti myötätuntoa hiljentymällä rukoushetkeen kansainvälisenä Namibia-päivänä. ${ }^{164}$ Sen sijaan yleisen valmistusvaliokunnan toinen osasto, jota johti Kokkolan suomalaisen seurakunnan kirkkoherra Heikki Vaahtoniemi, katsoi, että aloite meni kirkolliskokouksen toimivallan ulkopuolelle. Valiokunta totesi, että asia oli jo Suomen luterilaisessa kirkossa asianomaisten elinten käsittelyssä, ja toivoi, että Etelä-Afrikassa ja sen naapurivaltioissa vallitsisi rauha. ${ }^{165}$ Täysistunnossa nousi voimakasta vastustusta mietintöä kohtaan. Tapiolan kirkkoherra Tapio Saraneva pelkäsi mietinnön kuvastavan kirkon sosiaalieettistä toimintatapaa, jossa yleisellä tasolla kyllä todettiin asioiden tärkeys mutta samalla kartettiin vähäistäkin sitoutumista: "Ja suurimmat synnit, mitkä kirkko on historiassaan tehnyt, eivät ole suinkaan niitä, kun kirkko on erehdyksessä sanonut jostakin konkreettisesta asiasta jonkin väärän mielipiteen, vaan suurimmat synnit ovat niitä, jolloin kirkko on vaiennut." 166

Kirkolliskokous palautti asian valiokuntaan, joka seuraavaksi ehdotti, että kirkon ulkomaanasiain keskus seuraisi tarkoin tilanteen kehittymistä eteläisessä Afrikassa ${ }^{167}$ Syksyn täysistuntokeskustelussa kuultiin jo aiempaa pidättyvämpiä ääniä ja kyseltiin, missä määrin kirkolliskokouksen tehtävänä oli ottaa kantaa monimutkaisiin kansainvälisiin asioihin. Joka tapauksessa kirkolliskokous päätti edelleen terävöittää mietinnön ponsia: kirkon ulkomaanasiain neuvosto velvoitettiin julkistamaan solidaarisuuden ilmaus eteläisen Afrikan kirkoille ja tiedottamaan siitä eteenpäin. ${ }^{168}$

Pitkällisen ponnistelun ja kolmen mietinnön jälkeen kirkolliskokous sai sanotuksi asiasta jotakin. Tosin kriisin sovittelu oli tuossa vaiheessa jo lähellä ratkaisua. Kyselytutkimusten mukaan suomalaiset toivoivat 
kirkon ottavan kantaa ihmisoikeuskysymyksiin, kuten rotusyrjintään ja kolmannen maailman ongelmiin ${ }^{169}$. Kirkolliskokous joutui toimimaan ristipaineessa, jossa oli yritettävä ottaa huomioon yhtälälä hädänalaisten tarve ja kirkon jäsenten odotukset, toisaalta taas kirkkolain määrittämien tehtävien rajat. Täysistunto tulkitsi kirkolliskokouksen tehtäväalaa suurpiirteisemmin kuin valiokunta - aivan samoin kuin Reinikaisen aloitteen käsittelyssä. Täysistunnon edustajille lakipykäliä tärkeämpää oli se, millaisen sanoman kirkolliskokous toiminnallaan välitti kokoussalin ulkopuolelle.

Vaikka reagoiminen Afrikan ongelmiin aiheutti kirkollisessa päätöksenteossa ongelmia, kirkolliskokous pyrki muuten edistämään kansainvälistä diakoniaa päätösvaltansa puitteissa. Se päätti 1987 kirkon ulkomaanavun organisaatiouudistuksesta ja perusti samalla ulkomaanapuun uusia virkoja. Edelleen kirkolliskokous myönsi ulkomaanavulle oikeuden käyttää aiempaa suuremman osuuden, yhteensä kymmenen prosenttia, keräystuloistaan kotimaantyöhön. ${ }^{170}$ Vuoden 1988 talousarviokeskustelussa edustajilla oli puolestaan huoli Baltiasta. Kirkolliskokous hyväksyi yksimielisesti toivomusponnen, jossa se toivoi kirkon ulkomaanavun jaoston ottavan erityisesti keräysvaroista avustettavaksi Baltian maiden kirkot ja inkeriläiset. ${ }^{171}$

Neuvostoliiton avautuminen ja maan uskontopolitiikan vapautuminen antoivat kirkolliskokouksellekin mahdollisuuden puhua suoraan Itä-Euroopan ongelmista ja alueen asukkaiden auttamisesta - aivan samoin kuin tukea sankarivainajien muistojulkaisua. Liikkumatilan lisääntyminen johti siihen, että kirkolliskokous pohti kansainvälisen vastuun teemoja erityisen paljon juuri 1988 alkaneella vaalikaudella eli kansainvälisesti katsottuna verraten myöhään. Enemmistökirkon päättäjät eivät halunneet lähteä koettelemaan Suomen virallisen, varovaisen ulkopolitiikan rajoja, vaan he elivät mukana kansainvälisen tilanteen ja liikkumatilan muutoksessa.

Kaikkiaan rauhankysymyksen, siviilipalveluksen tai kansainvälisten kriisien käsittely oli kirkolliskokoukselle vaikeaa. Suurimmat erimielisyydet eivät läheskään aina koskeneet varsinaista asiasisältöä vaan toimintatapaa. Esimerkiksi edustajien teologiset käsitykset kirkon tehtävästä tai ekumeenisten järjestöjen toiminnan oikeutuksesta saattoivat olla hyvin erilaisia ja johtaa kes- kenään päinvastaisiin toimenpide-ehdotuksiin. Tilaa tällaisten periaatteellisten erimielisyyksien käsittelyyn ei kuitenkaan usein ollut: edustajien huomio kohdistui siihen, millaisen viestin kirkolliskokous lähettäisi ulospäin. Tällöin keskusteluasetelmat yksinkertaistuivat ja kärjistyivät.

\section{TALOUDEN KASVUKAUDEN KIIREET JA HILJENTYMISEN TARVE}

Kirkolliskokouksen talousvaliokunta oli toistuvasti toivonut, että kokonaiskirkossa päästäisiin pitkäjänteiseen talouden ja toiminnan suunnitteluun. Toive toteutui 1980-luvulle siirryttäessä, kun kirkkohallitus alkoi säännöllisesti tuoda kirkolliskokouksen hyväksyttäväksi nelivuotisen toiminta- ja taloussuunnitelman. ${ }^{172}$ Suunnitelma ei ollut sitova, mikä sitten tulikin hyvin esiin ensimmäisinä suunnitelmavuosina: kirkkohallituksen esittämät uudet virat ylittivät huomattavasti kaavaillun määrän, eivätkä talousvaliokunnan leikkaukset auttaneet saamaan kustannuksia toiminta- ja taloussuunnitelman asettamiin rajoihin. Vaalikaudella 1982-1985 perustettiin ennätykselliset 39 uutta virkaa. Talousvaliokunnan puheenjohtajana vuoteen 1987 asti toiminut Väinö Takala valitteli sittemmin, että tuo määrä oli selvästi liikaa. ${ }^{173}$ Myös kansliapäällikkö Pertti Mäkeläinen arvioi myöhemmin kriittisesti, että tuon ajan toimintaja taloussuunnitelmat olivat nimenomaan taloussuunnitelmia, joissa keskityttiin uusiin virkoihin mutta ei toiminnan painopisteiden tarkasteluun. ${ }^{174}$

Paine uusien virkojen perustamiseen syntyi paljolti hiippakuntien toiminnallisen puolen vahvistamisesta ja kirkon ulkomaanavun organisaatiouudistuksesta. Myös esimerkiksi tiedotuksen uudet tehtävät vaativat virkojen perustamista. ${ }^{175}$ Kirkkohallitus alkoi 1980-luvun puolivälissä päästä asetettuihin raameihin. Samalla kuitenkin kirkolliskokousedustajat ryhtyivät nousukauden huipulla tekemään aloitteita uusista viroista - näin varsinkin vaalikauden alkaessa $1986 .{ }^{176}$ Seuraava uusia virkoja koskeva aloitetulva koettiin 1989, vaikka samaan aikaan kirkolliskokouksessakin talouden asiantuntijat kertoivat synkentyvistä näkymistä. Talousvaliokunnan puheenjohtajana vuodesta 1988 toiminut Lahden seurakuntayhtymän hallintojohtaja Markku Porvari ihmetteli, että virka-aloitteet lisääntyivät samaan aikaan, kun kirkolliskokousedustajat olivat muuten huolissaan kirkon 
"monitouhuisuudesta"177. Talousvaliokunnan sanoma oli, että uusiin tarpeisiin tuli vastata viranhaltijoiden työnkuvia muuttamalla, ei enää uusia virkoja perustamalla. Virkojen perustamistahti pysyikin vuosikymmenen loppupuolella suunnilleen toiminta- ja taloussuunnitelman asettamissa rajoissa.

Keväisin kirkolliskokous perusti virkoja, syksyisin talousvaliokunta ja sen puheenjohtaja valittelivat, miten kirkon keskusrahaston talousarvio paisui jyrkästi vuosi vuodelta. Erityisesti kirkolliskokouksessa moitittiin kirkkohallituksen esittämiä lisätalousarvioita, joissa nousukauden aikana kertynyttä odottamatonta ylijäämää ohjattiin edustajien mielestä muuallekin kuin vain välttämättömiin ja ennakoimattomiin menoihin. ${ }^{178}$ Talousvaliokunnan edustajat huomauttivat toistuvasti, että muualla julkisella sektorilla vastaavat talousarvion kasvuprosentit eivät olisi olleet mahdollisia. ${ }^{179}$ Valiokunta supisti yleensä menoja kirkkohallituksen talousarvioesityksestä, kun taas täysistunnossa niitä tuli jonkin verran takaisin. Edustajat uskoivat edelleen kirkon tulojen pysyvän vakaina. Nopean kasvun vuosina 1984 ja 1985 valiokunta lisäsi itsekin menoja.

Kirkkohallitus halusi turvata kirkon keskusrahaston tulot ja taloussuunnittelun pitkäjänteisyyden pitämällä seurakuntien keskusrahastomaksut mahdollisimman vakaina. Talousvaliokunta taas pelkäsi, että seurakunnilta perittäisiin liikaa keskusrahastomaksuja, jolloin kokonaiskirkolla menisi hyvin mutta seurakunnilla huo-
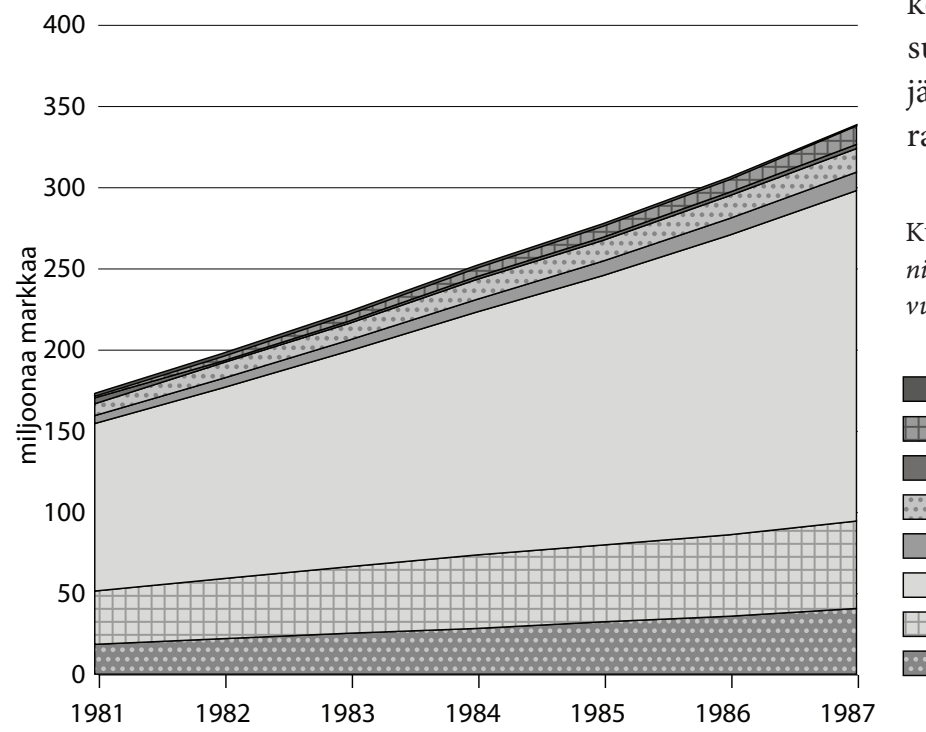

LUOTTAVAINEN KIRKOLLISKOKOUS EP ÄVAKAASSA MA A L M A S A 12 nosti. ${ }^{180}$ Perusmaksua alennettiinkin kahteen kertaan ja eläkemaksua kertaalleen 1980-luvun kasvuvuosina. Talousvaliokunta ei halunnut kasvattaa rahastoja pahan päivän varalle, ja esimerkiksi kirkon kasvatusasiain keskuksen pääsihteeri Veikko Pöyhönen totesi jo 1984, että kirkko eli kädestä suuhun ${ }^{181}$. Tavallaan kirkolliskokouksen linja oli johdonmukainen: sove-kysymyksessä kirkolliskokous korosti, että kirkollisvero oli jakovero, jota oli koottava vain kunkin vuoden tarpeisiin. Tätä periaatetta kirkolliskokous noudatti myös kootessaan seurakunnilta keskusrahastomaksuja. Samoilla perusteilla, joilla kokous torjui sove-rasituksen, se torjui itseltään mahdollisuuden ryhtyä kokoamaan rahastoja.

Vuonna 1985 kirkkohallitus esitti kirkolliskokoukselle, että seurakuntien eläkemaksu sidottaisiin veroäyrin sijasta kunkin seurakunnan suorittamiin palkkamaksuihin. Samalla siirryttäisiin osittain rahastoivaan eläkejärjestelmään. Kirkolliskokouksesta löytyi ymmärrystä uudistukselle, mutta talousvaliokunnan johdolla se katsottiin keskeneräiseksi. Valiokunta arvosteli erityisesti sitä, että esitys nostaisi vähävaraisten seurakuntien eläkemaksuja. Ei auttanut, että kirkkohallitus esitti vastapainoksi luopumista keskusrahastomaksuista, jotka koottiin vähävaraisille seurakunnille tärkeiden metsätulojen perusteella. Päinvastoin kirkolliskokous päätti toteuttaa nimenomaan tämän, seurakuntien kannalta mieluisan osan uudistuksesta. ${ }^{182}$ Myöhemmin vuonna 2009 kirkkoneuvos Leena Rantanen totesi kirkolliskokoukselle, että vuoden 1985 päätöksen hinta oli "aika suuri". Mahdollisuus eläkerahastoinnin aloittamiseen jätettiin käyttämättä. ${ }^{183}$ Kirkolliskokous hyväksyi eläkerahaston suunnitelmallisen kartuttamisen vasta vuosi-

Kuvio 7: Menoluokkien kehitys ja loppusumman muutos nimellisarvoltaan kirkon keskusrahaston talousarvioissa vuosille 1981-1987

Lainamenot

Siirrot rahastoihin

Vuokra- ja ki inteistömenot

Kirkon muut yhteiset tarpeet

Hiippakunnallinen toiminta

Eläkkeet

Avustukset seurakunnille

Hallintomenot 
kymmenen vaihtuessa. Tuolloin talousnäkymät olivat jo synkentyneet, ja 1989 voimaan tullut joustava eläkejärjestelmä varhais- ja osa-aikaeläkkeineen lisäsi muutenkin nopeasti kustannuksia. ${ }^{184}$

Talousvaliokunta suhtautui suopeasti hiippakunnallisen toiminnan menolisäyksiin. Sen sijaan valiokunta oli hyvin huolissaan kokonaiskirkon kasvavista hallintomenoista, joista suuri osa aiheutui kirkon keskuksista, entisistä toimikunnista. ${ }^{185}$ Seurakuntien avustamiseen varattujen rahojen osuus kasvoi jatkuvasti hitaammin kuin kirkon keskusrahaston muut menot. Talousvaliokunta ja erityisesti köyhien seurakuntien edustajat kantoivat huolta tästä keskusrahaston alkuperäisestä tehtävästä. Vastapainoksi muutamat kaupunkiseurakuntien edustajat, kuten henkilöstöpäällikkö Martti Paajanen Helsingistä, projektipäällikkö Seija Puha Vantaalta ja kansanedustaja Ulla Puolanne Lahdesta, pyrkivät määrätietoisesti lisäämään lainojen osuutta seurakuntien tukemisessa. Taustalla oli julkilausumaton, 1970-luvullakin havaittavissa ollut epäilys, että keskusrahaston antama tuki kannusti pieniä seurakuntia vastuuttomaan rahankäyttöön. Pitkään poissa näkyvistä pysynyt epäluulo maaseudun ja kaupunkien välillä palasi jälleen hetkeksi istuntosaliin. ${ }^{186}$ Toki sama vastakkainasettelu ilmeni myös eduskunnassa, ja 1987 se nousi sinipunahallituksen myötä hallitsemaan parlamentaarisia asetelmia: hallituksen ja opposition välisessä vastakkainasettelussa oli paljolti kyse maaseudun ja kaupunkien eturistiriidoista. ${ }^{187}$

Tietyt ajankohtaiset teemat, kuten evankelioimistyö, toistuivat 1980-luvun virka- ja talousarvioaloitteissa. ${ }^{188}$ Niin ikään matkailun vilkastuessa voimakkaan talouskasvun vuosina kasvoi paitsi tarve myös mahdollisuus turistien kirkolliseen palvelemiseen. ${ }^{189}$ Vuonna 1984 kirkolliskokous myönsi edustaja-aloitteen pohjalta 150 ooo markan avustuksen Kansan Raamattuseuran Revontulikappelin rakentamiseen Pelkosenniemelle. Kyseessä oli kirkolliskokouksen ensimmäinen varsinainen panostus Lapin turistien hengelliseen huoltoon. ${ }^{190}$ Seuraavina vuosina syntyi lisää päätöksiä niin Lapin turistien kuin Espanjan suomalaisten kirkollisten palvelujen järjestämiseksi. ${ }^{191}$

Edelleen 1987 kirkolliskokouksen asialistalle tuli Hiljaisuuden Ystävät -yhdistyksen retriittitoiminta ja myöhemmin mahdollisen hiljaisuuden keskuksen pe- rustaminen. ${ }^{192}$ Sekularisoituneissa länsimaissa oli spiritualiteetin syventämisen nälkää, joka ilmeni esimerkiksi Taizén ekumeenisen luostariyhteisön suosiona ja jota protestanttisten kirkkojen ekumeeniset yhteydet katolilaisiin ja ortodokseihin voimistivat. ${ }^{193}$ Niin ikään piispainkokouksen Kirkko 2000- ja Seurakunta 2000 -työskentelyssä painotettiin 1980-luvun loppupuolella hengellisen elämän vahvistamista ja ehdotettiin yhden tai useamman hiljaisuuden keskuksen perustamista. ${ }^{194}$

Kirkolliskokouksessa erityisesti lehtori Liisa Tuovinen ja apulaisprofessori Raija Sollamo ajoivat asiaa. Jotkut edustajat pitivät erillistä keskusta täysin tarpeettomana. Toiset taas valittivat hiljaisuuden viljelyn heikkoa tilaa luterilaisessa kirkossa ja katsoivat ihaillen ortodoksisen kirkon vastaavaa toimintaa. ${ }^{195}$ Eräässä vaiheessa Kuopion tuomiorovasti Matti Järveläinen varoittikin leimaamasta luterilaista seurakuntaelämää mustavalkoiseksi, jollaiseksi se tiedotusvälineissä oli kuvattu vastapainona ortodoksisen kirkon nelivärikuvalle. ${ }^{196}$ Liisa Tuovinen puolestaan totesi, että kirkon jäsenissä oli paljon sellaisia vastuullisissa ammateissa toimivia, jotka olivat kirkon toiminnasta kaukana mutta tunsivat tarvitsevansa hiljentymisen ja rukouksen tuomaa voimaa. ${ }^{197}$

Käsittelyn kuluessa julkistettiin tutkimustuloksia, joiden mukaan kirkosta eroamista harkitsivat entistä useammin akateemisesti koulutetut ja johtavassa asemassa olevat henkilöt. Aiemmin enemmistö kirkosta eronneista oli ollut työväestöä ja vasemmistopuolueiden kannattajia. ${ }^{198}$ Hiljaisuuden Ystävät oli huomannut "juppisukupolven" vieraantumisen kirkosta mutta toisaalta myös näiden ihmisten hiljentymisen kaipuun, johon järjestö halusi tarjota kristillisen vastauksen. Kirkolliskokouksen täysistunnolta liikeni lopulta lisää tukea Hiljaisuuden Ystäville ${ }^{199}$.

Syksyllä 1989 kirkkoneuvos Reijo Lehtinen varoitti talouden epävarmoista näkymistä, mutta silti kirkolliskokouksen täysistunto hyväksyi 220000 markan menolisäykset talousarvioon. ${ }^{200}$ Kokonaisuuden kannalta lisäys oli pieni mutta selvästi suurempi kuin täysistunnoissa yleensä. Takana oli hyviä vuosia, joita oli helpompi seurata kuin tulevaisuuden ennusteita. Samana syksynä kirkolliskokous tarkisti toiminta- ja taloussuunnitelman vuosiksi 1990-1993. Suunnitelman mukaan vuodessa tuli perustaa vain kahdesta neljään uutta keskusrahaston varoista rahoitettavaa virkaa. Heti seuraavana keväänä 

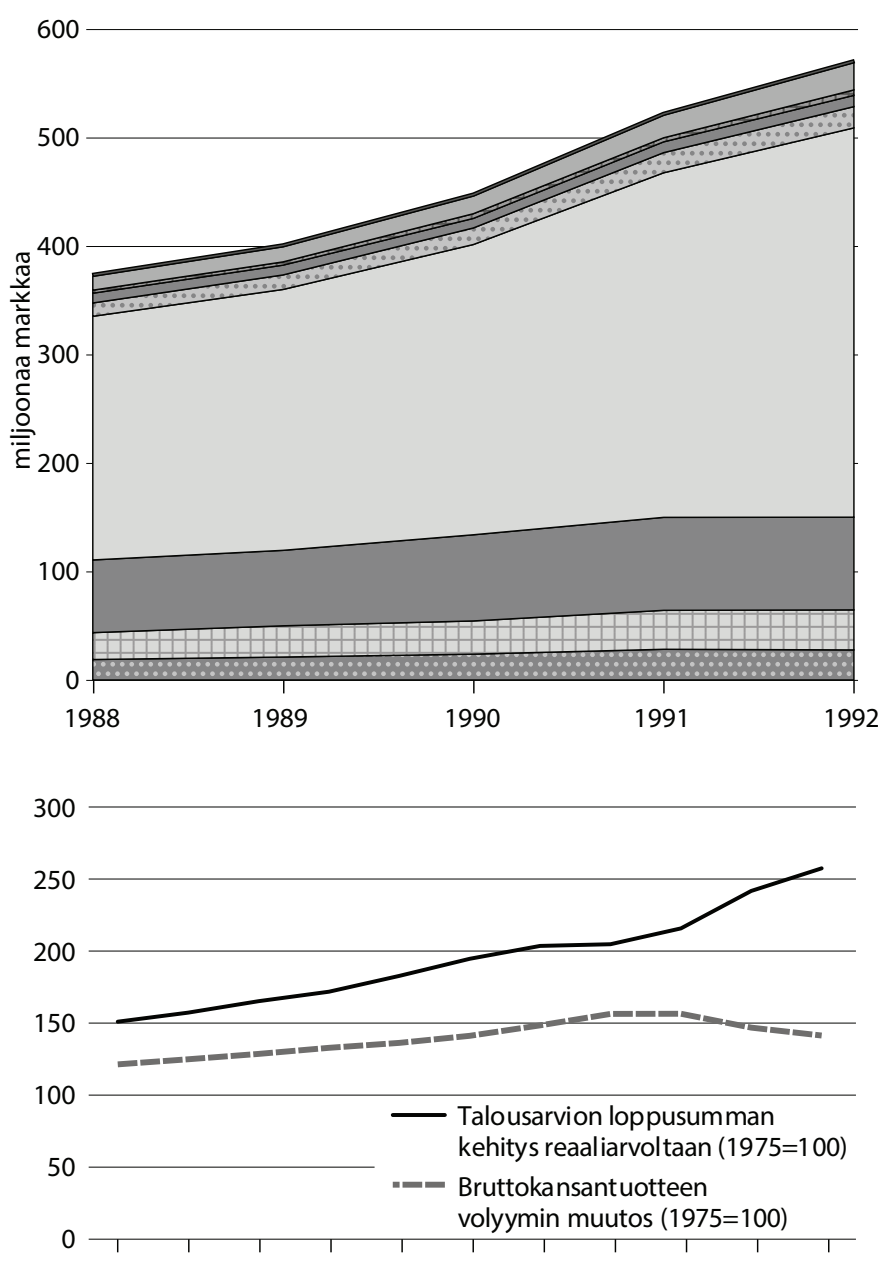

19821983198419851986198719881989199019911992

kirkkohallitus esitti kuitenkin kirkolliskokoukselle virkapaketin, jonka kustannukset olivat yli kaksinkertaiset suunniteltuun nähden. Talousvaliokunnan onnistui poistaa suunnitelmasta yksi virka. Siitä huolimatta lopputulokseksi jäi, että jälleen toiminta- ja taloussuunnitelmasta lipsuttiin heti uuden suunnittelukauden aluksi. Poikkeamisen vakavuus korostui, kun Markku Porvari varoitteli jo edessä olevista saneerauksista. ${ }^{201}$

Syksyn 1990 edetessä näkymät muuttuivat dramaattisesti. Kirkkoneuvos Reijo Lehtisen pohtiessa tulevaisuutta sana "lama" pääsi kirkolliskokouksen pöytäkirjoihin. Nousukausi oli alkanut sove-uudistuksen merkeissä, ja se päättyi päinvastaisiin muutoksiin, joilla valtio kavensi kirkon verotuspohjaa ja lisäsi veronkantokuluja. ${ }^{202}$ Talousvaliokunnan puheenjohtajan ennustus tulevai-
Kuvio 8: Menoluokkien kehitys ja loppusumman muutos nimellisarvoltaan kirkon keskusrahaston talousarvioissa vuosille 1988-1992

Pääomatalous

Rahoitustoimi

Kiinteistötoimi

Kirkon yhteiset tarpeet

Hiippakunnallinen toiminta

Eläkkeet

Avustukset

Kirkon keskukset

Kirkon keskushallinto

Kuvio 9: Loppusumman reaaliarvon mukainen kehitys kirkon keskusrahaston talousarvioissa vuosille 1982-1992

suudesta oli selvä: "Jos ensi vuodesta pitäisi sanoa jotakin hyvää, niin voisin sanoa, että se tulee olemaan parempi kuin sitä seuraava vuosi (hilpeyttä)." ${ }^{203}$ Syksyllä 1991 syöksy oli jo niin nopeaa, että talousvaliokunta joutui karsimaan seitsemän miljoonaa markkaa kirkkohallituksen esittämistä menoista. Vaalikauden viime hetkillä edustajat päättivät poistaa kirkon keskushallinnosta - mukaan lukien seuraavalta kirkolliskokoukselta - kokouspalkkiot. Käytännössä vain eläkemenot saivat kasvaa edes nimellisarvoltaan. ${ }^{204}$

Vaikka paineet menojen lisäämiseksi olivat kirkolliskokouksessakin kovia talouden hyvinä vuosina, kirkon päättäjät saivat pysäytetyksi kirkon keskusrahaston budjetin reaaliarvoisen kasvun hetkeksi keskellä kovinta nousukautta 1980-luvun loppupuolella. Myönteisessä mielessä tulos oli osoitus varovaisesta ja realistisesta taloudenpidosta. Kääntöpuolena oli, että kirkon keskusrahaston taloutta ei käytetty tasoittamaan suhdanteita. Vastoin kirkkohallituksen tahtoa kirkolliskokous ei halunnut ryhtyä kokoamaan seurakuntien kasvaneita verotuloja keskusrahastoon pahan päivän varalle. Verotulot jäivät seurakunnille, jotka pystyivät laajentamaan toimintaansa - muun muassa perustamaan virkoja ja rakentamaan kiinteistöjä. 
Eläkelainsäädännön uudistus ja lopulta kirkolliskokouksenkin tunnustama rahastoimisen tarve nostivat keskusrahaston menoja poikkeuksellisen voimakkaasti juuri niinä 1990-luvun alun vuosina, joiden aikana bruttokansantuote sukelsi. Kuvio 8 osoittaa, että muiden pääluokkien kuin eläkkeiden nimellisarvojenkin mukaan laskettu kasvu käytännössä lakkasi vuoden 1992 talousarviossa, mikä merkitsi näiden pääluokkien supistumista reaaliarvoltaan. Vuonna 1991 alkanut eläkerahastointi piti kuitenkin huolen siitä, että budjetin kokonaisuuden kasvu jatkui nopeana. Koska kasvavat menot olivat pitkälti lakisääteisiä, kirkolliskokouksella ei ollut suuria mahdollisuuksia puuttua tilanteeseen. Aiempina vuosina oli eletty kädestä suuhun ja vältetty ylimääräisen rahan keräämistä seurakunnilta. Rahaa alettiin kerätä lopulta samaan aikaan, kun talouden näkymät synkkenivät voimakkaasti.

\section{KIRKKOLAIN JA HALLINNON}

\section{SUURET UUDISTUKSET}

\section{PITKÄ KESKUSTELU VAALITUNNUKSISTA JOHTAA PÄ̈̈TÖKSEEN}

Seurakuntavaaleissa oli siirrytty suhteelliseen vaalitapaan 1970. Vaalien politisoitumisen välttämiseksi ehdokaslistat merkittiin kuitenkin pelkillä roomalaisilla numeroilla. Vaalitavan muutos nostatti välittömästi myös vaatimuksen avoimista tunnuksista. Kirkolliskokouksen käsitellessä asiaa 1975 rintamalinjat kulkivat paljolti maaseudun ja kaupunkien välillä. Maalaisseurakunnissa, joissa ehdokkaat tunnettiin, tunnusten pelättiin tuovan puoluepoliittiset asetelmat entistä voimakkaammin mukaan vaaleihin. Kaupungeissa taas ehdokaslistojen merkitseminen pelkillä roomalaisilla numeroilla johti arvailuun. Asiaa valmisteltiin, mutta yleinen asenne kirkon päätöksentekoelimissä oli 1970-luvun lopussa tunnusten vastainen. ${ }^{205}$

Asetelma muuttui seuraavalla vuosikymmenellä. Vuonna 1984 kirkkohallitus esitti Tampereen ja Mikkelin hiippakuntakokousaloitteiden pohjalta tunnusten hyväksymistä. ${ }^{206}$ Lakivaliokunnan mielestä kirkkohallituksen esitys suosi kuitenkin jo valmiiksi kiinteitä ryhmittymiä. Valiokunta ehdottikin tunnusten sijaan pidempiä selosteita kunkin valitsijayhdistyksen taustoista ja pyrkimyksistä. Seloste ei saanut olla sopimaton tai harhaan- johtava. ${ }^{207}$ Valiokunta oli siten valmis antamaan vaalilautakunnalle suuren vastuun päätettäessä, millaiset esittelytekstit olivat lainmukaisia. Taustalla oli myös realistinen arvio siitä, että kirkkohallituksen esittämillä lyhyillä tunnuksilla ei olisi kirkolliskokouksessa läpimenomahdollisuuksia. Moni edustaja pelkäsi kuitenkin lakiesityksen tulkinnanvaraisuuden johtavan siihen, että aiemmin rauhanomaisesti sujunut ehdokasasettelu siirtyisi oikeussaleihin. Samaten huomautettiin, että selosteeksi saattoi liittää vaikkapa lyhyen puoluetunnuksen, jolloin käytännön eroa kirkkohallituksen esitykseen ei olisi. ${ }^{208}$ Ratkaisevassa äänestyksessä enemmistö kirkolliskokousedustajista oli lakivaliokunnan kannalla, mutta määräenemmistöstä jäi puuttumaan yhdeksän ääntä. ${ }^{209}$

Vuosina 1986 ja 1987 kirkon tutkimuskeskuksen selvitykset osoittivat, että seurakuntavaalien ehdokasasettelussa poliittisilla puolueilla oli keskeinen osa. Kun puolueet olivat siten jo valmiiksi mukana seurakuntavaaleissa, vaatimukset avoimien tunnusten sallimisesta voimistuivat julkisuudessa. ${ }^{210}$ Asia tulikin kirkolliskokouksen käsittelyyn jälleen keväällä 1987 Kuopion ja Helsingin hiippakuntakokousaloitteiden myötä. Jatkovalmistelusta keskusteltaessa eniten kannatusta sai ponsi, jonka mukaan kirkkohallitus valmistelisi esityksen sekä tunnuksista että niihin mahdollisesti liittyvistä selosteista. Ponsi hyväksyttiin äänin $89-15 .{ }^{211}$ Enemmistö oli murskaava, mutta todellisuudessa ponnen puolesta äänesti kaksi keskenään erimielistä ryhmää, tunnusten ja selosteiden kannattajat.

Äänestystulos oli omiaan luomaan kuvaa todellista suuremmasta konsensuksesta. Joistakin lehdistä saattoi lukea, että tunnukset olivat tulossa jo seuraaviin seurakuntavaaleihin. Toiset lehdet suhtautuivat asiaan maltillisemmin ja kertoivat esimerkiksi arkkipiispa Vikströmin kielteisestä kannasta. ${ }^{212}$ Joka tapauksessa pettymys oli joissakin lehdissä melkoinen, kun ehdokaslistojen nimitysten - kuten uusi termi kuului - hyväksyminen jäi seuraavana syksynä edelleen kahdeksan äänen päähän. ${ }^{213}$

Täysistuntokeskusteluissa erilaiset regimenttiopin tulkinnat iskivät toisiaan vastaan. Monet uudistuksen vastustajat pelkäsivät, että puolueiden myötä maallinen regimentti tulisi kirkon hallintoon. Apulaisprofessori Fredric Cleve vastasi, ettei maallinen regimentti ollut 
sama kuin valtio eikä hengellinen regimentti sama kuin kirkkoyhteisö. Teologisesti ei hänen mukaansa ollut esteitä tunnusten käyttämiselle. ${ }^{214}$ Vastakkain olivat 1930-luvun luterilaisen teologian käsitykset ja Cleven edustama, vuosisadan loppupuolella noussut regimenttiopin tulkinta. ${ }^{215}$ Ajatus regimenttien limittymisestä näkyi myös niillä edustajilla, joiden mielestä oli tärkeää, että kirkollisesti aktiivisia henkilöitä toimi puolueissa. Näiden välityksellä kristilliset näkökohdat pääsivät esiin puolueiden sisällä. ${ }^{216}$ Voimakkaimmin keskustelussa näkyi kuitenkin edelleen jakolinja maaseudun ja kaupunkien, pienten ja suurten seurakuntien välillä. Ratkaisu oli maaseudun käsissä, koska suurten seurakuntien edustajat eivät yksin yltäneet määräenemmistöön.

Kaikkein keskeisimmin uudistuksen kaatumiseen niin 1984 kuin 1987 vaikutti arkkipiispa John Vikström. Vikström, joka puhui kirkolliskokouksessa muuten melko säästeliäästi, puolusti ahkerasti olemassa olevaa vaalijärjestelmää. Poikkeuksellista oli myös, että hän kääntyi avoimien tunnusten vastustajaksi vasta 1980-luvun alkuvuosina, jolloin muut kirkolliskokousedustajat alkoivat pikemminkin siirtyä tunnusten kannalle. Syynä Vikströmin mielipiteen muuttumiseen oli hänen kertomansa mukaan Ruotsin tilanne: maan kirkollisesta päätöksentekojärjestelmästä oli tullut poliittisten puolueiden areena, minkä johdosta valtio näytti saavan kirkon hallintaansa. Vikström pelkäsi, että tunnusten sallimisen myötä Suomessakin kirkon asioista päättäminen voisi siirtyä puolueiden keskinäisiin neuvotteluihin. Kirkosta tulisi aivan uudella ja vaarallisella tavalla valtiokirkko. Sitä paitsi tunnukset sallimalla kirkolliskokous saattaisi ikään kuin pakottaa puolueet kilpailemaan seurakuntavaaleissa. ${ }^{217}$ Ruotsin tilannetta kuvasti, ettei siellä 1988 enää herättänyt erityistä kummastusta, kun kirkolliskokoukselle jätettiin aloite erikseen mainiten "sosiaalidemokraattisen ryhmän puolesta". ${ }^{218}$

Arkkipiispa Vikström toivoi kirkon vaalien säilyvän vastaisuudessakin ennen kaikkea henkilövaaleina. Jaakko Voipio huomautti, että tällainen ajatus oli käsitteellisesti ristiriidassa suhteellisen vaalitavan kanssa - suhteellisissa vaaleissa kun oli aina ensin otettava huomioon ryhmä ja vasta toissijaisesti henkilö. ${ }^{219}$ Juuri tässä oli ristiriita, joka näkyi kirkolliskokouksen keskusteluissa hyvin selvästi. Avoimien tunnusten kannattajat pyrkivät toteuttamaan suhteellisen vaalitavan johdonmu- kaisesti, kun taas vastustajat pyrkivät säilyttämään sen omaleimaisuuden, joka erotti kirkolliset vaalit muun yhteiskunnan suhteellisista vaaleista.

Äidinkieleltään ruotsinkieliset edustajat näyttivät suhtautuvan tunnuksiin keskimääräistä varauksellisemmin. ${ }^{220}$ Porvoon hiippakunnassa oltiin muuta maata paremmin selvillä Ruotsin kirkon tilanteesta. Toisaalta pelättiin todennäköisesti myös hiippakunnan kirkollisten vaalien konsensushengen rikkoutumista. Syysistuntokaudella 1987 opetusministeri Christoffer Taxell asettui valtioneuvoston kahvitilaisuudessa näkyvästi arkkipiispa Vikströmin taakse, tunnuksia vas$\operatorname{taan}^{221}$. Avoimien tunnusten vastustajat saivat Taxellista uuden auktoriteetin, johon vedota, mutta opetusministerin puheen vastaanotto ei ollut varauksettoman myönteinen. ${ }^{222}$ Kotimaan päätoimittajan Tapani Ruokasen mielestä Taxellin ajatukset olivat pitkälti "ruotsalaisen kansanpuolueen sivistynyttä ja näkymätöntä politikointia”. Ruokasen mukaan vallinnut tilanne oli edullisin RKP:lle, kokoomukselle ja keskustalle eli ryhmille, joilla oli oma edustuksensa kirkossa ilman puoluetunnuksia. ${ }^{223}$ Tähän luetteloon saattoi jatkoksi lisätä alueellisesti vahvat ja kiinteät herätysliikkeet. Tällaisille ryhmille avoimet tunnukset olivat ongelma, koska tunnukset olivat omiaan johtamaan vakaista vaaliasetelmista kiristyvään kilpailuun.

Uuden vaalikauden alkaessa 1988 Tampereen hiippakuntakokous teki vuorostaan aloitteen tunnusten sallimisesta. ${ }^{224}$ Nyt kyseltiin jo, luottiko kirkko jäseniinsä, jos se ei uskaltanut hyväksyä heidän käyttöönsä ehdokaslistojen nimityksiä. Vanhat epäilykset politisoitumisesta näkyivät kuitenkin edelleen. SDP:n kansanedustaja Lea Savolainen tiedusteli,

olemmeko me käyttäytyneet niin, että tämä kammoksunta ja pelko on hyvin aiheellista. Olemmeko me jotenkin häiriökäyttäytyjiä, liki terroristeja täällä, pistämmekö me nurin kaikki arvomaailmat. Miten olemme luoneet teille sen pelon poliittisista ihmisistä, jotka tuovat tullessaan kirkkoon jonkun käsittämättömän politiikan, joka madaltaa kirkon arvoa niin kuin täällä mm. on sanottu. - - Olen tullut hyvin vakuuttuneeksi täällä siitä, että poliittiset puolueet näyttävät olevan aivan oppipojan asemassa sen kirkon sisäisen anarkian todellisuuden edessä, jota jotkut täällä viestittävät. ${ }^{225}$

Äänestettäessä määräenemmistö jäi jälleen saavuttamatta, tosin enää kolmen äänen päähän. ${ }^{226}$ Huomattavaa oli, 
että enemmistö piispoista vastusti edelleen avoimia nimityksiä. Uudistus ei kuitenkaan tuolla kertaa hautautunut neljäksi vuodeksi. Tampereen piispa Paavo Kortekangas totesi tuoreeltaan, että äänestystulos oli vihje hänen johtamalleen kirkkolain uudistamisvaliokunnalle. ${ }^{227}$ Koska selvä enemmistö oli nimitysten kannalla, valiokunta päätti liittää avoimet nimitykset osaksi kirkkolain kokonaisuudistusta. Valiokunta katsoi lisäksi, että asia kuului kirkon vaalijärjestykseen, joka hyväksyttäisiin yksinkertaisella ääntenenemmistöllä. ${ }^{228}$ Näiden linjausten myötä asia käytännössä ratkesi, ja uudistuksen vastustajat antoivat periksi. ${ }^{229}$ Uusimuotoisen kirkolliskokouksen lähes 20 ensimmäistä vuotta kestänyt kiivas tunnuskeskustelu päättyi huomiota herättävän rauhallisissa tunnelmissa.

Ratkaisun kannalta oli oleellista, että 1980-luvun loppuvuosina asian painoarvo alkoi laskea niin kannattajien kuin vastustajienkin keskuudessa. Seurakuntalehtien ja muiden tiedotuskanavien lisääntyminen johti siihen, etteivät vaalit enää kaupunkiseurakunnissakaan jääneet samanlaisiksi sokkovaaleiksi kuin vielä 1970-luvulla. Se avoimuus, johon tunnuksilla oli pyritty, oli ainakin osittain toteutunut jo ilman tunnuksia. Tilalle olivat nousseet uudet ongelmat. Pertunmaan kirkkoherra Hannu Niskanen totesi, että kasvava joukko ihmisiä vieroksui instituutioita - oli sitten kyse puolueista tai kirkosta - vaikka oli samaan aikaan kiinnostunut yhteiskunnan ja uskon kysymyksistä ${ }^{230}$. Ideologisten raja-aitojen madalluttua ja poliittisen konsensushengen vahvistuttua puolueet eivät enää 1980-luvun lopun Suomessa näyttäytyneet merkittävänä uhkana vaan ennemminkin kirkon kohtalotovereina. Kaiken lisäksi suuri osa kirkolliskokousedustajista oli jo kyllästynyt jatkuvaan tunnuskeskusteluun. Rintamalinjat säilyivät, mutta niiden molemmin puolin ajateltiin yhä laajemmin, että kirkollisen päätöksenteon tulevaisuuden ongelmat olivat muualla kuin ehdokaslistojen nimityksissä. Seurakuntavaalisäännökset muuttuivat kaupunkiseurakuntien tarpeita vastaaviksi vasta, kun uudistustarve alkoi monelta osin olla jo ohi.

\section{SEURAKUNNAN JÄSENYYS JA KIELI KIRKKOLAIN KOKONAISUUDISTUKSEN ONGELMINA}

Se, joka ottaa kirkkolain käteensä ja ryhtyy jakamaan sitä kahteen osaan, tarttuu tavattoman vaativaan tehtävään. Hän ottaa tulkitakseen yleistä kristillistä uskoa sen ytimestä käsin. Hänen on oltava tietoinen siitä, että hän on tässä maassa $80 o$ vuotta toimineen kirkon tulkki. Hänen on oltava selvillä siitä, että kirkkolain ja kirkkojärjestyksen uudelleen kirjoittaminen tapahtuu monitahoisen lainsäädännön verkostossa. Se, joka tähän tehtävään on nyt ryhtymässä, olemme me, kirkolliskokous. Tämä ja ilmeisesti pari seuraavaa, jotka tulevat työskentelemään 8o-luvulla. ${ }^{231}$

Vuoden 1980 kevätistuntokaudella kirkkolain uudistustyötä oltiin vasta käynnistämässä, mutta kirkkoherra Leino Hassinen ei vähätellyt uudistuksen vaatimaa työmäärää. Kirkolliskokouksessa kuulluissa puheenvuoroissa oli alkanut hahmottua, ettei kauan suunniteltu kirkkolain jakaminen olisi vain nopea tekninen toimenpide vaan vuosien mittainen hanke. Vuoden 1869 kirkkolakiin oli otettu yksityiskohtaista, sisältönsä puolesta lähinnä asetustasolle kuulunutta ainesta, jotta vierasuskoinen hallitsija ei voisi puuttua säännöksiin ohi Suomen valtiopäivien ${ }^{232}$. Kirkkolain yksityiskohtaisuus oli säilynyt läpi vuosikymmenten, joten lain supistaminen ei ollut helppo työ. Kahdeksan vuotta Hassisen sanojen jälkeen, kun kirkkolain uudistamiskomitea ja sen jaostot olivat pitäneet puolentuhatta kokousta, uudistustyö oli valmistumassa ${ }^{233}$. Odotukset eivät tuona aikana olleet ainakaan vähentyneet. Arkkipiispa John Vikström luonnehti keväällä 1988, että kirkkolain kokonaisuudistus oli tuolloin alkamassa olleen vaalikauden ylivoimaisesti tärkein - siis raamatunkäännöstäkin paljon tärkeämpi - asia ${ }^{234}$.

Komitea joutui tasapainoilemaan keskenään ristiriitaisten odotusten välillä. Periaatteena oli, ettei uudistustyöhön yhdistettäisi laajoja tai kiistanalaisia säännösmuutoksia, jotta koko hanke ei kaatuisi määräenemmistön puutteeseen. Periaatteen kannalta kyseenalaisesti kirkolliskokous ja muut elimet lähettivät kuitenkin komitealle lukuisia aloitteita. Oikeusneuvos Johannes Leivosen johtama työskentely oli lisäksi äärimmäisen tarkkaa ja hidasta: komitean lukuisien jaostojen huolellisesti valmistelemat ja yksimielisesti hyväksymät ehdotukset käytiin juurta jaksaen läpi vielä koko komitean istunnoissa ${ }^{235}$. Kun työ pitkittyi, odotukset merkittävistä uudistuksista kasvoivat.

Syksyllä 1988 valmistunut mietintö keskittyi komitean alkuperäiseen tehtävään eli kirkkolain jakamiseen. Jakamistyön jäljiltä komitean mietinnössä oli kolme 
osaa: entiseen tapaan säädettävä kirkkolaki, kirkolliskokouksessa määräenemmistöllä hyväksyttävä kirkkojärjestys ja kirkolliskokouksessa yksinkertaisella ääntenenemmistöllä hyväksyttävä kirkon vaalijärjestys. Uudistustyön tekninen luonne näkyi esimerkiksi siinä, ettei komitea ehdottanut suuria lisämuutoksia kirkon ja valtion keskinäisiin suhteisiin, vaikka toki kirkkolain jakaminen vahvisti jo sinänsä kirkon itsenäisyyttä ${ }^{236}$. Kirkon itsenäisyyden kannalta periaatteellinen ratkaisu oli esimerkiksi luopuminen kirkkolain kohdasta, jonka mukaan "kirkon ylin hallitus koko maassa on valtakunnan hallituksen asia". ${ }^{237}$

Pidättyvästä yleislinjastaan poiketen komitea esitti kuitenkin myös selviä uudistuksia, kuten äänioikeutettujen määrän lisäämistä arkkipiispan vaalissa ja kirkollisen äänioikeuden myöntämistä konfirmoimattomille kirkon jäsenille. Varsinkin viimeksi mainittu asia oli jakanut mielipiteitä kirkolliskokouksessa 1970-luvulla. Kolme komitean jäsentä jätti asiasta eriävän mielipiteen, mikä osoitti, että mietinnössä oli etukäteen pelättyä kiistanalaista ainesta. Komitea esitti myös, että seurakuntalaisten rankaisemista koskevat kirkkokurisäännökset poistettaisiin. Muutos oli seurakuntien käytännön elämän kannalta vähäinen mutta lakitekstin näkökulmasta suuri ja periaatteellinen. Komitea ehdotti vielä muun muassa, että rikosoikeudenkäynnistä tuomiokapitulissa luovuttaisiin ja kirkon työntekijöitä varten hyväksyttäisiin valtion virkamieslain mallin mukaiset säännökset kurinpitomenettelystä. Pappisedustajat taas valittaisiin kirkolliskokoukseen samanlaisella suhteellisella vaalilla kuin maallikkoedustajat. ${ }^{238}$

Suuriksi kasvaneiden odotusten vuoksi mietinnön vastaanotto oli kirkolliskokouksessa kahtalainen. Yhtäältä kiiteltiin komitean työtä ja tunnustettiin kirkkolain jakamisen suuri merkitys. Toisaalta jotkut valittivat komiteatyön tulosta jo etukäteen vanhentuneeksi. Kalevi Toiviainen kyseli, oliko lähes 20 vuotta kestänyt keskustelu ollut sittenkin melko turhaa: "Tämä ehdotus olisi käsittääkseni voitu laatia jo 1970-luvun alussa, niin vähän siihen on heijastunut esim. kirkkojärjestyskomitean mietintö." ${ }^{239}$ Arviolla oli pohjaa kirkon tunnustusta ja tehtävää koskevien säännösten osalta. Leivosen komitea päätti äänestyksen jälkeen ja vastoin kirkkojärjestyskomitean kantaa sijoittaa niin sanotun tunnustuspykälän kirkkojärjestyksen sijasta edelleen kirkkolakiin. ${ }^{240}$
Ratkaisu kuvasti laajemminkin kahden komitean välistä eroa. Kirkkojärjestyskomitea ja sen asiantuntijana toiminut Lars Erik Taxell korostivat kirkon itsenäistä toimivaltaa säätää kirkkojärjestys. Leivosen komitea taas painotti puheenjohtajansa ja juristijäsentensä Gunnar Träskmanin ja Jaakko Voipion johdolla, että kirkkojärjestys sai sitovuutensa kirkkolaista. Sen vuoksi kirkkolaissa oli mainittava monet varsinaisesti kirkkojärjestyksen piiriin kuuluvat asiat. ${ }^{241}$

Komiteoiden välisen linjaeron taustalla oli myös ajan muuttuminen. Seitsenkymmenluvulle ominainen kirkon itsenäisyyden korostus oli heikentynyt 1980-luvulla uskonto- ja kirkkomyönteisyyden lisääntyessä. ${ }^{242}$ Lopulta kirkolliskokous siirsi varsinaisen tunnustuspykälän kirkkojärjestykseen, ja uusi kirkon tehtäväpykäläkin sai muotoilun, jolla pyrittiin korostamaan kirkon työtä uskosta lähtevänä toimintana. Näin molemmat säännökset lähenivät kirkolliskokouksessa kirkkojärjestyskomitean ehdotusta. ${ }^{243}$ John Vikström ja Ossi Haaramäki, jotka olivat toimineet kirkkojärjestyskomiteassa, nostivat esiin komiteansa äänenpainoja. ${ }^{244}$

Kirkkolakiuudistuksen lähetekeskustelussa jotkut edustajat valittivat uuden kirkkolain laajuutta ja vaativat siirtämään useita säännöksiä kirkkojärjestykseen. ${ }^{245}$ Piispa Paavo Kortekankaan johdolla toiminut kirkkolain uudistamisvaliokunta yritti vastata arvosteluun ja siirsi tunnustuspykälän ohella eräitä muitakin säännöksiä pois lakitasolta. ${ }^{26}$ Seurauksena oli kirkkohallituksen huomautus, että valiokunta oli siirtänyt kirkkojärjestykseen asioita, joista tuli säätää lailla. ${ }^{247}$ Erimielisyydet siitä, mitkä asiat oli otettava lakiin ja mistä kirkkojärjestys sai sitovuutensa, jatkuivat loppuun asti.

Valiokuntakäsittely oli perusteellinen. Kirkkolain pykälistä vajaa neljännes ja kirkkojärjestyksen pykälistä vain kuudesosa läpäisi sen ilman muutoksia. Kokonaisuutena valiokunnan työ sai osakseen kiitosta niin lausunnonantajilta kuin kirkolliskokousedustajilta. ${ }^{248}$ Muutamat teemat aiheuttivat kuitenkin erimielisyyksiä läpi kirkolliskokouskäsittelyn, ja suurelta osin tällaiset säännökset koskettivat perustavalla tavalla kansankirkon luonnetta. Yhtäältä oli luotava säännöksiä kirkolle, joka palvelisi alttiisti ihmisiä. Toisaalta oli vaadittava jotakin kirkon jäseniltä ja varottava, ettei kirkko kuivuisi pelkäksi uskontohuoltolaitokseksi. Suomalaiseen kansankirkollisuuteen yhtä aikaa kuulu- 
neet avaruus ja tunnustuksellisuus olivat keskenään jännitteessä. Se ilmeni esimerkiksi keskusteltaessa kirkkokuria, äänioikeutta ja avioliittoa koskevista säännöksistä.

Suurimpia kiistanaiheita oli kirkkolain uudistamiskomitean esitys, että konfirmaatiosta kirkollisen äänioikeuden ehtona luovuttaisiin. Komitea mainitsi esityksensä perusteluksi, että myös konfirmoimattomilta kirkon jäseniltä koottiin kirkollisveroa. ${ }^{249}$ Samalla perusteella Lars Erik Taxell oli nostanut asian esille kirkolliskokouksessa 1970-luvulla. Kuten silloin myös tällä kertaa ehdotus sai kirkolliskokouksessa vastaansa arvostelua. Piispa Toiviainen piti komitean taloudellista perustelua banaalina. Hän totesi, että kansankirkon ydin oli perinteisesti ollut ehtoollisseurakunta, mikä perusteli konfirmaatioehtoa. ${ }^{250}$ Myös lähes kaikki asiaan puuttuneet lausunnonantajat, esimerkiksi piispainkokous yksimielisesti ja kaikki lausunnon antaneet seitsemän tuomiokapitulia, vastustivat konfirmaatioehdon poistamista. ${ }^{251}$ Kirkkolain uudistamisvaliokunta pitäytyi kuitenkin äärimmäisen tiukan äänestyksen jälkeen komitean kannalla. Toisin kuin komitea valiokunta perusteli ratkaisuaan lähinnä teologisesti: kirkossa oli vain yhdenlaista jäsenyyttä, johon liitettiin kasteessa. ${ }^{252}$

Kevään 1991 täysistuntokeskustelussa Helsingin uusi piispa Eero Huovinen nousi uudistuksen näkyvimmäksi vastustajaksi. Hän eritteli valiokunnan argumentaatiota ja totesi siinä olevan monia epäjohdonmukaisuuksia. Seurauksena oli vilkas keskustelu.
Valiokunnan kannattajista osa vetosi komitean tavoin lähinnä oikeudenmukaisuusperusteisiin. Erityisesti Päivi Varpasuo rinnasti kirkolliset vaalisäännökset valtiollisiin: "Äänioikeus kuuluu Suomen kansalaiselle. Samoin äänioikeuden pitää kuulua kirkon jäsenelle." Toiset, kuten arkkipiispa Vikström, vetosivat valiokunnan tavoin siihen, että kirkossa oli vain yhdenlaista jäsenyyttä. Konfirmaatioehdon puoltajat taas korostivat, että kaste ja opetus kuuluivat yhteen. Lisäksi monien mielestä äänioikeuden käyttäminen oli hengellistä toimintaa. Konfirmaatioehdon puoltajat saivat tukea ajankohtaisesta Kirkko 2000 -työskentelystä, jossa kirkkojärjestyskomitean mietintöön nojautuen painotettiin nimenomaan seurakunnan jäsenten identiteettiä ja sitoutumista. Valiokunnan kanta voitti kuitenkin täpärästi äänin $57-43 .^{253}$

Voitto oli niukka erityisesti siihen nähden, että kirkkolain muutos edellytti taakseen määräenemmistön. Tuolloin uusimmassa kirkon nelivuotiskertomuksessa todettiin, että ehtoollisella käyntien määrä oli kasvanut ja että jumalanpalvelusseurakunnasta oli tulossa myös ehtoollisseurakunta ${ }^{254}$. Kirkolliskokouksen päätöksen myötä äänestävä seurakunta irtaantui kuitenkin samaan aikaan ainakin periaatteessa ehtoollisseurakunnasta. Jälkeenpäin Eero Huovinen arvosteli erityisesti piispainkokouksen yksimielisen lausunnon sivuuttamista ja kysyi, mikä oli piispainkokouksen asema opista huolehtivana organisaationa ${ }^{255}$.

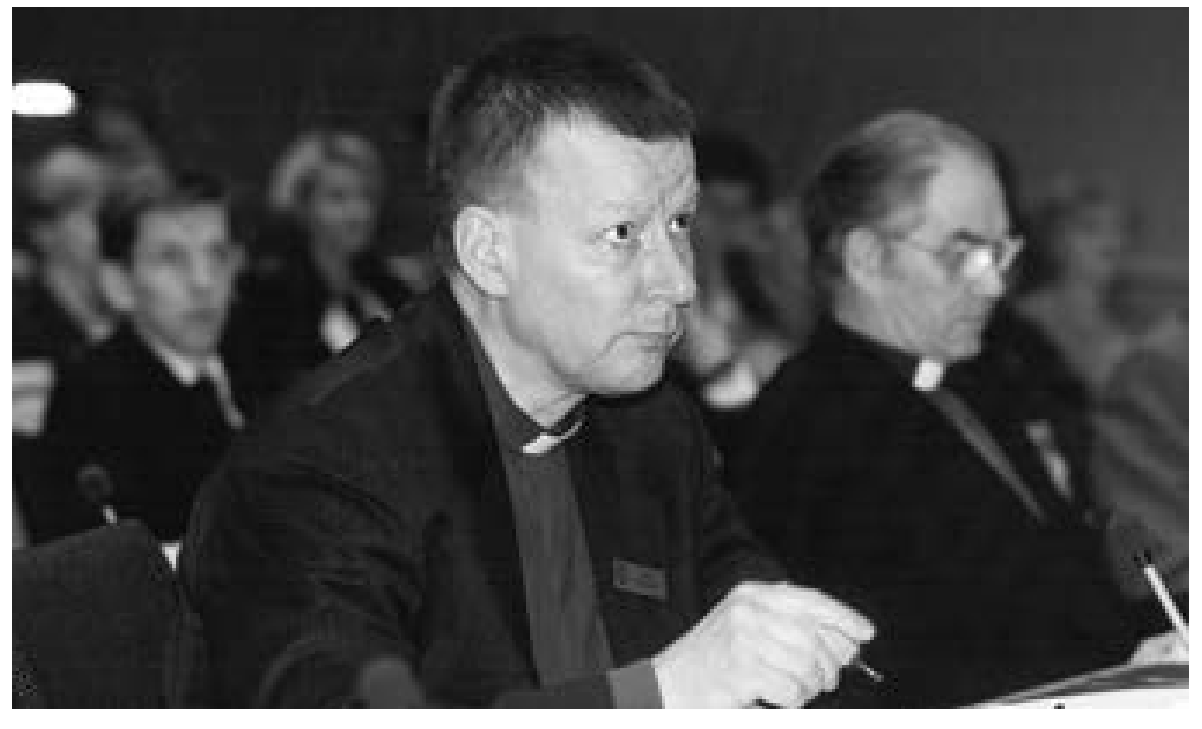

Helsingin piispa Eero Huovinen (vas.) ja Kuopion piispa Matti Sihvonen äänestivät tyhjää kirkkolain kokonaisuudistuksen ratkaisevassa käsittelyssä. Teologista arvostelua uudistusta kohtaan aiheutti erityisest $i$ se, ettei uusien säännösten mukaan konfirmaatio ollut enää kirkollisen äänioikeuden ehto. Kuva: Kirkkohallitus. 
Huovinen ilmoitti kirkolliskokoukselle, ettei hän voinut äänestää kirkkolain hyväksymisen puolesta. Lopullisessa äänestyksessä viisi edustajaa äänesti erilaisista syistä ehdotusta vastaan ja lisäksi kahdeksan edustajaa tyhjää - mukana piispoista Huovinen ja Kuopion piispa Matti Sihvonen. ${ }^{256}$ Vastaan äänestäneiden lukumäärä oli huomattava, kun ottaa huomioon, miten suuren riskin jokainen vastustajista otti: määräenemmistön puuttuminen kaataisi vuosikymmeniä valmistellun lakiuudistuksen kokonaan. Epäilemättä konfirmaatioehdon poistaminen vaikutti monen äänestyskäyttäytymiseen lakiesityksen toisessa käsittelyssä. Ensimmäisen käsittelyn äänestysluvut osoittivat vastaansanomattomasti, ettei tällä lakimuutoksella olisi ollut mahdollisuuksia mennä läpi yksittäisenä uudistuksena ilman kirkkolain kokonaisuudistuksen tuomaa selkänojaa.

Rippikoulu palasi keskustelunaiheeksi käsiteltäessä kirkkojärjestyksen säännöksiä avioliittoon vihkimisestä ja avioliiton siunaamisesta. Perinteisesti kirkollisen vihkimisen ehtona oli ollut, että molemmat kihlakumppanit kuuluivat kirkkoon. Kirkkolain uudistamiskomitea ehdotti kuitenkin muutosta, että vain toisen kihlakumppaneista tarvitsi olla rippikoulun käynyt kirkon jäsen. Pari voitiin vihkiä, vaikka toinen ei kuulunut mihinkään uskonnolliseen yhteisöön. ${ }^{257}$ Avioliiton siunaaminen taas oli toimitettava, jos muuten kuin luterilaisen kirkon järjestyksessä vihitty pari sitä pyysi. ${ }^{258}$ Komitea antoi papille harkintavaltaa kirkollisesta vihkimisestä päättämiseen mutta ei avioliiton siunaamiseen.

Valiokunta toimi päinvastoin. Saamiensa lausuntojen pohjalta se lisäsi harkintavaltaa avioliiton siunaamisessa mutta poisti sitä kirkollisesta vihkimisestä. Molemmat ratkaisut merkitsivät pidättyvämpää linjaa kuin komitealla. Avioliiton siunaaminen määriteltiin papille mahdolliseksi, ei velvollisuudeksi. Kirkollinen vihkiminen taas voitiin toimittaa vain, jos toinenkin kihlakumppaneista kuului johonkin kristilliseen kirkkoon tai uskontokuntaan. Kirkolliskokous hyväksyi valiokunnan ehdotukset, vaikka varsinkin viimeksi mainittu esitys jakoi mielipiteitä. Monet olivat sitä mieltä, että kirkko oli vaarassa kääntää tällä säännöksellä selkänsä paitsi "kadonneelle lampaalle" myös sille konfirmoidulle kirkon jäsenelle, jolle vihkiminen oli henkilökohtaisesti tärkeä. Taustalla kuului sama kysymys kuin väiteltäessä ääni- oikeudesta: miten oli mahdollista korostaa sitoutumista kirkon jäsenyyteen mutta samalla pitää ovet auki hengelliseen osallistumiseen?259

Kirkon jäsenen velvollisuuksien vähentäminen oli omiaan korostamaan välillisesti "ydinseurakunnan" ja "tavanomaisten jäsenten" välistä ajatuksellista eroa. Kuvaavaa oli, että jo vuosisadan alussa nimenomaan beckiläisen pietismin edustajat olivat toimineet kirkkokurin lieventämiseksi ${ }^{260}$. Kirkolliskokous pyrki paikoin kohottamaan kirkon jäsenyyden profiilia komitean mietintöön verrattuna. Kaikkiaan uudet säädökset sisälsivät kuitenkin aiempaa vähemmän odotuksia kirkon jäseniä ja heidän sitoutumistaan kohtaan ${ }^{261}$.

Kirkkolain uudistamisvaliokunnan mietintö johti yllättäen myös pitkään ja osin kiivaaseen kielikeskusteluun. Kahdesta kielikiistasta pienempi koski saamen kielen asemaa. Pohjois-Suomessa oli vedottu kirkkolain uudistamiskomiteaan saamen kielen aseman virallistamiseksi. ${ }^{262}$ Alueella koettiinkin suuri pettymys, kun lopullinen mietintö ei sisältänyt tällaisia säännöksiä. ${ }^{263}$ Lukuisat Pohjois-Suomen keskeiset elimet vetosivat kirkolliskokoukseen asian korjaamiseksi. ${ }^{264}$ Samaan aikaan toteutettiin muutoksia valtiollisessa kieli- ja vähemmistölainsäädännössä: laki saamen kielen käyttämisestä viranomaisissa vahvistettiin maaliskuussa 1991, vain pari kuukautta ennen kuin kirkolliskokous kokoontui päättämään kirkkolain uudesta tekstistä. ${ }^{265}$

Kirkkolain kokonaisuudistus oli jo loppusuoralla, mutta silti piispa Olavi Rimpiläinen ehdotti kirkkolakiin kokonaan uutta säännöstä: saamelaisten kotiseutualueelle voitaisiin perustaa kaksikielinen suomalais-saamelainen seurakunta. Ehdotus perustui saamelaisvaltuuskunnan valmisteluun. Valiokunnan puheenjohtaja Paavo Kortekangas ilmoitti, ettei näin myöhäisessä vaiheessa tullut enää laatia uutta säännöstä asiasta, joka vaati paljon tutkimista. Rimpiläisen muutosehdotus hyväksyttiin kuitenkin äänin 51-39. ${ }^{266}$ Valiokunnan vastustuksesta huolimatta kirkolliskokous pysyi kannassaan loppuun asti ja hyväksyi hyvin kiireellisesti valmistellun uuden kielisäännöksen. Päätöksen taustalla oli tietoisuus siitä, että saamelaisen identiteetin säilyttäminen vaati nopeita toimenpiteitä. ${ }^{267}$ Samalla kyseessä oli suora jatko saamelaisten asemaa koskeneille uudistuksille, joita kirkolliskokous oli piispa Rimpiläisen johdolla 1980-luvulla tehnyt. 
Toinen ajankohtainen valtiollinen lainsäädäntöhanke oli Ahvenanmaan uusi itsehallintolaki, jonka eduskunta hyväksyi helmikuussa 1991. Lain mukaan valtion viranomaisten ja kunnallishallinnon virkakieli maakunnassa oli ruotsi. Sama koski kirkkoakin, ellei kirkkolaista muuta johtunut. ${ }^{268}$ Kirkkolain uudistamiskomitean ehdottamat uudet kielisäännökset olivat itsehallintolain mukaiset: lakiesityksessä oli erillinen Ahvenanmaata koskeva lisäys, jossa alueen seurakunnat määrättiin ruotsinkielisiksi. ${ }^{269}$ Valiokunta poisti kuitenkin tämän lisäyksen, koska kaksikielisten seurakuntien kielto saattoi valiokunnan mukaan "loukata perusoikeuksiin kuuluvaa uskonnonvapautta tavalla, johon Ahvenanmaan

\section{Kirkolliskokous herää saamelaisten asiaan}

Huhtikuussa 1982 Kotimaa-lehden haastattelu sisälsi rohkean ehdotuksen: kirkolliskokoukseen oli syytä saada pysyvä saamelaisedustaja. Ehdotuksen lausuja oli utsjokelainen talollinen Ola Pieski, joka oli juuri valittu kirkolliskokoukseen ensimmäisenä saamelaisena. ${ }^{I}$ Saamelaisten asia nousi 1980-luvun kuluessa kirkolliskokouksessa merkittäväksi teemaksi. Taustalla oli Pohjoismaiden laajuinen saamelaisten kansannousu, johon Oulun hiippakunnassa oli entistä tietoisemmin alettu vastata ${ }^{\text {II }}$. Yksi osoitus oli hiippakunnan maallikkovalitsijoiden toiminta vuoden 1982 kirkolliskokousvaaleissa.

Oulun hiippakuntakokous ehdotti 1983 selvitystyötä siitä, miten saamen kieli voitaisiin sisällyttää kirkkolain kielipykälään. Kirkolliskokous lähetti asian kirkkolain uudistamiskomitealle. ${ }^{\text {III }}$ Kun lainsäädäntöä koskeva tutkimustyö oli näin saatu liikkeelle, hiippakunnan edustajat siirtyivät edistämään saamenkielistä seurakuntatyötä käytännön keinoin. ${ }^{\text {IV }}$ Erityisesti piispa Olavi Rimpiläinen ajoi kirkolliskokouksessa saamelaisten asiaa, ja kirkolliskokous suhtautui aloitteisiin yleisesti hyvin myötämielisesti. ${ }^{V}$ Vuonna 1988 Rimpiläinen saattoikin todeta, että kirkolliskokous ja kirkkohallitus olivat tehneet todella paljon saamelaisten hyväksi. ${ }^{\mathrm{VI}}$

Kirkolliskokous asetti 1986 komitean valmistelemaan virsikirjaa sekä pohjois- että inarinsaameksi. Varsinkin inarinsaamen osalta hanke oli uraauurtava, koska kieliryhmällä ei ollut ennestään äidinkielistä virsikirjaa. Keskustelua herätti lähinnä se, oliko saamenkielisten virsikirjojen hyväksyminen kirkolliskokouksessa hallinnollisesti liian raskas menettelytapa. Oulun hiippakunnan edustajat korostivat, että kirkolliskokouksen hyväksyntä ilmentäisi arvostusta saamelaisia koh- itsehallintoa koskevat säädökset eivät anna aihetta". ${ }^{270}$ Valiokunta vetosi myös siihen, että uuden kirkkolain myötä kaksikieliset seurakunnat olivat muutenkin harvenemassa: vähemmistökielen eli tässä tapauksessa suomen puhujia oli oltava huomattavasti aiempaa enemmän. ${ }^{271}$ Valiokunnan esitys ei antanut Ahvenanmaalle mitään erityisasemaa ja poikkesi siten Ahvenanmaan itsehallintolaista - tosin lain itsensä antamin valtuuksin. Valiokunnan tekemä muutos osoittautui kuitenkin herkäksi asiaksi tilanteessa, jossa kielikeskustelu oli muutenkin itsehallintolain myötä vilkasta.

Täysistunnossa Paavo Kortekangas vakuutti, ettei valiokunnan tarkoituksena ollut ollut heikentää vähem-

taan. Myös Porvoon hiippakunnan edustajien oli helppo asettua pohjoisen hiippakunnan tueksi vastustamaan sellaista ajattelutapaa, että kielivähemmistöjen kirkolliset kirjat pitäisi pystyä laatimaan halvemmalla kuin suomenkieliset kirjat. Päätettiin, että kirkolliskokouksen kuului hyväksyä kirjat. ${ }^{\text {VII }}$

Lopulta 1990 Oulun hiippakuntakokous ryhtyi toteuttamaan Ola Pieskin näkyä: kokous ehdotti opettaja Terttu Kauvosaaren aloitteesta kirkolliskokoukseen pysyvää saamelaisedustajaa. ${ }^{\mathrm{VIII}}$ Yleisen valmistusvaliokunnan epäilyksistä huolimatta kirkolliskokouksen täysistunto lähetti asian kirkkohallitukselle toimenpiteitä varten. ${ }^{\text {IX }}$ Saamelaisten asemaa koskevia aloitteita perusteltiin ensinnäkin tulevaisuuden uhilla: saamelaisten kansannousussa kristillinen perintö ei ollut saanut juuri sijaa, ja nuori sukupolvi oli vieraantumassa esimerkiksi vanhoista saamenkielisistä virsistä. ${ }^{\mathrm{x}}$ Oli yhdestoista hetki toimia saamelaisten tavoittamiseksi. Toinen perustelu koski velkaa: valtio ja kirkko olivat aikojen saatossa laiminlyöneet alkuperäiskansan oikeuksia, ja oli tullut velanmaksun aika.

I Kmaa 20.4.1982 Ola Pieski, 62, Utsjoelta Turkuun (Tapani Erämaja).

II Kirk.kok. kptk-k. 1983, 24 \$; Kirk.kok. ptk-k. 1983, liite IX Oulu 1.

III Kirk.kok. ptk-k. 1983, liite IX Oulu 1; Kirk.kok. ptk-k. 1984, 44 §.

IV Kirk.kok. kptk-s. 1984, 10 \$; Kirk.kok. ptk-k. 1987, liite V 6; Kirk.kok. ptk-k. 1988, liite IX 5.

V Kirk.kok. kptk-s. 1984, 10 \$; Kirk.kok. kptk-k. 1988, 23 \$, 33 §; Talonen 2012, 537.

VI Kirk.kok. kptk-k. 1988, 23 \$.

VII Kirk.kok. kptk-s. 1986, 17 \$; Kirk.kok. ptk-s. 1986, liite VIII-C 3; Kirk.kok. ptk-s. 1988, liite VII-C 5.

VIII Kirk.kok. ptk-k. 1990, liite VI 1.

IX Kirk.kok. kptk-k.1990, 53 \$.

X Kirk.kok. ptk-k. 1983, liite IX Oulu 1; Kirk.kok. ptk-s. 1986, liite VIII-C 3. 
mistönsuojaa. Porvoon piispa Erik Vikström ja Ahvenanmaalta valittu edustaja, rehtori Pehr-Olof Böckelman eivät olleet asiasta yhtä varmoja. Vikströmin mukaan poikkeaminen valtion linjasta tulkittaisiin niin, että "kirkko ja vain kirkko ryhtyy vanhojen lupausten rikkojaksi”. Böckelmanin mukaan valiokunta ei ollut ymmärtänyt itsehallintolain henkeä ja tarkoitusta tai Ahvenanmaan erityisasemaa. Hänen mukaansa kaksikielisen seurakunnan kielivaatimukset olisivat uhka esimerkiksi täysin ruotsinkielisen koululaitoksen läpi kulkeneille ahvenanmaalaisille, jotka eivät voisi työllistyä tällaiseen seurakuntaan. Sitä paitsi Böckelman kertoi valiokunnan linjan lisäävän Ahvenanmaalla kirkosta eroamista ja voimistavan vaatimuksia itsenäisen kirkon perustamisesta. ${ }^{272}$

Puheenvuoroista sai kuvan, että kaksikieliset seurakunnat olisivat valiokunnan esityksen mukanaan tuoma uutuus. Tosiasiassa Ahvenanmaalla oli tuolloin kolme kaksikielistä seurakuntaa, jotka olivat muuttumassa yksikielisiksi paitsi komitean myös valiokunnan esittämien säännösten perusteella. Vikström ja Böckelman eivät kuitenkaan verranneet valiokunnan esitystä voimassa olleeseen kirkkolakiin vaan kirkkolain uudistamiskomitean esitykseen ja valtiolliseen itsehallintolakiin. Komitean esitykseen suhtauduttiin annettuna lupauksena, jolloin valiokunnan kanta näyttäytyi heikennyksenä tai suorastaan itsehallinnon loukkauksena.

Näkyväksi argumentiksi nousi se, että ahvenanmaalaiset olivat tahtomattaan joutuneet osaksi Suomea. Böckelman sovelsi A. I. Arwidssonin suuhun pantuja sanoja: "suomalaisia emme ole, ruotsalaisiksi emme saaneet tulla, olkaamme siis ahvenanmaalaisia."273 Samoilla linjoilla oli arkkipiispa Vikström, jonka mukaan kirkonkin tuli nyt kielisäännösten muodossa maksaa korvausta Ahvenanmaalle siitä, että maakunta oli aikoinaan saatu Suomelle. Kirkkolain uudistamisvaliokunnan jäsen Fredric Cleve jäi keskustelussa pitkälti yksin vastatessaan, että tätä korvausta ei maksaisi kirkko vaan Ahvenanmaan pieni suomenkielinen vähemmistö. Leena Huima huomautti, että tämä vähemmistö oli itse muuttanut Ahvenanmaalle tietäen, mistä oli kysymys. Monet keskustelijat muistuttivat siitä, että kielisäännökset koskivat vain hallintoa ja että suomenkielinen hengellinen toiminta oli mahdollista yksikielisessäkin seurakunnassa. Siitä Cleve ja Huima olivat yhtä mieltä, että mahdollisuus yksikielisen suomenkielisen seurakunnan perustamiseen olisi ahvenanmaalaisille parempi ratkaisu kuin kaksikieliset seurakunnat. ${ }^{274}$

Komitean kannalla olleet tarkastelivat asiaa perustuslaissa määriteltyä Ahvenanmaan itsehallintoa koskevana kysymyksenä, valiokunnan kannattajat taas uskonnonvapausasiana. Komitean linjaa kannattaneiden puheenvuoroissa näkyivät samat perustelut, jotka olivat ilmenneet aiemmin saamen kielen asemasta keskusteltaessa: uhka tietyn väestöryhmän irtaantumisesta kirkosta ja ajatus velan maksamisesta. Suomenkieliset edustajat seurasivat keskustelua pääasiassa sivusta, ja jyrkin raja kulkikin Porvoon hiippakunnan sisällä Fredric Cleven ja muiden hiippakunnan edustajien välillä. Clevellä ja hänen valiokunnallaan oli kuitenkin hiljaista tukea, joka tuli esille äänestettäessä: kirkolliskokous asettui keskustelun sävyyn nähden vain melko niukasti äänin 52-40 komitean kannalle ${ }^{275}$.

Seuraavassa mietinnössään valiokunta asettui Cleven ja Huiman ehdottamalle välittävälle kannalle: Ahvenanmaan seurakunnat olisivat yksikielisiä, mutta laissa ei määriteltäisi, mikä tuo kieli olisi. Siten myös suomenkielisen seurakunnan perustaminen olisi periaatteessa mahdollista. ${ }^{276}$ Ahvenanmaan kysymys vei yleiskeskustelun loppua kohden kaiken huomion, ja vuosikymmeniä valmistellun laajan lakiuudistuksen muut osat jäivät syrjään. Tunnelma salissa oli hyvin erilainen kuin puoli vuotta aiemmin. Monet suomenkieliset edustajat, jotka olivat keväällä vaienneet, nousivat nyt puolustamaan valiokunnan mietintöä. Ilmeisen monelle edustajalle selvisi vasta tässä vaiheessa, että Ahvenanmaalla oli jo ennestään kaksikielisiä seurakuntia. Tämän uuden tiedon valossa Erik Vikströmin uhkaus, että valiokunnan ehdotus oli Ahvenanmaalla "kirkon ja kirkkoelämän kannalta aika katastrofaalinen", ei saanut edustajien keskuudessa samanlaista vastakaikua kuin keväällä ${ }^{277}$.

Sanailu Porvoon hiippakunnan sisällä koveni entisestään. Vastakkain olivat Erik Vikström ja Fredric Cleve. "Minä en voi ymmärtää muuta, kuin että professori Cleve tietoisesti yrittää harhauttaa tämän kokouksen", Vikström puuskahti. Porvoon piispan puheenvuoroista kuului, että hänellä oli suuri huoli hiippakuntansa yhtenäisyydestä - olihan kansankirkollisuudella Ahvenanmaan maakunnassa vahva asema ja kirkon päätöksillä siten merkitystä. Selvä enemmistöäänesti 
lopulta valiokunnan kannan puolesta. Pettynyt PehrOlof Böckelman poistui salista, kun myöhemmin aloitettiin äänestys koko uuden kirkkolain hyväksymisestä. Hän ei voinut antaa ääntään sen puolesta. ${ }^{278}$

Ahvenanmaan kielisäännökset puhuttivat vielä marraskuussa 1993, kun eduskunta keskusteli uudesta kirkkolaista. Keskustaa edustanut ministeri Tytti Isohookana-Asunmaa harmitteli, että kirkolliskokous oli luopunut valiokunnan alkuperäisestä kannasta. Mahdollisuus perustaa kaksikielisiä seurakuntia myös Ahvenanmaalle olisi hänen mielestään sopinut parhaiten perusoikeuksien henkeen. ${ }^{279}$ Opetusministeriön ministerit suhtautuivat tuohon aikaan ylipäätään kriittisesti ruotsin kielen asemaan opetuksessa ja opetushallinnossa, minkä vuoksi kielikeskustelu oli jännittyneessä vaiheessa. ${ }^{280}$ Suomen Maaseudun Puolueen (SMP) kansanedustajat esittivät kirkkolain käsittelyn yhteydessä kielipoliittiset näkemyksensä erityisen painokkaasti. Kirkolliskokouksessa kielisäännösten saama muoto oli saanut Ahvenanmaan edustajan poistumaan kokouksesta, mutta eduskunnassa oli toisin. Ahvenanmaan edustaja Gunnar Jansson puolusti voimakkaasti kirkolliskokouksen esitystä SMP:n arvostelua vastaan. Hän jopa totesi, että kirkolliskokouksen esitys seurasi johdonmukaisesti Ahvenanmaan itsehallintolakia. ${ }^{281}$ Turun "katastrofaalinen" tappio näyttäytyi Arkadianmäen kovemmassa kielipoliittisessa ilmapiirissä merkittävänä voittona.

\section{AIEMPAA VAHVEMPI KIRKKOHALLITUS}

Avatessaan viimeistä kertaa kirkolliskokouksen keväällä 1982 arkkipiispa Mikko Juva lausui kuin testamentikseen ajatuksiaan kirkon keskushallinnosta. Hän moitti jälleen keskushallinnon hajanaisuutta, valtuuksien puutetta sekä kaksijakoisuutta talouden ja toiminnan välillä. Kirkon mahdollisuudet ottaa kantaa ja hoitaa asioita suhteessa valtiovaltaan olivat heikot. Kaiken lisäksi toimikuntalaitos "oli päästetty kasvamaan sekavaksi viidakoksi, jota kukaan ei tunne ja josta kukaan kokonaisuudessaan ei vastaa". ${ }^{82}$ Lehdistössä puhetta kommentoitiin paljon. Se sai tukea, mutta ei enää yhtä varauksettomasti kuin Juvan aiempi kirkon hallintoon kohdistama kritiikki. ${ }^{283}$ Esimerkiksi sosiaalidemokraattinen Eteenpäin, joka muuten ei epäröinyt arvostella kirkon hallintoa, piti hyvänä toimikuntien mahdollisuutta nopeisiin, itsenäisiin kannanottoihin. ${ }^{284}$
Kirkolliskokouksessa pääsihteeri Veikko Pöyhönen vastasi Juvan esittämään arvosteluun ja puolusti toimikuntia, minkä johdosta Juva käytti entistäkin voimakkaamman puheenvuoron kirkon keskushallinnon ongelmista. Arkkipiispan mukaan kirkkohallitus joutui tuolloisessa tilanteessa jatkuvasti ylittämään kokonaiskirkon toimintaa koskevan valtansa, joka oli kirkkolaissa kirjattu liian niukaksi. Juvan mielestä kulissientakaista valtaa taas käytti epävirallinen toimikuntien pääsihteerien kokous, ja pääsihteerit pyrkivät muutenkin vaikuttamaan kirkolliskokousedustajiin oman toimikuntansa puolesta. Myönteiset sanat jäivät väistyvältä arkkipiispalta vähiin, ja nekin olivat pisteliäät: "On tietysti kaunista ja lohdullista todeta, että toimikuntien pääsihteereillä - - on kaunis käsitys omasta toiminnastaan ja siitä, miten suuremmoisella tavalla toimikunnat edistävät yhteyksiä kirkossa." ${ }^{285}$

Toimikuntalaitosta koskeva keskustelu tyyntyi kirkolliskokouksessa joksikin aikaa, kun kokous hyväksyi 1983 kaikille toimikunnille uudet ohjesäännöt. Toimikunnat sulautettiin laajemmiksi toiminnallisiksi yksiköiksi, kirkon keskuksiksi. Toisaalta kirkolliskokous piti arkkipiispa Vikströmin johdolla huolen, että ennakkosuunnitelmista poiketen kirkon ulkomaanasioita hoitava elin säilyisi edelleen hyvin itsenäisenä. Samassa yhteydessä tämä aiempi kirkon ulkomaanasiain toimikunta nimettiin kirkon ulkomaanasiain neuvostoksi. Ohjesääntöuudistukset vakiinnuttivat toimintaa. Samaan suuntaan vaikutti sekin, että kirkolliskokouksen toimikuntavaliokunnan jaostot kokoontuivat säännöllisesti neuvottelemaan eri keskusten edustajien kanssa. ${ }^{286}$ Valiokunnan vaikuttamismahdollisuudet suhteessa keskuksiin olivat edelleen hyvin rajalliset, mutta tämä seikka ei puhuttanut enää 1980-luvun kuluessa niin paljon kuin aiemmin. Sen sijaan keskusteltiin välillä kiivaastikin siitä, pystyivätkö seurakunnat ja luottamushenkilöt vaikuttamaan tarpeeksi kirkon sopimusvaltuuskunnan toimiston toimintaan. Erityisesti oli merkille pantavaa, että jopa sopimusvaltuuskunnan tehtävissä toimineet esittivät ankaraa arvostelua valtuuskunnan toimiston vallankäyttöä kohtaan. ${ }^{287}$

Kirkon keskushallinnon uudistaminen jatkuikin saman tien kirkon keskusten luomisen jälkeen. Keväällä 1983 asiasta jätettiin laajapohjainen edustaja-aloite. ${ }^{288}$ Seuraavana vuonna kirkolliskokous asetti komitean 


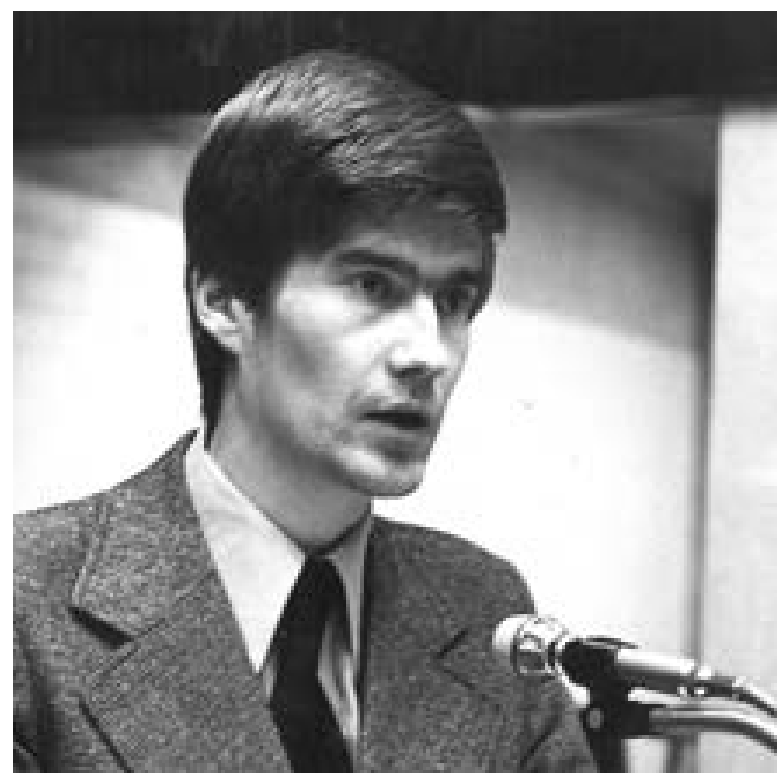

Teologian tohtori Heikki Mäkeläisen johtama hallintovaliokunta suunnitteli 1987 kirkolle uutta, entistä vahvempaa keskushallintoelintä. Kirkkoneuvoksen virassa toimivilla ei enää ollut päätösvaltaa tämän elimen täysistunnossa. Muutos kosketti lopulta henkilökohtaisesti Mäkeläistäkin, joka oli hallinnonuudistuksen toteutuessa kirkkoneuvoksen virassa. Kuva: Kirkkohallitus / Yrjö Vainio.

selvittämään piispa Erik Vikströmin johdolla keskushallinnon muutosta. Komitea hahmotteli monia vaihtoehtoja, mutta Larkion komitean ja kirkkohallituksen esitysten kohtalot saivat sen varovaiseksi. Vikströmin komitea korosti kirkon hallinnon klassisten elementtien tasapainoa ja pyrki tekemään vain pieniä korjauksia vallinneeseen hallintomalliin. Näkyvin uudistusehdotus oli, että kirkkohallituksen täysistuntoon lisättäisiin kolme pappisjäsentä. ${ }^{289}$

Kirkolliskokouksessa 1987 komitean ajattelutapa ja varovaisuus saivat osakseen arvostelua. Keskustelu osoitti, ettei kirkon hallinnon klassisia elementtejä pidetty enää teologienkaan keskuudessa samalla tavalla itsestään selvinä kuin vielä vajaat kymmenen vuotta aikaisemmin. Kuopion tuomiorovasti Matti Järveläinen päinvastoin epäili liiasta tasapainosta olevan haittaa. Vastakkaiset voimat kumoaisivat toisensa, eikä mitään syntyisi: "Taikka kyllä syntyy, nimittäin paperia (hilpeyttä)." 290 Myös uudistushankkeen käsittelyä varten perustettu erityisvaliokunta, Heikki Mäkeläisen johtama hallintovaliokunta, kyseenalaisti perinteisen käsityksen hal- lintoelementtien tasapainosta. Valiokunnan mielestä ei ollut teologisia perusteita sijoittaa konsistoriaalista elementtiä eli virassa toimivia kirkkoneuvoksia päätöksenteossa synodaalisen ja episkopaalisen elementin rinnalle. Muutenkin valiokunta meni pidemmälle kuin Erik Vikströmin komitea. ${ }^{291}$

Hallintovaliokunnan mielestä kirkkohallituksen tilalle oli perustettava uusi keskusneuvosto, jolle siirrettäisiin tehtäviä piispainkokoukselta. Piispallinen ja synodaalinen edustus kasvaisivat hieman aiempaan verrattuna, kun taas kirkkoneuvoksen virassa olevat jäisivät pois kokoonpanosta. ${ }^{292}$ Eräänlaisena tausta-ajatuksena oli, että 1970-luvun alussa keskushallinnon uudistus oli jäänyt puolitiehen. Tuolloin lainsäädäntö- ja budjettivalta oli keskitetty yhdelle elimelle, mutta samalla toiminnallistaloudellista hallintovaltaa oli jouduttu hajauttamaan entisestään. Nyt oli tullut aika keskittää myös hallintovalta. Keskeiset periaatteet olivat samoja, joita arkkipiispa Juva oli korostanut vaatiessaan hallinnonuudistusta.

Piispainkokous asettui lausunnossaan jälleen toisenlaiselle periaatteelliselle kannalle. Sen mielestä uusi keskusneuvosto tuli perustaa olemassa olevien keskushallintoelinten rinnalle, ja kaikkien piispojen tuli olla sen jäseniä ${ }^{293}$. Malli olisi pitkälti merkinnyt paluuta laajennetun piispainkokouksen aikaan. Tällaisen ajattelutavan mukaan 1970-luvun alussa toteutettu hallinnonuudistus oli ollut liian raju, ja nyt oli palattava taaksepäin. Valiokunta korosti tarkoituksenmukaisuutta, piispainkokous teologiaa. Piispat yrittivät pitää kiinni kunkin piispan henkilökohtaisista vaikutusmahdollisuuksista ja pelkäsivät hiippakuntien itsenäisyyden puolesta. He eivät kuitenkaan saaneet enää samanlaista tukea kirkolliskokoukselta kuin 1970- ja 1980-luvun vaihteessa ${ }^{294}$. Tuolloin oli kiivaan uudistusvaiheen jälkeen vedetty henkeä ja mietitty hallinnon teologisia perusteita. Käytännön tehostamispaineet kasvoivat kuitenkin 1980-luvun edetessä niin valtiollisessa kuin kirkollisessakin hallinnossa - samoin kuin tarve vahvistaa hallitusvaltaa ${ }^{295}$.

Hallintovaliokunta esitti hyvin yksityiskohtaisen mallin kirkon keskushallinnon uudistamiseksi. Sitä olivat olleet muotoilemassa valiokunnan jäsenistä puheenjohtaja Heikki Mäkeläisen ohella erityisesti Fredric Cleve ja Seikko Eskola ${ }^{296}$. Tavallaan valiokunta toimi uudistusko- 
miteana. Se esitti, että kirkolliskokous asettaisi komitean laatimaan lakitekstin valiokunnan mietinnön peruslinjojen mukaan. ${ }^{297}$ Vaikka kirkolliskokouksen täysistunto ei halunnut sitoa uutta komiteaa yhtä selväsanaisesti valiokunnan mietintöön kuin valiokunta itse, Kalevi Toiviaisen johtama komitea seurasi hallintovaliokunnan viitoittamaa tietä. Periaatteellinen mutta käytännössä pieni ero oli siinä, että komitean mielestä kirkkohallitus tuli muuttaa uudenlaiseksi keskushallintoelimeksi, kun taas valiokunta oli ehdottanut uutta keskushallintoelintä kirkkohallituksen tilalle. Valiokunnan ehdotuksessa piispat ja papit muodostivat vain hieman yli kolmanneksen kirkkohallituksen kokoonpanosta, mutta Toiviaisen komitean ehdotuksessa maallikkoedustajien määrä supistui niin, että piispoja ja pappeja oli lähes puolet kirkkohallituksen jäsenistä. ${ }^{298}$ Tässä suhteessa Toiviaisen komitean esitys merkitsi paluuta kohti laajennettua piispainkokousta, jossa piispat ja papit olivat käyttäneet merkittävää valtaa. ${ }^{299}$

Komitea ehdotti, että kirkon keskukset siirrettäisiin uusimuotoisen kirkkohallituksen alaisuuteen ja että 1970-luvun alussa piispainkokoukselle uskotut hallintotehtävät siirrettäisiin kirkkohallitukselle. ${ }^{300}$ Komitea pyrki ottamaan huomioon erilaisia katsantokantoja, ja sen mietintö saikin melko suopean vastaanoton. Muutenkin jyrkät asenteet kirkon hallinnon uudistamista kohtaan olivat pitkien, väsyttävien kiistojen jälkeen lientyneet..$^{301}$ Keskushallinnon uudistamisessa oli siten havaittavissa 1980-luvun loppua kohti sama muutos kuin suhtautumisessa kirkollisten vaalien tunnuksiin. Piispainkokouksella oli kuitenkin edelleen huoli siitä, että valta keskittyisi liiaksi kirkkohallitukselle ja sen virkamiehille ${ }^{302}$.

Kirkolliskokous kuuli tämän huolen. Se päätti säilyttää piispainkokouksen toimivallan samoin kuin sen aloiteoikeuden kirkolliskokouksessa pääosin entisellään. Samaten kirkolliskokous säilytti vastoin komitean ehdotusta hiippakuntakokousten oikeuden lähettää aloitteita kirkolliskokoukselle. Kirkon sopimusvaltuuskuntakin päätettiin jättää erilliseksi elimeksi, joskin valtuuskunnan toimistosta muodostettiin kirkkohallituksen palkka- ja henkilöstöosasto. Kirkon keskusten osalta Mikko Juvan ajama hallinnonuudistus saatiin kuitenkin viedyksi johdonmukaiseen päätökseensä: keskukset siirtyivät hallinnollisesti kirkkohallituksen toimistoiksi. ${ }^{303}$
Kirkolliskokouksen tekemien tarkistusten myötä uudistukselle saatiin niin selvä kannatus, että se voitiin liittää osaksi kirkkolainsäädännön kokonaisuudistusta. ${ }^{304}$ Näin kirkkolain kokonaisuudistukseen, jonka alkuperäisenä tarkoituksena oli ollut välttää vaikeita periaatteellisia kysymyksiä, saatiin liitetyksi kirkolliskokouksessa kaikkein eniten kiistaa aiheuttanut hallinnollinen asiakokonaisuus. Vuodesta 1994 kirkolla olisi uudenlainen keskushallinto.

Koska kirkolliskokous vähensi kirkkohallituksen tehtäviä ja valtaa Toiviaisen komitean esitykseen verrattuna, se supisti myös elimen jäsenmäärää komitean ehdottamasta. Lopullisen päätöksen mukaan kirkkohallituksessa oli 13 jäsentä: arkkipiispa, kaksi muuta piispaa, kaksi pappia ja kahdeksan maallikkoa. ${ }^{305}$ Siten ainoaksi suureksi poikkeukseksi aiempaan kokoonpanoon jäi virassa olevien kirkkoneuvosten poistuminen täysistunnon kokoonpanosta. Keskusten liittäminen kirkkohallitukseen merkitsi johdonmukaista toiminnallisen hallinnon keskittämistä. Piispainkokous säilyi pitkälti entisenlaisena hallintoelimenä. Sen rooli oli kuitenkin heikosti hahmottunut, eikä sillä ollut kattavaa, pysyvää valmisteluorganisaatiota. Sen epäselvää asemaa kuvasti, että kirkolliskokous päätti säilyttää piispainkokouksen hallinnollisen aseman samalla nuijankopautuksella, jolla se sivuutti piispainkokouksen yksimielisen lausunnon kirkollisen äänioikeuden edellytyksistä.

\section{NAISEN PÄÄSY PAPIKSI JA PIISPAKSI PUHUTTAA KIRKOLLISKOKOUSTA \\ JA MEDIAA}

\section{NAISPAPPEUSALOITTEET KARIUTUVAT, PAINE KASVAA}

Pappisviran avaaminen naisille oli 1970-luvun lopulla ja seuraavan vuosikymmenen alussa piispainkokouksen käsiteltävänä. Asiaa selvitti Porvoon piispan John Vikströmin johtama työryhmä. Ilkon kurssikeskuksessa Kangasalla järjestettiin kaksi seminaaria, joihin kutsuttiin keskustelemaan niin naispappeuden kannattajia kuin vastustajia. ${ }^{306}$ Teologinen työskentely ei kuitenkaan enää loppuvaiheessa lisännyt merkittävästi yksimielisyyttä, eikä myöskään piispainkokous löytänyt yhtenäistä kantaa. Kirkolliskokouksen toimeksianto oli 
ollut, että piispainkokous tekisi asiasta esityksen sopivaksi katsomanaan ajankohtana. Sellaista ei näyttänyt olevan tulossa. Paineet kirkossa kuitenkin kasvoivat: kun naispappeuteen ei voinut puuttua, kirkolliskokoukseen tuli aloitteita lehtorin oikeuksien laajentamisesta lähes papin tehtäviä vastaaviksi. Syksyllä 1981 vaalikauden päättyessä Aimo T. Nikolainen ja Meeri Päivänsalo esittivät täysistunnossa toivomuksen, että "seuraava kirkolliskokous tekee sen, mihinkä tämä kirkolliskokous ei ole pystynyt". ${ }^{307}$

Piispainkokouksella ei ollut muuta vaihtoehtoa kuin saattaa asia kirkolliskokouksen käsittelyyn 1983. Vuoden 1976 tavoin se ei kuitenkaan edelleenkään saanut ilmaistuksi omaa kantaansa eikä siten tehdyksi esitystä, jota kirkolliskokous oli alun perin siltä pyytänyt. Kirkolliskokous sai tyytyä selontekoon asian valmisteluvaiheista ja saavutetuista teologisista tuloksista. ${ }^{308}$ Turun kristillisellä opistolla oltiin hyvin tyytymättömiä piispainkokouksen "nollaratkaisuun" ja vetäytymiseen jälleen kirkolliskokouksen selän taakse. ${ }^{309}$ Jaakko Voipio jätti edustaja-aloitteen pappisviran avaamisesta naisille, jotta kirkolliskokous voisi tehdä asiassa ratkaisun. ${ }^{310}$ "Voipio uskalsi enemmän kuin piispat ja edustaa varmasti useimpien kansankirkkomme jäsenten mielipidettä, totesi toimittaja Markku Laitinen Uudessa Suomessa. ${ }^{31}$

Yksi Ilkon seminaarien tuloksista oli, että lain ja evankeliumin erottelua ryhdyttiin soveltamaan kirkon virkaan. Tällöin keskeinen kysymys oli, kuuluiko pappisviran hoitajan sukupuoli muuttuvan rakkauden lain vai pysyvän, armoa välittävän evankeliumin alueelle. Naispappeuden sijoittaminen rakkauden lain alueelle tarjosi opillisen perustelun pappisviran avaamiseksi naisille. Vastustajat taas katsoivat, ettei lain ja evankeliumin erottelu ollut tarkoitettu Raamatun sanan tai yksittäisten opinkohtien sitovuuden määrittämiseen vaan omientuntojen hoitamiseen. ${ }^{312}$ Ilkon seminaarien ehkäpä merkittävimmäksi tulokseksi nousi arvioissa se, että niissä oli saavutettu laaja yksimielisyys konstitutiivisesta virkakäsityksestä: virka oli olemassa jumalallisesta asetuksesta. ${ }^{313}$ Tosin merkittävä siirtymä funktionalistisesta virkakäsityksestä konstitutiiviseen oli tapahtunut jo virkakomitean mietintöjen ja niiden kirkolliskokouskäsittelyn myötä vuosina 1975 ja 1976. Joka tapauksessa käsitysten tietty vakiintuminen näkyi siinä, ettei virkateologiasta enää puhuttu paljoakaan piispainkokouksen selontekoa käsiteltäessä. Moni katsoi sen tien kuljetuksi loppuun: oli ratkaisujen aika.

Keskustelussa kiinnitettiin huomiota tuoreeseen kyselytutkimukseen, jonka mukaan papiston keskuudessa naispappeuden vastustus oli voimakasta. Kantansa päättäneet jakautuivat lähes tasan naispappeuden kannattajiin ja vastustajiin, ja runsas kymmenesosa ei ottanut kantaa. Naispappeuden vastustajia oli erityisesti nuorten pappien keskuudessa. ${ }^{314}$ Tulokset heikensivät naispappeuden kannattajienkin optimismia siitä, että yhteistyöongelmat vähenisivät vuosien myötä. ${ }^{35}$ Lehdistössä vastustuksen syyksi luettiin yleisesti kilpailu papinviroista. ${ }^{316}$ Merkitystä oli kuitenkin myös nuorten pappien entistä vahvemmilla herätysliiketaustoilla sekä mahdollisesti myös sillä, että tätä pappispolvea olivat opettaneet monet aiempaa korkeakirkollisemman virkateologian omaksuneet teologit. Jotkin lehdet ottivatkin tällaiset seikat huomioon. ${ }^{317}$

Syysistuntokaudella 1983 sai suuren huomion arkkipiispa John Vikströmin lehdistötilaisuudessa esittämä ajatus. Hän ehdotti Fredric Cleven täysistuntopuheenvuoron pohjalta pehmeää laskua naispappeuteen: seurakunnat saisivat päättää, kutsuisivatko ne itselleen naispapin. Ajatus jakoi mielipiteitä niin naispappeuden kannattajien kuin vastustajien keskuudessa. Kysyttiin, muuttuisiko viran jumalallinen asetus tällä tavoin lähinnä kirkolliseksi asetukseksi. ${ }^{318}$ Esitetty ajatus vaikutti kuitenkin epäilemättä perustevaliokunnan mietintöön. Valiokunnan enemmistö esitti naispappeuden hyväksymistä mutta samalla tiettyjä varauksia. Valiokunnassa Jaakko Voipio laati kirkkolain muutosehdotukset, joiden myötä seurakunnalle varattaisiin vastaisuudessa tilaisuus antaa tuomiokapitulille lausunto ennen ylimääräisen papin määräämistä seurakuntaan. Samaten piispanvirkaan jo vihitty saisi oikeuden kieltäytyä vihkimästä naista papiksi. ${ }^{319}$

Piispainkokous asettui näitä perustevaliokunnan lisäyksiä vastaan. ${ }^{320}$ Esimerkiksi Olavi Rimpiläinen kieltäytyi määrätietoisesti kaikesta erityiskohtelusta, mikäli papeillekaan ei sellaista suotu. Myöhemmin kirkolliskokouksessa kaatuivat muutkin ehdotukset, joiden tarkoituksena oli lisätä yksittäisten seurakuntien mahdollisuuksia valita pappinsa sukupuoli. ${ }^{321}$ Kirkolliskokouksen mielestä oli parempi äänestää naispappeuden hyväksymisestä sellaisenaan, ilman läpimenoa helpottavia mutta 
samalla epätasa-arvoa lisääviä lainkohtia. Taustalla näkyivät myös suunnitelmat uudeksi tasa-arvolainsäädännöksi. Kirkolliskokous ei katsonut olevansa enää yhtä vapaa päättämään erilaisista omantunnonsuojista kuin 1970-luvulla.

Neljä perustevaliokunnan jäsentä jätti eriävän mielipiteen, jossa he torjuivat naispappeuden raamatullisin ja opillisin perustein. Lisäksi kirkkoherrat Jorma Laulaja ja Matti Sihvonen jättivät omat eriävät mielipiteensä, joita yhdisti ajatus, ettei naispappeuden toteuttamisen aika ollut vielä. ${ }^{322}$ Antaessaan lausuntonsa perustevaliokunnan mietinnöstä piispainkokouskaan ei voinut enää jättää ottamatta kantaa asiaan. Äänestyksessä selvä enemmistö asettui naispappeuden kannalle. Piispat Olavi Rimpiläinen ja Jukka Malmivaara sekä asessori Reijo Mattila äänestivät vastaan ja Helsingin piispa Samuel Lehtonen tyhjä. ${ }^{323}$

Kirkolliskokouksen täysistuntokeskustelun alkaessa keväällä 1984 tunnelma oli latautunut. Yhtenä syynä oli Uudessa Suomessa julkaistu, huomiota herättänyt ministeri Gustav Björkstrandin haastattelu. Haastattelun mukaan Björkstrand epäili, ettei valtiovalta sivuuttaisi vaieten kirkolliskokouksen mahdollista kielteistä äänestyspäätöstä. ${ }^{324}$ Kirkolliskokouksessa Björkstrand varasi puheenvuoron heti täysistuntokeskustelun alkuun rauhoittaakseen tilannetta ja vakuuttaakseen, että julkisuudessa esiintyneet tiedot olivat vääriä. Valtiovalta ei puuttuisi kirkon päätöksiin, eikä sillä olisi siihen valtaakaan. Björkstrand itse sen sijaan ilmaisi selvän mielipiteensä: voimassa olleet kirkkolain säännökset olivat ristiriidassa YK:n yleissopimuksen kanssa, eikä kirkolla ollut uskottavuutensa tähden varaa lykätä ratkaisua. Kannanotto oli sanonnaltaan selvästi voimakkaampi kuin ministeri Marjatta Väänäsen puheenvuoro kahdeksan vuotta aiemmin. Vuosien kuluessa tilanne oli kärjistynyt, mutta kyse oli myös siitä, että samalle vaalikaudelle alun perin pappisedustajaksi valitun Björkstrandin oli helpompi ottaa kantaa kuin kirkolliskokouksen ulkopuolelta tulevan ministerin..$^{325}$

Keskustelun alkaessa tilanne oli muillakin tavoin jännittynyt. Ortodoksisen kirkon arkkipiispa Paavali ja metropoliitta Johannes olivat ottaneet juuri ennen kirkolliskokousta voimakkaasti kantaa naispappeutta vastaan. ${ }^{326}$ Naispappeuden vastustajat - jopa muutoin ekumeniaan hyvin kielteisesti suhtautuneet viidennen herätysliikkeen ja vanhoillislestadiolaisuuden edustajat - vetosivat ortodoksisen kirkon kantaan. Kouvolan kappalainen Rafael Repo näki ortodoksisen kirkon aseman ja arvostuksen suomalaisessa yhteiskunnassa myös merkkinä siitä, ettei mukautuminen maailmaan kannattanut. ${ }^{327}$ Naispappeuden kannattajat taas totesivat hämmentyneinä, että vain luterilaista kirkkoa syytettiin epätasa-arvoisuudesta, vaikka toinen kansankirkko ei edes keskustellut pappisviran avaamisesta naisille. Naispappeuden kannattajat eivät kuitenkaan lähteneet kirkolliskokouspuheenvuoroissa arvostelemaan ortodoksipiispojen kannanottoja. ${ }^{328}$ Sen sijaan ministeri Björkstrand vaati mielipidekirjoituksessaan johdonmukaisuutta: samaan aikaan kun metropoliitta Johannes moitti häntä puuttumisesta kirkon asioihin, ortodoksipiispat itse ottivat voimakkaasti kantaa luterilaisen kirkon sisäisiin päätöksiin. ${ }^{329}$

Kirkolliskokousedustajat saivat monia muitakin vetoomuksia. Lehtien pääkirjoituksissa vaadittiin laajalti pappisviran avaamista naisille. ${ }^{330}$ Luterilaisilta naiskansanedustajilta tuli kirkolliskokousedustajille kirje, jonka yhteiskunnalliset tasa-arvoperustelut eivät tosin miellyttäneet kaikkia naispappeuden kannattajiakaan. ${ }^{331}$ Uudistuksen vastustajat saivat tuekseen SLEYKirjojen kustantaman kokoomateoksen Herran käsky, joka lähetettiin kirkolliskokousedustajille. Kirjan myötä myös evankelisessa liikkeessä vaikuttaneet erilaiset kannat virkakysymykseen nousivat aiempaa selvemmin julkisuuteen. ${ }^{332}$ Kirja sisälsi analyysia virkakeskustelun historiasta, mutta samalla tähtäyspiste oli selvä: jo esipuheessa Ruotsin edellisvuosien tapahtumat - valtiokirkollistuminen ja naispappeutta koskeneen omantunnonklausuulin poistaminen - rinnastettiin Saksan kirkkotaisteluun. ${ }^{333}$

Arkkipiispa Vikström tarttui kirjan raamattuargumentaatioon. Hän arvosteli sitä vedoten niin Pohjoismaiden eksegeettien valtaenemmistön kuin katolisen kirkon raamattukomission ja uskonopin kongregaation kantoihin. Vikströmin mukaan naispappeuskysymyksen traagisin puoli oli siinä, että virkaa koskeva ja rakkautta koskeva Jumalan käsky näyttivät sotivan toisiaan vastaan. Jotkut selittivät asian niin, ettei naispappeudessa ollutkaan kyse oikeudenmukaisuudesta ja tasa-arvosta, mutta Vikström kysyi: "Mitä on sellainen oikeudenmukaisuus, jota ei tarvitse toteuttaa? Onko kirkon virka 
ainoa paikka, jossa meidän on tyydyttävä vain periaatteelliseen tasa-arvoon? Onko viran kohdalla käytettävä sellaisia perusteluja, joilla muualla maailmassamme saatetaan ylläpitää mitä räikeintä syrjintää?"334

Lehdissä arkkipiispan puhetta luonnehdittiin vaikuttavaksi, ja hänen katsottiin asettaneen arvovaltansa peliin. ${ }^{335}$ Naispappeuden vastustajien keskuudessa arkkipiispaa moitittiin sen sijaan istuntosalin ulkopuolella siitä, että hän oli yrittänyt käyttää virkaansa hyväkseen asiansa ajamisessa. Vikström otti syytökset raskaasti ja ilmoitti vaikenevansa asiassa, vaikka oli valmistellut toisenkin puheenvuoron keskusteluun. ${ }^{336}$ Joka tapauksessa Vikströmin rooli oli aivan toisenlainen kuin Martti Simojoen 1970-luvulla. Simojoki oli varonut ottamasta kantaa, mutta Vikström vetosi voimakkaasti naispappeuden puolesta. Ulkoisen paineen koko ajan kasvaessa arkkipiispan olisi ollut vaikea vaieta.

Istuntokauden avauspuheessaan arkkipiispa Vikström oli vedonnut edustajiin, jotta kukin heistä pysyisi tarpeeksi riippumattomana omista taustaryhmistään. Vain siten todellinen keskustelu olisi mahdollista. ${ }^{337}$ Toive ei toteutunut, vaan edustajat lukivat valmiiksi kirjoitettuja, taustaryhmiensä lähtökohdista nousevia puheenvuoroja. ${ }^{338}$ Kuvaavaa oli, että naispappeuden vastustajat viittasivat "Herran käskyyn" arkkipiispan puheen jälkeen yhtä ongelmattomasti kuin ennenkin, vaikka Vikström oli kyseenalaistanut kyseisen perustelun. Kaikkiaan hieman yli puolet kirkolliskokousedustajista puhui täysistuntokäsittelyssä. Luku piti sisällään kirkolliskokouksen naisedustajien joukkoesiintymisen, jollainen oli nähty edellisenäkin vuonna asiasta keskusteltaessa ${ }^{339}$. Argumentaation painopiste oli siirtynyt Raamatusta ekumeniaan, mikä omalta osaltaan lisäsi ortodoksipiispojen lausuntojen painoarvoa ja myös herkisti tilannetta.

Ratkaisevassa äänestyksessä 73 edustajaa äänesti naispappeuden puolesta ja 32 vastaan. ${ }^{30}$ Tarvittava määräenemmistö jäi kuuden äänen päähän. Vaikka vastaan äänestäneiden määrä oli supistunut vuodesta 1976, se oli vähentynyt vain viidellä. Nopea asennemuutos 1960- ja 1970-luvulla oli nostattanut toiveita, että naispappeuden toteutuminen olisi lähellä, mutta 1980-luvun todellisuus oli toisenlainen. Pappisedustajien äänestystulos vastasi tarkalleen sitä kyselytutkimusta, joka oli toteutettu edellisenä vuonna papiston keskuudessa: kantansa ratkais- seiden äänet jakaantuivat tasan puolesta ja vastaan, ja lisäksi oli pieni joukko tyhjää äänestäneitä ${ }^{34}$. Vuoden 1982 kirkolliskokousvaaleissa naispappeus ei ollut ollut kantava teema, eikä vaaleissa ollut kohonnut ylittämättömiä raja-aitoja eri kantoja edustavien pappien välille. Tässä tilanteessa pappisedustajien enemmistövaali oli tuonut hyvin edustavan otoksen papistosta kirkolliskokoukseen. Kuvaavaa oli, että vain kahdessa hiippakunnassa kaikki pappisedustajat olivat äänestyksessä keskenään samalla kannalla.

Kyselytutkimukset osoittivat samoihin aikoihin, että noin 77 prosenttia kansasta kannatti naispappeutta. ${ }^{342}$ Luvun perusteella ainakin joidenkin lehtien oli helppo todeta, että kansan ylivoimainen enemmistö vaati naispappeuden toteuttamista ja että kirkolliskokous osoitti vanhoillisuutensa hylätessään esityksen. ${ }^{343}$ Osa kyselytutkimukseen vastanneista oli kannastaan epävarmoja, mutta siitä huolimatta on huomiota herättävää, että kannattajien osuus kaikista vastanneista ylitti vain niukasti kirkolliskokouksen määräenemmistövaatimuksen. Kaiken lisäksi naispappeuden puolesta äänestäneiden osuus maallikkoedustajista oli hyvin tarkasti sama kuin kyselytutkimuksen mukaan naispappeutta kannattavien osuus koko väestöstä. Kun vielä kirkolliskokouksen pappisedustajien kannat vastasivat koko papiston mielipidejakaumaa, voi päinvastoin arvioida kirkolliskokousvaalien toteutuneen edustuksellisen demokratian periaatteiden mukaisesti.

Esityksen kaatuminen sai lehdistössä aikaan pettymystä, joskin lopputulosta oli osattu odottaa. Samalla oltiin varmoja, että asia nousisi uudelleen esiin ja että seuraavat kirkolliskokousvaalit käytäisiin naispappeusvaaleina. ${ }^{344}$ Heti naispappeusesityksen kaaduttua seitsemän edustajaa jätti aloitteen lehtorin oikeuksien laajentamiseksi. Aloitteentekijät vetosivat vuoden 1976 kirkolliskokouksen päätökseen, jolla lehtori oli heidän mukaansa jo tuotu kirkollisen viran piiriin. Perustevaliokunta tosin oli tuolloin viimeisessä mietinnössään nimenomaan pidättynyt ottamasta kantaa lehtorinviran ja kirkon viran suhteeseen. Aloitteen perustelut kuvastivat hyvin sitä epäselvyyttä, joka oli sisältynyt vuoden 1976 päätökseen lehtorinviran kehittämisestä. ${ }^{345}$ Kirkolliskokous jätti aloitteen raukeamaan. ${ }^{346}$ Sen sijaan se asetti hieman myöhemmin komitean selvittämään kattavasti lehtorinviran hallinnollista ja kirkko-oikeudellista asemaa. ${ }^{347}$ 
Kirkosta erosi vuonna 1984 yli 22000 jäsentä. Määrä oli uuden veronkantojärjestelmän aikana ennätyksellinen, ja varsinkin kirkolliskokouksen päätöksen jälkeisinä viikkoina tavallista useampi eroaja oli nainen..$^{348}$ Eroaalto oli päällimmäisenä syynä siihen, että kirkolliskokous sai käsiteltäväkseen vielä saman vaalikauden aikana uuden naispappeusaloitteen. Sen ensimmäisinä allekirjoittajina olivat Meeri Päivänsalo ja Jaakko Voipio. Aloitteeseen oli kytketty monia lainmuutoksia, joiden tarkoituksena oli hidastaa naispappeuden toimeenpanoa. Näin "myös sen vastustajilla olisi aikaa siihen kypsyä".349

Aloite ei saanut kirkolliskokouksessa ymmärtämystä, vaikka sen tekijät yrittivät selittää, että käynnistyneet hankkeet lehtorinviran teologiseksi selvittämiseksi vaativat rinnalleen myös naispappeusaloitteen. Ehdotuksen aloitteen suorasta hylkäämisestä teki lopulta mahdollisimman arvovaltainen henkilö, Kalevi Toiviainen, jonka johtamalle perustevaliokunnalle aloite oli suunniteltu lähetettäväksi. Mikkelin piispan mukaan ei juuri olisi voitu menetellä epäonnistuneemmalla tavalla kuin aloitetta jätettäessä. Aloite aliarvioi kirkolliskokousedustajia. Naispappeuden vastustajia ei voinut vakuuttaa "käytännön pikkunäpertelyllä".350 Kirkolliskokouksen varapuheenjohtaja ja Toiviaisen oman valiokunnan juristi saivat kuulla harvinaisen suorat sanat.

Kaikkein ongelmallisimpana Toiviainen piti kuitenkin aloitteeseen sisältyneitä lievennyksiä, jotka asettivat hänen mielestään naisen ja miehen keskenään entistä huomattavasti räikeämpään epätasa-arvoon. Aloitteessa miehille ja naisille oli määritelty samat tehtävät, mutta niihin valitseminen oli sidottu sukupuoleen: "Jos tämä ei ole silkkaa sovinismia niin mikä sitten." Voipio huomautti, että pehmennyksiä oli kyllä mahdollisuus poistaa, mutta niitä oli vaikea enää kirkolliskokouksen aikana lisätä. Lisäksi osa pehmennyksistä oli otettu Toiviaisen puheenjohdolla syntyneestä perustevaliokunnan mietinnöstä: "Sovinismia ne kai olivat sielläkin." ${ }^{351}$ Vuonna 1985 kirkolliskokouksessa käytiin kirpeämpää naispappeuskeskustelua kuin pitkään aikaan - ja pitkälti nimenomaan naispappeuden kannattajien kesken. Lopulta kaksi kolmesta kirkolliskokousedustajasta kannatti aloitteen hylkäämistä valiokuntaan lähettämättä352. Paitsi kirkolliskokouksen enemmistö myös lehdistö piti aloitetta huonosti harkittuna. ${ }^{353}$ Kielteistä naispappeuspäätöstä välittömästi seuranneet edustaja- aloitteet osoittivat vastaansanomattomasti, miten jännittyneessä vaiheessa naispappeuskysymys oli 1980-luvun puolivälissä.

\section{VUODEN 1986 ENNAKOITU HYVÄKSYMIS- PÄ̈̈TÖS JA ARVAAMATON OMANTUNNONSUOJA}

Vuoden 1986 kirkolliskokousvaalien jälkeen oli selvää, että pappisvirka avattaisiin naisille. Kyselyt osoittivat, että asialla oli takanaan määräenemmistö. ${ }^{354}$ Keskustelun painopiste siirtyi uudistuksen perusteluista tulevaisuudennäkymiin ja kirkon ykseyden säilyttämiseen. ${ }^{355}$ Naispappeuden vastustajat eivät kuitenkaan täysin luovuttaneet. Timo Holma ja Enon kirkkoherra Jouko Pesonen jättivät aloitteen kirkolliskokouksen työjärjestyksen muuttamiseksi siten, että määräenemmistöä vaativissa asioissa toisen käsittelyn äänestys olisi mahdollista toteuttaa suljettuna lippuäänestyksenä. ${ }^{356}$ Näin aloitteentekijät yrittivät järjestää naispappeuden kannattajiksi ilmoittautuneille edustajille mahdollisuuden vaihtaa mielipidettään ilman julkisuuden painolastia. Useimmat edustajat korostivat kuitenkin kirkolliskokoustyön julkisuutta ja pelkäsivät suljetun lippuäänestyksen aiheuttavan spekulaatioita. Aloite hylättiin suoraan. ${ }^{357}$ Naispappeuskeskustelulle olivat pitkin matkaa tyypillisiä aloitteet, jotka eivät varsinaisesti käsitelleet naispappeutta mutta nousivat suoraan tästä pääkysymyksestä.

Naispappeus tuli kirkolliskokouksen käsittelyyn keväällä 1986 kahden aloitteen pohjalta. Porvoon hiippakuntakokous lähetti yleisluonteisen aloitteen naispappeuden hyväksymisestä, kun taas 77 maallikko- ja pappisedustajaa jätti yksityiskohtaisen lakitekstin sisältävän aloitteen. ${ }^{358}$ Teologian tohtori Tapani Vuorela hoiti nimien keruun edustaja-aloitteeseen. ${ }^{359}$ Edustajaaloitteen lakiteksti seurasi perustevaliokunnan mietintöä vuodelta 1984. Johannes Leivosen johdolla siihen oli kuitenkin laadittu lisäys, jonka mukaan vakinaisen papinviran täyttö voitiin painavista syistä keskeyttää, mikäli toisenkin hakuajan jälkeen virkaan oli ilmoittautunut vain yksi hakija ${ }^{360}$ Lisäys sai kirkolliskokouksessa tukea erityisesti naispappeuden kannattajilta: lainkohta ei ollut ketään syrjivä, mutta se antoi tuomiokapitulille harkintavaltaa tilanteessa, jossa seurakunta ei halunnut ottaa vastaan ainoana hakijana ollutta naispappia. ${ }^{361}$ Myös perustevaliokunta otti tämän lainkohdan mukaan esittäessään naispappeuden hyväksymistä. ${ }^{362}$ 
Kevätistuntokaudella 1986 edustajilta kerättiin allekirjoituksia aloitteeseen pappisviran avaamiseksi naisille. Aloitetta allekirjoittajamassa rehtori Esko Tokola, jonka vierellä aloitteen lakiteksteistä vastannut oikeusneuvos Johannes Leivonen. Kuvassa lisäksi etualalla tuomiorovasti Jussi Ranta sekä teologian tohtorit Kyllikki Tiensuu, Heikki Mäkeläinen ja Tapani Vuorela. Vuorela vastasi nimien keruusta ja sai lopulta kokoon 77 allekirjoitusta. Kuva: Kotimaan kuva-arkisto / Jukka Granström.

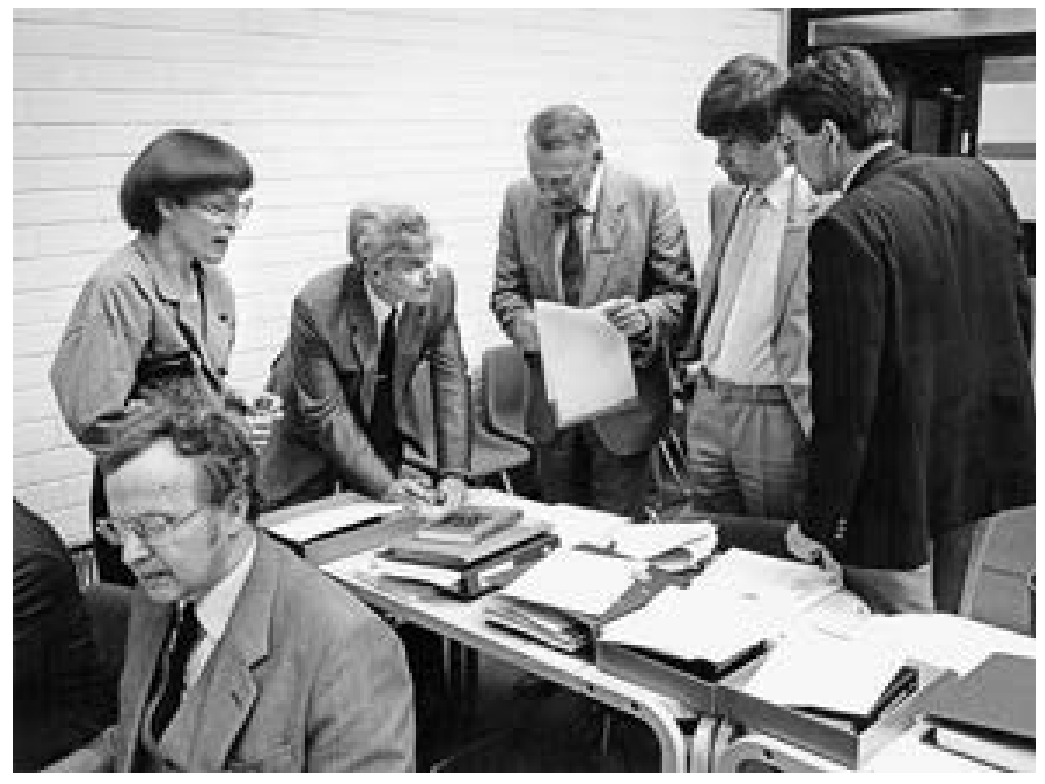

Perustevaliokunnassa virkapäätöksen jälkivaikutukset ja kysymys omantunnonklausuulista olivat muutenkin polttavimpia ja veivät enemmän huomiota kuin päätöksen varsinaiset teologiset perustelut. Perusteltaessa pappisviran avaamista naisille mietinnössä korostui viran tehtävä. ${ }^{363}$ Piispainkokous huomauttikin lausunnossaan perustevaliokunnan painottaneen viran funktiota siinä määrin, että viran konstitutiivinen luonne jäi sivuun. ${ }^{64}$ Professori Jouko Martikainen ja häneen liittyen monet naispappeutta vastustavat kirkolliskokousedustajat ilmaisivat asian suorempaan todeten mietinnön olevan "löysää, kiireessä tehtyä ja suoraan sanoen kevytmielistä edessä olevan kauaskantoisen ratkaisun kannalta". ${ }^{65}$ Arvio oli hyvin värittynyt, mutta ainakin sikäli sillä oli pohjaa, että periaatteellisesti yleisen hyväksynnän saanut konstitutiivinen virkakäsitys uhkasi jälleen kerran rakoilla ratkaisuvaiheessa.

Piispa Yrjö Sariola esitti lähetekeskustelussa huolensa kirkon ykseydestä ja ajatuksen erillisestä ponsilausumasta. ${ }^{366}$ Piispainkokous liittyi Sariolan ilmaisemaan huoleen ja ehdotti kirkolliskokouksen hyväksyttäväksi lisäponsia. Ensinnäkin piispainkokous ehdotti toteamusta, ettei kirkko päätöksellään muuttanut oppiperustaansa. Toiseksi piispainkokous ehdotti hyväksyttäväksi periaatteen, jonka mukaan "myös niillä kirkon jäsenillä ja viranhaltijoilla, jotka suhtautuvat torjuvasti pappisviran avaamiseen naisille, tulee edelleen olla kirkossamme täysi toiminnan vapaus ja mahdollisuus tulla vihityksi ja nimitetyksi Suomen evankelis-luterilaisen kirkon eri virkoihin" ${ }^{367}$

Piispainkokouksen sovitteleva henki sai kiitosta erityisesti maakuntalehdistöltä ja herätti toiveita siitä, että uudistus voitaisiin toteuttaa sopuisasti. ${ }^{368}$ Erityisen merkittävä oli Mikko Juvan puheenvuoro Turun Sanomissa huhtikuussa 1986. Entinen arkkipiispa peräänkuulutti naispappeutta vastustavien kotipaikkaoikeutta kirkossa. ${ }^{369}$ Tunnelmat alkoivat kuitenkin muuttua lokakuussa ratkaisevan kirkolliskokouskäsittelyn lähetessä. Tuolloin julkisuuteen tuli tietoja naispappeuden vastustajien kokoamasta kirjelmästä, jonka oli allekirjoittanut yli 400 pappia. Nyt puhuttiin jo jonkinlaisesta hajaannuksesta ja pohdittiin seurauksia, jos 15 prosenttia papistosta kieltäytyisi yhteistyöstä naispuolisten kollegojensa kanssa. ${ }^{30}$ Koska varsinaisen naispappeusäänestyksen tulos oli jo etukäteen selvä, kirjelmän päällimmäinen tarkoitus oli saada kirkolliskokous takaamaan vastustajille omantunnonvapaus. ${ }^{37}$

Aloitteentekijät ja perustevaliokunta olivat pyrkineet parantamaan seurakuntalaisten omantunnonvapautta lakimuutoksilla, ja piispainkokous yritti ottaa ponsiehdotuksellaan lisäksi huomioon kirkon työntekijöiden omantunnonvapauden. Yllättäen ensin mainitut 


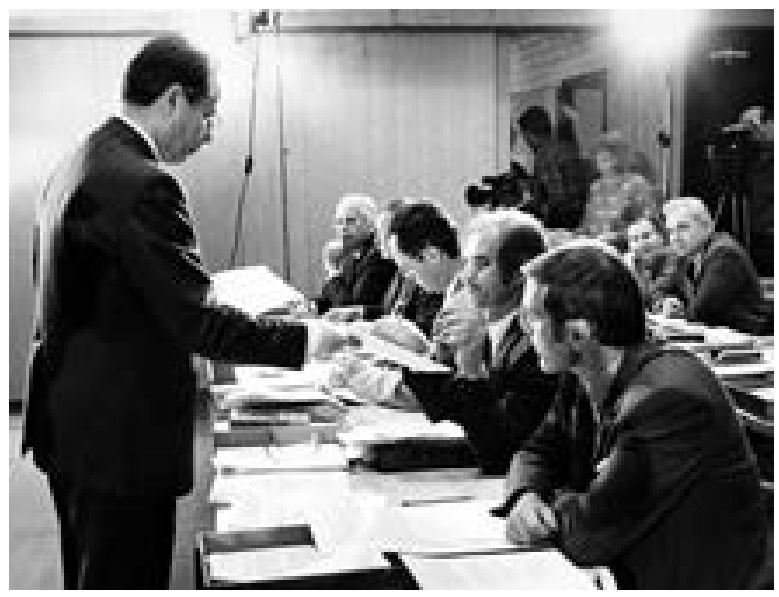

Kirkkoherra Timo Holma luovutti kirkolliskokouksessa piispoille Paavalin synodin kokoaman vetoomuksen, jonka oli allekirjoittanut yli 400 pappia. Vastaanottovuorossa Kuopion piispa Matti Sihvonen, joka vielä pari vuotta aiemmin oli vastustanut pappisviran avaamista naisille silloisessa tilanteessa. Vuonna 1986 hän antoi kuitenkin jaa-äänen. Kuva: Kotimaan kuva-arkisto / Jukka Granström.

toimenpiteet saivat osakseen eniten arvostelua naispappeuden vastustajilta, joita palvelemaan ne oli alun perin tarkoitettu. He arvelivat, että lainkohtaa käytettäisiin ennemminkin muissa tarkoituksissa. ${ }^{372}$ Timo Holman mukaan lähinnä poliittisesti valittu, ehtoollisyhteydestä vieraantunut kirkkoneuvosto saattaisi jossakin seurakunnassa torjua tämän lainkohdan perusteella ainoan hakijan, jota ydinseurakunta kuitenkin tarvitsi. ${ }^{373}$ Naispappeuden vastustajaa ei ehkä suostuttaisikaan ottamaan seurakunnassa vastaan. Kaikkiaan Holman perustelut eivät ilmentäneet erityistä luottamusta seurakunnan päättäjiä kohtaan. Tällaisista epäilyksistä huolimatta uusi säännös hyväksyttiin selvällä enemmistöllä ${ }^{374}$.

Myöhemmin vielä kirkkolain uudistamiskomitea liitti mietintöönsä perustevaliokunnan 1984 ehdottaman lainkohdan, jonka mukaan tuomiokapitulin tuli hankkia seurakunnalta lausunto ennen kuin se määräsi papin seurakuntapastorin virkaan..$^{375}$ Naispappeusasian käsittelyn kylkiäisenä seurakunnat saivat selvästi aiempaa enemmän vaikutusvaltaa pappiensa valinnassa. Toki samaan aikaan monet muutkin kehityskulut veivät tähän suuntaan. Työalojen eriytyessä seurakunnat halusivat päästä valitsemaan sopivan papin kuhunkin tehtävään. Samaten seurakunnat palkkasivat entistä useampia maallikkotyöntekijöitä, jotka ne saivat valita hyvin vapaasti. Tässä tilanteessa se mahdollisuus, että tuomiokapituli määräisi ylimääräisen papin seurakuntaa kuulematta, näytti vanhentuneelta.

Vuoden 1986 keskusteluissa naispappeuden vastustajat puhuivat hyvin aktiivisesti. Vaikka ratkaisu oli jo etukäteen selvillä, sellaisetkin, jotka aiempina vuosina olivat vaienneet, intoutuivat lausumaan mielipiteensä pöytäkirjaan ja täyttämään siten äänestäjien odotukset. Samaa asiaa ajoivat eri herätysliikkeiden nimissä pidetyt ryhmäpuheenvuorot. Varsinkin lähetekeskustelussa moni edustaja kiitteli keskustelun hyvää henkeä, mutta päätöksen lähetessä mielipiteet kovenivat ja kiitokset vähenivät. Huomiota herättivät lähinnä naispappeutta vastustaneen Henrik Perret'n sovittelevat puheenvuorot. ${ }^{376}$

Kirkolliskokous päätti äänin 87-21 esittää pappisviran avaamista naisille. ${ }^{377}$ Median edustajien salamavalot täyttivät kokoussalin, mutta muuten tunnelma oli rauhallinen. Naisedustajat olivat jo etukäteen sopineet pidättyvänsä suosionosoituksista kunnioittaakseen vähemmistöön jääneitä ${ }^{37}$. Yhteensä yli puolet vastustajista tuli Oulun ja Kuopion hiippakunnista. Aiempiin äänestyksiin verrattuna naispappeuden kannattajien määrä oli kuitenkin kasvanut näissäkin hiippakunnissa. Ainoa hiippakunta, jonka edustajien keskuudessa vastustus oli vuosien saatossa lisääntynyt, oli Porvoo. Åbo Underrättelser muisteli kaiholla aikoja, jolloin yksikään hiippakunnan edustaja ei ollut äänestänyt naispappeutta vastaan. ${ }^{379}$ Nyt vastaan äänestäneitä oli kaksi, mikä pienessä hiippakuntaryhmässä merkitsi jo huomattavaa osuutta.

Erityisesti oli kuitenkin merkille pantavaa, että naispappeutta kannattaneiden maallikkoedustajien määrä nousi vain kahdella verrattuna vuoteen 1984 . Esimerkiksi Helsingin Sanomat tulkitsi tämän tuloksen siten, että kirkolliskokousvaalit olivat heijastelleet lähinnä kirkon johdon eivätkä sen jäsenten mielipiteitä̈ ${ }^{80}$. Naispappeuden kannattajien ja vastustajien suhdeluku kirkolliskokouksessa vastasi kuitenkin edelleen hyvin pitkälti sitä kuvaa, jonka tutkimukset antoivat koko kansan mielipidejakaumasta. ${ }^{381}$ Valtakunnan päälehden syytöksellä ei ollut kovinkaan vahvaa pohjaa. Kirkolliskokous eteni muun yhteiskunnan tahtia siinäkin mielessä, että monet 1970-luvulla voimakkaasti ajetut uudistukset, kuten tasa-arvolaki, naisen oikeus päättää sukunimestään ja 
aiempaa vapaampi avioerolainsäädäntö, toteutuivat valtiollisessa lainsäädännössä nimenomaan 1980-luvulla ${ }^{382}$.

Jos naispappeuden kannattajien ja vastustajien suhdeluku olisi muuttunut muissa edustajaryhmissä saman verran kuin maallikkoedustajien keskuudessa, naispappeus olisi edelleen 1986 jäänyt hyväksymättä. Naispappeuspäätöstä ei ratkaissut 1986 käyttöön otettu maallikkoedustajien suhteellinen vaalitapa vaan se, että naispappeuskannan mukaan vedetyt rintamalinjat läpäisivät pappisedustajien enemmistövaalin. Naispappeutta vastustavien pappisedustajien määrä puolittui vuodesta 1984 vuoteen 1986, ja lopputuloksena oli, että kannattajien ja vastustajien suhdeluku oli lähes prosentilleen sama maallikko- ja pappisedustajien keskuudessa. Enemmistövaalitavan vuoksi naispappeutta vastustavat papit jäivät useimmissa hiippakunnissa kokonaan kirkolliskokouksen ulkopuolelle.

Vuonna 1984 vain kahdessa hiippakunnassa kaikki pappisedustajat olivat olleet keskenään samalla kannalla, mutta kaksi vuotta myöhemmin vain kahdessa hiippakunnassa oli enää hajontaa pappisedustajien mielipiteissä. Vuoden 1986 naispappeuspäätös, joka tulkittiin tuoreeltaan yleisesti demokratian voitoksi, perustuikin pappisedustajien vaalissa enemmistön muodostaneiden yksinvaltaan, joka toi kirkolliskokoukseen yksipuolisen otoksen papistosta. Tuolla kerralla yksipuolisuus tarkoitti sitä, että naispappeutta kannattanut pappien enemmistö rynnisti vaaleissa. Naispappeutta vastustanut merkittävänkokoinen vähemmistö ei saanut suhteellista osuuttaan vastaavaa paikkamäärää.

Ne kirkollisten vaalien piirteet, joita monet naispappeuden puoltajat olivat aiemmin syyttäneet epädemokraattisiksi, koituivat lopulta heidän voitokseen. Samalla tulos osoitti kouriintuntuvasti, että tiukassa kiistatilanteessa kolmen neljäsosan määräenemmistö oli paljon helpompi saavuttaa enemmistövaalitavalla, joka oli ollut käytössä määräenemmistösäännöksen syntyaikaan 180o-luvulla, kuin suhteellisella vaalitavalla, joka 190o-luvun jälkipuoliskolla vähitellen tuli kirkolliskokousvaaleihin. Ottaessaan suhteellisen vaalitavan kauttaaltaan käyttöön kirkolliskokous tiukensi käytännössä määräenemmistövaatimusta.

Median huomio ja julkisuuden paine keskittyivät erityisesti yhteen henkilöön, piispa Olavi Rimpiläiseen. Hän poistui istuntosalista annettuaan äänensä lakiesi- tyksen hylkäämiseksi. ${ }^{{ }^{83}}$ Sosiaalidemokraattinen Turun Päivälehti kertoi, miten "valokuvaajien armada" oli hyvissä ajoin sitä ennen polvistunut Rimpiläisen ympärille ja miten piispa oli joutunut antamaan äänensä kymmenien salamavalojen välkkyessä. Tilanne oli käynyt ylivoimaiseksi, ja Rimpiläinen oli poistunut. Saman puolueen Eteenpäin taas kertoi Rimpiläisen herättäneen ulosmarssillaan "hyvin maallista huomiota". Missä toinen näki "äärimmäisen suojattoman" piispan, toinen havaitsi ylpeän ulosmarssijan. ${ }^{84}$ Pelkästään Rimpiläisen poistumisen tulkinnat osoittavat, miten suhtautuminen Oulun piispaan vaihteli voimakkaasti keskenään ideologisesti hyvin samanlaisissakin tiedotusvälineissä ja miten tarkan seurannan alla hän oli.

Kun päätös oli tehty, keskustelu lisäponsista pääsi alkuun. Piispa Yrjö Sariola esitti kirkolliskokoukselle piispainkokouksen ponnet. Vaikka ponsien takana oli selvästi suurin osa piispoista, Sariola kantoi asiassa erityistä vastuuta. Evankelisesta liikkeestä tulevana ja SLEY:n johtokunnan jäsenenä hänellä oli huoli paitsi hiippakuntansa myös herätysliikkeensä ykseydestä. Hänen vastuutaan kasvatti sekin, että evankelisessa liikkeessä toimivat papit olivat kärsineet kirkolliskokousvaaleissa suuren tappion eivätkä olleet käyttämässä ääntään. Piispainkokouksen ensimmäinen ponsi, jonka mukaan kirkko ei päätöksellään muuttanut oppiperustaansa, viritti periaatteellisen keskustelun päätöksen luonteesta. ${ }^{385}$ Lopulta Sariola luopui ongelmalliseksi osoittautuneesta ponnesta: kirkolliskokouksen ei tullut lähteä arvioimaan päätöstään, jossa jo alusta pitäen oli lähdetty kirkkolain tunnustusperiaatteesta. ${ }^{386}$

Sitäkin tiukemmin Sariola ajoi toista pontta, joka koski naispappeutta vastustavien toiminnanvapautta kirkossa. Hän teki ponteen vielä lisäyksen, jonka mukaan kaikki olivat yhdessä vastuussa siitä, että muutoksen aiheuttamat vaikeudet pyrittäisiin voittamaan "keskinäisen yhteistyön avulla ja kirkon ykseyttä varjellen". Esitellessään lisäpontta Sariola vakuutti naispappeuden vastustajille, että ponnen muotoon puettu kirkolliskokouksen kannanilmaisu oli "merkittävästi vahvempi kuin pelkkä valiokunnan teksti" ${ }^{387}$ Naispappeuden kannattajat nostivat esiin epäilyksiä ponnen todellisesta sisällöstä. Erityisesti Oulun hiippakunnan edustajat, joilla oli tiedossa piispansa toimintalinja, pelkäsivät, että lisäpontta käytettäisiin kirkkolaista poikkeamiseen. ${ }^{388}$ Sariola, joka 
oli aiemmin puhunut lisäponnen merkittävyydestä naispappeuden vastustajille, joutuikin keskustelun edetessä korostamaan ponsiehdotuksensa olevan puhtaasti pastoraalinen: "Painokkaasti tahdon todeta, että tämä ponsi ei ole luonteeltaan juridinen." 389

Emäntä Helli Karvinen Kerimäeltä kertoi saaneensa käsityksen, että ponnessa mainittu toiminnanvapaus antoi naispappeuden torjujille mahdollisuuden kieltäytyä virkatehtävien hoidosta naispapin kanssa. Hän ei voinut kannattaa Sariolan ehdotusta. ${ }^{390}$ Ponnen vastustajat antoivatkin itse asiassa ponnelle sisältöä, jota ponnen kannattajat eivät olleet tuoneet esille. Syntyi äänestystilanne, joka kasvatti ponnen periaatteellista merkitystä. Jos ponsi olisi hyväksytty yksimielisesti, se olisi ollut helppo tulkita Sariolan toivomalla tavalla vain pastoraaliseksi yhteisen tahdon ilmaisuksi. Käyty keskustelu lisäsi kuitenkin ponteen uusia merkityksiä ja tulkintoja, ja ponnen painoarvo kasvoi. Kun ponnesta äänestettiin, moni ei kokenutkaan enää äänestävänsä siitä, tuliko ongelmat pyrkiä kohtaamaan lähimmäisenrakkauden hengessä, vaan siitä, tarvitsiko kirkossa noudattaa kirkkolakia.
Kilpailevien ponsiehdotusten sanamuodot muuttuivat keskustelun kuluessa moneen kertaan. Lopulta vastakkain olivat Sariolan ehdotus, jossa puhuttiin lyhyesti toiminnanvapauden turvaamisesta, ja hallintoneuvos Olli Sakin ehdotus, jossa mainittiin nimenomaisesti "kirkkolaissa taattu" toiminnanvapaus. $\mathrm{Ne}$, jotka pyrkivät pastoraalisesti mahdollisimman kattavaan ponteen, kannattivat Sariolaa. Ne taas, jotka pyrkivät juridisesti ongelmattomaan ja mahdollisimman yksimielisesti hyväksyttävissä olevaan ponteen, kannattivat Sakkia. Ensimmäisessä äänestyksessä Sariolan ponsi voitti Sakin ponnen kahdella äänellä 53-51. Jäi tila kysymykselle, tarkoittiko kirkolliskokous jotakin sillä, että se jätti kirkkolain mainitsematta. Sen jälkeen Sariolan ponsi hyväksyttiin äänin 85-9. ${ }^{391}$ Tavallaan myös pontta vastaan annetut äänet antoivat ponnelle sisältöä: ponsi, jota täytyi vastustaa, ei voinut olla merkitykseltään pelkästään symbolinen.

Pappisviran avautuminen naisille oli yksittäisen päätöksen sijaan pitkä prosessi, joka oli alkanut kauan ennen vuotta 1986 ja jatkui tuon vuoden jälkeen. Jo 1970-

Piispa Yrjo Sariolan ponsiehdotukset:

Ponsi nco 1

Kirkolliskokous toteak, etga Saomen evankelis-luterilainen kirkiko ei muuta oppiperustaansa avatessasp pappisviran naisille; kirkolain 1 s:n ilmaisema Raamattuja tunnustusperiaaye on siten muuttumattomana volmassa.

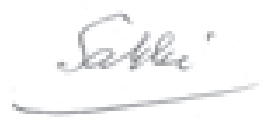

Ponsi no $2^{5}$

(H.jä Milila kirkon jasenilla ja viranhaltijoilla, jotka suhtautuvat torjuvasti pappisviran avaasisece naistlle, tulee edelleen olla kirkossamme kaysiftoiminnanvapaus ja mahdollisus tulla viaityksi ja nimitetyksi Supenen evankelis-luterilaisen kirkon eri virkoihin. Kaikki kirkon jasenet ja viranhaltijat ovat ydessa vastuussa silta, etta muuroksen aiheuttamat vaikeudet pyritsan voittamaan keskinaisen yeteistyoe avalla ja kirkon ykseytu varjellen.

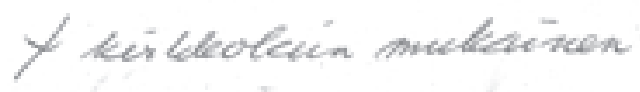

Naispappeusäänestyksen ponsiehdotus sellaisena kuin se oli puheenjohtajan käsissä. Yrjö Sariola luopui ehdotuksestaan ensimmäiseksi ponneksi, ja keskustelu käytiin toisesta ponnesta. Keskustelun edetessä Sariola taipui poistamaan maininnan "täydestä" toiminnanvapaudesta. Hallintoneuvos Olli Sakki taas teki lisäyksen, jonka mukaan toiminnanvapauden tuli olla "kirkkolain mukainen". Lisäys pehmeni vielä muotoon "kirkkolaissa taattu". Mitä enemmän ponnen muodosta keskusteltiin, sitä moninaisempia tulkintoja esitettiin ja sitä enemmän painoarvoa erilaiset vivahteet - samoin kuin koko ponsi-alkoivat saada. Kuva: Kirkkohallitus. 
luvulla kirkolliskokous oli tuonut lehtorin niin lähelle pappisvirkaa, että monen mielestä oli jo kyse pappisvirasta. Toisaalta vuoden 1986 päätökseen jäi varaumia, kuten piispanviran säilyttäminen miehen virkana ja tulkinnanvarainen lisäponsi. Nämä varaumat jättivät naispappien aseman suhteessa mieskollegoihinsa vielä jossain määrin epäselväksi. Kirkolliskokouksen enemmistö yritti kerran toisensa jälkeen liikkua niin paljon naispappeuden suuntaan kuin kyseisellä hetkellä oli mahdollista, eikä vuosi 1986 ollut tällä tiellä lopullinen päätepiste.

Tilaa jatkokeskustelulle jättivät paitsi varsinaiset päätökset myös niiden perustelut. Paine nopean ratkaisun saavuttamiseksi oli kova, joten aiemmissa valmisteluvaiheissa jäljelle jääneitä teologisia erimielisyyksiä ei valiokuntatyössä enää ehditty perinpohjaisesti selvitellä. Rintamalinjat olivat myös vakiintuneet siinä määrin, ettei mielipiteiden lähentyminen näyttänyt todennäköiseltä. Valiokunnan laatimat perustelut jättivät sijaa erilaisille tulkinnoille siitä, mikä oli naispappeuspäätöksen suhde kuluneen vuosikymmenen aikana voimistuneeseen virkateologiseen keskusteluun.

\section{HAPUILEVAA VIRKATEOLOGIAA YHDEN Ä̈̈NEN ENEMMISTÖLLÄ}

Vuonna 1973 asetettu käsikirjakomitea jätti ehdotuksensa kirkollisten toimitusten kirjaksi kirkolliskokoukselle 1982. Professori Martti Parvion johtaman komitean tehtävänä oli muun ohella miettiä, ketkä kirkon työntekijöistä vihittiin, ketkä taas siunattiin tehtäväänsä. Rukouksen laki oli myös uskon laki, ja valmistellessaan virkaan vihkimisen ja siunaamisen kaavoja komitea joutuikin luomaan kirkolle virkateologiaa.

Kirkkolaissa säädettiin, että pappi, piispa ja diakoni tai diakonissa vihittiin virkaan. Nämä vihkimyskaavat olivat myös voimassa olleessa kirkkokäsikirjassa. Koska käsikirjauudistuksen yhteydessä ei ollut tarkoitus puuttua kirkkolakiin, toimitusten kirjan tuli sisältää ainakin nämä vihkimykset. Ongelmana oli, miten muissa tilanteissa meneteltäisiin. Komitea valitteli, ettei sillä ollut käytössään täsmällistä virkateologista selvitystä. Lopulta se esitti, että kaikki täystoimiset kirkon hengellisen työn tekijät - siis myös lehtorit, nuorisotyöntekijät ja kanttorit - vihittäisiin tehtäväänsä. Muut siunattaisiin työhön. Komitean pyrkimyksenä oli vahvistaa työhön lähettämisen ajatusta ja työntekijöiden identiteettiä. ${ }^{392}$ Komitea pyrki kuitenkin vastapainoksi korostamaan pappisvirkaa kirkon perusvirkana siten, että kaavan otsikkona oli "Papiksi vihkiminen", kun muut vihkimykset olivat johonkin "virkaan" vihkimisiä. ${ }^{393}$ Komitean linja tuki lähinnä kolmisäikeistä virkarakennetta, joka muodostui piispanvirasta, pappisvirasta ja diakonaatista mutta jossa pappisvirka tietyllä tavalla erottui muista.

Piispainkokous piti henkilövihkimysten kaavoja komiteamietinnön ongelmallisimpana kohtana sekä teologisesti että käytännössä. Äänin 11-4 se ilmaisi kantanaan, että käsikirjaan tulisi sisällyttää vihkimykset vain papiksi ja piispanvirkaan. Kaikki muut viranhaltijat siunattaisiin virkaan. Keskeisenä perusteena oli, että vihkimysten lisääntyminen heijastuisi monin tavoin myös kirkko-oikeudellisiin kysymyksiin, joita komitea ei ollut selvittänyt. ${ }^{394}$ Kyse oli siitä, syntyisikö vihkimysten perusteella viranhaltijoille pysyviä oikeuksia tai velvollisuuksia. Piispainkokous omaksui hyvin pelkistetyn linjan: jopa voimassa olleessa käsikirjassa ollut diakonian virkaan vihkiminen haluttiin jättää pois. Pyrkimyksenä oli korostaa viran ykseyttä ja nimenomaan pappisvirkaa kirkon virkana.

Kirkolliskokouksen käsikirjavaliokunta päätyi seuraamaan lähinnä piispainkokouksen linjaa, mutta sitäkään valiokunta ei voinut tehdä loppuun saakka. Piispainkokous ehdotti luopumista diakonin ja diakonissan vihkimisestä, mutta voimassa ollut kirkkolaki edellytti näitä vihkimyksiä. Valiokunta päätyi siihen, että pappi, piispa ja diakoni tai diakonissa vihittäisiin virkaansa. ${ }^{395}$ Valiokunnan kantaan saattoi vaikuttaa myös useiden diakonian virkaan opiskelevien lähettämä kirjelmä. Allekirjoittajat toivoivat, että diakonian virkaan vihkiminen säilyisi ennallaan ja että liturginen palvelu pyrittäisiin palauttamaan viran tehtäviin..$^{396}$

Kirkolliskokous ryhtyi käsittelemään käsikirjavaliokunnan mietintöä syksyllä 1984. Ensimmäiseksi oli otettava kantaa piispan virkaanasettamisen kaavaan. Kuten edellisen vuosikymmenen virkakeskusteluissa tälläkin kertaa erityisesti Porvoon hiippakunnan edustajat halusivat korostaa pappisviran ykseyttä. Niinpä apulaisprofessori Fredric Cleve ja piispa Erik Vikström ehdottivat kaavan poistamista. Näkyvimmäksi perusteluksi nousi se, että kaavaa tarvittiin "erittäin harvoin".397 Perustelu oli ontuva siihen nähden, että 1980-luvun alkuvuosina kaavaa olisi tarvittu jo kahteen kertaan Paavo 


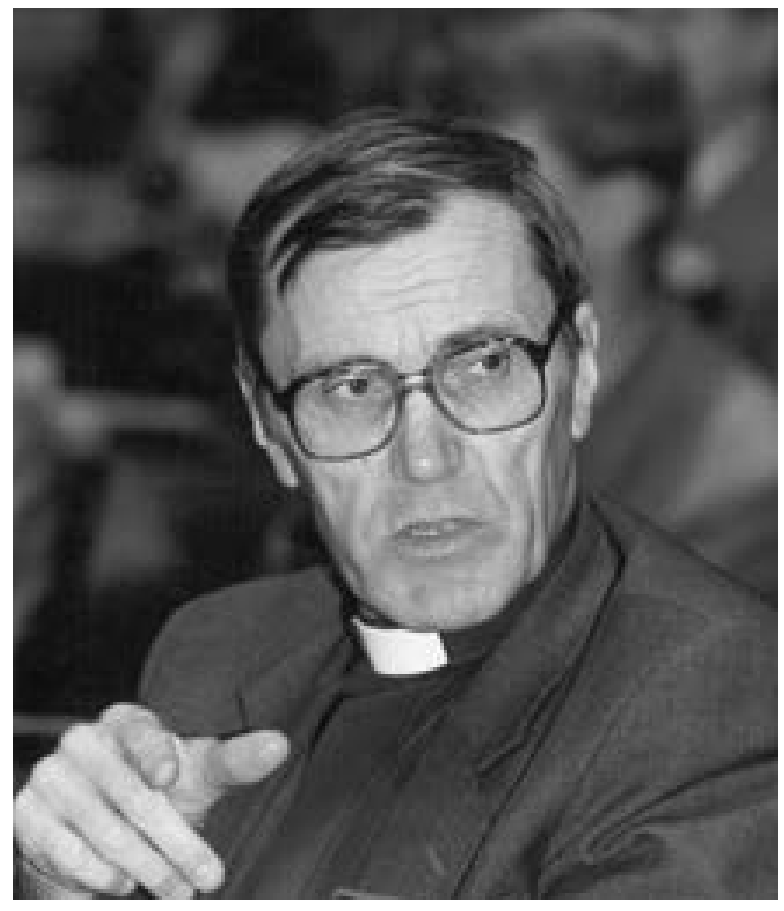

Porvoon piispa Erik Vikström otti aktiivisesti kantaa kirkon virkateologiaan. Åbo Akademin piirissä vallalla olleen virkateologisen näkemyksen mukaisesti hän painotti viran ykseyttä mutta toisaalta myös piispallista kaitsentaa. Vuonna 1984 Vikström vaikutti keskeisesti siihen, että ehdotettu erillinen piispan virkaanasettamisen kaava jäi pois kirkollisten toimitusten kirjasta. Kuva: Kirkkohallitus.

Kortekankaan ja John Vikströmin siirtyessä hiippakunnasta toiseen. Varsinainen teologinen perustelukaan ei ollut yksiselitteinen. Erik Vikströmin mukaan kaavan poistamisen myötä piispan vihkiminen virkaan saisi "enemmän sen luonteen, joka sille kuuluu, nimittäin että on kysymys asettamisesta" ${ }^{398}$. Erik Vikström korosti viran ykseyttä, mutta hänen kantansa tarkoitti samalla, ettei kirkollisten toimitusten kirjaan edes pyrittäisi luomaan yhtenäistä vihkimyksen teologiaa. Eri vihkimyksissä olisi kyse eri asioista.

Kaavan yksityiskohtainen käsittely kattoi vain nämä kaksi puheenvuoroa, joiden jälkeen kirkolliskokouksen oli otettava kantaa vaikeaan ja monitahoiseen kysymykseen piispanviran luonteesta. Vain hieman yli puolet edustajista, 63 henkilöä, katsoi olevansa valmis äänestämään. Heistä 32 kannatti valiokunnan, 31 Cleven ehdotusta. ${ }^{399}$ Kirkolliskokouksen tahto jäi todella epäselväksi. $\mathrm{Ne}$, jotka kannattivat hävinnyttä ehdotusta tai äänesti- vät tyhjää, ylsivät melkeinpä kolmen neljäsosan määräenemmistöön. Käsikirjavaliokunta päätyikin toisessa mietinnössään varmuuden vuoksi Cleven edustamalle, niukasti hävinneelle kannalle ${ }^{400}$. Muodollisesti ratkaisu oli kirkolliskokouksen työjärjestyksen näkökulmasta kyseenalainen, joskin tämä seikka oli pienimpiä ongelmia vihkimyskaavojen käsittelyssä. Erik Vikströmin esittämät perustelut puolestaan unohtuivat nopeasti. Hänen mielestään pelkän vihkimiskaavan säilyttäminen korosti piispanviran paikkaa pappisviran osana, mutta esimerkiksi piispa Matti Sihvosen johtama tuomiokapitulikomitea katsoi myöhemmin ratkaisun nimenomaan osoittaneen, että "piispanvirka on kirkossamme oma ordo" ${ }^{401}$.

Seuraavana oli vuorossa diakonian virkaan vihkimisen kaava. Tällä kertaa ongelmien syynä oli ennen kaikkea kirkkolaki: diakonian virkaan vihkiminen katsottiin yleisesti siunaamiseksi, mutta kirkkolain vihkimissäännöksen takia toimitus oli määriteltävä vihkimiseksi. Johdonmukaisuussyistä vihkimyksen muoto poikkesi aiemmasta käytännöstä: vain ne, joilla oli kutsu seurakunnan, kirkon tai kirkollisen järjestön palvelukseen, vihittäisiin, kun aiemmin koko valmistunut kurssi oli vihitty. Kirkolliskokous päätyi kuitenkin käytännön syistä ja jälleen yhdellä äänellä (46-45) säilyttämään entisenlaisen yhteisvihkimyksen. Vihittävää varten ei tarvinnut olla tiedossa seurakuntavirkaa. ${ }^{402}$ Syntyi jo toinen virkateologinen ratkaisu, jonka takana ei ollut edes kaikkien kirkolliskokousedustajien yksinkertaista enemmistöä määräenemmistöstä puhumattakaan. Merkittävät virkateologiset linjaukset hautautuivat toimitusten kirjan kokonaisuuden alle.

Ongelmat kärjistyivät, kun edettiin lehtorin siunaamisen kaavaan. Lehtorinvirka muistutti monella tavalla diakonian virkaa, joten kirkkolain edellyttämä aiempi päätös diakonian virkaan vihkimisestä vaikutti keskusteluun. Toisten mielestä diakonian viran yhteydessä tehdyn teologisen poikkeaman oli jäätävä poikkeukseksi. Toisten mielestä taas poikkeuksesta oli tehtävä johdonmukaisuussyistä sääntö ja vihittävä myös lehtorit virkaansa. Lisäksi keskusteluun heijastui voimakkaasti naispappeuskysymys. Naispappeuden kannattajat ajoivat lehtoreille vihkimystä yhtenä askelena kohti pappisviran avaamista naisille. Jotkut paljastivat suoraan vaativansa lehtorien vihkimistä siksi, että naisia ei vihitty 
papiksi. Yhtä lailla kuitenkin myös naispappeuden vastustajilta kuultiin lehtorin vihkimystä puolustavia puheenvuoroja. ${ }^{403}$ Näin he pyrkivät määrittelemään lehtorinviran osaksi diakonaattia ja arvioivat pystyvänsä siten vähentämään paineita naispappeuden toteuttamiseksi. Toiminnallaan he lunastivat myös lupauksiaan lehtorinviran kehittämisestä. Äänestyksestä tuli jälleen melko tiukka, ja äänin 57-41 kirkolliskokous päätti muuttaa lehtorien siunaamisen vihkimiseksi ${ }^{404}$.

Keskustelussa jotkut vastustivat vihkimistä siksi, että lehtorius ei ollut pappisviran tapainen pysyvä ja sanktioitu virka vaan yksittäisen seurakunnan kutsuun sidottu tehtävä. Toisten mielestä taas lehtorius oli pappeuden tapaan elinikäinen velvoitus. ${ }^{405}$ Molemmat perustelut olivat omalla tavallaan oikeita. Taustalla oli kirkolliskokouksen aiempiin päätöksiin sisältynyt periaatteellinen ristiriita, johon Jyväskylän kaupunkiseurakunnan kirk-

\section{"...ja Pojasta"}

Avatessaan kirkolliskokouksen keväällä 1976 arkkipiispa Martti Simojoki käsitteli sitä, saattoiko kirkolliskokous muuttaa kirkon oppia vai ainoastaan tulkita sitä. Hän päätyi jäl-

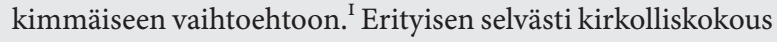
joutui Simojoen esittämän kysymyksen eteen 1985. Ruotsin kirkon edustajat tiedustelivat, aiheutuisiko kirkkojen välille ongelmia, mikäli Ruotsin kirkko poistaisi Nikean uskontunnustuksesta niin sanotun filioque-lisäyksen. Kyseessä oli lännen kirkossa 8oo-luvulle mennessä yleistynyt ja lopullisesti 1014 hyväksytty lisäys, jonka mukaan Pyhä Henki lähtee paitsi Isästä myös Pojasta. Koska idän kirkko ei ollut hyväksynyt muutosta, lisäys nousi keskustelunaiheeksi ekumeenisessa liikkeessä. Luterilaisen maailmanliiton yleiskokous pyysi 1984 kirkkoja harkitsemaan mahdollisuutta löytää uskontunnustukselle yhteinen sanamuoto. ${ }^{\text {II }}$

Ruotsin kirkon opillinen lautakunta (läronämnden) katsoi, ettei filioque-lisäyksen poisto merkinnyt opin muuttamista vaan ainoastaan paluuta alkuperäiseen sanamuotoon. Myös Suomessa piispainkokous totesi laatimassaan vastausehdotuksessa ykskantaan, että kysymys oli nimenomaan liturgisesta käytännöstä, jonka muutoksesta ei aiheutuisi ongelmia Ruotsin ja Suomen luterilaisten kirkkojen välisille suhteille. ${ }^{\text {III }}$

Piispainkokouksen teologien ongelmaton suhtautuminen törmäsi esteisiin kirkolliskokouksessa. Varsinkin evankeliseen liikkeeseen ja vanhoillislestadiolaisuuteen lukeutuvat edustajat kyseenalaistivat tulkinnan, jonka mukaan muutos koski vain sanamuotoa tai liturgista käytäntöä. ${ }^{\mathrm{IV}}$ Perus- koherran Otso Sovijärven johtama lehtorikomitea kiinnitti pari vuotta myöhemmin huomiota. Yhtäältä lehtorinvirka oli nähty paikallisseurakuntaan sidottuna maallikkovirkana, mutta toisaalta vuoden 1976 kirkolliskokous oli nopeasti valmistelluilla päätöksillään luonut epäjohdonmukaisesti "lehtoriuden" erillisenä virkanaan: muukin kuin tiettyyn seurakuntaan sijoitettu lehtori saattoi hoitaa seurakunnan tehtäviä riippumatta seurakunnan kutsusta. ${ }^{406}$ Vuoden 1984 kirkolliskokouksen päätös lehtorien vihkimisestä vei lehtorinvirkaa entistäkin selvemmin pysyvän lehtoriuden suuntaan. Lehtorikomitean tuomio päätöksestä oli tyly: koska vihkimisestä oli säädettävä kirkkolaissa, kirkolliskokouksen päätös oli syntynyt virheellisessä järjestyksessä, eikä piispalla ollut velvollisuutta vihkiä lehtoria virkaan ${ }^{407}$.

Kirkolliskokouksessa monet katsoivat, että hyväksyessään lehtorinvirkaa koskevan vihkimyskaavan kirkol-

tevaliokunnankin mielestä päätös kosketti laajemmin uskon tulkintaa. Valiokunnan laatima kirjelmä oli selvästi pidättyväisempi kuin piispainkokouksen esitys. Enää ei vakuutettu, ettei muutoksesta koituisi ongelmia kahden kirkon suhteisiin. Sen sijaan todettiin, että ratkaisun kaikkia vaikutuksia oli vaikea arvioida. ${ }^{\mathrm{V}}$ Perusperiaate oli sama kuin Leuenbergin konkordiaa käsiteltäessä: oppilauseen sanamuotoa ei voinut ongelmattomasti irrottaa opin sisällöstä.

Samalla istuntokaudella kirkolliskokouksen tehtäväksi tuli antaa Kirkkojen maailmanneuvoston Faith and Order -komissiolle lausunto Kaste, ehtoollinen ja virka -asiakirjasta. Piispainkokouksen esitys lausunnoksi meni kirkolliskokouksessa läpi melko pienin tarkistuksin, lähinnä lisäten joitakin varauksia asiakirjaa kohtaan. ${ }^{\mathrm{VI}}$ Tässäkin tapauksessa kirkolliskokous tiukensi piispainkokouksen sanamuotoja, kuten se oli tehnyt jo Leuenbergin konkordiaa käsiteltäessä. Kirkolliskokouksessa oli jotakin, joka piispainkokouksesta puuttui: tunnustusta korostavat ja usein samalla ekumeniakriittiset maallikkoedustajat. SLEY:n piirisihteeri Pentti Heikkilä ja SRK:n puheenjohtaja Erkki Reinikainen vaikuttivat erityisesti filioque-kysymyksen käsittelyyn. Tuo käsittely sisälsi myös tärkeän periaatteellisen kannanoton: kirkolliskokous tiedosti, että sen oppia koskeva päätösvalta oli rajattu.

I Kirk.kok. kptk-k. 1976, 2.

II Kirk.kok. ptk-s. 1985, liite II 2 \& VI-A 5; Toiviainen 2004, 116-117.

III Kirk.kok. ptk-s. 1985, liite II 2.

IV Kirk.kok. kptk-s. 1985,6§.

V Kirk.kok. ptk-s. 1985, liite VI-A 5; Toiviainen 2004, 117.

VI Kirk.kok. ptk-k. 1985, liite II 1; Kirk.kok. ptk-s. 1985, 15 \$, liite VI-A 4. 
liskokous hyväksyi käsikirjakomitean periaatteet. Siksi myös seuraavana käsittelyyn tullut kanttorinvirkaan siunaamisen kaava tuli muuttaa vihkimiseksi. Arkkipiispa Vikström sen sijaan katsoi, että nyt oli saavutettu kynnys, jonka yli ei enää tullut edetä. Piispa Toiviainen puolestaan oli jo vaipunut kyynisyyteen: "Viran teologian johdonmukaisuus on kirkolliskokouksen tänään tekemien ratkaisujen johdosta jo mennyt niin sekaisin, että vihitäänpä nyt sitten tässä yhteydessä tai ei, niin ei se enää paljon sekoita lisää." ${ }^{408}$ Arvio oli todenmukainen, joskin epäjohdonmukaisuus oli jo aiemmassa kirkkokäsikirjassa ja osittain myös kirkkolaissa, jota kirkolliskokouksen oli noudatettava. Valiokunnan esitys siunaamisen kaavasta voitti tällä kertaa selvästi 70-23 $3^{409}$.

Toimitusten kirjan käsittelyyn heijastui ekumeeninen keskustelu kirkon virasta. Vuonna 1984 tuo keskustelu kytkeytyi erityisesti Kirkkojen maailmanneuvoston Faith and Order -komission asiakirjaan Kaste, ehtoollinen ja virka (BEM). Kirkolliskokouksen päätökset toivat lisäkysymyksiä tähän pohdintaan: oliko Suomen luterilaisessa kirkossa kolme tai lehtori mukaan lukien peräti neljä erityistä virkaa tai viran säiettä? ${ }^{410}$ Vastatessaan seuraavana vuonna BEM-asiakirjaan kirkolliskokous ei turhaan todennut, että viran kolmijako oli syytä tutkia uudelleen Suomen luterilaisessa kirkossa. ${ }^{411}$

Kirkolliskokouksen keskusteluissa oli kyse myös eri työntekijäryhmien arvostuksesta. Hiljan oli toteutettu pitkäksi ja vaikeaksi venynyt kanttorinviran uudistusprosessi. Tuolla hetkellä puolestaan lehtorinviran kehittäminen puhutti voimakkaimmin, ja pari vuotta myöhemmin pappisviran avaaminen naisille pakotti arvioimaan lehtorinvirkaa aivan uusista lähtökohdista. ${ }^{412}$ Lehtorikomitea esitti kirkolliskokoukselle, että lehtorin oikeuksia supistettaisiin teologisen johdonmukaisuuden vuoksi. ${ }^{413}$ Kirkolliskokous ei kuitenkaan ryhtynyt välittömiin toimiin, koska naispappeuspäätöksen vaikutuksista ei ollut vielä kokemuksia. Kirkolliskokous kehotti piispainkokousta seuraamaan tilannetta. ${ }^{414}$

Samoihin aikoihin kirkolliskokouksessa kiinnitettiin huomiota nuorisonohjaajien asemaan ja arvostukseen. Taustalla oli tietoisuus siitä, että monet nuorisotyöntekijät hakeutuivat seurakunnista muihin tehtäviin. ${ }^{415}$ Keväällä 1987 olikin vuorossa eräänlainen nuorisotyön istuntokausi: kirkolliskokous sai hiippakuntakokouksilta ja edustajilta peräti seitsemän aloitetta, jotka koski- vat joko nuorisonohjaajien tai diakoniatyöntekijöiden asemaa. ${ }^{416}$ Täysistuntokeskusteluissa ja yleisessä valmistusvaliokunnassa ongelmat liitettiin perustavaan kysymykseen kirkon virasta. Oli pohdittava viran kolmisäikeisyyttä ja mahdollisuutta laajentaa diakonian virkaa. Näillä evästyksillä kirkolliskokous lähetti kaikki aloitteet piispainkokoukselle tutkittaviksi ja mahdollisia toimenpiteitä varten. ${ }^{47}$ Kun 1970 -luvulla kanttorinviran ongelmia oli lähdetty ratkaisemaan pitkälti taloudellisista lähtökohdista, seuraavalla vuosikymmenellä nuorisonohjaajien osalta pääpaino olikin teologiassa ja identiteetissä. Aika oli muuttunut.

Helsingin hiippakuntakokous lähetti keväällä 1988 kirkolliskokoukselle aloitteen piispanviran avaamisesta naisille. ${ }^{418}$ Kysymys piispanviran suhteesta pappisvirkaan tuli jälleen sivujuonteena esille, mutta - kuten neljä vuotta aiemmin - teologisista perusteista keskusteltiin edelleen vähän. Pohdittiin, oliko kirkko valmis ottamaan vastaan lainmuutoksen. Piispainkokouksen enemmistö vastasi tähän kysymykseen kieltävästi. Piispainkokouksen lausunto johti julkisuudessa arvosteluun siitä, että piispojen "herraseura" sulki yhä naiset ulos. ${ }^{419}$ Kysyttiinkin, millaisen kuvan kirkolliskokouksen mahdollinen kielteinen päätös antaisi kirkosta. ${ }^{420}$

Kirkolliskokouksen perustevaliokunta lähti liikkeelle viran ykseydestä ja tulkitsi myös kirkkolakia siten, että piispaksi vihkiminen oli "enemmänkin asettaminen tiettyyn erityistehtävään pappisviran puitteissa kuin uusi vihkimys toisenlaiseen virkaan". ${ }^{21}$ Valiokunnan puheenjohtaja Erik Vikström myönsi kuitenkin, ettei valiokunta ollut pystynyt löytämään kaikille täysin tyydyttävää yhteistä kieltä: toisten mielestä piispuus oli vain yksi pappisvirkaan kuuluva tärkeä ulottuvuus, joka voitiin järjestää tilanteen mukaan, kun taas toisten mielestä piispanvirka oli erillinen ja muuttumaton säätämys pappisviran sisällä. Valiokunnan perustelujen näkökulmasta ero ei kuitenkaan ollut oleellinen, ja piispanviran teologia jäi taka-alalle. ${ }^{422}$

Kevään 1990 istuntokaudella piispanvirka avautui naisille. ${ }^{423}$ Ennakkoasetelmiin nähden päätös oli yllätyksellinen. Ilmeisesti monien uudistuksen vastustajien jyrkät puheenvuorot olivat vaikuttamassa siihen, että epävarmoja edustajia ja jopa aiempia vastustajia, kuten piispa Toiviainen, siirtyi uudistuksen kannalle ${ }^{424}$. Äänestystulos 82-25 ylitti niukasti - jälleen yhdellä 
äänellä - alimman määräenemmistövaatimuksen. ${ }^{425}$ Taas kerran hieman epäselväksi jäi ainoastaan, mikä tuo naisille avautunut virka lopulta oli.

\section{TOIMITUSTEN JA VIRSIEN ROHKEISTA UUDISTUSESITYKSISTÄ KIRKOLLIS- KOKOUKSEN KOMPROMISSEIHIN}

\section{KORKEAKIRKOLLINEN LITURGIA, KASTEKAAVA JA SAIRAAN VOITELU KANSANKIRKON KIPUKOHTINA}

Vuoden 1973 kirkolliskokous asetti käsikirjakomitean uudistamaan kirkollisten toimitusten kirjan. Komitean työvuosina kirkollisten toimitusten asema oli Suomessa huomattavasti vahvempi kuin yleisesti Pohjoismaissa. Useimpiin toimituksiin osallistui väestöstä suurempi osuus kuin kuului kirkkoon..$^{426}$ Toisaalta samaan aikaan suomalaisten arvot moninaistuivat ja uskonto privatisoitui. Tutkimusten mukaan yhä useampi ilmoitti uskovansa Jumalaan eri tavalla kuin kirkko opetti, mikä herätti huomiota myös kirkolliskokouksessa, kun se pohti toimituksia. Uskonnollisuus ajankohtaistui vain tietyissä elämänvaiheissa. ${ }^{427}$ Tilanne, jossa toimitusten asema oli vahva mutta seurakunnan jäsenten suhde niiden sanomaan aiempaa höllempi, asetti paljon odotuksia ja vaatimuksia uutta toimitusten kirjaa kohtaan.

Käsikirjakomitea uudisti käytössä olleet kaavat ja lisäsi myös uusia toimituksia, kuten kodin siunaamisen kaavan. ${ }^{428}$ Komitean puheenjohtajana toimi käytännöllisen teologian professori Martti Parvio ja varapuheenjohtajana kirkkoherra, teologian kunniatohtori Samuel Lehtonen. Komiteatyössä mukana olleista kuudesta papista peräti kolme, Lehtonen, Yrjö Sariola ja Olavi Rimpiläinen, nimitettiin piispaksi ennen kuin mietintö oli käsitelty kirkolliskokouksessa. ${ }^{429}$ Komitean jäsenistön taustassa näkyivät melko vahvasti evankelinen herätysliike ja - osin siihen liittyen - 190o-luvun kansainvälinen liturginen uudistusliike sekä ekumeeninen herääminen jumalanpalveluselämän kehittämiseen. Molemmat puheenjohtajat olivat kuuluneet 1940- ja 1950-luvun vaihteessa Turussa vaikuttaneeseen epäviralliseen "liturgisten veljien" piiriin, joka oli korostanut rikasta liturgista elämää ${ }^{430}$. Komitean sihteerinä toiminut Rimpiläinen oli myös omaksunut korkeakirkollisen, liturgiaa painottavan teologian. Sitä hän oli edistänyt työssään kirkon koulutuskeskuksen johtajana - pappien koulutuksen avainpaikalla. ${ }^{431}$ Liturginen painotus näkyi selvästi komitean laatimassa ehdotuksessa. ${ }^{432}$

Liturgisten veljien kovimpia arvostelijoita olivat aikoinaan olleet Turun kristillisen opiston johtaja Olavi Kares ja Helsingin yliopiston käytännöllisen teologian professori Aarni Voipio. ${ }^{433}$ Kun käsikirjakomitean mietintö saapui kirkolliskokoukselle keväällä 1982, Voipion veljenpoika ja Kareksen henkinen seuraaja kirkolliskokouksessa, professori Jaakko Voipio, jatkoi arvostelua samaan tyyliin:

Sota on, arvoisa puheenjohtaja, niin vakava asia, ettei sitä pidä jättää kenraaleille. - - Yhteinen jumalanpalvelus on niin tärkeä asia, ettei sen järjestystä voida jättää liturgian tuntijoille, musiikkimiehille tai mystikoille (hilpeyttä). Kun nämä liturgian asiantuntijat, musiikkimiehet ja mystikot jättävät meille mietintönsä, he kertovat - - pyrkineensä paneutumaan tehtäväänsä tieteellisesti. He esittävät kuitenkin niin lyhyet ja mitäänsanomattomat perustelut, että esitys on kaukana tieteestä. ${ }^{434}$

Kirkolliskokouksessa näkyvintä ja jyrkintä matalakirkollista linjaa edustanut Voipio ei ollut ainoa, joka arvosteli perustelujen puutetta. Piispainkokous kiinnitti lausunnossaan huomiota samaan asiaan. Vaikka komitea oli pyrkinyt tuomaan yksityisen seurakunnan jäsenen toimituksen aktiiviseksi osallistujaksi, piispainkokouksen mielestä monet toimitusten osat uhkasivat jäädä juhlallisen kaukaisiksi. ${ }^{435}$ Piispainkokous piti ehdotusta vielä siinä määrin keskeneräisenä, että sen mielestä erillisen tarkistuskomitean oli syytä tutkia ja muokata ehdotusta perusteellisesti. ${ }^{436}$ Asian käsittelyssä ilmeni monia kansankirkollisia ja opillisia kipupisteitä. Kysyttiin, karkottiko liturginen rikkaus seurakuntalaisia ja oliko se luterilaisuudelle vierasta. Mietittiin, korottiko kastetilaisuudessa vanhemmille ja kummeille esitettävä kysymys kynnystä tuoda lapsi kastettavaksi tai hämärsikö komitean ehdottama sairaan voitelun kaava luterilaista sakramenttiopetusta.

Lähetekeskustelussa kiinnitettiin paljon huomiota seurakuntalaisten näkökulmaan. ${ }^{437}$ Laukaalainen lehtori Hilkka Kaikkonen arvosteli Voipion kanssa komiteaehdotuksen "muotomenoa". Leino Hassinen taas painotti uutta viestinnällistä tilannetta: jos ei saatu pastoraalista 
otetta ihmisten elämäntilanteeseen, toimitukset uhkasivat jäädä irrallisiksi saarekkeiksi. Huoli oli pohjimmiltaan sama kuin piispainkokouksella, ja Hassinen saikin ajatuksilleen kannatusta. ${ }^{438}$ Synodaalikokousten lakisääteinen oikeus antaa lausuntonsa kirkollisista kirjoista oli poistunut kirkolliskokousuudistuksen myötä. Kirkolliskokous ei kuitenkaan kantanut huolta siitä, miten ilman lausunto-oikeutta jäänyt papisto reagoisi toimitusten kirjaan.

Jotkut pitivät komitean mietintöä perusteiltaan hyvänä ja toivoivat asian ripeää etenemistä: kirkolliskokouksen valiokunnan lisäksi ei enää tarvittu muita valmisteluelimiä. Voimakkaimpien arvostelijoiden mielestä taas jo tietty "henkilöunioni" käsikirjakomitean ja -valiokunnan välillä edellytti tarkistuskomitean asettamista. ${ }^{439}$ Samuel Lehtosen johtama käsikirjavaliokunta pyrki työskentelemään nopeasti, koska toimituksiin liittyvät ja suuritöiset hankkeet, virsikirjauudistus ja raamatunkäännöstyö, olivat valmistumassa. Valiokunta katsoi edustavansa kattavasti erilaisia maantieteellisiä alueita ja kirkollisia suuntauksia. Lisäksi se lupasi hankkia seurakuntalaisten arviointeja ehdotuksestaan. ${ }^{40}$ Viimeistä kertaa kirkolliskokouksessa istunut Aimo T. Nikolainen, joka oli ollut linjaamassa piispainkokouksen lausuntoa, epäili valiokunnan linjaa: valiokunta oli tehnyt itsestään käytännössä tarkistuskomitean, jolloin normaalit valiokunnan tehtävät olivat jäämässä kirkolliskokouksen täysistunnolle. Kirkolliskokous hyväksyi kuitenkin yksimielisesti valiokunnan esityksen asian jatkokäsittelystä. ${ }^{41}$

Keskustelu liturgisesta rikkaudesta ja seurakuntalaisten oppimiskyvystä jatkui senkin jälkeen, kun ehdotus kirkollisten toimitusten kirjaksi oli lähetetty valiokuntaan. Perhejumalanpalvelus oli syntynyt 1950-luvun lopulla käytännön tarpeista käsin. Suurten ikäluokkien myötä seurakunnissa oli alettu kiinnittää aiempaa enemmän huomiota lapsityöhön, ja esimerkiksi pyhäkoululaisten määrä oli tuolloin kasvanut ikäluokkien kasvun mukana voimakkaasti. Perhejumalanpalvelukset olivat hyvin ajankohtaisia jälleen 1980-luvulla: päiväjumalanpalvelusten kävijämäärien laskettua seurakunnat järjestivät entistä enemmän erityisjumalanpalveluksia. Keväällä 1983 piispainkokous lähetti kirkolliskokoukselle perhejumalanpalveluksen uudet kaavat hyväksyttäväksi väliaikaiseen käyttöön. ${ }^{42}$ Tässä yhteydessä kirkolliskokous omaksui käytännön, että se lauloi käsiteltäviä kaavan kohtia yhdessä läpi. ${ }^{43}$ Nilsiäläinen kanttoriurkuri Matti Ranta näyttää lausuneen kirkolliskokouksen enemmistön hiljaisen mielipiteen duurisävelmien täyttämästä kaavasta: "Uusi ja entistä valoisampi aika on alkamassa kirkossamme."444

Aivan kaikki eivät olleet yhtä innostuneita. Jaakko Voipio havaitsi käsittelyn loppuvaiheessa, että uuden kaavan mukaan seurakunta seisoi Herran siunauksen aikana. Tapa oli lähtenyt liikkeelle 1940-luvun lopulla Helsingin Norra svenska församlingenista ja levinnyt Porvoon hiippakunnassa. Suomenkielisissä seurakunnissa tapa oli uusi, mutta perhejumalanpalveluksen kaavan myötä se oli tarkoitus tuoda myös suomenkielisiin jumalanpalveluksiin. Voipio näki ehdotuksessa vain sekaannuksen aineksia. Ainoana edustajana hän äänesti kaavaehdotusta vastaan. ${ }^{45}$ Edelleen 1984 Voipio huolestui korkeakirkollisuudesta, kun esillä oli säännöstön laatiminen kirkollisista vaakunoista. Hänen mielestään risti oli ainoa tunnus, jonka kirkko tarvitsi. Voipio maalasi vielä tulevaisuuden uhkakuvia: "Toistaiseksi me olemme, ainakin pääsäännön mukaan, välttyneet näkemästä hiippaa, mutta jollemme ole valppaina, yhtenä päivänä niitä meilläkin on joka piispalla." ${ }^{446}$

Voipion ääni oli kirkolliskokouksessa voimakas mutta samalla yksinäinen. Kokoussalissa vallitsi kyllä laaja yksimielisyys siitä, että liiallista liturgista rikkautta tuli välttää, mutta perustelut olivat käytännöllisiä: toimitusten tuli olla ihmisläheisiä ja turvallisia. Uudet rituaalit haittasivat tämän päämäärän saavuttamista. Sen sijaan ohjelmallinen matalakirkollisuus oli 1980-luvun alkupuolella selvästi harvempien edustajien varassa kuin vielä kymmenen vuotta aiemmin Osmo Alajan ja Olavi Kareksen aikana. Seremoniallisuutta teologisista syistä vierastaneet, herännäisyyteen lukeutuneet Kaikkonen ja Voipio eivät myöskään saaneet tukea läheskään kaikilta herätysliikkeensä edustajilta.

Käsikirjavaliokunnassa mietinnön tarkistamista hoiti jaosto, johon kuului neljä pappia sekä kielellisenä asiantuntijana yksi maallikkoedustaja, toimittaja Raili Malmberg. Valmistelu oli siis edelleen varsin teologipainotteista, ja kun myös Samuel Lehtonen oli mukana jaostossa, jatkumo komiteasta kirkolliskokoukseen säilyi katkeamattomana. ${ }^{447}$ Vuonna 1984 valmistuneessa mietinnössään valiokunta pyrki kiinnittämään entistä 
enemmän huomiota siihen, että toimitukset liittyisivät niin seurakunnan jumalanpalveluselämään kuin seurakuntalaisen omaan elämään. Lisäksi toimitukseen osallistuvilla seurakuntalaisilla tuli olla aktiivinen osuus tapahtumassa. Valiokunta ei lupauksistaan huolimatta keskittynyt hankkimaan seurakuntalaisten palautetta vaan sen sijaan esitti, että toimitusten kirja hyväksyttäisiin vain väliaikaiseen käyttöön. Tänä aikana kirkon jumalanpalvelus- ja musiikkitoiminnan keskus keräisi palautetta. ${ }^{448}$

Kirkolliskokouksen mielestä tällaisella väliaikaisuudella ei kuitenkaan ollut mitään oikeudellista merkitystä. Kirja tuli hyväksyä virallisesti. Näin kirkolliskokous joutui päättämään kirjan lopullisesta hyväksymisestä ilman seurakuntalaisilta saatua kattavaa palautetta. Koska valiokunta oli tehnyt suuria muutoksia komitean ehdotukseen, kirkolliskokouksen piti täysistunnossaan ottaa kantaa moniin täysin uusiin asioihin. Oltiin tilanteessa, josta Aimo T. Nikolainen oli aiemmin varoittanut. Hidasta, uuvuttavaa ja lukuisia muutosehdotuksia sisältävää käsittelyä kuvattiin kokoussalissa "hulinaksi".449 Lopulta kolmen päivän käsittelyn jälkeen keskiviikkoiltana asia lähti takaisin valiokuntaan, joka teki työnsä nopeasti: koko yön kestäneen monistamisen jälkeen kirkolliskokouksen kanslia toimitti jo perjantaiksi uuden ehdotuksen toimitusten kirjaksi.

Kaikkein suurimmaksi ongelmaksi osoittautui papistossa virinnyt vastustus: vallitsi ilmapiiri, että papit oli ohitettu täysin asian valmistelussa. Toimitusten kirjan pääasialliset käyttäjät seurakunnissa eivät olleet edes nähneet komitean tai valiokunnan ehdotusta. Vasta käsikirjavaliokunnan mietintöä käsiteltäessä kirkolliskokous törmäsi niihin seurauksiin, joita lakisääteisen lausunto-oikeuden poistaminen synodaalikokouksilta oli aiheuttanut. Pitkällisen keskustelun jälkeen kirkolliskokous joutui toteamaan, ettei sen arvovaltaan sopinut pyytää lausuntoja enää valiokunnan mietinnöstä. "Me todellakin olemme tänne valitut sitä varten, että ratkaisemme tietyt kysymykset", Ulvilan kirkkoherra Heikki Huhtala ilmaisi asian. ${ }^{450}$

Tapahtuma ei unohtunut mielistä. Seuraavan vaalikauden alkaessa 1986 peräti kolmen hiippakunnan hiippakuntakokoukset vaativat lakisääteisen lausuntooikeuden palauttamista synodaalikokouksille. ${ }^{451}$ Uuden vaalikauden alulle ominainen jännittynyt tunnelma takasi sen, että seurauksena oli pappien ja heidän "erioikeuksiaan" vastustavien maallikkojen voimakas kiista. ${ }^{452}$ Lopulta kirkolliskokous lisäsi työjärjestykseensä kohdan, jonka mukaan kirkollisia kirjoja koskevissa merkittävissä uudistuksissa oli pyydettävä synodaalikokousten lausunnot. ${ }^{453}$

Papiston yleistä tyytymättömyyttä ei riittänyt hälventämään edes se, että pappisedustajat olivat pääosassa käsiteltäessä käsikirjavaliokunnan ehdotusta toimitusten kirjaksi. Vain yksi pappisedustaja 32:sta jätti puhumatta. Keskimäärin yksittäinen pappisedustaja käytti syksyllä 1984 asiasta yli kuusi puheenvuoroa, lähes kolme kertaa niin monta kuin keskimääräinen maallikkoedustaja. Maallikkoedustajien puheenvuorot keskittyivät tietyille henkilöille, joiden puhemäärä lähenteli pappisedustajien lukemia. Lähes puolet maallikkoedustajista vaikeni kokonaan. Pappisedustajista erityisesti pappislinjan lestadiolaisuuteen lukeutuneet Timo Holma ja Timo Kökkö yrittivät vaikuttaa täysistuntokäsittelyyn. Toisaalta esimerkiksi piispa Yrjö Sariola, joka oli ollut mukana käsikirjakomiteassa, nousi vain kerran puhujakorokkeelle. Lapuan piispa halusi antaa kirkolliskokouksen ruotia vapaasti hänen edustamansa komitean mietintöä.

Maallikkojen osalta lakimiesten aktiivisuus kiinnittää huomiota: Jaakko Voipio puhui yhtä usein kuin aktiivisimmat papit, ja Johannes Leivonenkin oli ahkerimpia keskustelijoita. Juristien aktiivisuuteen näyttää vaikuttaneen olennaisesti se, että kesken olleessa kirkkolain uudistustyössä oli alettu korostaa kirkkokäsikirjan luonnetta asetustasoisena säännöstönä454. Toimitusten kirjan sanamuotoihin ja yhdenmukaisuuteen kirkkolain kanssa oli siksi kiinnitettävä huomiota.

Valiokunnan valmistamaa ehdotusta pidettiin täysistuntopuheenvuoroissa selvästi parempana kuin komitean mietintöä. ${ }^{455}$ Virkaan vihkimisten ohella erimielisyyttä oli lähinnä kahdesta jo lähetekeskustelussa puhuttaneesta kaavasta, kasteesta ja sairaan voitelusta. Vanhoillislestadiolaiset edustajat toivat kastekaavan käsittelyyn pitkin matkaa oman "suolansa". Varsinkin Erkki Reinikainen arvosteli toimitusten kirjan kasteteologiaa. Hän piti aluksi välttämättömänä, että kirjaan otettaisiin myös vanhoillislestadiolaisen uskonvakaumuksen mukainen kastekaava, jossa lasta pidettäisiin jo ennen kastetta uskovana ja uudestisyntyneenä. ${ }^{456}$ 
Ehdotus erillisestä kaavasta ei toteutunut, ja vanhoillislestadiolaiset edustajat tyytyivät lopulta esittämään kastekaavaan oman liikkeensä kasteteologian mukaisia mainintoja kasteesta liittona. Yksi tällaisista lisäyksistä hyväksyttiinkin melko niukalla ääntenenemmistöllä. ${ }^{457}$ Toimitusten kirjaa käsiteltäessä ei kuitenkaan syntynyt sanottavaa väittelyä luterilaisesta kasteteologiasta, mikä kuvastaa 1980-luvun pääosin hillittyä, toista osapuolta ymmärtävää ja samalla myös erimielisyyksiä silottelevaa keskustelukulttuuria kirkolliskokouksessa. Vanhoillislestadiolaisuutta koskenut, erityisesti 1970- ja 1980-luvun vaihteessa vellonut julkinen keskustelu saattoi myös lisätä kirkolliskokousedustajien varovaisuutta ${ }^{458}$.

Varsinainen sananvaihto käytiin kastetilaisuudessa esitettävästä kastekysymyksestä. Käsikirjakomitea ja -valiokunta pitivät tarpeellisena, että vanhemmat ja kummit julkisesti sitoutuivat antamaan lapselle kristil- lisen kasvatuksen. Lähetekeskustelun ja valiokuntatyöskentelyn myötä kysymyksen muoto pehmeni, mutta siitä huolimatta istuntosalissa monet pitivät kysymystä kansankirkkotilanteeseen sopimattomana. ${ }^{459}$ Lehtori Hilkka Kaikkonen ehdotti lisäystä, että vanhemmat ja kummit lupaisivat huolehtia lapsen kristillisestä kasvatuksesta "yhdessä seurakunnan kanssa". Lisäksi kysymyksen vaihtoehdoksi kaavaan sisällytettäisiin kehotus vanhemmille ja kummeille. Kaikkosen ehdotus sai nopeasti laajan tuen, eikä lopulta kukaan noussut äänestämään sitä vastaan. ${ }^{460}$ Kastekysymys säilyi mutta pehmennetyssä muodossa ja vapaaehtoisena. Kirkolliskokouksen täysistunto jätti näin selvän puumerkkinsä kirkon keskeisimmän toimituksen kaavaan. Säilyttäessään kastekysymyksen kirkolliskokous liittyi kirkkojärjestyskomitean linjaukseen, että kirkon jäsenyyttä tuli vahvistaa ja jäseniltä myös edellyttää sitoutumista. Samalla haluttiin

\section{Viivytystaistelu avioliittokuulutuksesta}

Kirkolliskokous joutui miettimään näkemystään avioliitosta ja avioerosta, kun se käsitteli 1980-luvun alkupuolella kirkollisten toimitusten kirjaa. Vuonna 1983 kokouksen oli lisäksi annettava lausunto avioliittotoimikunnan mietinnöstä. Toimikunta ehdotti muun muassa, että julkisesta avioliittokuulutuksesta luovuttaisiin, avioeron saantia helpotettaisiin ja eroon liittyvä syyllisyysharkinta lopetettaisiin. Kirkolliskokous yhtyi viimeksi mainittuun ehdotukseen mutta painotti avioerossa sovittelumenettelyä, harkinta-aikaa ja lasten näkökulmaa. ${ }^{\mathrm{I}}$

Avosuhteet yleistyivät kovaa vauhtia. II Tässä tilanteessa perustevaliokunta arvosteli avioliittotoimikuntaa siitä, että sen ratkaisut olivat omiaan siirtämään avioliitonkin entistä korostetummin kahden ihmisen väliseksi yksityisasiaksi. Valiokunnan enemmistö asettui puolustamaan julkista avioliittokuulutusta. ${ }^{\text {III }}$ Täysistunnossa jotkut edustajat vastasivat valiokunnalle, ettei avioliittokuulutuksen poistaminen valtiollisesta lainsäädännöstä heikentäisi kirkon mahdollisuuksia jatkaa kirkollisen kuuluttamisen perinnettä. ${ }^{\text {IV }}$

Keskustelu kiertyi erityisesti oikeusneuvos Johannes Leivosen ja professori Jaakko Voipion sananvaihdoksi. Leivonen katsoi perustevaliokunnan liioitelleen siviiliavioliittoon kuuluttamisen julkisuutta ja tästä käytännöstä luopumisen seurauksia. Valiokunnan juristi Voipio vastasi, että toistuvat pyrkimykset tehdä avioliitosta yksityisasia olivat saaneet varovaiseksi. Sitä paitsi siviilikuulutuskin saattoi olla ihmiselle merkkitapaus. Voipio kertoi olleensa aiemmin avioliitto- toimikunnan kannalla mutta muuttaneensa mielipiteensä perustevaliokunnan pappis- ja maallikkoedustajia kuunneltuaan:"Juristinkin pitää joskus muuttaa aikaisempia kannanottojaan, ja se käy vapaalta tutkijalta ehkä helpommin kuin ylituomarilta, joka on tottunut siihen, että kun hän hyvän prejudikaatin antaa, sitä ei muuteta kuin lailla."v

Voipio nousi harvinaisen selväsanaisesti vastustamaan Leivosta ja sai tällä kertaa yhdessä perustevaliokunnan enemmistön kanssa kaksi kolmasosaa edustajista kuulutuksen säilyttämisen taakse. ${ }^{\text {VI }}$ Lausunnosta huolimatta kuulutus poistui avioliittolainsäädännöstä. Kirkolliskokouksen oli sopeuduttava tilanteeseen ja esitettävä johdonmukaisuuden vuoksi myös kirkollista kuulutusta koskevien säännösten kumoamista. Perustevaliokunta pohti vielä, voitaisiinko kirkkolaissa säilyttää maininta avioliittoaikomuksen ilmoittamisesta päiväjumalanpalveluksessa, mutta melko tiukan äänestyksen jälkeen valiokunta päätyi jättämään asian kirkkokäsikirjan ohjeiden varaan. ${ }^{\text {VII }}$ Valtion päätöksen johdosta kirkolliskokous joutui joustamaan avioliiton ehdottoman julkisuuden vaatimuksesta. $^{\text {vII }}$

I Avioliittotoimikunnan mietintö 1983, 20-26; Kirk.kok. ptk-s. 1983, 40 §, liite VIII-B 3; SEK 1980-83, 29; Yli-Opas 2010, 108.

II SEK 1980-83,30; Yli-Opas 2010, 46.

III Kirk.kok. ptk-s. 1983, liite VIII-B 3.

IV Kirk.kok. kptk-s. 1983, 40 \$.

V Kirk.kok. kptk-s. 1983, 40 \$.

VI Kirk.kok. ptk-s. 1983, 40 §.

VII KKHA KKA Cib 1 ptk. 4.11.1987 \$ 3; Kirk.kok. ptk-s. 1987, $43 \$, 48 \$, 51$ \$, liite VII-B 1; Autio 1997, 200.

VIII Kirk.kok. ptk-s. 1987, 48 \$, 51 \$. 
kuitenkin korostaa, että sitoutumisen vaatimuksella ei saanut pelottaa ketään pois sakramenttien vaikutuspiiristä. Kirkolliskokous pyrki mahdollisimman tarkasti yhdistämään kansankirkollisen ja tunnustusta korostavan kirkkonäkemyksen.

Aivan samoin tasapainoiltiin käsiteltäessä avioliittoon vihkimisen kaavoja. Vuoden 1963 kirkollisten toimitusten kirjassa oli ollut eronneiden vihkimistä varten erillinen, riisuttu kaava, joka oli painottanut toimituksen juridista luonnetta. ${ }^{461}$ Kirkolliskokouksen käsikirjavaliokunta ei pitänyt tällaista kaavaa enää tarpeellisena, mutta täysistunto päätti säilyttää sen. Kaavaa toivoivat ensinnäkin ne papit, joille oli vaikeaa vihkiä eronneita, mutta myös ne, jotka halusivat tarjota vaihtoehdon yksinkertaista kaavaa toivoville seurakuntalaisille. Tunnustusta ja kansankirkollista palvelua korostavien päämäärät kohtasivat. Samalla papille lisättiin lyhyeenkin kaavaan mahdollisuus julistaa vihittävät aviopuolisoiksi nimenomaan kolmiyhteisen Jumalan nimeen, jotta kaavaa ei koettaisi "tuomion makuiseksi". ${ }^{462}$ Erikseen ei myöskään enää mainittu, että B-kaava olisi tarkoitettu eronneille. ${ }^{463}$

Kirkolliskokous keskusteli pitkään sairaan voitelusta. Kyseessä oli käsikirjakomitean ehdottama täysin uusi kaava, jossa rukoiltiin sairaan paranemista. Myös lehdistössä tämä "käsittämätön kömmähdys, jonka kirkolliskokous toivottavasti visusti pyyhkii pois", sai huomiota. ${ }^{464}$ Piispainkokous suhtautui toimitukseen varauksellisesti, koska ilman opetusta ja teologista perustelua toimitus uhkasi sekoittua katoliseen viimeisen voitelun sakramenttiin..$^{465}$ Käsikirjavaliokunta jakoi saman huolen mutta näki myös toimituksen raamatulliset ja pastoraaliset perustelut. Vaikka valiokunta sai kirkon sairaalasielunhoidon keskuksesta toimitusta arvostelevan kirjeen, se ehdotti kaavan ottamista mukaan toimitusten kirjaan. ${ }^{466}$ Täysistunnossa mielipiteet jakautuivat voimakkaasti. Lopulta päädyttiin Turun kristillisen opiston rehtorin Mauno Mäntymaan ehdotuksesta kompromissiin: piispainkokous laatisi toimituksesta ohjeet, jotta voitelua haluavat ja sen toimittavat eivät jäisi pulaan. Toimitusten kirjaan kaavaa ei kuitenkaan otettu, jotta sitä ei olisi normalisoitu samanarvoiseksi ehtoollisen kanssa. ${ }^{467}$

Toimitusten kirjan uudistus toi mukanaan monia merkittäviä käytäntöjä, jotka hyväksyttiin kirkollisko- kouksessa vastalauseitta. Esimerkiksi ristinmerkin käyttöä pyrittiin lisäämään ja siihen rohkaisemaan. Hautaan siunaamisen kaava muuttui selvästi aiempaa rikkaammaksi, mihin oltiin kirkolliskokouksessa tyytyväisiä. Pitkä tupaantuliaisseurojen perinne taas sai jatkokseen kodin siunaamisen kaavan, johon kirkolliskokous tosin joutui hetkeksi pysähtymään. Apulaisrehtori Alma Saari huomautti, ettei kaava sisältänyt tekstivaihtoehtoa yksin asuvan henkilön kodin siunaamiseen. ${ }^{468}$ Vasta kaavaehdotuksen yksityiskohtaisessa käsittelyssä havahduttiin yksipuolisen perhekeskeiseen ajattelutapaan, ja valiokunta muokkasi kiireesti kaavaa. ${ }^{469}$

Käsikirjavaliokunta pyrki kuuntelemaan tarkasti kirkolliskokouksen ääntä, jolloin toimitusten kirja läheni edeltäjäänsä ja erkani komitean mietinnöstä. Valiokunnan nopeasti valmistama toinen mietintö saikin osakseen paljon kiitosta. Myös uuden toimitusten kirjan näkyvin arvostelija Jaakko Voipio, joka ei istuntoviikon alussa ollut valmis hyväksymään ehdotusta, antoi viikon päätteeksi vilpitöntä tunnustusta valiokunnalle ja sen tekemälle ehdotukselle. ${ }^{470}$ Uusi toimitusten kirja hyväksyttiin yksimielisesti. ${ }^{471}$

\section{VALIOKUNTA PERÄ̈̈NTYY}

\section{VIRSIPALAUTTEEN EDESS Ä}

Vuoden 1973 kirkolliskokous käynnisti Mikkelin ja Lapuan hiippakuntakokousten aloitteesta suomenkielisen virsikirjan uudistustyön. Kirkolliskokouksen käsikirjavaliokunta kiinnitti huomiota siihen, että käytössä olleessa vuoden 1938 virsikirjassa koraalien rytmiasut poikkesivat alkuperäisistä muodoista ja että virsien kieliasu kaipasi muutosta. Valiokunnan laatima toimeksianto sisälsi myös vaikeita yhtälöitä: virsikirjaa oli supistettava huomattavasti, mutta toisaalta mukaan tuli saada monipuolisesti uutta virsiainesta, erityisesti nuorten ja teollisuusyhteiskunnan virsiä. ${ }^{472}$ Taustalla vaikuttivat myös kansainväliset jumalanpalvelusmusiikin kehityssuunnat, jotka veivät samaan aikaan entistä kauemmas historiaan ja entistä lähemmäs nykyhetkeä: vanhojen sävelmien restaurointi sai rinnalleen pyrkimyksen tuoda jumalanpalvelukseen aiempaa monipuolisempia musiikkityylejä. .73

Apulaisprofessori Pentti Lempiäinen johti virsikirjakomiteaa, jolle 27-henkinen palauteryhmä antoi kommentteja. ${ }^{474}$ Komitea julkaisi 1976 uudistuksen periaat- 
teet. Seurasi vilkas julkinen keskustelu, jossa mielipiteet jakautuivat ja komitea sai kovaakin palautetta. Siitä huolimatta kirkolliskokous hyväksyi komitean esittämät uudistusperiaatteet vain pienin muutoksin ja pidemmittä keskusteluitta. Uudistus jatkui pitkälti omaksutulla linjalla: sävelmiä palautettiin vanhempaan muotoon, kun taas teksteistä poistettiin vanhentuneiksi katsotut kielimuodot. ${ }^{475}$ Kirkolliskokouksen päähuomio oli virkakysymyksessä, jossa abstraktin periaatekeskustelun vaihe oli jo jäänyt taakse ja oli tullut päätöksenteon aika - toisin kuin virsikirjauudistuksessa.

Vuonna 1975 liikkeelle lähtenyt ruotsinkielisen virsikirjan uudistaminen eteni samojen suuntaviivojen mukaan lääninrovasti Alvar Kurténin johtamassa komiteassa. ${ }^{476}$ Virsikirjakomiteat tekivät yhteistyötä keskenään ja kansainvälisesti Ruotsin, Norjan, Viron ja Unkarin virsikirjakomiteoiden kanssa. Samalla ne pyrkivät ekumenian hengessä ottamaan huomioon muiden kirkkokuntien ja kristillisten yhteisöjen laulujen sekä virsien kirjon. ${ }^{477}$ Kirkolliskokous katsoi 1970-luvulla runokielen vaatimusten ja ylipäätään maailman muuttuvan nopeasti, mikä näkyi komiteoille annetuissa evästyksissä ja tietyissä muissakin päätöksissä. Linjaukset olivat vastassa seuraavalla vuosikymmenellä, jolloin 1970-luvun alkuvuosien teknistaloudellinen edistysusko oli osin vaihtunut perinteiden ja uskonnollisuuden uuteen nousuun $^{478}$. Isänmaallisuutta ja kansallista historiaa arvostettiin avoimesti, mikä näkyi esimerkiksi arkkipiispa Juvan aborttipuheenvuorojen kommentoinnissa. Tällainen asenneilmasto kasvatti myös käytössä olleen virsikirjan painoarvoa - olihan sitä alettu veisata seurakunnissa adventtina 1939, ensimmäisenä talvisodan sunnuntaina.

Ruotsinkielinen virsikirjakomitea jätti mietintönsä hyvissä ajoin 1983, joten Porvoon hiippakunnan seurakunnille jäi aikaa palautteen antamiseen. Suomenkielisen komitean työ sen sijaan kesti vuoteen 1984 asti, ja työtä riitti paljon viime hetkille saakka. "Emmekö huomanneet aikanaan, kun lauloimme: Miitä raaha, taavaraa - -, että ei tämä veisuu oikein hyvältä kuulosta?", valitteli komitean toinen runoilija Niilo Rauhala komiteatyön viimeisinä viikkoina. Ajan loppuessa vanhan, 160o-luvulta periytyneen virren "Millainen on elämä?" kolmannen säkeistön alku jouduttiin jättämään ennalleen. ${ }^{479}$ Virsikirjaehdotuksesta julkaistiin seurakuntakäyttöön perusvirsikirjan kokoinen laitos, mutta kirkolliskokouk- sen vaalikauden käännyttyä jo loppupuolelle suomenkielisen virsikirjaehdotuksen palauteaika jäi lyhyeksi, loppuvuoteen 1984. Kiirettä arvosteltiin paljon seurakunnissa ja julkisessa sanassa. ${ }^{480}$ Satakunnan Kansa tuskaili joulukuussa 1984, että kaikissa seurakunnissa ei vielä ollut uusia virsikirjoja, vaikka seurakuntien lausunnot tuli antaa parin viikon kuluessa. ${ }^{481}$

Myös virsikirjaehdotusten sisältö viritti vilkkaan julkisen keskustelun..$^{482}$ Kirkolliskokous olikin 1980-luvun puolivälissä virsikirjauudistuksen ja naispappeuskysymyksen vuoksi ainutlaatuisen huomion kohteena. Voimakkaita mielipiteitä esitettiin perehtymättä kunnolla virsikirjakomiteoiden työn tuloksiin. Ne, jotka perehtyivät, myönsivät yleisesti komiteatyön korkean tason. Laajalti oltiin tyytyväisiä siihen, että virsitekstejä ja -sävelmiä oli käsitelty ja uudistettu samanaikaisesti, mikä oli uutta suomalaisissa virsikirjauudistuksissa. ${ }^{483}$ Silti hahmottuivat nopeasti tietyt arvostelun kohteet, jotka toistuivat lehdistössä, piispainkokouksen lausunnossa, kirkolliskokouksen lähetekeskustelussa ja seurakuntien antamassa palautteessa. Kritiikki kohdistui pitkälti samoihin asioihin niin suomen- kuin ruotsinkielisessä virsikirjaehdotuksessa.

Yksimielisimmin hyväksyttiin uusien virsien lisääminen. Suomenkielinen virsikirjaehdotus sisälsi lopulta peräti 642 virttä. Virret kattoivat laajasti erilaiset teemat ja käyttötilanteet. Tosin ehdotus sai moitteita siitä, että komitea oli ottanut mukaan lauluja, jotka eivät olleet ehtineet vielä vakiintua käyttöön. Ruotsinkielisen virsikirjan uudet virret olivat jo valmiiksi koetellumpia. ${ }^{484}$ Toisaalta suomenkieliseen virsikirjaan toivottiin vielä lisää sellaisia tunnettuja lauluja, jotka ruotsinkielisellä puolella luettiin virsiksi - esimerkiksi "Hoosianna" tai "Jouluyö, juhlayö". ${ }^{485}$ Yhteiskunnan muutos ja kirkon teologinen siirtymä näkyivät uudistustyössä sosiaalisen vastuun korostuksena ja virsien aiempaa valoisampana ihmiskäsityksenä. ${ }^{866}$

Virsien poistot aiheuttivat odotetusti paljon enemmän ristiriitoja kuin uudet virret. Kaikkien mielestä vähän käytettyjä virsiä oli poistettava, mutta komiteoiden tekemiä - ennakoitua laajempia - poistoja pidettiin usein liiallisina. ${ }^{487}$ Suomenkielinen komitea poisti 209 virttä eli lähes joka kolmannen käytössä olleen virsikirjan virsistä. Ruotsinkielinen komitea poisti vieläkin suuremman osuuden, peräti 43 prosenttia virsistä (yhteensä 273 
virttä). ${ }^{488}$ Ruotsinkielisestä ehdotuksesta palautetta antaneet seurakunnat pitivät säilytettyjen ja uusien virsien tasapainoa yleisesti hyvänä, mutta lehdistössä ja ruotsinkielisen kulttuurielämän vaikuttajien piirissä virsipoistot aiheuttivat vastustusta. Kirkolliskokouksen virsikirjavaliokunnan varapuheenjohtajana ja nelihenkisen ruotsinkielisen jaoston puheenjohtajana toiminut apulaisprofessori Fredric Cleve korosti virsikirjan merkitystä suomenruotsalaiselle identiteetille. Hän huomautti, että erityisesti komitean poistamia tai muokkaamia Johan Ludvig Runebergin virsiä oli palautettava, mikäli virsikirjan haluttiin olevan koko ruotsinkielisen väestönosan eikä vain aktiivisten seurakuntalaisten kirja. ${ }^{489}$

Kaikkein eniten arvosteltiin vanhojen virsien muokkaamista. ${ }^{49 \circ}$ Luovuttaessa lyhennetyistä persoonapronomineista suomenkielisiin virsiin oli ollut pakko lisätä toistuvasti tiettyjä sanoja, kuten "nyt" tai "saan". Virsikirjakomitean johdonmukaisuuden katsottiin vieneen sekä kielelliseen köyhtymiseen että sisällölliseen latistumiseen. "Mä"-sanan korvaaminen monin paikoin toisella yksitavuisella pronominilla "me" vähensi henkilökohtaista puhetta. ${ }^{491}$ Kirkolliskokouksen lähetekeskustelussa kysyttiin, oliko virsirunoudesta tulossa virsiproosaa. ${ }^{492}$

Piispainkokous huomautti lausunnossaan, että seurakunnan iäkkäitä jäseniä lyhennetyt muodot eivät häirinneet ja että nuoriso taas käytti nimenomaan niitä normaalissa puheessaan. ${ }^{493}$ Piispainkokoukselle asiantuntijalausunnon antanut, raamatunkäännöstyössä samaan aikaan mukana ollut filosofian maisteri Aarre Huhtala oli sitä mieltä, että hyttysiä eli pronomineja siivilöitäessä oli nielaistu kameli. Virsikirjaehdotukseen oli jäänyt ja osin jopa tullut yleiskielestä etäällä olevaa hengellistä erityiskieltä. ${ }^{494}$ Edelleen yksi arvostelun aiheista oli, että vastuu monista uusista virsistä ja vanhojen virsirunojen muokkauksesta oli jäänyt pitkälti kahdelle runoilijalle, vanhoillislestadiolaiselle Niilo Rauhalalle ja lestadiolaistaustaiselle, sittemmin hiljaisuuden liikkeeseen kotiutuneelle Anna-Maija Raittilalle. ${ }^{495}$ Vastaavasti arvosteltiin, että ruotsinkielisessä virsikirjaehdotuksessa oli liian ehdottomasti luovuttu vanhasta kieliasusta. ${ }^{496}$

Virsikirjakomiteoiden yhteistyön johdosta aiempaa selvästi useammat virret voitiin veisata samalla sävelmällä niin suomeksi kuin ruotsiksi. ${ }^{497}$ Yhteisten virsien määrän kasvua pidettiin yleensä hyvänä asiana, samoin kuin virsien aiempaa valoisampaa ilmettä. Sen sijaan siirtyminen vanhempiin, yleiseurooppalaisiin sävelmämuotoihin sai aikaan hämmennystä. Piispainkokous tiivisti yleisen mielipiteen todetessaan, että sävelmärestauraatiossa olisi pitänyt ottaa paremmin huomioon oman kirkon perinne. Virsikirjakomiteat olivat pyrkineet karsimaan jokaisesta virrestä rinnakkaissävelmät. Kriittisissä kommenteissa ratkaisun arveltiin vähentävän virsien käyttöä. ${ }^{498}$

Lehdistössä vallitsi asenne, että kirkolliskokouksen tuli korjata komiteoiden linjaa ja palauttaa muokattuja virsiä lähemmäs käytössä olleen virsikirjan muotoja. ${ }^{499}$ Virsikirjavaliokunnan puheenjohtaja Paavo Kortekangas vastasikin tähän huutoon puhuessaan kirkolliskokouksen lähetekeskustelun alkajaisiksi marraskuussa 1984: valiokunnan oli nyt kuunneltava kansan ääntä. Hän vakuutti, että valiokunta paneutuisi palautteeseen ja erityisen huolellisesti seurakuntien lausuntoihin. Toimitusten kirjan sekavaksi luisuneesta kirkolliskokouskäsittelystä otettiin opiksi ainakin sikäli, että valiokunta toivoi edustajien tekevän muutosehdotuksia etukäteen kirjallisina. Lähetekeskustelut syksyllä 1984 ja keväällä 1985 säilyivätkin tiiviinä..0o

Seurakuntien lausunnot vaihtelivat yksityiskohtaisesta ja tarkasta palautteesta julkisen keskustelun referointiin. ${ }^{501}$ Lausunnoissa näkyivät jonkin verran alueelliset erot. Arkkihiippakunnassa esimerkiksi Eurajoen ja Yläneen palautteissa toivottiin, että virsikirja jätettäisiin ennalleen ja tyydyttäisiin lisävihkoon, kun taas Turun Henrikin seurakunta antoi tunnustusta virsikirjaehdotukselle. ${ }^{502}$ Ilmiselvästi vuoden 1701 vanhaan virsikirjaan tukeutuneen rukoilevaisuuden vaikutus näkyi Eurajoen ja Yläneen kriittisissä palautteissa. Vastaavasti Oulun hiippakunnassa virsitekstien muokkaukset saivat seurakunnilta keskimääräistä myönteisempää palautet$\mathrm{ta}^{503}$. Vahvojen lestadiolaisalueiden kiitokset eivät olleet yllättäviä, kun ottaa huomioon lestadiolaistaustaisten Rauhalan ja Raittilan keskeisen osuuden uudistustyössä. Virsikirjavaliokunta oli kovan paineen alla ja osin erimielinen siitä, miten radikaaliin uudistukseen tulisi lähteä. ${ }^{504}$ Vielä tammikuussa 1985 ratkaisun saavuttaminen näytti hyvin epävarmalta. Otso Sovijärvi tiivisti valiokunnan kokouksessa: "Vastaanotto on ollut tyrmäävä, mutta tehtävä on suoritettava." ${ }^{505}$ Virsikirjavaliokunnan jäsenten keskustellessa työn linjasta Porvoon hiippa- 


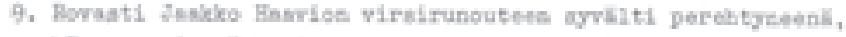

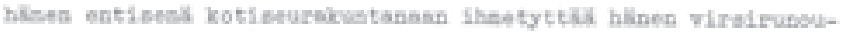
tedan voinakankin muttasines, ailia oikeodella?

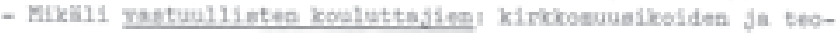
logien pula jatkuu ja pahimaass tapauknessa syvenes "uudista-

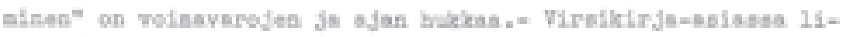
aliviziko risetiri.

Tausunnon rakuudeket

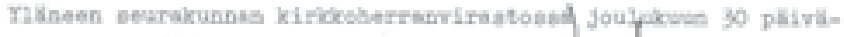
nil $198 \mathrm{es}$

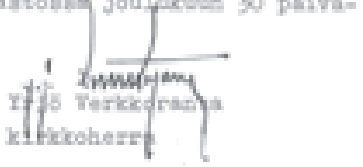

Paikallinen identiteetti nousi esiin monien seurakuntien palautteessa. Varsinaissuomalainen Yläneen seurakunta arvosteli kriittisessä palautteessaan entisen kirkkoherransa Jaakko Haavion virsirunojen muuttamista: "millä oikeudella?" Eteläsavolainen Jäppilän seurakunta taas yritti turhaan vakuuttaa, että pitäjä oli oikea kotipaikka kansantoisinnoille, jotka virsikirjakomitea oli merkinnyt pieksämäkeläisiksi. Kuvat: Kirkkohallitus.

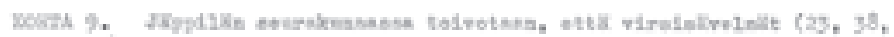

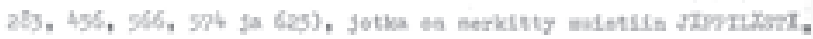

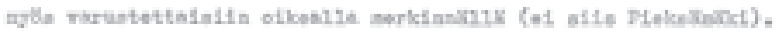

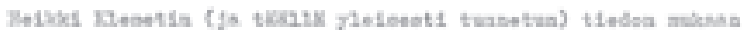

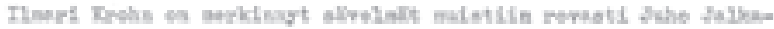

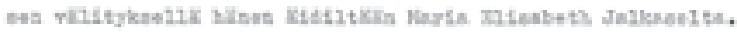

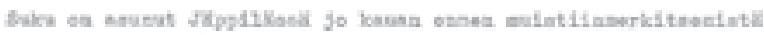

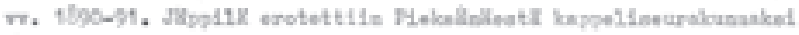

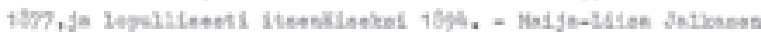

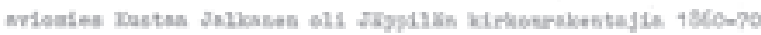

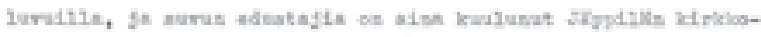

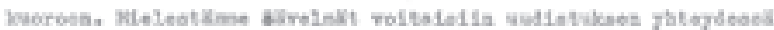

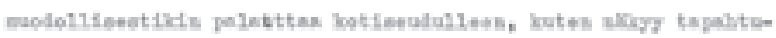

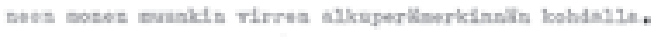

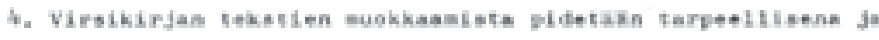
sidea ea dowisestu kehtataisen hyvif. Seurakunta phoyy kui-

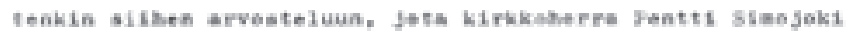

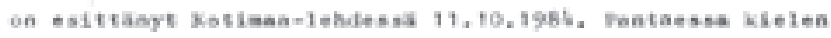
seikoys ja senbenan puhdas seese etusigeilo ea virren pur butteletebhe heikeatyeyt, Esimerkikos nykyisen virren 392 saneata "Sah haltuus, rakas Iokni, ex aina aanaa itceni"

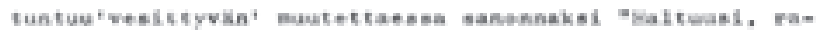
kas foask. sean aina astak itsent" (ehdetus 307). Bewa

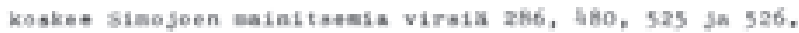

Juankosken seurakunta suhtautui tekstiuudistukseen huomattavasti myönteisemmin kuin Varsinais-Suomen maalaisseurakunnat. Sävelmien muuttamista sen sijaan arvosteltiin toisaalla lausunnossa: Pohjois-Savossa virsiä veisattiin hyvin harvoin yhdessä muiden maiden luterilaisten kanssa, joten pyrkimystä yhteisiin sävelmiin suomalaisten toisintojen kustannuksella ei nähty tarpeelliseksi. Kuva: Kirkkohallitus. kunnan edustajat olivat avoimimpia uudistuksille. Esimerkiksi Ruotsista tulleiden vaikutteiden johdosta hiippakunnassa oli jo ennestään laulullisempi virsiperinne kuin suomenkielisissä hiippakunnissa. Keskenään erilaiset lähtökohdat suomen- ja ruotsinkieliselle jaostolle toi myös se, että suomenkielinen komitea oli ollut virsien poistamisessa ja sävelmärestauraatiossa sisarkomiteaansa maltillisempi. ${ }^{506}$ Valmistelutyötä vaikeutti vielä se, että kanttoriurkuri Matti Rannan jäätyä pois edustajantyöstä kirkolliskokouksessa ei ollut keväästä 1984 lähtien yhtään kanttoria eikä myöskään sellaisia hymnologian asiantuntijoita kuin vaikkapa filosofian maisteri Tauno Väinölä vielä edellisellä vaalikaudella.

Valiokunnan puheenjohtaja Kortekangas otti henkilökohtaisestikin vastaan kärjekästä ja yleensä vajavaisiin tietoihin perustuvaa yleisöpalautetta. Tällöin hän joutui - kun virsikirjakomiteaa ja -valiokuntaa ei useinkaan osattu erottaa toisistaan - vastaamaan myös komitean 


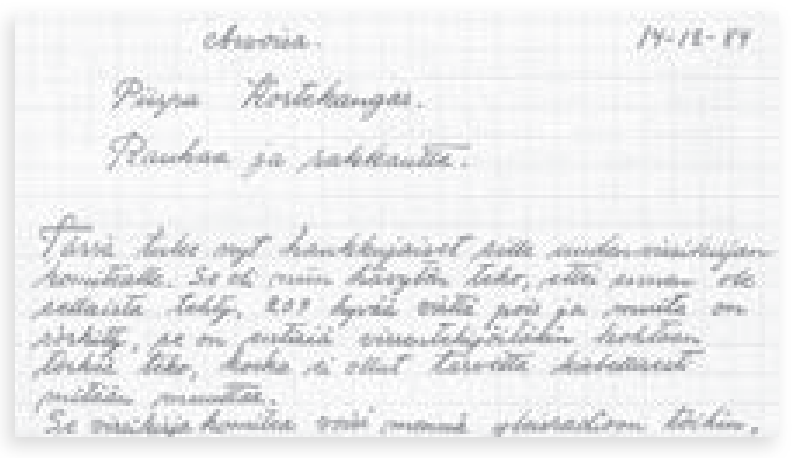

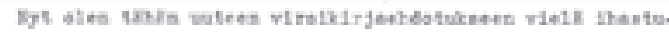

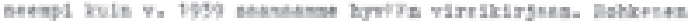

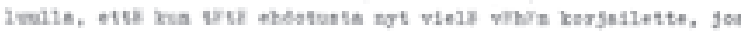

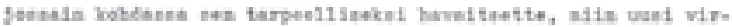

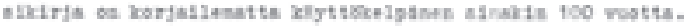

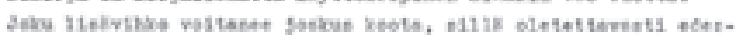

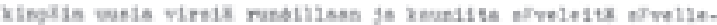

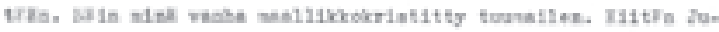

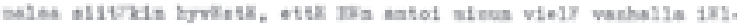
lint tutasta evelut.kinkese wutees virikiryes.

Virsikirjavaliokunta sai kosolti palautetta yksityisiltä ihmisiltä. Osa palautteesta oli maltillista ja kiittävääkin, osassa taas julistettiin tuomiota. Kuvat: Kirkkohallitus.

teoista. ${ }^{507}$ Yksittäisten henkilöiden lähettämän palautteen ohella valiokunta otti vastaan laajoja vetoomuksia. Pohjois-Karjalassa koottiin lähes 2000 nimen adressi käytössä olleen virsikirjan virsien säilyttämiseksi ennallaan..$^{508}$ Veteraanijärjestöt paheksuivat vetoomuksessaan "Isänmaan vähättelyä" virsikirjaehdotuksessa. ${ }^{509}$ Palaute keskittyi tiettyihin virsiin, joiden perusteella usein tuomittiin koko työ. Erityisesti isänmaan virret muodostuivat symboleiksi, joiden vähäinenkin muuttaminen nähtiin Kortekankaan sanoin "koko elämää ja kristillisyyttä järkyttävänä asiana”. ${ }^{510}$ Monet kokivat käytössä olleen virsikirjan kantaneen raskaiden sotavuosien läpi, minkä vuoksi virsien muokkaaminen kosketti tuntoja. Julkisuudessa virsikirjaehdotus sai paljon myös myönteistä huomiota, mutta se jäi kielteisen palautteen varjoon ${ }^{511}$.

Virsikirjaehdotuksen aikaansaama vilkas sananvaihto oli kansankirkon voimannäyte: lehdistössä käytiin kautta linjan laajaa keskustelua virsistä, ja posti välitti satoja kirjeitä, kun ihmiset lähtivät puolustamaan lempivirsiään. Tapahtumissa oli kuitenkin samalla piirteitä, jotka panevat kysymään, oliko tuo voimannäyte vii-

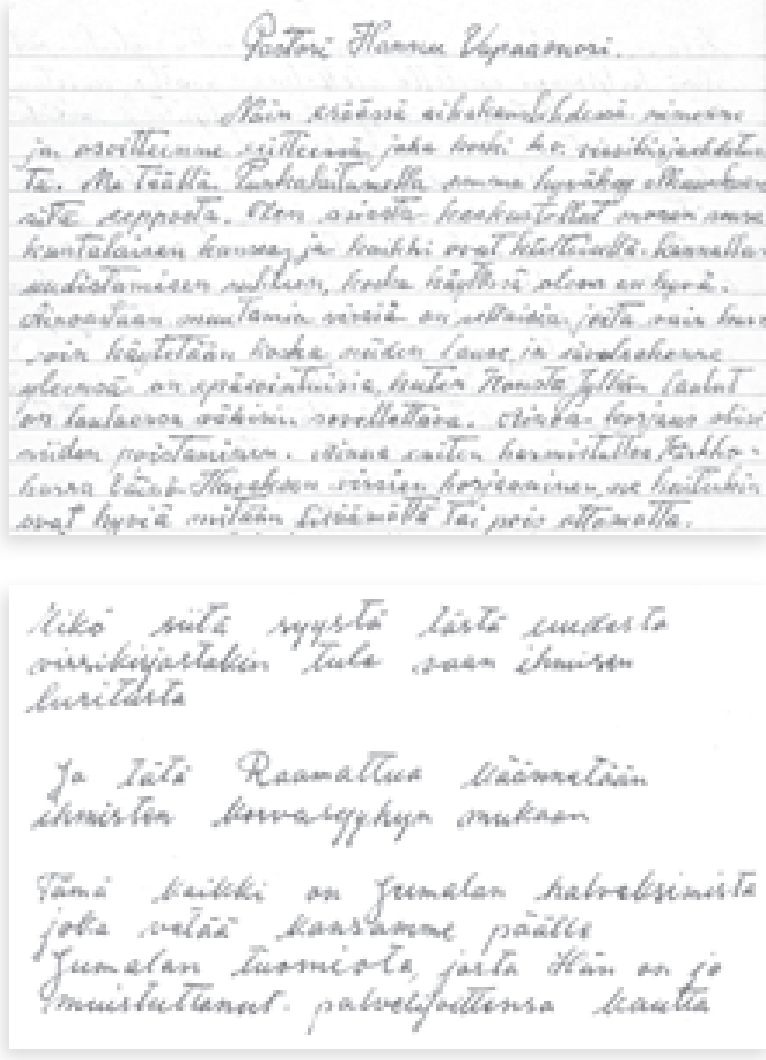

meinen laatuaan. Oli kyse menneisyyden tai lapsuuden kansankirkollisuudesta: monet arvostelijat eivät uskoneet saavansa virsikirjasta uutta rakasta kirjaa. Oli mahdollista vain joko säilyttää tai menettää oma virsikirja. Vastaavasti siellä, missä virsikirjaehdotukseen pyrittiin todella tutustumaan ja sitä veisaamaan, palaute oli selvästi myönteisempää. Toinen huomattava piirre oli, että aika monessa palautekirjeessä uhkailtiin kirkosta eroamisella. Naispappeusesityksen kaatumista seurannut eroaalto oli juuri osoittanut, etteivät eropuheet välttämättä jääneet uhkailun tasolle. Kynnys astua ulos kirkosta oli yhä useammalle matalampi kuin kynnys sietää epämieluisia päätöksiä.

Piispainkokouksen lausunto sai kirkolliskokousedustajilta paljon kiitosta ja osoitti suunnan valiokunnan työlle. ${ }^{512}$ Molemmat virsikirjavaliokunnan jaostot antoivat tunnustusta komiteoiden esityksille ja pyrkivät säilyttämään niiden päälinjan. Samalla jaostot lähtivät palaamaan taaksepäin kohti käytössä olleiden virsikirjojen 
sävelmiä ja sanamuotoja. ${ }^{513}$ Palautetta kuunneltiin tarkasti. Puheenjohtajansa mukaan valiokunta olisi ollut valmis seuraamaan komitean linjaa pidemmällekin. Se piti kuitenkin tärkeämpänä saada aikaan tuttu ja turvallinen virsikirja, joka silti toisi piristystä jumalanpalveluselämään ja koko kristillisyyteen. ${ }^{14}$

Virsikirjavaliokunta ei työnsä aikana etsinyt yhteyksiä komiteoiden jäsenistöön. Ensin suomenkieliseen komiteaan ja sitten virsikirjavaliokuntaan kuulunut kirkkoherra Heikki Vaahtoniemi tosin pystyi pitämään komitean ajatuksia esillä valiokunnassa. Sen sijaan ruotsinkieliseen komiteaan ja sittemmin virsikirjavaliokunnan ruotsinkieliseen jaostoon kuulunut kirkkoherra Henrik Perret osallistui molempien elinten kokouksiin vain harvoin. ${ }^{515}$ Yleisistä linjoista päätettiin koko valiokunnan kokouksissa, mutta muuten nelijäseninen ruotsinkielinen jaosto ja 11-henkinen suomenkielinen jaosto työskentelivät erillään. Ruotsinkielisen virsikirjan yksityiskohdat ratkesivat puhtaasti ensin mainitun päätöksillä. ${ }^{16}$ Suomenkieliset jäsenet katsoivat kielitaitonsa niin puutteelliseksi tai ruotsinkielisen virsikirjan itselleen sen verran vieraaksi, että pienen ruotsinkielisen jaoston jäsenillä oli suuri valta muokata virsiä itsenäisesti. Tätä valtaa nämä myös käyttivät. ${ }^{517}$

Valiokunnan suomenkielisen jaoston pitäessä yhtä monista kokouksistaan samassa leirikeskuksessa oli koolla jatkorippikoululaisten ryhmä. Järjestettiin virsiraati, jossa rippikoululaiset olivat tuomareina. Vastakkain olivat virsikirjaehdotuksen ja käytössä olleen virsikirjan versiot. Lopuksi nivalalainen maanviljelijä Arvi Ruuttunen veisasi kunkin arvosteltavan virren vuoden 1701 virsikirjasta. Hänen yhden miehen veisuuryhmänsä sai murskavoiton. Otso Sovijärvi arvioi, että Ruuttusen "persoonalla lienee ollut osansa voitossa, mutta ei se pelkästään voittoa ratkaissut". ${ }^{118}$ Virsiraadin tulos antoi omaa hiljaista tukeaan valiokunnan pidättyvälle linjalle, jonka mukaan oli tärkeämpää säilyttää väkevä ilmaisu kuin päästä täysin oikeakieliseen mutta samalla usein sisällöllisesti lievennettyyn sanamuotoon. Virsikirjan kieltä oli pyritty uudistamaan nuorisoa varten, mutta leirikeskuksen nuoriso veti mattoa uudistajien jalkojen alta.

Virsikirjavaliokunta säilytti suomenkielisen virsikirjaehdotuksen virsiteksteistä 45 prosenttia komitean ehdottamassa muodossa. Muokkauksistakin monet olivat pieniä, mutta toiset muuttivat käytännössä koko virren. ${ }^{19}$ Komitea oli jättänyt kaksi suomenkielistä virsitekstiä täysin vuoden 1938 virsikirjan muotoon, mutta valiokunta lisäsi määrää peräti 24 virsitekstillä. Samaten valiokunta palautti entiseen muotoonsa erityisesti sellaisia sävelmiä, joihin komitea oli tehnyt restaurointityössään vain pieniä muokkauksia. Kun komitea ehdotti vaihtoehtoista sävelmää vain kahteen suomenkielisen virsikirjan virteen, valiokunnassa tällaisten virsien määrä nousi 35 :een. ${ }^{520}$

Ruotsinkielisen virsikirjan osalta valiokunta päätyi samantyyppisiin ratkaisuihin - esimerkiksi vanhahtavia verbien monikkomuotoja palautettiin silloin, kun tällainen muoto katsottiin teologisesti tai tyylillisesti perustelluksi. ${ }^{521}$ Keskeisenä oli Fredric Cleven jo työn alkuvaiheessa ilmaisema periaate: komitea oli laatinut seurakuntalaisten virsikirjan, jonka valiokunta halusi laajentaa koko suomenruotsalaisen väestönosan virsikirjaksi. ${ }^{522}$ Valiokunta pyrki edelleen kiinnittämään huomiota siihen, että mahdollisimman moni virsi olisi veisattavissa samalla sävelmällä suomen- ja ruotsinkielisessä virsikirjassa. ${ }^{223}$

Monet seurakunnat katsoivat palautteessaan, että suomenkielinen komitea oli poistanut liikaa vanhoja virsiä. Valiokunta palauttikin kahdeksan vuoden 1938 virsikirjan virttä. Lisätessään kokoelmaan virsiä valiokunta nojasi pitkälti seurakuntien ja piispainkokouksen lausuntoihin mutta käytti harkintaansa siinä, mitkä toivotuista virsistä se hyväksyi mukaan. Erityisesti valiokunta kuitenkin karsi komitean ehdottamia uusia virsiä, ja lopulta valiokunnan virsikirjaehdotuksessa oli 41 virttä vähemmän kuin komitean ehdotuksessa. ${ }^{524}$ Samaan aikaan valiokunnan ruotsinkielinen jaosto lisäsi virsien kokonaismäärää - olihan ruotsinkielisen komitean tekemät poistot yleisesti todettu liiallisiksi. ${ }^{25}$ Valiokunnan työn jäljiltä suomenkielisessä virsikirjaehdotuksessa oli 601 virttä, ruotsinkielisessä 573 . Vaikka takana oli useita kompromisseja, kaikki valiokunnan jäsenet halusivat asettua ehdotusten taakse. "Työ on ollut meille henkisesti ja fyysisesti vaikea ja vaativa, hyvin raskas mutta myös hyvin rakas", Paavo Kortekangas luonnehti. ${ }^{526}$

Lehdistössä huomio keskittyi tälläkin kertaa paljolti isänmaan virsiin ja erityisesti yhteen valiokunnan tekemistä poistoista: komitean virsikirjaehdotuksessa ollut Uuno Kailaan ja Taneli Kuusiston rakastettu 


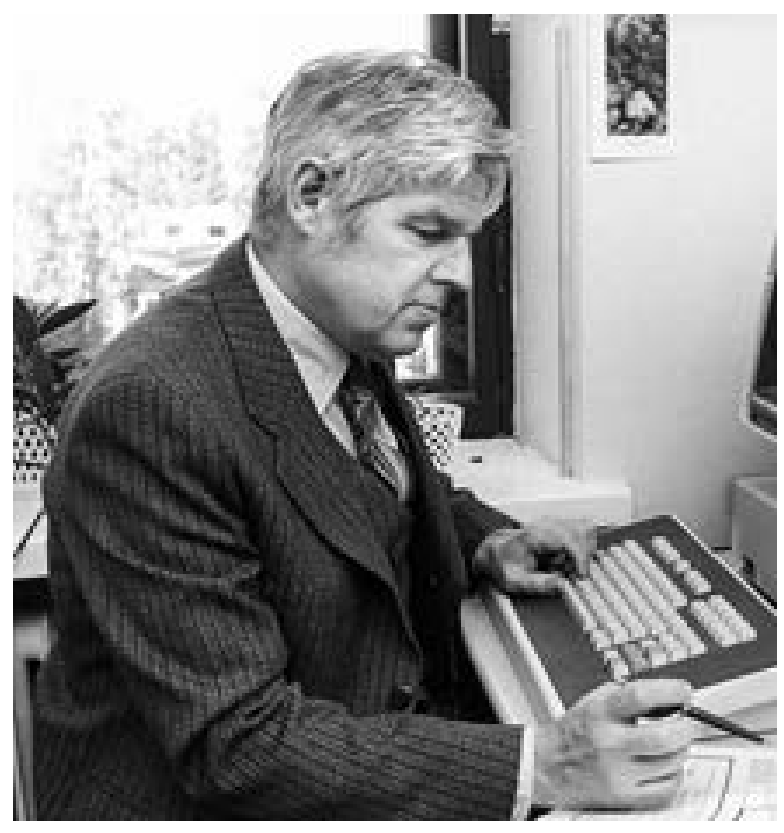

Virsikirjakomiteoiden jäsenet olivat yleisesti tyytymättömiä siihen, ettei kirkolliskokouksen virsikirjavaliokunta ollut heihin yhteydessä vaan luopui voimakkaan palautteen edessä monin paikoin komiteoiden linjasta. Suomenkielisen komitean puheenjohtaja, Kotimaan päätoimittaja Pentti Lempiäinen arvosteli lehdessään voimakkaasti valiokunnan ratkaisuja. Kuva: Kotimaan kuva-arkisto / Jukka Granström.

"Suomalainen rukous" ei ollut päässyt valiokunnan ehdotukseen. ${ }^{27}$ Virttä koskeneet odotukset olivat olleet niin ristiriitaisia, että valiokunta oli katsonut parhaaksi jättää sen kokonaan pois. ${ }^{528}$ Muuten lehdistö antoi yleisesti tunnustusta valiokunnan perinteitä vaalivalle linjalle. ${ }^{529}$ Kotimaan pääkirjoitus poikkesi tästä rintamasta. Se olikin luonnollista, koska lehden päätoimittajana oli suomenkielistä virsikirjakomiteaa johtanut Pentti Lempiäinen. Lehti valitti lasten virsien vähenemistä ja sitä, että osasto oli jäämässä tyylillisesti ja kielellisesti yhä kauemmaksi lasten maailmasta. Useiden virsitekstien jättäminen vanhaan muotoonsa saattoi vähentää virsien käyttöä. Valiokunnan mietintö suuntautui lehden mukaan aikakaudelle tyypillisesti taaksepäin: "Tulevaisuutta varten virsikirja kuitenkin pitäisi tehdä." ${ }^{530}$ Se, ettei virsikirjakomiteoiden jäseniä ollut kuultu valiokunnassa, näkyi lopputuloksessa ja johti jännitykseen erityisesti joidenkuiden komiteoiden jäsenten ja valiokunnan välillä. ${ }^{31}$
"ON IS ̈̈T TÄÄLLÄ TAISTELLEET"

- PERINTEEN JA MUUTOKSEN JÄNNITE UUDESSA VIRSIKIRJASSA

Kirkolliskokous keskusteli syysistuntokaudella 1985 ja ylimääräisellä istuntokaudella helmikuussa 1986 yhteensä viisi päivää virsikirjavaliokunnan ehdotuksista. Käytännössä keskusteltiin suomenkielisestä virsikirjasta. Useimmat edustajat olivat valiokunnan työhön pääosin tyytyväisiä, mutta salissa esitettiin voimakkaastikin vastakkaisiin suuntiin käyviä mielipiteitä. Joidenkuiden mukaan valiokunta oli tärvellyt komitean linjakkaan työn, kun taas toisten mielestä olisi pitänyt palauttaa vieläkin enemmän käytössä olleen virsikirjan muotoja. Osa jakoi Pentti Lempiäisen huolen siitä, että tuttujen virsien jättäminen täysin ennalleen vähentäisi vastaisuudessa näiden virsien käyttöä. Toiset päinvastoin pelkäsivät, että ennallaan säilytetyt virret jäisivät lähes ainoiksi veisattaviksi. ${ }^{52}$ Johtopäätökset riippuivat siitä, katsoiko edustaja asiaa lyhyellä vai pitkällä aikavälillä, aikuisten vai lasten näkökulmasta.

Valiokunta oli karsinut voimakkaasti suomenkielisen virsikirjaehdotuksen virsiä, minkä vastapainoksi täysistunnossa kuultiin paljon lisäysehdotuksia. Niistä jopa yli kaksi kolmasosaa - yhteensä 31 virttä - hyväksyttiin. Uusia virsiä otettiin komitean ehdotuksesta suunnilleen neljä kertaa niin usein kuin käytössä olleesta virsikirjasta. Tässä suhteessa täysistunto palautti virsikirjaa komitean ehdotuksen suuntaan. Edustajat ehdottivat myös seitsemää täysin uutta virttä, joita ei ollut sen enempää edellisessä virsikirjassa kuin komitean ehdotuksessakaan. Nämä laulut ja virret olivat jo vakiintuneet käyttöön, ja kaikki niistä hyväksyttiin mukaan. Rukoilevaisuuteen lukeutunut 4H-neuvoja Irja Vuorenpää ehdotti mukaan virren "Jo mahtaisimme yötä ja päivääkin kiittää". Herätysliike, jolla ei ollut ollut omaa edustajaa komiteassa eikä valiokunnassa, sai kirkolliskokouksen täysistunnossa mukaan yhden keskeisimmistä virsistään - vieläpä virsikirjavaliokunnan puheenjohtajan Paavo Kortekankaan tuella. Valiokunta nousi muutenkin vastustamaan lisäyksiä lähinnä vain, kun ehdotettiin valiokunnan itsensä poistamien virsien palauttamista. ${ }^{533}$

Edustajat arvostelivat erityisesti lasten ja nuorten virsiä samaan tapaan kuin Pentti Lempiäinen pääkirjoituk- 


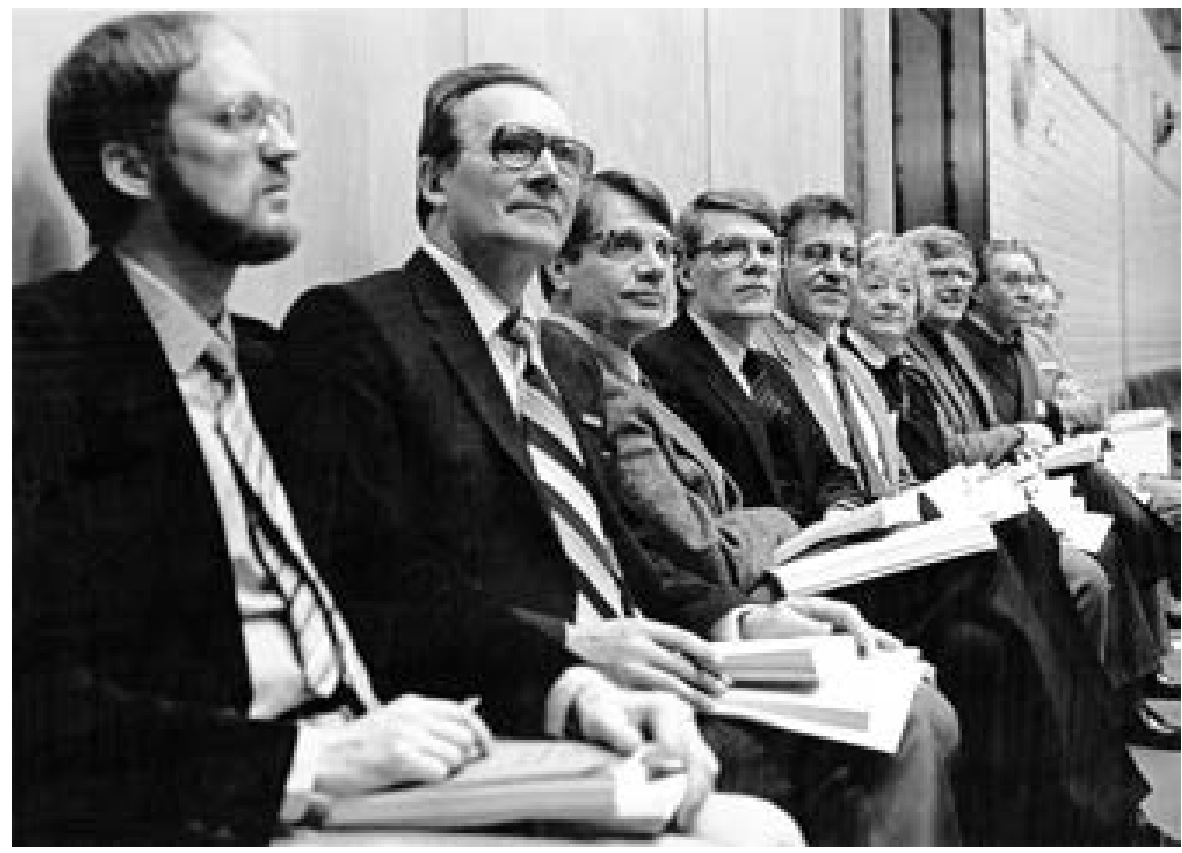

Virsikirjavaliokunta istui kokoussalin laidalla puhujakorokkeen lähistöllä valmiina puolustamaan näkemyksiään tai pitämään tarvittaessa pikapalaverin. Kuvassa vasemmalta filosofian maisteri Göran Stenlund, lehtori Reino Ylimäki, puheenjohtaja, piispa Paavo Kortekangas, asessori Reijo Mattila, kirkkoherra Heikki Vaahtoniemi, päätoimittaja Raili Malmberg, asessori Otso Sovijärvi ja maanviljelijä Arvi Ruuttunen. Kuva: Kotimaan kuva-arkisto / Jukka Granström. sessaan. Kajaanin kappalainen Petri Karttunen ehdotti peräti kolmea uutta laulua lisättäväksi lasten virsiksi: Jaakko Löytyn ja Enoch Sontongan "Kuule, Isä taivaan" sekä Anna-Mari Kaskisen ja Pekka Simojoen "Taivaan Isä suojan antaa" ja "Jeesus, meitä kosketa nyt". Virret hyväksyttiin varsin yksimielisesti mukaan. Arkkipiispa Vikström päätti keskustelun toteamukseen, että kirkolliskokous oli lasten virsiä käsitellessään uuden virsikirjan portilla: kirjan käyttö riippuisi siitä, rupeaisivatko lapset veisaamaan sitä. ${ }^{534}$

Piispa Kortekangas taas totesi myöhemmin, että kirkolliskokouksessa oli oltu "aika herkällä mielellä" hyväksymään uusia lasten virsiä. ${ }^{535}$ Hänen johtamansa valiokunta päätyi jättämään pois laulun "Taivaan Isä suojan antaa": "Siinä on pitkät säkeistöt ja vaikea sävel. Lasten yksinlauluksi se on liian vaikea, eikä muutenkaan tuo mitään oleellista lasten virsiin." ${ }^{36}$ Karttunen taas kertoi saaneensa juuri tästä virrestä erityisen paljon kiittävää palautetta lasten kanssa työskenteleviltä. Lapset olivat ottaneet virren omakseen. Heille se ei ollut vaikea, toisin kuin tasatahtiseen veisuuseen tottuneelle kirkolliskokousedustajien sukupolvelle. Kirkolliskokous pysyi kannassaan ja otti laulun virsikirjaan valiokunnan vastusteluista huolimatta. ${ }^{537}$ Uusia virsiä lisättäessä täysistunto osoittautui monipuolisemman virsilaulun kan- nattajaksi kuin valiokunta, joka oli saanut palautetta lähinnä vanhemmalta sukupolvelta. Eniten lisäysehdotuksia tekivät evankeliseen liikkeeseen lukeutuneet piispa Yrjö Sariola (9) ja professori Lauri Koskenniemi (5) ${ }^{538}$.

Virsien lisäysehdotukset menivät täysistunnossa helposti läpi, mutta poistoehdotuksille kävi toisin. Uusia virsiä aktiivisesti ehdottanut Lauri Koskenniemi oli koko ajan myös huolissaan virsikirjan paisumisesta. Hän teki yksistään puolet kaikista virsien poistoehdotuksista - lopulta jo lähes toivonsa menettäen. Täysistunnossa poistettiin kuitenkin vain yksi virsi, ja senkin valiokunta palautti takaisin toisessa mietinnössään. Moni edustaja puolusti virsien lisäämistä tai säilyttämistä kertomalla, miten virsi oli vaikuttanut hänen elämäänsä. Henkilökohtaiset tilitykset ja tunteet näyttävät myös vaikuttaneen merkittävästi asian käsittelyyn. ${ }^{539}$ Lopputuloksena oli, että virsikirjan virsien määrä ei kirkolliskokouksen käsittelyssä juuri muuttunut komitean laajaan ehdotukseen verrattuna.

Keskustelu suomen- ja ruotsinkielisestä virsikirjasta keskeytyi viitisenkymmentä kertaa siihen, että kirkolliskokous veisasi käsiteltäviä virsiä eri muodoissaan. Joissakin tapauksissa veisaaminen selvästikin vaikutti kirkolliskokouksen päätökseen. Jonas Anderssonin säveltämä ja Leonard Typön sanoittama, lestadiolaisille 


\section{Picture removed from the open access version of this book.}

Virsikirjauudistusta koskeneet täysistuntokeskustelut keskeytyivät puolensataa kertaa siihen, että kirkolliskokous veisasi erilaisia virsivaihtoehtoja. Näin saatu käytännön tuntuma vaikutti paikoin selvästi myös kokouksen kantaan. Kirkolliskokousta säesti ruotsinkielisen virsikirjakomitean ja virsikirjavaliokunnan jäsen, kirkkoherra Henrik Perret avustajanaan kokouksen notaari Risto Cantell. Kuva: Kotimaan kuva-arkisto.

läheinen pääsiäisvirsi "Aurinkomme ylösnousi" sai aluksi niin valiokunnassa kuin täysistunnossa osakseen epäilyjä, mutta virren laulaminen muutti monen mielen..$^{50}$

Virsien muodosta keskusteltaessa kirkolliskokousedustajat kiinnittivät enemmän huomiota teksteihin kuin sävelmiin. Tekstejä koskevia muutosehdotuksia tehtiin yli sata, ja vajaa puolet niistä hyväksyttiin. Selvästi eniten muutosehdotuksia teki Lauri Koskenniemi, ja muutkin aktiivisimmat muutosehdotusten tekijät olivat herätysliikkeisiin lukeutuneita pappeja: Timo Kökkö, Tapani Vuorela, Risto Heikkilä ja Heikki Vaahtoniemi. Kukin heistä jätti kymmenkunta ehdotusta. Aktiivisin maallikko oli runoutta harrastanut Irja Vuorenpää viidellä muutosehdotuksellaan.
Virsikirjavaliokunta oli siirtynyt johdonmukaisesti lähemmäksi käytössä olleen virsikirjan sanamuotoja, mutta kirkolliskokouksen täysistunnossa virsitekstien kokonaislinja ei enää muuttunut: kokous palasi yhtä usein vielä valiokuntaakin pidemmälle käytössä olleen virsikirjan suuntaan kuin palautti komitean ehdotuksen. Joissakin tapauksissa täysistunnossa syntyi aivan uuttakin runoutta. Esimerkki virrestä, jonka teksti palautettiin täysistunnossa käytössä olleen virsikirjan suuntaan, on Philipp Friedrich Hillerin virren "Mä elän laupeudesta" ensimmäinen säkeistö. Simo Korpela oli suomentanut virren 1903, ja se oli otettu virsikirjaan 1938.

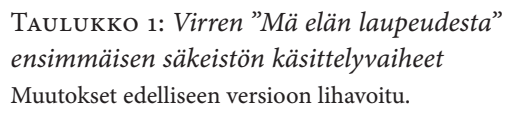

1) Virsikirja 1938 (344:1)

Mä elän laupeudesta

ja armon antimista,

en ansainnut mä autuutta,

se tuotiin taivahista.

Tää lohdutus on ainoa:

Mä elän laupeudesta.

3) Virsikirjavaliokunta 1985 (262:1)

Mä elän laupeudesta ja armon antimista.

En itse voikaan ansaita autuutta taivaallista.

Lohdutus kantaa ainoa:

Mä elän laupeudesta.
2) Virsikirjaehdotus 1984 (286:1)

Saan elää laupeudesta,

On Jeesus armon suonut.

En ansaita voi autuutta,

Hän itse on sen tuonut.

Lohdutus kantaa ainoa:

Saan elää laupeudesta.

4) Kirkolliskokous 1986 (VK 275:1)

Mä elän laupeudesta

ja armon antimista.

En ansainnut mä autuutta,

se tuotiin taivahista.

Tää lohdutus on ainoa:

Mä elän laupeudesta.
Virsikirjakomitea uudisti virren ensimmäisen säkeistön lähes täydellisesti: vain muutama sana jäi ennalleen. Komitean paljon käyttämä sana "saan" toistui säkeistössä kaksi kertaa "mä"-pronominien korvaajana. Piispainkokous kiinnitti lausunnossaan huomiota "saan"-verbin toistuvuuteen ja ongelmallisuuteen. ${ }^{541}$ Kannelmäen kirkkoherra Pentti Simojoki puolestaan käytti Teologisen Aikakauskirjan artikkelissaan juuri tätä virttä esimerkkinä sisältöön vaikuttaneesta kielellisestä uudistuksesta. Simojoen mukaan verbimuoto "saan" johti juridiseen jumalasuhteeseen: ihmiselle oli annettu oikeus elää laupeudesta, ja hänen omasta ratkaisustaan 
ja vapaasta tahdostaan riippui, miten hän tätä oikeutta käytti. ${ }^{542}$ Teologisen Aikakauskirjan teemanumero luettiin virsikirjavaliokunnassa tarkkaan. ${ }^{53}$

Valiokunta laati säkeistöön tekstin, joka asettui hyvin tarkasti käytössä olleen virsikirjan ja komitean ehdotuksen välimaastoon. Kirkolliskokous palautti piispa Kortekankaan ehdotuksesta täysistunnossaan vielä lisää alkuperäisiä ilmaisuja, tavoitteenaan saada "tiettyä tuttuutta ja turvallisuutta". Lopulta virren ensimmäinen säkeistö hyväksyttiin täysin samassa muodossa kuin se oli käytössä olleessa virsikirjassa. ${ }^{54}$ Säkeistö, jossa oli kolme "mä"-sanaa, "tää" ja vielä "taivahista", soti kaikkia virsikirjauudistuksen kielellisiä periaatteita vastaan, mutta tekstimuodon katsottiin olevan seurakuntalaisille tuttu ja teologisesti kestävä.

Toisissa tapauksissa kirkolliskokous piti virsikirjakomitean uudistamaa tekstiä parempana kuin valiokunnan palauttamaa aiempaa muotoa. Esimerkiksi käy Elias Blixin runoileman pääsiäis- ja lähetysvirren "Oi nouse, aurinkomme" ensimmäinen säkeistö. Virsi oli otettu virsikirjan lisävihkoon 1963 Jaakko Haavion uudelleen suomentamana.

\begin{tabular}{|c|c|}
\hline 1) Lisävihko 1963 (660:1) & 2) Virsikirjaehdotus 1984 (102:1) \\
\hline 3) Virsikirjavaliokunta 1985 (94:1) & 4) Kirkolliskokous 1986 (VK 101:1) \\
\hline Oi nouse, aurinkomme & Oi nouse, aurinkomme \\
\hline Sä kirkas, suloinen. & kirkas ja suloinen, \\
\hline Suo päästä pakanoiden & ja auta kaikki kansat \\
\hline Jo yöstä orjuuden. & pois yöstä orjuuden. \\
\hline Kun paaden haudaltasi & Kuin paaden haudaltasi \\
\hline sä heitit, heitä myös & vieritti Jumala, \\
\hline pois taikauskon usvat, & niin valhe, taikausko \\
\hline tee, Jeesus, armotyös.[/!] & myös, Jeesus, kukista. \\
\hline
\end{tabular}

Täysistuntokeskustelussa Lauri Koskenniemi piti raamatullisempana komitean ajatusta, että Jumala herätti Poikansa, kuin valiokunnan palauttamaa sanamuotoa, jonka mukaan Kristus heitti paaden haudaltaan. Heikki Vaahtoniemi kiinnitti lisäksi huomiota sanaan "pakanoiden", joka hänen mukaansa koettiin ivasanana. Kaikki eivät yhtyneet tähän tulkintaan, mutta kirkolliskokous palautti lopulta selvällä enemmistöllä säkeistön komitean esittämään muotoon. ${ }^{55}$ Ratkaisua helpotti se, ettei "Oi nouse, aurinkomme" kuulunut virsikirjan tunnetuimpiin virsiin. Sen osalta oli helpompi hyväksyä komitean uudistama virsiteksti kuin paljon käytetymmän virren "Mä elän laupeudesta" ollessa kyseessä.

Joissakin tapauksissa kirkolliskokouksen täysistunnossa syntyi aivan uusia säkeitä. Lyhimmillään valmistelu oli Paul Gerhardtin virren "Pyhä Henki, lohduttaja" seitsemännessä säkeistössä. Virsikirjaehdotuksen mieskeskeiset ilmaukset olivat aiheuttaneet arvostelua jo julkisuudessa, minkä voi nähdä osana yleismaailmallista keskustelua. Yhä harvemmat naiset suostuivat itseään kutsuttavan "veljiksi", ja ekumeenisessa liikkeessä oli varsinkin 1970-luvulta lähtien esiintynyt vaatimuksia inklusiivisesta kielestä. Lisäksi Yhdistyneitten kansakuntien naisten vuosikymmenen päättyminen juuri 1985 johdatti kiinnittämään asiaan huomiota. ${ }^{546}$ Kirkolliskokouksessa emäntä Helli Karvinen arvosteli Gerhardtin virren suomennoksessa säkeitä "että voisin veljiäni rakastaa kuin itseäni”. Heikki Vaahtoniemi tarttui heti Karvisen ajatukseen "veljien" korvaamisesta "lähimmäisillä":

Tässä näköjään sopisi laulaa kyllä niin. Se olisikin siis:"armo voimakseni suo, että lähimmäisiäni .... Jaa. Ei. Siitä jäisi silloin verbi pois. Ei käy. "Että lähimmäisiäni rakastan kuin itseäni", niin se käy."Mieli nöyrä minuun luo, armo voimakseni suo, että lähimmäisiäni rakastan kuin itseäni”. Esitän tätä. ${ }^{547}$

Puhujakorokkeella syntyivät uudet sanat, joilla virttä laulettiin sittemmin uudessa virsikirjassa. Päivät olivat pitkiä, mutta väsymys ei näyttänyt ainakaan tyrehdyttävän edustajien runosuonta. Eräässä iltaistunnossa Paavo Kortekangas totesi: "Näyttää siltä, että täällä nyt tulee runoutta, joka ei ehkä siedä huomispäivän valoa (hilpeyttä)." Valiokunnan puheenjohtajan arviosta huolimatta tuokin istunto kesti vielä pitkään, lähes puoleenyöhön. ${ }^{548}$

Ajankohtainen rauhankysymys nousi esille myös virsikirjaa käsiteltäessä. Ensimmäisen kerran aiheeseen pysähdyttiin keskusteltaessa virsiehdotuksesta "Nouskaamme vuorelle korkeimmalle". Keskustelu alkoi siitä, julistiko virsi maanpäällistä paratiisia, mutta pian jo virren epäilijät joutuivat puolustautumaan ja vakuuttelemaan, että hekin kannattivat rauhaa. ${ }^{549}$ Julkisuudessa paljon esillä ollut "Suomalainen rukous" ei sen sijaan 
juuri puhuttanut kirkolliskokousta, koska Paavo Kortekangas ilmoitti jo yleiskeskustelun alussa, että virsi voitaisiin palauttaa. ${ }^{550}$ Varsinainen kädenvääntö syntyi virrestä "Sun kätes, Herra, voimakkaan", jota komitea oli muokannut mutta jonka valiokunta oli runsaan palautteen saattelemana muuttanut takaisin käytössä olleen virsikirjan sanamuotoon.

TAULUKко 3: Virren "Sun kätes, Herra, voimakkaan" käsittelyvaiheet

1) Virsikirja 1938 (462)

2) Virsikirjaehdotus 1984 (613)

3) Virsikirjavaliokunta 1985 (553)

4) Kirkolliskokous 1986 (VK 577)

1. Sun kätes, Herra, voimakkaan suo olla turva Suomenmaan niin sodassa kuin rauhassa ja murheen, onnen aikana. - -

3. On isät täällä taistelleet[,] ja uskoneet ja toivoneet. Me saimme saman asunnon, ja samat vaiheet meidän on. - -

6. Sä siunaa mielet vakaiset ja hurskaat työt ja aikehet. Lyö maahan maansa pettäjät, tuo julki juonet ilkeät. - -

\section{Kätesi, Herra, voimakkaan suo olla turva Suomen maan niin sodassa kuin rauhassa ja murheen, onnen aikana. - - \\ 3. Kun isät täällä asuivat, he uskoivat ja toivoivat. Me saimme saman isänmaan ja saman osan onnekkaan. - - \\ 5. Myös siunaa toimet vakaiset ja uskolliset sydämet. Vaienna pahan kylväjät, vahvista rauhantekijät.}

Tällä kertaa ne edustajat, jotka kannattivat komitean uudistamia sanamuotoja, joutuivat puolustautumaan ja vakuuttelemaan isänmaallisuuttaan. Mukaan tulivat myös sisällissodan traumat: mitä tarkoitettiin rukouksella, että Jumala löisi maahan maansa pettäjät, ja repivätkö sanat auki vanhoja haavoja? Keskusteluun toi oman lisänsä sekin, että komitean muotoilu vastasi tällä kohden ajatukseltaan paremmin J. L. Runebergin alkuperäistä runoa kuin vuoden 1938 virsikirjan sanamuoto. Pienetkin muutokset virren sanoihin koettiin kuitenkin vaikeiksi. Virrestä oli ehtinyt tulla virsikirjauudistuksen symboli, ja pelättiin, että sen vähäinenkin muuttaminen tulkittaisiin loukkaukseksi veteraanisukupolvea kohtaan. Jotkut pitivät virttä myös kirkon ja puolustusvoimien keskinäisen suhteen koetinkivenä. Kirkollis-

kokouksen enemmistö ei lopulta halunnut ottaa riskejä. Nopeatempoinen sananvaihto jätti tilaa väärinymmärryksille, ja keskustelu äityi kärjekkäämmäksi kuin todelliset mielipide-erot olisivat antaneet aihetta. ${ }^{51}$

Kirkolliskokouksen täysistunnossaan hyväksymät tekstimuutokset koskivat lopulta useimmiten yksittäisiä säkeitä tai sanoja, joten tekstien kokonaisuus ei paljon muuttunut valiokunnan esittämästä muodosta. ${ }^{552}$ Paavo Kortekangas puolusti täysistunnossa voimakkaasti valiokuntansa tekstiehdotuksia. "Tunnelatausta ja jylinääkin tuli mukaan, lähes ylivainiolaisittain", kuvaili Kalevan toimittaja ${ }^{553}$. Erityisesti mystiikka, väkevä sanoma ja synnin todellisuus olivat asioita, joiden Kortekangas pelkäsi vesittyvän monien muutosehdotusten myötä: "Tämä virsikirja on ollut täynnä toivoa, se on tullut fraasiksi tässä virsikirjassa. - - Olemme riemulliset katseet yms. jo hyväksyneet, mutta älköön sieltä poistuko tätä synnintuntoa." ${ }^{554}$ Taustalla näkyi erityisesti Anna-Maija Raittilan kauneutta ja toivoa huokunut virsirunous, josta valiokunta halusi tulla muutaman piirun takaisin vuoden 1938 virsikirjassa koruttomasti ilmaistun syntikurjuuden suuntaan. Samalla virsikirjavaliokunta halusi kuitenkin säilyttää komitean virsikirjaehdotuksen sisältämän uudenlaisen mystiikan.

Virsitekstien vilkkaan täysistuntokäsittelyn lomassa piispa Yrjö Sariola piti yllä sävelmäkeskustelua. Kirkon jumalanpalvelus- ja musiikkitoimikunnan ${ }^{555}$ jäsenenä ja puheenjohtajana pitkään toiminut Sariola tunsi koraaliuudistuksen tarpeet ja ymmärsi virsikirjakomitean linjaa. Hän teki selvästi yli puolet sävelmiä koskevista muutosehdotuksista, ja hänen 15 ehdotuksestaan peräti 13 hyväksyttiin. Sariola luonnehti valiokunnan ehdotusta "ylimenokauden virsikirjaksi", jossa sävelmistö oli köyhtynyt ja sävelmärestauraation anti eloisan virsilaulun edistämiseksi jäänyt paljolti käyttämättä. Hän myös valitteli, ettei valiokunnan suomenkielinen jaosto ollut kuullut riittävästi sävelmäasiantuntijoita, kun se oli poistanut sävelmiä tai palauttanut niitä käytössä olleen virsikirjan muotoon. ${ }^{556}$ Sariolan toimet lähensivät virsikirjan sävelmiä komitean ehdotukseen. Toisaalta kirkolliskokous poikkesi komitean linjasta siinä, että rinnakkaissävelmien määrä lisääntyi edelleen täysistunnossa. Kirkolliskokouksen tavoitteena oli tälläkin kohden virsien elävöittäminen, mutta sitä ei tullut tehdä "pakottaen" virret tiettyyn sävelmään vaan tarjoten vaihtoehtoja. 
Vilkkaasta keskustelusta huolimatta lopulta yli yhdeksän kymmenestä virrestä hyväksyttiin virsikirjavaliokunnan ehdottamassa muodossa. Tiiviiseen ja rakentavaan keskusteluun oltiin myös kirkolliskokouksessa tyytyväisiä. ${ }^{557}$ Suomenkielistä virsikirjaehdotusta käsiteltäessä piispoista Paavo Kortekangas ja Yrjö Sariola olivat usein kantoineen vastakkain, ja myös Olavi Rimpiläinen otti aktiivisesti osaa keskusteluun. Kaikki pappisedustajat osallistuivat suomenkielisen virsikirjaehdotuksen käsittelyyn, ja kukin heistä käytti keskimäärin yli 17 puheenvuoroa. Pappi puhui lähes neljä kertaa siinä missä maallikkoedustaja kerran. ${ }^{58}$

Maallikkoedustajissa oli havaittavissa hienoisia miesten ja naisten välisiä eroja. Miesmaallikoista selvästi yli neljännes ei osallistunut keskusteluun lainkaan, kun taas naisedustajat puhuivat paljon laajemmalla rintamalla. Naisedustajissa oli monia opetusalalla työskenteleviä henkilöitä, jotka ammatissaan lauloivat ja opettivat virsiä. Useat miesmaallikot taas olivat hallinnon ja talouden asiantuntijoita, jotka eivät katsoneet asiakseen ottaa kantaa virsiin. Sen sijaan ne maallikkomiehet, jotka osallistuivat keskusteluun, käyttivät lukuisia puheenvuoroja. 559

Niin maallikkojen kuin pappien keskuudessa aktiivisimmat puhujat olivat hyvin pitkälti samoja kuin toimitusten kirjaa käsiteltäessä. Useimmilla oli selvä herätysliiketausta ${ }^{560}$. Herätysliikkeeseen kuuluminen ei toisaalta tarkoittanut sitä, että henkilö olisi välttämättä osallistunut keskusteluun. Puheenvuorojen keskittyessä tietyille henkilöille samoin kävi lopulta äänestyksissäkin: äänestyksiin osallistuvien määrä pieneni koko ajan virsikirjaehdotuksen käsittelyn edetessä. Lopulta hädin tuskin puolet oli käyttämässä ääntään, ja kolmasosa kaikista kirkolliskokousedustajista saattoi hyvin muodostaa äänestyksessä enemmistön. Eri vaihtoehtojen puntarointi oli nopeatempoisessa täysistuntotyössä hankalaa, joten moni jäi epäröimään ja pidättyi äänestämästä.

Vuoden 1985 syysistuntoviikon perjantaina, hieman ennen iltayhdeksää, kun valiokunnan suomenkielinen virsikirjaehdotus oli neljän työpäivän jälkeen saatu käsitellyksi, siirryttiin ruotsinkieliseen virsikirjaan. Ruotsinkielinen edustajaryhmä oli työskennellyt ahkerasti istuntoviikon tauoilla ja toi monistettuina valmiit muutosehdotukset. Käsittely eteni joutuisaan. Muutosehdotuksia oli yhteensä 6o, ja niistä ainoastaan pari tuli ruotsinkielisen edustajaryhmän ulkopuolelta. Ehdotukset myös hyväksyttiin vaivatta: vain parista jouduttiin äänestämään. ${ }^{561}$ Ruotsinkielinen edustajaryhmä palautti muutoksillaan virsikirjaa lähinnä komitean ehdotuksen suuntaan. ${ }^{562}$ Jo suomenkielisen virsikirjan täysistuntokäsittelyssä lisättiin jonkin verran yhdenmukaisuutta ruotsinkielisten virsisävelmien kanssa, mutta ruotsinkielisen virsikirjan sävelmien muutoksia leimasi vahvasti pyrkimys mahdollisimman samanlaisiin sävelmiin kuin suomenkielisessä virsikirjassa. ${ }^{563}$

Aivan käsittelyn loppumetreillä pysähdyttiin yllättäen periaatekeskusteluun siitä, oliko virsisävelmällä joitakin erityisiä kriteerejä. Komitea oli ehdottanut mukaan laulua "Jag ska gråtande kasta mig ner", jonka valiokunta oli kuitenkin jättänyt kielteisen seurakuntapalautteen vuoksi pois omasta ehdotuksestaan. Täysistunnossa Henrik Perret ehdotti muiden ruotsinkielisten edustajien kannattamana, että laulu otettaisiin virreksi. Paavo Kortekangas ei lämmennyt ajatukselle. Hänen mielestään kappale "oli kyllä enemmän ravintolamusiikkia kuin virsi”. Kun ruotsinkielinen edustajaryhmä oli yksimielisesti virren takana, Kortekangas ei ehdottanut sen poistamista. Myös Erkki Reinikainen tyytyi iloitsemaan, ettei virttä ollut suomenkielisessä virsikirjassa. Tässäkin tapauksessa enemmistö antoi Porvoon hiippakunnan edustajien päättää ruotsinkielisestä virsikirjasta. Keskustelu osoitti ruotsinkielisen virsikirjan väljemmät musiikilliset rajat suomenkieliseen virsikirjaan verrattuna. Kirpeäksikin kehkeytynyt sanailu päättyi sopuisasti, kun Göran Stenlund ehdotti, että Henrik Perret säveltäisi virrelle b-melodian. ${ }^{564}$ Tämä tekikin sävellyksen, jonka valiokunta valitsi anonyymien ehdotusten joukosta. ${ }^{565}$ Perret omisti sävelmänsä Tampereen piispalle pahoitellen, ettei ravintolamusiikista ollut päästy eroon: virsi oli sävelletty Turun lentoaseman ravintolassa..$^{566}$

Helmikuun 13. päivänä 1986 molemmat virsikirjat hyväksyttiin perinteiseen tapaan kiitosvirren säestämänä. Aivan yksiääninen tuo kiitosvirsi ei ollut. Seurakuntaneuvos Kaarlo Salminen Nokialta oli sitä mieltä, että uudesta suomenkielisestä virsikirjasta oli jätetty pois liian paljon virsiä, jotka palautteessa oli sinne haluttu. Hän antoi ei-äänen. ${ }^{567}$ Päinvastainen arvostelu kuului lehtereiltä. Kirkolliskokousta seuraamassa ollut virsikirjakomitean jäsen Markku Kilpiö valitteli, etteivät valiokunta ja kirkolliskokous olleet osoittaneet kiinnostusta komi- 


\section{Picture removed from the open access version of this book.}

Kirkolliskokous hyväksyi suomen- ja ruotsinkielisen virsikirjan ylimääräisellä istuntokaudellaan Helsingissä helmikuussa 1986. Päätösten jälkeen edustajat nousivat perinteiseen tapaan veisaamaan juuri hyväksytyistä kirjoista kiitosvirren. Kuva: Kotimaan kuva-arkisto / Ritva Neuvonen.

tean perusteluita kohtaan. Monet pitkäaikaiseen tutkimukseen pohjautuneet, johdonmukaiset ratkaisut oli muutettu nopeasti. Kielellistä epäjohdonmukaisuutta saattoi tulla jopa saman virren sisälle: "Nyt on valittu tuttuuden helppo ja turvallinen tie, joka on katalan lyhytnäköistä." ${ }^{568}$ Samaa pettymystä tunsivat muutkin virsikirjakomitean jäsenet. ${ }^{569}$ Kilpiö antoi oman ei-äänensä vetämällä vielä virsikirjan toimitusvaiheessa pois yhden virsisävelmänsä, jolle kirkolliskokous oli lisännyt Kilpiön mielestä epätyydyttävän rinnakkaissävelmän. ${ }^{570}$ Soraäänet hukkuivat täysistunnon veisuuseen.

Päättäessään kirkollisten toimitusten kirjasta ja virsikirjauudistuksesta kirkolliskokous toimi eräänlaisena "perusseurakuntalaisten" edunvalvojana. Molemmissa uudistushankkeissa käytännön palautteen saaminen keskittyi prosessin loppuvaiheeseen, ja arvostelun kuunteleminen jäi kirkolliskokouksen tehtäväksi. Komiteoiden linja ei aiheuttanut useinkaan kovinta arvostelua seurakunta-aktiivien keskuudessa. Heillä oli valmiutta omaksua muokattuja virsisävelmiä ja -tekstejä sekä uusia liturgisia käytäntöjä. Myös herätysliikkeiden omien laulukokoelmien vahva asema virsikirjan rinnalla saattoi vähentää tämän joukon keskuudessa kriittisyyttä virsikirjauudistusta kohtaan: monien rakkaiden virsien sanamuodot ja sävelmät säilyisivät edelleen näissä kirjoissa. Kovin arvostelu tuli niiltä, joille virsikirja oli ainoa ja muuttumaton lapsuuden virsikokoelma.

Asetelma näkyi kirkolliskokouksessakin. Useat edustajat kiittelivät komiteoiden korkeatasoista työtä, mutta heidän oli otettava huomioon myös muut kuin itsensä kaltaiset kirkon jäsenet. Varsinkaan virsikirjauudistuksessa perustavimmat erimielisyydet eivät koskeneet kirkolliskokousedustajien omaa suhtautumista uuteen virsikirjaan vaan sitä, millaisiksi nähtiin tavallisten seurakuntalaisten odotukset ja tulevien sukupolvien tarpeet. Kirkolliskokouksen jäsenet joutuivat edustamaan sitä joukkoa, jonka keskuudesta ei juuri valittu kirkolliskokousedustajia. Heidän oli pohdittava lasten, nuorten ja harvoin kirkossa käyvien suhtautumista. Lisäksi he joutuivat tarkkaamaan erityisesti isänmaan virsien symbolista merkitystä. Lopputuloksena tutkimukseen perustuneet, tyylillisesti yhtenäiset asiantuntijamietinnöt joutuivat antamaan tietä monimuotoisuudelle yhtä lailla tuttujen sanamuotojen vaalimiselle kuin ennakkoluulottomasti lisätyille lasten virsille.

\section{ASIANTUNTIJAMIETINNÖSTÄ KOHTI HERÄTYSLIIKKEIDEN JA KIRKON RAAMATTUA}

\section{EHE Ä KIRJA VAI KAKSI SUJUVASTI KÄ̈̈NNETTYÄ TESTAMENTTIA?}

Tuomaan päivänä 1990 Aimo T. Nikolainen, 80. ikävuottaan lähestyvä emerituspiispa, lausui kiitossanat johtamalleen raamatunkäännöskomitealle. Tilaisuus oli koruton: päätöksessä oli tiivis kuuden tunnin kokous, yksi lukemattomista. ${ }^{571}$ Tehdystä työstä muistutti 22 paksua mappia, joihin vuodesta 1974 lähtien karttunut pöytäkirjamateriaali koottiin. Varsinaisen käännöstyön teh- 
neiltä Raamatun eri kirjojen käännösyksiköiltä oli tuona aikana kertynyt aineistoa vielä seitsenkertainen määrä. Työn mittavuus jätti jälkensä myös muuten. Nikolaisen sanoin Vanhan testamentin käännöstyön "peruspilari oli murtunut" 1983, kun professori Jussi Aro, Raamattua virkatyönsä ohella kääntänyt assyriologi, oli kuollut yllättäen vain 54 vuoden iässä. ${ }^{572}$

Nikolaisen ja Aron ohella komitean alkuperäiseen kokoonpanoon kuuluivat eksegeetit professori Ilmari Soisalon-Soininen, apulaisprofessori Esko Haapa, teologian tohtori, sittemmin professori Jukka Thurén ja piispa Aarre Lauha, joka myöhemmin pyysi eroa heikentyneen terveytensä vuoksi. Opillista erityisasiantuntemusta edusti aluksi ekumeniikan professori Kalevi Toiviainen, joka jätti kuitenkin komitean siirtyessään piispaksi 1978. Toiviainen oli 1990-luvun alussa ainoa kirkolliskokousedustaja, joka oli ollut varsinaisen käännöskomitean jäsen. Hänet valittiinkin kirkolliskokouksen raamatunkäännösvaliokunnan puheenjohtajaksi.Komiteanjäseniin kuului edelleen professoriHeikki Koskenniemi, joka oli klassisen filologian erityistuntija. Suomen kielen asiantuntijoita olivat professori Osmo Ikola ja kirjailija Lassi Nummi. Myöhemmin komiteaan nimettiin teologian lisensiaatti, sittemmin dosentti Juha Pihkala, professori Heikki Palva ja apulaisprofessori, sittemmin professori Timo Veijola. Komitealla oli suurimman osan ajasta kaksi sihteeriä. Pitkäaikaisimmin sihteerinä toimi dosentti Aarne Toivanen. ${ }^{573}$

Työnsä alussa 1974 komitea haki vertailukohtia erityisesti Ruotsista, missä oli myös meneillään raamatunkäännöstyö. Päälinjoiltaan komitea seurasi Ruotsin esimerkkiä, joskaan se ei halunnut luopua perinteisestä kirkkokielestä yhtä ehdottomasti kuin ruotsalainen käännöskomitea. ${ }^{574}$ Sittemmin Porvoon hiippakunnan edustajat vaativat kirkolliskokouksessa, että myös Suomen ruotsinkielisten tuli päästä kommentoimaan naapurimaan liian radikaaleiksi koettuja käännösratkaisuja. Ruotsin kirkon käyttämä raamatunkäännös oli perinteisesti ollut käytössä myös Suomessa, ja Porvoon hiippakunnan edustajat kokivat, että heidän uutta raamatunkäännöstään laadittiin heitä kuulematta. ${ }^{575}$

Nikolaisen johtama komitea jätti 1975 kirkolliskokoukselle osamietinnön käännös- ja työskentelyperiaatteistaan. Kirkolliskokous hyväksyi niin sanotun dynaamisen vastaavuuden periaatteen, jonka mukaan
Raamattua käännettäessä oli lähdettävä alkutekstin kokonaissanomasta eikä yksittäisistä sanoista. Kielen tuli olla käännösajankohdan selkeää ja luontevaa yleiskieltä, joskaan teologisesta erityissanastosta ei tarvinnut täysin luopua..$^{576}$ Seitsenkymmenluvun alkupuolen henkeen sopivasti Osmo Alajan johtama käsikirjavaliokunta kysyi, oliko komitean käännösnäytteiden sanavalinta "tapahtunut yleisesti ottaen sittenkin liian varovaisesti nykyiseen kirkkoraamattuun verrattuna". Sisälsiväthän käännösnäytteet sellaisia raamattukielen sanoja kuin "paratiisi", "opetuslapsi" ja "puhdassydäminen".577 Valiokunta kannusti komiteaa rohkeuteen. Hyväksyessään komitean esittämät käännösperiaatteet kirkolliskokous päätti myös koota palauteryhmän kommentoimaan komitean käännösehdotuksia ${ }^{578}$.

Raamatunkäännöskomitea päätti jo ensimmäisessä kokouksessaan kutsua läsnäolo- ja puheoikeutetuiksi lisäjäsenikseen Suomen ortodoksisen kirkon ja Suomen Vapaitten Kristittyjen Neuvoston edustajat. ${ }^{579}$ Ensimmäistä kertaa suomalaisten raamatunkäännösten historiassa yhtenä peruslähtökohtana oli, että käännös palvelisi mahdollisimman hyvin maan kaikkia kristillisiä yhteisöjä. ${ }^{580}$ Vapaakristillisyyden edustajan apuna oli eri taustayhteisöjen jäsenistä koottu työryhmä. Takaisku käännöshankkeen ekumeenisuudelle oli, että baptistien edustajat jättäytyivät pois tästä työryhmästä 1983. Heidän mielestään "uusi tekele" oli "liberaaliteologinen selitysteos". Samalla lausuttiin osaltaan syntysanoja Raamattu Kansalle -yhdistykselle ja vaihtoehtoiselle raamatunkäännökselle. ${ }^{581}$

Ortodoksit arvostelivat komiteaa lievemmin ja yleisluonteisemmin luterilaisen tulkintaperinteen suosimisesta. Erityisesti Paavalin kirjeiden käännösratkaisut aiheuttivat pohdintaa, saattoiko ortodoksinen kirkko ottaa käännöstä käyttöön komitean ehdottamassa muodossa. ${ }^{582}$ Vapaakristillisyyden edustajana komiteassa olleen toimitusjohtaja Valtter Luodon roolia voimisti erityisesti se, että hänen apunaan käännöstyön kommentoinnissa oli Raamatun alkukielten asiantuntija, luterilainen pastori Matti Liljeqvist. Ortodoksien edustajista varsinkin filosofian lisensiaatti Merja Merraksen panos oli huomattava. ${ }^{58}$

Komitean työskentely-ympäristöä sävytti 1980-luvulla ajoittain kiivas keskustelu Raamatun auktoriteetista ja historialliskriittisestä raamatuntutkimuksesta..$^{84}$ 
Keskustelu heijastui myös kirkolliskokoukseen, kun se perusti 1984 raamattuteologian kouluttajan viran kirkon koulutuskeskukseen. Ainakin jotkut tulkitsivat viran perustamisen reaktioksi Helsingin yliopiston eksegetiikan opetukseen..$^{55}$ Kiistat Raamatun luonteesta eivät kovin suoraan heijastuneet raamatunkäännöstyöhön - olihan sitä paitsi erimielisyyksien keskipisteessä ollut professori Heikki Räisänen jätetty aikoinaan valitsematta käännöskomiteaan.

Komitean julkistamista käännösehdotuksista ei syntynyt samanlaista julkista keskustelua tai palauteryöppyä kuin virsikirjaehdotuksesta. Virret koskettivat suomalaisten sisintä toisella tasolla kuin Raamattu. ${ }^{56} \mathrm{Oma}$ vaikutuksensa vastaanoton erilaisuuteen oli silläkin, että virsikirjaehdotus oli ilmestynyt prosessin loppuvaiheessa kokonaisuutena, kun taas raamatunkäännöskomitea pyrki pohjustamaan uudistusta esittelemällä käännösperiaatteita ja julkistamalla pitkin matkaa käännösehdotuksia. ${ }^{57}$ Lisäksi erona oli, että raamatunkäännöstyö herätti eniten tunteita melko suppeassa aktiiviseurakuntalaisten joukossa, kun taas virsikirjauudistus oli saanut liikkeelle ne, jotka eivät useinkaan muuten osallistuneet seurakunnan toimintaan. Raamatunkäännöskomitea joutui pyytelemään itsekin palautetta, ja työn loppua kohden palautteen määrä lisääntyi ${ }^{58}$. Aarne Toivasen myöhemmän arvion mukaan palautteen ja kirkolliskokouksen nimeämän palauteryhmän merkitys jäi lopulta vähäiseksi. ${ }^{589}$

Aimo T. Nikolainen johti komiteaa sovittelevasti ja onnistui välttämään erimielisyyksien kärjistymistä. Muutamissa kysymyksissä komiteaan syntyi kuitenkin sisäinen oppositio, jonka muodostivat evankeliseen herätysliikkeeseen lukeutuneet professorit Heikki Koskenniemi ja Jukka Thurén. Nämä turkulaiset professorit puolustivat samalla Åbo Akademin eksegeettisen opetuksen ja tutkimuksen linjaa. Sen näkökulmasta Helsingin yliopiston raamatuntutkijoiden ja komitean enemmistön näkemykset olivat liian radikaaleja ja vapaamielisiä. Sekä Koskenniemi että Thurén jättivät seikkaperäiset eriävät mielipiteensä komitean käännösehdotukseen. ${ }^{590}$ Julkisessa keskustelussa heidän linjansa sai tukea esimerkiksi professori Tuomo Mannermaalta sekä herätysliikkeiden piiristä, kuten evankelisten teologien Simo Kivirannan ja Erkki Koskenniemen puheenvuoroista. ${ }^{591}$ Kiista koski pitkälti Paavalin kirjeiden teologiaa, kuten Paavalille tyypillisten "Kristuksessa"ilmausten kääntämistä. ${ }^{592}$ Komitean puheenjohtaja Aimo T. Nikolainen oli mukana Paavalin kirjeiden käännösyksikössä, ja keskustelu henkilöityikin paljolti juuri häneen. ${ }^{593}$

Uuden testamentin käännösehdotuksen esipuheessa, jota Nikolainen käsitteli omana tekstinään, todettiin "Kristuksessa"-ilmausten kääntämisen vaikeus. Esipuheen mukaan eksegeettinen tutkimus oli osoittanut, ettei näitä sanontoja tullut käsittää lokaalisesti. Sen sijaan kyse oli kristityn kohtalonyhteydestä ja persoonallisesta uskonsuhteesta Kristukseen. ${ }^{594}$ Käännösehdotuksessa puhuttiin "Kristuksessa" olemisen sijaan esimerkiksi "Kristuksen yhteyteen liitettynä" olemisesta. Jukka Thurén ja Heikki Koskenniemi katsoivat, että komitea oli syyllistynyt tässä kohden liialliseen selittämiseen ja ettei suomen kielen kannalta Paavalin alkuperäinen inessiivi-ilmaus ollut yhtään sen ongelmallisempi kuin kreikankaan näkökulmasta. ${ }^{595}$

Samanlaisia moitteita kuului komitean ulkopuolelta. Useat tutkijat arvostelivat Teologisessa Aikakauskirjassa käännöstyön sidonnaisuutta 1900-luvun alun Luthertutkimukseen ja kiistanalaisiin eksegeettisiin perusteluihin. ${ }^{596}$ Kuten virsikirjaa uudistettaessa kirkolliskokouksen valiokunta perehtyi sittemmin tarkasti aikakauskirjan artikkeleihin ja viittasi niihin mietinnössään yliopistojen virallisten lausuntojen rinnalla. ${ }^{597}$ Aimo T. Nikolaisen valmistelemia, kirkon virkaa koskevia perustevaliokunnan mietintöjä oli 1970-luvulla moitittu siitä, että ne rakentuivat aiempien vuosikymmenten teologisten suuntausten varaan. Sama arvostelu oli vastassa raamatunkäännösehdotuksen valmistuttua. Nikolaisen ura oli ollut harvinaisen näyttävä ja pitkä, mutta loppuvuosikymmeninä hänen tulkintojaan arvosteltiin osin vanhentuneiksi.

Kaikkiaan kirkolliskokouksessa käytiin lähetekeskustelua raamatunkäännösehdotuksen osista neljällä istuntokaudella, syksystä 1989 kevääseen 1991. Käännöksen kieltä kuvattiin sujuvaksi, mutta joidenkuiden mielestä se oli samalla aiempaa latteampaa. ${ }^{598}$ Ensimmäisenä lähetekeskusteluun tullut Uusi testamentti puhutti kirkolliskokousta suhteellisen vähän. Raamatunkäännösvaliokuntakin ihmetteli keskustelun vaisuutta ${ }^{599}$. Yhtenä syynä oli todennäköisesti se, että suurin tyytymättömyys koski sittenkin melko harvoja 
kysymyksiä, kuten Paavalin "Kristuksessa"-ilmauksia tai Herran rukouksen sanamuotoa. Monella oli myös korkea kynnys ryhtyä lyhyen valmistautumisen pohjalta ruotimaan asiantuntijakomitean kahden vuosikymmenen työtä. Hieman kipakampi periaatteellinen keskustelu syntyi Vanhan testamentin ensimmäisen osan ilmestyttyä. Tuolloin kirkolliskokousedustajilla oli mahdollisuus verrata toisiinsa kahden testamentin käännösehdotuksia, eivätkä vertailun tulokset miellyttäneet kaikkia.

Moni edustaja kiinnitti huomiota siihen, että Vanhasta testamentista oli poistunut liittymäkohtia Uuteen testamenttiin. Ainakin voimakkaimmista kannanotoista välittyi käsitys, että Raamattu oli eheä kokonaisuus mutta että komitean työn tuloksena kirkolliskokouksella oli edessään kaksi toisistaan erillistä testamenttia. Timo Holma epäili kaikkein selväsanaisimmin, että käännösratkaisujen takana oli ideologinen ohjelma: "Kun nyt tätä [Vanhan ja Uuden testamentin] yhteyttä ollaan ohentamassa tieteen nimessä, niin pelkään, että joku professori ja ehkä useammatkin pyrkivät tekemään tiedettä omasta epäuskostaan." ${ }^{600}$ Toisaalta jotkut edustajat, kuten Helsingin hiippakunnan varaedustaja, diplomi-insinööri Arvo Aho ja kirkkoherra Jussi Talasniemi, puolustivat komiteaa ja vaativat rehellisyyttä: Vanhaa testamenttia oli käännettävä sen itsensä kannalta, eikä sitä tarvinnut ryhtyä erikseen kristillistämään. Holma huomautti, että yhtenäistämisvaatimukset koskivat vain tilanteita, joissa saattoi valita kahden yhtä perustellun vaihtoehdon välillä. ${ }^{601}$

Kalevi Toiviaisen johtaman raamatunkäännösvaliokunnan sihteeriksi valittiin komitean sihteerinä toiminut dosentti Aarne Toivanen. Kirkolliskokouksessa jotkut epäilivät valinnan johtavan siihen, ettei valiokunta uskaltaisi irrottautua riittävän selvästi komitean käännösehdotuksesta. Toiviaisen täytyi vakuutella, miten tärkeää oli komitean edustajan läsnäolo valiokunnassa. Lisäksi Toiviainen joutui monia kertoja painottamaan, että valiokunta otti palautteen huomioon, ja jopa kertomaan väliaikatietoja valiokunnan toteuttamista muutoksista, koska hänen mukaansa liikkeellä oli niin paljon vääriä tulkintoja valiokunnan työskentelystä. ${ }^{602}$ Kirkolliskokousedustajat edellyttivät niin virsikirjakuin raamatunkäännösvaliokunnan kuuntelevan palautetta. Muuten nämä kaksi valiokuntaa poikkesivat työ- tavoiltaan toisistaan. Virsikirjauudistuksessa oli haluttu katkaista jatkumo komiteoista kirkolliskokouksen valiokuntaan, mikä oli näkynyt esimerkiksi sihteerien valinnassa. Raamatunkäännöstyössä pyrittiin sen sijaan ottamaan kirkolliskokouskäsittelynkin aikana huomioon komitean edustajien näkemykset.

Kulissien takana väännettiin kättä piispainkokouksen linjasta. Vuoden 1990 alussa raamatunkäännösvaliokunnan puheenjohtaja ja sihteeri olivat huolissaan ennakkotiedoista, joiden mukaan piispainkokouksessa harkittiin työn lykkäämistä ja edellytettiin kirkon uskonsisällön nostamista keskeiseksi käännöskriteeriksi. Toiviaisen ja Toivasen mielestä juuri Raamatun tuli ohjata kirkon uskoa, ja näin päin asia esitettiinkin piispainkokouksen lopullisessa lausunnossa Uudesta testamentista. ${ }^{603}$

Tilanne kärjistyi uudelleen maalis-huhtikuussa 1991, kun Olavi Rimpiläinen, Yrjö Sariola ja Eero Huovinen esittivät piispainkokouksen istunnoissa tarkistuskomitean asettamista. ${ }^{604}$ Vanhan testamentin toinen osa oli viivästynyt, ja seurakunnille oli jäämässä vain pari kuukautta aikaa tutustua siihen ja antaa lausuntonsa. Kotimaa-lehdessä virisi vilkas keskustelu siitä, tuliko raamatunkäännöksen hyväksymistä siirtää. Kalevi Toiviainen katsoi, että ongelmana oli jälleen ratkaisevan askelen pelko aivan samoin kuin virsikirjaehdotuksesta keskusteltaessa. Huovinen taas otti yhtenä ensimmäisistä virkatöistään - jo ennen vihkimistään piispanvirkaan - näkyvästi kantaa tarkistuskomitean puolesta, mikä aiheutti arvostelua käännöstyössä pitkään mukana olleiden keskuudessa. ${ }^{605}$ Julkisuudessa esitetyt erilaiset arvelut lopullisesta aikataulusta vaikeuttivat työn suunnittelua niin seurakunnissa kuin valiokunnassa. ${ }^{606}$

Piispainkokous ei lopulta esittänyt tarkistuskomiteaa, mutta kevään 1991 kirkolliskokouksessa Sariola ja Huovinen ehdottivat hankkeen lykkäämistä muulla tavoin seuraavalle vaalikaudelle. Heidän mukaansa lausunnonantajille ja myös kirkolliskokoukselle voitiin vain siten taata tarpeeksi aikaa perehtyä aineistoon. Toiviainen vastusti ehdotusta jyrkästi. Hänen mukaansa dynaamisen vastaavuusperiaatteen sisäistäminen vaati aikaa, ja todennäköisesti seuraavallakin kirkolliskokouksella olisi lopulta kiire. ${ }^{607}$ Kirkolliskokous päätti säilyttää lausuntoajan ennallaan. Siitä huolimatta vaatimukset aikataulun muuttamisesta jatkuivat kirkollis- 
kokouksessa vieden tilaa käännöstyön sisältökysymyksiltä. ${ }^{608}$

Samaan aikaan piispainkokouksen ja raamatunkäännöskomitean edustajien välillä ilmeni edelleen jännitteitä. Piispainkokouksen lausuntoa Vanhan testamentin käännöksestä valmisteli työryhmä, jonka jäsenistä Olavi Rimpiläisen ja teologian tohtori Antti Laaton tiedettiin suhtautuvan kriittisesti käännökseen. Ilmari SoisalonSoinisen mielestä eräät kohdat työryhmän laatimassa lausunnossa asettivat komitean asiantuntemuksen kyseenalaiseksi. Hänen kommenteissaan lausunto henkilöityi juuri Laatoon. ${ }^{609} \mathrm{Se}$, että Laato oli Åbo Akademin tutkija, alleviivasi raamatunkäännösprosessissa taustalla näkynyttä yliopistojen välistä eksegeettistä linjaeroa. Laaton ja Jukka Thurénin väliset sukulaisuussuhteet saattoivat vielä vahvistaa mielikuvaa siitä, että piispainkokouksen työryhmän laatima lausunto oli jatkoa komitean vähemmistön kannanotoille. Raamatunkäännös jakoi piispainkokousta. Yrjö Sariola toi esille SLEY:n äänenpainoja ja juuri dogmatiikan professorin tehtävät jättänyt Eero Huovinen teologisessa tiedekunnassa esitettyä arvostelua. Evankelista herätysliikettä lähellä olevat teologit olivat kirkollisten toimitusten kirjaa uudistettaessa käyttäneet sananvaltaa käsikirjakomiteassa, mutta raamatunkäännösuudistuksessa he olivat altavastaajan asemassa.

Asetelmaa mutkistivat vielä eri herätysliikkeiden valmistamat ja jakamat lausunnot. Esimerkiksi SLEY:n palautetyöryhmän laatimaa laajaa ja yksityiskohtaista arviointi- ja korjausehdotusasiakirjaa painettiin ja lähetettiin seurakuntiin. Yhtäältä tällainen asiakirja saattoi tehostaa seurakuntien palauteprosessia: se auttoi seurakuntalaisia yli herätysliikerajojen löytämään laajasta käännösehdotuksesta kiistanalaiset kohdat. Toisaalta asiakirja oli omiaan ohjaamaan varsinkin liikkeen vahvoilla alueilla palautetta tiettyyn suuntaan, minkä vuoksi jotkut pitivät asiakirjaa kielteisenä yrityksenä kauko-ohjata seurakuntien palautetta. ${ }^{610}$

Uuden testamentin käännösehdotuksesta antoi lausunnon 79 prosenttia suomenkielisistä seurakunnista, mikä oli peräti 15 prosenttiyksikköä vähemmän kuin virsikirjauudistusta kommentoineiden osuus. Vanhan testamentin käännösehdotuksesta lausui lyhyeksi jääneen palauteajan kuluessa mielipiteensä vain alle puolet seurakunnista. ${ }^{611}$ Siitä huolimatta seurakunnat jättivät yli 21000 muutosehdotusta raamatunkäännökseen. Lapuan hiippakunnan synodaalikokous edellytti Paavalin kirjeiden kääntämistä uudelleen, mikä vastasi piispa Yrjö Sariolan ja hänen kotiliikkeensä evankelisuuden kattojärjestön kantaa. Yksittäisiin ongelmakohtiin keskittyneiden lausuntojen joukossa vaatimus jäi kuitenkin poikkeukseksi. ${ }^{612}$

Seurakunnat antoivat raamatunkäännöksen kielestä erittäin korkean arvosanan. Luettavuutta piti kiitettävänä suunnilleen kolme neljästä lausunnon antaneesta seurakunnasta. ${ }^{613}$ Kaupunki- ja maaseutuseurakuntien lausunnoissa ei ollut tässä suhteessa mainittavia eroja, joskin kaikkein suurimpiin seurakuntayhtymiin kuuluneet seurakunnat pitivät käännösehdotuksen kieltä keskimääräistä parempana. ${ }^{614}$ Tulos antoi viitteitä siitä, että komitea oli päässyt uudenaikaiseen kieleen. Lähes puolet palautetta antaneista seurakunnista piti Uuden testamentin käännöstä liian tulkitsevana, mutta Vanhan testamentin osalta tällainen arvostelu jäi hyvin vähäiseksi. Uudesta testamentista käyty julkinen keskustelu vaikutti siihen, että seurakuntien muutosehdotukset keskittyivät paljolti tiettyihin jakeisiin, kun taas Vanhaan testamenttiin ehdotetut muutokset hajaantuivat laajalle. ${ }^{615}$ Valiokunnan oli Vanhan testamentin osalta siten melko vaikea saada selville seurakuntien tahtoa.

\section{YHTEISYMMÄRRYS VAHVISTUU KIIREISESSÄ KOKOUKSESSA}

Raamatunkäännösvaliokunta joutui tekemään työtään kovan paineen alla. Aika oli vähissä, ja lisäksi puheet tarkistuskomiteasta loivat epävarmuutta. Komiteatyössä mukana olleiden henkilöiden merkitys korostui. Yksi heistä oli filosofian maisteri Aarre Huhtala, joka työskenteli ahkerasti taustalla komitean ja valiokunnan välisenä linkkinä ja jolla oli keskeinen osuus sittemmin myös Raamatun toimitustyössä. ${ }^{616}$ Vuonna 1988 kirkolliskokoukseen valittu Raamatun alkukielten apulaisprofessori Raija Sollamo oli puolestaan ollut mukana useassa Vanhan testamentin käännösyksikössä. ${ }^{617}$ Hän toi valiokuntaan tärkeää akateemista asiantuntemusta ja kokemusta käännösperiaatteiden toteuttamisesta. ${ }^{618}$

Puhtaasti teknisten korjausten lisäksi valiokunta teki muutoksia lähes 800 raamatunkohtaan. Muutoksista yli kaksi kolmasosaa koski Uutta testamenttia. Aiemman keskustelun pohjalta valiokunta pyrki myös lähentä- 
mään Vanhan ja Uuden testamentin sanamuotoja toisiinsa silloin, kun se oli mahdollista. ${ }^{619}$ Tästä työstä vastasi pääasiassa Raija Sollamon ja Oulun hiippakunnan pääsihteerin, teologian tohtori Keijo Nissilän muodostama työryhmä. ${ }^{60}$ Valiokunta pyrki säilyttämään komitean peruslinjan, mutta se oli samalla valmis kompromisseihin, joilla pyrittiin varmistamaan käännöksen hyväksyminen ratkaisevassa käsittelyssä. ${ }^{621}$

Paavalin "Kristuksessa"-ilmaukset puhuttivat käännösehdotuksen käsittelyn edetessä. Seurakuntien palautteessa kiinnitettiin kysymykseen paljon huomiota, ja myös muiden kirkkojen edustajat vaativat inessiivimuotojen palauttamista. ${ }^{622}$ Raamatunkäännösvaliokunnassa Janakkalan kirkkoherra Timo Komulainen valmisteli asiaa ja esitti erityisesti professori Heikki Räisäsen näkökantoihin nojaten palaamista "Kristuksessa"-muotoon tietyissä keskeisissä kohdissa ${ }^{623}$. Monet Paavalin kirjeiden kohdat muutettiinkin. ${ }^{624}$ Siitä huolimatta Paavalitutkijat valittelivat myöhemmin, ettei tätä muutosta tehty riittävän kattavasti ja johdonmukaisesti. ${ }^{625}$

Täysistunnossa nimenomaan Vanha testamentti, joka oli valiokuntakäsittelyssä selvinnyt vähäisemmin muutoksin kuin Uusi testamentti, kuohutti edustajien mieliä. Tilanteeseen vaikutti osaltaan se, että Uuden testamentin käsittely jäi suureksi osaksi syksyn 1991 pitkän istuntokauden loppuun, jolloin edustajat valittivat väsymystään ja valmistautumattomuuttaan ${ }^{626}$. Pisimmät keskustelut ehdittiin käydä Vanhasta testamentista. Valiokunnan toimet Vanhan ja Uuden testamentin sanamuotojen lähentämiseksi eivät riittäneet kaikille. Tyytymättömyys purkautui heti Raamatun ensi lehtiä käsiteltäessä. Käännösehdotuksen mukaan Jumalan "henki" liikkui luomisessa vetten yllä, mutta Timo Holma ehdotti tilalle "Henkeä" isolla kirjoitettuna. Käännösehdotuksen mukaan Jumala lupasi panna vihan käärmeen suvun ja naisen suvun välille. Liisi Jokiranta ehdotti "suvun" palauttamista "siemeneksi", joka voitiin tulkita viittaukseksi käärmeen pään polkevaan Kristukseen. Kumpaakaan ehdotusta ei hyväksytty, eikä useimpia muitakaan Raamatun alkusivuille ehdotettuja muutoksia. ${ }^{627}$

Komitean ja valiokunnan puolustajat perustelivat käännösehdotusta hyvin käytännönläheisillä seikoilla, esimerkiksi pyrkimyksellä luontevaan käännökseen ja hyvään suomen kieleen. Muutamat vastustajista taas ideologisoivat voimakkaasti puolustajien kantoja. "Olen ihmetellyt sitä antikristillistä henkeä, joka täällä tänään on vallinnut", puuskahti Eeva Laato. Tuossa vaiheessa kirkolliskokous oli useita tunteja kestäneen vaivalloisen työskentelyn jälkeen saanut lähestulkoon käsitellyksi Ensimmäisen Mooseksen kirjan kaksi ensimmäistä lukua, eikä kokouksen enemmistö ollut tuonut Pyhää Kolminaisuutta esille noissa luvuissa siinä määrin kuin jotkut olisivat toivoneet. ${ }^{628}$ Kun sitten isot

\section{Picture removed from the open access version of this book.}

Kirkolliskokouksen pitkä ja yksityiskohtainen keskustelu raamatunkäännöksestä ja muun muassa Paholaisen nimityksestä asettui syksyllä 1991 taloudellisen laman ja maailman kriisien taustaa vasten. Henrik Karlssonin pilapiirros Helsingin Sanomissa 13. marraskuuta 1991. 
profeettakirjatkin oli saatu käsitellyksi, SLEY:n piirisihteeri Hannu Kippo Oulusta surkutteli apostoli Paavalia. Kirkolliskokouksen päätösten jäljiltä tämän olisi ollut Kipon mukaan "hyvin vaikea kyllä enää lähteä kirjoituksista osoittamaan, että Jeesus on Kristus". ${ }^{629}$

Aistittavissa oli myös arvovaltajännitteitä. Heti yleiskeskustelun aluksi Eero Huovinen syytti Kalevi Toiviaista ylimielisestä esiintymisestä kirkolliskokouksen edessä. Toiviainen taas piti hieman kiusallisena, että Huovinen esitti kirkolliskokoukselle komitean jäsenen, professori Timo Veijolan laatimia muutosehdotuksia. Sillä tavoin ajatukset, jotka eivät olleet toteutuneet komitean mietinnössä, tulivat "kyökin kautta" käsittelyyn. ${ }^{630}$ Joka tapauksessa Huovisen ajamat muutokset - niin hänen omansa kuin Veijolalta saadut - osoittautuivat hyvin merkittäviksi. Ensinnäkin kirkolliskokous palautti ruumiillisia kuvia Vanhan testamentin jumalakuvauksiin: Jumala esimerkiksi käänsi kasvonsa tai kallisti korvansa. Toiseksi käännökseen palautettiin Vanhan testamentin kuvauksia "häpeään joutumisesta", vaikka monien mielestä häpeä oli sosiaalisessa elämässä me- nettänyt merkitystään. ${ }^{61}$ Häpeätutkimus nousi pinnalle vasta myöhempinä vuosina. Kolmanneksi Huovinen vaati valiokunnan esittämän "Vihollinen"-sanan muuttamista Uudessa testamentissa "Paholaiseksi" ${ }_{332}$. Näin kirkolliskokous päätti tehdä, vaikka myös entisellä "Perkele"-nimityksellä oli vankkaa kannatusta. ${ }^{633}$ Tämä yksittäinen päätös sai osakseen paljon huomiota. ${ }^{634}$

Raamatunkäännöstyössä oli jo 1970-luvulla jouduttu väittelemään paljon psalmirunouden kääntämisestä. Psalmien käännösyksikkö oli runoilijajäsentään Kirsi Kunnasta seuraten pyrkinyt luovaan runouteen, kun taas tarkastusjaosto ja varsinainen käännöskomitea olivat vaatineet useiden kohtien kääntämistä tieteellisen tarkasti. Lopulta komitea oli päätynyt kahden käännöstavan väliseen kompromissiin. ${ }^{635}$ Erityisesti psalmi 23 puhutti myös kirkolliskokouksessa.

Neljännen jakeen uudet sanat "Sinä suojelet minua kädelläsi, johdatat paimensauvallasi" voi nähdä osana laajempaa muutosta uudessa raamatunkäännöksessä. Sievin kirkkoherra Martti Takala kysyi lähetekeskustelussa erityisesti Jobin kirjan osalta, miksi kuvaus

TAUlukкo 4: Psalmin 23 käsittelyvaiheet

\section{1) Raamattu $1933 / 1938$ \\ 1. Daavidin virsi.}

Herra on minun paimeneni, ei minulta mitään puutu.

\section{Viheriäisille niityille hän vie minut lepäämään; virvoittavien vetten tykö hän minut johdattaa.}

3. Hän virvoittaa minun sieluni. Hän ohjaa minut oikealle tielle nimensä tähden.

4. Vaikka minä vaeltaisin pimeässä laaksossa, en minä pelkäisi mitään pahaa, sillä sinä olet minun kanssani; sinun vitsasi ja sauvasi minua lohduttavat.

5. Sinä valmistat minulle pöydän minun vihollisteni silmien eteen. Sinä voitelet minun pääni öljyllä; minun maljani on ylitsevuotavainen.

6. Sula hyvyys ja laupeus seuraavat minua kaiken elinaikani; ja minä saan asua Herran huoneessa päivieni loppuun asti.

\section{2) Raamatunkäännöskomitea}

1. Daavidin psalmi.

Herra on minun paimeneni,

ei minulta mitään puutu.

2. Hän vie minut vihreille laitumille,

hän johtaa minut vetten ääreen,

siellä saan levätä.

3. Hän virvoittaa minun henkeni,

hän ohjaa minua oikeaa tietä

nimensä kunnian tähden.

4. Vaikka minä kulkisin pimeässä laaksossa, en pelkäisi mitään, sillä sinä olet minun kanssani. Sinä suojelet minua kädelläsi, johdatat paimensauvallasi.

5. Sinä katat minulle pöydän

vihollisteni silmien eteen.

Sinä voitelet pääni tuoksuvalla öljyllä,

ja täytät maljani ääriään myöten.

6. Sinun hyvyytesi ja rakkautesi ympäröi minut kaikkina elämäni päivinä, ja minä saan asua Herran temppelissä päivieni loppuun asti. 
Jumalasta oli parissa kohdassa kääntynyt päälaelleen aiempaan käännökseen verrattuna: vuoden 1933 käännöksen mukaan vastoinkäymiset selitettiin Jumalan tekoina, mutta uuden käännöksen mukaan Jumala katsoi niiden aikana toisaalle ja oli poissa. Takalan mukaan jumalakuvaan oli kiinnitettävä huomiota, koska se oli muutenkin yleisesti ohentunut. Jumalasta oli tehty "hyväntahtoinen 'isukki'". Salatun Jumalan kuvaamisesta oli huolissaan myös toinen herännäispappi, kirkkoherra Jussi Talasniemi: "Onko ehdotetusta käännöksestä siis tullut harmaata mustaan ja valkoiseen verrattuna? Onko Jumalan hirmuisuus ja hänen ihanuutensa liikahtanut kohtuullisuuden suuntaan?" ${ }_{36}$

Tunnetun psalmitekstinkään kuvassa Jumala ei ollut enää voimakastahtoinen kasvattaja, joka "vitsallaan ja sauvallaan" paimensi lammastaan, vaan ennemminkin hellä holhooja, joka suojeli kädellään ja johdatti paimensauvallaan. Timo Holma yritti muuttaa sanamuotoa aikaisempaan juuri Takalan ja Talasniemen toisessa yhteydessä mainitsemilla perusteilla: kun ihminen sai kokea olevansa Jumalan käsissä niin myötä- kuin vastoinkäymisissä, hän sai lohdutuksen. Holma ei kuitenkaan saanut taakseen riittävää kannatusta. ${ }^{67}$ Päätös vaikutti osaltaan siihen, että uuden virsikirjan kuva "Taivaan Isä suojan antaa" löytyi aiempaa selvempänä myös raamatunkäännöksen lehdiltä. Näkemykset lasten kasvattamisesta olivat sodanjälkeisinä vuosikymmeninä muuttuneet voimakkaasti, ja lasten kurittaminen oli vuoden 1984 alussa - juuri virsikirjaehdotuksen valmistuessa - muuttunut lain mukaan rangaistavaksi teoksi. Myös kirkon virallisten kirjojen kuva Taivaan Isästä muuttui 1980-luvulla tietyissä kohdin uusien kasvatusihanteiden suuntaan.

Käytössä olleessa raamatunkäännöksessä Herra virvoitti psalmin 23 laulajan sielun, komitean ehdotuksessa taas hengen. Muutoksen taustalle kätkeytyi hyvin laaja, koko Vanhan testamentin kääntämiseen liittynyt ongelma heprealaisen "sielu"-käsitteen tulkinnasta. Komitean näkemys oli, että kyseinen heprean sana (nefeš) tarkoitti ihmisessä olevaa elämänvoimaa tai ihmistä itseään elävänä olentona. Komitea välttikin yleensä "sielu"-käännöstä, jottei heprealaista käsitystä sekoitettaisi kreikkalaiseen sielu-ruumis-erotteluun. Yksi käännöksistä oli "henki", jota komitea käytti myös psalmissa $23 .{ }^{638}$ Piispainkokous arvosteli komitean ratkaisua: pyrkiessään välttämään kreikkalaista käsitystä sielusta komitea karsi heprealaisenkin "sielu"-käsitteen Vanhasta testamentista, vaikka juuri viimeksi mainittu oli keskeinen tausta Uudelle testamentille. ${ }^{639}$ Piispa Huovinen puuttui lähetekeskustelussa erityisen voimakkaasti komitean ja sen puheenjohtajan näkemykseen heprealaisesta sielukäsityksestä. ${ }^{60}$

Raamatunkäännösvaliokunta ei lähtenyt laajamittaisesti palauttamaan "sielu"-sanaa mutta teki niin tietyissä runomuotoisissa teksteissä, kuten tässä tunnetussa psalmissa ${ }^{641}$ Keskustelu henkilöityi jälleen osittain Aimo T. Nikolaiseen, jota useat arvostelijat näyttävät pitäneen vahvana auktoriteettina komiteatyössä. Komitean edus-

Apulaisprofessori Raija Sollamo oli raamatunkäännöstä käsiteltäessä suuren työtaakan alla. Hän vastasi asiantuntijana edustajien kysymyksiin niin täysistunnoissa kuin niiden ulkopuolella. Vieressä salin laidalla istunut valiokunnan puheenjohtaja Kalevi Toiviainen pitkitti tarvittaessa puheenvuoroillaan täysistuntokeskustelua sen verran, että Sollamo ehti selvittää alkutekstistä perustelut valiokunnan kannalle. Kuva: Kotimaan kuva-arkisto / Jukka Granström.

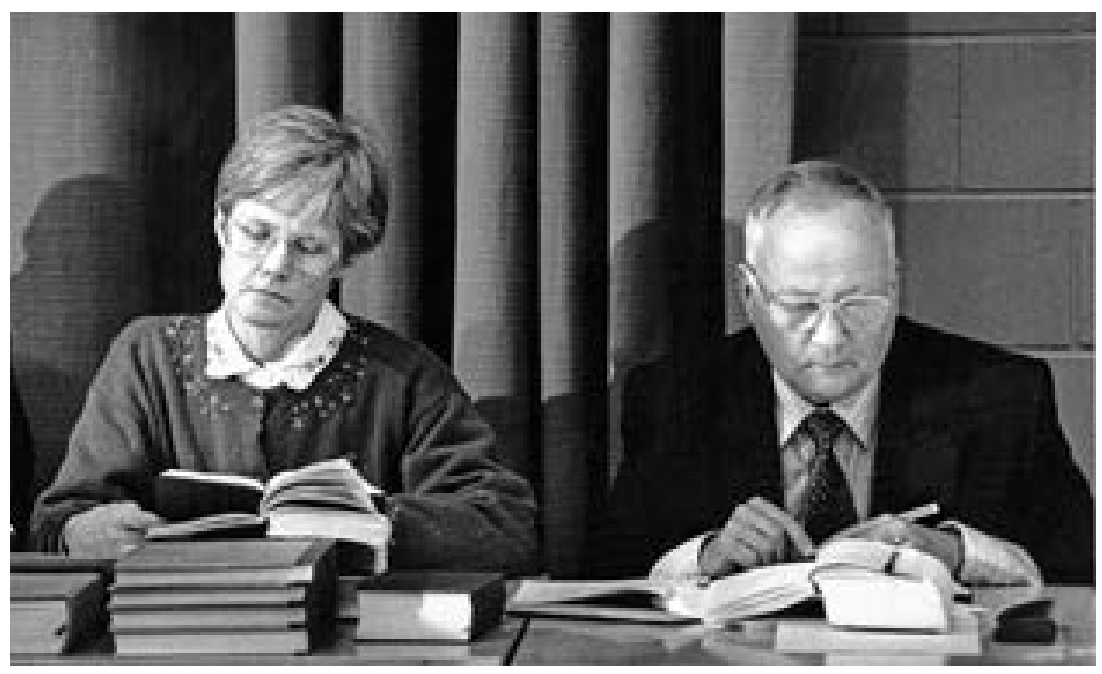


tajien myöhemmissä muistelmissa Nikolainen ei kuitenkaan näyttäydy henkilönä, joka olisi pyrkinyt ajamaan omia ajatuksiaan voimakkaasti läpi ${ }^{642}$. Sen sijaan Nikolaisen kädenjälki ja teologia näkyivät selvästi komitean mietinnön perusteluosassa.

Laajojen periaatteellisten muokkausten lisäksi kirkolliskokous teki muutamia vain tätä psalmia koskevia muutoksia. Kirkolliskokouksessa keskusteltiin vuoden 1933 käännöksen "niityn" ja komitean ehdottaman "laitumen" aikaansaamista erilaisista mielikuvista ja päädyttiin ensin mainittuun sanaan. ${ }^{63}$ Lisäksi täysistunnossa korvattiin kuvaus "ääriään myöten" täynnä olevasta maljasta aiemman käännöksen ilmauksella "ylitsevuotavainen". Helsingin hiippakunnan edustaja, maanviljelijä Olavi Aunola perusteli tätä ehdotustaan sillä, että

TAULuкко 5: Herran rukouksen (Matt. 6:9-13) käsittelyvaiheet

1) Raamattu $1933 / 1938$

9. - - Isä meidän, joka olet taivaissa! Pyhitetty olkoon sinun nimesi;

10. tulkoon sinun valtakuntasi; tapahtukoon sinun tahtosi myös maan pälllä niinkuin taivaassa;

11. anna meille tänä päivänä meidän jokapäiväinen leipämme;

12. ja anna meille meidän velkamme anteeksi, niinkuin mekin annamme anteeksi meidän velallisillemme;

13. äläkä saata meitä kiusaukseen; vaan päästä meidät pahasta,

3) Raamatunkäännösvaliokunta 1991

9. - - Isämme, joka olet taivaissa!

Olkoon sinun nimesi pyhitetty.

10. Tulkoon sinun valtakuntasi.

Toteutukoon sinun tahtosi,

niin kuin taivaassa,

niin myös maan päällä.

11. Anna meille tänä päivänä

jokapäiväinen leipämme.

12. Ja anna meille velkamme anteeksi,

niin kuin mekin annamme anteeksi

niille, jotka ovat meille velassa.

13. Äläkä anna meidän joutua ahdinkoon, vaan päästä meidät pahasta. perinteinen sanamuoto korosti parhaiten Jumalan rakkauden runsautta. Raija Sollamo ei alkutekstin näkökulmasta löytänyt oleellista eroa näiden kahden vaihtoehdon väliltä, joten teologisesti kirkolliskokouksella oli hyvin vapaat kädet asiassa. ${ }^{644}$ Valiokunta yritti vielä palata komitean sanamuotoon, jottei syntyisi kuvaa Jumalasta, joka temppelin juhlassa kaatoi viiniä "yli laitojen, vähän niinkuin sinne päin”. Kirkolliskokous pysyi kuitenkin kannassaan. ${ }^{645}$ Aarne Toivasen myöhemmän arvion mukaan komiteassa pidettiin tuota sanaa "ylitsevuotavan mahdottomana, pitkänä, rytmiin täydellisesti sopimattomana kummajaisena".646

Monet kirkolliskokouksen keskustelunaiheista varsinkin Vanhan testamentin osalta koskettivat kielellisiä seikkoja. Raamatunkäännösvaliokunta joutui esimer-

2) Raamatunkäännöskomitea

9. - - Isä, meidän taivaallinen isämme!

Olkoon sinun nimesi pyhitetty.

10. Tulkoon sinun valtakuntasi.

Toteutukoon sinun tahtosi,

niin kuin taivaassa,

niin myös maan päällä.

11. Anna meille tänä päivänä

jokapäiväinen leipämme.

12. Ja anna meille velkamme anteeksi,

niin kuin mekin annamme anteeksi

niille, jotka ovat meille velassa.

13. Äläkä anna meidän joutua ahdinkoon, vaan päästä meidät pahasta.

4) Kirkolliskokous 1992

9. - - Isä meidän, joka olet taivaissa!

Pyhitetty olkoon sinun nimesi.

10. Tulkoon sinun valtakuntasi.

Tapahtukoon sinun tahtosi,

myös maan päällä

niin kuin taivaassa.

11. Anna meille tänä päivänä

jokapäiväinen leipämme.

12. Ja anna meille velkamme anteeksi,

niin kuin mekin annamme anteeksi

niille, jotka ovat meille velassa.

13. Äläkä anna meidän joutua kiusaukseen, vaan päästä meidät pahasta. 
kiksi käyttämään huomattavan paljon aikaa uhrieläimen anatomiaan. Komitea oli muuttanut vuoden 1933 käännöksen mukaisen "maksanlisäkkeen" ehdotuksessaan "maksan häntälohkoksi". Kirkolliskokouksen täysistunto palautti sen lähes ennalleen "maksan lisäkkeeksi", mutta valiokunta valitsi lopulta nimikkeeksi "maksan takalohkon". Kirkolliskokouksessa ei ollut eläinlääkäriä, mutta lääkärijäsenet ja lahtelainen lihakauppias Martti Drachman toimivat istuntosalissa asiantuntijoina. ${ }^{647}$ Raamatunkäännöstyö edellytti kirkolliskokoukselta harvinaisen monipuolista perehtyneisyyttä.

Paimenpsalmi palautui kirkolliskokouksessa monilta osin aiempaan sanamuotoonsa. Todella moni seurakunta olikin toivonut, että näin kävisi ${ }^{648}$. Psalmin käsittely muistutti sitä, miten tutuimpia virsiä oli muokattu kirkolliskokouksessa kuusi vuotta aiemmin. Onkin ilmeistä, että tunnesiteet rakastettuun psalmiin olivat hyvin samanlaisia kuin suhde lempivirsiin. Monet tähän psalmitekstiin tehdyistä muutoksista kuvastivat kirkolliskokouksen linjauksia muissakin yhteyksissä, mutta palaaminen vanhaan sanamuotoon tässä määrin oli harvinaista. Toinen kohta, jossa palattiin poikkeuksellisen voimakkaasti entiseen, oli Herran rukous.

Jo lähetekeskustelussa herätti huolta, muuttuisiko Herran rukouksen liturginen muoto uuden raamatunkäännöksen mukaiseksi. ${ }^{649}$ Lausunnoissaan lähes kaksi kolmasosaa seurakunnista toivoi rukouksen säilyttämistä entisessä muodossaan. Keskeinen peruste oli nimenomaan rukouksen liturginen käyttö. ${ }^{650}$ Käsittelyn edetessä varmistui, ettei raamatunkäännös suoraan vaikuttanut Herran rukouksen liturgiseen muotoon. Siitä huolimatta paineet rukouksen palauttamiseksi aiempaan sanamuotoonsa olivat suuret. Raamatunkäännösvaliokunnassakin rukousta koskevat linjaukset elivät ${ }^{651}$. Valiokunta pitäytyi kuitenkin lopulta lähinnä komitean ehdotuksessa.

Heti kun täysistuntokeskustelu Matteuksen evankeliumin kuudennesta luvusta alkoi, Markku Porvari teki poikkeuksellisen ehdotuksen: käsittelyn nopeuttamiseksi kirkolliskokous mittauttaisi koeäänestyksellä, mitä muotoa edustajien enemmistö kannatti rukouksen alkupuhutteluksi. Porvarin ehdotus sai kannatusta, ja arkkipiispa Vikström päätti toteuttaa ainutlaatuisen koeäänestyksen. Vuoden 1938 käännöksen alkupuhuttelu, jonka komitea oli todennut kielellisesti vanhentu- neeksi, sai taakseen kahden kolmasosan enemmistön. Kirkolliskokouksen päätös syntyi nopeasti, ja samalla määrittyi linja koko rukouksen käsittelylle. Täysistunto palasi pitkälti vanhaan sanamuotoon. Seija Puha sanoitti yleisen mielipiteen:

Minusta koko Isä meidän -rukous on runo, joka on saanut varsin sointuvan ja kauniin muodon meidän rukouksissamme ja todella toivon, että se säilyy tämmöisenä koko meidän aikamme ja vaikka iankaikkisesti, jos tässä yhteydessä tätä termiä sallitaan käytettävän. Sen verran kaunis tämä Isä meidän -rukous on. ${ }^{652}$

Erityisen pitkä keskustelu syntyi rukouksen viimeisestä jakeesta. Komitean ehdotuksessa aiemman "kiusauksen" tilalla oli "ahdinko". Raamatuntutkimuksessa katsottiin yleisesti, että kohta viittasi suureen lopunajalliseen ahdinkoon, ei yksittäisiin, ehkä pieniksikin käsitettäviin kiusauksiin. Joka tapauksessa komitean sanavalinta sai aikaan heti julkistamisensa yhteydessä kiivaan keskustelun. ${ }^{653}$

Kirkolliskokouksessakin asia nousi esiin jo lähetekeskustelussa. Ylilääkäri Timo Sahi ilmoitti pitävänsä ongelmallisena, että jakeen merkitys oli muuttunut aiemmasta: ahdingossa ihminen oli nurkkaan ajettuna tekemättä välttämättä itse mitään, kun taas kiusauksessa oli sisäisesti halu tehdä jotakin. ${ }^{654}$ Valiokunta pitäytyi komitean sanamuodossa, mutta täysistunnossaan kirkolliskokous palasi Olavi Rimpiläisen ehdotuksesta "kiusaus"sanaan. Kalevi Toiviainen ilmoitti olevansa erittäin huolestunut kokouksen kannasta: edustajien enemmistö oli valinnut kaikkein perinteisimmän linjan vain siksi, että sanamuotoon oli totuttu. ${ }^{655}$ Toisessa mietinnössään valiokunta yritti vielä kerran palauttaa rukouksen kolmannen pyynnön komitean esittämään muotoon, mutta kirkolliskokous ei suostunut muutokseen. ${ }^{656}$

Raamatunkäännöskomitea oli pyrkinyt välittämään lukijalle tekstin alkuperäisen kokonaismerkityksen. Kirkolliskokouksen täysistuntokäsittelyssä, jossa päätöksiä tehtiin nopeaan tahtiin, keskeiseksi kriteeriksi nousi kuitenkin usein sananmukainen vastaavuus. Myös valiokunnan edustajat puolustivat valiokunnan kantaa monta kertaa juuri tästä näkökulmasta, mihin Erkki Reinikainen kiinnitti kriittisesti huomiota. ${ }^{657}$ Lehdistössäkin pohdittiin, oliko täysistuntoon kokoontunut kirkolliskokous oikea elin päättämään nopeasti sanamuodoista, joita komitea oli vuosikausia hionut 
pyrkien käännösehdotuksen sisäiseen johdonmukaisuuteen. ${ }^{658}$ Toisaalta raamatunkäännöstä koskevassa täysistuntokeskustelussa argumentaatio oli selvemmin kristin- ja kieliopillista kuin virsikirjasta päätettäessä. Tuolloin oli kuultu monia tunnepitoisia puheenvuoroja virsien sanamuotojen merkityksestä edustajalle tai seurakuntalaisille.

Useat edustajat lausuivat täysistuntokeskustelussa oman herätysliikkeensä asettaman palauteryhmän kantoja. Voimakasta arvostelua nousi erityisesti evankelisuuden, rukoilevaisuuden ja viidennen herätysliikkeen piiristä. Myös lestadiolaisuuden eri suuntausten edustajat osallistuivat aktiivisesti keskusteluun, mutta esimerkiksi vanhoillislestadiolaisten puheenvuorot olivat hyvin maltillisia. Keijo Nissilä ymmärsi eksegeettinä komitean perusteluja, ja valiokunnan jäsenenä hän puolusti käännösehdotusta. SRK:n puheenjohtaja Erkki Reinikainen taas oli jo vuosia ennen käännöstyön valmistumista ilmoittanut, että vanhoillislestadiolaiset pitäytyisivät hyvin todennäköisesti vuoden 1776 käännöksessä ${ }^{659}$. Koska oli jo etukäteen selvää, ettei oltu päättämässä liikkeen virallisesta käyttökirjasta, ei arvosteluunkaan ollut niin paljon syitä kuin monien muiden herätysliikkeiden edustajilla. Reinikaisen sovitteleva linja näkyi lopulta siten, että vanhoillislestadiolaiset edustajat äänestivät ratkaisevassa käsittelyssä käännöksen hyväksymisen puolesta. Muutenkin ne kriittiset henkilöt, joiden ääni hallitsi raamatunsuomennoksen täysistuntokäsittelyä, muodostivat lopulta vain pienen osuuden kirkolliskokousedustajista.

Selvästi suurin osa edustajista oli tyytyväisiä käännöstyöhön - varsinkin valiokunnan tekemien muutosten ja viimeistään täysistuntokäsittelyn jälkeen. Valiokunnan ensimmäisestä mietinnöstä äänestettiin lähes 300 kohdassa. Lähes kolmannes äänestyksistä päätyi edustajan tekemän muutosehdotuksen voittoon, ja Vanhaan testamenttiin tehtiin miltei yhtä paljon muutoksia kuin Uuteen testamenttiin. Täysistuntokäsittelyn edetessä kirkolliskokous palasi ajoittain aiempiin sanamuotoihin tai lisäsi selventäviä alaviitteitä, mikä liennytti ilmapiiriä verrattuna Ensimmäistä Mooseksen kirjaa koskeneeseen tiukkaan sananvaihtoon. Keskimäärin piispa sai läpi 3,7 muutosta, pappisedustaja o,8 muutosta ja maallikkoedustaja o,6 muutosta. Siten piispojen kädenjälki pääsi näkyviin selvästi keskimääräistä useammin.
Korkeasta luvusta vastasi kolme piispaa. Eero Huovisen ehdottamista muutoksia hyväksyttiin kymmenen, Olavi Rimpiläisen ehdotuksista seitsemän ja Matti Sihvosen esittämistä muutoksista viisi. Aiemmissa vaiheissa muutoksia vaatinut Yrjö Sariola ei osallistunut syksyn 1991 istuntokauden työskentelyyn.

Erot hyväksyttyjen muutosten määrässä eivät olleet suuria pappien ja maallikkoedustajien kesken. Tilasto todistaakin osaltaan maallikkoedustajien aktiivisuudesta raamatunkäännöksestä päätettäessä - varsinkin kun pappisedustajien keskiarvoa kohotti selvästi yksi henkilö. Timo Holma teki lukuisia muutosehdotuksia ja sai niistä läpi kahdeksan. Erkki Reinikaisen esittämistä vanhoillislestadiolaisten muutosehdotuksista hyväksyttiin viisi. Lisäksi erottui kirkolliskokouksen lääkärijäsenten panos: Timo Sahin ehdotuksista hyväksyttiin viisi ja varaedustajana istuntokaudelle osallistuneen apulaisylilääkäri Urpo Saaren ehdotuksista neljä.

Kirkolliskokouksen Vanhaan testamenttiin tekemistä muokkauksista miltei joka toinen muuttui vielä valiokunnassa. Lähes kaikissa tapauksissa oli kuitenkin kyse vain hienosäädöstä. Uuden testamentin osalta valiokunta hyväksyi suoraan noin neljä viidestä kirkolliskokouksen tekemästä muutoksesta. ${ }^{660}$ Ylimääräisellä istuntokaudella 10.-11. tammikuuta 1992 kirkolliskokous poikkesi valiokunnan kannasta enää viidessä kohdassa. Niihin kuuluivat sanat "ylitsevuotavainen" psalmissa 23 ja "kiusaus" Herran rukouksessa. ${ }^{661}$ Täysistunnon tekemistä muutoksista huolimatta raamatunkäännös oli kirkolliskokouskäsittelyn jälkeenkin sisäisesti selvästi yhtenäisempi kuin virsikirja kuusi vuotta aiemmin. Toisaalta raamatunkäännökseen ei kohdistunut samanlaista palauteryöppyä ja julkista arvostelua kuin virsikirjaan, joten kirkolliskokouksellakaan ei ollut samanlaisia paineita poiketa komiteavalmistelun linjasta.

Vastaan äänesti lopulta viisi edustajaa, ja läsnä olleista samaten viisi pidättyi äänestämästä. ${ }^{662}$ Monet näistä edustajista perustelivat päätöstään nimenomaan sillä, että heidän mielestään Vanhan ja Uuden testamentin välisiä yhteyksiä oli katkottu liiaksi. ${ }^{663}$ Näiden edustajien taustassa näkyivät evankelisuus, viides herätysliike, rukoilevaisuus, karismaattisuus sekä Rauhan Sanan ja Elämän Sanan lestadiolaisuus. Samalla on huomattava, että esimerkiksi lukuisat evankeliset ja viidesläiset edustajat äänestivät hyväksymisen puolesta. 
Hiippakunnittain käännösehdotus sai vähiten kannatusta Porvoon hiippakunnan edustajilta. Erityisen huomattavaa oli, että professori Fredric Cleve äänesti vastaan: keskustelun kuluessa hänkin oli vaatinut Vanhan ja Uuden testamentin yhtenäistämistä, ja ratkaisevassa vaiheessa hän oli sitä mieltä, ettei raamatunkäännös vielä käynyt kirkon uskon pohjaksi. ${ }^{664}$ Kun lisäksi Henrik Perret ja Göran Stenlund pidättyivät äänestämästä, vain niukka enemmistö hiippakunnan edustajista antoi varsinaisesti tukensa suomenkieliselle raamatunkäännökselle. Asetelma oli päinvastainen siihen nähden, että ruotsinkielistä virsikirjaa käsiteltäessä suomenkieliset edustajat olivat antaneet omista mielipiteistään riippumatta jaaäänensä Porvoon hiippakunnan edustajien ehdotuksille. Taustalla voi nähdä herätysliikkeiden vaikutuksen sekä Helsingin yliopiston ja Åbo Akademin eksegeettien linjaerimielisyydet, jotka heijastuivat muutenkin raamatunkäännöstyöhön. Äänestystulokseen saattoi myös heijastua se tyytymättömyys, jota Porvoon hiippakunnassa koettiin Ruotsin kirkon raamatunkäännöstyötä kohtaan.

Raamatunkäännöskomitean jäsenet olivat helpottuneita. Äänestystä seuraamassa olleen Aimo T. Nikolaisen silmistä valuivat kyynelet ${ }^{665}$. Tunnelma oli varsin toisenlainen kuin virsikirjakomitean jäsenten keskuudessa kirkolliskokouksen päättäessä uudesta virsikirjasta. Kirkolliskokous hyväksyi uuden raamatunkäännöksen otettavaksi käyttöön vuoden 1992 ensimmäisenä adventtisunnuntaina. Aikataulu oli kunnianhimoinen. Toimituskunnalle jäi vain vajaa vuosi aikaa saattaa käännös painokuntoon ja laatia Raamatun kirjojen keskinäiset viitteet. Käännös haluttiin kuitenkin käyttöön samana vuonna, jona suomenkielinen Raamattu täytti 350 vuotta, ja lopulta siinä onnistuttiin.

Yhtä hyvin ei käynyt niin sanottujen apokryfikirjojen osalta. Piispainkokous oli jo 1984 esittänyt kreikankieliseen Septuagintaan eli katolisen ja ortodoksisen kirkon Vanhan testamentin kaanoniin kuuluvien kirjojen kääntämistä, ja kirkolliskokous oli tehnyt asiasta periaatepäätöksen ${ }^{666}$ Valtiolta ei kuitenkaan saatu riittävää taloudellista tukea, joten raamatunkäännöskomitea ei päässyt jatkamaan työtään apokryfikirjojen kääntämisellä. ${ }^{667}$ Joka tapauksessa kirkolliskokouksen päätökset kirkollisista kirjoista 1980-luvulla osoittivat, että uudistettu kirkolliskokous pystyi viemään suuret hankkeet päätökseen nopeasti.

\section{VAKIINTUNEESEEN PÄÄTÖKSENTEKOON}

\section{SIS ÄISIÄ UUDISTUKSIA}

\section{JULKISUUDEN VALOKEILASSA}

Kärjistäen ilmaistuna kirkolliskokouksessa keskusteltiin 1970-luvulla yhteiskunnasta, mutta seuraavalla vuosikymmenellä yhteiskunnassa keskusteltiin kirkolliskokouksesta. Kirkko - ja kirkolliskokous - ei ollut milloinkaan aiemmin ollut samalla tavalla yhteiskunnallisen keskustelun keskipisteessä kuin päätettäessä arkipyhien siirtämisestä, uudesta virsikirjasta tai naispappeudesta. Laajentunut ja teknisesti kehittynyt media piti asiasta huolen. Kun Uusi Suomi teetti mielipidetutkimuksen vuoden 1986 tärkeimmiksi koetuista kotimaisista tapahtumista, ylivoimaisella kärkisijalla oli pappisviran avaaminen naisille, ja arkipyhien siirron lykkääntyminen vuoteen 1992 nousi seitsemännelle tilalle ${ }^{668}$. Kirkkoa ei tiedotusvälineissä juuri vähätelty, sillä kirkolliset tapahtumat ymmärrettiin laajaa ihmisryhmää koskettaviksi, merkittäviksi uutisiksi. ${ }^{69}$

Yhteiskunnan asenneilmasto oli kirkon kannalta myönteinen, mikä antoi kirkolliskokoukselle liikkumatilaa. Kokous saattoi toimia aiempaa itsenäisemmin suhteessa valtiovaltaan, mikä näkyi sove-päätöksessä ja arkipyhien palauttamista koskeneessa lakiesityksessä. Kirkolliskokouksen asema ei kuitenkaan ollut ongelmaton. Virsikirjauudistus ja raamatunkäännöstyö, jotka oli aloitettu teknistaloudellisen edistysuskon leimaamina vuosina, näyttäytyivät 1980-luvulla ihmisten etsiessä juuriaan liiankin radikaaleina. Jotkut sellaisetkin kirkon päättäjät, jotka olisivat itse olleet valmiita 1970-luvun alkuvuosina hahmoteltuihin selväpiirteisiin uudistuksiin, joutuivat perääntymään ja etsimään kompromisseja. Kaikkiaan vuoteen 1992 ulottuneella "pitkällä 1980-luvulla" kirkolliskokous joutui mutta myös uskalsi hakeutua arvioinnin ja julkisen keskustelun kohteeksi uudella tavalla.

Kirkollisten toimitusten kirjaa käsiteltäessä ongelmana oli ihmisten elämän sekä katsomusten yksityistyminen ja eriytyminen: kirkon kontakti toimituksiin saapuviin jäseniinsä oli yhä heikompi, ja näistä ihmisistä entistä useampi uskoi tutkimusten mukaan eri tavoin kuin kirkko opetti. Tässä tilanteessa oli paitsi kiinnitettävä huomiota toimitusten kristilliseen sanomaan ja jäsenten sitoutumiseen myös pyrittävä pitämään toi- 

1980-luvulla monta kertaa julkisen mielenkiinnon keskipisteessä - erityisesti käsitellessään pappisviran avaamista naisille. Kuva: Kirkkohallitus.

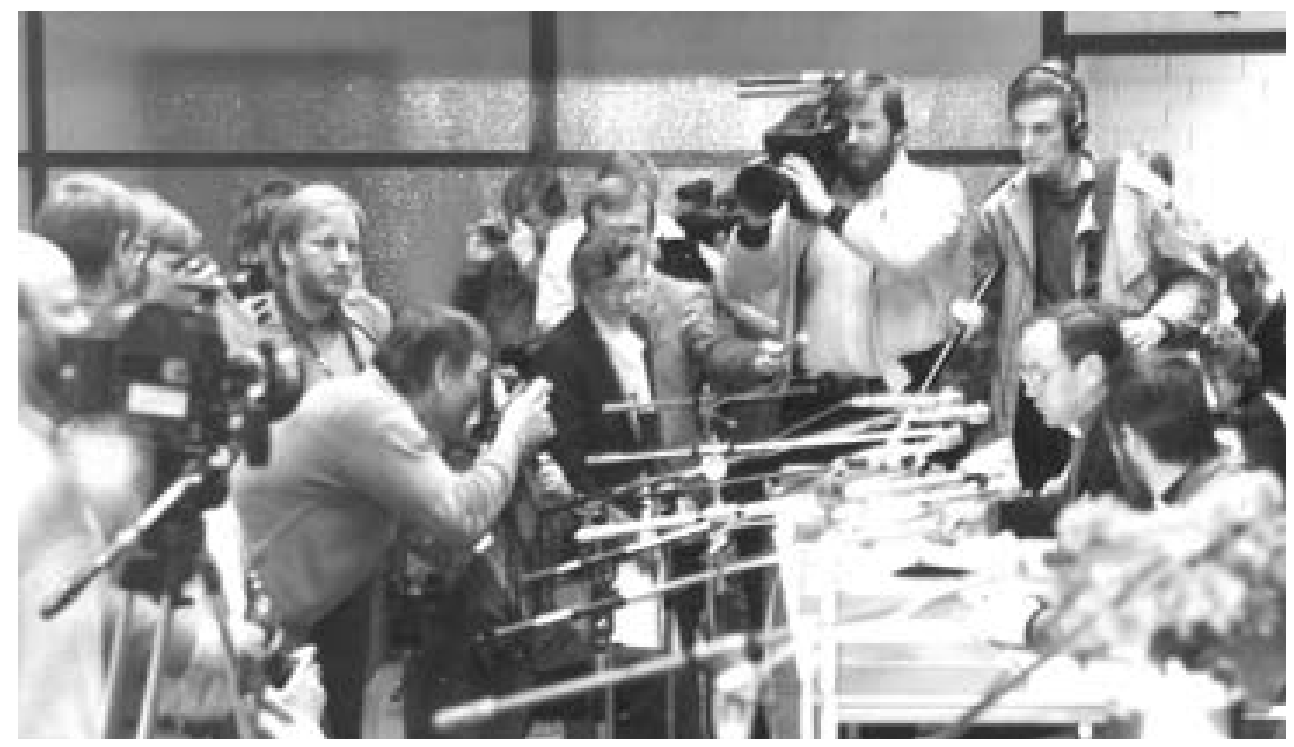

mitusten kynnys matalana. Kirkon jäsenten heikentyvä sitoutuminen ilmeni siten, että kirkosta eroamisesta tuli näkyvä painostuskeino. Eroaalto toteutui 1984, kun pappisvirka ei avautunut naisille, ja erolla uhkailtiin myös seuraavana vuonna kirkolliskokouksen päättäessä uudesta virsikirjasta. Kirkolliskokous joutui ottamaan uhkaukset huomioon.

Suomalaisten kiinnostus puoluepolitiikkaa kohtaan alkoi heiketä 1980-luvulla, mikä näkyi myös kirkolliskokouksen työssä: henkilövalinnoissa 1970-luvun loppupuolella ajoittain esille nousseet puoluepoliittiset asetelmat jäivät taka-alalle. Edustajien puoluepoliittinen jakauma myös monipuolistui. Maallikkoedustajien suhteellisen vaalitavan myötä kirkolliskokoukseen tuli erityisesti 1980-luvun loppupuolelta lähtien näkyviä sosiaalidemokraattisia vaikuttajia. Heidänkin puolueensa oli jo 1970-luvun lopulta lähtien pyrkinyt määrätietoisesti konsensuspolitiikkaan. Kolme suurinta puoluetta olivat lähentyneet toisiaan, eivätkä sosiaalidemokraattiset vaikuttajat tuoneet tullessaan puoluepoliittista taistelua myöskään kirkolliskokoukseen. Vuonna 1987 nimitetty Harri Holkerin sinipunahallitus symboloi oikeiston ja maltillisen vasemmiston raja-aidan rikkoutumista ${ }^{670}$.

Sinipunahallitus oli myös osoituksena siitä, että vasemmisto-oikeisto-rajanvedon sijaan valtakunnanpolitiikassa alkoi saada lisää merkitystä keskuksien ja periferian, kaupunkien ja maaseudun, välinen vastak- kainasettelu. Kirkolliskokouksen kannalta tilanteessa ei sikäli ollut uutta, että kaupunkien ja maaseudun välinen jännite oli ollut perinteisesti hallitsevin yleispoliittinen jakolinja kokouksen maltillisessa yleisporvarillisessa ilmapiirissä. Toisaalta valtakunnanpolitiikan muutokset heijastuivat kirkolliskokoukseenkin, jossa muutamat kaupunkiseurakuntien edunvalvojat terästäytyivät 1980-luvun loppupuolella.

Suomalaisen puoluepolitiikan jäädessä kirkolliskokouksessa taka-alalle esiin nousivat kansainvälisen politiikan kysymykset, jotka eivät 1970-luvulla olleet juurikaan puhuttaneet edustajia. Ensin kylmän sodan kiristyminen sai aikaan periaatteellista keskustelua rauhankysymyksestä. Sitten eteläisen Afrikan rotusorron aiheuttamat levottomuudet kiihtyivät. Lopulta Neuvostoliiton alkava avautuminen ja viimein sosialistisen järjestelmän romahtaminen loivat kirkolliskokoukselle tilaa keskustella vapaasti myös Itä-Euroopan kristittyjen avuntarpeesta. Kirkolliskokouksen varsinaiset toimet jäivät kuitenkin vähäisiksi ja varovaisiksi.

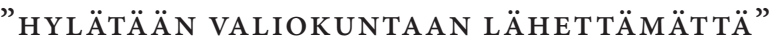
Kirkolliskokouksen työskentelytavat vakiintuivat monelta osin 1980-luvun kuluessa, mikä näkyi esimerkiksi työjärjestyksen pysyvyytenä. Uusimuotoisen kirkolliskokouksen kahden ensimmäisen vaalikauden aikana vuosina 1974-1981 kirkolliskokous oli jättänyt vain kahtena 
vuonna muuttamatta työjärjestystään. Sittemmin muutostahti kuitenkin hidastui. Toinen vakiintumista osoittanut kehityskulku oli, että puhemiesneuvosto ja kansliavaliokunta alkoivat vuodesta 1983 lähtien suunnitella aiempaa tarkemmin istuntokauden tavoiteaikataulun. Yötyöstä pyrittiin ja melko hyvin myös päästiin eroon.

Ehkä kaikkein tärkein työskentelyn vakiintumiseen liittynyt piirre oli, että valmisteluelinten valta kasvoi. Täysistunnossa hyväksyttiin muutoksia valiokuntien esityksiin paljon harvemmin kuin 1970-luvulla. Vuosina 1986-1987 täysistunnoissa tehtyjen muutosehdotusten määrä oli istuntokautta kohden vain kolmannes siitä mitä kymmenen vuotta aiemmin vaalikaudella 1974-1977. Vaalikaudet muistuttivat toisiaan siten, ettei kummankaan aikana ollut käsiteltävänä suuria yksityiskohtaisia uudistuksia, jotka olisivat tuottaneet paljon muutosehdotuksia. Edustajien into ja tarve esittää muutoksia oli vuosikymmenen aikana laskenut selvästi.

Täysistunnossa tehtyjen muutosehdotusten hyväksymisprosentti putosi melkein puoleen aiemmasta. Vaalikaudella 1974-1977 lähes kaksi kolmasosaa muutosehdotuksista oli hyväksytty, mutta kymmenen vuotta myöhemmin hyväksyttyjen osuus putosi hieman runsaaseen kolmannekseen kaikista muutosehdotuksista. Kirkolliskokouksen työskentely läheni eduskuntatyötä, jossa valiokunnilla oli ratkaiseva rooli. Kyse ei ollut täysistunnon vallan häviämisestä, koska edelleen huomattavan suuri osa muutosehdotuksista hyväksyttiin, vaan nimenomaan työskentelyn vakiintumisesta.

Uusimuotoisen kirkolliskokouksen alkuvaiheessa lukuisat täysistunnossa syntyneet, heikosti valmistellut päätökset olivat ajoittain koetelleet kirkolliskokouksen arvovaltaa. Seuraavalla vuosikymmenellä ongelma ei ollut yhtä merkittävä. Erityisesti suuret kirkollisten kirjojen uudistukset asettivat kuitenkin kirkolliskokouksen työskentelyn johdonmukaisuuden ja pitkäjännitteisyyden koetteelle. Hankkeet oli saatava päätökseen tietyn istuntokauden aikana, minkä vuoksi istuntokauden loppua kohden päätöksiä jouduttiin tekemään nopeasti ja usein vähäisin perusteluin. Moni edustaja jäi näissä tilanteissa epävarmaksi ja jätti äänestämättä. Valta saattoi keskittyä pienelle, kannastaan varmojen edustajien joukolle.

Valiokuntien aseman vahvistuminen kertoi yhtäältä siitä, että valmistelun taso oli kohonnut. Kirkkohal- lituksella ja valiokunnilla oli käytössään selvästi enemmän resursseja kuin 1970-luvulla. Tuolloin suuritöisiäkin uudistuksia valmistellut valiokunta oli saattanut joutua valitsemaan sihteerin keskuudestaan. Toisaalta valiokuntien koon kasvattaminen mahdollisti sen, että valiokunta pystyi ottamaan eri viiteryhmien ajatukset huomioon paremmin kuin ennen. Epäilemättä myös edustajien keskinäinen luottamus ja yhteishenki olivat parantuneet, mikä näkyi luottamuksena valiokuntiin. Näyttää siltä, että suuret ja työläät kirkollisten kirjojen ja lainsäädännön uudistukset hitsasivat kirkolliskokousta yhteen.

Päätöksenteon ennustettavuudella oli kääntöpuolia. Vaikka täysistunnon valta säilyi, kirkolliskokous ei keskustellut enää aivan yhtä avoimesti kuin 1970-luvulla. Muutos koski erityisesti henkilövalintoja. Kuvaavaa on, että lehdistössä eniten palstatilaa saattoivat saada keskustelut, jotka eivät lainkaan päätyneet viralliseen pöytäkirjaan. Asioita ratkottiin epävirallisissa ryhmäkokoontumisissa. Esimerkiksi piispat ryhtyivät arkkipiispa John Vikströmin aloitteesta pitämään epävirallisia neuvotteluja kirkolliskokouksen aikana ${ }^{671}$. Näin tarve piispojen keskinäiseen sananvaihtoon istuntosalissa väheni.

Kun edustajat olivat 1970-luvulla suunnanneet täysistunnoissa tarmonsa toistensa vakuuttamiseen, 1980-luvulla puheiden ensisijaisena kohderyhmänä olivat joissakin keskusteluissa ne kirkon jäsenet, jotka lukisivat tapahtumista seuraavan päivän lehdestä tai katsoisivat raporttia televisiouutisista. Mediakentän voimakas laajeneminen ja tiedotusvälineitä kiinnostaneiden asioiden käsittely kirkolliskokouksessa toivat toimittajia entistä sankemmin joukoin Turun kristilliselle opistolle. Heidän läsnäolonsa muutti puolestaan keskustelukulttuuria: kirkolliskokouksen täysistuntoihin juurtui eduskunnalle tyypillinen, julkisuuteen suunnattu keskustelutapa, joka erkani kulissientakaisesta "todellisesta" keskustelusta. Erot eduskunnan ja kirkolliskokouksen työskentelytavoissa pysyivät kuitenkin edelleen suurina ja kirkolliskokouksen ryhmätoiminta löyhänä.

Vaalikaudella 1982-1985 kirkolliskokoukselle tuli hiippakuntakokouksilta ja edustajilta joka kevät keskimäärin 14 aloitetta. Erityisesti hiippakuntakokousten lähettämien aloitteiden taso puhutti kirkolliskokousta: usein hiippakuntakokouksen valmistusvaliokunta oli ehdottanut aloitteen hylkäämistä, mutta kokouksen enem- 
mistö oli päättänyt lähettää sen kirkolliskokoukselle. Ongelmat kasaantuivat seuraavalla vaalikaudella 19861987, jolloin kirkolliskokouksen saavutti suoranainen aloitetulva. Hiippakuntakokous- ja edustaja-aloitteiden vuosittainen keskiarvo yli kaksinkertaistui ja nousi 30 aloitteeseen.

Seurauksena oli, että lähetekeskusteluissa tehtiin ennenkuulumattoman paljon ehdotuksia aloitteiden hylkäämiseksi suoraan. Kahden vuoden aikana tällaisia ehdotuksia tehtiin seitsemän, ja neljä äänestystä päättyi aloitteen hylkäämiseen. Myös suoran hylkäämiskäytännön isä Juhani Linkola palasi jälleen "oman" työjärjestyspykälänsä kannattajaksi ja teki hylkäysehdotuksia.
Kriittisyys aloitteita kohtaan ei jäänyt lyhytaikaiseksi ilmiöksi. Seuraavan nelivuotiskauden aikana hylkäysehdotuksia ja myös -päätöksiä tehtiin edelleen paljon, vaikka aloitteiden määrä jonkin verran pieneni. Vähitellen alettiin kuitenkin uudelleen muistuttaa, että aloite oli helpompi hylätä tunteenomaisesti ja liian kevein perustein lähetekeskustelussa kuin valiokuntatyöskentelyn jäljiltä.

Vuosien 1986-1987 aloitetulvalle oli useita syitä. Nuoriso- ja diakoniatyöntekijöiden ongelmat nousivat tuolloin voimakkaasti keskusteluun. Nousukauden huippukohta innosti puolestaan laatimaan aloitteita uusien virkojen perustamisesta. Poikkeuksellisen

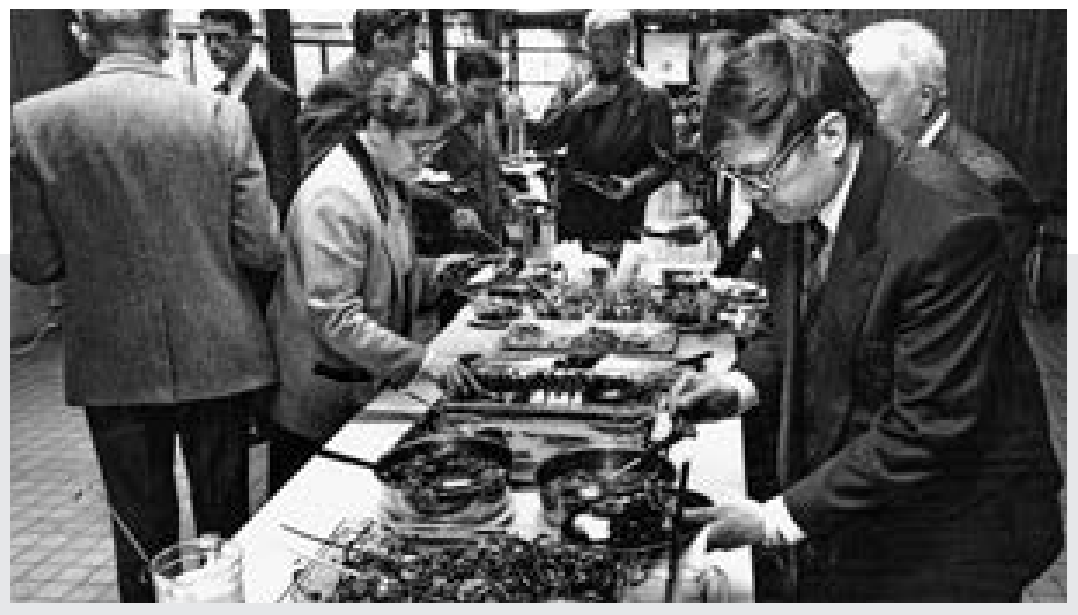

Turun kristillisen opiston keittiön antimet jäivät kirkolliskokouksessa olleiden mieleen ja saivat tilaa myös uutisoinnissa. Kirkkoneuvos Reijo Lehtinen ja hovioikeudenneuvos Sirkka Puotunen saapumassa ruokailuun syysistuntokaudella 1991. Kuva: Kotimaan kuva-arkisto / Jukka Granström.

\section{Yhteiselämää opistolla}

Suurin osa kirkolliskokousedustajista asui kahden hengen huoneissa Turun kristillisellä opistolla. Tiivis yhteiselämä joukkuepeleineen ja saunomisineen yhdisti edustajia ja vaikutti myönteisesti kirkolliskokouksen ilmapiiriin. Professori Lauri Koskenniemi kertoo muistelmissaan elämästä opistolla. Hän majoittui ensin apulaisprofessori Seikko Eskolan, sitten kirkkoherra Leino Hassisen kanssa. Herkkäuniselle Koskenniemelle kahden hengen huoneessa nukkuminen aiheutti ongelmia: "Kerran sitten otin vuoteeni ja kävelin. Nukuin oleskelutilan sohvalla. Aamuvarhaisella aamutoimiin saapuva kerrossiivooja pelästyi pahanpäiväisesti."

Koskenniemen ja Hassisen huonetoveruus näkyi myös täysistunnossa, kun 1985 keskusteltiin uudesta virsikirjasta. Koskenniemi esitti virsiehdotuksen "Nouskaamme vuorelle korkeimmalle" poistamista. Hassinen ilmoitti vastustavansa poistoa: "Soisin, että vaikka huonetoverini Lauri Koskenniemi on toisella kannalla, että me voisimme elää rauhassa
keskenämme!’II Ilmeisesti Hassisen toive toteutui molemmilta osiltaan: virsiehdotus päätyi virsikirjaan, eikä huonetoverien rauhakaan näytä järkkyneen.

Lapuan tuomiorovastin Jussi Rannan ja asessori Otso Sovijärven yhteistyö tuomiokapitulissa oli alkanut vaivalloisesti, mutta myöhemmin monivuotinen yhteisasuminen kirkolliskokouksessa teki heistä ystäviä. ${ }^{\text {II }}$ Sovijärvi kertoo muistelmakirjassaan huonetoveruuden jännittävästä alusta vuonna 1982. Hän heräsi kovaan mätkimiseen ja huomasi Rannan heittävän saapasta. Aamulla selvisi tapahtumien syy: tuomiorovasti kertoi tappaneensa unissaan kukkoa. ${ }^{\text {IV }}$ Yhteiselämä edellytti väliin joustavuutta, mutta jos toisen henkilön kanssa kykeni jakamaan huoneen, kykeni hänen kanssaan myös rakentavaan keskusteluun istuntosalissa.

I L. Koskenniemi 2000, 216-217.

II Kirk.kok. kptk-s. 1985,34\$.

III Sovijärvi 2008, 66-67,

IV Sovijärvi 2008,79. 


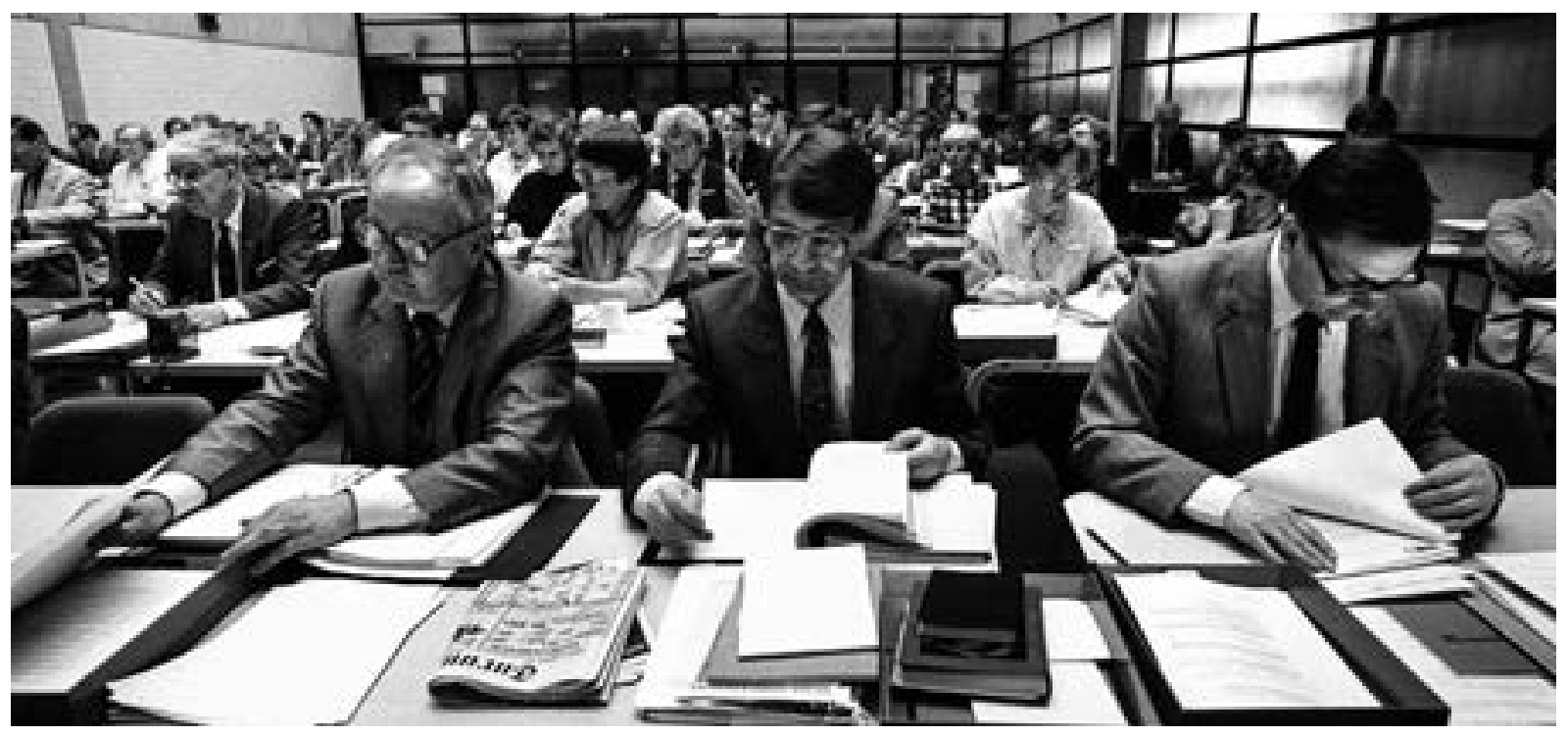

Piispat Kalevi Toiviainen (vas.), Paavo Kortekangas ja Yrjö Sariola etsivät käsiteltäviä asiakirjoja keväällä 1987. Tuolloin kirkolliskokouksen esityslistalle tuli muiden asioiden ohella 15 aloitetta hiippakuntakokouksilta ja 11 aloitetta edustajilta. Aloitetulvan myötä kirkolliskokouksen kriittisyys aloitteita kohtaan kasvoi. Kuva: Kotimaan kuva-arkisto / Jukka Granström.

monet kevään 1986 edustaja-aloitteista oli allekirjoittanut suuri joukko edustajia. Naispappeusvaalien myötä kirkolliskokous oli ikään kuin jo valmiiksi järjestäytynyt tai ainakin järjestäytyi nopeasti kokouspaikalla uuden vaalikauden alkaessa. Erityisesti ne, jotka vastustivat pappisviran avaamista naisille, tiivistivät yhteistyötään. Ryhmätoiminta loi selviä jakolinjoja herätysliikkeiden ja hiippakuntaryhmien sisälle.

Hiippakuntakokousaloitteet olivat 1980-luvulla korostetun hallinnollisia. Edellisellä vuosikymmenellä nähtyjä vaatimuksia yhteiskunnallisiin ongelmiin puuttumisesta tuli kirkolliskokoukselle vain harvoin. Kirkon sisäiset uudistukset veivät huomion. Hiippakunnissa ja kirkolliskokouksessa ei myöskään enää koettu samanlaista tarvetta arvostella kuuluvasti yhteiskunnan kulkusuuntaa kuin edellisellä, vielä vasemmistoradikalismin leimaamalla vuosikymmenellä.

Vaalikauden 1986-1987 aikana kirkolliskokous lähetti selvästi eniten asioita talousvaliokuntaan ja yleiseen valmistusvaliokuntaan - suunnilleen samassa suhteessa kuin kaudella 1974-1977. Suurin muutos oli, että käsikir- javaliokunnan asiat lisääntyivät selvästi, mikä kuvaakin 1980-lukua kirkollisten kirjojen uudistamisen vuosikymmenenä. Perustevaliokunnan asiamäärä väheni huomattavasti, mutta toisaalta sillä oli käsissään sitäkin kuumempi naispappeuskysymys. Toisin kuin 1970-luvulla, jolloin kaikki valiokunnat olivat työskennelleet monien melko rajattujen uudistushankkeiden parissa, pelkät asiamäärät eivät 1980-luvun osalta anna lainkaan todellista kuvaa valiokuntien työmäärästä. Suurimman kuorman joutuivat kahdeksankymmenluvulla yleensä kantamaan vain yhtä mutta sitäkin suurempaa uudistusta varten perustetut erikoisvaliokunnat.

\section{TÄYSISTUNTO TASA-ARVOISTUU}

Vuosina 1986-1987 kirkolliskokousedustajat puhuivat suunnilleen yhtä aktiivisesti kuin uusimuotoisen kirkolliskokouksen ensimmäisellä nelivuotiskaudella. Hiippakunnat, joissa vanhoilla herätysliikkeillä oli vahva asema, olivat puheenvuorojen määrässä mitaten edelleen aktiivisia. Vastaavasti eteläiset, kaupunkivaltaiset hiippakunnat olivat muita vaiteliaampia. Kirkolliskokouksen puhuvimpaan kymmenekseen kuului kolme piispaa, Paavo Kortekangas, Kalevi Toiviainen ja Samuel Lehtonen. Pappisedustajista selvästi eniten puhui Timo Holma, ja seuraavana - joskin vain noin puolet Holman puheenvuorojen määrästä käyttäneenä - oli Timo Kökkö. Molemmat lukeutuivat Elämän Sanan lestadiolaisuuteen. 
2,5

$\mathrm{kpl}$

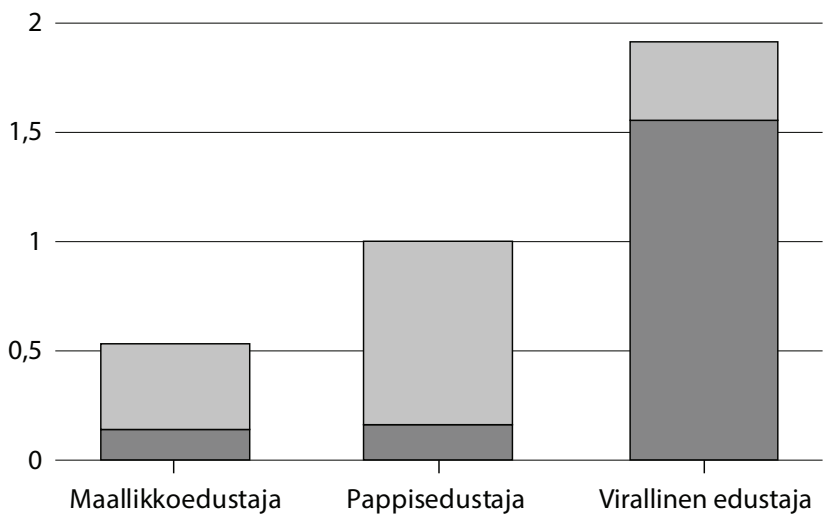

Maallikkoedustajista puhuvimpaan kymmenekseen kuuluivat Väinö Vähäsarja, Mauno Hyyryläinen ja Erkki Reinikainen sekä talousvaliokunnan puheenjohtajan tehtävässä Väinö Takala. Näistä neljästä peräti kolme oli lukeutunut puhuvimpien kirkolliskokousedustajien ryhmään jo vaalikaudella 1974-1977. Nähtävästi aktiivisuus täysistunnoissa auttoi edustajapaikan säilyttämisessä. Kokeneimmat, vähintään neljännen kauden maallikkoedustajat puhuivatkin kaikkiaan selvästi enemmän kuin kokemattomammat kollegansa. Pappisedustajien osalta kokemus ei sen sijaan vaikuttanut puhemäärään. Naisedustajat puhuivat keskimääräistä vähemmän. Halu esiintyä varovaisesti käsiteltäessä naispappeuskysymystä vuonna 1986 saattoi osaltaan vaikuttaa asiaan.

Täysistunnossa tehtyjen muutosehdotusten osalta asetelma oli tietyiltä osin samanlainen kuin nelivuotiskaudella 1974-1977. Muutosehdotuksia tekivät edelleen keskimäärin selvästi eniten viralliset edustajat ja toiseksi eniten pappisedustajat. Sen sijaan muutosehdotusten määrä väheni kaikissa ryhmissä, erityisesti virallisten edustajien keskuudessa. Muutos kuvastaa osaltaan valmistelukoneiston voimistumista: täysistunnoissa tarvitsi entistä harvemmin ehdottaa muutoksia pohjaesitykseen.

Virallisten edustajien tekemistä muutosehdotuksista hyväksyttiin edelleen ylivoimaisesti suurin osa - joskin hieman pienempi osuus kuin kymmenen vuotta aiemmin. Tällä mittarilla vaikutusvaltaisimmaksi osoittautui piispa Paavo Kortekangas, jonka kaikki yhdeksän muutosehdotusta hyväksyttiin. Sen sijaan hiippakunnittain valittujen pappien ja maallikkoedustajien mahdolli-
Kuvio 10: Yksittäisen edustajan täysistunnoissa tekemien muutosehdotusten keskiarvo kaudella 1986-1987

Virallisten edustajien osalta valtioneuvoston määräämää edustajaa ei ole otettu huomioon, koska hän ei juuri osallistunut noina vuosina kirkolliskokouksen työskentelyyn.

Hylätyt

Hyväksytyt

suudet saada muutosehdotuksiaan läpi täysistunnossa romahtivat. Pappisedustajien tekemistä muutosehdotuksista hyväksyttiin vain alle kuudesosa, kun vuosina 1974-1977 selvästi yli puolet heidän muutosehdotuksistaan oli mennyt läpi. Maallikkoedustajien tekemistä muutosehdotuksista hyväksyttiin hieman yli neljännes. Naismaallikkojen muutosehdotuksista meni läpi yli kolmannes, joten heidän vaikutusvaltaansa ei voinut pitää enää 1980-luvulla miehiä heikompana.

Tulos viittaa siihen suuntaan, että papisto oli menettänyt auktoriteettiaan kirkolliskokouksessa. Toisaalta monien maallikkoedustajien kynnys puhua ja tehdä muutosehdotuksia oli todennäköisesti korkeampi kuin papeilla, minkä johdosta heidän muutosehdotuksensa olivat keskimääräistä koetellumpia. Pappis- ja maallikkoedustajien edustajakokemuksella ei ollut merkitystä muutosehdotusten läpimenossa. Vaikka edustajan puhumisaktiivisuudella oli positiivinen yhteys hänen uudelleenvalintaansa, muutosehdotusten käsittelyn valossa runsas puhemäärä ei näyttänyt lisäävän vaikutusvaltaa kirkolliskokouksessa. Ratkaisevia olivat kulloisetkin asiaperusteet, puhui edustaja sitten muuten paljon tai vähän.

Arkkipiispa John Vikström toimi kirkolliskokouksen puheenjohtajana syksystä 1982 lähtien. Hän ei yleensä ottanut voimakkaasti kantaa käsiteltäviin asioihin, joten hänen työskentelynsä kokouksen johdossa oli lähempänä Martti Simojoen kuin Mikko Juvan toimintalinjaa. Toisaalta Vikström oli Simojokea huomattavasti joustavampi käsittelyjärjestyksestä päätettäessä ja työjärjes- 
tystä sovellettaessa. Näiltä osin hänen toiminnassaan oli yhtymäkohtia varapuheenjohtajana toimineiden oikeusoppineiden Lars Erik Taxellin ja Johannes Leivosen johtamistapoihin. Vikströmin kaudella varapuheenjohtajat saivat entistäkin enemmän vastuuta.

Johannes Leivosella oli vuoteen 1986 eli eläkkeelle jäämiseensä asti poikkeuksellinen rooli kirkolliskokouksen varapuheenjohtajana. Yleensä varapuheenjohtajilla ei ollut muita merkittäviä kirkolliskokoustehtäviä, mutta Leivonen toimi kirkkolakivaliokunnan puheenjohtajana ja hallitsi kirkkolainsäädäntötyötä. Seitsenkymmenluvun loppupuolella Leivonen oli ollut kirkolliskokouksessa ehdoton auktoriteetti, jota ei juuri ollut noustu täysistunnossa vastustamaan. Sen sijaan seuraavalla vuosikymmenellä Jaakko Voipiolla oli riippumattoman yliopistomiehen asemansakin puolesta uskallusta asettua tarvittaessa eri kannalle korkeimman oikeuden arvostetun jäsenen kanssa ${ }^{672}$ Voipiossa voi nähdä yhtymäkohtia Mikko Juvaan - molemmat olivat matalakirkollisia, voimakastahtoisia ja suoraviivaisia vaikuttajia. Vastaavasti John Vikströmin ja Johannes Leivosen sovittelevissa toimintatavoissa on nähtävissä keskinäistä samankaltaisuutta muutenkin kuin kokousteknisessä työskentelyssä.

Piispojen asema muuttui selvästi 1980-luvulla. Edellisellä vuosikymmenellä hiippakuntien mahdol- lisuudet suunnitella toimintaa alueellaan olivat olleet heikot, mutta 1980-luvulla tilanteeseen saatiin korjaus kirkolliskokouksen perustettua lukuisia toiminnallisia virkoja tuomiokapituleihin. Päätökset kasvattivat piispojen mahdollisuuksia osallistua seurakunnallisen työn kehittämiseen. Sen sijaan kirkon keskushallinnossa piispojen arvovalta heikkeni edelleen. Kirkolliskokouksen toiminnan kannalta muutos merkitsi sitä, että edustajien välinen tasa-arvo vahvistui. Piispat eivät enää 1980-luvulla olleet vuoden 1974 tapaan pelottavan arvovaltainen joukko, joka varjeli paikkaansa kirkolliskokouksen eturivissä. Oli paradoksaalista, että samaan aikaan tämän muutoksen kanssa kirkollisessa keskustelussa vakiintui konstitutiivinen virkakäsitys ja alettiin korostaa virkaa teologisesti.

Itse asiassa piispojen roolin arkipäiväistymiseen kirkolliskokouksessa vaikutti eniten Olavi Rimpiläinen, joka edusti piispojen joukossa kaikkein korkeakirkollisinta virkateologiaa. Hän puhui usein hyvin kansanomaisesti, mikä todennäköisesti rohkaisi muitakin edustajia ottamaan vapauksia 1970-luvulla kuullusta virallisesta yleiskielestä. Esimerkiksi virsikirjauudistuksesta keskusteltaessa Rimpiläinen saattoi yhtyä "tuohon Paavo-piispan vetoomukseen". ${ }^{673}$ Tai sitten hän puheli, miten "tuo Heikki [Vaahtoniemi] keksi siitä riimivirheen. - - Mikäs vika se tässä on? Ja olispa kerrankin 
oikein vahva latinki tuota kirkkoa, kun sitä sanotaan pyhäksi." ${ }^{674}$ Aiempaa tasa-arvoisemmasta ilmapiiristä kertoi pienenä yksityiskohtana sekin, että useat edustajat alkoivat puheidensa alkupuhuttelussa muistaa puheenjohtajan ohella myös edustajatovereitaan.

Kirkolliskokouksen sisäisen tasa-arvokehityksen kääntöpuolena oli teologinen kysymys piispainkokouksen opillisesta vallasta ja vastuusta. Kun suunniteltiin uutta keskushallintoelintä, päätettiin piispanviran avaamisesta naisille tai keskusteltiin kirkollisen äänioikeuden ehdoista, piispainkokouksen antamien lausuntojen painoarvo osoittautui vähäiseksi. Vastaavasti määräämättömäksi ajaksi valittujen kirkkoneuvosten arvovalta näytti kasvavan vuosikymmenen kuluessa. Sove-päätöksessä 1982 kirkolliskokous vielä hylkäsi kirkkoneuvosten tarjoaman neuvotteluratkaisun, mutta kokonaisuutena kirkolliskokousedustajien luottamus kirkkohallitukseen oli 1980-luvulla toisella tasolla kuin edellisellä vuosikymmenellä. Kirkkoneuvoksia ei enää ajettu puolustusasemiin, vaan heitä kuunneltiin tarkalla korvalla asiaintuntijoina. Esimerkiksi uudesta keskushallintoelimestä keskusteltaessa kirkkoneuvosten ajatukset osoittautuivat monin kohdin piispainkokouksen mielipiteitä painavammiksi. Luottamuksen kasvaminen oli yksi edellytys sille, että kirkolliskokous uskalsi liittää kirkon keskukset tiiviisti kirkkohallitukseen. 


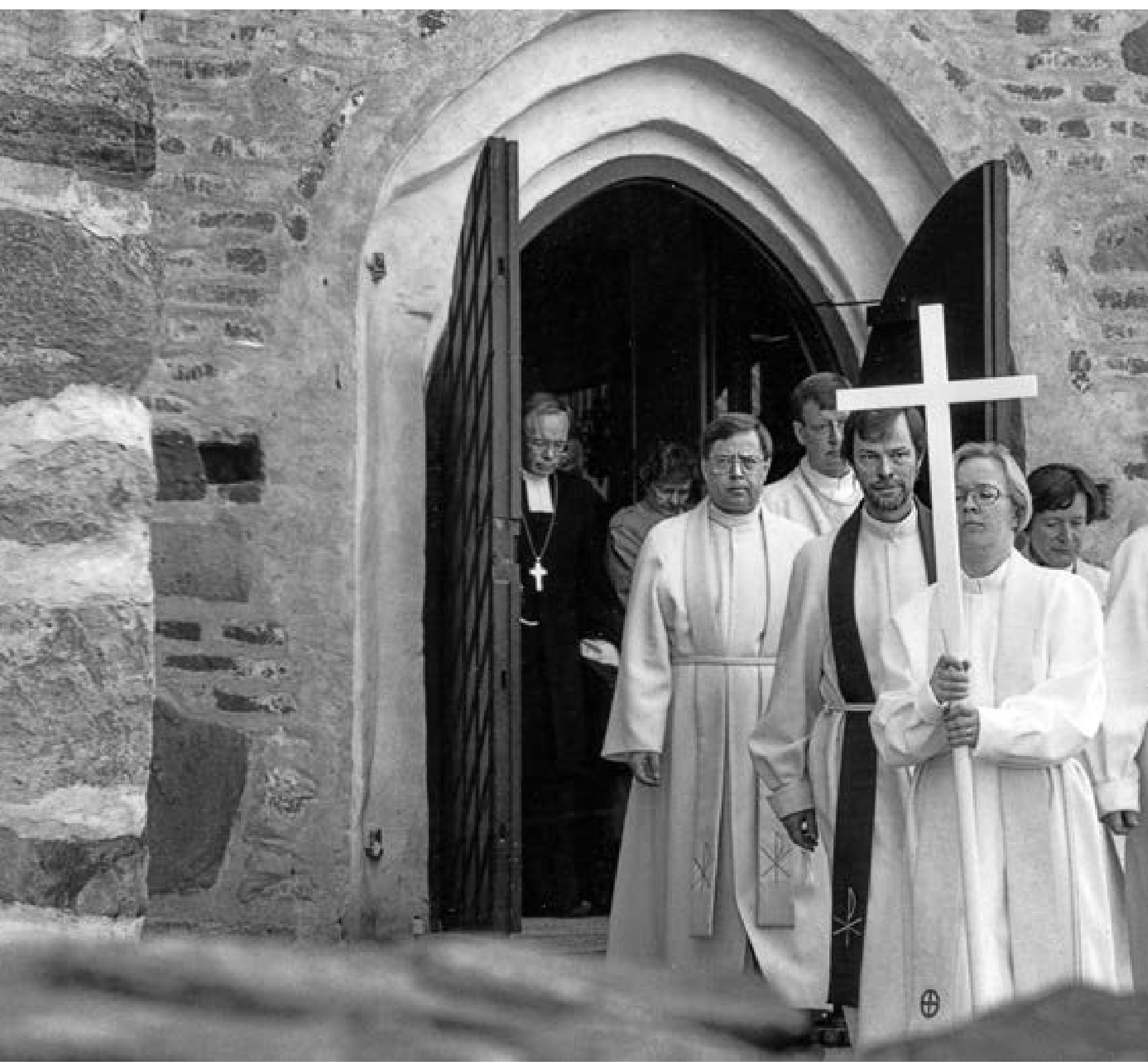




\section{KIRKON}

\section{H A L L IN T O \\ IT SEN ÄIST YY \\ 1992-2000}




\section{MONIPUOLISTUVA EDUSTAJISTO}

\section{PYRKII JATKUVAAN UUDISTUKSEEN}

\section{MURROSVUODET VAUHDITTAVAT}

KANSANKIRKOLLISTA OHJELMAA

Vuonna 1988 valittu kirkolliskokous piti viimeisen istuntonsa tammikuussa 1992. Paljon ehti tapahtua, ennen kuin uusi kirkolliskokous kokoontui saman vuoden toukokuussa. Pankkikriisi syveni, kun julkisuuteen tuli tietoja pankkien valtavista tappioista. Työttömyys jatkoi nopeaa kasvuaan, ja korot pysyivät korkealla․ Maaliskuussa John Vikström avasi arkkihiippakunnan hiippakuntakokouksen todeten, että Suomen kodeissa oli harvoin valvottu niin paljon kuin kuluneen talven öinä: "Tiedämme myös, että on entistä enemmän niitä, jotka eivät yksinkertaisesti jaksa. Ei jakseta valvoa, ei jakseta elää." ${ }^{2}$ Helmikuussa Euroopan yhteisön (EY) johtajat kokoontuivat Maastrichtissa ja päättivät, että seuraavan vuoden marraskuussa perustettaisiin Euroopan unioni (EU). Maaliskuussa Suomi haki EY-jäsenyyttä3. Uusi kirkolliskokous kokoontui keskellä syvää lamaa ja nopeasti etenevää Euroopan yhdentymisliikettä.

Kirkolliskokouksella oli takanaan suurten kokonaisuudistusten kausi. Kokous oli tehnyt kirkon sisäisiä päätöksiä, jotka olivat olleet usein julkisen huomion keskipisteessä. Yhteiskunnan ja maailmanpolitiikan mullistukset jättivät 1990-luvulla kirkon päätökset sivuosaan. Myös kirkolliskokouksessa koitti aika, jolloin oli puhuttava jälleen yhteiskunnan suunnasta. Toisaalta taloudellinen lama pakotti kirkolliskokouksen miettimään kirkon taloutta ja hallinnollisia rakenteita. Tällöin eivät kuitenkaan tulleet kyseeseen sellaiset vuosikausia kestäneet raskaat valmisteluprosessit, joiden avulla oli uudistettu kirkkolaki tai siirretty toimikunnat osaksi kirkkohallitusta. Oli toimittava nopeasti tilanteessa, jossa edes seuraavasta vuodesta ei ollut paljon tietoa.
Uuden vuosikymmenen teemat näkyivät niissä esityksissä ja aloitteissa, jotka kirkolliskokous sai käsiteltäväkseen vaalikauden alkaessa keväällä 1992. Laman syvetessä tehdyn haastattelututkimuksen mukaan moni koki kirkon paikalleen pysähtyneeksi, byrokraattiseksi ja etäiseksi ${ }^{4}$. Tässä tilanteessa yhteensä 89 kirkolliskokousedustajaa kirjoitti nimensä aloitteeseen, jonka tarkoituksena oli kirkon hallinnon keventäminen. Samalla purkautuivat ne hallinnon uudistamispaineet, jotka luonteeltaan pitkälti teknisen kirkkolain kokonaisuudistuksen aikana olivat patoutuneet. Kirkolliskokouksessa haluttiin astua uuteen aikaan, jota kuvaisivat kevyet, jatkuvat ja alhaalta päin lähtevät uudistukset. Niiden ei tullut pakottaa kaikkia samaan muottiin, vaan erilaisille paikallisille ratkaisuille oli jäätävä tilaa. Uudenlaisia hankkeita kuvaamaan vakiintui nopeasti yhteinen avainsana: prosessi.

Uudistuspaineet kohdistuivat kaikkein voimakkaimmin hiippakuntahallintoon. Piispa Matti Sihvosen johtama tuomiokapitulikomitea selvitti tuomiokapitulien siirtämistä valtiolta kokonaan kirkon ylläpidettäviksi. Monet toivoivat, että siirron myötä kirkko pääsisi kehittämään hiippakuntahallintoa vapaasti ja itsenäisesti. Keväällä 1992 odotukset näkyivät siten, että kirkolliskokousedustajat saivat käsiinsä Lapuan hiippakuntakokouksen aloitteen Keski-Suomen hiippakunnan perustamisesta. Kirkkohallituksessa taas valmisteltiin kauan vireillä ollutta arkkipiispan viran uudelleenjärjestelyä. Ennen vuosikymmenen päättymistä Turussa oli kaksi piispaa.

Kevään 1992 edustaja-aloitteissa näkyivät myös työttömyys, ylivelkaantuminen sekä henkinen ja aineellinen hätä. Kirkolliskokoukselta vaadittiin toimia seurakunnissa tehtävän avustustyön tukemiseksi. ${ }^{5}$ Arkkipiispa Vikström totesikin aloitteiden ja kirkolliskokouksen toimien osoittavan, että "me tahdomme kansankirkkona seistä kansamme rinnalla". 6 Samaan aikaan kirkon oma taloudellinen pohja horjui, kun valtiovalta oli lisäämässä seurakuntien verorasitusta ja vastaavasti poistamassa kirkon osuutta yhteisöverotuloista. Valtion leikkaukset uhkasivat kohdistua myös uskonnonopetukseen. Keväällä 1992 kirkolliskokouksen tehtävänä oli antaa lausunto suunnitellusta pääomatulojen verotuksen ja yritysverotuksen uudistuksesta sekä opetusministeriön tuntijakotyöryhmän mietinnöstä.7 Kirkon ja valtion 
Avajaisjumalanpalveluksesta poistuvia kirkolliskokousedustajia keväällä 1993. Raija-Liisa Mikkola ja Kalevi Nummi olivat kokeneita varapuheenjohtajia, jotka jatkoivat tehtävässään myös vuosina 1992-1995. Matti Sihvosen johtama tuomiokapitulikomitea oli siirtämässä tuomiokapituleja valtiolta kirkolle yli 400 vuoden kauden jälkeen, ja Mikko Heikan komitea suunnitteli vaalikauden aikana seurakuntahallinnon uudistamista. Yrjö Sariola ja Risto A. Ahonen olivat aktiivisia kirkkokäsikirjan ja diakonaatin uudistustyössä. Kuva: Kotimaan kuva-arkisto / Matti Karppinen.

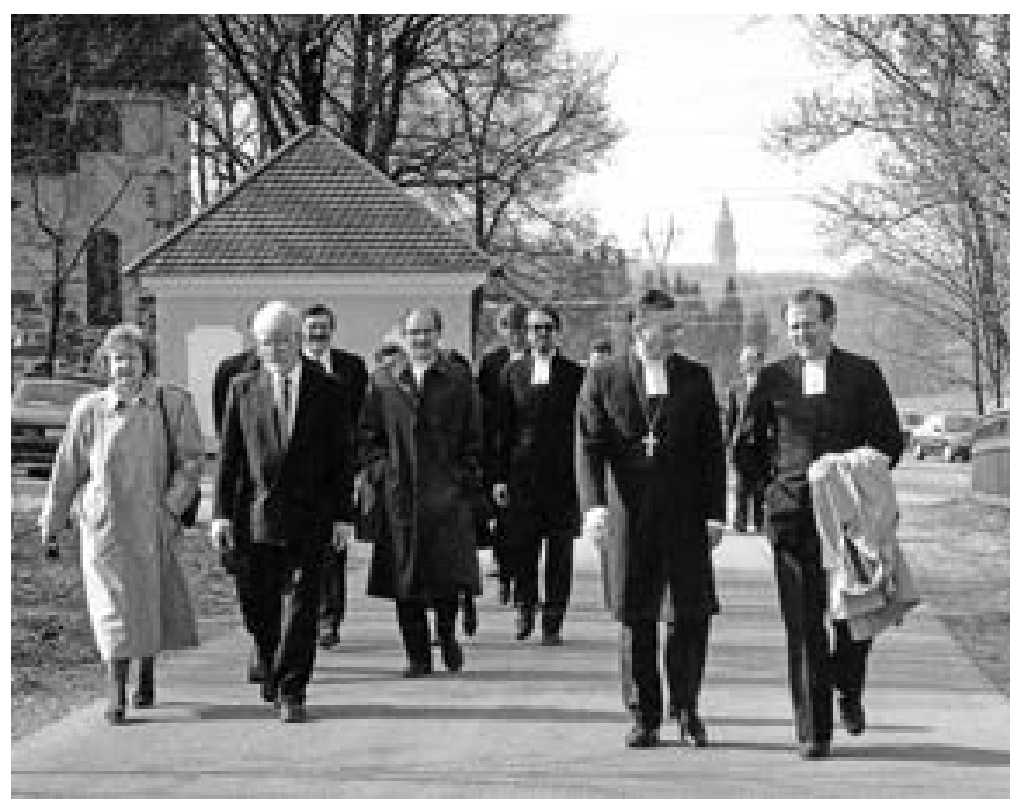

suhteet olivat nousemassa nopeasti yhdeksi 1990-luvun tärkeimmistä teemoista kirkolliskokouksessa.

Lama-aika korosti diakoniatyön merkitystä seurakunnissa. Samalla verotulojen supistuminen pakotti seurakunnat vähentämään työntekijämäärää ja miettimään työalojen keskinäistä tärkeysjärjestystä. Eri työntekijäryhmien suhde kirkon virkaan nousi entistä polttavammaksi kysymykseksi. Vuonna 1992 kirkon virkarakenne oli teologisen selvittelyn kohteena piispainkokouksessa, mutta sieltä sen oli tarkoitus tulla myöhemmin kirkolliskokouksen käsittelyyn. Keväällä 1992 diakonissa Terttu Pohjolainen Lahdesta yritti nopeuttaa asioiden etenemistä edustaja-aloitteella, jonka mukaan diakoniatyöntekijöille tuli antaa oikeus jakaa ehtoollista virkatehtävissään - myös sielunhoidollisissa tapaamisissa. ${ }^{8}$ Pohjolaisen aloitteessa yhdistyi kaksi 1990-luvun suurta teologista uudistushanketta, diakonaattiuudistus ja jumalanpalvelusuudistus. Molempia hankkeita leimasi ajatus, että diakonia ja jumalanpalvelus tuli liittää aiempaa tiiviimmin toisiinsa.

Virkarakenne liittyi myös anglikaanien ja katolisen kirkon kanssa käytyihin merkittäviin ekumeenisiin neuvotteluihin. Niiden tuloksiin kirkolliskokous pääsi ottamaan kantaa 1990-luvulla. Vuosikymmeniä jatkunut teologinen työskentely yhdistyi tuossa maailmantilanteessa Euroopan nopeaan yhdentymiseen. Keväällä 1992 kirkolliskokous sai hiippakuntakokousaloitteen, jonka mukaan tuli selvittää, mitä Suomen mahdollinen EYjäsenyys ja muut Euroopan muutosprosessit merkitsisivät kirkon näkökulmasta. ${ }^{9}$

Uuden kirkolliskokouksen edessä olivat lama, kirkon suhteet valtioon, yhdentyvä Eurooppa sekä viran ja jumalanpalveluksen teologia. Harvoin näin erilaiset asiat olivat kuitenkaan kytkeytyneet toisiinsa niin tiiviisti kuin 1990-luvulla. Erilaisissa uudistushankkeissa yhdistyivät ne tavoitteet, joita kirkkojärjestyskomitea oli runsas vuosikymmen aiemmin hahmotellut ja jotka sittemmin tarkentuivat piispainkokouksen aloittamassa Kirkko 2000 -prosessissa. John Vikströmin johdolla määritelty kansankirkollinen ohjelma pääsi hänen arkkipiispuuskautensa loppupuolella ohjaamaan taustaajatuksena monia kirkolliskokouksenkin käsittelemiä uudistushankkeita. Taloudellinen lama ja Euroopan yhdentyminen vauhdittivat osaltaan ohjelman toteuttamista.

Kirkkojärjestyskomitean mukaan kirkon tuli pyrkiä mahdollisimman suureen henkiseen, hallinnolliseen ja taloudelliseen riippumattomuuteen valtiosta. Vastaavasti tavoitteena oli samastua aiempaa voimakkaammin maailmanlaajuiseen kirkkoon. ${ }^{10}$ Kirkko katkoi 1990-luvulla siteitään valtioon ja vahvisti sidoksiaan erityisesti lännen vanhoihin kirkkoihin. Kirkkojärjestyskomitea 
oli korostanut kirkon itsenäistä vastuuta kristillisestä opetuksesta ja kasvatuksesta ${ }^{11}$. Kirkolliskokous uudisti 1990-luvulla kristinopin ja pyrki vahvistamaan muiden muassa kasvatustyötä tekevien nuoriso- ja lapsityönohjaajien asemaa. Kirkkojärjestyskomitean mukaan tuli panostaa kirkon jäsenyyteen ja yhteisöluonteeseen - esimerkiksi kiinnittämällä huomiota pieniin toimintayksikköihin $^{12}$. Lamavuosina kirkolliskokous ja sen asettamat komiteat pohtivat seurakuntarakennetta ja miettivät myös maantieteellisistä rajoista riippumattomien henkilöseurakuntien mahdollisuutta.

\section{KOKONAAN SUHTEELLISIIN}

\section{KIRKOLLISKOKOUSVAALEIHIN}

Vuonna 1992 pappisedustajat valittiin viimeistä kertaa enemmistövaalilla ja ilman ehdokasasettelua. Melkein puolet pappisedustajista vaihtui. Kirkkoherrat joutuivat antamaan tietä kirkon erityistehtävissä toimiville papeille. ${ }^{13}$ Esimerkiksi Lapuan hiippakunnassa kaikki kolme pappisedustajaa olivat kirkon erityisviroissa, ja seurakuntapapit jäivät varasijoille. ${ }^{14}$ Helsingin hiippakunnassa enemmistövaali merkitsi äänten keskittymistä pääkaupunkiseudulle: Helsingin ja Espoon papit jakoivat edustajapaikat muun Uudenmaan jäädessä ilman edustajia. Sen sijaan Oulun hiippakunnassa pappisedustajien alueellinen jakauma tasapainottui, kun Lapin alue sai pappisedustajan Tornion kirkkoherrasta Risto Junttilasta. ${ }^{15}$ Naispuolisten pappisedustajien määrä kasvoi kirkolliskokouksessa kahdesta neljään.

Naispappeuskanta ei ollut enää ratkaiseva peruste maallikkoedustajien vaalin ehdokasasettelulle. Alueellinen rovastikuntajako näkyi selvimmin Helsingin, Mikkelin, Kuopion ja Porvoon hiippakunnissa. Sen sijaan Turun, Tampereen ja Lapuan hiippakunnissa puoluejako oli ulkoisesti näkyvin tekijä. Yhden ehdokkaan listoja oli peräti seitsemän. Esimerkiksi Helsingissä Munkkivuoren seurakuntaneuvosto oli professori Mikael Hidénin takana ehdokaslistalla, joka edusti valtiosääntöoikeuden korkeaa asiantuntemusta mutta ei vaalimatematiikan arjen realismia. Yhden nimen ehdokaslistat korostivat toisinaan seurakunnan yhteishenkeä, toisinaan taas ilmaisivat pettymystä muuta ehdokasasettelua kohtaan. Vanhoillislestadiolaisia lukuun ottamatta yksittäiset herätysliikkeet eivät lähteneet omin listoin vaaliin. Omaleimaisin ehdokasasettelu oli Oulun hiip- pakunnassa, jossa oli vain kaksi listaa, vanhoillislestadiolaisten ja muiden. Viimeksi mainitulla listalla oli edellisvaalien tapaan poliittisesti jyrkempää vasemmistoa - tällä kertaa uutta Vasemmistoliittoa - edustava ehdokas, mikä oli edelleen hyvin harvinaista kirkolliskokouksen ehdokaslistoilla. ${ }^{16}$

Vanhoillislestadiolaisilla oli oma lista Oulun lisäksi myös Lapualla ja Kuopiossa. Molemmilla viimeksi mainituilla listoilla oli mukana naisehdokas. ${ }^{17}$ Tämä seikka oli huomionarvoinen - olihan herätysliikkeen edustus kirkolliskokouksessa ollut perinteisesti miesten vastuulla. Kaikkiaan naisehdokkaiden määrä kasvoi 15 prosenttia, mutta heidän osuutensa valituista maallikkoedustajista supistui suunnilleen saman verran. ${ }^{18}$ Naisten valitsemista ei enää koettu yhtä tärkeäksi päämääräksi kuin kiivaan naispappeuskeskustelun aikaan. Vaalikauden kuluessa maallikkoedustajan tehtävään valittujen naisteologien pappisvihkimykset pienensivät edelleen naisten osuutta.

Naisten osuuden muutokset kirkolliskokouksessa ja eduskunnassa muistuttivat toisiaan. Molemmissa elimissä osuus oli huipussaan 1990-luvun alkaessa: vuoden 1991 eduskuntavaaleissa valittiin ennätysmäärä naisia $(38,5 \text { prosenttia })^{19}$. Sen jälkeen naisten määrä lähti laskuun niin kirkolliskokouksessa kuin eduskunnassa. ${ }^{20}$ Vuonna 1988 hiippakunnittain vaaleilla valituista kirkolliskokousedustajista naisia oli ollut noin 40 prosenttia, mutta 1990-luvun vaaleissa osuus pysytteli 36 prosentin tienoilla. Näin tapahtui siitä huolimatta, että samaan aikaan pappisedustajien vaalissa äänioikeutettujen ja vaalikelpoisten naisten määrä kasvoi kovaa vauhtia. Naisehdokkaiden lukumäärän kasvaessa äänten keskittäminen vaikeutui.

Helsingin hiippakunnassa vuoden 1992 maallikkoedustajien vaalin uutuutena oli nuorten aikuisten ehdokaslista. Sen taustalla oli nuorten aikuisten Uusi viini -ryhmä, joka oli järjestänyt myös varjokirkolliskokouksen 1991. Vaikka suhteellinen vaalitapa oli ollut käytössä vuodesta 1986, vasta nyt kirkkopoliittisella ohjelmalla varustettu, aiempaa tiiviimpi valitsijayhdistys alkoi murtaa henkilövaalin perinnettä. Muutos oli kuitenkin vasta aivan aluillaan, eivätkä Uusi viini -ryhmänkään tavoitteet olleet kovin tarkasti määriteltyjä. Ehdokaslistan päämääränä oli uudistaa kirkkoa ja yksinkertaistaa sen hallintoa. ${ }^{21}$ 
Kehitysvammalaitoksen osastonhoitaja, diakonissa Ritva Puruskainen Ylöjärveltä jätti valtakirjansa kirkolliskokouksen uudelle sihteerille Kari Ventälle keväällä 1992. Taustalla arkkipiispa John Vikström ja notaari Hannu Kamppuri. Kuva: Kotimaan kuvaarkisto / Jukka Granström.

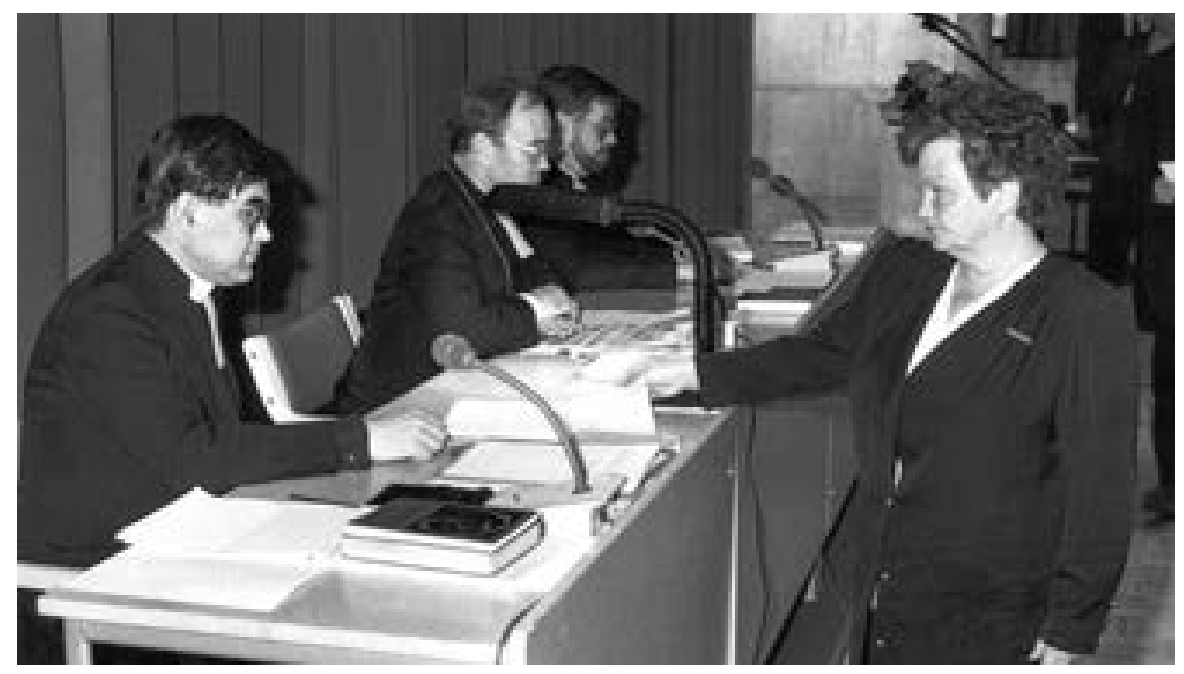

Kohtalon ivaa oli, että hallinnon yksinkertaistamista ajanut ryhmä joutui melko monimutkaisen vaalisäännöstön uhriksi. Pitäjänmäen seurakunnassa äänesti yksi yhteisen kirkkovaltuuston jäsen, vaikka äänioikeus oli vain seurakuntaneuvoston jäsenillä22 ${ }^{22}$ Vaalilautakunta hylkäsi kaikki Pitäjänmäen äänet, jolloin Uusi viini -ryhmän listalta nousi kirkolliskokoukseen proviisori Outi Avelan sijaan sosiaalipsykologi Pekka Sormunen. ${ }^{23}$ Lopulta korkeimman hallinto-oikeuden päätöksellä äänet hyväksyttiin, ja syksyllä 1993 Sormunen menetti paikkansa Avelalle. ${ }^{24}$

Viidestä Helsingissä ehdolla olleesta toimittajasta peräti kolme valittiin kirkolliskokoukseen. Työntekijäväestön edustus Helsinginkin ehdokkaissa oli edelleen pieni ja laskettavissa yhden käden sormin - toisin kuin vaikkapa professoriehdokkaat. Uusi viini -ehdokaslistan 28 ehdokkaasta peräti puolet oli opiskelijoita, mutta nämä eivät päässeet listansa kärkipaikoille. ${ }^{25}$ Sen sijaan kirkolliskokoukseen valittiin opiskelijajäsen Lapuan hiippakunnasta, jonka 55 ehdokkaan joukossa oli vain yksi opiskelija, teologian ylioppilas Juha Rintamäki Lapualta. Kokoomuksen listalta valittu Rintamäki oli 22-vuotiaana samalla kirkolliskokouksen kaikkien aikojen nuorin edustaja. ${ }^{26}$

Lapuan hiippakunnan ehdokasasettelun erityispiirteenä 1992 oli kanttorien ehdokaslista. Samanlainen kanttorilista oli myös Turussa, ja muutenkin jokaisessa hiippakunnassa oli ehdolla vähintään yksi kanttori. Taustalla olivat kanttorien karvaat pettymykset 1980-luvulta.
Virsikirja oli uudistettu ilman, että kirkolliskokouksessa olisi ollut yhtään kanttoria vaikuttamassa asiaan. Kirkkomuusikot ja seurakuntien luottamushenkilöt olivat päättäneet, ettei sama saanut toistua jumalanpalvelusuudistuksen osalta. ${ }^{27}$ Jumalanpalvelusuudistus ja keskustelu diakonaatista antoivatkin ehdokasasettelulle jossain määrin vauhtia, mutta muuten vaalityö oli laimeampaa kuin aiemmin. Tiedossa ei ollut naispappeuden kaltaista kuohuttavaa teemaa, joka olisi motivoinut työhön. ${ }^{28}$

Kanttorien omat ehdokaslistat eivät menestyneet, mutta muilta listoilta valittiin kirkolliskokoukseen kolme kirkkomuusikkoa. ${ }^{29}$ Kaikkiaan kirkon tehtävissä työskenteli maallikkoedustajista useampi kuin joka kymmenes. Suurimpana yksittäisenä ammattiryhmänä säilyi edelleen opetusala, jolla toimi neljännes maallikkoedustajista. ${ }^{30}$ Istuvien kansanedustajien mielenkiinto kirkolliskokousta kohtaan kasvoi. Heitä oli ehdokkaina seitsemän, ja lisäksi entisiä kansanedustajia oli ehdolla kolme. ${ }^{31}$ Istuvista kansanedustajista pääsi läpi vain kaksi, kokoomuslaiset Päivi Varpasuo Helsingin hiippakunnasta ja Kyösti Toivonen Tampereen hiippakunnasta. Tulos osoitti, etteivät valitsijat edelleenkään painottaneet poliittisia ansioita. ${ }^{32}$ Toisaalta ehdokasasettelu paljasti, että 1980-luvulla voimistunut korkeiden valtiollisten päättäjien kiinnostus kirkollista päätöksentekoa kohtaan säilyi. Tätä kuvaa vahvisti sittemmin kirkon ulkoasiain neuvoston jäsenen, valtiosihteeri Martti Ahtisaaren valinta tasavallan presidentiksi. Kyösti 
Toivonen toimi vuoden 1995 alusta lähtien europarlamentaarikkona. Kirkolliskokoukselle ei kuitenkaan syntynyt hänen kauttaan kosketuspintaa Euroopan unionin päätöksentekoon, koska uusi luottamustehtävä esti osallistumisen kirkolliskokouksen työhön ${ }^{33}$.

Vuoden 1996 kirkolliskokousvaaleissa pappisedustajat valittiin ensi kertaa suhteellisella vaalitavalla ja virallisen ehdokasasettelun pohjalta. Maallikkoehdokkaisiin verrattuna pappisehdokkaita oli suhteellisesti hieman vähemmän: yhtä maallikkoedustajan paikkaa tavoitteli keskimäärin noin kahdeksan ehdokasta, kun taas jokaista pappisedustajan paikkaa kohti oli seitsemän ehdokasta. Naisia oli pappisehdokkaista 20 prosenttia, kun maallikkoedustajien vaalissa naisten osuus vakiintui 1990 -luvulla 40 prosenttiin. ${ }^{34}$ Pappisedustajien vaalissa ehdokaslistoja syntyi moninaisin perustein, joskus alueellisesti, toisinaan taas naispappeuskantoja mukaillen. Myös nuoret "apupapit" kokosivat paikoin omia listojaan. ${ }^{35}$

Maallikkoedustajien vaalissa ehdokaslistoja muodostettiin pitkälti samoin perustein kuin neljä vuotta aiemmin, näin myös Helsingin ja Lapuan hiippakunnissa. ${ }^{36}$ Lapualla kanttorien ehdokaslistan korvasi diakoniatyön lista. ${ }^{37}$ Diakonaattikomitean mietintö oli tulossa kirkolliskokouksen käsittelyyn, ja diakoniatyöntekijät halusivat päästä vaikuttamaan asiaan. Yhden työntekijäryhmän ehdokaslista ei kuitenkaan edelleenkään

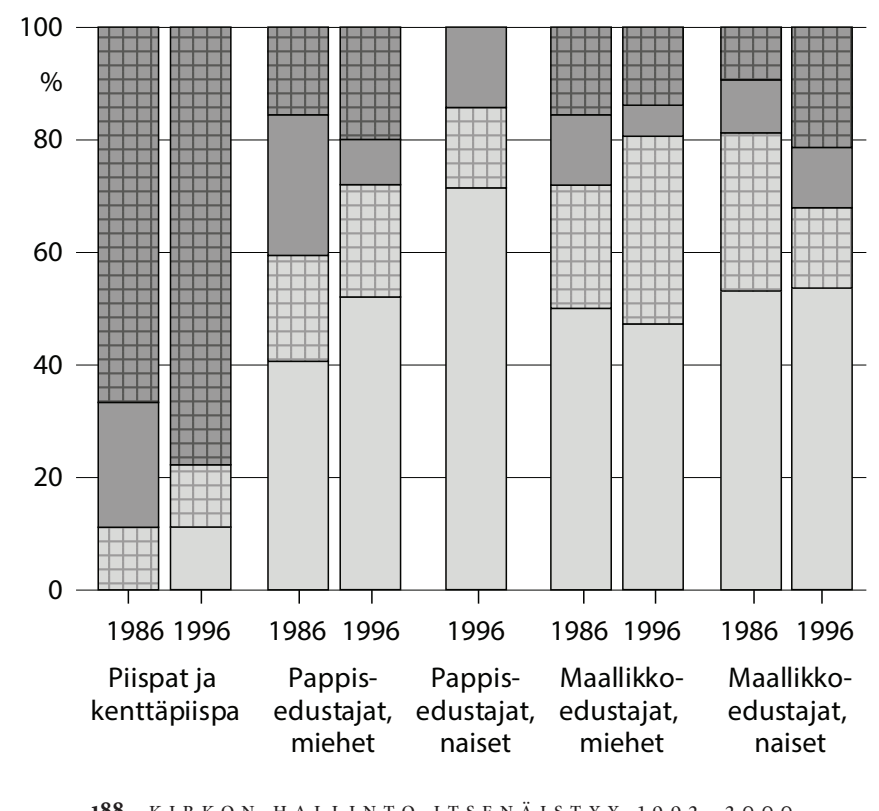

menestynyt ${ }^{38}$. Helsingissä kahden perinteisen alueellisen listan ja herätyskristillisen listan rinnalla oli lähinnä nuorista aikuisista koostunut "Uudistusmielinen ehdokaslista". Yksi näkyvimmistä eroista ehdokaslistojen kesken olikin ehdokkaiden ikä. Viimeksi mainitun listan ehdokkaiden keski-ikä oli 36 vuotta, kun se helsinkiläisten listalla oli 60 vuotta. Kaikkiaan helsinkiläisten ehdokaslistalla oli viisi 1920-luvulla syntynyttä, kun taas "Uudistusmielisellä ehdokaslistalla" oli yhtä monta 1970-luvulla syntynyttä. ${ }^{39}$

Pappisedustajien vaihtuvuus oli suurta: selvä enemmistö oli uusia edustajia. Esimerkiksi Helsingin seitsemästä pappisedustajasta ketään ei ollut aiemmin valittu kirkolliskokoukseen pappiskiintiössä. Naispappien määrä kirkolliskokouksessa nousi neljästä seitsemään, mikä vastasi suunnilleen naisten osuutta pappisehdokkaista. Edellisten kausien naispuolisista pappisedustajista ainoastaan perheasiain neuvottelukeskuksen johtaja Marjatta Kaartinen Porista uusi paikkansa. Apulaisprofessori Raija Sollamo puolestaan teki historiaa kolmessa suhteessa. Yleensä papiksi vihittyjen entisten maallikkoedustajien oli vaikea päästä uudessa kiintiössään läpi, mutta kaksi kautta maallikkoedustajana ollut Sollamo valittiin pappisedustajaksi heti ensimmäisissä vaaleissaan pappisehdokkaana. Toiseksi Sollamo oli kolmannen kauden edustajana tuohon mennessä kokenein naispuolinen pappisedustaja. Kolmanneksi Raija Solla-

Kuvio 11: Kirkolliskokouksen jäsenten edustajakokemus vuosina 1986 ja 1996: Kuinka mones kausi kirkolliskokousedustajilla oli meneillään eri ryhmissä?

\section{4. tai useampi}

3.

$\boxplus 2$. 
mo ja kauppateknikko Matti Sollamo olivat ensimmäiset aviopuolisot, jotka istuivat yhtä aikaa kirkolliskokouksessa.

Pappisedustajien vaihtuvuus ei merkinnyt nuorennusta. Heidän keski-ikänsä oli 1996 hieman alle 49 vuotta, kuten se oli ollut kymmenen vuotta aiemminkin. Sen sijaan 1992 alkanut selektiivi- ja järjestötyössä toimivien voittokulku sai jatkoa. Lapuan hiippakunnassa seurakuntapapit joutuivat jälleen tyytymään varaedustajan paikkoihin, eikä myöskään Helsingin, Espoon tai Vantaan suomenkielisistä seurakunnista valittu kirkolliskokoukseen yhtään seurakuntapappia ${ }^{40}$. Suhteellinen vaalitapa yhdistettynä pieneen äänestäjämäärään teki vaalista ennakoimattoman, mikä herättikin arvostelua. ${ }^{41}$ Vuonna 1986 lähes kolme neljäsosaa pappisedustajista oli ollut kirkkoherroja, mutta 1996 heitä oli alle puolet. Asessorien määrä puolittui samassa ajassa. Sen sijaan kirkon erityisvirassa tai kristillisen järjestön palveluksessa olevia pappeja oli 1996 jo yli 40 prosenttia pappisedustajista - lähes yhtä paljon kuin kirkkoherroja. Seurakuntapappien perinteinen valta-asema kirkolliskokouksen pappisedustajien keskuudessa alkoi 1990-luvulla nopeasti murtua.

Teologisen jatkotutkinnon suorittaneiden osuus pappisedustajista laski samaten huomattavasti: 1986 se oli ollut lähes puolet, mutta vuosikymmen myöhemmin se oli vain runsas kolmannes. Osuus oli jopa selvästi pienempi kuin 1974. Muutos tapahtui kaiken lisäksi samaan aikaan, kun teologian tohtorien määrä alkoi kasvaa voimakkaasti. Nähtävästi jatkotutkintojen yleistyminen vaikutti siten, että tutkintoa ei enää entiseen tapaan pidetty erityisenä ansiona kirkon päättäjäksi pyrkivälle. Taustalla näkyi myös sama seikka, joka pudotti monen kirkkoherran kirkolliskokouksesta: omaa ehdokasta ei enää valittu virka-aseman tai tutkinnoilla osoitetun oppineisuuden perusteella, vaan lama-aika kannusti etsimään uudenlaisia vaikuttajia.

Tällaisen ilmapiirin vallitessa kristillisen järjestön työntekijällä oli etulyöntiasema. Usein hän liikkui ympäri hiippakuntaa ja oli siten paljon laajemmin tunnettu kuin yksittäisen seurakunnan pappi. Sitä paitsi hän ei ollut työssään sidottu jäykäksi koettuun seurakuntahallintoon. Hän edusti juuri sellaista dynaamista työntekijäkuvaa, joka taloudellisesti vaikeana aikana nousi ihanteeksi. Monessa mielessä muutos oli ristiriitainen.
Piispainkokouksen aloittamassa Kirkko 2000 -prosessissa oli pitkin 1980-luvun loppua ja 199o-luvun alkua painotettu pieniä alueellisia seurakuntayksikköjä, joissa työntekijät voisivat toimia monipuolisesti eri ihmis- ja ikäryhmien parissa ${ }^{42}$. Kirkolliskokouksessa seurakuntapapit menettivät kuitenkin paikkojaan selektiivityön ja kristillisten järjestöjen edustajille.

Maallikkoedustajien vaalissa kristillisten järjestöjen työntekijät ja seurakuntien kanttorit kasvattivat osuuttaan. Samaten yksityisen sektorin edustajat menestyivät selvästi aiempaa paremmin. Kun kirkossa yritettiin löytää virtaviivaisia toimintatapoja, toimitusjohtaja alkoi saada ehdokaslistoilla osakseen uudenlaista huomiota verrattuna vaikkapa opettajaan. Opetusalalla työskentelevien osuus miltei puolittui verrattuna vuoteen 1986, joskin se säilyi edelleen huomattavana, viidenneksenä maallikkoedustajien kokonaismäärästä. Vertailukohtana voi jälleen pitää eduskuntaa, jossa 1970-luvulta vuoteen 1991 yrittäjien osuus niin ikään kasvoi ${ }^{43}$.

Lähes puolella maallikkoedustajista oli 1996 ylempi korkeakoulututkinto. Maallikkoedustajat olivat siten edelleen keskimääräistä korkeammin koulutettuja, vaikkakin myös suomalaisten yleinen koulutustaso nousi jatkuvasti. Neljännes maallikkoedustajista kertoi istuvansa parastaikaa kotipaikkansa kunnanvaltuustossa. ${ }^{44}$ Edustajien kirkollinen tausta monipuolistui. Suomen Evankelisluterilaiseen Kansanlähetykseen lukeutuvien edustajien määrä nousi 1990-luvulla viiteen ${ }^{45}$. Vuoden 1996 vaaleissa valittiin puolestaan useita Tuomasmessu-toiminnan vastuunkantajia. Heitä olivat esimerkiksi Helsingin hiippakunnasta valitut toimitusjohtaja Reijo Telaranta, sosiaalipsykologi Pekka Sormunen, kanttori Mari Lamminen ja toimittaja Sirkku Nyström. ${ }^{46}$ Tulos heijasteli tilastoja, joiden mukaan Helsingissä kävi erityisjumalanpalveluksissa enemmän väkeä kuin päiväjumalanpalveluksissa. ${ }^{47}$ Tuomasmessu-aktiivien edustus oli huomionarvoinen sikälikin, että kyseisellä vaalikaudella oli määrä hyväksyä kirkolle uusi jumalanpalvelusten kirja ja evankeliumikirja. Vaikka nuoret aikuiset olivat alkaneet aktivoitua maallikkoedustajien vaalissa, edustajien keski-ikä, 53 vuotta, ei poikennut olennaisesti kymmenen vuoden takaisesta.

Maallikkoedustajien vaalissa näkyi 1996 uusi piirre niin Helsingin kuin Lapuan hiippakunnassa. Kirkon vaalijärjestys ei tuntenut ehdokaslistojen nimityksiä, 
mutta valitsijayhdistysten perustajat alkoivat kirjoittaa perustamiskaavakkeen kulmaan epävirallisia tunnuksia. Helsingissä näin tekivät muiden kuin helsinkiläisten valitsijayhdistys "Kirkko keskelle elämää" sekä "Uudistusmielinen ehdokaslista". ${ }^{8}$ Lapuan hiippakunnassa taas perustettiin "Keskiryhmien valitsijayhdistys", jonka puoluepoliittista kytköstä korosti vielä se, että yhden ehdokkaan kohdalle oli erikseen merkitty "sitoutumaton". ${ }^{49}$ Lakimiesasessorin puututtua asiaan valitsijayhdistyksen asiamies veti nimityksen ja sitoutumattomuusmerkinnän pois. ${ }^{50}$ Valitsijayhdistykset tunsivat tarvetta profiloida itsensä entistä selvemmin varsinkin, kun nimitykset oli sallittu seurakuntavaaleissa. Silti enemmistö kirkolliskokousedustajista vastusti edelleen nimitysten tuomista kirkolliskokousvaaleihin ${ }^{51}$. Valitsijayhdistysten perustamisasiakirjat osoittivat joka tapauksessa, että ehdokaslistojen nimitykset olivat käytännössä tosiasia.

Niin vuoden 1992 kuin vuoden 1996 vaalien yhteydessä lehdistössä esiintyi vaatimuksia siirtymisestä suoriin, yleisiin vaaleihin..$^{52}$ Molemmilla kerroilla kirkolliskokous sai käsiteltäväkseen asiaa koskevan aloitteen, ja samat perustelut puolesta ja vastaan toistuivat. ${ }^{53}$ Aloitteet eivät johtaneet muutoksiin. Enemmistö kirkolliskokouksen jäsenistä halusi kokouksen edustavan vastaisuudessakin ennemmin seurakuntia kuin yksittäisiä seurakuntalaisia. Ainoaksi tulokseksi aloitteista jäi se, että täydellisessä yhteistaloudessa olevissa seurakunnissa myös yhteisen kirkkovaltuuston jäsenille annettiin äänioikeus kirkolliskokousvaaleissa. Ratkaisu tasapainotti hieman yksittäisten äänten painoarvoa pienten ja suurten seurakuntien välillä. Seurakuntien kokonaisäänimäärien suhde säilyi sen sijaan ennallaan. ${ }^{54}$

\section{TUOMARIEN RIIPPUMATTOMUUS \\ JA SAAMELAISTEN OIKEUDET KOKOONPANOMUUTOSTEN TAUSTALLA}

Korkeimpien oikeusistuinten valitsemat edustajat - erityisesti Johannes Leivonen - olivat olleet kirkolliskokouksessa hyvin aktiivisia 1980-luvun puoliväliin saakka. Pinnan alla oli kuitenkin jo tuolloin itänyt muutos. Vuonna 1988 kirkolliskokoukseen valittu oikeusneuvos Göran Portin otti heti kautensa aluksi korkeimmassa oikeudessa puheeksi ne ongelmat, joita kirkolliskokousedustus hänen mielestään aiheutti niin oikeusistuimen riippumattomuudelle kuin kirkon itsenäisyydelle. Kirkkolain kokonaisuudistuksen hyväksymisen jälkeen keväällä 1992 korkein oikeus ja korkein hallinto-oikeus esittivät Portinin aloitteesta kirkkohallitukselle, että korkeimpien oikeusistuinten valitsemasta edustuksesta luovuttaisiin. ${ }^{55}$ Korkeimman oikeuden jäsenet lähtivät asiassa liikkeelle siis lähes välittömästi Leivosen jäätyä eläkkeelle, ja konkreettinen aloite tehtiin heti, kun tilanne sen salli. Johannes Leivosen, Pekka Kurvisen ja Olli Sakin kaltaisten aktiivisten ja halukkaiden kirkolliskokousedustajien toiminta oli pitänyt yllä mielikuvaa, että korkeimpien oikeusistuinten jäsenille osallistuminen kirkolliskokouksen työhön oli ongelmatonta. Todellisuus alkoi kuitenkin paljastua nopeasti miesten jäätyä eläkkeelle.

Esitys oli poikkeuksellinen, koska se tuli elimiltä, joilla ei ollut lain mukaan kirkolliskokouksessa aloiteoikeutta. Kirkkohallitus välitti kuitenkin esityksen eteenpäin, joten virallisesti kyseessä oli kirkkohallituksen esitys. Korkein oikeus oli asiassa yksimielinen. Korkeimman hallinto-oikeuden esitykseen liittyi hallintoneuvos Olli Rikkosen äänestyslausunto, jossa hän ilmoitti vastustavansa muutosta. Hänen mukaansa asiaa oli valmisteltu salassa, ja uudistuksesta olisi haittaa niin kirkolliskokouksen lainsäädäntötyölle kuin ylimmille oikeusistuimille. Rikkonen ilmoitti myös saaneensa tiedon, että opetusministeriössä vastustettiin kirkolliskokouksen kokoonpanon muuttamista. Hän ei uskonut esityksen saavan muutenkaan tukea kirkolliskokouksessa. ${ }^{56}$ Vaikka oikeusistuimet olivat asiassa muodollisesti lähes yksimieliset, jatkokäsittelyn näkökulmasta synnytti jännitettä, että hankkeen keulahahmo Portin ja sen tiukin vastustaja Rikkonen olivat molemmat edustajina 1992 valitussa kirkolliskokouksessa. Rikkonen joutui kuitenkin jäämään pois kirkolliskokoustyöskentelystä ennen kuin asia ehti käsittelyyn keväällä 1993. Hän kuoli hieman myöhemmin. ${ }^{57}$

Korkeimpien oikeusistuinten esityksen taustalla oli osittain kansainvälistymiseen liittynyt muutos. Ei enää riittänyt, että oikeusistuimet olivat tosiasiallisesti riippumattomia, vaan niiden toiminnan piti myös näyttää ulospäin kaikin puolin riippumattomalta. Nämä periaatteelliset perustelut saivat kirkolliskokouksessa vastaansa tarkoituksenmukaisuusperusteluja, kuten huolen kirkolliskokouksen oikeudellisesta asiantuntemuksesta. 


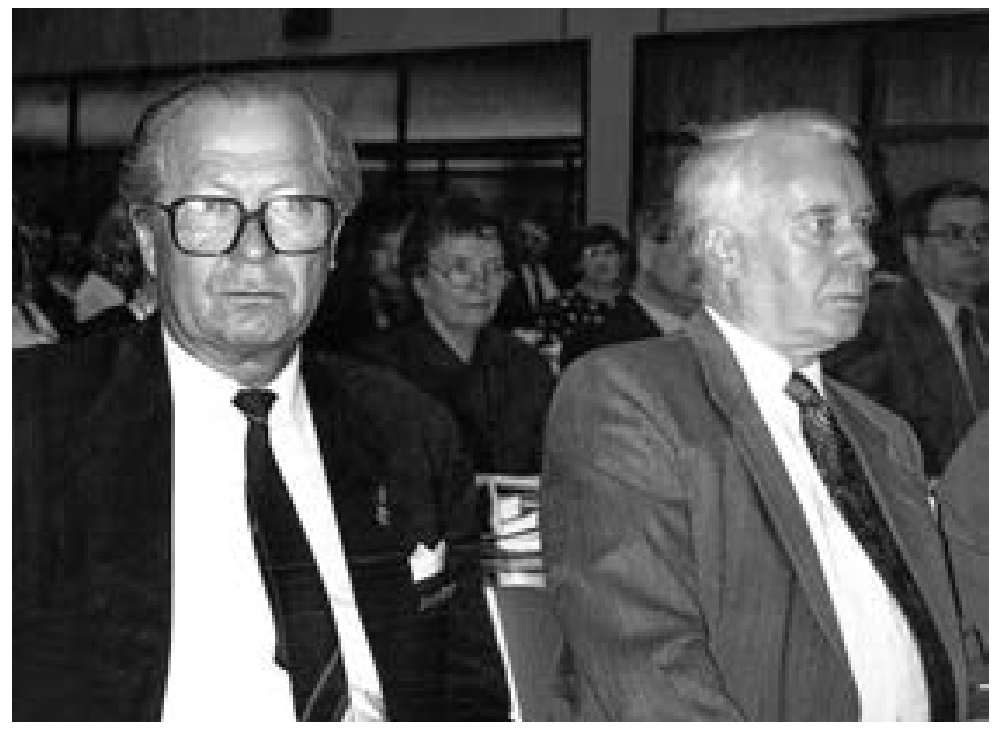

Korkeimpien oikeusistuinten valitsemat edustajat Olli Rikkonen (vas.) ja Göran Portin olivat erimielisiä siitä, tuliko kirkolliskokouksessa säilyttää heidän tuolinsa. Oikeusneuvos Portin ajoi edustajapaikkojen poistamista. Niiden säilyttämistä kannattanut hallintoneuvos Rikkonen jäi $y$ ksin korkeimmissa oikeusistuimissa, mutta kirkolliskokouksessa hänen näkemykselleen riitti ymmärtäjiä. Asian käsittelyn aikaan Rikkonen ei kuitenkaan enää pystynyt osallistumaan kirkolliskokouksen työhön. Kuva: Kotimaan kuva-arkisto / Ritva Rasila.
Monet edustajat huolestuivat myös kirkon ja valtion välisistä suhteista: oliko lainmuutos johtamassa joidenkin muidenkin siteiden katkeamiseen ja kyseenalaistamassa esimerkiksi valtioneuvoston määräämän edustajan tai kenttäpiispan aseman kirkolliskokouksessa?58

Jotkut edustajat, kuten piispa Eero Huovinen, lausuivat myös periaatteellisia perusteluja korkeimpien oikeuksien esitystä vastaan. Entisen dogmatiikan professorin mielestä esitys kuvasteli luterilaisuudelle vierasta ajattelutapaa, jossa kirkon lainjulistuksella ei ajateltu olevan yhtymäkohtia yhteiskunnan moraalitajuun ja luonnollisen lain ymmärtämiseen. Kouvolan kirkkoherra, oikeusteologian dosentti Mikko Reijonen taas totesi, että oikeusistuinten edustajien eristäytyminen erilaisista yhteiskunnallisista instituutioista oli vaarassa johtaa oikeuspositivismiin, jossa laki ja oikeus irrotettiin yhteiskunnan edustamasta arvomaailmasta. ${ }^{59}$ Valtakunnan korkeimpien oikeusistuinten lähes yksimielinen tulkinta omasta asemastaan joutui kirkolliskokouksessa kriittisen tarkastelun kohteeksi.

Esitys, jonka kirkkohallitus oli välittänyt mutkattomasti eteenpäin, alkoi kirkolliskokouksessa saada tielleen esteitä. Syysistuntokauteen 1994 mennessä asia oli käynyt jo pariin otteeseen kirkkohallituksella, minkä lisäksi perustevaliokunta suhtautui siihen lausunnossaan hyvin epäilevästi. Valiokunta halusi korostaa kirkon "myönteistä liittymistä yhteiskuntaan ja sen rakenteisiin", minkä vuoksi kirkolliskokouksessa tuli olla "yhteiskun- nan oikeuslaitoksen virallinen edustus siten, että sen edustajat ovat kirkolliskokouksessa varsinaisina jäseninä". Lakivaliokuntakaan ei ollut yksimielisesti puheenjohtajansa Portinin takana. ${ }^{60}$ Portinin äänessä alkoi olla jo kitkeryyttä hänen puhuessaan täysistunnolle:

Mielestäni olisi hyvin outoa, että kirkolliskokous yrittäisi pakottaa maan korkeimpia tuomioistuimia tekemään itselleen eli siis kirkolliskokoukselle palveluja, jotka tuomioistuinten mielestä periaatteellisella tasolla haittaavat niiden toimintaa. - - Millä perusteella tai oikeudella perustevaliokunta esittää, että tuomioistuinten jäsenten pitää toimia vastoin omaatuntoaan ${ }^{61}$

Perustevaliokunnan puheenjohtaja Eero Huovinen vastasi toteamalla muun muassa, ettei kirkolliskokouksessa ollut vedottu riippumattomuuden periaatteeseen silloin, "kun aloitteen käsittelyä on johtanut valiokunnan puheenjohtaja, joka samalla on sen instituution edustaja, josta aloite on lähtenyt". ${ }^{62}$ Taustalla oli nimenomaan ollut alun perin Portinin henkilökohtainen aloite korkeimmalle oikeudelle. ${ }^{63}$ Lakivaliokunnan varapuheenjohtaja, Lapuan hiippakunnan pääsihteeri Ossi Haaramäki muistutti tästä seikasta ja totesi, ettei tällaisten aloitteiden pohjalta ollut oikein lähteä suoraan muuttamaan lakia. ${ }^{64}$

Portinin keskeinen rooli asian alullepanossa ja sittemmin sen valmistelussa kirkolliskokouksessa johti siihen, että asia henkilöityi häneen. Toteutui sama ilmiö kuin 
aiemmin Mikko Juvan valittaessa arkkipiispan työtaakkaa ja vaatiessa muutoksia kirkon keskushallintoon: ymmärtämystä ei liiennyt helposti silloin, kun joku alkoi arvostella omaa asemaansa kirkon hallinnossa. Ei auttanut, että Portin korosti jäävänsä pian eläkkeelle, joten kirkkolain muutos ei koskettaisi häntä itseään. Portinin näkökulmasta hankalinta oli, että esityksen näkyvimpiin arvostelijoihin kuuluivat hänen oman valiokuntansa varapuheenjohtaja Haaramäki sekä asiaa kirkon opin perusteista käsin tarkastelleen valiokunnan puheenjohtaja Huovinen.

Lakivaliokunnan vähemmistön mielestä asia tuli selvittää "laajemmassa kirkon ja valtion välisiä suhteita koskevassa asiayhteydessä". Oli huomattava, että eriävän mielipiteen allekirjoittajiin kuului valtioneuvoston määräämä edustaja Marjatta Lehtinen. ${ }^{65}$ Lehtinen teki ratkaisunsa itsenäisesti. ${ }^{66}$ Tosin hän liittyi sen myötä esimiehensä Jaakko Nummisen linjaan, jonka mukaan kirkon ja valtion keskinäisiä siteitä tuli vaalia. Se, että valtioneuvoston määräämä edustaja allekirjoitti jossakin asiassa eriävän mielipiteen, oli hyvin harvinainen ja siten poikkeuksellisen voimakas kannanotto ${ }^{67}$. Samaan aikaan kun korkeimmat oikeusistuimet pyrkivät irrottautumaan kirkolliskokouksesta, aukkoa paikkaamaan tuli valtioneuvoston määräämä edustaja, jonka rooli kirkolliskokouksessa voimistui tasaisesti 1980-luvulta lähtien. Eriävä mielipide oli myös sikäli huomionarvoinen, että sen allekirjoittajista Lehtinen ja Haaramäki olivat olleet vastikään tuomiokapitulikomiteassa linjaamassa kirkon ja valtion suhteita.

Täysistunnossa vielä kenttäpiispa Jorma Laulaja ilmoitti kannattavansa asian jättämistä tässä vaiheessa raukeamaan ja sen selvittämistä osana laajempaa kokonaisuutta. ${ }^{68}$ Näin molemmat valtioon kiinteimmin sidoksissa olleet viralliset edustajat asettuivat avoimesti vastustamaan esityksen nopeaa hyväksymistä. Kirkon ja valtion keskinäiset suhteet olivat tuolloin herkässä vaiheessa: lama-aika oli tuonut jännitteitä taloudellisiin suhteisiin, kysymys tuomiokapitulien siirtämisestä kirkolle oli ajankohtainen ja keskustelu väestökirjanpidon siirtämisestä valtiolle kävi kiivaana. Siksi oli ymmärrettävää, että kirkon ja valtion välisten suhteiden kokonaisuus vaikutti asian käsittelyyn.

Osa kirkolliskokousedustajista näki asian periaatekysymyksenä, joka koski oikeusistuinten riippumatto- muutta. Portinin ohella näihin edustajiin kuului moni muukin Porvoon hiippakunnasta lähtöisin ollut edustaja - mukaan lukien arkkipiispa Vikström. On luultavaa, että suomenruotsalainen liberaali perinne näkyi tietynlaisena periaatteellisena puhdaslinjaisuutena tässäkin ratkaisussa ${ }^{69}$. Huomattavan moni lakimuutoksen kannattajistakin tosin ilmoitti taipuneensa esityksen taakse vain siksi, ettei halunnut pakottaa oikeusistuimia toimimaan vasten tahtoaan. Kaiken lisäksi monet niistä, jotka olisivat periaatteellisista syistä kannattaneet esitystä, epäröivät, koska tilalle tarjotut vaihtoehdot - kuten laintarkastustoimikunnan vahvistaminen - eivät heidän mielestään turvanneet kirkolliskokouksen oikeudellista asiantuntemusta. Göran Portin jäi melko yksin todetessaan, että ratkaisu oli hänelle helppo. ${ }^{\circ}$

Kirkkolain muutos hyväksyttiin toisessa käsittelyssä niukasti äänin 81-24. Alin määräenemmistövaatimus ylittyi kahdella äänellä. ${ }^{71}$ Piispoista vastaan äänestivät Huovinen ja Rimpiläinen. ${ }^{72}$ Vaalikauden päättyessä syksyllä 1995 arkkipiispa Vikström kiitti lyhyesti korkeimpien oikeuksien valitsemia edustajia. ${ }^{73}$ Kaikesta huomasi, että neljä vuotta kestäneet jäähyväiset eivät olleet kirkolliskokouksen näkökulmasta helpot. Päätös jättää korkeimpien oikeusistuinten jäsenet kirkolliskokouksen ulkopuolelle oli yksi vaihe muutosprosessissa, jossa kirkon keskushallintoon tuli enenevässä määrin montesquieuläisen vallanjaon piirteitä. Kirkkolain kokonaisuudistuksen yhteydessä kirkolliskokouksen hallintotehtävät oli pyritty siirtämään kirkkohallitukselle, ja sen jälkeen lainkäyttövaltaa alettiin irrottaa kirkollisesta lainsäädäntövallasta. Vuonna 1993 kirkon hallinnon keventämiskomitea ehdotti muutosta siihen suuntaan, että tuomiokapitulien lainkäyttötehtävät siirrettäisiin yleisille hallintotuomioistuimil$\mathrm{le}^{74}$. Kirkkoneuvos Matti Halttunen oli samalla kannalla tuomiokapitulikomiteassa mutta jäi yksin. ${ }^{75}$ Kirkolliskokous kypsyi kuitenkin lainkäyttötehtävien siirtoon samalla, kun vastaava muutos eteni valtiossa ja kunnissa. Kokous teki asiasta periaatepäätöksen 1999. ${ }^{76}$

Oikeus- ja hallintoneuvosten poistuminen jätti kirkolliskokouksen juridiseen asiantuntemukseen suuren aukon, jonka paikkaamista pohdittiin pitkään. Lopulta kirkolliskokous päätyi valitsemaan itselleen lainoppineet asiantuntijat. Samalla valtiovalta sai valtuudet korjata kirkolliskokouksen tekemissä esityksissä mahdollisesti 
ilmenevät tekniset virheet. ${ }^{77}$ Uuden vaalikauden alkaessa keväällä 1996 lainoppineille asiantuntijoille tuli todellakin tarvetta: hiippakunnittain valittujen edustajien joukossa ei ollut lainkaan oikeusoppineita. Vuonna 1986 oli jouduttu poikkeusjärjestelyihin, kun edustajien joukossa oli ollut vain kolme juristia. Kymmenen vuotta myöhemmin ongelmat kasvoivat monta mittaluokkaa suuremmiksi: riippui valtioneuvoston määräämän edustajan koulutustaustasta, oliko kirkkolakia ehdottamassa ja kirkon sisäisiä säädöksiä antamassa yhtäkään äänivaltaista juristia. Tilanne oli ainutlaatuinen kirkolliskokouksen siihenastisessa historiassa. Kirkkohallituksen esityksestä kirkolliskokous valitsi lainoppineiksi asiantuntijoiksi oikeusneuvos Markku Pellisen ja hallintoneuvos Pirkko Ignatiuksen. ${ }^{78}$

Valinnan myötä molempien korkeimpien oikeusistuinten jäsen istui edelleen kirkolliskokouksen penkissä. Äänioikeuden poistuminen ei merkinnyt suurta muutosta käytännön työskentelyyn: Leivosen ajan jälkeen korkeimpien oikeusistuinten valitsemat edustajat olivat mieltäneet itsensä lähinnä asiantuntijoiksi ja välttäneet puuttumista sisältökysymyksiin - omaa kirkolliskokousjäsenyyttään lukuun ottamatta. Sen sijaan yksi muutos tapahtui, ja se oli jossain määrin vastakkainen Portinin ajaman uudistuksen kanssa. Kirkolliskokouksessa, johon ei ollut hiippakunnista valittu lainkaan juristijäseniä, korkeimpien oikeuksien jäsenillä oli aiempaakin raskaampi vastuu päätösten juridisesta oikeellisuudesta.

Samaan aikaan kun kirkolliskokouksen virallisten edustajien määrä putosi kahdella, kiihtyivät vaatimukset saada tilalle uusi edustaja saamelaisten keskuudesta. Aiempi, 1990 kirkolliskokouksessa käsitelty aloite oli kaatunut kirkkohallituksessa vaaliteknisiin ongelmiin: saamelaisvaltuuskunta oli halunnut valita kirkolliskokousedustajan, mutta mikään kirkollisista lausunnonantajista ei ollut hyväksynyt tällaista menettelyä. Muunlaiset vaalitavat oli puolestaan katsottu liian vaikeiksi toteuttaa. ${ }^{79}$

Asia palasi kirkolliskokoukseen keväällä 1996. Professori Seikko Eskolan alullepaneman ja opettaja Terttu Kauvosaaren valmisteleman edustaja-aloitteen allekirjoitti tuolloin 21 henkilöä eri hiippakunnista. ${ }^{80}$ Tilanne oli muutamassa vuodessa muuttunut huomattavasti. Saamelaiset oli kansainvälisten sopimusten mukaisesti tunnustettu alkuperäiskansaksi, jolla oli perustuslaissa taattu kulttuuri-itsehallinto ja sen myötä mahdollisuus vaikuttaa itseään koskevaan lainsäädäntöön. Saamelaisvaltuuskunta oli vuoden alusta korvautunut saamelaiskäräjillä, joka oli sekä kooltaan että toimivallaltaan aiempaa laajempi elin. ${ }^{81}$ Kirkolliskokous ei voinut enää katsoa itseään siinä määrin edelläkävijäksi kuin 1990. Nyt oli kyse siitä, miten kirkko vastaisi valtiovallan toteuttamiin uudistuksiin.

Yleisvaliokunnan ensimmäinen osasto päätyi samalle kannalle kuin kirkkohallitus muutamaa vuotta aiemmin. Valiokunnan mielestä uudistuksen aiheuttamat vaalitekniset ongelmat olisivat liian suuria. Saamelaisten etniset ja kulttuuriset tarpeet oli mahdollista ottaa parhaiten huomioon paikallisseurakunnan ja hiippakunnan työssä. ${ }^{82}$ Täysistunnossa nousi kuitenkin esiin vahva tahto saada kirkolliskokoukseen saamelaisten edustus, ja vastoin valiokunnan kantaa kirkolliskokous lähetti aloitteen kirkkohallitukselle toimenpiteitä varten selvin luvuin $80-20 .{ }^{83}$ Aloitteen kannattajien osuus kaikista kirkolliskokousedustajista oli yli kolme neljäsosaa, mikä vahvisti pohjaa aloitteen jatkokäsittelylle - edellyttihän uudistus määräenemmistöä.

Syksyllä 1998 kirkkohallitus esitti saamansa toimeksiannon mukaisesti, että saamelaisille varattaisiin kirkolliskokoukseen edustajapaikka seuraavasta vaalikaudesta lähtien. Kyseessä olisi maallikkoedustaja, jonka edustajapaikka ei kuitenkaan olisi pois muiden hiippakunnittain valittavien maallikkoedustajien määrästä. Vaalin toimittaisivat saamelaiskäräjien kirkkoon kuuluvat jäsenet. Edustaja osallistuisi kirkolliskokouksen lisäksi Oulun hiippakunnan hiippakuntakokoukseen ja Lapin rovastikunnan rovastikuntakokoukseen. ${ }^{84}$ Lakivaliokunnan enemmistö yhtyi kirkkohallituksen esitykseen. Eriävän mielipiteen jättänyt erityisasiantuntija Päivi Varpasuo ajoi loppuun asti voimakkaasti kantaansa, jonka mukaan saamelaisten vaikuttamismahdollisuudet tuli turvata kuulemismenettelyllä. Hänen mielestään ei ollut oikein, että saamelaiskäräjien kaltainen kirkon ulkopuolinen elin saisi nimetä edustajansa kirkolliskokoukseen. Vaalitapaa arvosteli omassa eriävässä mielipiteessään myös Kauniaisten kirkkoherra Arto Laitinen, joka kuitenkin muuten kannatti saamelaisten edustajaa kirkolliskokoukseen. ${ }^{85}$

Varpasuon esittämälle arvostelulle antoi painoa, että hän oli aiemmin ollut eduskunnassa perustuslakivalio- 
kunnan jäsenenä - vedottiinhan esityksen perusteluissa perustuslakiin. Lisäksi samat perusteet, joiden pohjalta oli hieman aiemmin poistettu korkeimpien oikeusistuinten valitsema edustus, puhuivat saamelaiskäräjien valitsemaa edustajaa vastaan. Esityksen kannattajat taas kysyivät, millaisen signaalin kielteinen päätös antaisi ulospäin ja erityisesti saamelaisille aikana, jona vanhojen luonnonuskontojen asema oli vahvistumassa. ${ }^{86}$ Esityksen puolustajien mielestä asia oli ratkaistava "tunteella eikä järjellä - eikä katsomalla hallinnollisiin linjoihin ja niiden tyylipuhtauteen", kuten Tampereen piispa Juha Pihkala tiivisti kantansa. ${ }^{87}$

Vastustajien äänekkyydestä huolimatta määräenemmistö ylittyi toisessa käsittelyssä yhdeksällä äänellä luvuin $77-13 .{ }^{88}$ Päätöksellään kirkolliskokous tuli melko lähelle Norjan mallia. Siellä saamelaisia oli 20000 eli noin kolminkertainen määrä Suomeen verrattuna, ja heillä oli myös kolme edustajaa Norjan kirkon kirkolliskokouksessa. Ruotsin kirkolliskokouksessa ei ollut vastaavaa järjestelmää. ${ }^{89}$ Kirkolliskokouksen kokoonpanon muutos vahvisti samaa kehityslinjaa, joka näkyi pappisja maallikkoedustajien vaaleissa: virkamiesten, kuten seurakuntien ja opetustoimen viranhaltijoiden, tilalle tuli yrittäjiä ja työsopimussuhteessa olevia. Samaten keskusteltaessa niin saamelaisten edustajasta kuin korkeimpien oikeusistuinten valitsemista edustajista nousi esiin riippumattomuuden ihanne, joka oli ristiriidassa tarkoituksenmukaisuuskysymysten kanssa.

Sama ristiriita tuli esiin muissakin yhteyksissä, esimerkiksi silloin, kun lehtori Rauni Rautavuori kyseenalaisti edustaja-aloitteessaan kirkolliskokouksen pappiskiintiön koon. Päällimmäisenä perusteluna hänellä oli papiston mahdollinen jääviys: pappisedustajat kykenivät periaatteessa estämään määrävähemmistön turvin itseään koskevan epämieluisan uudistuksen. ${ }^{\circ}$ Aloite ei johtanut lainmuutokseen, mutta ironista oli, että aloitteen näkyvimpiä tukijoita olivat kirkolliskokouksen kanttorijäsenet. Heidän mielestään pappiskiintiötä tuli pienentää ja tuoda siten lisää tilaa kanttoreille ja muille työntekijäryhmille. ${ }^{91}$ Työntekijöiden korvautuminen toisilla ei olisi välttämättä helpottanut jääviysongelmaa. Yhteiskunnallisessa keskustelussa ja lainsäädännössä korostuneet tasapuolisuuden ja riippumattomuuden ihanteet heijastuivat kirkolliskokouksen työskentelyyn, mutta samalla ne sekoittuivat tarkoituksenmukaisuus- kysymyksiin ja eri ryhmien edunvalvontaan. Taistelun ensimmäinen uhri oli johdonmukaisuus.

\section{PYRKIMYS TEHOKKAASEEN TYÖSKENTELYYN JA MONIPUOLISIIN HENKILÖVALINTOIHIN}

Kirkkolain kokonaisuudistus ja siihen liittynyt kirkon keskushallinnon uudistus pakottivat kirkolliskokouksen uudistamaan työjärjestystään. Vuonna 1994 voimaan tulleessa työjärjestyksessä yksi näkyvimmistä muutoksista koski valiokuntia. Koska vastuu kokonaiskirkon toiminnallisesta ohjauksesta siirtyi kirkkohallitukselle, toimikuntavaliokunta lakkautettiin. Kirkkohallituksen toimintakertomusten käsittely siirtyi yleiselle valmistusvaliokunnalle, jonka nimi muutettiin yleisvaliokunnaksi. Vuonna 1993 ylimääräisenä valiokuntana jälleen kerran asetettu hallintovaliokunta muutettiin pysyväksi. ${ }^{92}$ Raha-asia-aloitteen nimi muutettiin talousarvioaloitteeksi, kuten eduskunnassa oli tehty $1991 .{ }^{93}$

Työjärjestykseen tehtiin myös lukuisia muita muutoksia, joista suuri osa johtui kirkolliskokouksen siirtymisestä Turun kristillisen opiston uuteen auditorioon. Uuden istuntosalin tekniset apuvälineet muuttivat huomattavasti kirkolliskokouksen käytännön työskentelyä. Äänestyslaitteiden myötä voitiin luopua niin seisomaan nousten toimitetuista äänestyksistä kuin suullisista nimenhuudoista. Tekniikka mahdollisti varsinkin vastauspuheenvuorojen pyytämisen vaivattomasti. Jokaisen edustajan edessä oli mikrofoni, joten lyhyet puheenvuorot oli mahdollista pitää omalta paikaltaan. Muutokset loivat edellytyksiä sellaiselle nopeatempoiselle mielipiteenvaihdolle, jota eduskunnassakin oli pyritty edistämään.

Eduskunnasta haettiin mallia myös aloitettaessa kirkkohallituksen kyselytunnit. Uuteen työjärjestykseen ei vielä otettu kyselytunteja koskevaa säännöstä, mutta niitä järjestettiin vuodesta 1993 lähtien kokeiluluonteisesti ja epävirallisesti pöytäkirjan ulkopuolella. ${ }^{94} \mathrm{Ky}$ selytuntien taustalla oli pyrkimys vähentää aloitteiden määrää tarjoamalla vaihtoehtoisia tapoja nostaa asioita keskusteluun..$^{95}$ Kyselytuntien tarvetta lisäsi myös se, että kirkkohallituksen asema vahvistui 1994 voimaan tulleen keskushallinnon uudistuksen myötä. Vastapainona spontaania keskustelua edistäneille toimille oli, että edustaja-aloitteet määrättiin jätettäväksi hyvissä ajoin ennen istuntokautta, jolloin niihin tutustumiseen ja etukäteisvalmisteluihin jäi aikaa ${ }^{96}$. 


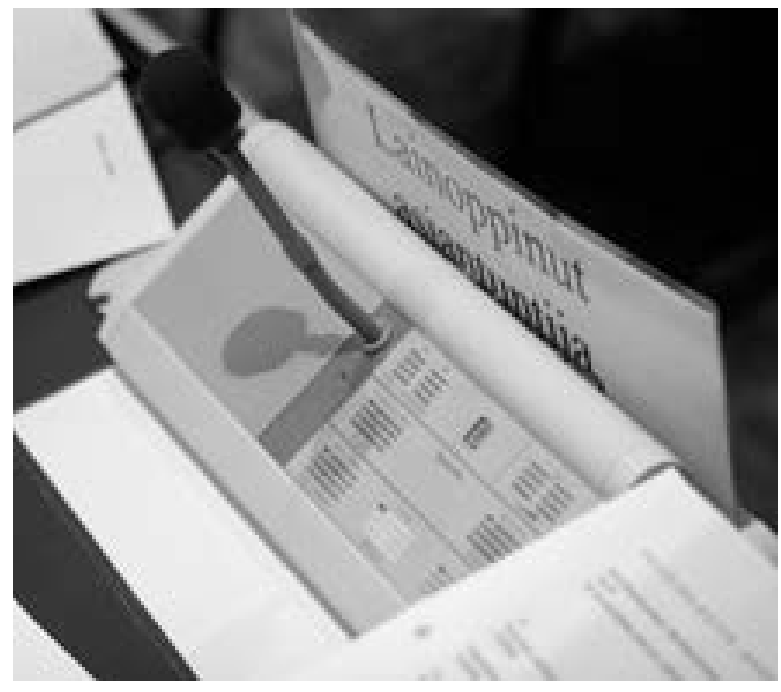

Ä̈̈nestäminen ja puheenvuorojen pyytäminen muuttuivat 199o-luvulla sähköisiksi. Uusilla laitteilla oli helppo pyytää myös erillinen vastauspuheenvuoro, jonka pystyi pitämään paikaltaan. Uudistus paransi keskustelumahdollisuuksia mutta vaati myös paljon totuttelua: puheenjohtajat joutuivat toistuvasti muistuttamaan vastauspuheenvuoropyyntöjen oikeasta käyttötarkoituksesta. Kuva: Kirkkohallitus / Aarne Ormio.

John Vikström jatkoi arkkipiispana vuoteen 1998 asti. Hänen seuraajakseen arkkihiippakunnan ja samalla kirkolliskokouksen johdossa nimitettiin aiempi Turun tuomiorovasti Jukka Paarma. Varapuheenjohtajien vaali oli 1992 pelkkä muodollisuus, koska Raija-Liisa Mikkola ja Kalevi Nummi jatkoivat kirkolliskokousedustajina. ${ }^{97}$ Sen sijaan he eivät olleet kirkolliskokouksessa enää keväällä 1996. Hyvin laaja yksimielisyys vallitsi siitä, että ensimmäinen varapuheenjohtaja olisi edelleen nainen. Niin ikään moni ajatteli, että jommankumman varapuheenjohtajan tuli olla Helsingin hiippakunnasta. Maan suurimman hiippakunnan vaaleilla valituista edustajista yksikään ei ollut vielä toiminut kirkolliskokousuudistuksen jälkeen tässä tehtävässä. Tältä pohjalta valikoitui käytännössä kaksi vaihtoehtoista varapuheenjohtajaparia: ensiksi toimittaja Leena Huima Helsingin ja valtiopäiväneuvos Sakari Knuuttila Lapuan hiippakunnasta sekä toiseksi dosentti Kyllikki Tiensuu Kuopion ja rajavartiolaitoksen ylilääkäri Timo Sahi Helsingin hiippakunnasta. Tiensuu ja Sahi voittivat lopulta äänestykset.98

Knuuttilan nousu ehdokkaaksi tarkoitti, että ensimmäistä kertaa Viljami Kalliokosken kauden jälkeen pitkäaikainen parlamentaarikko oli lähellä päästä varapuheenjohtajaksi. Kaiken lisäksi Knuuttilan puolue oli SDP, jota edustaneita kansanedustajia oli valittu kirkolliskokouksen maallikkoedustajiksi vasta 1980-luvun lopulta lähtien. Jo 1992 oli saavutettu yksi virstanpylväs, kun sosiaalidemokraatteihin lukeutunut koulutoimenjohtaja Jukka Tamminen Kaarinasta oli valittu määräaikaiseksi kirkkoneuvokseksi ${ }^{99}$. Lama-aikana puheet kirkon johdon ja työväenliikkeen lähentymisestä voimistuivat, ja ainakin sosiaalidemokraattien aseman vakiintuminen kirkolliskokouksessa antoi tukea väitteille.

Tiensuun ja Sahin valinta johti siihen, että hetken aikaa kaikki kolme puheenjohtajaa arkkipiispa Vikström mukaan lukien olivat yliopiston dosentteja. Toinen erottuva piirre oli, että kirkolliskokouksen johdossa oli 1990-luvun jälkipuoliskolla poikkeuksellisen monta upseeria. Lääkintäprikaatikenraali Sahi johti puhetta täysistunnossa, kenttäpiispa Hannu Niskanen yleisvaliokunnan toisessa osastossa ja yleisesikuntaeversti Seppo Ahtikoski kansliavaliokunnassa. Vaikka kirkolliskokousvaaleissa tohtorien ja valtion viranhaltijoiden menestys heikkeni, kirkolliskokouksen sisäisissä valinnoissa ei näkynyt samanlaista suuntausta.

Vuoden 1992 valiokuntavalinnoissa pappeja tuli enemmistö peruste- ja käsikirjavaliokuntaan sekä seuraavana vuonna vielä ylimääräisenä perustettuun hallintovaliokuntaan. Juuri nämä valiokunnat käsittelivät kirkolliskokouksen laajimpia uudistushankkeita. Pappisenemmistö tarkoitti myös miesten enemmistöä. Peruste- ja käsikirjavaliokunnan yhteenlasketusta jäsenmäärästä alle kymmenesosa oli naisia, mikä tarkoitti selvää aliedustusta naisten kokonaisosuuteen verrattuna. Sen sijaan toimikuntavaliokunnassa ja yleisessä valmistusvaliokunnassa naisia oli suhteellista osuuttaan enemmän.

Yleinen valmistusvaliokunta oli jo pitkään ollut maallikkoedustajien ja naisten valiokunta, mutta sen johtoon oli perinteisesti valittu pappeja. Vuonna 1992 tilanne muuttui. Puheenjohtajaksi valittiin toimittaja Leena Huima, jonka valinta oli kahdella tavalla merkittävä: ensimmäistä kertaa valittiin nainen kirkolliskokouksen valiokunnan puheenjohtajaksi, ja ensimmäistä kertaa talousvaliokunnan ohella jonkin muunkin suuren valiokunnan puheenjohtajaksi tuli hiippakunnallisella vaalilla valittu maallikkoedustaja. Yleisen valmistusvaliokunnan toisen osaston puheenjohtajavalinta oli myös 
huomionarvoinen: osastossa ollut piispa Yrjö Sariola ei halunnut puheenjohtajaksi, joten tehtävään valittiin ensimmäisen kauden pappisedustaja, Kankaanpään kirkkoherra Keijo Rainerma ${ }^{100}$.

Vuonna 1996, jolloin toimikuntavaliokuntaa ei enää asetettu, naisedustajien määrä yleisvaliokunnassa kasvoi entisestään ja nousi jo lähelle 6o:tä prosenttia. Perustevaliokunta jäi ainoaksi valiokunnaksi, jossa naiset olivat selvästi aliedustettuina. Leena Huima jatkoi yleisvaliokunnan ensimmäisen osaston puheenjohtajana, ja myös valitsijamiehet olivat vähällä saada naisen puheenjohtajakseen. Naisedustajat olivat tyytymättömiä siihen, että naisten valitseminen kirkon keskuselimiin kaatui usein valitsijamiehissä. He päättivät ehdottaa naista valitsijamiesten johtoon. ${ }^{101}$ Taustalla oli lisäksi tyytymättö-

\section{Sukupuolikiintiöt kirkon keskushallintoon}

Jos yksi nainen vain otetaan joukkoon, siellä jää hän helposti kukkana loukkoon. Tai ehkä tarvitaan sihteerin kättä. Ei, kiintiöt tarpeen on välttämättä. ${ }^{\mathrm{I}}$

Näillä sanoilla lehtori Rauni Rautavuori perusteli, miksi kirkon keskushallinnossa tarvittiin sukupuolikiintiöitä. Hän oli ensimmäinen allekirjoittaja 15 edustajan aloitteessa keväällä 1993. Tuohon aikaan kirkon keskushallinnon neuvottelu- ja toimikunnissa sekä työryhmissä vain alle viidennes jäsenistä oli naisia. Kaiken lisäksi lähes puolessa näistä ryhmistä ei ollut lainkaan naisedustajia. Samaan aikaan pyrittiin kansainvälisestikin edistämään naisten asemaa kirkkojen hallinnossa. Aloitteentekijät myönsivät kiintiöiden ongelmallisuuden mutta esittivät, että asetettaessa ja täydennettäessä keskushallinnon työryhmiä naisia tuli vastaisuudessa olla vähintään kolmannes. ${ }^{\text {II }}$

Yleisen valmistusvaliokunnan mielestä naisten osuutta oli ryhdyttävä kasvattamaan ilman kiintiöitä. Kirkolliskokous päätyi epäviralliseen suulliseen sopimukseen, jota valitsijamiehet ryhtyivätkin heti noudattamaan. ${ }^{\text {III }}$ Sopimuksen vaikutus ei kuitenkaan ulottunut kaikkialle kirkon keskushallintoon: parissa vuodessa naisten osuus toimielimissä kasvoi vain pari prosenttiyksikköä. Sen sijaan valtiolliseen tasa-arvolainsäädäntöön tuli tällä välin määräys, jonka mukaan esimerkiksi valtion komiteoissa ja neuvottelukunnissa tuli olla kumpaakin sukupuolta vähintään 40 prosenttia jäsenistä. Poikkeaminen oli mahdollista vain erityisistä syistä. Keväällä 1995 Rautavuori uusi aloitteensa, mutta nyt kiintiövaatimus oli sama kuin valtiollisessa lainsäädännössä. ${ }^{\text {IV }}$ myyttä pitkäaikaisen puheenjohtajan Paavo Kortekankaan voimakkaaseen johtamistapaan. ${ }^{102}$ Kokoonkutsuja Kortekangas ja valitsijamiesten sihteeri eivät olleet odottaneet äänestystä eivätkä siksi olleet varanneet kokouspaikalle vaalilippuja. Tunnelma olikin jännittynyt, kun Raija Sollamo ehdotti puheenjohtajaksi seurakuntaneuvos Kaisu Rantalaa Kauhajoelta. Kaiken lisäksi päädyttiin tasaääniin, mutta arpa ratkaisi puheenjohtajuuden Kortekankaalle. ${ }^{103}$ Vaikka puheenjohtaja ei vaihtunut, Sollamon myöhemmän arvion mukaan tapahtumasar-

\section{Picture removed from the open access version of this book.}

Proviisori Outi Avela, pastori Hannele Repo, lehtori Rauni Rautavuori, arkkipiispa John Vikström, toimittaja Leena Huima ja pastori Ari Tammi poseerasivat kameralle, kun sukupuolikiintiöt oli hyväksytty kirkon keskushallintoon. Kuva: Kotimaan kuva-arkisto / Kyllikki Krapinoja.

Yleisvaliokunta myönsi nyt, että tarvittiin virallinen toimintaohje. ${ }^{\mathrm{V}}$ Ohje ei sittemmin päästänyt kirkolliskokousta helpolla. Esimerkiksi kirkon sopimusvaltuuskunnan uusi kokoonpano oli talousvaliokunnan jäsenten mukaan "monen, monen päivän työn tulos siitä, että saataisiin naiskiintiö toteutetuksi" ${ }^{\text {VI }}$ Yleisvaliokunnan puheenjohtajan Leena Huiman mukaan toimintaohje oli pelkästään siirtymävaiheen tilapäinen järjestely. ${ }^{\text {VII }}$ Toimintaohje jäikin väliaikaiseksi mutta päinvastaisella tavalla kuin Huima ennakoi: vuonna 2003 kirkolliskokous esitti sukupuolikiintiöiden siirtämistä kirkkolakiin. Toimintaohjeen tilalle tuli tasa-arvolain mukainen velvoittava säännös. ${ }^{\text {VIII }}$

I Kirk.kok. kptk-s. 1993,35\$.

II Kirk.kok. ptk-k. 1993, liite IX 1; Raiser 2004, 260.

III Kirk.kok. kptk-s. 1993, 53 \$; Kirk.kok. ptk-s. 1993, 35 \$, liite VII-E 10.

IV Kirk.kok. ptk-k. 1995, liite VIII 5; Liljeström 2008, 235.

V Kirk.kok. ptk-k. 1995, liite IX-D 7.

VI Kirk.kok. kptk-s. 1997, 80 \$.

VII Kirk.kok. kptk-k. 1995, 57 \$.

VIII Kirk.kok. ptk-s. 2002, liite III 8; Kirk.kok. ptk-k. 2003, 59 \$. 
ja paransi naisten menestymismahdollisuuksia valitsijamiesten toimittamissa henkilövalinnoissa. ${ }^{104}$

Kokeneet edustajat ja ensikertalaiset sijoittuivat 1996 tasaisemmin eri valiokuntiin kuin kymmenen vuotta aiemmin. Edustajakokemuksen sijaan muut perustelut, kuten omat toiveet ja erityisosaaminen tai henkilökohtainen vaalimenestys, olivat saaneet lisää merkitystä. Kehityssuunta vastasi muutosta, joka eduskunnassa oli tapahtunut valiokuntapaikkojen jaossa ${ }^{105}$. Vuoden 1986 tavoin yleisvaliokunta erottui edelleen ensikertalaisten valiokuntana ja hallintovaliokunta puolestaan kokeneiden edustajien valmisteluelimenä. Toisaalta yleisvaliokunta hoiti 1990-luvulla aiempaa näkyvämpiä tehtäviä, joita sille siirtyi erityisesti lakkautetulta toimikuntavaliokunnalta.

Naisten ja nuorten aikuisten edustus nousi keskeisimmäksi puheenaiheeksi valittaessa kirkkohallituksen täysistunnon jäseniä 1996. Valitsijamiesten ehdotuksessa kahdeksasta maallikkojäsenestä kolme oli naisia. Raija Sollamo valitteli valitsijamiesten puolesta, että "hyvästä tahdostamme huolimatta" niin vähän naisia oli päässyt läpi. Syynä oli, että Turun ja Porvoon hiippakunnat eivät olleet nimenneet lainkaan naispuolisia ehdokkaita. ${ }^{106}$ Vaikka tavoitteesta jäätiin, yleinen ilmapiiri oli aivan toisenlainen kuin kaksi vuosikymmentä aiemmin, jolloin yksi nainen oli valittu "koeajalle" kirkkohallitukseen. Naisten osuus kasvoi vielä hieman täysistunnossa, kun perheasiain neuvottelukeskuksen johtaja Marjatta Kaartinen nousi pappisjäseneksi yhdessä kirkkoherra Risto Junttilan kanssa ${ }^{107}$.

Toinen valitsijamiesten huolenaihe oli nuorten aikuisten edustus. Valitsijamiesten onneksi Lapuan hiippakunnan ehdokkaiden joukosta löytyi alle 40-vuotias henkilö, 36-vuotias lakimies Jyri Klemola, joka ohitti valitsijamiesten toimittamassa vaalissa niukasti pitkäaikaisen kirkkohallituksen jäsenen Leo L. Norjan. Täysistunnossa miehet saivat saman äänimäärän, mutta arpa ratkaisi vaalin Norjan hyväksi. ${ }^{108}$ Kirkolliskokouksessa vahvassa nousussa olleista ehdokkaista Klemola oli Kirkon hallintovirkamiehet -järjestön sihteeri, kun taas Kaartinen oli Suomen kirkon pappisliiton valtuuskunnan jäsen. Keskushallinnon uudistuksessa kirkon sopimusvaltuuskunnan toimisto oli liitetty entistä tiiviimmin kirkkohallituksen virasto-organisaatioon, joten ammattijärjestöjen aktiivien menestys kirkkohallituk- sen täysistunnon jäseniä valittaessa sekoitti edelleen eri sopijapuolten välisiä rajoja. Näin tapahtui samaan aikaan, kun toisaalla pyrittiin selkeyttämään vallanjakoa ja lisäämään riippumattomuutta.

Risto Junttilan ja Marjatta Kaartisen valinta kirkkohallituksen täysistunnon jäseniksi osoittautui sittemmin merkittäväksi myös kansliapäällikön valinnan kannalta. Vaali oli edessä syksyllä 1997 Pertti Mäkeläisen jäädessä eläkkeelle. Valitsijamiesten keskuudessa loppusuoralle pääsivät Risto Junttila ja kirkkoneuvos Heikki Mäkeläinen melko tasaväkisinä. Täysistunnossa Kaartinen piti pitkän puheen Mäkeläisen puolesta, ja Seikko Eskola vastasi puhumalla Junttilan puolesta. ${ }^{109}$ Myöhemmin muistelmissaan Eskola on suoraan todennut, että hänen tarkoituksensa ei ollut niinkään perustella Junttilan paremmuutta Mäkeläiseen nähden kuin vastustaa Marjatta Kaartista, jonka epäiltiin pyrkivän Heikki Mäkeläisen virkaan kirkkoneuvokseksi. ${ }^{110}$ Junttila voitti Mäkeläisen äänin 63-39. ${ }^{111}$ Kaartiselle koitui kompastuskiveksi pitkälti sama asia kuin aiemmin Mikko Juvalle ja Göran Portinille: kirkolliskokoukselta ei liiennyt ymmärtämystä, jos jonkun ounasteltiin ajavan omaa asiaansa.

\section{LEIKKAUSTEN, RAHASTOINNIN JA IHMISTEN HÄDÄN AIKA}

\section{"KIRVES ON PANTU PUUN JUURELLE"}

Vuonna 1993 kirkkohallitus esitti muutosta kirkolliskokouksen työjärjestyksen kohtaan, joka koski kirkon keskusrahaston lisätalousarviota. Voimassa olleen työjärjestyksen mukaan lisätalousarviolla oli mahdollista vain lisätä määrärahoja varsinaiseen talousarvioon. Nyt haluttiin mahdollisuus myös vähentää määrärahoja kesken vuotta, mikäli tilanne niin vaati. ${ }^{12}$ Pieni työjärjestyksen muutos osoitti kouriintuntuvasti sen murroksen, jonka keskelle kirkolliskokous joutui sotien jälkeen pahimman taloudellisen laman yllättäessä yhteiskunnan. Aiemmin ei ollut tarvinnut ajatella edes periaatteessa sellaista mahdollisuutta, että määrärahoja jouduttaisiin karsimaan kesken vuotta. Niin vakaa ja tasaisesti kasvava kokonaiskirkon talous oli pitkään ollut. Toisin oli 1990-luvun alkuvuosina. Työttömien määrä nelinkertaistui, ja samalla seurakuntien veroäyrimäärän - kirkon keskusrahaston talouden perustan - pelättiin aluksi 
vajoavan jopa viidenneksen ${ }^{113}$. Keskusrahastonkin osalta sellaiset prosenttiluvut, joilla aiemmin oli kuvattu talousarvion kasvua, osoittivat leikkauksia.

Uuden kirkolliskokouksen aloittaessa työskentelynsä keväällä 1992 kirkon talouden vastuuhenkilöt olivat huolissaan: kirkko oli liian myöhään heräämässä laman todellisuuteen. Talousvaliokunnan puheenjohtaja Markku Porvari luennoi kirkolliskokoukselle, miten vuonna 1991 kirkon henkilöstömäärä oli kasvanut vielä 1,6 prosentilla ja palkkasumma lähes 12 prosentilla: "Me olemme vielä puheiden tasolla, vaikka olisi korkea aika jo vähentää kustannuksia henkilöstömenoja leikkaamalla." ${ }^{114}$ Tässä tilanteessa entisenlainen toiminta- ja taloussuunnitelma osoittautui liian kankeaksi, ja suunnitelmaa oli tarkistettava tiheään. Kirkon hallintoyksiköt saivat ohjeet supistaa vuoden 1993 menoistaan kahdeksan prosenttia, seuraavana vuonna viisi prosenttia, ja vielä vuosina 1995-1996 kolme prosenttia. Samalla oli tosin varauduttava vielä tätäkin suurempiin leikkauksiin. ${ }^{115}$

Leikkaukset purivat jo keskusrahaston vuoden 1992 tilinpäätökseen, joka oli 38 miljoonaa markkaa ylijäämäinen. Vielä 1980-luvulla vastaava ylijäämä olisi johtanut kirkolliskokouksessa syytöksiin, että seurakunnilta oli kerätty liikaa rahaa. Nyt kuultiin kuitenkin kiitoksen sanoja. Keskusrahastomaksuja ei enää mielletty pelkästään jakoveroksi, vaan rahastointiajatus valtasi alaa talousennusteiden synkentyessä. ${ }^{116}$ Talousvaliokunnan puheenjohtaja Porvari ehdotti ylijäämän rahastoimista "pahan päivän varalle".117 Totta olikin, että keskusrahaston vuoden 1992 talous perustui vielä hyvän vuoden 1990 verotuloille. Silti säästäminen pahan päivän varalle syvimpinä lamavuosina 1992-1993 antoi kuvan siitä synkkyydestä ja epävarmuudesta, joka tuohon aikaan hallitsi talousnäkymiä. Vuoden 1993 talousarvion käsittelyssä ei päästy kaikilta osin suunnitellun suuruisiin leikkauksiin, mutta edustaja Porvarin sanat enteilivät linjan tiukkenemista. Hän antoi talousarviolle otsikon "Kirves on pantu puun juurelle". ${ }^{118}$ Lama muutti politiikan julkisuutta siten, että päätöksiä leimasi tyytyminen taloudellisiin lainalaisuuksiin. ${ }^{119}$ Samaa oli huomattavissa pahimpina lamavuosina myös kirkolliskokouksessa.

Vuonna 1993, kun talouden pahin kriisivaihe alkoi helpottaa, kirkolliskokouksesta rupesi kuulumaan toisenkinlaisia ääniä. Kevätistuntokauden avauspuheessa arkkipiispa Vikström kehotti välttämään päätöksiä, jot- ka kriisin keskellä näyttivät ajanmukaisilta mutta eivät ehkä enää myöhemmin asianmukaisilta. ${ }^{120}$ Käsittelyyn tuli viimeistä kertaa virkapaketti, ennen kuin kirkon yhteisten virkojen perustaminen ja lakkauttaminen siirtyivät vuoden 1994 alussa kirkkohallitukselle. Virkapaketti ei enää ollut esitys uusien virkojen perustamisesta vaan vanhojen lakkauttamisesta. Kirkolliskokousedustajat eivät kuitenkaan hyväksyneet lakkauttamislinjaa yhtä ongelmattomasti kuin edellisenä vuonna. Yhä useammat epäilivät, olivatko leikkaukset liian paniikinomaisia. "Sen sijaan, että vaan varpaat leikattaisiin, heti mennään panemaan reidestä poikki", varoitti lääkintöneuvos Håkan Hellberg oman ammattialansa vertauksin. Edellisen vuosikymmenen nopeaa virkojen lisäämistä oli nyt seuraamassa toinen äärimmäisyys. ${ }^{121}$ Talousvaliokunta lykkäsikin monien virkojen lakkauttamista ja sai täysistunnossa kiitoksia "lempeydestä". ${ }^{122}$

Kirkolliskokous edellytti kirkkohallitukselta myös kokonaisstrategiaa virkojen lakkauttamisesta, jotta summittaiselta karsimiselta vältyttäisiin. ${ }^{123}$ Lisäksi kokous kantoi huolta kirkon tehtäviin valmistuvista. Helsingin tuomiorovastin Mikko Heikan toivomusponnesta lähti liikkeelle väliaikainen käytäntö: kirkolliskokous myönsi vuodesta 1994 lähtien kolmena vuonna miljoonan markan määrärahan, jotta kirkon tehtäviin valmistuvia voitiin työllistää valtion työllistämistuen avulla. ${ }^{124}$ Talousvaliokunnan oli taipuminen kirkolliskokouksen enemmistön tahtoon, vaikka valiokunta pitikin työllistämistukea lyhytnäköisenä ratkaisuna. ${ }^{125}$

Kirkolliskokouksen aiempi päätös siirtää kirkon yhteisten virkojen perustaminen ja lakkauttaminen kirkkohallitukselle tuli voimaan 1994. Käytännön päätöksenteon näkökulmasta näin ei tapahtunut yhtään liian aikaisin. Virkoja perustettaessa oli voitu keskittyä puhumaan yleisellä tasolla viran tarpeesta, mutta kun oli yhtäkkiä kyse virkojen lakkauttamisesta, keskustelu meni täysistunnossakin ajoittain puheeksi yksittäisistä työntekijöistä, heidän menestymisestään, eläkeiästään ja myöhemmistä työllistymismahdollisuuksistaan. ${ }^{126}$ Tällainen keskustelu osoitti inhimillisyyttä ja huolta työntekijöistä mutta sopi huonosti isoon saliin. Vuodesta 1994 lähtien kirkolliskokous käsitteli virkoja talousarvion yhteydessä ja ohjasi määrärahojen avulla kirkkohallituksen virkapäätöksiä. Yksilöihin käyvää keskustelua ei silloinkaan täysin vältetty, mutta ongelma pieneni. 
Valtiovallan toimet vaikeuttivat kirkon tilannetta. Vuoden 1993 kiinteistöverouudistuksessa seurakunnat menettivät osuutensa asuntotulon verotuksesta ja kiinteistöjen harkintaverotuksesta. Päinvastoin seurakunnista tuli uuden kiinteistöveron maksajia. Kesäkuussa 1994 tuli voimaan arvonlisäverolaki, jonka mukaan seurakuntien tietyt toiminnot muuttuivat veronalaisiksi. Verouudistukset tarkoittivat seurakunnille noin sadan miljoonan markan vuotuista menetystä. ${ }^{127}$ Uudistukset saivat aikaan voimakasta tyytymättömyyttä myös kirkolliskokouksessa. Kokous velvoitti kirkkohallituksen ryhtymään neuvotteluihin verohelpotusten saamiseksi. ${ }^{128}$ Uudet verot yllättivät kirkkohallituksen ohella kirkolliskokouksen talousvaliokunnan, joka joutui syksyllä 1993 sovittamaan lisämenot muutenkin tiukkaan talousarvioon. Valiokunta herätteli kirkkohallitusta kysymällä, oliko kirkolla toimintakykyinen organisaatio tällaisten asioiden hoitoon. Kirkon oli määriteltävä strategiansa ja tavoitteensa suhteessa valtiovaltaan. ${ }^{129}$

Eniten huolta herätti kuitenkin kirkon yhteisöverotulojen tulevaisuus. Lapsi- ja yksinhuoltajavähennyksen sekä lapsenhoitovähennyksen poistuminen vuoden 1994 alussa olisi lisännyt seurakuntien verotuloja noin 150 miljoonaa markkaa. Hallitus halusi kuitenkin periä summan takaisin poistamalla kirkon yhteisövero-osuuden ja korottamalla kirkon sosiaaliturvamaksua kolmella prosenttiyksiköllä. ${ }^{30}$ Kirkon näkökulmasta ehdotus oli hyvin ongelmallinen, koska sille tuleva yhteisöveron tuotto oli ehdotuksessa laskettu roimasti alakanttiin jopa lama-ajan mittapuun mukaan. Hallituksen ehdotus aiheutti vastalauseita myös julkisuudessa ${ }^{131}$. Alkoivat pitkät ja vaikeat neuvottelut kirkon ja valtion edustajien välillä. ${ }^{132}$ Kirkon neuvottelijat saivat lopulta torjuntavoiton: kirkko säilytti yhteisövero-osuutensa, ja kiinteistö- sekä arvonlisäverosta koituneet sadan miljoonan markan menetykset luettiin sille hyväksi. Sosiaaliturvamaksua nostettiin 3,5 prosenttiyksikköä eli vain hieman alkuperäistä ehdotusta enemmän. ${ }^{133}$

Kirkolliskokous oli sivussa neuvotteluista ja päätöksenteosta. Sove-ratkaisun jälkeen valtion verouudistusten vaatimia toimia ei ollut enää tuotu sen päätettäväksi. Koska kirkolliskokous oli osoittautunut haluttomaksi palauttamaan vapaaehtoisesti verotuloja, valtio oli ryhtynyt säätelemään niitä kirkon ja valtion välisiä rahavirtoja, joista se pystyi itsenäisesti päättämään. Tärkein kei- no oli sosiaaliturvamaksun nostaminen, joka oli nytkin käytössä ${ }^{134}$. Valtion itsenäiset ja ennakoimattomat toimenpiteet osoittivat viimeistään 1990-luvun alussa, että kirkolliskokouksen sove-päätös oli ollut monella tavalla Pyrrhoksen voitto. Siinä missä kirkolliskokous oli ajautunut sivuun kirkon ja valtion taloussuhteita koskevasta päätöksenteosta, kirkkohallitus, jonka neuvotteluratkaisu ei 1980-luvun alussa ollut kelvannut kirkolliskokoukselle, otti aktiivisen roolin ${ }^{135}$. Tällä kertaa sillä oli takanaan myös kirkolliskokouksen tuki, ja lopputulos olikin kirkon näkökulmasta parempi kuin 1980-luvulla kirkon ja valtion yksipuolisesti tekemien päätösten aikaan.

Verotuspäätöksiin verrattuna kirkolliskokous oli vieläkin selvemmin sivustaseuraajana toisessa keskustelussa, jossa se oli 1980-luvun alussa ollut ratkaisijan paikalla. Kirkolliskokouksen tahto loppiaisen ja helatorstain palauttamisesta entisille paikoilleen toteutui viivästyneenä vuoden 1992 alussa, mutta samaan aikaan nousivat pintaan suunnitelmat vapauttaa kauppojen aukioloa $\operatorname{sunnuntaisin}^{136}$. Kirkolliskokous oli 1982 tehnyt itsenäisesti ja toimintamahdollisuuksiinsa luottaen ratkaisun niin arkipyhistä kuin verotuloistaan, mutta kymmenen vuotta myöhemmin sekä pyhäpäivän viettämisestä että kirkon vero-osuuksista neuvoteltiin kaukana Turun kristilliseltä opistolta.

Seurakunnat selvisivät lamasta lopulta varsin hyvin. ${ }^{137}$ Verotulot eivät romahtaneet lamavuosina niin jyrkästi kuin oli pelätty, ja toisaalta 1980-luvun nousukauden varovainen taloudenpito oli suojana seuraavalla vuosikymmenellä. Lisäksi seurakuntien menot sopeutettiin melko synkkiin talousnäkymiin: kirkon henkilöstön määrä vähentyi vuosina $1992-1995$ noin 15 prosenttia. ${ }^{138}$ Näiden toimien johdosta lainaa ei tarvinnut juurikaan ottaa eikä rahastoja käyttää. Seurakuntia myös arvosteltiin julkisuudessa siitä, että rahastoja kartutettiin samaan aikaan, kun työntekijämäärää vähennettiin ja kun avuntarve kasvoi. ${ }^{139}$ Voimakas rahastointi oli ymmärrettävää siitä näkökulmasta, että lamavuodet osoittivat kerralla seurakuntien veropohjan - erityisesti yhteisöverotulojen - haurauden ja ailahtelevuuden. Aiemmille vuosille tunnusomainen eläminen kädestä suuhun ei enää lamakokemusten jälkeen käynyt laatuun. Tulojen voimakkaan vaihtelun kääntöpuoli oli, että 1995 seurakuntien verotulot olivat jo suuremmat kuin koskaan ai$e^{e m m i n}{ }^{140}$. 
Näihin aikoihin - keväällä 1995 - kirkolliskokouksen talousvaliokunta arvioi keskusrahaston taloudellista tilannetta. Rahastoissa oli kuluneina vuosina saavutettu tavoitetaso lukuun ottamatta eläkerahastoa, joka sekin oli kasvanut nopeasti. ${ }^{141}$ Kun lama oli ollut syvimmillään, kirkon päättäjät olivat sopineet menoleikkauksista ja seurakunnat jäädyttäneet investointinsa. Hallintotalousarvion menoja osoittava kuvio havainnollistaa, että erityisesti keskusrahaston varoista maksetut avustukset olivat laskeneet voimakkaasti lamavuosina. Tämän kehityksen johdosta keskusrahaston tilinpäätökset olivat tuottaneet ylijäämää, jonka kirkolliskokous oli ra- hastoinut "pahan päivän varalle". Leikkaukset olisivat tosin olleet entistäkin voimakkaampia, mikäli kirkolliskokous olisi seurannut täysin kirkkohallituksen esityksiä. Kun aiempaa pahempaa päivää ei tullut, talousvaliokunta suunnitteli lopettavansa säästämisen samaan aikaan, kun ympärillä talous alkoi uudelleen kuumeta. Lamaajan toimet pitivät kirkon keskusrahaston talouden kunnossa, mutta suhdannevaihteluita ne eivät auttaneet tasoittamaan. Kirkko ei ollut keynesiläinen.

Talousvaliokunta kylläkin hillitsi menolisäyksiä uuden nousun alkaessa. Esimerkiksi syksyllä 1997 valiokunnan puheenjohtaja Markku Porvari valitteli, että

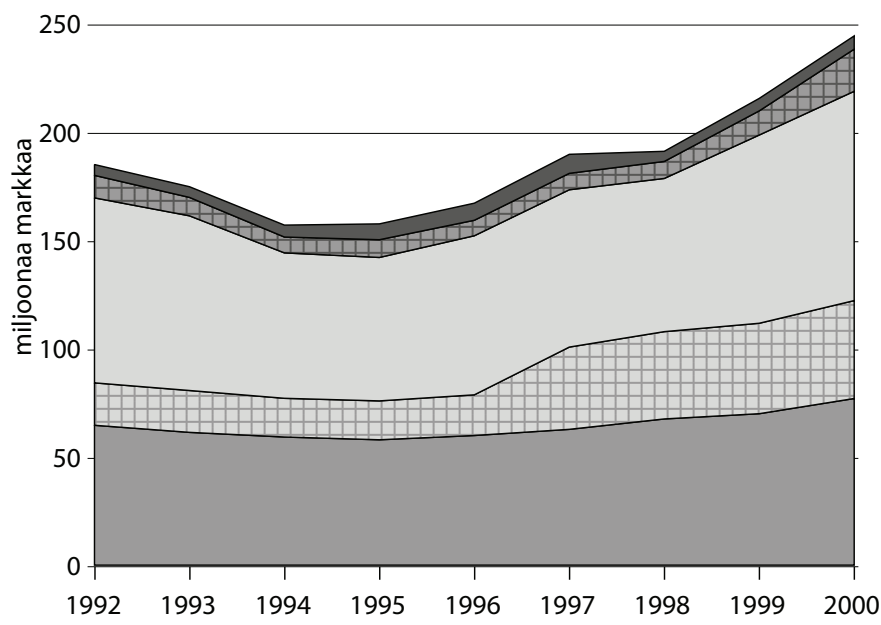

Kuvio 12: Hallintotalousarvion pääluokkien menot kirkon keskusrahaston talousarvioissa vuosille 1992-20oo

Kuviossa ei ole mukana eläketoimintaa.
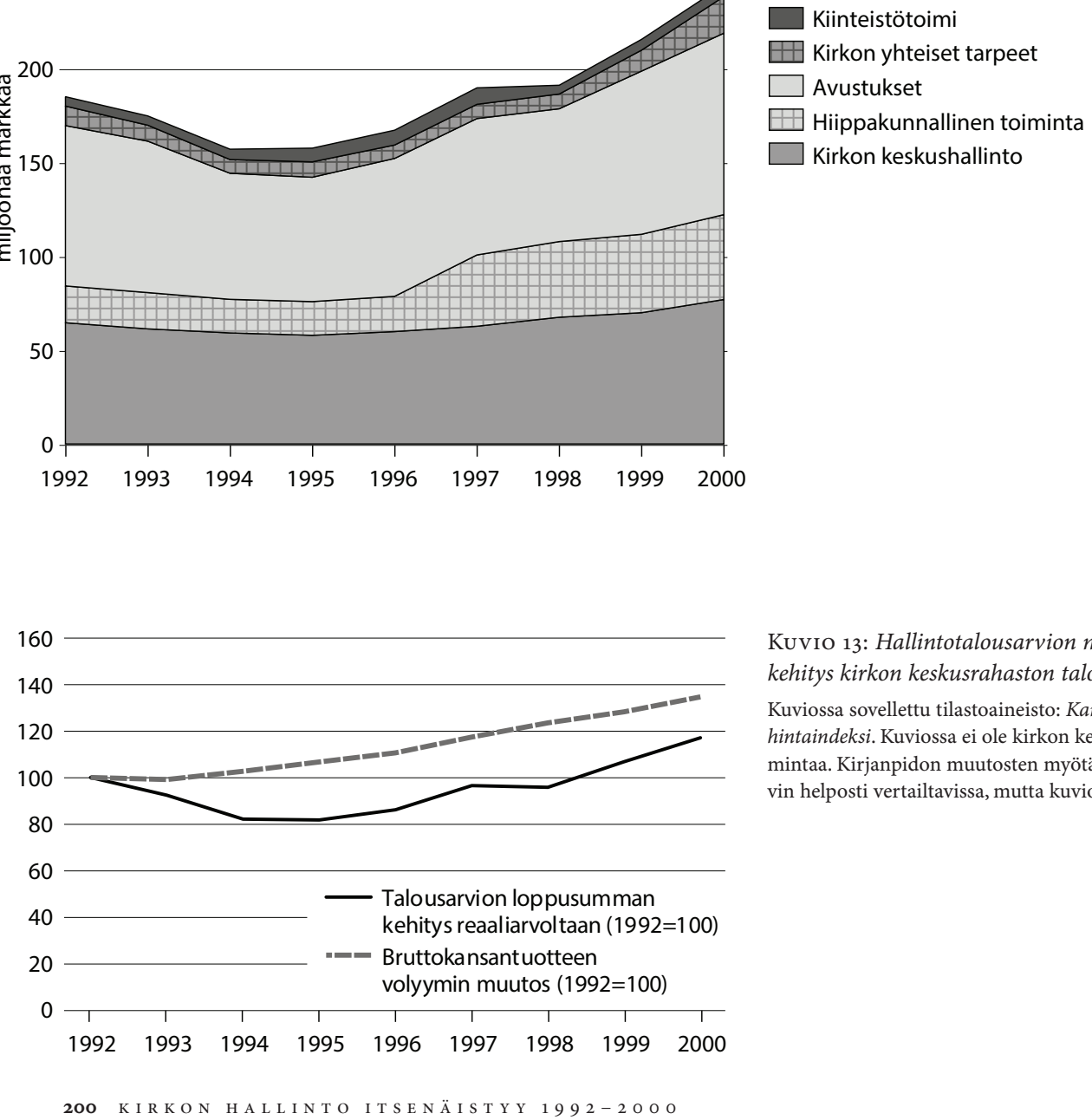

Kuvio 13: Hallintotalousarvion menojen reaaliarvon mukainen kehitys kirkon keskusrahaston talousarvioissa vuosille 1992-200o

Kuviossa sovellettu tilastoaineisto: Kansantalouden tilinpito 2006; Kuluttajahintaindeksi. Kuviossa ei ole kirkon keskusrahaston osalta mukana eläketoimintaa. Kirjanpidon muutosten myötä eri vuosien talousarviot eivät ole kovin helposti vertailtavissa, mutta kuvio antaa suuntaa. 
kirkkohallituksessa näytti syttyneen "takavuosien halu" perustaa virkoja uusia tehtäviä varten. ${ }^{142}$ Talousvaliokunta vetosi toiminta- ja taloussuunnitelmaan, mutta täysistunnossa asiakirja menetti painoarvoaan samaan tapaan kuin 1980-luvun nousukaudella. ${ }^{143}$ Kaivattiin uudenlaista suunnittelua. Vuosikymmenen lopulla siirryttiinkin uuteen toiminta- ja taloussuunnitelmaan, jonka kirkkohallitus jätti vuosittain ja joka kattoi kolme seuraavaa vuotta. ${ }^{144}$ Samalla talousvaliokunta alkoi vaatia entistä voimakkaammin pitkän ajan strategioita. ${ }^{145}$ Lama-ajan ihanne prosessista ja nopeasta reagoinnista muuttuvaan tilanteeseen alkoi olojen vakiintuessa vaihtua pitkäaikaisten visioiden ja strategioiden tavoitteluun. Talousvaliokunnan toimet olivat lopulta yhtenä tekijänä siinä, että kirkon keskusrahaston menot kasvoivat vuoteen 1998 asti hyvin maltillisesti. Niitä lisäsi lähinnä vain 1997 toteutettu tuomiokapitulien siirto kirkolle.

Kirkon ja valtion taloudelliset suhteet säilyivät ailahtelevina, mikä vaikeutti suunnittelua. Opetusministeriö asetti 1996 kirkolliskokouksen pyynnöstä toimikunnan laatimaan ehdotuksen valtion ja kirkon välisestä kustannusten jaosta. Eläkkeelle jääneen kansliapäällikön Jaakko Nummisen johtama toimikunta jätti mietintönsä seuraavana vuonna. Se ehdotti esimerkiksi, että kulut, joita syntyi tuomiokapitulien ylläpidon siirtymisestä kirkolle, korvattaisiin alentamalla pysyvästi kirkon työnantajana maksamaa sosiaaliturvamaksua. ${ }^{166}$ Toimikunta sai kirkolliskokouksessa osakseen kiitosta, ja kirkon ja valtion taloussuhteet näyttivät toimikunnan työn myötä viimeinkin vakiintuvan. ${ }^{147}$

Ilo oli lyhytaikainen, kun samaan aikaan valtiovalta päätti melko yllättäen leikata seurakuntien yhteisöverotuloja. "Hyvän hallintomenettelyn mukaista on, että kuullaan niitä osapuolia, joihin muutokset vaikuttavat", totesi talousvaliokunta happamasti. Se huomasi kirkon joutuneen taas kerran 1990-luvun aikana tapahtuneiden tosiasioiden eteen. ${ }^{148}$ Kahdessa vuodessa 1998-1999 kirkon yhteisövero-osuus putosi 3,36 prosentista kahteen prosenttiin, ja yllättäen eduskunnan päätöksellä vuodesta 2000 lähtien 1,63 prosenttiin. Muutamassa vuodessa osuus puolittui. Vaikka osa leikkauksesta oli tarkoitus kompensoida pienentämällä seurakuntien sosiaaliturvamaksuja, kirkon keskusrahaston taloudelle leikkaus oli dramaattinen. ${ }^{149}$ Talousvaliokunta totesi syksyllä 1999, että runsaan vuoden kuluttua kirkon keskus- rahaston talous olisi kriisissä. ${ }^{150}$ Kokonaiskirkon taloudenpidossa 1990-luku alkoi kriisitunnelmista ja päättyi niihin. Saman vuosikymmenen aikana kokonaiskirkon talousarvio kasvoi kuitenkin reaaliarvoltaan. Kirkon koko henkilöstömäärä kasvoi vuosina 1996-1999 jo kuusi prosenttia ${ }^{151}$. Suurista peloista huolimatta kirkko selvisi 1990-luvusta taloudellisesti sittenkin melko vähäisin vaurioin.

\section{"RAJASEUTUPIIRIEN TAPPOSUUNNITELMASTA" LOMAUTUKSIIN JA UUDENLAISEEN VIRKA-AJATTELUUN}

Kirkolliskokouksessa oli pitkään väännetty kättä rajaseututyöstä, mutta lopulta lama näytti pakon edessä johtavan rajaseututyön lakkaamiseen kokonaiskirkon työmuotona. Talousvaliokunta ehdotti syksyllä 1992, että rajaseututyön tehtävät pyrittäisiin siirtämään mahdollisuuksien mukaan seurakuntien hoidettaviksi. ${ }^{152}$ Täysistunnossa varsinkin Oulun ja Kuopion hiippakuntien edustajat kävivät puolustamaan syrjäisten rajaseutujen kansaa ja 6o-vuotiasta työmuotoa. Monien mielestä kirkon yhteisten virkojen leikkaukset koskivat kovemmin syrjäseutuja kuin keskushallintoa. Keskustelu sai ajoittain myös turvallisuuspoliittisia sävyjä, jotka olivat olleet mukana erityisesti rajaseututyön alkuvaiheessa. Noissa sävyissä näkyi maailmanpoliittinen tilanne, vaikka sitä ei ääneen julistettukaan: Neuvostoliitto oli juuri hajonnut, ja ensi askeleitaan ottanut Venäjän federaatio oli epävakaa rajanaapuri. Kuopion piispa Matti Sihvonen tulkitsi valiokunnan ehdotuksen "rajaseutupiirien tapposuunnitelmaksi". Hänen oma vaihtoehtoinen ehdotuksensa rajaseututyön tilanteen ja työvoimantarpeen selvittämisestä hävisi yhdellä äänellä. ${ }^{153}$ Siitä alkoi idän ja pohjoisen pitkä viivytystaistelu.

Kirkkohallitus ei aikaillut vaan ryhtyi jo seuraavana keväänä virkapaketissa ajamaan alas rajaseututyötä. Vastapainoksi kirkolliskokous sai käsiteltäväkseen kolme rajaseututyön puolesta jätettyä aloitetta, eikä aloitevirta kuivunut myöhemminkään. ${ }^{154}$ Niin talousvaliokunta kuin täysistunto olivat aloitteille myötämielisiä, eikä virkoja lakkautettu kirkkohallituksen esittämässä tahdissa. ${ }^{155}$ Lopulta 1995 toiminta- ja taloussuunnitelmaa uudistettaessa rajaseutuvirat päätettiin lakkauttaa. ${ }^{156}$ Kirkkohallitus teki asiasta päätöksen tammikuussa 1997. Kun seurakunnat eivät vielä silloin olleet perustaneet 
vastaavia virkoja, Suomen kirkon pappisliiton toiminnanjohtaja Osmo Setälä valitti 16 rajaseutuviranhaltijan valtuuttamana korkeimpaan hallinto-oikeuteen. ${ }^{157}$

Vuoden 1997 loppuun mennessä tilanne rauhoittui, kun seurakunnat perustivat pääasiassa määräaikaisia virkoja entisten rajaseutuvirkojen tilalle. Kirkolliskokoukseen varaedustajan paikalta noussut Kuhmon Lentiiran rajaseutupappi Jukka Pirttijoki näki kuitenkin rajaseutujen tulevaisuuden lohduttomana: "Sota, nälkä ja taudit eivät näitä seutuja nujertaneet, mutta tälle hyvinvoinnille emme voi mitään." ${ }_{158}$ Talouslaman ohella keskushallinnon keventämispyrkimykset johtivat rajaseutuvirkoja koskeneen keskustelun päätökseen. Kirkon toimintarakenteen periaatteiden näkökulmasta virkojen siirto paikallisseurakunnille oli johdonmukaista, mutta rajaseutualueilta katsottuna prosessi oli hyvin vaikea. Tilannetta hankaloittivat entisestään Suomen EU-jäsenyysaikeet ja sittemmin jäsenyyden toteutuminen: joidenkuiden edustajien näkökulmasta sekä EU että kirkkohallitus uhkasivat syrjäseutujen tulevaisuutta.

Yksi voimakkaimmista rajaseututyön puolustajista ja kirkkohallituksen arvostelijoista oli Kainuun Sanomien toimittaja Mauno Hyyryläinen. Hän työskenteli lehdessä, jonka päätoimittaja Keijo Korhonen oli 1994 EU-vastaisen vaaliliiton presidenttiehdokkaana. Hyyryläinenkin maalasi kirkolliskokouksessa avoimesti uhkakuvia siitä, miten Suomi joutuisi jäsenyysneuvotteluissa "antautumaan Brysselille, jolloin Suomen itsenäisyys ja itsemääräämisoikeus on menetetty" ${ }^{\prime 59}$. Syrjäseutujen vastarinta alkoi kirkolliskokouksessa hiipua, kun Suomi oli jo kolmatta vuotta EU:n jäsenenä. Tuolloin maata hallitsivat pääministeri Paavo Lipposen sateenkaarihallitukset, jotka olivat vasemmisto-oikeisto-ulottuvuudella hajanaisia mutta keskusta-periferia-ulottuvuudella keskushakuisia ja Eurooppa-myönteisiä ${ }^{160}$. Rajaseututyöstä ja EU-jäsenyydestä keskusteltaessa sama jakolinja ilmeni kirkolliskokouksessa - kuten se oli ilmennyt aiemminkin huomattavasti vasemmisto-oikeisto-jaottelua selvemmin.

Kirkon lainsäädäntöä ei ollut suunniteltu taloudellisia lamakausia ajatellen. Mahdollisuus supistaa talousarviota kesken vuoden oli lisättävissä helposti kirkolliskokouksen työjärjestykseen, mutta paljon suurempi ongelma oli, ettei kirkon virkalainsäädäntö tuntenut lomautusta. Seurakuntien ainoa mahdollisuus vähentää palkkakuluja oli lakkauttaa virka ja irtisanoa viranhaltija. Vuonna 1992 vastavalittu kirkolliskokous hyväksyikin omalta osaltaan esityksen lomauttamista koskeviksi väliaikaisiksi laeiksi. ${ }^{161}$ Lomauttamisen tarve osoittautui kuitenkin pysyväksi. Vuonna 1997 kirkolliskokous lähetti eduskunnalle esityksen, jonka myötä kirkkolakiin lisättiin erillinen lomauttamista koskeva säännös. ${ }^{162}$

\section{Picture removed from the open access version of this book.}

Kirkon lomautussuunnitelmat herättivät huomiota lehdistössäkin. Oton (Jari Elsilä) pilapiirros Ilta-Sanomissa 9. marraskuuta 1992. 
Lama-aika toi eteen muitakin uusia tilanteita. Yksi niistä oli kirkon tehtäviin valmistuvien työttömyys, joka oli kuitenkin vähäisempää kuin useimmilla muilla aloilla. ${ }^{163}$ Kirkolliskokouksen asialistalle tämä ongelma tuli ensimmäisen kerran keväällä 1993 Helsingin hiippakuntakokousaloitteen välityksellä. Hiippakuntakokous oli huolissaan valmistuvien teologien työttömyydestä. ${ }^{164}$ Samaan aikaan ponnahti uudelleen esille myös teologisen tiedekunnan tiedekuntapastorin tarve. ${ }^{165} \mathrm{Juu}$ ri teologian opiskelijoiden ongelmat nousivat ensimmäiseksi keskusteluun, mikä osoitti pappien asemaa niin kirkon jäsenten arvostuksissa kuin kirkon tunnustuksessa ja hallinnossa. Kun lisäksi Helsingin yliopiston ja Åbo Akademin teologisten tiedekuntien dekaanit istuivat kirkolliskokouksessa, kokous sai tuoreita tietoja teologien ongelmista. Täysistuntokeskusteluissa pohdittiin eri yhteyksissä uusia tapoja teologien työllistämiseksi, kuten osa-aikaisten papinvirkojen sallimista tai mahdollisuutta vihkiä pappiskandidaatti jo puolen vuoden määräaikaisen virkasuhteen perusteella. ${ }^{166}$

Huomion kiinnittäminen vain teologien hätään sai kuitenkin nopeasti aikaan vastustusta - myös teologien itsensä keskuudessa. ${ }^{167}$ Kirkolliskokous päätti täysistunnossaan myöntää työllistämistukea laajasti tulkittuna kaikille "kirkon virkaan valmistuville". Tällainenkaan rajaus ei tyydyttänyt kaikkia. Hyvinkääläinen insinööri Pekka Kiuttu ja pietarsaarelainen teknikko Svante Österbacka valittivat, että kirkolliskokous oli huolissaan vain kirkon omista työntekijöistä eikä tukenut muita työttömiä. Määrärahan kannattajat vastasivat, että palkatut kirkon työntekijät auttoivat työttömiä ja että kirkon keskusrahaston varat oli käytettävä kirkon omaan työhön. Vaikka kirkolliskokouksen selvä enemmistö kannatti työllistämistukea, keskustelussa näkyi kirkon työntekijöiden ja muiden edustajien välinen jakolinja. ${ }^{168}$ Myöhempien kyselytutkimusten perusteella seurakuntalaiset olivat tyytymättömimpiä kirkon toiminnassa siihen, ettei kirkko ollut heidän mielestään tukenut riittävästi työttömiä. ${ }^{169}$ Vaikka seurakunnat toimivatkin monin tavoin työttömien hyväksi, tutkimustulokset osoittivat, että Kiutun ja Österbackan esittämällä arvostelulla oli laajempaa kaikupohjaa seurakuntalaisten keskuudessa.

Ristiriidat jatkuivat, kun talousvaliokunta ryhtyi mietinnössään tarkentamaan, mitkä työntekijäryhmät olivat oikeutettuja tukeen. ${ }^{170}$ Valiokunnan laatimaan määritte- lyyn havahduttiin istuntosalissa vasta, kun puheenjohtaja oli jo julistanut keskustelun päättyneeksi. Syntyi vielä keskustelu, johon ennen pitkää kytkeytyivät teologiset kysymykset siitä, miten "kirkon virka" oli ymmärrettävä. ${ }^{171}$ Kirkolliskokous joutui talousarviokeskustelussa pohtimaan kysymystä, jonka edessä piispainkokous oli nostanut kätensä pystyyn ja jonka selvittämiseksi kirkolliskokous itse oli juuri asettanut komitean.

Kirkon virkarakenteen teologinen selvittely pääsi kirkolliskokouksessa liikkeelle 1990-luvun puolivälin lähestyessä. Samaan aikaan lama ajoi käytännön ratkaisuihin, jotka muuttivat käsitystä erityisesti pappisviran luonteesta enemmän kuin yksikään virkarakennemietintö vähään aikaan. Mahdollisuus saada pappisvihkimys selvästi aiempaa lyhyempään virkasuhteeseen lisäsi pappisvihkimysten määrää. Samalla yleistyivät väistämättä tilanteet, joissa papiksi vihitty oli töissä muualla kuin kirkossa. Osa-aikaisuus papin työssä taas oli omiaan vahvistamaan ajatusta tarkasti määritellystä työajasta.

\section{PIENESTÄ ALUSTA KAHDEN MILJARDIN MAR- KAN ELÄKERAHASTOKSI}

Kirkon hallinnon ja toiminnan kuluja leikattiin lamavuosina voimakkaasti, mutta talousarvioiden loppusummat jatkoivat kasvuaan. Syynä oli eläkerahasto, joka muodosti kaksi kolmannesta budjetin loppusummasta. Eläkerahastointi aloitettiin 1991, ja seuraavina vuosina eläkerahaston kartuttamista kiihdytettiin entisestään. Kirkolla oli kiire, koska rahastointi aloitettiin myöhemmin kuin muualla julkisella sektorilla. Vuonna 1992 kirkon eläkevastuuksi laskettiin noin 9,5 miljardia markkaa. Kun rahastointiin ryhdyttiin, eläkemaksu muutettiin äyrimäärään sidotusta penniverosta palkkaperusteiseksi maksuksi. Aloitusvuonna 1991 rahastoitiin prosentti palkkasummasta, seuraavana vuonna kaksi ja sen jälkeen viisi prosenttia. Vuoden 1995 lopussa eläkerahastossa oli jo noin 890 miljoonaa markkaa. ${ }^{172} \mathrm{Ne}$, jotka olivat varoitelleet kasvavasta eläkevastuusta ja vaatineet rahastointia, olivat vielä 1980-luvulla jääneet vähemmistöön. Seuraavalla vuosikymmenellä eläkevastuu tiedostettiin aivan toisella tavalla. Vaikka kansantalous oli syöksyssä, eläkerahaston nopeaa kasvattamista arvostelevat edustajat jäivät kirkolliskokouksessa yksinäisiksi.

Talousvaliokunnan pitkäaikaisena tavoitteena oli, että eläkebudjetti erotettaisiin aiempaa selvemmin keskus- 
rahaston muusta talousarviosta. Vuonna 1993 myös kirkon hallinnon keventämiskomitea päätyi samalle kannalle. ${ }^{173}$ Lama-aikana tämä toivomus oli sikälikin tähdellinen, että eläkevarat vääristivät julkista kuvaa kirkon taloudesta: pakon sanelema eläkerahastointi paisutti syvimpinäkin lamavuosina keskusrahaston talousarviota ja peitti alleen muualla talousarviossa toteutetut leikkaukset. ${ }^{174}$ Mielikuva rikkaasta kirkosta vallitsi edelleen melko laajalti 1990-luvun alussa, eikä keskusrahaston talousarvioiden jatkuva kasvu ollut omiaan muuttamaan sitä. ${ }^{175}$

Kirkon keskusrahaston yhtenäinen rakenne ei enää sopinut kasvavan eläkerahaston hallintaan. Esimerkiksi kirkkohallituksen virastokollegiota ei ollut koottu sijoittamistoiminnan näkökulmasta, mutta se joutui vastaamaan koko ajan kasvavasta rahastosta. Kirkolliskokous ja kirkkohallitus olivat yhtä mieltä muutoksen tarpeesta. ${ }^{176}$ Uudistuksen myötä asiantuntijoista koottu johtokunta korvasi virastokollegion rahaston johdossa, ja eläkerahasto muuttui vuoden 1999 alussa erilliskatteiseksi rahastoksi. ${ }^{177}$ Samana vuonna kirkkohallituksessa valmistuivat ohjeet eettisestä sijoittamisesta. Vuoden 1999 lopussa eläkerahaston koko oli jo noin 2,1 miljardia markkaa. ${ }^{178}$ Kirkossa $1990-l u k u$ oli leikkaamisen ja rahastoinnin aikaa, säästämisen ja sijoittamisen vuosikymmen.

Eläkerahaston eriyttämisen myötä suurin osa kirkon keskusrahaston varoista siirtyi kauas kirkolliskokouksen päätöksenteosta. Aivan sama muutos oli tapahtunut eduskunnassa, jonka yksityiskohtainen taloudellinen päätösvalta oli kaventunut olennaisesti yhtiöiden, liikelaitosten ja rahastojen luomisen myötä. Painopiste oli sen sijaan siirtynyt valvontaan. ${ }^{179}$ Merkkejä viimeksi mainitusta ilmiöstä oli havaittavissa kirkolliskokouksessakin: keskusrahaston tilintarkastajien valinta oli ollut pitkään pelkkä muodollisuus, mutta 1990-luvun puolivälissä edustajien keskuudessa oli halukkuutta ottaa tilintarkastuksesta aiempaa tiiviimpi ote. ${ }^{180}$

\section{"KIRKON AIKA" AUTTAMISTYÖSS JA TIEDONVÄLITYKSESSÄ}

"Nyt on kirkon aika", julisti tuomiorovasti Mikko Heikka vastavalitulle kirkolliskokoukselle kevätistuntokaudella $1992 .{ }^{181}$ Yhteiskunnan kriisi kutsui kirkon kantamaan vastuuta ja toimimaan hädänalaisten hyväksi. Varsinkin diakoniatyön vaatimukset kasvoivat. Edellisellä vuosikymmenellä kirkolliskokouksessa oli mietitty niitä tarkkarajaisia toiminta-alueita, joilla diakoniatyöntekijöillä oli vielä tehtävää, mutta 1990-luvulla oli edessä paluu kokonaisvaltaiseen, kaikkia ikäryhmiä koskettavaan auttamistyöhön. ${ }^{182}$ Samaan aikaan vähennettiin virkoja, mikä lisäsi entisestään työntekijöiden uupumusta. Kirkolliskokous oli huolissaan työntekijöiden jaksamisesta. ${ }^{183}$

Vuosikymmenen alussa kirkosta erosi ennätyksellisen paljon väkeä, mutta seuraavina vuosina eroamisluvut romahtivat ja kirkkoon liittyi entistä useampi. Laman myötä yhteisöllisten arvojen merkitys korostui, ja mielipidetutkimuksissa kansalaiset kertoivat arvostavansa kirkkoa. ${ }^{184}$ Tässäkin mielessä 1990-luku osoittautui edetessään kirkon ajaksi. Kirkolliskokousedustajat eivät kuitenkaan tuudittautuneet myönteisiin uutisiin. Keskusteluissa näkyivät uhkakuvat muualta Euroopasta. Vaikka erityisesti kirkon sosiaalinen työ sai osakseen arvostusta, kirkolliskokouksessa oltiin huolissaan tuloksista, joiden mukaan kirkon jäsenten tieto kirkon opista heikkeni jatkuvasti. ${ }^{185}$ Myös uususkontojen ja islamin leviämiseen alettiin kiinnittää huomiota. ${ }^{186}$ Muiden uskontojen kohtaaminen korosti lähetystyön merkitystä, joskin samaan aikaan lama oli omiaan siirtämään huomiota kansainvälisestä työstä kotimaan avuntarpeeseen. Lähetystyössä oli tarvittu jo pitkään sellaisia kohtaamistaitoja, jotka olivat tulossa ajankohtaisiksi myös Suomessa. ${ }^{187}$

Vuonna 1994 kirkolliskokous hyväksyi yksimielisesti Radiolähetysjärjestö Sanansaattajat kirkon viralliseksi lähetysjärjestöksi. Samalla lähetystyön periaatekysymykset nousivat hetkellisesti esiin. Kanta-Espoon kappalainen Marjatta Laitinen kyseenalaisti erillisten lähetysjärjestöjen mallin ja vaati siirtymistä yhteen koko kirkon lähetysväylään. ${ }^{188}$ Muutenkin kannettiin huolta lähetysjärjestöjen välisestä yhteistyöstä ja työnjaosta, jossa toisaalta nähtiin myös muutosta oikeaan suuntaan. ${ }^{189}$ Moneen muuhun teemaan verrattuna lähetystyö pysyi kirkolliskokouksessa kuitenkin taka-alalla. Esimerkiksi piispa Erik Vikströmin kriittiset kysymykset lähetystyön hallinnollisesta asemasta uudessa kirkkohallituksessa jäivät täysin kirkon sopimusvaltuuskuntaa koskeneen keskustelun varjoon. ${ }^{190}$

Laman johdosta valtion kehitysyhteistyövarat laskivat 0,7 prosentista 0,31 prosenttiin kansantuotteesta. ${ }^{191}$ 
Kirkolliskokouksessakaan ei käyty samanlaisia keskusteluja ulkomaisista kriiseistä kuin 1980-luvulla. Asiaan vaikutti sekin, etteivät vaikkapa Ruanda ja Jugoslavia olleet suomalaisille yhtä läheisiä kuin edellisen vuosikymmenen lopun puheenaiheet Namibia ja Inkeri. Kirkolliskokouksessa erityisesti Rauni Rautavuori ja Tapio Saraneva pyrkivät kasvattamaan kirkon ulkomaanavulle maksettavaa tukea kirkkohallituksen ja talousvaliokunnan esittämistä luvuista. He jäivät vähemmistöön, mutta siitä huolimatta kirkon tuessa ei tapahtunut läheskään samanlaista romahdusta kuin valtion kehitysapumäärärahoissa. ${ }^{192}$

\section{Huoli ympäristöstä}

Kemijärveläinen kirkolliskokousedustaja, insinööri Rafael Nyqvist oli pitänyt ympäristöasioita esillä 1970-luvulla. Hänen edustajakautensa jälkeen 1980-luvulla huoli ympäristön tilasta ei kuitenkaan enää näkynyt kokoustyössä. Yllättävästi muutos tapahtui samaan aikaan, kun julkisuudessa keskusteltiin paljon ympäristöuhista ${ }^{\mathrm{I}}$. Vuonna 1983 vihreä liike saavutti ensimmäiset kansanedustajansa, ja muutamaa kuukautta myöhemmin perustettiin ympäristöministeriö. Edelleen samana vuonna Kirkkojen maailmanneuvosto käynnisti niin sanotun ORLE-prosessin, jonka myötä oli tarkoitus kannustaa jäsenkirkkoja toimimaan oikeudenmukaisuuden, rauhan ja luomakunnan eheyden hyväksi ${ }^{\text {II }}$.Vuosikymmenen aikana vakavat teollisuusonnettomuudet - huomattavimpana Tšernobylin ydinvoimalaturma - vauhdittivat prosessia. ${ }^{\text {III }}$

Mielipidetutkimukset osoittivat 1980-luvun lopulla, että kirkon odotettiin ottavan kantaa luonnonsuojeluun. ${ }^{\text {IV }}$ Suomessa ORLE-työskentely pääsikin vauhtiin 1988, jolloin kirkkojen yhteinen Vastuuviikko liittyi ympäristöteemaan. Monet seurakunnat alkoivat laatia ympäristöohjelmia. Vuonna 1991 silloinen kirkon yhteiskunnallisen työn keskus julkaisi yhdessä Kirjapajan kanssa ympäristöraportin Ekologinen elämäntapa, ja muutkin kirkon keskukset käsittelivät ympäristökysymyksiä. ${ }^{\mathrm{V}}$ Kirkolliskokous havahtui ympäristöasioihin 1992. Kahdeksan edustajaa jätti pastori Hannele Revon johdolla aloitteen kirkon ympäristöohjelman laatimiseksi. ${ }^{\mathrm{VI}}$ Kylmän sodan päättyessä rauhantyö menetti entisen ajankohtaisuutensa, ja myös kansainvälisesti huomio siirtyi rauhantyöstä luomakunnan eheyteen. ${ }^{\mathrm{VII}}$ Sama siirtymä näkyi kirkolliskokouksessa.

Kirkon keskukset toimittivat aloitteen käsittelyä varten tietoa ympäristöasioista. Kirkolliskokous päätti lähettää käy-
Vuosikymmenen lopulla avustusinto elpyi yhtä aikaa talouden kanssa. Esimerkiksi inkeriläisten auttaminen, joka oli pysynyt ajankohtaisena yhteiskunnallisessa keskustelussa ja kirkollisten järjestöjen työssä, palasi myös kirkolliskokouksen puheenaiheeksi. Kokous hyväksyi 1999 Suomen ja Inkerin kirkkojen yhteistyöasiakirjan. Osaltaan tähän asiakirjaan vedoten kirkolliskokous myönsi vielä samana vuonna talousarvioaloitteen pohjalta kolme miljoonaa markkaa Pietarin Pyhän Marian kirkon peruskorjaukseen. ${ }^{193}$ Lamavuosien tarkat laintulkinnat, joiden mukaan kirkon keskusrahaston varoja oli mahdollista käyttää vain kirkon omaan toimintaan,

tännössä saman informaation takaisin keskuksille otettavaksi huomioon. Diakonia- ja yhteiskuntatyön keskuksen puheenjohtajan Erik Vikströmin mielestä kirkolliskokouksen toiminta viestitti, että "edustajat nyt vasta heräävät hoksaamaan tämän asian tärkeyttä, joka jo kauan on tiedetty seurakunnissa, kirkkohallituksessa". ${ }^{\text {VIII }}$ Tietyissä seurakunnissa ja kirkkohallituksessa oli ehtinyt tapahtua paljon sillä aikaa, kun kirkolliskokous oli keskittynyt kirkollisten kirjojen ja kirkkolain uudistamiseen.

Kirkolliskokous omaksui 1990-luvulla linjan, jonka mukaan ympäristöä koskevat ohjelmat ja toimenpiteet tuli suunnitella paikallistasolla eikä keskushallinnon määräyksin. ${ }^{\mathrm{IX}}$ Seurakuntien luonnonsuojelu- tai eko-ohjelmat jäivät tosin 1990-luvulla vielä melko harvinaisiksi. ${ }^{\mathrm{X}}$ Sen sijaan kirkolliskokouksen käsittelemät aloitteet osoittivat, että osalla edustajista oli uudenlaista harrastuneisuutta ympäristöasioihin. Aloitteet liittyivät toiseenkin kirkolliskokouksen työskentelyssä näkyneeseen muutokseen. Edustajien kiinnostus puuttua toiminnallisiin kysymyksiin lisääntyi samaan aikaan, kun keskushallinnon uudistuksen myötä toiminnan ohjausvastuu poistui kirkolliskokoukselta.

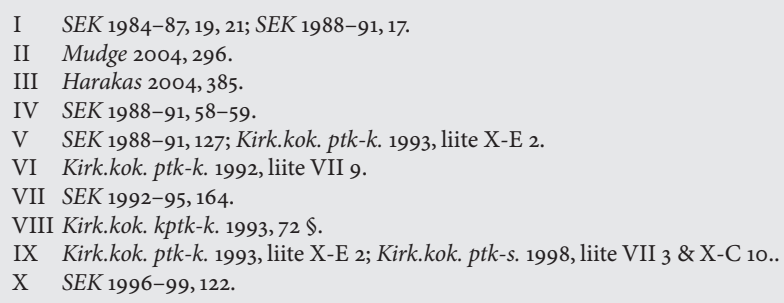


eivät taloudellisesti hyvinä vuosina enää pidätelleet kirkolliskokousta.

Vuonna 1999 kirkolliskokous halusi muutenkin tarjota apua sitä tarvitseville. Taustalla oli osin nähtävissä arvostelu, jota kirkon menoleikkaukset ja rahastointi olivat lamavuosina aiheuttaneet. Lisäksi tuloerot kasvoivat edelleen, ja niin sanotut kovat arvot lisäsivät kannatustaan, mikä sai kirkon edustajat puolustamaan hyvinvointivaltiota. Näkyvin puheenvuoro oli piispojen paastokirje Kohti yhteistä hyvää keväällä 1999. Kirkolliskokous puolestaan hyväksyi riemuvuodelle 2000 kymmenen miljoonan markan erityismäärärahan diakonian avustustoimintaan ja syrjäytymisen ehkäisemiseen. ${ }^{194}$

Tiedotustoiminta säilyi kirkolliskokouksen silmäteränä. Kokous sai kerran toisensa jälkeen todeta, että hartausohjelmien asema Yleisradion ykkösverkossa oli vankka. Siihen ilonaiheet olivatkin monena vuonna jäädä. Kirkolliskokouksessa kiinnitettiin huomiota siihen, että kyseisellä kanavalla oli keskimääräistä vähemmän kuuntelijoita. Varsinkaan nuoria ei sen kautta tavoitettu. ${ }^{195}$ Televisio aiheutti erityisen paljon murhetta: kristillisillä ohjelmilla oli kirkolliskokouksen mielestä niukalti ohjelma-aikaa, ja jos ohjelma-aikoja tarjottiin, ne olivat heikkoja. ${ }^{196}$ Kokouksen toivomia lasten- ja nuortenohjelmia ei saatu käynnistetyksi. ${ }^{197}$

Kirkon tiedotuskeskuksen itselleen asettamia päämääriä moitittiin siitä, että ne olivat kuin minkä tahansa viestintäorganisaation tavoitteita, jotka eivät ottaneet huomioon kirkon omaa tehtävää. Julkisuuteen levinneitä virheellisiä tietoja kirkosta ei myöskään ollut kyetty oikaisemaan tarpeeksi tehokkaasti. ${ }^{198}$ Arvostelua kirjattiin mietintöihin ja lausuttiin pöytäkirjoihin, mutta puolustajat olivat vähissä. Itsekin tiedotustehtävissä parhaillaan työskennellyt helsinkiläinen pastori Jaakko Heinimäki totesi 1996:

Joskus tuntuu siltä, että kaikki muut paitsi tiedottajat ja toimittajat itse tietävät parhaiten, miten heidän hommansa tulisi hoitaa. Tämä pikkuisen tulee mieleen, kun lukee [yleis] valiokunnan arviota kirkon tiedotuskeskuksen toimintakertomuksesta. Saattaa kuitenkin olla, että syy siihen, että me kirkollinen establishment olemme milloin tyytymättömiä Kotimaahan, milloin Aatos Erkkoon ja hänen vehkeisiinsä, milloin kirkon tiedotuskeskukseen ja aika usein kaikkiin näihin vielä yhtä aikaakin, niin se vika voi olla siinä, että odotuk- set medialta ovat usein vähän liian korkeat, joskus jopa ihan mahdottomat, ainakin peräti ristiriitaiset. ${ }^{199}$

Perinteisten kanavien rinnalle oli viestintään tulossa uusi kartoittamaton alue. Vuosituhannen viimeinen vuosikymmen oli tietoteknisen murroksen ja Internetin nousun aikaa. Nopea muutos edellytti toimenpiteitä myös kirkolta. Vuonna 1992 talousvaliokunta suhtautui epäilevästi atk-menojen kasvuun. Valiokunnan tekemistä lähes miljoonan markan menoleikkauksista kaksi kolmasosaa kohdistui näihin määrärahoihin. ${ }^{200}$ Valiokunta kehotti kirkkohallitusta selvittämään, mitä aiemmilla panostuksilla oli saavutettu ja kuinka paljon tietojenkäsittelyn kehittäminen vielä vaatisi määrärahoja. ${ }^{201} \mathrm{Va}-$ liokunnan epäilykset saivat vastakaikua täysistunnossa, jossa insinööri Pekka Kiuttu ehdotti erillistä pontta atk-selvityksestä. Samaa asiaa ajoi Lapuan hiippakunnan pääsihteeri Ossi Haaramäki, joka oli kadottanut uskonsa siihen, "että joku tapsi Helsingistä Lapuan kapituliin tällä vuosituhannella vielä tulisi, josta voisi lukea jotakin ruudusta". Kiutun ponsi hyväksyttiin selvin numeroin. ${ }^{202}$ Hallitsevana ajatuksena oli, että kunhan tietojenkäsittelyä kehitettäisiin tarpeeksi, kustannuspaineet helpottaisivat.

Toive ei toteutunut. Tietojenkäsittelyn kehittämismäärärahat olivat tulleet jäädäkseen. Vaikka kirkkohallituksessa atk-asioita hoidettiin pienellä henkilökunnalla, talousvaliokunnan asenne säilyi nihkeänä. Syksyllä 1994 se leikkasi jälleen kirkkohallituksen esittämiä atkmäärärahoja ja hidasti siten kirkkoneuvos Heikki Mäkeläisen arvion mukaan kirkon pääsyä Internetiin. ${ }^{203}$ Kun sitten vuotta myöhemmin arkkipiispa Vikström avasi kirkolliskokouksen yhteydessä kirkon Internetpalvelun ja toivotti sille Jumalan siunausta, talousvaliokunnan tervehdys oli edelleen kylmä: valiokunta poisti määrärahan atk-suunnittelijan palkkaamiseksi. ${ }^{204}$ Tuohon aikaan Suomessa oli jo suhteellisesti selvästi eniten Internet-yhteyksiä maailmassa. ${ }^{205}$ Asenneilmasto oli kirkolliskokouksessakin vähitellen muuttumassa sitä mukaa kuin tietotekniikan uudet mahdollisuudet selvisivät. Täysistunnossa ei hyväksytty valiokunnan ajatusta, että suunnittelutyön voisi hoitaa ostopalveluina. Määräraha palautettiin talousarvioon. ${ }^{206}$

Näiden tapahtumien jälkeen ei ollut enää paluuta aiempien vuosien asenteisiin. Kirkon yhteisten Internet- 


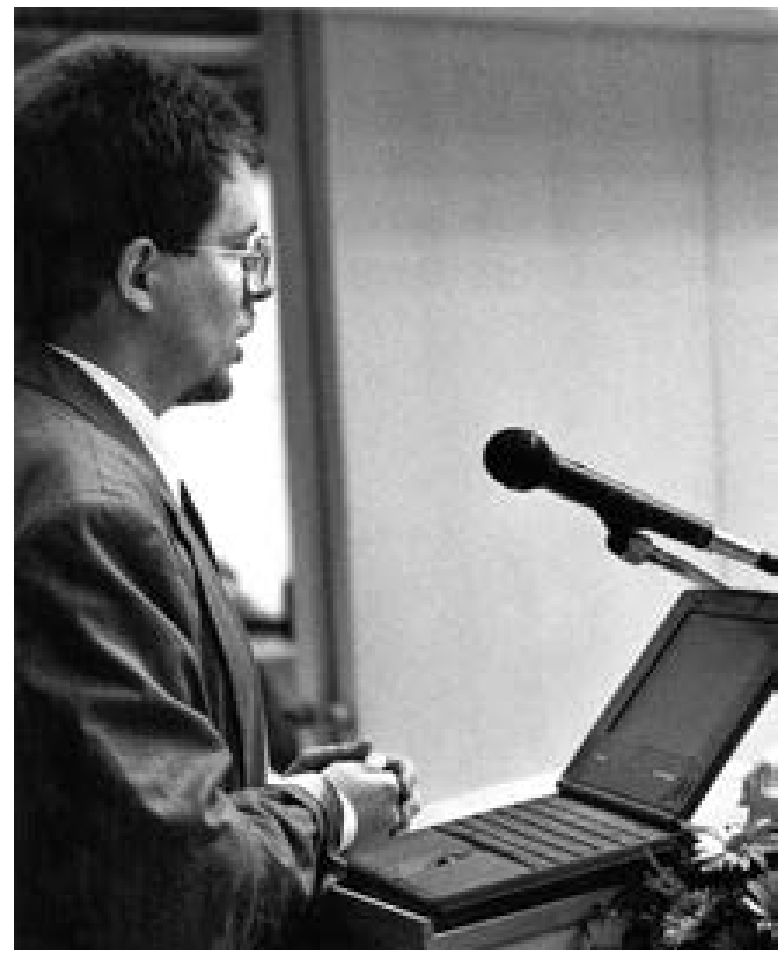

Vuonna 1993 kirkolliskokouksen täysistunnossa pidettiin jo puheita kannettavan tietokoneen ruudulta, mutta kokouksessa oli pitkään epäilyksiä tietotekniikkaa varten suunniteltuja määrärahoja kohtaan. Kuvassa sosiaalipsykologi Pekka Sormunen Helsingin hiippakunnasta. Kuva: Kotimaan kuva-arkisto / Matti Karppinen.

palvelujen käyttö 25-kertaistui vuosina 1996-1999²07. Samalla atk-menoista tuli kirkon keskusrahaston painopistealue, jonka osuus talousarviosta kasvoi jatkuvasti. Suomessa elettiin informaatioteknologian huuman vuosia, eikä kirkolliskokouksessakaan kuultu arvostelua voimakkaasti kasvavia atk-menoja kohtaan. Tietotekniikka lisäsi työn tehokkuutta, eikä kehitys enää kenenkään mielestä näyttänyt polkevan paikallaan. Viimeistään arvostelun vaimensi se seikka, että valtaosa keskusrahaston atk-menoista koitui suoraan paikallisseurakuntien hyväksi. ${ }^{208}$ Seurakuntia palvelemaan valmistui KIRKKO-verkko, jonka "tapsit" ulottuivat Lapuan tuomiokapituliakin pidemmälle. Kysymys ei kuulunut, kuinka kauan vielä piti panostaa tietotekniikan kehittämiseen, vaan kuinka monta miljoonaa määrärahoja tuli kasvattaa edelliseen vuoteen verrattuna.

\section{VALTION KYLJESTÄ KOHTI}

\section{KANSALAISYHTEISKUNTAA}

\section{TUOMIOKAPITULIEN YLLÄPITO JA PIISPOJEN NIMITTÄMINEN KIRKON VASTUULLE}

Arkkipiispa John Vikström totesi keväällä 1992 avatessaan kirkolliskokouksen, että oli hyvä "vailla vähäisintäkään dramatiikkaa" totutella joihinkin muutoksiin kirkon ja valtion suhteissa. ${ }^{209}$ Kirkkolain kokonaisuudistus raivasi tilaa tällaisille muutoksille. Lama taas lisäsi valtion kiinnostusta varsinkin kirkon ja valtion taloussuhteisiin. Oma vaikutuksensa oli myös presidentti Mauno Koivistolla, joka vaati kirkon ja valtion etäännyttämistä toisistaan ja pohti jopa luopumista kirkon virallisesta asemasta. Kotimaan haastattelussa hän totesi, että kirkolla oli vallitsevassa tilanteessa lähinnä oikeuksia mutta ei velvollisuuksia. ${ }^{210}$ Martti Ahtisaaren valinta tasavallan presidentiksi 1994 vähensi muutospaineita, mutta jo seuraavana vuonna keskustelu vilkastui uudelleen, kun Ruotsissa tehtiin periaatepäätös kirkon ja valtion erottamisesta toisistaan vuoden 2000 alusta lukien ${ }^{211}$. Esimerkiksi Helsingin Sanomat vaati pääkirjoituksessaan voimakkaasti kirkon ja valtion eroa. ${ }^{212}$

Lehden saman numeron artikkelissa luotiin voimakas kontrasti naapurimaiden välille: Suomessa "ero olisi monin verroin mutkikkaampaa" kuin Ruotsissa, koska "Suomen luterilaisen valtionkirkon perusta nojaa vuoden 1686 kirkkolakiin, eikä se siitä ole paljoakaan muuttunut". ${ }^{213}$ Tosiasiassa F. L. Schaumanin kirkkolaki ja uskonnonvapauslaki olivat Suomessa katkoneet keskeisimmät kirkon ja valtion väliset sidokset jo kauan ennen kuin Ruotsissa. Vähitellen selvisi myös, että "kirkon ja valtion ero" Ruotsissa merkitsi käytännössä siirtymistä sellaiseen järjestelmään, joka jo vallitsi Suomessa erityisesti ortodoksisen kirkon mutta monin tavoin luterilaisenkin kirkon osalta. ${ }^{214}$ Joka tapauksessa monet paineet vaikuttivat 1990-luvulla siihen, että edelliselle vuosikymmenelle ominainen "uusvaltiokirkollisuus" alkoi antaa tietä kirkon ja valtion välisten sidosten purkamiselle. Tässä mielessä suunta muistutti Ruotsia, jossa kuitenkin murros 1980-luvun voimakkaasta valtiokirkollisuudesta 1990-luvun irrottautumiseen oli huomattavasti rajumpi kuin Suomessa.

Kirkon ja valtion välisten sidosten höllentämistä vaikeutti, että muutosten seurauksia oli monen mielestä 
vaikea ennakoida. Piispainkokouksessa kirkon ja valtion väliset suhteet saivat vertauskuvakseen halkopinon, jota tiettyjen halkojen poistaminen ei heiluttanut mutta joka saattoi toisten halkojen poistamisesta romahtaa. ${ }^{215}$ Vertaus oli kirkolliskokouksessa ahkerassa käytössä: joidenkuiden mielestä tietty uudistus oli vaarassa johtaa arvaamattomiin seurauksiin, kun taas toisten mielestä halkopinoa ei ollut enää edes olemassa. Aivan erityisesti "halkopinosta" oltiin huolissaan, kun käsiteltiin tuomiokapitulien ylläpitoa ja piispojen nimittämistä. ${ }^{216}$ Näiden tehtävien siirtäminen kirkolle oli myös Ruotsissa osa valtion ja kirkon erottamista. ${ }^{217}$ Kaksi tukevaa halkoa oli ollut paikallaan Kustaa Vaasan ajoista. Vaikka monet hiippakuntahallinnon toiminnot olivat Suomessa jo kirkon kustantamia, pitkä perintö sai aikaan varovaisuutta lopullisen askelen edellä.

Kirkolliskokouksen 1989 asettama tuomiokapitulikomitea sai mietintönsä valmiiksi 1994. Piispa Matti Sihvosen johdolla työskennellyt komitea oli selvitellyt niin tuomiokapitulien siirtämistä kokonaan kirkolle kuin hiippakuntahallinnon kehittämistä entiseltä pohjalta kaksijakoisen hallintomallin avulla. Yhteistyö kirkon ja valtion edustajien kesken oli sujunut komiteassa hyvässä hengessä - myös taloudellisten kysymysten osalta. Komitea asettui tuomiokapitulien siirron kannalle. ${ }^{218}$

Vuosina 1994 ja 1995 tuomiokapitulikomitean mietintö oli kirkolliskokouksen näkyvimpiä keskustelunaiheita. Jo lähetekeskustelu osoitti, etteivät edustajat olleet varsinkaan taloudellisesti vaikeana aikana yhtä halukkaita siirtämään tuomiokapitulien ylläpitoa kirkolle kuin komitea. Puhuja toisensa jälkeen vaati kolmatta tietä, yhdistelmää kahdesta tuomiokapitulikomitean selvittämästä mallista. ${ }^{219}$ Erityisen herkäksi asiaksi osoittautui komitean ehdotus, että piispojen nimittäminen siirrettäisiin pois tasavallan presidentiltä. Ehdotus vastasi Kirkko ja valtio -komitean ilmaisemaa kantaa, jonka taakse kirkolliskokouksen enemmistö oli asettunut 1970-luvun lopulla mutta ei enää 1980-luvulla. Vanhan nimityskäytännön tilalle komitea ehdotti kaksivaiheista vaalia, jossa kymmenellä äänioikeutetulla olisi mahdollisuus asettaa ehdokas. Toinen kierros oli tarkoitettu tilanteisiin, joissa kukaan ehdokkaista ei saisi ensimmäisellä kierroksella yli puolta annetuista äänistä. ${ }^{220}$ Ehdotettu vaalijärjestelmä muistutti vastikään käyttöön otettua kaksivaiheista presidentinvaalia.

Joidenkuiden mielestä tuomiokapitulien valtiollinen asema ja piispan nimittämiskäytäntö turvasivat kirkon julkisoikeudellista asemaa ja liittivät kansankirkon myönteisellä tavalla korkeimpaan valtiojohtoon. Muutoksen kannattajat taas katsoivat, että tuomiokapitulit ja piispat kuuluivat kirkolle, eivätkä ehdotetut muutokset siksi vaikuttaneet kirkon ja valtion keskinäisiin suhteisiin. Esityksen arvostelijat sanoivat, että voimassa ollut lainsäädäntö piti piispat varteenotettavina keskustelukumppaneina ja sanankäyttäjinä yhteiskunnassa. ${ }^{221}$ Kuopion tuomiorovasti Matti Järveläinen pelkäsi piispojen joutuvan uudistusten myötä huutelemaan katsomosta. Hänen mielestään oli "uljasta", että vallinnut järjestel-
Suomi voitti jääkiekon maailmanmestaruuden kevään 1995 istuntokauden aattona. Voitto sai osakseen huomiota myös kirkolliskokouksen täysistunnoissa, joskin hyvin hillitysti verrattuna Iltalehden piirroksen antamaan kuvaan. Edustaja Juha Kauppinen kävi kokouksen lomassa mestaruusjuhlissa Turun torilla ja kiitti kirkon puolesta maajoukkuepelaajia. Piirros: Jouko Innanen (Iltalehti 9.5.1995).
Picture removed from the open access version of this book. 
mä pakotti piispan "sille kentälle, jossa yhteiskuntamme asioista vastaavat seisovat ja kaatuvat ja ryvettyvät". ${ }^{222}$ Joidenkuiden muiden mielestä voimassa ollut lainsäädäntö taas rajoitti kirkon toimintamahdollisuuksia. ${ }^{223}$

Keskustelu muistutti sananvaihtoa, jota samaan aikaan käytiin korkeimpien oikeusistuinten valitsemien kirkolliskokousedustajien asemasta: uudistuksen vastustajat vetosivat menneisyyden hyviin kokemuksiin, kannattajat taas tulevaisuuden uhkakuviin, joiden vuoksi ratkaisut oli tehtävä hyvän sään aikana. ${ }^{224}$ Kokonaisuutena lähetekeskustelun henki oli uudistusta kohtaan

\section{Kirkkomuseo väärään aikaan ja väärään paikkaan}

Keskustelu tuomiokapitulien kustannusten siirtämisestä kirkolle sai monet kirkolliskokousedustajat kiinnittämään huomiota kirkon hoitamiin valtiollisiin tehtäviin. Yksi tällainen tehtäväalue oli kulttuurisesti arvokkaan rakennus- ja esineperinnön ylläpito. ${ }^{\mathrm{I}}$ Euroopan yhdentyessä kansallista kulttuuriperintöä alettiin ylipäätään arvostaa uudella tavalla. Kirkossakin havahduttiin siihen, että monissa seurakunnissa arvokas esineistö kärsi huonosta säilytyksestä. Hanke luterilaisen kirkkomuseon perustamiseksi lähti etenemään kirkolliskokouksessa 1995 Helsingin hiippakuntakokouksen esityksestä, jonka taustalla oli hiippakuntakokousedustaja, aforistikko Maija Paavilainen ${ }^{\text {II }}$.

Kirkkohallitus piti museota tarpeellisena ja esitti keväällä 1998, että kirkolliskokous tekisi periaatepäätöksen kirkkomuseon perustamisesta Turkuun. ${ }^{\text {III }}$ Kirkolliskokouksessa myös Kuopio, missä jo sijaitsi ortodoksinen kirkkomuseo, sai tukea varsinkin Itä-Suomen edustajilta. Kirkolliskokous myönsi lopulta kirkkohallitukselle määrärahan kirkkomuseon toteutusvaihtoehtojen selvittämiseksi. ${ }^{\text {IV }}$ Kirkkohallitus vertaili Turkua, Kuopiota ja Pieksämäkeä ja esitti edelleen Turussa Aurakadulla sijainneen koulukiinteistön ostamista museoksi. ${ }^{\mathrm{V}}$

Suunnittelutyön edetessä hankkeen vastustus voimistui kirkolliskokouksessa. Maailmanlaajuinen lama uhkasi, ja kirkko oli menettämässä valtion päätöksellä suuren osan yhteisöverotuotoistaan. ${ }^{\text {VI }}$ Jotkut kyseenalaistivat, saisiko museo esineistöä seurakunnilta. Lisäksi useat vastustajat rinnastivat kalliin museon ihmisten hätään. ${ }^{\text {VII }}$ Kirkolliskokouksessa kuultiin harvoin aplodeja, mutta Raija Sollamo sai sellaiset puheestaan, jonka hän päätti sanoihin: "Pelkään, että - - kirkkomuseon perustava kirkko on itsekin museo."VIII

Lopullisessa äänestyksessä kirkkomuseohanke kaatui äänin $65-31 .{ }^{\mathrm{IX}}$ Monien mielestä leipäjonojen aikakaudella oli niin kriittinen, että arkkipiispa Vikström joutui julkisuudessa korostamaan, ettei lähetekeskustelu kuvastanut koko kirkolliskokouksen kantaa. ${ }^{225}$

Suurin yksittäinen erimielisyys kirkon ja valtion edustajien välillä koski taloudellisia järjestelyjä. Valtiovarainministeriössä hyväksyttiin enintään viiden vuoden siirtymäaika, jonka kuluessa valtio korvaisi kirkolle koko ajan alenevasti tuomiokapitulien ylläpitämisestä aiheutuvia kuluja. ${ }^{226}$ Kirkolliskokouksen mielestä valtiovalta oli vapautumassa pysyvästä velvoitteesta, minkä vuoksi oli pyrittävä pysyvän korvauksen saamiseen. ${ }^{227}$ Jotkut

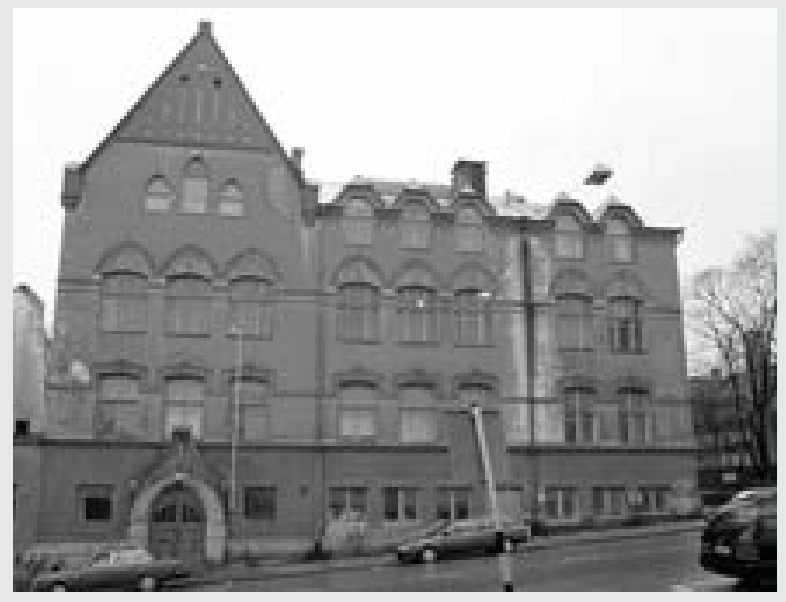

Kirkkomuseon paikaksi suunniteltiin myyntiin tullutta koulukiinteistöä Turun Aurakadulla. Museohankkeen kaaduttua Turun ja Kaarinan seurakuntayhtymä osti ja kunnosti talon. Kuva: Kotimaan kuva-arkisto / Jukka Granström.

väärä hetki toteuttaa museohanke. Tutkimusten mukaan suomalaiset myös pitivät kirkkoa vanhanaikaisena, eikä kirkkomuseon perustamista katsottu parhaaksi keinoksi korjata tätä mielikuvaa. Ortodoksisen kirkon myönteistä julkisuuskuvaa oma museo ei haitannut vaan tuki, mutta luterilaisessa kirkolliskokouksessa historian leima koettiin ongelmaksi. Lopullisesti hankkeen kohtalon sinetöivät ne, jotka kyllä kannattivat museota mutta vastustivat Turkua.

I Kirk.kok. kptk-s. 1994, 45 \$; Kirk.kok. kptk-k. 1995, 33\$.

II Kirk.kok. ptk-k. 1995, liite VII 7; Kirk.kok. ptk-s. 1995, liite VI-E 13.

III Kirk.kok. ptk-k. 1998, liite III 2; SEK 1996-99, 71.

IV Kirk.kok. kptk-k. 1998, 24\$, 61 §.

V Kirk.kok. ptk-s. 1998, liite IV 16.

VI Kirk.kok. kptk-s. 1998, 13 \$; Kirk.kok. ptk-s. 1998, liite X-C 12.

VII Kirk.kok. kptk-s. 1998, 13 \$, 53 §; S. Eskola 2012a, 131.

VIII Kirk.kok. kptk-s. 1998, 53 \$.

IX Kirk.kok. kptk-s. 1998, 53 \$. 
muistuttivat jopa Kustaa Vaasan "ikuisiksi ajoiksi" antamasta lupauksesta hoitaa tuomiokapitulien kustannukset. Toukokuun 1995 tunnelmissa helsinkiläinen korkeakoulupastori Ari Tammi kuitenkin vastasi, että tällaiset lupaukset olivat kumoutuneet ja muutkin ruotsalaisten ylivallan rippeet karisseet, kun "kolmen kruunun miehet polvistuivat suomalaisten kiekkoleijonien edessä". ${ }^{228}$

Valtio oli koko ajan valmis luovuttamaan tuomiokapitulien kiinteistöt kirkolle vastikkeetta. ${ }^{229}$ Kirkolliskokouksessa talouden asiantuntijat eivät kuitenkaan olleet avokätisyydestä erityisen innoissaan. He laskivat suojeltujen rakennusten myöhempiä ylläpito- ja korjauskuluja. ${ }^{230}$ Valtiovarainministeriö toivoi näkevänsä tuomiokapitulilaitoksen miljoonat mahdollisimman pian kirkon budjetissa, mutta opetusministeriöstä saapuneet valtioneuvoston määräämät edustajat eivät kiirehtineet ratkaisua vaan korostivat, että kirkko sai vapaasti harkita kantaansa. ${ }^{231}$

Lausunnonantajista kirkkohallitus, piispainkokous ja tuomiokapitulien enemmistö asettuivat komitean perusratkaisun kannalle. ${ }^{232}$ Piispainkokouksen ja kirkkohallituksen yhteenlasketusta jäsenmäärästä yli neljäsosa kuitenkin vastusti enemmän tai vähemmän tiukasti tuomiokapitulien siirtämistä kirkolle. ${ }^{233}$ Kirkolliskokouksessa vastaava osuus edustajista olisi riittänyt hankkeen kaatumiseen. Lausunnot eivät osoittaneet kirkolliskokoukselle selvää tietä, ja kirkolliskokousedustajat olivat epätietoisia erilaisten vaihtoehtojen vaikutuksista. Ratkaisevinta oli, millaiseksi edustajat arvioivat kirkon vaikutusvallan tuolloin ja vastaisuudessa ${ }^{234}$.

Mielipiteet elivät, eikä istuntosalissa päässyt syntymään selviä rintamalinjoja. Ne, jotka kaikkein voimakkaimmin olivat vastustaneet pappisviran avaamista naisille, kannattivat tuomiokapitulien ja piispannimityksen siirtämistä kirkolle. Näin valtiovalta ei pääsisi Ruotsin tapaan syrjäyttämään piispanvaaleissa menestyneitä naispappeuden vastustajia. Toisaalta vanhoillislestadiolaiset korostivat johdonmukaisesti kristillistä esivaltaa ja vastustivat kirkon ja valtion suhteiden höllentämistä. ${ }^{235}$ Piispoista erityisesti Helsingin piispa Eero Huovinen ja Lapuan piispa Jorma Laulaja vaativat piispainkokouksen lausuntoon viitaten laajempaa selvitystä kirkon ja valtion suhteista. ${ }^{236}$ Heidän kantansa oli siis hyvin samanlainen kuin korkeimpien oikeusistuinten ja kirkolliskokouksen välistä suhdetta käsiteltäessä.
Asian painoarvo näkyi valiokuntatyössä. Perustevaliokunta valmisteli lausuntonsa hallintovaliokunnalle perinpohjaisesti. ${ }^{237}$ Mikkelin piispan Voitto Huotarin johdolla toimineen hallintovaliokunnan paneutumista taas kuvastivat asiantuntijasihteerien käyttö ja korkean tason asiantuntijakuulemiset. ${ }^{238}$ Hallintovaliokunnan ensimmäinen periaatteellinen ehdotus muistutti kirkolliskokouksen 1980-luvun kantoja: tuomiokapitulien ylläpito siirrettäisiin kirkolle, mutta presidentti nimittäisi edelleen piispat. Hallintovaliokunnan mielestä tuomiokapitulien ylläpito ei ollut kirkon ja valtion suhteiden osatekijä mutta piispojen nimityskäytäntö oli. ${ }^{239}$ Lähetekeskustelussa arvostelu oli kohdistunut kaikkein voimakkaimmin piispan nimityskäytännön muuttamiseen, joten hallintovaliokunta saattoi myös laskea, ettei kahden halon siirtäminen kirkon pinoon samanaikaisesti saisi välttämättä taakseen tarvittavaa määräenemmistöä. ${ }^{240}$

Piispan vaalitavan osalta hallintovaliokunta seurasi piispainkokouksen ja perustevaliokunnan kantaa ja esitti ehdokasasettelun sijaan koevaalia. Näin ehdokkaat eivät joutuisi pyrkimään piispaksi. Vastaavasti tasavallan presidentille oli tarkoitus esittää vain yksi ehdokas, joka presidentillä olisi oikeus joko nimittää tai olla nimittämättä. ${ }^{241}$ Valiokunta halusi siis säilyttää presidentin nimitysvallan mutta aiempaa rajoitetumpana, samassa muodossa kuin ortodoksisten piispojen osalta. Valiokunnan vanavedessä kirkolliskokous hyväksyi komitean ehdotuksen, jonka myötä piispan maallikkovalitsijoiden määrä nostettiin yhtä suureksi äänioikeutettujen pappien ja lehtorien määrän kanssa. Samalla kyseisestä hiippakunnasta kirkolliskokoukseen valitut maallikkoedustajat saivat äänioikeuden. ${ }^{242}$

Hallintovaliokunnan enemmistö päätyi ehdottamaan tuomiokapitulien ylläpidon siirtämistä kirkolle, vaikka talousvaliokunnan ja perustevaliokunnan lausunnot olivat varauksellisia. ${ }^{243}$ Perustevaliokunnan lausuntoon heijastui valiokunnan puheenjohtajan Eero Huovisen kielteisyys uudistusta kohtaan. ${ }^{244}$ Valiokuntien välinen asetelma oli hyvin samanlainen kuin laki- ja perustevaliokunnan välinen suhde käsiteltäessä korkeimpien oikeusistuinten valitsemaa kirkolliskokousedustusta: laki- ja hallintovaliokunta päätyivät puhdaslinjaisiin periaatteellisiin ratkaisuihin, kun taas perustevaliokunta toimi molemmissa tapauksissa "tarkoituksenmukai- 
suusvaliokuntana”. Se katsoi teologisista perusteista käsin, että kyse oli asioista, joita tuli arvioida käytännön seurausten mukaan.

Kun hallintovaliokunnan mietintö tuli täysistuntokäsittelyyn, yleinen asenne tuomiokapitulien siirtämistä kohtaan oli huomattavasti myönteisempi kuin lähetekeskustelussa. ${ }^{245}$ Yhtenä syynä saattoi olla laman taittuminen: kirkon taloudellinen tulevaisuus ei enää näyttänyt yhtä synkältä kuin aiemmin. Monen edustajan kannassa näytti tapahtuneen myös valtion tehtävien hahmottamista koskeva periaatteellinen muutos, joka näkyi jo hallintovaliokunnan mietinnössä. Asiantuntijalausuntojen pohjalta tuomiokapitulien siirto alettiin nähdä osana siirtymistä huoltajavaltiosta kohti kansalaisyhteiskuntaa ${ }^{246}$.

Seitsenkymmenluvun huoltaja- tai holhousvaltio oli pyrkinyt keskittämään kaikki arvostamansa toiminnot itselleen. Julkishallinnon oli ajateltu ratkaisevan yhteiskunnalliset ongelmat. Yhä 1990-luvulla kirkossa monet ajattelivat huoltajavaltion aikakaudelle ominaisesti, että kirkon arvostus oli kiinni kirkon ja valtion hallinnollisista suhteista. Tosiasiassa oli alkanut siirtymä kohti kansalaisyhteiskuntaa: valtio oli luopunut monista tehtävistä ja hoiti niitä yhteistyössä muiden toimijoiden kanssa. Siten kirkossakin oli aika siirtyä hallinnollisten siteiden ajasta yhteistyön aikaan. Varsinkin professori Markku Temmes selvitti asiantuntijanlausunnossaan tätä kehityslinjaa. ${ }^{247}$ Hallintovaliokunnan organisatorinen analyysi jätti varjoonsa perustevaliokunnan esiin nostamat, julkiseen valtaan kohdistuneet uudenlaiset eettiset odotukset. ${ }^{28}$ Kun tuomiokapitulien siirron edellytykseksi määriteltiin, että valtion oli korvattava tuomiokapitulien ylläpitokustannukset vallinneen kustannustason mukaisesti, kirkolliskokous asettui äänin 91-10 periaatteellisesti siirron kannalle. Lähtökohtiin nähden tulos oli yllättävän yksimielinen. ${ }^{249}$

Uudistukseen kytkeytyi teologisia ja muita kirkon sisäisiä kysymyksiä. Piispainkokous ja monet kirkolliskokouksessa istuvat hiippakuntatason viranhaltijat pelkäsivät, että tuomiokapitulit menettäisivät uudistuksen myötä itsenäisyyttään suhteessa kirkon keskushallintoon. Kaikkia pelkoja ei hälventänyt sekään, että hiippakunnallisten virkojen perustaminen ja lakkauttaminen päädyttiin siirtämään kirkkohallitukselta hiippakuntiin..$^{250}$ Vielä 1970-luvulla piispat olivat valitelleet, että tuomiokapitulien valtiollinen asema oli vakava rasite, joka vaikeutti hiippakunnallisen toiminnan kehittämistä. Kaksi vuosikymmentä myöhemmin olisi joistakin puheenvuoroista voinut melkeinpä päätellä, että valtiovalta oli hiippakuntien itsenäisyyden paras turva kirkkohallituksen ylivaltaa vastaan.

Piispojen nimittäminen taas kytkeytyi kirkon virkateologiaan. Hallintovaliokunnan ehdotus koevaalista pohjautui ajatukseen, että kirkossa oli vältettävä piispaksi pyrkimistä ja henkilökohtaista vaalitaistelua. Ehdotettu vaalijärjestelmä ei kuitenkaan kaikkien mielestä ilmaissut valitsijoiden kantaa riittävän yksiselitteisesti. Kirkolliskokous päätyi täysistunnossaan periaatteellisesti professori Seikko Eskolan esittämään vaihtoehtoon, joka sisälsi koevaalin ja varsinaisen vaalin ohella mahdollisen toisen kierroksen eniten ääniä saaneiden kesken. ${ }^{251}$ Sama kirkolliskokous, joka oli hieman aiemmin kovaäänisesti vaatinut kirkon hallinnon keventämistä, oli muuttamassa piispanvaalia yksivaiheisesta enimmillään kolmivaiheiseksi. Oli huomattavasti helpompaa esittää periaatteellisia vaatimuksia kuin toimia käytännössä niiden mukaan.

Piispa Yrjö Sariola ehdotti, että piispan nimittäminen siirrettäisiin kirkolle, mutta hänen ehdotuksensa hävisi melko niukasti äänin 53-44. Kirkolliskokous pysyi hallintovaliokunnan kannalla myös siinä, että presidentille oli määrä tarjota vain yksi ehdokas nimitettäväksi. ${ }^{252}$ Kun päätöksenteon aika oli käsillä syksyllä 1995, kirkolliskokouksessa keskusteltiin lähinnä piispanvaalista ja piispojen nimittämisestä. Tuolloin kevään periaatepäätös näytti ristiriitaiselta, koska kirkon ja valtion kytkös vain korostuisi, mikäli presidentti nimittäisi kirkon palkkaaman henkilön. ${ }^{253}$

Nimitystehtävän siirtämistä kirkolle vaikeutti kuitenkin uusi pulma. Hallitusmuodon uudistushanke, jonka myötä virkanimityksiä koskevia säännöksiä oli tarkoitus siirtää hallitusmuodosta erityislakeihin, oli kaatunut vähän aiemmin presidentti Ahtisaaren vastustukseen. Näin ollen tasavallan presidentin tehtävänä oli hallitusmuodon mukaan edelleen nimittää luterilaisen ja ortodoksisen kirkon piispat. Hallitusmuodon muuttaminen vain luterilaisen kirkon osalta olisi saattanut nämä kirkot keskenään erilaiseen perustuslailliseen asemaan. Tässä tilanteessa valtioneuvoston määräämä edustaja, opetusministeriön hallitusneuvos Lauri Lehto- 
nen rohkaisi kirkolliskokousta pidättymään muutoksesta. Jälleen kerran opetusministeriön viranhaltija varoitti kirkon ja valtion suhteiden liian nopeasta höllentämisestä. ${ }^{254}$

Keskustelun edetessä kirkolliskokouksen vaihtoehdot rajautuivat entisestään: tasavallan presidentin kansliasta saapui tieto, että presidentille oli tarkoituksenmukaista tarjota useampi kuin yksi ehdokas, mikäli nimitysvalta säilytettiin edelleen hänellä. ${ }^{255}$ Vastaus oli sikäli mielenkiintoinen, että kirkolliskokouksessa oli kannettu huolta luterilaisen ja ortodoksisen kirkon lainsäädännöllisen aseman keskinäisestä vastaavuudesta. Ei haluttu tehdä yksipuolisia ratkaisuja, jotka loisivat painetta myös ortodoksisen kirkon aseman muuttamiseen. ${ }^{256}$ Kun sitten hallintovaliokunta ehdotti luterilaisen kirkon piispoille nimityskäytäntöä, joka oli käytössä ortodoksisessa kirkossa, ratkaisu ei ollutkaan presidentin kanslialle mieleinen. Sellaiset symboliset kytkökset, joilla voitiin korostaa ortodoksisen kirkon kansankirkollista asemaa, eivät sopineet enemmistökirkon osalle.

Päällimmäiseksi vaihtoehdoksi jäi, että presidentille esitettäisiin edelleen kolme ehdokasta nimitystä varten. Hallintovaliokunta ja monet kirkolliskokousedustajat olivat lisäksi alkaneet välittömästi arvostella keväällä periaatteellisen tuen saanutta kolmivaiheista vaalia liian raskaaksi vaalitavaksi ${ }^{257}$. Joensuun kirkkoherra Petri Karttunen teki muutosehdotuksen, jonka mukaan koevaalin jälkeen olisi vain yksi kierros: kolme eniten ääniä saanutta sijoitettaisiin perinteiseen tapaan ehdokassijoille ja esitettäisiin tasavallan presidentille. Kirkolliskokous asettui Karttusen ehdotuksen taakse. ${ }^{258}$ Kokouksen kanta oli 1970-luvulla ollut, että valtion tuli kustantaa tuomiokapitulien ylläpito mutta kirkon nimittää piispat. Kaksi vuosikymmentä myöhemmin lopputulos oli täysin päinvastainen.

Tuomiokapitulien siirtäminen valtiolta kirkolle eteni, ja valtion sekä kirkon edustajat kävivät neuvotteluja kustannusten korvaamisesta. Jotkut kirkolliskokousedustajat epäilivät kirkon neuvotteluasemia ja valtion halukkuutta korvata kustannuksia, mutta neuvotteluihin osallistuneet kiittelivät keskustelujen hyvää henkeä. ${ }^{259}$ Lopulta ratkaisuvaiheessa asia ei enää aiheuttanut suuria intohimoja. ${ }^{260}$ Tuomiokapitulit siirtyivät kirkolle vuoden 1997 alussa, ja pian Jaakko Nummisen johtama toimikunta esitti, että valtio korvaisi kustannukset alen- tamalla pysyvästi kirkon työnantajana maksamaa sosiaaliturvamaksua. Vuonna 1986 kirkolliskokouksen kanta oli ollut, että tuomiokapitulien siirtämistä kokonaan kirkolle tuli tutkia pitkän tähtäimen ratkaisuvaihtoehtona. Asiat etenivät 1990-luvun puolivälissä kuitenkin vinhaan, ja niin tämä "pitkän tähtäimen ratkaisuvaihtoehto" toteutui nopeammin kuin monet kiireellisiksi julistetut kirkolliset uudistukset.

Myöskään piispanvaali ei jäänyt pitkäksi aikaa ennalleen. Turun arkkihiippakunnan hiippakuntakokouksen esityksestä kirkolliskokous päätti jo 1998 ryhtyä muutoksiin ehdokasasettelun toteuttamiseksi. Taustalla olivat kielteiset kokemukset erityisesti ensimmäisestä Turun piispan vaaliprosessista. ${ }^{261}$ Kirkkohallituksen laatima esitys vastasi Sihvosen komitean ehdottamaa vaalitapaa: presidentin nimitysvallasta luovuttiin, ja siirryttiin ehdokasasetteluun sekä kaksivaiheisuuteen. Muutoksen mahdollisti osaltaan se, että perustuslakiuudistuksen myötä nimityssäännösten siirto hallitusmuodosta tavallisiin lakeihin oli jälleen etenemässä. Lisäksi presidentti Ahtisaari ilmoitti syyskuussa 1998 toimitetun arkkipiispanvaalin jälkeen, että hän toivoi nimitystehtävän siirtämistä kirkolle. ${ }^{262}$

Kun kirkolliskokous keskusteli lakimuutoksesta toukokuussa 1999, SDP:n presidenttiehdokkaaksi oli jo valittu ulkoasiainministeri Tarja Halonen, joka ei kuulunut kirkkoon. Keskustelun henkilöitymistä ei täysin vältetty. ${ }^{263}$ Ratkaisevassa äänestyksessä lakimuutokset hyväksyttiin niukasti äänin 78-24. ${ }^{264}$ Alin määräenemmistövaatimus ylittyi yhdellä äänellä. Muutos astui voimaan uuden perustuslain kanssa 1. maaliskuuta 2000 eli sattumalta samana päivänä, jona katkesi kirkkoon kuuluneiden presidenttien pitkä ketju. Kirkkolain kokonaisuudistus, jonka jälkeen "kirkon ylin hallitus koko maassa" ei enää ollut "valtakunnan hallituksen asia", avasi tien monien pinnan alla kyteneiden uudistusvaatimusten nopeaan toteutumiseen. Tuomiokapitulit sekä piispannimitys siirtyivät kirkolle, ja korkeimpien oikeusistuinten valitsemat kirkolliskokousedustajat jäivät pois. Ainakin tässä mielessä "halkopino" näytti siis olevan olemassa. Muutosvauhti olisi saattanut olla vieläkin nopeampi, ellei ortodoksisen kirkon vahva valtiollinen asema olisi jarruttanut irtaantumisyrityksiä.

Vuonna 1999, kun säännös tasavallan presidentistä piispojen nimittäjänä oli voimassa viimeistä vuotta, 


\section{Picture removed from the open access version of this book.}

Kirkolliskokouksen puheenjohtajat arkkipiispa Jukka Paarma, ylilääkäri Timo Sahi ja dosentti Kyllikki Tiensuu tervehtivät tammikuun 2000 ylimääräiselle istuntokaudelle saapunutta kokoomuslaista kulttuuriministeriä Suvi Lindéniä. Pian oli tulossa voimaan lakimuutos, jonka mukaan ministeri ei enää esitellyt piispannimityksiä tasavallan presidentille. Kuva: Kotimaan kuva-arkisto / Bo Strandén.

luterilaisen kirkon piispat ottivat historiallisen voimakkaasti kantaa hyvinvointivaltion puolesta. Eero Huovisen johtaman "nälkäryhmän" lausumia tavoitteita kirjattiin Paavo Lipposen toisen hallituksen ohjelmaan. Piispojen paastokirje Kohti yhteistä hyvää, jossa piispat arvostelivat yksipuolista markkinatalouden ihannointia ja muistuttivat hyvinvointiyhteiskunnan luterilaisesta perustasta, sai aikaan vilkkaan keskustelun. ${ }^{265}$ Arvostelijat, joita löytyi lähinnä poliittisesta oikeistosta, syyttivät piispoja populismista. ${ }^{266}$

Kirkon ja valtion suhteiden muuttamista vaatineiden kirkolliskokousedustajien mielestä kirkko oli ottanut tärkeitä askelia kansalaisyhteiskuntaa kohti ja itsenäistynyt henkisesti valtiosta. Tästä näkökulmasta saattoi tulkita, että piispat valmistivat kannanotoillaan tietä uudenlaiseen ajattelutapaan, jossa he eivät enää olleet sidoksissa ylimpään valtiovaltaan vaan saattoivat arvostella sitä vapaasti. Vai oliko sittenkin kyse siitä, että piispat toimivat vielä viimeistä kertaa näkyvästi yhteiskunnan pelikentällä - julkisuutta saaden mutta myös kolhuille altistuen - ennen siirtymistään katsomoon huutelemaan? Molemmat tulevaisuuden ennustukset oli lausuttu kirkolliskokouksessa 1990-luvun kuluessa.

\section{VALTIO UHKAA VIED ̈̈ "KERMAN" VÄESTÖKIRJANPIDON TEHTÄVÄNJAOSSA}

Tuomiokapitulien siirtäminen kokonaan kirkolle sopi yleislinjaan, jonka mukaan valtio pyrki 199o-luvulla karsimaan tehtäviään. Sen sijaan vuosikymmenen alussa oli suunnitteilla täysin päinvastainen muutos. Sisäasiainministeriö kaavaili tiettyjen väestökirjanpidon tehtävien siirtämistä valtiolle. Jo 1984 kirkolliset väestörekisterinpitäjät oli asetettu väestökirjanpitoa koskevissa sisällöllisissä kysymyksissä valtion viranomaisten ohjaukseen ja valvontaan $^{267}$. Seuraavassa uudistuksessa tietojen ylläpitäminen ja päivittäminen oli ehdotuksen mukaan määrä siirtää valtiolle, jolta kirkko joutuisi ostamaan jäseniään koskevat tiedot. Seurakunnat olisivat velvollisia ylläpitämään arkistoja siirtoajankohdasta taaksepäin ja luovuttamaan niistä tietoja. Vuonna 1994 kirkolliskokouksen tehtäväksi tuli antaa lausunto ehdotetuista uudistuksista. ${ }^{268}$ Täysistunnossa professori Gustav Björkstrand tiivisti uudistuksen taloudelliset vaikutukset siten, että yhteiskunta oli kuorimassa "kerman pois" ja jättämässä ikävän työn kirkon hoidettavaksi. ${ }^{269}$

Asian käsittelyä kirkolliskokouksessa hillitsi hieman, että kulttuuriministeri Tytti Isohookana-Asunmaa puhui juuri ennen lähetekeskustelua valtioneuvoston kahvitilaisuudessa. Hän esitti pelin viheltämistä poikki, koska asia vaati hänen mukaansa vielä paljon lisäselvi- 
tyksiä. ${ }^{270}$ Siitä huolimatta sananvaihto oli vilkasta. Periaatteellisesti oli kyse samasta kirkon ja valtion työnjaosta kuin monissa muissakin ajankohtaisissa muutoshankkeissa. Kirkon näkökulmasta tarkoituksenmukaisuuskysymykset olivat kuitenkin erityisen painavia juuri väestökirjanpidon osalta. Taloudellisesti uudistus katsottiin kalliiksi niin kirkolle kuin valtiolle. Tuomiorovasti Mikko Heikan mielestä kyse oli "kansantaloudellisesta haaskauksesta”. Moni edustaja kiinnitti huomiota myös siihen, ettei valtio pystynyt tarjoamaan läheskään samanlaista palvelupisteiden verkkoa kuin kirkko. Näin suurimmalla osalla kansasta palvelutaso oli uudistuksen myötä heikentymässä. ${ }^{271}$

Aivan erityisesti kirkolliskokousedustajien silmäteränä oli kuitenkin kirkon tehtävän toteuttaminen: elämän iloissa ja suruissa oli kyse muustakin kuin lomakkeiden täyttämisestä. Asioiden hoitaminen kirkkoherranvirastossa tarjosi mahdollisuuden sielunhoidolliseen keskusteluun. Lisäksi voimassa olleen järjestelmän puitteissa ei tarvinnut asioida kahdessa toimipisteessä. Moni oli huolissaan myös kirkollisten toimitusten tulevaisuudennäkymistä, mikäli rekisteriasioiden hoitamisen jälkeen pitäisi saapua vielä erikseen kirkkoherranvirastoon sopimaan toimituksista. Toimittaja Mauno Hyyryläinen, joka oli kirkon ja valtion välisten siteiden voimakkaimpia puolustajia, maalasi tulevaisuuden uhkakuvia:

Jos kirkko luopuu nyt väestökirjanpidosta, se menettää lapsen pesuveden mukana. Lapsi jää kastamatta. Hän ei tule pyhäkouluun, ei päiväkerhoon, ei partioon, ei rippikouluun. Hän ei kysele kirkollista kuulutusta eikä kristillistä avioliittoa.

Jos nyt veräjä avataan, niin lampaat karkaavat seurakunnasta maailmaan. ${ }^{272}$

Perustevaliokunta nojautui kirkkohallituksen laatimiin lausuntopohjiin, joiden ansiosta valiokunnan mietintö oli valmis parissa päivässä. Ehdotuksen toteuttamiseen ei nähty riittäviä perusteita. Sen vuoksi valiokunta ei edes selvittänyt, millaisia kirkkolain muutoksia ehdotus edellyttäisi. ${ }^{273}$ Kirkolliskokous muun muassa totesi ehdotuksen johtavan palvelujen heikkenemiseen. Uudistusehdotus oli periaatteellisestikin ongelmallinen, koska väestökirjanpidon osa-alueista juuri arkistojen ylläpitäminen liittyi kaikkein löyhimmin kirkon oman tehtävän toteuttamiseen. Kaiken lisäksi tämä tehtävä oli kirkolliskokouksen mukaan työläin osa väestökirjanpitoa. Kir- kolliskokous piti parhaana vaihtoehtona yhteisen väestötietojärjestelmän luomista. Seurakunnat päivittäisivät sitä omien jäsentensä osalta ja saisivat vastineeksi jäseniään koskevat tiedot. ${ }^{274}$ Hieman myöhemmin ortodoksisen kirkon ylimääräinen kirkolliskokous asettui samalle kannalle. ${ }^{275}$

Keväällä 1997 Turkuun saapui sisäasiainministeriöltä lausuntopyyntö uudesta suunnitelmasta. Ehdotus noudatti kirkolliskokouksen kolme vuotta aiemmin hahmottelemia linjoja. Seurakunnat eivät olisi enää väestörekisterinpitäjiä, mutta ne saisivat silti hoitaa tiettyjä viranomaistehtäviä, kuten tutkia avioliiton esteitä ja antaa virkatodistuksia. Näin kirkon jäsenten ei tarvitsisi uudistuksen jälkeenkään asioida kahdessa paikassa. Kirkon elimet suhtautuivat ehdotukseen suopeasti. Se oli luontevaakin, koska ehdotusta laatimassa olivat olleet kirkkohallituksesta kirkkoneuvos Matti Halttunen ja tarkastaja Erkki Huhta. ${ }^{276}$

Uusi yhteistyöhön perustunut järjestelmä otettiin käyttöön 1999. Uudistus oli valtiolle edullinen, koska se sai käytännössä ilmaiseksi käyttöönsä kirkon ylläpitämän rekisterin. ${ }^{277}$ Kirkon voitto oli kuitenkin se, että seurakunnat säilyttivät tärkeän yhteyskanavan jäseniinsä. Lama-aikana kasvanut kirkon arvostus saattoi osaltaan vaikuttaa siihen, että uudistuksen luonne muuttui vuodesta 1994 vuoteen 1997. Alkuperäisessä ehdotuksessa näkyi negatiivinen uskonnonvapauskäsitys, jonka mukaan uskonnonharjoitus oli erotettava rekisteröintitoimista. Sen sijaan kirkolliskokouksen lausuntoja leimasi positiivinen uskonnonvapauskäsitys: väestörekisteritietoja päivitettäessä oli luontevaa tarjota mahdollisuus sielunhoitoon ja kirkollisiin toimituksiin.

\section{USKONNONOPETUKSEN}

\section{PUOLUSTAMISEN VUOSI 1992}

Koulujen uskonnonopetus ei periaatteessa ollut osa kirkon ja valtion suhteiden kokonaisuutta, vaan se kuului valtion sääntelemään koulujärjestelmään. Käytännössä uskonnonopetus liittyi kuitenkin kiinteästi siihen keskusteluun, jota kirkolliskokouksessa käytiin 1990-luvulla kirkon ja valtion suhteista. Maaliskuussa 1992 valmistui opetusministeriön tuntijakotyöryhmän mietintö, josta lausunnon antaminen oli uuden kirkolliskokouksen ensimmäisiä tehtäviä. Koulutuspolitiikassa suosittiin tuohon aikaan kevyitä rakenteita, joustavuutta 
ja valinnaisuutta, joiden avulla pyrittiin vastaamaan työelämän muutoksiin: tarpeet olivat eriytyneet ja liukuhihnatyö korvautunut entistä useammin luovuutta edellyttävillä tehtävillä. Tuntijakotyöryhmän keskeisiä periaatteita olivatkin valinnaisuuden lisääminen ja opetussuunnitelmia koskevan päätösvallan siirtäminen alaspäin kuntatasolle. Matemaattisluonnontieteellisten aineiden osuutta lukiossa pyrittiin vahvistamaan, ja vastaavasti katsomusaineiden rakennetta oltiin muuttamassa ratkaisevasti. Lukion viisi pakollista uskonnon kurssia olivat supistumassa yhteen. Etiikka oli määrä erottaa omaksi kaikille yhteiseksi aineekseen, ja lisäksi filosofia oli tulossa kaikille yhteiseksi katsomusaineeksi. Niin etiikan kuin filosofian osuus otettiin siis aiemmin uskonnolle ja elämänkatsomustiedolle kuuluneesta kurssimäärästä. ${ }^{278}$

Pitkin kevättä 1992 piispat arvostelivat voimakkaasti työryhmän mietintöä. Erityisen lyhytnäköisenä he pitivät uskonnon tuntimäärän vähentämistä samaan aikaan, kun kansainvälistyminen eteni ja uskontojen kirjo monipuolistui. Muualla Euroopassa päinvastoin kaavailtiin uskonnonopetuksen lisäämistä. ${ }^{279}$ Uutta tuntijakoa suunniteltiin porvarihallituksen alaisuudessa, mutta piispat saivat kannanotoilleen tukea juuri porvarilliselta lehdistöltä. ${ }^{280}$ Avatessaan kirkolliskokouksen arkkipiispa Vikström mainitsi tuntijakotyöryhmän ehdotuksen yhtenä esimerkkinä Suomessa alaa vallanneesta negatiivisesta uskonnonvapauskäsityksestä: "Meidän on aiheellista sanoa mahdollisimman yksiselitteisesti, ettei suomalaisella yhteiskunnalla ole varaa lähteä sellaisen kokeilun tielle, mitä uskonnonopetuksen ja siihen sisältyvän etiikan opetuksen voimakas supistaminen merkitsisivät yhteisönormiemme ja koko kulttuurimme kannalta." ${ }^{281}$

Arkkipiispan sanat viitoittivat tien asian käsittelylle kirkolliskokouksessa. Laaja yksimielisyys vallitsi siitä, että oikeudenmukainen opetusmäärä uskonnolle olisi kolme pakollista ja kaksi syventävää kurssia. Sen sijaan tunnustuksellisen uskonnonopetuksen käsite herätti keskustelua. Kirkon kasvatusasiain keskuksen johtokunnan puheenjohtaja Gustav Björkstrand piti tunnustuksellisuuteen kiinnittymistä syynä siihen, että uskonnonopetuksen asema lukiossa oli huononemassa ja ettei ammatilliseen koulutukseen ollut saatu vakiinnutetuksi katsomuksellista opetusta. Varsinkaan lama-aikana oppilaiden jakaminen eri opetusryhmiin uskontokunnan perusteella ei näyttänyt taloudellisesti tarkoituksenmukaiselta. Björkstrandin mukaan kirkon vaatimus tunnustuksellisesta opetuksesta antoi kuvan, että kirkko halusi edelleen holhota koululaitosta. Kirkolliskokouksessa alettiinkin pohtia, mitä kursseja olisi mahdollista opettaa kaikille yhteisesti. Björkstrand, joka osallistui myös julkisuudessa aktiivisesti etiikanopetusta koskevaan keskusteluun, kannatti etiikan ja maailmanuskontojen opettamista kaikille yhteisesti. ${ }^{282}$

Kouluneuvos Samuel Lindgrén, joka oli sekä tuntijakotyöryhmän että kirkolliskokouksen jäsen, ei halunnut ottaa kantaa työryhmänsä mietintöön. Hän piti kuitenkin työvoittona, että uskonnonopetus erillisenä aineena oli sentään säilynyt, ja muistutti, että moni lukiolainen kertoi syyksi kirkosta eroamiselleen halun päästä mukaan elämänkatsomustiedon opetukseen. Entinen ministeri Björkstrand ja opetushallituksen viranhaltija Lindgrén tunsivat realiteetit ja katsoivat asiaa paitsi kirkon myös valtion näkökulmasta. Heidän puheenvuoroistaan huolimatta yleinen asenne keskustelussa oli, että kirkolliskokouksen oli puolustettava uskontokuntien mukaan jaotettua uskonnonopetusta, josta ei saanut erottaa etiikkaa kaikille yhteiseksi oppiaineeksi. ${ }^{283}$

Täysistunnossa esitetyt kannanotot saivat jatkoa valtioneuvoston kahvitilaisuudessa, jossa ministeri Isohookana-Asunmaa asettui oman ministeriönsä tuntijakotyöryhmää vastaan. Hän arvosteli lukion katsomuksellisen opetuksen pirstaloimista, uskonnonopetuksen tuntimäärän rajua leikkaamista ja eettisen opetuksen erottamista uskonnollisesta arvopohjasta. ${ }^{284}$ Puheenvuoro antoi rohkeutta lausuntoa valmistelevalle perustevaliokunnalle. Samalla se osoitti ministerien välisiä jännitteitä opetusministeriössä. Kokoomuslainen opetusministeri Riitta Uosukainen ei halunnut julkisesti ottaa kantaa uskonnonopetusta koskevaan keskusteluun, mutta hänen tiedettiin antaneen tukensa tuntijakotyöryhmän linjauksille ${ }^{285}$.

Peruskoulun osalta tuntijakotyöryhmän ehdottamat muutokset olivat huomattavasti pienempiä kuin lukiossa. Ne jäivät keskustelussa sivuosaan, vaikka opettaja Terttu Kauvosaari nostikin toistuvasti esiin ala-asteen uskonnonopetuksen. Kirkolliskokous vaati lausunnossaan lukioon vähintään kolmea pakollista ja kahta syventävää uskonnon tai elämänkatsomustiedon kurssia. 
Samalla kokous totesi kuitenkin "tunnustuksellisen uskonnonopetuksen" ongelmalliseksi nimitykseksi, jota parempi olisi esimerkiksi "oppilaan uskontokunnan mukainen opetus". Kirkolliskokous piti myös filosofian opetusta tarpeellisena mutta ei katsonut sen korvaavan millään tavalla uskonnonopetusta. Sen sijaan kirkolliskokous ehdotti, että myöhemmin selvitettäisiin maailmanuskontojen kurssin muuttamista kaikille yhteiseksi. Raija Sollamon ehdotuksesta lausunnossa painotettiin myös pätevien uskonnonopettajien työllisyyttä, joka taas oli kiinteästi sidoksissa uskonnonopetuksen tasoon. ${ }^{286}$ Maaliskuussa 1993 valtioneuvosto teki periaatepäätöksen tuntijaon uudistamisesta. Siinä kirkolliskokouksen esittämät vaatimukset toteutuivat lukion uskonnonopetuksen osalta täysin: uskonnolle tuli kolme pakollista ja filosofialle yksi pakollinen kurssi. ${ }^{287}$

Keväällä 1992 yhteensä 23 kirkolliskokousedustajaa jätti jyväskyläläisen valtiopäiväneuvoksen Sakari Knuuttilan johdolla vielä erillisen aloitteen, joka tähtäsi uskonnon- ja katsomuksellisen opetuksen kehittämiseen ja lisäämiseen kauttaaltaan nuorisoasteen koulutuksessa. ${ }^{288}$ Viisi vuotta aiemmin ammatillisen koulutuksen tehtäviin oli liitetty kasvatus, mikä oli raivannut tilaa myös eettiselle ja katsomukselliselle opetukselle. Kun vuoden 1992 tilanteessa arvokasvatus oli hyvin polttava keskustelunaihe, yleinen valmistusvaliokunta päätyi ehdottamaan kirjelmän lähettämistä opetusministeriölle. KKK:n asiantuntemusta apuna käyttäen syntyi kirjelmä, jossa vaadittiin nuorisoasteelle katsomuksellista opetusta koulumuodosta riippumatta. Kirkolliskokouksen oma-aloitteisesti lähettämät kirjelmät olivat käyneet 1980-luvun aikana harvinaisiksi, mutta 1990-luvun alun koulutusuudistukset saivat kokouksen ottamaan jälleen aktiivisesti kantaa. ${ }^{289}$

Tälläkin kertaa merkittävin erimielisyys koski opetuksen tunnustuksellisuutta. Valiokunta edellytti kirjelmäehdotuksessaan "oman uskontokunnan mukaista" opetusta, vaikka se toisaalla vetosi yhteiseen arvoperustaan. Kirkolliskokous ratkaisi tämän ristiriidan poistamalla vaatimuksen tunnustuskunnittain jaotellusta opetuksesta. ${ }^{290}$ Lukio-opetuksessa, jonka osalta oli kyse uskonnonopetuksen perinteisen aseman puolustamisesta, kirkolliskokous yritti pitää kiinni vallinneesta tilanteesta eli tunnustuskuntarajojen mukaan jaetuista opetusryhmistä. Sen sijaan ammatillisessa koulutuksessa, jos- sa oli kyse uuden oppiaineen juurruttamisesta, tärkeintä oli saada yleensäkin eettistä ja uskonnollista opetusta.

Opetusministeriö päätti marraskuussa 1994, että kaikille opiskelijoille yhteisiin opetussisältöihin kuului yhtenä uutena valinnaisena oppiaineena etiikka, johon sisältyi uskonnollisten perusarvojen tuntemus. ${ }^{291}$ Tilanne ammatillisessa koulutuksessa muuttui muutenkin nopeasti 1990-luvulla, kun keskiasteen opintojen joustavuutta lisättiin ja opiskelijoille avattiin muun muassa mahdollisuus yhdistää ammatillisten oppilaitosten ja lukion opintoja. ${ }^{292}$ Kirkolliskokouksen yleistä huolta uskontokasvatuksesta koulunuudistusten keskellä kuvasti, että laman synkimpinä hetkinä 1992 kokous myönsi vastoin talousvaliokunnan kantaa jatkon päivähoidon uskontokasvatuksen projektimäärärahalle. ${ }^{293}$ Laaja-alainen huolenpito uskontokasvatuksesta ja uskonnonopetuksesta tuotti tulosta.

\section{POSITIIVISEN USKONNONVAPAUDEN PUOLESTA}

Kirkolliskokous sai 1990-luvun alkupuolella käsiteltäväkseen useita valtiovallan uudistushankkeita, joissa näkyi negatiivinen uskonnonvapauskäsitys: kansalaisia oli ennemminkin suojeltava uskonnonharjoitukselta kuin taattava siihen mahdollisuuksia. Kehityssuunta oli sikäli yllättävä, että samaan aikaan kansainvälisessä keskustelussa uskonnonvapauden positiivinen korostus oli vahvistumassa ${ }^{294}$. Kaikkein selvimmin kirkolliskokous joutui kasvokkain uskonnonvapauden tulkintojen kanssa, kun sen tehtävänä oli antaa lausunnot perusoikeus- ja uskonnonvapauslainsäädännön uudistushankkeista.

Valtioneuvoston 1989 asettama perusoikeuskomitea ehdotti Suomen perusoikeusjärjestelmän uudistamista kokonaisuudessaan. ${ }^{295}$ Kirkossa mietintöä arvosteltiin siitä, että se turvasi vain mahdollisuudet yksityiseen uskonnonharjoitukseen mutta ei kiinnittänyt huomiota uskonnon yhteisölliseen puoleen. Mietinnön päähuomio oli siinä, ettei kukaan ollut velvollinen osallistumaan uskonnon harjoittamiseen eikä tukemaan uskonnollista yhdyskuntaa, jonka jäsen hän ei ollut. ${ }^{296}$ Kirkolliskokous yhtyi marraskuussa 1992 antamassaan lausunnossa arvosteluun, jota kirkkohallitus oli jo esittänyt. Kirkolliskokous totesi, ettei se voinut hyväksyä uskonnonvapautta koskevaa perusoikeussäännöstä ehdotetussa muodossa. Toisaalta kokous ei nähnyt tarpeelliseksi erottaa 
uskonnonvapautta selvästi vakaumuksenvapaudesta, ja tässä suhteessa se oli myöntyvämpi perusoikeuskomitean linjaa kohtaan kuin kirkkohallitus. ${ }^{297}$

Kirkolliskokous puuttui myös muihin kohtiin mietinnössä. Vuonna 1992 maallikkoedustajaksi valittu Sakari Knuuttila oli ensimmäinen ja tuohon mennessä ainoa kansanedustaja, jonka lakialoitteen pohjalta oli muutettu Suomen hallitusmuotoa. Vuoden 1972 valtiopäivillä oli hallitusmuotoon lisätty lause, jonka mukaan valtiovallan asiana oli "tarvittaessa järjestää Suomen kansalaiselle mahdollisuus tehdä työtä, mikäli laissa ei ole toisin säädetty". ${ }^{298}$ Perusoikeuskomitea ehdotti luopumista tästä säännöksestä. Knuuttila ei ollut enää eduskunnassa puolustamassa lainkohtaansa, mutta kirkolliskokouksessa hän taisteli näkyvästi sen säilyttämiseksi. Lama-aika antoi erityistä ajankohtaisuutta Knuuttilan vaatimuksille. ${ }^{299}$

Perustevaliokunnan jäsenenä Knuuttila pääsi vaikuttamaan suoraan kirkolliskokouksen lausuntoon ja saikin siihen kohdan, jonka mukaan vallinneen suuren työttömyyden aikana kirkolliskokous ei nähnyt perusteita heikentää perusoikeutta työhön. ${ }^{300}$ Vielä myöhemminkin Knuuttila sai perustuslakiuudistusta koskevaan lausuntoon muistutuksen työnsaannin perusoikeudesta. ${ }^{301}$ "Lex Knuuttila" jäi kuitenkin historiaan vuonna 2000 voimaan tulleen perustuslakiuudistuksen myötä. ${ }^{02}$ Sen sijaan kirkkohallituksen ja kirkolliskokouksen lausunnot vaikuttivat muuten perusoikeusuudistukseen 1990-luvun puolivälissä. Lopullisessa laissa näkyi paitsi uskonnonvapauslain negatiivinen myös sen positiivinen ulottuvuus. ${ }^{303}$

Seuraavan kerran kirkolliskokous sai ottaa kantaa uskonnonvapauden tulkintaan 1996 antaessaan lausunnon perustuslakiuudistuksesta. Alkuperäisessä perustuslakiluonnoksessa ei mainittu kirkkoja tai uskonnollisia yhdyskuntia. Lisäksi perustuslakityöryhmä halusi antaa eduskunnalle oikeuden tehdä muutoksia kirkolliskokouksen jättämään kirkkolakiehdotukseen. Molemmissa ehdotuksissa oli kyse kirkon yhteisöllisestä uskonnonvapaudesta. Kirkkohallitus ja kirkolliskokous asettuivat määrätietoisesti vastustamaan aikeita. Kirkon elimet vetosivat siihen, että uskonnollisten yhteisöjen jättäminen pois perustuslaista poikkeaisi muiden Pohjoismaiden linjasta. Erityisesti kirkolliskokouksessa pidettiin vanhakantaisena ajatusta, että uskonnonvapaus koskettaisi vain yksilöitä. ${ }^{304}$ Kirkolliskokous sai kannanotoilleen tukea opetusministeriön tervehdyksen tuoneelta kansliapäällikkö Vilho Hirveltä. ${ }^{305}$

Kirkolliskokous ei täysin tyytynyt seuraavaankaan perustuslakiehdotukseen, jossa kirkkolain säätämisjärjestys oli palautettu ennalleen. Tällöin vain luterilainen kirkko mainittiin perustuslaissa. Sitä kirkolliskokous ei suinkaan halunnut, koska ratkaisu oli omiaan korostamaan mielikuvaa yhdestä valtiokirkosta. Kirkolliskokous katsoi velvollisuudekseen puolustaa myös muiden uskonnollisten yhteisöjen asemaa ja niiden yhteisöllistä uskonnonvapautta. ${ }^{306}$ Kirkkolain säätämisjärjestys säilyi, ja lopullisessa lakitekstissä toteutui aiempia ehdotuksia paremmin yhteisöllinen uskonnonvapaus. Sen sijaan luterilaisen kirkon lisäksi muita uskonnollisia yhdyskuntia ei mainittu. ${ }^{307}$

Ajatukset neutraaliudesta ja riippumattomuudesta alkoivat vallata alaa uudella tavalla 1980-luvulta lähtien..$^{308}$ Sinänsä vaatimukset kirkon ja valtion erottamisesta olivat vanhoja. Ne olivat kuitenkin 1960- ja 1970-luvulla olleet selvemmin sidoksissa puoluepolitiikkaan kuin seuraavina vuosikymmeninä. Politisoituneena aikana neutraaliuteen oli suhtauduttu melko varauksellisesti - esimerkiksi vasemmiston näkökulmasta se oli usein ollut vain verhottua oikeistolaisuutta. Kahdeksankymmenluvulla puoluepoliittinen innostus laimeni, ja samalla vaatimukset riippumattomuudesta alkoivat kasvaa uusista, yksilöllistyvän yhteiskunnan lähtökohdista. Tällöin vaakakupissa ei painanut enää se, miten kirkko ja oikeuslaitos voisivat olla instituutioina hedelmällisessä vuorovaikutuksessa. Keskeistä oli, että oikeuslaitoksen toiminta näytti riippumattomalta oikeusprosessissa mukana olevan yksilön näkökulmasta. Tällaisen ajattelutavan mukaan kirkon ja valtion riippumattomuus edellytti näiden kahden hallinnollista irtaantumista toisistaan. Neutraaliusvaatimuksia voimisti vielä Suomen alkava monikansallistuminen.

Kirkolliskokous ei 1990-luvulla esiintynyt suhteessa valtiovaltaan yhtä suorasukaisesti kuin 1970-luvulla tai 1980-luvun alussa. Vaikka kirkolliskokous terävöitti edelleen monin paikoin kirkkohallituksen kannanottoja, jotkut edustajat katsoivat kirkolliskokouksen nöyristelevän. Maltillisten kannanottojen myötä keskusteluyhteys säilyi kuitenkin rakentavana. Väestökirjanpidon, lukion uskonnonopetuksen, tuomiokapitulien kustannusten ja 
uskonnonvapaussäännösten osalta lopputulos oli pitkälti kirkolliskokouksen toivoma.

Kirkon ja valtion suhteissa 1990-luvulla jännitteisintä aikaa oli porvarihallituksen kausi vuosina 1991-1995. Toki nämä laman synkimmät vuodet olivat ylipäätään hankalien päätösten ja kiivaan yhteiskunnallisen keskustelun aikaa. Tässä tilanteessa arkkipiispa Vikström kantoi huolta siitä, etteivät kirkon edustajien yhteiskunnalliset kannanotot muuttuisi puoluepolitiikaksi. Avatessaan kirkolliskokousta keväällä 1994 hän korosti, että kirkon tuli elää "puoluepoliittisessa selibaatissa". ${ }^{309}$ Lehdistössä puhe sai osakseen poikkeuksellisen laajaa huomiota, ja se tulkittiin yleisesti muistutukseksi kahdelle kirkolliselle lehdelle, Kotimaalle sekä Helsingin seurakuntien Kirkko ja kaupunki -lehdelle. ${ }^{30}$ Lehdet olivat aiemmin arvostelleet voimakkaasti Esko Ahon hallitusta, mistä pääministeri Aho ja Suomen Keskustan varapuheenjohtaja Olli Rehn olivat närkästyneet. ${ }^{311}$

Vuosikymmenen lopun laajapohjaisilla sateenkaarihallituksilla oli taloudellisen nousun alettua aiempaa paremmat mahdollisuudet järjestellä asioita kirkolliskokouksen toivomalla tavalla. Talous ei kuitenkaan selitä kaikkea. Näyttää siltä, että 1980-luvun lopun nousukauden yksilöllisyyttä ja teknologian arvoja korostanut kulttuuri alkoi heijastua lainsäädäntöön vasta viiveellä 1990-luvun alussa. Negatiivinen uskonnonvapausnäkemys ilmeni vuosikymmenen alussa väestörekisteriä, opetussuunnitelmia ja perusoikeussäännöksiä koskevissa uudistussuunnitelmissa. Kirkon näkökulmasta yllättävintä oli, että epäsuotuisat uudistusehdotukset sijoittuivat kahden perinteisesti luotetun puolueen - keskustan ja kokoomuksen - hallituskaudelle. Arvostelun aiheet koskivat kuitenkin lähinnä virkamiesvalmistelua, ja ministerit suhtautuivat yleensä ymmärtäväisesti kirkon kannanottoihin. Kirkon näkemykset jäivät usein syrjään valmisteluvaiheessa, mutta ne otettiin huomioon lainsäädäntötyön loppumetreillä. Kirkolliskokoukselle 1990-luku oli torjuntavoittojen vuosikymmen, joka päättyi kokouksen kannalta valoisissa merkeissä: syksyllä 1999 kokous sai antaa kiitosta uskonnonvapauskomitean välimietinnöstä, jonka peruslinjana oli positiivinen näkemys uskonnonvapaudesta ${ }^{312}$.

Muutosta korosti vielä rikoslain uudistusprosessi. Kirkolliskokous antoi 1993 opetusministeriölle lausunnon uskonrauhaa ja hautarauhaa koskevista säännöseh- dotuksista. Vastoin lakiehdotuksen perusteluja kirkolliskokous oli sitä mieltä, että uskontoon kohdistuvien tunteiden lisäksi myös uskonto sellaisenaan - tunnustuksessa pyhäksi määritelty sisältö - vaati suojelua. Sen sijaan kirkolliskokouksen perustevaliokunnan enemmistö asettui lakiehdotuksen taakse siinä, ettei Jumalan nimeä tarvinnut enää erikseen mainita lakipykälässä: ehdotettu rikoksen tunnusmerkistö kattoi jumalanpilkan ilman kyseistä mainintaakin. ${ }^{313}$ Täysistunnossa perustevaliokunnan enemmistön kannalla olleet ajattelivat lainsäädäntöä kokonaisuutena, kaikkien uskonnollisten yhdyskuntien näkökulmasta sekä uskonnonvapauden kannalta. Mietinnön arvostelijat taas miettivät asiaa luterilaisen kirkon kannalta. Monet heistäkin ymmärsivät lakimuutosta mutta pohtivat, millaisen signaalin myöntyminen antaisi ulospäin. ${ }^{314}$

Lain perinteisen sanamuodon kannatus osoittautui täysistunnossa vahvaksi. Lopulta arkkipiispa Vikström totesi painokkaasti, ettei kirkolliskokouksen tullut yrittää puhua kaikille tahoille vaan nimenomaan lainsäätäjälle: kirkon tehtävä oli tässä yhteydessä vaikuttaa eikä tunnustaa tai todistaa. Puheenvuoro vaikutti todennäköisesti siihen, että valiokunnan enemmistön kanta voitti äänin $61-37.315$ Sen sijaan viisi vuotta myöhemmin eduskunnan täysistunnossa päädyttiin tiukan äänestyksen jälkeen ja vastoin pohjaesitystä säilyttämään Jumalan pilkkaamista koskenut perinteinen muotoilu..$^{316}$ Eduskunnan ratkaisu herätti runsaasti julkista keskustelua. ${ }^{317}$ Paitsi ajan muuttumista päätös kuvasti sitä eroa, joka vallitsi useissa tapauksissa ministeriöiden virkamiesvalmistelun ja kansanedustajien enemmistön mielipiteiden välillä. Vuosikymmenen alkupuolella kirkolliskokous oli joutunut taistelemaan uskonnonvapauden positiivisen tulkinnan puolesta virkamiesvalmistelua vastaan, mutta vuosikymmenen lopulla eduskunta vaati positiivisen uskonnonvapauden julistamista voimakkaammin kuin kirkolliskokous. 


\section{KASVAVA PAINE}

\section{TEHOKKAASEEN HALLINTOON}

\section{BYROKRATIAN JA DEMOKRATIAN LIITTO ESTÄ̈̈ HALLINNON KEVENTÄMISTÄ}

Heti kun kirkkolain kokonaisuudistus oli 1991 valmistumassa, kirkolliskokouksen jäsenet jättivät lukuisia aloitteita kirkon hallinnon uudistamiseksi. Kaikkein radikaalein oli kansanedustaja Päivi Varpasuon johdolla syntynyt edustaja-aloite, jonka mukaan oli asetettava kirkkolain uudistamiskomitea. Komitean nimi oli sama kuin työnsä päättäneellä Leivosen komitealla, mikä kuvasti avointa tyytymättömyyttä: monen edustajan mielestä kokonaisuudistus oli jäänyt puolitiehen. ${ }^{318}$ Vuonna 1991 ei vielä lähdetty muuttamaan juuri hyväksyttyä kirkkolainsäädäntöä, mutta paineet purkautuivat uuden kirkolliskokouksen aloittaessa työskentelynsä keväällä 1992. Laman syveneminen voimisti vielä entisestään uudistusvaatimuksia, kun 89 edustajaa allekirjoitti aloitteen kirkon hallinnon keventämiseksi. ${ }^{319}$

Aloitteessa vaadittiin esimerkiksi alistussäännösten karsimista ja siten seurakuntien itsenäisen päätösvallan lisäämistä. Samaten kirkon sisäistä elämää koskevia säännöksiä tuli siirtää kirkkolaista kirkkojärjestykseen. ${ }^{320}$ Jo ennen kuin uudistettu kirkkolainsäädäntö astui voimaan, kirkolliskokouksessa oli voimakasta halua lähteä siirtämään kirkkolain ja kirkkojärjestyksen välistä rajalinjaa. Aloitteen voi nähdä osana julkisen sektorin muutosta Suomessa ja koko Euroopassa: erityisesti hallinnon hajauttamiskomitean 1986 julkistetusta mietinnöstä lähtien valtio oli pyrkinyt keventämään hallintoa, vähentämään normiohjausta ja siirtämään päätösvaltaa lähemmäksi niitä, joita päätökset koskivat $^{321}$. Nämä päämäärät mainittiin myös Esko Ahon hallituksen ohjelmassa. Vuosina 1992-1993 valtioneuvosto päätti keventää keskus- ja aluehallinnon rakennelmia, vähentää hallinnon moniportaisuutta ja lopulta poistaa kokonaan kuntiin kohdistuvan ohjauksen. ${ }^{322}$

Kirkossa puolestaan eteni piispainkokouksen 1980-luvulla aloittama Kirkko 2000 -prosessi. Tammikuussa 1992 valmistui seurantaryhmän muistio Kirkon suunta 200o. Alhaalta kasvava kirkko, jossa vaadittiin hallinnon keventämistä ja sääntelyn purkamista. ${ }^{323}$ Suunnitelmat olivat pitkälti samanlaisia niin kuntien kuin seurakuntien hallinnossa. Tosin taloudellisen tilanteen heikke- neminen aiheutti sen, että muodollisen itsenäisyyden lisääntymisestä huolimatta kuntien käytännön liikkumatila ei kasvanut ${ }^{324}$.

Edustaja-aloitteen ensimmäinen allekirjoittaja Eero Huovinen ei elätellyt illuusiota, että aloitteen kannattajien toiveet olisivat keskenään samanlaisia. Nopeasti ilmenikin, ettei kenelläkään ollut selvää näkemystä muutoksen sisällöstä. Sen sijaan puhuttiin yleisestä "väreilystä", joka vaati kirkolliskokousta toimimaan. Yleinen valmistusvaliokunta esitti pienen komitean asettamista tavoitteiden konkretisoimiseksi. Sen tuli yhdeksässä kuukaudessa laatia suunnitelma kirkon hallinnon keventämiseksi kiinnittäen huomiota erityisesti niihin toimiin, jotka olivat mahdollisia vallitsevan lainsäädännön pohjalta. Kirkolliskokouksen väreilevää ilmapiiriä ja kiirettä kuvasi, että iltakymmeneltä pidetyn lähetekeskustelun jälkeen valiokunnan mietintö toimenpide-ehdotuksineen oli jaettuna pöydille jo seuraavana päivänä heti puolenpäivän jälkeen. ${ }^{325}$

Kaikki eivät pitäneet kiireestä ja valiokunnan avoimesta tehtävänannosta. Kirkkoneuvos Heikki Mäkeläinen kuvaili, miten edustajat olivat liittyneet aloitteeseen "lähes hurmion vallassa". Hänen mukaansa toimeenpanevan elimen eli kirkkohallituksen tuli miettiä keinoja, joiden avulla hallintoa saattoi tehostaa voimassa olevan lainsäädännön puitteissa. Jos kirkolliskokoukseen tuotiin tällaisia ehdotuksia, kirkon hallintoa lähdettiin keventämään raskaimmalla mahdollisella tavalla. Paavo Kortekangas ilmoittautui periaatteessa hallinnon keventämisen kannattajaksi mutta totesi, ettei kirkon varsinainen ongelma ollut hallinto. Kirkon hallintojärjestelmä mahdollisti tuolloisessakin muodossaan evankeliumin elämisen todeksi. Pääpuutteet olivat Kortekankaan mukaan hengellisessä elämässä ja sitoutumisessa Jumalan valtakunnan työhön. Kortekangas totesi myös, että edustuksellisuus jo itsessään lisäsi hallinnon raskautta: "Byrokratian paras liittolainen on demokratia."326 Tampereen piispa, joka oli ollut 1960-luvulla vaatimassa kirkkoa avoimeksi korjauksia varten, oli 1990-luvulla rauhoittelemassa seuraavan sukupolven innokkaita kirkonkorjaajia.

Kirkolliskokous asetti lopulta kirkon hallinnon keventämiskomitean ja nimesi äänestyksen jälkeen sen jäseniksi Helsingin yliopiston käytännöllisen teologian professorin Markku Heikkilän, kirkkoherra Petri Karttusen 
ja hallintojohtaja Markku Porvarin. ${ }^{327}$ Heikkilän johdolla toiminut komitea laati mietintönsä säädetyssä ajassa niin, että se ehti kirkolliskokouksen käsittelyyn keväällä 1993. Komitea nojautui Kirkko 2000 -työskentelyyn, jossa pyrittiin kirkkojärjestyskomitean piirtämien suuntaviivojen mukaisesti vahvistamaan kirkon kansankirkkoluonnetta. Paikallistasolla painotettiin pieniä toiminnallisia yksikköjä, joiden toimintaedellytyksiä tukisivat suuremmat taloudellishallinnolliset yksiköt. Vastuuta oli määrä siirtää paikallistasolle ja normiohjausta keventää. ${ }^{328}$

Heikkilän komitea luonnosteli uudenlaisia ratkaisuja kirkon hallinnon kaikille tasoille. Keskushallinnon uudistusprosessi ja tuomiokapitulikomitean työ olivat kuitenkin kesken, joten keskus- ja hiippakuntahallinnon tasoilla ei voinut vielä tuossa vaiheessa edetä. Näin ollen seurakuntahallinto oli ainoa alue, jonka osalta saatettiin 1993 lähteä välittömästi jatkamaan uudistushanketta. Hallintovaliokunta esitti saman tien uutta kevytrakenteista komiteaa linjaamaan seurakuntahallinnon uudistamista. ${ }^{229}$ Kirkolliskokous asettikin syksyllä 1993 "seurakunnan hallinnon uudistamisen perusratkaisujen vaihtoehtoja käsittelevän komitean". ${ }^{330}$ Nimi ei erityisesti symboloinut uudenlaista, kevyttä hallintoajattelua. Tämä sinänsä pieni yksityiskohta osoitti piirteen, joka sittemmin leimasi kirkolliskokouksen toimintaa hallinnonuudistuksessa: kirkolliskokouksessa kyllä vaadittiin hallinnon keventämistä, mutta kokouksen omat toimenpiteet eivät useinkaan tukeneet päämäärän saavuttamista.

Tuomiorovasti Mikko Heikan johtama kuusijäseninen komitea nimesi itsensä seurakunnan hallinnon uudistamiskomiteaksi, ja se teki työnsä yhtä nopeasti kuin Heikkilän komitea. ${ }^{331}$ Heikan komitea pyrki hahmottamaan erilaisia toiminta- ja yhteistyömalleja erilaisille seurakunnille. ${ }^{332}$ Kirkko 2000 -mietinnön mukaan oli lisättävä seurakuntalaisten mahdollisuuksia valita seurakuntansa saman seurakuntayhtymän sisällä.. ${ }^{333}$ Toisaalta saman prosessin jatkotyöryhmä suhtautui Seurakunta 2000 -mietinnössään ajatukseen varauksellisesti peläten A- ja B-luokan seurakuntien syntymistä. ${ }^{334}$ Sama jännite säilyi myöhemmin. Heikan komitea ehdotti kokeiltavaksi maantieteellisistä rajoista riippumattomia henkilöseurakuntia, joihin saman seurakuntayhtymän seurakuntien tai yhtymän naapuriseurakuntien jäsenet voisivat liittyä. ${ }^{335}$ Ehdotus sai kirkolliskokouksessa ai- kaan vilkasta keskustelua. Monien mielestä malli johtaisi seurakunnat kilpailemaan keskenään ja poimimaan "rusinoita pullasta". Mietinnön puolustajien mukaan komitea oli tuntenut aitoa huolta kirkon tulevaisuudesta ja pyrkinyt löytämään avuksi muissa maissa koeteltuja malleja. ${ }^{336}$

Heikkilän komitea kiinnitti huomiota siihen, että voimassa ollut seurakuntahallinto oli monikerroksista. Lisäksi erilaisissa seurakuntatyypeissä oli vaihteleva määrä tasoja. Komitea pyrki yksinkertaistamaan ja yhtenäistämään paikallistason hallintorakenteita. ${ }^{337}$ Heikan komitea taas katsoi, että lainsäädännössä edellytettiin tuolloin liiankin yhtenäisiä malleja erilaisissa seurakunnissa. Komitea pyrki lisäämään vaihtoehtoisten hallintomallien määrää. ${ }^{338}$ Linjaerot kahden Kirkko 2000 -prosessin tavoitteisiin nojanneen komitean välillä osoittivat, että prosessin tavoitteita alhaalta kasvavasta kirkosta ja kevyestä hallintorakenteesta oli vaikea toteuttaa samanaikaisesti. Mikäli etsittiin eri alueita ja kaupunginosia varten räätälöityjä, alhaalta lähteviä hallintomalleja, hallinnon tasot eivät suinkaan vähentyneet ja yhtenäistyneet, vaan lopputulos oli päinvastainen.

Kummankin mietinnön käsittelylle oli tyypillistä, että tekstistä esitettiin moninaisia, joskus keskenään lähes päinvastaisia tulkintoja. Nopeasti syntyneissä mietinnöissä oli runsaasti erilaisia ja osittain eri suuntiin vieviä ehdotuksia, jolloin joku saattoi arvostella mietintöä pappiskeskeisyydestä, toinen taas papiston aseman horjuttamisesta. Kirkkojärjestyskomitean 1970-luvun lopulla tekemät hallinnolliset linjaukset olivat joidenkuiden mielestä olleet liian teologispainotteisia. Kaksi vuosikymmentä myöhemmin syytökset olivat päinvastaisia. Piispainkokous ja kirkkohallitus esittivät toistuvasti valituksia kirkon järjestysmuodon sivuuttamisesta. ${ }^{339}$

Heikkilän ja Heikan komiteat joutuivat laatimaan mietintönsä nopeasti ilman aikaa tarkkoihin pohdintoihin. Lisäksi prosessimainen työskentelytapa johti siihen, että liikkeelle lähdettiin ennemminkin käytännön ongelmista kuin ehyen teoreettisen hallintomallin luomisesta. Nopeasti syntyneet mietinnöt olivat Mikko Heikan sanoin lähinnä ranskalaisia viivoja keskusteluun, mutta lausunnoissa mietintöjä kohdeltiin kuin pitkään työskennelleiden komiteoiden perinteisiä, laajoja mietintöjä. ${ }^{340}$ Siirtymä uudenlaiseen, kevyeen valmistelukulttuuriin ei onnistunut helposti. 


\section{Picture removed from the open access version of this book.}

Helsingin tuomiorovasti Mikko Heikka (vas.) ja Lahden seurakuntayhtymän hallintojohtaja Markku Porvari pohdiskelivat lamavuosina kirkon hallintorakenteita. Kirkolliskokous halusi vaikeassa taloudellisessa tilanteessa keventää hallintoa ja asetti kaksi pientä komiteaa miettimään vaihtoehtoja. Heikka johti niistä toista, kun taas talousvaliokunnan puheenjohtaja Porvari oli jäsenenä toisessa komiteassa. Kuva: Kotimaan kuva-arkisto / Kyllikki Krapinoja.

Erityisesti Heikan komitean työssä perinteisen teologisen erityissanaston tilalla alkoi näkyä yritysmaailman termejä ja uudistetun kunnallishallinnon sanastoa. Kun kirkkolain kokonaisuudistuksen yhteydessä oli vielä vanhaan tapaan pohdittu kaitsentaa ja kirkkokuria, nyt mietittiin operationaalista vastuuta ja pyrittiin standardiajattelusta kohti responsiivisuutta. Monet katsoivat kirkon historialliset hallinnolliset mallit riittämättömiksi ja halusivat lähteä etsimään ratkaisua muilta päätöksenteon aloilta.

Aiempien hallinnonuudistusten ja kirkollisten kirjojen uudistusprosessien tavoin erimielisyydet kasvoivat sitä mukaa kuin ehdotukset tarkentuivat. Linjausten konkretisoituessa jokainen alkoi pitää kiinni omasta hallinnollisesta asemastaan. Esimerkiksi Heikkilän komitean periaatteellisiin korostuksiin oltiin yleisesti tyytyväisiä, mutta heti komitean esittäessä selkeitä uudistusehdotuksia puolelta ja toiselta nousi vastustusta. Yhtenä konkreettisena ehdotuksena komitea väläytti hiippakuntien lisäämistä ja siinä yhteydessä mahdollisuutta keventää tuomiokapitulilaitosta muun muassa lakkauttamalla toiminnalliset osastot. ${ }^{341}$ Jo kirkolliskokouksessa hiippakuntien viranhaltijat hyökkäsivät ehdotusta vastaan. ${ }^{32}$ Varsinainen tyrmäys tuli kuitenkin piispainkokoukselta. Se valitteli, ettei komitea ollut juurikaan kiinnittänyt huomiota tuomiokapitulilaitok- seen. Tämä seikka ei kuitenkaan estänyt piispainkokousta keskittymästä tähän suppeaan mietinnön osioon. Piispainkokouksen mielestä mietinnön toteuttamisesta seuraisi "hiippakunnallisen toiminnan lähes täydellinen alasajo". ${ }^{43}$ Piispainkokous näyttäytyi asiassa hiippakuntatason edunvalvojana, mikä vähensi sen lausunnon painoarvoa kirkolliskokouksessa. ${ }^{344}$

Alkuinnostuksen ja "väreilyn" jälkeen voimistuivat tasaisesti puheenvuorot, joissa puolustettiin vallitsevaa tilannetta. Kun itse kukin huomasi ehdotettujen uudistusten kaventavan tavalla tai toisella omaa valtaa, voimassa ollut tilanne alkoi näyttää yllättävän myönteiseltä. Sitä paitsi uudistettu kirkkolainsäädäntö osoittautui voimaan tultuaan joustavammaksi kuin oli etukäteen ajateltu. Kun kirkolliskokouksen tilaamat mietinnöt alkoivat valmistua, huomattiin, että seurakunnissa olikin jo toteutettu monia keventämistoimia. ${ }^{345}$ Viimeistään laman hellittäminen katkaisi kirkolliskokouksen kiireen. ${ }^{346}$

Nopeimmin hallinnon keventäminen toteutui kirkon keskushallinnossa. Tosin keskushallinnon osalta prosessi oli saanut alkunsa jo ennen keventämiskomiteoiden asettamista ja eteni pitkälti näistä komiteoista riippumatta. Kirkon keskusten yhdistäminen, joka oli pitkään ollut mahdoton tehtävä, sai vauhtia 1990-luvun alkuvuosina taloudellisten näkymien heikentyessä. ${ }^{347}$ Kirkkohallituksen uusi ohjesääntö tuli kirkollisko- 
kouksen hyväksyttäväksi samaan aikaan Heikkilän komitean mietinnön kanssa, ja näin komitea pääsi hahmottelemaan näkemyksensä myös uudesta kirkkohallituksesta. Komitea halusi korostaa kansliapäällikön asemaa ja ehdotti hänelle apulaispiispan nimikettä. ${ }^{348}$

Piispainkokous ja kirkkohallitus suhtautuivat nihkeästi ajatukseen uudesta hiippakunnattomasta piispasta. ${ }^{349}$ Siitä huolimatta ehdotus kuvasti myös kirkolliskokouksessa laajalle levinnyttä uutta ajattelutapaa: aiemmin kirkkohallitus ja toimikuntalaitos oli mielletty lähinnä seurakuntien palveluorganisaatioksi, mutta 1990-luvulla uuden kirkkohallituksen tärkeimpänä tehtävänä alettiin pitää yhteiskuntasuhteiden hoitamista ja kirkon edunvalvontaa. ${ }^{350}$ Erityisesti kansliapäällikölle haluttiin taata mahdollisuudet edustaa kirkkoa neuvottelupöydässä valtion kanssa. Suunnanmuutos oli ymmärrettävä, kun ottaa huomioon, miten paljon epämieluisia ehdotuksia kirkon päättäjät joutuivat 1990-luvulla ottamaan vastaan valtiovallalta. Asioiden suuntaan oli päästävä vaikuttamaan jo valmisteluvaiheessa eikä vasta loppumetreillä virallisten lausuntojen välityksellä.

Toisaalta kirkkohallituksen ohjesäännön käsittely osoitti hallinnon keventämiseen liittyneet ristiriitaiset odotukset. Hallintotehtävien siirtäminen viranhaltijoille kevensi organisaatiota, mutta kirkolliskokouksessa kuului epäilyjä, että kirkkoneuvoksista koottu uusi virastokollegio oli saamassa liikaa valtaa. Kirkolliskokouksen hallintovaliokunta taas korosti Heikkilän komitean mietintöä käsitellessään joustavuutta, mutta samaan aikaan niin valiokunta itse kuin täysistunto pyrki määrittelemään kirkkohallituksen ohjesäännön mahdollisimman aukottomaksi. ${ }^{351}$ Hallinnon keventäminen oli vaikeaa, jos luottamushenkilöt eivät uskoneet viranhaltijoiden kykenevän oikeisiin toimenpiteisiin ilman tarkkoja säännöksiä.

Ensimmäinen konkreettinen asia, joka tuli päätettäväksi hallinnon keventämistyöskentelyn pohjalta, koski alistus- ja vahvistussäännöksiä. Heikkilän komitea ehdotti noin 30 alistussäännöksen poistamista, jotta seurakunnat itsenäistyisivät päätöksenteossaan. ${ }^{352}$ Dosentti Risto A. Ahonen Lapualta huomautti eri yhteyksissä, että säännökset olivat osa sitä verkostoa, joka yhdisti seurakunnat ja hiippakunnat hallinnollisesti yhtenäiseksi kirkoksi. Lisäksi kuntien ja seurakuntien eturistiriidat mietityttivät edustajia. ${ }^{353}$ Terttu Kauvosaari muistutti, että seurakuntapäättäjien joukossa oli paljon kahdella tuolilla istuvia: "En varmaankaan ole tässä salissa ainoa, joka on todennut, kummalla pallilla istutaan leveämmin." 354

Joka tapauksessa asia eteni keväällä 1993 kirkkohallitukseen erillisen aloitteen pohjalta. Kiirettä osoitti, että hallintovaliokunta oli aluksi valmis antamaan kirkkohallitukselle vain muutaman kuukauden aikaa selvityksen tekemiseen. ${ }^{355}$ Lopulta 1997 kirkolliskokous poisti osan alistus- ja vahvistussäännöksistä. ${ }^{356}$ Vuosituhannen vaihtuessa selvitystyö, jonka oli aluksi arveltu valmistuvan parissa kuukaudessa, jatkui edelleen kirkkohallituksessa. ${ }^{357}$ Kirkon hallinnon keventäminen osoittautui raskaaksi tehtäväksi.

Keventämistyöskentelyn yhteydessä kirkolliskokouksessa näkyi vastakkainasettelua kirkon työntekijöiden ja muiden edustajien välillä. Muualla kuin kirkossa työskentelevät puolustivat laajaa edustuksellisuutta. ${ }^{35^{8}}$ Kun vuosikymmenen lopussa kirkkohallitus viimein esitti seurakuntien hallinnon keventämistä luottamuselimiä pienentämällä, kirkolliskokouksen maallikkoedustajat tyrmäsivät suunnitelmat. ${ }^{359}$ Paavo Kortekankaan sanat kävivät toteen: laajaan edustuksellisuuteen nojannut järjestelmä johtokuntineen ja suurikokoisine päätöksentekoelimineen oli osoittautunut keskeiseksi byrokratian ylläpitäjäksi. Maallikkoedustajat eivät kuitenkaan halunneet lähteä kaventamaan edustuksellisuutta. Samalla menetettiin yksi keino hallinnon keventämiseen.

Sen sijaan maallikkoedustajat olivat yleensä erittäin halukkaita keventämään hallintoa purkamalla alistussäännöksiä. ${ }^{60} \mathrm{He}$ halusivat paikallisseurakuntien elimille lisää valtaa. Kirkon työntekijöiden keskuudessa taas oli epäilyksiä tätä toimintatapaa kohtaan. Varsinkin papisto puolusti tuomiokapitulin osallistumista seurakuntahallintoon: alistussäännöksissä ei ollut kyse holhoamisesta vaan yhteistyöstä. Jotkut kirkossa työskentelevät edustajat kuvailivat seurakunnan luottamushenkilöiden joukkoa "pieneksi sisäpiiriksi", joka saattaisi päätyä "lyhytnäköisiin" ratkaisuihin ilman tuomiokapitulin tai kirkkohallituksen valvontaa. ${ }^{361}$ Jos siis toisaalla kirkolliskokouksessa ilmeni epäilyksiä viranhaltijoita kohtaan, kaikkien viranhaltijoidenkaan puheenvuorot eivät henkineet luottamusta seurakuntapäättäjiä kohtaan. Teologisten perustelujen ja epäluulojen myötä umpeutui tämäkin reitti hallinnon keventämiseen. Eri osapuolet olivat valmiit keventämään hallintoa vain sellaisilla 
toimilla, jotka lisäsivät omaa valtaa tai ainakin säilyttivät sen ennallaan. Kun vielä laman tuoma pakkotilanne ohitettiin, muutoksen aikaansaaminen mihin suuntaan tahansa osoittautui vaivalloiseksi.

\section{KIRKKOHERRA}

\section{- PAIMEN JA TOIMITUSJOHTAJA}

"Haluammeko me - - toimitusjohtajaa vai sielunpaimenta?", kysyi Oulun hiippakunnan pääsihteeri Keijo Nissilä. Oli vuosi 1993, ja kirkolliskokouksen käsittelyyn oli tullut papinvaalin uudistamiskomitean mietintö. ${ }^{362} \mathrm{Tu}$ run tuomiorovastin Jukka Paarman johtama komitea oli saanut työnsä valmiiksi jo syksyllä 1989, mutta mietinnön käsittely oli siirtynyt suurten kokonaisuudistusten tieltä. Komitea ehdotti sekä kirkkoherran- että kappalaisenvaalin muuttamista välilliseksi. Itse asiassa kirkkolakikomitea oli ehdottanut jo vuoden 1963 kirkolliskokoukselle siirtymistä välilliseen papinvaaliin, mutta ehdotus ei ollut tuolloin saanut laajempaa kannatusta. Ruotsissa sen sijaan oli toteutettu tämänsuuntainen muutos 1989. Papinvaalin uudistamiskomitean mietinnön mukaan ehdollepanosta luovuttaisiin, joten vaalissa voisivat olla mukana kaikki vaalikelpoiset hakijat. Yli 10 ooo henkilön seurakunnan kirkkoherran virkaan hakevalta oli määrä edellyttää johtamistutkintoa. ${ }^{363}$

Käsittelyyn tullessaan mietintö vastasi monin tavoin ajankohtaisen hallinnon keventämisprosessin tavoitteita. Toisaalta arvostelijat katsoivat, että uudistusehdotukset olivat ristiriidassa Kirkko 2000 -prosessin ja alhaalta kasvavan kirkon ajatuksen kanssa. Nissilän tavoin monet ajattelivat, että kirkkoherrasta oltiin tekemässä väärällä tavalla toimitusjohtajaa. Toisten mielestä taas seurakuntien työntekijämäärän noustua voimakkaasti kirkkoherrasta oli jo käytännössä tullut toimitusjohtaja. Heidän mielestään lainsäädäntö oli muutettava vastaamaan tätä tilannetta, jotta seurakunnille saataisiin parhaat mahdolliset johtajat. ${ }^{364}$

Lähetekeskustelun aikana yli neljännes edustajista kävi puhujakorokkeella, mikä osoitti asian herättämiä intohimoja. Isojen kaupunkiseurakuntien ja maaseudun välinen rajalinja hahmottui keskustelusta selvästi. Varsinkin pääkaupunkiseudun edustajat vaativat välillistä vaalia. Mietinnön vastustajat taas olivat sitä mieltä, ettei seurakuntalaisilta saanut viedä oikeutta valita kirkkoherraa. Kannattajat vastasivat, että myös välillinen vaali säilyttäisi valinnan seurakunnalla. Lisäksi vallinneessa tilanteessa seurakunnan omien pappien etulyöntiasema oli niin selvä, ettei suurtenkaan seurakuntien virkoihin tahtonut löytyä seurakunnan ulkopuolisia hakijoita. Kirkkomusiikin apulaisprofessori Erkki Tuppurainen Kuopiosta taas piti omankin alansa kannalta parhaana, että kirkkoherrat valittaisiin lähinnä muiden ominaisuuksien kuin vaalinäytteessä osoitetun laulutaidon perusteella. ${ }^{365}$

Mietinnön kannattajat korostivat seurakunnan luottamuselinten mahdollisuuksia arvioida ehdokkaita monipuolisesti. Vastaavasti varsinkin maaseudun edustajat, joiden kotiseudulla kunnallis- ja kirkkopolitiikka kulkivat usein käsi kädessä, pelkäsivät välillisten vaalien politisoitumista. Heidän mielestään suora vaali pysytti vallan aktiiviseurakuntalaisten käsissä. ${ }^{366}$ Sama ajatus saattoi olla takana, kun monet naisten pääsyä pappisvirkaan vastustaneet edustajat ilmoittivat kannattavansa suoraa vaalia. Vaaliuurnille kokoontuvilta aktiiviseurakuntalaisilta löytyi todennäköisesti enemmän ymmärtämystä kirkon virkaratkaisua vastustavalle papille kuin seurakunnan luottamuselimiltä. Joka tapauksessa keskustelu osoitti jälleen, että kirkkolaki oli tehty maaseutuympäristöön ja että sen matka etelärannikon kaupunkiseurakuntien laiksi oli pitkä ja vaivalloinen.

Piispainkokous esitti lausunnossaan vain kappalaisenvaalin muuttamista välilliseksi. Seurakunnan johtajana kirkkoherra tuli valita suoralla vaalilla. ${ }^{367}$ Lausunnosta kuvastui reaalipolitiikka: uudistuksella ei kokonaisuutena näyttänyt olevan menestymismahdollisuuksia, joten piispainkokous tyytyi kompromissiin. Samalla seurasi kuitenkin lukuisia ongelmia, kun kirkkoherran ja kappalaisen virat alettiin nähdä erilaisina. Timo Sahi kysyi, eikö Kristuksen läsnäoloa ja Pyhän Hengen johdatusta tarvittukaan kappalaisenvaalissa samaan tapaan kuin kirkkoherranvaalissa, jonka piispainkokouksen mielestä tuli liittyä koko seurakunnan yhteiseen jumalanpalvelukseen. Toisen Helsingin hiippakunnan edustajan Seikko Eskolan mielestä piispat olivat kulkeneet helpointa tietä ja päättäneet pysyä entisessä,

- - mutta kuitenkin on katsottu välttämättömäksi heittää joku luu vihaiselle koiralle; ja se luu on kappalainen. Perustelut päätökseen on sitten annettu jonkun asessorin muotoiltaviksi. Asessori ei kuitenkaan ole ollut kovinkaan innokas, vaan on vetänyt sen vasemmalla kädellä. ${ }^{68}$ 


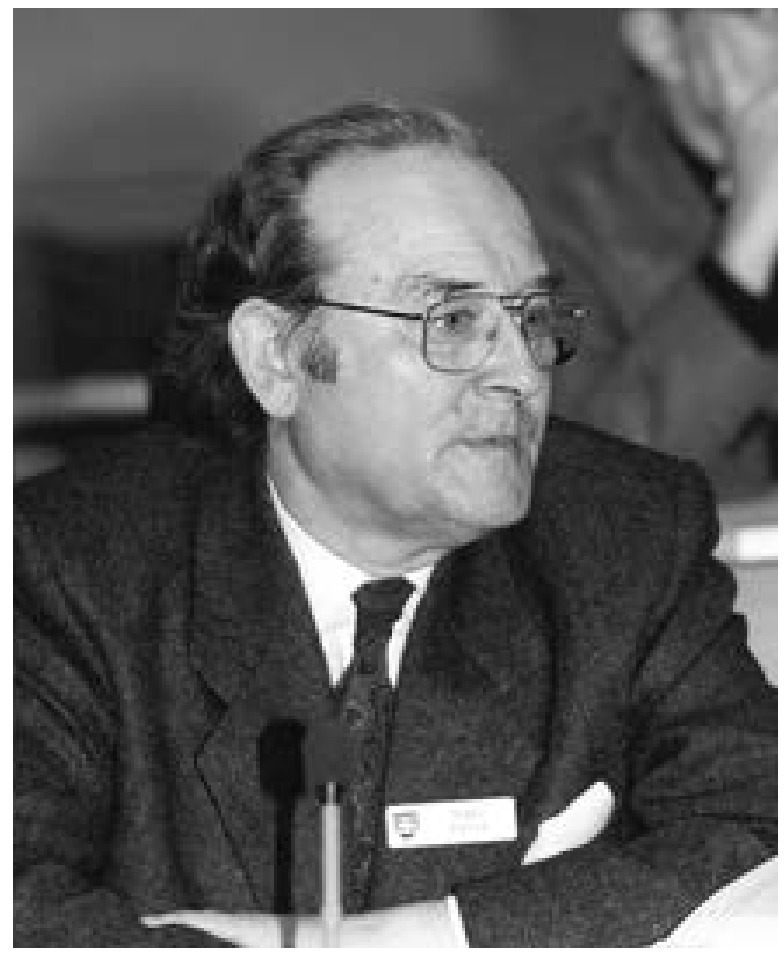

Apulaisprofessori Seikko Eskola vaati monen muun Helsingin hiippakunnan edustajan tavoin sekä kirkkoherran- että kappalaisenvaalin muuttamista välilliseksi. Suoran vaalin koettiin aiheuttavan ongelmia varsinkin kaupunkiseurakunnissa. Kuva: Kirkkohallitus.

Kirkon hallinnon keventämiskomitean mietinnöstä antamassaan lausunnossa piispainkokous näyttäytyi tuomiokapitulilaitoksen edunvalvojana. Samaan aikaan papinvaaliuudistuksesta annettu lausunto herätti vähintään yhtä voimakasta vastustusta. Sellainen korkea opillinen auktoriteetti, jollaisena piispainkokous oli nähty kirkolliskokousuudistuksen aikaan, ei kaksi vuosikymmentä myöhemmin juurikaan piirtynyt kirkolliskokousedustajien arvioidessa piispainkokouksen toimintaa. Ilmeisen keskeisenä syynä oli, ettei piispainkokous tyytynyt toimimaan opillisena asiantuntijana. Se pyrki ikään kuin kirkolliskokouksen yhtenä valiokuntana etsimään käytännön ratkaisuja kysymyksissä, jotka koskettivat tavalla tai toisella useimpia piispainkokouksen jäseniä. Asian voi nähdä niinkin, että 1970-luvulla piispainkokous oli pyrkinyt varjelemaan arvovaltaansa pidättymällä ristiriitatilanteissa yksityiskohtaisista kannanotoista, kun taas 1990-luvulla se ei enää arastellut ottaa kantaa ja altistaa itseään arvostelulle.
Lakivaliokunta päätyi piispainkokouksen kannalle, mutta se ei yrittänytkään peitellä ehdotuksensa kompromissiluonnetta. Kirkolliskokous muutti kappalaisenvaalin välilliseksi. ${ }^{369}$ Sekä kirkkohallitus että piispainkokous pitivät parhaana ratkaisuna, että johtamiskoulutusta edellytettäisiin vasta kirkkoherraksi valinnan jälkeen. Näin koulutus voitaisiin parhaiten liittää osaksi käytännön työtä, eikä koulutettavien määrä kasvaisi liian suureksi. Piispainkokous ja kirkkohallitus katsoivat myös pienen seurakunnan johtamisen edellyttävän koulutusta. ${ }^{370}$ Komitean edustajien mielestä taas koulutus oli järjestettävä ennen vaaliin osallistumista, jotta asianomainen itse voisi huomata, oliko hänellä kirkkoherralta vaadittavia ominaisuuksia. ${ }^{371}$ Lakivaliokunnan johdolla kirkolliskokous palasi kohti komitean linjaa. Ennen vaalia suoritettu johtamistutkinto määrättiin kirkkoherran pätevyysehdoksi seurakunnan koosta riippumatta.. ${ }^{32}$ Kirkolliskokous yritti vaalisäännöksiä muokatessaan säilyttää kirkkoherran paimenena, jolta kuitenkin edellytettiin myös "toimitusjohtajan" valmiuksia.

Samaan aikaan kun kirkolliskokous käsitteli papinvaalia, Mikko Heikan johtama komitea mietti seurakuntahallinnon ja seurakunnan johtamisen uusia suuntaviivoja. Komitea lähti etsimään malleja ulkomaisista kirkoista, uudesta kunnallishallinnosta ja yritysmaailmasta. Se ehdotti kirkkovaltuuston tilalle aiempaa pienempää elintä, uudenlaista kirkkoneuvostoa. Kirkkoherralle komitea kaavaili entistä suurempaa kokonaisvastuuta seurakunnan johtamisesta. ${ }^{373}$ Hänestä oli määrä tulla tietyssä mielessä seurakunnan toimitusjohtaja, mikä sai aikaan arvostelua kirkolliskokouksessa. ${ }^{374}$ Ennemminkin istuntosalissa alkoi voimistua aivan päinvastainen vaatimus: kirkkoneuvoston puheenjohtajuus oli siirrettävä kirkkoherralta luottamushenkilölle. Aiheesta oli jätetty vuosikymmenten kuluessa lukuisia aloitteita ja sitä oli käsitelty eri komiteoissa, mutta 1990-luvun edetessä muutosvaatimukset kiihtyivät.

Kirkkoherran vaalitavan säilyminen ennallaan saattoi voimistaa vaatimuksia. Keskusteltaessa niin papinvaalista kuin kirkkoneuvoston puheenjohtajuudesta taustalla väikkyivät ainakin jossain määrin ongelmat seurakuntien johtamisessa. Papinvaalin uudistamisessa kysymys kuului, miten seurakunnille saataisiin mahdollisimman hyviä kirkkoherroja. Kun sitten luottamushenkilöt eivät 
päässeet vastaisuudessakaan valitsemaan kirkkoherraa, kysymykseksi tuli, miten voitiin turvata kirkkoneuvoston tehokas toiminta silloinkin, kun kirkkoherran johtamiskyky oli puutteellinen.

Vuonna 1997 vaalikausi vaihtui, ja oli uuden kirkolliskokouksen vuoro lähteä innolla uudistamaan seurakuntahallintoa. Helsingin hiippakuntakokous jätti aloitteen puheenjohtajuuden siirtämisestä luottamushenkilölle. Maallikkoedustajat vetosivat voimakkaasti kunnallishallinnon käytäntöihin: heidän mielestään esittelijä ei mitenkään voinut toimia puheenjohtajana ilman, että hänelle keskittyisi liikaa valtaa. Pitkään seurakuntaneuvoston varapuheenjohtajana toiminut kirkolliskokouksen varapuheenjohtaja Timo Sahi kutsui kirkkoa tässä suhteessa jäänteeksi ja korosti, että myös luottamushenkilö osasi toimia puheenjohtajana. Papit vastasivat, ettei kyse ollut taidosta vaan kirkon järjestysmuodosta ja sen piispallisesta rakenteesta. Erik Vikström painotti, ettei maallikko voinut toimia puheenjohtajana samanlaisella virkavastuulla kuin tuomiokapitulin valvonnassa oleva kirkkoherra. Papit vetosivat myös siihen, että kirkkoherra oli valittu tehtäväänsä yleisellä vaalilla - toisin kuin kunnanjohtaja. ${ }^{375}$

Lääninrovasti Arto Laitinen ihmetteli aloitteentekijöiden jättäneen asian puolitiehen: jos kirkkoherra ei voinut johtaa itseoikeutetusti kirkkoneuvostoa, oli johdonmukaisuuden vuoksi poistettava puheenjohtajuus piispalta tuomiokapitulissa ja arkkipiispalta kirkolliskokouksessa. Laitinen kertoi hämmästelevänsä, mistä asenteet nousivat: "Toinen vaihtoehto on se, että me jättäisimme koko seurakuntahallinnon ja annamme kunnallishallinnon se hoitaa. Voihan kirkkoherra käydä kunnanhallituksessa esittelemässä asiat.” Tunnelma alkoi kiristyä, ja piirinjohtaja Pertti Rajala Ulvilasta kysyi vastineeksi, "mitä meillä maallikoilla sitten tehdään. Pitäkää te papit kirkkonne ja hoitakaa se kaikessa rauhassa." Vastakkainasettelu pappis- ja maallikkoedustajien välillä oli jälleen valmis. ${ }^{376}$

Kirkolliskokous ei päässyt asiassa selvyyteen vaan lähetti sen kirkkohallituksen tutkittavaksi. ${ }^{377}$ Kirkkohallitus esitti 1999 mietinnössään Seurakuntahallinnon kehittäminen, että kirkkoherra säilyisi vastaisuudessakin virkansa puolesta kirkko- ja seurakuntaneuvoston puheenjohtajana. ${ }^{378}$ Esitys syntyi tasaäänin puheenjohtajan äänen ratkaistessa. Lähes yhtä tiukkaa oli kirkollis- kokouksen hallintovaliokunnassa, joka päätyi äänin 9-8 esittämään, että kirkkoneuvoston puheenjohtaja valittaisiin vaalilla. ${ }^{379}$ Maallikkoedustajien ja pappien välinen jännite kasvoi täysistunnossa huippuunsa. Ensin mainitut vetosivat kunnallisdemokratian esikuviin, jälkimmäiset teologiaan. Piispat, jotka olivat piispainkokouksen jäseninä moneen kertaan leimautuneet papiston edunvalvojiksi, olivat pitkään hiljaa, mitä jotkut voimassa olleen lainsäädännön puolustajat ihmettelivätkin..$^{80}$

Kirkolliskokous päätti lopulta ensimmäisessä käsittelyssä niukasti äänin 53-51 pidättyä lainmuutoksista. ${ }^{38}$ Pappien ja piispojen rintama oli hyvin yhtenäinen. Muutoksen puolesta äänesti vain kaksi pappisedustajaa, Jaakko Heinimäki ja Tuusulan seurakuntapastori Jaakko Launikari, jotka muissakin yhteyksissä kyseenalaistivat perinteisiä kirkollisia auktoriteettiasemia. Maallikkoedustajista vajaa neljännes äänesti vallitsevan käytännön puolesta. ${ }^{382}$ On todennäköistä, että osa tästä joukosta kannatti vanhaa järjestelmää varmistaakseen laajan seurakuntahallinnon uudistushankkeen hyväksymisen ratkaisevassa käsittelyssä.

Vuonna 1992 lähes 90 edustajaa oli allekirjoittanut aloitteen kirkon hallinnon keventämiseksi. Aloitteeseen oli sisältynyt lausuma, että paikallisseurakuntien hallinnossa oli "seurattu liiankin orjallisesti kunnallisdemokratian periaatteita" ${ }^{383}$. Vuosikymmenen lopulla maallikkoedustajat vaativat edelleen hallinnonuudistusta, mutta tällä kertaa he vetosivat siihen, että seurakunnissa tuli toteuttaa kunnallishallinnossa hyviksi havaitut toimenpiteet. Oli selvinnyt, että kunnallisdemokratian seuraamisessa olikin käytännössä kyse seurakuntalaisten edustuksellisesta vallasta. Viimeistään vuosikymmenen loppuun tultaessa oli myös varmistunut, että vuoden 1992 yhtenäinen vaatimus hallinnon keventämisestä oli kätkenyt sisälleen aloitteentekijöiden keskenään täysin vastakkaisia tavoitteita.

\section{TURKUUN TOINEN PIISPA}

"Haluammeko me nyt muuttaa arkkipiispan viran Suomen evankelis-luterilaisen kirkon toimitusjohtajan viraksi?" Helsingin piispa Eero Huovinen lausui saman kriittisen kysymyksen, joka oli kuultu kirkkoherranvaalista keskusteltaessa. ${ }^{384}$ Arkkipiispan työtaakka oli ollut esillä vuodesta 1918 lähtien, ja se oli puhuttanut käytännössä yhtäjaksoisesti vuodesta 1968. Arkkipiis-

KAS VAVA PAINE TEHOKKA A S E N H A L L IN TOON $\mathbf{2 2 5}$ 
pan kirkolliset hallinto- ja edustustehtävät olivat koko ajan lisääntyneet, eikä aikaa jäänyt riittävästi seurakuntamäärältään kirkon suurimman hiippakunnan johtamiseen. Myös Helsingin hiippakunnan jakamisesta oli keskusteltu 1970-luvulta lähtien, ja keväällä 1992 Lapuan hiippakuntakokous toisti aloitteen Keski-Suomen hiippakunnan perustamisesta ${ }^{385}$. Arkkihiippakunnan tilanne oli 1990-luvulla päällimmäisenä huolenaiheena, mutta muissa hiippakunnissa piilleet odotukset vaikuttivat asian käsittelyyn. Jotkut Helsingin ja Lapuan edustajat pelkäsivät, että liiallinen keskittyminen Turkuun veisi huomion pois näiden hiippakuntien ongelmista ${ }^{386}$.

Kirkkohallitus esitti keväällä 1995 toisen piispan viran perustamista arkkihiippakuntaan. Keskeisimmät perustelut olivat poissulkevia: kirkolliskokous oli aiemmin 1980-luvulla hylännyt arkkihiippakunnan jakamisen, eikä hiippakuntakokousaloite apulaispiispan viran perustamisesta ollut menestynyt. Myöskään ehdotukset arkkipiispan kokonaiskirkollisten tehtävien karsimisesta eivät olleet saaneet kannatusta. Ratkaisuksi jäi lähinnä toisen piispan viran perustaminen: kaksi piispaa johtaisi samaa kapitulia, ja seurakunnista suurin osa olisi uuden piispan vastuulla. Kirkkohallitus ehdotti arkkipiispan vastuualueeksi tuomiorovastikuntaa. ${ }^{387}$

Kirkolliskokouksessa esityksen arvostelu oli käytännöllistä ja teologista. Sakari Knuuttila kiinnitti huomiota käytännölliseen puoleen, kahden johtajan ongelmaan. Myös arkkipiispa Vikström tunnusti, että ehdotettu järjestelmä oli tässä suhteessa haavoittuvainen. Suurin osa keskustelusta koski kuitenkin teologisia ongelmia. Eero Huovinen käytti heti lähetekeskustelun aluksi puheenvuoron, joka heijasteli useiden muidenkin piispojen näkemyksiä. Arkkipiispan työalueen rajaaminen tuomiorovastikuntaan oli Huovisen mielestä viemässä virkaa titulaaripiispan suuntaan, minkä vuoksi hiippakuntajaon uudistaminen oli parempi vaihtoehto kuin toisen piispan viran perustaminen. Huovisen mukaan arkkipiispan yhteys seurakuntiin oli kapenemassa tai jäämässä nimelliseksi. ${ }^{388}$ Suomen luterilaisen kirkon mittakaavassa 150 ooo hengen kaitsenta-alue olikin pieni. Huovinen lähestyi hiippakuntapiispuutta teologisesti: piispan yhteys seurakuntiin toteutui silloin, kun hiippakunta oli tarpeeksi suuri. Kirkkohallitus taas näytti katsovan samaa asiaa käytännön ja yksittäisen seurakunnan näkökulmasta: yhteys seurakuntiin oli vaarassa jäädä löyhäksi nimenomaan siinä tapauksessa, että arkkipiispan vastuulla oli liian monta seurakuntaa.

Huovinen näki ongelmia myös kokonaiskirkon tasolla: kirkkohallituksen esitys oli luomassa uudenlaisen kirkon johtajan viran. Kokonaiskirkossa valta ja vastuu olivat liiaksi keskittymässä kirkkohallitukselle ja arkkipiispalle. Huovinen nosti esiin kirkkojärjestyskomitean ehdotuksen, että arkkipiispalta poistettaisiin kirkkohallituksen puheenjohtajuus ja mahdollisesti jäsenyyskin..$^{38}$ Huovinen osoitti suuntaviivat myöhemmälle keskustelulle. Ongelmana oli, että hänen tarjoamansa vaihtoehdot oli aiemmin hylätty kirkolliskokouksessa.

John Vikström oli virkakautensa aikana vaiennut julkisuudessa arkkipiispan työtaakasta. Tilannetta oli helpotettu matalan profiilin toimilla, erityisesti siirtämällä tehtäviä tuomiorovasti Jukka Paarmalle, josta oli tullut käytännössä eräänlainen apulaispiispa. Tällä kertaa arkkipiispa puolusti kuitenkin avoimesti kirkkohallituksen esitystä ja kertoi ongelmista. ${ }^{30 \circ}$ Huovinen oli moittinut kirkon hallintojärjestelmää liiasta keskityksestä, mutta Vikströmin mielestä järjestelmä oli pitkälle hajautettu. Jonkun oli pidettävä huolta, että yhteys toimi keskushallinnon eri elinten välillä. Parhaiten tehtävä onnistui arkkipiispalta. Lisäksi Vikström huomautti, ettei kirkkohallituksen esitys lisäisi lainkaan arkkipiispan tehtäviä ja valtaa kokonaiskirkossa "sillä ei kai se ole ongelma, että arkkipiispa saisi aikaa ja voimia hoitaa niitä tehtäviä, jotka hänelle on annettu, mahdollisimman hyvin." ${ }^{391}$

Eero Huovinen puhui laajasti myös piispainkokouksessa, jonka tehtävänä oli antaa lausunto asiasta. Hän nosti esiin Helsingin hiippakunnan tilanteen. Kiihkeätunnelmaisessa keskustelussa tärkeäksi teemaksi tulikin, miten Turkuun löydettäisiin malli, jota olisi myöhemmin mahdollista soveltaa myös muihin hiippakuntiin. Piispainkokous löysi ratkaisuksi jo kertaalleen hylätyn apulaispiispan. ${ }^{392}$ Arkkipiispan välittämät viestit Ruotsista, missä apulaispiispajärjestelmästä oli saatu kielteisiä kokemuksia, eivät painaneet piispainkokouksessa. ${ }^{393}$ Lisäksi piispainkokouksen mielestä oli tutkittava mahdollisuuksia vähentää arkkipiispan kokonaiskirkollista vastuuta ja kehitettävä piispojen työnjakoa esimerkiksi mediassa ja ekumeenisissa suhteissa. Äänin 13-4 piispainkokous katsoi, ettei asia ollut vielä valmis päätettäväksi. Se ehdotti, että kirkolliskokous asettaisi komitean valmistelemaan apulaispiispan viran perustamista ark- 


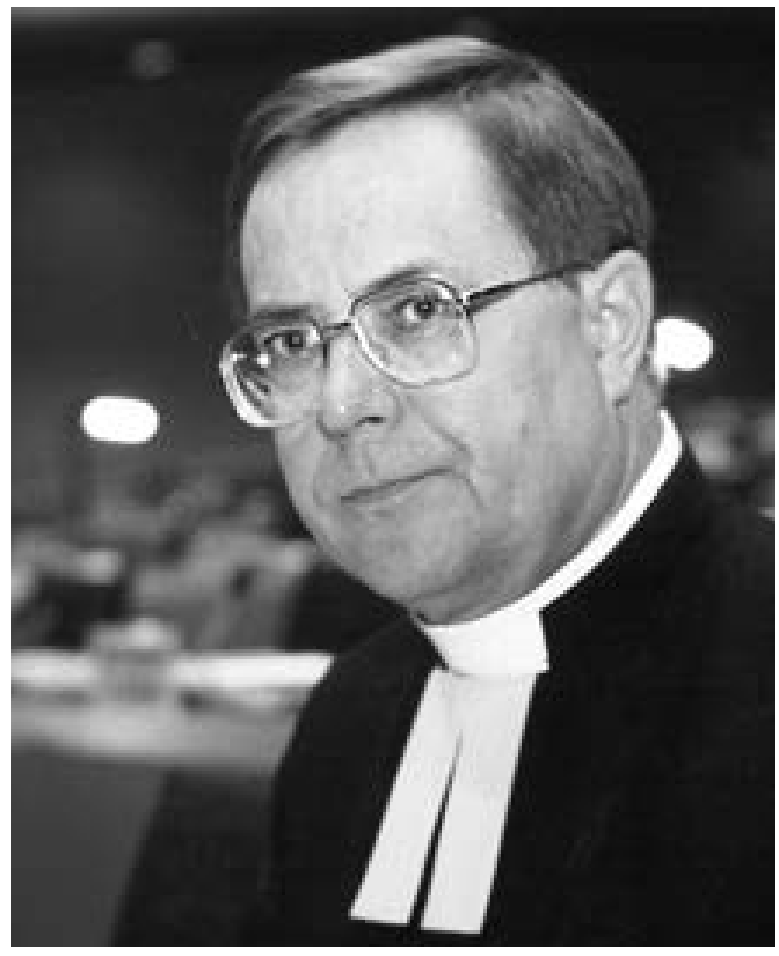

Turun tuomiorovasti Jukka Paarma istui kirkolliskokouksessa arkkihiippakunnan pappisedustajana vuodesta 1986. Arkkipiispa John Vikströmin suuren työmäärän vuoksi hän hoiti myös monia arkkipiispan tehtäviä. Sittemmin hänet nimitettiinkin arkkipiispaksi 1998. Kuva: Kirkkohallitus / Bo Strandén.

kihiippakuntaan ja laatimaan selvityksen arkkipiispan asemasta kokonaiskirkon hallinnossa. ${ }^{394}$

Piispainkokouksen lausunto jätti jälleen tilaa tulkinnalle, että kyse oli edunvalvonnasta: piispat pelkäsivät kahden piispan mallin leviävän muihinkin hiippakuntiin, jolloin he joutuisivat jakamaan valtansa toisen tasavahvan johtajan kanssa. Hiippakuntien välillä haluttiin säilyttää piispojen keskinäinen tasa-arvo ja välttää arkkipiispan aseman korostumista, mutta hiippakuntien sisälle ei haluttu kahden tasa-arvoisen johtajan mallia. Ehdottaessaan apulaispiispan virkaa piispainkokous tarjosi John Vikströmin avuksi ratkaisua, jonka Vikströmin itsensä johtama kirkkojärjestyskomitea oli aikoinaan todennut epäluterilaiseksi ${ }^{395}$. Arkkipiispa oli joutumassa ajamansa kirkkohallituksen esityksen kanssa hieman samaan tilanteeseen kuin aiemmin Mikko Juva tai Göran Portin.
Piispainkokouksen lausuntoa kuvailtiin kirkolliskokouksessa muun muassa "varsinaiseksi tajuntapommiksi" tai "melkoiseksi pohjanoteeraukseksi". Kirkkojärjestyskomiteassa itsekin mukana ollut Ossi Haaramäki kummeksui, että piispainkokous torjui kahden piispan järjestelmän uutuutena, vaikka "apulaispiispahan vasta uutuus on". Haaramäki huomautti, että apulaispiispajärjestelmä vaatisi myös suuria muutoksia kirkkolakiin. Edustajat olivat hyvin tyytymättömiä asioiden etenemättömyyteen. ${ }^{396}$ Arkkipiispa Vikströmin virkaveljiä ei imarrellut myöskään turkulaisen varatuomarin Pekka Soinin arvio: "Lienee myöskin luonnon lain mukainen sääntö, että kanssajohtajilla näyttää olevan taipumus leikata joukosta nousevan nuppi pois. Se on niin kuin voikukka tai ruohontupsu nurmikolla; se ajetaan ruohonleikkurilla yli." ${ }^{397}$

Kirkkohallituksen esityksen näkyvimpiin vastustajiin lukeutunut Eero Huovinen johti kirkolliskokouksessa perustevaliokuntaa, jonka tehtävänä oli antaa asiasta lausunto. Hän jäi kuitenkin vähemmistöön, ja lausuntoa valmistelleen työryhmän johdolla valiokunta antoi tukensa kirkkohallitukselle. Samaten hallintovaliokunta asettui kirkkohallituksen esityksen kannalle. Se vastasi piispainkokoukselle, ettei kahden piispan mallin leviämistä muualle tarvinnut pelätä. Valiokunnan puheenjohtajan Voitto Huotarin mukaan arkkipiispan kokonaiskirkollisia tehtäviä oli mahdollista arvioida myöhemmin erikseen..$^{398}$ Samaan aikaan tuomiokapitulien siirtäminen kokonaan kirkolle sekä alkava talouskasvu vapauttivat kirkon suunnittelemaan hiippakuntien tulevaisuutta aiempaa itsenäisemmin. Kirkolliskokous asettikin syksyllä 1995 komitean valmistelemaan hiippakuntahallinnon uudistusta. ${ }^{399}$ Edelleen kirkolliskokous antoi hieman myöhemmin kirkkohallitukselle tehtäväksi selvittää hiippakuntajaotuksen kokonaisuudistuksen tarvetta. ${ }^{400}$

Paineet Helsingin piispan työtaakan keventämiseksi olivat kovat. Kirkolliskokous päätti varata ensiapuna määrärahan teologisen aputyövoiman palkkaamiseksi Helsingin tuomiokapituliin..$^{401}$ Keskustelu Turun arkkihiippakunnan tilanteesta puolestaan äityi ajoittain kovaksi sanailuksi. Lopulta kirkolliskokous teki äänin 84-18 periaatepäätöksen toisen piispan viran perustamisesta. ${ }^{402}$ Piispoista Eero Huovinen, Paavo Kortekangas ja Olavi Rimpiläinen äänestivät vastaan. ${ }^{403}$ Jälleen ker- 
ran osoittautui, että hallinto herätti vähintään yhtä voimakkaita tunteita kuin perusluonteeltaan opilliset kysymykset.

Vastavalittu kirkolliskokous kävi 1996 osin uudelleen saman keskustelun kuin edeltäjänsä. Tällä kertaa huomio oli kuitenkin aiempaa enemmän hiippakuntarajoissa ja valtion uudistuvassa aluehallinnossa. Jotkut halusivat rinnastaa hiippakunnat lääneihin, joiden määrä oli vähenemässä. Tältä pohjalta myös hiippakuntien määrässä katsottiin olevan vähentämisen varaa. Useimpien mielestä taas itsenäisten hiippakuntien rinnastaminen valtion väliportaan hallintoon oli väärin. Luontevampi vertailukohta oli maakuntahallinto, joka oli nousemassa EU:n myötä ajankohtaiseksi. ${ }^{404}$ Kirkolliskokous päätti lopulta perustaa Turun piispan viran. ${ }^{405}$ Monissa puheenvuoroissa ja myös hallintovaliokunnan mietinnössä näkyi kuitenkin ajatus, että kahden piispan järjestelmä olisi vain väliaikainen. Odotukset kohdistuivat hiippakuntajaon uudistukseen, jonka toivottiin korjaavan niin arkkihiippakunnan kuin monen muunkin hiippakunnan rajoja. ${ }^{406}$

Voitto Huotarin johtama hiippakuntahallintokomitea sai mietintönsä valmiiksi 1998. Komitea painotti hiippakuntien itsenäisyyttä niin hallinnollisesti kuin taloudellisesti, pyrki keventämään hallintorakenteita ja korosti hiippakuntien toiminnallista, seurakuntaelämää palvelevaa luonnetta. ${ }^{407}$ Nimensä mukaisesti komitea keskittyi hiippakuntien hallintoon eikä pystynyt vastaamaan niihin suuriin odotuksiin, joita kohdistui hiippakuntajaon uudistamiseen. ${ }^{408}$ Tälläkin kerralla yritys keventää hallintoa törmäsi kirkolliskokouksessa erityisesti maallikkoedustajien syytöksiin, että edustuksellisuutta oltiin kaventamassa. Komitea pyrki keskittämään hallinnollisen vallan tuomiokapitulille, johon se ehdotti vastineeksi lisättävän maallikkojäseniä. Kirkolliskokoukselle tällainen kompensaatio ei riittänyt. Terttu Kauvosaari kuvasi komitean mietintöä sanoilla: "Piiri pieni pyörii, papit siinä hyörii." ${ }^{409}$ Kirkolliskokous katsoi, että hallintovaltaa oli jaettava sekä tuomiokapitulille että hiippakuntakokouksen pohjalta muodostettavalle uudelle hiippakuntavaltuustolle. Uudistuksen valmistelu siirtyi kirkkohallitukselle. ${ }^{410}$ Kirkon hallinnon keventämiskomitean pyrkimys lisätä hiippakuntien määrää ja keventää niiden hallintoa ei toteutunut 1990-luvulla. Tälläkin saralla edustuksellisuus ja hallinnon keventäminen jou- tuivat keskenään ristiriitaan, ja ensin mainittu osoittautui voittajaksi.

\section{ULKOMAILLE JA YKSEYTEEN TÄHYÄVÄ KIRKKO}

\section{BRYSSEL, PORVOO JA EUROOPAN YHDENTYVÄT KIRKOT}

Helsingin Sanomat omisti toukokuussa 1995 pääkirjoituksensa ekumenialle. Lehden mukaan Porvoon julistus oli "selkeä osoitus kirkkojen halusta olla mukana eurooppalaisessa yhdentymiskehityksessä", vaikka sopimus sinänsä ei liittynytkään Euroopan unionin asiakirjoihin. ${ }^{411}$ Ekumenian eteneminen ja Euroopan yhdentyminen linkittyivät toisiinsa kirkolliskokouksessakin, joka kantoi huolta kirkon asemasta Euroopassa. Jo keväällä 1992 Lapuan hiippakuntakokous jätti aloitteen mahdollisen EY-jäsenyyden vaikutuksista kirkolle. Kirkolliskokous antoi kirkkohallitukselle tehtäväksi seurata tilannetta ja tiedottaa siitä. ${ }^{412}$

Pitkin 1990-lukua kirkolliskokouksessa ilmeni tyytymättömyyttä siihen, ettei kirkkohallitus tehnyt tarpeeksi. Keskeinen erimielisyys koski sitä, tuliko kirkon lähteä aktiivisin toimin vaikuttamaan unionin tulevaisuuteen vai tuliko sen ennemminkin tukea olemassa olevia Euroopan kirkkojen vaikuttamiskanavia. Kirkkoherra Tapio Saraneva taas muistutti, ettei kirkon tullut keskittyä vain omaan edunvalvontaansa vaan myös vaikuttaa EU:n kehitysyhteistyöpolitiikan suuntaan köyhien maiden puolesta. Saranevan lisäksi varsinkin pappisedustajat Mikko Reijonen, Ari Tammi, Arto Laitinen ja Jaakko Launikari pitivät esillä EU-asioita. Yksi teema oli, tuliko evankelisten kirkkojen pyrkiä myös teologisesti aiempaa syvempään yhteistyöhön pystyäkseen vaikuttamaan EU:ssa. ${ }^{413}$

Porvoon julistus liittyi osittain tähän kokonaisuuteen. Se oli Britannian ja Irlannin anglikaanisten sekä Pohjoismaiden ja Baltian luterilaisten kirkkojen ekumeeninen asiakirja, jonka tarkoituksena oli luoda entistä syvempi yhteys näiden kirkkojen välille. Taustalla olivat kirkkojen aiemmat keskinäiset sopimukset ehtoollisyhteydestä sekä Kirkkojen maailmanneuvoston puitteissa syntynyt Kaste, ehtoollinen ja virka -asiakirja. Julistus oli osa Porvoon yhteistä julkilausumaa, joka oli valmis- 
tunut 1992. Julistus merkitsi piispan, papin ja diakonin virkojen vastavuoroista hyväksymistä sekä toisten kirkkojen kastettujen jäsenten pitämistä myös oman kirkon jäseninä. Lisäksi kirkot sitoutuivat julistuksen mukaan jatkamaan yhteistyöneuvotteluja ja pyrkimään yhteiseen näkemykseen diakoninvirasta. ${ }^{414}$ Siten julistus vauhditti Suomessakin kirkon virkaa koskevia selvityksiä.

Julistus tuli kirkolliskokouksen käsittelyyn toukokuussa 1995, kun edustajat kokoontuivat ensimmäistä kertaa Suomen EU-jäsenyyden aikana. Oli kulunut vain puoli vuotta neuvoa-antavasta kansanäänestyksestä, joka oli osoittanut kansan kahtiajaon suhtautumisessa jäsenyyteen ${ }^{415}$. Tätä taustaa vasten oli ymmärrettävää, että kaksi uutta yhteenliittymää, Euroopan unioni ja Porvoon kirkkoyhteisö, vertautuivat toisiinsa myös kirkolliskokouksessa. Epäilijät pelkäsivät julistuksen johtavan kirkkojen osalta samanlaiseen blokkiutumiseen kuin Euroopan unioni valtioiden tasolla. Paavo Kortekangas taas korosti kirkkojen säilyttävän itsenäisyytensä: "Mitään sellaista Maastrichtia ei ole, josta tulisi meille tämän jälkeen erilaisia direktiivejä." ${ }^{416}$ Euroopan unioniin liittyvät mielikuvat vaikuttivat siihen, millaisena kirkolliskokousedustajat näkivät syntymässä olleen Porvoon kirkkoyhteisön.

Lähetekeskustelu alkoi maltillisesti, mutta vähitellen mielipiteet tiukkenivat. Arvostelu kohdistui niin asiakirjan sisältöön kuin sen käsittelyyn Suomen luterilaisessa kirkossa. Korkeakoulupastori Ari Tammi oli julkisesti luvannut aloittaa kriittisen keskustelun täysistunnossa, ja hän piti sanansa. ${ }^{417}$ Tammen mukaan sinänsä hyvää hanketta olivat vieneet eteenpäin vain kirkon ylätason ekumeenikot, toisin sanoen kirkon ulkoasiain osasto. Sen sijaan seurakuntatasolla ei ollut syntynyt tarpeeksi keskustelua, kuten "alhaalta kasvavassa luterilaisessa kirkossa" olisi pitänyt. Jotkut kaipasivat myös herätysliikkeiden kannan kysymistä. Arkkipiispa Vikström korosti, että julistuksesta oli kyllä tiedotettu. Asian valmistelijat eivät kuitenkaan voineet mitään sille, että keskustelulla oli kirkossa taipumus alkaa vasta kalkkiviivoilla. Monet edustajat tulkitsivat seurakuntien vaikenemisen myöntymisen merkiksi. ${ }^{418}$ Julkisen keskustelun ja seurakuntien palautteen kaipuu oli uutta verrattuna Leuenbergin konkordiaa koskeneeseen päätöksentekoon. Tosin päätöksentekotilannekin oli erilainen kuin 1970-luvulla, jolloin Leuenber- gin konkordiaa ei ollut edes ehdotettu hyväksyttäväksi.

Muistuttaessaan "alhaalta kasvavasta kirkosta" Ari Tammi vertasi Porvoon julistusta kriittisesti Kirkko 2000 -prosessin tavoitteisiin. Teema liittyi myös julistuksen virkateologiaan. Jotkut kertoivat pelkäävänsä, että anglikaaneille ominainen piispanviran korostaminen uhkasi luterilaista kirkkokäsitystä. Piispa Kortekangas ja tuomiorovasti Matti Järveläinen huomauttivat, ettei Kirkko 2000 -prosessin iskulauseella voinut kuvata kirkon järjestysmuotoa. ${ }^{49}$ Myös Erik Vikström puolusti voimallisesti asiakirjaa. Toki jo julistuksen nimestä saattoi päätellä Porvoon piispan kannan, mutta kannatus oli huomattavaa sikäli, että Vikström tunnettiin kolmisäikeisen virkakäsityksen arvostelijana. Toiminnallaan hän valoikin luottamusta siihen, ettei julistus merkinnyt uutta virkateologista näkemystä. ${ }^{420}$

Leena Huima arvosteli piispallista korostusta toisenlaisesta näkökulmasta. Hänen mielestään ei olisi ongelma, jos kirkon ykseys toteutettaisiin lainsäädännöllisillä päätöksillä ilman erillistä julistusta. Ongelmana oli itse julistus, jossa luterilaisiin tunnustuskirjoihin verrattuna esitettiin uusia kriteerejä kirkon ykseydelle. Luterilaisuuden näkökulmasta oli ongelmallista, että piispuudesta oli tulossa tärkeä ykseyden kriteeri ja näkyvä merkki. ${ }^{421}$ Istuntokauden kuluessa entinen kirkolliskokousedustaja, professori Jaakko Voipio kiinnitti Kotimaa-lehdessä huomiota myös siihen, että kirkkojärjestyksen mukaan tuomiorovasti tai pappisasessori saattoi edelleen toimittaa pappisvihkimyksen. Säännös oli kuitenkin Porvoon julistuksen näkökulmasta hyvin ongelmallinen. ${ }^{422}$

Asiakirjan tulkintaongelmat olivat sekä teologisia että juridisia. Kirkkohallitus puuttui lausunnossaan siihen, ettei ollut täysin selvää, millaisiksi julistuksen oikeudelliset seuraukset oli tulkittava. Julistuksen hyväksyminen oli nähtävä ainakin moraaliseksi velvoitukseksi ryhtyä muuttamaan lainsäädäntöä. Kirkkohallitus huomautti, että julistus saattoi edellyttää muutoksia myös uskonnonvapauslakiin. Kirkolla ei kuitenkaan ollut valtuuksia sitoutua tällaisiin muutoksiin. ${ }^{423}$ Kaiken lisäksi kirkolliskokous unohti itsekin Porvoon julistuksen antaessaan 1999 lausunnon uskonnonvapauslain uudistuksesta. Kirkolliskokous edellytti ehdotonta kaksoisjäsenyyden kieltoa, vaikka Porvoon julistuksen jäsenkirkkojen osalta olisi ollut painavia perusteluja toisenlaiselle ratkaisulle. ${ }^{224}$

U L K O M A I L L E J A Y K S E Y T E E N T ÄH Y ÄV Ä K I R K K O 229 
Opilliset epäselvyydet taas liittyivät virkateologian ohella ennen kaikkea sakramenttiteologiaan ja vanhurskauttamisoppiin. Jotkut epäilivät, että julistuksen lausumien taakse oli kätketty kalvinilaista ehtoollisteologiaa. Kalvinilaisuuden pelon kanssa oli hienoisessa ristiriidassa se, että samat kriitikot pelkäsivät asiakirjan vievän luterilaista kirkkoa kohti Roomaa. Itse asiassa Porvoon julistuksen opillinen vastustus kytkeytyi paljolti Yhteiseen julistukseen vanhurskauttamisopista, odotettavissa olleeseen luterilais-katoliseen asiakirjaan. Suomen Evankelisluterilaisen Kansanlähetyksen kouluttajan Liisi Jokirannan mielestä kirkko oli "askeltamassa anglikaanikirkon kautta kohti Roomaa". ${ }^{25}$ Kirkkoneuvos Risto Cantell kiisti epäilyt ja totesi, että katolisen kirkon piirissä Porvoon julistusta oli vastustettu, koska sen oli katsottu vievän anglikaaneja etäämmäksi katolisuudesta ja kohti luterilaisuutta. Arkkipiispa Vikström tulkitsi puolestaan Jokirannan sanat niin, että hänen ja muiden asiaa valmistelleiden päällä leijui moraalinen syytös motiivien salailemisesta. ${ }^{426}$ Lähetekeskustelu päättyi jännittyneeseen tunnelmaan. Perustevaliokunta tosin pyrki lauhduttamaan välittömästi mielialoja. Se päätti antaa tilaa keskustelulle ja valmistaa mietintönsä vasta seuraavalle istuntokaudelle. ${ }^{427}$

Vaikka asiakirjan arvostelijat saivat aikaan vilkkaan keskustelun, heitä oli melko vähän. Edelleen näytti olevan niin kuin kaksi vuosikymmentä aiemmin Leuenbergin konkordiaa käsiteltäessä: suurin osa edustajista luotti piispainkokoukseen ja seurasi sen linjaa. Arkkipiispa John Vikström nousi lähetekeskustelussa kolmeen kertaan puolustamaan Porvoon julistusta. Hän suhtautui asiakirjaan henkilökohtaisesti ja ajoi kantaansa aktiivisesti, mikä muistutti selvästi Martti Simojoen toimintaa Leuenbergin konkordiaa käsiteltäessä. Arkkipiispa oli vaihtunut mutta säilynyt kirkon ekumeenisena suunnannäyttäjänä.

Keskustelu Porvoon julistuksesta muistutti sananvaihtoa, jota kirkolliskokouksessa oli 199o-luvun alkuvuosina käyty Suomen mahdollisesta EU-jäsenyydestä. Toisten mielestä EU-jäsenyys mullistaisi kaiken, toisten mukaan hyvin vähän. ${ }^{428}$ Samalla tavalla Porvoon sopimuksen kannattajat argumentoivat, että kyse oli lähinnä jo olemassa olevan ykseyden vahvistamisesta, kun taas vastustajat korostivat niitä muutoksia, joita sopimus voisi tuoda kirkon opintulkintaan. Huolta kansal-

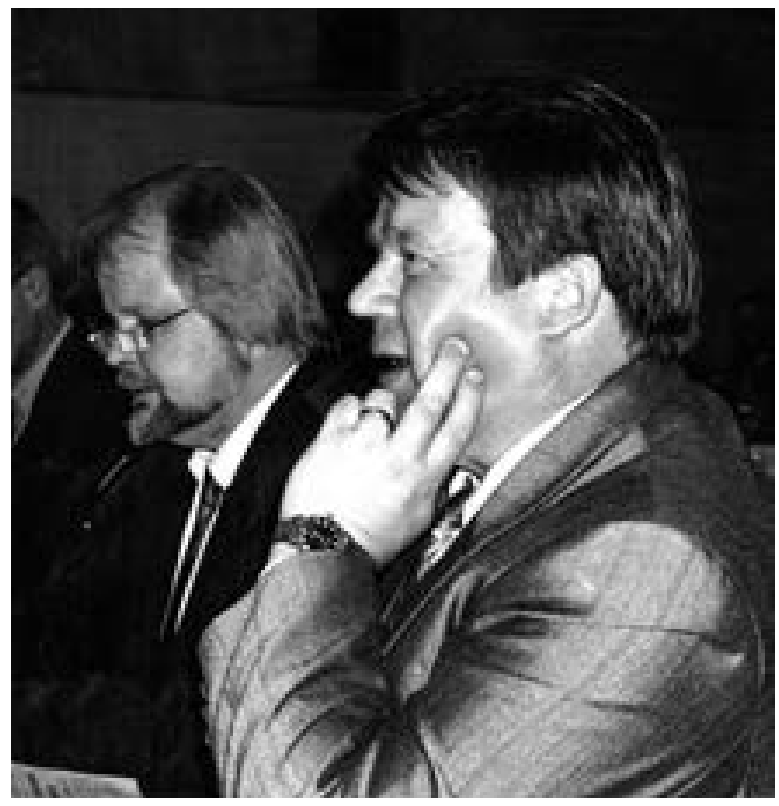

Kuopion hiippakunnan edustajista tuomiorovasti Matti Järveläinen (vas.) puolusti Porvoon julistuksen episkopaalista lähestymistapaa asiakirjan arvostelijoita vastaan. Insinööri Heimo Karhapää taas äänesti ratkaisevassa käsittelyssä julistuksen hyväksymistä vastaan. Suomen Evankelisluterilaisen Kansanlähetyksen puheenjohtaja Karhapää oli tutkimuskauden pitkäaikaisin kirkolliskokousedustaja, jonka edustajuus kesti yhtäjaksoisesti kolme vuosikymmentä 19782008. Kuva: Kotimaan kuva-arkisto / Ritva Rasila.

lisesta "luterilais-suomalaisesta" kristillisyydestä ei kuitenkaan enää ilmennyt samalla tavoin kuin Leuenbergin konkordiaa käsiteltäessä, vaan epäilykset koskettivat luterilaisuuden yleistä opillista suuntaa.

Piispa Eero Huovisen johtama perustevaliokunta pohti seikkaperäisesti julistuksen ongelmia, kuten sitä, oliko virka nostettu asiakirjassa sanan ja sakramenttien rinnalle armonvälineeksi. Valiokunnan enemmistö katsoi, ettei näin ollut. ${ }^{429}$ Valiokunta halusi helpottaa julistuksen hyväksymistä muuttamalla käännöstä. Asiakirjan suomennoksessa oli "sitouduttu" (we commit ourselves) pyrkimään moniin yhteisiin päämääriin, kuten yhteiseen näkemykseen diakoninvirasta. Perustevaliokunta muutti sitoutumisen "velvoittautumiseksi", joka ei valiokunnan mukaan ollut yhtä vahva ilmaus. Valiokunta halusi välttää etukäteen sitomasta käsiä Suomen luterilaisen kirkon virkateologisessa valmistelussa. ${ }^{430} \mathrm{Li}$ säksi valiokunta rauhoitteli kirkolliskokousta toteamal- 
Arkkipiispa John Vikström allekirjoitti Porvoon julistuksen Suomen luterilaisen kirkon puolesta Nidarosin tuomiokirkossa Trondheimissa 1. syyskuuta 1996. Kuva: Kotimaan kuvaarkisto / Jukka Granström.

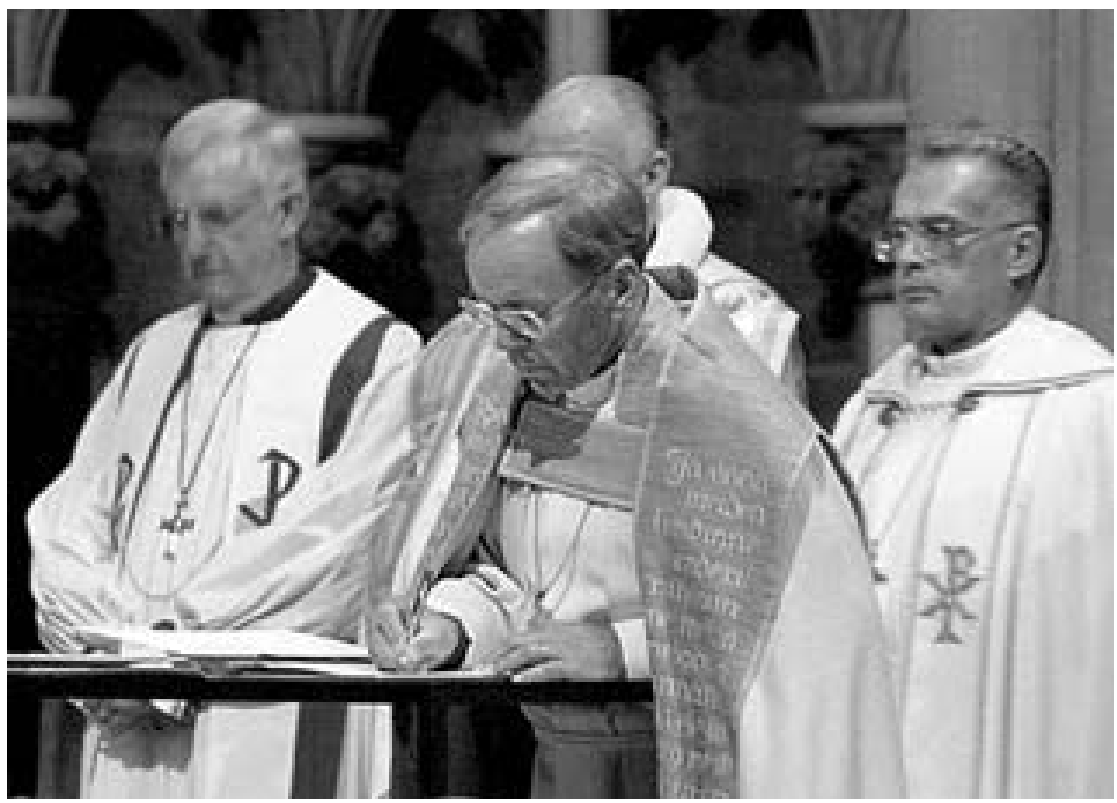

la mietintönsä perusteluissa, ettei Porvoon julistus ollut uusi tunnustusasiakirja. ${ }^{431}$ Kaikkia mietintö ei vakuuttanut. SRK:n pääsihteeri Voitto Savela ja kouluttaja Liisi Jokiranta jättivät eriävän mielipiteen. ${ }^{432}$ Jokiranta oli kuulunut yhdessä Pielisensuun kirkkoherran Tapani Nuutisen ja Kannelmäen kirkkoherran Pentti Simojoen kanssa perustevaliokunnan mietintöä valmistelleeseen työryhmään. ${ }^{433}$

Kirkolliskokous hyväksyi Porvoon julistuksen marraskuussa 1995. Vakuuttaakseen epäilijöille ja erityisesti julkisuuteen, ettei kyse ollut tunnustuksen muuttamisesta, kirkolliskokous mainitsi erikseen hyväksyvänsä julistuksen "kirkkomme tunnustuksen pohjalta". ${ }^{434}$ Toisessa käsittelyssä vastaan äänesti Savelan ja Jokirannan ohella viisi muuta edustajaa. ${ }^{435}$ Herätysliikkeistä vain vanhoillislestadiolaiset olivat selvästi yhtenäisenä ryhmänä julistusta vastaan, ja tästä joukosta löytyi myös ainoa vastaan äänestänyt pappisedustaja, Keijo Nissilä. Sen sijaan on huomattava, että esimerkiksi esikoislestadiolainen Martti Drachman kannatti julistukseen liittymistä. Kriittisiä kysymyksiä näkyvästi esittäneistä edustajista Ari Tammi äänesti julistuksen hyväksymisen puolesta ja Leena Huima tyhjää. ${ }^{436}$ Mielipiteet jakautuivat herätyskristillisyyttä tai tunnustuksellisuutta painottavien edustajien joukossa. ${ }^{437}$ Kaikesta päätellen Olavi Rimpiläisen puoltava kanta vaikutti siihen, että osa näistä edustajista asettui asiakirjan hyväksymisen kannalle. ${ }^{438}$

Porvoon julistuksen käytännön seuraukset alkoivat nopeasti tulla kirkolliskokouksen pohdittaviksi. Ongelmana oli esimerkiksi, mitä tarkoitti asiakirjassa mainittu voimavarojen jakaminen. ${ }^{439}$ Talousvaliokunta tulkitsi 1996, että kirkon keskusrahaston avustuksia oli jaettava myös julistuksen piiriin kuuluville Suomen ulkomaalaisseurakunnille. ${ }^{440}$ Asiaa pohdittaessa kirkkoneuvos Matti Halttunen valitteli julistuksen oikeudellista epäselvyyttä, joka oli aiheuttanut vaikeuksia myös Ruotsissa ja Norjassa. ${ }^{441}$ Vuosikymmenen päättyessä kirkolliskokous joutui entistäkin lähemmin kasvokkain Porvoon julistuksen kanssa, kun se sai pohdittavakseen, tuliko kirkkojärjestyksestä poistaa mahdollisuus tuomiorovastin tai pappisasessorin toimittamaan pappisvihkimykseen. Ratkaisut jäivät 200o-luvun kirkolliskokouksille. ${ }^{42}$

\section{YHTEINEN JULISTUS MAAILMALLE VAI}

PORTTI ULOS AIDOSTA LUTERILAISUUDESTA?

Luterilaisten ja katolilaisten väliset oppikeskustelut olivat alkaneet 1960-luvun alkupuolella pidetyn Vatikaanin toisen kirkolliskokouksen myötä. Kolme vuosikymmentä myöhemmin Luterilainen maailmanliitto ja katolisen kirkon paavillinen kristittyjen ykseyden edistämisen neuvosto saivat valmiiksi Yhteisen julistuksen vanhurs- 
kauttamisopista. Asiakirjan myötä reformaatiokaudella puolin ja toisin lausutut, vanhurskauttamista koskevat oppituomiot oli määrä todeta kohteettomiksi. ${ }^{443}$ Yhteinen julistus ei sisältänyt täydellistä yksimielisyyttä vanhurskauttamisopista mutta kuitenkin riittäväksi katsotun yhteisymmärryksen. ${ }^{444}$

Suomen luterilainen kirkko sai asiakirjan 1995, ja seurauksena oli vilkas keskustelu. Ensimmäiseksi asiakirjaa käsitteli kirkon ulkoasiain neuvosto. Se esitti lukuisia korjauksia, mikä kuvasti Suomessa vallinnutta, moneen muuhun luterilaiseen kirkkoon verrattuna kriittistä suhtautumista asiakirjaan. Julistusta muutettiinkin vielä ulkoasiain neuvoston toivomaan suuntaan prosessissa, jossa oli mukana myös useita suomalaisia teologeja - näkyvimpänä piispa Eero Huovinen. ${ }^{45}$ Muutosten jälkeen piispainkokous asettui yksimielisesti asiakirjan taakse, ja kirkolliskokous sai julistuksen käsiteltäväkseen syksyllä 1997.446

Keskeisenä erona Porvoon julistuksen käsittelyyn verrattuna oli, ettei kukaan moittinut julkisen keskustelun vähäisyyttä. Piispainkokous olikin pyrkinyt pitämään huolen siitä, ettei tällä kertaa olisi aihetta salailusyytöksiin. ${ }^{447}$ Kirkolliskokouksessa useat piispat kiirehtivät vastaamaan arvosteluun, jota oli esitetty esimerkiksi "tunnustuksellisen rintaman" julkaisemassa Turhentuuko uskonpuhdistus? -pamfletissa. ${ }^{448}$ Lisäksi kaksitoista kristillistä järjestöä vetosi kirkolliskokousedustajiin, jotta julistusta ei hyväksyttäisi. ${ }^{449}$ Arvostelijoiden puheenvuoroissa toistuivat monet Porvoon julistusta käsiteltäessä esitetyt perustelut. Nytkin pohdittiin, oliko uusi asiakirja tunnustuskirjojen yläpuolella, ja jälleen ilmeni epäselvyyttä asiakirjan konkreettisista ekumeenisista seurauksista. Tälläkin kerralla jotkut pelkäsivät asiakirjan vievän ennen pitkää Rooman syliin. ${ }^{450}$

Myös EU-vertauskuvilla oli edelleen oma paikkansa. Kun kirkolliskokous alkoi käsitellä Yhteistä julistusta vanhurskauttamisopista syksyllä 1997, kiisteltiin valtakunnanpolitiikassa Suomen osallistumisesta Euroopan talous- ja rahaliiton kolmanteen vaiheeseen eli yhteisvaluuttaan. Mielipidetutkimusten mukaan kansalaisten enemmistö, enimmillään kaksi kolmasosaa vastaajista, vastusti hanketta. ${ }^{451}$ Aivan kuten Porvoon julistuksen osalta kirkolliskokouksen ekumeeninen päätöksenteko ajoittui Euroopan yhdentymisen kannalta hyvin jännittyneeseen vaiheeseen. Asetelma heijastui keskusteluun, jossa Rooma rinnastui välillä Brysseliin. Henrik Perret epäili katolisen kirkon sitoutumista asiakirjaan ja kysyi, "käykö näin, niin kuin EU:ssa on käynyt, että suomalainen osapuoli tunnollisesti noudattaa sopimuksia ja Etelä-Euroopassa viis veisaavat siitä ja joku espanjalainen kunnallispoliitikko päättää meidän kurkuista ja tomaateista". ${ }^{452}$

Perret'n esittämään arvosteluun liittyi hyvin keskeinen keskustelunaihe: miten katolinen kirkko opetti muissa yhteyksissä vanhurskauttamisesta, ja muuttuisiko katolisen kirkon opetus käytännössä yhteisen julistuksen mukaiseksi? Erityisesti tarkattiin muutamaa vuotta aiemmin valmistunutta katolisen kirkon katekismusta. Julistuksen puolustajien mielestä toista osapuolta ei tullut epäillä, vaan oli luotettava katolisen kirkon tahtoon sitoutua julistukseen. Julistuksen kannattajien mielestä katolinen kirkko oli tullut huomattavasti luterilaisia vastaan. ${ }^{453}$ Tärkeään osaan keskustelussa nousivat kummankin kirkkokunnan erityiskorostukset, jotka oli kirjattu julistukseen. Julistuksen puolustajien mielestä ne osoittivat rehellisyyttä, kun taas vastustajien mielestä ne kyseenalaistivat koko sopimuksen. ${ }^{454}$

Kirkkokuntien oppijärjestelmien epäsuhtaan kiinnitettiin paljon huomiota: vanhurskauttamisoppi oli luterilaisille luovuttamaton kirkon ykseyden kriteeri mutta katoliselle kirkolle vain yksi monista kriteereistä. Kyseltiin, oliko muissa opeissa sellaisia erimielisyyksiä, jotka veisivät pohjaa yhteiseltä julistukselta. Erityisesti oppi synnistä ja kysymys vanhurskautetun ihmisen syntisyydestä herättivät epäilyksiä. Asiakirjan arvostelijat vetosivat siihen, että ihminen oli vanhurskauttamisen jälkeenkin paitsi täysin vanhurskas myös täysin syntinen. Uuteen suomalaiseen Luther-tutkimukseen nojanneet julistuksen kannattajat taas korostivat vanhurskauttamista paitsi anteeksiantamuksena myös Kristuksen pyhittävänä läsnäolona. ${ }^{455}$

Leena Huima kiinnitti lähetekeskustelussa huomiota Luterilaisen maailmanliiton esittämään väitteeseen, johon jäsenkirkkoja pyydettiin vastaamaan. Huiman mukaan väite oli rakennettu siten, että siihen oli loogisesti pakko yhtyä sellaisenkin, joka piti asiakirjan sisältöä ongelmallisena. Lisäksi Huiman mukaan oli vaikeaa ottaa kantaa oppituomioihin, koska luterilaisissa tunnustuskirjoissa ei juuri ollut nimenomaan katoliseen vanhurskauttamisoppiin kohdistuvia tuomioita. ${ }^{456}$ Perustevalio- 
kunta käsitteli tarkkaan Huiman esille tuomia ongelmia ja puuttui niihin myös pitkässä ja yksityiskohtaisessa mietinnössään. Valiokunnan enemmistön mielestä oli kuitenkin mahdollista antaa myönteinen vastaus - tosin muutamin tarkennuksin. ${ }^{457}$ Valiokunnan ratkaisu muistutti jossain määrin varsinaisen julistuksen metodia, joskin valiokunta korosti, että kyseessä olivat vain tarkennukset, eivät varaumat. ${ }^{45^{8}}$ Valiokunnan jäsenet Liisi Jokiranta, Voitto Savela, Risto Taipale ja Svante Österbacka esittivät kahdessa eriävässä mielipiteessä opillisin perustein, ettei julistusta hyväksyttäisi. ${ }^{459}$

Kevätistuntokautta 1998 edeltäneen valiokuntakäsittelyn aikana julkinen sananvaihto jatkui kiivaana. Perustevaliokunnan varapuheenjohtajan Juha Pihkalan mukaan koettiin myös "pitkästä aikaa oikein tosissaan ilmiö, josta on ollut tapana käyttää nimitystä teologien raivo 'rabies theologorum"' ${ }^{460}$ Valiokuntatyön lopputulokseen keskustelu ei sen sijaan näytä enää oleellisesti vaikuttaneen. Pihkala myönsi kirkolliskokoukselle, että valiokunnan enemmistön johtopäätökset vastasivat niitä oletuksia, joita asiaa valmistelleilla oli alun perinkin ollut. Toisaalta Pihkalan mukaan "kohtuullisen sitkeistä taivutteluyrityksistä huolimatta" julistusta arvostelleet valiokunnan jäsenet eivät olleet suostuneet mietintöä valmistelleeseen työryhmään. ${ }^{461}$ Puolin ja toisin poterot oli kaivettu syviksi ja loppupäätelmät lyöty lukkoon jo ennen valiokuntatyöskentelyä. Vaikka näin oli, julistuksen käsittelyprosessi Suomessa oli kokonaisuudessaan varovainen ja perusteellinen. Monet niistäkin, jotka kirkolliskokouksessa puolustivat voimakkaasti julistusta, olivat arvioineet kriittisesti julistuksen aiempien versioiden teologiaa. Siten julistuksen käsittelyssä voi nähdä samaa pyrkimystä teologiseen perinpohjaisuuteen kuin jo 1970-luvulla Leuenbergin konkordiasta päätettäessä.

Kirkolliskokousedustajat saivat postia useista herätysliikkeistä, ja asian käsittely repi herätysliikekenttää. Herättäjä-Yhdistyksen aluesihteeri Eeva Eerola Alavieskasta kertoi herätysliikkeensä joutuneen tulilinjalle, kun se ei ollut lähtenyt vastustamaan julistusta: kysyttiin, oliko Kristuksen armo syntistä ihmistä kohtaan vaihtumassa paavin oppiin..$^{462}$ Julistuksen käsittely aiheutti säröjä myös herätysliikkeiden sisälle. Lähellä viidettä herätysliikettä ollut Viinikan kirkkoherra Erkki Ranta kertoi olleensa aiemmin vaatimassa muutoksia asiakirjaan. Kun muutokset oli saatu, hän oli siirtynyt asiakirjan kannal- le mutta jäänyt yksin saaden takinkääntäjän leiman. ${ }^{463}$ Tällaiset kokemukset muistuttivat edellisinä vuosikymmeninä naispappeuskeskusteluissa kuultuja mietteitä, ja vuosien 1997-1998 keskustelu näyttääkin olleen pienimuotoinen vanhurskauttamisopillinen jatko aiemmalle virkateologiselle rajanvedolle herätysliikkeiden sisällä ja välillä.

Perustevaliokunnan mietintö tuli kirkolliskokouksen käsittelyyn keväällä 1998. Istuntokausi oli sikälikin historiallinen, että arkkipiispa Vikströmin sairausloman vuoksi kirkolliskokouksen avasi ensimmäinen varapuheenjohtaja Kyllikki Tiensuu. Avauspuheessaan Tiensuu viittasi ristiriitojen sävyttämään kristittyjen julkisuuskuvaan ja yhteisen todistuksen tarpeeseen. ${ }^{464}$ Perustelut toistuivat asian täysistuntokäsittelyssä. Julistuksen puolustajat korostivat, miten merkittävä yhteinen todistus asiakirja oli maallistuneille ihmisille ja ei-kristitylle maailmalle. Turkulaisen diakoniajohtajan Kaarlo Kallialan ja helsinkiläisen sosiaalipsykologin Pekka Sormusen tavoin jotkut totesivat, että historian painolastin purkaminen raivasi tilaa käsitteiltään ajanmukaiselle julistukselle. ${ }^{465}$

Tulkinnat olivat kuitenkin osin keskenään vastakkaisia. Dosentti Risto A. Ahonen näki asiakirjan luterilaisten ja katolilaisten yhteisenä taisteluna ihmiskeskeistä uskonnollisuutta ja synkretismiä vastaan, kun taas porilainen toimittaja Marjaana Perttula piti julistusta porttina näihin molempiin. Perttula viittasi pastori Antti Kylliäisen tuoreeseen kirjaan Kaikki pääsevät taivaaseen ja epäili, että ekumeeninen julistus oli väljentämässä entisestään luterilaisen opetuksen raameja. ${ }^{66}$ Puolustajien mielestä asiakirja saattoi päinvastoin kiinnittää pappien huomiota vanhurskauttamiseen ja kohentaa sananjulistuksen tasoa. ${ }^{467}$ Suomen teologisen instituutin pääsihteeri Eero Junkkaala vastasi, ettei vanhurskauttamisopetuksen aiempi epäselvyys kirkossa oikeuttanut avaamaan "uusia ovia uudelle epäselvyydelle". ${ }^{68}$

Asetelman ehdottomuutta kuvasti, ettei lopulta kukaan valiokunnan päätelmiin tyytymättömistä ehdottanut muutoksia valiokunnan valmistelemaan vastauskirjeeseen Luterilaiselle maailmanliitolle ${ }^{469}$. Vaihtoehtoina olivat vain asiakirjan hyväksyminen tai hylkääminen. Ratkaisevassa toisessa käsittelyssä valiokunnan kanta saavutti taakseen määräenemmistön äänin $88-17.470$ Vastaan äänestäneistä vain kolme oli pappeja. ${ }^{411}$ Kuten 
Porvoon julistusta käsiteltäessä nytkin maallikkoedustajilla oli suurin huoli luterilaisen tunnustuksen säilymisestä. Tosin asiakirjan kriitikkojen johtohahmoksi nousi kirkolliskokouksessa nimenomaan pappisedustaja Eero Junkkaala ${ }^{472}$.

Vastaan äänestäneiden taustoissa näkyivät monet herätysliikkeet. ${ }^{473}$ Erityisen paljon joukossa oli viidenteen herätysliikkeeseen kuuluvia, joiden määrä kirkolliskokouksessa oli kasvanut. Toisaalta läheskään kaikki viidesläiset eivät vastustaneet sopimusta, ja tälläkin kertaa vain vanhoillislestadiolaiset kirkolliskokousedustajat olivat yhtenäisesti herätysliikeryhmänä sopimusta vastaan. Viimeksi mainitut tosin vakuuttivat uskollisuuttaan kirkolle ja pyysivät ylivieskalaisen kanttorin Yrjö Koskimäen suulla "tässä rakkaassa kansan kirkossa edelleen jotakin nurkkaa tai parrun pätkää". ${ }^{774}$

Vastaan äänestäneissä oli kahdeksan sellaista, jotka olivat istuneet kirkolliskokouksessa edellisellä kaudella. Heistä kuusi oli antanut ei-äänen myös Porvoon julistuksesta päätettäessä. Suhtautuminen 1990-luvun kahteen suureen ekumeeniseen asiakirjaan noudatti kirkolliskokouksessa melko yhtenäisiä jakolinjoja. Se, että Yhteinen julistus vanhurskauttamisopista sai osakseen enemmän vastustusta kuin Porvoon julistus, näyttää johtuneen pitkälti tunnustuksellisuutta painottaneiden ryhmien menestymisestä vuoden 1996 kirkolliskokousvaaleissa. Vaalien tulokseen saattoi hyvinkin vaikuttaa samaan aikaan meneillään ollut julkinen keskustelu asiakirjasta. Se osoitti, että katolinen kirkko herätti seurakuntalaisten keskuudessa voimakkaampia tunteita kuin yhteistyö anglikaanien kanssa. Suhteellisen vaalitavan leviäminen pappisedustajien vaaliin ja kirkkopoliittisen ryhmänmuodostuksen vähittäinen vahvistuminen maallikkoedustajien vaalissa loivat puolestaan rakenteellisia edellytyksiä vaalimenestykselle.

Kirkolliskokouksessa ei juuri kuultu 1990-luvulla sellaista ohjelmallista ekumeniakritiikkiä kuin aiempina vuosikymmeninä. Ekumeenisten asiakirjojen arvostelijat keskittyivät asiakirjojen sisällöllisiin ongelmiin, mikä kuvasti asenteiden muuttumista. ${ }^{475}$ Liisi Jokiranta nosti Yhteistä julistusta vanhurskauttamisopista koskevassa eriävässä mielipiteessään esille keskieurooppalaisen vastajulistuksen, joka oli julkaistu myös Perusta-lehdessä. ${ }^{476}$ Jo vetoaminen vastajulistukseen osoitti keskustelun luonnetta: ei ollut kyse suomalaiskansallisen luteri- laisen identiteetin säilyttämisestä, vaan niin julistusta kannattaneet kuin vastustaneet ryhmät ylittivät valtioiden ja kirkkojen väliset rajat. Tässä jaossa sopimusta vastustaneet, viidenteen herätysliikkeeseen lukeutuneet edustajat näyttäytyivät osana yleismaailmallista evankelikaalista liikehdintää ${ }^{47}$.

Pentti Laasosen kuvaama luterilaisuus katsoi 160o-luvulla kohti Roomaa ja piti vain pikkusormella kiinni kalvinilaisista. ${ }^{478}$ Tämä kuvaus sopi Suomen luterilaiseen kirkkoon ja sen kirkolliskokoukseen edelleen 1900-luvun viimeisinä vuosikymmeninä. Liisi Jokirannan esille nostama keskieurooppalaisten teologien vetoomus menetti painoarvoaan jo, kun täysistunnossa mainittiin, että allekirjoittajat olivat paljolti reformoitujen tai unioitujen kirkkojen teologeja ${ }^{479}$. Suomen luterilainen kirkolliskokous ei ainoastaan katsonut Roomaan ja Canterburyyn vaan löi kättä niiden kanssa. Samaan aikaan se pidättyi lähtemästä mukaan Keski-Euroopassa edenneeseen luterilaisten ja reformoitujen yhdentymiskehitykseen..$^{80}$

\section{KYSYMYS TYÖNTEKIJÖIDEN TASA-ARVOSTA SEKOITTUU EKUMEENISEEN VIRKATEOLOGIAAN}

Suomen luterilaisen kirkon henkilöstö miltei kolminkertaistui vuosina 1975-1991. Kirkossa oli 1990-luvulla käytössä 838 ammattinimikettä. ${ }^{481}$ Virkojen ja työtehtävien kirjo oli poikkeuksellisen laaja verrattuna lähes mihin tahansa muuhun kirkkoon. Suomessa oli 1900-luvulla syntynyt lukuisia omaleimaisia virkoja, joiden lähtökohdat olivat käytännön tarpeissa eivätkä yhtenäisessä teologisessa mallissa. Professori Seppo A. Teinosen johtaman virkakomitean ajatus kolmisäikeisestä virasta oli 1976 jäänyt naispappeuskeskustelun varjoon, mutta 1990-luvulla viran rakenne nousi kirkolliskokouksessa esiin lähes kaikkien merkittävimpien asiakokonaisuuksien yhteydessä. Se oli vastassa keskusteltaessa kirkon hallinnon järjestämisestä, tuomiokapitulien tehtävistä, jumalanpalveluksesta tai ekumeenisista asiakirjoista. Kirkolliskokouksen vuodesta 1987 lähtien käsittelemät ja piispainkokoukselle lähettämät virka-aloitteet alkoivat myös johtaa mietintöihin.

Samoin kuin aikoinaan virkojen luominen myös pyrkimys teologisesti yhtenäiseen virkamalliin lähti moninaisista käytännön tarpeista. Diakonia- ja nuorisotyöntekijöiden keskuudessa oli omaa asemaa kohtaan 
tyytymättömyyttä, jota kirkolliskokouksen 1980-luvulla käsittelemät aloitteet kuvastivat. Virkarakenteen määrittelemisen tarve nousi toisaalta voimakkaasti esiin ekumeenisessa kanssakäymisessä. Diakonaatin kehittäminen olikin 1900-luvun lopulla ajankohtaista kaikissa tunnustuskunnissa - myös Pohjoismaiden luterilaisissa kirkoissa ${ }^{482}$.

Piispa Erik Vikströmin johtama piispainkokouksen virkarakennetyöryhmä esitti kaksi vaihtoehtoista mallia: joko kirkolla katsottiin olevan yksi virka, jonka säie diakonaatti oli, tai sitten diakonaattia tuli kehittää omana virkanaan. Kummassakin mallissa diakonaatti voitiin mieltää joko karitatiiviseksi viraksi tai laajaksi palveluviraksi, johon oli mahdollista liittää useita työntekijäryhmiä. ${ }^{483}$ Kirkko 2000 -työskentelyssä oli hieman aiemmin nostettu esille jälkimmäinen ratkaisu. ${ }^{84}$ Virkarakennetyöryhmän enemmistö asettui kolmisäikeisen viran kannalle, kun taas puheenjohtaja Vikström puolusti diakonaattia erillisenä virkana. ${ }^{485}$

Piispainkokouskaan ei pitkistä keskusteluista huolimatta päässyt yksimielisyyteen 1993. Tilanteen vaikeutta osoitti, että myös työryhmän linjaa arvostelleiden piispojen ajatukset poikkesivat toisistaan. Piispainkokous ei halunnut tehdä asiassa esitystä äänestyspäätöksellä, joten aihealue siirtyi kirkolliskokoukselle ilman selviä suuntaviittoja. ${ }^{486}$ Koska virkarakenteen kokonaisuuteen keskittynyt uudistustyö oli johtanut erimielisyyksiin, piispainkokouksen mielestä oli lähdettävä liikkeelle toisesta suunnasta, diakonian virasta. Piispainkokous esitti, että kirkolliskokous asettaisi komitean selvittämään "diakonian viran kehittämiseen liittyviä teologisia ja käytännöllisiä kysymyksiä". ${ }^{487}$ Kirkolliskokouksen perustevaliokunta liittyi piispainkokouksen valmisteluun ja esitti viisijäsenistä komiteaa. Komitean tuli tehdä diakonian viran kehittämistä koskevat esitykset, valmistella alustavasti muutoksia kirkkolainsäädäntöön ja kirkkokäsikirjaan sekä miettiä uudistusten vaikutusta koulutukseen sekä virka- ja työehtosopimukseen..$^{48}$

Teologisesti piispainkokous ja perustevaliokunta nojasivat sana-käsitteen laajaan määritelmään: sananjulistukseen kuului aina olennaisena myös rakkaus, minkä vuoksi diakonaatti oli mahdollista ymmärtää osana kirkon virkaa. ${ }^{489}$ Täysistunnossa Voitto Huotari korosti sen sijaan voimakkaasti, että nuorisotyöntekijöiden ja diakonian viranhaltijoiden asemaa tuli käsitellä heidän pe- rustehtävästään käsin, ei kirkon virkaa korostavasta liturgian näkökulmasta. Ari Tammi ja Leena Huima taas katsoivat, että piispainkokouksen ja valiokunnan sanakäsitys toi vastoin tunnustuskirjoja rakkauden osaksi kirkon olemusta sanan ja sakramenttien rinnalle. ${ }^{490}$ Kaikki kolme kriitikkoa vastustivat rakkaudenpalvelun liiallista samastamista sananpalvelun virkaan. Tämäkin kiista nivoutui lopulta uuteen suomalaiseen Luthertutkimukseen: sen tulosten mukaisesti rakkautta alettiin yhä laajemmin pitää uskon seurauksen sijasta osana uskon ydintä, sananpalvelua ja jumalanpalveluselämää. Nuorta Lutheria lukevassa kirkossa Melanchthon-tutkija Tammi ja Schmalkaldenin opinkohtia siteeraava Huima olivat oppositiossa.

Kirkolliskokouksen täysistunto nosti komitean jäsenmäärän seitsemään. Olavi Rimpiläisen johtamaan komiteaan tulivat kaikkien laaja-alaiseen diakonaattiin kaavailtujen työntekijäryhmien edustajat kanttoreita lukuun ottamatta. ${ }^{491}$ Täysistunnossa puhui kaksi kanttoria, ja pöytäkirjaan tallentui samalla kaksi melko lailla päinvastaista mielipidettä siitä, tuliko kanttorit nähdä osana diakonaattia. ${ }^{492}$ Viranhaltijaryhmä, joka oli asiassa kaikkein erimielisin, jäi komitean ulkopuolelle.

Asetetun diakonaattikomitean työ liittyi ekumeeniseen työskentelyyn, kuten Kaste, ehtoollinen ja virka -asiakirjaan ja samaan aikaan käsittelyssä olleeseen Porvoon julistukseen. ${ }^{493}$ Komitean virallisena tehtävänä oli selvittää diakonian virkaa. Toisaalta tehtävänannon laatinut perustevaliokunta oli mietinnössään käsitellyt diakonaattia laajempana kokonaisuutena kuin pelkkänä diakonian virkana. Diakonaattikomitea päättikin jo ensimmäisessä kokouksessaan laajentaa tarkastelunäkökulmaansa ja ottaa lähtökohdakseen koko diakonaattia koskevan uudistuksen. ${ }^{494}$ Näin komitea tietyssä mielessä luopui alun perin tarkoitetusta pienten askelten tiestä ja otti käsiteltäväkseen melko laajan aihealueen. Diakonaatista se puolestaan ajautui nopeasti miettimään virkarakenteen kokonaisuutta, jota selvittäessään piispainkokous oli joutunut umpikujaan ja jonka käsittely oli ollut tarkoitus pitää taka-alalla uudessa komiteassa ${ }^{495}$.

Mietintönsä ratkaisevissa kohdissa komitea tyytyi tarkastelemaan diakonaattia. Komitea nojautui laaja-alaiseen käsitykseen sananpalvelusta ja ehdotti diakonaatin perustamista pappisvirasta erilliseksi osaksi kirkon virkaa. Komitean kaavailema diakonaatti sisälsi diakonian, 
kanttorin ja kasvatuksen virat, joista viimeksi mainittuun kuuluivat lehtorit. Komitea seurasi tässä asiassa piispainkokouksen virkarakennetyöryhmän enemmistön linjaa. Diakonaattiin tultaisiin vihkimyksen kautta, ja diakonaatilla olisi kiinteä yhteys jumalanpalveluselämään: siihen kuuluvat saisivat esimerkiksi saarnata jumalanpalveluksessa kirkkoherran luvalla ja viedä jumalanpalveluksessa pyhitetyn ehtoollisen yksityiselle henkilölle. ${ }^{496}$ Kun mietintö tuli kirkolliskokouksen käsittelyyn syksyllä 1997, komitea joutui kahden tulen väliin. Jotkut arvostelivat ehdotusta laaja-alaisesta diakonaatista, kun taas toisten mielestä komitean olisi pitänyt laajentaa tehtäväänsä entisestään ja käsitellä kirkon virkaa kokonaisuudessaan. ${ }^{497} \mathrm{Ne} 14$ kirkolliskokousedustajaa, jotka olisivat uudistuksen toteutuessa lukeutuneet diakonaattiin, olivat paljon vartijoina.

Diakonaattikomitean mietinnön otsikko Yhdessä kirkon virassa sisälsi paitsi virkarakenteellisen kannanoton myös käytännön pyrkimyksen: komitean ehdotusten myötä oli tarkoitus vähentää työntekijöiden kokemaa eriarvoisuutta. ${ }^{498}$ Tätä pyrkimystä oli kiitelty myös komitean saamassa palautteessa. Sen sijaan muutokset työtehtävissä olivat herättäneet epäilyksiä: diakoniatyöntekijät pelkäsivät liturgisten tehtävien vievän tilaa karitatiiviselta työltä, kun taas kanttoreilla oli päinvastainen pelko. ${ }^{499}$ Kirkolliskokouksessa Kalajoen seurakunnan kanttori Veli Ainali epäili, että kanttorien "epäluuloisuus alun alkaen lähti paljolti siitä, ettei komiteaan huolittu kanttoriedustusta, jota virhettä - - älköön toiste tehtäkö" ${ }^{500}$

Jotkut kirkolliskokousedustajat epäilivät, että komitean ehdottamat uudistukset olivat lähinnä syventämässä kuilua paitsi eri työntekijäryhmien välillä myös viranhaltijoiden ja seurakuntalaisten välillä. Monet pelkäsivät pappisviran kaventuvan niin, ettei se enää olisikaan diakoniaa. ${ }^{501}$ Piispa Huotarin mielestä mietintö korosti kirkon erityistä virkaa, vaikka tuolloisessa tilanteessa piti päinvastoin työskennellä maallikkouden hyväksi. ${ }^{502}$ Sen sijaan esimerkiksi Kuopion piispa Wille Riekkinen ja Tampereen piispa Juha Pihkala puolustivat komiteaa eivätkä nähneet mietinnössä Huotarin mainitsemaa vastakkainasettelua. Täysistunnossa sukeutui piispojen välille harvinaisen vilkasta ja voimakassanaista keskustelua. ${ }^{503}$

Piispainkokous piti laajaa, pappisvirasta erillistä palveluvirkaa mahdollisena mutta epäili toisaalta liturgi- sen tehtävän liiallista korostumista diakonaattikomitean mietinnössä. Piispainkokous katsoi, että uudistusta kohti oli edettävä hitaammin kuin komitea oli esittänyt. ${ }^{504}$ Uudistus tuli aloittaa voimassa olleista diakonian ja nuorisotyön viroista - eli suunnilleen siten kuin piispainkokous oli jo 1994 ehdottanut. ${ }^{505}$ Pitkin matkaa oli kuitenkin osoittautunut tällaisen osittaisuudistuksen vaikeus: yhtäkin palikkaa liikuteltaessa oli jouduttu ottamaan kantaa vähintään koko laaja-alaiseen diakonaattiin ja yleensä myös koko virkarakenteeseen.

Perustevaliokunnan mietintö ehti kirkolliskokouksen käsittelyyn vasta ylimääräisellä istuntokaudella vuoden 2000 alussa, yli kaksi vuotta lähetekeskustelun jälkeen. Valiokunnan diakonaattijaoston puheenjohtaja, kirkkoherra Erkki Ranta totesi valiokunnan mietinnön syntyneen "pitkän ja osin hankalan prosessin tuloksena". Rannan mukaan valiokunta oli kuitenkin löytänyt tien ulos pattitilanteesta ja esittänyt selkeät suunnitelmat jatkotyöskentelylle. Taas kerran valmistelijat katsoivat, että oli alkamassa se vaihe, jonka aikana todella päästäisiin konkreettisiin tuloksiin. Toisaalta kirkolliskokouksen keskustelussa ilmeni toisistaan poikkeavia tulkintoja valiokunnan mietinnöstä, mikä ei enteillyt helppoa jatkotyötä. ${ }^{506}$

Perustevaliokunnan mielestä diakonaattikomitea ei ollut onnistunut vahvistamaan tuolloisten virkojen omaa identiteettiä eikä määrittelemään teologisesti liturgisten tehtävien suhdetta muihin tehtäviin. Lisäksi kirkon virkarakenne oli jäänyt epäselväksi. Komitea oli kuljettanut mietinnössään pitkin matkaa kolmisäikeistä virkaa mutta jättänyt ratkaisevassa vaiheessa kysymyksen siitä avoimeksi. Näin komitea oli pyrkinyt noudattamaan tehtävänantoaan mutta samalla esittänyt käytännössä kaksisäikeisen virkamallin. ${ }^{507}$

Esittämästään arvostelusta huolimatta perustevaliokunta ehdotti valmistelutyön jatkamista pitkälti diakonaattikomitean viitoittamalla tiellä. Se tosin piti diakonaatin käsitettä liian suppeana ja otti tilalle termin "erityisen palvelun virat". Samaten vastoin komitean kantaa valiokunta erotti pappeuden ja piispuuden erillisiksi säikeiksi, jolloin virkarakenteesta tuli kolmisäikeinen. Valiokunta seurasi piispainkokouksen sijaan diakonaattikomiteaa siinä, että se halusi pitää valmistelussa koko ajan mukana myös kanttorit. Erityisen palvelun virkoja yhdistävänä tekijänä eivät kuitenkaan olleet jumalan- 
palvelustehtävät, kuten diakonaattikomitea oli katsonut, vaan kasvatus ja opetus. ${ }^{508}$ Valiokunnan esityksestä kirkolliskokous asetti kymmenjäsenisen komitean kokoamaan diakonian, musiikin ja kasvatuksen virat yhteen. Puheenjohtajaksi valittiin Launeen kirkkoherra Jaakko Ripatti. ${ }^{509}$ Valmistelu oli kestänyt jo pitkään, ja esimerkiksi Kotimaan päätoimittaja Jaakko Elenius kuvasi virkateologista uudistustyötä pääkirjoituksessaan "loputtomaksi vetkutteluksi”. ${ }^{10}$ Komitean odotettiin tuovan ratkaisun vihdoin 200o-luvun ensimmäisellä vuosikymmenellä.

\section{OPILLISESTA POHDINNASTA KOHTI KÄYTÄNNÖN JUMALANPALVELUSTA JA KRISTINOPPIA}

\section{JUMALAN KANSAN JUHLA JA ARKI}

Vuonna 1988 Suomen luterilaisessa kirkossa oli käytössä 20 vuoden ikäinen kirkkokäsikirja. Sitä oli tosin jo tietyin kohdin muokattu, ja sen tuorein osa, kirkollisten toimitusten kirja, oli ollut käytössä vain pari vuotta. Siitä huolimatta kirkolliskokous päätti piispainkokouksen esityksestä lähteä uudistamaan koko kirkkokäsikirjaa. ${ }^{511}$ Kirkon jumalanpalvelus- ja musiikkitoiminnan keskus oli itse asiassa jo 1980-luvun alusta valmistellut käsikirjauudistusta, ja uudistustarve oli sittemmin noussut esiin Kirkko 2000 -työskentelyssä. ${ }^{512}$ Uudistustahti oli siten selvästi nopeampi kuin virsikirjan tai raamatunkäännöksen osalta. Toisaalta näiden molempien suurten uudistushankkeiden valmistuminen kiirehti myös kirkkokäsikirjan uudistamista. Samaan suuntaan ajoivat jumalanpalveluselämän ongelmat: varsinkin 1980-luvun loppupuolella puhuttiin saarnan kriisistä, ja päiväjumalanpalveluksen osallistujamäärän lasku kiihtyi. Kirkolliskokouksen käsikirjavaliokunnan mukaan esimerkiksi jumalanpalveluksen rukousten teologiaa ja kieltä oli uudistettava. Laajan kokonaishankkeen puolesta puhui sekin, että aiemmat osauudistukset olivat olleet melko hajanaisia..$^{513}$

Kyse oli samalla ekumeenisesta uudistusliikkeestä. Vatikaanin toinen kirkolliskokous oli toteuttanut katolisessa kirkossa laajan liturgisen reformin. Eri maissa - myös Pohjoismaiden luterilaisissa kirkoissa - oli sittemmin aloitettu käsikirjauudistuksia, ja Suomessa kir- kollisten toimitusten kirjan uudistaminen oli jo liittynyt samaan prosessiin. ${ }^{514}$ Edelleen Kaste, ehtoollinen ja virka -asiakirja vaikutti liturgiseen uudistukseen protestanttisissa kirkoissa. ${ }^{515}$ Uudet vaihtoehtojumalanpalvelukset sekä liturgisten tekstiilien ja ehtoollisjumalanpalvelusten yleistyminen taas veivät jumalanpalvelusuudistusta eteenpäin seurakunnissa jo ennen kuin kokonaisuudistus ehti virallisesti alkaa. ${ }^{516}$

Teologisesti taustalla oli liturginen seurakuntakäsitys, jonka edustajille ei riittänyt se, että seurakuntalaiset kävivät "kuluttajina" tai "yleisönä" kirkossa silloin tällöin ja koko ajan harvemmin. Jumalanpalveluksen oli tultava seurakuntaelämän keskukseksi. ${ }^{517}$ Kirkolliskokouksen täysistunnossa 1988 tuomiorovasti Matti Järveläinen korostikin, että uudistuksen perusteena usein mainittu jumalanpalveluksen kriisi oli pohjimmiltaan jotakin muuta. Kyseessä oli ensisijaisesti "seurakunnan elämän todellisuuden ja elämän totuudellisuuden kriisi”. Järveläinen sai paljon tukea ajatukselleen. ${ }^{518}$ Oltiin lähdössä toteuttamaan uudistusta, joka ei olisi vain käsikirjauudistus vaan nimensä mukaisesti koko seurakuntaelämää koskettava jumalanpalvelusuudistus.

Uudistusta haittasivat kuitenkin alusta lähtien ristiriitaiset odotukset. Kirkolliskokouksessa jotkut korostivat uudistushankkeelle ominaiseen tapaan monipuolisuutta, kun taas toisten mielestä jumalanpalveluksen tuli olla turvallinen ja tunnistettava riippumatta siitä, missä seurakunnassa siihen osallistui. Erityisesti seurakuntalaisten aktiivinen rooli jumalanpalveluksessa jakoi mielipiteitä. Varapuheenjohtaja Raija-Liisa Mikkola piti ristiriitaisena sitä, että kirkolliskokous vaati seurakuntalaisten aktiivista osallistumista jumalanpalveluksen toteuttamiseen samaan aikaan, kun se puhui toisaalla hiljaisuuden tarpeesta ja pohti hiljaisuuden keskuksen perustamista. Myös Pertunmaan kirkkoherra Hannu Niskanen korosti jumalanpalvelusta hiljentymisen paikkana. Myöhemmin kenttäpiispaksi nimitetty Niskanen ei halunnut, "että esimerkiksi joku maireasti hymyilevä henkilö kättelee mennen tullen kirkon ovella. Itselläni ainakin siinä vaiheessa palautuu välittömästi mieleeni armeijassa oppimani itsepuolustustaito. Ja käytän sitä myös kaikessa rakkaudessa."519

Kirkolliskokous asetti yhdeksänjäsenisen käsikirjakomitean, jonka tuli keskustelevalla otteella toteuttaa jumalanpalvelusuudistus palautteen ja kokeilutoiminnan 


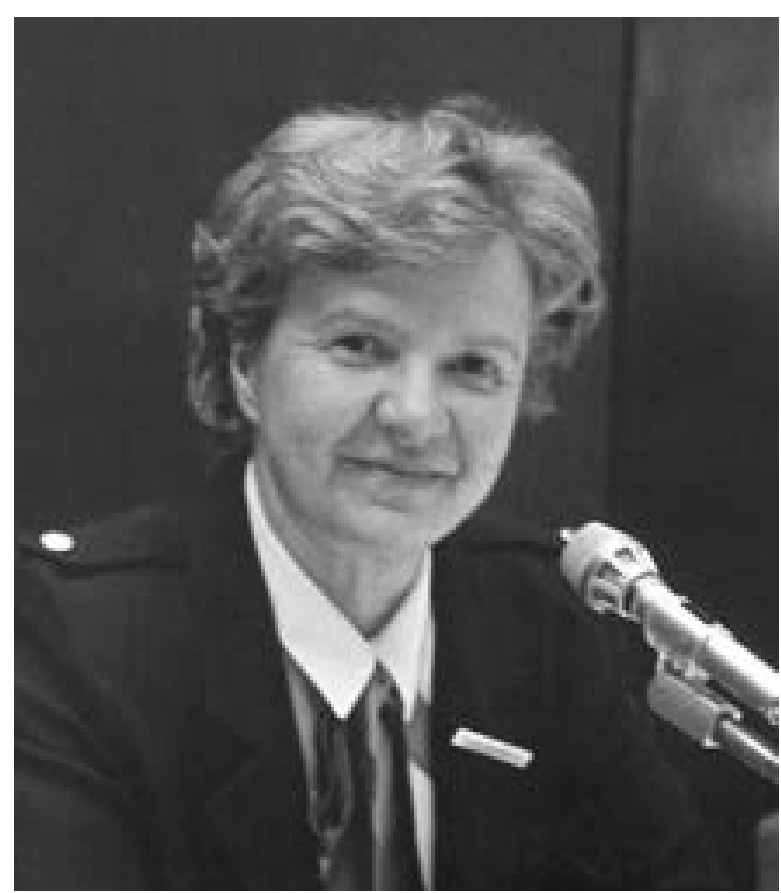

Filosofian maisteri Raija-Liisa Mikkola toimi kirkolliskokouksen varapuheenjohtajana vuosina 1988-1995. Jumalanpalvelusuudistuksesta keskusteltaessa hän pohti kriittisesti sitä, että kirkolliskokous korosti samanaikaisesti niin hiljaisuuden tarvetta kuin seurakuntalaisten aktiivista osallistumista jumalanpalveluksen toimittamiseen. Kuva: Kirkkohallitus / Ritva Neuvonen.

pohjalta. ${ }^{20}$ Suunnitelmat muistuttivat Ruotsissa edellisenä vuonna valmistunutta kirkkokäsikirjan uudistustyötä. ${ }^{52}$ Samalla ne poikkesivat olennaisesti tavasta, jolla kirkollisten toimitusten kirja oli Suomessa juuri valmistettu. Komitean tuli uudistaa samanaikaisesti sekä suomen- että ruotsinkielinen kirkkokäsikirja. Kirkolliskokouksen käsikirjavaliokunnan mukaan komitean tuli pyrkiä mahdollisimman pitkälle yhteiseen liturgiseen aineistoon..$^{522}$

Komitean puheenjohtajaksi valittiin piispa Yrjö Sariola. Varapuheenjohtajaksi sekä ruotsinkielisen jaoston puheenjohtajaksi tuli vs. professori Fredric Cleve. ${ }^{523}$ Kirkolliskokous edellytti komitealta välimietintöä, jonka oli määrä olla selvitys käsikirjauudistuksen periaatteista ja samalla apuväline kokeilutoiminnan edellyttämää koulutusta varten..$^{52}$ Syksyllä 1992 kirkolliskokouksen käsittelyyn tullut välimietintö Jumalan kansan juhla olikin perusteellinen esitys jumalanpalveluksen teologiasta.
Entinen ekumeniikan professori Kalevi Toiviainenkin kertoi oppineensa siitä paljon. Kääntöpuolena oli vaikeaselkoisuus, jota varsinkin maallikkoedustajat valittelivat. ${ }^{525}$

Välimietintöä varten seurakuntien työntekijöille tehty kysely osoitti odotusten ristiriitaisuuden. Toiset kaipasivat tuttuutta, turvallisuutta, hiljentymistä ja saarnakeskeisyyttä, toiset taas painottivat uudistamista, vaihtelua, osallistumista ja ehtoollista. ${ }^{526}$ Piispainkokouskin joutui toteamaan lausunnossaan, etteivät ristiriitaiset odotukset antaneet uudistukselle selviä suuntaviivoja. ${ }^{527}$ Seurakuntalaisille tehdyt kyselytutkimukset taas osoittivat, että kirkon kultista oli tullut henkinen kulutusartikkeli. Kirkko ei enää ollut useimmille jäsenilleen merkittävää todellisuutta. ${ }^{528}$ Tällaiseen tilanteeseen jumalanpalvelus oli määrä kontekstualisoida.

Käsikirjakomitea pyrki rakentamaan luterilaisen perinteen ja ekumeenisen liturgisen kehityksen pohjalle seurakunnan kiitosjuhlaa, jossa jokaisella jäsenellä olisi oma paikkansa ja vastuunsa Kristuksen ruumiin rakentamisesta. ${ }^{529}$ Lähtökohtana oli ehtoollisjumalanpalvelus, jota oli tarkoitus viettää joka pyhä ja jonka oli määrä jäsentää jumalanpalveluselämää. Nimenä olisi läntisen perinteen mukaisesti messu. Messun rakenteessa oli tarkoitus vahvistaa ripin, raamatunluvun ja seurakunnan vastauksen asemaa. Sanajumalanpalvelusta varten oli suunnitteilla oma erillinen kaavansa, ja komitean mukaan jumalanpalveluksen yksittäisten osien toteutuksessa tuli olla tilaa vapaudelle sekä vaihtoehdoille. ${ }^{530}$

Kirkolliskokouksen lähetekeskustelu syksyllä 1992 oli vilkas. Pappisedustajista puhui niukka enemmistö, maallikkoedustajistakin runsas kolmannes. Sen sijaan piispoista vain kaksi, Sariola ja Toiviainen, nousi puhujakorokkeelle - Sariolakin komitean puheenjohtajana esitelläkseen mietintöä. ${ }^{531}$ Piispoilla oli toki ollut mahdollisuus sanoa kantansa hieman aiemmin piispainkokouksen lausunnossa, mutta siitä huolimatta heidän vaikenemisensa oli merkille pantavaa.

Lähetekeskustelun sävy oli kriittinen. Vaikka uudistuksen teologinen valmistelu tunnustettiin perusteelliseksi, puheenvuoroissa viitattiin piispainkokouksen lausunnossa ja Teologisen Aikakauskirjan teemanumerossa esitettyihin huomautuksiin. ${ }^{532}$ Tällainen oli esimerkiksi vaatimus Pyhän Kolminaisuuden korostamisesta jumalanpalveluksessa ja sen teologiassa. ${ }^{533}$ Niin piispain- 
kokous kuin jotkut kirkolliskokousedustajat arvostelivat komitean periaatteita osin niin yleisluonteisiksi, etteivät ne auttaneet eteenpäin. ${ }^{53}$ Tosin piispainkokouksen omakaan lausunto ei ollut täysin vapaa tästä ongelmasta, kun piispat ja asessorit yrittivät tasapainoilla erilaisten odotusten välillä. Piispainkokous piti hyvänä Raamatun sanan vahvistamista ja sitä, että komitea oli lisännyt kaavaan Vanhan testamentin lukukappaleen. ${ }^{535}$ Toisaalta niin piispainkokous kuin monet kirkolliskokousedustajat olivat sitä mieltä, ettei jumalanpalvelus saanut pidentyä. ${ }^{536}$ Piispainkokous painotti, ettei virren asemaa saanut heikentää, mutta totesi vähän myöhemmin, että monipuolista musiikillista toteutusta tuli tukea ja käyttää virsien ohella muita lauluja. ${ }^{537}$

Kirkolliskokousta puhutti jumalanpalveluksen ja diakonian yhteenkuuluvuus, joka liittyi osaltaan ajankohtaiseen virkarakennekeskusteluun. Erityisesti taustalla oli kuitenkin pyrkimys saada elämän todellisuus mukaan jumalanpalvelukseen..$^{538}$ Komitea oli etsinyt Jumalan kansan juhlaa, mutta ihmisten hädän ja diakoniatyön ongelmien keskellä kirkolliskokousedustajat halusivat nähdä jumalanpalveluksen myös osallisuutena Kristuksen ja lähimmäisen kärsimykseen..$^{539}$ Siten lama-aika heijastui keskusteluun jumalanpalveluksen luonteesta: Jumalan kansan juhlaan oli tuotava Jumalan kansan arki.

Varsinkin herätysliikkeisiin lukeutuvien edustajien keskuudesta kuului puheenvuoroja, joissa kyseenalaistettiin koko jumalanpalvelusuudistus. Filosofian maisteri Eeva Laato huomautti, ettei käsikirjaa uudistamalla ollut aiemmin täytetty kirkkoja ja että uudistuksella oltiin vaarassa karkottaa uskollisetkin kirkossakävijät. Oli toki odotettavissakin, että Laaton edustaman suunnan rukoilevaiset, joiden käyttämä kirkkokäsikirja täytti seuraavana vuonna 300 vuotta, eivät olleet uudistuksen hanakimpia kannattajia. Myös esimerkiksi herännäisyyteen lukeutunut kirkkoherra Martti Takala ja vanhoillislestadiolainen kanttori Yrjö Koskimäki yrittivät hillitä uudistusintoa. Takala valitteli, miten Suomessa oli "vuosikymmenet julistettu koko kansalle, että meillä on huonot jumalanpalvelukset". ${ }^{40}$

Ainakin osassa tällaisista puheenvuoroista jumalanpalvelusta katsottiin tuolloisten kirkossakävijöiden näkökulmasta. Sen sijaan toiset edustajat kiinnittivät huomionsa niihin, jotka eivät jumalanpalveluksiin osallistuneet. Monet olivat sitä mieltä, ettei komitea ollut mennyt ehdotuksissaan tarpeeksi pitkälle. ${ }^{541}$ Tuomiorovasti Jukka Paarma ilmaisi huolen, että uudistuksen myötä syntyisi teologisesti, kielellisesti, liturgianhistoriallisesti ja ekumeenisesti korkeatasoinen uudistus, joka kokoaisi kuitenkin yhtä paljon seurakuntalaisia kuin ennenkin. Siinä tapauksessa uudistus olisi epäonnistunut. ${ }^{542}$

Huopalahden kappalainen Hannele Repo, joka kuului Helsingin hiippakunnan nuorten "apupappien" vaikuttajaryhmään, varoitti unohtamasta, keitä seurakuntalaiset olisivat seuraavan vuosituhannen alussa. Revon sanoma oli hyvin samanlainen kuin ne muistutukset, joita virsikirjakomiteoiden jäsenet olivat lausuneet kirkolliskokoukselle virsikirjauudistuksen yhteydessä. ${ }^{43}$ Nuorten näkökulmaa korostavat edustajat vaativat myös uudenlaista asennoitumista jumalanpalveluksen musiikkiin. Kirkkoherra Keijo Rainerman mukaan musiikin vapauttamisella voitiin merkittävästi vaikuttaa kansanjuhlan luomiseen. Tulokset näkyivät vaihtoehtomessuissa. ${ }^{54}$ Suomen Raamattuopistoa tai Suomen Evankelisluterilaista Kansanlähetystä lähellä olevat suhtautuivat esimerkiksi 1990-luvun ekumeenisiin asiakirjoihin aivan toisella kriittisyydellä kuin herännäisyyteen lukeutuvat edustajat. Kun sen sijaan puhuttiin jumalanpalveluksen muotojen uudistamisesta, herätysliikkeiden keskinäinen asetelma muuttui hyvin toisenlaiseksi.

Varauksellisuus uudistuksia kohtaan ei johtunut pelkästään aktiivisten kirkossakävijöiden kuuntelemisesta. Kyse oli myös teologisista painotuksista. Esimerkiksi jotkut herännäisyyteen ja vanhoillislestadiolaisuuteen lukeutuvat edustajat vierastivat korostusta, että seurakunta oli jumalanpalveluksessa subjekti, aktiivinen toimija. Heidän mielestään oleellista jumalanpalveluksessa ei ollut seurakunnan toiminta vaan Jumalan armahtava työ. Oli myös niitä, joiden mukaan jumalanpalveluksen tulevaisuus oli ennen kaikkea saarnan varassa, eikä siihen voinut vaikuttaa rakenteita uudistamalla. ${ }^{545}$

Kirkolliskokouksessa päähuomio oli koko ajan jumalanpalvelusten kirjassa. Sen sijaan julkisuudessa evankeliumikirja sai paljon huomiota. Syynä oli komitean ajatus, että vuoteen 1772 asti vietettyä pyhien vuotta oli syytä vahvistaa uudelleen. Komitean mielestä apostolien ja evankelistojen muistopäivien lisäksi evankeliumikirjaan oli mahdollista ottaa aineistoa esimerkiksi luterilai- 
sen kirkon merkkihenkilöiden, Suomen herätysliikkeiden perustajahahmojen tai Inkerin kirkon marttyyrien muistopäiviksi. ${ }^{546}$ Uudistus oli osa komitean pyrkimystä palauttaa historiallisia käytäntöjä. Inkerin kirkon marttyyrien mainitseminen taas kuvasti uutta, vapautunutta ulkopoliittista tilannetta: aiemmin heistä ei ollut puhuttu julkisesti kokonaiskirkon päätöksenteossa, mutta Neuvostoliiton hajottua Inkerin kirkon asia koettiin voimakkaasti Suomen luterilaisen kirkon omaksi.

Monissa tiedotusvälineissä uudistusehdotus leimautui nopeasti "pyhimyskalenteriksi". ${ }^{47}$ Kirkolliskokouksen lähetekeskustelussakin herätti epäilyksiä, että erilaisten järjestöjen kirkkopyhien lisääntyessä oli otettava huomioon "vielä Hammarskjöldit ja Hieronymukset". ${ }^{548}$ Piispainkokous piti muistopäiviä mahdollisina mutta korosti, että ne eivät saaneet milloinkaan korvata kirkkovuoden mukaisen sunnuntain viettämistä. Piispainkokous myös kehotti ottamaan mukaan lähinnä Raamatun ja jakamattoman kirkon pyhiä. ${ }^{549}$ Käsikirjavaliokunta yhtyi piispainkokouksen kantaan. ${ }^{550}$

Muutenkin käsikirjavaliokunta seurasi pitkälti piispainkokouksen lausuntoa. Lisäksi se totesi lähetekeskustelussa kuultujen puheiden mukaisesti ja ajankohtaan sopivasti, että komitean oli kiinnitettävä huomiota ihmisten elämän reaalitodellisuuteen ja hätään. Hyvin ristiriitaisiksi osoittautuneet odotukset taas johtivat siihen, että valiokunnan mukaan messun kaavan rinnalle tarvittiin myös toinen kaava. Siinä olisivat vain messun välttämättömät osat sekä esimerkkejä rakenteen rikastuttamiseen. ${ }^{551}$ Kirkolliskokouksessa arvosteltiin erityisesti komitean suunnitelmia työn organisoimiseksi: ne koettiin liian jäykiksi ja kustannusarvio ylimitoitetuksi syvimmän laman keskellä. ${ }^{552}$ Martti Takala muistutti, ettei kansa kutsunut jumalanpalvelusta messuksi vaan kirkonmenoiksi: "Nyt se taitaa saada uuden ulottuvuuden, kirkon menot." 553 Sekä kirkkohallitus että piispainkokous vaativat hankkeen keventämistä ja kokeiluajan lyhentämistä. ${ }^{554}$ Toisaalta piispainkokous esitti, että jokainen seurakunta saisi käyttää kokeilumateriaalia, kun komitea oli ehdottanut vain viiden kokeiluseurakunnan valitsemista joka hiippakunnasta. ${ }^{55}$ Laajennettu kokeilutoiminta oli omiaan paisuttamaan hanketta.

Käsikirjavaliokunnan ratkaisu oli vahvistaa uudistuksen prosessiluonnetta. Päädyttiin malliin, jota korostettiin sittemmin myös muissa 1990-luvun uudistushank- keissa. Valiokunta ei halunnut asettaa komiteatyölle tarkkoja rajoja. Samalla kokeilutoiminta sallittiin kaikille seurakunnille, kuten piispainkokous oli ehdottanut. Prosessiajattelu mahdollisti sen, ettei valiokunnan tarvinnut lyödä ennalta lukkoon hankkeen kokonaistalousarviota. Seurakunnille oli annettava tilaa, eikä prosessin tullut päättyä edes uuden käsikirjan valmistumiseen. ${ }^{556}$

Valiokunnan mietinnön täysistuntokäsittely keväällä 1993 oli sävyltään toisenlainen kuin lähetekeskustelu puoli vuotta aiemmin. Usko ja into näyttivät palautuneen. ${ }^{557}$ Ilmapiiri muistutti hieman viiden vuoden takaista. Silloin jumalanpalvelusuudistus oli aloitettu suurin odotuksin. Sittemmin käsikirjakomitean konkreettiset ehdotukset olivat aiheuttaneet tyytymättömyyttä, mutta nyt oli tietyllä tavalla palattu takaisin kohti lähtötilannetta: tulevaisuus oli jälleen avoin, ja se riippui alhaalta kasvavasta prosessista. Uudistusinnon hintana oli, että kirkolliskokous vältti tekemästä mitään merkittäviä periaatepäätöksiä uuden jumalanpalveluksen sisällöstä. Syksy 1992 oli kuitenkin jo osoittanut, että tässäkin asiassa oli paljon helpompi olla yhtä mieltä uudistuksen tarpeesta kuin sen varsinaisesta sisällöstä.

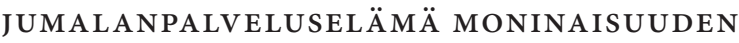 JA HAJANAISUUDEN JÄNNITTEESS $\ddot{A}$}

Kirkolliskokous antoi käsikirjakomitealle hyvin vapaat kädet, mutta komiteakaan ei halunnut ottaa tuossa vaiheessa kovin näkyvästi vastuuta uudistuksesta. Se halusi painottaa paikallisseurakuntien asemaa jumalanpalvelusuudistuksen kasvualustana ${ }^{58}$. Laajat kyselyt kokeilun eri vaiheissa korostivat prosessimaista etenemistapaa. ${ }^{59}$ Kaikesta huolimatta seurakuntien oma panos jäi lopulta vähäiseksi: kaavoihin ei tullut kokeilutoiminnan aikana olennaisia muutoksia. ${ }^{560}$ Komitea jätti suomen- ja ruotsinkieliset ehdotuksensa jumalanpalvelusten kirjaksi ja evankeliumikirjaksi $1997 .^{561}$

Lähetekeskustelu jakautui peräti kolmelle istuntokaudelle syksystä 1997 syksyyn 1998. Tuona aikana käsikirjavaliokunta pyysi palautetta vielä seurakunnilta ja muokkasi jatkuvasti jumalanpalvelusten kirjaa. Lähetekeskustelu painottui lähes täysin suomenkielisen uudistuksen käsittelyyn, joskin monet perusratkaisut olivat samoja niin suomen- kuin ruotsinkielisessä ehdotuksessa. Ilmiö oli samanlainen kuin aiemmin virsikirjaa kä- 
siteltäessä, mutta tällä kertaa osasyynä oli myös se, että komitean resurssipulan vuoksi ruotsinkielinen jumalanpalvelusten kirja ehti kaikkien kirkolliskokousedustajien saataville vasta lähetekeskustelujen ollessa jo pitkällä. ${ }^{562}$ Kirkolliskokous muokkasi evankeliumikirjan ja jumalanpalvelusten kirjan lopulliseen muotoonsa vuoden 1999 aikana.

Lähetekeskusteluissa jälleen muutamat varsinkin maaseudulta ja vanhojen herätysliikkeiden piiristä tulevat edustajat vaativat maltillista uudistusta ja vanhan jumalanpalveluskaavan säilyttämistä uuden rinnalla. ${ }^{563}$ Esimerkiksi jumalanpalvelusuudistusta kiitellyt Mauno Hyyryläinen muistutti, että uudistuksella oli hänen kotiseudullaan lukuisia vastustajia, jotka tuli hoitaa "kunnialla hautaan". ${ }^{64}$ Kuten virsikirjauudistuksesta päätettäessä Kainuun maallikkoedustajan osana oli tuoda terveisiä uudistusta vastustavilta seurakuntalaisilta. Maaseutualueiden ja vanhojen herätysliikkeiden edustajien joukko oli kuitenkin tällä kertaa huomattavan moniääninen. Eri alueilta saapuneet edustajat kertoivat onnistuneista jumalanpalvelusuudistuksista esimerkiksi Kestilässä, Nivalassa ja Kauhajoella. Sitä paitsi nimenomaan suurkaupungin maallikkoedustaja saattoi kaivata kiivaan elämäntavan keskellä hiljaisuutta, kun taas hiljaisen maaseutukylän asukas iloitsi toiminnallisesta Jumalan kansan juhlasta. ${ }^{565}$

Seurakuntalaiset olivat kyselytutkimusten valossa tyytyväisiä uudistettuun jumalanpalvelukseen. Tosin melko suuren osan mielestä jumalanpalvelus oli muuttunut niin vähän, ettei muutosta juuri huomannut. Tässä joukossa oli erityisen paljon alle 40-vuotiaita. Samassa ikäryhmässä oli myös tavanomaista enemmän - vaikkakin kokonaisuutena pieni osuus - niitä, joiden mielestä uudistus ei ollut vastannut odotuksia. ${ }^{566}$ Seurakuntien työntekijöistä suurin osa halusi uudistaa jumalanpalvelusta pidemmälle kuin komitea. ${ }^{567}$ Kirkolliskokouksen lähetekeskustelussa tämä ryhmä sai äänensä kuulumaan, mutta niin saivat nekin, joiden mielestä uudistuksessa oli menty aivan liian pitkälle. ${ }^{568}$ Yhteisen linjan löytäminen näiden mielipiteiden välillä ei ollut helppo tehtävä.

Piispa Olavi Rimpiläisen johtaman käsikirjavaliokunnan jäsenet jakoivat keskenään vastuualueet käsikirjakomitean ehdotuksen läpikäymistä varten. Yleensä kutakin vastuualuetta kohden nimettiin kaksi valiokunnan jäsentä, mutta musiikki oli niin laaja ja tärkeä kokonai- suus, että sitä varten nimettiin nelihenkinen työryhmä. Toisen suuren kokonaisuuden, ruotsinkielisen aineiston, saivat valmisteltavakseen piispa Erik Vikström ja Ahvenanmaan rovastikunnan lääninrovasti Juanita Fagerholm-Urch, joilla oli siten painava vastuu ruotsinkielisen uudistuksen läpiviennistä. ${ }^{569}$

Kirkon työntekijät toivoivat muutoksia erityisesti rukouksiin, ja kokeiluvaiheessa olikin tullut kiitosta uusista rukouksista. ${ }^{570}$ Kiitokset saivat jatkoa kirkolliskokouksen lähetekeskustelussa, joskaan evankeliumikirjaan lisätyt uudet päivän rukoukset eivät tyydyttäneet kaikkia. Pastori Jaakko Heinimäen mielestä tyylipisteiden jakaminen rukouksista oli tyylitöntä, mutta koska se oli kirkolliskokouksen tehtävä, hän pureutui rukousten sisältämiin ilmauksiin, kuten toistuvaan huoleen "tajuntaamme" tunkeutuvista asioista. Hän varoitti myös siitä, että pyrkimys ajankohtaisuuteen saattoi nopeasti johtaa rukousten vanhenemiseen: "Miltä teistä kuulostaisi jos nyt käytössä olevissa rukouksissa puhuttaisiin siitä, että televisio hämmentää meitä? Kirkolla on - ollakseni kaunopuheinen - perinteensä kellarissa hienoja vuosikertaviinejä. Miksi meidän pitäisi tyytyä hetken kiljuihin?"571

Piispainkokouskin katsoi lausunnossaan, etteivät kaikki uudet ilmaukset olleet kestäviä ja että jotkin rukoukset vaikuttivat aikasidonnaisilta. ${ }^{572}$ Pääosin piispainkokous oli kuitenkin tyytyväinen siihen, että komitea oli lisännyt päivän rukouksen vaihtoehtoja, uudistanut kieltä ja siirtynyt juhlavista ilmauksista kohti yleiskieltä. ${ }^{573}$ Käsikirjavaliokunta taas totesi kokouksessaan, että ruotsinkieliset rukoukset sisälsivät joskus liian suuria ja dramaattisia kuvia. ${ }^{574}$ Valiokunta tekikin rukouksiin kielellisiä muokkauksia pyrkien samalla yhtenäistämään suomen- ja ruotsinkielisiä rukouksia. Jotkin arvostelua osakseen saaneet päivän rukoukset valiokunta vaihtoi kokonaan uusiin. 575

Vanhan testamentin lukukappale oli otettu seurakunnissa hyvin vastaan, ja muutenkin kirkolliskokouksessa kiiteltiin evankeliumikirjan raamatunkohtien rikastuttamista. ${ }^{576}$ Kirkolliskokouskeskustelujen ja piispainkokouksen lausunnon pohjalta käsikirjavaliokunta lisäsi raamatunteksteihin Markuksen evankeliumin kohtia ja toi profeettakirjojen tilalle Vanhan testamentin kertovia tekstejä. Lisäksi valiokunta tiivisti evankeliumikirjaa ja muutti jonkin verran sen rakennetta. Komiteaehdotuksessa helluntain jälkeisetkin pyhät kuuluivat pää- 
siäisjaksoon, mutta käsikirjavaliokunta lisäsi erillisen helluntaijakson. Lisäksi se laati esimerkiksi kaikille joulun jumalanpalveluksille omat aineistonsa. ${ }^{577}$

Komitea oli luopunut erillisistä pyhäpäivien otsikoista ja laatinut niiden tilalle pyhäpäivän sisällön kuvauksen. ${ }^{578}$ Komitean saamassa palautteessa, kirkolliskokouksen lähetekeskustelussa ja piispainkokouksen lausunnossa pyhäpäiville toivottiin kuitenkin otsikoita, joten valiokunta laati sellaiset. ${ }^{579}$ Muistopäivien saaman ristiriitaisen palautteen vuoksi valiokunta päätyi jättämään materiaalin käsikirjan ulkopuolelle edelleen valmisteltavaksi. ${ }^{50}$ Käsikirjakomiteassa evankeliumikirjajaostoa johtaneen professori Pentti Lempiäisen pisteliään toteamuksen mukaan kirkolliskokous poisti monipuolisen muistopäiväaineiston ja toi tilalle Pyhän Henrikin muistopäivän, "ihmisläheisen asennoitumisen ylvään ilmentymän".581

Monissa ratkaisuissaan valiokunta palasi kohti käytössä ollutta evankeliumikirjaa ja sai kirkolliskokousedustajilta paljon kiitosta toiminnastaan. ${ }^{582}$ Asetelma oli siten paljolti samanlainen kuin virsikirja- ja raamatunkäännösuudistuksessa. Täysistunnossa suomenkieliseen evankeliumikirjaan tehtiin vielä 11 muutosta ${ }^{583}$. Evankeliumikirjan laajuuteen nähden muutosten määrä oli vähäinen, joskin täysistunnossa tehdyistä muutosehdotuksista hyväksyttiin huomattavan suuri osuus, lähes kaksi kolmasosaa. Voitto Huotari teki yksinään kolmanneksen muutosehdotuksista. Evankeliumikirja ei herättänyt samalla tavalla tunteita kuin jumalanpalvelusten kirja. ${ }^{584}$

Jumalanpalvelusten kirjan osalta huomio keskittyi pitkälti musiikkiin. Jumalanpalvelusten sävelmäsarjojen tiedettiin vaikuttavan ratkaisevasti siihen, miten seurakuntalaiset kotiutuisivat uuteen jumalanpalvelukseen. Tutkimuksen mukaan seurakuntalaiset painottivat jumalanpalveluksessa runsasta ja monipuolista musiikkia $^{585}$. Komitea oli sisällyttänyt sekä suomen- että ruotsinkieliseen jumalanpalvelusten kirjaan viisi vaihtoehtoista sävelmäsarjaa ${ }^{586}$. Niin seurakuntien palautteessa, kirkolliskokouksen lähetekeskustelussa kuin piispainkokouksen lausunnossa suomenkielistä ehdotusta arvosteltiin siitä, että se sisälsi liian monia toisiaan muistuttavia sävelmäsarjoja. ${ }^{587}$ Ruotsinkielisen jumalanpalvelusten kirjan sävelmävaihtoehdot todettiin sitä vastoin monimuotoisiksi mutta samalla usein monimutkaisiksi. Käsikirjavaliokunnan jäsen Juanita Fagerholm-

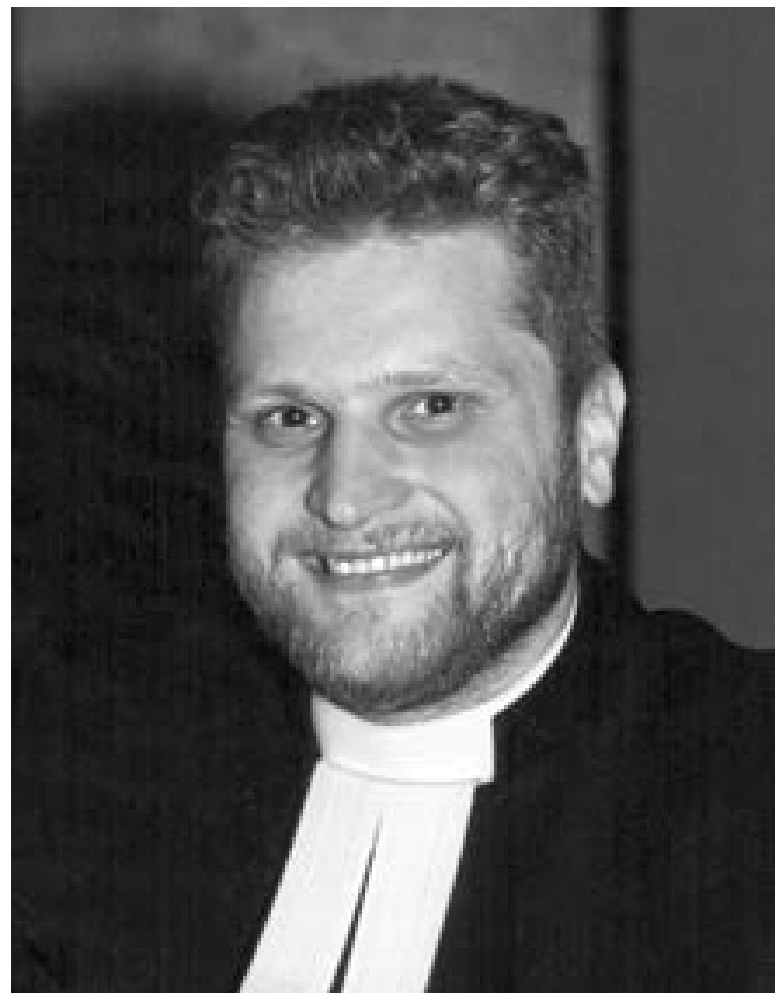

Pastori Jaakko Heinimäki varoitti liiallisesta ajankohtaisuuden tavoittelusta kirkkokäsikirjan rukouksissa. Lisäksi hän kiinnitti huomiota siihen, että Markuksen evankeliumi oli saanut komitean ehdotuksessa osakseen vähemmän huomiota kuin muut evankeliumit. Kuva: Kirkkohallitus.

Urch totesi viidennestä messuvaihtoehdosta, "että tavallinen seurakuntalainen ei opi sitä koskaan".588

Sävelmäsarjojen keskinäisen suhteen lisäksi ongelmana oli suomen- ja ruotsinkielisten ehdotusten suhde toisiinsa. Professori Erkki Tuppurainen kiinnitti huomiota siihen, että musiikin tyylin osalta "kaksoset" olivat "hyvin epäidenttiset". ${ }^{89}$ Suomen- ja ruotsinkielisen liturgian yhdistäminen, joka oli ollut alusta lähtien julkilausuttuna tavoitteena, näytti jääneen pahasti puolitiehen. ${ }^{59 \circ}$ Valiokunta päätyi supistamaan sävelmäsarjojen määrän neljään niin suomen- kuin ruotsinkielisessä jumalanpalvelusten kirjassa. ${ }^{591}$ Samalla valiokunta pyrki voimistamaan tyylillistä vaihtelua suomenkielisissä messusävelmistöissä ja lähentämään suomen- ja ruotsinkielisiä sävelmistöjä tyylillisesti toisiinsa. Valiokunta sai täysistunnossa kiittävän arvion yhtenäistämistyöstään. ${ }^{592}$ Täysistunnossa monet seurakuntapapit vaativat 
vielä karsimaan vaihtoehtoisuutta sävelmäsarjojen sisältä, jotta seurakuntalaiset pysyisivät mukana jumalanpalveluksen kulussa. Kanttorit vastustivat tällaisia ehdotuksia, ja heidän mielipiteensä vei voiton. Jumalanpalvelusmusiikista keskusteltaessa erityisesti Erkki Tuppurainen sai useille muutosehdotuksilleen kirkolliskokouksen tuen. ${ }^{593}$

Käsikirjavaliokunta pyrki vaalimaan samanaikaisesti sekä riittävää yhtenäisyyttä että vaihtelevuutta. ${ }^{594}$ Paitsi sävelmävaihtoehtojen myös jumalanpalveluksen rakenteen osalta valiokunta vähensi jonkin verran vaihtoehtoja. Tarkoituksena oli, että jumalanpalveluksen kulku hahmottuisi paremmin kuin komitean ehdotuksessa. Valiokunta poisti esimerkiksi saarnavirren mahdollisuuden evankeliumitekstin ja saarnan välistä. Täysistunnossa erityisesti maallikkoedustajat vaativat kuitenkin saarnavirren palauttamista, jottei puheosuus muodostuisi liian pitkäksi. Toisaalta varsinkin jotkut papit korostivat evankeliumitekstin ja saarnan yhteenkuuluvuutta. ${ }^{595}$ Täysistunto palautti lopulta äänin 56-44 saarnavirren mahdollisuuden..$^{596}$

Uskontunnustus oli kirkolliskokouksen tärkeimpiä keskustelunaiheita. Käsikirjakomitea ehdotti, että messussa käytettäisiin ensisijaisesti Nikean uskontunnustusta. Lähetekeskustelussa muutokselle ei kuitenkaan löytynyt paljon tukea. Nikean uskontunnustusta pidettiin vaikeana. Koska seurakuntalaiset eivät osanneet sitä ul- koa, sen pelättiin edistävän vieraantumista jumalanpalveluksesta. ${ }^{597}$ Käsikirjavaliokunta seurasi tässäkin kohden palautetta: se siirsi apostolisen uskontunnustuksen ensisijaiseksi ja sai ratkaisulleen kirkolliskokouksen enemmistön tuen. ${ }^{598}$

Uskontunnustuksen valinnan ohella kirkolliskokous joutui ottamaan kantaa uskontunnustusten sanamuotoihin. Sanamuotojen uudistus oli lähtenyt liikkeelle 1992 edustaja-aloitteena, jonka tavoitteena oli ollut korvata sana "seurakunta" termillä "kirkko". Asian palatessa kirkolliskokoukseen 1999 teologiset seikat jäivät kuitenkin sivuosaan. ${ }^{599}$ Kokouksessa keskusteltiin lähinnä siitä, miten uudistettu uskontunnustus omaksuttaisiin seurakunnissa. Kirkolliskokous päätyi lopulta selvin luvuin 81-16 säilyttämään apostolisen uskontunnustuksen kokonaan entisessä muodossaan. ${ }^{600}$ Ratkaisu oli samanlainen kuin virsikirjaa uudistettaessa: muutoksen keskellä tutuimmat osat säilytettiin ennallaan.

Ehtoollisosa oli koko jumalanpalvelusuudistuksen ydin. Käsikirjavaliokunta uudisti ja lyhensi ehtoollisrukouksen tekstejä komitean ehdotukseen verrattuna. Joidenkuiden edustajien mielestä rukoukset olivat edelleen liian pitkiä, mutta vanhakirkolliset esikuvat painoivat vaakakupissa paljon. ${ }^{601}$ Sen joutui huomaamaan istuntopäivän illalla myös kenttäpiispa Hannu Niskanen. Hän ehdotti, että asetussanojen ympärillä olevat rukoukset muutettaisiin vapaaehtoisiksi, vaikkakin hän samalla
Kenttäpiispan virasta Lapuan piispaksi siirtynyt Jorma Laulaja tarjosi täysistunnon lomassa pastillin seuraajalleen Hannu Niskaselle. Miehet pitivät yhtä myös päätettäessä uudesta messusta 1999: he pelkäsivät messun rakenteen paisumista ja vaativat mahdollisuutta lyhennettyyn ehtoollisrukoukseen. Taustalla perheasiain neuvottelukeskuksen johtaja Marjatta Kaartinen. Kuva: Kirkkohallitus.

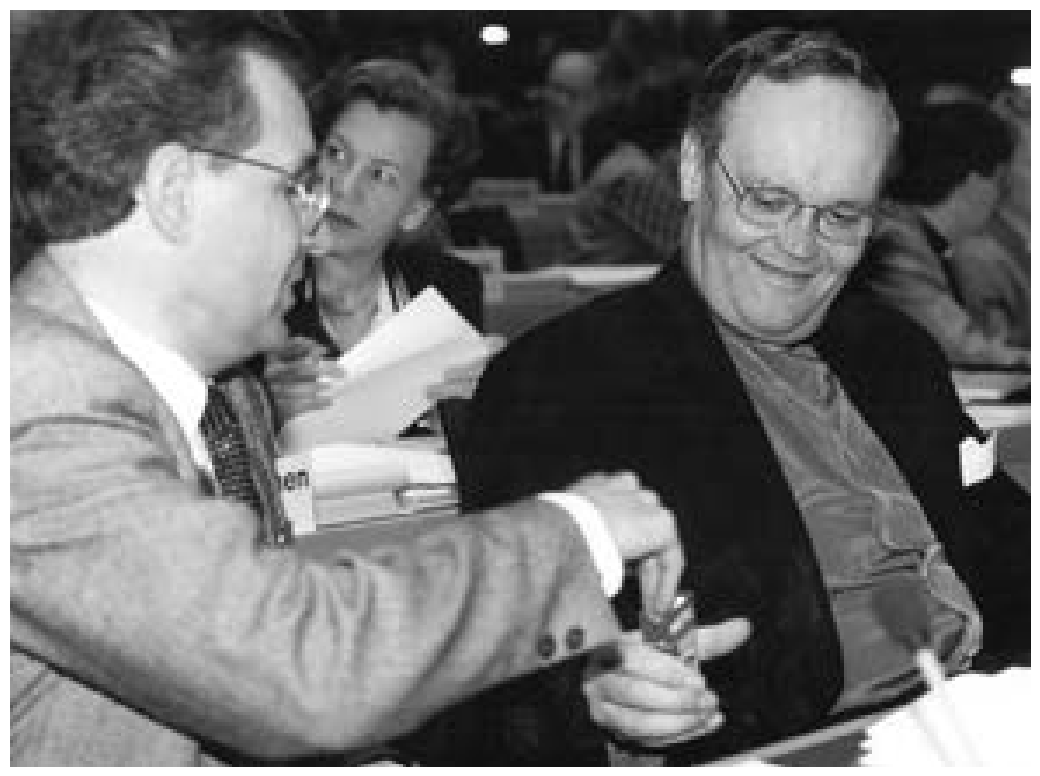


tunnusti, ettei voinut vedota "mihinkään Hippolytokseen". Hän pelkäsi, että pitkä ehtoollisrukous voisi häivyttää asetussanojen merkitystä. Myös piispa Jorma Laulajan mielestä tarvittiin lyhennetty, sanonnaltaan tiivistetty versio ehtoollisrukouksesta. ${ }^{602}$ Valiokunnan jäsenen, Sulkavan kirkkoherran Taisto Salmenkiven mielestä taas oltiin

kävelemässä komitean ja valiokunnan ylitse ja koko sen liturgisen uudistuksen ylitse, joka ei vain meidän kirkossamme, vaan kaikkialla viimeisten vuosikymmenien aikana on tehnyt suurena löytönä eukaristisen rukouksen rikkaamman muodon. Jos tässä yhtäkkiä klo 21.02 huitaistaan kaikki sisennetyksi [vapaaehtoiseksi], niin saavutamme ainakin mainetta. $^{603}$

Tämän maineen kirkolliskokous jätti hankkimatta, mutta silti äänestyksessä merkittävä vähemmistö - kaksi viidesosaa - asettui vaatimaan lyhennettyä vaihtoehtoa. ${ }^{604}$

Uudistetut ehtoollisen asetussanat aiheuttivat puolestaan keskustelua ruotsinkielistä ehdotusta käsiteltäessä. ${ }^{605}$ Erkki Tuppuraisen ja Henrik Perret'n ehdotuksesta hyväksyttiin muutoksia, joiden tarkoituksena oli yhtenäistää suomen- ja ruotsinkielisiä asetussanoja ja jotka palauttivat käytännössä ruotsinkielisiä asetussanoja lähemmäksi vanhan käsikirjan muotoa. ${ }^{606}$ Suomenkielisetkin ottivat nyt kantaa asiaan. Porvoon hiippakunnan edustajat olivat keskenään erimielisiä, joten muun kirkolliskokouksen oli otettava pakostakin ratkaisijan rooli. Kuten virsikirjauudistusta käsiteltäessä kirkolliskokous pyrki monin tavoin lähentämään suomen- ja ruotsinkielisiä kirjoja toisiinsa.

Esirukousaiheista keskusteltaessa erityisesti työnteko nousi kirkolliskokouksessa esille. Toimittaja Sirkku Nyström arvosteli sitä, että seurakuntia varten laaditut esirukousaiheet oli kirjoitettu perinteiseen tapaan julkisen sektorin näkökulmasta. Samaan aikaan suurin osa suomalaisista sai palkkansa yksityisiltä työnantajilta: "Meitä vaivaa semmoinen kumma häveliäisyys, että raha ja talous on jotenkin vähän likaista ja epämääräistä ja outoa. Rahan tienaaminen ja tekeminen on rumaa, mutta sen jakaminen on ihan paikallaan, siitä voidaan puhua avoimesti." ${ }^{607}$

Valiokunta otti Nyströmin ehdotukset huomioon. Toisaalta valiokunnan puheenjohtaja Rimpiläinen muistutti esirukousaineiston olevan tilanteen mukaan muuttu- vaa, "että sitä ei kannattane pilkun tarkkuudella viilata". Siitä huolimatta monin paikoin hiottiin rukousten yksityiskohtia ja mietittiin niiden tulkintamahdollisuuksia. Eri ammattiryhmien mahdollisesta erilaisesta arvostuksesta kertovia vivahteita tarkattiin hyvin huolellisesti. ${ }^{608}$ Välillisesti keskustelu liittyi kirkon nälkäryhmän työhön ja piispojen Kohti yhteistä hyvää-kannanottoon, jotka olivat tuolloin ajankohtaisia: edustajat painottivat omista lähtökohdistaan eri ammatti- ja sosiaalisten ryhmien asiaa.

Jumalanpalvelusuudistuksen tavoitteena oli ollut lisätä niin liturgian rikkautta kuin seurakuntalaisten aktiivista osallistumista jumalanpalveluksen toimittamiseen. Näiltä osin kirkolliskokous kävi rajaa moninaisuuden ja hajanaisuuden välillä: edustajan kannan mukaan valinnanvapaus saattoi näyttää myönteiseltä rikkaudelta tai koko uudistusta haittaavalta hajanaisuudelta. ${ }^{609}$ Yleisesti kirkolliskokous pyrki yksinkertaistamaan kaavoja. Toisaalta monet uudet käytännöt, kuten vastaussanat raamatunluvun yhteydessä, sallittiin vapaaehtoisina. ${ }^{610}$

Ongelmallisimpia kysymyksiä oli ehtoollisliturgian kohta, jossa valiokunnan ehdotuksen mukaan voitiin kehottaa rauhan toivottamiseen. Tavalla oli vanhat juuret jopa Uuden testamentin ajan jumalanpalveluselämässä, mutta Suomen luterilaisessa jumalanpalveluksessa se oli uutuus. Uskonnosta tuli 1990-luvun kuluessa aiempaa julkisempi asia, mikä näkyi esimerkiksi siinä, että julkisuuden henkilöt ja tavalliset suomalaiset puhuivat entistä useammin uskonasioista ${ }^{611}$. Tämän muutoksen saattoi katsoa rohkaisevan myös jumalanpalveluselämän osalta rauhan toivottamisen kaltaisiin uudistuksiin. Jotkut kirkolliskokousedustajat taas katsoivat tavan sotivan peräti suomalaista luonteenlaatua vastaan, ja rauhan toivottamisesta näytti tulevan suurin uhka rauhassa olemiselle. Lopulta kirkolliskokous salli tämänkin käytännön vapaaehtoisena. ${ }^{612}$

Viimeinen kädenvääntö koski sitä, miten jumalanpalvelusuudistuksen vastustajat tuli ottaa huomioon. Kanttori Yrjö Koskimäki esitti lisäpontta, jossa mainittaisiin mahdollisuus käyttää edelleen tarvittaessa ja erityistilanteissa entistä jumalanpalvelusjärjestystä. Ponnen vastustajien mielestä kirkkojärjestys takasi jo tämän mahdollisuuden, eikä ponnen myötä muutenkaan ollut syytä antaa jumalanpalvelusuudistuksessa passiivisille seurakunnille eräänlaista epävirallista lupaa pitäytyä entisessä. 
Lisäponsi kaatui äänestyksessä selvin luvuin 67-18. ${ }^{613}$ Ponnen puolesta äänestäneet olivat taustaltaan hyvin epäyhtenäinen joukko, joskin eniten heissä oli maaseutuympäristössä asuvia. ${ }^{614}$ On huomattava, että ne, jotka olivat olleet aktiivisia - usein kriittisiäkin - kirjojen sisältöä koskeneessa keskustelussa, vastustivat yleensä lisäpontta. Sen sijaan ponsi sai tukea niiltä "maan hiljaisilta”, jotka eivät juuri muuten olleet osallistuneet käsikirjaehdotusten käsittelyyn. Kyse ei siis näyttänyt olevan ensisijaisesti siitä, että edustajat olisivat olleet erimielisiä uudistuksen sisällöstä ja että vähemmistöön jääneet olisivat pettyneet. Sen sijaan alusta asti jotkut jättäytyivät kokonaan sivuun uudistuksesta. Heille tärkeintä ei ollut uudistuksen sisältö vaan mahdollisuus vanhan säilyttämiseen.

Suomenkielisen jumalanpalvelusten kirjan täysistuntokäsittelyssä hyväksyttiin hieman yli kolmannes edustajien tekemistä muutosehdotuksista. Jos käsikirjavaliokunnan puheenjohtajana toimineen Olavi Rimpiläisen puheenvuorot jätetään huomiotta, kukin piispa käytti keskimäärin noin viisi puheenvuoroa. Papeilla vastaava keskiarvo oli korkeampi, noin seitsemän puheenvuoroa. Lisäksi on huomattava, että piispoista Jukka Paarma, Wille Riekkinen ja Eero Huovinen vaikenivat, kun taas 32 pappisedustajasta vain muutama jätti osallistumatta keskusteluun. Maallikkoedustaja puhui keskimäärin neljä kertaa, mutta jos erotellaan kanttorit muista maallikkoedustajista, erot kasvavat tuntuvasti: kukin kanttori puhui keskimäärin lähes 19 kertaa, muu maallikkoedustaja taas hieman alle kolme kertaa. Kanttorit olivat joutuneet seuraamaan virsikirjauudistusta täysin kirkolliskokouksen ulkopuolelta, mutta runsas vuosikymmen myöhemmin he olivat erittäin näkyvässä osassa jumalanpalvelustekstejä ja -sävelmiä uudistettaessa.

Ruotsinkielinen jumalanpalvelusten kirja hyväksyttiin lopulta käytännössä keskustelutta. Asiaan saattoi vaikuttaa se, että mielipiteitä jakaneet asiat, kuten ehtoollisen asetussanat, oli hyväksytty erilliskysymyksinä. Toinen merkittävä seikka oli kuitenkin ajanpuute: piispa Erik Vikström valitteli, että ruotsinkielisen jumalanpalvelusten kirjan käsittely oli jätetty niin myöhäiseen vaiheeseen, että kirja oli käytännössä pakko saada nopeasti hyväksytyksi. ${ }^{615}$ Suomen- ja ruotsinkielinen evankeliumikirja ja jumalanpalvelusten kirja hyväksyttiin toisessa käsittelyssä yksimielisesti. ${ }^{616}$
Liturgianhistoriallisesti ja systemaattisteologisesti uudistus oli korkeatasoinen, mutta vahva asiantuntijaote vei huomion herkästi yksityiskohtiin. Eukaristisen rukouksen sanamuodot tai sen osien keskinäinen järjestys olivat tästä näkökulmasta tarkasteltuina merkittäviä kysymyksiä, vaikka aktiivinenkaan kirkossakävijä tuskin huomasi eri vaihtoehtojen välisiä eroja. Käsikirjakomitea korosti yhtenä periaatteenaan jumalanpalveluksen kontekstualisointia tuolloiseen Suomen tilanteeseen, mutta samaan aikaan oli palattava vuosisatojen taakse kohti vanhakirkollista messua.

Vuonna 1988 oli toivottu seurakuntaelämän tai ainakin jumalanpalveluselämän kokonaisvaltaista uudistusta. Hieman yli kymmenen vuotta myöhemmin hyväksyttiin evankeliumikirja ja jumalanpalvelusten kirja, jotka olivat monella mittarilla tasokkaita mutta ennakko-odotuksiin nähden monen mielestä silti varovaisia. Taustalla näkyi myös ajan muuttuminen. Uudistusta aloitettaessa 1980-luvun lopulla yhteiskunta oli tutkimusten mukaan moniarvoistumassa ja sitoutuminen kristinuskon opetuksiin heikentymässä ${ }^{617}$. Tässä tilanteessa lähdettiin suunnittelemaan radikaalia uudistusta. Ilmapiiri muuttui kuitenkin 1990-luvulla: vuosikymmenen alussa kolmannes suomalaisista ilmoitti uskovansa kristinuskon opettamaan Jumalaan, mutta laman myötä vuosikymmenen lopulla näin ilmoitti puolet kansalaisista. Myös kirkon arvostus kasvoi. ${ }^{618}$ Kaiken lisäksi laman ja Euroopan unionin jäsenyyden aiheuttama rakennemuutos vaikutti erityisesti maaseutuun, jossa myös epäilykset jumalanpalvelusuudistusta kohtaan olivat voimakkaimpia. Tällaisten mullistusten keskellä ja toisaalta kirkkoon kohdistuneiden muutospaineiden helpottaessa radikaali jumalanpalvelusuudistus ei näyttänyt yhtä houkuttelevalta ja välttämättömältä kuin 1980-luvun lopussa.

Ainakin yhdessä suhteessa jumalanpalvelusuudistus merkitsi kuitenkin ajattelutavan muutosta. Jumalanpalvelusta koskevaa päätösvaltaa siirtyi kirkolliskokoukselta paikallisseurakuntaan. ${ }^{619}$ Kirkkolain kokonaisuudistuksen aikaan 1980-luvulla oli korostettu, miten kirkkokäsikirja oli kirkkojärjestykseen rinnastettavaa, sitovaa säännöstöä. Jumalanpalvelusuudistuksessa siirryttiin kerralla väljään "puitelainsäädäntöön". Kaikesta päätellen muutos liittyi myös kirkolliskokouksen itseymmärrykseen. Kirkolliskokous oli 1980-luvulla ja 1990-luvun alussa uudistanut lakia ja mieltänyt itsensä 


\section{Kirkollisia kirjoja saameksi ja viittomakielellä}

Suomen- ja ruotsinkieliset kirkolliset kirjat uudistettiin melko säännöllisesti muutaman vuosikymmenen välein. Kirkolliskokous hyväksyi 1990- ja 2000-luvulla kuitenkin myös teoksia, joita ei ollut uudistettu pitkiin aikoihin tai joiden osalta oltiin liikkeellä ensimmäistä kertaa. Kestilän kirkkoherra Tapio Leinonen muisteli kirkolliskokouksessa pappisuransa alkua saamelaisten pappina vuonna 1969. Tuolloin oli pitänyt pärjätä virsikirjalla ja raamatunkäännöksellä, joiden ikä oli yli sata vuotta ja joista jälkimmäisen painos oli kauan sitten loppunut. ${ }^{\text {I }}$ Kirkolliskokouksen toimien myötä tilanne oli uuden vuosituhannen alussa toisenlainen.

Suomalaisessa yhteiskunnassa ja kirkossa huomio kiinnittyi vasta 1980-luvulta lähtien laajemmin saamen- ja viittomakielisten äidinkieliseen palveluun. Molempien kieliryhmien osalta muutoksen taustalla oli valtioiden rajat ylittänyt poliittinen herääminen, jota seurasivat kansainväliset sopimukset. Niiden pohjalta Suomessakin saamen- ja viittomakielisten henkilöiden kielelliset oikeudet kirjattiin perustuslakiin 1990-luvun puolivälissä. Kirkko oli jo kauan palkannut työntekijöitä molempien kieliryhmien keskuuteen, mutta yhtenäiset käännökset monista keskeisistä kirkollisista teksteistä puuttuivat. Perustuslakimuutos velvoitti kirkon toimimaan. ${ }^{\text {II }}$ Vuonna 1986 asetettu saamelaisvirsikomitea sai työnsä päätökseen 1993. Tuloksena oli ensinnäkin pohjoissaamenkielinen Sálbmagirji, joka sisälsi 491 virttä. Kirjaa valmisteltaessa oli pyritty mahdollisimman pitkälti pohjoismaiseen yhteistyöhön. Sata virttä sisältänyt inarinsaamenkielinen Salmâkirje taas oli nimenomaan suomalainen virsikokoelma. Sen jumalanpalvelusliite oli kautta aikain ensimmäinen inarinsaamenkielinen kirkkokäsikirjan kaavojen julkaisu. ${ }^{\text {III }}$ Kirkolliskokous hyväksyi rajatulla asiantuntemuksellaan mutta lukuisin kiitoksin nämä virsikirjat ja veisasi päätteeksi kiitosvirren molemmilla kielillä. ${ }^{\text {IV }}$

Myöhemmin 200o-luvun alkuvuosina seurasivat pohjoisja inarinsaamenkieliset versiot jumalanpalvelusten kirjasta, evankeliumikirjasta ja kirkollisten toimitusten kirjasta. Ensimmäistä kertaa kirkolliskokous hyväksyi saamenkielisen kirkkokäsikirjan. ${ }^{v}$ Toimitusten kirjaa käsiteltäessä saamelaisten edustaja Pekka Aikio puhui historiallisesti melko pitkän osuuden saamea kirkolliskokouksen pöytäkirjaan. Hän kiitti käännöstä, joka hänen mielestään oli "selvästi paremmin luettavaa ja paremmin ymmärrettävää" kuin saameksi käännetyt valtion lakitekstit. ${ }^{\mathrm{VI}}$

Kirkkokäsikirjan keskeisten osien viittomakielinen käännös lähti liikkeelle kuurojenpappien aloitteiden pohjalta 1997

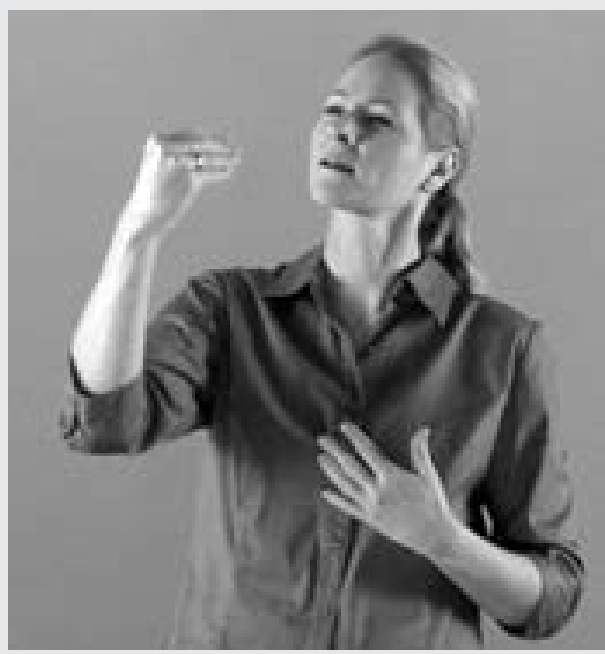

Kirkolliskokous sai 2009 hyväksyttäväkseen videon, joka sisälsi evankeliumikirjan viittomakielisen käännösehdotuksen. Pysäytyskuva on jouluaaton Vanhan testamentin lukukappaleen käännösehdotuksesta Jesajan kirjasta. Kuva: Kirkkohallitus / Evankeliumikirja $2009 a$.

ja valmistui neljä vuotta myöhemmin. ${ }^{\text {VII }}$ Kirkolliskokouksen päätöksenteon näkökulmasta prosessi oli helppo. Varsinainen käännöstyö oli sen sijaan vaativaa pioneeritoimintaa, joka vertautui monessa suhteessa Mikael Agricolan työhön. ${ }^{\text {vII }}$ Kun sitten Luukkaan evankeliumin käännösvideo oli kirkolliskokouksen hyväksyttävänä 2007, voitiin jo todeta käännösperiaatteiden menneen eteenpäin. ${ }^{\mathrm{IX}}$ Seuraavina vuosina olivat vuorossa evankeliumikirjan, Vanhan testamentin alkukertomusten ja Johanneksen evankeliumin käännökset. ${ }^{\mathrm{x}}$ Lopulta syksyllä 2011 kirkolliskokous hyväksyi messun ja kirkollisten toimitusten keskeisimmät osat tulkittuina suomenruotsalaiselle viittomakielelle. ${ }^{\mathrm{xI}}$

I Kirk.kok. kptk-s. 1998, 27 \$.

II Vuorinen 2008, 6-14; Mustakallio 2010, 243-247; Rantala 2010, 215-216, 229-242.

III Sálbmagirji 1993; Salmâkirje 1993; Kirk.kok. ptk-s. 1993, liite VII-B 2; Pajamo \& Tuppurainen 2004, 481.

IV Kirk.kok. kptk-s. 1993, 31 \$, 33\$.

V Kirk.kok. ptk-s. 1998, 27 \$, liite X-D 1; Kirk.kok. kptk-s. 2000, 44 \$; Girkolaš doaimmahusaid girji 2004; Kirholij toimâttâsâi kirje 2004; Kirk.kok. kptk-s. $2004,6 \$, 40 \$, 48 \$$.

VI Kirk.kok. kptk-s. 2004, $6 \$$.

VII Kirk.kok. ptk-k. 1997, liite IV 6; Kirk.kok. kptk-k. 1998, 43 \$; Kirk.kok. kptks. 2001, 17 \$; Vuorinen 2008, 16-19, 25, 67.

VIII SEK 2000-03, 109; Vuorinen 2008, 68-70, 74-75.

IX Kirk.kok. kptk-k. 2007,36\$.

X Evankeliumikirja 2009a \& 2009b; Kirk.kok. ptk-k. 2009, liite VII-B 2; Kirk. kok. kptk-k. 2010, 9 \$; Kirk.kok. ptk-s. 2011, 35 \$, liite V-A 2.

XI Kirk.kok. ptk-s. 2011,34\$, liite V-A 1. 
lainsäädäntöelimeksi. Sen sijaan 1990-luvulla voimistui toiminnallisuuden ja kirkon käytännön elämän korostus, mikä sopi hyvin siihen, ettei kirkkokäsikirjaakaan käsitelty ensisijaisesti säännöstönä.

Turun arkkihiippakunnan pääsihteeri Ilkka Kantola näki jumalanpalvelusuudistuksessa läheisen yhteyden kirkkolainsäädännön alistussäännösten purkamiseen 1990-luvulla. ${ }^{620}$ Tosin alistussääntöjen purkamisessa alkuajan radikaalit suunnitelmat eivät lopulta toteutuneet. Samoin kävi sittemmin jossain määrin jumalanpalvelusuudistuksessakin, mutta peruslinja ei muuttunut ${ }^{621}$. Käsikirjavaliokunnan puheenjohtaja Olavi Rimpiläinen totesi valiokuntansa pyrkineen osoittamaan jumalanpalvelusten kirjan tuleville käyttäjille, että kirja oli "polku ja jos siitä askeleen astuu joku paikallisseurakunta sivuun, niin se ei oo vielä eksyksissä". ${ }^{622}$ Jumalanpalvelusuudistuksessa näkyi samaa ajattelutapaa kuin esimerkiksi Heikan komitean työssä seurakuntien hallinnon osalta: erilaisiin seurakuntiin ja eri puolille Suomea oli tarjottava erilaisia vaihtoehtoja.

\section{VUORISAARNAN ETIIKKAA AKTIIVI- KRISTITYILLE VAI EL ÄM ̈̈NLÄHEIST $\ddot{A}$ POHDINTAA JOKA KOTIIN?}

Vuoden 1948 kirkolliskokous oli hyväksynyt kirkolle kristinopin ${ }^{623}$, joka pohjautui Kuopion piispan Eino Sormusen työhön. Seuraavalla vuosikymmenellä kuultiin kuitenkin jo ensimmäiset vaatimukset kristinopin uudistamisesta. Taustalla olivat kristinopin pedagogiset puutteet, jotka osaltaan johtivat erilaisten rippikoulun oppikirjojen syntyyn ja kristinopin syrjäytymiseen rippikouluopetuksesta. ${ }^{624}$ Kirkolliskokous käsitteli 1970-luvun loppupuolella kristinopin uudistamista ja mahdollisen erillisen "kansankatekismuksen" tai "aikuiskatekismuksen" laatimista. Kristinopin uudistushanke ei kuitenkaan toteutunut, eikä myöskään Leino Hassisen laatima aikuiskatekismus saanut täysin virallista asemaa. ${ }^{625}$ Kristinopin uudistamista jarrutti luultavasti se, että opillisesti kirjassa ei nähty suuria puutteita. ${ }^{626}$

Uusi katekismus oli 1980-luvulla esillä Kirkko 2000 -prosessissa, ja muutenkin laaja kirkollisten kirjojen uudistustyö piti asian ajankohtaisena. ${ }^{627}$ Lopulta keväällä 1993 Ilmajoen rovastikuntakokous ehdotti Peräseinäjoen kirkkoherran Olli T. Rajamäen aloitteesta Lapuan hiippakuntakokoukselle, että ryhdyttäisiin toimiin uuden kristinopin laatimiseksi. ${ }^{628}$ Asia eteni kirkolliskokoukseen, joka totesi hankkeen tärkeäksi ja kiireelliseksi. Vielä saman istuntoviikon aikana kokous pyysi piispainkokousta ryhtymään toimiin. ${ }^{629}$

Yleinen valmistusvaliokunta katsoi moniarvoisen ajan lisänneen tarvetta laatia tiivis kristinoppi, "johon sisältyisi kirkon uskon peruskuvaus ja lyhyt, nykyajan ihmisille tärkeitä eettisiä kysymyksiä käsittelevä esitys". ${ }^{630}$ Valiokunnan sanoissa näkyi huoli, joka ilmeni muutenkin kirkolliskokouksessa: kyselytutkimuksissa suuri osa kirkon jäsenistä ilmoitti uskovansa eri tavoin kuin kirkko opetti, eikä kovin moni edes välttämättä tiennyt, mitä tuo opetus piti sisällään. Lisäksi uususkontojen saama näkyvyys ja sekoittuminen kristinuskoon puhuttivat. ${ }^{631}$ Tällaiset uskonnollisuuden muutokset lisäsivät jatkuvasti odotuksia uutta kristinoppia kohtaan.

Piispainkokous tarttui toimeen yhtä nopeasti kuin kirkolliskokous. Se asetti piispa Eero Huovisen johtaman työryhmän suunnittelemaan kristinopin laatimista. Työ eteni vauhdikkaasti: jo alkuvuodesta 1995 piispainkokous hyväksyi suunnitelman ja valitsi Huovisen uuden kristinopin kirjoittajaksi. ${ }^{632}$ Kirjoitustyötä tukemaan perustettiin 13-jäseninen palauteryhmä, jonka jäsenistä Porvoon suomalaisen seurakunnan kappalainen Matti Poutiainen ja toimittaja Leena Huima muodostivat Huovisen kanssa niin sanotun kirjoittajatyöryhmän. Tämä tiiviisti työskennellyt kolmikko muokkasi tekstejä palauteryhmää varten. ${ }^{63}$

Alusta asti oli havaittavissa tietty jännite dogmatiikan ja pedagogiikan välillä. Huovinen muokkasi tekstejä kirjoittajatyöryhmän kanssa pyrkien tiiviiseen, aikaa kestävään ilmaisuun. Piispainkokouksen suunnitelman mukaisesti lähdettiin liikkeelle käskyjen selittämisestä ja seurattiin siten Lutherin Vähän katekismuksen jaottelua. Asioista kirjoitettiin monikon ensimmäisessä persoonassa. Ratkaisut sopivat varsinkin monille palauteryhmän pappismiehistä, ja opillisesti tekstiä pidettiin yleisesti korkeatasoisena. Sen sijaan palauteryhmässä oli useita jäseniä, joiden mielestä esitystavan lähtökohdat olivat vääriä: me-muoto oli heidän mielestään liian holhoava, ja liikkeelle olisi pitänyt lähteä arjen keskeltä kaikenlaista hengellistä erityissanastoa välttäen. Perusratkaisujen osalta piispa Huovinen pysyi kuitenkin loppuun asti linjallaan. Sitä paitsi hänen ratkaisuillaan oli palauteryhmässä myös monia kannattajia. ${ }^{634}$ 
Palauteryhmän työskentelyn perusteella Huovisen kristinoppi jakoi mielipiteitä pitkälti samasta syystä kuin edeltäjänsä: epäiltiin, kykenikö opillisista lähtökohdista laadittu teos lunastamaan paikkansa rippikouluopetuksessa tai tavallisen seurakuntalaisen yöpöydällä. Kirkon kasvatustyön kokonaisohjelma oli saanut 1970-luvulla osakseen arvostelua siitä syystä, että se lähti liikkeelle yksilön elämäntilanteesta opin sijaan. Kristinoppia uudistettaessa lähtökohta oli päinvastainen, mutta tämäkin ratkaisu aiheutti erimielisyyksiä. Joka tapauksessa kahden vuosikymmenen väliset erot olivat nähtävissä: kirkossakin oli 1970-luvun puolivälissä pyritty vastaamaan muuttuvan yhteiskunnan vaatimuksiin ajankohtaisin pedagogisin keinoin. Sen sijaan 1990-luvun puolivälistä eteenpäin, kun kirkko sai tehdä työtään aiempaa rauhallisemmassa ympäristössä, opilliset lähtökohdat korostuivat. Oppia painottava ajattelutapa näkyi sekä jumalanpalvelus- että kristinoppiuudistuksessa.

Piispainkokous hyväksyi omalta osaltaan Huovisen Katekismus-nimisen kristinoppiehdotuksen vähäisin sisällöllisin muutoksin. Kokous hyväksyi myös piispa Erik Vikströmin kääntämän ruotsinkielisen version. ${ }^{635}$ Lehdistössä keskusteltiin sen sijaan ehdotuksen julkistamisen jälkeen vilkkaasti, ja mielipiteet jakautuivat pitkälti samoissa kysymyksissä kuin aiemmin palauteryhmässä. ${ }^{636}$ Kirkolliskokous puolestaan joutui ensimmäistä kertaa ottamaan kantaa kristinoppiin tilanteessa, jossa se ei vielä pystynyt vaikuttamaan kirjan sisältöön. Kirkkohallitus esitti keväällä 1998, että Katekismus jaettaisiin riemuvuoden 2000 kunniaksi jokaisen seurakuntalaisen talouteen. ${ }^{67}$ Talousvaliokunta ja sittemmin kirkolliskokouksen täysistunto hyväksyivät esityksen sellaisenaan. Vaikka kirkolliskokous ei vielä ollut saanut piispainkokouksen ehdotusta uudeksi kristinopiksi, päätös syntyi yhtä ongelmattomasti kuin kristinoppiuudistuksen aiemmissakin valmisteluvaiheissa. Vain diakoniajohtaja Kaarlo Kalliala epäili julkisesti jakamishanketta. ${ }^{638}$

Piispainkokouksen esitys tuli kirkolliskokouksen käsittelyyn syksyllä $1998 .{ }^{639}$ Tällä kertaa mielipiteet jakaantuivat osin voimakkaastikin ja edelleen samoin perustein kuin palauteryhmässä. Useimmat puhujat olivat ainakin pääosin tyytyväisiä ehdotukseen, mutta samalla sen katsottiin vaativan seurakunnissa rinnalleen opetusta. Alettiin myös jälkikäteen miettiä, oliko sittenkään oikea päätös jakaa nimenomaan tämä kirja kaikkien seurakuntalaisten koteihin. Kirkolliskokouksen yleinen valmistusvaliokunta oli 1993 edellyttänyt kristinopilta tiiviyttä ja selkeyttä sekä tuon ajan ihmisille tärkeiden eettisten kysymysten käsittelyä. Työn päättyessä oltiin yksimielisiä, että tiiviys oli toteutunut, mutta joidenkuiden mielestä näin oli tapahtunut kahden muun tavoitteen kustannuksella. ${ }^{640}$

Kaikki kirkolliskokousedustajat eivät tyytyneet jättämään Katekismuksen selittämistä seurakunnissa tapahtuvan opetuksen varaan. Varsinkin nuorempiin sukupolviin kuuluvat edustajat vaativat, että myös kirjaa itseään oli muutettava helpommin lähestyttäväksi. Pastori Jaakko Heinimäki edellytti johdantoluvun laajentamista, koska Katekismus lähti liikkeelle vahvalla teologisella latauksella: "Lukija joutuu kylmiltään semmoisen painon alle, että vahvempaakin hirvittää." Toimittaja Marjaana Perttula ehdotti kirjan loppuun sanastoa, jossa keskeiset termit selitettäisiin. Ehdotukset saivat paljon kannatusta. ${ }^{611}$ Perustevaliokunta, jossa asiaa valmisteli piispa Juha Pihkalan johtama kristinoppijaosto, ottikin toivomukset osittain huomioon: sanaston sijasta valiokunta lisäsi kirjan loppuun hakemiston, ja esipuheen alkuun tuli uutena osana "nykyihmistä hänen aatteellisessa ympäristössään puhutteleva kappale". ${ }^{642}$ Rakenteellisesti perustevaliokunta piti kristinoppia muuten toimivana, ja sen tekemät muutokset olivat vähäisiä. ${ }^{643}$

Yksittäisistä kohdista eniten huomiota kiinnitettiin lähetekeskustelussa kuudennen käskyn selitykseen. Kohdassa mainittiin avioeron mahdollisuus mutta ei uudelleen avioitumista. Jaakko Heinimäki ehdotti sanottavan "reilusti", että avioeron jälkeenkin oli mahdollista yrittää uudestaan ja että siksi kirkko hyväksyi myös eronneiden vihkimisen. Heinimäki sai tukea istuntosalista. ${ }^{64}$ Perustevaliokuntakin harkitsi asiaa mutta päätyi yhtenäiseen linjaan, jonka mukaan anteeksiantamuksen ja uudelleen alkamisen mahdollisuutta ei erikseen mainittu yksittäisten käskyjen selityksissä. Sen sijaan valiokunta vaihtoi sanan "parisuhde" tilalle termin "aviosuhde" haluten korostaa avioliiton ja seksuaalielämän yhteenkuuluvuutta. ${ }^{645}$

Keskustelu jatkui täysistunnossa keväällä 1999, ja edelleen erityisesti kuudes käsky säilyi puheenaiheena. Espoolainen lääkäri Paula-Maria Lehtipuu oli tyytymätön valiokunnan ratkaisuun säilyttää käskyn selitys pitkälti ennallaan. Hän kiinnitti huomiota esimerkiksi selityk- 
sen toteamukseen, että elinikäisessä avioliitossa miehen ja naisen suhde toteutui Jumalan tarkoittamalla tavalla:

Ikään kuin siis siitä, että avioliitto on elinikäinen, automaattisesti seuraisi se, että parisuhde on Jumalan tahdon mukainen. Toisin sanoen, ikään kuin tärkein kriteeri tässä mielessä olisi parisuhteen ulkoinen muoto eikä sisällöllisillä kriteereillä kuten vaikkapa rakkaudella tai keskinäisellä kunnioituksella olisi kirkon mielestä mitään merkitystä. Pääasia, että kulissit ovat pystyssä, oli niiden takana sitten millainen perhehelvetti tahansa, niin Jumalan tahto toteutuu. Tätäkö me

\section{Arkkipiispa, apupapit ja seksuaalietiikka}

Turun piispa Johannes Terserus oli joutunut 1664 eroamaan virastaan harhaoppisuussyytösten vuoksi, mutta kaikkiaan tällaiset syytteet Pyhän Henrikin istuimen haltijaa kohtaan olivat sangen harvinaista. Huomio olikin taattu, kun arkkipiispa John Vikström joutui 1993 vastaamaan harhaoppisuussyytöksiin tuomiokapitulin edessä. Keskustelu samaa sukupuolta olevien parisuhteesta oli lähtenyt liikkeelle eri maissa ja kirkoissa. Suomen eduskunnassa aloite parisuhdelaista johti alkuvuodesta 1993 kovaan sanankäyttöön, joka puolestaan sai arkkipiispa Vikströmin puolustamaan homoseksuaalien ihmisarvoa huhtikuisessa radiohaastattelussa. ${ }^{I}$ Paavalin synodin piirissä alettiin haastattelun jälkeen kerätä vastinetta, jonka allekirjoitti huhtikuun loppuun mennessä yli 140 teologia, mukana myös kirkolliskokousedustajia. ${ }^{\text {II Keskuste- }}$ lu huipentui yksityishenkilön jättämään harhaoppisuuskanteluun. ${ }^{\text {III }}$

Asia nousi esiin myös kevään 1993 kirkolliskokouksessa. Kuusi edustajaa vaati aloitteessaan, että piispojen 1984 julkaisemaa perhe- ja seksuaalieettistä kannanottoa Kasvamaan yhdessä oli arvioitava uudelleen. Piispojen kannanoton mukaan esimerkiksi avosuhde ei ollut avioliittoon verrattava yhteiselämän muoto. Edelleen homoseksuaalisen taipumuksen vuoksi ei ketään tullut pitää moraalisesti epäilyttävänä, mutta toisaalta homoseksuaali oli heteroseksuaalin tavoin vastuullinen siitä, miten hän ilmensi taipumustaan. ${ }^{\text {IV }}$ Aloitteen ensimmäiset allekirjoittajat Hannele Repo ja Ari Tammi kuuluivat niin sanottuun Helsingin hiippakunnan apupappien ryhmään, joka halusi uudistusten avulla tuoda kirkon aiempaa paremmin ihmisten rinnalle. ${ }^{\mathrm{V}}$ Repo tiivisti aloitteen taustan: "Kirkko ei saa vaieta ja ohittaa - - kipeitä kysymyksiä ja puolustaa vain keskivertoisia, elämässä onnistuneita parisuhteessa turvallisesti eläviä ihmisiä.,"VI

Arkkipiispa John Vikström käytti aloitetta koskevassa keskustelussa pitkän puheenvuoron, jossa hän perusteli ja tar- kirkkona haluamme sanoa ihmisille - -? Toivoakseni ja ymmärtääkseni emme. ${ }^{646}$

Lehtipuu ehdotti arvostelemansa lauseen tilalle muotoilua: "Avioliitossa miehen ja naisen suhde voi parhaiten toteutua Jumalan tarkoittamalla tavalla." Siten Lehtipuu halusi karsia kohdasta ehdottomuutta ja avioliiton elinikäisyyden ensisijaisuutta. Perustevaliokunnan jäsen Kaarlo Kalliala puolestaan ehdotti kokonaan uutta lisäystä, jonka myötä uudelleen avioitumisen mahdollisuus

kensi kuukauden takaista lausuntoaan. Vikström kertoi sitoutuvansa edelleen piispojen kannanottoon: mikä oli yhdessä sanottu, oli yhdessä tarkistettava. Kyse oli Vikströmin mukaan paljolti siitä, miten kirkolliskokous suhtautuisi jätettyyn edustaja-aloitteeseen. Kovin laajaa keskustelua ei kuitenkaan syntynyt. ${ }^{\text {VII }}$ Kirkolliskokousta koskevissa uutisissa aloite sai sen sijaan osakseen päähuomion. ${ }^{\mathrm{VIII}}$ Arkkipiispan kanta ei tyydyttänyt kovimpia parisuhteen rekisteröinnin vastustajia sen enempää kuin homoseksuaalien asiaa ajaneitakaan. ${ }^{\mathrm{IX}}$ Kirkolliskokous lähetti aloitteen piispainkokoukselle, joka totesi Kasvamaan yhdessä -kannanoton vastaavan edelleen kirkon eettisen opetuksen peruslinjoja. ${ }^{\mathrm{X}}$ Kirkolliskokous joutui tosin itsekin palaamaan kuudennen käskyn tulkintaan muutamaa vuotta myöhemmin, kun käsittelyyn tuli ehdotus uudeksi kristinopiksi.

I SEK 1992-95, 33; SS 15.7.1993 Arkkipiispaa syytetään harhaoppisuudesta; Strömsholm 1997, 78-82, 98-101; Malkavaara 2000, 262; Liljeström 2008, 241; Koivisto 2011, 40.

II Sisarenpoika 2/1993 Avoin kirje Arkkipiispalle 30.4.1993; Strömsholm 1997, 109-112, 119-124.

III SS 15.7.1993 Arkkipiispaa syytetään harhaoppisuudesta; Strömsholm 1997, 148-153, 208-209.

IV SEK 1984-87, 28; Kirk.kok. ptk-k. 1993, liite IX 5; Kasvamaan yhdessä 1984, 47, 60-63; Luukkonen $2005,56$.

V Il 15.4.1994 Seksuaalimoralismista moraaliseen seksuaalisuuteen; SS 28.12.1994 Nuorkirkollinen ajattelutapa voimistuu kirkossa (Matti Helin); IS 27.5.1995 Nuoret papit protestoivat kirkon seksiopetusta (Heli Karhumäki); HS 28.5.1995 Vaasan kirkkopäivistä tuli värikäs kansanjuhla (Eeva Palm); Luukkonen 2005, 58-59.

VI Kirk.kok. kptk-k. 1993, 52\$.

VII Kirk.kok. kptk-k. 1993, 52 \$; Strömsholm 1997, 137-145.

VIII HS 5.5.1993 Kuuden edustajan aloite vaatii kirkolta uutta seksuaalietiikkaa (Jaakko Kangosjärvi); TS 7.5.1993 Arkkipiispa Vikström varoittaa kivittämästä homoja, 8.5.1993 Homokysymys koettelee kirkon suvaitsevuutta (pääk.), 12.5.1993 Kolumni: Rakkauden ja kirkon rajat (Anna-Maija Tuomala); Hbl 14.5.1993 I dag: Äktenskap? (Merete Mazzarella); KS 16.5.1993 Saako mies rakastaa miestä (pääk.).

IX IS 16.7.1993 Seta ei tue arkkipiispaa (Tarja Penttinen); Strömsholm 1997, 238-239, 250, 306-307, 313.

X Kirk.kok. ptk-k. 1993, 78 \$, liite X-B 2; Kirk.kok. ptk-s. 2003, liite VII-B 2, 3; Strömsholm 1997, 276-277. 
tulisi osaksi käskyn selitystä: "Päätös uudelleen avioitumisesta on vastuullinen ja vakava. Sen tuominen Jumalan ja ihmisten eteen ei kysy vain tahtoa sitoutua vaan myös armoa ja anteeksiantamusta." ${ }^{477}$ Perustevaliokunnan linjalla olleet taas katsoivat, ettei käskyjen terävyyttä tullut himmentää: käskyihin liittyi olennaisesti se, että jokainen joutui syylliseksi niiden edessä. ${ }^{648}$

Kuudennen käskyn selitykseen kertyi Lehtipuulta, Kallialalta ja Heinimäeltä yhteensä viisi muutosehdotusta, jotka kaikki hyväksyttiin - useimmiten suunnilleen kahden kolmasosan enemmistöllä. ${ }^{649}$ Perustevaliokunta tosin palautti maininnan elinikäisestä avioliitosta, ja lopulta myös täysistunto tyytyi siihen. ${ }^{650}$ Kuudennen käskyn selitystä käsitellessään kirkolliskokous jatkoi vuosikymmenen kuluessa virinnyttä keskustelua avioliitosta ja mahdollisesta tarpeesta päivittää kirkon opetusta parisuhteesta. Samalla käytiin rajaa, tuliko seurakunnan jäsenille saarnata ensin ehdotonta vuorisaarnan etiikkaa ja vasta sen jälkeen uuden alun mahdollisuutta vai oliko jo käskyjen selityksissä otettava huomioon ihmisten rikkonainen elämäntodellisuus. Varsinkin nuorten aikuisten tai "apupappien" vaikuttamistoiminnassa mukana olleet nuorempien sukupolvien edustajat ajoivat jälkimmäistä kantaa. Luterilaisen teologian näkökulmasta keskusteltiin siitä, mikä oli lain ja evankeliumin suhde: etääntyikö evankeliumi liian kauas painavasta laista, jos se saarnattiin vasta kristinopin myöhemmissä luvuissa, vai sekoittuivatko laki ja evankeliumi väärällä tavalla toisiinsa, jos jo käskyjen selityksissä julistettiin anteeksiantamusta ja uutta alkua?

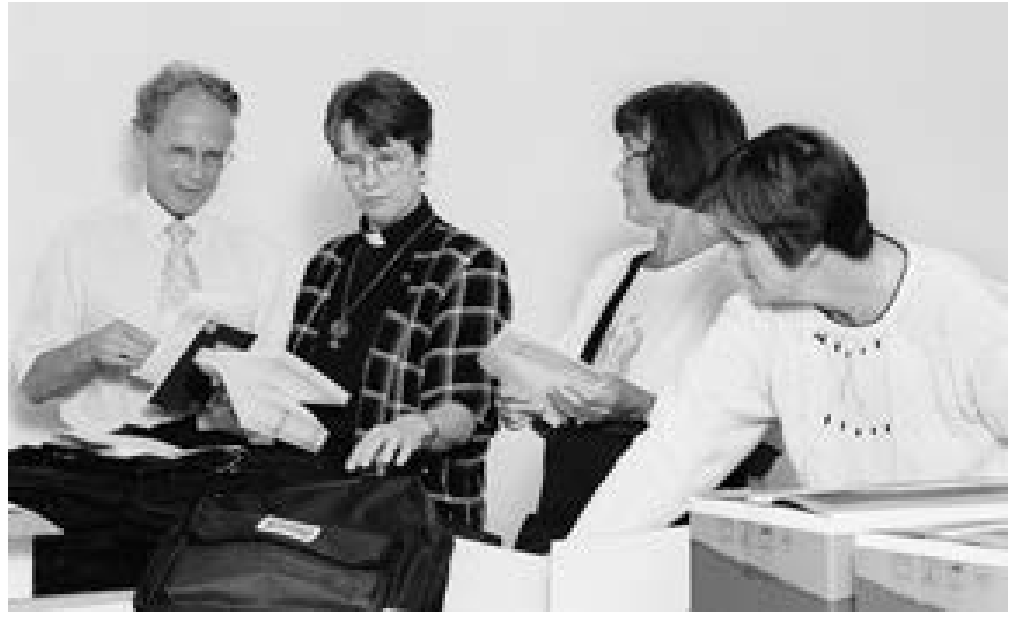

Katekismuksen toimittaminen jokaisen seurakuntalaisen kotiin riemuvuonna 2000 saavutti myönteistä julkisuutta. ${ }^{659}$ Keravalla kirjat jaettiin henkilökohtaisesti. Jakajien reppuja täyttämässä Veikko Lahtinen (vas.), Eeva Airola, Marja Lahtinen ja Marjatta Kumpusalo. Kuva: Kotimaan kuva-arkisto / Matti Karppinen.
Toinen mielipiteitä jakava aihealue oli pahan käsittely. Teema nousi pinnalle päätettäessä Herran rukouksen selityksestä. Perustevaliokunnan ehdotuksessa käsiteltiin pahan voimaa ja valtaa mutta ei erikseen mainittu Saatanaa. ${ }^{61}$ Kirkolliskokouskäsittelyn aikaan saatananpalvonta oli kuitenkin voimakkaasti esillä julkisuudessa. ${ }^{652}$ Ilmiöön viitaten pastori Eero Junkkaala toivoi persoonallisen pahan näkyvämpää käsittelyä. Seurasi pitkä keskustelu pahasta, ja lopulta kirkolliskokous lisäsi toteamuksen, että Jumalan valta oli Saatanan valtaa suurempi. ${ }^{653}$ Kirkolliskokousedustajat olivat lopulta tyytyväisiä kristinoppiehdotuksen kokonaisuuteen: ehdotuksen 48 luvusta täysistunnossa hyväksyttiin suoraan $39 .{ }^{654}$ Piispojen puheenvuoroilla näyttää olleen erityisen suuri merkitys: jos joku piispa otti kantaa yksittäiseen kysymykseen, muutamaa poikkeusta lukuun ottamatta hänen kantansa voitti. Pohjatekstin kirjoittajan Eero Huovisen ilmaisemaa kantaa vastaan täysistunto asettui vain kerran. ${ }^{65}$

Teknikko Svante Österbacka johti valiokunnassa ruotsinkielisen Katekes-ehdotuksen valmistelua. Työn aikana pidettiin yhteyttä ruotsinkielisiin kirkolliskokousedustajiin. ${ }^{656}$ Varsinainen sisältö hyväksyttiin jo suomenkielisestä kristinopista päätettäessä, mutta joitakin kielen vivahteita pohdittiin vielä syksyn 1999 täysistuntokäsittelyssä. Katekes-teoksen käsittely sujui nopeasti ja vaivatta ruotsinkielisten edustajien johdolla. ${ }^{657}$ Svante Österbacka kuoli vain kaksi viikkoa ruotsinkielisen kristinopin hyväksymisen jälkeen. ${ }^{658}$ 


\section{VAHVAN VALMISTELUKONEISTON}

\section{AIKAAN}

\section{UUDEN KESKUSHALLINNON ELIMET ETSIVÄT VALTANSA RAJOJA}

Vuonna 1994 voimaan tullut kirkon keskushallinnon uudistus lisäsi kirkkohallituksen valtaa ja tehosti siten kokonaiskirkon valmistelukoneistoa. Uudistuksen oli myös määrä selkeyttää keskushallinnon elinten keskinäisiä toimivaltasuhteita. Sopeutuminen muuttuneeseen tilanteeseen ei kuitenkaan sujunut ongelmitta. Yhtenä esimerkkinä oli suhtautuminen kirkkohallituksen toiminnalliseen osastoon, joka oli muodostettu yhdistämällä toisiinsa useimmat perinteiset keskukset. Vielä 1990-luvun päättyessä kirkolliskokouksen talousvaliokunta arvosteli toiminnallista osastoa siitä, että se toimi edelleen keskusten jäljiltä seitsemänä toisistaan riippumattomana asiantuntijayksikkönä: yhteistyön tuomat edut olivat jääneet saavuttamatta ${ }^{660}$.

Kommentit olivat hyvin samanlaisia kuin se arvostelu, joka oli 1974 johtanut vaivalloisen toimikuntauudistuksen aloittamiseen. Toiminnallisen osaston johtaja, kirkkoneuvos Heikki Mäkeläinen tosin totesi, että hänen kokemuksensa mukaan yhteistyö oli lisääntynyt ${ }^{661}$. Kirkolliskokouksellakin oli vaikeuksia sopeutua uuteen tilanteeseen. Syksyllä 1995 Mäkeläinen joutui huomauttamaan, että kirkolliskokouksessa käsiteltiin kirkkohallitusta usein edelleen pikemminkin muutamana erillisenä osastona kuin yhtenä kirkkohallituksena. ${ }^{662}$ Jos siis yhdistymisprosessi oli vielä kesken kirkkohallituksessa, sama koski kirkolliskokousedustajien ajatuksiakin.

Keväällä 1994 kirkolliskokous sai käsiteltäväkseen kolme kirkon keskushallinnon virkoja koskevaa edustaja-aloitetta. ${ }^{663}$ Virka-aloitteiden määrä oli suunnilleen sama kuin aiempina keväinä. Tilanteessa ei ollut muuta poikkeuksellista kuin se, että saman vuoden alussa päätöksenteko tässä asiassa oli siirtynyt kirkolliskokoukselta kirkkohallitukselle. Virkoja koskevia määrärahoja sai esittää vain syksyisin talousarvioaloitteilla. Puhemiesneuvosto esitti, että kaikki kolme aloitetta hylättäisiin suoraan valiokuntaan lähettämättä. Välillä pitkiksi venähtäneiden periaatteellisten keskustelujen jälkeen näin myös tehtiin. ${ }^{664}$

Kirkkolaki oli asiassa selvä. Aloitteiden määrä osoitti kuitenkin, että useilla kirkolliskokousedustajilla oli tässäkin asiassa käytännön vaikeuksia sopeutua hallinnonuudistuksen seurauksiin ja irrottaa ote siitä vallasta, jonka kirkolliskokous oli pari vuotta aiemmin sangen ongelmattomasti luovuttanut säädöstasolla kirkkohallitukselle. Varsinkin ensimmäistä kauttaan edustajana ollut Ari Tammi peräänkuulutti kirkolliskokouksen valtaa. Pidemmän aikaa kokouksessa istuneet taas muistuttivat, että kirkolliskokous oli itse halunnut poistaa jokakeväisen virkojen "huutokaupan" isosta salista ja luopua käytännöstä, jonka mukaan jokaista uutta tehtävää varten perustettiin mekaanisesti uusi virka. Keskustelun edetessä ongelmat kiertyivät kirkolliskokouksen työjärjestyksen ympärille. ${ }^{665}$ Se oli hyväksytty nopeasti edellisenä syksynä, mutta vasta seuraavan kevään ongelmat paljastivat erimielisyydet työjärjestyksen tulkinnassa.

Talousarvioaloite oli mahdollista jättää vasta talousarvion valmistelun loppuvaiheessa lokakuussa. Jos edustaja halusi ehdottaa määrärahaa otettavaksi huomioon jo kirkkohallituksen budjettivalmistelussa, ainoa keino oli ehdottaa lisäpontta keväisissä keskusteluissa. Toivomusponsille ei kuitenkaan voinut saada yhtä perusteellista käsittelyä kuin aloitteille. Keskustelussa kysyttiin, saattoiko kirkolliskokous toivomusponsilla ohjata kirkkohallituksen työtä tarpeeksi tehokkaasti. Samaten mietittiin, oliko talousarvioaloitteiden hyvin lyhyt jättöaika lokakuun alkuviikkoina riittävä. ${ }^{666}$ Periaatteessa asetelma oli pysynyt samanlaisena jo vuodesta 1974, mutta ongelmat kärjistyivät vasta, kun kirkon yhteisten virkojen perustamis- ja lakkauttamistehtävä siirtyi kirkkohallitukselle. Kirkolliskokousedustajat eivät olleet ainoita, joille uusi tilanne oli epäselvä. Kirkkohallitus itsekin antoi kirkolliskokoukselle virkaesityksen keväällä 1994. Sitä kohdeltiin hellävaraisemmin kuin edustaja-aloitteita: se lähetettiin takaisin kirkkohallitukselle käsiteltäväksi kirkon keskusrahaston talousarvion valmistelun yhteydessä ${ }^{667}$.

Keväällä 1994 puhemiesneuvosto perusteli virkaaloitteiden hylkäämisehdotustaan työjärjestyksellä, mutta tuossa vaiheessa neuvoston rooli myös muuttui hetkellisesti. Saman vuoden syksyllä puhemiesneuvosto ehdotti työjärjestysaloitteen hylkäämistä vedoten pelkkiin tarkoituksenmukaisuusseikkoihin. Aloite oli jätetty oikeassa järjestyksessä, mutta puhemiesneuvoston mielestä se oli yksinkertaisesti tarpeeton. Menettely poikkesi selvästi aiemmasta käytännöstä, jonka mukaan 
puhemiesneuvosto oli esittänyt kaikkien lainmukaisten aloitteiden lähettämistä johonkin valiokuntaan. $\mathrm{Pu}$ hemiesneuvoston hylkäysesitys sai istuntosalissa vastaansa voimakasta arvostelua, ja kirkolliskokous päätti lähettää aloitteen valiokuntaan. ${ }^{668}$ Kirkolliskokousedustajat eivät olleet enää 1990-luvulla yhtä innokkaita hylkäämään aloitteita valiokuntaan lähettämättä kuin edellisellä vuosikymmenellä. Sen sijaan puhemiesneuvosto pyrki tässä tapauksessa lisäämään karsintaa.

Puhemiesneuvoston esitys jäi yksittäiseksi, mutta se kuvasti valmisteluelinten vallankäytön voimistumista 1990-luvulla. Laintarkastustoimikuntakaan ei aina rajoittunut arvioimaan pelkästään esitysten lakiteknistä puolta, eivätkä toisaalta esimerkiksi laki- ja hallintovaliokunta joka kerta hyväksyneet sellaisinaan laintarkastustoimikunnan esittämiä muutosvaatimuksia ${ }^{669}$. Vastaavasti piispainkokous ja perustevaliokunta eivät rajanneet lausuntojaan vain asioiden opilliseen arviointiin vaan ottivat kantaa yksityiskohtaisiinkin tarkoituksenmukaisuusseikkoihin.

Seurauksena oli, että piispainkokous alkoi näyttäytyä hiippakuntatason edunvalvojana. Vuonna 1998 myös hiippakuntahallintokomitea totesi, että oli korostettava piispainkokouksen tehtävää hiippakuntien yhteisen edunvalvonnan elimenä ${ }^{60}$. Tällaisen ajattelutavan johdosta kirkolliskokous alkoi kuitenkin suhtautua epäillen myös piispainkokouksen teologisiin perusteluihin. Jotkut arvelivat, että piispainkokous etsi valikoiden perusteluja, jotka korostivat tuomiokapitulien ja kirkon viran asemaa. Sellainen voimakas tuomiokapitulien puolustaminen, jota piispat olivat aiemmin harjoittaneet kirkolliskokouksessa, alkoi siirtyä piispainkokoukselle. Muutos loi kuitenkin varjoa piispainkokouksen toiminnan ylle. Tarkoituksenmukaisuusseikkojen sekoittuminen valmistelussa opilliseen ja lakitekniseen arviointiin oli merkille pantavaa erityisesti siihen nähden, että samaan aikaan yritettiin tuoda vallanjaon periaatteita myös kirkkoon ja poistettiin riippumattomuuden nimissä kirkolliskokouksesta korkeimpien oikeusistuinten valitsemat edustajat.

Vaikeimmat kirkkolakia koskevat uudistukset ohjautuivat hallintovaliokuntaan, joka kuului vuodesta 1994 pysyvien valiokuntien joukkoon. Oli myös ymmärrettävää, ettei oikeusneuvos Göran Portin, joka piti omaa jäsenyyttään kirkolliskokouksessa jo periaatteessa vää- ränä, halunnut ylläpitää lakivaliokunnan puheenjohtajana korkeaa profiilia. Päinvastoin hänen pyrkimyksenään oli osoittaa, että kirkolliskokouksen työskentely onnistui hyvin ilman korkeimpien oikeusistuinten valitsemia edustajia. Tehokkain tapa todistaa oma tarpeettomuutensa oli vaieta. Niin korkeimman oikeuden ja korkeimman hallinto-oikeuden jäsenet tekivätkin vuosina 19921995. Työjärjestyksen muutokset ja henkilövaihdokset olivat johtamassa siihen, että lakivaliokunnasta tuli entistä selvemmin lakitekninen valiokunta, joka hioi jo aiemmissa vaiheissa pitkälle valmisteltuja, usein yleisesti hyväksyttyjä uudistuksia. Johannes Leivosen johtaman, kirkkolainsäädännön suuntaa linjanneen lakivaliokunnan ajat olivat takana. Hallintovaliokunnan keskeisyyttä kaudella 1992-1995 osoittaa se, että esimerkiksi 1995 valiokunta piti 21 kokousta ja että syksyllä 1995 valiokunnalta tuli kirkolliskokoukselle käsiteltäväksi liitteineen lähes sata sivua tiheää, kaksipalstaista mietintötekstiä.

Seuraavalla vaalikaudella hallintovaliokunta menetti näkyvyyttään. Vastaavasti yleisvaliokunnan profiili kohosi vuosikymmenen kuluessa. Tämä muutos johtui osittain siitä, että hyvin moni huomiota saanut uudistus lähti 1990-luvulla liikkeelle hiippakuntakokouksista tai edustaja-aloitteista. Yleisvaliokunta käsitteli näitä asioita ensimmäisenä. Myös hallinnolliset edustaja-aloitteet ja hiippakuntakokousesitykset lähetettiin kuormitettuun yleisvaliokuntaan, vaikka hallintovaliokunta kärsi vaalikaudella 1996-200o toimettomuudesta ${ }^{671}$. Lisäksi tehtävien siirtyminen lakkautetulta toimikuntavaliokunnalta yleisvaliokunnalle kasvatti valiokunnan painoarvoa. Yleisvaliokunta valmisteli asioita myös aiempaa pidemmälle. Pyysipä se kertaalleen lausunnon piispainkokoukseltakin ${ }^{672}$.

Yleisvaliokunta pyrki eroon perinteisestä julkisuuskuvastaan, jonka mukaan valiokunta ehdotti nopeasti ja lyhyin perusteluin suuren osan aloitteista raukeamaan. Kääntöpuolena oli, että kynnys hylätä aloite oli aiempaa korkeampi sekä lähetekeskustelussa että valiokuntatyössä. Hiippakuntakokousten esityksistä ja edustajaaloitteista kasvava osa lähetettiin 1990-luvun kuluessa jatkovalmisteluun. Kuvaavaa oli, että yleisvaliokunnan puheenjohtajat joutuivat vuosikymmenen lopussa täysistunnossa valittelemaan ja erityisesti perustelemaan valiokuntansa raukeamisesityksiä. Mitä ilmeisimmin kirkkohallituksen valmisteluresurssien kasvaminen madalsi 
osaltaan kynnystä lähettää asioita jatkovalmisteluun.

Muutos ei ollut kuitenkaan aivan suoraviivainen. Samaan aikaan kun kirkkohallitus vahvistui ja sen toimivalta lisääntyi, kirkolliskokous alkoi ponsien sanamuodoilla osoittaa kirkkohallitukselle haluamansa toiminnan suunnan. Usein kirkolliskokous "velvoitti" kirkkohallituksen tekemään jotakin. Tietty kontrollin lisääntyminen näkyi myös siinä, että kirkolliskokous otti käyttöön kyselytunnit ja kiinnostui aiempaa enemmän esimerkiksi kirkon keskusrahaston tilintarkastuksesta. Vielä 1970-luvulla kirkkoneuvokset olivat välillä näkyvästikin puolustaneet kirkkohallituksen itsenäisyyttä, mutta 1990-luvulla kirkkohallitus ja kirkolliskokous olivat aiempaa selvemmin sidoksissa toisiinsa.

\section{HUOMIOTA KIRKON TOIMINTAAN}

Vastuu kokonaiskirkon toiminnallisesta ohjauksesta siirtyi vuoden 1994 alkaessa kirkolliskokoukselta kirkkohallitukselle. Muutos ei kuitenkaan juuri näkynyt kirkolliskokouksen käytännön työssä. Ennemminkin edustajat innostuivat 1990-luvulla entistä aktiivisemmin puuttumaan kokonaiskirkon toimintaan. Yksi syy muutokseen oli lama, joka pakotti kyseenalaistamaan aiemmat toimintatavat ja miettimään, mitkä toiminnot olivat keskeisimpiä. Toinen syy oli se, että osana uudistettua kirkkohallitusta entiset toimikunnat ja keskukset olivat sittenkin paljon lähempänä kirkolliskokousta kuin aiemmin: vaikka lainsäädännön tasolla kirkolliskokous menetti toiminnallisen johtovastuunsa, käytännössä sen mahdollisuudet puuttua kokonaiskirkon toimintaan paranivat huomattavasti. Kirkkohallitus lähetti toimintasuunnitelmia tihenevään tahtiin, ja kirkkoneuvokset olivat niin täysistunnoissa kuin uusilla kyselytunneilla vastaamassa toimintaa koskeviin kysymyksiin. Myös toimintaa koskevat aloitteet lisääntyivät, ja niitä käsitellyt yleinen valmistusvaliokunta, sittemmin yleisvaliokunta, näytti olevan tässä suhteessa ajoittain merkittävämmässä osassa kuin aiempi toimikuntavaliokunta.

Kirkolliskokouksen aktivoituminen ei koskenut pelkästään yleisesti toimintaa vaan useissa tapauksissa nimenomaan kirkon julistusta. Laman myötä kasvoivat kansalaisten odotukset, että kirkko ottaisi kantaa yhteiskunnallisiin kysymyksiin, kuten työttömyyteen ${ }^{673}$. Kirkolliskokouksessa varsinkin nuoren polven edustajat toivoivat kokoukselta lisää kantaaottavuutta. ${ }^{674}$ Kir- kolliskokouksen huomio siirtyi yhä enemmän toiminnan puitteita koskevista päätöksistä toiminnan sisältöön. Leena Huima, jonka johtama yleisvaliokunta sai näitä teemoja koskevat aloitteet käsiteltäväkseen, puuttui aloitteiden ongelmallisuuteen. Kirkolliskokous sai Huiman sanoin "'tarttis tehdä jotain' -aloitteita", joissa todettiin jokin ongelma mutta ei esitetty selviä toimia tilanteen korjaamiseksi. ${ }^{675}$

Kirkolliskokouksessa ja ylipäätään kirkon keskushallinnossa valmistelu nopeutui ja valmisteluorganisaatiot kevenivät hallinnonuudistuksen myötä. Komiteoita asetettiin aiempaa harvemmin, ja ne olivat usein lyhytaikaisia ja jäsenmäärältään pieniä. Useimmiten valmistelutehtävät annettiin kirkkohallitukselle, joka asetti tarpeen mukaan työryhmiä. Kirkon keskushallinnossa seurattiin samaa toimintatapojen muutosta, joka oli toteutettu valtionhallinnossa. Valtion tasolla yksi nopeutuvan valmistelun seurauksista oli, että ministeriöillä oli entistä vähemmän aikaa odotella kirkon lausuntoja. Aikapulan vuoksi kirkkohallitus joutui toistuvasti vastaamaan ensi alkuun kirkon puolesta, vaikka tehtävä kuului kirkkolain mukaan kirkolliskokoukselle. Kun lakiehdotukset sitten ehtivät kirkolliskokouksen käsittelyyn, lausunto oli yleensä saatava aikaan saman istuntoviikon aikana. Aiemmin kirkolliskokouksen valiokunnat olivat joutuneet luomaan lausuntoja hyvin itsenäisesti, 1970-luvun lopulla jopa öisin, mutta 1990-luvulla kirkkohallitus alkoi järjestelmällisesti laatia valmiit lausuntoluonnokset kirkolliskokouksen käyttöön. Vahvistunut kirkkohallitus antoi siis kirkolliskokoukselle suuntaa ja ohjasi asioiden valmistelua, mutta se myös helpotti toiminnallaan valiokuntien työpaineita.

Kirkon hallintoa sekä kirkon ja valtion suhteita koskevissa uudistusprosesseissa näkyi varsinkin 1990-luvun alkupuolella muutamia erityispiirteitä. Ensinnäkin pitkään kestäneen kirkkolain uudistustyön valmistuminen vapautti pinnan alla piilleet uudistuspaineet. Toiseksi lama lisäsi yleistä lyhytjännitteisyyttä ja vauhditti uudistuksia. Nämä pikaisiin toimiin kannustaneet muutosvoimat olivat todennäköisesti osasyynä siihen, ettei valmistelussa kiinnitetty kovinkaan paljon huomiota teologisiin seikkoihin. Niitä katsottiin selvitetyn jo tarpeeksi aiempina vuosikymmeninä. Aika suosi valmistelua, jossa lähdettiin liikkeelle prosessimaisesti käytännön ongelmista. Samalla oli huomattavissa, että 
tietoisuus kirkon järjestysmuodosta heikentyi, mikä saattoi osaltaan liittyä yleiseen sisältöjen ohentumiseen. Varsinkin monet maallikkoedustajat pyrkivät kyseenalaistamaan kirkon järjestysmuodon periaatteita. Heidän mielestään pappisviralla oli liian paljon valtaa kirkon hallinnossa.

Hallintovaliokunnan toiminta tuomiokapitulikomitean mietintöä käsiteltäessä kuvasti hyvin 1990-luvun uudenlaista, prosessimaista valmistelutapaa. Valiokunnan puheenjohtaja Voitto Huotari ilmoitti jo aluksi, että valiokunta toisi kirkolliskokoukselle useita mietintöjä. Näin olisi mahdollista tiedustella kokouksen periaatteellista kantaa valiokunnan vielä keskeneräisiin pohdintoihin. Vain vuosikymmen aiemmin usean mietinnön laatiminen oli ollut valiokunnalle häpeä. Piispat eivät myöskään 1990-luvulla sitoneet omaa arvovaltaansa johtamansa valiokunnan kantaan samalla tavalla kuin usein aiemmin. Kirkolliskokouksen valmistelutyö oli tasa-arvoistumassa. Muutoksen kääntöpuolena oli, että piispojen rivistä kuului entistä harvemmin voimakkaita linjapuheenvuoroja.

Seurakuntatasolla Kirkko 2000 -työskentely toteutui vaihtelevasti ja laantui tutkimusten mukaan nopeasti. ${ }^{676}$ Pyrkimys toteuttaa prosessin tavoitteita leimasi sen sijaan voimakkaasti kirkolliskokouksen työskentelyä 1990-luvulla. Tosin läheskään kaikissa tapauksissa Kirkko 2000 -prosessi ei ollut alkuperäinen lähtölaukaus, vaan hankkeessa asetuttiin tukemaan jo aiemmin virinnyttä uudistustyöskentelyä ja kirkkojärjestyskomitean kansankirkollista ohjelmaa. Monet Kirkko 2000 -prosessin tavoitteet jäivät myös toteutumatta tai ainakin siirtyivät uudelle vuosituhannelle. Siitä huolimatta "Kirkko 2000” oli näkyvin yksittäinen avainkäsite, joka yhdisti kirkolliskokouksen 1990-luvun asiakokonaisuuksia. Myös jumalanpalvelus ja palveluvirka läpäisivät tavalla tai toisella todella monet kirkolliskokouksen 1990-luvulla käsittelemistä asioista - eivät ainoastaan messu- ja diakonaattiuudistusta. Tuomiokapitulien siirto kirkolle merkitsi piispanviran valtiollisten kytkösten poistumista. Väestökirjanpidon siirto valtiolle taas näyttäytyi uhkana kirkon jumalanpalveluselämän yhdelle keskeisimmistä osista - toimituksille: kirkolliskokouksessa pohdittiin, kuinka moni pyytäisi toimituksia, jos niistä ei voisi enää sopia väestörekisteritietojen päivittämisen yhteydessä. Pyrkimykset keventää kirkon hallintoa taas nostivat esille pappisviran ja yhteisen pappeuden välisen suhteen kirkon hallinnossa. Papinvaalia ja kirkkoherran kelpoisuusvaatimuksia koskevat lukuisat aloitteet osoittivat kirkkoherran työn luonteen muuttumista ja vaatimustason kasvua samalla, kun seurakuntien työntekijämäärät olivat edellisinä vuosikymmeninä kasvaneet todella nopeasti. Ekumeeniset lähentymispyrkimykset anglikaanisen ja katolisen kirkon suuntaan taas nostivat luonnostaan virkateologian pintaan.

Jumalanpalvelusuudistusta ja virkateologiaa käsiteltäessä omat ratkaisut nähtiin aiempaa tietoisemmin osana eurooppalaisia kehityssuuntia ja maailmanlaajuista kirkkoa. Jos esimerkiksi muiden kirkkojen jumalanpalveluselämässä oli laajalti omaksuttu jokin piirre, tarvittiin äärimmäisen hyvät perustelut, mikäli haluttiin estää sen siirtyminen Suomen oloihin. Myös ekumeenisten asiakirjojen arvostelulle kävi kirkolliskokouksessa 1990-luvulla samoin kuin EU-kritiikille suomalaisessa päätöksenteossa: se saattoi välillä olla äänekästäkin, mutta päätöksenteon suuntaan sillä ei juuri ollut vaikutusta. Sitä paitsi ekumeenisten asiakirjojen vastustuskin oli paljolti valtioiden rajat ylittävää liikehdintää. Vuosituhannen viimeisellä vuosikymmenellä oltiin hyvin eurooppalaisessa kirkolliskokouksessa.

\section{TIEDOSTETTUJA TAUSTARYHMIÄ}

Kirkolliskokousedustajat olivat kirkkolain mukaan kirkon edustajia, jotka olivat riippumattomia taustaryhmistään aivan samoin kuin perustuslain mukaan kansanedustajat. Kirkolliskokouksessa tämä ajattelutapa oli pitänyt pitkään pintansa myös käytännössä - toisin kuin eduskunnassa, jossa eduskuntaryhmät hallitsivat työskentelyä. Kirkolliskokouksessakin alkoi kuitenkin 1990-luvulla näkyä merkkejä muutoksesta. Käsitellessään keväällä 1996 oikeusministeriön työryhmän Perustuslaki 2000 -mietintöä perustevaliokunta liittyi kirkkohallituksen arvioon, että valtiovallalla oli riittävästi mahdollisuuksia puuttua kirkkolain säätämiseen: "Valtiovallalla on mm. aloiteoikeus, koska sillä on edustajansa kirkolliskokouksessa." ${ }^{677}$ Tällainen lausuma merkitsi huomattavaa muutosta siinä, miten edustajan asema ymmärrettiin. Kirkkolain mukaan kirkolliskokouksessa oli valtioneuvoston "määräämä" edustaja, ei "valtioneuvoston edustajaa", kuten valiokunta antoi ymmärtää. Kirkkolain näkökulmasta tämä edustaja oli muiden 
edustajien tavoin nimenomaan kirkon edustaja, eikä hän ollut periaatteessa sidottu taustaryhmänsä kantaan sen enempää kuin edustajakollegansakaan.

Kukaan ei puuttunut valiokunnan esittämiin perusteluihin. Myös valtioneuvoston määräämä edustaja, kansliapäällikkö Vilho Hirvi hyväksyi perustelut ilman epäilyksiä puhuessaan kirkolliskokouksen kahvitilaisuudessa. ${ }^{678}$ Ajattelutavan muutos oli tapahtunut huomaamatta. Sitä kuvasti osaltaan, että korkeimpien oikeuksien jäsenten asemasta keskusteltaessa kirkolliskokousedustajat puhuivat "korkeimpien oikeuksien edustajista", eivät näiden oikeusistuinten "valitsemista edustajista", kuten asia ilmaistiin kirkkolaissa. Göran Portin joutuikin puuttumaan edustajien epätarkkaan puheeseen. ${ }^{679}$ Pieni yksityiskohta oli myös, että uusi saamelaisedustaja oli nimikkeeltään "saamelaisten edustaja" eikä esimerkiksi "saamelaiskäräjien valitsema edustaja" samaan tapaan kuin "korkeimman oikeuden valitsema edustaja" tai "valtioneuvoston määräämä edustaja". Saamelaisten edustaja edusti tietyssä mielessä nimensäkin perusteella taustaryhmäänsä.

Omalla tavallaan kirkolliskokousvaalien puoluepoliittiset ehdokaslistat olivat pitäneet yllä henkilövaalin luonnetta vielä senkin jälkeen, kun oli siirrytty suhteelliseen vaalitapaan: puoluepoliittiset listat olivat niin löyhiä, ettei ryhmätoiminta saanut kovinkaan tiivistä jatkoa kirkolliskokouksessa. Tässäkin suhteessa tilanne alkoi muuttua 1990-luvulla, kun ilmaantui ensimmäisiä merkkejä kirkkopoliittisista ehdokaslistoista. Tällaisilla nimenomaan kirkollisia vaaleja varten syntyneillä ryhmillä oli yksityiskohtaisia päämääriä, joita edustajat pyrkivät yhdessä toteuttamaan myös kirkolliskokouksessa. Esimerkiksi Uusi viini -ryhmän jäsenet saattoivat täysistunnossa viitata suoraan valitsijayhdistyksensä tavoitteisiin, mikä oli uutta kirkolliskokouskeskusteluissa.

Kaikkia lueteltuja esimerkkejä yhdistää se, että niissä kirkolliskokousedustaja nähtiin oman taustaryhmänsä edustajana eikä enää yksittäisenä, riippumattomana päättäjänä. Vuodesta 1986 käytössä ollut suhteellinen vaalitapa aikoi nyt näkyä - joskin vasta hämyisästi ryhmätavoitteina myös kirkolliskokouksen istuntosalissa. Samalla virallisten edustajien riippumattomuus alkoi periaatteellisellakin tasolla hämärtyä. Muutos saattoi olla lisäämässä korkeimpien oikeusistuinten jäsenten halua irrottautua kirkolliskokouksesta.
Ylipäätään samaan aikaan, kun kuva kirkolliskokousedustajista itsenäisinä kirkon edustajina alkoi muuttua, lisääntyivät pohdinnat edustajien jääviydestä. Kun vieressä istuva edustaja ei enää näyttäytynytkään taustaryhmistään irrallisena kirkon edustajana, hänen motiivinsa alkoivat herättää kysymyksiä. Esteellisyyssäännösten tarkentaminen lainsäädännössä vaikutti todennäköisesti samansuuntaisesti. Monien kirkollisten tehtävien keskittyminen samoille henkilöille taas johti siihen, että edustajat olivat usein hyvin lähellä niitä tahoja, joiden asiaa he kirkolliskokouksessa ajoivat. Esimerkiksi syksyn 1996 budjettikeskustelussa rajaseutupastori Jukka Pirttijoki ajoi voimakkaasti rajaseututyön asiaa ${ }^{680}$. Samassa täysistunnossa Suomen Poikien ja Tyttöjen Keskuksen järjestösihteeri Heikki Alanen esitti miljoonan markan määrärahaa Partaharju-säätiön ja siten välillisesti oman työnantajansa pelastamiseksi. Asiaa käsiteltäessä puhetta johti Partaharju-säätiön hallituksen jäsen Timo Sahi. Sekä Pirttijoki että Alanen saivat kirkolliskokouksen asiansa taakse. ${ }^{681}$ Kirkolliskokouksen esteellisyyssäännökset olivat alaltaan rajatumpia kuin monessa muussa päätöksentekoelimessä. Uudessa tilanteessa kuitenkin myös sellaiset sidonnaisuudet, jotka eivät lain mukaan merkinneet esteellisyyttä, herättivät aiempaa enemmän huomiota.

Täysistuntojen puheenvuorot alkoivat 1990-luvulla jakaantua uudella tavalla. Aiemmin maaseutuvaltaiset hiippakunnat, joissa vanhoilla herätysliikkeillä oli vahva asema, olivat olleet kärjessä. Nyt kuitenkin eteläiset hiippakunnat Helsinki, Tampere ja Turku olivat keskiarvon yläpuolella. Kirkon uudistamista vaadittiin erityisesti etelän suurissa kaupungeissa. Näissä hiippakunnissa oli erinäisiä uudistusmielisiksi nimettyjä ehdokaslistoja, joilta valitut edustajat olivat sittemmin aktiivisia täysistunnoissa. Lisäksi hallinnolliset ja taloudelliset kysymykset, joissa kaupunkien edustajat olivat aina olleet aktiivisia, painottuivat laman myötä.

Keskustelutyyli arkipäiväistyi edelleen. Toisista edustajista puhuttiin entistä useammin etunimellä. Murteella pidetyt puheenvuorot yleistyivät, mikä saattoi osittain liittyä vuosikymmenen yleiseen murreinnostukseen: murretta ei enää koettu rahvaanomaiseksi, virallisiin yhteyksiin sopimattomaksi puhetavaksi, vaan se oli tietoinen osoitus omasta taustasta. Tärkeänä syynä keskustelutyylin muuttumiseen oli uuden istuntosalin tekniikka. 
Vastauspuheenvuoroja oli vaivatonta pyytää koneellisesti, ja ne saattoi pitää omalta paikaltaan. Ennalta kirjoitetuista puheista siirryttiin näin aiempaa nopeatempoisempaan ja aidompaan keskusteluun.

Uuteen työskentelytapaan sopeutuminen ei sujunut ongelmitta. Vastauspuheenvuoroja pyydettiin silloinkin, kun ei varsinaisesti kommentoitu edellisen puhujan sanoja. Pitkään kansanedustajana toiminut Sakari Knuuttila oli tottunut eduskunnassa vallinneeseen tapaan taistella suunvuorosta vastauspuheenvuoroja pyytämällä. Niinpä Knuuttila pyysi kirkolliskokouksessa vastauspuheenvuoroa usein silloinkin, kun hänen ei ollut tarkoitus varsinaisesti kommentoida edeltävää puheenvuoroa. Hän sai nostettua puheenvuoropyyntönsä ensimmäiseksi, mutta arkkipiispa Vikströmin oli lopulta puututtava asiaan puheenjohtajan paikalta ${ }^{682}$.

Oheiseen kuvioon on laskettu edustajien vuosina 1996-1999 tekemät muutosehdotukset. Kirkollisten kirjojen käsittely poikkesi lukuisine puheenvuoroineen ja muutosehdotuksineen olennaisesti kirkolliskokouksen muusta työskentelystä. Jotta eri vaalikausien tilastot olisivat keskenään vertailukelpoisia, kuviossa ei ole otettu huomioon evankeliumikirjan ja jumalanpalvelusten kirjan yksityiskohtaista käsittelyä - eikä myöskään vuoden 2000 ylimääräistä istuntokautta.

Kauteen 1986-1987 verrattuna selvä muutos oli, että virallisten edustajien aktiivisuus muutosehdotusten tekemisessä lähes puolittui eikä erottunut enää kovinkaan voimakkaasti pappisedustajien tekemistä muutosehdotuksista. Toinen suuri muutos koski muutosehdotus-

2,5

$\mathrm{kpl}$

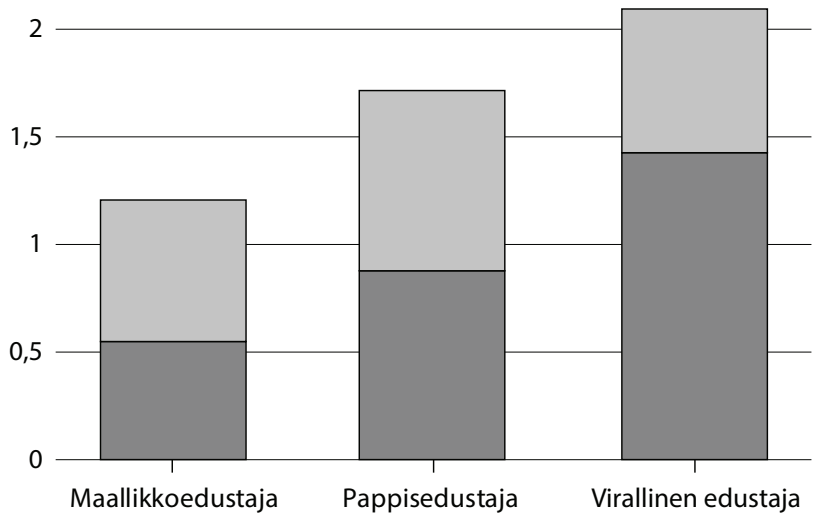

256

KIRKON HALLINTO ITSEN ÄISTYY $1992-2000$ ten hyväksymistä. Pappis- ja maallikkoedustajien muutosehdotuksista hyväksyttiin selvästi suurempi osuus kuin vuosina 1986-1987, noin puolet. Virallisten edustajien ehdotuksista hyväksyttiin noin kaksi kolmasosaa. Osuus oli edelleen suurempi kuin muissa edustajaryhmissä mutta huomattavasti pienempi kuin virallisten edustajien keskuudessa aiemmin kausina 1974-1977 ja 1986-1987. Tuolloin hyväksyttyjen muutosehdotusten osuus oli ollut yli 80 prosenttia.

Muutos osoittaa täysistunnon tasa-arvoistumista: piispat eivät enää saaneet muutosehdotuksiaan läpi aivan yhtä helposti kuin aiemmin, mikä saattoi myös nostaa kynnystä ehdotusten tekemiseen. Toisaalta esimerkiksi arkkipiispa John Vikströmin auktoriteetti oli edelleen varsin vahva. Syksyllä 1995 keskusteltaessa henkilöseurakuntakokeilusta ja seurakuntalaisen oikeudesta valita seurakuntansa yhtymän sisällä kirkolliskokous näytti yksimielisesti jättävän asian raukeamaan, kuten valiokunta oli ehdottanut. Lopulta Vikström teki vastakkaisen ponsiehdotuksen, että asia lähetettäisiin kirkkohallitukselle tutkittavaksi. Ehdotus hyväksyttiin lähes välittömästi äänin $72-29 .{ }^{683}$

Hiippakunnittain valittujen edustajien osalta palattiin pitkälti 1970-luvun tilanteeseen: niin edustaja-aloitteisiin kuin pappis- ja maallikkoedustajien muutosehdotuksiin oli 1980-luvun puolivälissä suhtauduttu penseästi, mutta 1990-luvun lopulla tilanne oli jälleen toinen. Edustajan kokemus näkyi edelleen selvästi siinä, millainen kohtalo hänen muutosehdotuksillaan keskimäärin oli. Niin pappis- kuin maallikkoedustajissa

Kuvio 14: Yksittäisen edustajan täysistunnoissa tekemien muutosehdotusten keskiarvo kaudella 1996-1999

Virallisten edustajien osalta valtioneuvoston valitsema edustaja on nyt otettu huomioon, koska hän osallistui 199o-luvulla kirkolliskokouksen työskentelyyn. Sen sijaan korkeimpien oikeusistuinten valitsemat edustajat olivat poistuneet kokoonpanosta.

Hylätyt

Hyväksytyt 


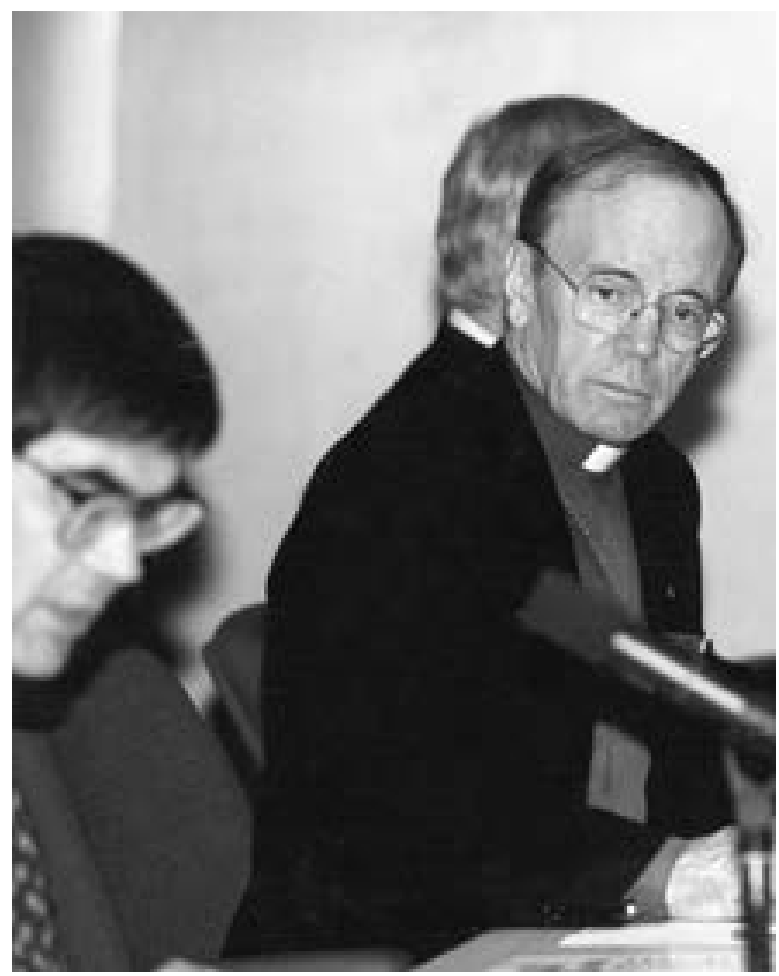

Arkkipiispa John Vikström oli edeltäjiensä tavoin arvovaltainen johtohahmo kirkolliskokouksessa. Puheenjohtajana hän joutui opastamaan kirkolliskokousta uuden istuntosalin mukaiseen työjärjestykseen ja muun muassa lyhyiden vastauspuheenvuorojen oikeaan käyttöön. Etualalla kirkolliskokouksen sihteeri Kari Ventä. Kuva: Kirkkohallitus. kolmannen ja neljännen kauden edustajien muutosehdotuksista hyväksyttiin selvästi suurin osa, kun taas ensimmäisen kauden edustajien ehdottamista muutoksista hyväksyttiin vain kolmannes. Näistä eroista huolimatta jo 1980-luvulla nähtävissä ollut tasa-arvoistuminen sai jatkoa.

Kirkolliskokouksen näkökulmasta 199o-luku oli kaksijakoinen. Vuosikymmenen alun lama-aikana kokous joutui toimimaan nopeasti monella tavalla epäsuotuisassa ympäristössä. Sen täytyi puolustaa kirkon taloudellista asemaa ja positiivista uskonnonvapauskäsitystä. Kokouksen oli pohdittava leikkauksia ja kirkon hallinnon keventämistä. Talousnäkymien parannuttua nopeasti kirkolliskokous saattoi kuitenkin keskittyä vuosikymmenen loppupuolella - 1980-luvun tapaan - kirkon sisäisiin hankkeisiin, kuten ekumeniaan, virkateologiaan sekä jumalanpalveluksen ja kristinopin uudistamiseen. Hankkeet eivät herättäneet kansalaisten keskuudessa samanlaisia intohimoja kuin vaikkapa virsikirjauudistus. Siten kirkolliskokous ei ollut näistä asioista päättäessään julkisen huomion keskipisteenä, vaan se sai toimia melko vapaasti. Kun vielä lamavuosien aikana yleinen luottamus kirkkoa kohtaan kasvoi, kirkolliskokous saattoi toteuttaa 1990-luvun lopun uudistuksia pitkälti omista lähtökohdistaan ja opillisista perusteistaan käsin. Vuonna 1992 kirkolliskokous oli varautunut selviytymistaisteluun, mutta muutamaa vuotta myöhemmin se saattoikin keskittyä pohdiskelemaan liturgian ja opin kysymyksiä kirkon kannalta myönteisessä ilmapiirissä. Moni tosin mietti, miten kauan seesteisyys kestäisi. 


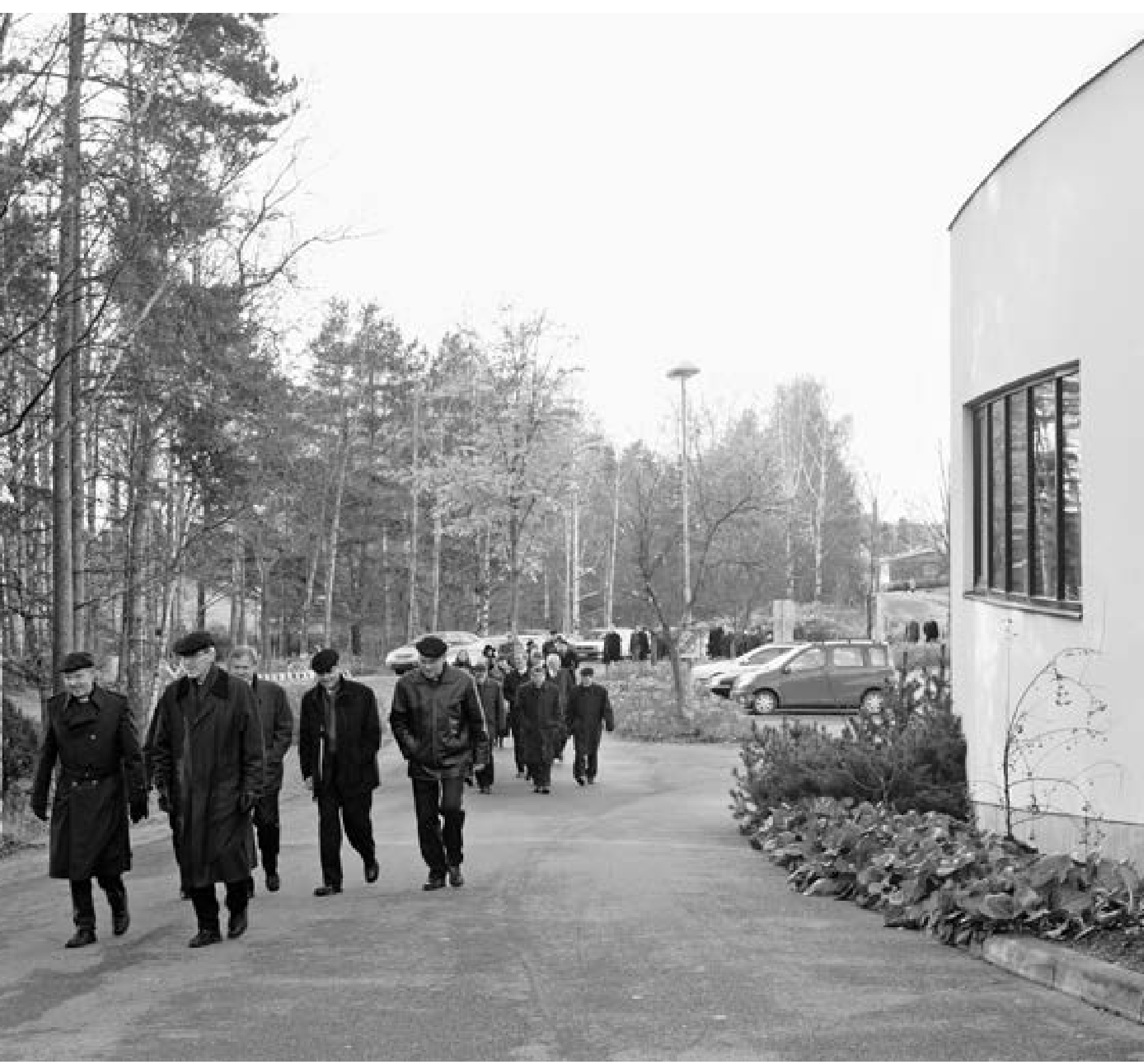




\section{KIRKOLLISKOKOUS POLARISOITUU $2000-2011$}




\section{VAALIKAMPANJOINTI VILKASTUU, VASTAKKAINASETTELUT VOIMISTUVAT}

\section{HILJAINEN KIRKKOTIE KUOHUVASSA MAAILMASSA}

Turun Räntämäellä avautui 200o-luvun edetessä kahtena viikkona vuodessa uusi joka-aamuinen näkymä. Kirkolliskokousedustajien virta eteni Maarian kirkolta kohti Turun kristillistä opistoa. Jumalanpalvelusuudistuksen viimeiset osat olivat valmistuneet vasta muutamaa vuotta aiemmin, mutta uudistus oli jo tuoreeltaan osoittautunut monien kirkolliskokousedustajien mielestä menetetyksi mahdollisuudeksi. Useimmat suomalaiset kyllä ilmoittivat olevansa tyytyväisiä kirkon tapaan hoitaa jumalanpalvelukset, mutta niihin osallistuminen väheni jatkuvasti ${ }^{1}$. Ongelmissa ei siten ollut ensisijaisesti kyse jumalanpalveluksen toteutuksesta vaan hengellisen elämän todellisuudesta, johon uudet kirkolliset kirjat ja jumalanpalveluskoulutus eivät yltäneet. Arkkipiispa Jukka Paarma ei kuitenkaan luovuttanut. Hänen mielestään kirkolliskokouksen oli oltava esimerkkinä ajattelutavasta, että jumalanpalvelus oli osa tavallista elämää: kirkolliskokouksen jokainen työpäivä oli tarpeen aloittaa messulla ${ }^{2}$.

Edustajat kulkivat kirkkotietään etäämpänä valtakeskittymistä kuin edeltäjänsä keväällä 1974. Ympärillä olivat hallintorakennusten sijasta omakotitalot. Niiden elämään, ihmisten arjen kysymyksiin, kirkolliskokous paneutui 200o-luvulla. Vaikka tutkimusten mukaan kirkollinen osallistuminen oli heikentymässä, vuosituhannen alkaessa suomalaisten luottamus kirkkoon oli vahva ${ }^{3}$. Saatettiin jopa sanoa, että kirkko oli muodissa. ${ }^{4}$ Kymmenen vuotta myöhemmin tilanne oli varsin toisenlainen. Kirkkoa kohtaan tunnettu luottamus laski kyselytutkimusten mukaan lähelle 1990-luvun alun alhaisia lukemia, ja moniin kristinuskon perusopetuksiin uskovien osuus puolittui vuosikymmenen aikana. ${ }^{5}$
Kirkon jäsenyyteen kaikkein vahvimmin sitoutuneiden seurakuntalaisten osuus puolittui vain neljässä vuodessa 2007-2011. Samassa ajassa niiden, jotka eivät uskoneet lainkaan Jumalan olemassaoloon, osuus kaksinkertaistui. ${ }^{6}$ Kirkosta eroaminen lisääntyi voimakkaasti: vuoden 2000 alkaessa luterilaiseen kirkkoon kuului kirkon väestötilastojen mukaan 85,1 prosenttia maan väestöstä, vuoden 2011 lopussa 77,2 prosenttia. $^{7}$

Kirkolliskokous oli hyväksynyt seurakuntalaisten osallistumista tukevan kirkollisten toimitusten kirjan, mutta Turun katuja kävelevät edustajat olivat selvillä siitä, että aiempaa harvemmassa talossa saatiin kosketus kirjan kaavoihin. ${ }^{8}$ Kirkon jäsenyyttä oli pyrittävä vahvistamaan. Kirkolliskokous keskittyi entistä enemmän kirkon toimintaan. Kevätistuntokaudella 2009 rovasti Hilkka Olkinuora aloitti puheenvuoronsa kerran toisensa jälkeen puhuttelulla "Arvoisat sisaret ja veljet huolessa kirkon tulevaisuudesta" pukien siten sanoiksi kokouksen tunnelman ${ }^{9}$. Huolta aiheutti varsinkin se, että nuoret aikuiset erosivat kirkosta kiihtyvään tahtiin..$^{10}$ Vuonna 2011 luterilaiseen kirkkoon kuului 15-vuotiaista yli 88 prosenttia mutta 30 -vuotiaista enää kaksi kolmesta. ${ }^{11}$ Nuorten ikäluokkien löyhä yhteys kirkkoon oli kuitenkin vain yksi huolenaihe: kouluampumiset ja kasvava nuorisotyöttömyys voimistivat yleistä huolta nuorisosta ja nuorista aikuisista.

Maan sisäinen muuttoliike saavutti Suomessa kaikkien aikojen huippunsa. ${ }^{12}$ Kirkolliskokouksen nelivuotiskauden aikana 2000-2003 Turun väkiluku kasvoi 3 ooo hengellä. ${ }^{13}$ Koko maan tasolla uuteen seurakuntaan muutti tuona aikana 1,35 miljoonaa henkilöä, ja muuttoliike jatkui vilkkaana seuraavinakin vuosina. ${ }^{14}$ Varsinkin pääkaupunkiseutu keräsi väkeä, ja useimpien kirkolliskokousedustajien mielestä Helsingin hiippakunnan jakamisella oli kiire. Vastaavasti monilla paikkakunnilla taisteltiin muuttotappiota vastaan. Muuttoliike loi painetta seurakunnille niin voittavilla kuin häviävillä alueilla. Hälyttävän monen pienen seurakunnan talous painui tappiolliseksi vuosikymmenen alkaessa. Seurakuntien talouden tasausjärjestelmän kehittäminen ja seurakuntaliitokset nousivat kirkolliskokouksessakin toistuviksi keskustelunaiheiksi.

Tässä tilanteessa keväällä 2001 arkkipiispa Paarma painotti, että kirkkoa tarvittiin kipeästi "niin Etelä-Suomen asutuskeskuksissa kuin Pohjois- ja Itä-Suomen syr- 
jäseuduilla, kansainvälisen politiikan ja talouselämän kasvavissa metropoleissa ja siellä, missä eri uskonnot ja aatesuunnat käyvät kilpaa kannattajista tai missä aineellinen köyhyys ja hengellinen tai henkinen tyhjyys uhkaa viedä ihmisiltä elämänhalun" ${ }^{15}$. Muutama kuukausi myöhemmin New Yorkin World Trade Centerin terroriiskut käänsivätkin katseet kotimaan ulkopuolisiin kriiseihin. Pian Yhdysvallat hyökkäsi liittolaisineen Afganistaniin ja keväällä 2003 Irakiin. Kylmän sodan jälkeen taustalle painunut keskustelu oikeutetusta sodasta tuli jälleen ajankohtaiseksi. Avatessaan kirkolliskokouksen toukokuussa 2003 arkkipiispa Paarma saattoi todeta, etteivät kirkot sitten rotuerottelupolitiikan vastustamisen aikojen olleet päässeet mistään asiasta niin laajaan yksimielisyyteen kuin siitä, että ennaltaehkäisevä hyökkäysisku Irakiin oli eettisesti epäoikeutettu ${ }^{16}$.

Samaan aikaan maahanmuutto lisääntyi Suomessa, ja seurakunnat saivat julkisuutta auttaessaan turvapaikanhakijoita. ${ }^{17}$ Internetin myötä maahanmuuttokriittisyys muuttui aiempaa näkyvämmäksi ilmiöksi, jota kansainvälisen terrorismin pelko vahvisti. Arkkipiispa Paarma ilmaisi avauspuheessaan 2009 huolensa suvaitsemattomuudesta. ${ }^{18}$ Suomalaisen yhteiskunnan monikansallistuminen merkitsi myös sitä, että kirkolliskokous joutui toimimaan ympäristössä, jossa kristilliset perinteet eivät olleet samalla tavalla itsestään selviä kuin aiemmin.

Läheisen teollisuusalueen valot kajastivat välillä kirkolliskokousedustajien kirkkotielle. Kirkolliskokous ei voinut 200o-luvulla jättää huomiotta yritysmaailman tapahtumia. Oli menossa rakennemuutos, jonka myötä erityisesti teollisuuden työpaikkoja siirtyi nopeasti pois Suomesta. Irtisanomisten keskellä johtajat saivat huippupalkkoja ja -eläkkeitä. Arkkipiispa Paarma varoitti tällaisen kahtiajaon rapauttavan yhteiskuntamoraalia, kun hän avasi kirkolliskokouksen kansainvälisen talouskriisin keskellä $2009^{19}$. Samaan aikaan kirkon talous oli tiukemmin kuin koskaan aiemmin sidoksissa yritysten menestykseen. Valtion tilittämän yhteisöveron määrä riippui suomalaisyhtiöiden tuloksesta. Lisäksi laskevan jäsenmäärän ja nousevan eläkeläismäärän paineessa kirkon eläkerahaston kasvutavoitteet oli asetettava korkealle. Työntekijöiden eläketurva oli suureksi osaksi kiinnitettävä riskialttiisiin osakesijoituksiin. Tässä tilanteessa sijoitustoiminnan eettisyys tuli entistä tärkeämmäksi puheenaiheeksi: sijoituskohteiden valikoin- ti ei riittänyt, vaan oli pyrittävä aktiivisesti vaikuttamaan yrityksiin. Myös huoli ilmastonmuutoksesta voimistui varsinkin 2000-luvun puolivälissä, jolloin kirkolliskokous pani alulle kirkon ilmasto-ohjelman valmistelun.

Tehtaan valot heijastuivat niin ikään keskusteluun kirkollisista toimituksista. Monet kyselivät, oliko oikein siunata teollisuuslaitoksia, kun samaan aikaan ei ollut luvallista siunata kaikkia parisuhteita. Vuonna 2001 hyväksytty ja seuraavana vuonna voimaan tullut laki samaa sukupuolta olevien rekisteröidystä parisuhteesta aloitti vilkkaan keskustelun, joka löi leimansa koko vuosikymmeneen. Ristiriitojen merkit olivat nähtävissä jo uuden kirkolliskokouksen aloittaessa työtään keväl̈llä 200o. Vaalikauden avauspuheessa arkkipiispa Paarma kiinnitti huomiota arvomaailman nopeaan muutokseen ja kirkon raamatulliseen tehtävään olla yhteiskunnan suolana $^{20}$. Aivan samaa aihetta Martti Simojoki oli käsitellyt avatessaan uudistuneen kirkolliskokouksen keväällä 1974. Kirkolliskokous oli taas keskellä yleistä arvomurrosta. Murros kosketti erityisesti seksuaalietiikkaa, jonka käsittelyyn kirkolla ei ollut samanlaisia välineitä ja valmiuksia kuin vaikkapa sosiaalisen oikeudenmukaisuuden pohdintaan 1990-luvulla.

Keskustelu kirkon suhtautumisesta rekisteröityihin parisuhteisiin huipentui marraskuun 12. päivän aamuna 2010. Aamumessun jälkeen Turun kristillisen opiston pihalla oli tavallista enemmän kuhinaa, kun median edustajat saapuivat seuraamaan äänestystä. Jakolinjat kirkolliskokouksen sisällä olivat 200o-luvulla muodostuneet ehkä jyrkemmiksi kuin milloinkaan aiemmin opistolla kokoonnuttaessa. Vuoden 2010 kuluessa myös arkkipiispan ja Helsingin piispan vaaliprosessit olivat tuoneet julkisuuteen kirkon sisäisiä ristiriitoja ${ }^{21}$. Arkkipiispa Kari Mäkinen ja Helsingin piispa Irja Askola, ensimmäinen piispaksi valittu nainen, aloittivat työtään herkässä tilanteessa. Yhteiskunnallisen konsensuksen ajat näyttivät olevan ylipäätään toistaiseksi ohi, mutta kirkko oli erityisellä tavalla jännitteiden keskipisteessä. "Näyttää siltä, että kaikki yhteisessä elämässä vallitseva vaikeus kohdata ja käsitellä homoseksuaalisuutta on laskettu kirkon harteille", arkkipiispa Mäkinen totesi. Hänen mielestään kirkon kuului kuitenkin ottaa vaikea tehtävä vastaan. ${ }^{22}$

Marraskuisena aamuna kaikki olivat selvillä siitä, miten tarkasti kirkolliskokouksen äänestystä seurattiin. 
Päivälleen kuukautta aiemmin Yleisradion Ajankohtainen kakkonen oli lähettänyt teemaillan homoseksuaalisuudesta. Ohjelma oli laukaissut erovyöryn kirkosta: pelkästään lokakuun loppupuolella oli eronnut noin 40000 ihmistä, ja Internetin kautta eronneiden määrä oli kiihkeimpinä aikoina lähestynyt 7 ooo:ta henkilöä päivässä. Internetin uudella, nopeasti kasvaneella sosiaalisella medialla oli ollut suuri vaikutus ilmiön syntyyn. ${ }^{23}$ Kirkolliskokouskin oli aiempina vuosina tiedostanut tämän uuden toimintaympäristön merkityksen ja osoittanut määrärahoja kirkon verkkotyön kehittämiseen. Toisaalta eroilmiö osoitti, että julkisen yleisradioyhtiön ohjelmalla saattoi vielä olla suuri vaikutus - sen verran yhtenäisessä sähköisen tiedonvälityksen maailmassa edelleen elettiin.

\section{VALTAKUNNALLINEN}

\section{VAALIKAMPANJOINTI ALKAA}

Kirkolliskokousvaaleihin vaadittiin 200o-luvun ensimmäisellä vuosikymmenellä koko ajan äänekkäämmin lisää avoimuutta. Erityisesti vuoden 2000 kirkolliskokousvaalien yhteydessä keskusteltiin Kotimaan palstoilla siitä, pitäisikö maallikkoedustajien valinnassa siirtyä suoraan vaaliin ${ }^{24}$. Kun kirkolliskokous ei edelleenkään lämmennyt asiaa koskevalle aloitteelle, päätoimittaja Jaakko Elenius hyökkäsi pääkirjoituksessaan voimakkain sanoin aloitteen hylkäysperusteluja vastaan. ${ }^{25} \mathrm{Vä-}$ lillisen vaalitavan ohella myös vaalitulosten viipyminen säilyi arvostelun aiheena. ${ }^{26}$ Vaalijärjestelmä pysyi kuitenkin pitkälti ennallaan, eivätkä edes vuoden 2008 vaaleissa käyttöön otetut ehdokaslistojen nimitykset vaimentaneet arvostelua ehdokasasettelun salamyhkäisyydestä. ${ }^{27}$ Vähitellen valtakunnallinen, avoin kampanjointi alkoi kuitenkin lisääntyä lähinnä Internetin myötä. Ensin asialla olivat nuoret aikuiset, sitten 2008 myös uusi Tulkaa kaikki -liike.

Vuoden 2000 vaaleissa oli suhteessa yhtä paljon pappis- kuin maallikkoehdokkaita. Erot hiippakuntien kesken olivat kuitenkin suuria: Turun arkkihiippakunnassa jokaista pappisedustajan paikkaa kohden oli 11 ehdokasta, kun taas Mikkelissä joka neljäs pappisehdokas sai edustajapaikan. ${ }^{28}$ Helsingin hiippakunnan maallikkoedustajien vaalissa SDP:1lä oli aiemmasta poiketen erillinen ehdokaslistansa. Muut kuusi listaa oli koottu lähinnä kirkollisten mielipidesuuntausten mukaan tai alueellisin perustein. Ehdokkaiden ikähaarukka oli monella listalla suuri - esimerkiksi sosiaalidemokraattien listalla 21 vuodesta 74 vuoteen. Poikkeuksen teki nuorten aikuisten lista, jonka keski-ikä oli 24 vuotta ja vanhin ehdokas 31-vuotias. Lista jäi kuitenkin vaille edustajapaikkoja, ja kaiken lisäksi se vei mahdollisuuksia muiden ehdokaslistojen nuorilta aikuisilta. Helsingin hiippakunnassa tapahtui sama kuin kaikkialla maassa: nuoria oli ehdolla verrattain paljon, mutta kirkolliskokoukseen ei valittu yhtään alle 30 -vuotiasta. ${ }^{29}$ Tosin kokonaisuutena edustajisto nuorentui, ja Tampereen hiippakunnan nuorten pappien listalta pääsi läpi kaksi ehdokasta. ${ }^{30}$

Helsingissä useimmat edustajapaikat menivät niin pappis- kuin maallikkoedustajien vaalissa perinteiseen tapaan alueellisin perustein koottujen listojen ehdokkaille. ${ }^{31}$ Lapuan hiippakunnassa taas puoluepoliittiset listat hallitsivat edelleen maallikkoedustajien vaalia. ${ }^{32}$ Pappisedustajien vaalissa näkyi puolestaan tyytymättömyys siihen, että hiippakunnasta oli valittu kirkolliskokoukseen seurakuntapappi viimeksi 1980-luvulla. Kaikkiaan 15 pappisehdokkaasta 13 oli seurakuntatyössä, ja lopulta myös kaikki valitut olivat seurakuntapappeja. ${ }^{33}$ Pappisvaalin ryhmänmuodostuksessa virka-asema oli Lapuan hiippakunnassa näkyvin tekijä: toinen ehdokaslista oli kirkkoherrojen, erityisesti lääninrovastien, lista, kun taas toisen listan taustalla oli seurakuntapastoreita. ${ }^{34}$ Asetelmat kertoivat, että mielipideryhmittymien mukainen vaalitoiminta oli vasta vähitellen saamassa sijaa. Turun arkkihiippakunnassa autuaan Hemmingin apupappien ryhmä julkisti näkyvästi vaaliohjelmansa ja oli siten edelläkävijänä murtamassa henkilövaalin perinnettä ${ }^{35}$.

Naisten määrä kirkolliskokouksessa pysyi ennallaan, hieman runsaana kolmanneksena hiippakunnittain valituista edustajista. Piispa Olavi Rimpiläisen johtamasta Oulun hiippakunnasta valittiin pappisedustajaksi ensimmäinen nainen, Rovaniemen sairaalapastori Sirkku Eho, joka oli myös ainoa nainen hiippakunnan pappisehdokkaiden joukossa. ${ }^{36}$ Toisaalta kirkolliskokoukseen valittiin myös useita kirkon virkaratkaisun vastustajia, joten vaalitulos enteili kipakkaa keskustelua kirkolliskokouksessa. ${ }^{37}$ Oulun hiippakunnasta valittiin kirkolliskokoukseen myös hallinto-oikeustuomari Pirjo Pyhäjärvi. Kun vielä Ahvenanmaan edustaja, laamanni 
Kim Fröman nimitettiin vaalikauden aikana hovioikeudenneuvokseksi, alueellisista oikeusistuimista oli vankka edustus muutama vuosi sen jälkeen, kun korkeimmat oikeusasteet olivat saaneet vedetyksi valitsemansa edustajat pois.

Vuoden 2002 seurakuntavaaleissa nuoret aikuiset kampanjoivat näkyvästi, ja heidän osuutensa luottamushenkilöistä nousi kahdesta prosentista lähes kymmeneen. Kampanjointi sai jatkoa vuoden 2004 kirkolliskokousvaaleissa. Myös arkkipiispa Paarma painotti nuorten aikuisten saamista päättäjiksi. Taustalla näkyi huoli siitä, miten nuoret saataisiin juurtumaan kirkkoon..$^{8}$ Työ tuotti tulosta kirkolliskokousvaalien ehdokasasettelussa. Alle 30-vuotiaiden ehdokkaiden määrä yli kaksinkertaistui ja oli lopulta $58 .{ }^{39}$ Erityisesti uudessa Espoon hiippakunnassa oltiin nuorten aikuisten asialla: maallikkovaalin ehdokkaista yli neljännes odotti vielä 3o-vuotisjuhliaan. ${ }^{\circ}$

Nuorten aikuisten esiinmarssi näkyi myös pappisedustajien vaalissa. Esimerkiksi Helsingin hiippakunnassa jokaisella pappislistalla oli alle 30-vuotias ehdokas, vaikka vaalikelpoisia tuon ikäluokan edustajia oli suhteellisesti paljon vähemmän kuin maallikkoedustajien vaalissa.$^{41}$ Nuorten Keskuksen yhteydessä toiminut nuorten aikuisten vaikuttamisryhmä NAVI pyrki saamaan kirkolliskokoukseen vähintään yhden alle 30-vuotiaan edustajan jokaisesta hiippakunnasta. ${ }^{42}$ Tavoite jäi saavuttamatta, mutta kirkolliskokoukseen valittiin sentään yhteensä kolme alle 30-vuotiasta maallikkoedustajaa Turun ja Helsingin hiippakunnista. ${ }^{43}$

Helsingin hiippakunnassa oli vuonna 2000 todettu, että omalla listalla nuorten äänet menivät hukkaan. Siksi nuoria aikuisia pyrittiin neljä vuotta myöhemmin saamaan tasaisesti eri listoille. Tälläkin kerralla osoittautui, että nuorten ehdokkaiden paljous oli lähinnä haitta, joka vaikeutti äänten keskittämistä. Helsingin hiippakunnan molemmat alle 30-vuotiaat edustajat, teologian ylioppilaat Riikka Myllys ja Antti Siukonen, pääsivät läpi listoilta, joiden keski-ikä oli kaikkein korkein ja joilla oli vain yksi tai kaksi alle 30-vuotiasta ehdokasta. Sama ilmiö näkyi Espoon hiippakunnassa, jossa nuorten ehdokkaiden todella suuri osuus ei johtanut vaalimenestykseen.

Nuorten aikuisten ehdokkuuden voimakas painottaminen johti ainakin Helsingin hiippakunnassa siihen,

\section{Picture removed from the open access version of this book.}

Heimo Kuha Oulujoen seurakunnasta äänesti 2004 maallikkoedustajien vaalissa Myllyojan seurakuntatalolla Oulussa. Kuva: Kotimaan kuva-arkisto / Heikki Sarviaho.

että todellinen puuttuva sukupolvi maallikkoedustajien vaalissa olivat noin 40 -vuotiaat. Koko hiippakunnassa oli maallikkoedustajien vaalissa mukana vain kolme 1960-luvulla syntynyttä ehdokasta, eikä kukaan heistä päässyt läpi. Heidän osuutensa oli neljä prosenttia ehdokkaista, kun alle 30-vuotiaita oli sentään yli 15 prosenttia. ${ }^{44}$ Kuusikymmenluvulla syntyneiden sukupolvi ei ollut saavuttanut aikoinaan nuorina aikuisina vakiintunutta asemaa kirkollisen päätöksenteon huipulla. Kun sitten 2004 havahduttiin maallikkoedustajiston nuorentamiseen, tuon polven edustajat eivät enää olleet niitä hieman yli 20-vuotiaita seurakuntalaisia, joita tavoiteltiin.

Nuorten tavoin naisia oli vuonna 2004 ehdolla edelliskertaa enemmän. ${ }^{45}$ Esimerkiksi Oulun hiippakunnassa naisehdokkaiden määrä nousi pappisedustajien vaalissa yhdestä kuuteen..$^{46}$ Uusi piispa Samuel Salmi hyväksyi naisten toimimisen pappisvirassa, ja hänen 
piispuuskauteensa liittyi hiippakunnan naispappien keskuudessa suuria odotuksia. ${ }^{47}$ Aikakauden vaihtuminen näkyi myös hiippakunnan ehdokasasettelussa. Sen sijaan kirkolliskokoukseen valittujen naisten kokonaismäärä pieneni niin pappis- kuin maallikkoedustajien vaalissa $^{48}$. Maallikkoedustajien osalta lasku oli jatkunut jo vuodesta 1988, jolloin naisia oli valittu ensimmäisen ja ainoan kerran enemmistö. Tuolloin alkaneella vaalikaudella piispanvirka oli avattu naisille, minkä jälkeen naisten yhteistoiminnalle ei enää nähty entisenlaista tarvetta. ${ }^{49}$ Vuonna 2004 ainoastaan Espoon hiippakunnassa enemmistö valituista edustajista oli naisia. Vaalit olivat ideologisesti hiljaiset, eikä esimerkiksi suhtautuminen rekisteröityihin parisuhteisiin noussut näkyväksi vaaliteemaksi. Seksuaali- ja sukupuolivähemmistöjen oikeuksia puolustaneessa Yhteys-liikkeessä kylläkin todettiin, että erityisesti pappisehdokkaissa oli monia liikkeeseen kuuluvia tai sitä lähellä olevia. ${ }^{50}$

Kampanjoinnin hiljaisuus alkoi kuitenkin vähitellen jäädä taakse. Ennen vuoden 2006 seurakuntavaaleja sai alkunsa Tulkaa kaikki -liike. Sen pyrkimyksenä oli Internetin kautta koota yhteen keskenään samanmielisiä seurakuntalaisia, jotka vaativat avointa keskustelua ja ajoivat esimerkiksi sukupuoli- sekä seksuaalivähemmistöjen oikeuksia. ${ }^{51}$ Tuolloin julkisuudessa keskusteltiin paljon kirkon suhtautumisesta niihin työntekijöihin, jotka kieltäytyivät jumalanpalvelusyhteistyöstä naispappien kanssa. Samaten oli tiedossa, että kannan määritteleminen parisuhteensa rekisteröineisiin homoseksuaaleihin oli piakkoin tulossa ratkaisevaan käsittelyyn. Tässä tilanteessa Tulkaa kaikki -liikkeen ohjelmassa todettiin, etteivät aikaan sidotut ihmiskäsitykset, maailmankuvat ja elämänohjeet enää olleet uskon perustotuuksia. Lisäksi korostettiin maailmanlaajaa auttamisvastuuta, naispappien syrjinnän kitkemistä sekä eronneiden ja avoliitossa elävien ratkaisujen kunnioittamista.52 Vuoden 2006 seurakuntavaaleissa liikkeellä oli lista 77 seurakunnassa, ja listoilta valittiin yli sata seurakuntapäättäjää. Suurimmaksi ryhmäksi liike nousi kolmessa helsinkiläisseurakunnassa sekä Kotkan Langinkosken seurakunnassa. ${ }^{53}$

Seurakuntavaaleissa syntyi pohja, jolta liike lähti vuoden 2008 hiippakuntavaltuusto- ja kirkolliskokousvaaleihin. Helsingissä liike kokosi erillisen "Tulkaa kaikki" -listan niin pappis- kuin maallikkoedustajien vaaliin.

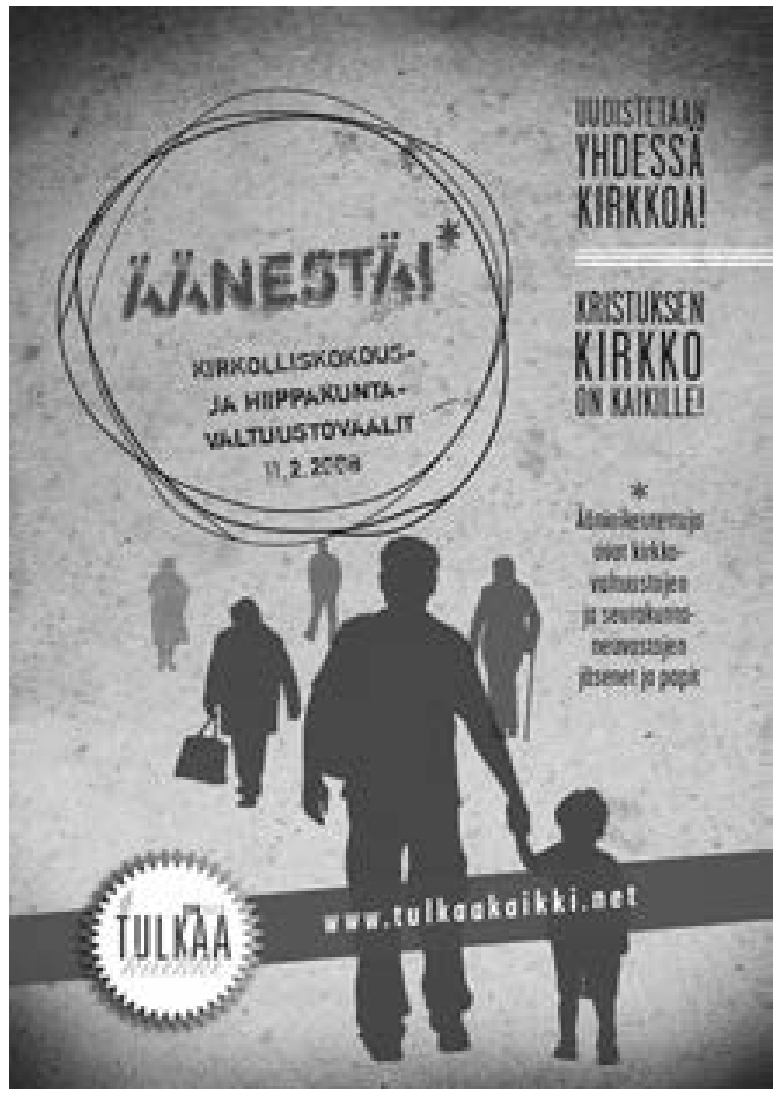

Tasa-arvoa ja avoimuutta peräänkuuluttanut Tulkaa kaikki -liike toi vuoden 2008 kirkolliskokousvaaleihin uudenlaista, näkyvää kampanjointia. Liike muun muassa laati julisteen kirkolliskokous- ja hiippakuntavaltuustovaaleja varten. Kuva: Tulkaa kaikki-liike.

Mukana oli myös kokeneita kirkolliskokousedustajia, kuten professorit Raija Sollamo ja Heikki Kotila. Langinkosken vaalimenestyksen innoittamana niin ikään Mikkelin hiippakuntaan syntyi erillinen "Tulkaa kaikki" -lista. Ehdokaslistojen nimitykset olivat ensi kertaa käytössä, mikä tuki "Tulkaa kaikki” -nimen vakiinnuttamista valtakunnallisesti. Liikkeen johto ei kuitenkaan vaalimatemaattisista syistä kannustanut erillisten listojen perustamiseen. Sen sijaan mahdollisimman monille yleisilmeeltään kansankirkollisille listoille pyrittiin saamaan liikkeen tavoitteiden takana olevia ehdokkaita. ${ }^{54}$ Heidät koottiin valtakunnalliselle suosituslistalle, jolle kertyi suomenkielisistä hiippakunnista 79 nimeä. Ehdokasmäärät vaihtelivat Oulun ja Lapuan kahdesta Helsingin 36:een. Autuaan Hemmingin pappien ehdokaslista Turussa otettiin suosituslistalle sellaisenaan. ${ }^{55}$ 
Tulkaa kaikki -liike toi kirkolliskokousvaaleihin uudenlaisen, valtakunnallisen ja näkyvän kampanjoinnin. Sen mahdollistivat pitkälti Internet ja sosiaalinen media, jotka osoittautuivat merkittäviksi myös samaan aikaan pidetyissä Yhdysvaltain presidentinvaaleissa ${ }^{56}$. Kirkolliskokousvaalien ehdokasasettelu ei saanut osakseen pelkkää kiitosta. Mikkelin piispa Voitto Huotari piti huonona asiana, että suhtautuminen homoseksuaalisuuteen tai naispappeuteen oli tullut paikoitellen ehdokasasettelua määrittäväksi jakolinjaksi. Kirkollisen elämän kehittämisen keskiössä olivat hänen mielestään aivan muut asiat. ${ }^{57}$ Toisaalta useimmissa hiippakunnissa Huotarin arvostelemat vaaliteemat säilyivät edelleen taka-alalla. ${ }^{5}$ Helsingin hiippakunnasta Tulkaa kaikki -liike sai lopulta läpi neljä ehdokasta, joten kolmannes hiippakunnan kirkolliskokousedustajista tuli liikkeen piiristä. Muista hiippakunnista valittiin sen sijaan yhteensä vain kolme liikkeen suosituslistalla ollutta henkilöä. Esimerkiksi Espoossa yli viidennes kaikista ehdokkaista oli liikkeen suosituslistalla, mutta tästä joukosta yksikään ei päässyt kirkolliskokoukseen. ${ }^{59}$

Vaaleissa moni ehdokaslista ilmaisi tunnuksellaan toimivansa elävän tai avoimen kirkon puolesta. ${ }^{60}$ Esimerkiksi Helsingissä kaikki valitut pappisedustajat tulivat ehdokaslistoilta, jotka nimityksellään puhuivat kirkon avoimuudesta: "Tulkaa kaikki", "Avara armo" ja "Kaikkien kirkko". ${ }^{61}$ Lapuan hiippakunnassa jo parissa maallikkoedustajien vaalissa keskustan ja kokoomuksen valitsijayhdistykset olivat yrittäneet tuoda ehdokaslistoihin puoluetunnuksia. Kun sitten 2008 tarjoutui mahdollisuus nimetä ehdokaslista vapaasti, innostus laantui: keskustapainotteisen valitsijayhdistyksen valinta oli "Ihmisten kanssa elävä kirkko", kokoomustaustaisen taas "Kirkko keskellä ihmisten arkea". Vain sosiaalidemokraatit esiintyivät avoimesti "Sosialidemokraattien ehdokaslistalla". ${ }^{62}$

Tulkaa kaikki -liikkeen ohella nuoret aikuiset olivat jälleen toinen ryhmä, joka kampanjoi valtakunnallisesti. Kampanjan organisoijien mielestä elettiin ratkaisevia hetkiä, mikäli nuorten aikuisten virta ulos kirkosta haluttiin saada tyrehtymään. Jälleen päämääränä oli saada kirkolliskokoukseen vähintään yksi alle 30-vuotias jokaisesta hiippakunnasta. Ehdokasasettelu sujuikin suotuisasti, ja alle 30-vuotiaiden ehdokkaiden määrä kasvoi edelleen. ${ }^{63}$ Esimerkiksi Helsingissä kaikista ehdokkaista joka viides kuului tähän ikäryhmään. ${ }^{64}$ Varsinkin pappisvaalin ehdokaslistojen keski-iät olivat alhaisia, 36 vuodesta 45 vuoteen. ${ }^{65}$ Taas kerran nuorten ehdokkaiden suuri määrä oli kuitenkin pahin uhka heidän vaalimenestykselleen. Yksikään Helsingin hiippakunnassa ehdolla olleista 24 nuoresta aikuisesta ei päässyt läpi ${ }^{66}$. Sitä vastoin kirkolliskokouksen ainoa alle 30-vuotias edustaja, jyväskyläläinen kauppatieteilijä Signe Jauhiainen, valittiin Lapuan hiippakunnasta, jossa tuon ikäryhmän edustajia oli ehdolla vain kaksi. ${ }^{67}$ Äänten keskittäminen oli helppoa.

Espoon hiippakunta aloitti toimintansa 2004, mikä merkitsi pääkaupungin aseman korostumista pienentyneen Helsingin hiippakunnan vaaleissa. Ennen hiippakuntajakoa muu Uusimaa oli tarjonnut tasaisen vastapainon Helsingille, mutta esimerkiksi hiippakuntajaon jälkeisissä vuoden 2004 vaaleissa lähes kaikki pappisehdokkaat olivat helsinkiläisiä. Vantaaltakin tuli muutama ehdokas, mutta Porvoon rovastikunnasta, johon kuului sentään lähes neljännes hiippakunnan seurakunnista, oli vain yksi ehdokas. Kaikki kirkolliskokoukseen valitut papit olivat helsinkiläisiä. ${ }^{68}$ Vuonna 2008 vantaalaiset seurakuntapäättäjät perustivat puolestaan kaksi pientä ehdokaslistaa hiippakunnan varsinaisten päälistojen rinnalle, mikä osaltaan kertoi Helsingin ulkopuolisten seurakuntien vaikeuksista löytää paikkaansa ehdokasasettelussa. ${ }^{69}$

Vuonna 2008 valitusta kirkolliskokouksesta ei tullut kokoonpanoltaan muutosten kirkolliskokousta. Huomiota herätti varsinkin pappisedustajien laimea kiinnostus vaaleja kohtaan: Helsingin ja Espoon hiippakunnissa äänesti vain kaksi kolmasosaa äänioikeutetuista papeista. ${ }^{70}$ Uusien edustajien määrä putosi edellisten vaalien 55:stä 49:ään. Naisten määrä kirkolliskokouksessa jatkoi laskuaan ja putosi 31:een. Tämä kolmanneksen osuus oli vähäinen varsinkin siihen nähden, että seurakuntavaaleissa enemmistö valituista luottamushenkilöistä oli naisia. ${ }^{71}$ Esimerkiksi Helsingin hiippakunnan maallikkoehdokkaista 45 prosenttia oli naisia, mutta valituista maallikkoedustajista vain neljännes. ${ }^{72}$ Hiippakunnan pappisehdokkaista 40 prosenttia oli naisia, mutta kukaan tästä joukosta ei päässyt kirkolliskokoukseen. ${ }^{73}$

Naisedustajien vähenemisen ohella toinen 200o-luvun ominaispiirre oli valtiollisten päättäjien kaikkoaminen kirkolliskokouksesta. Nämä kaksi muutosta näyt- 
tävät osittain kytkeytyneen toisiinsa - olivathan puolueiden naisjärjestöt vaikuttaneet 1970- ja 1980-luvulla keskeisesti siihen, että naisten määrä kirkolliskokouksen maallikkoedustajien joukossa oli kasvanut. Samaisen toiminnan ansiosta kirkolliskokoukseen oli valittu istuvia naiskansanedustajia. Kun pappis- ja piispanvirka sitten oli avattu naisille, poliittisten naisjärjestöjen mielenkiinto alkoi heiketä. On myös luultavaa, että 199o-luvulla toteutetut, kirkon ja valtion keskinäisiä sidoksia katkoneet lainmuutokset vaikuttivat henkisesti samaan suuntaan.

Vuoden 2008 kirkolliskokousvaaleihin oli kuljettu pitkä tie vuodesta 1974. Enemmistövaalin tilalle oli tullut suhteellinen vaalitapa niin maallikko- kuin pappiskiintiön osalta. Lopulta myös ehdokaslistojen nimitykset oli otettu käyttöön. Samalla kirkolliskokousvaalien luonne oli uudistusten myötä muuttunut. Vaalisäännökset eivät enää lähteneet siitä, että mahdollisimman laajalla konsensuksella valittaisiin luotettuja kirkon edustajia alueellisesti, vaan oleellista oli turvata oikeudenmukainen paikkamäärä erilaisille mielipideryhmittymille. Vaalisäännökset muuttuivat kuitenkin nopeammin kuin asenteet. Henkilövaalin perinne istui lujassa, vaikka se sopi huonosti yhteen suhteellisen vaalitavan kanssa. Uudella vuosituhannellakin samalla ehdokaslistalla saattoi olla hyvin eri tavoin ajattelevia henkilöitä. Vasta 2008 yleistyivät valitsijayhdistykset, jotka oli koottu yhteisen, julkisesti esitetyn ohjelman pohjalle.

\section{AKTIIVISEURAKUNTALAISTEN NÄKÖINEN KOKOUS?}

Vuoden 2011 syysistuntokaudella kirkolliskokousedustajat vastasivat tätä historiateosta varten kyselyyn, jossa selvitettiin koulutusta, ammattiasemaa sekä hengellistä ja puoluepoliittista taustaa. Mikko Juva oli selvittänyt pitkälti samoja kysymyksiä uusimuotoisen kirkolliskokouksen ensimmäisellä vaalikaudella keväällä 1976, joten on mahdollista tarkastella muutosta tutkimuskauden alusta sen loppuun. Koulutusta, ammattiasemaa ja hengellistä taustaa koskevaan osioon vastasi 2011 yhteensä 99 henkilöä eli hieman yli 90 prosenttia edustajista.

Hiippakunnittain valituista maallikkoedustajista hieman yli puolella oli 2011 ylempi korkeakoulututkinto. Vuoden 1976 kyselyssä osuus oli ollut 42 prosenttia. ${ }^{74}$
Kasvu ei ollut suuri siihen nähden, että samaan aikaan korkea-asteen tutkinnon suorittaneiden osuus 15 vuotta täyttäneestä väestöstä oli lähes kolminkertaistunut. ${ }^{75}$ Maallikkoedustajat olivat keskimääräistä koulutetumpia läpi tutkimuskauden, mutta kauden lopussa ero väestön keskiarvoon ei ollut lainkaan niin suuri kuin alussa. Yleisin tutkinto vuonna 2011 oli lääketieteen lisensiaatin tai tohtorin tutkinto, joka oli kahdeksalla edustajalla. Lakimiehiä ja teologeja oli molempia kuusi. Kaikkiaan 45 prosentilla kaikista kirkolliskokouksen jäsenistä oli teologinen koulutus. Korkeaan lukuun vaikutti osittain se, että papiston lakimääräinen osuus oli kasvanut 38 prosentista 39,4 prosenttiin: piispojen määrä oli lisääntynyt kahdella, ja vastaavasti saamelaisten edustaja oli täyttänyt vain toisen niistä maallikkopaikoista, jotka olivat jääneet tyhjilleen korkeimpien oikeuksien valitsemilta edustajilta.

Kansanedustajien joukossa keski-ikäisillä oli perinteisesti suhteellinen yliedustus, kun taas nuoria ikäluokkia ja eläkeläisiä oli vähemmän kuin väestössä keskimäärin. Eläkeiässä siirryttiin pois kuluttavasta kansanedustajan työstä. ${ }^{76}$ Nuorten ikäluokkien osalta kirkolliskokouksen koostumus muistutti eduskuntaa mutta ei eläkeläisten osalta, varsinkaan tutkimuskauden lopussa. Kyselyyn vastanneista maallikkoedustajista hieman yli 40 prosenttia oli eläkkeellä vuonna 2011. Tämä seikka näkyi myös maallikkoedustajien keski-iässä: vaalikauden alkaessa 2008 se oli 57 vuotta - viisi vuotta korkeampi kuin esimerkiksi vuonna 2000 alkaneella vaalikaudella. Muutos tapahtui samaan aikaan, kun nuorten aikuisten valitsemiseksi kampanjoitiin ennennäkemättömän voimakkaasti. Kirkolliskokouksen jäsenyys ei ollut sellainen rasittava luottamustehtävä, joka haluttiin jättää eläkkeelle jäätäessä, vaan päinvastoin eläkeiässä oli aikaa omistautua kirkolliskokoukselle. Kirkon jäsenistön ikääntyminen heijastui väistämättä kirkolliskokoukseen.

Kun maallikkoedustajien ammattiasemaa kysyttiin 2011, vastaajista 15 prosenttia ilmoitti olevansa parhaillaan tai olleensa viimeksi kirkon tai kristillisen järjestön työntekijä. Sosiaali- ja terveydenhuoltoalalla kertoi olevansa 17 prosenttia, useimmat vastaajista johtavassa asemassa. Osuus oli kaksinkertainen verrattuna perinteisesti vahvaan opetusalaan, ja juuri sosiaali- ja terveydenhuoltoalan osuuden kasvu oli selvin muutos vuoteen 1976 verrattuna $^{77}$. Kaikkiaan maallikkoedustajista selväs- 
ti yli puolet oli julkisen sektorin tehtävissä. Lisäksi selvä enemmistö vastanneista oli omalla alallaan johtavassa asemassa. Kirkon koko jäsenistön näkökulmasta edustajajoukko oli näiltä osin yksipuolinen. Toisaalta kokoonpano oli monipuolistunut ajoista, jolloin miltei puolet maallikkoedustajista oli toiminut opetusalalla.

Pappisedustajista hieman yli neljänneksellä oli yliopistollinen jatkotutkinto, joka vielä 20 vuotta aiemmin oli löytynyt suunnilleen puolelta. Osuus oli laskenut samaan aikaan, kun teologian tohtorien valmistumistahti oli kiihtynyt ennätykselliseksi. Pappisedustajista edelleen puolet oli kirkkoherroja, mutta takana olivat ne ajat, jolloin heitä oli ollut kolme neljäsosaa. Vajaa puolet kirkkoherroista oli lääninrovasteja, mutta asessoreita ei juurikaan valittu kirkolliskokoukseen. Yhteys hiippakuntaorganisaatioon säilyi kuitenkin muun muassa edustajantehtävään valittujen hiippakunnan viranhaltijoiden kautta. Yli neljännes pappisedustajista työskenteli kirkon erityisvirassa tai kristillisen järjestön palveluksessa. Kirkolliskokouksessa istuivat kahden kirkon virallisen lähetysjärjestön johtajat, Suomen Lähetysseuran Seppo Rissanen ja Suomen Evankelisluterilaisen Kansanlähetyksen Timo Rämä. Siitä huolimatta lähetystyö ei edelleenkään noussut erityisen näkyväksi teemaksi.

Oppiarvo tai ammattiasema ei ollut varsinkaan pappisedustajien vaalissa enää ratkaiseva äänestysperuste.
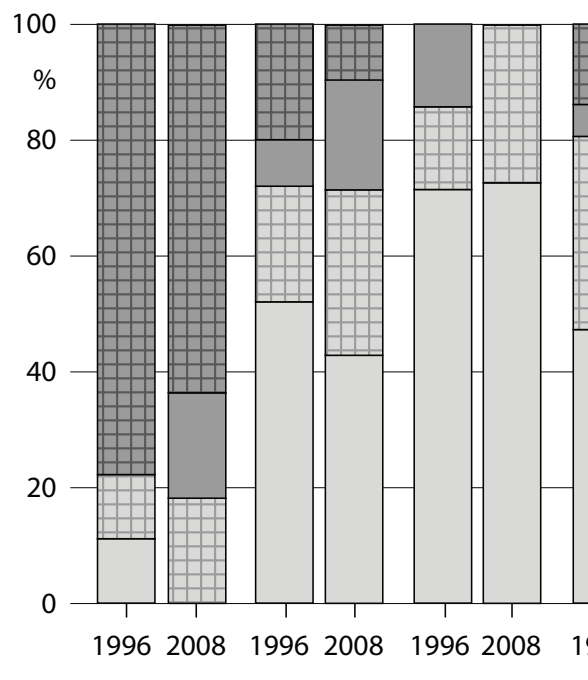

$\begin{array}{ccccc}\text { Piispat ja } & \begin{array}{c}\text { Pappis- } \\ \text { kenttäpiispa } \\ \text { edustajat, } \\ \text { miehet }\end{array} & \begin{array}{c}\text { Pappis- } \\ \text { edustajat, } \\ \text { naiset }\end{array} & \begin{array}{c}\text { Maallikko- } \\ \text { edustajat, } \\ \text { miehet }\end{array} & \begin{array}{c}\text { Maallikko- } \\ \text { edustajat, } \\ \text { naiset }\end{array}\end{array}$

Myöskään luottamustehtävien keskittymistä samoille henkilöille ei enää pidetty ihanteena. Siirtyminen suhteelliseen vaalitapaan oli voimistanut tätä muutosta ja lisännyt 1990-luvulta lähtien pappisedustajien vaihtuvuutta. Kaikkein kokeneimmat, vähintään neljännen kauden edustajat kävivät harvinaisiksi niin pappis- kuin maallikkoedustajien keskuudessa.

Sitoutumista kirkollisiin liikkeisiin mitattiin neliportaisella asteikolla: "en kuulu", "en kuulu, mutta ajattelussani on vaikutteita", "kuulun löyhästi" tai "kuulun kiinteästi". Valmiiden vaihtoehtojen lisäksi vastaajalla oli mahdollisuus nimetä muita kirkollisia viiteryhmiä. Hiippakunnittain valituista pappisedustajista puolet ilmoitti kuuluvansa kiinteästi tai löyhästi vähintään yhteen liikkeeseen. Yleisin vastaus oli herännäisyys. Piispoista ja pappisedustajista siihen ilmoitti kuuluvansa vähintään löyhästi 11 vastaajaa. Myös maallikkoedustajista noin puolet kertoi kuuluvansa vähintään löyhästi johonkin liikkeeseen, ja tällöinkin herännäisyys oli yleisin yksittäinen liike (kymmenen edustajaa). Herännäisyyteen näyttää lukeutuneen suunnilleen yhtä suuri osuus edustajista kuin vuonna $1976^{78}$. Kun mukaan lasketaan ne, jotka ilmoittivat ajattelussaan olevan herännäisvaikutteita, kaikista vastaajista lähes puolella oli 2011 jonkinlainen side herännäisyyteen. Herännäisyydestä oli vuosikymmenten kuluessa muotoutunut yleiskirkollinen liike.

Vanhoillislestadiolaisuuteen laskettiin kuuluvaksi yhdeksän edustajaa. ${ }^{79}$ Heistä kahdeksan ilmoittautui kyselyssä liikkeen jäseneksi. Vanhoillislestadiolaisten osuus oli aiempiin vaalikausiin verrattuna hyvin suuri - kak-

Kuvio 15: Kirkolliskokouksen jäsenten edustajakokemus vuosina 1996 ja 20o8: Kuinka mones kausi kirkolliskokousedustajilla oli meneillään eri ryhmissä?

4. tai useampi

3.

2 
sinkertainen vuoteen 1976 nähden. Muista herätysliikkeistä poiketen vanhoillislestadiolaisuus oli kirkolliskokouksessakin tarkkarajainen: muihin liikkeisiin oli yleisempää sitoutua löyhästi kuin kiinteästi, mutta vanhoillislestadiolaisuuteen joko ei kuuluttu tai sitten kuuluttiin kiinteästi. Espoon hiippakunnan kuudesta maallikkoedustajasta kaksi kuului vanhoillislestadiolaisuuteen. Tämä kolmanneksen osuus oli suurempi kuin Oulun hiippakunnassa, mikä kuvasti liikkeen levittäytymistä Etelä-Suomeen.

Sen sijaan 1976 vahvasti edustettuna olleen Elämän Sanan lestadiolaisuuden vaikutus oli miltei hävinnyt kirkolliskokouksesta samalla, kun SRK-vanhoillislestadiolaisuudesta aikoinaan erotetut papit olivat jääneet eläkkeelle. Myös evankelisuuden asema oli heikentynyt

Kuvio 16: Kirkolliskokousedustajien hengelliset viiteryhmät syksyllä 2011 (99 vastaajaa)

Länsi-Suomen Rukoilevaisten Yhdistys Suomen rukoilevaisen kansan yhdistys Herännäisyys Suomen Luterilainen Evankeliumiyhdistys (/SLEF) Evankelinen lähetysyhdistys Vanhoillislestadiolaisuus Elämän Sanan lestadiolaisuus Esikoislestadiolaisuus

Rauhan Sanan lestadiolaisuus Lestadiolainen uusiheräys Kyrkans Ungdom

Suomen Raamattuopisto Kansan Raamattuseura Suomen Ev.lut. Opiskelija- ja Koululaislähetys (/FSSM) Suomen Ev.lut. Kansanlähetys Karismaattinen liike Luther-Säätiön jumalanpalvelusyhteisö Nokia Missio Tuomasyhteisö Hiljaisuuden liike

Taizén ekumeeninen luostariyhteisö Muu: Nuorten Miesten Kristillinen Yhdistys Muu: uukuniemeläisyys Muu: Suomen Lähetysseura Muu: Tulkaa kaikki -liike Muu: Medialähetys Sanansaattajat Ei vaikutteita mistään tietystä liikkeestä selvästi. Romahdus ilmeni erityisesti Lapuan hiippakunnan edustajistossa. Hiippakunnan alueella virkakysymys oli jakanut liikettä monin paikoin, mikä ilmeisesti heikensi niin kirkon virkaratkaisua vastustaneen SLEY:n kuin ratkaisua kannattaneen Evankelisen lähetysyhdistyksen piirissä toimineiden menestymismahdollisuuksia ${ }^{80}$.

Vuonna 1976 kolme kirkolliskokousedustajaa oli lukeutunut viidenteen herätysliikkeeseen. ${ }^{81}$ Vuonna 2011 kiinteästä kuulumisesta liikkeeseen ilmoitti neljä edustajaa, jotka kaikki kertoivat kuuluvansa Suomen Evankelisluterilaiseen Kansanlähetykseen. Järjestön luottamus- tai työtehtävissä oli kuitenkin yhteensä seitsemän edustajaa $^{82}$. Vielä huomattavasti useampi ilmoitti kuuluvansa löyhästi vähintään yhteen viidennen herätysliik-

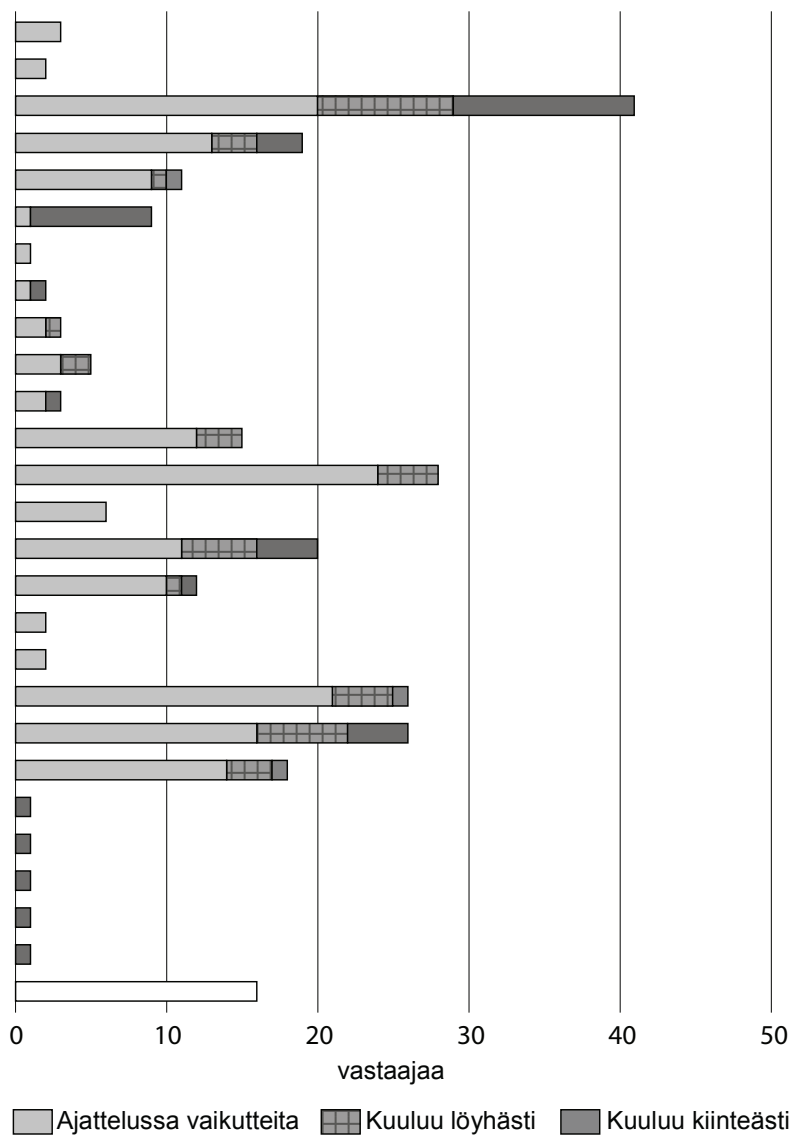


keen haaroista, ja todella moni kirkolliskokousedustaja oli saanut ajatteluunsa vaikutteita tästä liikkeestä. Voikin arvioida, että viidennen herätysliikkeen asema kirkolliskokouksessa oli vahvistunut selvästi vuodesta 1976. Seurakuntien toiminnassa viidennen herätysliikkeen osuus oli pysynyt suhteellisen vakaana 1970-luvun puolivälistä 2010-luvulle ${ }^{83}$. Kyse näyttääkin olleen lähinnä siitä, että liikkeen juurtuminen kirkon päätöksentekoon sujui hitaammin kuin toiminnan levittäytyminen seurakuntiin. Luultavasti oma vaikutuksensa oli suhteellisella vaalitavalla, joka tarjosi mahdollisuuksia erityisesti niille, joilla oli esittää selväpiirteinen ohjelma - oli sitten kyse Suomen Evankelisluterilaisen Kansanlähetyksen tai Tulkaa kaikki -liikkeen piirissä toimivista.

Tietyt liikkeet esiintyivät samoissa vastauslomakkeissa. Herännäisyys, Evankelinen lähetysyhdistys ja Kansan Raamattuseura olivat usein läheisiä samalle kirkolliskokousedustajalle. Vastaavasti useat viidennen herätysliikkeen haarat olivat monissa tapauksissa tärkeitä tietylle henkilölle, ja usein tähän kokonaisuuteen liittyi SLEY. Myös Tuomasyhteisö, hiljaisuuden liike ja Taizén ekumeeninen luostariyhteisö kytkeytyivät luontevasti yhteen. Runsas kolmannes vastaajista mainitsi vähintään yhden näistä kolmesta. Mikäli henkilö ilmoitti kuuluvansa kiinteästi tiettyyn liikkeeseen, hänellä oli tavallista harvemmin löyhiä yhteyksiä johonkin toiseen liikkee- seen. Sen sijaan niillä edustajilla, jotka eivät kuuluneet kiinteästi mihinkään liikkeeseen, oli usein löyhiä sidoksia moniin ryhmiin. Kirkolliskokousedustajien ja kirkon työntekijöiden herätysliiketaustojen välillä voi nähdä yhtymäkohtia, joskin vanhoillislestadiolaisten osuus oli kirkolliskokouksessa huomattavasti suurempi kuin seurakuntien työyhteisöissä ${ }^{84}$.

Maallikkoedustajista neljännes ilmoitti 2011 toimivansa seurakunnan vapaaehtoistyöntekijänä, ja joka kymmenes kertoi tehneensä joskus aiemmin vapaaehtoistyötä. Ilmoitettu työmäärä nousi enimmillään sataan työtuntiin kuukaudessa. Seitsemän maallikkoedustajaa kertoi parhaillaan käyttävänsä keskimäärin vähintään kymmenen tuntia kuukaudessa seurakunnan vapaaehtoistyöhön. Kyselyn perusteella maallikkoedustajissa oli seurakunnan vapaaehtoistyöntekijöitä suunnilleen yhtä paljon - noin 40 prosenttia - kuin niitä, joilla oli kokemusta kunnallispolitiikasta. Sen sijaan nämä kaksi ryhmää olivat pitkälti toisistaan erilliset: ne, joilla oli taustaa sekä kunnallispolitiikassa että seurakunnallisessa vapaaehtoistyössä, saattoi laskea yhden käden sormin.

Noin kolmannes kirkolliskokousedustajista istui myös hiippakuntavaltuustossa. Helsingin hiippakunnassa osuus oli peräti kolme neljäsosaa, kun taas Lapuan hiippakunnan kirkolliskokousedustajissa hiippakuntavaltuutettuja ei ollut lainkaan. ${ }^{85}$ Noin kaksi kolmasosaa

Kuvio 17: Vuonna 2008 alkaneen vaalikauden

pappis- ja piispajäsenten puoluekanta

eduskuntavaaleissa 2007 ja 2011

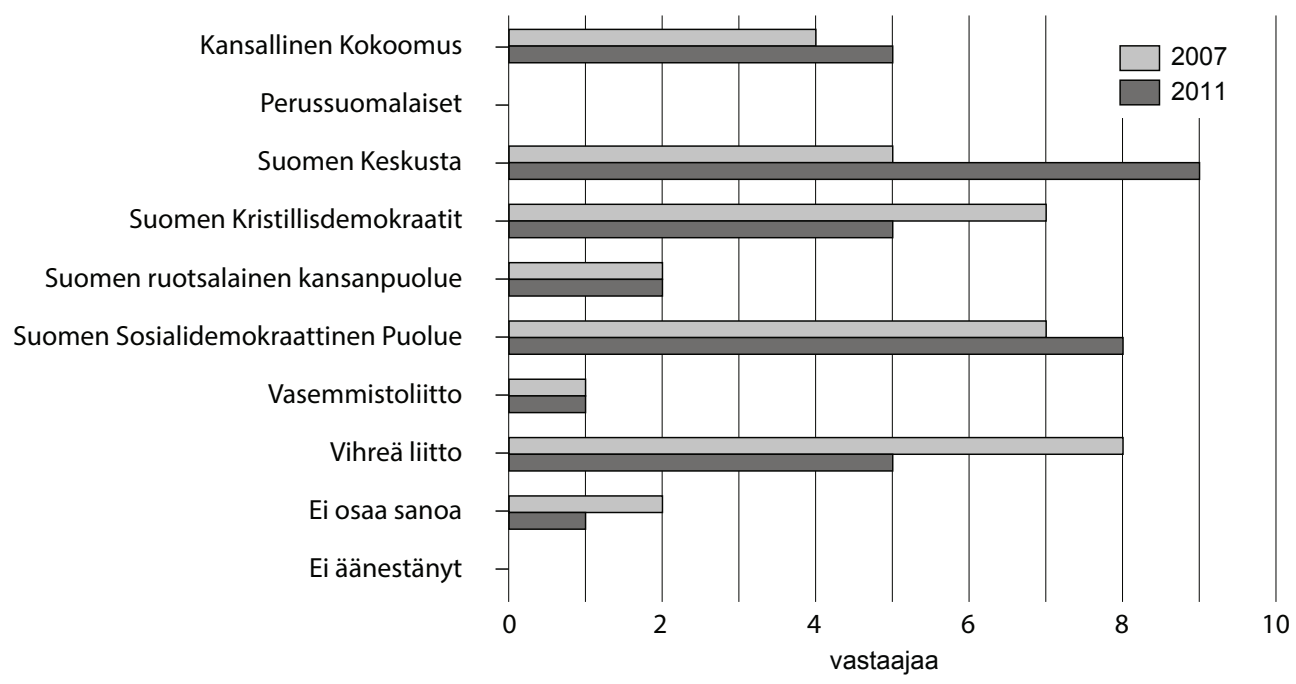


maallikkoedustajista istui parastaikaa seurakuntatasolla valtuustossa tai neuvostossa. Vain muutamilla maallikkoedustajilla ei ollut lainkaan kokemusta jäsenyydestä näissä elimissä. Tilanne oli hyvin samanlainen kuin $1976^{86}$. Tyypillinen maallikkoedustaja oli edelleen kokenut seurakunnan luottamushenkilö.

Edustajien poliittista kantaa kysyttiin erillisellä, nimettömällä lomakkeella. Kirkolliskokouksessa oli pappeja ja piispoja yhteensä 43, ja heistä 36 eli noin 84 prosenttia vastasi tähän kyselyyn. Lähes kaikki vastaajat (35) kertoivat, mitä puoluetta he olivat äänestäneet vuosien 2007 ja 2011 eduskuntavaaleissa.

Kirkolliskokousvaaleja edeltäneiden vuoden 2007 eduskuntavaalien valossa porvarilliset ja punavihreät sävyt näkyivät melko tasaisina pappien ja piispojen vastauksissa. Vihreät oli suosituin puolue, ja sosiaalidemokraatit sekä kristillisdemokraatit jakoivat toisen sijan. Muilta osin papiston kannatus jakautui usealle porvarilliselle puolueelle. Silmiinpistävää oli, että eduskuntavaalien valtakunnallisesti suurimmat puolueet keskusta ja kokoomus olivat vastaajien keskuudessa vasta neljännellä ja viidennellä tilalla. Näiden kahden puolueen yhteenlaskettu kannatus oli samaa luokkaa kuin vihreiden yksinään. Tässä mielessä kyselyyn vastannut kirkolliskokouksen paimenten joukko oli punavihreämpi kuin kansalaiset keskimäärin vuoden 2007 vaaleissa.

KUVIO 18: Vuonna 2008 alkaneen vaalikauden maallikkojäsenten puoluekanta eduskuntavaaleissa $2007 \mathrm{ja} 2011$
Kyselyyn vastanneista kukaan ei äänestänyt perussuomalaisia sen enempää 2007 kuin neljä vuotta myöhemmin, jolloin puolue nousi kolmanneksi suurimmaksi puolueeksi. Päinvastoin keskusta, joka kärsi 2011 historiallisen suuren vaalitappion, miltei kaksinkertaisti kannatuksensa kyselyyn vastanneiden pappien keskuudessa ja nousi tässä joukossa suosituimmaksi puolueeksi. Vaalien 2011 siirtymä "vanhoilta puolueilta" perussuomalaisille heijastui siis kirkolliskokouksen papistoon enintään käänteisesti: kun perussuomalaiset lisäsivät kannatustaan, puolueen vastavoimana maaseudulla nähty, voimakkaassa syöksyssä ollut keskusta vahvistui pappisedustajien keskuudessa.

Maallikkoedustajista 61 vastasi puoluepoliittista kantaa koskevaan kyselyyn. Vastausprosentti oli siten yli 95 ja tuloksista saatava kuva näin ollen selvästi kattavampi kuin kirkolliskokouksen piispojen ja pappien osalta.

Keskusta oli selvästi suosituin puolue. Vähintään kolmannes maallikkoedustajista äänesti sitä niin 2007 kuin 2011. Seuraavana oli kokoomus, joka oli perinteisesti toinen maallikkoedustajien keskuudessa vahva puolue. Maallikkoedustajien puoluepoliittisessa jakaumassa oli koko tutkimuskaudella tuskin tapahtunut suuria muutoksia. Perussuomalaiset jäivät tyystin vaille kannatusta myös vastanneiden maallikkoedustajien keskuudessa. Mikäli kyselyyn vastaamatta jättäneiden tai poissa ollei-

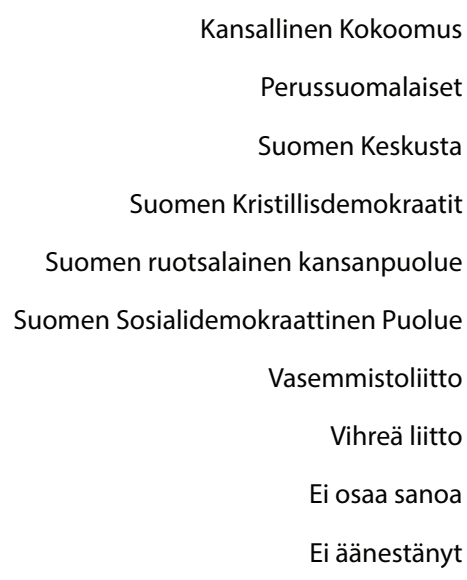

Kansallinen Kokoomus

malaise

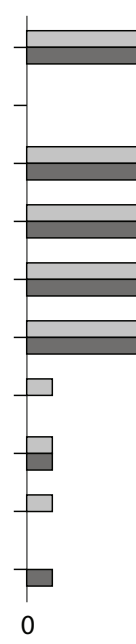

0

5

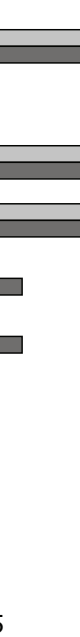

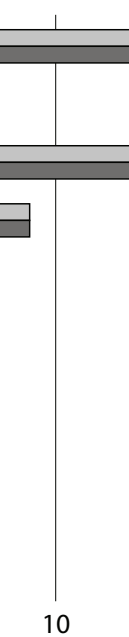

10

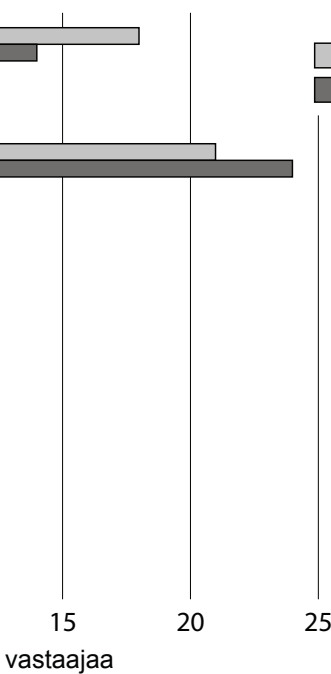


den edustajien kannat noudattelivat samaa jakaumaa, tulos oli hätkähdyttävä: valtakunnan kolmanneksi suurin puolue ei ollut saanut kannatusta kirkolliskokousedustajien joukossa. Tässä suhteessa perussuomalaisten asema muistutti Suomen Kansan Demokraattisen Liiton ja kirkolliskokouksen välistä suhdetta muutama vuosikymmen aiemmin.

Asetelman teki erityisen mielenkiintoiseksi se, että kyselytutkimusten perusteella perussuomalaiset oli suosituin puolue itsensä hyvin uskonnollisiksi katsovien keskuudessa. Vastaavasti monen pappisedustajan äänestämä vihreät oli tässä ryhmässä vähiten suosittu. Toisaalta ristiriitaa hieman lievensi se, ettei perussuomalaisten kannattajien uskonnollisuus näkynyt useinkaan vahvana sitoutumisena luterilaiseen kirkkoon. ${ }^{87}$ Joka tapauksessa kirkolliskokouksen puoluepoliittinen jakauma tuskin vastasi täysin aktiiviseurakuntalaisten koostumusta.

Kirkolliskokouksen maallikkoedustajien vaali ei ollut perusluonteeltaan puoluepoliittinen. Kokoomuksella, keskustalla ja sosiaalidemokraateilla oli ehdokasasettelussa kuitenkin niin vahva ja perinteinen asema, etteivät muutokset poliittisessa kentässä heijastuneet vaaliin nopeasti. Tätä kuvaa vahvisti vielä kysely, joka toteutettiin 2012 valituille kirkolliskokousedustajille. Yksikään vastanneista edustajista ei ilmoittanut äänestäneensä perussuomalaisia saman vuoden kunnallisvaaleissa ${ }^{88}$. Näin oli siitäkin huolimatta, että kirkolliskokousvaaleissa äänestäneet seurakuntapäättäjät oli valittu syksyllä 2010, jolloin perussuomalaisten kannatus oli ollut mielipidetutkimusten mukaan erittäin suuri. ${ }^{89}$

Maallikkoedustajien puoluejakauma oli leimallisen porvarillinen. Vasemmistoa tai vihreitä äänesti vuoden 2007 eduskuntavaaleissa vain runsaat 11 prosenttia vastanneista, kun taas kyselyyn vastanneiden piispojen ja pappien keskuudessa osuus oli hieman yli 44 prosenttia. Vuoden 2007 vaalien valtakunnallisessa kokonaistuloksessa vasemmiston pääpuolueiden ja vihreiden yhteiskannatus oli vajaat 39 prosenttia. Kyselyn perusteella kirkolliskokoukseen valittu papisto vastasi puoluekannatukseltaan kansan keskiarvoa selvästi paremmin kuin maallikkoedustajat. Pappiskiintiö oli usein nähty kirkolliskokouksen "epädemokraattisena" osana, mutta kyselyn valossa nimenomaan pappiskiintiö turvasi kirkolliskokoukseen tiettyjä puolueita äänestäneiden seurakuntalaisten edustuksen.
Mikko Juva totesi 1976, että kirkolliskokousta leimasi "tietty veto poliittiseen keskustaan". ${ }^{\circ}$ Toteamuksen voi allekirjoittaa maallikkoedustajien osalta edelleen vuonna 2011. Sen sijaan varsinkin vuoden 2007 äänestyskäyttäytymisen perusteella kristillisdemokraatit ja vihreät olivat vahvoja pappien ja piispojen vastaajaryhmässä. Näiden puolueiden osalta ei ole selvää vertailukohtaa vuoteen 1976, koska Suomen Kristillinen Liitto oli tuolloin vasta vakiinnuttamassa asemaansa, kun taas vihreitä ei puolueena ollut olemassa. Nämä kaksi puoluetta rikkoivat 2011 kirkolliskokouksen keskustahakuisuutta, koska tutkimuksen mukaan ne näyttäytyivät moraali- ja kulttuuriarvoilla mitattuina toistensa vastapooleina $^{91}$. On luultavaa, että suhteellisen vaalitavan omaksuminen pappisedustajien vaalissa, tunnusten salliminen ja sittemmin alkanut valtakunnallinen kirkkopoliittinen ryhmänmuodostus olivat muuttaneet tilannetta. Keskusta- ja konsensushakuinen vaalitapa oli vaihtunut kampanjointiin, jossa selvästi konservatiivisen tai vapaamielisen ohjelman esittäneet hankkivat ja saivat parhaiten näkyvyyttä. Maallikkoedustajien vaalissa perinteisten puolueiden hallitsema ehdokasasettelu ehkäisi monessa hiippakunnassa tällaista kärjistymistä, mutta pappisedustajien vaalin osalta vastaavia hidasteita ei ollut.

Kyselyyn vastanneet papit ja piispat olivat liikkuvampia äänestäjiä kuin maallikkoedustajat. Silti heidänkin puoluekantansa oli koko kansan mittakaavassa vakiintunut: vaalitutkimusten tuloksiin suhteutettuna kirkolliskokousedustajien puolueuskollisuus oli vähintään kaksinkertaista koko suomalaiseen äänestäjäkuntaan verrattuna $^{92}$. Puolueen vaihtaminen oli hieman yleisempää vuoden 1960 jälkeen kuin sitä ennen syntyneiden edustajien keskuudessa. Ero ei ollut suuri, mutta sen voi katsoa noudattaneen koko äänestäjäkunnassa havaittua ilmiötä ${ }^{93}$. Yhteensä 37 saarnaviran edustajaa otti vastauksessaan kantaa puoluepoliittisen sitoutumisensa vahvuuteen. Noin 40 prosentilla oli vakiintunut puoluekanta, mutta tästä joukosta vain yksi vastaaja ilmoitti olevansa puolueen jäsen. Sen sijaan vastanneista maallikkoedustajista yli puolella, 54 prosentilla, oli jonkin puolueen jäsenkirja, ja ilman vakiintunutta puoluekantaa ilmoitti olevansa vain vajaa kolmannes.

Mikäli kirkolliskokousedustajan poliittinen kanta oli julkinen, hänellä oli mahdollisuus kirjoittaa oma ni- 
mensä kyselylomakkeeseen. Runsas kolmannes kyselyyn vastanneista maallikkoedustajista ilmoitti poliittisen kantansa omalla nimellään. Korkein osuus oli Turun arkkihiippakunnassa (kuusi kahdeksasta edustajasta). Vastaavasti Espoon hiippakunnasta valitut maallikkoedustajat eivät vastanneet omalla nimellään eivätkä kertoneet olleensa mukana kunnallispolitiikassa. Vastauksissa näkyi se, miten joissakin hiippakunnissa puoluepoliittiset ryhmittymät olivat olleet vahvempina tekijöinä ehdokasasettelussa kuin toisissa. Pappisedustajista tai piispoista kukaan ei ilmoittanut poliittisen kantansa olevan julkinen, ja vain yksi pappisedustaja toimi kyselyn aikaan kunnanvaltuutettuna. Tulos kuvastaa sitä läpi tutkimuskauden näkynyttä ilmiötä, että poliittisesti aktiivisia pappeja ei juuri valittu kirkolliskokoukseen. Säätypapiston aikakausi, jolloin pitkälti samat papit oli valittu niin valtiopäiville kuin kirkolliskokoukseen, näytti olevan lopullisesti takana. Puoluepoliittisesta aktiivisuudesta oli tullut papistolle kirkollisten luottamustehtävien kannalta ennemminkin rasite. Poikkeuksena tästä yleiskuvasta oli Porvoon hiippakunta: papin toiminta RKP:ssa, kieliryhmän laaja-alaisessa kansanliikkeessä, ei ollut samalla tavalla äänestäjiä jakava tekijä kuin osallistuminen poliittiseen toimintaan muissa puolueissa.

\section{PYRKIMYS AVOIMEEN KESKUSTELUUN PÄÄTÖKSENTEOSSA JA HENKILÖVALINNOISSA}

Kirkkohallituksen kyselytunnit olivat alkaneet epävirallisina 1990-luvulla. Vuosituhannen vaihtuessa kirkolliskokouksen yhteydenpito kirkkohallitukseen ja piispainkokoukseen koettiin kuitenkin edelleen vähäiseksi. Eduskunnassa oli puolestaan menneinä vuosina pyritty ohjaamaan keskustelua aiempaa nopeatempoisemmaksi, vapaamuotoisemmaksi ja aidommaksi. ${ }^{94}$ Kirkolliskokous asetti syksyllä 2000 varapuheenjohtaja Timo Sahin johtaman työryhmän tarkistamaan kokouksen työjärjestystä. ${ }^{95}$ Jälleen kerran eduskunnan työjärjestys toimi esikuvana, kun kirkolliskokouksen työtä pyrittiin joustavoittamaan. Lopputuloksena oli 2002 hyväksytty työjärjestys, jonka avulla oli tarkoitus yhtälttä tiivistää puheenvuoroja, toisaalta lisätä keskustelumahdollisuuksia jo asioiden valmisteluvaiheessa. ${ }^{96}$

Aiemmin kirkkohallitus ja piispainkokous olivat voineet antaa kirkolliskokoukselle vain esityksiä. Koska esi- tyksen tuli tähdätä suoraan päätökseen, valmistelu oli jo tehty ja keskustelumahdollisuudet rajautuneet asian tullessa kirkolliskokoukseen. Uusi työjärjestys sen sijaan antoi kirkkohallitukselle ja piispainkokoukselle mahdollisuuden ehdottaa keskustelua aiheista, jotka eivät vielä olleet vireillä kirkollisissa elimissä tai joiden valmistelusta oli tarpeen vaihtaa ajatuksia. Toiseksi kirkkohallitus, sen kansliapäällikkö ja kirkkoneuvokset saivat vastedes antaa kirkolliskokoukselle ilmoituksia, joista oli mahdollista keskustella. Tällainen tarve saattoi syntyä vaikkapa silloin, kun valtionhallinnossa oli valmisteilla kirkkoa koskevia uudistuksia tai kun kirkkohallitus päätyi jättämään jonkin kirkolliskokoukselta saamansa asian raukeamaan. Kolmanneksi kyselytunti virallistettiin ja siirrettiin osaksi täysistuntoa, jolloin se tallentui keskustelupöytäkirjoihin. ${ }^{97}$

Näiden uusien keskustelumuotojen yhteydessä annettiin puheoikeus myös sellaisille kirkkohallituksen täysistunnon jäsenille, jotka eivät istuneet kirkolliskokouksessa. Tarkoituksena oli parantaa kirkolliskokouksen yhteyttä näihin luottamushenkilöihin. ${ }^{98}$ Myöhemmin professori Seikko Eskola ehdotti kirkkohallituksen jäsenille puheoikeutta myös kirkkohallituksen esityksiä koskeviin lähetekeskusteluihin, mutta ehdotus kaatui äärimmäisen niukasti äänin 51-49. ${ }^{99}$ Kirkkohallituksen esitysten perusteleminen ja puolustaminen jäi siten vastaisuudessakin pitkälti esittelijöiden eli kirkkoneuvosten - ei niinkään varsinaisten päättäjien - harteille.

Kirkolliskokouksen uudet keskustelumuodot hyväksyttiin helposti, mutta ehdotukset puheenjohtajan vallan lisäämisestä osoittautuivat ongelmallisiksi. Vuonna 2000 voimaan tullut eduskunnan uusi työjärjestys sisälsi säännökset nopeatahtisesta keskustelusta, jonka aikana puhemiehellä oli oikeus rajoittaa puheenvuorojen pituutta $^{100}$. Samalla tavalla ehdotus kirkolliskokouksen uudeksi työjärjestykseksi sisälsi säännöksen, joka tarjosi puheenjohtajalle mahdollisuuksia rajoittaa puheenvuorojen pituutta ja myöntää puheenvuoroja oman harkintansa mukaan kyselytunnilla tai keskusteltaessa ilmoituksesta. Säännöksen tarkoituksena oli taata kaikille edustajille tasapuolinen mahdollisuus lausua kantansa. Kirkolliskokous katsoi kuitenkin säännöksen edellyttävän muutoksia kirkkolakiin, minkä vuoksi asia lykkääntyi muutamalla vuodella seuraavaan työjärjestysuudistukseen. Tuolloin keskustelumahdollisuuksia paransi 


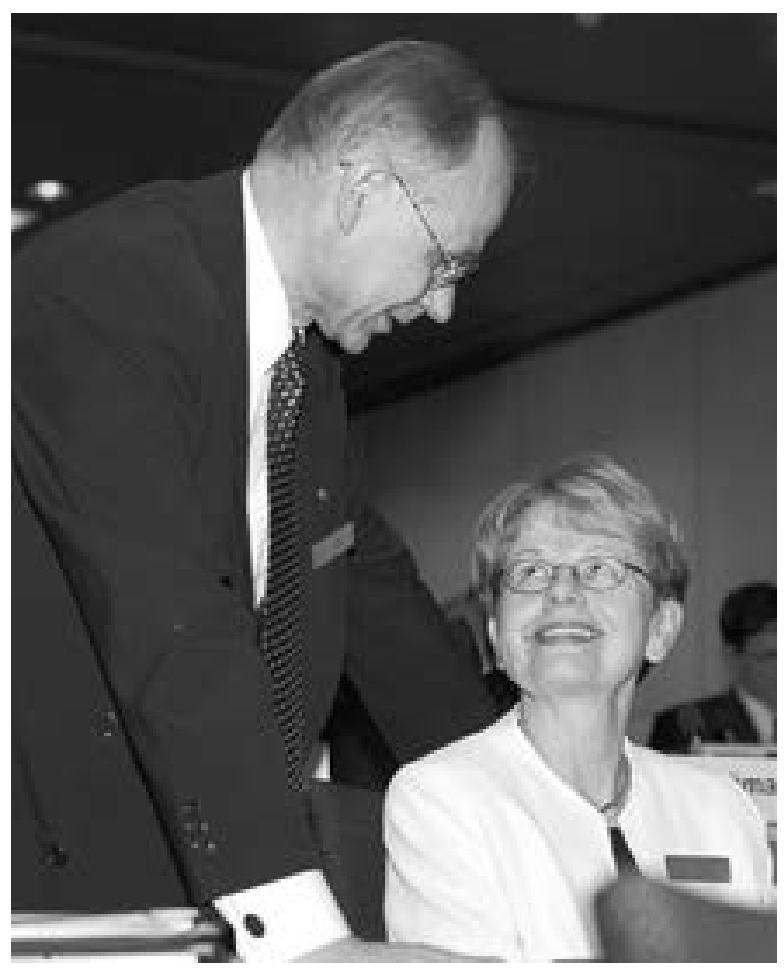

Lääkintäkenraalimajuri Timo Sahi ja opetusneuvos Kaisa Rönkä valittiin kirkolliskokouksen varapuheenjohtajiksi vuosina 2004 ja 2008 alkaneilla vaalikausilla. Sahi johti 2000 -luvun alkuvuosina myös kirkolliskokouksen työjärjestyksen kehitystyötä.

Kuva: Kotimaan kuva-arkisto / Matti Karppinen.

lisäksi se, että samassa yhteydessä otettiin käyttöön lähetekeskustelu talousarvioesityksestä. ${ }^{101}$

Avoimuuteen pyrittiin myös kirkolliskokouksen valitessa henkilöitä eri tehtäviin. Henkilövalinnoista helpoimpia olivat 200o-luvulla varapuheenjohtajien vaalit. Dosentti Kyllikki Tiensuu ja lääkintäprikaatikenraali, sittemmin lääkintäkenraalimajuri Timo Sahi valittiin jatkokaudelle vuonna 2000. ${ }^{102}$ Yhtä selvä oli Sahin ja kotkalaisen opetusneuvoksen Kaisa Röngän valinta vuosina 2004 ja 2008. Vuonna 2004 tosin katkesi vuodesta 1988 vallinnut tapa, että naisedustaja toimi ensimmäisenä varapuheenjohtajana. Ratkaisu herätti jonkin verran kriittistä huomiota, ja kirkolliskokouksen enemmistö asettui neljä vuotta myöhemmin keskustelun jälkeen sille kannalle, että Sahin sijasta Rönkä tuli valita ensimmäiseksi varapuheenjohtajaksi. ${ }^{103}$

Valitsijamiesten vaalissa painoi 2000-luvulla edelleen edustajakokemus: kokeneimmista edustajista suurin osa pääsi varsinaiseksi valitsijamieheksi, kun taas ensikertalaisille se oli vaikeaa. Asetelma ei tosin ollut enää yhtä selvä kuin muutama vuosikymmen aiemmin. Valiokuntien suhteen tilanne oli 2008 siinä mielessä ennallaan, että kaikkein kokeneimmat edustajat keskittyivät laki- ja perustevaliokuntaan. Lakivaliokunnan luonne "lakimiesvaliokuntana" vahvistui. Entiseen "kirkkoherravaliokuntaan" valittiin esimerkiksi 2004 vain yksi piispa ja yksi pappisedustaja, kun taas muita edustajia oli 14 - heistä enimmillään puolet juristeja. Puheenjohtajana toimi ensin Kim Fröman ja hänen jälkeensä Pirjo Pyhäjärvi. Göran Portinin kauden jälkeisen lyhyen tauon jälkeen puheenjohtajuus palasi jälleen tuomioistuinten jäsenille.

Papiston kaikotessa lakivaliokunnasta perustevaliokunnan pappisenemmistö kasvoi vuosikymmenen kuluessa, kunnes 2008 alkaneella vaalikaudella piispat ja papit muodostivat lähes kolme neljäsosaa valiokunnasta. Naisten määrä valiokunnassa oli huomattavan alhainen. Kokonaisuudessaan valiokuntien sukupuolijakauma noudatteli perinteisiä linjoja. Toisaalta talousvaliokunnan puheenjohtajaksi valittiin 2004 salolainen ylilääkäri Marjatta Hyttinen. Siten tämä perinteisesti hyvin miesvaltainen valiokunta oli lopulta kirkolliskokouksen ensimmäinen erikoisvaliokunta, jonka puheenjohtajaksi valittiin naisedustaja. Seuraavan vaalikauden alkaessa tehtävään valittiin puolestaan Malmin kirkkoherra Pertti Simola, joka oli ensimmäinen pappisedustaja erikoisvaliokunnan puheenjohtajana uusimuotoisen kirkolliskokouksen aikana. Molempiin valintoihin sisältyi reaalipolitiikkaa. Salon ja Helsingin alueen seurakunnat olivat verotuloiltaan kirkon kärkeä ja siten suurimpia häviäjiä 200o-luvun mittavissa tasaushankkeissa. Vaikeiden päätösten tekemistä helpotti, että noita päätöksiä olivat kirkolliskokouksessa viemässä läpi suurimmista menettäjäseurakunnista saapuneet edustajat.

Valiokunnan tehtävien vaikutus jäsenistöön näkyi kaikkein selvimmin käsikirjavaliokunnassa. Vuonna 2000 alkaneella vaalikaudella valiokunnan käsittelyyn tuli kirkollisten toimitusten kirjan uudistus. Tuolloin jäsenistä kolme neljäsosaa oli pappeja, ja teologien osuus oli vieläkin suurempi. Hetken aikaa valiokunnassa oli samanaikaisesti peräti kolme piispaa. Vuoteen 2008 mennessä merkittävät kirkollisten kirjojen uudistushankkeet oli saatu päätökseen. Tuolloin valiokunta 
ei enää kiinnostanut pappeja, vaan enemmistö jäsenistä oli maallikkoedustajia. Myöskään kokeneet edustajat eivät enää halunneet käsikirjavaliokuntaan. Sen sijaan erityisesti lakivaliokunnan toivomuksesta valitsijamiehet lisäsivät 2000-luvun kuluessa kokeneita edustajia yleisvaliokuntaan: monet aloitteet toistuivat vaalikaudesta toiseen, minkä vuoksi asioiden käsittelyyn yleisvaliokunnassa haluttiin jatkuvuutta ${ }^{104}$. Samaten papiston osuutta yleisvaliokunnassa kasvatettiin, mikä paransi lähtökohtia teologiseen valmistelutyöhön.

Valitsijamiehet pyrkivät ottamaan henkilövalinnoissaan huomioon nuorten aikuisten osuuden, mikä näkyi esimerkiksi kirkon ulkoasiain neuvoston kokoonpanossa. Lisäksi kirkkolakiin 200o-luvulla otetut tasa-arvolain vaatimukset vaikuttivat selvästi ulkoasiain neuvoston sekä kirkon sopimusvaltuuskunnan - sittemmin kirkon työmarkkinalaitoksen valtuuskunnan - jäsenten valintaan. ${ }^{105}$ Vuonna 2004 enemmistö kirkolliskokouksen valitsemista kirkkohallituksen täysistunnon jäsenistä oli ensi kertaa naisia. Seurakuntatalous ja -rakenteet olivat 200o-luvulla ajankohtaisia keskustelunaiheita, mikä näkyi myös siinä, että monissa hiippakunnissa ehdotettiin kirkkohallituksen jäseneksi talous- tai hallintojohtajaa. Ongelma oli sama kuin 1970-luvulla, jolloin ehdolla oli ollut monia seurakuntien viranhaltijoita. ${ }^{106}$ Valitsijamiehet pyrkivät monipuolistamaan kirkkohallituksen kokoonpanoa mutta pitämään samalla mahdollisuuksien mukaan kiinni hiippakuntien ehdotuksista. ${ }^{107}$

Kirkolliskokouksen ryhmätoiminta voimistui vuosikymmenen kuluessa, joskin eduskuntaan verrattuna se säilyi edelleen löyhänä. Niin sanotulla tunnustuksellisella ryhmällä oli pitkät perinteet, mutta "uudistusmielisten ryhmä" organisoitui uudella tavalla 2008. Noin parinkymmenen edustajan ryhmän ytimen muodostivat Tulkaa kaikki -liikkeen suosituslistalta valitut edustajat. Vastuuhenkilönä oli Korson kirkkoherra Kari Pekka Kinnunen. Myös Tulkaa kaikki -liikkeen toimintaryhmä kävi istuntokausien molemmin puolin läpi kirkolliskokouksen asioita ja valmisteli toimintaa kirkolliskokouksessa. ${ }^{108}$

Ryhmäjako näkyi selvästi valittaessa pappisjäsentä kirkkohallituksen täysistuntoon vuonna 2009. Valitsijamiesten ehdokas oli Hamina-Vehkalahden seurakunnan kirkkoherra Jari Pennanen, jolla oli "uudistusmielisten ryhmän" ja useiden kansankirkollisuutta korostavien edustajien tuki. "Tunnustukselliset" edustajat nostivat kuitenkin täysistunnossa esille kirkolliskokousedustajan, Savonlinnan kristillisen opiston rehtorin Teuvo V. Riikosen, joka ei ollut ollut lainkaan esillä valitsijamiesten kokouksessa. Vaalista tuli kahden kamppailu, jossa Jari Pennanen sai lopulta kaksi kolmasosaa äänistä. Keskustelu äityi hyvin kiivaaksi. Arkkipiispa Paarma esitti puheenjohtajan paikalta jopa poikkeuksellisia nuhteluja, kun oli epäilty, että kirkkohallitus itse oli halunnut ohjata uuden jäsenensä valintaa. ${ }^{109}$

Vaalien valmistelu oli 200o-luvulla avoimempaa ja ehdokkaiden tutkiminen tarkempaa kuin aiemmin. Muutos oli alkanut jo 1990-luvun lopulla. Se koski erityisesti kirkkoneuvosten valintaa, jossa valitsijamiehet ottivat käyttöön haastattelut ja psykologiset henkilöarvioinnit. ${ }^{110}$ Toisaalta täysistunto käytti vielä uuden vuosituhannen alkaessa epäröimättä valtaansa. Kirkolliskokous valitsi vuonna 2000 talousosaston johtajana toimivaksi kirkkoneuvokseksi hallintojohtaja Leena Rantasen, vaikka valitsijamiehet olivat esittäneet virkaan johtavaa konsulttia Juha Tuohimäkeä. Äänestystulokseen vaikutti mitä ilmeisimmin myös tasa-arvolaki, johon viitattiin usein 2000-luvun kirkollisissa henkilövalinnoissa. Entinen kaupunginviskaali Ritva Santavuori epäili täysistunnossa, oliko valitsijamiesten esitys lainmukainen, koska Rantanen oli ansioituneempi ja kokeneempi ehdokas. Rantanen oli kirkkoneuvoksen virassa kautta aikain ensimmäinen nainen. ${ }^{111}$

Vuonna 2001 toiminnallisen osaston johtajaa valittaessa täysistunto väläytti jälleen valtaansa. Kankaanpään kirkkoherra Keijo Rainerma nousi täysistunnossa näkyväksi haastajaksi Heinolan maaseurakunnan kappalaiselle Seppo Häkkiselle. Vaalissa ilmeni selvää herätyskristillisyyden ja kansankirkollisuuden välistä vastakkainasettelua. Valitsijamiesten toteuttamat uudenlaiset testit hakivat puolestaan vielä sikäli muotoaan, että psykologisten henkilöarvioiden tuloksia päätyi jopa julkiseen täysistuntokeskusteluun. ${ }^{112}$ Lopulta Häkkinen valittiin kirkkoneuvokseksi 80 äänellä Rainerman saadessa 22 ääntä. ${ }^{113}$

Vuosina 2008-2010 kirkkohallituksen johdossa tapahtui suuri muutos, kun kuudesta kirkkoneuvoksesta neljä vaihtui. Ensin hallinto-osaston johtoon valittiin Matti Halttusen seuraajaksi Mikkelin hiippakunnan lakimiesasessori Pirjo Pihlaja ${ }^{114}$. Vuonna 2009 Mikkelin 


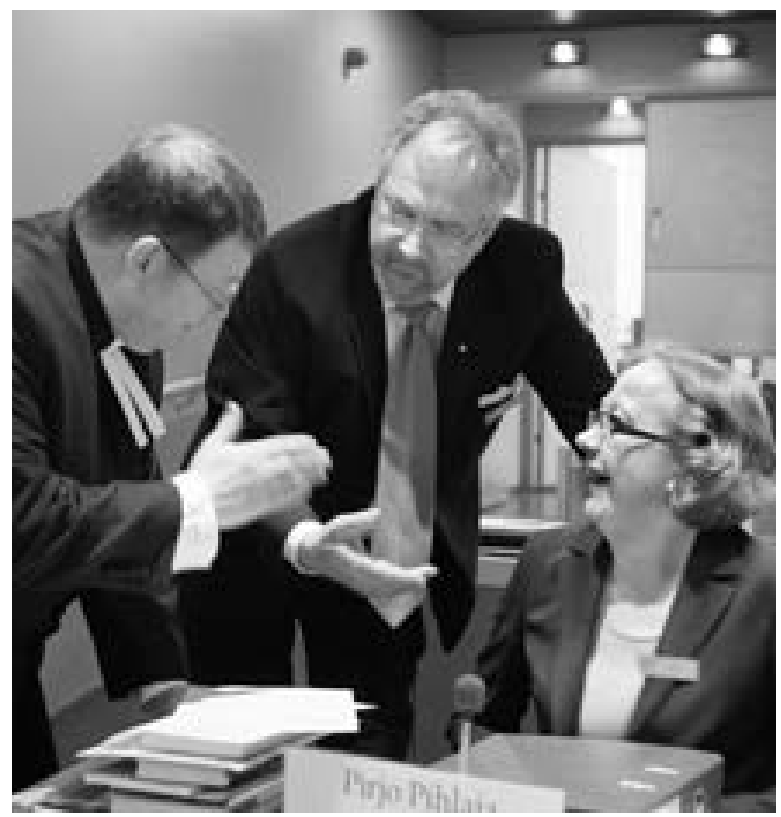

Vuonna 2008 kirkkohallitukseen matkasi useita henkilöitä Mikkelin hiippakunnasta. Mikkelin maaseurakunnan kirkkoherra Pekka Huokuna (vas.) valittiin täysistunnon pappisjäseneksi ja hieman myöhemmin kirkkoneuvoksen virkaan. Toinen kirkolliskokousedustaja, seurakuntaneuvos Risto Rasimus valittiin täysistunnon maallikkojäseneksi, ja tuomiokapitulin lakimiesasessori Pirjo Pihlaja puolestaan siirtyi kirkkoneuvokseksi. Kuva: Kotimaan kuva-arkisto / Matti Karppinen.

maaseurakunnan kirkkoherra Pekka Huokuna valittiin toiminnallisen osaston johtajaksi, kun Seppo Häkkinen siirtyi Mikkelin piispaksi. Tällä kertaa valitsijamiehet pyrkivät huolehtimaan ehdokkaiden yksityisyyden suojasta, mikä taas osaltaan aiheutti täysistunnossa arvostelua salailusta. ${ }^{115}$ Vuotta myöhemmin kirkolliskokous valitsi kansliapäälliköksi Jyväskylän kirkkoherran Jukka Keskitalon ja ulkoasiain osaston johtajaksi kirkon tutkimuskeskuksen johtajan Kimmo Kääriäisen. ${ }^{116}$ Edellisen vuoden arvostelun johdosta edustajat saivat käyttöönsä salaiset henkilöarvioinnit. Varsinainen keskustelu ehdokkaista käytiin suljetuin ovin ja pöytäkirjan ulkopuolella, mikä oli aivan uutta kirkolliskokouksen täysistunnoissa. Täysistunnon julkisuusperiaate murtui, mutta toisaalta edustajien tiedonsaanti ja ehdokkaiden tietosuoja parantuivat.
HUOLI NUORISTA AIKUISISTA JA KIRKON JÄSENYYDESTÄ UUDISTUSTEN PONTIMENA

\section{STRATEGIATYÖSKENTELY EPÄVARMAN TULEVAISUUDEN EDESSÄ}

Epävarmojen tulevaisuudennäkymien edessä kirkon keskushallinnossa alkoi vuosituhannen vaihtuessa strategiatyö. Suunnittelutyön ajankohtaisena taustana voi osaltaan nähdä sen, että strategiatyöskentely oli alkanut levitä yritysmaailmasta niin valtionhallintoon kuin eri kirkkoihinkin. Kirkon strategiatyö laajentui sittemmin voimakkaasti ja löi leimansa koko seuraavaan vuosikymmeneen. Aluksi kirkkohallituksen asettama toimikunta ryhtyi valmistelemaan kirkon yleistä missiota, visiota ja strategiaa vuotta 2010 ajatellen. Luonnos Läsnäolon kirkko valmistui keväällä 2002. Asiakirjassa pohdittiin erityisesti ihmisten kohtaamista ja mahdollisuuksia säilyttää kansankirkko. Myös kirkon tuleva työntekijäkunta ja talous olivat esillä. Valmisteluprosessin aikana kirkolliskokousedustajat saivat vuosina 2002-2003 esittää kommenttejaan luonnoksista. ${ }^{117}$ Tällöin sovellettiin ensi kertaa uuden työjärjestyksen säännöstä, joka mahdollisti kirkkohallituksen ilmoituksen. ${ }^{118}$

Kyseessä oli varsinaisesti kirkon keskushallinnon strategiaprosessi, mutta tavoitteena oli antaa nopeiden muutosten keskellä yhteinen suunta koko kirkolle. Kirkolliskokouksessa jotkut pelkäsivät, että talousmaailmasta omaksutun strategiakielen mukana kirkkoon kulkeutuisi vaivihkaa kristilliselle opetukselle vieraita ajattelutapoja. Espoolainen koulutuskonsultti Linda Lawast-Slotte katsoi ensimmäisen strategialuonnoksen sisältävän markkinatalousajattelua: kirkon jäsen maksoi vapaaehtoista jäsenmaksuaan saadakseen tiettyjä tuotteita. Myöhempi ehdotus painotti tässä mielessä enemmän kirkon omaleimaisuutta. Oleellista oli kohdata ihmiset henkilökohtaisella tasolla, vahvistaa jäsenten siteitä kirkkoon ja liikkua ihmisten luokse. Siten kirkon oli asiakirjan mukaan mahdollista säilyä kansankirkkona, vaikka kirkkoon kuuluvien osuus pienentyisikin. ${ }^{119}$

Harva osasi kuvitella, miten ajankohtaisia tällaiset pohdinnat olivat. Seuraavana vuonna tuli voimaan uusi uskonnonvapauslaki, joka helpotti kirkosta eroamista huomattavasti: henkilökohtaisen ilmoituksen sijasta ero oli mahdollista hoitaa kirjallisesti tai sähköisesti ${ }^{120}$. 
Vuoden 2004 alussa astui voimaan uusi hautaustoimilaki, joka takasi kirkkoon kuulumattomalle samanhintaiset hautausmaksut kuin kirkon jäsenelle. ${ }^{121}$ Kun samaan aikaan entistä useampi suomalainen koki kirkon itselleen melko merkityksettömäksi, tällaiset uudistukset toimivat käytännön pontimina kirkosta eroamiselle. Monet kirkolliskokousedustajat katsoivat hautaustoimilain murentavan kirkon jäsenyyttä. Ylipäätään keskustelu kirkon jäsenyydestä voimistui, ja jotkut pa- pit kieltäytyivät julkisesti siunaamasta hautaan kirkkoon kuulumattomia. ${ }^{122}$ Yhtäkkiä elettiin strategiassa kuvaillussa tilanteessa: oli pyrittävä toimimaan kansankirkkona jäsenmäärän vähenemisestä huolimatta, ja kirkon siteitä jäseniinsä oli yritettävä vahvistaa samaan aikaan, kun näiden samojen jäsenten hautausmaksuja jouduttiin korottamaan.

Kirkon jäsenyys pysyi sittemmin jatkuvasti esillä kirkolliskokouksessa. Keväällä 2004 kaksi Espoon hiip-

\section{Helppo ero, edullinen hautapaikka}

Kirkolliskokous antoi keväällä 2001 lausunnon uskonnonvapauskomitean mietinnöstä. Kokous oli kaikkiaan tyytyväinen komitean esityksiin, joskin se katsoi, että uskonnollisesta yhdyskunnasta eroavalta tuli vastaisuudessakin edellyttää henkilökohtaista ilmoitusta. Vaatimus ei toteutunut. Kokonaisuuteen sisältyi myös esitys hautaustoimilaiksi. Hautaustoimi määriteltiin luterilaiselle kirkolle viranomaistehtäväksi, minkä vuoksi hautaamista koskevat maksut eivät saaneet riippua seurakuntaan kuulumisesta. Kirkolliskokous hyväksyi tämän periaatteen. ${ }^{\mathrm{I}}$

Elokuussa 2003 uskonnonvapauslain tullessa voimaan tunnelma oli kirkossa rauhallinen. Kirkosta eroamisen ei uskottu

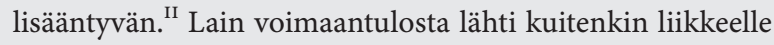
kirkosta eroaminen, joka osoittautui pitkäkestoiseksi ilmiöksi. Merkittäviksi sysäyksiksi paljastuivat eroamisen helppous sekä se, etteivät seurakunnan jäsenet enää saaneet alennuksia hautaustoimen maksuista. Suomalaiset pitivät hautausmaiden ylläpitoa yhtenä kirkon tärkeimmistä toimintamuodoista, joten asia oli herkkä. ${ }^{\text {II }}$

Samalla ääni muuttui kirkolliskokouksessa. Vaalikauden päätöspuheessaan syksyllä 2003 arkkipiispa Jukka Paarma luonnehti hautaustoimen maksujen lakisääteistä tasaamista "suomalaisten oikeustajua loukkaavaksi asiaksi". ${ }^{\text {IV }}$ Seuraavana keväänä oikeustieteen kandidaatti Ritva Santavuori jätti edustaja-aloitteen, jonka yhtenä päämääränä oli kartoittaa edellytykset samanmaksuisuuden periaatteesta poikkeamiseksi. ${ }^{\mathrm{V}}$ Kulttuuriministeri Tanja Karpela joutui tervehdyssanoissaan huomauttamaan, ettei kirkolliskokous ollut aikanaan arvostellut yhdenhintaisuutta. ${ }^{\text {VI }}$ Kirkolliskokous pidättyi melko tiukan äänestyksen jälkeen välittömistä toimista mutta piti tilanteen seuraamista tarpeellisena. ${ }^{\text {VII }}$

Edellisen, vuoden 1923 uskonnonvapauslain voimaantulon alla kirkossa oli pelätty joukkoeroa. Sitä ei ollut kuitenkaan tullut. ${ }^{\text {VIII }}$ Kahdeksan vuosikymmentä myöhemmin kävi tie-

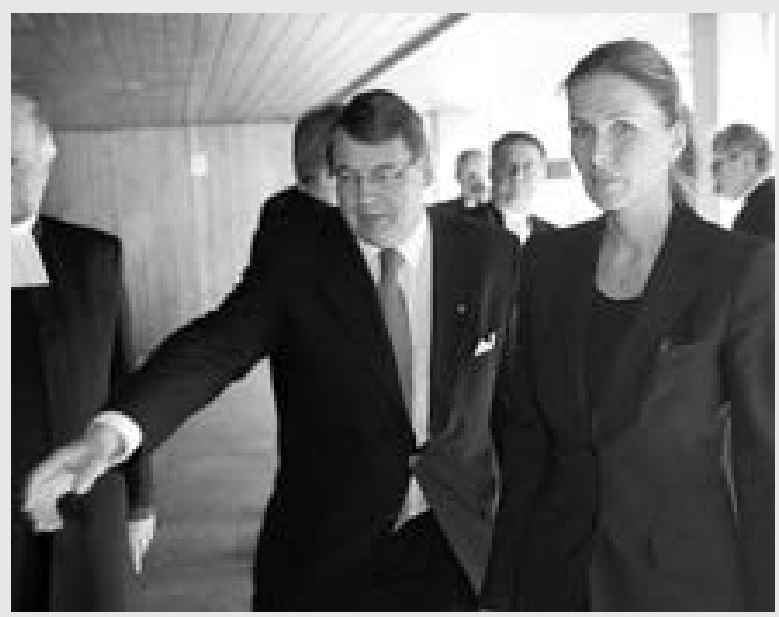

Valtioneuvoston määräämä edustaja, kulttuuriministeri Tanja Karpela ja hänen varaedustajansa, hallintojohtaja Håkan Mattlin saapuivat Turun kristilliselle opistolle vaalikauden avajaispäivänä toukokuussa 2004. Voimaan tullut hautaustoimilaki puhutti kirkolliskokouksessa ja oli keskeinen aihe myös ministerin tervehdyspuheessa. Kuva: Kotimaan kuva-arkisto / Matti Karppinen.

tyssä mielessä päinvastoin: kirkolliskokouksen kiittämä lainsäädäntö laukaisi yllättäen eroamisten vyöryn. Kirkon jäsenyyden pidikkeet osoittautuivat heikommiksi kuin aikoinaan nuoressa tasavallassa.

I Kirk.kok. ptk-k. 2001,52 \$; SEK 200o-03, 27, 29; Seppo 2003b, 93.

II Kmaa 15.8.2003 Uskonnonvapauslaki ei vauhdittane kirkosta eroamista (Juliska Lehtinen).

III SEK 2000-03, 29, 57, 61, 89, 97, 261.

IV Kirk.kok. kptk-s. 2003, 61 \$.

V Kirk.kok.ptk-k. 2004, liite IX 3.

VI Kmaa 7.5.2004 Kulttuuriministeri Karpela vieraili maanantaina Turussa kirkolliskokouksen avajaisissa: Tekijänoikeuslain kritiikki on otettava vakavasti (Johannes Ijäs).

VII Kirk.kok. ptk-k. 2004, 78 \$, liite X-D 3 .

VIII Seppo 2003b, 45. 
pakunnan edustajaa, Radio Dein toimitusjohtaja Kirsi Rostamo ja kirjailija Anna-Mari Kaskinen, ehdotti asiantuntijatyöryhmän perustamista kirkon jäsenyyden vahvistamiseksi. ${ }^{123}$ Kirkkohallitus käynnisti pian kolmivuotisen projektin aloitteen pohjalta. ${ }^{124}$ Jäsenyyden vahvistamisen ohella yksi strategian pääkysymyksistä oli sitoutuneen työvoiman saaminen. Kirkolliskokous kohtasi tämänkin teeman käytännön työssään. Vuonna 2004 yhteensä 13 edustajaa jätti tutkija, pastori Pauliina Kainulaisen johdolla aloitteen, joka tähtäsi kirkon työhön opiskelevien hengellisen kasvun tukemiseen. Taustalla oli tietoisuus siitä, että yhä harvemmalla opiskelijalla oli herätysliiketausta tai muunlainen kosketus käytännön seurakuntaelämään. ${ }^{125}$ Kirkolliskokous lähetti aloitteen kirkkohallitukselle toimenpiteitä varten. ${ }^{126}$

Kirkolliskokouksen kriisitietoisuus lisääntyi varsinkin vuonna 2004. Tuoreen nelivuotiskertomuksen laskevat tilastokäyrät antoivat aihetta pohdiskeluun. Edustajat kaipasivat visioita, dynaamisuutta ja missionaarisuutta. ${ }^{127}$ Myös arkkipiispa Paarma totesi syysistuntokauden päätöspuheessa, että oli yritettävä hahmottaa visioita, joiden avulla voisi aiempaa paremmin ohjata kirkon toimintaa, taloutta ja hallintoa. ${ }^{128}$ Aika oli jo kypsä uudelle strategiatyöskentelylle, joka alkoi seuraavana vuonna Lapuan piispan Simo Peuran johdolla. Tähtäyspisteenä oli vuosi $2015 .{ }^{129}$ Kirkon ydinsanoma pyrittiin turvaamaan strategiatyössä jo alusta lähtien. ${ }^{130}$ Kun kirkolliskokous keskusteli 2007 strategiatyöryhmän väliraportista, edustajat kiinnittivät huomiota muun muassa vapaaehtoistyöhön, kirkon jäsenyyteen ja yhteisöllisyyteen. Teemat olivat hyvin ajankohtaisia kirkon jäsenmäärän pienentyessä ja taloudellisten näkymien heiketessä. Esille nousivat myös lähetystyö, kristillinen kasvatus ja lunastus, jotka edustivat kristinuskon erityistä sanomaa. ${ }^{131}$

Kirkkohallitus hyväksyi helmikuussa 2008 lopullisen strategian Meidän kirkko - osallisuuden yhteisö. Strategia loi vision kirkosta, jossa jäsenet kuulivat Jumalan äänen, jonne tultiin löytämään vastauksia elämän suuriin kysymyksiin ja josta lähdettiin palvelemaan Jumalan maailmaa. Vision toteutumiseksi oli vahvistettava hengellistä elämää ja kirkon jäsenyyttä, huolehdittava heikko-osaisista ja pyrittävä vuorovaikutteiseen viestintään. ${ }^{132}$ Asiakirjan pohjalta syntyi seuraavan nelivuotiskauden aikana miltei parikymmentä strategiaa kirkon eri työmuodoille. ${ }^{133}$
Strategian valmistuminen ei riittänyt 2008 valitulle kirkolliskokoukselle, vaan vaalikauden alkaessa varsinkin pappisedustajat kantoivat huolta strategian siirtämisestä käytännön toimintaan. Seinäjoen kirkkoherra Tapio Luoma ehdotti, että kirkkohallituksen ja hiippakuntien toimintasuunnitelmat ja -kertomukset jäsennettäisiin vastaisuudessa strategian pohjalta. ${ }^{134}$ Yleisvaliokunta yhtyi ajatukseen. ${ }^{135}$ Seuraavissa toimintasuunnitelmia ja -kertomuksia koskevissa mietinnöissään kirkolliskokouksen valiokunnat saivatkin jo kiitellä sitä, että strategian tavoitteet olivat näkyvästi esillä. ${ }^{136}$ Kirkolliskokous pyrki muutenkin seuraamaan ajankohtaisia signaaleja, joista yksi oli uusateismin nousu otsikoihin 2008. ${ }^{137}$

Edelleen vuonna 2008 kaikkiaan 18 edustajaa jätti aloitteen, jonka mukaan kirkolliskokouksen työtä oli entistä laajemmin suunnattava tulevaisuuden visiointiin. Mahdollisina toimenpiteinä mainittiin tulevaisuusvaliokunnan perustaminen ja tulevaisuusselonteon laatiminen kerran vaalikaudessa. ${ }^{138}$ Eduskunnassa vastaavat toimet olivat toteutuneet laman keskellä 1993, ja tulevaisuusvaliokunnan asema oli vakiinnutettu perustuslakiuudistuksessa. ${ }^{139}$ Sen jälkeen kirkolliskokouksessa oli toistuvasti keskusteltu tulevaisuusvaliokunnan perustamisesta, ja kirkossakin nimenomaan kriisitunnelmat olivat vauhdittaneet keskustelua. ${ }^{140}$ Kirkolliskokouksessa tulevaisuusvaliokunnan tehtävä oli ollut aluksi epävirallisesti yleisvaliokunnan toisella osastolla, joka oli kutsunut myös eduskunnan tulevaisuusvaliokunnan vieraakseen. ${ }^{141}$ Eduskunnassa kansainvälisesti ainutlaatuisen valiokunnan asema oli jäänyt alusta lähtien hiukan avoimeksi. ${ }^{142}$ Kirkolliskokouksessakaan ehdotukset erillisestä tulevaisuusvaliokunnasta eivät olleet vuosien kuluessa johtaneet tulokseen.

Vuonna 2008 kävi toisin. Kirkolliskokous päätti perustaa seuraavan toimikautensa alussa pysyvän tulevaisuusvaliokunnan. Samalla toimintasuunnitelmien ja -kertomusten käsittely päätettiin keskittää talousvaliokunnalle. Näin toiminnallinen vastuu, joka oli aluksi ollut pääasiassa toimikuntavaliokunnalla ja siirtynyt siltä yleisvaliokunnalle, päätyi lopulta keskitetysti talousvaliokunnalle. Edelleen päätettiin, että kirkkohallitus antaisi kirkolliskokoukselle neljän vuoden välein tulevaisuusselonteon - aivan samoin kuin valtiollisessa päätöksenteossa hallitus antoi tällaisen selonteon eduskunnalle. ${ }^{143}$ 
Kirkolliskokous sai syksyllä 2010 ensimmäisen selonteon, joka nojautui monipuoliseen tutkimustietoon. ${ }^{144}$ Selonteko käsiteltiin perusteellisesti kirkolliskokouksessa: valmistelutyöhön osallistuivat yleisvaliokunnan toisen osaston johdolla lähes kaikki valiokunnat sekä lisäksi piispainkokous ja hiippakuntavaltuustot. ${ }^{145}$

Kirkolliskokouksessa selontekoa ja sen valiokuntakäsittelyä kiiteltiin laajalti. Edustajien katseet olivat kuitenkin paljolti menneisyydessä ja erityisesti aiemmissa pettymyksissä. Vaikka käsittelyssä oli nimenomaan tulevaisuusselonteko, harvassa olivat ne, jotka innokkaasti katsoivat kirkon tulevaisuuteen. ${ }^{146}$ Kirkon jäsenmäärän laskiessa ja sisäisten ristiriitojen vaivatessa edustajien oli vaikea tähytä eteenpäin. Edessä näkyi lähinnä varautumista puolustustaisteluun kirkon asemasta tai omasta asemasta kirkossa. Viimeksi mainittu huoli oli omiaan vaikeuttamaan todellista strategisten painopistealueiden valikoimista.

Espoon hiippakuntadekaani Kai Peltonen tiivisti, että kirkolliskokouksenkin huomio oli kasvuun tähtäävien toimien sijasta säilyttävissä ja tehostavissa toimenpiteissä. Peltonen totesi, ettei hän vuosia kestäneen strategiatyöskentelyn jälkeen osannut tyydyttävästi kertoa, mikä oli kirkolliskokouksen kanta kirkon perustehtävään tai näky kirkosta:

Kirkolliselle strategia- ja visiopuheelle on ominaista eräänlainen ylidiplomaattinen ote. Dokumentteja kirjoitetaan sillä silmällä, ettei mikään tärkeä kirkollinen toimija tai organisaation osa kokisi itseään unohdetuksi tai syrjäytetyksi. Tämä johtaa siihen, että strategiadokumentit ovat pääosin hahmotonta massaa, jossa on työlästä erottaa oleellista epäoleellisesta ja toteuttamiskelpoista konkretiaa hurskaasta toiveajattelusta. - - Kun hehtaaripyssyllä ammutaan, lukuisten hutien sekaan mahtuu aina joku osumakin. Sen perusteella voidaan sitten sanoa, että strategia toteutui. Samanaikaisesti kokonaisuus ei ole kuitenkaan muuttunut miksikään ja ongelmat ovat entisiä. ${ }^{147}$

Vaikka konkreettisten tavoitteiden yksilöiminen ei ollut kirkolliskokoukselle helppoa, moni edustaja kaipasi Peltosen tavoin terävöitettyjä tavoitteita ja käytännön toimia. Espoon piispan Mikko Heikan ehdotuksesta kirkolliskokous pyysi, että seuraavalla vaalikaudella asetettava tulevaisuusvaliokunta esittäisi konkreettisia toimenpide-ehdotuksia tulevaisuustyöskentelyn pohjalta. ${ }^{148}$
Arkkipiispa Paarma peräänkuulutti kirkolliskokouksessa visiointia, mutta vaalikauden avauspuheessa keväällä 2008 hän myös määritti kirkolliskokouksen toiminnan rajat. Kirkolliskokouksen tehtävänä oli pitää huolta siitä, että kirkon rakenteet antoivat hengelliselle elämälle tilan ja mahdollisuudet voida hyvin: hallinnollisilla päätöksillä voitiin luoda mahdollisuuksia mutta harvoin kestäviä toiminnan uudistuksia. Viimeksi mainitut lähtivät yleensä seurakuntatasolta. ${ }^{149}$ Hieman samanlaisia äänenpainoja oli kuultu 1975, jolloin Porvoon piispa John Vikström oli varoittanut sitomasta "kirkon hulluja" eli käytännön toiminnasta vastaavia henkilöitä "kirkon viisaiksi" eli osaksi päätöksenteko-organisaatiota. Vikströmin pelkona oli ollut, että kirkolliskokous olisi kytkenyt kirkon toiminnan liian tiukasti itseensä, ja sama huoli kuulsi arkkipiispa Paarman sanoista.

Paarman sanoista huolimatta "hullujen" ja "viisaiden" välinen raja madaltui kirkon keskushallinnossa 1990-luvulta lähtien siten, että kirkolliskokouksen huomio kiinnittyi lakipykälien ja rakenteiden sijasta entistä enemmän toiminnalliseen strategiatyöhön. Tutkimuskauden päättyessä saldona oli lukuisia kirkkohallitukselle välitettyjä toiminnallisia aloitteita ja satoja sivuja strategista pohdintaa. Nämä tekstit ja täysistunnossa käydyt strategiakeskustelut johtivat kuitenkin vain harvoihin muutoksiin varsinaisissa rakenteissa eli sillä alalla, jonka Vikström ja Paarma olivat määritelleet kirkolliskokouksen todelliseksi vastuualueeksi.

\section{KUMMIUS KIRKON JÄSENYYDEN \\ ILMAPUNTARINA}

Vuosituhannen alussa kirkon keskushallinnossa tutkittiin uuden nelivuotiskertomuksen sisältämiä tietoja. Niiden mukaan perheiden ongelmat olivat lisääntyneet. Jos kirkon jäsenyyttä oli määrä vahvistaa, liikkeelle oli lähdettävä kodeista ja niiden kristillisestä kasvatuksesta. ${ }^{150}$ Piispainkokous ja kirkkohallitus kirjasivat nelivuotiskertomusta koskevaan lausuntoonsa, että kummiuden merkitys alkoi korostua ja että kummeille tarvittiin siksi valmennusta. ${ }^{151}$ Sittemmin kummius pysyi kirkolliskokouksen esityslistalla pitkin vuosikymmentä ilmentäen samalla muutoksia kirkon jäsenyydessä.

Piispainkokous asetti 2002 työryhmän selvittämään kummiuden teologista perustaa ja käytännön toteutumista sekä tekemään ehdotuksen kummiuden tuke- 
miseksi ja vahvistamiseksi. Valmistelun pohjalta piispainkokous pyysi 2004 valtuuksia määrätä tietyistä kummiutta koskevista asioista. Tällaisia olivat esimerkiksi kummiuden riistämisen tai kummien lisäämisen edellytykset. ${ }^{152}$ Taustalla olivat seurakunnissa koetut paineet. Alun perin kummien lisääminen oli tarkoitettu tilanteisiin, joissa kummius ei lainkaan toiminut esimerkiksi adoption tai kummien kuoleman vuoksi. Myöhemmin seurakunnissa oli kuitenkin jouduttu jossain määrin tinkimään näistä tiukoista periaatteista. ${ }^{153} \mathrm{Ko}$ konaisuuteen liittyivät lisäksi muut kummiusinstituution ongelmat. Launeen kappalainen Markku Tynkkynen vei täysistunnossa huomiota kirkkoherranviraston ulkopuoliseen maailmaan, jossa vanhemmat eivät välttämättä tyytyneet kirkon määrittelemiin kummin kelpoisuusehtoihin vaan antoivat itsenäisesti kummin statuksen esimerkiksi kirkkoon kuulumattomille ystävilleen. ${ }^{154}$

Kirkolliskokous katsoi piispainkokouksen esittämän säännöksen olevan kirkkolainsäädännön kokonaisuuden kannalta ongelmallinen ja jätti esityksen raukeamaan. Erimielisyyttä oli myös siitä, missä määrin kummiudessa oli kyse kristillisestä kasvatuksesta, missä määrin taas kasteen todistamisesta. Todistamistehtävän kannalta kummien lisääminen ei ollut yhtä perusteltua kuin kristillisen kasvatuksen näkökulmasta. ${ }^{155}$ Mediassa piispainkokouksen esitys ja sen käsittely kirkolliskokouksessa saivat osakseen paljon huomiota. Yleissävy oli kummiutta arvostava. ${ }^{156}$ Kirkolliskokous ei saanut yhtä myönteistä arviota. Kotimaa-lehti otsikoi: "Seurakunnat kaipaavat ohjeita, kirkolliskokous junnaa". ${ }^{157}$ Arkkipiispa Paarma lupasi tosin jo tuoreeltaan, että asian käsittely jatkuisi piispainkokouksessa. ${ }^{158}$

Seuraavana vuonna piispainkokous esitti, että kummien asemasta säädettäisiin kirkkojärjestyksessä. Esityksen mukaan kummin tehtävää ei voinut riistää, mutta kummien lisääminen oli erityisistä syistä mahdollista lapsen kristillisen kasvatuksen turvaamiseksi. Tällaisina syinä mainittiin esimerkiksi kummin kuolema tai eroaminen kirkosta. Varsinkin jälkimmäinen peruste oli tuolloin ajankohtainen. Piispainkokous ehdotti, että päätöksen kummien lisäämisestä tekisi seurakunnan kirkkoherra vanhempien esityksestä. Kirkolliskokous päätti lisätä säännöksen kirkkojärjestykseen. Säännös ilmensi pyrkimystä vastata joustavasti seurakuntalaisten tarpeisiin, mutta toisaalta ehdot kummien lisäämisek- si yritettiin pitää mahdollisimman tiukkoina: kummiuden tuli olla kirkon tehtävä eikä ystäväpiirin laajentamislaitos. ${ }^{159}$

Kirkon jäsenyyden löyhtyminen alkoi vähitellen uhata kristillisen kasvatustehtävän lisäksi myös kasteiden toteutumista. Entistä useammin lapsi oli jäädä kastamatta sen vuoksi, etteivät vanhemmat löytäneet kahta kelpoisuusehdot täyttävää kummia. Vuonna 2009 kirkolliskokous sai sekä Helsingin hiippakuntavaltuuston esityksen että edustaja-aloitteen, joiden tarkoituksena oli mahdollistaa yhden kummin järjestelmä. ${ }^{160}$ Aloitteiden keskeinen perustelu oli kasteen ensisijaisuus: oli pidettävä kiinni siitä, ettei yksikään aiottu kaste jäänyt toteuttamatta. Toisaalta kirkolliskokouksessa heräsi kysymys, toteutuivatko lapsikasteen edellytykset - myöhempi kasteopetus ja yhteys uskonyhteisöön - Suomen tilanteessa silloinkaan, kun kummeja oli säädetty määrä. ${ }^{161}$

Aloitteita puolsi se, että yhden kummin vaatimus oli monissa kirkoissa vallitseva. ${ }^{162}$ Toisaalta kysyttiin, miten ehdotettu muutos sopi pyrkimykseen korostaa kirkon jäsenyyttä. Oliko viisas tapa perääntyä ja väljentää jäsenyyden kriteerejä, vai tuliko ryhtyä vastaiskuun ja pyrkiä siten vahvistamaan kirkon jäsenyyttä? Piispa Seppo Häkkinen kysyi, oliko esimerkiksi kummiksi ehdotetuille kirkkoon kuulumattomille tarjottu riittävän rohkeasti mahdollisuutta liittyä kirkkoon. ${ }^{163}$ Edustajat miettivät myös aloitteiden antamaa viestiä. Kummien vähimmäismäärän alentamisella oli tarkoitus korostaa kastetta ja helpottaa sen toimittamista, mutta aiottu muutos näytti ulospäin ennemminkin kummiuden väheksymiseltä. ${ }^{164}$

Kirkolliskokous lähti ratkaisemaan ristiriitaista tilannetta muuttamalla kirkkojärjestystä siten, että kirkkoherra saattoi erityistapauksissa sallia kastettavalle yhden kummin. Toisaalta kirkolliskokous antoi kirkkohallituksen tehtäväksi valmistella kummeja tukevaa aineistoa seurakuntien käyttöön. ${ }^{165}$ Siten kokous pyrki samanaikaisesti yhtäl̈lä helpottamaan kirkkoon liittymistä ja toisaalta vahvistamaan kummiutta sekä kirkon jäsenyyttä. Kirkolliskokouksen vaikeana tehtävänä oli painottaa missionaarisuutta ja laskea kynnys kirkon sisälle mahdollisimman alas mutta samaan aikaan pyrkiä korottamaan jäsenten kynnystä astua ulos.

Sama jännite tuli esiin, kun kirkolliskokous ryhtyi uuden uskonnonvapauslain nojalla tarkentamaan kirkkolakia ja tulkitsemaan kirkkoon liittymisen ikärajoja. 
Asiaa kirkolliskokouksessa käsitellyt lakivaliokunta lähti siitä, että huoltajat voisivat kaikissa tapauksissa liittää 12 vuotta täyttäneen, alle 15-vuotiaan lapsensa tämän suostumuksella luterilaiseen kirkkoon. Näin kirkkoon kuulumattomien huoltajien lapsi voisi liittyä esimerkiksi rippikoulun yhteydessä seurakuntaan. Vastaavasti huoltajien erotessa kirkosta lapsi voisi suostumuksellaan pysyä kirkon jäsenenä. ${ }^{166}$ Perusteluissa ei kuitenkaan kiinnitetty huomiota siihen, että samoilla perusteilla kirkkoon kuuluvat huoltajat saattoivat ilmoittaa 12-14-vuotiaan lapsensa kirkosta eronneeksi tämän suostumuksella. ${ }^{167}$

Myöhemmin eduskunnan hallintovaliokunta lausui kirkolliskokouksen tekemän esityksen johdosta vakavia kysymyksiä. Valiokunta pohdiskeli, olivatko perheen uskonnollinen yhtenäisyys ja lapsen uskonnollisen aseman pysyvyys saaneet tarpeeksi huomiota uskonnonvapauslaissa ja sitä seuranneessa kirkolliskokouksen esityksessä. ${ }^{168}$ Tälläkin kertaa kirkolliskokous pyrki helpottamaan kirkkoon liittymistä. Kokous ei kuitenkaan ottanut huomioon, että samalla tingittiin perheen uskonnollisesta yhtenäisyydestä. Siten heikennettiin kristillisen kasvatuksen edellytyksiä ja näin ollen välillisesti myös kirkon jäsenyyttä. Lisäksi perusteet kirkkoon liittymisen helpottamiseksi toimivat myös toisin päin ja poistivat pidäkkeitä erota kirkosta.

Piispainkokouksessa ja kirkkohallituksessa oli 2000luvun alkuvuosina suunnitteilla lakimuutos, jonka myötä myös vailla kotikuntaa tai henkilötunnusta oleva ulkomaalainen maahanmuuttaja voisi liittyä seurakuntaan. Esitys osoittautui kuitenkin lainsäädännöllisesti niin hankalaksi, että kirkolliskokous palautti 2005 asian uudelleen kirkkohallitukselle valmisteltavaksi. ${ }^{169}$ Kirkkohallituksen esitys viipyi syksyyn 2011, mutta silloin se voitiin hyväksyä nopeasti ja kiitosten kera. ${ }^{170}$ Lakiesitys ja kirkolliskokouksen päätös kuvastivat maahanmuuton lisääntymistä ja halua toivottaa myös lyhyen aikaa maassa oleskelevat seurakunnan jäseniksi. Vaikka vuosikymmenen edetessä maahanmuuttokriittisyys voimistui yhteiskunnallisessa keskustelussa, kirkolliskokouksessa vastaavaa ilmiötä ei ollut havaittavissa ${ }^{171}$.

Kirkolliskokouksen päätös oli myös yksi esimerkki pyrkimyksistä helpottaa kirkkoon liittymistä. Tälläkin kertaa asialla oli kääntöpuolensa. Lakimuutoksen alkuperäiset ongelmat näet liittyivät osittain siihen, että samoilla perusteilla, joilla oli määrä mahdollistaa ulkomaalaisen väliaikainen jäsenyys kirkossa, pelättiin kirkon joutuvan määrittelemään suuri joukko ulkomaille muuttaneita suomalaisia kirkosta eronneiksi ${ }^{172}$. Kokonaiskuvaksi muodostuu, että kirkolliskokous pyrki 200o-luvun ensimmäisellä vuosikymmenellä helpottamaan monin tavoin kirkkoon liittymistä. Samalla kirkolliskokous tuli kuitenkin tietyillä toimillaan välillisesti heikentäneeksi kirkon jäsenyyttä. Näin tapahtui aikana, jolloin kirkon jäsenyyden vahvistaminen oli kirkolliskokouksen ja koko kirkon keskushallinnon keskeisimpiä strategisia tavoitteita. Kirkon kynnystä oli vaikea höylätä niin, että se olisi madaltunut vain tulijoille.

\section{KUUNTELEMAAN NUORTEN Ä̈̈NTÄ}

\section{VAALEISSA JA VERKOSSA}

Toimittaja Mauno Hyyryläinen jätti 1991 edustaja-aloitteen, jossa hän ehdotti äänioikeusikärajan laskemista kirkollisissa vaaleissa:

Seurakuntien luottamuselinten ikärakenne ei vastaa seurakuntien jäsenten ikäjakaumaa. Seurakuntien hallinnon ukkoutuminen ja akkautuminen jatkuu, jos nuorille ei anneta ajoissa vaikuttamisen mahdollisuuksia. - - Äänioikeus olisi annettava rippikoulun käyneille ja konfirmoiduille seurakunnan jäsenille välittömästi. Tällöin rippikoulussa aktivoituneita nuoria saataisiin ajoissa seurakunnan luottamustehtäviin ja päätöksentekoon. Rippikoulun käy lähes koko ikäluokka, joten heitä on kuultava. Vaalikelpoisuuden ikärajan alentaminen on eri asia. Seurakuntavaaleihin osallistuminen on nykyisin huolestuttavan vähäistä. - - Tässä tilanteessa on tehtävä kaikki voitava, jotta äänestysaktiivisuus lisääntyisi ja seurakuntien luottamustehtäviin saataisiin nykyistä enemmän nuoria. Kirkko voisi olla edelläkävijä ja näyttää, että se arvostaa ja haluaa kuulla nuorisoaan. Nuorten vallan kaappauksesta ei ole pelkoa. Vain nuoret itse tietävät ja tuntevat parhaiten, mitä he tarvitsevat ja mitä he odottavat kirkolta ja seurakunnalta. ${ }^{173}$

Aloitteessa tiivistyivät perustelut, jotka sittemmin kuultiin lukuisia kertoja kirkolliskokouksessa. Hyyryläinen yritti saada äänioikeusikärajan muutoksen myös osaksi kirkkolain kokonaisuudistusta, mutta tuo yritys sen enempää kuin edustaja-aloitekaan ei tuottanut tulosta. Keskustelut osoittivat kuitenkin, että lakimuutoksella oli kirkolliskokouksessa vahvat - joskin tuolloin melko vähälukuiset - tukijansa. ${ }^{174}$ 
Seuraavan kerran asia nousi kirkolliskokouksessa esille viisi vuotta myöhemmin, kun 11 edustajaa jätti lääkäri Paula-Maria Salosen (sittemmin Lehtipuu) johdolla edustaja-aloitteen. Perustelut olivat pitkälti samoja kuin edellisessä aloitteessa. ${ }^{175}$ Aloite sai tarkemman käsittelyn kuin edeltäjänsä mutta ei johtanut tulokseen. ${ }^{176}$ Kirkkojen maailmanneuvostossakin alettiin 1990-luvun lopulla keskustella näkyvästi nuorten osuuden voimistamisesta päätöksenteossa, ja Ruotsin kirkolliskokous päätti 1999 vilkkaan keskustelun jälkeen alentaa äänioikeusikärajan 16 vuoteen. ${ }^{177}$ Suomessakin äänioikeusikärajan alentaminen palasi kirkolliskokouksen esityslistalle jälleen uuden vuosituhannen alkaessa. ${ }^{178}$ Edelleen vuoden 2002 seurakuntavaalien yhteydessä syntyi keskustelua asiasta. ${ }^{179}$

Vuonna 2003 tutkimustulokset osoittivat, että nuorten aikuisten sitoutuminen kirkkoon ja luottamus kirkon kykyyn antaa vastauksia olivat heikentyneet. Tässä tilanteessa seurakunnat käynnistivät uusia työmuotoja nuorten aikuisten parissa. ${ }^{180}$ Samana vuonna kirkolliskokous havahtui todella nuorten aikuisten tavoittamiseen. Herättelijänä toimi erityisesti kokouksen nuorin edustaja, Helsingin oppilaitospastorin viransijaisuutta hoitanut Heli Pruuki. Hänen johdollaan syntyi edustaja-aloite, jonka tarkoituksena oli parantaa nuorten aikuisten mahdollisuuksia osallistua seurakuntien ja kirkon päätöksentekoon. ${ }^{181}$ Yleisvaliokunta esitti aloitteen jättämistä raukeamaan, mutta Pruukin vetoavan pu- heenvuoron jälkeen täysistunto lähetti sen selvin luvuin 75-25 kirkkohallitukselle toimenpiteitä varten. ${ }^{182}$

Vuonna 2004 alkaneella vaalikaudella nuorten aikuisten asia oli monin tavoin esillä. Silloin jätettiin esimerkiksi aloitteet nuorten aikuisten messusta ja jumalanpalveluksen alkamisajankohdan vapauttamisesta - osaltaan nuorten aikuisten tavoittamiseksi. ${ }^{1{ }^{83}}$ Samaan aikaan vaatimukset kunnallisvaalien äänioikeusikärajan laskemisesta voimistuivat, ja 2005 oikeusministeriön Kansalaisyhteiskunta 2006 -toimikunta ehdotti asian selvittämistä. ${ }^{184}$ Vuoden 2005 kirkkopäivillä pidetyssä nuorten aikuisten kirkolliskokouksessa arkkipiispa Paarma ilmoitti olevansa valmis äänioikeusikärajan laskemiseen. ${ }^{185}$ Samalla kun nuorten aikuisten eroaminen kirkosta kiihtyi, perustelut äänioikeusikärajan laskemiseksi saivat painoa.

Keväällä 2006 teologian ylioppilas Antti Siukonen, teologian maisteri Riikka Myllys, pastori Pauliina Kainulainen ja Tampereen Messukylän kirkkoherra Juha Kauppinen ehdottivat seurakuntavaalien äänioikeuden laskemista 16 ikävuoteen. Päätöksentekoon tarvittiin aloitteentekijöiden mielestä nuorten aikuisten osaamista, ja konfirmoidut nuoret oli pyrittävä sitouttamaan seurakunnan toimintaan - myös päätöksentekoon. ${ }^{186}$ Hallintovaliokunta viittasi mietinnössään esimerkiksi Keski-Euroopasta saatuihin kokemuksiin. Valiokunta kiinnitti huomiota myös siihen, että kirkollisia vaaleja olivat seurakuntavaalien ohella kirkkoherranvaalit.

\section{Picture removed from the open access version of this book.}

Keskustelu kirkollisen äänioikeusikärajan laskemisesta 16 vuoteen sai uuden sysäyksen 2005, kun arkkipiispa Jukka Paarma ilmoitti olevansa valmis uudistukseen. Börjen pilapiirros Hämeen Sanomissa 30. toukokuuta 2005. 
Valiokunta ehdotti, että kirkkohallitus valmistelisi esityksen äänioikeusikärajan laskemiseksi 16 ikävuoteen molemmissa vaaleissa. ${ }^{187}$

Vuodesta toiseen monet edustajat vetosivat muuhun lainsäädäntöön. Sieltä löytyi tukea niin aloitteen kannattajille kuin vastustajille. Kannattajat viittasivat esimerkiksi siihen, että 15-vuotias konfirmoitu kirkon jäsen oli kelpoinen vaativiin kummin, kerhonohjaajan ja rippikouluisosen tehtäviin tai että samanikäinen kantoi jo raskasta rikosoikeudellista vastuuta. Vastustajat taas vetosivat muun muassa siihen, että henkilö saattoi päättää itsenäisesti kuulumisestaan uskonnolliseen yhdyskuntaan vasta 18 -vuotiaana tai että kirkolliset vaalit edellyttivät äänestäjiltä samanlaista kypsyyttä kuin valtiolliset ja kunnalliset vaalit. ${ }^{188}$

Jotkut näkivät äänioikeusikärajan alentamisen uhkana nuorisotyölle, mutta aloitteen kannattajien mielestä tällaiselle vastakkainasettelulle ei ollut mitään syytä. ${ }^{189}$ Monet vastustajat syyttivät aloitetta populismista, kun taas kannattajien mielestä oli kyse vakavasta viestistä nuorille: heitä arvostettiin, ja heitä haluttiin aidosti kuunnella. ${ }^{190}$ Keskusteltiin myös siitä, oliko äänioikeusikärajan alentaminen omiaan lyhentämään lapsuutta. Jotkut epäilivät, olivatko nuoret itsekään halukkaita ottamaan vastaan äänioikeutta. ${ }^{191}$ Heli Pruuki vastasi arvosteluun toteamalla, ettei nuoren tarvinnut äänestää, jos hän ei tuntenut itseään siihen kypsäksi: "Hän saa, kuten kuka tahansa muukin meistä, itse valita äänestääkö hän." ${ }^{192}$ Perustelu sisälsi vahvan korostuksen äänestämisestä nimenomaan oikeutena, jota saattoi käyttää mutta jonka käyttämättä jättämisessä ei ollut mitään paheksuttavaa. Vastaavasti uudistuksen vastustajien argumenteissa näkyi ajattelua, että äänioikeus oli "seurakuntalaisvelvollisuus", jonka sälyttäminen nuorten harteille lyhensi lapsuutta.

Äänioikeusikärajan alentamisella pyrittiin nimenomaan sitouttamaan nuoria seurakuntaan, mutta uudistuksen taustalla oli nähtävissä ajattelutapaa, joka painotti seurakuntalaisten oikeuksia velvollisuuksien sijaan: äänestäminen oli vapaaehtoinen mahdollisuus, ei moraalinen velvoite. Voi kysyä, tukiko tällainen korostus omalta osaltaan sitä yleistynyttä asennoitumista, jossa seurakuntalaisen saamat palvelut ja oikeudet korostuivat velvollisuuksien kustannuksella. Tällöin kynnys liittyä kirkkoon luultavasti madaltui, mutta niin madaltui jälleen kerran myös kynnys lähteä. Kirkon jäsenyyden vahvistaminen ei ollut helppoa.

Hallintovaliokunnan mietintöä käsiteltäessä erityisen merkittäväksi osoittautui kirkkoneuvos Matti Halttusen esittämä arvostelu. Hän oli hyvin pettynyt siihen, ettei valiokunta ollut kuullut kirkkohallituksen tai oikeusministeriön edustajia vaan oli lähtenyt liikkeelle ulkomaisten esikuvien turvin. ${ }^{193}$ Kirkollisen äänioikeusikärajan kytkeytymistä muuhun vaalilainsäädäntöön olisi pitänyt vielä selvittää. Myöskään äänioikeus- ja vaalikelpoisuusikärajan irrottaminen toisistaan ei ollut itsestään selvää. Lopulta vielä kirkkoherranvaalin liittäminen uudistukseen oli Halttusen mielestä ongelmallista, koska tuossa vaalissa käytettiin suoraa ratkaisuvaltaa. Halttusen puheenvuoron jälkeen hallintovaliokunnan mietinnön epäilijöiden määrä lisääntyi. Siitä huolimatta valiokunnan ponsi voitti selvin numeroin 80-22. ${ }^{194}$ Vastaan äänestäneet, jotka kannattivat avoimemman selvitystehtävän antamista kirkkohallitukselle, olivat pääasiassa maallikkoedustajia. Paikalla olleista piispoista Simo Peura kuului tähän joukkoon, ja pappisedustajista siihen lukeutuivat rehtori Teuvo V. Riikonen sekä lähetysjohtaja Timo Rämä. ${ }^{195}$

Lehdistön kommentit päätöksestä jakautuivat. Esimerkiksi Kainuun Sanomien mielestä kirkolliskokous olisi voinut mennä pidemmällekin ja alentaa samalla vaalikelpoisuusikärajaa. ${ }^{196}$ Myönteinen kanta uudistukseen oli ymmärrettävä - olihan asian ensimmäinen ajaja Mauno Hyyryläinen lehden toimittaja. Kaleva ja Helsingin Sanomat olivat sen sijaan varauksellisia ${ }^{197}$. Viimeksi mainittu ihmetteli, että päätös oli syntynyt puolessa vuodessa, kun naispappeuden hyväksymiseen oli mennyt yli vuosikymmen. Lehti luonnehti päätöstä "paniikkiratkaisuksi", josta se löysi "kummallisia" puolia. ${ }^{198}$ Valtakunnan päälehti ei ottanut huomioon, että äänioikeusikärajakin oli ollut kirkolliskokouksen asialistalla lähes 16 vuotta. Kaikkiaan tulkintahorisontti näytti olevan monessa tapauksessa kirkolle lähtökohtaisesti kielteinen. Jos kirkolliskokous ei uudistanut, sen katsottiin olevan hidasliikkeinen ja menneisyyteen jämähtänyt. Kun kokous sitten oli viemässä läpi säännösmuutoksia, joiden toteuttamista muussa lainsäädännössä vasta harkittiin, sen voitiin tulkita olevan populistinen tai paniikissa.

Kirkkohallituksen valmistelussa korostuivat ne puolet, jotka kirkkoneuvos Halttusen mukaan olivat jääneet 
hallintovaliokunnalta liian vähälle huomiolle. Aloitteen takana olleet Antti Siukonen ja Riikka Myllys arvostelivat jatkovalmistelua eritoten siitä, että kirkkohallitus keskusteli oikeusministeriön kanssa uudistuksen vaikutuksista muihin vaaleihin. ${ }^{199}$ "Tietääkseni teimme päätöksen, ja tietääkseni emme päättäneet mitään eduskuntavaaleista, kunnallisvaaleista tai tasavallan presidentin vaaleista", Siukonen sanoi. ${ }^{200}$ Oikeusministeriön kanssa käydyissä keskusteluissa ilmenikin ongelmia, mutta opetusministeriö oli asialle myönteinen. ${ }^{201}$

Lopulta kirkkohallitus toi vaalikauden viimeiselle istuntokaudelle syksyllä 2007 esityksen seurakuntavaalien äänioikeusikärajan laskemisesta 16 vuoteen. Halttusen kannan mukaisesti kirkkoherranvaali oli rajattu pois esityksestä. ${ }^{202}$ Hankkeen kaatuminen olisi vaikuttanut hyvin kielteisesti kirkolliskokouksen julkisuuskuvaan, ja uudistuksen arvostelijat vaikenivatkin päätöksenteon loppumetreillä. ${ }^{203}$ Ratkaisevassa äänestyksessä kirkolliskokous asettui yksimielisesti kirkkolain muutosesityksen kannalle. ${ }^{204}$ Tyhjää äänesti viisi edustajaa, joita yhdisti vahva herätysliiketausta. ${ }^{205}$ Lopullisen päätöksen jälkeen myös median arvio oli myönteisempi kuin vuotta aiemmin. ${ }^{206}$ Kirkko kiinnitti paljon huomiota vuoden 2010 seurakuntavaalien viestintään ja pyrki tavoittamaan erityisesti nuoria äänestäjiä. Kokonaisuutena äänestysprosentti nousi edellisvaalien 14,5 prosentista 17:ään. Nuorten 16-17-vuotiaiden osalta se

\section{Edustajan päiväkirja verkossa}

Vuonna 2004 nähtiin kansainvälisesti ensimmäiset merkit verkkopäiväkirjojen läpimurrosta politiikassa ja vaaleissa. ${ }^{\mathrm{I}}$ Suomessa eduskunnan nuorin kansanedustaja, vihreiden Oras Tynkkynen laati Internet-jakeluun tuolta vuodelta kertomuksen omasta toiminnastaan. ${ }^{\text {II }}$ Keväällä 2004 vaihtui myös kirkolliskokouksen vaalikausi, ja samalla sai alkunsa ensimmäinen kirkolliskokouksen tapahtumia raportoiva ja kommentoiva verkkopäiväkirja. Sitä piti 24-vuotias helsinkiläinen teologian opiskelija Antti Siukonen, joka oli tuolloin nuorin kirkolliskokousedustaja.

Siukosen päiväkirjan lukija sai tuoreeltaan tietää täysistunnon tapahtumista ja niiden taustoista sekä kirjoittajan omista mielipiteistä. Lisäksi tekstit valaisivat kirkolliskokouksen muuta toimintaa. Toukokuussa 2004 saattoi esimerkiksi lukea piispa Mikko Heikan saarnanneen avajaisjumalanpalveluksessa hyvin kantaaottavasti Kioton ilmastosopimuksen oli keskimääräistä alempi, 15,3 prosenttia, mutta toisaalta näiden ikäluokkien äänestysaktiivisuus oli sekä edellisvaalien kokonaisprosenttia että kyselytutkimusten antamia ennakkoarvioita korkeampi. ${ }^{207}$

Nuorten tavoittaminen ei rajoittunut vain äänioikeusikärajan laskemiseen. Kahdeksan edustajaa jätti keväällä 2009 aloitteen nuorten osallisuuden vahvistamiseksi kirkossa. Tarkoituksena oli taata nuorten vaikutusmahdollisuudet seurakunnissa ja kokonaiskirkossa esimerkiksi perustamalla nuorten kirkolliskokous. ${ }^{208}$ Edelleen keväällä 2009 Porvoon hiippakuntavaltuusto esitti aloiteoikeuden laajentamista hiippakuntavaltuustossa, jotta ruotsinkielisellä alueella vuosikymmeniä järjestettyjen nuorten kirkkopäivien osanottajat saisivat helpommin ehdotuksiaan eteenpäin. ${ }^{209}$ Lisäksi vielä 17 edustajaa allekirjoitti aloitteen lapsen oikeuksien ja lapsivaikutusten arvioinnista kirkossa. Valtioneuvosto oli aiemmin kiinnittänyt huomiota lapsi- ja perhevaikutuksiin, ja Ruotsin kirkko oli jo 1999 antanut seurakunnille ohjeistuksen lapsivaikutusten arvioinnista. ${ }^{210}$ Kaikki hankkeet lähtivät etenemään, mikä osoitti kirkolliskokouksen huolta tulevaisuudesta ja niistä, jotka eivät perinteisiä vaikuttamiskanavia pitkin saaneet ääntään kuuluville. ${ }^{211}$

Suunnitelmat nuorten aikuisten tavoittamiseksi liittyivät kiinteästi kirkon toimintaan tietoverkoissa. Vuosikymmenen kuluessa monet tragediat paljastivat Internetin merkityksen nuorille ikäryhmille niin hyvässä

puolesta. Keskiviikkoaamun jalkapallo-ottelussa taas piispat Wille Riekkinen ja Erik Vikström olivat osoittaneet "hämmästyttäviä pelitaitoja". ${ }^{\text {III }}$

Kirkolliskokouksen seuraaminen helpottui huomattavasti 2006, jolloin täysistunnon puheenvuorot alettiin julkaista Internetissä tuoreeltaan, vielä tarkistamattomina. ${ }^{\text {IV }} \mathrm{Seu}$ raavalla, 2008 alkaneella vaalikaudella luterilaisen kirkon Internet-sivustolla oli linkki jo 18 kirkolliskokousedustajan verkkopäiväkirjaan. ${ }^{\mathrm{V}}$

I Strandberg 2012, 81-82.

II Laaksovirta 2007, 191.

III Antti Siukonen Maanantai 3.5.2004 \& Keskiviikko 5.5.2004. <http://www. nuorikirkko.net/index.php?option=com_content\&task=view\&id=18\&Ite mid=26>. Katsottu 4.11.2010.

IV KKHA KKA Valiokuntien ptk:t 2004- Kansliavaliokunta ptk. 8.5.2006 $\$ 5$

V Suomen ev.lut. kirkko: Kirkolliskokous Kirkolliskokousedustajien blogeissa suoraa puhetta kirkolliskokouksesta. <http://web.archive.org/ web/20120125142519/http://evl.fi/EVLfi.nsf/Documents/F33D236ECDD $\mathrm{B}_{2} \mathrm{D} 82 \mathrm{C} 22574240023528 \mathrm{~F}$ ? OpenDocument\&lang=FI $>$. Katsottu 4.3.2013. 
kuin pahassa ja muuttivat samalla kirkolliskokouksen suhtautumista tietoverkkoihin. Vuonna 2001 talousvaliokunta karsi Internet-viestintään suunniteltuja määrärahoja - samaan tapaan kuin 1990-luvun alkupuolella ${ }^{212}$. Vuotta myöhemmin Myyrmäen pommiräjähdyksen jälkeisissä tunnelmissa forssalainen apulaisylilääkäri Ritva Vastamäki kyseenalaisti päätökset: "Nuoriso löytää kyllä pommin valmistusohjeet ja huumeitten valmistusohjeet, mutta kirkon sivut on vaikea löytää." ${ }^{13}$ Vähitellen Internet alettiin nähdä kirkon strategioissa viestintävälineen sijasta toimintaympäristönä, ja kirkolliskokouksessa toimitusjohtaja Kirsi Rostamo nosti kyselytunnilla 2006 esille seurakuntien toiminnan verkossa. ${ }^{214}$

Samaan aikaan kirkkohallituksen työryhmissä valmisteltiin Hengellinen elämä verkossa -hanketta. Kyseessä oli yksi vuosikymmenen lopun suurista strategisista hankkeista: Meidän kirkko -strategian päämääriin kuului hengellisen elämän toteutuminen Internetissä. ${ }^{215}$ Kirkolliskokous käsitteli hanketta syysistuntokaudella 2008, ja jälleen kerran tragediat - oppilaitosampumiset Jokelassa vuotta aiemmin ja Kauhajoella runsas kuukausi ennen istuntokautta - antoivat vauhtia asian käsittelylle. Helsinkiläinen nuorisotyönohjaaja Sami Ojala suhteutti Kauhajoen tapahtumien jälkeiset verkkokeskustelut siihen, että seurakunnat olivat pitäneet auki kirkkojaan tuona iltana:

Helsingissä Laajasalon ja Roihuvuoren kahdessa kirkossa sen tunnin aikana vieraili yksi ihminen. Yhteensä. Se oli Laajasalon kirkossa. Roihuvuoreen ei ollut tungosta. Samaan aikaan oli yli 370.000 keskustelijaa, keski-iältään vajaa kaksikymppisiä,jotka keskustelivat yhdessä ainoassa keskustelussa yli kymmenen tuhannen rivin verran. Ja Irc-gallerian ylläpidon mukaan siellä ei tiettävästi ollut, ei kirkon eikä muunkaan tahon aikuisia nuorisotyön ammattilaisia mukana keskustelu[ssa]. Nuoret keskustelivat tai nuoret aikuiset keskustelivat siellä ihan omillaan. Puivat tätä tapahtunutta ja surivat. ${ }^{216}$

Seinäjoen koulutusyhtymän oppilaitospastori Markku Orsila kertoi myös, miten Kauhajoen tragedian jälkeen opiskelijat olivat käsitelleet monet asiat verkossa jo ennen kuin auttajat olivat ehtineet tarjota keskusteluapua. Internet oli osoittautunut hyväksi paikaksi purkaa tapahtumia, mutta sinne tarvittiin mukaan myös aikuisia. ${ }^{217}$

Talousvaliokunta ja kirkolliskokouksen täysistunto antoivat tukensa Hengellinen elämä verkossa -hankkeel- le. Osa edustajista oli kuitenkin sitä mieltä, että liikkeelle oli lähdettävä vielä suunniteltuakin määrätietoisemmin. Kuusi edustajaa jätti talousarvioaloitteen kolmen nuorisotyön ammattilaisen palkkaamisesta verkkokeskustelijoiksi. Talousvaliokunnan kielteisestä kannasta huolimatta täysistunnossa enemmistö asettui aloitteen puolelle - niin kiireellisenä asia näyttäytyi tragedioiden jälkeisessä tilanteessa. ${ }^{218}$

Syksyllä 2011 voitiin jo katsoa hankkeen tuloksia. Viestintäjohtaja Tuomo Pesonen kertoi, että erityisesti läsnäolo valtakunnallisilla keskustelufoorumeilla oli osoittautunut menestykselliseksi. Vuoden 2011 loppuun mennessä oli koulutettu yli 1200 kirkon työntekijää käyttämään työssään verkkoa. ${ }^{219}$ Kirkkohallitus ja kirkolliskokouksen talousvaliokunta totesivat, että oli aika vähitellen siirtää päävastuu seurakuntiin. ${ }^{220}$ Uusi työmuoto oli syntynyt nopeasti tragedioiden vauhdittamana.

\section{MUUTTOLIIKE JA KIRKOSTA EROAMINEN SYNKENTÄVÄT TALOUSNÄKYMIÄ}

PUHETTA PIENISTÄ YHTEISÖISTÄ, PÄÄTÖKSIÄ VAHVOISTA TALOUSYKSIKÖISTÄ

Kirkolliskokouksen talousvaliokunnan pelko kirkon keskusrahaston kriisitilasta ei toteutunut uuden vuosituhannen alkaessa. Seurakuntien verotulot kasvoivat. Ne eivät kuitenkaan jakautuneet tasaisesti, mihin oli osasyynä se, että valtio tilitti seurakuntien osuuden yhteisöverosta samoin jakoperustein kuin kunnille. Seurakuntataloudet, joiden alueella oli tuottoisaa yritystoimintaa, saivat huomattavat yhteisöverotulot joidenkin seurakuntien jäädessä lähes kokonaan ilman niitä. Seurakuntien verotulot kasvoivat 1990-luvun lopun nousukautena Helsingin hiippakunnassa 37 prosenttia, mutta Kuopion hiippakunnassa kasvu oli vain seitsemän prosenttia $^{221}$. Väestön vanheneminen ja muuttotappio koskettivat monia alueita, ja tappiollisen tuloksen tehneiden seurakuntien määrä kasvoi huolestuttavan nopeasti. ${ }^{222}$ Tässä tilanteessa piispainkokous ja kirkkohallitus totesivat, että seurakuntien taloudellisen eriarvoisuuden tasaaminen oli yksi kirkon eettisen uskottavuuden mittareista. ${ }^{223}$ 
Mittari ei osoittanut rohkaisevia lukemia. Kirkkoneuvos Leena Rantanen joutui miltei ensi töikseen toteamaan kirkolliskokoukselle, ettei kirkon keskusrahaston avustusjärjestelmä toiminut kunnolla. Tuesta noin kymmenen miljoonaa markkaa meni sellaisille seurakunnille, jotka eivät olisi sitä tarvinneet, kun taas vastaava määrä jäi puuttumaan todellisilta tarvitsijoilta. Lisäksi Rantanen valitteli, että avustusjärjestelmästä puuttuivat porkkanarahat, jotka tukisivat seurakuntien vapaaehtoista yhdistymistä. ${ }^{224}$ Nämä kaksi teemaa, seurakuntien välisen tasausjärjestelmän kehittäminen ja seurakuntaliitokset, olivat sittemmin läpi vuosikymmenen kuumia keskustelunaiheita kirkolliskokouksessa.

Vuonna 2000 valittu kirkolliskokous suhtautui tasaamiseen alusta asti myönteisesti. Piispa Jorma Laulaja totesi, että rikkaiden seurakuntien rahastointi-into oli heikentänyt kirkon julkisuuskuvaa ja lisännyt seurakuntien eriarvoisuutta: "Voidaan varautua niin varautuneesti, että varautumisesta tulee itse asia." Laulaja sai ajatuksilleen tukea varakkaan seurakunnan johtajalta, Kauniaisten suomalaisen seurakunnan kirkkoherralta Arto Laitiselta. ${ }^{225}$ Kirkolliskokous toivoikin, että kirkkohallitus selvittäisi muun muassa mahdollisuuksia jakaa yhteisöveron tuotto aiempaa tasapuolisemmin ja porrastaa seurakuntien keskusrahastomaksut progressiivisesti kunkin seurakunnan maksukyvyn mukaan. ${ }^{226}$

Kirkkohallituksen vastaus oli nopea. Jo keväällä 2001 se esitti, että yhteisöverotuloja voitaisiin kerätä seurakunnilta progressiivisesti. Kirkolliskokous kiitti ripeydestä ja hyväksyi uudistuksen. ${ }^{227}$ Vuonna 2000 yhteensä 114 seurakunnalla oli ollut negatiivinen vuosikate, mutta 2002 tällaisten seurakuntien määrä oli vain 32. Avustusjärjestelmän kehittäminen ja muut tasaustoimet vaikuttivat muutokseen. ${ }^{228}$ Kirkon keskusrahaston avustusmäärärahoja lisättiin varsinkin vuodelle 2002, mutta sen jälkeen niitä voitiin jälleen vähentää seurakuntatalouden elpyessä. ${ }^{29}$

Valtiovalta oli menossa vielä näitäkin toimia pidemmälle: se suunnitteli seurakuntien yhteisövero-osuuden korvaamista lakisääteisellä valtionavustuksella. Päätösvalta oli valtiolla, mutta kirkolliskokous saattoi vaikuttaa asiaan lausunnollaan. Kirkolliskokous ilmoitti hyväksyvänsä uudistuksen, kunhan valtionavun lähtötaso määriteltäisiin tarpeeksi korkeaksi ja avustus sidottaisiin kuluttajahintaindeksiin. Uudistushanke oli erityi- sen merkittävä siksi, että valtionapu oli määrä tulouttaa kirkon keskusrahastolle, joka jakaisi sen seurakunnille kuntien väkiluvun mukaisessa suhteessa. ${ }^{230}$ Suunnitelma merkitsi suurta tulojen tasausta seurakuntien kesken.

Valtionavustukseen ei lopulta siirrytty, mutta seurakuntien välinen tulojen tasaus toteutui, joskin alkuperäistä suunnitelmaa maltillisempana. Uuden hautaustoimilain perusteella hautaustoimi oli vastaansanomattomasti yksi kirkon yhteiskunnallisista tehtävistä, joista yhteisövero-osuus oli korvauksena. Opetusministeriön asettama työryhmä kiinnitti huomiota siihen, ettei tämä korvausajatus toteutunut niissä seurakunnissa, joiden yhteisöverotulot olivat pienet. Tilanteen korjaamiseksi kirkkohallitus esitti keväällä 2004 kirkolliskokoukselle, että vastaisuudessa puolet yhteisöveron tuotosta tuloutettaisiin seurakunnille entiseen tapaan ja puolet kunnan väkiluvun mukaisesti. Muutosta lievensi, että samalla oli määrä luopua yhteisöveron perusteella seurakunnilta perittävistä lisämaksuista. ${ }^{231}$

Kirkolliskokouksella oli erityisesti kaksi huolenaihetta. Ensinnäkin edustajien mielestä uudistuksen perusteluissa korostettiin liiaksi hautaustointa kirkon yhteiskunnallisena tehtävänä. Edustajat pelkäsivät, että uudistus oli rajaamassa vain hautaustoimen valtion tukemaksi tehtäväksi ja että esimerkiksi väestökirjanpito, lapsityö, nuorisotyö, diakoniatyö sekä kulttuurisesti arvokkaiden rakennusten ylläpito olivat vaarassa unohtua. ${ }^{232}$ Sittemmin kirkolliskokouksen valiokunnat pyrkivät korostamaan, että kirkolla oli lukuisia yhteiskunnallisia tehtäviä, joista lähinnä vain yksi - hautaustoimi - pystyttiin hoitamaan yhteisöveron tuotolla. ${ }^{233}$

Toinen huolenaihe koski uudistuksen häviäjiä. Etelä-Suomen kaupunkiseurakuntien jäsenet muistuttivat, että hautaustoimeen tarvittiin kasvukeskuksissa koko ajan lisää investointeja. Kiinnitettiin myös huomiota siihen, että uudistuksen voittajien joukossa oli verrattain suuriakin seurakuntia. ${ }^{234}$ Talousvaliokunta asettui kuitenkin yksimielisesti uudistuksen kannalle. ${ }^{235}$ Erityisen näkyvästi uudistusta puolustivat valiokunnan salolainen puheenjohtaja Marjatta Hyttinen ja helsinkiläinen jäsen Pertti Simola, jotka molemmat tulivat uudistuksen suurimmista häviäjäseurakunnista. Häviäjäseurakunnissa vallinneita epäilyjä taas sanoitti eritoten Espoon yhteisen seurakuntatyön päällikkö Jukka Huttunen - omien sanojensa mukaan voidakseen palata Turusta kotiseu- 
rakuntaansa ja välttääkseen pakomatkan Ruotsiin. Hän ehdotti siirtymäaikaa ja sai kirkolliskokouksessa vallinneessa "sovinnon hengessä" tukea toholampilaiselta yhteiskuntatieteiden tohtori Erkki Kujalalta. Simola kuitenkin vastusti monimutkaisia siirtymäsäännöksiä. Hän muistutti, että sentään puolet yhteisöveron tuotosta ehdotettiin jaettavaksi entisin perustein: "Tehdään niin, että minä lähden Ruotsiin ja hyväksytään talousvaliokunnan esitys." ${ }_{236}$ Huttusen ehdotus siirtymäajasta kaatui lopulta selvin luvuin 92-9..$^{237}$

Tulojen tasausjärjestelmän ohella myös seurakuntien avustusjärjestelmä oli muutoksessa. Kirkkohallitus antoi syksyllä 2001 esityksen, jonka oli tarkoitus mahdollistaa avustustoiminnassa siirtymä kohti seurakuntien yhteistyöhankkeiden tukemista. Kirkolliskokous hyväksyi esityksen jälleen nopeasti. ${ }^{238}$ Jo muutamaa kuukautta myöhemmin kirkkohallituksen täysistunto päätti siirtää avustusten painopistettä kehittämisavustukseen, jolla tuettiin seurakuntien yhteistyötä. Yhdistymisavustusta myönnettiin vain muodostettaessa uusia yksittäisseurakuntia, elleivät jotkin erityissyyt, kuten kielelliset perusteet, edellyttäneet seurakuntayhtymän muodostamista. ${ }^{239}$ Avustus- ja tulontasausjärjestelmän muutokset olivat nopeita, ja suunta oli kohti seurakuntaliitoksia.

Taloudelliset kannustimet toimivat. Kirkkoneuvos Rantanen saattoi todeta kirkolliskokoukselle 2004 erityisinä ilonaiheina, että seurakuntien yhdistymisiä oli hyvin paljon ja etteivät yhdistyneet seurakunnat juu- ri olleet avustusjärjestelmän asiakkaina. ${ }^{240}$ Seuraavana vuonna harkinnanvaraisista tuista luovuttiin kokonaan. Seurakuntia pyrittiin näin ohjaamaan yhteistyöhön ja yhdistymisiin paitsi kannustamalla myös sulkemalla rahahanoja. ${ }^{241}$ Aina 1960-luvulle asti seurakuntarakenteen historia oli ollut jakaantumisen historiaa, ja sen jälkeenkin seurakuntien määrä oli pysynyt vakaana. ${ }^{242}$ Vuosituhannen vaihteessa tapahtui kuitenkin käänne: vuosina 2000-2005 seurakuntien lukumäärä laski 25:llä. ${ }^{243}$ Noina vuosina kirkon talous oli keskeinen huolenaihe, ja seurakuntiakin tarkasteltiin pitkälti talouden näkökulmasta.

Seurakuntien omaehtoisten yhdistymisten aika alkoi jäädä taakse, kun sisäasiainministeriö käynnisti toukokuussa 2005 laaja-alaisen kunta- ja palvelurakenneuudistushankkeen. ${ }^{244}$ Ensimmäiset uudistusehdotukset valmistuivat syyskuun lopulla. Asiat etenivät nopeasti, ja kirkolliskokouksen marraskuun istuntokaudella valtiovallan tervehdyssanat lausunut keskustalainen kulttuuriministeri Tanja Karpela kehotti pohtimaan seurakuntarakenteen tulevaisuutta. ${ }^{245}$ Niin kirkolliskokous tekikin kansliapäällikkö Risto Junttilan jättämän ilmoituksen pohjalta. ${ }^{246}$ Vuosikymmenen alkupuoli oli kulunut seurakuntataloudesta keskusteltaessa, mutta nyt huolenaiheiksi nousivat seurakuntaelämä ja -identiteetti. Kemijärven kirkkoherra Lasse Marjokorpi esitti ajatuksia, joita sittemmin kuultiin kirkolliskokouksessa alati taajenevaan tahtiin. Hänen mielestään suurkun-
Valiokuntien ovet eivät olleet auki ulkopuolisille, mutta talousvaliokunta kuvattiin kokoushuoneen ikkunan läpi vuonna 2001. Vuosikymmenen alkupuolella talousvaliokunnalla oli käsiteltävänään monia suuria asioita, jotka liittyivät seurakuntien tasausja avustusjärjestelmään. Kuva: Kotimaan kuva-arkisto / Matti Karppinen.

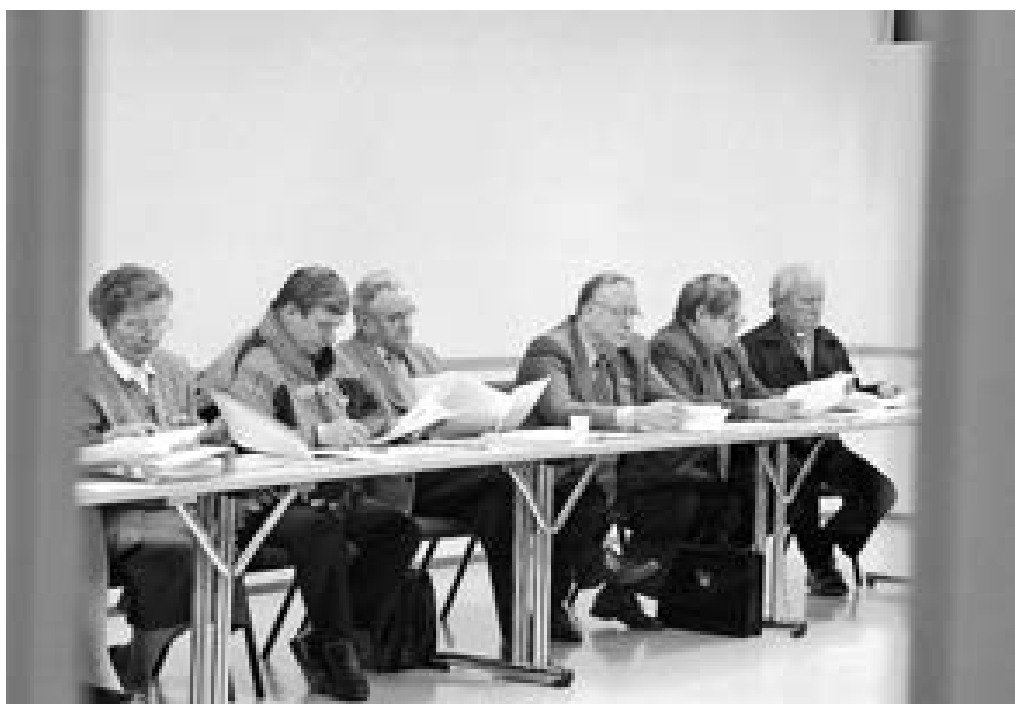


tien perustaminen ei saanut johtaa suurseurakuntien syntyyn:

Silloin kyllä käy niin, että tästä kolmikohtaisesta ohjelmasta saattaa tulla missio, visio ja passio. Eli olisi kiire toimia siten, että muodostetaan tällainen suurempi yksikkö, jolla on joku muu nimi kuin seurakunta. Sen nimi voisi olla esimerkiksi kirkkopitäjä maaseudulla tai alueseurakunta kaupunkialueella. Tähän keskitetään hallinto ja talous ja nykyiset seurakunnat säilytetään tai palautetaan pieniksi kirkkorakennuksen, kirkkoherran ja kirkkoneuvoston ympärillä toimiviksi tutuiksi yhteisöiksi, jotka ovat toiminnallisia yksikköjä, jotka säilyttävät paikkakunnan identiteetin ja joilla voi olla myös hiukan omaleimainen profilil. Parokiaaliperiaate pitäisi ulottaa koskemaan nimenomaan tätä suurempaa hallinnollista yksikköä, kirkkopitäjää. ${ }^{247}$

Piispa Voitto Huotari johti seurakuntarakennetyöryhmää, jonka kirkkohallitus oli asettanut juuri lokakuun lopulla 2005 seuraamaan kuntarakenteen muutoksia ja suunnittelemaan seurakuntien toimia. ${ }^{248}$ Huotarikin painotti, että huomiota oli siirrettävä menojen supistamiseen tähdänneistä seurakuntarakenteen muutoksista tulopohjaa rapauttavan jäsenkadon ehkäisemiseen. Ensisijaista oli saada aikaan toimiva pienyhteisörakenne, joka oli mahdollista saavuttaa monenlaisten seurakuntamallien puitteissa. ${ }^{249}$ Edelleen yleisvaliokunnan toinen osasto kirjasi mietintöönsä, että seurakuntarakenteen muutosten tuli perustua toiminnallisiin tarpeisiin. ${ }^{250}$ Osaston puheenjohtaja, kouluneuvos Raili Kemppainen totesi suoraan, että valiokunnassa oli vierastettu kirkon keskushallinnon halukkuutta suoraviivaisiin seurakuntaliitoksiin. ${ }^{251}$ Myös julkisuudessa huomio kiinnittyi aiempaa enemmän siihen, miten syvästi kuntaliitokset vaikuttivat seurakuntiin. ${ }^{252}$ Vuoden 2005 syyskuukausina alkoi uusi vaihe keskustelussa seurakuntarakenteesta.

Piispa Huotari herätteli vastakin kirkolliskokousta: seurakuntarakenteet olivat "historiansa kaikkein laajakantoisimmassa ja kaikkein syvälle käyvimmässä muutoksen tilassa", mutta seurakunnissa tyydyttiin aivan liiaksi seurailemaan, mitä tuleman piti. Sen sijaan tuli Huotarin mukaan lähteä suunnittelemaan tulevaisuutta aktiivisesti ja luovasti. ${ }^{253}$ Mikkelin piispan mielestä oli vaarana, että luotiin rakenteita miettimättä toimintaa. Hieman kirkkoherra Marjokorven tapaan hän ehdotti siirtymistä kaksitasoiseen seurakuntarakenteeseen, jossa olisi perustasona seurakunta ja sen ohella yhteistyö- tasona seurakuntayhtymä tai rovastikunta. ${ }^{254}$ Sittemmin myös Huotarin johtama työryhmä päätyi tällaiseen ratkaisumalliin, jonka juuret olivat jo kirkkojärjestyskomitean mietinnössä ja jota oli sittemmin ehdotettu Kirkko 2000 -prosessissa ja 1990-luvun komiteatyössä. ${ }^{255}$

Keskustelu ei johtanut nopeisiin käytännön toimiin. Kuvaavaa oli, että Huotarin puheenvuoron jälkeen kirkkoneuvos Rantanen esitteli uutta avustusjärjestelmää, joka oli "rakennettu, kuten kuntapuolellakin, sellaiseksi, että sitä suurempi tuki, mitä isompi yksikkö muodostetaan ja mitä useampi seurakunta siihen liittyy". Seurakuntayhtymiä tuettiin vain poikkeustapauksissa. ${ }^{256}$ Kirkolliskokouksen keskusteluissa visioitiin toiminnallisista lähtökohdista pieniä perusyksikköjä ja suuria yhteistyöyksikköjä. Pohdinnoilla ei kuitenkaan ollut käytännön merkitystä, kun samaan aikaan kirkkohallitus suosi talouden ja hallinnon lähtökohdista suuria perusyksikköjä ja vierasti yhteistyöyksikköjen - seurakuntayhtymien - perustamista.

Kirkolliskokousedustajat siirtyivät keskustelun tasolta todellisiin toimiin vasta uuden vaalikauden alettua 2008. Silloin oltiin tosin jo hieman myöhässä: kuntaliitosten myötä ovella oli historiallisen laajamittainen seurakuntaliitosten vuosi 2009, jolloin seurakuntien määrä pieneni 49:llä eli noin kymmenesosalla ${ }^{257}$. Lapuan hiippakuntavaltuusto esitti, että muodostuvissa suurissa seurakunnissa varsinainen seurakunta-nimi varattaisiin jumalanpalvelusyhteisöille, kun taas koko seurakunnasta hallinnollisena yksikkönä käytettäisiin toista nimeä. ${ }^{258}$ Esitys ilmensi huolta seurakunnan identiteetistä ja liittyi niihin ajatuksiin, joita kirkolliskokouksessa oli aiempina vuosina kuultu. Ei ollutkaan ihme, että esitys sai edustajilta paljon tukea ${ }^{259}$. Hallintovaliokunta käsitteli asiaa kuitenkin lähinnä hallinnon näkökulmasta, ja valiokunnan ehdotuksesta aloite jätettiin raukeamaan. ${ }^{260}$ Pian sen jälkeen 15 edustajaa ehdotti yleisemmin selvitystä seurakuntien aluetyön rakenteiden ja nimitysten toimivuudesta. Tämä asia eteni kirkkohallitukselle. ${ }^{261}$

Edelleen 2008 kymmenen edustajaa jätti aloitteen parokiaalijärjestelmän kehittämisestä. Aloite sisälsi monenlaista ainesta. Yhtäältä siinä vastustettiin seurakuntarakenteen riippuvuutta kuntaliitoksista. Toisaalta siinä ehdotettiin mahdollisuutta perustaa henkilöseurakuntia ja valita kotiseurakunta asuinpaikasta riippumatta. ${ }^{262}$ Täysistunnossa vilahtelivat perusteluina kuntaliitokset, 
kuuluminen seurakuntaan äidinkielen perusteella tai kirkon virkaratkaisun vastustajien toimintamahdollisuudet. Aloitteen tulkinnat ja siihen ladatut odotukset olivat ristiriitaisia. Joidenkuiden mielestä kysymys henkilöseurakunnista oli niin hallitseva, että oli epäselvää, oliko päämääränä parokiaalijärjestelmän kehittäminen vai sen purkaminen. ${ }^{263}$ Epäluuloja aiheutti myös se, että samaan aikaan muutamat kirkon virkaratkaisua arvostelevat liikkeet vahvistivat jumalanpalvelusyhteisöjään. ${ }^{264}$

Nelivuotisen vaalikauden aikana aloitetta ehdittiin painottaa ja tulkita monin eri tavoin. Kun asia sitten palasi kirkkohallituksesta kirkolliskokoukseen 2011, suuret odotukset vaihtuivat monilla pettymykseen. Kirkolliskokous merkitsi asian tiedoksi ja jäi odottamaan kirkkohallituksen muiden työryhmien työn tuloksia. Valmistelu oli keskittynyt lähinnä siihen, voitiinko asuinpaikka ja seurakunnan jäsenyys irrottaa toisistaan. Seurakuntien koon miettiminen eli varsinainen parokiaalijärjestelmän kehitystyö oli jäänyt sivuosaan. ${ }^{265}$ Selvitystä odotti edelleen se, "haluammeko me, jos vähän karrikoidaan, erityissairaanhoitoalueen koon olevan se tekijä, joka määrää myöskin seurakunnan tai seurakuntayhtymän koon ja laajuuden", kuten Porvoon piispa Björn Vikström tiivisti kysymyksen. ${ }^{266}$

Kirkolliskokous teki vuoteen 2005 mennessä merkittäviä taloudellisia tasauspäätöksiä, eikä havaittavissa ollut samanlaista pohjoisen ja etelän vastakkainasettelua kuin joskus aiempina vuosikymmeninä. Yhteinen huoli seurakuntien taloudesta sai edustajat tinkimään kotiseurakuntansa eduista. Toisaalta sama huoli sai kirkolliskokouksen ja kirkkohallituksen katsomaan seurakuntarakennetta lähinnä talouden ja hallinnon näkökulmasta. Vasta vuosikymmenen puolivälissä, kun tärkeimmät päätökset taloudellisesta tasauksesta oli saatu tehdyksi, alettiin pohtia seurakuntaliitosten vaikutusta hengelliseen elämään ja seurakuntaidentiteettiin. Keskustelut eivät kuitenkaan johtaneet suoriin käytännön toimiin. Tutkimuskauden lopussa kirkolliskokouksen tunnelmaa synkistivät entisestään 2011 esille tulleet tiedot, joiden mukaan liitosten myötä seurakuntien talous ei ollut välttämättä parantunut eikä resursseja vapautunut hallinnosta hengelliseen työhön, ei ainakaan lyhyellä aikavälillä̈ ${ }^{267}$.

Syksyllä 2011 yleisvaliokunta tiivisti tulevaisuusselonteon pohjalta kirkon hallinnon lähimenneisyyttä. Keskusjohtoisuus oli lisääntynyt ja ratkaisuja tehty talouden sekä hallinnon ehdoilla. Näistä tarpeista käsin myös seurakuntien kasvamista oli tietoisesti tuettu, vaikka kirkon perinteinen hallintonäky rakentui läheisyysperiaatteelle. ${ }^{268}$ Arvio 2000-luvun alun tapahtumista oli aika tavalla päinvastainen verrattuna ehdotuksiin, joita oli aikoinaan kirjattu Kirkko 2000 -prosessin asiakirjoihin tai 1990-luvun alkupuolella toimineiden komiteoiden mietintöihin. Menneisyyden miettimisen lisäksi yleisvaliokunta kirjasi tulevaisuuden tavoitteita, jotka muistuttivat monessa suhteessa Mikko Heikan komitean lähes kaksi vuosikymmentä aiemmin laatimia ehdotuksia ${ }^{269}$.

Vuosina, jotka erottivat Heikan komitean ja yleisvaliokunnan mietintöjä, kirkolliskokous oli puhunut visioista enemmän kuin koskaan aiemmin ja hahmotellut tulevaisuuden kuvia ihmisläheisestä seurakunnasta. Teologiset pohdinnat seurakunnan olemuksesta jäivät kuitenkin mietintöjen lehdille. Käytännön aikaansaannokset olivat taloudellisia tehostamistoimia, joihin lama-aika oli opettanut. Tutkimuskauden lopussa katseet kääntyivät kirkkohallituksessa toimineeseen rakennemuutosprosessin ohjausryhmään, joka oli päättämässä työtään ja hahmottamassa vihdoin konkreettisia malleja paikallistason rakenteiden uudistamiseksi ${ }^{270}$.

\section{KEHYSBUDJETOINTIIN JA STRATEGISIIN HANKKEISIIN}

Kirkolliskokouksen rooli taloudesta päättävänä elimenä muuttui monin tavoin 2000-luvun ensimmäisellä vuosikymmenellä. Lähetekeskustelun tuominen talousarvion käsittelyyn paransi edustajien mahdollisuuksia saada kädenjälkensä talousvaliokunnan lopulliseen budjettiesitykseen. Uuden työjärjestyksen mahdollistamat kirkkohallituksen ja kirkkoneuvosten ilmoitukset edistivät kirkolliskokouksen tiedonsaantia. Lisäksi kirkkoneuvos Leena Rantanen otti heti virkaan tultuaan käyttöönsä havainnolliset diasarjat kuvioineen esitellessään kokonaiskirkon taloudellisia näkymiä ${ }^{271}$.

Vuodesta 2006 lähtien kirkkohallitus alkoi antaa keväällä talousarviota koskevan ilmoituksen. Uusi käytäntö vastasi eduskunnassa 1990-luvulla vakiintunutta tapaa, jonka mukaisesti hallitus ilmoitti keväisin eduskunnalle talousarviokehykset ${ }^{272}$. Samalla kirkolliskokousedustajat saivat oikeuden tehdä suoraan kirkkohallitukselle talousarvioehdotuksia, mikä paransi heidän vaikutusmahdollisuuksiaan: keväällä tehdyt ehdotuk- 


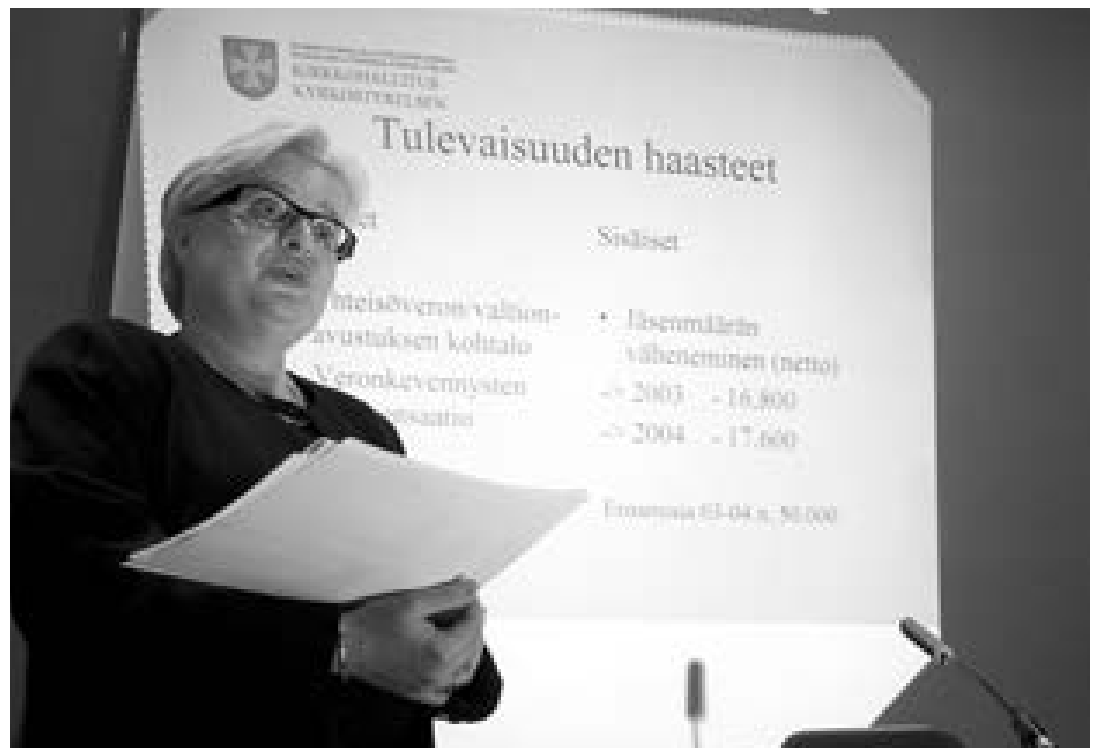

Kirkkoneuvos Leena Rantanen otti käyttöön tekniset apuvälineet esitellessään kirkolliskokousedustajille kokonaiskirkon taloudellista tilaa ja tulevaisuudennäkymiä. Uuden vuosituhannen ensimmäisellä vuosikymmenellä diaesitykset sisälsivät yleensä myönteisiä tietoja toteutuneista tilinpäätöksistä mutta myös alati kasvavaa huolta tulevasta. Kuva: Kotimaan kuva-arkisto / Jukka Granström. set saivat perusteellisemman valmistelun kuin perinteiset talousarvioaloitteet. Nopeasti osoittautui myös, että näillä ehdotuksilla oli paremmat mahdollisuudet menestyä valmistelussa kuin talousarvioaloitteilla ${ }^{273}$. Uusi käytäntö supisti talousarvioaloitteiden määrää: syysistuntokausilla 2000-2005 jätettiin keskimäärin yli kolme talousarvioaloitetta, mutta vuosina 2006-2011 keskiarvo oli vain 1,5 . Tosin myös kirkon nopeasti heikkenevä taloudellinen tilanne vaikutti luultavasti muutokseen. Uudistukset toivat pitkäjänteisyyttä talousarvion valmisteluun kirkolliskokouksessa.
Toiminta ja talous pyrittiin yhdistämään aiempaa kiinteämmin toisiinsa. Yleisvaliokunnan toinen osasto, joka käsitteli kirkkohallituksen ja hiippakuntien kertomukset toiminnan osalta, ryhtyi vuodesta 2006 lähtien antamaan mietintönsä kevätistuntokaudella. Näin toimintaa koskevat arviot ja kannanotot ehtivät vaikuttaa seuraavan vuoden talousarvion valmisteluun. ${ }^{274}$ Edelleen toiminnallinen näkökulma vahvistui, kun yleisvaliokunnan toinen osasto antoi syksystä 2007 lähtien talousarvion käsittelyn yhteydessä lausuntonsa kirkon toiminnan tavoitteista ja ajankohtaisista hankkeista. ${ }^{275}$

\section{Kolmen viikon tulevaisuusselonteko}

Talouden ja toiminnan vaatimusten ennakointi oli vaikeaa, mutta hyvinkääläinen insinööri Pekka Kiuttu onnistui tehtävässä harvinaisen ja valitettavan hyvin keväällä 2006. Tulipalo Helsingin rautatiemakasiineilla sai hänet ottamaan kyselytunnilla esille seurakuntien kiinteistöjen palosuojauksen:

Enkä voi pelkästään kysyä, vaan kun on näin paljon seurakuntien edustajia paikalla, niin minulla heräsi sellainen huoli, että kun me menemme seurakuntiin, huolehdimme siitä, että meidän kiinteistönhoitajat varmistavat, että hälytys- ja alkusammutusvälineistöt ovat kunnossa ja että kaikki mitä tulee kiinteistöihin, varsinkin vanhempiin kiinteistöihin, olisi reilassa. ${ }^{\mathrm{I}}$

Kansliapäällikkö Risto Junttila kertoi vastauksessaan asioiden olevan hyvällä tolalla."

Kolme viikkoa myöhemmin Porvoon tuomiokirkko sytytettiin tuleen. Kirkon sisällä olleet paloturvalaitteet eivät

auttaneet, kun tuli lähti etenemään ulkoapäin. Lokakuussa vuorossa oli Kaivokselan kirkko Vantaalla, ja lehdistössä lisääntyivät kriittiset kysymykset kirkkojen palosuojauksesta. ${ }^{\text {II }}$

Kun kirkolliskokousedustajat kokoontuivat seuraavan kerran Kiutun kysymyksen jälkeen, kaksi kirkkoa oli vaurioitunut pahoin tuhopoltossa. Eläkkeelle jäämässä ollut piispa Erik Vikström joutui lähes viimeiseksi työkseen kirkolliskokouksessa anomaan yhdessä piispa Eero Huovisen kanssa varoja Porvoon historiallisen tuomiokirkon pelastamiseksi. ${ }^{\mathrm{IV}}$

I Kirk.kok. kptk-k. 2006, 28 \$.

II Kirk.kok. kptk-k. 2006, $28 \S$.

III Il 30.5.2006 Kirkot suojattava paremmin tulelta (pääk.); KS 18.10.2006 Kirkkojen suojaaminen on otettava tosissaan (pääk.); Kmaa 19.10.2006 Kirkkopalo on viesti hädästä (Olav S. Melin, pääk.), Poliisiylijohtaja: Seurakunnat suojautuneet alimitoitetusti (Johannes Ijäs).

IV Kirk.kok. ptk-s. 2006, liite VI 1. 
Talous- ja yleisvaliokunnan yhteistyön tiivistämisen jälkeen seuraava vaihe oli toiminnallisten kysymysten keskittäminen yhdelle valiokunnalle: vuodesta 2012 talousvaliokunta käsitteli kirkkohallituksen ja hiippakuntien kertomukset sekä talouden että toiminnan osalta. ${ }^{27}$

Uudet käytännöt tähtäsivät osaltaan siihen, että kirkolliskokouksella olisi mahdollisimman paljon tilaisuuksia keskustella taloudenpidon peruslinjoista. Varsinkin vuosikymmenen alkupuolella kuultiin vielä perinteisiä talousarviokeskusteluja, joissa päähuomio oli yksityiskohdissa - eritoten talousarvioaloitteissa. Esimerkiksi 2004 talousvaliokunnan jäsen Pertti Simola huomautti, että pitkässä täysistuntokeskustelussa oli käsitelty kahden miljardin euron budjetista vain 150000 euron osuutta. Hänen tulkintansa tilanteesta oli, että kirkkohallitus oli valmistellut isot linjat niin hyvin, ettei niihin ollut tarvetta puuttua. ${ }^{277}$ Vuosikymmenen kuluessa huomio alkoi siirtyä pois yksityiskohdista. Muutosta edisti kehysbudjetointi. Kun oli mahdollista siirtää määrärahoja joustavasti talousarvion sisällä, ei ollut entisenlaista tarvetta puuttua yksityiskohtiin. Useimmiten tosin kävi niin, että keskustelu ennemminkin hiipui kuin siirtyi linjakysymyksiin. Tutkimuskauden loppuvuosina maailmantalouden kriisi ja kiihtyvä kirkosta eroaminen heikensivät kuitenkin talousnäkymiä ja pakottivat ottamaan kantaa isoihin periaatekysymyksiin myös täysistunnossa.

Kirkolliskokouksen täysistunto oli aiempina vuosikymmeninä jakanut rahaa hölläkätisemmin kuin talousvaliokunta. Vielä syksyllä 2003 koettiin tällainen talousarviokäsittely. Lähestyvillä kirkolliskokousvaaleilla saattoi olla oma vaikutuksensa, kun edustajat hyväksyivät täysistunnossa 414 ooo euron menolisäykset. ${ }^{278}$ Sen jälkeen tiukka taloudenpito tavoitti myös täysistunnon. Toisaalta kirkkohallitus alkoi päinvastoin laatia alijäämäisiä talousarvioita. Aluksi talousvaliokunnan puheenjohtaja Marjatta Hyttinen epäröi linjanmuutosta. ${ }^{279}$ Jo vuotta myöhemmin Hyttisen johtama valiokunta muutti kuitenkin omaehtoisesti talousarvion noin kaksi miljoonaa euroa alijäämäiseksi haluten siten pienentää seurakuntien maksurasitusta. ${ }^{280}$ Keskusrahaston kassavarat ja pitkäaikaiset sijoitukset vastasivat puolentoista vuoden seurakuntamaksuja, mutta talousvaliokunta katsoi vuoden seurakuntamaksujen riittävän. ${ }^{281}$ Alijäämäiset talousarviot tulivat jäädäkseen, ja erikseen ni- mettyihin strategisiin hankkeisiin käytettiin vuosittain miljoonia euroja.

Suurhankkeet pohjautuivat kirkon strategiaan, ja niiden oli määrä hyödyttää yhtäläisesti kaikkia seurakuntia. Osa hankkeista kosketti kirkon toimintaa, kuten Meidän kirkko -strategian jalkauttaminen ja Hengellinen elämä verkossa -hanke. Useimmat hankkeet liittyivät organisaatioiden uudistamiseen, kuten seurakuntarakenteeseen, kirkon yhteisen jäsentietojärjestelmän luomiseen tai henkilöstö- ja taloushallinnon järjestämiseen. ${ }^{282}$ Kirkolliskokous oli strategisten hankkeiden suhteen hyvin yksimielinen lukuun ottamatta henkilöstö- ja taloushallintoa koskevaa niin sanottua HeTa-hanketta. Kirkolle oli määrä perustaa palvelukeskus tuottamaan seurakuntien ja kirkon keskushallinnon tarvitsemat kirjanpito- ja palkanlaskentapalvelut. Tarkoituksena oli parantaa palvelujen laatua sekä helpottaa seurakuntien tilannetta jäsenmäärän laskiessa ja työntekijöiden eläköityessä. ${ }^{283}$

Kirkkohallitus pyrki järjestämään kirkolliskokousedustajille mahdollisimman paljon tietoa asiasta, mutta talousvaliokunta kiinnitti huomiota siihen, ettei viestintä tavoittanut kunnolla seurakuntia. Lisäksi hankkeen arvostelijat epäilivät todellisia säästöjä ja pelkäsivät päätösvallan siirtyvän pois seurakunnista. ${ }^{28}$ Aivan samoin kuin seurakuntarakenteen osalta kirkkohallitus oli lähtenyt tukemaan nopeita talouden sopeuttamistoimia. Kirkolliskokouksessa oli kuitenkin jälleen vastassa huoli seurakuntaidentiteetistä. Tällä kertaa jouduttiin hivenen hidastamaan tahtia ja keskittymään hanketta koskevaan tiedotukseen.

Talousvaliokunta arvioi HeTa-hanketta tarkasti monilta eri kannoilta. ${ }^{285}$ Hankkeen edellyttämät säännösmuutokset tulivat päätettäviksi keväällä 2010, eikä tiedotus ollut siihen mennessä kitkenyt vastustusta seurakunnista tai kirkolliskokouksesta. Oli kirkkoherra Pertti Simolan vuoro viedä talousvaliokunnan puheenjohtajana läpi vaikea uudistushanke. Jännitteet olivat selvästi voimakkaampia kuin päätettäessä aiemmin yhteisöveron uudesta jaosta. Tällä kertaa ei ollut kyse taloudellisesta tasauksesta, vaan hankkeen hyödyt pienille seurakunnille olivat keskimääräistä vähäisempiä. ${ }^{286}$ Huomion kiinnittyessä tähän epäsuhtaan tutkija Signe Jauhiainen muistutti, että alueiden välisen tasapuolisuuden lisäksi oli mietittävä myös sukupolvien välistä tasaarvoa: kalliiden rakenteiden ylläpitäminen olisi elämistä 
tulevien sukupolvien rahoilla. Piispat seurasivat keskustelua lähinnä sivusta, mutta Porvoon piispa Björn Vikström asettui näkyvästi hanketta vastaan:

Jos haluamme nähdä kirkkoa yhtenä isona keskusjohtoisena yrityksenä, jolla on tytäryhtiöitä ympäri Suomen, tottakai Heta on oikein hyvä malli. Ja jos haluamme nähdä kirkon yhtenä laitoksena, jolla on palvelupisteitä eri puolella Suomea, toistaiseksi vielä kaikilla paikkakunnilla ja tulevaisuudessa ainakin isoimmissa asutuskeskuksissa, niin tottakai tähän voidaan mennä. - - Heta tekee kirkosta yhä keskusjohtoisemman, tätä en toivo. Heta vahvistaa kirkon laitosmaisia piirteitä, tätä en halua. Heta kasvattaa entisestään kirkon keskushallintoa, tätä pidän vääränä kehityksenä. Heta edustaa ajattelutapaa, jonka mukaan hallinto ja toiminta kirkossa voidaan erottaa toisistaan, tätä en usko. Päinvastoin pitäisin tärkeänä, että kirkon seurakunnat voisivat olla niin pieniä, että toiminta ja hallinto voisivat olla tiheässä vuorovaikutuksessa keskenään. ${ }^{287}$

Ratkaisevassa toisessa käsittelyssä hanke saavutti määräenemmistön äänin 83-20. ${ }^{288}$ Piispoista Björn Vikström äänesti vastaan, ja vaaleilla valittujen edustajien joukossa hänen hiippakuntansa erottui yhtä lailla kriittisimpänä: viidestä paikalla olleesta edustajasta neljä äänesti vastaan. Myös Lapuan hiippakunnan edustajista enemmistö antoi ei-äänen. ${ }^{289}$ Vastustavia ääniä näyttää tulleen varsinkin alueilta, joilla seurakunnalla oli erityisen suuri merkitys paikallisidentiteetille. Kun seurakuntaliitokset

$$
70
$$

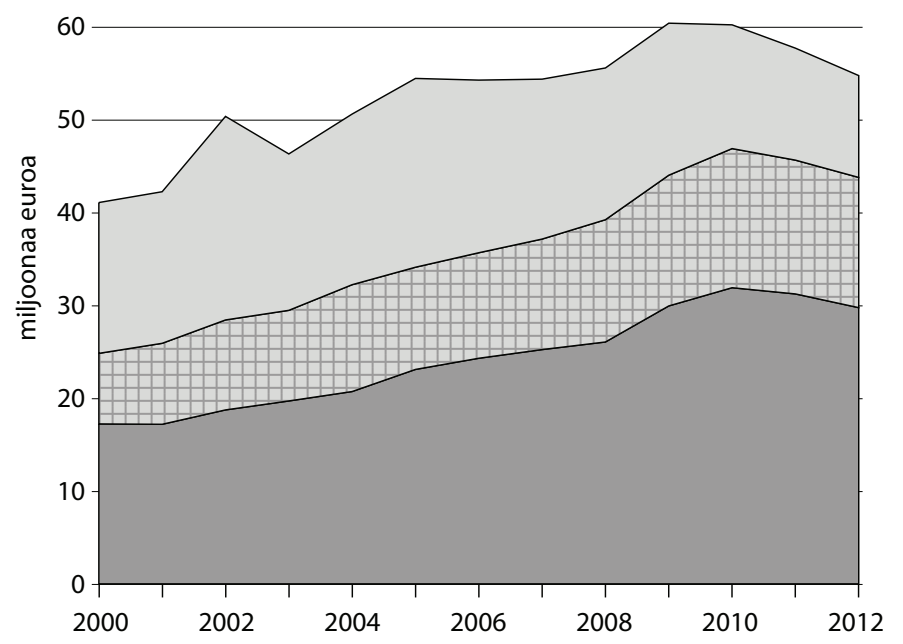

olivat jo entisestään kiristäneet ilmapiiriä monilla tällaisilla alueilla, palvelujen keskittämiselle ei liiennyt ymmärtämystä.

Tilanteeseen toi oman mausteensa se, että samaan aikaan palkkahallinnon keskittämisen kanssa siirryttiin palkkausjärjestelmässä päinvastoin paikallistason sopimiseen. Tämäkään muutos ei sujunut ongelmitta. ${ }^{290}$ HeTa-hankkeen melko kuuluvaa vastustusta selitti vielä se seikka, että hankkeella yritettiin ehkäistä myöhempiä ongelmia. Kun useimmissa seurakunnissa asiat hoituivat toistaiseksi perinteisillä toimintatavoilla, tulevaisuuden uhkiin ei ollut aina helppo asennoitua. Keväällä 2010 tuo asennoituminen oli kirkon talouden nopeasti heikennyttyä jo vaivattomampaa kuin aiemmin: kirkolliskokous hyväksyi nopeasti yhden istuntoviikon aikana kirkkohallituksen esityksen hankkeen toteuttamisesta. Uusi kirkon palvelukeskus saattoi siten aloittaa toimintansa vuoden 2012 alussa.

Tutkimuskauden loppuvuosina kirkkohallitus joutui esittämään voimakkaita supistuksia keskusrahaston talousarvioon. Kirkon yhteisen toiminnan kulut kääntyivät laskuun. Maailmanlaajuisen talouskriisin lisäksi kirkosta eroaminen alkoi selvästi näkyä seurakuntien taloudessa: vaikka kunnallisverotulot lähtivät kriisivuoden 2009 jälkeen nousuun, vastaavaa ei tapahtunut seurakuntien verotuloissa. ${ }^{291}$ Vuoden 2012 talousarvioesityksessä kirkkohallituksen määrärahat olivat

Kuvio 19: Kirkon yhteisen toiminnan kulut kirkon keskusrahaston talousarvioissa vuosille 2000-2012 Kuviossa ei ole mukana eläketoimintaa eikä muutenkaan omakatteisia rahastoja.

\section{Avustukset}

Hiippakunnallinen toiminta

Kirkkohallitus 


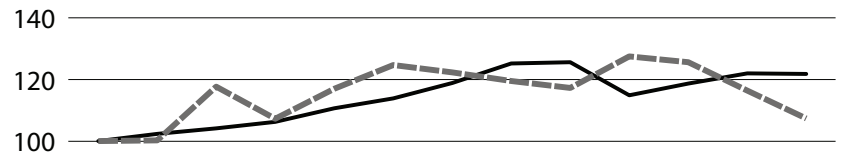

80

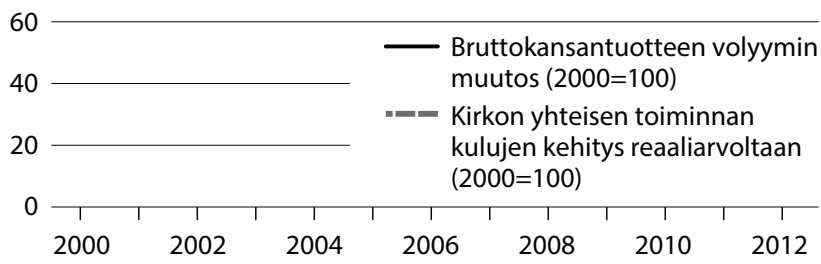

viisi prosenttia pienemmät kuin edellisen vuoden varsinaisessa talousarviossa. Lisäksi strategiset hankkeet ja kirkkohallituksen toimitilojen investointitarpeet uhkasivat pienentää keskusrahaston varallisuuden vain seitsemän kuukauden seurakuntamaksuja vastaavalle tasolle. ${ }^{292}$ Viisi vuotta aiemmin kirkolliskokous oli lähtenyt keventämään kirkon keskusrahaston tasetta, mutta lopputuloksena oli, että tase oli vaarassa keventyä jo liiaksi. Reaaliarvoltaan kirkon yhteisen toiminnan kulut palasivat kymmenen vuoden takaiselle tasolle.

Kaikkiaan talousvaliokunnan ja laajemminkin kirkolliskokouksen suhtautumista kirkkohallitukseen leimasi talousasioissa vuosina 2000-2011 luottamus. Talousvaliokunnan puheenjohtaja Pertti Simola ilmaisi sen 2008:

Ei millään voi ajatella, että kirkkohallitus on mutkikas rakennus Katajanokalla, jossa virkamiehet tekevät työtään elämästä irrallisena ja lähtevät kotiin, niin kuin vanhan ajan hyvät virkamiehet, hyvin levänneenä ja lehden lukeneena. Kirkkohallituksen toimintaote on tämän kirjan perusteella dynaaminen ja eteenpäin katsova ja sen tähden on jo tässä vaiheessa syytä esittää kirkas kiitos niin kirkkohallituksen täysistunnolle - - kuin kansliapäällikölle, kaikille kirkkoneuvoksille ja laajasti koko kirkkohallituksen henkilöstölle. ${ }^{293}$

Epäilemättä kirkolliskokousedustajien tihentyneet mahdollisuudet saada tietoja ja tehdä ehdotuksia eri valmisteluvaiheiden aikana vähensivät epäluuloja. Toisaalta kädenvääntöä kirkolliskokouksessa saattoi hillitä sekin, että monet taloutta koskettavat asiat olivat siirtyneet kirkolliskokoukselta kirkkohallituksen päätösvaltaan.

Taloudellisessa päätöksenteossa kirkolliskokouksen ja kirkkohallituksen välillä tapahtuneet muutokset muistuttivat monelta osin eduskunnan ja hallituksen keski-
Kuvio 20: Kirkon yhteisen toiminnan kulujen reaaliarvon mukainen kehitys kirkon keskusrahaston talousarvioissa vuosille 200o2012

Kuviossa sovellettu tilastoaineisto: Kansantalouden tilinpito 2012; Kuluttajahintaindeksi. Kuviossa ei ole kirkon keskusrahaston osalta mukana eläketoimintaa eikä muutenkaan omakatteisia rahastoja.

näisessä suhteessa tapahtuneita muutoksia. Eduskunnan finanssivallan on kuitenkin arvioitu ennemminkin heikentyneen kuin vahvistuneen noiden muutosten myötä ${ }^{294}$. Niin valtion kuin kokonaiskirkon taloudessa koko ajan kasvavat rahasummat siirtyivät eduskunnan ja kirkolliskokouksen suoran vallankäytön ulkopuolelle. Kirkon yhteinen toiminta, johon kirkolliskokouksen päätösvalta keskittyi, oli kirkon keskusrahaston kokonaisuuden näkökulmasta sivuasia. Tärkein ja kriittisin osa oli eläkerahasto.

\section{KASVAVA ELÄKELAITOS JA} KIRKON EETTINEN VASTUU

"Jokaisella meillä kirkon työntekijöillä on nimikkoeläkeläinen tai kummieläkeläinen. Sehän on tietysti herttainen ajatus mutta taloudellisessa mielessä aika suuri haaste."295 Vuonna 2009 kirkkoneuvos Leena Rantanen kertoi kirkolliskokoukselle, että yksi rajapyykki kirkon eläkevastuun toteutumisen historiassa oli saavutettu: eläkkeensaajia oli yhtä paljon kuin työntekijöitä. Rantanen oli ilmoittanut heti valintansa jälkeen keväällä 2000, että eläkerahasto oli hänen työnäkynsä ${ }^{296}$. Kirkon eläkelaitostoiminnassa tapahtuikin sitten vuosikymmenen kuluessa suuria mullistuksia, jotka johtuivat osin suomalaisen eläkejärjestelmän nopeista muutoksista, osin taas kirkon eläkejärjestelmän erityisongelmista. Muutokset toteutuivat Rantasen ja kirkkohallituksen johdolla. Kirkolliskokouksen osana oli seurata tilannetta, tukea uudistustyötä ja tehdä päätöksiä tietyissä käännekohdissa. Helppoja tai mieluisia nuo päätökset eivät olleet, sillä ne olivat joka kerta yrityksiä vastata kirkon suurimpaan taloudelliseen uhkaan, eläkevastuun kasvamiseen.

Vuosikymmenen alussa eläkerahaston virallinen tavoitetaso oli vielä vaatimaton: kirkon palkkasumma puolitoistakertaisena. Eläteltiin myös mahdollisuutta luopua kirkon omasta eläkejärjestelmästä tai ainakin alentaa työnantajan 27 prosentin eläkemaksua, joka kirkolla oli valtakunnan korkein. ${ }^{297}$ Uhkakuvina näyttäytyi- 
vät lähinnä monien seurakuntien heikko taloudellinen tilanne ja mahdolliset valtion verohelpotukset, mutta toisaalta seurakuntien jäsenmäärä näytti vakaalta. ${ }^{298}$ Näkymät muuttuivat vuonna 2001. Kirkon eläkejärjestelmän tulevaisuutta selvittänyt komitea osoitti, ettei kirkon omasta eläkejärjestelmästä luopuminen ollut mahdollista. Eläkerahastolla ei ollut liioin mahdollisuuksia tuolloisessa tilanteessa päästä osalliseksi yhteistakuusta, jonka piirissä olevat eläkelaitokset turvasivat toistensa eläkemaksuja. Ainoa mahdollisuus oli kasvattaa eläkerahastoa määrätietoisesti. ${ }^{299}$

Samalla suunnitelmat eläkemaksun alentamisesta jäivät - varsinkin kun vuosituhannen alkuvuosina eläkerahaston sijoitusten tuotto oli hyvin heikko. ${ }^{300}$ Päinvastoin alkoivat voimakkaat tehostamistoimet, joiden tarkoituksena oli saada kirkon eläkejärjestelmä vastaamaan mahdollisimman pitkälle muita eläkejärjestelmiä. ${ }^{301}$ Muissa järjestelmissä oli esimerkiksi käytössä maksu, joka perittiin työnantajalta silloin, kun työntekijä jäi eläkkeelle ennen vanhuuseläkeikää. Kirkkohallitus halusi ulottaa käytännön kirkkoon ja saada siten seurakunnat huolehtimaan aiempaa paremmin työntekijöidensä työkyvystä. Kirkolliskokous hyväksyi esityksen 2003. Erityisen paljon työtä kirkkohallitukselle aiheutti siirtyminen järjestelmään, jossa henkilön työuran viimeinen eläkelaitos hoiti kaikki tehtävät ja maksoi eläkkeet. ${ }^{302}$ Kun eläkelaitoksilta edellytettiin samaan aikaan vielä muitakin muutoksia, kirkkoneuvos Rantanen kuvaili syksyllä 2002 eläkejärjestelmän näkymää "painajaismaista tilannetta lähenteleväksi”. ${ }^{303}$

Kirkon eläkejärjestelmän tulevaisuus näytti läpi vuosikymmenen kaksijakoiselta. Yhtäältä eläkemaksutulot riittivät eläkemenoihin jatkuvasti suunniteltua pidemmälle: 2002 niiden arveltiin riittävän vuoteen 2007 asti, mutta 2011 niiden laskettiin kattavan eläkemenot vielä 2015. ${ }^{304}$ Vähitellen myös valtiovallan kaavailemat eläkkeiden leikkaukset paransivat järjestelmän näkymiä. Toisaalta kirkon eläkevastuu kasvoi samaan aikaan..$^{305}$ Eläkevarojen riittävyys oli myös äärimmäisen riippuvaista sijoitustoiminnan onnistumisesta. Vuodesta 2008 lähtien maailmantalouden epävarmuus ja länsimaiden kiihtyvä velkaantuminen nostattivat kysymyksen, saattoiko eläkerahasto saavuttaa vastaisuudessa läheskään yhtä hyviä tuottoja kuin toimintansa kahtena ensimmäisenä vuosikymmenenä. Ehkä kaikkein suurimpana uhkana oli kuitenkin seikka, jota ei vielä vuosituhannen alussa ollut osattu ottaa lukuun: seurakunnista erosi jäseniä kiihtyvään tahtiin..$^{306}$ Kirkolliskokouksessakin jouduttiin toteamaan, että suurimmat virheet oli tehty jo silloin, kun kirkolle ylipäätään oli perustettu oma eläkejärjestelmä ja kun rahastoinnin aloittamista oli viivytetty. ${ }^{307}$

Tutkimuskauden viimeisinä vuosina kirkon eläkerahasto oli sijoitustoiminnaltaan tuottoisin eläkelaitos. Menestys ei auttanut, kun samaan aikaan valmistuivat uudet eläke-ennusteet. Ne pakottivat kiristämään varainkeruun tahtia entisestään. ${ }^{308}$ Tähtäyspiste oli vuodessa 2080. Aivan samoin kuin HeTa-hankkeessa tarkoituksena oli helpottaa myöhempien sukupolvien maksutaakkaa. Keväällä 2011 kirkkohallitus ehdotti kirkkolain muuttamista siten, että seurakunnilta voitaisiin kerätä erityistä eläkerahastomaksua. Näin oli määrä turvata kirkon eläkejärjestelmän rahoitus tilanteessa, jossa palkkasummaan perustuvan eläkemaksun ei enää katsottu yksin riittävän. Yritettiin olla liikkeellä hyvissä ajoin, jotta eläkerahastomaksun vaikutus sijoitustoiminnan tuottoon olisi mahdollisimman suuri. ${ }^{309}$

Kirkolliskokous hyväksyi sinänsä vaikean ja seurakunnille raskaan esityksen keskustelutta. ${ }^{30}$ Talousarviossa varauduttiin kymmenen miljoonan euron suuruiseen, kirkollisverotuloista 1,2 prosenttia vievään eläkerahastomaksuun vuodesta 2013 alkaen. Lisäksi työnantajan eläkemaksua nostettiin prosenttiyksiköllä 28 prosenttiin. ${ }^{311}$ Kirkolliskokouksessa oli vuosituhannen alkaessa toivottu helpotusta eläkemaksuihin, mutta kymmenen vuotta myöhemmin tie vei jäsenkadon vuoksi täysin päinvastaiseen suuntaan. Uusi eläkerahastomaksu merkitsi tietyssä mielessä paluuta kohti aiempaa järjestelmää, jossa eläkemaksu oli perustunut kirkollisveroäyriin. Palkkasummaan perustuvaa eläkemaksua ei voitu nostaa loputtomasti, mikäli haluttiin seurakuntien työllistävän vastakin.

Vuonna 1999 oli julkaistu kirkon sijoitustoiminnan eettiset periaatteet, mutta aihe pysyi ajankohtaisena. Kirkon yhteisövero-osuuden epävarma tulevaisuus sai monet seurakunnat rahastoimaan voimakkaasti. ${ }^{32}$ Korkeat tuottotavoitteet pakottivat puolestaan pitämään kirkon eläkerahaston varoista suuren osan kiinni osakkeissa. Vuosituhannen alkuvuosina korkea riski kostautui, mutta toisaalta eläkerahasto hyötyi nopeasti, kun osak- 


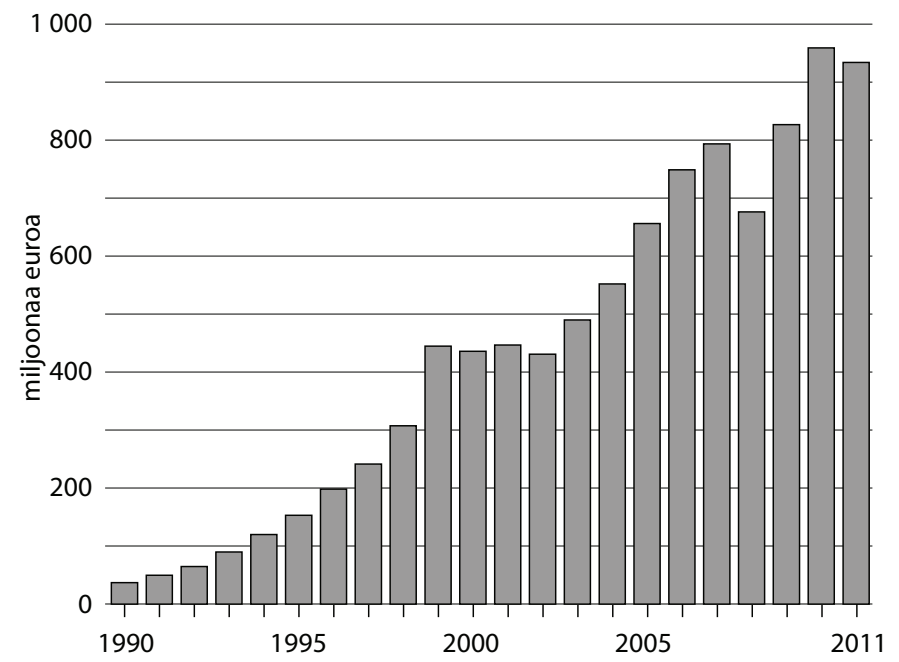

keet lähtivät nousuun. Vuonna 2005 eläkerahaston tuotto oli lähes 16 prosenttia, ja rahasto kasvoi yli sata miljoonaa euroa. ${ }^{313}$ Taloudellisen kasvun huippuvuosina mielikuva rikkaasta kirkosta vahvistui suomalaisten keskuudessa hyvin nopeasti. ${ }^{314}$

Asetelma oli kirkon näkökulmasta sikälikin epäedullinen, että samaan aikaan useat suomalaisyhtiöt irtisanoivat suuria määriä työntekijöitä ja siirsivät tuotantoaan pois Suomesta. Keväällä 2006 kirkolliskokouksessa nousi esille kysymys, oliko kirkko ollut käytännössä muiden osakkeenomistajien kanssa vaatimassa yrityksiltä entistä parempaa tulosta ja vauhdittamassa siten toimintojen siirtämistä ulkomaille. Kotimaisiin osakkeisiin sijoittaminen, joka oli tarkoitettu yhteiskuntavastuun kantamiseksi, näyttikin kääntyvän vastakohdakseen. Jo pari viikkoa ennen kirkolliskokousta kirkkohallitus oli asettanut työryhmän päivittämään kirkon sijoitustoiminnan eettisiä ohjeita. Kirkkoneuvos Rantanen ilmoitti edustajille, että kirkon omistajapolitiikkaa oli arvioitava uudelleen. Aiemmin kirkko oli ollut passiivinen omistaja, mutta eläkerahaston kasvaessa oli mietittävä, oliko tarpeen pyrkiä vaikuttamaan yritysten toimintaan. ${ }^{315}$ Suomalaisen teollisuuden irtisanomiset nousukauden aikana olivat kääntämässä kirkkoa aktiiviseksi omistajaksi.

Kirkkohallitus hyväksyi huhtikuussa 2007 uudet vastuullisen sijoittamisen ohjeet, jotka oli osittain laadittu yhdessä Ruotsin kirkon kanssa. Päämääränä oli sijoittaa yrityksiin, jotka tunsivat "vastuuta yksilöstä, ympäristöstä ja yhteiskunnasta”. Epäeettisten sijoituskohtei-
Kuvio 21: Kirkon eläkerahaston koko 1990-2011 (vuoden päättyessä)

Kirk.kok. ptk-k. 2011, liite III 10; Kirk.kok. ptk-k. 2012, liite IX-B 1. den karsiminen ei kuitenkaan riittänyt, vaan tarvittiin myös vaikuttamista yritysten toimintaan. ${ }^{316}$ Apuna pyrittiin käyttämään sijoittajien joukkovoimaa. Eläkerahaston omistukset oli määrä käydä yksityiskohtaisesti läpi puolen vuoden välein. ${ }^{317}$ Vastuullisen sijoittamisen ohjeet saivat kirkolliskokouksessa kiittävän vastaanoton, ja kirkkohallituksen esityksestä kirkolliskokous käynnisti erillisen vastuullisen sijoittamisen projektin. Yhtenä päämääränä oli herätellä myös seurakunnat samalle asialle. ${ }^{318}$ Projektin päätyttyä vuoden 2010 lopussa kirkolliskokouksen talousvaliokunta totesi sen onnistuneeksi. Yhteistyöllä oli pystytty vaikuttamaan yritysten toimintaan, ja vastuullinen sijoittaminen oli omaksuttu pysyväksi osaksi keskusrahaston toimintaa. ${ }^{319}$

Ympäristöasiat liittyivät kiinteästi vastuullisen sijoittamisen ohjeisiin. Ohjeiden hyväksymisen aikaan 2007 ympäri maailmaa puhutti ilmastonmuutos, jota koskevan tiedon jakaminen oli tuolloin muun muassa Nobelin rauhanpalkinnon perusteena ${ }^{320}$. Saman vuoden keväällä kirkolliskokous vietti ruokailussaan erityistä luomupäivää, ja 12 edustajaa eri hiippakunnista jätti aloitteen ilmasto-ohjelman laatimiseksi. Ensimmäisenä allekirjoittajana oli ekoteologiaa esillä pitänyt Pauliina Kainulainen. Allekirjoittajien joukossa oli myös piispa Mikko Heikka, joka oli jo muissa yhteyksissä ehdottanut kirkolle ilmasto-ohjelmaa. ${ }^{321}$ Kainulaisen mukaan aloitteen tarkoituksena ei ollut kulkea muodissa mukana vaan ottaa huomioon suomalaisessa keskustelussa tapahtunut liikahdus: ihmiset pohtivat ilmastonmuutosta, 
ja kirkonkin oli pysähdyttävä tarkastelemaan uskoaan, elämäänsä ja raamatuntulkintaansa. Ympäristölle vahingollisia tulkintamalleja oli purettava. ${ }^{322}$

Aloite sai laajaa tukea, joskin muutamat - varsinkin Suomen Luterilaista Evankeliumiyhdistystä lähellä olevat - edustajat esittivät eri vaiheissa epäilyjään. Mielipide-erojen taustalla voi nähdä erot ihmiskäsityksessä sekä vanhurskauttamisopin ja regimenttiopin tulkinnassa. Aloite kuvasti uskoa muutokseen ja vaikuttamismahdollisuuksiin, kun taas Lasse Marjokorpi epäili ihmisten tahtoa muuttaa vapaaehtoisesti käyttäytymistään. Aloitteentekijät korostivat luomista, mutta toiset muistuttivat langenneisuudesta. ${ }^{323}$ Ympäristöasioita painottavien mielestä pelastus oli ymmärrettävä laajemmin kuin vain yksilöä koskevana, kun taas arvostelijoiden mukaan uhkana oli tekovanhurskaus. ${ }^{324}$ Regimenttiopin tulkinnat puolestaan tulivat esiin pohdittaessa kirkolliskokouksen tehtävää. Toisten mielestä se oli kytköksissä ihmiskunnan tulevaisuuteen, kun taas esimerkiksi kirkkoherra Marjokorpi, piirijohtaja Hannu Kippo ja maanviljelijä Tuomas Lankinen korostivat eri yhteyksissä, ettei kirkolliskokous ollut oikea paikka pohtia ympäristökysymyksiä. ${ }^{225}$

Perustevaliokunnan johdolla kirkolliskokous asettui aloitteen taakse: ilmastonmuutos oli vakava ilmiö, ja ilmasto-ohjelman todettiin liittyvän luontevasti kirkon muihin ympäristöhankkeisiin, kuten 2001 käyttöön otettuun ympäristödiplomiin. ${ }^{326}$ Kirkkohallitus hyväksyi ilmasto-ohjelman Kiitollisuus, kunnioitus, kohtuus kesällä 2008, ja ohjelmalle asetettiin seurantaryhmä. ${ }^{327}$ Kirkolliskokouksessa keskustelu ilmasto-ohjelmasta laajeni eri vaiheissa periaatekeskusteluksi kirkon tehtävästä. Myöhemmin piispa Seppo Häkkinen, joka oli kirkkoneuvoksena vienyt eteenpäin muun muassa ilmasto-ohjelmaa, arvioi kriittisesti kirkon toiminnan painopisteitä. Huomio oli kohdistunut yhteiskunnallisiin ongelmiin, kuten köyhyyteen, ilmastokysymyksiin ja tasa-arvoon. Hengellinen puoli oli jäänyt vähemmälle, jolloin uskon sisältö oli ollut vaarassa muuttua pelkäksi yleishumanismiksi: "Tällaisesta yleishumanistisesta hyväntekeväisyyskirkosta tai uskonnollisesta palvelulaitoksesta on helppo erota." 328

Ilmasto-ohjelman, kuten monen muunkin toiminnallisen uudistuksen, alullepanijat lähtivät teologisista perusteluista, mutta siitä huolimatta vuosikymmenen päättyessä kirkon toimintaa arvosteltiin kirkolliskokouksessa entistä useammin ohuesta hengellisyydestä. Arvostelua ei kuulunut vain niin sanotusta tunnustuksellisesta edustajaryhmästä vaan myös kirkon johdosta. Talouden kriisit veivät ihmisten huomiota pois maailmanlaajuisista ongelmista omaan kansallisvaltioon ja henkilökohtaiseen toimeentuloon. Jossain määrin samaa muutosta oli nähtävissä myös kirkolliskokouksen keskusteluissa. Lukuisien yhteiskunnallisten toimintamuotojen sijasta tapetille oli uudelleen nousemassa henkilökohtainen pelastussanoma.

\section{VAPAUTTA ALUEELLISEEN PÄ̈̈TÖKSENTEKOON}

\section{TEKNOLOGIAKESKUKSEN VAI MAASEUTU- IDYLLIN HIIPPAKUNTA LÄNTISELLE UUDELLEMAALLE?}

Keväällä 2001 kirkolliskokouksessa keskusteltiin kirkon nelivuotiskertomuksesta. Yksi huolenaiheista oli, että muuton yhteydessä kirkon jäsenten suhde seurakuntaan höltyi. ${ }^{329}$ Koska ongelma kosketti erityisesti kasvukeskusten seurakuntia, ei ollut ihme, että Helsingin hiippakunnan jakaminen nousi esiin samalla istuntokaudella. Jakohanke oli tuolla erää lähtenyt liikkeelle 1996 jätetystä edustaja-aloitteesta. Sen jälkeen Helsingin hiippakunta ja kirkkohallitus olivat selvittäneet asiaa. Helsingin tuomiokapituli oli asettunut hiippakunnan jakamisen kannalle. Sen sijaan kirkkohallituksen täysistunto oli äärimmäisen tiukassa äänestyksessä jättänyt jakamisehdotuksen raukeamaan ja päättänyt selvittää vielä muita vaihtoehtoja. ${ }^{330}$ Sitä kirkolliskokouksessa ei jääty vaieten seuraamaan.

Seitsemän Helsingin hiippakunnan edustajaa jätti kirkolliskokoukselle aloitteen, jonka mukaan kirkkohallitukselle oli annettava tehtäväksi laatia esitys hiippakunnan jakamisesta. Aloitteentekijät vetosivat muun muassa hiippakunnan seurakuntien ja seurakuntayhtymien toiveisiin: kantaa ottaneista 60 seurakunnasta 52 oli puoltanut jakamista, minkä lisäksi kahdeksasta kirkkohallituksen kyselyyn vastanneesta seurakuntayhtymästä seitsemän oli ollut jakamisen kannalla. ${ }^{331}$ Keskustelu kirkolliskokouksessa avasi tilanteen monitahoisuuden: puheenvuoroissa risteili erilaisia teemoja koko kirkon hiip- 
pakuntajaosta Turun arkkihiippakunnan tilanteeseen ja arkkipiispan vaalitapaan. Keskustelu kuvasti myös kirkolliskokouksen yhteishenkeä taloudellisissa ja hallinnollisissa kysymyksissä vuosikymmenen alussa. Kun pääkaupunkiseudun edustajat tunsivat toisaalla huolta verotulojen tasaamisesta, tässä asiassa maaseudun edustajat osoittivat tukea Helsingin hiippakunnan jakamisel- le. Ennen kaikkea käytiin kuitenkin periaatteellista keskustelua kirkkohallituksen toimivallasta. ${ }^{332}$

Jotkut edustajat syyttivät kirkkohallitusta valtuuksien ylittämisestä, kun se oli jättänyt hiippakunnan jakamisesityksen raukeamaan. Kirkkohallituksen jäsenet puolustautuivat todeten, ettei jakamisajatusta ollut haudattu lopullisesti. Oli vain edellytetty muidenkin vaih-

\section{Kirkolliskokouksen paras ystävä}

Vuoden 2001 kevätistuntokaudella kirkolliskokouksessa kuultiin kiivasta ja värikästä keskustelua kirkkohallituksen asemasta ja toimivallasta. Suunnitelmat Helsingin hiippakunnan jakamiseksi olivat hieman aiemmin kaatuneet kirkkohallituksen täysistunnossa. Useiden kirkolliskokousedustajien mielestä kirkkohallitus oli ylittänyt toimivaltansa ja kävellyt kirkolliskokouksen yli. ${ }^{I}$ Jyväskyläläinen seurakuntapastori Arvi Tuomi kuului tyytymättömien joukkoon. Saksanpaimenkoirien kasvattajana hän löysi vertauskuvan läheltä:

Nykyinen Alex-koirani on rotunsa tyyppiedustajana vahvaluonteinen, mutta myös alistuvainen, jos isäntä muistaa pitää komennon. Aina silloin tällöin se kuitenkin kokeilee yksittäisissä tilanteissa, voisiko annettua hierarkiaa uhmata ja yrittää nousta isännöimään. Silloin pitää taas kerran osoittaa tuolle luontokappaleelle, mikä sen oikea paikka perhekokonaisuudessa on. Niin, mistähän johtuu, että kirkkohallituksen entisenä työntekijänä ja kirkolliskokouksen jo aika pitkäaikaisena edustajana tämä asetelma on tullut toistuvasti mieleen, kun näiden kahden instituution suhteita olen seuraillut. ${ }^{\text {II }}$

Säkylän seurakunnan nuorisotyönohjaaja Kimmo Koivisto ei voinut hyväksyä tällaista rinnastusta:

Jotenkin koen, että Bernin paimenkoira olisi paljon oikeampi koira, koska berniläinen on uskollinen, itsepäinen, älykäs, lempeä ja poikkeaa aina omille teillensä. Berniläistä ei pysty kasvattamaan lyömällä eikä komentelemalla vaan kiittämällä ja kehumalla ja se on ihmisen paras ystävä ja isännälleen täysin uskollinen. ${ }^{\text {III }}$

Tuskin oli kuitenkaan kyse kasvatuspyrkimyksistä, kun samalla istuntokaudella kirkkohallitusta kiiteltiin vuolaasti nopeasta puuttumisesta seurakuntien eriarvoistumiseen. Kirkolliskokouksen asennoitumisessa kirkkohallitukseen näkyi 1970-luvulta lähtien muutos: kirkolliskokousuudistuksen jälkeisinä vuosina kirkkohallitukselle oli ajoittain osoitettu paikkaa kuin saksanpaimenkoiralle konsanaan, kun taas 1980- ja 1990-luvulla siihen oli suhtauduttu kirkolliskokouksessa ennemminkin kuin itsenäiseen berniläiseen. Oli oltu valmiit lisäämään lakimuutoksilla kirkkohallituksen liikkumatilaa ja myös käytännössä nojaamaan kirkkohallitukseen

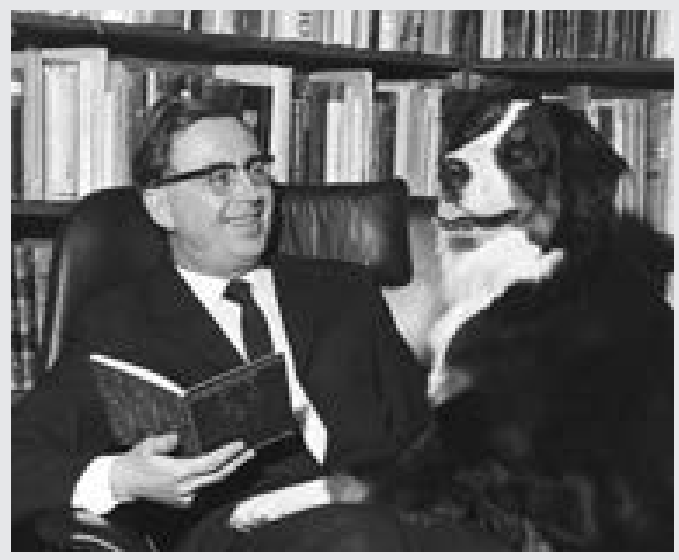

Virkakomiteaa 1960- ja 1970-luvulla johtanut dogmatiikan professori Seppo A. Teinonen tunsi berninpaimenkoiran luonteen. Kevätistuntokaudella 2001 sama koirarotu toimi vertauskohtana, kun keskusteltiin kirkkohallituksesta kirkolliskokouksen palveluksessa. Kuva: Kirkkohallitus / Laatukuva.

koko ajan enemmän. Viimein 20oo-luvulla pysähdyttiin jälleen miettimään kirkkohallituksen toimivallan rajoja.

Helsingin hiippakunnan jakamisongelmien ohella kirkolliskokouksessa aiheutti paljon arvostelua ja jopa suuttumusta se, että kirkkohallitus pidättyi toteuttamasta kirkolliskokouksen antamaa toimeksiantoa, joka tähtäsi missiologian lahjoitusprofessuurin perustamiseen Helsingin yliopistoon. ${ }^{\text {Iv }}$ Lopulta kirkolliskokous tyytyi siihen, että missiologiaa varten perustettiin yliopistonlehtorin virka. ${ }^{\mathrm{v}}$ Kirkkohallitus oli 20oo-luvulla vahva elin, ja sellaisena se joutui ajoittain törmäyskurssille kirkolliskokouksen kanssa. Kaikesta huolimatta se oli kirkolliskokouksen paras ystävä, jonka toimintamahdollisuuksia kirkolliskokous oli myös omilla toimillaan vahvistamassa.

I Kirk.kok. kptk-k. 2001,31\$.

II Kirk.kok. kptk-k. 2001,31 §.

III Kirk.kok. kptk-k. 2001,31\$.

IV Kirk.kok. ptk-s. 2000, liite VII-F 11; Kirk.kok. kptk-s. 2003, 24 \$, 28 \$; Kirk. kok. ptk-s. 2003, liite VI 1.

V Kirk.kok. kptk-s. 2003, 28 \$; Kirk.kok. ptk-s. 2003, liite VI 1. 
toehtojen tutkimista. Lakimiehet taas korostivat, ettei hiippakunnan jakaminen ollut enää kirkkohallituksen päätöksen jälkeen vireillä. Kirkollisen päätöksenteon hitauteen tuskastunut suuronnettomuustutkija, varatuomari Kari Lehtola totesi oudoksuneensa keskustelun aikana sitä, "että kirkon päättäjät eivät kaikki tiedä verbin raueta merkitystä, kun muistetaan toisaalta mitä muita päätöksiä me ylipäänsä teemme kuin erilaisia raukeamispäätöksiä”. ${ }^{333}$ Kirkolliskokous antoi lopulta kirkkohallituksen tehtäväksi tutkia ja valmistella mahdolliset vaihtoehdot Helsingin hiippakunnan lisääntyvien tehtävien hoitamiseksi. Vaihtoehtoihin piti sisältyä hiippakunnan jakaminen. ${ }^{334}$ Yleinen asenne näytti olevan, että kiistely paikkakuntien välillä ei saanut kaataa hanketta, kuten aikoinaan oli pitkälti käynyt suunniteltaessa uutta teologista tiedekuntaa tai kirkkomuseota. ${ }^{335}$

Kun sitten kirkkohallitus antoi esityksensä keväällä 2002, Helsingin hiippakunnan jakaminen sai kirkolliskokouksessa odotetusti tukea. Vain muutamat edustajat toivoivat toisenlaista ratkaisua. Yksi heistä, erityisasiantuntija Päivi Varpasuo, otti vertailukohdaksi valtion väliportaanhallinnon, jossa oli lähdetty suurentamaan läänejä. ${ }^{336}$ Kirkkohallitus taas nojautui 1998 toteutettuun maakuntajakoon. Samaan aikaan Helsingin hiippakunnan jakosuunnitelman kanssa kirkkohallitus näet esitti suomenkielisten hiippakuntien rajojen vetämistä siten, että kunkin maakunnan seurakunnat kuuluisivat samaan hiippakuntaan. ${ }^{337}$ Rajamuutokset herättivät seurakunnissa sen verran voimakasta arvostelua, että kirkolliskokous jätti esityksen raukeamaan ja keskittyi pelkästään Helsingin hiippakunnan tilanteeseen. ${ }^{338}$ Oli kuitenkin merkitystä, otettiinko hiippakuntien vertailukohdaksi läänit vai maakunnat: ensin mainitusta lähtökohdasta käsin hiippakunnat näyttäytyivät keskushallinnon alaisena väliportaanhallintona, kun taas rinnastus maakuntiin otti paremmin huomioon hiippakuntien itsehallinnon.

Pyrkimys maakuntarajojen mukaisiin hiippakuntarajoihin heijastui myös keskusteluun Helsingin hiippakunnan jakamisesta. Uuden hiippakunnan rajat virittivätkin huomattavasti enemmän keskustelua kuin varsinainen kysymys siitä, tuliko hiippakunta jakaa vai ei. ${ }^{339}$ Kirkkohallitus esitti, että uuteen hiippakuntaan liitettäisiin tuolloisen Helsingin hiippakunnan länsiosat. Pääkaupunkiseudusta Espoo kuuluisi uuteen hiippakuntaan. ${ }^{340}$
Joidenkuiden mielestä pääkaupunkiseudun jakaminen eri hiippakuntiin soti maakuntajaon periaatetta vastaan, kun taas toiset katsoivat, ettei hiippakuntarajan vetäminen pääkaupunkiseudun ja muun Uudenmaan välille pienentäisi Helsingin hiippakuntaa riittävästi. Jotkut taas halusivat jättää Helsingin hiippakuntaan vain pelkän Helsingin kaupungin alueen. ${ }^{341}$ Hallintovaliokunnan ehdotuksesta kirkolliskokous päätyi lopulta varsin yksimielisesti kirkkohallituksen esittämien hiippakuntarajojen kannalle. ${ }^{342}$

Kiivain kädenvääntö koski piispanistuimen sijoituspaikkaa. Kirkkohallitus esitti Lohjaa, mutta esitys sisälsi professori Seikko Eskolan eriävän mielipiteen Espoon puolesta. Taas syntyi jännitettä kirkkohallituksen ja kirkolliskokouksen välille. Ensinnäkin ihmetystä herätti, että eriävä mielipide oli lähetetty edustajille mietinnön mukana, vaikka menettelystä oli Matti Halttusen aiemman ilmoituksen mukaan luovuttu. ${ }^{343}$ Toiseksi KantaEspoon kirkkoherra Marjatta Laitinen oli osallistunut kirkkohallituksessa asian käsittelyyn ja liittynyt eriävään mielipiteeseen, mikä nostatti kysymyksen esteellisyydestä - olisihan Espoon valinta käytännössä tehnyt hänestä tuomiorovastin. Lainoppinut asiantuntija, oikeusneuvos Mikael Krogerus arvosteli voimakkaasti kirkkohallituksen jääviystulkintoja ja sitä, että äänestyslausunnot päätyivät sattumanvaraisesti kirkolliskokoukselle. ${ }^{344}$ Helsingin hiippakunnan jakaminen koetteli monin tavoin kirkon keskushallinnon elinten välejä.

Keskustelu piispanistuimen sijoituspaikasta linkittyi uuden hiippakunnan rajoihin, kun jotkut edustajat ounastelivat pääkaupunkiseudun kuntaliitosta. Oikeusneuvos Krogerus, joka ei muutenkaan lainoppineena asiantuntijana toimiessaan rajoittunut ottamaan kantaa vain tiukimmassa mielessä lainmukaisuuskysymyksiin, kehotti selvittämään pääkaupunkiseudun mahdollisen kuntaliitoksen vaikutuksia hiippakuntarajoihin. ${ }^{345}$ Hallintovaliokunta ei kuitenkaan selvitysten perusteella nähnyt estettä Espoon liittämiselle uuteen hiippakuntaan. ${ }^{346}$ Säkylän seurakunnan nuorisotyönohjaaja Kimmo Koivisto ei sen sijaan uskonut ratkaisun pysyvyyteen: "- - niin kuin Savonlinnassakin on tuomiokirkko, niin on se kiva, että espoolaisilla joskus on tuomiokirkko vaikkei olisikaan hiippakuntaa. Koska minä epäilen, että joskus Helsingin hiippakuntaan kuuluu myöskin Espoon seurakunta." ${ }^{47}$ 
Kirkkohallituksen tavoin kirkolliskokouksen hallintovaliokunnassa enemmistö asettui Lohjan kannalle mutta äärimmäisen niukasti äänin $9-8 . .^{348}$ Edustajien kantoihin heijastui se, katsoivatko he asiaa ensisijaisesti seurakuntien työyhteisön vai yhteiskunnan ja tavallisten kirkon jäsenten kannalta. Ensimmäinen näkökulma puolsi Lohjaa - olihan valtaenemmistö alueen seurakunnista sen kannalla. Lohjan valinta olisi vahvistanut uuden hiippakunnan identiteettiä nimenomaan pääkaupunkiseudun ulkopuolisen Uudenmaan hiippakuntana. Yhteiskunnan ja tavallisten kirkon jäsenten näkökulmasta taas piispa oli vaarassa jäädä Lohjalla syrjään. Hänellä olisi parhaat mahdollisuudet toimia yhteiskunnallisena vaikuttajana ja espoolaisten piispana nimenomaan Espoosta käsin. ${ }^{349}$

Toinen näkökulmaero koski sitä, tuliko kirkon tunnustaa tosiasiat vai pyrkiä muuttamaan niitä. Jälkimmäiseltä kannalta katsottuna kirkko antoi itsestään kielteisen kuvan, jos se lähti mukaan keskittämiseen ja sijoitti tuomiokapitulin Espooseen. Lohja näyttäytyi keskustelussa usein eräänlaisena maaseutuidylliä edustavana vastakohtana kasvottomalle teknologiakeskukselle. Tämä asetelma ei näyttänyt aina miellyttävän sen enempää espoolaisia kuin lohjalaisiakaan. Tosiasioiden tunnustamisen linja taas lähti siitä, että piispan oli oltava siellä, missä ihmiset ja suurimmat ongelmat olivat. ${ }^{350}$ Everstinä palvellut Seppo Ahtikoski kysyi lyhyesti: "Joukkoja johdetaan edestä. Mistä hiippakuntaa johdetaan."351 Tosin tässäkään suhteessa asetelmat eivät olleet mustavalkoiset. Jotkut Lohjan kannattajat muistuttivat, että muuttoliikkeen painopiste oli jo alkanut siirtyä pääkaupunkiseudulta ympäröivälle Uudellemaalle. Heidän mielestään Lohjan valinta olisi tulevaisuuteen suuntautuva ratkaisu. ${ }^{352}$

Täysistunnossakin äänestys oli tiukka, mutta tällä kertaa tulos kääntyi Espoon hyväksi äänin 57-45. Helsingin piispan Eero Huovisen puheenvuoro Espoon puolesta keskustelun loppuvaiheessa saattoi vaikuttaa ratkaisevasti lopputulokseen. ${ }^{353}$ Koska asia oli monitahoinen ja voimakkaita tunteita herättävä, edustajien kannat vaihtelivat ilman näkyviä ryhmäjakoja: Espoo sai runsaasti kannatusta myös maaseudulta tulevilta edustajilta, kun taas esimerkiksi espoolainen Linda Lawast-Slotte äänesti Lohjan puolesta. Selvin tulos oli piispojen keskuudessa: yhdeksästä piispasta seitsemän kannatti Espoota, ja vain Jukka Paarma ja Erik Vikström antoivat äänensä Lohjalle. ${ }^{354}$ Lohjalla ilmestyneessä Länsi-Uusimaa-lehdessä päätös tulkittiin periaatteelliseksi: kirkko oli hylännyt maaseudun. ${ }^{355}$

\section{HIIPPAKUNTAHALLINTO ITSENÄISTYY \\ JA PAISUU}

Hiippakuntahallinnon uudistaminen lähestyi päätöksentekovaihetta samaan aikaan, kun Helsingin hiippakunnan jakamisesitys oli kirkolliskokouksen käsittelyssä. Kirkkohallitus jätti keväällä 2001 esityksen, jonka se oli laatinut edellisen kirkolliskokouksen asettamien suuntaviivojen mukaisesti. Kirkkohallitus ehdotti, että hiippakunnan taloudellisen ja toiminnallisen aseman vahvistamiseksi perustettaisiin hiippakuntaedustajisto, jossa maallikot olisivat enemmistönä mutta jonka puheenjohtajana toimisi piispa. Nelivuotiskaudeksi valittava edustajisto hyväksyisi hiippakunnan toiminta- ja taloussuunnitelman, tekisi talousarvioesityksen kirkon keskusrahastolle, perustaisi ja lakkauttaisi hiippakunnan virat ja hyväksyisi osaltaan hiippakunnan talousarvion ja tilinpäätöksen. Hiippakuntaedustajisto saisi tehdä esityksiä kirkolliskokoukselle. ${ }^{356}$

Edellinen kirkolliskokous oli ehdottanut hiippakuntaedustajiston kokoamista hiippakunnan kirkolliskokousedustajista, mutta kirkkohallitus esitti edustajistolle erillistä vaalia. ${ }^{357}$ Edelleen esitykseen sisältyi hiippakuntakokouksen ja rovastikuntakokousten lakkauttaminen. ${ }^{358}$ Tuomiokapituliin oli määrä lisätä kaksi luottamustoimista maallikkojäsentä, mutta vastaavasti lakimiesasessorille varattiin vain läsnäolo- ja puheoikeus, kuten hiippakunnan pääsihteerille. Lainkäyttöasiat oli pääosin tarkoitus siirtää tuomiokapituleilta hallintooikeuksille. ${ }^{359}$ Laajaan, noin sataa kirkkolainsäädännön pykälää koskevaan esitykseen sisältyi myös muutos, jonka myötä hiippakuntajakoa tai hiippakuntarajoja koskevia päätöksiä ei enää alistettaisi valtioneuvostolle. ${ }^{360}$ Siten esitys oli viemässä päätökseen 1990-luvulla alkaneen siteiden purkamisen hiippakunta- ja valtionhallinnon väliltä.

Rovastikuntakokousten lopettaminen hyväksyttiin yleisesti kirkolliskokouksessa, mutta samalla monet painottivat, ettei rovastikuntia muuten saanut unohtaa. Päinvastoin tuli kehittää niiden suomia yhteistyömahdollisuuksia. Enin huomio kohdistui hiippakunnan 
elinten kokoonpanoon. Porvoon piispa Erik Vikström ja Turun piispa Ilkka Kantola arvostelivat uudistusta liian raskaaksi ja halusivat säilyttää lakimiesasessorin tuomiokapitulin jäsenenä. Hiippakuntahallintokomitea oli pohtinut joko laajaa hiippakuntavaltuustoa tai tuomiokapitulin laajentamista ja päätynyt jälkimmäiseen vaihtoehtoon. Kirkkohallitus oli sen sijaan lähtenyt toteuttamaan molempia vaihtoehtoja, ja Kantola kysyi, oliko tällainen hallinto enää kevyttä. Vikström väläytti jopa koko lakipaketin hylkäämistä toisessa käsittelyssä. ${ }^{361}$ Kahden piispan puheenvuoroissa tuli jälleen näkyville 1990-luvulla kohdattu vastakkainasettelu: hallinnon keventäminen merkitsi käytännössä virkamiesten aseman vahvistumista vastapainona raskaaksi koetulle edustukselliselle hallinnolle.

Kirkolliskokouksen hallintovaliokunta yhtyi pääosin kirkkohallituksen esitykseen. Se tosin nimesi päätöksentekoelimen hiippakuntavaltuustoksi, koska elimen tehtävät muistuttivat kirkkovaltuuston tehtäviä. ${ }^{362} \mathrm{Li}$ säksi valiokunta halusi korostaa maallikkojen asemaa siten, että hiippakuntavaltuuston puheenjohtajana toimisi aina maallikko. Piispalla olisi valtuustossa vain läsnäolo- ja puheoikeus, kuten muillakin tuomiokapitulin jäsenillä. ${ }^{63}$ Voimakkaimmin ehdotusta arvosteli jälleen Erik Vikström, jonka mukaan uudistusten myötä piispa ei enää olisi hiippakuntansa ylin kaitsija vaan valmisteleva ja toimeenpaneva virkamies. Kirkolliskokous hyväksyi kuitenkin hallintovaliokunnan esityksen hiippakuntavaltuustosta. ${ }^{36}$ Ydinkysymykseksi jäi tuomiokapitulin kokoonpano.

Piispainkokous vastusti niin maallikkojäsenten lisäämistä tuomiokapituliin kuin lakimiesasessorin poistamista kokoonpanosta. Lakivaliokunta asettui lausunnossaan samalle kannalle: laintuntemuksen turvaamiseksi tuomiokapitulin kokoonpano tuli säilyttää ennallaan. ${ }^{365}$ Hallintovaliokunta päätyi äärimmäisen niukasti äänin 9-8 kompromissiin kirkkohallituksen esityksen ja näiden kahden lausunnon välillä. Tuomiokapitulin jäsenten määrä oli hallintovaliokunnan esityksessä ennallaan, mutta lakimiesasessorin tilalla äänivaltaisena jäsenenä oli luottamustoiminen maallikko. Äänestyksessä niukasti vähemmistöön jääneiden mielestä pelkkä läsnäolo- ja puheoikeus ei riittänyt lakimiesasessorille ja hiippakunnan pääsihteerille - jonka uudeksi nimikkeeksi valiokunta esitti hiippakuntadekaania. ${ }^{366}$ Hallintovalio- kunnan mietintö oli yksimielinen, vaikka puheenjohtaja Huotarin mukaan asian käsittely oli ollut "varsin monitahoista, paikoin varsin jännitteistä" ${ }^{367}$ Huotarilla olikin keskeinen osa uudistuksen läpiviemisessä niin hiippakuntahallintokomitean kuin seuraavalla vuosikymmenellä hallintovaliokunnan puheenjohtajana.

Piispat osallistuivat poikkeuksellisen tiiviisti keskusteluun. Ilkka Kantola muistutti, että uudistuksessa oli korostettu hiippakunnallista toimintaa. Siihen nähden oli hänen mielestään epäjohdonmukaista, ettei valiokunnan esityksessä ollut annettu hiippakuntadekaanille jäsenyyttä tuomiokapitulissa. Samaten Kantolan mielestä lakimiesasessorin korvaaminen maallikkojäsenellä hämärsi tuomiokapitulin roolia hiippakunnan hallinnossa. Myös Erik Vikström ja Samuel Salmi olivat tyytymättömiä siihen, että todella vaikutusvaltainen maallikko eli lakimiesasessori oli poistumassa kokoonpanosta. Tällöin pappisvalta uhkasi vain voimistua entisestään. Etelä-Savon sairaanhoitopiirin johtajalla, varatuomari Jukka Männistöllä oli sama huoli:

Näyttäisi todellakin oudolta ja ulkoisen kuvamme kannalta jopa kielteiseltä, jos teologivirkojen kurinpitoasioissa tuomiovaltaa käyttäisi toimielin, jonka jäsenenä on neljä teologia ja yksi maallikko, kuten hallintovaliokunta esittää.

Tuomiokapitulin päätöksenteossa ns. kurinpitoasiat eivät ole toimintamme kannalta keskeisimpiä kysymyksiä, mutta juuri ne valitettavan usein ylittävät uutiskynnyksen ja tarpeettomasti pilaavat kirkkomme ulkoista kuvaa. ${ }^{368}$

Tuomiokapitulin kokoonpanon osalta jatkui tavallaan se tuomioistuinten riippumattomuuskeskustelu, jonka myötä korkeimpien oikeusistuinten jäsenet oli aiemmin jätetty pois kirkolliskokouksesta.

Jotkut maallikkoedustajat halusivat lisätä kirkkohallituksen esityksen mukaisesti tuomiokapituliin toisenkin luottamushenkilöjäsenen. Yleinen vaatimus oli, että elimeen oli saatava lisää maallikkovaltaa, oli sitten kyse lakimiesasessorista tai luottamushenkilöjäsenistä. Lukuisien keskustelussa tehtyjen muutosehdotusten myötä äänestyksestä tuli monimutkainen. Voittajaksi selviytyi kokoonpano, jossa olivat piispa, tuomiorovasti, kaksi pappisasessoria, yksi maallikko, lakimiesasessori ja hiippakuntadekaani. ${ }^{369}$ Vuosikausia valmisteltu uudistus kulminoitui kirkolliskokouksen täysistunnon nopeaan, osin sekavaan ja vaikeasti ennakoitavaan äänestyspro-

VAPAUTTA A L U E E L L ISE EN P Ä ÄT ÖKSENTEKO ON 
sessiin. Viisijäsenisen tuomiokapitulin tilalle tuli seitsenjäseninen elin. Uusi, suuri hiippakuntavaltuusto sai rinnalleen suuren tuomiokapitulin hallinnonuudistuksessa, jonka tavoitteena oli ollut hallinnon keventäminen. Laihialaisen agronomin Maaria Perälän sanoin kirkolliskokoukselle "kävi äsken tuossa fibaus, että tästä tuli niin suuri tästä tuomiokapitulista" ${ }^{370}$.

"Fibaus" ei kuitenkaan estänyt Perälää ehdottamasta seuraavana päivänä, että myös hiippakuntavaltuuston puheenjohtaja saisi läsnäolo- ja puheoikeuden tuomiokapitulissa. Muuten maallikkoluottamushenkilö oli jäämässä Perälän mielestä tuomiokapitulissa kovin yksin. ${ }^{371}$ Tällaista ratkaisua oli jo aiemmin väläytetty keskustelussa muun muassa tuomiokapitulin ja hiippakuntavaltuuston välisen tiedonkulun parantamiseksi. ${ }^{372}$ Piispa Huotari ei pitänyt hyvänä, jos tällä tavalla yritettiin kiertoteitse toteuttaa aiemmin tappiolle jäänyt ehdotus kahdesta luottamustoimisesta maallikkojäsenestä. ${ }^{373}$

Edelleen Huotarin mielestä tuomiokapituli käsitteli niin vähän hiippakuntavaltuustoa koskettavia asioita, ettei ehdotettu säännös ollut tarpeen. Perälän kannalla olleiden näkökulmasta taas oltiin pyrkimässä sellaiseen hallintoon, jossa yhteisiä asioita voisi olla aiempaa enemmän. ${ }^{374}$ Myös lakimiesasessorin roolia korostaessaan piispat vetosivat aiempiin kokemuksiinsa, kun taas useat maallikkoedustajat lähtivät siitä, että oltiin luomassa aivan uudenlaista hiippakuntahallintoa.

Maaria Perälän muutosehdotus voitti äänin $61-41 .^{375}$ Tulos myötäili edustajakiintiöitä. Läsnä olleista piispoista vain Ilkka Kantola ja Wille Riekkinen äänestivät muutosehdotuksen puolesta, ja pappisedustajistakin selvä enemmistö oli valiokunnan kannalla. Vastaavasti maallikkoedustajan ääni meni selvästi useammin Perälän ehdotukselle kuin valiokunnalle. ${ }^{376}$ Kirkolliskokouskäsittelyn jäljiltä tuomiokapitulit saivat hankkia istuntosaliinsa kolme lisätuolia. Aiemmissa käsittelyvaiheissa oli pyritty hakemaan tasapainoista mutta mahdollisimman suppeaa kokoonpanoa. Tämä tasapainoilu ei enää onnistunut kirkolliskokouksen suuressa salissa: kaikilla oli omat vaatimuksensa siitä, keiden ainakin oli istuttava tuomiokapitulissa, ja lopulta kaikki saivat tahtonsa läpi. Häviäjänä oli hallinnon keventämisen periaate.

Toinen huomionarvoinen piirre keskustelussa oli piispojen aktiivisuus. Useiden piispojen puheenvuoroista heijastui kokemus, ettei heitä ollut kuultu. Ensinnäkään kirkkohallituksen esityksestä ei ollut pyydetty piispainkokouksen lausuntoa, vaan piispainkokous oli antanut sen omatoimisesti vedoten kirkkolaissa mainittuihin tehtäviinsä. ${ }^{377}$ Sen jälkeen kirkolliskokouksen hallintovaliokunta oli monen piispan mielestä sivuuttanut piispainkokouksen lausunnon. ${ }^{378}$ Kokemus oli sitä paitsi paljolti sama kuin 1990-luvun hallinnonuudistushankkeissa. Kun vielä Helsingin hiippakunnan jakamishanke kärjisti kirkolliskokouksen ja kirkkohallituksen suhteita, hiippakuntahallinnon järjestäminen näyttää koetelleen 1990- ja 2000-luvulla kirkon keskushallintoa poikkeuksellisen voimakkaasti.

Uudistunut hiippakuntahallinto aloitti toimintansa vuoden 2004 alussa. Julkisuudessa kuului kuitenkin vielä pitkään puheenvuoroja, joiden mukaan uusilla hiippakuntavaltuustoilla oli vaikeuksia löytää oma paikkansa hiippakuntahallinnossa. ${ }^{379}$ Sitä paitsi heti vuosina 2005 ja 2006 kirkolliskokouksen talousarviokäsittelyssä väännettiin kättä kahden hiippakunnan uusista viroista, vaikka kirkolliskokous oli juuri aiemmin perustanut hiippakuntavaltuustot päättämään näistä asioista. ${ }^{380}$ Lisäksi kirkolliskokous oli tyytymätön hiippakuntavaltuustojen esitysten tasoon, mikä huipentui siihen, että kokous hylkäsi syksyllä 2010 molemmat saamansa hiippakuntavaltuustoesitykset suoraan valiokuntaan lähettämättä. ${ }^{31}$ Viesti oli selvä - varsinkin siihen nähden, että muuten 2000-luvulla kirkolliskokous käytti tätä kovaa keinoaan sangen säästeliäästi. Seuraavana vuonna yksikään hiippakuntavaltuusto ei enää uskaltautunut esittämään kirkolliskokoukselle mitään. Hiippakuntahallinnon uudistaminen oli ollut pitkällinen prosessi, mutta hiippakuntien itsenäistymisen ja vahvistumisen tie osoittautui käytännössä vielä paljon pidemmäksi.

Hiippakuntahallinnon uudistaminen tähtäsi hiippakunnallisen itsemääräämisoikeuden lisäämiseen, mutta Turun arkkihiippakunnan osalta kirkolliskokous kulki päinvastaiseen suuntaan. Vuoden 1998 arkkipiispanvaalin yhteydessä lehdistössä arvosteltiin voimakkaasti arkkihiippakunnan valtaa vaalissa ${ }^{382}$. Asian pohdinta alkoi kirkolliskokouksessa seuraavana vuonna. ${ }^{383}$ Kokous hyväksyi marraskuussa 2003 uudistuksen, jonka myötä hiippakuntavaltuustojen ja kirkkohallituksen jäsenille annettiin äänioikeus. Uudistus kasvatti muiden hiippakuntien äänivaltaisten edustajien osuuden 13 prosentista 
29 prosenttiin. ${ }^{84}$ Arkkipiispan näkyvä kokonaiskirkollinen asema heijastui vaalitapaan aiempaa selvemmin.

\section{LIS ̈̈̈̈ LIIKKUMAVARAA} SEURAKUNTAYHTYMIIN

Uusi kuntalaki tuli voimaan asteittain 1990-luvun puolivälin jälkeen. Se oli väljä puitelaki, joka antoi tilaa paikallisille ratkaisuille. ${ }^{385}$ Kevyen ja joustavan hallinnon mahdollistava puitelainsäädäntö oli tavoitteena myös, kun kirkkohallitus antoi syksyllä 2001 kirkolliskokoukselle esityksen seurakuntayhtymähallinnon kehittämisestä. ${ }^{866}$ Esityksen myötä oli määrä luopua jaosta osittaiseen ja täydelliseen yhteistalousmalliin. Vaikutteita haettiin molemmista yhtymämuodoista, ja uudistuksen oli tarkoitus antaa aiempaa enemmän päätösvaltaa täydellisessä yhteistaloudessa oleville seurakunnille. Kirkkohallitus esitti, että yhtymän hallintoeliminä olisivat yhteinen kirkkovaltuusto ja yhteinen kirkkoneuvosto. Jokaisella seurakunnalla olisi oma seurakuntaneuvosto, joka valittaisiin suoralla vaalilla. Neuvostot valitsisivat puolestaan keskuudestaan yhteisen kirkkovaltuuston. ${ }^{387}$

Kirkolliskokouksen hallintovaliokunta piti esitystä oikeansuuntaisena ja hallintoa yksinkertaistavana. ${ }^{388}$ Eniten erimielisyyksiä aiheutti yhteisen kirkkovaltuuston vaalitapa. Kirkkohallituksen esitys välillisestä vaalista alleviivasi sitä, että seurakunta oli kirkon hallinnon perusyksikkö ja seurakuntayhtymä taasen palveluyksikkö. Lisäksi kahden vaalin toimittaminen samanaikaisesti oli aiheuttanut äänestäjien keskuudessa sekaannuksia, joista oli määrä päästä uudistuksen myötä eroon. Lakivaliokunta korosti kuitenkin lausunnossaan kansanvaltaperiaatetta, jonka mukaisesti kirkollisverosta päättävä elin - yhteinen kirkkovaltuusto - tuli valita suoralla vaalilla. Lausunnosta huolimatta hallintovaliokunta asettui äänin 8-4 välillisen vaalin kannalle. ${ }^{389}$

Täysistunnossa lääkintäprikaatikenraali Timo Sahi puolusti perusteellisesti suoraa vaalitapaa. Hän käsitteli Helsingin seurakuntayhtymää, jossa yhtymähallinto oli hyvin eriytynyttä: valtaosa seurakuntaneuvostoihin pyrkivistä ehdokkaista ei halunnut mukaan yhteisen kirkkovaltuustoon vaaliin, ja sama päti usein myös päinvastaiseen suuntaan. Tehtävät edellyttivät erilaista suuntautuneisuutta, ja molempien hoitaminen samanaikaisesti vei paljon aikaa. Uhkana oli, että seurakuntayhtymän toiminnasta kiinnostuneet eivät aset- tuisi ehdolle lainkaan tai joutuisivat toimimaan vastentahtoisesti seurakuntaneuvostossa. Toisaalta jotkut saattaisivat joutua vastoin tahtoaan kirkkovaltuutetuiksi. Edelleen vähemmistöryhmien olisi todennäköisesti aiempaa vaikeampi saada edustajiaan yhteiseen kirkkovaltuustoon. ${ }^{390}$ Sahi katsoi asiaa erityisesti ehdokkuudesta ja luottamustehtävästä käsin, hallintovaliokunta taas äänestämisen kannalta. Siirtyminen yhteen vaaliin oli omiaan helpottamaan äänestämistä mutta toisaalta myös nostamaan kynnystä ryhtyä ehdokkaaksi.

Täysistunnossa tamperelaisen talousjohtajan Marja Karvon ehdotus, jonka mukaan yhteinen kirkkoneuvosto valittaisiin suoralla vaalilla, voitti selvästi äänin 75-24. ${ }^{391}$ Valiokunnan mietintöön verrattuna asetelma kääntyi päälaelleen, mihin vaikuttivat todennäköisesti Sahin ja muiden helsinkiläisedustajien puheenvuorot. Selvään äänestystulokseen nähden on merkille pantavaa, että paikalla olleista kahdeksasta piispasta vain kaksi, Eero Huovinen ja Ilkka Kantola, äänesti voittaneen muutosehdotuksen puolesta. ${ }^{392}$ Piispat hakivat teologista linjakkuutta, kun taas muu kirkolliskokous painotti kansanvaltaisuutta ja katsoi isoimpien seurakuntayhtymien tilannetta. Sittemmin Espoon hiippakuntavaltuusto esitti toistuvasti siirtymistä yhden vaalin järjestelmään, mutta kirkolliskokous jätti esitykset raukeamaan ${ }^{393}$.

Kirkolliskokouksen käsittelyssä oli 200o-luvun alkuvuosina kaksi laajaa hallinnollista uudistushanketta: hiippakunta- ja seurakuntayhtymähallinnon uudistukset. Samanaikaisesti kirkolliskokous päätti vielä lukuisista suppeammista säännösmuutoksista. Kuvaavaa oli, että pelkästään syksyllä 2002 kirkolliskokouksen käsittelyyn tuli lähes 150 sivua hallintovaliokunnan mietintötekstiä, eivätkä sivumäärään sisältyneet mietintöjen laajat liitteet. Lakivaliokunta ei jäänyt työmäärässä paljon jälkeen antaessaan seikkaperäisiä lausuntoja lakiesityksistä. Kun kirkolliskokous vielä teki melko suuria muutoksia esityksiin, edustajien vastuulla oli laaja pykäläviidakko. Tilanteella oli seurauksensa. Kun esitykset yhdistettiin opetusministeriössä, löytyi lukuisia teknisiä virheitä ja epätarkkuuksia, joiden korjaamiseksi ministeriö joutui seuraavina vuosina pyytämään kirkon lausuntoa $^{394}$.

VA PAUTTA A L UEELLISEEN P ̈̈̈̈TÖKSENTEKOON 301 
VAATIVA SEURAKUNTAHALLINTO JA KIISTA KIRKKOHERRANVAALISTA

Uutena edustajana olen aika yllättynyt ja hämmentynyt siitä, miten usein seurakuntien johtajuusasiat, työilmapiiriasiat ja seurakuntaelämän kehittämiseen liittyvät ongelmakohdat ovat olleet esillä täällä kokouksen asialistoilla. - - Aika-ajoin tuntuu, että ikävimmät ongelmakohdat ikään kuin kulminoituisivat meihin pappeihin. ${ }^{395}$

Tapiolan seurakunnan kappalainen Leena Heinonen tiivisti 2001, mikä oli ollut yksi kirkolliskokouksen keskeisimmistä keskustelunaiheita vaalikauden kahtena ensimmäisenä vuonna. Vaatimukset kirkkoherran tehtävää kohtaan olivat kasvaneet tasaisesti. Muutokseen pyrittiin vastaamaan yhtäältä vastuuta jakamalla, toisaalta kirkkoherran vaalitapaa kehittämällä. Ensin mainittua ratkaisumallia edustivat ehdotukset kirkkoneuvoston puheenjohtajuuden muuttamisesta. Jälleen keväällä 2000 kirkolliskokous sai kaksi asiaan liittyvää edustaja-aloitetta. Toinen aloitteista pyrki kompromissiin, jossa kirkkoherran puheenjohtajuus säilytettäisiin mutta varapuheenjohtajan asemaa vahvistettaisiin..$^{396}$ Piispa Jorma Laulaja oli pitänyt ajatusta esillä kirkolliskokouksessa jo aiemmin.

Aloite sai yleisesti myönteisen vastaanoton. ${ }^{397}$ Kirkkoherran asemasta keskusteltaessa näkyi kuitenkin edelleen maallikkojen ja pappien välinen vastakkainasettelu. Erityisesti Helsingin hiippakunnan maallikkoedustajat olivat innokkaita uudistamaan puheenjohtajuusjärjestelmää. ${ }^{398}$ Aloitteen pohjalta kirkkohallitus ja viime vaiheessa kirkolliskokouksen hallintovaliokunta muovasivat säännökset, joiden puitteissa puheenjohtajantehtäviä voitiin jakaa kirkkoherran ja varapuheenjohtajan kesken yhteisymmärryksessä ja määräaikaisesti. ${ }^{399}$ Jotkut pitivät pitkän työn jälkeen 2002 löytynyttä kompromissia hyvänä, kun taas toiset epäilivät sen tuottavan entistä enemmän ongelmia. ${ }^{400}$ Ratkaisevassa käsittelyssä säännökset hyväksyttiin kuitenkin yksimielisesti. ${ }^{01}$ Näin kirkolliskokous lisäsi paikallista sopimisvaltaa seurakuntayhtymähallinnon lisäksi myös yksittäisessä seurakunnassa.

Keväällä 2006 kirkolliskokoukseen saapui seuraava aalto hiippakuntavaltuustoesityksiä ja edustaja-aloitteita, jotka koskivat hallinnon joustavoittamista ja keventämistä. Istuntokauden ilmapiiriä voikin jossain määrin verrata kevään 1992 henkeen. Porvoon hiippakuntaval- tuuston mukaan seurakunnat saivat jatkuvasti hallintoa koskevia ohjeita ja määräyksiä, jotka veivät erityisesti kirkkoherrojen aikaa ja etäännyttivät kirkon keskeisestä tehtävästä ${ }^{402}$. Hallintovaliokunnan mielestä ongelmien syynä oli kuitenkin paljolti seurakuntien pienuus ja lääkkeenä vastaavasti yhteistyön lisääminen..$^{403}$ Hiippakuntavaltuuston esitys jäi raukeamaan..$^{404}$

Hallintotehtävien karsiminen ei onnistunut, joten vaihtoehdoksi jäi etsiä sellaisia keinoja, joilla kirkkoherranvirkaan saataisiin valikoiduksi parhaat johtajat ja kykenevimmät hallintohenkilöt. Kevään 2006 aloitteiden joukossa oli 16 edustajan jättämä aloite, jossa ehdotettiin siirtymistä välilliseen kirkkoherranvaaliin. ${ }^{405}$ Edelleen samalla istuntokaudella jätettiin edustaja-aloite, jossa ehdotettiin piispanvaalin siirtämistä laajennetulle hiippakuntavaltuustolle. ${ }^{406}$ Molempien aloitteiden osalta keskustelu kulki pitkälti samoja polkuja. Muutoksen kannattajien mielestä voimassa ollut vaalitapa ei tarjonnut äänestäjille riittäviä tiedonsaantimahdollisuuksia: pieni valitsijajoukko voisi parhaiten punnita ehdokkaita. Toisaalta käytössä olleen vaalitavan kannattajat vetosivat molemmissa tapauksissa siihen, että pienessä äänestäjäjoukossa erilaiset painostusryhmät kykenisivät vaikuttamaan tehokkaimmin. Epäiltiin myös, että vaalin siirtäminen pienelle elimelle saattaisi uhata kirkkoherran tai piispan riippumattomuutta valitsijoistaan. ${ }^{407}$ Kirkolliskokous jätti piispanvaalialoitteen raukeamaan, mutta kirkkoherranvaalin osalta oli edessä pidempi pohdiskelu. ${ }^{408}$

Lähetekeskustelussa Helsingin yliopiston käytännöllisen teologian professori Heikki Kotila kyseenalaisti ajattelutavan, että erilaisissa seurakunnissa tuli olla yhtenäinen vaalitapa. Tarpeet pohjoisessa ja etelässä sekä pienissä ja suurissa seurakunnissa poikkesivat toisistaan, joten Kotila ehdotti harkittavaksi sekä suoran että välillisen vaalitavan sallimista. ${ }^{409}$ Lausunnon antanut perustevaliokunta päätyi jäsenensä Kotilan kannalle, mutta varsinaisen mietinnön laatinut yleisvaliokunta katsoi valinnaisuuden antavan mahdollisuuksia taktikointiin ja pidentävän vaaliprosessia entisestään. Valiokunta asettui välillisen vaalin kannalle ja ehdotti, että aloite lähetettäisiin kirkkohallitukselle valmisteltavaksi ja toimenpiteitä varten..$^{410}$

Täysistunnossa kirkkoherra Pertti Simola esitti, että kirkkohallitus velvoitettaisiin vielä selvemmin sanoin 
valmistelemaan välillisen vaalin säännöstö, kun taas Luvian kirkkoherra Tapio Seppälä ehdotti aloitteen jättämistä raukeamaan. Vastakkain olivat suuren ja pienen seurakunnan näkökulmat. Äänestyksessä nämä kaksi ehdotusta joutuivat ensin vastakkain, ja Simolan ehdotus voitti äärimmäisen niukasti äänin 52-51. Sen jälkeen valiokunnan ponsiehdotus päätyi voittajaksi selvemmin numeroin. ${ }^{411}$ Äänestystulokset osoittivat, että valtaenemmistö valiokunnan ehdotuksen kannattajista oli sellaisia, jotka olivat mieluummin valmiita jättämään koko asian raukeamaan kuin asettumaan selvästi välillisen vaalin kannalle. Lähtökohdat välilliseen vaaliin siirtymiselle eivät olleet kaksiset.

Kirkkoherranvaalista keskusteltaessa näkyi sama jännite kuin päätettäessä läntisen Uudenmaan hiippakunnan keskuspaikasta: oliko pyrittävä sopeutumaan tilanteeseen vai muuttamaan sitä? Ensin mainittua ajattelutapaa edustavien mielestä seurakuntaliitokset höllensivät kirkkoherran henkilökohtaista sidettä seurakuntalaisiin ja lisäsivät hallinnollisia vaatimuksia, minkä vuoksi välillinen vaalitapa oli perusteltu. Toisten mielestä taas nimenomaan seurakuntaliitosten keskellä oli pyrittävä kaikin keinoin ylläpitämään seurakuntalaisten siteitä kirkkoon. Yksi tapa oli suora kirkkoherranvaali. ${ }^{412}$

Sopeutuva ajattelutapa päätyi tässäkin asiassa voitolle. Kirkolliskokouksessa kyllä visioitiin pieniä seurakuntayksikköjä, mutta käytännön päätöksenteossa tyydyttiin lähinnä reagoimaan seurakuntakoon kasvuun ja otettiin kehityssuunta annettuna tosiasiana. Argumentaatio oli lisäksi sikäli ristiriitaista, että hallintovaliokunnan mielestä liian pienet seurakunnat ja yhteistyön puute olivat lisänneet kirkkoherrojen ja muiden viranhaltijoiden hallinnollista taakkaa, kun taas toisaalta yleisesti katsottiin nimenomaan uusien suurseurakuntien asettavan kirkkoherrojen hallinto- ja johtamistaidoille erityisiä vaatimuksia. Näyttääkin siltä, että vaatimukset lisääntyivät kaikkialla seurakunnan koosta riippumatta.

Täysistunnossa hyväksytty yleisvaliokunnan ponsiehdotus tulkittiin kirkolliskokouksessa yleisesti väljäksi. Esimerkiksi yleisvaliokunnassa "nykyisen vaalitavan vankkumattomaksi kannattajaksi" tunnustautunut emäntä Aira Jussila asettui ponnen taakse. ${ }^{413}$ Kirkkohallituksessa ponsi tulkittiin kuitenkin tarkkarajaiseksi ja velvoittavaksi. Kirkkohallituksen täysitunnon jäsenet olivat keskenään hyvin erimielisiä kirkkoherranvaa- lin toteuttamistavasta, mutta tehtävänannon mukaisesti kirkkohallitus esitti keväällä 2009 säännösmuutoksia, joiden mukaan kirkkoherra valittaisiin välillisesti. ${ }^{414}$ Edellisenä vuonna uuden vaalikauden alkaessa Kotimaa-lehti oli kysynyt kirkolliskokousedustajien kantaa välilliseen kirkkoherranvaaliin. Suurin osa vastanneista oli ilmoittanut vastustavansa sitä. ${ }^{415}$ Esityksen menestymismahdollisuudet eivät edelleenkään näyttäneet järin hyviltä.

Tällä kertaa kirkolliskokouksessa ei kuitenkaan ilmennyt yhtä voimakasta pohjoisen ja etelän välistä vastakkainasettelua kuin aiemmin. Ennemminkin samanlaiset perustelut toistuivat asuinpaikasta riippumatta. Suoran vaalin kannattajat saivat kirkon uudesta, "osallisuuden yhteisöä" painottavasta strategiasta tukea kannalleen. Toisaalta heilläkin oli uutta valmiutta ottaa välillinen vaali rinnakkaiseksi vaihtoehdoksi. Vastaavasti harva välillisen vaalin kannattaja uskoi kirkkohallituksen esityksen läpimenomahdollisuuksiin. Puolin ja toisin alettiin olla valmiita hyväksymään kahden vaalitavan järjestelmä. ${ }^{416}$ Kirkolliskokous jätti kirkkohallituksen esityksen raukeamaan ja antoi kirkkohallitukselle uuden valmistelutehtävän kahden vaalitavan pohjalta. ${ }^{417}$ Tällä kertaa ongelmaksi oli osoittautunut se, että kirkkohallitus oli toteuttanut saamaansa tehtävänantoa tunnollisesti, vaikka sen piirissä oli ollut kannatusta kahdelle vaihtoehtoiselle vaalitavalle. Ongelmat olivat siten hyvin toisenlaisia kuin Espoon hiippakunnan syntyvaiheissa.

Kirkkohallituksen uusi esitys tuli käsittelyyn keväällä 2011. Kirkkohallitus asetti ensisijaiseksi vaihtoehdoksi välillisen vaalin, joka toimitettaisiin suunnilleen samoin kuin kappalaisen valinta. Seurakunnan pyynnöstä tuomiokapituli voisi kuitenkin päättää kirkkoherran valinnasta välittömällä vaalilla. Tällöin vaalitapa olisi pitkälti entisenlainen, mutta ylimääräistä vaalisijaa ei enää olisi käytössä. ${ }^{418}$ Erimielisyydet kirkolliskokouksessa liittyivät siihen, kumman vaalitavan tuli olla ensisijainen. Muutamien edustajien mielestä kirkkohallitus oli kehittänyt välillistä vaalia houkuttelevaksi mutta jättänyt välittömän vaalitavan puutteineen lähes ennalleen. Jotkut taas kiinnittivät huomiota siihen, että edellisvuonna perustevaliokunta oli lausunnossaan asettanut välittömän vaalin ensisijaiseksi. Vaikka kirkolliskokous ei ollut ottanut varsinaisesti kantaa asiaan, näiden edustajien

VA PAUTTA A L U E E L I S E E N P Ä ÄT ÖKSENTEKOON 303 
mielestä kirkkohallituksen olisi pitänyt seurata perustevaliokunnan lakivaliokunnalle antamaa lausuntoa. ${ }^{419}$ Arvostelun aiheena oli jälleen vuorostaan kirkkohallituksen itsenäinen toiminta.

Lakivaliokunta kuunteli arvostelua tarkalla korvalla ja muutti välittömän vaalitavan ensisijaiseksi. ${ }^{420}$ Rovasti Jukka Huttunen, joka kuului vuoden 2006 edustajaaloitteen allekirjoittajiin, piti ratkaisua epäonnistuneena: kynnys välillisen vaalin käyttämiseksi nousi korkeaksi, kun seurakunnan luottamushenkilöt joutuivat "laillisesti kaappaamaan" vallan kansalta. ${ }^{421}$ Lakivaliokunta pyrki muutenkin lisäämään välittömän vaalin houkuttelevuutta. Vaalin jouduttamiseksi se poisti mahdollisuuden hakea erikseen muutosta vaaliehdotukseen, joten vaalisijajakoon saattoi esityksen mukaan hakea muutosta vasta vaalin jälkeen. ${ }^{422}$ Mietintöä esitellessään lakivaliokunnan puheenjohtaja Pirjo Pyhäjärvi myönsi, että säännösmuutos saattoi "muodostaa jonkinlaisen hallinnollisen aikapommin", kun ehdollepano oli mahdollista kumota vasta pitkän vaaliprosessin jälkeen. Hän kuitenkin huomautti, että säännösmuutos todennäköisesti nosti kynnystä muutoksenhakuun. ${ }^{423}$ Hallinto-oikeustuomari esitteli mietinnön, jonka hän suoraan myönsi nostavan muutoksenhakukynnystä - eivätkä tuomarikollegat luultavasti panneet pahakseen.

Valiokunnan esityksen taakse löytyi kirkolliskokouksen tuki, ja pitkään valmisteltu muutos saatiin aikaan. ${ }^{224}$ Tietoisina määräenemmistövaatimuksesta välillisen vaalin kannattajat olivat valmiit palaamaan valmistelun kuluessa kohti voimassa olleita säännöksiä. Vastaavasti suoran vaalin kannattajilta liikeni jatkuvasti enemmän ymmärrystä suurten kaupunkiseurakuntien asialle, ja seurakuntaliitokset vauhdittivat asenteen muutosta. Siten oli mahdollista päästä kompromissiin. Kirkolliskokouksen päätös jatkoi sitä kivuliasta ja hidasta, koko tutkimuskauden jatkunutta prosessia, jonka myötä alun perin maaseutuympäristöön suunniteltuja säännöksiä muokattiin kaupunkeihin sopiviksi. Lisäksi päätös liittyi muihin 200o-luvun hallinnollisiin uudistuksiin. Yhdistävä piirre Helsingin hiippakunnan jakamiselle, kirkkoherran vaalitavan muuttamiselle ja hiippakunta- sekä seurakuntayhtymähallinnon uudistukselle oli pyrkimys alueellisen päätösvallan ja valinnanvapauden vahvistamiseen. Uudistukset olivat askelia puitelainsäädännön suuntaan. Päämääränä oli myös hallinnon keventäminen, joka tietyissä tapauksissa toteutuikin.

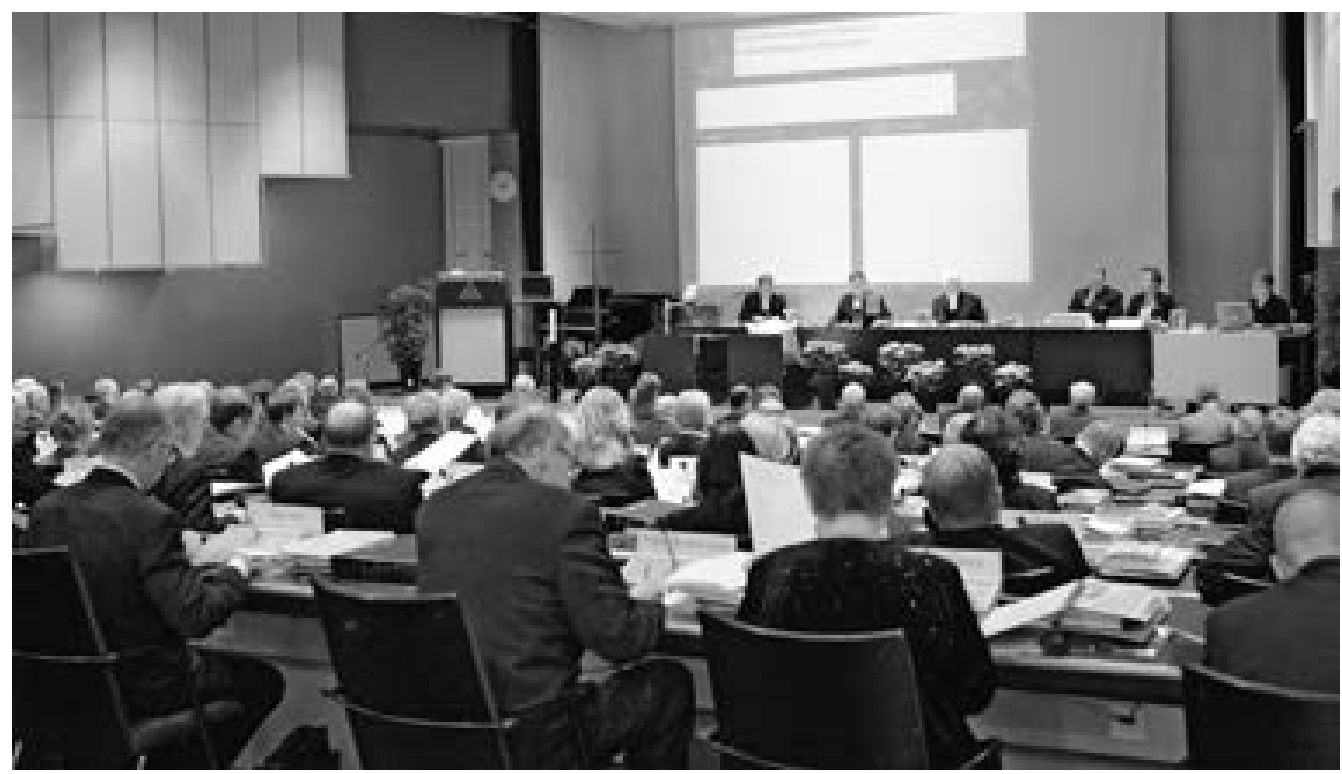

Varsinkin istuntosalin takariveillä, Helsingin ja Espoon hiippakuntien edustajien keskuudessa, vaadittiin vuosien kuluessa, että kirkkoherranvaalissa tuli sallia välillinen vaalitapa. Lopulta näin kävikin syksyllä 2011. Kuva: Kirkkohallitus / Aarne Ormio. 


\section{JUMALANPALVELUSELÄMÄN KIIVAAN UUDISTUSVAIHEEN LOPPUSUORA}

\section{VIRAN YKSEYDESTÄ UUTEEN EROTTELUUN}

Kirkon virkaa koskeva selvitystyö oli vuosituhannen alussa hetken poissa kirkolliskokouksesta, kun vuonna 2000 asetettu virkarakennekomitea teki työtään. Kirkolliskokous joutui kuitenkin jatkuvasti tekemisiin virkarakenneuudistukseen liittyvien osakysymysten kanssa. Yksi niistä oli pappis- ja piispanvirkaan vihkimisen rajaaminen vain piispan tehtäväksi. Kirkkojärjestyksen muutosesitys johtui Porvoon sopimuksesta, ja sen oli määrä olla vain muodollinen. Käytännössä piispat toimittivat muutenkin nämä vihkimykset, eikä tarkoitus ollut puuttua virkateologiaan. Kirkolliskokouksessa ilmeni kuitenkin epäilyksiä, voitiinko kirkkojärjestyksen säännöksiä muuttaa irrallaan opista. Lisäksi kuului huolta suomalaisen identiteetin säilymisestä. ${ }^{425}$ Samaan aikaan kyselytutkimusten valossa suomalaisten suhtautuminen Euroopan unioniin muuttui aiempaa kielteisemmäksi, ja työpaikkojen siirtyminen ulkomaille lisäsi epäilyksiä kansainvälistymistä kohtaan. ${ }^{426}$ Näyttää siltä, että 1990-luvun Eurooppaan hakeutumisen aikakautta seurasi niin valtakunnanpolitiikassa kuin kirkolliskokouksessa tietynlainen vastavaikutus.

Kirkkojärjestyksen muutos hyväksyttiin keväällä 2001 hyvin niukasti äänin 77-24. Alin määräenemmistövaatimus ylittyi yhdellä äänellä. ${ }^{227}$ Vastustajien joukossa oli paljon herätysliikkeisiin lukeutuvia, mutta toisaalta vanhat jakolinjat murtuivat äänestyksessä. Vastustajia löytyi esimerkiksi perinteisesti ekumeniamyönteisen herännäisyyden piiristä. Vastaavasti vanhoillislestadiolainen kanttori Yrjö Koskimäki, joka oli esittänyt sovittelevia kantoja jo käsiteltäessä 1990-luvulla Yhteistä julistusta vanhurskauttamisopista, äänesti muutoksen puolesta. Vanhoillislestadiolaisten suhtautumisessa kirkon johdon linjaan oli havaittavissa muutosta. ${ }^{228}$

Keväällä 2001 nousi esille myös toinen virkarakenneuudistukseen liittyvä teema. Piispainkokous ja kirkkohallitus totesivat nelivuotiskertomuksen johdosta, että diakonia- ja nuorisotyönohjaajien koulutustaso oli noussut mutta kirkollinen osaaminen ohentunut huolestuttavasti. ${ }^{429}$ Pastori Heli Pruuki jätti edustaja-aloitteen, joka tähtäsi nuorisotyön teologian pohtimiseen ja nuorisotyön suunnan tarkistamiseen. ${ }^{430}$ Hänen mu- kaansa yhteinen työnäky ja yhteiset tavoitteet olivat kateissa. ${ }^{431}$ Kirkolliskokous piti aloitetta tärkeänä ja lähetti sen kirkkohallitukselle tarvittavia toimenpiteitä varten. ${ }^{432}$ Kyse oli paljolti työntekijöiden hengellisestä identiteetistä, jota virkarakennetyöskentelyn oli tarkoitus vahvistaa.

Teologian tohtori Jaakko Ripatin johtama virkarakennekomitea työskenteli vuosina 2000-2002. ${ }^{433}$ Kirkolliskokous oli antanut tehtäväksi koota yhteen diakonian, musiikin ja kasvatuksen virat sekä selvittää samalla 11:tä erikseen mainittua kysymystä. ${ }^{434}$ Tehtävänannossa näkyi halu suunnata tarmo viimein käytännön toteutukseen. Komitea ei kuitenkaan katsonut näin rajattua tehtävää mahdolliseksi. Sen huomio kiinnittyi siihen, että perustevaliokunnan ja kirkolliskokouksen julkilausumana lähtökohtana oli muodostaa kirkon erityisen viran yhteyteen siitä erillinen virka. Komitean mielestä juuri muodostettavan viran suhde pappisvirkaan oli todellinen ongelmakohta ja perusteellista teologista selvitystä kaipaava asia, ei niinkään diakonian, musiikin ja kasvatuksen virkojen yhdistäminen keskenään. ${ }^{435}$

Kirkolliskokouksen perustevaliokunta oli yrittänyt ratkaista pitkään hiertäneet virkateologian ongelmat moniselitteisellä "yhteydessä erillinen" -muotoilulla, jonka tyyli lähenteli ekumeenisten kirkolliskokousten kristologisia formulointeja. Komitea ei kuitenkaan suostunut ohittamaan asiaa ilman perusteellista teologista selvittelyä. Samaan tapaan 199o-luvulla toiminut diakonaattikomitea oli laajentanut tehtäväänsä. Aina kun jokin virkarakenneuudistuksen osa-alue oli katsottu ratkaistuksi, jatkovalmistelussa oli jouduttu palaamaan lähtökuoppiin ja avaamaan aiempien linjausten perustelut.

Tällä kertaa valmistelutyötä helpotti, että virkarakennekomitea toimi samaan aikaan, kun käsikirjakomitea työsti kirkollisten toimitusten kirjaa. Virkateologisesti merkittävistä vihkimis- ja siunaamiskaavoista oli 1980-luvulla päätetty kirkolliskokouksessa melko sattumanvaraisesti, mutta 20 vuotta myöhemmin toimitusten kirjan virkateologiset ulottuvuudet tiedostettiin hyvin. Komiteat muun muassa pitivät yhteiskokouksia ${ }^{436}$. Käsikirjakomitean edustajat ilmoittivat korostavansa viran ykseyttä, mutta he ehdottivat käytännön syistä kirkon virkaan vihkimisen kaavan rinnalle erillistä piispanvihkimyksen kaavaa. Virkarakennekomitean jäsenet 
pelkäsivät tällaisen ratkaisun johtavan "kaksisäikeiseen" virkakäsitykseen. Siitä huolimatta käsikirjakomitea pysyi kannassaan. ${ }^{437}$

Käsikirjakomitean ehdotus ei saanut suurta ymmärrystä kirkolliskokouksen lähetekeskustelussa eikä piispainkokouksessa. Yleisesti toivottiin erillistä vihkimiskaavaa niin pappeutta, piispuutta kuin kolmatta säiettä varten. ${ }^{43^{8}}$ Myös virkarakennekomitea päätyi vähän myöhemmin kolmeen kaavaan. Samalla se kuitenkin totesi, että vihkimys kirkon hengelliseen virkaan oli ainutkertainen: mahdollinen myöhempi "vihkimys" - vaikkapa diakonin pappisvihkimys tai papin vihkiminen piispaksi - tuli ymmärtää virkaan asettamiseksi. Kyse oli alusta loppuun samasta virasta, jonka sisällä vain jaettiin erilaisia tehtäviä. ${ }^{439}$

Virkarakennekomitea halusi ratkaisullaan välttää kolmijaon, johon aiemmissa 1990-luvun valmisteluvaiheissa oli päädytty ja joka komitean jäsenen, diplomiurkuri Marjukka Anderssonin mukaan oli tulkittu jakona "piispat, papit ja rupusakki".440 Kirkon koulutuskeskuksen johtaja, dosentti Simo Peura, joka oli ollut mukana diakonaattikomiteassa, kommentoi virkarakennekomitean perusratkaisua komitean jäsenille työskentelyn loppuvaiheessa. Hänen mielestään kyseessä oli eräänlainen uutuus, joka oli erityisen ongelmallinen ekumeenisesti. ${ }^{441}$

Lopulta komitea esitti, että diakonaattiin luettaisiin diakonian viroissa olevat, kanttorit, lehtorit, nuorisotyönohjaajat, lapsityönohjaajat sekä päätoimiset lähetyssihteerit. Ekumeenisen virkateologisen työskentelyn ajankohtaisia painotuksia seuraten komitea luopui pitkälti sananteologisesta pohjasta ja lähti sen sijaan kristologisista sekä kirkko-opillisista perusteista. Lopputuloksena oli yksi kirkon hengellinen virka, johon diakonaatti kuului. ${ }^{422}$ Komitea ehdotti, että virkaan vihityt saisivat pysyvän oikeuden saarnata ja avustaa ehtoollisen vietossa. Samaten he voisivat erityistapauksissa toimittaa sanajumalanpalveluksen. Edelleen diakonian viranhaltijat ja lehtorit voisivat asettaa ja jakaa ehtoollisen erityistapauksissa. Myös hautaan siunaaminen ja avioliiton siunaaminen avautuisivat kaikille kirkon hengelliseen virkaan vihityille. ${ }^{433}$ Komitea ehdotti kirkolliskokouksen pappiskiintiön muuttamista hengellisen viran kiintiöksi, jonka puitteissa papeilla olisi 19 ja diakonaatin edustajilla 13 paikkaa. ${ }^{444}$ Viran ykseys oli saavuttanut virkarakennekomitean ehdotuksessa huippunsa.
Virkarakennekomitean perusteellinen mietintö tuli kirkolliskokouksen käsittelyyn syksyllä 2002. Mietintöä valmistelleista henkilöistä kirkolliskokouksessa istuivat tuolloin Iitin seurakunnan nuorisotyönohjaaja Risto Rasimus ja komitean sihteeri, teologian tohtori Matti Repo. Piispa Juha Pihkala, jonka hiippakunnan papit olivat olleet keskeisillä paikoilla komiteassa, kehui tätä "viime vuosikymmenien merkittävintä virkateologista puheenvuoroa Suomessa”. ${ }^{45}$ Professori Heikki Kotila taas oli mietinnön näkyvin kriitikko. Hän arvosteli mietintöä hyvin samanlaisilla perusteilla kuin Simo Peura komiteatyön aikana: perusratkaisu oli teologinen uutuus, joka yhtenäisti väärällä tavalla erilaiset tehtävät ja teki diakonaatista "tukahdutettua pappeutta". Esitys ei ratkaissut ekumeenisia ongelmia vaan synnytti niitä. Piispa Samuel Salmi, jonka johdolla piispainkokouksen asettama työryhmä alkoi valmistella lausuntoa komitean mietinnöstä, jakoi saman huolen. Hänen mielestään komitean muotoilema kirkon hengellinen virka oli

loistava, älyllinen innovaatio, näky ja harmittelen, että tähän työryhmään osallistuneet eivät aikanaan ole olleet mukana Augsburgin tunnustusta tekemässä! Sillä siinä on varmasti jotakin hyvin tuoretta ja tärkeää sanottuna eräästä näkökulmasta. Mutta se, että me kotoisessa Suomessamme, omissa Impivaaroissamme, - - luomme uuden teologisen käsitteen ja lähdemme sitä soveltamaan, on ilman muuta asia, joka on meidän kirkkomme sisällä oleva uutuus. ${ }^{446}$

Huoli Suomen luterilaisten ekumeenisesta asemasta toistui lukuisissa kirkolliskokouksen pyytämissä lausunnoissa. ${ }^{447}$ Vaikka piispainkokous karsikin Salmen työryhmän lausuntoehdotuksesta ekumeenisiin näkökohtiin perustuvaa kritiikkiä, se esimerkiksi katsoi Porvoon sopimuksen edellyttävän erillistä vihkimystä piispanvirkaan - samoin kuin pappis- ja diakonivihkimyksen erottamista toisistaan. ${ }^{448}$ Toisaalta Porvoon yhteistä julkilausumaa sorvaamassa ollut Erik Vikström huomautti, ettei sopimus sitonut käsiä niin tiukasti kuin jotkut tulkitsivat. ${ }^{449}$ Jyväskylän kaupunkiseurakunnan kappalaisen Arvi Tuomen mielestä piispainkokouksen lausunto osoitti "arveluttavaa matelevaisuutta ekumeenisia sopimuksia ja muiden kirkkojen käytänteitä kohtaan".450

Keskustelu virkateologian ekumeenisista kytkennöistä oli kääntynyt päälaelleen. Aiemmin diakonaatin muodostamista oli toistuvasti perusteltu ekumeenisilla 
tarpeilla ja vaatimuksilla. Nyt kuitenkin virkauudistuksesta oli tullut ekumeeninen ongelma, ja sen vastustajat vetosivat ekumeniaan. Kirkolliskokous itse oli juuri määritellyt pappis- ja piispanvihkimyksen vain piispan tehtäväksi mutta kieltänyt puuttuneensa asian teologiseen perustaan. Käytännössä näyttää kuitenkin tapahtuneen juuri sellaista siirtymää, jota säännösmuutoksen vastustajat olivat pelänneet: piispanvirka oli alettu erottaa entistä selvemmin pappeudesta. Porvoon julistuksen teologiaa oli kyllä analysoitu kirkolliskokouksessa 1990-luvulla, mutta julistuksen edellyttämiä käytännön toimia ryhdyttiin tulkitsemaan toden teolla vasta julistuksen hyväksymisen jälkeen. Hyväksytyn Porvoon julistuksen tulkinta ja toimeenpano osoittautuivat kirkolliskokouksessa tietyiltä osin lopulta vaikeammiksi tehtäviksi kuin julistuksen hyväksyminen.

Ekumeenisten ongelmien ohella puhuttivat useat muutkin teemat. Liturgisten tehtävien antaminen diakonaattiin kuuluville arvelutti monia. ${ }^{45}$ Diakonaattikomitean mietinnöstä käyty keskustelu toistui: arvostelijoiden mielestä mietintö ilmensi viranhaltijakeskeisyyttä. ${ }^{452}$ Toisaalta niin lausunnoissa kuin kirkolliskokouksessa valiteltiin sitä, että keskeinen hengellistä työtä tekevä ryhmä, lastenohjaajat, oli jäämässä diakonaatin ulkopuolelle. ${ }^{453}$ Virkateologisessa uudistuksessa, jossa pyrittiin soveltamaan vanhakirkollisia malleja, keskeiseksi virkateologiseksi kriteeriksi ja vihkimyksen edellytykseksi oli käytännössä muodostumassa muutaman vuoden ikäinen ammattikorkeakoulujärjestelmä tutkintoineen. ${ }^{454}$ Hengellisen viran ulkopuolelle oli rajautumassa paljon hengellisen työn tekijöitä siksi, että heiltä puuttui ammattikorkeakoulututkinto.

Ongelmallisimpia yksittäisiä kysymyksiä oli edelleen kanttorien asema. Myös kirkolliskokouksessa kanttorien mielipiteet jakautuivat: Kalajoen seurakunnan kanttori Veli Ainali ja arkkihiippakunnan jumalanpalvelus- ja musiikkisihteeri Mika Mäntyranta kannattivat painokkaasti kanttorien ottamista mukaan diakonaattiin, kun taas Mellunkylän seurakunnan kanttori Mari Lamminen vastusti ehdotusta yhtä ponnekkaasti. ${ }^{455}$ Kanttorien asemasta käytiin myös vilkasta julkista keskustelua esimerkiksi Helsingin Sanomissa. ${ }^{456}$ Kirkolliskokouksen lähetekeskustelussa Heikki Kotila kiinnitti huomiota siihen, ettei musiikin virka ollut muissa kirkoissa osa diakonaattia. Lisäksi komitean ehdotus asetti hänen mukaansa kanttorit toisenlaiseen asemaan kuin muiden taiteiden - esimerkiksi kirkkoarkkitehtuurin - edustajat. Edelleen Kotilan mielestä virsilaulu nousi luontevasti yhteisestä pappeudesta. ${ }^{457}$ Piispainkokous seurasi lausunnossaan Kotilan esittämiä kantoja. ${ }^{458}$

Kirkolliskokouksessa Arvi Tuomi nousi vastustamaan näitä perusteluja. Hänen mielestään piispainkokous sovelsi tiukempia kriteerejä kanttoreihin kuin muihin diakonaattiin aiottuihin työntekijäryhmiin. Veli Ainali taas vakuutti arvostelijoille, ettei uudistus pystyttänyt muuria työntekijöiden välille. Myöhemmin samassa puheenvuorossaan hän tosin korosti, ettei kanttorikuntaa ollut "viisasta sivuuttaa".459 Jonkinlainen muuri näytti sittenkin olevan olemassa. Oleellista oli kuitenkin, että kirkolliskokous oli aikoinaan asettanut virkarakennekomitean kokoamaan yhteen diakonian, musiikin ja kasvatuksen virat. Kun kirkolliskokouksessa arvosteltiin komitean koostamaa diakonaattia, arvosteltiin käytännössä sitä, että komitea oli noudattanut edelliseltä kirkolliskokoukselta saamaansa tehtävää.

Diakonaatin asema kirkon hallinnossa - erityisesti kirkolliskokouksessa - oli myös keskeinen puheenaihe. ${ }^{660}$ Piispainkokouksen mielestä pappien määrää kirkolliskokouksessa ei tullut vähentää, koska heillä oli koulutuksensa ja kokemuksensa perusteella erityisiä edellytyksiä teologisten ja hallinnollisten kysymysten hoitamiseen. ${ }^{461}$ Kirkolliskokouksessa jotkut olivat sitä mieltä, että suurimpia syitä virkarakenneuudistuksen kohtaamiin ongelmiin oli papiston halu pitää kiinni vallastaan. ${ }^{462}$ Piispainkokouksen kannanotto antoi tukea tällaisille epäilyille. Kirkolliskokouksessa jotkut olivat aiempina vuosikymmeninä vaatineet pappiskiintiön pienentämistä todeten, että teologinen asiantuntemus oli mahdollista saavuttaa muutenkin. Kiintiötä puolustaneet olivat vastanneet, ettei kyse ollut asiantuntemuksesta vaan virkateologiasta: kirkon viran tuli olla tarpeeksi vahvasti edustettuna. Kun sitten virkarakennekomitea ehdotti tämän ajattelutavan mukaisesti kirkon viran kiintiön säilyttämistä mutta sen sisäisen jakauman muuttamista, vasta-argumentiksi nousikin jälleen teologisen asiantuntemuksen säilyttäminen. Tilanteen mukaan papiston edustajat perustelivat kiintiötään lähes päinvastaisin argumentein.

Toukokuun 7. päivänä 2003 Suomi johti Ruotsia jääkiekon maailmanmestaruuskisojen puolivälieräottelus- 
sa maalein 5-1 mutta hävisi yhdellä maalilla ja putosi jatkokierroksilta. Seuraavana päivänä perustevaliokunnan puheenjohtaja Ilkka Kantola vertasi virkarakennekomitean mietinnön käsittelyä ottelun kulkuun. Alkuinnostus oli palautteen myötä muuttunut epävarmuudeksi, joskin Kantola jaksoi toivoa, ettei vielä oltu edellispäivän tappiolukemissa. ${ }^{463}$ Perustevaliokunta joutui kuitenkin taas kerran - hidastamaan vauhtia. Se piti ongelmallisena, että komitea oli nojannut kirkko-opillisiin perusteluihin ja irtaantunut siitä sananteologisesta perustelusta, jolle koko uudistus oli 1990-luvulla rakennettu. ${ }^{464}$

Perustevaliokunta katsoi virkarakennekomitean mietinnön vastaanoton olleen niin ristiriitainen, ettei uudistusta ollut mahdollista sellaisenaan toteuttaa. Sen sijaan kirkkohallituksen tuli valmistella ratkaisua, jossa ainakin aluksi diakonian viranhaltijat ja nuorisotyöntekijät vihittäisiin tehtäviltään pitkälti entisenlaiseen virkaan. ${ }^{465}$ Valiokunta palasi ratkaisuun, jota piispainkokous oli esittänyt kirkolliskokoukselle jo vuosina 1994 ja 1999 mutta jota kirkolliskokous oli laajentanut varsinkin virkarakennekomitean asettamisen yhteydessä. Komitean puheenjohtajan Jaakko Ripatin mielestä virkakeskustelussa otettiin kymmenen vuoden taka-askel. ${ }^{466}$

Syksyllä 2003 kirkolliskokous käsitteli sekä perustevaliokunnan mietinnön virkarakenneuudistuksesta että käsikirjavaliokunnan esityksen kirkollisten toimitusten kirjaksi. Viimeksi mainitun osalta kirkolliskokous päätyi kolmeen erilliseen mutta toisiaan muistuttavaan vihkimiskaavaan niin diakonian virkaa, pappisvirkaa kuin piispanvirkaa varten. ${ }^{467}$ Päätös oli tasapainoilua. Käsikirjakomitean ehdotus kahdesta kaavasta oli omiaan korostamaan välillisesti piispuuden erillisyyttä papistosta ja diakonaatista sekä vastaavasti kaventamaan papiston ja diakonaatin eroa maallikkoihin. Tällöin erityinen pappisvirka johdettiin joidenkuiden mielestä liian suoraviivaisesti yhteisestä pappeudesta, mikä oli ollut aikoinaan toistuvana ongelmana myös valmisteltaessa pappisviran avaamista naisille. Virkarakennekomitean malli taas korosti viran ykseyttä niin pitkälle, ettei ratkaisu arvostelijoiden mielestä tehnyt oikeutta erilaisiin tehtäviin valituille ja erilaisen koulutuksen saaneille viranhaltijoille. Samalla ainutkertainen vihkimys tähän kirkon hengelliseen virkaan saattoi monien mielestä korottaa entisestään muuria virkaan kuuluvien ja siihen kuulumattomien välillä.
Virkarakennekomitean linjaa vastustavat kanttorit toivat läpi prosessin kantansa esiin paljon äänekkäämmin kuin uudistuksen kannattajat. Tämä seikka oli todennäköisesti osasyynä siihen, että perustevaliokunta rajasi jatkotyöskentelyn lähinnä diakonian viranhaltijoihin ja nuorisotyöntekijöihin. ${ }^{668}$ Kirkolliskokouksen täysistunto lisäsi kuitenkin Veli Ainalin ehdotuksesta kanttorit uudistuksen piiriin. ${ }^{669}$ Puolitoista vuotta myöhemmin lähetystyön nuorisosihteeri Mikko-Matti Rinta-Harri ehdotti edustaja-aloitteessaan vielä lapsityönohjaajien ja päätoimisten lähetyssihteerien liittämistä uudistukseen. ${ }^{470}$ Kirkolliskokous jätti aloitteen raukeamaan. Tiedossa oli jo, miten suuriin vaikeuksiin jatkovalmistelussa oli jouduttu, kun kirkolliskokous oli ottanut kanttorit mukaan vastoin valiokuntansa esittämiä perusteluja. ${ }^{41}$ Joka tapauksessa Ainalin ja Rinta-Harrin ehdotukset toistivat perinteistä asetelmaa: kun jälleen kerran valmistelutyössä oli jouduttu tosiasioiden edessä ehdottamaan etenemistä pienin askelin, kirkolliskokouksessa oli halua palata kokonaisvaltaisen uudistuksen tielle. Näyttää siltä, että lisäämällä kanttorit ratkaisevalla hetkellä mukaan uudistuksen piiriin kirkolliskokous jarrutti sekä 1990- että 2000-luvulla diakonaattikysymyksen ratkaisemista.

Kirkkohallituksen työryhmä ajautui työssään umpikujaan ja joutui toteamaan, että peruskysymys diakonaatin teologisesta luonteesta oli liian epäselvä työskentelyn jatkamiseksi. Sen jälkeen professori Heikki Kotila selvitti kirkkoneuvos Seppo Häkkisen pyynnöstä virkarakenneuudistuksen etenemismahdollisuuksia. ${ }^{472} \mathrm{Seu}-$ raavassa vaiheessa asiaa valmisteli Kotilan johtama työryhmä, jota seurasi vielä kolmas työryhmä. Lopulta keväällä 2011 - yhdeksän vuotta virkarakennekomitean työn valmistumisen jälkeen - kirkkohallitus esitti kirkolliskokoukselle diakonaattia koskevien säännösten lisäämistä kirkkolakiin ja -järjestykseen. ${ }^{473}$

Esitys rakentui Kotilan työryhmän teologisille linjauksille, mutta 2010 kuollut Kotila ei ollut enää mukana asian käsittelyssä. Kirkkohallituksen esityksessä diakonaatti oli pappisvirasta erillinen vihkimysvirka, johon vihityille ehdotettiin oleellisesti vähemmän liturgisia oikeuksia kuin virkarakennekomitea oli aikoinaan esittänyt. Esitys sai kirkolliskokouksessa pääosin myönteisen vastaanoton. Esitykseen sisältyi kuitenkin sen verran erityisesti vihkimykseen ja kaitsentaan liittyviä ongel- 
mia, että kirkolliskokous lähetti asian syksyllä 2011 vielä kirkkohallituksen valmisteltavaksi. ${ }^{474}$

Muutenkin paine nopean ratkaisun saavuttamiseksi alkoi 200o-luvun kuluessa heikentyä. Heikki Kotila oli 2002 muistuttanut kirkolliskokoukselle, että luterilaisen virkateologian ongelmat Suomessa olivat kansainvälisessä mitassa rikkaan kirkon ongelmia. Monipuolisen ja laajan työntekijäjoukon sijoittaminen virkateologian lokeroihin oli paljon hankalampaa kuin vastaava luokittelu köyhissä kirkoissa. ${ }^{475}$ Kasvava huoli kirkon taloudesta saattoikin osaltaan hillitä 200o-luvun aikana uudistushanketta, jonka tiedettiin lisäävän tuomiokapitulien tehtäviä ja siten myös uusien virkojen tarvetta. Samaten huomio alkoi kiinnittyä siihen, miten seurakuntien tehtävät kyettäisiin hoitamaan pienenevällä työntekijäjoukolla ja vapaaehtoisten tuella. Ratkaisut, jotka saattoivat korottaa aitaa vihittyjen työntekijöiden ja maallikkojen välillä, houkuttelivat aiempaa vähemmän.

\section{JUMALANPALVELUKSEN KAAVASTA KOHTI JOUSTAVIA TOIMITUKSIA}

Kokoonpanoltaan paljolti uudistunut käsikirjakomitea keskittyi vuodesta 1997 lähtien kirkollisten toimitusten kirjan valmistamiseen uuden puheenjohtajansa, piispa Olavi Rimpiläisen johdolla. ${ }^{476}$ Samaan aikaan tutkimustulokset kertoivat yhtälltä kirkon jäsenyyden heikentymisestä, toisaalta taas kirkollisten toimitusten suuresta merkityksestä jäsenyyden siteiden säilymiselle. Toimitusten suosio laski vähitellen, ja kirkossa tiedostettiin, että niiden aseman puolustaminen vaati ponnisteluja. Odotukset valmistelutyötä kohtaan olivat suuret. ${ }^{477}$ Käsikirjakomitea keräsi palautetta aivan eri mitassa kuin edeltäjänsä kaksi vuosikymmentä aiemmin. ${ }^{478}$ Siitä huolimatta tälläkin kertaa kirkolliskokouksessa oli niitä, joiden mukaan komitea ei tehnyt työtään tarpeeksi avoimesti. ${ }^{479}$ Ongelmana oli myös, ettei suurimmassa osassa seurakunnista uudistusta katsottu erityisen tarpeelliseksi. ${ }^{40}$

Komitea jätti 2001 ehdotuksensa suomen- ja ruotsinkielisiksi toimitusten kirjoiksi. ${ }^{41}$ Komitea oli todennut 1992 välimietinnössään Jumalan kansan juhla, että kirkollisten toimitusten jumalanpalvelusluonnetta ja seurakunnan osallistumista tuli vahvistaa. ${ }^{482}$ Tätä linjaa komitea noudattikin. Seurakuntalaisille pyrittiin antamaan tilaa toimitusten valmistelussa ja toteutuksessa. Ehdo- tetut toimitukset pohjautuivat useimmiten sanajumalanpalveluksen, joskus myös messun, rakenteeseen. Komitea ilmoitti lähtökohdikseen samat periaatteet, joista jumalanpalvelusta oli uudistettu, kuten Pyhän Kolminaisuuden korostamisen ja kontekstuaalisuuden..$^{48}$

Toimitusten jumalanpalvelusluonteen korostaminen keräsi kirkolliskokouksessa tietyiltä osin kiitosta. Esimerkiksi raamatunluvun lisäämistä ja raamatunkohtien valikoiman laajentamista kehuttiin. Toisaalta huomautettiin, että toimitukset oli liian tiukasti sidottu jumalanpalveluksen rakenteeseen, jolloin ne pidentyivät. ${ }^{484}$ Myös piispainkokous ja kirkkohallitus kiinnittivät huomiota tähän seikkaan. ${ }^{485}$ Edelleen piispa Juha Pihkalan johtama käsikirjavaliokunta huomautti, että toimitusten sitominen jumalanpalvelusrakenteeseen oli paikoin ristiriidassa komitean lausuman kontekstuaalisuuden periaatteen kanssa. ${ }^{486}$

Käsikirjavaliokunnan merkittävin periaatteellinen suunnanmuutos olikin siinä, että se irrotti toimituskaavoja jumalanpalvelusrakenteesta. Komitea oli esimerkiksi ottanut jumalanpalvelusten kirjasta suoraan rukouksia, mutta valiokunta muokkasi niitä toimituksen omaa luonnetta korostaviksi. Lukukappale ja evankeliumiteksti yhdistettiin joustavaksi "Raamatunlukua"-kohdaksi, ja kirkkovuoden ajankohdan sijasta painotettiin kunkin toimituksen omaa sanomaa. ${ }^{487}$ Valiokunnassa Kaarinan kirkkoherran Pirjo Vahtolan johtamalla rakennejaostolla ja myös professori Heikki Kotilalla oli näkyvä osa kaavoja muokattaessa. ${ }^{48}$

Valiokunnan ratkaisut saivat kirkolliskokoukselta laajan hyväksynnän. ${ }^{489}$ Joiltain osin kaavoja irrotettiin täysistunnossa vielä hieman lisää jumalanpalveluksen rakenteesta. Seurakuntaneuvos Hilkka Kaikkonen oli osallistunut kirkolliskokouksessa aktiivisesti jo edellisen toimitusten kirjan käsittelyyn 198o-luvulla, ja jälleen hän puhui tiiviiden toimitusten puolesta. Kaikkosen ehdotuksesta täysistunto hyväksyi mahdollisuuden lyhentää sairaan luona vietettävän ehtoollisen kaavaa. ${ }^{490}$ Kysymys valinnanvapaudesta jakoi mielipiteitä - aivan samoin kuin aiemmin jumalanpalvelusten kaavoista keskusteltaessa. Esimerkiksi Voitto Huotari korosti läsnäolijoiden elämäntilanteen ottamista huomioon, mikä osittain liittyi valinnanmahdollisuuksiin. Toisaalta Eero Huovinen oli sitä mieltä, että käsikirjakomitea oli liiaksi ihannoinut valinnanvapautta. Tällainen painotus seura- 


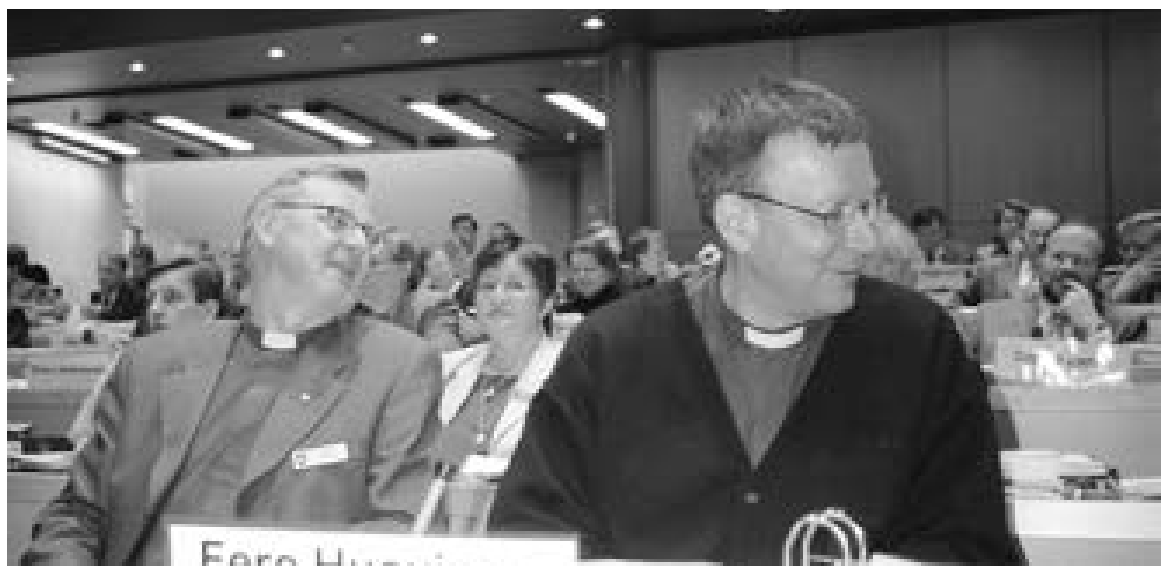

Mikkelin piispa Voitto Huotari (vas.) piti tärkeänä, että läsnäolijoiden elämäntilanne otettiin huomioon suunniteltaessa jokaista kirkollista toimitusta. Helsingin piispa Eero Huovinen toivoi toimituksilta riittävää yhtenäisyyttä. Kuva: Kotimaan kuva-arkisto / Olli Seppälä.

si postmodernia kulttuuriajattelua eikä ottanut huomioon tietyn yhtenäisyyden tuomia etuja. Äänessä olivat ennen kaikkea toimitusten kirjan käyttäjät eli piispat ja papit, huomattavan vähän taas toimituksissa seurakuntalaisina olleet maallikkoedustajat. ${ }^{491}$

Valinnanmahdollisuus kytkeytyi osaltaan kaavojen lukumäärään, jonka kasvua kirkolliskokouksessa arvosteltiin. Keskustelussa todettiin jopa konkreettisesti, että ehdotus uudeksi toimitusten kirjaksi painoi 1350 grammaa entisen 450 gramman sijasta. ${ }^{492}$ Toisaalta käsikirjakomitea ei ollut pelkästään lisännyt kaavoja. Se oli poistanut avioliiton vihkimisestä riisutun B-kaavan, jota perinteisesti oli käytetty eronneita vihittäessä. Komitean mielestä vihkiminen oli toimitettava samoin periaattein kaikille siihen oikeutetuille ja sitä pyytäville seurakuntalaisille. ${ }^{493}$ Mitään erityisiä teologisia perusteluja komitea ei esittänyt. ${ }^{494}$ Ratkaisu ja sen saama hiljainen hyväksyntä kuvastivat asenteen muutosta: 2000-luvulle tultaessa enää vain muutama prosentti suomalaisista kielsi ehdottomasti avioeron oikeutuksen. ${ }^{495}$ Avioero ei ollut myöskään kirkollisessa keskustelussa yhtä paheksuttu asia kuin vielä 1980-luvun alussa toimitusten kirjan edellisen uudistuksen aikaan.

Käsikirjakomitea oli jakanut ehdotuksensa viiteen osaan, mutta kirkolliskokouksessa käsikirjavaliokunta tiivisti osat kolmeen. Komitea oli lisännyt voimakkaasti siunaustoimitusten määrää, mutta palautteen ja siunaamisen teologiaa koskeneiden selvitysten pohjalta käsikirjavaliokunta rajasi siunaustoimitukset vain pelastushistorian ydinasioita koskettaviin hetkiin. Suuri osa siunaustoimituksista muutettiin rukoushetkiksi, joita ei useimmiten enää kirjoitettu erillisiksi kaavoiksi: rukoushetken perusrakenteen rinnalle koottiin vain erilaisia aineistokokoelmia. Toisaalta valiokunta laati aivan uuden rukoushetken kaavan kriisitilanteita varten, koska Yhdysvaltain vuoden 2001 terrori-iskut ja Myyrmäen vuoden 2002 pommi-isku olivat osoittaneet tällaisen kaavan tarpeen. ${ }^{496}$

Kirkolliskokouksen käsikirjavaliokunta liittyi komitean ilmaisemaan periaatteeseen, jonka mukaan seurakunnan tuli toimia liturgian subjektina. Sen sijaan valiokunnan mielestä periaate saattoi toteutua muutenkin kuin tehtäviä jakamalla, eikä seurakuntaa tullut pakottaa aktiivisuuteen. Valiokunta nostikin perinteisen virsilaulun keskeiseksi osaksi seurakunnan liturgista tehtävää ja halusi samalla vahvistaa virren asemaa toimituksissa. ${ }^{497}$ Ylipäätään käsikirjavaliokunta kiinnitti huomiota siihen, ettei käsikirjakomitea ollut juuri pohtinut toimitusten musiikin asemaa. Valiokunta liittyi piispainkokouksen lausuntoon painottaessaan, että jokaisessa toimituksessa oli oltava ainakin yksi virsi tai siihen rinnastettava toimituslaulu. ${ }^{498}$ Aivan samoin kuin jumalanpalvelusten kirjaa käsiteltäessä juuri virren ja musiikin asema nousi kirkolliskokouksessa tärkeäksi kysymykseksi. ${ }^{499}$

Huolta musiikista kannettiin edelleen täysistunnossa. Kirkolliskokous päätti erikseen kirjata, että virren tilalle mahdollisesti otettavan musiikin tuli olla sopivaa. Pyrkimyksenä oli välttää tilanne, johon seurakunnat olivat paikoin Pohjoismaissa joutuneet, kun ne eivät enää kyenneet asettamaan rajoja musiikkivalinnoille. ${ }^{500}$ Avioliittoon vihkimisen B-kaavaan liittynyt käytäntö, jonka mukaisesti pappi oli voinut eräällä tavalla ylhäältä kä- 
sin soveltaa tiettyä kaavaa tietynlaiseen tilanteeseen, ei enää kirkollisten toimitusten kirjaa uudistettaessa näyttänyt realistiselta vaihtoehdolta. Asetelma oli muuttunut puolustustaisteluksi, jossa yritettiin pitää kiinni seurakunnan työntekijöiden oikeudesta määritellä toimituksiin sopiva musiikki.

Toisaalta kirkolliskokouksen täysistunto halusi tietyissä kohdin antaa tilaa musiikin valintaan. Käsikirjavaliokunta oli tiukan äänestyksen jälkeen määritellyt, että avioliiton vahvistamisen ja aviopuolisoiden siunaamisen jälkeen tuli olla pakollinen virsi. ${ }^{501}$ Esittävän musiikin mahdollisuutta kannattaneet Mari Lamminen ja Henrik Perret kokivat asian niin tärkeäksi, että he jättivät eriävän mielipiteen. ${ }^{502}$ Heidän mielestään pakko ei ollut paras keino virsikasvatukseen. Monet edustajat olivat lisäksi sitä mieltä, että kirkolliskokouksen oli luotettava seurakuntien työntekijöiden kykyyn arvioida ehdotetun musiikin sopivuus. Täysistunnossa päädyttiin eriävän mielipiteen kannalle, ja samalla lisättiin lauluesityksen mahdollisuus hautaan siunaamisen kaavaan siunaussanojen jälkeen. ${ }^{503}$

Seurakunnissa saadut kokemukset osoittautuivat tärkeiksi. Kuopion Puijon kappalainen Jaana Marjanen kertoi siirtäneensä "keneltäkään lupaa kysymättä" kastetoimituksessa nimen kysymisen tai toteamisen asetussanojen ja sakramentin välistä aiempaan ajankohtaan, jotta nimen paljastaminen ei katkaisisi kasteen kohokohtaa. ${ }^{504}$ Seurakunnista saatu palaute ja vanhakirkolliset esikuvat tukivat tätä ratkaisua, joten valiokunta muokkasi kastekaavan rakennetta. ${ }^{505}$ Sen jälkeen täysistunnossa vielä Savonlinna-Säämingin kappalainen Kai Jantunen kertoi huomanneensa, että monet vanhemmat toivoivat papin sanovan kastettavan nimen mutta toisaalta halusivat vastata kastetta ja kristillistä kasvatusta koskeviin kysymyksiin. Jantusen ehdotuksesta täysistunto lisäsi selvällä enemmistöllä tällaisen mahdollisuuden..$^{506}$ Kokeilutoiminnan ansiosta kirkolliskokous saattoi muokata kaavoja käytännönläheisemmin kuin edellisellä kerralla kirkollisten toimitusten kirjaa uudistettaessa. Käytännön seikat, kuten toimitusten pituus, saivat myös usein osakseen enemmän huomiota kuin teologiset periaatteet.

Käsikirjakomitea oli pyrkinyt muokkaamaan toimitusten kieltä ajanmukaiseksi ja kaikkia paikallaolijoita puhuttelevaksi. ${ }^{507}$ Uudistustyöhön lähdettäessä työnte- kijöiden muutosvaatimukset olivat kohdistuneet erityisesti rukouksiin, ja tutkimukset osoittivatkin työntekijöiden ottaneen uudet rukousehdotukset tyytyväisinä vastaan. ${ }^{508}$ Kirkolliskokouksessa esimerkiksi sairaalapastori Sirkku Eho kiitti komitean ehdottamia rukouksia: niissä otettiin huomioon sairaus, kärsimys ja erilaiset elämäntilanteet. Piispa Huovinen taas oli tyytymätön rukouksiin: niiden määrä oli vähäinen, ne olivat hyvin lyhyitä ja monet niistä olivat "melko laimeahkoja, hieman kärjistäen sanottuna voidaan sanoa, niissä pyydetään vähän".509

Valiokunta muokkasi rukouksia jonkin verran palautteen perusteella. Täysistunnossa Huovinen sai vielä palautetuksi monia edellisen toimitusten kirjan sanamuotoja, jotka olivat hänen mielestään rikkaita ja keskitettyjä. ${ }^{510}$ Kääntöpuolena oli, että toisten mielestä niiden tyyli rikkoi uuden toimitusten kirjan yhdenmukaisen asun. Kirkkoherra Lasse Marjokorpi sai puolestaan täysistunnossa läpi ehdottamansa uuden vaihtoehdon hautaan siunaamisen johdantosanoiksi. Siihenkin valiokunta halusi tyylillisiä muutoksia, mutta edustajien enemmistö ei niihin suostunut. ${ }^{511}$ Täysistunnon jäsenet halusivat lyhyiden, toisiaan seuraavien toteamuslauseiden väliin vaihtelevia lauserakenteita. Eri näkökulmista katsottuna kirkollisten toimitusten kirjan kielellinen tyyli joko rikkoutui tai rikastui kirkolliskokouksessa - kuten oli tapahtunut aiemmin esimerkiksi virsikirjalle.

Jo vuoden kuluttua siitä, kun kirkolliskokous oli hyväksynyt uuden toimitusten kirjan ja saattanut näin jumalanpalvelusuudistuksen keskeisimmät vaiheet päätökseen, alkoi näkyä tyytymättömyyttä. Se juontui jumalanpalvelusten laskevista kävijämääristä. Ne pelot, joita esimerkiksi Turun silloinen tuomiorovasti Jukka Paarma oli sanoittanut uudistuksen alkuvaiheessa, näyttivät toteutuneen. Myös kirkolliskokouksen yleisvaliokunta totesi, ettei jumalanpalvelusuudistusta voinut pitää kaikilta osin onnistuneena. ${ }^{512}$ Tunnelmat olivat monessa suhteessa samanlaiset kuin 1980-luvulla ennen jumalanpalvelusuudistuksen aloittamista: jumalanpalveluselämä oli vaikeuksissa. Jo tuolloin jotkut olivat korostaneet, etteivät vaikeudet olleet varsinaisesti jumalanpalveluksen ongelmia vaan syvempiä hengellisen elämän ongelmia. Seuraavien vuosikymmenien muutokset sitoutumisessa kirkon uskoon ja jäsenyyteen osoittivat arvion oikeaksi. Oireen hoitaminen ei ollut auttanut 
varsinaiseen vaivaan. Kirkolliskokous käynnisti 2008 edustaja-aloitteen pohjalta uuden hankkeen jumalanpalveluselämän kehittämiseksi ${ }^{513}$.

Sikäli jumalanpalvelusuudistus oli lyönyt itsensä läpi, ettei 200o-luvulla kirkollisia toimituksia uudistettaessa käyty samanlaista keskustelua korkeakirkollisuudesta kuin 1980-luvulla. Erilaiset kaavan rikkaudet ja seurakuntalaisten aktiivista osallistumista painottavat kohdat eivät olleet enää epäilyttäviä uutuuksia. Silti edelleen perussuunta läpi koko kirkolliskokouskäsittelyn oli kaavojen yksinkertaistaminen - samaan tapaan kuin oli ollut jumalanpalvelusten kirjaa uudistettaessa. Toisaalta toimitusten kirjan käsittelyn aikana keskeisimmät toimituksia koskevat kiistat käytiin muissa yhteyksissä kuin kaavojen rakenteesta päätettäessä. Eniten keskusteltiin kaavasta, jota ei edes ollut ehdotetussa toimitusten kirjassa - rekisteröidyn parisuhteen siunaamisesta. Ruotsinkielisen toimitusten kirjan osalta taas kädenvääntö

Vaalikauden päätösillalliset olivat hupaisia tilaisuuksia. Kirkolliskokouksen mieskuoro resitoi savon kielellä viimeisenä yhteisenä iltana marraskuussa 1995. Kuva: Kotimaan kuva-arkisto / Ritva Rasila.

\section{Päättäjäisten naurua}

Kirkolliskokouksen luovuus ja itseironia olivat huipussaan, kun kansliavaliokunnan asettaman toimikunnan johdolla järjestettiin vaalikauden päättäjäistilaisuuksia ja arkkipiispan läksiäisjuhlia. Erityisesti suurin odotuksin laaditut mutta usein raukeamaan jätetyt edustaja-aloitteet olivat ehtymättömän inspiraation lähteinä, samoin kuin eri puolilta maata saapuvien edustajien kohtaaminen. Tosin aina ei voinut irrotella yhtä vapaasti. Vuoden 2007 päätösjuhlan luonne muuttui äkisti, kun tieto samana päivänä tapahtuneesta Jokelan kouluampumisesta saavutti kirkolliskokouksen ${ }^{\mathrm{I}}$. Vuonna 2010 arkkipiispa Jukka Paarman läksiäisjuhlan suunnittelutoimikunta taas totesi, että ohjelmalta vaadittiin hienotunteisuutta: samalla istuntokaudella käsiteltiin vaikeita asioita, kuten suhtautumista rekisteröityyn parisuhteeseen. ${ }^{\text {II }}$

Suuret uudistushankkeet näkyivät päätösjuhlissa. Esimerkiksi vietettäessä päättäjäisiä marraskuussa 1999 kirkolliskokous oli juuri käsitellyt jumalanpalvelusjärjestyksen ja kristinopin uudistamista. Niinpä päätösjuhla rakentui uudis- koski sitä, miten teokseen oli kirjattava Pyhän Hengen nimi.

\section{"...OCH PÅ DEN HELIGA ANDEN" \\ - HELPOISTA PÄ̈̈TÖKSISTÄ \\ VAIKEAAN KESKUSTELUUN}

Pyhän Hengen nimen ruotsinkielinen kirjoitusasu muuttui vähitellen ja osin vaivihkaa kirkollisissa kirjoissa 1900-luvun lopulla. Pyhän Hengen persoonallisuutta korostanut maskuliinimuoto den helige Ande muuttui kieliasultaan uudenaikaisempaan ja merkitykseltään avoimempaan muotoon den heliga Anden. Ensimmäinen rajapyykki oli Uuden testamentin käännöksen valmistuminen Ruotsissa 1981. Pyhästä Hengestä käytettiin muotoa den heliga anden/Anden ${ }^{514}$.

Suomessa käsikirjakomitea ei 1990-luvulla omaksunut uutta muotoa jumalanpalvelusuudistukseen, koska muotoilu oli komitean mielestä sisällöllisesti ja teologi-

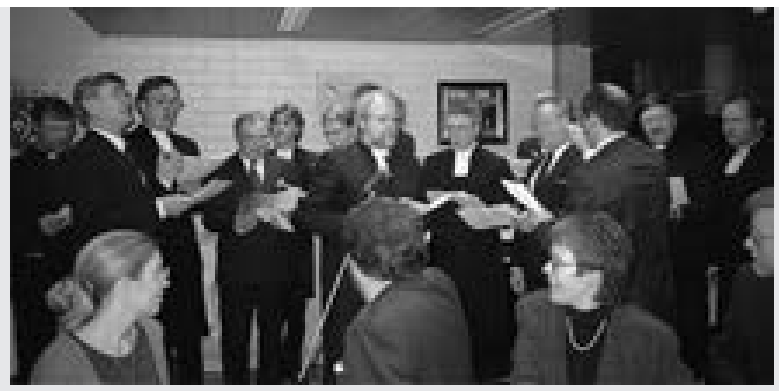

tetulle messun kaavalle, ja edustajille jaettiin Leena Huiman suunnittelema "kevennetty katekismus" Katetta ja skismoja. ${ }^{\text {III }}$ Seuraavalla vaalikaudella kirkolliskokouksen käsittelyssä oli ehdotus uudeksi kirkollisten toimitusten kirjaksi. Ehdotusta arvosteltiin kirkolliskokouksessa siitä, että se sisälsi liian monia osia ja liikaa erillisiä toimituksia. Arvostelu kanavoitui huumoriksi vaalikauden päättäjäisissä marraskuussa 2003. Kirkkoherra Pekka Huokunan johtama juhlatoimikunta painatti päätösjuhlaa varten kirjasen Kirkolliskokouksen toimitusten kirja. XX Päätöstoimitukset. Se noudatti tarkoin aidon toimitusten kirjan ulkoasua ja rakennetta sekä parodioi kirkolliskokouksen juuri hyväksymän teoksen ilmaisutapaa. ${ }^{\mathrm{IV}}$

I Kirk.kok. kptk-s. 2007, 95.

II KKHA KKA Valiokuntien ptk:t 2008-12 Kansliavaliokunta suunnittelutoimikunnan ptk. 19.2.2010 $\$ 8$.

III KKHA KKA Valiokuntien ptk:t 1996-99 Kansliavaliokunta ohjelmatoimikunnan ptk. 26.8.1999\$3, 7.11.1999\$4.

IV KKHA KKA Valiokuntien ptk:t 2000-03 Kansliavaliokunta ptk. 2.11.2003 $\$ 2$, "Kirkolliskokouksen toimitusten kirja. XX Päätöstoimitukset". 
sesti ongelmallinen: se mahdollisti tulkinnan, että Pyhä Henki olisi persoonaton voima. Sitä paitsi Ruotsin kirkkokaan ei ollut vielä uudistanut käsikirjaansa uuden raamatunkäännöksen mukaiseksi. Professori Fredric Cleven johtama komitean ruotsinkielinen jaosto päätyi yksimielisesti säilyttämään jumalanpalveluselämässä muodon den helige Ande. ${ }^{515}$ Ratkaisun seurauksena oli, ettei uusi sanamuoto ollut mukana seurakuntien kokeilutoiminnassa.

Kirkolliskokous lähti etenemään toiseen suuntaan. Se teki pienen mutta kauaskantoisen päätöksen 1998, kun se hyväksyi koekäyttöön uskontunnustusten ekumeeniset ruotsinkieliset muodot. Käsikirjavaliokunta perusteli uutta den heliga Anden -sanamuotoa, mutta täysistunnossa muutokseen ei kiinnitetty juuri lainkaan huomiota. ${ }^{516}$ Keväällä 1999 käsikirjavaliokunta saattoikin jo vedota tuoreeseen koekäyttöpäätökseen, kun se jätti esityksensä ruotsinkieliseksi evankeliumikirjaksi. ${ }^{517}$ Seuraavaksi piispainkokous esitti syksyllä 1999 uskontunnustusten uusia käännöksiä, joissa oli käytössä uudistettu Pyhän Hengen nimimuoto. Ekumeenisten sanamuotojen koekäytöstä oli edetty nopeasti jumalanpalveluselämän keskeisimpiin teksteihin, mutta edelleenkään uusi sanamuoto ei herättänyt huomiota. ${ }^{518}$ Läpi jumalanpalvelusuudistuksen oli korostettu kokeilutoimintaa. Käsikirjakomitean ja kirkolliskokouksen linjaerimielisyyden johdosta yksi ruotsinkielisen jumalanpalvelusuudistuksen näkyvimmistä yksittäisistä muutoksista hyväksyttiin kuitenkin lähes täysin ilman kokeilua ja seurakuntalaisilta saatua palautetta.

Yksittäisten henkilövalintojen merkitys oli suuri. Kirkolliskokouksen käsikirjavaliokunnan ruotsinkielisen jaoston muodostivat piispa Erik Vikström ja lääninrovasti Juanita Fagerholm-Urch. Heidän tukenaan ruotsinkielisenä sihteerinä oli dosentti Yngvill Martola, joka oli toiminut käsikirjakomitean ruotsinkielisen jaoston sihteerinä. Tässä tapauksessa komitean sihteerin valinta valiokunnan sihteeriksi ei kuitenkaan tuonut jatkuvuutta. Päinvastoin Fredric Cleve totesi, ettei valiokunnasta ollut pidetty yhteyttä komitean jäseniin. Uutta sanamuotoa kannattanut Martola oli jäänyt komiteassa yksin, mutta kirkolliskokouksen käsikirjavaliokunnan pienessä ruotsinkielisessä jaostossa asetelma oli toinen. ${ }^{519}$

Kirkolliskokouksen käsikirjavaliokunnassa kaksi kirkolliskokousedustajaa vastasi sihteerin tuella aineistos-

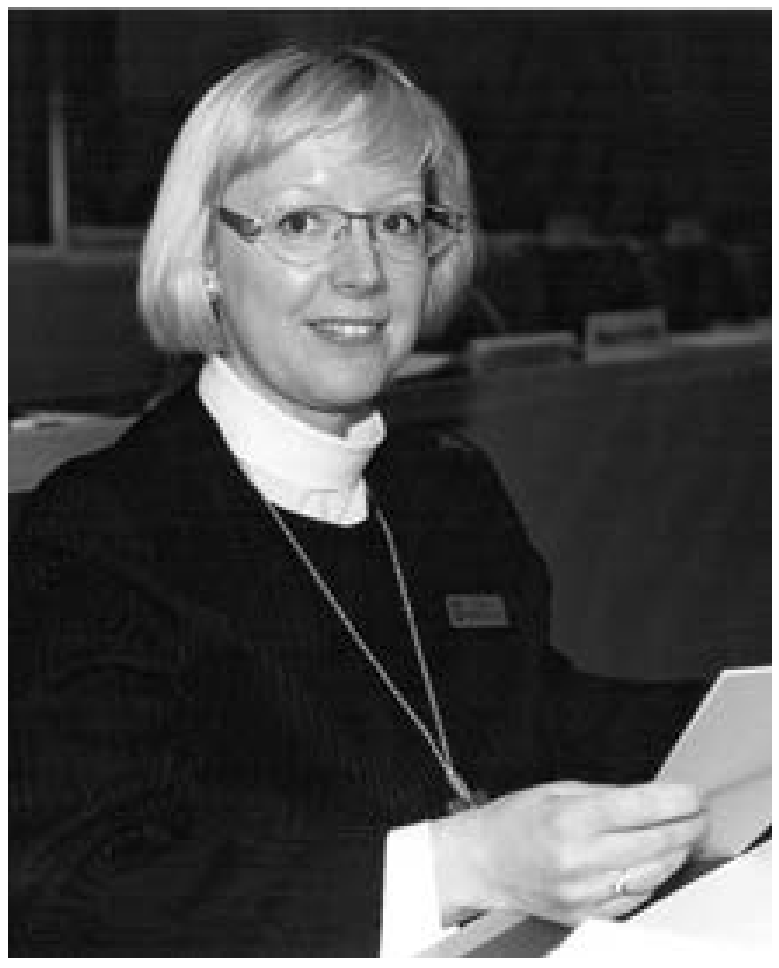

Lääninrovasti Juanita Fagerholm-Urch sai yhdessä piispa Erik Vikströmin kanssa käsikirjavaliokunnassa päävastuun ruotsinkielisen jumalanpalvelusten kirjan ja evankeliumikirjan valmistelusta 199o-luvun lopulla. Pienen ruotsinkielisen jaoston työskentely ei tuolloin herättänyt tunteita, mutta jälkeenpäin oli edessä kiivas keskustelu Pyhän Hengen nimen kirjoitusasusta. Kuva: Kirkkohallitus.

ta, jota käsikirjakomiteassa oli valmistellut 14-henkinen ruotsinkielinen jaosto - kooltaan kaksinkertainen verrattuna Porvoon hiippakunnasta tulleiden kirkolliskokousedustajien yhteismäärään. Käsikirjan valmistelussa tapahtui sama ilmiö kuin ruotsinkielisessä virsikirjauudistuksessa. Suppeassa asiantuntijakomiteassa valmisteltu esitys tuotiin periaatteessa laajaan päätöksentekoelimeen, mutta käytännössä kävi päinvastoin: varsinaisten päättäjien määrä väheni komiteasta kirkolliskokoukseen siirryttäessä, ja vastaavasti sattumanvaraisuus kasvoi. Tällä kertaa Fredric Cleve, joka oli virsikirjauudistuksen yhteydessä ollut ratkaisijan paikalla kirkolliskokouksessa, joutui komitean jäsenenä sivustaseuraajaksi. Satunnaistekijöiden vaikutusta korosti, että Porvoon hiippakunnan edustajaryhmän koostumus oli vaalikaudella 1996-200o poikkeuksellisen otollinen uu- 
den sanamuodon hyväksymiselle: esimerkiksi kirkkoherra Henrik Perret ja filosofian maisteri Göran Stenlund, jotka olivat vuosia istuneet kirkolliskokouksessa ja usein puolustaneet perinteisiä teologisia tulkintoja, olivat tuon vaalikauden poissa kirkolliskokouksesta.

Kirkolliskokous hyväksyi ruotsinkielisen Bibel 2000 -käännöksen koekäyttöön 1999, ja seuraavan vuoden syksyllä piispainkokous esitti käännöksen hyväksymistä varsinaiseen käyttöön. Piispainkokous käsitteli esityksessään käännösratkaisuja mutta ei puuttunut Pyhän Hengen nimen muotoon, joka oli vuoden 1981 Uuden testamentin käännöksen mukaisesti den heliga anden/ Anden..$^{520}$ Kirkolliskokouksen kokoonpano oli kuitenkin vaihtunut, ja Henrik Perret sekä Göran Stenlund olivat palanneet Turkuun. Tuosta hetkestä eteenpäin ruotsinkielisten kirkollisten kirjojen uudistaminen ei enää sujunut yhtäyksimielisestija helpostikuin 1990-luvun lopulla. Toisaalta edelleenkään Pyhän Hengen nimitys ei noussut täysistunnossa esiin, vaan keskustelu koski sitä, tuliko uusi raamatunkäännös hyväksyä suoralta kädeltä. ${ }^{521}$

Osa edustajista halusi antaa seurakunnille edes symbolisen mahdollisuuden kommentoida käännöstä, vaikka käännöksen yksityiskohtiin ei voinutkaan vaikuttaa. Lausunnot olisivat myös saattaneet tukea vaatimuksia saada Ruotsissa laadittu vaihtoehtokäännös Svenska Folkbibeln rinnakkaiskäyttöön. ${ }^{522}$ Ensimmäisessä käsittelyssä ne, jotka kannattivat käännöksen suoraa käyttöönottoa, voittivat äänin 69-21. ${ }^{223}$ Porvoon hiippakunta jakaantui äänestyksessä kahtia. Suoraa hyväksymistä vastaan äänesti erityisen paljon evankelisuuteen ja viidenteen herätysliikkeeseen lukeutuvia edustajia eri hiippakunnista. ${ }^{524}$

Toisessa käsittelyssä raamatunkäännöksen hyväksymistä vastaan äänesti seitsemän edustajaa. Suuri osa vastustuksesta muuttui hiljaisuudeksi: kolme edustajaa äänesti tyhjää, ja poissa oli peräti 17 edustajaa. ${ }^{525}$ Viimeksi mainittuun joukkoon kuuluivat Henrik Perret, Göran Stenlund ja Tampereen ruotsinkielisen seurakunnan kirkkoherra Bror Träskbacka, jotka olivat ensimmäisessä käsittelyssä vastustaneet käännöksen hyväksymistä. Porvoon hiippakunnan edustajina he eivät halunneet asettua kieliryhmänsä raamatunkäännöstä vastaan enää ratkaisuvaiheessa. Sen sijaan seitsemän vastaan äänestäneen joukossa oli piispa Olavi Rimpiläinen. ${ }^{526}$ Oli poikkeuksellista, että piispa äänesti ratkaisevassa käsittelyssä raamatunkäännöksen tai ylipäätään minkään kirkollisen kirjan hyväksymistä vastaan.

Suomenkielistä raamatunkäännöstä käsiteltäessä kirkolliskokouksessa oli käyty kiperiä keskusteluja Jumalan nimityksistä aina siitä lähtien, pitikö luomiskertomuksen yhteydessä henki kirjoittaa isolla vai pienellä alkukirjaimella. Koska uusi ruotsinkielinen käännös voitiin vain joko hyväksyä tai hylätä, vastaava keskustelu jäi käymättä. Ongelmat olivat edessä jälkikäteen ja entistäkin visaisempina. On lisäksi huomattava, että Ruotsi oli näyttäytynyt 1990-luvulla suomalaisessa julkisuudessa usein esimerkkinä siitä, miten kirkon ja valtion välisiä suhteita olisi pitänyt purkaa. Tosiasiassa Ruotsin käytännöt aiheuttivat sen, että Suomessa luterilainen kirkko joutui ottamaan annettuna raamatunkäännöksen, josta vastasi Ruotsin valtio.

Kohu seurasi vain muutaman viikon kuluttua siitä, kun ruotsinkielinen raamatunkäännös oli hyväksytty marraskuussa 200o. Uudet kirkolliset kirjat otettiin käyttöön adventtina, ja ruotsinkielisessä mediassa, erityisesti Kyrkpressen-lehdessä, alkoi kiivas keskustelu Pyhän Hengen nimen muodosta. ${ }^{527}$ Monet papit pitäytyivät vastoin käsikirjaa vanhassa sanamuodossa. ${ }^{528}$ Seuraavan kevään kuluessa sananvaihto kärjistyi entisestään. Hufvudstadsbladet moitti piispa Erik Vikströmiä arvostelukyvyn puutteesta tämän yritettyä hillitä keskustelua auktoriteetillaan kulissien takana. ${ }^{529}$ Vikström taas kertoi tuntevansa häpeää hiippakuntansa puolesta: maailman hädän keskellä keskityttiin kiistelemään kirjaimista. ${ }^{530}$

Keskustelun velloessa Porvoon hiippakuntakokous esitti kirkolliskokoukselle, että toimitusten kirjaa uudistettaessa kiinnitettäisiin erityistä huomiota Jumalan kolmannen persoonan nimitykseen ja tutkittaisiin mahdollisuutta säilyttää joissakin kohdin vanha nimitys den helige Ande. Henrik Perret'n vastaehdotus, jonka mukaan aiempi nimitys pyrittäisiin palauttamaan kirkkokäsikirjaan, hävisi hiippakuntakokouksessa niukasti äänin $17-14 \cdot{ }^{531}$ Käsikirjakomitea taas sai huhtikuussa 2001 valmiiksi ehdotuksensa kirkollisten toimitusten kirjaksi. Komitea piti kiinni perinteisestä sanamuodosta niin pitkälle, että se kirjasi järjestelmällisesti vaihtoehtoisina näkyviin molemmat Pyhän Hengen nimen muodot. ${ }^{532}$

Kirkolliskokouksessa Stenlund ja Perret perustelivat seikkaperäisesti, miksi heidän mielestään aiempi nimitys oli säilytettävä vähintään uuden rinnalla..533 Asian 
käsittely kirkolliskokouksessa ulottui keväästä 2001 syksyyn 2002, ja esimerkiksi ruotsinkielisen toimitusten kirjan lähetekeskustelu keskittyi täysin Pyhän Hengen nimimuotoihin..$^{534}$ Kiistan pitkittyessä äänenpainot jyrkkenivät. Perret'n mukaan häntä oli johdettu harhaan, ja kirkkoherra Lasse Marjokorpi arvosteli voimakkaasti Yngvill Martolan toimintaa. ${ }^{53}$ Piirijohtaja Hannu Kippo taas kertoi saaneensa Alavetelistä hätääntyneen yhteydenoton, kun seurakuntalainen oli saanut tietää, että uusi sanamuoto oli sama kuin Jehovan todistajien käyttämä. Piispa Erik Vikström piti tällaisia viestejä esimerk- keinä siitä, "miten pitkälle Henrik Perret'n propaganda on yltänyt". ${ }^{36}$ Ristiriita näyttäytyi arvovaltakysymyksenä, mutta kärjekkäiden puheenvuorojen taustalla kirkolliskokouksessa oli alusta asti mittava yksimielisyys siitä, että Pyhän Hengen aiemman nimityksen käyttö tuli tavalla tai toisella sallia. Tätä mieltä oli myös Erik Vikström. ${ }^{537}$

Kirkolliskokouksen käsikirjavaliokunta päätyi lopulta esittämään, että kirkkokäsikirjaan kirjattaisiin järjestelmällisesti uusi muoto den heliga Anden mutta että myös perinteisen sanamuodon käyttäminen olisi edel-

\section{Apokryfikirjojen epäselvä asema}

Vuonna 1984 kirkolliskokous teki periaatepäätöksen, että heprealaisesta kaanonista puuttuvat mutta kreikankieliseen Septuagintaan sisältyvät Vanhan testamentin apokryfikirjat käännettäisiin raamatunkäännöstyön yhteydessä. ${ }^{\text {I }}$ Kokous teki varsinaisen päätöksen asiasta kolme vuotta myöhemmin mutta asetti ehdoksi, että valtion tuli osallistua kustannusten maksamiseen. ${ }^{\text {II }}$ Opetusministeriö oli hankkeen tukemiselle myötämielinen, mutta ratkaisevassa asemassa ollut valtiovarainministeriö ei. ${ }^{\text {III }}$ Lopulta lama hautasi toiveet käännöstyöhön ryhtymisestä.

Hanke lähti uudelleen liikkeelle piispainkokouksessa 1998. Tällä kertaa voitiin nojautua uuden raamatunkäännöksen tekijänoikeusmaksuista saatuihin rahavaroihin. Kirkolliskokous asetti professori Raija Sollamon johtaman käännöskomitean, johon se nimesi luterilaisen kirkon edustajiksi neljä jäsentä. Komitea toteutti käännöstyön pitkälti 1980-luvulla laadittujen suunnitelmien mukaisesti, mutta ekumeenisen työskentelyn rakenne oli kevyt verrattuna varsinaiseen raamatunkäännöskomiteaan. ${ }^{\text {IV }}$ Komitean ehdotukset ilmestyivät vaiheittain vuosina $2003-2007$. $^{\mathrm{V}}$ Kulttuuriset ja tieteelliset seikat näkyivät selvästi komitean työssä - komitea esimerkiksi käänsi Sirakin kirjan erikseen heprean- ja kreikankielisestä alkutekstistä. Toisaalta komitea esitti, että apokryfikirjat lisättäisiin mahdollisuuksien mukaan kaikkiin Raamatun painoksiin. ${ }^{\text {VI }}$ Ehdotus antoi kirjakokoelmalle hengellistä painoa.

Kirkolliskokouksessa keskusteltiin apokryfikirjojen asemasta. Päätoimittaja Leif Nummelan mielestä kirjojen liittäminen kaikkiin Raamatun painoksiin hämärtäisi Raamatun asemaa Jumalan sanana ja palauttaisi "meidät siihen, mistä uskonpuhdistus meidät vapautti”. ${ }^{\text {II }}$ Käsikirjavaliokunta lievensi päätösesitystä siten, että kirkkoraamattu voitaisiin julkaista myös ilman apokryfikirjoja. Antamassaan lausunnossa perustevaliokunta ei katsonut kokoelmaa kirkolliseksi kirjaksi, minkä vuoksi asia käsiteltiin ilman määräenemmistövaati-

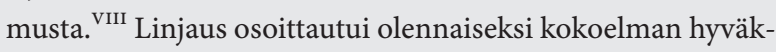
symisen kannalta: äänestyksessä paljastui, että yli neljännes edustajista vastusti apokryfikirjojen sisällyttämistä kirkko-

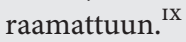

Myös apokryfikirjojen kokoelman määritelmä puhutti kirkolliskokousta. Professori Heikki Kotila huomautti lähetekeskustelussa, että käännöskomitean ehdotuksessa kirjojen kokoelma oli laajempi kuin ruotsinkielisessä Bibel 2000 -käännöksessä. Kotilan mielestä viralliset raamatunkäännökset eivät saaneet poiketa kokoonpanoltaan toisistaan. ${ }^{\mathrm{x}} \mathrm{Kä-}$ sikirjavaliokunta oli samaa mieltä, ja tässä yhtenäistetyssä muodossa kirkolliskokous hyväksyi apokryfikirjojen kokoelman syysistuntokaudella 2007. ${ }^{\mathrm{XI}}$ Ruotsin valtiollisen raamatunkäännöskomitean ratkaisut määräsivät Suomen luterilaisessa kirkossa paitsi ruotsinkielisen raamatunkäännöksen muodon myös apokryfikirjojen suomenkielisen kokoelman sisällön. Kirkolliskokous ei ollut aikoinaan saanut valtiota kantamaan taloudellista päävastuuta käännöstyöstä, mutta merkittävä osa päätösvaltaa oli lopulta valtiolla - tosin Pohjanlahden toisella puolella.

I Kirk.kok. ptk-s. 1984, 28 \$, liite VI-B 7.

II Kirk.kok. ptk-k. 1987,39 \$, liite VII-B 1; Kirk.kok. ptk-s. 1989, 20 \$, liite VII 3 \& VIII-E 9; Sollamo 2006, 80-81.

III Kirk.kok. kptk-k. 1987,39 \$; Sollamo 2006, 80.

IV Kirk.kok. ptk-s. 1999, liite VIII-C 7; Kirk.kok. ptk-s. 2006, liite VIII 1; Sollamo 2006, 81-82.

V Apokryfikirjat 2003 \& 2004 \& 2005 \& 2006; Kirk.kok. ptk-s. 2007, liite V.

VI Kirk.kok. ptk-s. 2006, liite VIII 1; Kirk.kok. ptk-s. 2007, liite VI-B 2; Sollamo $2006,86$.

VII Kirk.kok. kptk-s. 2006,12 \$.

VIII Kirk.kok. ptk-s. 2007, liite VI-B 2.

IX Kirk.kok. kptk-s. 2007,14\$.

X Kirk.kok. kptk-s. 2006, 12 \$.

XI Kirk.kok.ptk-s. 2007, 14 §, liite VI-B 2. 
leen sallittua. ${ }^{538}$ Valiokunnan puheenjohtajan Juha Pihkalan mukaan ratkaisu ei ollut tyylikäs, mutta se edusti "ehkä sellaista konsensusta, mikä tällä hetkellä on saavutettavissa tässä monille eksistenttisessä kysymyksessä”. ${ }^{539}$ Bror Träskbacka totesi:

Herran siunauksessa luemme rukouksen: anna meille rauha. Nyt on tämä rukous kuultu, mitä tulee ehdotukseen pyhän kolminaisuuden kolmannen persoonan nimitykseen ruotsin kielellä kirkossamme. Haluan kiittää käsikirjavaliokuntaa ehdotuksesta, joka on hyvä ja jonka kanssa eri tahot kirkossamme ja Porvoon hiippakunnassa voivat elää. - - Antakaamme rauhan laskeutua. ${ }^{540}$

\section{VALTIOLLINEN JA KIRKOLLINEN LAINSÄÄDÄNTÖ HANKAUKSESSA}

\section{HALLINNON KIELI, RAKENNUSTEN SUOJELU JA KIRKON PERUSTEHTÄVÄ}

Opetusministeriön kansliapäällikkö Vilho Hirvi toi keväällä 2000 ministeriön tervehdyksen uudelle kirkolliskokoukselle. Piispojen nimittäminen oli pari kuukautta aiemmin siirtynyt tasavallan presidentiltä kirkolle, minkä Hirvi totesi lisänneen kirkon itsenäisyyttä ja riippumattomuutta valtiovallasta: "Suomen evankelis-luterilaista kirkkoa ei ole enää mitään syytä kutsua valtiokirkoksi." ${ }^{411}$ Toisaalta kuluneen vuosikymmenen aikana oli tapahtunut päinvastainen muutos. Vuonna 1994 voimaan tullut kirkkolain kokonaisuudistus oli osaltaan tähdännyt kirkon itsemääräämisoikeuden vahvistamiseen, mutta jo seuraavana vuonna oli toteutettu perusoikeusuudistus. Sen katsottiin edellyttävän, että tietyt kirkkojärjestykseen ja siten kirkolliskokouksen päätösvaltaan siirretyt säännökset palautettaisiin lain tasolle. Jo kirkkolain kokonaisuudistuksessa kirkkolaki oli jätetty melko laajaksi, ja uudistuksen voimaantulon jälkeen paineet sen laajentamiseksi edelleen kasvoivat. ${ }^{542}$

Myös EU-jäsenyys asetti uusia vaatimuksia lainsäädännölle. ${ }^{543}$ Siitä huolimatta EU:sta puhuttiin kirkolliskokouksessa uudella vuosituhannella selvästi harvemmin kuin 1990-luvulla, jolloin jäsenyys oli ollut tuore asia. ${ }^{544}$ Edelleen kirkon itsemääräämisoikeuteen vaikutti se, että valtio oli alkanut muuttaa lainsäädäntöään entistä laaja-alaisemmaksi. Tällöin kirkkolakia ei useinkaan jätetty yleisen lain soveltamisalan ulkopuolelle. Kirkkoa koskevia säännöksiä oli lisääntyvässä määrin sellaisessa lainsäädännössä, johon kirkolliskokouksella ei ollut oikeutta esittää muutoksia. Päättäessään kirkkolain jakamisesta kirkolliskokous oli itsekin hyväksynyt sen, että kirkkolakiin otettiin viittaussäännöksiä muuhun lainsäädäntöön. Näin kirkkoa koskevaa normistoa siirrettiin kirkkolain ulkopuolelle. ${ }^{545}$

Yksi tällaisista säännöksistä oli viittaus kielilakiin: seurakunta oli kaksikielinen, kun kunta vastaavien kielilain säännösten mukaan olisi kaksikielinen. ${ }^{546}$ Kun valtiovalta uudisti kielilakia 2000-luvun alussa, viittaukset muuttuivat kohteettomiksi. Kirkon oli pakko uudistaa kirkkolain kielisäännökset. Samalla se joutui kohtaamaan valtion yleisen lainsäädännön ja kirkkolain välisen riippuvuuden - teeman, joka sittemmin puhutti kirkolliskokousta pitkin 200o-lukua.

Uusi kielilaki ja saamen kielilaki olivat tulossa voimaan vuoden 2004 alussa. Marraskuussa 2003 kirkolliskokous sai kiireellisellä aikataululla käsiteltäväkseen kirkkohallituksen esityksen uusista kielisäännöksistä. Seurakuntayhtymän osalta esitys nojasi kuntayhtymää koskeviin uuden kielilain säännöksiin: kaikki seurakuntayhtymät, joihin kuului erikielisiä seurakuntia, olisivat kaksikielisiä. Hiippakunnan viranomaisten oli määrä olla kaksikielisiä, jos hiippakuntaan kuului vähintään yksi kaksikielinen seurakunta. ${ }^{547}$ Säännökset muistuttivat vuoteen 2002 asti voimassa ollutta valtioneuvoston päätöstä seurakuntayhtymien ja hiippakuntien kielestä. ${ }^{548}$ Tämä päätös oli kuitenkin unohtunut, ja esitys näyttäytyi kirkolliskokouksessa uusina velvollisuuksina seurakuntayhtymille ja hiippakunnille.

Kirkolliskokouksen hallintovaliokunnan mukaan säännökset eivät palvelleet sen enempää kielilain kuin hallinnon tarkoitusta. Kirkossa oli ruotsinkielisiä seurakuntia varten Porvoon hiippakunta, jota vastaavaa järjestelmää ei ollut valtiollisessa tai kunnallisessa hallinnossa. Hallintovaliokunta ehdotti, että seurakuntayhtymän yksi- tai kaksikielisyys asetettaisiin riippuvaksi yhtymän alueella olevan kunnan yksi- tai kaksikielisyydestä. Hiippakunnasta valiokunta ehdotti kaksikielistä, mikäli siihen kuului vähintään viisi kaksikielistä seurakuntaa. ${ }^{549}$ Varsinaisen mietinnön laatinut lakivaliokunta liittyi kuitenkin kirkkohallituksen esitykseen taatakseen seurakuntalaisten oikeusturvan. Valiokunta tosin esitti, ettei hiippakunnan kaksikielisyys koskisi yksikielisen seurakunnan henkilöstöhallintoa..$^{50}$ 
Lakivaliokunnan mietintö saapui täysistuntokäsittelyyn istuntoviikon päätteeksi lauantaina. Salista nousi äänekästä arvostelua. Esityksen vastustajat vetosivat siihen, että hieman yli puolen prosentin ruotsinkielinen väestö oli muuttamassa Tampereen seurakuntayhtymän kaksikieliseksi tai että o,2 promillen väestönosuus saattoi tehdä hiippakunnasta kaksikielisen. Laskettiin käännöspalvelujen kustannuksia ja kysyttiin, kuinka paljon summalla voitaisiin tehdä varsinaista seurakuntatyötä. ${ }^{551}$ Esityksen kannattajat saattoivat tukeutua maan perustuslaissa taattuun kaksikielisyyteen. ${ }^{552}$ Vastustajien mielestä taas hallintovaliokunnan kannan noudattaminen ei heikentäisi vähemmistön oikeuksia, vaan ennemminkin lakivaliokunnan esitys oli vaarassa lisätä kirkosta eroamista ja johtaa kieliryhmien välien kärjistymiseen. Tilanne oli epäselvä varsinkin hiippakunnan osalta. Lakivaliokunnan puheenjohtaja Kim Fröman joutui myöntämään, ettei hän tarkalleen tiennyt valiokuntansa ehdottaman lainkohdan vaikutusta hiippakuntien arkeen. ${ }^{553}$

Paine oli kova, koska lakivaliokunnan ehdotus oli ajanpuutteen vuoksi joko hyväksyttävä tai hylättävä. Kirkkoneuvos Matti Halttusen mukaan lakiesityksen kaatumisen seurauksena olisi "täysin mahdoton tilanne". ${ }^{54}$ Lauantai oli jo edennyt pitkälle ja runsaasti edustajia poistunut Turusta, kun asia tuli ratkaisevaan käsittelyyn. Paikalla olivat kuitenkin ne, jotka voimakkaimmin vastustivat lakiesitystä, ja äänin 64-22 määräenemmistö jäi yhden äänen päähän. ${ }^{55}$ Ei-äänet keskittyivät Tampereen ja Helsingin hiippakuntiin. ${ }^{556}$ Molemmissa hiippakunnissa oli suuria, erikielisistä seurakunnista koostuvia seurakuntayhtymiä, joita lakiehdotus olisi koskettanut. Seurauksena kiireestä ja tyytymättömyydestä oli kirkkoneuvos Halttusen pelkäämä "täysin mahdoton tilanne", jossa kirkkolain kielisäännökset eivät viitanneet mihinkään.

Jo seuraavana keväänä kirkkohallitus toi periaatteiltaan lähes edellissyksyn kaltaisen esityksen kirkolliskokoukselle. ${ }^{557}$ Tällä välin kirkolliskokouksen edustajisto oli vaihtunut, ja uusi kirkolliskokous kävi paljolti samanlaisen keskustelun kuin edeltäjänsä. ${ }^{558}$ Uusiutuneet laki- ja hallintovaliokunta pysyivät myös pitkälti entisillä linjoillaan. Asian saamaa painoa osoitti se, että lakivaliokunta kuuli useita asiantuntijoita, muiden muassa kielilakikomitean puheenjohtajana toiminutta korkeim- man hallinto-oikeuden presidenttiä Pekka Hallbergiä. 559 Laki- ja hallintovaliokunta olivat edelleen eri mieltä kielisäännöksistä. Näillä valiokunnilla oli erimielisyyksiä myös hiippakuntahallinnon uudistamisesta. Tuolloinkin lakivaliokunta painotti korkeatasoista lakiasioiden hoitamista, hallintovaliokunta taas käytännön toimintaa. Painotuseroissa näkyi se, että perinteisesti kirkkoherroista koostunut lakivaliokunta oli muuttunut lakimiesten valiokunnaksi, kun taas kirkkoherrat olivat siirtyneet hallintovaliokuntaan.

Lakivaliokunnan esityksen puolustajat saattoivat tällä kertaa vedota valtioneuvoston aiempaan päätökseen, joka palautui kirkolliskokouksen tietoisuuteen. ${ }^{560}$ Uutena perusteluna nousi lisäksi esiin kirkon julkisoikeudellinen asema. Lakivaliokunnan puheenjohtaja Kim Fröman kysyi, oliko "kirkolla varaa kielilainsäädäntökysymyksessä poiketa maassa vakiintuneesta yleisestä linjasta, jos kirkko haluaa jatkaa julkisoikeudellisena, jopa verotusoikeuden omaavana yhteisönä". ${ }^{561}$ Piispa Samuel Salmi ja hallinto-oikeustuomari Pirjo Pyhäjärvi yhtyivät kyselyyn. ${ }^{562}$ Tällä kerralla myös hallintovaliokunnan kannattajat pitivät vanhentuneen kirkkolain korjaamista ensisijaisena, ja lakivaliokunnan esitys hyväksyttiin. ${ }^{563}$ Enemmistö kirkon keskushallinnon elinten jäsenistä halusi soveltaa valtion kielilakia johdonmukaisesti kirkon hallintoon. Se katsottiin kirkon moraaliseksi velvoitteeksi, mikäli kirkko halusi säilyttää vastaisuudessa asemansa julkisoikeudellisena yhteisönä. Julkisoikeudellinen asema rajoitti käytännössä - vaikkakaan ei periaatteessa - kirkolliskokouksen mahdollisuuksia esittää valtiollisesta lainsäädännöstä poikkeavia säännöksiä.

Vuonna 2008 kirkkohallitus esitti uusien rakennussuojelusäännösten lisäämistä kirkkolakiin. Kirkkohallitus esitti, ettei kirkollisen rakennuksen olennaista muutosta tai purkamista koskevaa päätöstä enää alistettaisi opetusministeriölle. Museoviraston asemaa lausunnonantajana oli määrä vastaavasti vahvistaa ja antaa sille oikeus valittaa kirkollista rakennusta koskevasta seurakunnan tai kirkkohallituksen päätöksestä. ${ }^{564}$ Laintarkastustoimikunta ja lakivaliokunta pitivät uutena ja poikkeuksellisena tällaista säännöstä, jonka nojalla kirkollishallinnon ulkopuolinen viranomainen saisi muutoksenhakuoikeuden kirkkolain alaan kuuluvassa asiassa. Museovirastolla oli lakivaliokunnan mukaan riittävät vaiku- 
tusmahdollisuudet ilman valitusoikeuttakin. ${ }^{565}$ Kuten aiempina vuosina lakivaliokunnan silmäteränä oli kirkkolainsäädännön periaatteellinen johdonmukaisuus, mutta - toisin kuin kielisäännöksistä päätettäessä - tällä kertaa valiokunnan kanta oli tuomassa kirkolle lisää itsemääräämisoikeutta alkuperäiseen esitykseen verrattuna.

Valtioneuvoston määräämä edustaja, vanhempi hallitussihteeri Joni Hiitola jätti eriävän mielipiteen lakivaliokunnan mietintöön. Hänen mukaansa kirkkohallituksen esittämät lakimuutokset lisäsivät kokonaisuutena merkittävästi kirkon itsehallintoa kirkollisten rakennusten suojelussa. ${ }^{56}$ Valtioneuvoston määräämän edustajan eriävä mielipide oli poikkeuksellinen. Kun sellainen oli nähty edellisen kerran 1990-luvulla, edustaja oli kertomansa mukaan toiminut yksin. Hiitola ilmoitti sen sijaan, että hän oli päätynyt ratkaisuun keskusteltuaan esimiestensä ja kulttuuriperinnön suojelusta vastaavien virkamiesten kanssa. ${ }^{567}$

Tilanne sai aikaan epätietoisuutta: lakivaliokunta ja valtiovalta olivat eri linjoilla, eikä ollut varmuutta siitä, saisiko ehdotettu kirkkolaki eduskunnan hyväksynnän. Toisaalta valtiovallan kannan hyväksymisen ehtona alettiin nähdä se, että valtio korvaisi kirkolle kulttuuriperinnön vaalimisesta aiheutuvat ylimääräiset kustannukset. Hiitola teki täysistunnossa eriävän mielipiteensä mukaisen muutosehdotuksen, joka oli tutkimuskaudella ainoa valtioneuvoston määräämän edustajan tekemä muutosehdotus. Hiitola sai asian palautetuksi lakivaliokuntaan. Valiokunta pysyi kuitenkin kannassaan ja sai lopulta tuekseen kirkolliskokouksen enemmistön asian ensimmäisessä käsittelyssä. ${ }^{568}$

Ruotsissa valtio tuki kirkon kulttuurihistoriallisesti arvokkaan omaisuuden ylläpitämistä. ${ }^{569}$ Suomessakin kirkolliskokous oli sitkeästi painottanut, että kulttuurisesti arvokkaiden rakennusten ylläpitäminen oli yhteiskunnallinen tehtävä, josta valtion tuli maksaa asianmukainen korvaus. Kirkolliskokouksen enemmistön kanta seurasi tätä linjaa. Toisaalta kirkolliskokouksen toiminnassa oli havaittavissa myös muutosta. Suhteessa valtiovaltaan kirkolliskokouksen taktiikkana oli usein ollut tulla vastaan ja luoda siten valtiovallalle moraalinen velvoite toimia kirkon toivomalla tavalla.

Tällainen ajattelutapa oli näkynyt vahvasti esimerkiksi niissä tapahtumissa, jotka olivat johtaneet Joensuun yliopiston teologisen tiedekunnan perustamiseen 2002.
Arkkipiispa Vikström oli ehdottanut tiedekunnan perustamista Joensuuhun avatessaan kirkolliskokouksen keväällä $1990^{570}$. Kirkolliskokous oli puolestaan jo seuraavana vuonna myöntänyt määrärahan suunnitteluprofessuuria varten ja mahdollistanut siten läntisen teologian koulutuksen alkamisen. ${ }^{571}$ Edelleen vuonna 2000 kirkolliskokous oli päättänyt kattaa kolmena vuonna kolmasosan niistä varoista, jotka tarvittiin kolmen professorin palkkaamiseen. Päätös oli luonut välttämättömät edellytykset tiedekunnan perustamiselle. ${ }^{572}$

Varsinkin 1990-luvun alun rahoituspäätöksiin oli sisältynyt suuria riskejä, koska taloudellinen lama oli jäädyttänyt valtionhallinnossa tiedekunnan perustamissuunnitelmat. Kirkolliskokouksessa olivat kuitenkin olleet enemmistönä ne edustajat, joiden mielestä oli lähdettävä rohkeasti liikkeelle ja luotettava siihen, että valtio vastaisi myönteisesti kirkolliskokouksen aloitteellisuuteen..$^{573}$ Sen sijaan myöhemmin rakennussuojelusäännöksistä keskusteltaessa oli pääsemässä voitolle päinvastainen toimintatapa: valtiovallan oli ensin tultava taloudellisesti kirkkoa vastaan, jos se halusi saada mieleisiään säännöksiä kirkkolakiin.

Kirkolliskokous ei ollut kuitenkaan yksimielinen. Lakivaliokunnan ehdottaman muodon saanut esitys saavutti ratkaisevassa toisessa käsittelyssä kyllä enemmistön äänin 70-31 mutta kaatui määräenemmistön puutteeseen. ${ }^{574}$ Kirkolliskokouksesta löytyi määrävähemmistö, joka ei halunnut kaventaa museoviranomaisten vaikutusvaltaa tai luoda jännitteitä kirkon ja valtiovallan välille. Lopulta kirkolliskokous hyväksyi 2012 yksimielisesti kirkkohallituksen esityksen, joka takasi Museovirastolle sekä lausunnonanto- että valitusoikeuden ${ }^{575}$.

Niin kielilain kuin rakennussuojelusäännösten osalta keskustelun eräinä pohjavirtoina olivat kysymykset siitä, mitkä asiat kuuluivat kirkon perustehtävään ja missä määrin kirkon oli päätöksillään tuettava asemaansa julkisoikeudellisena yhteisönä. Molemmissa päätöksentekoprosesseissa voitolle päätyi tiukkojen vaiheiden jälkeen kirkon julkisoikeudellista luonnetta painottava näkökulma. Kirkollisen itsehallinnon rajoja ei haluttu lähteä koettelemaan, vaan tehtiin päätöksiä, joita valtiovallan tiedettiin tai oletettiin toivovan. 
TASA - ARVOLAKI, PARISUHDELAKI

\section{JA VAPAUS VALITA TYÖNTEKIJÄT}

Vuonna 1986 hyväksytty laki naisten ja miesten välisestä tasa-arvosta sisälsi säännöksen, jonka mukaan lakia ei sovellettu uskonnollisten yhdyskuntien uskonnonharjoitukseen liittyvään toimintaan. Toisaalta vielä uuden vuosituhannen alkaessakaan kirkkolaissa ei ollut säännöstä siitä, miten tasa-arvolakia kuului soveltaa kirkossa. "Uskonnonharjoitukseen liittyvän toiminnan" rajojen määrittäminen jäi tuomioistuimille, ja vuoden 2001 alkupuolella korkeimmat oikeusasteet vetivätkin noita rajoja. Korkein hallinto-oikeus linjasi, että seurakunnan hauta- ja kiinteistötoimen johtokunta kuului tasaarvolain alaan, kun taas uskonnonharjoitukseen liittyvä kasvatustyön johtokunta ei kuulunut. Korkeimman oikeuden päätöksen mukaan taas kappalaisenvaalissa oli sovellettava tasa-arvolakia. ${ }^{576}$ Siten seurakunnan kirkkovaltuusto ei voinut luonteeltaan usein arvaamattomassa suljetussa lippuäänestyksessäkään valita kappalaiseksi muuta ehdokasta kuin pätevimmäksi arvioidun - ainakaan, mikäli ehdokkaat olivat eri sukupuolta.

Vielä samana keväänä kirkkoherra Arto Laitinen ja hallinto-oikeustuomari Pirjo Pyhäjärvi vaativat aloitteissaan, että tilannetta oli selvennettävä kirkkolain säännöksin. ${ }^{577}$ Pyhäjärven ohella lainoppinut asiantuntija, oikeusneuvos Mikael Krogerus asettui kannattamaan lainsäädännön selkiyttämistä. ${ }^{578}$ Kaikesta näkyi, ettei tuomioistuimissakaan oltu tyytyväisiä tilanteeseen. Kirkolliskokous yhtyi Pyhäjärven ehdotukseen, jonka mukaan kirkkolakiin oli valmisteltava säännökset tasa-arvolain soveltamisesta kirkon hallintoon ja henkilövalintoihin sekä tarvittaessa esitettävä muutoksia tasaarvolakiin $^{579}$. Pari vuotta myöhemmin kirkolliskokous määrittikin tasa-arvolain koskemaan aiempaa selvemmin kirkon hallintoa. ${ }^{580}$

Aloitteita käsiteltäessä ilmeni harvinaisen vähän ymmärtämystä korkeimpien oikeusasteiden päätöksiä kohtaan. Arto Laitinen esimerkiksi kummasteli, että korkein oikeus oli tehnyt päätöksensä kokoonpanossa, jossa oli ollut vain yhden sukupuolen edustajia. Verrattiinpa korkeimman oikeuden päätöstä jopa "Neuvostoliiton käytäntöön": äänestäminen oli kyllä mahdollista, mutta todellisuudessa sai olla vain yksi ehdokas. ${ }^{581}$ Korkeimmat oikeusistuimet olivat edellisellä vuosikymmenellä halunneet purkaa kytköksensä kirkolliskokoukseen, ja keskustelujen pohjalta näytti siltä, ettei riippuvuutta ollut ainakaan kirkolliskokousedustajien keskuudessa havaittavissa. Ennemminkin saattoi kysyä, minkä verran lakia ehdottavassa elimessä oli vallanjaon näkökulmasta sopivaa kyseenalaistaa korkeimpien oikeusasteiden päätöksiä.

Rajaa tuomioistuimiin käytiin samaan aikaan myös hiippakuntahallinnon uudistamisen yhteydessä. Periaatteellisesti merkittävä osa uudistusta oli lainkäyttöasioiden siirtäminen tuomiokapituleilta hallinto-oikeuksille ja hallintolainkäyttölain järjestelmän tuominen kirkollishallintoon. ${ }^{582}$ Ajankohta asian käsittelylle kirkolliskokouksessa ei ollut kaikkein otollisin, kun ilmassa oli samaan aikaan viljalti tyytymättömyyttä oikeusistuinten tuoreisiin päätöksiin..$^{53}$ Hallintovaliokunta asettui kuitenkin kannattamaan muutosta. ${ }^{584}$

Piispa Erik Vikström, joka muutenkin pyrki uudistusprosessissa säilyttämään piispojen kaitsentavälineet, yritti pitää lainkäyttöasiat kirkolla. Hän ei kuitenkaan saanut mainittavaa tukea. Päinvastoin oikeusoppineet - mukaan lukien lainoppinut asiantuntija, hallintoneuvos Pirkko Ignatius - painottivat, että tuolloisten periaatteiden mukaan lainkäyttöasiat oli siirrettävä hallinnon sisältä tuomioistuimille. Keskeisenä perusteluna näyttäytyi Euroopan ihmisoikeussopimus, johon vedoten hieman aiemmin myös korkeimpien oikeusistuinten valitsemat edustajat oli poistettu kirkolliskokouksesta. Osana hiippakuntahallinnon uudistusta kirkko otti jälleen yhden askelen kohti valtiollisessa päätöksenteossa tunnettua vallanjakoa. ${ }^{58}$

Erityisen kiperäksi kysymys kirkon oikeudesta valita työntekijänsä ja valvoa heitä muuttui, kun eduskunta hyväksyi syksyllä 2001 lain samaa sukupuolta olevien rekisteröidystä parisuhteesta. Kysymys ei noussut esille yllättäen, koska homoseksuaaliset parisuhteet olivat jakaneet 1990-luvulta lähtien monia läntisiä kirkkoja ja voimistaneet keskustelua kirkollisesta auktoriteetista. ${ }^{56}$ Suomen näkökulmasta läheisin vertailukohta oli Ruotsin kirkko, jossa piispainkokous oli laatinut 1994 pastoraalisen ohjeen esirukouksesta parisuhteensa rekisteröineiden puolesta. Ohjeistusta oli vielä 1999 muutettu aiempaa julkisemman toimituksen suuntaan. ${ }^{587}$

Suomessakin seksuaalivähemmistöihin kuuluvien seurakuntalaisten alkava verkostoituminen ja lopulta 
sateenkaarijumalanpalvelukset olivat 1990-luvun edetessä tuoneet näitä vähemmistöjä vähitellen näkyviksi. ${ }^{58}$ Kirkolliskokous oli keskustellut homoseksuaalisista parisuhteista 1993. Keskustelu ei ollut kuitenkaan aiheuttanut muutoksia seksuaalieettisen opetuksen peruslinjaan, jonka mukaan homoseksuaalisen taipumuksen toteuttamisesta tuli pidättyä. Myöskään kirkkohallitus, joka oli antanut lausunnon parisuhdelakia valmistelleen työryhmän ehdotuksesta, ei katsonut hyväksi luoda avioliittoa muistuttavia instituutioita. Sen sijaan se piti tarpeellisena selvittää parien oikeudelliseen asemaan liittyviä epäkohtia ja kannatti avioliitosta selvästi poikkeavaa, seksuaalisesta suuntautumisesta riippumatonta asuinkumppanuuden rekisteröintimallia. ${ }^{589}$ Lopullinen lakiteksti takasi parisuhteen solmineille pääosin samat oikeudet ja velvollisuudet kuin aviopuolisoille.590

Parisuhdelain hyväksymisen jälkeen piispat julkaisivat yhteisen kannanoton, joka seuraili kirkkohallituksen lausunnon linjaa. Piispojen mukaan yhteiskunnan oli tuettava naisen ja miehen välistä parisuhdetta vahvistavaa opetusta ja kasvatusta. ${ }^{591}$ Mediassa taas kiinnitettiin huomiota piispojen varovaisiin kannanottoihin. Heidän toimintaansa kuvattiin esimerkiksi ilmauksin "kierrellä kuin mato koukussa", "olla kieli keskellä suuta" tai "kiertää kuin kissa kuumaa puuroa".592 Tilanne olikin jännittynyt. Keväällä 2002 kirkolliskokous sai käsiteltäväkseen kaksi käytännössä vastakkaista aloitetta. ${ }^{593}$

Viisi edustajaa - ensimmäisenä allekirjoittajana kirkkoherra Lasse Marjokorpi - ehdotti kirkkojärjestykseen säännöstä, jonka mukaan samaa sukupuolta olevan kanssa parisuhteen rekisteröinyt henkilö ei voisi toimia kirkon viranhaltijana tai työntekijänä. Kukin aloitteentekijä oli lähellä joko evankelisuutta, esikoislestadiolaisuutta tai viidettä herätysliikettä. Aloitteentekijät totesivat, että valtion lainsäädäntö oli irtautumassa kristillisestä uskosta ja etiikasta. He viittasivat muun muassa Saksan kirkkotaisteluun, jota monet naispappeuden vastustajat olivat käyttäneet vertailukohtana jo edeltäneinä vuosikymmeninä..94 Norjan kirkolliskokous oli 1995 todennut, ettei piispojen tullut omavaltaisesti vihkiä papiksi homoseksuaalisessa suhteessa eläviä henkilöitä. ${ }^{595}$ Suomessa kirkon liikkumatila ei kuitenkaan näyttänyt suurelta: oikeuskansleri Paavo Nikula ja sosiaalidemokraatteihin lukeutunut oikeusministeri Johannes Koskinen arvioivat aloitetta julkisuudessa hyvin kriittises- ti jo ennen sen tuloa kirkolliskokouksen käsittelyyn. ${ }^{596}$

Kun ensimmäisessä aloitteessa korostuivat periaatteelliset ja teologiset näkökohdat, toinen aloite käsitteli hyvin käytännöllisiä seikkoja. Lähtökohtana oli se, että parisuhteensa rekisteröineitä ja heidän kotejaan siunattiin joka tapauksessa. Jotta siunaaminen voitiin toteuttaa "tyylikkäästi kaikkien osapuolten yhteiseksi rakennukseksi", käsikirjavaliokunnan oli syytä valmistella muutamia vaihtoehtoisia siunaamiskaavoja tällaisia tilanteita varten. Aloitteen takana oli kahdeksan edustajaa kauppateknikko Matti Sollamon johdolla. ${ }^{597}$ Aloitteen käytännönläheistä linjaa tuki se, että käsikirjakomitea ehdotti samaan aikaan kirkollisten toimitusten kirjaan lukuisia uusia siunaamiskaavoja. Jotkut aloitteen kannattajat kysyivät, miksei heidän ehdottamiaan siunaamiskaavoja voitaisi toteuttaa, kun esineille ja rakennuksillekin omistettiin erillisiä kaavoja. ${ }^{598}$

Kirkolliskokoukseen kohdistui ristiriitaisia odotuksia. Kyselytutkimusten mukaan suomalaisten mielipiteet jakautuivat, mutta enemmistö mielipiteensä muodostaneista vastusti niin rekisteröidyn parisuhteen kirkollista siunaamista kuin parisuhteensa rekisteröineen henkilön oikeutta toimia pappina.. ${ }^{599}$ Tämä asenneilmasto vaikutti luultavasti osaltaan siihen, että kahdesta vastakkaisesta aloitteesta nimenomaan virkakieltoa koskeva aloite sai kirkolliskokouksessa enemmän huomiota: toisen aloitteen mahdollisuudet näyttivät niin vähäisiltä, etteivät edes aloitteentekijät lähteneet taistelemaan kovin voimakkaasti sen puolesta. Toisaalta homoseksuaalisuutta kohtaan ei enää kuultu yhtä jyrkkiä sanoja kuin vielä 1993. Joka tapauksessa vastakkaiset aloitteet osoittivat julkisuuteen konkreettisesti, että kirkon päättäjienkin keskuudessa vallitsi hyvin erilaisia mielipiteitä suhtautumisesta rekisteröityyn parisuhteeseen.

Aloitteiden käsittely kiinnitti median huomion tavalla, jota oli koettu viimeksi käsiteltäessä pappisviran avaamista naisille. ${ }^{600}$ Hyvissä ajoin ennen lähetekeskustelun alkua toimittajat täyttivät puhujakorokkeen mikrofoneilla.$^{601}$ Herkässä tilanteessa piispa Eero Huovinen aloitti lähetekeskustelun perusteellisella, tasapainottelevalla puheenvuorolla, jolla oli piispallisen linjapuheen luonne. Puhe myös viitoitti asian käsittelyvaiheet seuraavien kahdeksan vuoden aikana. Huovinen ilmoitti pitävänsä arvossa esivaltaa, joka antoi kirkolle tilaa selvittää teologiset kysymykset itsenäisesti - sallihan esivalta 
myös katolisen kirkon pappeja ja ortodoksisen kirkon piispoja koskevan selibaattivaatimuksen. ${ }^{602}$ Sanat voi nähdä viestinä niille valtiovallan edustajille, jotka olivat torjuneet kirkon mahdollisuuden rajoittaa pääsyä virkoihin rekisteröidyn parisuhteen perusteella.

Toisaalta Huovinen epäili, ettei eduskunta hyväksyisi kirkkolakiin tällaista rajoitusta, joten ensimmäinen aloite näyttäytyi ongelmallisena. Ongelmallinen oli piispan mukaan myös toinen aloite, koska rekisteröidyn parisuhteen siunaamisen yhteydessä olisi vaikea välttää suhteen rinnastumista avioliittoon. Huovinen näki ratkaisuna lähinnä esirukouksen, jollaista Ruotsin kirkon piispat olivat suosittaneet 1990-luvulla. Samalla hän painotti, että aloitteet pakottivat ennemminkin tekemään kysymyksiä kuin antamaan vastauksia. Yhtäläinen kysely kuului muutamien muidenkin piispojen puheenvuoroissa ${ }^{603}$ Julkinen tila jäi niille, joilla oli antaa selviä vastauksia.

Keskustelussa puututtiin moniin periaatteellisiin kysymyksiin, kuten opin ja etiikan väliseen suhteeseen, siunaamisen teologiaan ja kirkon itsemääräämisoikeuden rajoihin. ${ }^{604}$ Jorma Laulaja ja Juha Pihkala peräänkuuluttivat perusteellista selvitystä siitä, mitkä olivat kirkon mahdollisuudet asettaa työntekijöilleen elämänratkaisuja koskevia rajoituksia. ${ }^{605}$ Kirkolliskokouksen poliisijäsenet huomauttivat, että myös heidän ammatissaan viranhaltijoita kohdeltiin lain edessä toisin kuin muita kansalaisia: näin toimittiin, jotta viranhaltijoiden uskottavuus säilyisi. Tilanteet olivat edustajien mielestä monin tavoin verrannollisia. ${ }^{606}$

Piispoista Wille Riekkinen antoi tukensa ehdotetulle siunaamisen kaavalle. Riekkinen näki kaavan jopa korostavan avioliiton ja rekisteröidyn parisuhteen välistä eroa: uuden kaavan myötä siunaamistoimituksiin, joita pidettäisiin luultavasti vastaisuudessakin, ei tarvitsisi soveltaa avioliiton siunaamisen kaavaa. ${ }^{607}$ Siunaamiskaavan kannattajille olikin ominaista, että he kertoivat haluavansa säilyttää avioliiton ja rekisteröidyn parisuhteen välisen eron. ${ }^{608}$ Muutenkin huolet olivat eri osapuolilla hyvin samanlaisia mutta johtopäätökset täysin vastakkaisia. Molemmat osapuolet korostivat suhtautuvansa vakavasti syntiin: siunaamiskaavan kannattajien mielestä vastustajat projisoivat synnin yksipuolisesti vain homoihin, kun taas virkakiellon ajajien mielestä siunaamisen kannattajat painoivat synnin todellisuuden syrjään.
Monet siunaamisaloitteen kannattajat nostivat esille yksittäisen homoseksuaalin ja hänen omaistensa näkökulman ja siirsivät siten huomiota juridisista ja opillisista periaatekysymyksistä käytännön pastoraaliseen kohtaamiseen. He olivat huolissaan homoseksuaalien kotipaikkaoikeudesta kirkossa, kun taas vastapuolella oli aivan sama huoli konservatiivien toimintamahdollisuuksista. ${ }^{609}$

Kyseessä oli laajalti kirkkoja ravistellut ja kirkkojen välisiin suhteisiin vaikuttanut teema. Asian ekumeeniset ulottuvuudet alkoivat kuitenkin nousta esiin vasta lähetekeskustelun lopussa, kun puolensataa puheenvuoroa oli kuultu. ${ }^{60}$ Kirkolliskokous käsitteli kysymystä nimenomaan Suomen luterilaisen kirkon asiana, ja sellaisena keskustelu paljasti jälleen jakolinjoja herätysliikkeiden välillä ja sisällä. Erityisesti herännäisyyden piiristä löytyi kannatusta siunaamisaloitteelle. Kirkkohallituksen jäsen Maaria Perälä allekirjoitti aloitteen, mikä sai evankelisuuteen lukeutuneen Hannu Kipon kaipaamaan jopa välikysymysmenettelyä kirkkohallituksen jäsenen luottamuksen mittaamiseksi. ${ }^{61}$

Vanhoillislestadiolaisen Yrjö Koskimäen kannanotto oli huomattava. Hänen mukaansa kumpikin aloite hipoi äärilaitoja. ${ }^{612}$ Jo tuoreimpia ekumeenisia sopimuksia käsiteltäessä oli ollut havaittavissa, etteivät vanhoillislestadiolaiset kirkolliskokousedustajat enää esittäneet 1970-luvun kaltaista voimakasta vastarintaa vaan olivat valmiita kompromisseihin. Sama piirre näkyi parisuhdelain seurausten käsittelyssä: herätysliikkeessä pyrittiin vahvistamaan keskinäistä luottamusta kirkon johdon kanssa ja välttämään tiukkojen rajalinjojen vetoa. Tosin herätysliikkeen sittemmin suviseurojen yhteydessä antamassa julkilausumassa homoseksuaaliset suhteet määriteltiin yksiselitteisesti synniksi ${ }^{613}$.

Aloitteet lähetettiin perustevaliokuntaan, jossa valmistelutehtävän sai viisijäseninen, pastori Heli Pruukin johtama jaosto. Mietinnön keskeisyyttä osoitti jo se, että asiantuntijoita oli kuultavana todella suuri joukko. ${ }^{614} \mathrm{Pe}-$ rustevaliokunnan sisäisessä lähetekeskustelussa hahmottui nopeasti, ettei yksimielistä mietintöä luultavasti saataisi aikaan. Oli tunnustettava useiden erilaisten ajattelutapojen olemassaolo. Valiokunta tiedosti, että mietinnöstä luettaisiin kirkon kanta homoseksuaalisuuteen, mikä todennäköisesti osaltaan rohkaisi etsimään varovaista ja tasapainoilevaa linjaa. Eero Huovinen totesi 


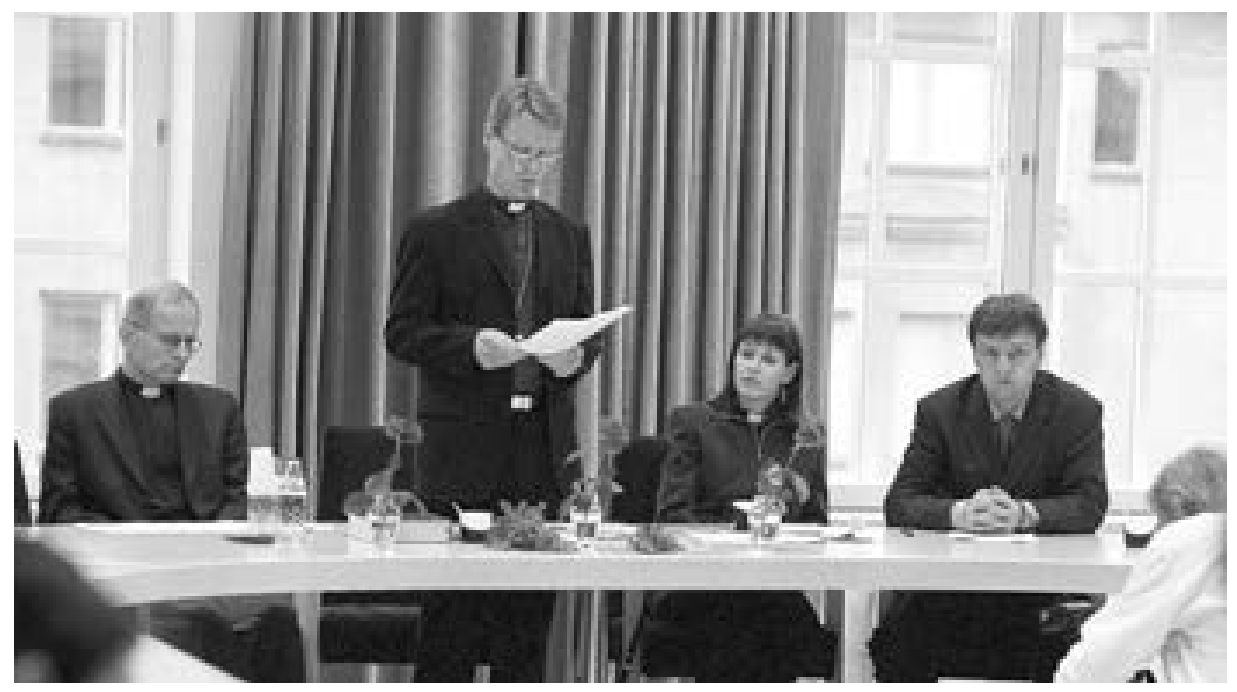

Parisuhdelain seurausten käsittely kirkolliskokouksessa sai niin paljon huomiota, että perustevaliokunta piti poikkeuksellisesti tiedotustilaisuuden. Valiokunnan puheenjohtajan, piispa Ilkka Kantolan vieressä mietinnön valmisteluun osallistuneet pääsihteeri Eero Junkkaala (vas.), pastori Heli Pruuki sekä valiokunnan sihteeri Olli Hallamaa. Kuva: Kotimaan kuva-arkisto / Matti Karppinen.

valiokunnan kokouksessa, että mietinnön tekstin tuli olla kuvailevaa ja kysymyksiä esiin nostavaa. ${ }^{615}$

Nämä ominaisuudet kuvasivatkin lopullista mietintöä. Siinä aloitteita käsiteltiin monista näkökulmista, kuten pohtien raamatuntulkintaa tai opin ja etiikan välistä suhdetta. Lähes järjestään tuotiin esille vastakkaiset tulkintalinjat ottamatta kuitenkaan kantaa niiden välillä. Mietintö ei määritellyt kirkon lopullista linjaa vaan tietyn perustavan yksimielisyyden miehen ja naisen välisen avioliiton tukemisesta sekä toisaalta siitä, että myös homoseksuaaleille tuli olla tilaa kirkossa. ${ }^{616}$ Lopuksi valiokunnan enemmistö ehdotti molempien aloitteiden jättämistä raukeamaan, joskin se samalla peräänkuulutti keskustelun jatkamista ja piispojen vastuuta. ${ }^{617}$

Viisi valiokunnan jäsentä, joista neljä kuului myös virkakieltoa koskevan aloitteen allekirjoittajiin, jätti Lasse Marjokorven johdolla eriävän mielipiteen. Joukossa oli mietintöä valmistelleeseen jaostoon kuulunut pääsihteeri Eero Junkkaala. Eriävän mielipiteen jättäjien mielestä valiokunnan enemmistö ei ollut uskaltanut loppuun asti seurata niitä periaatteita, jotka mietintöön oli kirjattu. ${ }^{618}$ Myös Heli Pruuki arveli, että valiokunnan kokoonpanon johdosta mietintö oli sävyltään konservatiivisempi kuin kirkolliskokousedustajien kanta keskimäärin. ${ }^{619}$ Olikin totta, että valiokunta oli kirjannut perusteluja, joiden saattoi katsoa tukevan rajoituksia kirkon virassa toimimiselle. Valiokunta totesi esimerkiksi, ettei samaa sukupuolta olevien parisuhde vastannut "kirkon opetta- maa ihannetta, jonka mukaan naisen ja miehen seksuaalisuus toteutuu parhaiten avioliitossa". ${ }^{20}$

Parisuhdekysymyksen käsittelyssä kirkkolain määräenemmistösäännökset nousivat tärkeään osaan. Riittävän yksimielisyyden saaminen kumman tahansa aloitteen taakse näytti mahdottomalta. Valiokunta tyytyi toteamaan, että kirkossa työskentelevältä homoseksuaalilta voitiin "esimerkiksi edellyttää sitoutumista siihen, että hän ei opeta vastoin kirkon käsitystä avioliiton ja perheen esikuvallisuudesta". ${ }^{21}$ Useat kirkolliskokousedustajat ihmettelivät tilannetta, jossa kirkon kasvatustehtävässä toimiva opetti avioliiton esikuvallisuutta mutta puhui rekisteröidyllä parisuhteellaan toisenlaista kieltä. ${ }^{622}$

Kirkolliskokouksen täysistunnossa käytiin jälleen pitkä keskustelu. Ehkä kaikkein polttavimman kysymyksen esitti piispa Laulaja: jos kirkkolain tasolle ei nyt saatu homoseksuaalisen parisuhteen kieltävää pykälää, oliko vastaisuudessa seurakunnan pakko valita rekisteröidyssä parisuhteessa elävä hakija? Ritva Santavuori totesi kysymyksen vaikeaksi mutta katsoi, että tuolloisten säännösten perusteella pätevän, julkisesti homoseksuaalisen henkilön syrjäyttäminen oli rangaistavaa, "ja ainakin minä syyttäjänä syyttäisin kirkon asianomaisia vastuuhenkilöitä työsyrjinnästä’. Kirkkoneuvos Risto Voipio huomautti lisäksi, että eduskunnassa oli käsiteltävänä laki yhdenvertaisuuden turvaamisesta ja että lain oli määrä koskea myös kirkkoa. Kumpikin juristi 
piti virkakiellon säätämistä käytännössä miltei mahdottomana. Kansanedustajan näkökulmasta eduskunnan tuntenut agrologi Johannes Leppänen ei kuitenkaan nähnyt tilannetta samoin. Hänen mukaansa eduskunnasta löytyi ihmisiä, jotka suhtautuivat vakavasti kirkon kantaan. ${ }^{623}$ Lainsäädännöllisten ongelmien lisäksi jonkin verran huomiota sai myös virkakiellon periaatteellinen puoli. Piispa Wille Riekkinen totesi:

Voitaisiin myös pohtia kaventaako yhden ihmisryhmän sulkeminen kirkon työn ulkopuolelle sanomaa Jumalan armosta, joka kuuluu kaikille. Kuka täyttää kriteerit, jos Suomen lain ja kultaisen säännön lisäksi kirkolla on työntekijöilleen aivan omat rajoitukset ja määräykset heidän yksityiselämänsä suhteen? - - toivon, että kirkon työntekijöitä arvioidaan heidän tekemästään työstä käsin, ei heidän seksuaalisesta suuntautumisestaan tai ihmissuhteistaan kuten ystävistään tai rakastamastaan ihmisestä käsin. ${ }^{624}$

\section{Spongin ja Obaren välissä}

Ulkomailta saapuneet piispat havainnollistivat Suomen luterilaisen kirkon sisäistä polarisoitumista 20oo-luvulla. Yhdysvaltain episkopaalisen kirkon piispa John Shelby Spong vieraili keväällä 2003 Helsingin kirkkopäivillä järjestäjien kutsusta. Vapautusta teismistä ja perinteisistä opeista vaatineen Spongin vierailu sai osakseen runsaasti huomiota myös kirkolliskokouksessa saman vuoden syksyllä. Kirkkoherra Lasse Marjokorven mukaan tämä "puhtaan ateismin" ja "naiivin tieteisuskon" edustaja oli otettu vastaan suurilla suosionosoituksilla, mikä osoitti Marjokorven mielestä parisuhdelain edessä taipuvan kirkon kulkusuuntaa. ${ }^{\mathrm{I}}$ Kirkkohallitus oli ollut ensimmäistä kertaa edustettuna kirkkopäivien johtoryhmässä, minkä vuoksi kirkkoneuvokset joutuivat kyselytunnilla tekemään tiliä Spongin vierailusta. Seppo Häkkinen totesi, ettei hän ollut valitettavasti ollut paikalla ohjelmasta sovittaessa. Hänen mukaansa seuraavien kirkkopäivien osalta oli kuitenkin jo tehty selväksi, "että tämäntapaista julkisuutta - - kirkkohallitus ei jatkossa toivo"."

Keväällä 2004 tunnustuksellisuutta korostaneen Suomen Luther-säätiön pastorit kehottivat piispa Eero Huovista jäämään pois ehtoolliselta säätiön jumalanpalveluksessa, mikä herätti paljon huomiota. ${ }^{\text {III }}$ Piispojen rajanveto säätiöön sai myöhemmin samana vuonna julkisuutta ja loi pohjaa ounasteluille, että kirkko oli hajoamassa. ${ }^{\mathrm{IV}}$ Lopulta Kenian luterilaisen kirkon johtava piispa Walter Obare vihki ruotsalaisen
Äänestyksessä valiokunnan raukeamisesitys voitti äänin 63-41 ponsiehdotuksen, jonka mukaan virkakieltoa koskeva aloite lähetettäisiin piispainkokoukselle selvitettäväksi. Sen sijaan kirkolliskokous hyväksyi lisäponnen, jolla "parisuhteen rekisteröinnin seurauksia kirkossa koskeva asia" lähetettiin piispainkokoukselle teologisten ja juridisten näkökohtien selvittämiseksi. ${ }^{625}$ Keskustelu päättyi lähes yksimieliseen äänestykseen melko täydellisen erimielisyyden vallitessa.

Joidenkin lehtien pääkirjoituksissa ymmärrettiin kirkolliskokouksen tasapainoilua, toisissa taas arvosteltiin sen vanhoillisuutta. ${ }^{626}$ Arvostelu näyttää liioitellulta siihen nähden, että mielipidetutkimuksen mukaan parisuhteensa rekisteröineen henkilön toimiminen pappina sai kansalaisilta useammin vastustusta kuin kannatusta. Jättäessään virkakieltoaloitteen raukeamaan kirkolliskokous oli siten tavallaan jopa vapaamielisempi kuin kan-

luterilaisen papin Arne Olssonin lähetyspiispaksi Ruotsin ja Suomen alueelle. Tämä alkoi vihkiä pappeja myös Luthersäätiön palvelukseen. ${ }^{\mathrm{V}}$

Tässä vaiheessa ongelmat päätyivät myös kirkolliskokouksen käsittelyyn. Oli arkkipiispa Jukka Paarman vuoro arvioida kyselytunnilla tapahtumien seurauksia. ${ }^{\mathrm{VI}}$ Vuosien 20032005 kyselytunneilla ja muissakin kirkolliskokouskeskusteluissa alkoi hahmottua tulevaisuudenkuva, jossa kirkon uskontunnustus näytti murtuvan yhdeltä laidalta ja kirkon järjestys puolestaan päinvastaiselta suunnalta. Tässä jännitteessä kirkolliskokous yritti pitää kirkkoa koossa.

I Kirk.kok. kptk-s. 2003, 21 \$; Kmaa 30.5.2003 Evankeliumi kutsuu vapauteen - ei turvaan (Taneli Kylätasku).

II Kirk.kok. kptk-s. 2003, 24 §.

III Kmaa 8.4.2004 Helsingin piispa ei kelvannut ehtoolliselle Luther-säätiössä (Johannes Ijäs); Al 18.4.2004 Pappi syyllistyi virkarikokseen torjumalla piispan ehtoolliselta (Pekka Parantainen).

IV Kmaa 20.8.2004 Piispa Eero Huovinen kysyy: Repeääkö kansankirkko? (Eero Huovinen); Hämeen Sanomat 21.8.2004 Huovinen: Naispappeuden vastustajat voisivat perustaa oman kirkon; ESS 24.8.2004 Naispappeus repii yhä kirkkoa (pääk.); Il 26.8.2004 Kirkossa isojakoon? (pääk.); Kmaa 27.8.2004 Naispappeuden torjujat ahtaalla (Jaakko Elenius, pääk.); $S K$ 27.8.2004 Hukattu tilaisuus (pääk.); $\AA U$ 27.8.2004 Tydlighet nu (= hösten 2005) (ledare); HS 29.8.2004 Piispat haluavat Luther-säätiön tekevän lopullisen ratkaisunsa (Meri Toivanen); Knen 29.8.2004 Myös kirkko edellyttää sisäistä sitoutumista (pääk.); Kp 5.9.2004 Kirkko tarvitsee naisia (Arto Hietalahti, pääk.); SkK 11.9.2004 Hajottaako naispappeus kirkon? (Maarit Raunio).

V SEK 2004-07, 257; Al 27.8.2004 Luther-säätiö lähettää teologin Ruotsiin pappisvihkimykseen; Kmaa 27.8.2004 Luther-säätiö aloittaa omat pappisvihkimykset Ruotsissa (Johannes Ijäs).

VI Kirk.kok. kptk-k. 2005, 37 \$. 
san enemmistö. Ainakaan kokouksen linja ei näyttänyt mitenkään keskimääräistä tiukemmalta. Siitä huolimatta - aivan samoin kuin naispappeudesta päätettäessä mielipidetutkimusten keskiarvokäyrille sijoittunut kirkolliskokous oli otollinen kohde arvostelulle.

Piispa Laulajan esittämä kysymys ei ollut pelkkää teoreettista pohdintaa, vaan se nousi käytännön tilanteesta. Pari kuukautta myöhemmin Laulajan johtama tuomiokapituli alkoi käsitellä kappalaisenvaalia, jossa yhtenä hakijana oli homoseksuaalisessa parisuhteessa elävä pappi. Tuomiokapituli totesi hänet hakukelvottomaksi siitäkin huolimatta, että kirkolliskokouksen juristit olivat jo julistaneet menettelyn laittomaksi. Tällä kertaa vastaus saapui hallinto-oikeudesta: tuomiokapitulin päätös oli kumottava lainvastaisena. ${ }^{627}$ Piispan kyselemät kirkon vapauden rajat olivat viimeistään tuolloin selvillä.

\section{SYRJINNÄN KIELTO}

\section{VAI VAKAUMUKSEN OIKEUS?}

Pappisvirka oli avattu naisille 1980-luvulla. Seuraavalla vuosikymmenellä näytti siltä, että kirkko voisi keskittyä muihin asioihin. Hiljaisuus perustui kuitenkin tilanteeseen, jossa piispa Olavi Rimpiläinen loi Oulun hiippakunnasta "turvapaikan" kirkon virkaratkaisun vastustajille ${ }^{628}$. Muutenkin naispapit sietivät joidenkuiden kollegojensa harjoittamaa väistelyä eräänlaisena siirtymäajan hankaluutena. Vuosituhannen vaihtuessa tilanne muuttui radikaalisti. Piispa Rimpiläinen jäi eläkkeelle, ja ulkonaisen rauhan tuonut poikkeusaika päättyi. $\mathrm{Ne}$, jotka eivät suostuneet jumalanpalvelusyhteistyöhön papiksi vihittyjen naisten kanssa, kokivat joutuneensa nurkkaan. Toisaalta yhä useammat naispapit alkoivat saada tarpeekseen siitä, etteivät jotkut suostuneet yhteistyöhön heidän kanssaan.

Julkisuudessa keskusteltiin vuosina 2001-2003 siitä, saiko seurakunnan työntekijä kieltäytyä yhteistyöstä naispappien kanssa. Alkusysäyksenä oli Valkealan kirkkoherranvaali. Valitun kirkkoherran katsottiin välttävän yhteistyötä papiksi vihittyjen naisten kanssa, ja naispapit jättivät seurakunnan. Myöhemmin Mikkelin tuomiokapituli totesi, ettei se löytänyt aihetta ryhtyä toimiin, mutta Valkealasta tuli symboli kädenväännölle vuoden 1986 lisäponnen tulkitsemisesta. ${ }^{629}$ Lehtien pääkirjoitukset vilisivät kannanottoja asiaan. ${ }^{630}$ Myös kokoomuslainen kulttuuriministeri Kaarina Dromberg otti huolestuneena kantaa tapaukseen muun muassa vieraillessaan kirkolliskokouksessa syksyllä 2002. ${ }^{631}$

Valkealan tilanne oli keskeisenä syynä siihen, että keväällä 2003 sekä Mikkelin hiippakuntakokouksen esityksessä että edustaja-aloitteessa vaadittiin kirkolliskokousta kieltämään yksiselitteisesti yhteistyöstä pidättäytyminen. ${ }^{632}$ Tilanteen herkkyyttä osoitti se, että täysin poikkeuksellisesti kirkolliskokouksen avajaisjumalanpalvelus joutui arvostelun kohteeksi täysistunnossa. Pirjo Vahtola paheksui sitä, että naiset oli jätetty pois Erik Vikströmin ja Henrik Perret'n toimittaman messun vastuutehtävistä:

Miksi me naiset suostumme ottamaan vastaan Jumalan Sanan, ehtoollisen ja siunauksen miehiltä, jotka eivät meidän pappeuttamme hyväksy? Miksi me istumme kiltisti kirkon penkissä, kun vastaavassa tilanteessa ne henkilöt, jotka eivät pappeuttamme hyväksy, pysyvät kaukana ja kehottavat muita tekemään samoin? ${ }^{633}$

Enimmäkseen äänessä olivat kuitenkin kirkon virkaratkaisun vastustajat, joiden mielestä nimenomaan heitä syrjittiin. ${ }^{634}$ Perustevaliokunta päätyi täsmälleen samanlaiseen ratkaisuun kuin tuolloin käsittelyssä olleiden parisuhdealoitteiden osalta: aloitteet jätettiin raukeamaan, ja asia siirrettiin piispainkokoukselle, jolla oli siten marraskuussa 2003 yhtäkkiä käsissään kaksi kirkon ehkäpä vaikeinta tai ainakin julkisuudessa polttavinta ongelmaa. ${ }^{63}$

Piispainkokous asetti piispa Mikko Heikan johtaman työryhmän selvittämään asiaa. Vuoden 2006 alussa valmistuneessa mietinnössään työryhmä tuomitsi erillisvihkimykset ja kieltäytymisen yhteistyöstä naispappien kanssa. Työryhmä tulkitsi työvuorojärjestelytkin välilliseksi syrjinnäksi. ${ }^{66}$ Mietintö kirvoitti julkisuudessa jälleen uuden naispappeuskeskustelun. ${ }^{637}$ Keväällä 2006 arkkipiispa Paarma joutui kirkolliskokouksen avauspuheessa vetoamaan edustajiin toinen toistaan kunnioittavan, rehellisen ja sävyisän keskusteluilmapiirin saamiseksi kirkkoon. ${ }^{638}$ Keskusteluilmapiiri joutui testiin vielä samalla viikolla.

Työryhmän ehdotusten käsittely oli piispainkokouksessa kesken, mutta teema päätyi kirkolliskokouksen asialistalle Erkki Kujalan edustaja-aloitteen myötä. Kujalan mielestä kirkolliskokouksen tuli kieltää piispain- 
kokoukselta syrjintä, joka kohdistui naispappeuteen kielteisesti suhtautuviin miehiin. ${ }^{639}$ Aloitteen kannattajat maalasivat synkkiä kuvia kirkon tiestä, kun taas vastapuolella väsymys vuosikausia jatkuneeseen keskusteluun aiheutti tiukkoja, joskin sävyltään jo epätoivoisia puuskahduksia. ${ }^{640}$ Arkkipiispa Paarma piti päätöspuheen - mikä oli kevätistuntokaudella poikkeuksellista ja totesi, että toinen toisensa kuuntelemisessa ja kunnioittamisessa "meillä on vielä paljon parantamisen varaa". ${ }^{611}$ Kirkolliskokouksen ehkäpä kovasanaisimmat naispappeuskeskustelut kuultiin, kun asian päättämisestä oli kulunut 20 vuotta.

Kujalan aloite hylättiin suoraan, koska enemmistö katsoi sen menevän kirkolliskokouksen toimivallan ulkopuolelle. ${ }^{62}$ Aloite tarjosi kuitenkin edustajille mahdollisuuden puhua julkisuudessa paljon esillä olleesta ja tunteita kuohuttaneesta aiheesta. Piispainkokous puolestaan pysyi Heikan työryhmän linjoilla ${ }^{643}$. Työryhmän mietintöön eriävän mielipiteen jättänyt kirkkoherra Keijo Rainerma totesi pitävänsä huolestuttavana, että raamatullisteologinen virkakysymys oli pyritty muuntamaan työlainsäädännölliseksi ja virkamiesoikeudelliseksi asiaksi. ${ }^{64}$ Tällaiset äänenpainot ja kiivas keskustelu enteilivät vaikeaa päätöksentekoa, kun kirkkohallitus vielä samana vuonna, syksyllä 2006, jätti laajan esityksen kirkkolainsäädännön virkamiesoikeudellisten säännösten muuttamiseksi.

Kirkko oli työsopimuslain piirissä, mutta viranhaltijoita koskevat pykälät olivat kirkon omissa säädöksissä. Nuo virkasäännökset olivat säilyneet pitkään ennallaan, vaikka yleinen virkalainsäädäntö oli muuttunut. Kirkkohallituksen tavoitteena oli päivittää säännökset vastaamaan muuta virkalainsäädäntöä. Samalla oli määrä nostaa viranhaltijoiden oikeuksia ja velvollisuuksia koskevat säännökset lain tasolle, kuten jo vuoden 1995 perusoikeusuudistuksen oli katsottu edellyttävän. Palvelussuhteen päättämistä varten esitettiin irtisanomis- ja purkumenettelyä. Tarkoituksena oli luopua esimerkiksi papiston ja kanttorien poikkeuksellisen vahvasta oikeudesta pysyä virassa. Kirkkohallitus esitti niin ikään luopumista kurinpitomenettelystä, joka oli poistettu valtion virkamieslainsäädännöstä $1994 \cdot{ }^{645}$ Esimerkkiä haettiin myös Ruotsin kirkosta, joka noudatti maansa yleistä työlainsäädäntöä, ja Suomen ortodoksisesta kirkosta, jossa virkasuhteet oli muutettu työsopimussuhteiksi. ${ }^{646}$
Osana uudistusta oli tarkoitus kumota säännökset lehtorinvirasta, joskin virassa olevien lehtorien oli määrä säilyttää asemansa. ${ }^{647}$

Kirkolliskokouksessa monet piispat ja papit valittivat teologisten perustelujen puutetta ja kyselivät, oliko kirkon erityisluonne otettu tarpeeksi hyvin huomioon. Esityksen arvostelu muistutti kritiikkiä, jota papisto oli esittänyt kirkolliskokouksessa kirkon sopimusjärjestelmän alkutaipaleella. Toisaalta erityisesti kirkkoherrat näkivät uudistuksen mahdollisine pienine puutteineenkin selkeyttävän oleellisesti henkilöstöasioiden hoitamista. ${ }^{648}$ Piispainkokouksen linjaus naispappeutta koskevien yhteistyöongelmien käsittelemisestä tuli samaan aikaan voimaan, ja linjauksesta johtuneet muutamat kurinpitotoimet ja oikeusprosessit saivat julkisuutta pitkin vuotta 2007.649 Kirkolliskokouksessa näiden erimielisyyksien käsittely kanavoitui keskusteluun virkalainsäädännöstä. Vuoden 1986 virkaratkaisun vastustajat pitivät tiettyjä uusia säännöksiä keinoina hankkiutua eroon niistä työntekijöistä, jotka kieltäytyivät yhteistyöstä naispapin kanssa. Vaikka tämä pelko verhoutui usein vähemmän tulenarkoihin periaatekysymyksiin kirkon itsemääräämisoikeudesta, naispappeusasia oli jatkuvasti merkittävänä taustatekijänä. ${ }^{650}$

Toinen, virkakysymystä yleisemmin huolta herättänyt ja siksi helpommin sanoitettava teema oli kirkon suhtautuminen rekisteröityihin parisuhteisiin. ${ }^{651}$ Lakiesitys sisälsi syrjintäkiellon, jonka mukaan työnantaja ei saanut "virkasuhteeseen otettaessa eikä virkasuhteen aikana ilman hyväksyttävää perustetta asettaa hakijoita eikä viranhaltijoita eri asemaan henkilöön liittyvän syyn perusteella". ${ }^{52}$ Tällaisiin syihin kuului muun muassa seksuaalinen suuntautuminen. Kysyttiin, määrittikö lakiesitys tosiasiassa kirkon kannan parisuhteensa rekisteröineisiin työntekijöihin. Uudistuksesta lausunnon antanut perustevaliokunta edellytti, ettei näin saanut tapahtua. ${ }^{653}$ Varsinaisen mietinnön laatineen lakivaliokunnan vakuutteluista huolimatta kytemään jäi epävarmuus kirkon toimintavapaudesta. ${ }^{654}$ Uusi Tie -lehden päätoimittaja Leif Nummela jätti eriävän mielipiteen lakivaliokunnan mietintöön, mutta täysistunnossa syrjintäkielto säilyi muuttumattomana. ${ }^{65}$

Useimmat kirkolliskokousedustajat olivat tyytymättömiä siihen, että lakiesitys velvoitti vain virkasuhteessa olevat kuulumaan kirkkoon. Näiden edustajien mieles- 
tä esitys ei myöskään edellyttänyt tarpeeksi laajalti sitoutumista kirkon tunnustukseen. Perustevaliokunta yhtyi lausunnossaan arvosteluun, mutta lakivaliokunta ei lämmennyt muutoksille. ${ }^{656}$ Asetelmassa näkyi jälleen hieman se, että lakivaliokunta oli siirtynyt kirkkoherroilta lakimiehille. Täysistunnossa kirkkoherra Jukka Keskitalo totesi, että lakivaliokunnan esitys oli "voimakas irtiotto kaikesta siitä, mitä olemme viime aikoina puhuneet kirkon jäsenyyden vahvistamisesta”. Hän ehdotti, että virkasuhteen ohella myös toistaiseksi voimassa olevassa työsopimussuhteessa olevalta edellytettäisiin luterilaisen kirkon jäsenyyttä. Keskitalo sai tukea piispoilta, vaikka kirkkoneuvos Halttunen uhkasi, ettei näin tiukka linja menisi läpi eduskunnassa. Tiukennus hyväksyttiin selvin luvuin 74-28. ${ }^{657}$ Paikalla olleista piispoista vain Wille Riekkinen äänesti sitä vastaan, ja lopulta myös lakivaliokunta tyytyi ratkaisuun. ${ }^{658}$

Erityisesti syrjintäkielto synnytti kuitenkin edelleen niin paljon tyytymättömyyttä, että ratkaisevassa käsittelyssä määräenemmistön saavuttaminen jäi luvuin 6639 melko kauas, 13 äänen päähän. Näin tapahtui, vaikka lakivaliokunnan jäsenet vetosivat kokoukseen voimakkaasti vakuutellen uudistuksen välttämättömyyttä ja kiirettä. ${ }^{65}$ Papeista hieman yli viidennes äänesti uudistusta vastaan, mutta maallikkoedustajista niin teki peräti puolet. ${ }^{600}$ Lakimiestenkään rivit eivät olleet aivan yhtenäiset. Esimerkiksi vastaan äänestäneen Ritva Santavuoren mielestä edessä saattoi olla tilanne, jossa "kirkon vihdoin viimein pitää kokeilla autonomiansa rajoja". ${ }^{661}$ Vaikka arvostelu oli kovasanaista, kiistat koskivat hyvin kapeaa osaa uudistuksesta: täysistunnossa tehtiin muutosehdotus vain kolmeen kohtaan.

Valtioneuvoston määrämä edustaja, hallintojohtaja Håkan Mattlin valitteli päätöstä ja katsoi sen heikentävän kirkollista autonomiaa. ${ }^{662}$ Rintamalinjojen molemmin puolin kannettiin huolta kirkon itsemääräämisoikeudesta, mutta johtopäätökset olivat päinvastaiset. On lisäksi mielenkiintoista, että monet niistä kirkolliskokousedustajista, jotka olivat epäilleet kirkollisen äänioikeusikärajan irrottamista valtiollisen lainsäädännön ikärajoista, painottivat virkasäännöksistä keskusteltaessa kirkon riippumattomuutta valtiosta. Vastaavasti useat edustajat, joiden mielestä kirkon oli saatava laskea seurakuntavaalien äänioikeusikärajaa valtiosta riippumatta, korostivat nyt yhdenmukaisuutta valtiollisen lainsää- dännön kanssa. Puolin ja toisin argumentit vaihtelivat omien tavoitteiden mukaan.

Vuosi lakiuudistuksen kaatumisen jälkeen kirkkohallitus toi lakipaketin uudelleen kirkolliskokoukselle. Esitys oli pitkälti ennallaan, mutta epäluuloja aiheuttanut syrjintäsäännös oli jätetty pois. ${ }^{663}$ Tällä kertaa ongelmaksi muodostui kuitenkin nimenomaan säännöksen poisto: arvostelijoiden mukaan vain kirkon lähtökohdista laadittu syrjintäpykälä takaisi tarpeeksi hyvin tunnustusperusteiden noudattamisen. ${ }^{664}$ Kaikki olivat nyt yhtä mieltä pykälän tarpeellisuudesta, mutta sen sisältöä kohtaan oli hyvin erilaisia odotuksia. Lakivaliokunta katsoi, ettei pykälää voitu ottaa tuossa vaiheessa mukaan mutta että sitä oli ryhdyttävä viipymättä valmistelemaan. ${ }^{665}$ Valiokunta pyrki ottamaan palautteen mahdollisimman pitkälle huomioon. Se tiukensi kirkon työntekijöiden kelpoisuusvaatimuksia ja päätti jättää lehtorinvirkaa koskevat säännökset lakiin. ${ }^{666}$

Esityksen arvostelussa oli jälleen suureksi osaksi kyse naispappeuden vastustajien kotipaikkaoikeudesta kirkossa, vaikka siitä ei juuri puhuttukaan ääneen. ${ }^{667}$ Tällä kertaa lakiesityksen vastustajat olivat korostetusti puolustuskannalla eivätkä edes ehdottaneet konkreettisia pykälämuutoksia. Keskustelua käytiin alusta asti vain esityksen hyväksymisestä tai hylkäämisestä. Molemmat lainoppineet asiantuntijat vetosivat poikkeuksellisen voimakkaasti lakivaliokunnan mietinnön hyväksymiseksi, ja lopulta lakiesitys hyväksyttiinkin äänin 91-17.668

Kirkolliskokouksen vaikeudet tehdä päätöksiä johtuivat osin kirkon sisäisestä polarisaatiosta, osin taas siitä, ettei kirkolliskokous voinut esittää lakia yhtä vapaasti kuin aiemmin. Valtiollisen lainsäädännön alueen laajeneminen ja kirkolliskokouksen omat aiemmat ratkaisut rajasivat jatkuvasti liikkumatilaa. Samaan aikaan kun kirkolliskokous oli katkonut sidoksiaan valtioon, se oli toisaalla sitonut itseään entistä voimakkaammin valtion lainsäädäntöön. Seitsenkymmenluvun kirkolliskokous oli ollut paljon vapaampi luomaan kirkolle säännöksiä kuin kirkolliskokous 200o-luvulla, jolloin kirkko oli muodollisesti aiempaa itsenäisempi.

\section{EROAALLON HARJALLA 2010}

Lokakuussa 2010 nousi kirkosta eroamisten aalto. Kirkolliskokous oli poikkeuksellisen paineen alla, kun se marraskuussa kokoontui päättämään suhtautumises- 
taan parisuhteensa rekisteröineisiin. Ympäristö oli hyvin erilainen kuin kokouksen käsitellessä asiaa edellisen kerran. Ruotsissa avioliitto oli 2009 avattu samaa sukupuolta oleville pareille, ja samana vuonna myös Suomen eduskunnassa oli jätetty lakialoite sukupuolineutraalista avioliitosta. Yksi aloitteen kantavista voimista oli kulttuuriministerinä hieman aiemmin toiminut Tanja Karpela, joka oli ministerintehtävänsä myötä ollut myös kirkolliskokouksen jäsen. ${ }^{669}$

Kansalaisten mielipiteet olivat muuttuneet aiempaa sallivammiksi. Kun rekisteröidyn parisuhteen kirkollinen siunaaminen oli noussut ensimmäistä kertaa esille kirkolliskokouksessa, yli puolet kantansa muodostaneista suomalaisista oli kertonut vastustavansa toimitusta. Vajaa vuosikymmen myöhemmin kirkollista siunaamista kannatti lähes puolet kaikista vastaajista ja valtaenemmistö kantansa muodostaneista. ${ }^{60}$ Mahdollinen virkakielto, joka vuosina 2002-2003 oli ollut kirkolliskokouksessa päällimmäinen kysymys, painui epärealistisena taka-alalle. Kädenvääntö koski nyt sitä, miten parisuhteensa rekisteröineet ja liitolleen siunausta pyytävät parit oli kohdattava ja miten mahdolliseen sukupuolineutraaliin avioliittolakiin oli reagoitava.

Ympäröivät muutokset eivät vaikuttaneet kirkolliskokoukseen pelkästään yhdensuuntaisesti. Vaikka suhtautuminen homoseksuaalisiin parisuhteisiin oli muuttunut, mielipiteet jakautuivat kansalaisten keskuudessa voimakkaasti. Kirkon sisällä tilannetta kärjisti se, etteivät uskonnollisesti aktiivisen väestönosan moraalikäsitykset olleet muuttuneet samalla tavalla sallivammiksi kuin suomalaisten keskimäärin. ${ }^{671}$ Myös Ruotsin tapahtumat olivat omiaan lisäämään varovaisuutta. Avioliittosäännösten muuttamisen jälkeen valtiovalta oli edellyttänyt Ruotsin kirkolta nopeaa päätöstä, vihkisikö se myös uudenlaiseen avioliittoon vai luopuisiko se vihkimisoikeudestaan. Ruotsin kirkolliskokous oli hyväksynyt kirkollisen vihkimisen, vaikka esimerkiksi piispoista puolet oli suhtautunut asiaan kriittisesti. ${ }^{672}$ Ruotsin kirkko oli tietyllä tavalla ajautunut rekisteröidyn parisuhteen siunaamisesta avioliittoon vihkimiseen ilman teologista pohdintaa. ${ }^{673}$ Tapahtumasarja synnytti Suomessakin kysymyksiä rekisteröidyn parisuhteen siunaamisen seurauksista.

Esitystä, jonka piispainkokous jätti kirkolliskokoukselle 2010, edelsi pitkä ja huolellinen valmistelu. Piis- pa Mikko Heikka sai johdettavakseen valmistelutyön myös tässä mieliä kuohuttavassa asiassa. ${ }^{674}$ Selvitystyön aikana asia pysyi julkisuudessa. Esimerkiksi vuosina 2007-2008 tuli julki muutamia tapauksia, joissa pappi oli siunannut parisuhteensa rekisteröineen pariskunnan. Tapauksista aiheutuneita kanteluita käsitelleet tuomiokapitulit tulkitsivat kuitenkin toimitukset rukoushetkiksi eivätkä rangaisseet pappeja ${ }^{675}$ Tuomiokapitulit yrittivät välttää vaikutelmaa, että kyse olisi ennakkopäätöksistä. ${ }^{676}$ Siitä huolimatta ratkaisut väistämättä linjasivat yksittäisen papin liikkumatilaa ja vaikuttivat välillisesti piispainkokouksen valmisteluun. Edelleen 2008 piispat julkaisivat kirkon perhe- ja seksuaalietiikasta kirjan Rakkauden lahja. Wille Riekkinen ja Kari Mäkinen eivät liittyneet puheenvuoroon, koska pitivät julkaisuajankohtaa huonona ja katsoivat kirjan ohjaavan kirjan julkilausutusta tarkoituksesta poiketen - ennalta homoseksuaalisten parisuhteiden käsittelyä. ${ }^{677}$

Lopullisessa esityksessään kirkolliskokoukselle piispainkokous käsitteli homoseksuaalisia parisuhteita raamatuntulkinnan, luterilaisen etiikan, ekumenian, liturgisen perinteen, sielunhoidon ja lainsäädännön näkökulmasta. ${ }^{678}$ Piispainkokous nosti esille kuusi vaihtoehtoista toimintatapaa, ääripäinä parisuhteen siunaaminen ja erityinen kielto rukoilla parisuhteensa rekisteröineiden puolesta. ${ }^{679}$ Se suositteli piispainkokouksen tai piispan antamaa pastoraalista ohjetta, jonka mukaan olisi mahdollista rukoilla parisuhteensa rekisteröineiden puolesta. Samalla elin painotti yhtäältä miehen ja naisen avioliittoa, toisaalta kaikkien yhtäläistä ihmisarvoa. ${ }^{680}$ Tätä painotusta kiittelivät kirkolliskokouksessa yleisesti nekin, jotka pitivät piispainkokouksen varsinaista johtopäätöstä liian pitkälle menevänä. ${ }^{61}$ Piispainkokouksen esitys muistutti Ruotsin kirkon 1990-luvun toimintatapaa. ${ }^{682}$

Ympäröivän tilanteen nopeaa muutosta kuvasti, että piispainkokouksen linjauksia esitellessään piispa Simo Peura viittasi eduskunnassa esillä olleeseen sukupuolineutraaliin avioliittolakiin: "Jos ja kun se toteutuu, olemme kirkkona jälleen uudessa tilanteessa. Silloin keskustelu mahdollisesta rekisteröidyn parisuhteen siunaamisesta on vanhentunut." ${ }^{683}$ Myös arkkipiispa Paarman puheenvuorosta näkyi henkinen valmistautuminen sukupuolineutraaliin avioliittolakiin: kirkon tuli lakimuutoksen mahdollisesti toteutuessa, "niin kuin 


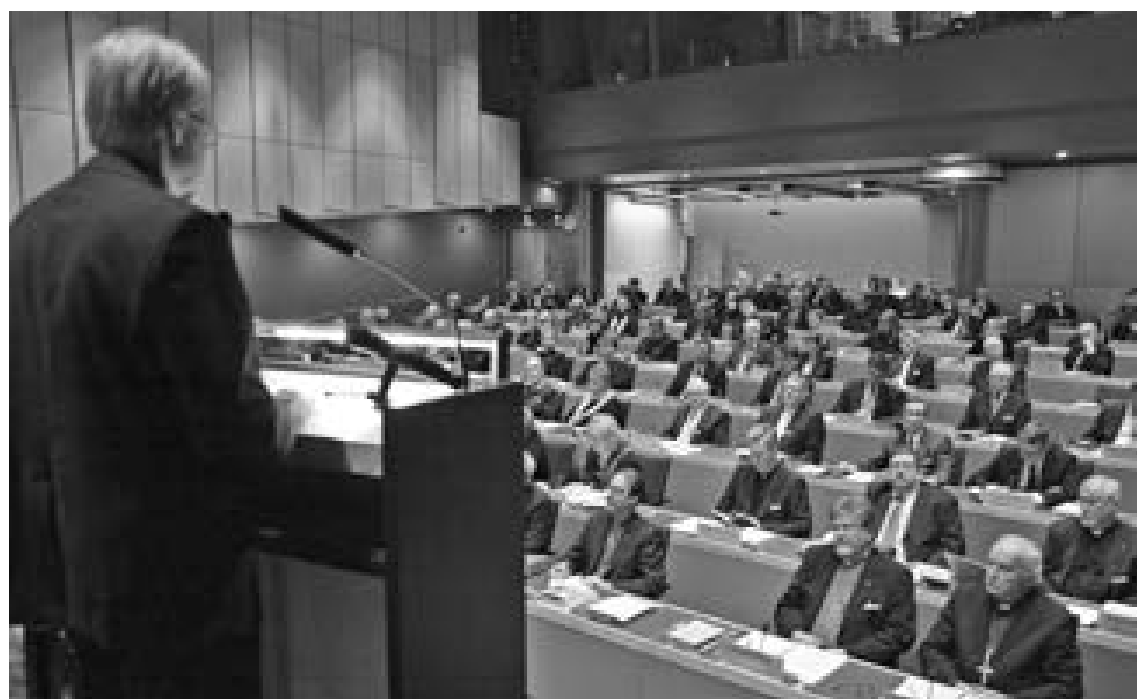

Arkkipiispa Kari Mäkinen avasi ensimmäistä kertaa kirkolliskokouksen syksyllä 2010. Kysymys parisuhdelain seurauksista kirkossa oli tulossa päätöksentekovaiheeseen. Jännittyneessä ilmapiirissä Mäkinen otti teeman esille puheessaan, joka sai kokoussalissa kaksijakoisen vastaanoton. Kuva: Kirkkohallitus / Aarne Ormio. pahalta näyttää", vakavasti pohtia vihkimisoikeudesta luopumista. ${ }^{684}$ Elettiin aikaa, jolloin oli yleisesti hyväksytty ajatus vääjäämättä etenevästä muutoksesta. Tuohon muutokseen ei kirkon johdossa kuitenkaan aiottu muitta mutkitta alistua.

Kirkolliskokouksessa asiaa käsitellyt perustevaliokunta kiinnitti erityistä huomiota siihen, miten piispainkokouksen suosittelema pastoraalinen kohtaaminen tuli tulkita ja mikä oli sen suhde kirkollisiin toimituksiin ja yksityiseen sielunhoitoon. ${ }^{685}$ Julkisuuden valokeila kohdistui valiokuntaan, eivätkä tiedot asian käsittelystä kirkossa olleet tällöin aina täysin oikeellisia. Helsingin Sanomat uutisoi piispainkokouksen "päättäneen" jo keväällä, että parisuhteen rekisteröinnin yhteydessä voitiin "pitää rukoushetki". 686 Tiedotusvälineet kärttivät kirkolliskokousedustajien mielipiteitä ennen ratkaisevaa syysistuntokautta ennakoidakseen päätöstä. ${ }^{687}$ Samaten ne seurasivat herkeämättä Turun tapahtumia. ${ }^{688}$

Istuntokauden avauspuheessa - ensimmäisessä puheessaan kirkolliskokouksen puheenjohtajana - arkkipiispa Kari Mäkinen ilmoitti odottavansa, että "täällä tehdään piispainkokouksen selvityksen pohjalta selkeä, homoseksuaalisia ihmisiä ja suhteensa rekisteröineitä pareja tukeva ja rohkaiseva päätös" ${ }^{689}$ Edelleen kulttuuriministeri, RKP:n Stefan Wallin viittasi samaan suuntaan tuodessaan tervehdyksen kirkolliskokoukselle: kirkon tuli palvella kaikkia ja ottaa kaikki vastaan. ${ }^{690}$ Oli aistittavissa poikkeuksellisen kova paine, jonka alla kaik- ki kirkolliskokouksessa olivat, eikä perustevaliokunnalla ollut käytännössä liikkumavaraa ainakaan olennaisesti tiukentaa piispainkokouksen ehdottamaa linjaa.

Perustevaliokunta seurasi piispainkokousta. Se painotti lähimmäisenrakkautta ja Raamatussa sekä tunnustuskirjoissa ilmaistua avioliittokäsitystä. Näistä asioista vallitsi valiokunnan mukaan laaja yksimielisyys. ${ }^{691}$ Valiokunnan enemmistö katsoi, ettei uudelle toimituskaavalle ollut riittäviä kirkon uskosta nousevia ja yhteisesti hyväksyttyjä perusteita. ${ }^{692}$ Valiokunnan mukaan pastoraalinen ohje oli suositus, josta ei seurannut kirkon työntekijälle virkavelvollisuutta mutta johon ei myöskään saanut lisätä varsinaisia kirkollisia toimituksia selvästi muistuttavia elementtejä. ${ }^{63}$ Valiokunnan enemmistön mielestä kirkolliskokous saattoi antaa piispainkokoukselle tehtäväksi laatia toimintaohjeen, joka olisi "myönteinen mahdollisuus kohdata pastoraalisesti seksuaalivähemmistöihin kuuluvat kirkon jäsenet". ${ }^{694}$ Äänin 11-6 valiokunta päätti sisällyttää mietintöönsä sukupuolineutraalia avioliittoa koskevan kannanoton. ${ }^{695}$ Valiokunta katsoi, ettei kirkko voinut "tältä osin muuttaa omaa avioliittokäsitystään, joka kuuluu sen uskonkäsitykseen ja ihmiskuvaan". ${ }^{696}$ Esitys oli hauras kompromissi, ja kirkolliskokouksen kuljettavana oli kapea polku. ${ }^{697}$

Viisi valiokunnan jäsentä jätti eriävän mielipiteen, jonka mukaan rukouksen laatiminen merkitsi tosiasiallisesti rekisteröidyn parisuhteen hyväksymistä. Samalla horjutettaisiin Raamatun ohjeellisuutta ja muutettaisiin 
kirkon perinteistä opetusta avioliitosta. Homoseksuaalien asian edistäminen nähtiin vahvan ideologisesti, mitä kuvasti toistuva puhe homoteologiasta. ${ }^{698}$ Pastoraalisten ohjeiden vastustajat arvelivat, ettei rukouksen ja siunaamistoimituksen välistä rajaa ollut käytännössä mahdollista vetää ja säilyttää. Monet heistä pelkäsivät ratkaisun johtavan yhä keskeisempien opinkohtien ja eettisten periaatteiden kyseenalaistamiseen. Toisaalta ne, jotka pohjimmiltaan kannattivat rekisteröidyn parisuhteen siunaamista, toivoivat pastoraalisten ohjeiden olevan askel siunaamisen suuntaan. Tällainen asenne voimisti vastustajien epäluuloja. Samaten monet rekisteröityyn parisuhteeseen kriittisesti suhtautuvat edustajat valittivat median painetta. ${ }^{699}$ Lopulta valiokunnan esitys pastoraalisten toimintaohjeiden laatimisesta voitti äänin 78-30 vastaehdotuksen, jonka mukaan tällaisten ohjeiden laatiminen tuli todeta tarpeettomaksi. ${ }^{700}$

Asian käsittely oli ollut raskasta. Kirkkoherra Tapio Seppälä totesi:

Vaikka lainsäätäjä on säätänyt parisuhdelain ja yhteiskunnassa käydään yleistä meteliä asian tiimoilta, varsinaista arvokeskustelua ilmeisesti ei pysty käymään oikeastaan tässä yhteiskunnassa mikään muu taho kuin kirkko. Aika kovalla hinnalla kirkko on pantu käymään tämä arvokeskustelu, että ihmiset tietäisivät, kuinka tässä meidän rakkaassa suomalaisessa yhteiskunnassamme pitäisi toimia. Meidän täytyy tämä haaste ottaa vakavasti vastaan ja niin se on myös otettu. En tiedä yhtäkään toista yhteiskunnallista tahoa, joka olisi keskustellut tästä teemasta enemmän, olisi tehnyt enemmän selvityksiä tästä aiheesta ja pitänyt enemmän seminaareja näistä kysymyksistä kuin mitä kirkko on pitänyt. ${ }^{701}$

Helsingin Sanomat yhtyi näihin ajatuksiin ja liitti ne pääkirjoitukseensa. ${ }^{702}$ Arvostellulta medialta löytyi ratkaisun jälkeen ymmärtämystä kirkolliskokoukselle.

Kirkolliskokouksen päätös jätti jälkeensä myös paljon tyytymättömyyttä. Monien päätöksen vastustajien mielestä asiasta olisi pitänyt päättää määräenemmistösäännöksen mukaan. Silloin jaa-äänet eivät olisi riittäneet esityksen läpimenoon. Valiokunta oli lähes loppuun asti harkinnut sellaisiakin ponsia, jotka olisivat vaatineet määräenemmistön. Lopullinen ponsi saatettiin valiokunnan enemmistön mielestä kuitenkin hyväksyä ilman määräenemmistöä, koska siinä sen enempää kuin mietinnössäkään ei useimpien jäsenten mukaan poikettu kirkon opetuksesta. ${ }^{703}$
On kuitenkin huomattava, että piispainkokous oli antanut esityksensä nimenomaan kirkolliskokouksen opillisia tehtäviä koskevan lainkohdan nojalla. ${ }^{704}$ Tuota kohtaa koskevat päätökset edellyttivät määräenemmistöä. Kun määräenemmistösäännöksen tulkitseminen oli lisäksi ollut kautta vuosikymmenten ongelmallista ja horjuvaa, asian käsittelyjärjestys jätti tilaa jälkipuinnille. ${ }^{705}$ Tilanne oli hyvin samanlainen kuin 1976, jolloin kirkolliskokous oli todennut, että pappisviran avaaminen naisille oli kirkon opin mukaista. Tuolloinkaan asian taakse ei ollut löytynyt määräenemmistöä, mutta paine ratkaisun saamiseksi oli ollut niin kova, että kirkolliskokouksen johto oli tulkinnut määräenemmistövaatimusta suppeasti.

Samalla voi nähdä tiettyä epäjohdonmukaisuutta myös siinä, miten syksyllä 2010 noudatetun käsittelyjärjestyksen voimakkaimmat vastustajat toimivat. Samat henkilöt nimittäin vetosivat toisissa yhteyksissä kirkolliskokouksen lisäponteen vuoden 1986 naispappeuspäätöksessä, joka seurauksineen oli näiden henkilöiden mielestä selvästi oppia koskeva päätös. Vuonna 1986 oli oppia koskevan asian yhteydessä hyväksytty kokousteknisesti yksinkertaisella enemmistöllä ponsi, johon muutamat kirkolliskokousedustajat vetosivat 200o-luvulla voimakkaasti. Toisaalta samat edustajat kiistivät oikeutuksen ponnelta, joka hyväksyttiin 2010 oppia koskevan asian yhteydessä samaa päätöksentekomenettelyä käyttäen.

Päätös aiheutti keskustelua myös vanhoillislestadiolaisessa herätysliikkeessä. Jo perustevaliokunnassa vanhoillislestadiolaiset edustajat, varatuomari Esa Koukkari Oulusta ja neuvontapäällikkö Pentti Salonen Vihdistä, olivat liittyneet enemmistön kantaan. ${ }^{706}$ Täysistuntokäsittelyssä kanttori Martti Murtoperä Haapavedeltä kertoi olleensa valiokunnan mietintöä lukiessaan "sisäisesti hyvin huojentunut ja rauhallisella mielellä, lukiessani perussävelenä soi Vivaldin piccolohuilukonserton C-duuri -teos". Murtoperän mukaan oli suorastaan helppo yhtyä perustevaliokunnan käsitykseen pastoraalisista ohjeista. ${ }^{707}$ Kaikki kirkolliskokouksen vanhoillislestadiolaiset edustajat äänestivät valiokunnan esityksen puolesta. ${ }^{708}$ Ilman näitä yhdeksää jaa-ääntä äänestystulos olisi ollut selvästi tasaisempi ja kirkon johdon kannalta ongelmallisempi.

Äänestyskäyttäytyminen herätti huomiota, mutta oikeastaan se oli vain suoraa jatkoa vuodelta 2002, jolloin 
Yrjö Koskimäki oli parisuhdelakia käsiteltäessä asettunut samalle välittävälle kannalle kuin myöhemmin perustevaliokunnan enemmistö. Uuden vuosituhannen vanhoillislestadiolaisuus halusi välttää kiistaa kirkon johdon kanssa - varsinkin kun kasvaneella vanhoillislestadiolaisella edustajajoukolla oli kirkolliskokouksessa aiempaa suurempi valta ja siten myös vastuu. Taustalla vaikutti todennäköisesti myös käsitys kirkollisen ja maallisen esivallan läheisestä ajatuksellisesta yhteydestä - eihän herätysliikkeessä ollut lähdetty protestoimaan näkyvästi sen enempää naispappeuspäätöstä kuin parisuhdelakia vastaan.

Vanhoillislestadiolaisten kannanmuodostukselle oli epäilemättä tärkeää myös se, ettei perustevaliokunta velvoittanut kirkon työntekijöitä osallistumaan parisuhderukoukseen. Valiokunnan mietinnöstä iloinnut Murtoperä totesi: "Minäkin voin perinteisine käsityksineni edelleen uskoa ja toimia tässä rakkaassa kirkossa Jumalan Sanaan sidotun omantuntoni mukaisesti."709 Istuntokauden jälkeisinä viikkoina piccolon keveät sävelet vaihtuivat Kohtalonsinfoniaan. Kirkolliskokouksen päätös herätti runsaasti vastustusta vanhoillislestadiolaisten keskuudessa, ja SRK:n johtoelimet totesivat päätöksen Raamatun vastaiseksi. Vanhoillislestadiolaiset kirkolliskokousedustajat pyysivät herätysliikkeensä piirissä anteeksi toimintaansa. ${ }^{70}$ Näyttää siltä, että nimenomaan arvostelu, joka päätöksen jälkeen nousi liikkeessä alhaalta päin, johti keskusorganisaation kannanottoihin ja kirkolliskokousedustajien anteeksipyyntöön - eiväthän äänestystä edeltäneet, julkisuudessa vähälle huomiolle jääneet mutta keskusorganisaation tiedossa olleet kirkolliskokousedustajien kannanotot olleet vielä johtaneet linjan korjaamiseen.

\section{KONSENSUS HIIPUU}

\section{JA AUKTORITEETIT MURTUVAT}

\section{PALJON VALMISTELTAVAA, VÄHÄN PÄÄTÖKSIÄ} Kirkolliskokous kärsi vuosituhannen alussa asiaruuhkasta. Pelkästään vuonna 2000 kokous käsitteli erinäisten laajempien uudistushankkeiden ohella yhteensä 23 hiippakuntakokousesitystä ja edustaja-aloitetta. Asiaruuhka oli omiaan vahvistamaan jo aiemmin yleistynyttä käytäntöä, jonka mukaan hiippakuntakokousesityk- siä ja edustaja-aloitteita lähetettiin kirkkohallitukselle "tutkittavaksi ja mahdollisia toimenpiteitä varten". Siten asiapaljous siirtyi kirkkohallitukselle, joka puolestaan toivoi saavansa vastaisuudessa yksilöidympiä ja selkeämpiä tehtävänantoja. ${ }^{71}$ Yleisvaliokunnan toinen osasto otti toivomuksen kuuliaisesti huomioon ja laati nuorisotyötä koskevan, yksilöidyn tehtävänannon: valiokunta esitti asian lähettämistä "kirkkohallitukselle asiantuntijaryhmän asettamista varten". ${ }^{12}$

Yleisvaliokunnan esittämä ratkaisu ongelmaan - työryhmän perustaminen - ei ollut mitenkään tavaton 2000-luvun kirkossa. Kirkolliskokous sai jatkuvasti aloitteita, joissa ehdotettiin työryhmän perustamista. Kyse oli jo 1990-luvulla yleistyneestä aloitetyypistä, jossa kirkolliskokouksen huomio kiinnitettiin johonkin ongelmaan ehdottamatta kuitenkaan konkreettisia toimia. Tällaiset aloitteet olivat kriisitietoisuuden herättelyä. Ne kuvastivat myös sitä, että oli paljon helpompi osoittaa ongelmia kuin löytää niihin ratkaisuja. Kirkkohallituksen työryhmien määrä kasvoi voimakkaasti. Vaikka kirkolliskokous vuosikymmenen loppua kohden alkoi suhtautua hyvin kriittisesti uusien työryhmien perustamiseen, kirkkohallitukselle edelleen välitetyt lukuisat aloitteet ja edustajien jatkuva huoli toiminnallisista kysymyksistä vauhdittivat työryhmien perustamista.

Vuonna 2000 yleisvaliokunnan esitys työryhmän perustamisesta kohtasi vaikeuksia. Täysistunnossa kirkkoneuvos Heikki Mäkeläinen totesi, että esitys määritti liian tarkasti kirkkohallitukselta edellytetyt toimet. Kirkkoneuvoksen kritiikin johdosta täysistunto lähetti asian kirkkohallitukselle - miltei kirkkohallituksen arvostelemaa perinteistä fraasia käyttäen - "tarvittavia toimenpiteitä varten" ${ }^{713}$ Tehtävänantojen laatiminen kirkkohallitukselle ei ollut helppoa. Istuntokauden tapahtumat antoivat viitteitä, etteivät päällimmäisenä ongelmana välttämättä olleet liian yleisluonteiset tehtävänannot vaan se, että kirkolliskokous oli välittänyt eteenpäin kirkkohallituksen resursseihin nähden liian monia hiippakuntakokousesityksiä ja edustaja-aloitteita.

Toisaalta kirkolliskokouksessa arvosteltiin valiokuntia ja erityisesti yleisvaliokuntaa siitä, että aloitteita käsiteltiin liian pinnallisesti ja ehdotettiin raukeamaan liian kevein perustein. Tällaista arvostelua oli kuultu jo esimerkiksi 1970- ja 1980-luvulla, mutta tyytymättömyys nousi esille erityisesti $2000-$ luvulla. ${ }^{714}$ Sitä lisäsi 
tapaus, jossa aloitteentekijä näki yleisvaliokunnan mietintöluonnoksen raukeamisehdotuksineen jo ennen lähetekeskustelun alkamista. ${ }^{75}$ Arvosteluun valiokuntavalmistelun ajoittaisesta pinnallisuudesta yhtyivät usein kirkkoneuvokset, joiden mielestä valiokunnat kuulivat asiantuntijoita - kuten heitä itseään - liian vähän. Tiedot kirkkohallituksen valmistelutoimista eivät aina välittyneet valiokunnille. ${ }^{716}$

Eduskunnan valtiontaloudellinen valta oli 1980-luvulta 200o-luvulle vähentynyt budjetin muututtua aiempaa yleispiirteisemmäksi, mutta muuten eduskunnan harjoittama parlamentaarinen valvonta oli monipuolistunut ja vahvistunut. ${ }^{77}$ Hyvin samanlainen muutos oli tapahtunut kirkon keskushallinnossa. Kirkolliskokous oli menettänyt yksityiskohtaista budjettivaltaansa, ja jatkuvasti suurempi osa kirkon taloudesta oli kirkolliskokouksen suoran päätösvallan ulkopuolella. Sen sijaan kirkolliskokouksen mahdollisuudet pysyä selvillä kirkkohallituksessa vireillä olevista asioista olivat aiempaa selvästi paremmat. Kirkkohallituksen ja kirkkoneuvosten ilmoituksista tuli tärkeä yhteydenpidon väline. Esimerkiksi keväällä 2007 kirkolliskokous vastaanotti neljä kirkkohallituksen ilmoitusta. ${ }^{718}$ Myös kyselytunnit paransivat tiedonsaantimahdollisuuksia. Arvostelua herätti kuitenkin se, ettei keskustelulle yleensä jäänyt juuri sijaa: tunti täyttyi kirkkoneuvosten vastauksista. ${ }^{79}$

Kirkkohallituksen täysistunnon jäsenten läsnäolo- ja puhemahdollisuudet kirkolliskokouksessa paranivat selvästi 200o-luvulla. Paikalla olleiden luottamushenkilöiden panos jäi kuitenkin vähäiseksi. Heistä ei tullut sellaisia kirkkohallituksen päätösten perustelijoita kuin jotkut olivat alun pitäen toivoneet. Myöskään kirkolliskokousedustajat eivät panneet kirkkohallituksen täysistunnon jäseniä tiukoille. Vasta syksyllä 2011 kirkkohallituksen luottamushenkilöjäsen joutui kyselytunnilla vastaamaan tehdyistä päätöksistä ${ }^{720}$. Käytännön päätöksenteossa ja mielikuvissa nimenomaan kirkkoneuvokset edustivat edelleen kirkkohallitusta, vaikka virallisesti heillä oli sen täysistunnossa vain valmistelijan ja esittelijän osa.

Vaikka vuosituhannen alussa tuskailtiin edustajaaloitteiden ja hiippakuntakokousesitysten kanssa, historiallisesti katsottuna niiden määrä ei ollut 200o-luvulla mitenkään erityisen suuri. Esimerkiksi vuosina 2008-2011 edustaja-aloitteiden määrä oli vain puolet vaalikauden 1974-1977 määrästä. Hiippakuntavaltuustojen esitykset taas olivat vuosina 2008-2011 vain neljäsosa siitä aloitenipusta, joka kirkolliskokousuudistuksen jälkeisinä vuosina oli saapunut hiippakuntakokouksilta. Kirkolliskokouksen työtavat olivat vakiintuneet ja kynnys aloitteiden jättämiseen noussut. Edustajilta ja hiippakunnista tulleiden asioiden väheneminen oli pitkälti syynä siihen, että kaikkien kirkolliskokoukselle saapuneiden asioiden määrä oli vuosina 2008-2011 selvästi alle puolet vaalikauden 1974-1977 luvusta.

Edustaja-aloite oli erityisesti maallikkoedustajien vaikuttamiskanava. Aloitteet keskittyivät usein tietyille edustajille: keväällä 2000 kuudesosa edustajista vastasi useammasta kuin joka toisesta edustaja-aloitteiden allekirjoituksesta. Niin edustaja-aloitteiden kuin hiippakunnista tulevien asioiden osalta näkyi tutkimuskauden edetessä selvä muutos: kauden alkupuolella pohjoisen edustajat ja Oulun hiippakuntakokous olivat olleet hyvin aktiivisia, kun taas loppupuolella aloitteet nousivat etelästä. Maaseudun näkökulmasta laaditut kirkkolain säännökset aiheuttivat lisääntyviä ongelmia ennen kaikkea etelän suurissa kaupungeissa, mikä johti jatkuvaan aloitteiden tekemiseen. Oulun hiippakunnasta oli tullut alkuvaiheessa paljon yhteiskunnallisia aloitteita, mutta jo 1980-luvulla tuo toiminta oli hiipunut. Yksi syy saattoi olla se, että vanhoillislestadiolaisuudessa omaksuttiin hiljainen myöntyvyyslinja niin suhteessa valtiolliseen kuin kirkolliseen lainsäädäntöön. Tuo linja ei merkinnyt aiemmin arvosteltujen asioiden hyväksymistä, mutta avoin vastustus jäi taakse.

Aloitteiden määrän vähenemisessä oli samalla kyse kirkkohallituksen vahvistumisesta. Vuosina 1974-1977 runsas neljännes kirkolliskokouksen päätettäväksi saapuneista asioista oli tullut kirkkohallitukselta, mutta tutkimuskauden lopussa osuus oli puolet. Kun kirkkohallituksen oma-aloitteiseen valmisteluun saattoi nojautua aiempaa enemmän, aloitteiden tarve väheni. Kirkkohallituksen esitysten määrää kohotti myös komitealaitoksesta luopuminen: vuosina 1974-1977 kirkolliskokoukselle tulleista asioista seitsemän prosenttia oli saapunut komiteoilta, mutta tutkimusjakson viimeisellä vaalikaudella komiteavalmistelua ei ollut lainkaan.

Kirkon keskushallinnon muutos 1970-luvun puolivälistä 2000-luvulle näkyi varsinkin kirkolliskokouksen tehtävänannoissa. Niistä asioista, jotka kirkolliskokous 
oli lähettänyt eteenpäin vuosina 1974-1977, se oli osoittanut vajaan kolmanneksen kirkkohallitukselle - suunnilleen saman verran kuin komiteoille tai toimikunnille. Vaalikauden 2008-2011 alkaessa kirkon keskushallinto oli jo pitkään toiminut ilman itsenäisiä toimikuntia, ja myös komiteatyö oli pysähdyksissä. Siten lähes kaikki eteenpäin lähetetyt asia siirtyivät kirkkohallitukselle. Tätä taustaa vasten olikin ymmärrettävää, että tutkimista varten eteenpäin lähetetyt aloitteet työllistivät kirkkohallitusta. Piispainkokoukselle lähetettyjen asioiden määrä pysyi vajaassa kymmenesosassa kaikista kirkon keskushallinnon elimille lähetetyistä asioista.

Kirkkohallituksen ja kirkolliskokouksen suhteessa näkyi toinenkin selvä muutos. Vuosina 1974-1977 kirkol-

\section{Julkilausuma juutalaisista ja kannan ottamisen vaikeus}

Kirkolliskokous antoi 1990- ja 200o-luvulla selvästi aiempaa harvemmin lausuntoja ja kannanottoja, kun taas kirkkohallituksen vastuu kirkon äänen käyttämisestä kasvoi. Kirkolliskokouksessa oli kuitenkin monia, joiden mielestä kirkon ylin päättävä elin oli palautettava aktiiviseksi arvokeskustelijaksi. ${ }^{I}$ Uuden vuosituhannen alussa kirkolliskokous yrittikin hetkeksi palata kannanottajaksi. Tuolloin eri maissa ja kirkoissa puitiin suhtautumista juutalaisvainoihin. ${ }^{\text {II }}$

Kevälllä 2000 Porvoon hiippakuntakokous esitti, että Suomen luterilainen kirkko sanoutuisi julkisesti irti kaikenlaisesta antisemitismistä ja edistäisi luottamusta herättävää keskustelua juutalaisuuden ja kristinuskon yhteisestä perinnöstä. ${ }^{\text {III }}$ Saman vuoden syksyllä, kun hiippakuntakokousesitys oli perustevaliokunnassa, Suomessa paljastettiin muistomerkki Saksaan vuonna 1942 luovutetuille juutalaisille. Pääministeri Paavo Lipponen pyysi hallituksen ja kaikkien suomalaisten puolesta anteeksi juutalaisyhteisöltä. ${ }^{\text {IV }}$

Tätä taustaa vasten oli luonnollista, että kirkolliskokouksen syysistuntokaudella median huomio keskittyi perustevaliokunnan mietinnön käsittelyyn. Perustevaliokunta pyrki vahvistamaan vuoropuhelua juutalaisten kanssa. Se ei kuitenkaan katsonut Suomen osuutta juutalaisvainoissa suureksi eikä nähnyt tarvetta erityiselle julkilausumalle. ${ }^{\mathrm{V}}$ Julkisuudessa ilmenneisiin odotuksiin nähden moni kirkolliskokousedustaja piti valiokunnan mietintöä mitättömänä. ${ }^{\mathrm{VI}}$

Asia palautettiin valiokuntaan, joka seuraavassa mietinnössään nosti esille suomalaisten osuuden juutalaisvainoissa ja kirkon vastuun asiassa. Edelleenkään mietintö ei päättynyt anteeksipyyntöön, mutta täysistunnossa osa edustajista liskokous oli laatinut valtioneuvostolle kuusi lausuntoa tai kirjelmää, mutta vaalikaudella 2008-2011 tällaisia kannanottoja ei ollut yhtäkään. Kaikki olivat yhtä mieltä siitä, että nimenomaan kirkkohallituksen tuli olla aktiivinen suhteessa valtiovaltaan ja pyrkiä vaikuttamaan uudistushankkeisiin jo valmisteluvaiheessa. ${ }^{721}$ Vuoden 2011 eduskuntavaalien alla kirkkohallituksessa määriteltiin ja koottiin ensimmäistä kertaa systemaattisesti kirkon hallitusohjelmatavoitteita. Prosessi herätti kiinnostusta myös kirkolliskokouksessa, mikä näkyi kysymyksinä ja kiitoksina kyselytunneilla vuosina 2010 ja 2011. ${ }^{722}$

Yhtä ongelmatonta ei ollut se, että myös virallisten lausuntojen antaminen siirtyi käytännön syistä kirkko-

vaati anteeksipyyntöä erilliseksi ponneksi. ${ }^{\text {VII }}$ Kolmatta kertaa mietintöä muokatessaan valiokunta ei taaskaan nostanut anteeksipyyntöä ponneksi mutta totesi mietinnön perusteluissa:"Kirkko myöntää vaienneensa juutalaisvainoista ja pyytää tätä anteeksi juutalaiselta yhteisöltä.”vıII

Jälkeenpäin esitettiin erilaisia näkemyksiä, oliko kyseessä kirkon anteeksipyyntö. Suhtautumisesta juutalaisiin ei kirkolliskokouksessa ollut juurikaan erimielisyyksiä, mutta menettely- ja esitystapa herättivät paljon keskustelua. ${ }^{\mathrm{IX}}$ Koko ajan pohdittiin, miten erilaiset ratkaisut nähtäisiin julkisuudessa. ${ }^{\mathrm{x}}$ Lopulta päädyttiin muotoiluun, joka oli mahdollista tulkita kirkon anteeksipyynnöksi. Toisaalta anteeksipyynnön sijoittaminen ponnen sijasta mietinnön sisälle ilmaisi halua osoittaa, että anteeksipyyntö oli itsestään selvä ja jo toteutunut asia. Julkisuuden paineessa tehtiin mietintö, jossa oli yritettävä miellyttää kaikkia mutta jonka merkitys jäi epäselväksi. Kun aloitteissa myöhemmin 2000-luvulla vaadittiin kirkolliskokouksen muuttamista aiempaa kantaaottavammaksi elimeksi, vaatimukset voitiin torjua vetoamalla juutalaisia koskevasta julkilausumasta saatuun varoittavaan esimerkkiin ${ }^{\mathrm{XI}}$.

I Kirk.kok. ptk-k. 2006, liite VI 9; Kirk.kok. ptk-k. 2008, liite VIII 2.

II Hirvonen 2004a, 163.

III Kirk.kok. ptk-k. 2000, liite VI 4.

IV Hirvonen 2004a, 163.

V Kirk.kok. ptk-s. 2000, liite VII-B 1

VI Kirk.kok. kptk-s. 2000, $15 \$$.

VII Kirk.kok. kptk-s. 2000, 40 \$; Kirk.kok. ptk-s. 2000, liite VII-B 1 a; Hirvonen 2004a, 172-173.

VIII Kirk.kok. kptk-s. 2000, 40 \$; Hirvonen 2004a, 175.

IX Hirvonen 2004a, 172, 176-177.

X Kirk.kok. kptk-s. 2000, $15 \$, 40 \$$.

XI Kirk.kok. kptk-k. 2008, 58 \$. 
hallitukselle. Vain se pystyi riittävän ripeästi laatimaan pyydetyt lausunnot. Ensinnäkin jatkuvasti kasvava lausuntojen määrä kuormitti kirkkohallitusta: vuonna 2000 se antoi eri viranomaisille kymmenen lausuntoa, mutta 2005 lausuntoja oli jo $34^{723}$. Toiseksi asialla oli periaatteellinen puolensa: aiempina vuosikymmeninä kirkolliskokous oli pohtinut eettisiä kysymyksiä nimenomaan antaessaan lausuntoja suunnitteilla olleista lainsäädäntöhankkeista, mutta 200o-luvulla tällainen periaatteellinen keskustelu saavutti kirkolliskokouksen usein vasta jälkikäteen. Esimerkiksi valmisteltaessa lakia rekisteröidystä parisuhteesta kirkkohallitus antoi lausunnon kirkon puolesta, ja kirkolliskokous sai pohdittavakseen vain sen, miten valmiin lain kanssa yritettäisiin elää.

Monet kirkolliskokousedustajat ilmaisivat 200o-luvun edetessä, ettei kirkkohallitus ollut paras elin lausumaan kirkon virallista kantaa opin ja etiikan kannalta merkittävistä lainsäädäntöhankkeista. Toisaalta kirkolliskokous oli tähän tehtävään liian hidasliikkeinen, joten katseet kääntyivät piispainkokoukseen. ${ }^{724}$ Sen suuri koko ja vähäiset resurssit taas vaikeuttivat vastuun lisäämistä. Vuonna 2004 kirkkoneuvos Matti Halttunen totesi lehtihaastattelussa piispainkokouksen esitysten olevan "kerrassaan metsässä", mikä ei antanut järin myönteistä kuvaa sen enempää piispainkokouksen valmistelun tasosta kuin kirkon keskushallintoelinten välisestä luottamuksesta. ${ }^{725}$ Muutenkin kirkon keskushallinnon rakenne herätti jatkuvasti enemmän tyytymättömyyttä. ${ }^{726}$ Kun vielä vuodesta 1993 asti vireillä ollut selonteko kirkkohallituksen uuden organisaation toimivuudesta viipyi, aika alkoi olla kypsä keskushallinnon kokonaisuuden pohtimiselle. ${ }^{727}$

Kirkkohallitus esitti 2008 keskushallinnon uudistamista muun muassa siten, että piispainkokouksesta tehtäisiin aiempaa selvemmin uskon ja opin tulkitsija. Samanlainen pyrkimys oli ollut jo kirkkojärjestyskomitealla 1970-luvun lopussa. Tämän päämäärän saavuttamiseksi kokoustahtia oli tarkoitus tiuhentaa ja tehdä elimestä pelkästään piispojen kokous. ${ }^{728}$ Kirkolliskokouksesta ei kuitenkaan löytynyt tarpeeksi tukea ehdotetuille muutoksille, ja esitys jäi tuossa vaiheessa raukeamaan. ${ }^{729}$ Lopputulos oli melko tavallinen 2000-luvun kirkolliskokouksissa. Monissa raukeamisissa näkyi lainsäädännön monimutkaistuminen. Kirkolliskokous ei voinut muokata säännösesityksiä yhtä vapaasti kuin vaikkapa 1970-luvulla, jolloin se oli ollut monessa mielessä paitsi päätöksentekoelin myös valmisteluorganisaatio. Sen sijaan 200o-luvulla valmistelu oli kirkkohallituksen käsissä, ja kirkolliskokouksen osana oli lähinnä joko hyväksyä tai hylätä esitykset.

Edelleen useissa äänestyksissä oli havaittavissa, että kynnys ei-äänen antamiseen ja esityksen kaatamiseen määrävähemmistöllä oli aiempaa matalampi. Osasyy tähän muutokseen saattoi olla hyvin käytännönläheinen. Koneellisessa äänestyksessä jokainen edustaja oli vain hetken näkyvä ympyrä valkokankaalla. Kaikki myös antoivat äänensä samanaikaisesti, joten jokaisen vastuu lopputuloksesta oli yhtäläinen. Aiemmin kunkin edustajan oli pitänyt lausua kantansa koko kirkolliskokouksen huomion ollessa keskittyneenä vuorossa olevaan edustajaan. Jos tilanne oli ollut tiukka, aakkosten loppupäässä olleiden oli ollut vaikea äänestää vastaan, koska esityksen kohtalo oli ollut heidän harteillaan.

Päätöksenteon vaikeutuessa kolmen neljäsosan määräenemmistövaatimus, joka koski kaikkia kirkkolain ja -järjestyksen muutoksia, herätti edustajien piirissä arvostelua. ${ }^{730}$ Määräenemmistösäännös oli luotu 180o-luvulla tilanteeseen, jossa kirkolliskokousedustajat valittiin enemmistövaalilla. Jos tuossa tilanteessa jokin yksittäinen kysymys olisi määrännyt vaalien rintamalinjat, vähemmistön olisi pitänyt olla paikallisesti enemmistönä suuressa osassa maata, jotta sen edustajat olisivat saaneet kirkolliskokoukseen neljänneksen osuuden. Tällöin vähemmistön osuuden olisi koko kirkon tasolla pitänyt olla huomattavasti yli neljännes - niin suuren osan vähemmistön äänivallasta enemmistövaali hävitti. Siirtyminen suhteelliseen vaalitapaan paransi vähemmistön mahdollisuuksia saada edustajansa läpi ja siten käytännössä tiukensi määräenemmistövaatimusta.

Edelleen raukeamispäätöksissä näkyi kirkolliskokouksen polarisoituminen. Kun vastakohdat olivat entistä etäämpänä toisistaan, ratkaisevassa toisessa käsittelyssä ei ollut helppo äänestää enemmistön kannan mukaan pelkästä velvollisuudentunnosta. Huoli kirkon yhtenäisyydestä ja kirkolliskokouksen keskustelukulttuurista näkyi 2000-luvulla monin tavoin ja voimistui vuosikymmenen edetessä. Kyseessä ei ollut vain kirkollinen ilmiö: kirkko eli mukana koko yhteiskuntaa koskettavassa muutoksessa, joka oli osin seurausta vuoden 2008 talouskriisistä ja sen jälkimainingeista. Pitkään 


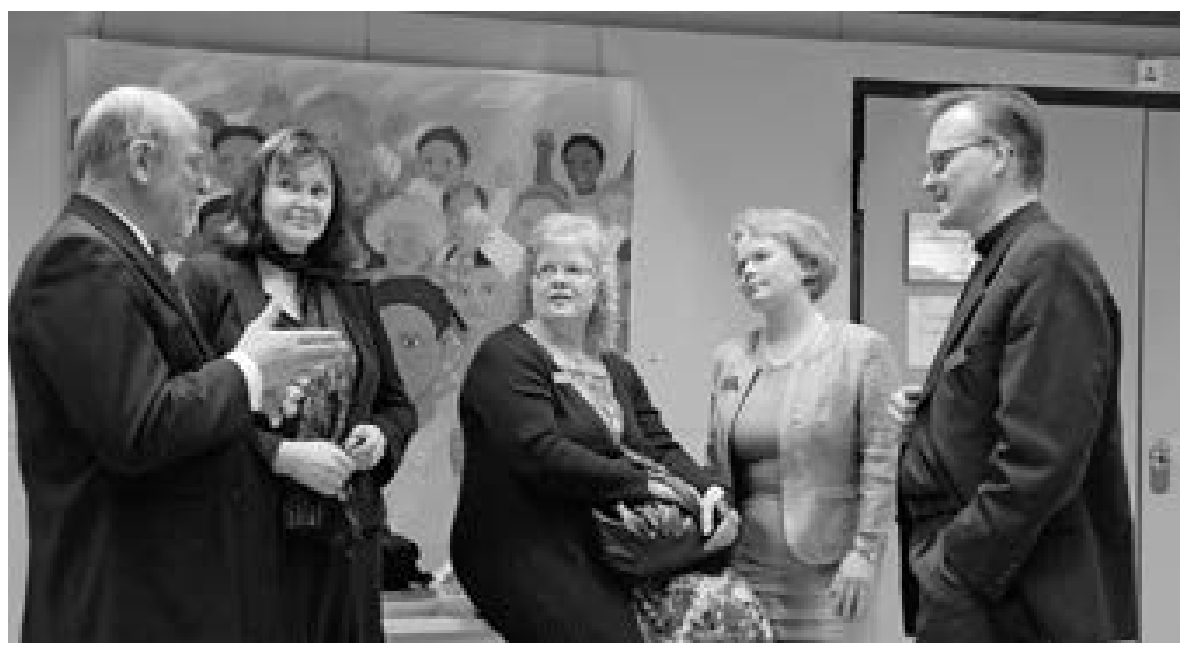

Osastonylilääkäri Matti Ketonen (vas.), kirjailija AnnaMari Kaskinen, toimittaja Marjaana Perttula, perheterapeutti Annika Määttänen ja kirkkoherra Tapio Luoma keskustelivat kirkolliskokouksen tauolla keväällä 2011. Kaskinen, Määttänen ja Luoma olivat tuolloin kärkiniminä aloitteessa, jonka päämääränä oli vahvistaa kirkon ykseyttä moniäänisyyden keskellä. Kuva: Kirkkohallitus / Aarne Ormio.

kestäneen konsensusvaiheen jälkeen poliittinen kenttä polarisoitui, mikä näkyi erityisesti kevään 2011 eduskuntavaaleissa ${ }^{731}$. Samana keväänä arkkipiispa Mäkinen ilmaisi kirkolliskokouksen avauspuheessa huolensa usein liian mustavalkoisesta kirkollisesta keskustelusta. ${ }^{732}$

Samanlaisia mietteitä sai lukea hiljattain eläkkeelle jääneiden piispojen muistelmista. Eero Huovisen mukaan erimielisyydet piispojenkin kesken olivat lisääntyneet ja kirkollinen keskustelu kärjistynyt riidoiksi. ${ }^{733}$ Juha Pihkala taas valitti eri katsomussuuntien etääntymistä kirkolliskokouksessa. ${ }^{734}$ Erityisesti kiista naispappeuden jyrkkien vastustajien kohtelusta oli "nostanut pönttöön puhujia, joista tuntuu, kuin heillä olisi pitkä viitta yllään, turbaani päässään ja Kalashnikov kainalossaan". ${ }^{35}$ Kahdella edellisellä vuosikymmenellä kuultujen melko hillittyjen täysistuntokeskustelujen jälkeen palattiin 1970-luvun tapaiseen kiivaaseen sanankäyttöön. Toisaalta keväällä 2011 kaikkiaan 11 kirkolliskokousedustajaa jätti aloitteen, jonka päämääränä oli vahvistaa kirkon ykseyttä moniäänisyyden keskellä736. Kirkolliskokousedustajilla oli edelleen halua etsiä pohjaa yhteiselämälle. Kääntöpuolena oli, että sisäisten kiistojen ratkominen vei jatkuvasti voimavaroja ulospäin suuntautuvalta toiminnalta.

Epävarma ilmapiiri ja keskittyminen omiin sisäisiin kysymyksiin olivat yleisiä piirteitä eri maiden kirkoissa 200o-luvun alkuvuosina. ${ }^{737}$ Eurooppa ja ekumenia olivat olleet 1990-luvulla lähes jatkuvasti esillä kirkolliskokouksessa, ja kokous oli seurannut kirkko- järjestyskomitean linjauksia pyrkiessään korostamaan yhteyttä maailmanlaajaan kirkkojen perheeseen. Sen sijaan 2000-luvulla kirkon sisäiset asiat veivät huomion. Taakse oli jäänyt myös 1980-luvun voimakas herääminen maailmanlaajuiseen diakoniseen vastuuseen. Niin ikään innostus ulkolähetystä kohtaan näytti olevan seurakunnissa hiipumassa, ja kirkolliskokouksessakin teema nousi esille lähinnä muutamina yksittäisinä aloitteina tai puheenvuoroina. ${ }^{738}$ Kaikkein selvimmin huoli lähetystyöstä näkyi keskusteltaessa missiologian lahjoitusprofessuurista. Tällöinkin huomio tosin kiinnittyi pitkälti kirkkohallituksen harkintavallan rajoihin. ${ }^{739}$ Kaikkiaan lähetystyö - ulkolähetyksen merkityksessä säilyi läpi tutkimuskauden kirkolliskokouksen näkökulmasta melko etäisenä aihealueena. Sen sijaan edustajat vaativat 2000-luvulla kirkolta uudenlaista missionaarisuutta suomalaisessa yhteiskunnassa, jossa kristinuskon vaikutus näytti heikentyvän.

\section{TÄYSISTUNNON MERKITYS VÄHENEE, PIISPAT VAIKENEVAT}

Kirkolliskokouksen täysistunnoissa tehtyjen muutosehdotusten määrä romahti kolmessa vuosikymmenessä. Osin romahdus selittyy sillä, että käsiteltävien aloitteiden ja esitysten määrä oli vaalikaudella 2008-2011 vain alle puolet vuosien 1974-1977 määrästä. Muilta osin vaalikaudet olivat kuitenkin keskenään pitkälti vertailukelpoiset: kummankaan aikana ei hyväksytty merkittäviä kirkollisia kirjoja, jotka tuottivat pöytäkirjaan aina ta- 
8

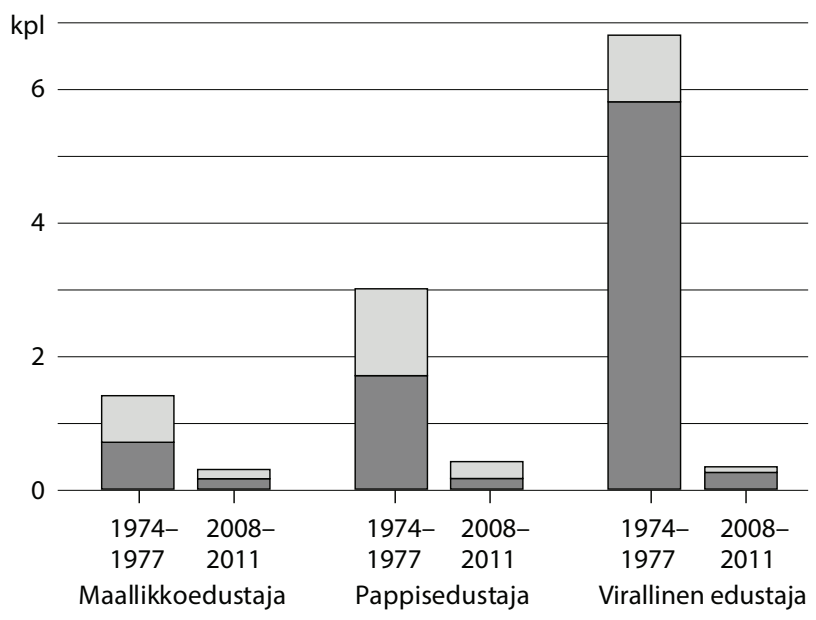

vallista suuremman määrän muutosehdotuksia. Täysistunnon luonteen muutos tapahtui vähittäin vuosikymmenten kuluessa mutta korostui 200o-luvulla.

Vuoden 1974 kirkolliskokousuudistuksen jälkeisinä vuosikymmeninä valiokunnat olivat voimistuneet Euroopan parlamenteissa. ${ }^{740}$ Sama havainto pätee kirkolliskokoukseen, jonka valiokunnilla oli 200o-luvulla käytettävissään selvästi enemmän sihteerityövoimaa kuin 1970-luvulla. Valmisteluorganisaation tehostuessa ja lainsäädännön monimutkaistuessa päätöksiä ei 200o-luvulla enää voinut eikä tarvinnut sorvata suuressa salissa samaan tapaan kuin 1970-luvulla. Kirkolliskokouksen työskentelytapa läheni eduskunnan valiokuntakeskeistä toimintaa. Silti toimintatapojen muutos koski enemmän muutosehdotusten määrää kuin niiden kohtelua. Vaalikaudella 1974-1977 lähes kaksi kolmesta täysistunnossa tehdystä muutosehdotuksesta oli hyväksytty, ja vuosina 2008-2011 niin kävi yhä puolelle muutosehdotuksista. Hyväksyttyjen muutosehdotusten osuus oli edelleen suuri, vaikka ehdotusten kokonaismäärä olikin pudonnut voimakkaasti.

Muutos ei koskenut pelkästään valmistelujärjestelmää vaan myös kirkolliskokouksen sisäistä auktoriteettiasetelmaa. Vuosina 1974-1977 virallinen edustaja oli tehnyt keskimäärin lähes viisinkertaisen määrän muutosehdotuksia maallikkoedustajaan verrattuna. Vaalikauteen 2008-2011 mennessä asetelma oli kääntynyt päinvastaiseksi: keskimääräinen maallikkoedustaja oli virallista edustajaa aktiivisempi muutosehdotusten esittäjä. Kai-
Kuvio 22: Yksittäisen edustajan täysistunnoissa tekemien muutosehdotusten keskiarvo kausilla 1974-1977 ja 2008-2011

Vuosien 1974-1977 osalta virallisiin edustajiin ei ole laskettu mukaan valtioneuvoston määräämää edustajaa, joka ei tuolloin osallistunut kirkolliskokouksen työskentelyyn. Vuosien 2008-2011 osalta taas saamelaisten edustaja, joka kirkolliskokouksen työssä luettiin Oulun hiippakunnan edustajien joukkoon, on myös taulukossa luettu maallikkoedustajaksi.

Hylätyt

Hyväksytyt

ken lisäksi virallisten edustajien ani harvoista muutosehdotuksista puolet oli valtioneuvoston määräämän edustajan käsialaa, mikä entisestään korosti täydellistä muutosta.

Kirkolliskokousuudistuksen jälkeisinä vuosina valtioneuvoston määräämä edustaja ei ollut käytännössä osallistunut kirkolliskokouksen työskentelyyn, kun taas piispat olivat olleet ehdottomia auktoriteetteja ja määränneet kirkolliskokouksen suunnan. Varsinkin jos he olivat keskustelleet keskenään täysistunnossa tehtävästä muutosehdotuksesta, he olivat saaneet arvovallallaan helposti kumotuksi valiokunnan kannan. Vastaavasti 200o-luvun piispat keskittyivät vaikuttamaan valiokuntakäsittelyn ja muiden valmisteluvaiheiden aikana. He puhuivat täysistunnossa lähinnä vain valiokunnan puheenjohtajan asemassa esitellen valiokunnan kantoja. Pappisedustajat tekivät selvästi useammin muutosehdotuksia ja ottivat muutenkin voimakkaammin kantaa kuin heidän esimiehensä. Yksi näkyvimmistä pappisedustajista oli Suomen kirkon pappisliiton puheenjohtajana vuodesta 2005 lähtien toiminut rovasti Jukka Huttunen, joka sanoitti tilannetta:

Tämä toiseksi viimeinen kohta, jonka olen omiin muistiinpanoihini laittanut, sen myötä menee aika paljon minulta, ainakin se, että en saa enää piispallista autokyytiä loppukirkolliskokouskaudella ja maine, kunnia ja moni muukin ystävyys taitaa mennä. - - Hyvät piispat, ohjatkaa, näyttäkää tietä, siunatkaa meitä, älkää istuko. ${ }^{711}$ 
On huomattava, että vuosina 2008-2011 piispojen vaihtuvuus oli voimakasta, mikä saattoi heijastua heidän aktiivisuuteensa kirkolliskokouksessa. Toisaalta piispoja oli vaihtunut myös vaalikaudella 1974-1977, joten kyse oli syvemmästä muutoksesta. Esiin astui kokonaan uudenlainen piispapolvi. Teologisesti se korosti yleensä virkaa jumalallisena asetuksena, mutta samalla se ymmärsi tehtävänsä lähinnä hengellisesti ja liturgisesti. Ehkä osin tästä syystä siltä puuttui kirkollisen päätöksenteon näkökulmasta peruuttamattomasti jotain, jota oli ollut 1970-luvun matalakirkollisilla, ilman hiippaa tai jopa albaa esiintyneillä piispoilla: säätypapiston ajalta muistona säilynyt piispallinen arvovalta.

Uusi piispasukupolvi oli tottunut aiempaa kansanvaltaisempaan päätöksentekoon. Näin oli paitsi kirkolliskokouksessa myös piispojen kollegiossa, jossa 1970-luvun kaltainen arkkipiispan auktoriteetti ei enää toiminut ja joka siksi oli aiempaa moniäänisempi ${ }^{74}$. Sen sijaan uusi piispapolvi varoi yleensä puimasta keskinäisiä erimielisyyksiään julkisuudessa. Piispat ennemminkin ilmaisivat toivovansa keskustelua kuin jyrähtivät kantansa. Heiltä ei myöskään kuultu sellaisia voimakkaita yhteiskunnallisia kannanottoja kuin 1990-luvun lopulla, mihin saattoi olla osasyynä piispojen valtiollisten kytkösten purkaminen - olivathan jotkut jo 1990-luvulla ennustaneet, etteivät puhtaasti kirkon viranhaltijoiksi siirretyt piispat enää joutuisi "ryvettymään" yhteiskunnan pelikentällä samalla tavoin kuin edeltäjänsä. Esimerkki uuden piispapolven edustajasta oli Turun hiippakunnan piispa, sittemmin arkkipiispa Kari Mäkinen, joka ei suuremmin kuluttanut kirkolliskokouksen aikaa. Vuoden 2006 alusta piispana toiminut Mäkinen käytti ensimmäisen puheenvuoronsa 2009. Se oli lauseen mittainen ${ }^{743}$.

Kirkolliskokouksen käsittelemien asioiden määrä oli vaalikaudella 2008-2011 pienempi kuin vuosina 1974-1977, ja myös täysistunnossa käytettyjen puheenvuorojen määrä laski kauttaaltaan. Jos puheenvuorojen määrän suhteuttaa asiamäärään, virallisten edustajien puheenvuorojen määrä laski selvästi. Sen sijaan hiippakunnittain valitut pappis- ja maallikkoedustajat puhuivat 2000-luvulla itse asiassa useammin kuin runsaat kolme vuosikymmentä aiemmin. Kuluneina vuosikymmeninä monet eduskunnassa toteutetut muutokset olivat tähdänneet siihen, että täysistunnosta saataisiin todellisen keskustelun foorumi - ei vain tiedotusväli- neille suunnattujen kannanottojen paikka ${ }^{744}$. Kirkolliskokouksessa oli toteutettu vastaavia uudistuksia, mikä edisti vuoropuhelua. Toisaalta varsinkin julkisuutta kiinnostaneissa keskusteluissa valmiiksi kirjoitettujen puheenvuorojen ketju korvasi usein vapaamuotoisen debatin.

Täysistunnon puheenvuoroissa oli 1970-luvulta 2000-luvulle huomattavissa sama muutos kuin edustaja-aloitteissa: painopiste oli siirtynyt eteläisiin hiippakuntiin. Tähän kokonaisuuteen liittyi se, ettei herätysliiketausta näkynyt puheenvuorojen määrässä samalla tavalla kuin aiemmin. Edeltäneinä vuosikymmeninä herännäisyydestä ja lestadiolaisuuden eri haaroista oli noussut aktiivisia puhujia, mutta nyt erottuivat Suomen Luterilaisen Evankeliumiyhdistyksen ja Suomen Evankelisluterilaisen Kansanlähetyksen piiriin lukeutuvat edustajat. Toisaalta myös Tulkaa kaikki -liikkeessä vaikuttavat henkilöt olivat aktiivisia puhujia ja aloitteentekijöitä. Kirkolliskokouksen keskustelupöytäkirjaa täyttivät Pohjois-Suomen maallikkosaarnaajien sijasta etelän kaupunkien asukkaat, jotka useissa tapauksissa edustivat keskenään hyvinkin vastakkaisia näkemyksiä. Mielipiteiden kirjossa välimaastoon sijoittui suuri, melko vähäpuheinen edustajajoukko.

Lainoppineet asiantuntijat omaksuivat nimenomaisesti asiantuntijaroolin. Heidän toimintansa korostui valiokuntatyössä, kun taas täysistunnossa he ottivat kantaa harvoin. Silloinkin he keskittyivät tehtävänsä mukaisesti asiakysymysten sijasta oikeudellisiin seikkoihin. ${ }^{74}$ Poikkeuksena oli 2000-luvun alkuvuosina oikeusneuvos Mikael Krogerus. Kirkkohallituksen entinen jäsen ei kieltänyt, "etteivätkö sormet joskus vähän syyhyäisi" ottaa kantaa myös varsinaiseen asiasisältöön. ${ }^{746}$ Krogerus lausuikin aktiivisesti ja usein oma-aloitteisesti näkemyksiään täysistunnossa, eikä hän aina pidättynyt arvioimasta asian tarkoituksenmukaisuutta. ${ }^{747}$ Kokonaan uusi tulokas kirkolliskokouksessa oli 2000-luvulla saamelaisten edustaja. Varsinkin tehtävässä aluksi toiminut saamelaiskäräjien puheenjohtaja Pekka Aikio oli hyvin aktiivinen saamelaisten asian ajaja. Hän ei tällöin esiintynyt niinkään yksityishenkilönä kuin nimenomaan saamelaiskäräjien edustajana. ${ }^{748}$

Kirkolliskokouksen asiamäärän ja puheenvuorojen kokonaismäärän laskiessa on silmiinpistävää, että yksittäisen kirkkoneuvoksen käyttämien puheenvuorojen 


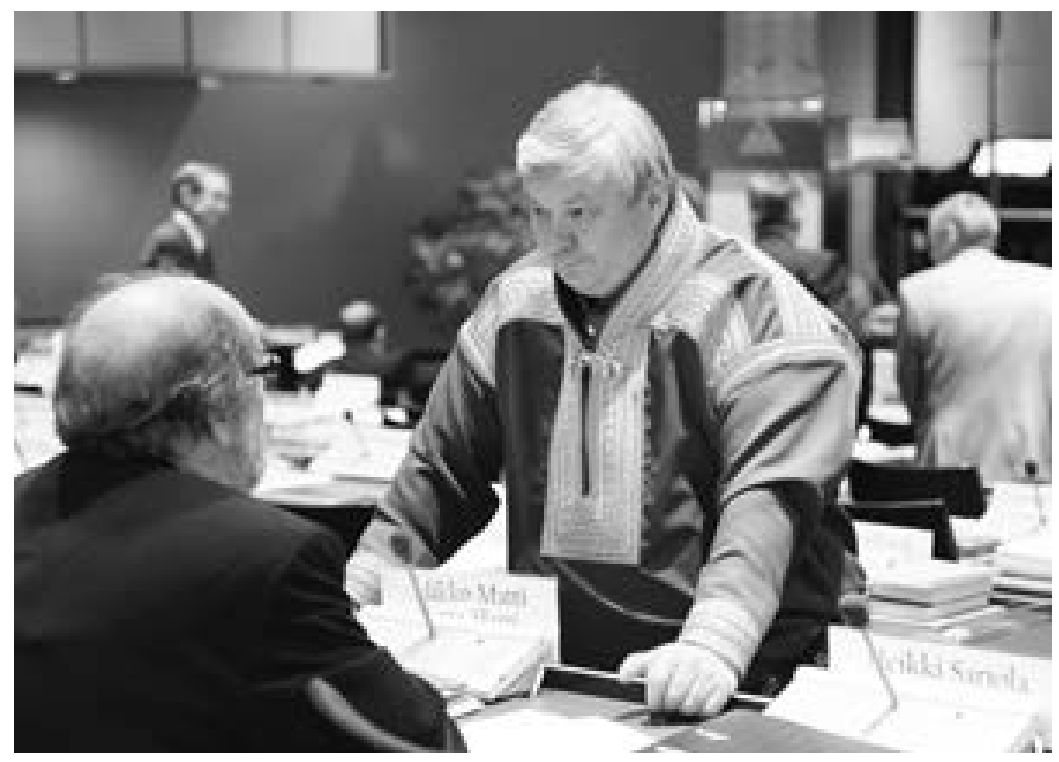

Saamelaisten edustaja Jouni Jomppanen keskusteli lähetystyön nuorisosihteerin Mikko-Matti Rinta-Harrin kanssa kevätistuntokaudella 2011. Saamelaisten edustajan kansallispuvun myötä tummanpuhuvaan edustajajoukkoon tuli vuosituhannen vaihtuessa uutta väriä. Erityisesti Jomppasen edeltäjä Pekka Aikio piti alkuperäiskansan asiaa näkyvästi esillä ja käytti ajoittain saamea myös puheenvuoroissaan. Kuva: Kirkkohallitus / Aarne Ormio. keskiarvo oli vuosina 2008-2011 korkeampi kuin vaalikaudella 1974-1977. Kyselytunnit, jotka on laskettu mukaan puheenvuoroihin, vaikuttivat luonnollisesti tähän tulokseen, mutta ne eivät selitä kaikkea. Kirkkoneuvokset ottivat yleensäkin näkyvän aseman kirkolliskokouksessa ja astuivat siten ainakin jossain määrin piispojen saappaisiin kirkon eturivin viranhaltijoina. Näin tapahtui sen jälkeen, kun konsistoriaalista elementtiä oli lainsäädännön tasolla heikennetty ja kirkkoneuvoksilta otettu pois äänivalta kirkkohallituksen täysistunnossa. Käytännössä kirkkoneuvoksilla ja heidän muodostamallaan kirkkohallituksen virastokollegiolla oli kuitenkin vahva asema. ${ }^{79}$

Muutoksessa ei ollut kyse pelkästään siitä, että piispat olisivat omaehtoisesti luopuneet auktoriteetistaan. Erilaiset tutkimukset osoittivat arvojen muuntuneen 200o-luvulla, ja yksi tulos oli, että perinteiset auktoriteetit olivat murtuneet. Arvovalta ei enää perustunut yhteiskunnalliseen asemaan, vaan se oli itse ansaittava. Tutkimukset osoittivat myös sitoutumisen kirkolliseen auktoriteettiin heikentyneen suomalaisten keskuudessa. ${ }^{750}$ Muutos näkyi kirkolliskokouksen työskentelyssä. Esimerkiksi 2005 rehtori Teuvo V. Riikonen kiinnitti kriittistä huomiota vallinneisiin megatrendeihin, kuten auktoriteettien halveksuntaan. Samassa puheessa hän hieman myöhemmin puuttui toiseen aikakauden ilmiöön, elämänkatsomusten sekoitukseen:
Hyvänä esimerkkinä tästä on kirkkoministerimme Tanja Karpela, joka käy täällä meille puhumassa kirkon merkityksestä hautausmaiden ylläpitäjänä, käväisee välillä halimassa äiti-Ammaa ja polvistuu uuden paavin edessä. Täydellisestä suorituksesta puuttuu enää Luther-säätiön jäsenyys. ${ }^{751}$

Vähintään yhtä paljon kuin ministerin suhtautumisesta paaviin tai halauksistaan tunnettuun intialaiseen uskonnolliseen äitihahmoon puheen sanat kertoivat siitä auktoriteettien murtumisesta, johon Riikonen itse oli kriittiseen sävyyn viitannut. Aiempina vuosikymmeninä ministereistä oli puhuttu kirkolliskokouksessa toisenlaiseen tyyliin, korostetun ammatillisesti. Heidän julkinen arvostelunsa oli ollut harvinaista.

Uudella vuosituhannella tilanne alkoi muuttua. Erityinen rajakohta oli vuosi 2010, jolloin paine kirkkoa kohtaan oli kova. Kesäkuussa Uusi Tie -lehden päätoimittaja, kirkolliskokousedustaja Leif Nummela totesi pääkirjoituksessaan, että kirkon johtajien luopuessa uskosta "väistämätön käytännön ratkaisu" oli "lakata kokonaan käyttämästä harhaopettajien hengellisiä palveluja”. Samalla Nummela nimesi viisi piispaa, jotka olivat ilmoittaneet kannattavansa samaa sukupuolta olevien parisuhteen siunaamista. ${ }^{752}$ Vähitellen mukaan tulivat myös kirkkokuntien väliset jännitteet. ${ }^{753}$ Olavi Rimpiläinen oli aikoinaan korostanut kirkon virkaa jumalallisena asetuksena ja edistänyt piispanviran tunnusten käyttöä. Toimimalla "tunnustuksellisten" piispana yli 


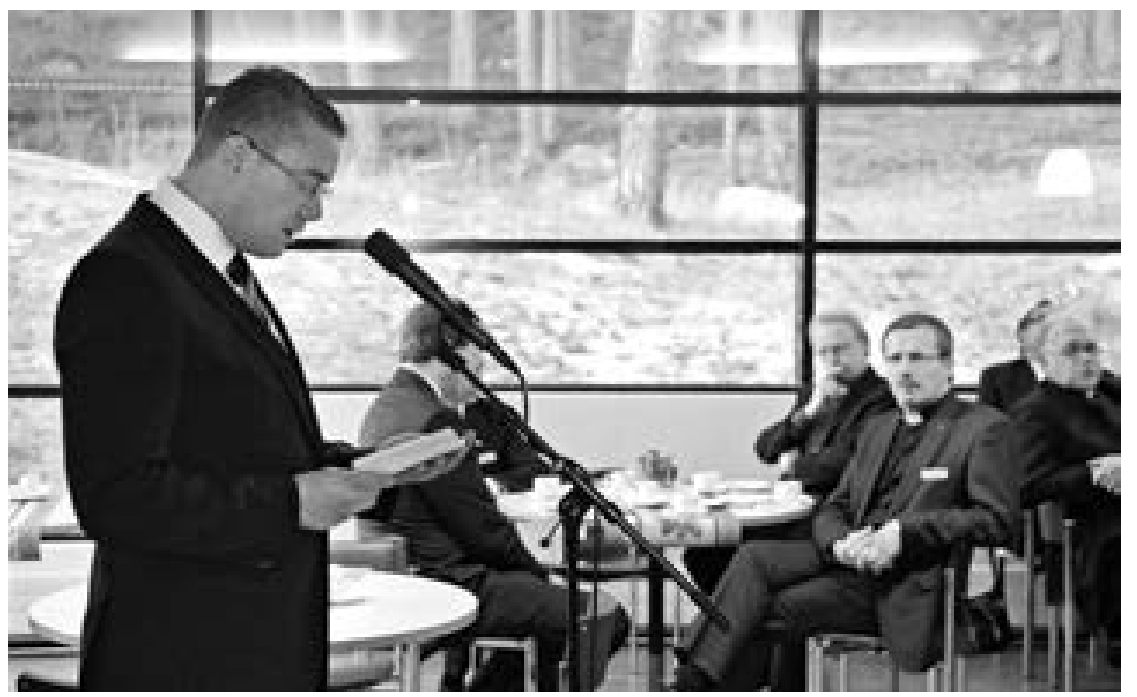

Kulttuuriministeri Stefan Wallin lausui valtioneuvoston tervehdyksen syksyllä 2010. Arkkipiispa Kari Mäkinen, kansliapäällikkö Jukka Keskitalo ja kirkkoherra Kari Pekka Kinnunen kuuntelivat keskittyneesti. Arkkipiispan tavoin Wallin otti esille parisuhdelain seuraukset, mikä johti myöhemmin täysistunnossa esitettyyn arvosteluun. Kuva: Kirkkohallitus / Aarne Ormio. hiippakuntarajojen hän oli kuitenkin paradoksaalisesti vauhdittanut muutosta, jossa hiippakuntaan sidottu piispan johtajuus oli alkanut murentua. "Omaa" piispaa oli alettu etsiä hiippakuntarajoista välittämättä.

Lopulta vuoden 2010 syysistuntokaudella sekä arkkipiispa Kari Mäkisen avauspuhe että kulttuuriministeri Stefan Wallinin tervehdyssanat joutuivat täysistunnossa arvioinnin kohteeksi. Jotkut edustajat katsoivat puheiden sisältäneen painostusta ja ohjailua parisuhdelain seurausten käsittelyä silmällä pitäen. ${ }^{754}$ Aiemmin nämä kaksi kirkolliskokouksen puitteisiin kuuluvaa puheenvuoroa oli jätetty täysistunnossa julkisen arvostelun ulkopuolelle. Niihin oli viitattu silloin, kun niistä oli etsitty tukea omille ajatuksille, mutta nyt tilanne oli muuttunut. Muutenkin piispat saivat kuulla hoitaneensa huonosti tehtäviään ${ }^{755}$. Erkki Kujala peräsi arkkipiispa Mäkiseltä jopa anteeksipyyntöä tämän lausunnoista televisiohaastattelussa. ${ }^{756}$ Kriittisen arvioinnin kohteeksi joutui vielä yksi alue, joka oli pitkään säilynyt erillään täysistunnon ristiriidoista - kirkolliskokouksen jumalanpalveluselämä. Piispallinen auktoriteetti ei säilynyt rikkumattomana edes saarnatuolissa. ${ }^{757}$

Piispojen asema seuraili tasavallan presidentin asemaa. Molemmissa tapauksissa siirryttiin 1990-luvulla kaksivaiheiseen vaaliin, jonka toisella kierroksella oli vastakkain kaksi ehdokasta. Varsinkin presidenttiä valittaessa vaaliasetelmat kärjistyivät toisella kierroksella, ja "koko kansan presidentit" alkoivat olla harvinaisia. Sama piirre alkoi olla huomattavissa piispojen osalta. Lisäksi valtiollisessa päätöksenteossa siirryttiin perustuslakiuudistuksen myötä 200o-luvun alkaessa ratkaisevasti parlamentarismiin. Muutos näkyi myös kirkossa: kirkkohallituksen asema korostui samaan tapaan kuin valtioneuvoston rooli, mutta samalla terävöityi molempien elinten parlamentaarinen valvonta. Kirkkohallituksen valmistelu- ja toimeenpanomahdollisuuksien vahvistuminen lisäsi siten välillisesti myös kirkolliskokouksen valtaa. 
Häviäjiä olivat niin valtiossa kuin kirkossa perinteiset yksittäiset auktoriteetit: tasavallan presidentti ja piispat. Piispainkokouksen valmisteluorganisaatio tosin vahvistui, mutta yksittäisen piispan asema heikkeni. Hiippakuntarajat ylittävä uusi ryhmätoiminta ja auktoriteetit kyseenalaistava ilmapiiri johtivat siihen, että hiippakuntaryhmät ja erityisesti niiden perinteiset johtohahmot - piispat - menettivät kirkolliskokouksessa merkitystään. Laajennetun piispainkokouksen toiminta oli päättynyt 1973, mutta sen perintö oli vielä pitkään heijastunut kirkolliskokouksen työskentelyyn. Kirkkoneuvos Ahti Auranen oli 1970-luvun lopulla valittanut, että vaaleilla valitut kirkolliskokousedustajat seurasivat äänestyksessä usein oman hiippakuntansa piispan linjaa ${ }^{758}$. Sen sijaan uudella vuosituhannella valta jakautui aiempaa tasaisemmin. Kirkolliskokous oli muuttunut "laajennetusta piispainkokouksesta" kohti kirkon edustajien kokousta. 


\section{Koroisten kokous}

Piispa Tuomas siirsi piispanistuimen 1200-luvun alkupuolella Nousiaisista Räntämäelle Koroisiin. Tuohon aikaan kristinusko oli vähintään ulkonaisesti voittanut alaa aina Hämettä myöten, mutta lähetyskausi oli kesken. Vanhat uskomukset pitivät pintansa vielä vuosisatoja. Koroisten kaudella hiippakunta vahvistui, kun sille perustettiin tuomiokapituli 1276. Koroisten aika kesti kuitenkin vain vuosisadan lopulle, jolloin uusi tuomiokirkko rakennettiin Unikankareelle. Koroisten vanha kauppapaikka oli jäänyt syrjään, ja tuomiokirkko haluttiin uuteen kaupalliseen keskukseen.

Kun Turun tuomiokapitulin perustamisesta oli kulunut 600 vuotta, tuomiokirkon kupeessa alkoi kokoontua luterilainen kirkolliskokous. Tällä kaupungin keskuspaikalla kokous säilyi lähes sata vuotta, kunnes se 1974 siirtyi Räntämäelle. Alkoi kirkolliskokouksen ”Koroisten kausi". Suomen kirkon korkein elin siirtyi valtakeskuksesta ja ihmisvilinästä takaisin Räntämäen hiljaisille omakotialueille, joiden niityiltä se - tosin silloin Turun tuomiokapitulin muodossa - oli aikoinaan etsiytynyt keskuspaikoille.

\section{KOHTI KANSANVALTAA}

Turun piispanistuimen siirtäminen Koroisista Unikankareelle oli ollut piispanvallan vahvistumisen aikaa. Kirkon johtajista oli vähitellen tullut hiippakuntansa alueen mahtimiehiä. Vuoden 1974 kirkolliskokousuudistuksen yhteydessä pyrittiin jossain määrin päinvastaiseen suuntaan: aikakauden yleisten ihanteiden mukaisesti kansanvaltaisuutta oli määrä vahvistaa kirkon hallinnossa. Laajennettu piispainkokous, jossa piispoilla oli ollut keskeinen valta-asema, lakkautettiin, ja siltä siirrettiin tehtäviä maallikkoenemmistöiselle kirkolliskokoukselle.
Kirkolliskokous oli aiemmin kokoontunut lakimääräisesti viiden vuoden välein, mutta uudessa järjestelmässä se piti istuntoviikon säännöllisesti kaksi kertaa vuodessa, touko- ja marraskuussa. Uudistettu kirkolliskokous päätti kirkollisista kirjoista ja kokonaiskirkon taloudesta sekä ohjasi kokonaiskirkon toimintaa. Lisäksi sillä oli perinteiseen tapaan yksinoikeus tehdä kirkkolakia koskevia ehdotuksia, jotka eduskunta saattoi vain hyväksyä tai hylätä. Uutena tehtäväalueena kirkolliskokous sai yleisvaltuutuksen käsitellä uskon ja opin kysymyksiä. Kirkolliskokouksen tehtävät lisääntyivät, mutta samalla elin siirtyi osaksi kirkon arkea.

Neljän vuoden välein valittiin hiippakunnittain 32 pappis- ja 64 maallikkoedustajaa. Maallikkoedustajien vaali säilyi välillisenä vaalina, jonka toimittivat seurakuntien luottamushenkilöiden valitsemat valitsijamiehet. Demokratian korostuksen mukaisesti vaalissa otettiin kuitenkin enemmistövaalin vaihtoehtona käyttöön suhteellinen vaalitapa - tosin ilman ehdokasasettelua. Käytännössä valmistelut ajautuivat kulissien taakse, ja vaalia arvosteltiin salamyhkäisyydestä. Maallikkoedustajat olivat edelleen valtaosin korkeasti koulutettuja virkamiehiä, joista erittäin suuri osa toimi opetusalalla. Maallikkoedustajien vaalin moninkertainen välillisyys vaikutti osaltaan kirkolliskokouksen jäsenten ammattijakauman kapeutumiseen. Pappisedustajat puolestaan olivat johtavaa papistoa. Lähes puolella kaikista kirkolliskokousedustajista oli selvä herätysliiketausta.

Vähitellen edustajien ammattijakauma monipuolistui ja kokouksen edustuksellisuus tässä suhteessa parantui. Erityisesti 1990-luvun alkuvuosien taloudellinen lama sai etsimään uutta dynaamisuutta, mikä heijastui myös edustajavalintoihin: maallikkoedustajien vaalissa yksi- 
tyisen sektorin edustajat menestyivät aiempaa paremmin, ja pappisedustajien vaalissa kirkkoherrat joutuivat antamaan tietä erityistehtävissä toimiville papeille. Silti tutkimuskauden loppuun asti tyypillinen maallikkoedustaja oli johtavassa asemassa oleva julkisen sektorin edustaja.

Keskustelu pappisviran avaamisesta naisille oli 1970ja 1980-luvulla vilkasta ja heijastui kirkolliskokousvaaleihin. Naisedustajien osuus kasvoi voimakkaasti, mikä myös osaltaan kasvatti opetusalalla toimivien määrää kirkolliskokouksessa - olivathan korkeasti koulutetut naiset toimineet perinteisesti juuri opetusalalla. Naisedustajien arvovalta oli aluksi heiveröinen. Vuodesta 1982 lähtien kirkolliskokouksen varapuheenjohtajaksi valittiin kuitenkin säännöllisesti nainen. Muutenkin naiset saivat vähitellen aiempaa näkyvämpiä tehtäviä kirkon keskushallinnossa muun muassa sukupuolikiintiöiden myötä. Sen sijaan naisten osuus kirkolliskokousedustajista alkoi laskea 1990-luvulla, kun vaaleihin ei enää liittynyt naisten asemaa koskevaa ohjelmallista tavoitetta. Sitä paitsi naisehdokkaiden määrän kasvaessa äänten keskittäminen vaikeutui.

Samoin kävi nuorten aikuisten osalta. Heidän valitsemisekseen tehtiin paljon työtä 200o-luvulla samaan aikaan, kun tutkimukset ja kirkon jäsentilastot osoittivat alle 30-vuotiaiden sitoutumisen kirkkoon heikentyneen nopeasti. Nuorten ehdokkaiden määrän kasvu vaikeutti kuitenkin käytännössä heidän pääsyään kirkolliskokoukseen. Maallikkoedustajien keski-ikä päinvastoin nousi selvästi 2000-luvulla, mikä heijasteli kirkon jäsenistön ikääntymistä. Seurakuntatasolla kirkolliskokous onnistui lisäämään nuorten mahdollisuuksia osallistua päätöksentekoon, kun se 2007 hyväksyi seurakuntavaalien äänioikeusikärajan alentamisen 16 vuoteen. Kirkolliskokous seurasi kansainvälisiä esikuvia, mutta suomalaisessa yhteiskunnassa, jossa samaan aikaan keskusteltiin kunnallisen äänioikeuden antamisesta 16-vuotiaille, se oli edelläkävijä.

Maallikkoedustajien vaalissa siirryttiin kokonaan suhteelliseen vaalitapaan vuonna 1986 ja pappisedustajien vaalissa kymmenen vuotta myöhemmin. Vaalisäännökset eivät enää lähteneet siitä, että mahdollisimman laajalla konsensuksella valittaisiin luotettuja kirkon edustajia alueellisesti. Sen sijaan oleellista oli turvata oikeudenmukainen paikkamäärä erilaisille mielipideryh- mittymille. Vaalisäännökset muuttuivat nopeammin kuin asenteet. Alueellisesti tai puoluepoliittisesti kootut ehdokaslistat olivat löyhiä ja ylläpitivät henkilövaalin perinnettä, vaikka tuo perinne sopi huonosti yhteen suhteellisen vaalitavan kanssa. Ehdokaslistojen ideologinen löyhyys oli myös paljolti syynä siihen, ettei kirkolliskokoukseen syntynyt kiinteitä edustajaryhmiä.

Tilanne alkoi muuttua vähitellen 1990-luvulla, ja muutos jatkui seuraavalla vuosikymmenellä, kun selvästi kirkkopoliittiset ehdokaslistat yleistyivät. Niillä oli yksityiskohtaisia päämääriä, joita edustajat pyrkivät yhdessä toteuttamaan kirkolliskokouksessa. Vaaleissa saivat eniten näkyvyyttä valitsijayhdistykset, joilla oli esittää yksiselitteinen ohjelma. Muutos heijastui kirkolliskokouksen keskusteluilmapiiriin. Kokous, joka oli 1980ja 1990-luvulla keskustellut melko hillitysti, alkoi arvomurroksen keskellä 2000-luvulla polarisoitua. Samalla riippumattoman edustajan ideaali, joka oli kirkolliskokouksessa - toisin kuin eduskunnassa - säilynyt pitkään myös käytännössä, alkoi väistyä. Entistä useammin ajateltiin, että kirkolliskokouksen jäsen edusti taustaryhmäänsä.

Vaikka kirkolliskokouksen maallikkoedustajien vaali ei ollut perusluonteeltaan puoluepoliittinen, kokoomus, keskusta ja vähitellen myös sosiaalidemokraatit vakiinnuttivat asemansa ehdokasasettelussa. Tästä syystä muutokset poliittisessa kentässä eivät heijastuneet nopeasti kirkolliskokoukseen. Läpi tutkimuskauden oli valtakunnallisesti merkittäviä puolueita, joiden kannattajia ei päätynyt kirkolliskokoukseen: tutkimuskauden alkupuolella kansandemokraatit ja kauden lopulla perussuomalaiset. Maallikkoedustajien puoluejakauma oli leimallisen porvarillinen. Edustajille 2011 tehdyn kyselyn perusteella kirkolliskokoukseen valittu papisto vastasi puoluekannatukseltaan kansan keskiarvoa selvästi paremmin kuin maallikkoedustajat. Pappiskiintiö, jota oli joskus pidetty kirkolliskokouksen "epädemokraattisena" osana, turvasi kokoukseen tiettyjä puolueita äänestäneiden seurakuntalaisten edustuksen.

Vuonna 2011 noin puolet edustajista ilmoitti kuuluvansa vähintään löyhästi johonkin herätysliikkeeseen. Osuus oli hyvin samanlainen kuin 1974, mutta herätysliikkeisiin kuuluvat edustajat eivät enää keskittyneet yhtä selvästi tietyille perinteisille herätysliikealueille. Alkuvaiheessa niin kirkolliskokoukselle jätetyissä aloit- 
teissa kuin täysistunnon keskusteluissa olivat olleet esillä pohjoisessa asuvat herätysliikkeiden maallikkovaikuttajat. Vähitellen aloitteiden ja keskustelun painopiste siirtyi kuitenkin etelään. Maaseudun näkökulmasta laaditut kirkkolain säännökset aiheuttivat ongelmia ennen kaikkea etelän suurissa kaupungeissa, mikä johti jatkuvasti aloitteiden tekemiseen. Myös selvästi kirkkopoliittisin päämäärin kootut ehdokaslistat keskittyivät eteläiseen Suomeen, minkä vuoksi kirkolliset rintamalinjat alkoivat hahmottua sieltä käsin.

Pyrkimys kansanvallan vahvistamiseen näkyi vuoden 1974 kirkolliskokousuudistuksessa vielä siten, että virallisten edustajien määrää vähennettiin. Erityisesti virallisia juristijäseniä karsittiin. Jäljelle jäivät korkeimman oikeuden ja korkeimman hallinto-oikeuden valitsemat edustajat, jotka olivatkin 1980-luvulle asti hyvin vaikutusvaltaisia: kirkkolain sisältöä olivat näkyvimmin muokkaamassa henkilöt, joilla ei ollut oikeutta toimia kansanedustajan tehtävässä. Vähitellen kirkon hallintoon tuli kuitenkin aiempaa enemmän montesquieuläisen vallanjaon piirteitä. Yksi vaihe muutosprosessissa oli, että korkeimpien oikeusistuinten valitsemat edustajat poistuivat kokoonpanosta 1996 tuomioistuinten omasta aloitteesta. Pyrkimys puhdaslinjaiseen vallanjakoon väistyi kuitenkin kirkolliskokouksen tärkeysjärjestyksessä vähemmistön oikeuksien tieltä: kokoonpanoon lisättiin saamelaiskäräjien valitsema saamelaisten edustaja, joka oli kirkolliskokouksen jäsen vuodesta 2000 lähtien.

Virallisina edustajina säilyivät läpi tutkimuskauden piispat, kenttäpiispa ja valtioneuvoston määräämä edustaja. Viimeksi mainitun merkitys kasvoi 1980-luvulta lähtien samaan aikaan, kun useat muut kiinnikkeet kirkon ja valtiovallan väliltä katkesivat. Piispat taas olivat kirkolliskokousuudistuksen jälkeisinä vuosina kokouksessa ehdottomia vallankäyttäjiä, joten kirkolliskokous oli työskentelytavoiltaan edelleen eräänlainen "laajennettu piispainkokous". Arkkipiispa toimi kirkolliskokouksen puheenjohtajana, ja toiset piispat johtivat useimpia valiokuntia. Sittemmin vaaleilla valittujen edustajien osuus valiokuntien johdossa kasvoi hitaasti. Vaikka myös eri valiokuntien koostumukset monipuolistuivat vähitellen, kaikkein merkittävimpiä kirkollisia uudistuksia valmistelleissa valiokunnissa oli läpi tutkimuskauden pappisenemmistö.
Piispojen itseoikeutettua jäsenyyttä sen enempää kuin 32 jäsenen pappiskiintiötä ei missään vaiheessa kyseenalaistettu kovin voimakkaasti. Päinvastoin 1970-luvun lopulla työskennellyt kirkkojärjestyskomitea totesi, että kirkon hallinnon kaikilla tasoilla oli turvattava niin seurakuntalaisten edustus kuin viran läsnäolo. Huomio alkoikin 1970-luvun edetessä siirtyä entistä selvemmin kirkon syvimpään olemukseen ja tehtävään. Uskonnollisuudelle ja kirkolle aiempaa myönteisempi ilmapiiri mahdollisti näkökulmanmuutoksen. Kehityssuunta oli päinvastainen kuin samaan aikaan Ruotsissa, missä kirkolliskokous sitoutui paljon lähemmin poliittiseen yhteiskuntaan kuin Suomessa.

Kirkolliskokousuudistuksen jälkeisinä vuosina viralliset edustajat tekivät täysistunnoissa ylivoimaisesti useimmin muutosehdotuksia pohjaesitykseen. Keskimäärin vain joka seitsemäs niistä hylättiin, mikä kertoo virallisten edustajien arvovallasta. Täysistunnon merkitystä kirkolliskokouksen päätöksenteossa taas kuvastaa, että maallikkoedustajienkin tekemistä muutosehdotuksista hyväksyttiin noin puolet. Vaikka piispojen valta oli täysistunnossa huomattava, hiippakunnallisen toiminnan kehittäminen oli jälkeenjäänyttä ja piispainkokouksen arvovalta horjuva. Hiippakuntien tilanne helpottui, kun kirkolliskokous perusti tuomiokapituleihin uusia virkoja. Sen sijaan piispainkokous alkoi vähitellen näyttäytyä hiippakuntatason edunvalvojana, minkä vuoksi kirkolliskokous suhtautui usein epäillen piispainkokouksen esittämiin teologisiin perusteluihin.

Tutkimuskauden loppuvuosina piispainkokouksen resurssit vahvistuivat, ja kirkolliskokous seurasi olennaisimmissa kysymyksissä piispainkokouksen linjaa. Sen sijaan hiippakuntarajat ylittävä uusi ryhmätoiminta ja auktoriteetit kyseenalaistava yleinen arvomuutos johtivat siihen, että alkuaikojen vallankäyttäjät, yksittäiset piispat, menettivät valtaansa. Oli paradoksaalista, että toisaalta tutkimuskauden aikana kirkollisessa keskustelussa vakiintui konstitutiivinen virkakäsitys ja alettiin teologisesti korostaa kirkon erityistä virkaa.

Kirkolliskokouksen työskentelytavat vakiintuivat erityisesti 1980-luvulta lähtien. Valiokuntien valta kasvoi samaan tapaan kuin yleisesti eurooppalaisissa parlamenteissa. Edustajien into ja tarve esittää muutoksia laskivat selvästi. Valtiollisessa päätöksenteossa siirryttiin perustuslakiuudistuksen myötä 2000-luvun alkaes- 
sa ratkaisevasti parlamentarismiin. Myös kirkossa näkyi muutos: kirkkohallituksen asema korostui samaan tapaan kuin valtioneuvoston rooli valtiossa, mutta samalla terävöityi molempien elinten parlamentaarinen valvonta. Eduskuntaa esikuvana käyttäen kirkolliskokouksen työjärjestykseen otettiin välineitä, joilla parannettiin edustajien tiedonsaantia ja vaikutusmahdollisuuksia jo asioiden valmisteluvaiheessa.

Kirkkohallituksen valmistelu- ja toimeenpanomahdollisuuksien lisääntyminen vahvisti välillisesti myös kirkolliskokouksen valtaa, joskin kirkolliskokouksessa arvosteltiin ajoittain kirkkohallitusta liian itsenäisestä vallankäytöstä. Kirkolliskokouksen työskentelyssäkin kirkkoneuvosten osa muuttui aiempaa näkyvämmäksi. He astuivat ainakin jossain määrin piispojen saappaisiin kirkon eturivin viranhaltijoina. Näin tapahtui sen jälkeen, kun kirkkohallituksen täysistunnossa kirkkoneuvoksen virassa olevat oli siirretty päätöksentekijöistä esittelijöiksi ja päätösvalta oli keskitetty luottamushenkilöille.

Erityisesti 1990-luvun alun lamavuosina kirkolliskokouksessa kasvoi halu keventää kirkon hallintoa valtionja kunnallishallinnon esikuvien mukaisesti. Maallikkoedustajat eivät kuitenkaan suostuneet kaventamaan edustuksellisuutta, jolloin menetettiin yksi keino hallinnon keventämiseen. Sen sijaan he olivat yleensä erittäin halukkaita keventämään hallintoa purkamalla alistussäännöksiä ja siirtämällä päätösvaltaa paikallisseurakuntiin. Kirkon työntekijät eivät kuitenkaan kovin usein kannattaneet tällaista keinoa. Eri osapuolet olivat valmiita keventämään hallintoa lähinnä sellaisilla toimilla, jotka lisäsivät omaa valtaa tai ainakin säilyttivät sen ennallaan. Kun vielä lama jäi taakse, muutokset osoittautuivat vaikeiksi. Vähitellen kirkolliskokous onnistui siirtämään päätösvaltaa paikallistasolle. Samalla alun perin maaseutuyhteiskuntaan suunniteltuja seurakuntahallinnon säännöksiä muutettiin hitaasti ja vaivalloisesti suuriin kaupunkiseurakuntiin sopiviksi.

Aina 200o-luvun alkupuolelle asti saattoi sanoa, että kirkolliskokous oli toimissaan pienoiskuva kansasta. Monissa julkisuutta saaneissa ratkaisuissa kokouksen mielipidejakauma ei olennaisesti poikennut koko kansan vastaavasta jakaumasta. Tässä mielessä kirkolliskokousuudistuksessa huomion kohteena ollut edustuksellisuus toteutui hyvin. Uuden vuosituhannen ensimmäisellä vuosikymmenellä tilanne alkoi kuitenkin muuttua: väestön enemmistön mielipiteet erkaantuivat nopeasti aktiivisten seurakuntalaisten näkemyksistä varsinkin seksuaalietiikan osalta. Keskeisenä kysymyksenä oli, miten kirkolliskokous kykenisi reagoimaan yhteiskunnan moniarvoistumiseen.

\section{KIRKOLLISKOKOUS MONIARVOISTUVASSA YHTEISKUNNASSA}

Koroisten kaudella 1200-luvulla tuomiokapitulin perustaminen oli tehostanut kirkollista hallintoa. Samanlainen päämäärä sisältyi kirkolliskokousuudistukseen 1970-luvun alkupuolella. Yhteiskunnan rakenteet ja arvot olivat nopeassa muutoksessa, ja kirkolliskokouksen kokoustahtia tiivistämällä kirkon päättäjät toivoivat pystyvänsä vastaamaan muutosvauhtiin. Viimeiset vanhamuotoiset kirkolliskokoukset olivat joko toteuttaneet tai käynnistäneet monia laajoja uudistushankkeita, mutta kirkolliskokousuudistuksen myötä siirryttiin jatkuvaan, vähittäiseen uudistamiseen. Kirkolliskokouksen ehdotukset kirkkolain muuttamiseksi kuormittivat kuitenkin valtiollista lainsäädäntöjärjestelmää ja törmäsivät siellä hidasteisiin. Toisaalta kirkolliskokouksen uusikin kokoontumistahti osoittautui valtiovallan lausuntopyyntöjen edessä liian verkkaiseksi. Lausunnonantotehtävä siirtyi vähitellen kirkkohallitukselle. Se kykeni reagoimaan nopeasti, mutta kirkolliskokous jäi sivuun monista kirkon kannalta tärkeistä valtiollisista lainsäädäntöhankkeista.

Kirkolliskokouksen työskentelyn nopeutuessakin kolmen neljäsosan määräenemmistövaatimus oli omiaan rauhoittamaan muutosvauhtia. Erityisesti kun esitykset pappisviran avaamisesta naisille kaatuivat vuosina 1976 ja 1984, lehdistössä virisi syytöksiä vanhoillisuudesta. Taustalle painui se, että kirkolliskokousedustajien äänestyskäyttäytyminen muistutti hyvin pitkälti koko kansan mielipidejakaumaa. Päätöksentekoa hidasti edelleen tutkimuskauden edetessä siirtyminen kokonaan suhteelliseen vaalitapaan kirkolliskokousvaaleissa. Esimerkiksi naispappeusesitys oli mahdollista hyväksyä 1986 paljolti siksi, että pappisedustajien vaalissa oli vielä tuolloin käytössä enemmistövaali: naispappeutta kannattanut papiston enemmistö valtasi useimmissa hiippakunnissa edustajapaikat.

Suhteellisen vaalitavan myötä erilaiset, toisistaan usein melko kaukana olleet mielipideryhmät alkoivat 
saada äänensä kuuluviin. Riittävän yksimielisyyden saavuttaminen vaikeutui. Kirkko eli tutkimuskauden loppuvuosina myös mukana länsimaisia kirkkoja, suomalaista yhteiskuntaa ja maan poliittista kenttää koskettaneessa polarisaatiokehityksessä, joka oli osin seurausta vuoden 2008 talouskriisistä. Monissa raukeamispäätöksissä näkyi lisäksi lainsäädännön monimutkaistuminen. Valtiollisen lainsäädännön alueen laajeneminen ja kirkolliskokouksen omat ratkaisut rajasivat kirkolliskokouksen liikkumatilaa, vaikka muodollisesti kirkon ja valtion väliset sidokset höllentyivät. Kirkolliskokous ei voinut 2000-luvulla muokata säännösesityksiä yhtä vapaasti kuin 1970-luvulla, jolloin se oli ollut monessa mielessä paitsi päätöksentekoelin myös valmisteluorganisaatio. Sen sijaan 200o-luvulla valmistelu oli kirkkohallituksen käsissä, ja tyytymättömyys esityksen johonkin osaan saattoi johtaa muokkausten tekemisen sijaan koko esityksen hylkäämiseen.

Kirkolliskokousuudistusta suunniteltaessa 1960-luvun lopulla ja 1970-luvun alussa oli eletty vasemmistoradikalismin vuosia. Kirkolliskokous oli joutunut sopeutumaan lukuisiin kirkon kannalta epämieluisiin muutoksiin, ja vielä uudistetun kirkolliskokouksen aloittaessa työtään keväällä 1974 tulevaisuus näytti hyvin epävarmalta. Tuolloin kirkolliskokouksen keskustelut ja kannanotot osoittivat kuitenkin uuden vaiheen alkaneen: kirkolliskokous ei ollut enää valmis antamaan periksi samalla tavalla kuin muutamaa vuotta aiemmin. Kirkolliskokous saavutti myös tuloksia esimerkiksi puolustaessaan uskonnonopetuksen tuntimäärää lukiossa. Vähitellen 1970-luvun lopulla yleisen asenneilmaston muuttuminen vähensi tarvetta vetää tiukasti rajaa muuhun yhteiskuntaan ja samanaikaisesti antoi kirkolle tilaa korostaa omalakisuuttaan. Kirkolliskokous toimi 1970-luvun lopulla ja 1980-luvun alussa aktiivisesti ja kirkon omista lähtökohdista käsin eräänlaisena kansan omanatuntona.

Kirkolliskokous pyrki yhdistämään kansankirkossa toisiinsa avaruuden ja tunnustuksellisuuden. Tälle pohjalle rakentui kirkkojärjestyskomitean 1970-luvun lopulla laatima kansankirkollinen ohjelma. Sama ajattelutapa näkyi myös vuoden 1986 naispappeuspäätöksessä: kirkolliskokous sisällytti päätökseen tahdonilmaisunaan lisäponnen, jolla oli määrä turvata päätöksen vastustajien toiminnanvapaus kirkossa. Vaikka ponsi ei ollut luon- teeltaan juridinen, ponnen vastustajien esittämät epäilykset lisäsivät täysistuntokeskustelun edetessä ponnen painoarvoa ja vaikeuttivat sen tulkintaa. Yhtä lailla kirkolliskokous joutui ristiriitaisiin tilanteisiin myöhemmin, kun se samanaikaisesti korosti kirkon jäsenyyden merkitystä mutta vähensi jäsenten velvollisuuksia. Osoittautui vaikeaksi yhtä aikaa korottaa kynnystä erota kirkosta ja helpottaa kirkkoon liittymistä.

Turun tuomiokapituli oli perustettu Koroisten piispanistuimen yhteyteen kirkon elimeksi. Sittemmin reformaatiokaudella valtio oli kuitenkin ottanut tuomiokapitulit omiksi virastoikseen. Jo kirkolliskokouksen perustamisen yhteydessä 18oo-luvulla oli ollut pyrkimyksenä vähentää kirkon riippuvuutta valtiovallasta. Kirkolliskokousuudistuksen suunnittelun aikaan 1960-luvun lopulla ja 1970-luvun alussa vaatimukset kirkon ja valtion välisten suhteiden höllentämisestä olivat voimakkaita. Keskustelunaiheisiin kuului, tuliko tuomiokapitulit palauttaa kokonaan kirkon virastoiksi.

Keskustelu kirkon ja valtion välisten siteiden katkaisemisesta vaimeni vähitellen 1970-luvun edetessä samalla, kun poliittinen radikalismi laantui ja yleinen ilmapiiri muuttui kirkon kannalta aiempaa myönteisemmäksi. Kirkolliskokousedustajillakin oli entistä vähemmän halua luopua kirkon ja valtion välisistä kytköksistä. Kirkolliskokouksen käytännön päätösten näkökulmasta uusi aika ei kuitenkaan merkinnyt itsenäisyyden vähenemistä. Päinvastoin kirkolliskokous arvioi asemansa niin vahvaksi, että se uskalsi 1982 tehdä päätöksiä, joilla se asettui valtiovarainministeriön ja työmarkkinajärjestöjen tahtoa vastaan. Kirkolliskokous esimerkiksi esitti kirkon omista lähtökohdista käsin, että loppiainen ja helatorstai, jotka vuoden 1971 ylimääräinen kirkolliskokous oli taipunut siirtämään lauantaihin, palautettaisiin entisille paikoilleen. Parlamentaarisen järjestelmän tuki ja uudet henkilöyhteydet valtakunnan hallitukseen olivat keskeisiä tekijöitä siinä, että kirkolliskokouksen tahto lopulta toteutui. Siten kirkon ja valtion läheiset suhteet saattoivat tietyissä tilanteissa lisätä kirkon itsenäisyyttä.

Taloudellinen lamakausi antoi 1990-luvun alussa uutta vauhtia kirkon ja valtion välisten sidosten purkamiselle. Kirkkolain kokonaisuudistus avasi tien monien pinnan alla kyteneiden uudistusvaatimusten nopeaan toteutumiseen. Edelleen Ruotsissa 1995 tehty periaate- 
päätös kirkon ja valtion erottamisesta vuoden 2000 alusta lukien vilkastutti keskustelua. Suomessakin kirkolliskokous hyväksyi lopulta nopealla tahdilla säännösmuutokset, joiden myötä tuomiokapitulien ylläpito ja piispojen nimittäminen siirtyivät valtiolta kirkolle. Vaikka kirkolliskokous ei missään vaiheessa todella koetellut kirkon itsemääräämisoikeuden rajoja vaan halusi pitää kirkkolain pitkälti yhdenmukaisena valtiollisen lainsäädännön kanssa, kokouksen voi katsoa noudattaneen 1990-luvulla kirkkojärjestyskomitean laatimaa ohjelmaa. Sen mukaan kirkon tuli pyrkiä riippumattomuuteen valtiosta ja vastaavasti samastua aiempaa voimakkaammin maailmanlaajuiseen kirkkoon.

Kirkolliskokous käsitteli 1970-luvulta 1990-luvulle merkittäviä ekumeenisia asiakirjoja. Päätösten valmistelussa pyrittiin kirkon keskushallinnossa teologiseen tarkkuuteen. Kirkolliskokous seurasi tätä valmistelua ja kuunteli erityisesti kulloisenkin arkkipiispan ääntä. Kokous jättäytyi 1970-luvulla Leuenbergin konkordian ulkopuolelle mutta hyväksyi 1990-luvulla Porvoon julistuksen ja Yhteisen julistuksen vanhurskauttamisopista. Ruotsin kirkon tavoin se säilytti tietyn etäisyyden reformoituihin mutta loi yhteyksiä katolilaisiin ja anglikaaneihin.

Läpi tutkimuskauden herätysliiketaustaiset maallikkoedustajat olivat kirkolliskokouksessa kriittisimpiä ekumeniaa kohtaan. Tässäkään joukossa ei ollut kuitenkaan havaittavissa yhtenäistä linjaa, vaan mielipiteet vaihtelivat niin herätysliikkeiden välillä kuin sisälläkin. Sitä paitsi kirkolliskokouksen kaikkein yhtenäisin herätysliikeryhmä, vanhoillislestadiolaiset, alkoi 1990-luvulta lähtien rakentaa luottamusta kirkon johtoon, mikä näkyi osaltaan ekumeniakritiikin hiipumisena. Muutenkin kirkolliskokouksessa kuullun arvostelun painopiste muuttui yleisluonteisesta, ohjelmallisesta ekumeniakritiikistä ekumeenisten asiakirjojen sisällön yksilöityyn arvosteluun. Kansallisesti värittynyt huoli suomalaisesta kristillisyydestä antoi tilaa opilliselle kritiikille, jonka osalta rintamalinjat kulkivat eri maiden ja kirkkojen läpi.

Ekumenian ohella kansainvälisistä teemoista nousivat 1980-luvulla esille rauhankysymys ja eteläisen Afrikan rotusorto. Sittemmin Neuvostoliiton alkava avautuminen ja viimein sosialistisen järjestelmän romahtaminen loivat kirkolliskokoukselle tilaa käsitellä vapaasti ItäEuroopan kristittyjen avuntarvetta. Seuraavina vuosina puolestaan keskustelu Euroopan unionista linkittyi vahvasti ekumeenisten asiakirjojen käsittelyyn.

Kirkkojärjestyskomitean tavoitteen mukaisesti kirkolliskokous korosti 1990-luvulla yhteyttään kirkkojen perheeseen, vaikka vuosikymmenen alkupuolella taloudellinen lama olikin kääntämässä huomiota kotimaan kysymyksiin. Erilaisia uudistuksia käsitellessään kirkolliskokous suhteutti omat ratkaisunsa osaksi eurooppalaisia kehityssuuntia ja maailmanlaajuista kirkkoa. Tietynlainen vastavaikutus seurasi 200o-luvulla, jolloin kirkolliskokous - aivan samoin kuin koko suomalainen yhteiskunta ja moni muu läntinen kirkko - alkoi kääntyä sisäänpäin ja keskittyä omiin ongelmiinsa. Sitä paitsi Porvoon julistuksen edellyttämiä käytännön toimia ryhdyttiin tulkitsemaan toden teolla vasta julistuksen hyväksymisen jälkeen: käytännössä ongelmat jouduttiin kohtaamaan pitkälti jälkikäteen.

Unikankareelta oli johdettu vuosisatojen ajan vahvaa ja vakiintunutta kirkkoa, mutta 1900-luvun lopun ja 200o-luvun alun kirkko alkoi löytää itsensä uudelleen lähetystilanteesta. Kuten Koroisten aikaan toimitukset olivat seurakunnan yhdysside jäseniinsä, mutta nytkin käsitykset kristinuskon sisällöstä olivat usein hyvin ohuita. Harvojen mielestä "Tapio metsissä pyynnit soi ja Ahti vedestä kaloja toi”, kuten Mikael Agricola oli runoillut sitkeästä kansanuskosta, mutta yhä useampi ilmoitti uskovansa eri tavoin kuin kirkko opetti.

Kirkolliskokous pyrki vastaamaan tilanteeseen uudistaessaan kirkollisia kirjoja. Kirkollisten toimitusten kirja, joka oli jäsenten tavoittamisen kannalta erityisen tärkeä, uudistettiin vain kahden vuosikymmenen välein 1980- ja 200o-luvulla. Liturgiset uudistuskomiteat hakivat vaikutteita kansainvälisestä liturgisesta liikkeestä ja nojautuivat korkeatasoiseen tutkimukseen sekä vanhakirkollisiin esikuviin. Kirkolliskokous taas pohti usein hyvinkin käytännönläheisiä seikkoja ja pyrki parantamaan kirjojen käytettävyyttä. Virsikirjauudistuksen, raamatunkäännöksen ja jumalanpalvelusuudistuksen käsittelyä yhdisti se, että kirkolliskokous pyrki säilyttämään kaikkein tutuimmat osat ennallaan. Eri näkökulmista katsottuna kirjojen tyyli joko rikastui tai rikkoutui kirkolliskokouksessa.

Varsinkin suomen- ja ruotsinkielisen virsikirjaehdotuksen sisältö viritti 1980-luvun puolivälissä vilkkaan julkisen keskustelun. Erityisesti kansallisesti ja kulttuu- 
risesti suuren symboliarvon saaneiden virsien muokkaamista arvosteltiin voimakkaasti niin suomen- kuin ruotsinkielisten keskuudessa. Kirkolliskokous joutui perääntymään palautteen edessä ja palaamaan kohti käytössä olleiden virsikirjojen sävelmiä ja sanamuotoja. Kirkolliskokous ei ollut milloinkaan aiemmin ollut samalla tavalla yhteiskunnallisen keskustelun keskipisteessä kuin 1980-luvun puolivälissä käsitellessään uutta virsikirjaa ja naispappeutta. Laajentunut ja teknisesti kehittynyt media piti asiasta huolen. Kirkolliskokouksessa oli 1970-luvulla keskusteltu paljon yhteiskunnasta, mutta seuraavalla vuosikymmenellä yhteiskunnassa keskusteltiin kirkolliskokouksesta.

Raamatunkäännöskomitean käännösehdotuksesta ei syntynyt samanlaista julkista keskustelua tai palauteryöppyä kuin virsikirjaehdotuksista. Virret koskettivat suomalaisten sisintä toisella tasolla kuin Raamattu. Samasta syystä kirkolliskokouksessa raamatunkäännöstä koskevan keskustelun argumentaatio oli selvemmin kristin- ja kieliopillista kuin virsikirjasta päätettäessä, jolloin oli kuultu monia henkilökohtaisia, tunteikkaita puheenvuoroja. Kirkolliskokouksella ei myöskään ollut paineita poiketa komiteavalmistelun linjasta siinä määrin kuin virsikirjoja uudistettaessa. Kirkolliskokouksen päätökset kirkollisista kirjoista 1980-luvulla ja 1990-luvun alussa osoittivat, että uudistettu kirkolliskokous pystyi viemään suuret hankkeet nopeasti päätökseen.

Kirkon tulevaisuus näytti 1990-luvun alussa hyvin epävarmalta. Sitoutuminen kristinuskon opetuksiin oli tutkimusten mukaan heikentymässä, ja laman myötä taloudelliset näkymät synkkenivät nopeasti. Kirkolliskokouksen aloittaessa jumalanpalvelusuudistusta yhteiskunnalliset ongelmat heijastuivat keskusteluun selvästi. Lisäksi kirkolliskokous joutui kohtaamaan edellisen vuosikymmenen lopulta lähtien voimistuneet, yksilöllistyvän yhteiskunnan lähtökohdista kasvaneet vaatimukset neutraaliudesta. Kirkolliskokous sai käsiteltäväkseen useita valtiovallan uudistushankkeita, joissa näkyi negatiivinen uskonnonvapauskäsitys: kansalaisia oli ennemminkin suojeltava uskonnonharjoitukselta kuin taattava siihen mahdollisuuksia.

Kirkon näkemykset jäivät usein syrjään valmisteluvaiheessa, mutta vähitellen vuosikymmenen edetessä ne otettiin huomioon viimeistään lainsäädäntötyön loppumetreillä. Samaan aikaan sitoutuminen kirkkoon vahvistui uudelleen: vuosikymmenen alussa vain kolmannes suomalaisista oli ilmoittanut uskovansa kristinuskon opettamaan Jumalaan, mutta vuosikymmenen lopulla näin ilmoitti puolet kansalaisista. Taloudellinen lamakausi jäi taakse. Kirkolliskokous saattoi jälleen keskittyä kirkon sisäisiin hankkeisiin, kuten ekumeniaan, virkateologiaan sekä jumalanpalveluksen ja kristinopin uudistamiseen. Kokous kiinnitti huomiota myös vähemmistöjen palvelemiseen tehostamalla saamen- ja viittomakielisten kirkollisten tekstien laatimista. Kirkolliskokous oli 1990-luvun alussa varautunut selviytymistaisteluun, mutta muutamaa vuotta myöhemmin se saattoikin keskittyä pohdiskelemaan liturgian ja opin kysymyksiä kirkon kannalta myönteisessä ilmapiirissä. Kirkolliskokoukselle 199o-luku oli torjuntavoittojen vuosikymmen. Ne ongelmat, joihin vuosikymmenen alussa oli varauduttu, jouduttiin kohtaamaan vasta 2000 -luvulla.

Suomalaisten arvojen muutos ja kirkolliskokouksen vastaus siihen näkyivät erityisen selvästi keskustelussa avioliitosta. Vielä 1970-luvun lopulla kirkolliskokouksessa pohdittiin vakavasti papin oikeutta kieltäytyä vihkimästä eronneita uuteen avioliittoon. Edelleen 1980-luvulla kirkollisten toimitusten kirjaa uudistettaessa kirkolliskokous palautti mukaan riisutun avioliittoon vihkimisen kaavan. Sitä ei kuitenkaan enää suoraan yhdistetty eronneiden vihkimiseen, ja siihen lisättiin aiempaa enemmän kristillistä ainesta. Katekismuksesta 1990-luvun lopulla päätettäessä kirkolliskokouksen täysistunto jo lisäsi kuudennen käskyn selitykseen uudelleenavioitumisen mahdollisuutta koskevia kohtia. Lopulta 2000-luvun alussa kirkolliskokouksessa ei uuteen kirkollisten toimitusten kirjaan enää vaadittu riisuttua vihkikaavaa. Kehityslinja kuvasti asennemuutosta: uuden vuosituhannen alkaessa enää muutama prosentti suomalaisista kielsi ehdottomasti avioeron oikeutuksen. Kirkolliskokouksenkin huomio siirtyi avioerosta vähitellen muihin parisuhdekysymyksiin.

Kirkolliskokous oli 200o-luvun ensimmäisellä vuosikymmenellä keskellä samantapaista yleistä arvomurrosta kuin kirkolliskokousuudistuksen valmistelun aikaan 1960- ja 1970-luvun vaihteessa. Murros kosketti erityisesti seksuaalietiikkaa, ja se eteni hyvin nopeasti sen jälkeen, kun laki samaa sukupuolta olevien rekisteröidystä parisuhteesta oli astunut voimaan 2002. Noina vuosina kirkolliskokous pohti kirkon kantaa asiaan ja joutui 
tasapainoilemaan toisistaan etääntyvien mielipidesuuntien välissä. Kirkolliskokoukseen kohdistuva ristipaine kasvoi suurimmilleen, kun lokakuussa 2010 juuri ennen ratkaisevaa äänestystä nousi kirkosta eroamisten aalto.

Kirkolliskokous päätyi herkkään kompromissiratkaisuun: se antoi piispainkokoukselle tehtäväksi laatia toimintaohjeen parisuhteensa rekisteröineiden pastoraaliseksi kohtaamiseksi. Päätös syntyi yksinkertaisella ääntenenemmistöllä. Tilanne oli hyvin samanlainen kuin 1976, jolloin kirkolliskokous oli todennut, että pappisviran avaaminen naisille oli kirkon opin mukaan mahdollista. Kummassakaan tapauksessa asian takana ei ollut määräenemmistöä, mutta paine jonkinlaisen viestin antamiseksi oli niin kova, että kirkolliskokouksen johto tulkitsi määräenemmistövaatimuksen alan suppeaksi.

Koroisissa piispanistuimen suojana oli 1200-luvulla ollut Liedon Vanhalinna. Uudistunut kirkolliskokous kokoontui toisella läheisellä linnavuorella, Linnasmäellä. Kirkolliskokousuudistuksen tavoitteena oli ollut yhteiskunnan muutoksiin nopeasti reagoiva päätöksentekojärjestelmä, mutta arvojen muutos merkitsikin samalla niiden polarisoitumista: kirkolliskokous joutui kiinnittämään huomionsa hitaaseen kompromissien etsimiseen. Linnavuoresta tuli varsinkin 200o-luvulla turvapaikka, jonka suojissa kohdattiin yhteiskunnan arvomurros ja pyrittiin estämään sisäinen hajoaminen.

\section{LAINSÄÄDÄNTÖTYÖSTÄ TALOUDENPITOON JA TOIMINNALLISIIN STRATEGIOIHIN}

Kaupankäynnin muutos ja väestön siirtyminen olivat johtaneet piispanistuimen siirtämiseen Koroisista Unikankareelle. Kirkolliskokous joutui vastaamaan samanlaisiin muutoksiin 1900-luvun viimeisillä vuosikymmenillä ja uuden vuosituhannen alussa. Kokouksen oli kiinnitettävä jatkuvasti enemmän huomiota niin kirkon omaan talouteen kuin maailmantalouden heilahduksiin. Maan sisäinen muuttoliike lisäsi seurakuntien taloudellista eriarvoisuutta, johon kirkolliskokouksen oli puututtava tasaustoimin. Aiempaa liikkuvamman jäsenistön tavoittamiseksi oli puolestaan mietittävä toiminnallisia keinoja. Ongelmana oli, etteivät toiminnalliset visiot siirtyneet kovin helposti käytäntöön.

Kirkon keskusrahaston talousarviot kasvoivat voimakkaasti 1970- ja 1980-luvulla. Kirkolliskokous perus- ti kymmeniä kirkon yhteisiä virkoja. Kokouksen talousvaliokunta pyrki tosin rajoittamaan menojen paisumista ja toivoi pidemmän aikavälin toiminta- ja taloussuunnittelua. Nelivuotinen toiminta- ja taloussuunnitelma otettiinkin käyttöön 1980-luvulle tultaessa, mutta sen raamit eivät estäneet talousarvioiden paisumista. Viimein vuosikymmenen lopun nopean talouskasvun vuosina kirkko onnistui hillitsemään oman kokonaistaloutensa kasvua. Kääntöpuolena oli, ettei kirkolliskokous vielä tuolloin suostunut aloittamaan eläkerahastointia, joka olisi lisännyt seurakuntien menoja mutta vähentänyt myöhempää painetta eläkemaksuja kohtaan.

Kirkolliskokouksen linja oli johdonmukainen: se katsoi, että niin seurakuntien kuin kokonaiskirkon oli koottava veroja vain kunkin vuoden tarpeisiin. Näillä perusteilla kirkolliskokous kieltäytyi palauttamasta valtiolle sosiaalietuuksien verotuksen tuomia lisätuloja, mutta samoilla perusteilla se torjui itseltään mahdollisuuden ryhtyä kokoamaan rahastoja. Rahastointiajattelu sai sijaa vasta talousennusteiden synkentyessä. Lamavuodet osoittivat seurakuntien veropohjan - erityisesti yhteisöverotulojen - haurauden ja ailahtelevuuden. Aiempien vuosien eläminen kädestä suuhun ei enää lamakokemusten jälkeen käynyt laatuun, ja niin voimakkaan rahastoinnin alkuvaihe ajoittui samaan aikaan leikkausten kanssa. Suurista peloista huolimatta kirkko selvisi 1990-luvusta kuitenkin taloudellisesti melko vähäisin vaurioin.

Myös eläkerahastointi pääsi vauhtiin keskellä lamaa vuonna 1991. Sijoitusten myötä kokonaiskirkon talous, johon jo ennestään vaikutti suhdanneherkkä yhteisövero-osuus, tuli entistäkin riippuvammaksi yritysten menestyksestä. Tässä tilanteessa sijoitustoiminnan eettisyys nousi tärkeäksi puheenaiheeksi. Myös huoli ilmastonmuutoksesta voimistui, ja kirkolliskokous pani 2000-luvulla alulle kirkon ilmasto-ohjelman valmistelun.

Vuodesta 2008 lähtien talouden kriisit veivät jälleen yleisesti huomiota pois maailmanlaajuisista ongelmista omaan kansallisvaltioon ja henkilökohtaiseen toimeentuloon. Jossain määrin samaa muutosta oli nähtävissä myös kirkolliskokouksen keskusteluissa. Lukuisien yhteiskunnallisten toimintamuotojen sijasta tapetille oli uudelleen nousemassa henkilökohtainen pelastussanoma. Edustajat alkoivat vaatia kirkolta uutta missionaarisuutta suomalaisessa yhteiskunnassa. Sen sijaan ulko- 
lähetys säilyi läpi tutkimuskauden kirkolliskokouksen näkökulmasta melko etäisenä aihealueena. Sitä koskevat käytännön linjaukset tehtiin muualla.

Tutkimuskauden kuluessa koko ajan kasvava osa kokonaiskirkon taloudesta siirtyi kirkolliskokouksen suoran päätösvallan ulkopuolelle. Aivan sama muutos koski valtiontalouden osalta eduskuntaa. Kirkon eläkejärjestelmää kehitettäessä kirkolliskokouksen tehtävänä oli ennen kaikkea seurata tilannetta ja tukea kirkkohallituksen toteuttamaa uudistustyötä. Lisäksi kirkolliskokous teki tärkeitä ja vaikeita päätöksiä tietyissä käännekohdissa. Kirkon ja valtion taloussuhteet, joissa kirkolliskokous oli ollut 1980-luvulla ratkaisijan paikalla, siirtyivät kirkkohallituksen hoitoon.

Kirkolliskokous siirtyi erinäisissä hallinnollisissa ratkaisuissa 1990- ja 2000-luvulla vähitellen kohti puitelainsäädäntöä, ja samaa ajattelutapaa näkyi kirkolliskokouksen muillakin tehtäväaloilla. Kirkon taloudesta päättäessään kirkolliskokous ei enää puuttunut yksittäisten virkojen kaltaisiin yksityiskohtiin, mutta samaan aikaan työjärjestysmuutoksin lisättiin edustajien mahdollisuuksia saada tietoja ja keskustella periaatteellisesti kokonaiskirkon taloudesta. Ajatus puitelainsäädännöstä näkyi myös jumalanpalvelusuudistuksessa: jumalanpalvelusta koskevaa päätösvaltaa siirtyi kirkolliskokoukselta paikallisseurakuntaan. Muutos liittyi kirkolliskokouksen itseymmärrykseen. Kirkolliskokous oli 1980-luvulla kirkkolain kokonaisuudistushankkeen aikaan mieltänyt itsensä lainsäädäntöelimeksi, joka oli käsitellyt myös jumalanpalvelusjärjestystä asetustasoisena säännöstönä. Sen sijaan 1990-luvulla voimistui toiminnallisuuden ja kirkon käytännön elämän korostus.

Kirkolliskokouksen toiminnallinen kiinnostus lisääntyi yllättäen samaan aikaan, kun vastuu kokonaiskirkon toiminnan ohjaamisesta siirtyi kirkolliskokoukselta kirkkohallitukselle. Lama pakotti kyseenalaistamaan aiemmat toimintatavat ja miettimään toimintamuotojen tärkeysjärjestystä. Sitä paitsi kirkon toimikuntien ja keskusten muuttaminen kirkkohallituksen yksiköiksi toi nämä elimet huomattavasti aiempaa lähemmäk- si kirkolliskokousta. Kirkolliskokouksen huomio siirtyi yhä enemmän toiminnan sääntelystä toiminnan sisältöön. Strategiatyö ja tulevaisuuden visiointi lisääntyivät voimakkaasti 200o-luvun alkaessa.

Samaan aikaan muuttoliike saavutti huippunsa, ja seurakuntien taloudellinen eriarvoisuus kasvoi. Kirkolliskokous teki vuoteen 2005 mennessä merkittäviä taloutta koskevia tasauspäätöksiä, eikä havaittavissa ollut samanlaista pohjoisen ja etelän vastakkainasettelua kuin joskus aiempina vuosikymmeninä. Yhteinen huoli seurakuntien taloudesta sai edustajat tinkimään kotiseurakuntansa eduista. Toisaalta sama huoli sai kirkolliskokouksen ja kirkkohallituksen katsomaan seurakuntarakennetta lähinnä talouden ja hallinnon näkökulmista. Päämääränä näyttäytyivät seurakuntaliitokset. Vasta vuosikymmenen puolivälissä alettiin pohtia seurakuntaliitosten vaikutusta hengelliseen elämään ja seurakuntaidentiteettiin.

Kirkolliskokous puhui 200o-luvulla visioista enemmän kuin koskaan aiemmin ja hahmotteli tulevaisuudenkuvia ihmisläheisestä seurakunnasta. Käytännön aikaansaannokset olivat kuitenkin taloudellisia tehostamistoimia, joihin lama-aika oli opettanut. Lukuisat toiminnalliset aloitteet ja mietinnöt sekä täysistunnossa käydyt strategiakeskustelut johtivat vain melko harvoihin muutoksiin varsinaisissa rakenteissa. Visiot eivät helposti muuttuneet säännöksiksi.

Kirkolliskokous joutui toimimaan 1970-luvulta 200o-luvulle ristipaineessa, joka välillä helpotti mutta toisinaan tuntui repivänä. Läpi vuosikymmenten kokouksen toiminnassa oli silti jotain pysyvää. Edustajat laskeutuivat säännöllisesti linnavuorelta kohti Koroistenniemeä jumalanpalvelukseen Maarian kirkkoon. Kirkolliskokouksen päätösten myötä uudella vuosituhannella vietettiin aiempaa vaihtelevampia ja kieleltään ajanmukaistettuja jumalanpalveluksia, joissa voitiin käyttää entistä useampia kieliryhmiä varten laadittuja kirkollisia kirjoja. Jumalanpalveluselämän asema kirkolliskokouksen omassa työssä pysyi vahvana. Erimielisyyksien keskelläkin se oli yhdessä rukoileva ja veisaava kokous. 


\section{VIITTEET}

\section{UUTTA KANSANKIRKKOA ETSIM ̈̈SS ̈̈ 1974-1981}

$1 \quad$ Murtorinne 1995, 296, 389.

SEK 1972-75, 32; Murtorinne 1995, 389; Ekström 2003, 108-109.

Kansanaho 1976, 227.

SEK $1972-75,32-33,72$.

SEK 1972-75, 32; Ekström 2003, 117.

SEK 1972-75, 43-45; Haapanen 1978, 59-6o.

Jaakko Nummisen haastattelu 4.7.2012; Autio 1994, 27, 46-47, 53, 340.

Pirinen 1979, 144; Seppo 1999, 42; Jalovaara 2013, 106-107.

Autio 1994, 345; Meinander 1999, 398.

o Juva 1976, 163-164.

SEK 1972-75, 82

2 Murtorinne $1997,89$.

3 SEK 1972-75, 12; Meinander 1999, 439; Paavonen 2006, 147.

4 SEK 1972-75, 61-62.

5 SEK 1972-75, 58.

6 SEK 1972-75, 58-59.

S. Häkkinen 2010, 25-26, 215.

$18 K L$ 33:521 (13.7.1973/607). Ks. Kirk.kok. kptk-k. 1978, $53 \$$.

9 Ruotsin osalta ks. Ekström 2003, 17-18.

$20 \quad K L$ 33:522 (13.7.1973/607); VJ 1928 1:3. Ks. Hidén 2006, 25; Mylly 2006, 156.

$21 K L$ 33:524-525 (13.7.1973/607).

22 Kirk.kok. ptk. 1973, 386-389; Kirk.kok. ptk-l. 1973, liite VI-A 20.

23 Kirk.kok. ptk. 1973, 378-387.

24 Kirk.kok. ptk-k. 1983, liite VIII, 9; Kirk.kok. kptk-s. 1983, 23 \$; Ksml 3.2.1974 Uudistuva kirkolliskokous ja sen jäsenten valitseminen (Paavo Ojalainen).

25 HTA Eec 2 kirkolliskokouksen maallikkoedustajien vaalikokouksen ptk. 4.2.1974 \$3, \$9.

26 HTA Eec 2 Kirkolliskokouksen maallikkoedustajien valitsijamiehet [1974]

27 S. Eskola 2004, 141; S. Eskola 2012a, 14.

28 HTA Eec 2 Tuusulan rovastikunnan pappeinkokouksen ptk. 4.2.1974 \$7; HTA Eec 2 kirkolliskokouksen pappisedustajien vaali 6.2.1978.

29 Kirkolliskokousedustajan mandaatti oli siis periaatteiltaan hyvin samantyyppinen kuin kansanedustajalla lainsäädännön perusteella. Ks. Hidén 2006,63. Eduskuntaryhmien toiminta on kuitenkin käytännössä muuttanut ajatusta kansanedustajan mandaatista.

$30 \quad K L$ 24:417 (23.12.1964/635)

31 LTA Eca rovastikuntien pappien vaalikokousten ptk:t 4.2.1974.

32 Kaleva 24.1.1978 Hiljaiset vaalit: Kirkolliskokous valitaan piakkoin (Kaarina Oittinen). Lestadiolaisuus jakautui niin sanotussa suuressa hajaannuksessa 1800- ja 1900-luvun taitteessa esikoislestadiolaisuuteen, uuteenheräykseen ja vanhoillislestadiolaisuuteen. Vanhoillislestadiolaisuudesta irtautui vuonna 1934 Rauhan Sanan ryhmä. Suomen Rauhanyhdistysten Keskusyhdistyksen ympärille järjestäytynyt vanhoillislestadiolaisuus ajautui vuosina 1960-1961 kiistoihin, joiden myötä valtaosa papeista joutui liikkeen ulkopuolelle. He muodostivat Elämän Sanan lestadiolaisuu- den eli niin sanotun pappislinjan. Talonen 2001, 13, 15-16; Talonen 2014, 26-29.

33 LTA Eca kirkolliskokouksen maallikkoedustajien valitsijamiesten kokouksen ptk. 6.2.1978 \$10, \$15; Antila 2010, 365 .

34 Lapuan hpk.kok. ptk. 1978, 29-32; Kmaa 28.4.1978 Onko Jyväskylä Lapuan takamaata? (Kirsti Ritopeura); Välimäki 2006, 71; Antila 2010, 365.

35 LTA Ca ptk. 27.2.1974, liite 16, $\$ 73$.

36 Toimittaja Kaarlo Lähteenmaan ääniä päätyi "Kaarlo Lähteenmäelle" ja "Paavo Lähteenmaalle".

37 Antila 2010, 135-136, 407, 412

38 Antila 2010, 257-259, 264.

39 KMA KPA Ja SV 1974- "Mitä on keskustalainen kirkko- ja seurakuntapolitiikka", 3-4; Antila 2010, 264-265.

40 TArk 329,5 C 1 ltptk. 7.2.1974 \$ 9, C 2 lkptk. 13.4.1975, liite: toimintakertomus, 9; Antila 2010, 266-267.

41 PTA KK Ce Ktr PM 5.9.1977 (Hannu Salokorpi); Antila 2010, 265, 267-268, 270, 344-345, 347, 361-362.

42 PTA KK Ce Ktr Tapiolan Kokoomuksen Naiset Kokoomuksen Naistenliitolle 14.11.1977.

43 TArk 329,5 C 1 ltptk. 7.2.1974 \$ 9; Juva 1976, 231.

44 Laurinkari 1976, 45.

45 Kortekangas \& Huotari 1974, 34, 86-88.

46 Kirk.kok. kptk-s. 1974, 342; SEK 1972-75, 36; Niiranen 2008, 81-85, 188, 295296; Antila 2010, 293-294; Seppo 2013, 223, 227, 230-231, 355, 417-422, 513514 .

47 SEK 1976-79, 77.

48 Antila 2010, 325

49 PTA KK Ce Ktr "Kirkolliskokouksen maallikkoedustajien valitsijamiehet 1978", "kirkkopoliittisia systeemejä" 12.10.1977, Hannu Salokorpi toiminnanjohtajille 12.10.1977, ptk. 8.11.1977, Veikko Tavastila ja Salokorpi toiminnanjohtajille 16.11.1977; ptk. 22.11.1977 \$5, ”Työryhmän kevään 1978 aikataulu" 27.12.1977; Antila 2010, 344, 361.

50 PTA KK Ce Ktr kokoomus toiminnanjohtajille (kirjeluonnos 1977), Hannu Salokorpi toiminnanjohtajille 12.10.1977; Antila 2010, 300, 345, 347, $360-361,363$

51 Mäkinen 2008, 17-19.

52 PTA KK Ce Ktr PM 20.9.1977 (Hannu Salokorpi), ptk. 12.1.1978 §5.

53 PTA KK Ce Ktr ptk. 4.1.1978 \$6, ptk. 12.1.1978 \$ 5 .

54 PTA KK Ce Ktr "Yhteenveto kirkolliskokouksen vaalista 6.2.1978".

55 Antila 2010, 363.

56 KMA KPA Ce KTmk 1977-78 "Kirkolliskokousedustajien vaalit 06.02.1978"; PTA KK Ce Ktr "Yhteenveto kirkolliskokouksen vaalista 6.2.1978".

$57 A l$ 7.2.1978 Kirkkovaali veti valitsijat totisiksi; US 9.2.1978 Kepu ja kokoomus kirkkovaalien voittajia; Kukkonen 1999, 32.

58 Kmaa 14.2.1978 Sitoutumattomien muistolle (pääk.). 
59 Antila 2010, 366.

60 Antila 2010, 347-348, 398-399.

61 PTA KK Ce Ktr ptk. 16.3.1978 § 5, ptk. 6.4.1978 § 5, Seikko Eskola ja Heimo Malve kokoomuslaisille kirkolliskokousedustajille 21.4.1978; Kauppinen 2004, 143-144; Seikko Eskolan kirjallinen tiedonanto 28.4.2013; Antila 2010, 272-275, 379-381.

62 S. Eskola 2004, 139; S. Eskola 2012a, 150.

63 Seikko Eskolan kirjallinen tiedonanto 28.4.2013.

64 Honka-Hallila 2003, 86-87.

65 SEK 1976-79, 59-60; US 10.2.1974 Kirkkotien varrelta (Vaeltaja); Kmaa 12.2.1974 Kehittämisen varaa on yhä (pääk.); Kmaa 7.2.1978 Kirkolliset salaseurat (pääk.); SS 8.2.1978 Kirkon parlamentti (pääk.); US 8.2.1978 Uudet kasvot (pääk.); ES 9.2.1978 Kirkolle uusi parlamentti (pääk.); KS 9.2.1978 Vanha vaalitapa (pääk.); $S k K$ 9.2.1978'Kirkon eduskunta' (pääk.); Knen 12.2.1978 Kirkolliskokousedustajain vaalista demokraattinen; TS 12.2.1978 Kirkon kulmalta (Sakari Huovinen); Kmaa 13.5.1980 Korjattava vaalitapa (pääk.)

66 Kirk.kok. ptk-k. 1978, liite X 2; Kirk.kok. kptk-k. 1978, 34 \$, 46 \$; S. Eskola 2012a, 15

67 Kirk.kok. kptk-k. 1978, 46 \$.

68 Kirk.kok. ptk-k. 1981, liite VII Helsinki 2 \& VIII 7.

69 Kirk.kok. ptk-s. 1981, 27\$.

$70 \quad$ Kmaa 19.4.1974 Uusi kirkolliskokous koolle ensi kerran 6.5

71 Kortekangas \& Huotari 1974, 105.

72 SEK 1972-75, 75; Laurinkari 1976, 41

73 Kansanaho 1976, 227.

74 KKHA KKA Cc 2 opetusministeri Ulf Sundqvistin puhe 4.11.1974.

75 Ylimääräisiä kirkolliskokouksia, joissa istuivat edelliseen varsinaiseen kirkolliskokoukseen valitut edustajat, ei ole laskettu tässä vertailussa omiksi kausikseen.

76 Lähteenmäki 2006, 159.

77 Ikola 2004, 305.

78 Juva 1976, 230-231

79 Vaasa 10.2.1974 Tapulista katsoen (Väkkäri); Kmaa 12.2.1974 Kehittämisen varaa on yhä (pääk.)

80 Paloheimo 2007, 345-346, 348.

81 Lähteenmäki 2006, 90-91; Paloheimo 2007,345, 347-349.

82 Ahlgren 2001, 86.

83 Seurakuntien luottamuselinten sosioekonomisesta koostumuksesta Kortekangas \& Huotari 1974, 106-107.

84 Elinkeinorakenteen muutoksesta Alestalo 1980, 104-106; Karisto \& Takala \& Haapola 2009, 63-65.

85 Juva 1976, 41-43.

86 LTA Eca Matti Maijala tuomiokapitulille 25.9.1975.

87 Isohookana-Asunmaa 2008, 112.

88 Kirk.kok. ptk-k. 1974, liite III 1.

89 Kirk.kok. kptk-k. 1974, 2 \$.

90 Kansanaho 1976, 224.

91 Autio 1994, 350-351; Helander \& Pekonen 2007, 34.

$92 K L$ 33:529 (23.12.1964/635) \& 33:529 (13.7.1973/607).

93 SEK 1976-79, 140-142; Juva 1976, 220.

94 Kirk.kok. kptk-s. 1974, 20 \$.

$95 K L 33: 529(23.12 .1964 / 635) \& 33: 529(13.7 .1973 / 607)$.

$96 K L$ 33:534 (13.7.1973/607).

97 Päätöksen syntyvaiheista ks. Björkstrand 1980.

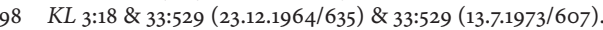

$99 K L 33: 529(23.12 .1964 / 635) \& 33: 529(13.7 .1973 / 607)$.

$100 K L$ 32:516 (13.7.1973/607)

$101 K L$ 28:488 (23.12.1964/635).

$102 K L 33: 529(13.7 .1973 / 607)$

103 KL 33:529 (13.7.1973/607).

104 KL 29:491 (13.7.1973/607).

105 Kirk.kok. kptk-s. 1974, 72 \$; Kirk.kok. ptk-s. 1974, liite VI-A 4.

$106 K L$ 33:529 (13.7.1973/607).

$107 K L$ 33:529 (13.7.1973/607)

108 Kirk.kok. kptk-k. 1974, 2-3; Pentikäinen 2009, 69.

109 Lindegård 1957.

110 Kirk.kok. ptk. 1971, 154

111 Kirk.kok.ptk-k. 1976, liite II 1, 1

112 Kirk.kok. ptk. 1971, 154, 291.
113 Kirk.kok. ptk. 1971, 292-293; Kansanaho 2001, 188

114 Kirk.kok. ptk-l. 1971, liite VI-B 1 a, 32. Kursivointi tekijän.

115 Kirk.kok. ptk-l. 1971, liite VI-B 1 a, 26.

116 Antila 2011, 350-351.

$117 K_{33: 534}(13.7 .1973 / 607)$

118 Antila 2011, 350-351.

119 Kirk.kok. ptk-s. 1974, liite VI-A 3, 1.

$120 K L$ 33:530 (13.7.1973/607)

121 VJ 1928 4:54; Kirk.kok. ptk-s. 1974, liite VI-A 3, 5-6 \$.

122 VJ 1928 4:39; Kirk.kok. ptk-s. 1974, liite VI-A 3, 8 \$

123 Kirk.kok. ptk-s. 1974, liite VI-A 3, 8 \$.

124 Murtorinne 1997, 80-81.

125 Kirk.kok. ptk-s. 1974, liite VI-A 3,10 §.

126 Kirk.kok. ptk-s. 1976, $20 \$$.

127 Kirk.kok. kptk-k. 1974, 4.

128 Kirk.kok. kptk-k. 1974, 2 \$; Kirk.kok. kptk-s. 1974, 20 \$.

129 Kirk.kok. ptk-s. 1974, liite VI-A 3,13\$, $15 \$$

130 VJ 1928 4:40.

131 Kirk.kok.ptk-s. 1974, liite VI-A 3, 3, 13 \$, $15 \$$

132 Kirk.kok. ptk-s. 1974, liite VI-A 3, 2.

133 Kirk.kok. kptk-k. 1974, 2 \$.

134 Kirk.kok. ptk-s. 1974, liite VI-A 3, 8 \$, 14\$.

135 VJ 1928 4:40; Kirk.kok. ptk-s. 1974, 44 §, liite VI-A 3, 19 \& \& VI-A 3 a.

136 Kirk.kok. ptk-s. 1974, liite VI-A 3, 14-15 \$.

137 Kirk.kok. kptk-s. 1978, 36 \$; Kirk.kok. ptk-k. 1979, 20 \$, liite X-A 4; Alma Saaren sähköpostihaastattelu 9.2.2012.

138 Kirk.kok. kptk-s. 1979, 22 \$.

139 Nousiainen 2006, 259-260; Honka-Hallila 2006, 253.

140 Kirk.kok. kptk-s. 1974, 20 \$.

141 Kirk.kok. kptk-s. 1974, 20 \$; Kirk.kok. ptk-s. 1974, liite VI-A 3, 4, 28 §.

142 Kirk.kok. ptk-s. 1974, liite VI-A 3, 29 \$.

143 KL 33:533 (13.7.1973/607); Kirk.kok. ptk-s. 1974, liite VI-A 3, 30 §.

144 Kirk.kok. ptk-s. 1974, liite VI-A 3, 53 \$

145 Kirk.kok. ptk-s. 1974, liite VI-A 3, 35 \$

146 Kirk.kok. kptk-s. 1974, 44 \$; Kirk.kok. ptk-s. 1974, liite VI-A 3, 37 § \& VI-A $3 \mathrm{a}$

147 Kirk.kok. kptk-s. 1974, 54 \$; Kirk.kok. ptk-s. 1974, liite VI-A 3, 47-48 \$.

148 Vaasa 10.10.1980 Kirkon budjetti (pääk.); LK 12.10.1980 Kirkon tiedotustyö (pääk.); Vaasa 14.10.198o Kirkon budjetti (Osmo Katajamäki).

149 VJ 1928 3:35; KL 33:534 (13.7.1973/607).

$150 K L$ 33:530 (23.12.1964/635) \& 33:530 (13.7.1973/607); Kirk.kok. ptk-s. 1974, liite VI-A 3, 5 .

151 Kansanaho 1976, 47, 52, 179; Pirinen 1985, 251-252.

152 Kirk.kok. kptk-k. 1974, 2 \$.

153 Kirk.kok. ptk-s. 1974, liite VI-A 3, 2, 4, 6

154 Kirk.kok. kptk-s. 1974, 69 \$.

155 Kirk.kok. kptk-k. 1978, $10 \$, 59 \$$.

156 Kirk.kok. kptk-k. 1974, 15 \$; Kirk.kok. ptk-k. 1974, liite II 1; Kirk.kok. kptk-s. 1974, 72 \$; Kirk.kok. ptk-s. 1974, liite VI-A 4.

157 Kirk.kok. kptk-s. 1974, 72 \$; Kirk.kok. ptk-s. 1974, liite VI-A 4; Murtorinne 1997,83 .

158 Ossi Haaramäen haastattelu 28.10.2010.

159 PTA KK Ce Ktr ptk. 27.1.1978 \$5, ptk. 10.10.1978 \$ 6; Antila 2010, 269-273, 378-381.

160 Antila 2010, 270.

161 Kirk.kok. kptk-k. 1974, 4 \$; Antila 2010, 272-274

162 Kirk.kok. kptk-k. 1974, $4 \$$.

163 Kirk.kok. kptk-k. 1974, 4\$; Antila 2010, 274.

164 Kirk.kok. kptk-k. 1974,73\$.

165 Kirk.kok. kptk-k. 1974, 73 \$; Antila 2013, 250.

166 Kirk.kok. kptk-k. 1974,73\$; Kirk.kok. ptk-k. 1974, 24 \$, 73\$.

167 Kirk.kok. kptk-k. 1974, 73 \$; Kirk.kok. ptk-k. 1974, 73 \$; Antila 2013, 251.

168 Kirk.kok. kptk-k. 1974, 73 \$; Antila 2013, 250.

169 Kirk.kok. ptk-k. 1974, $24 \$, 73 \$$.

170 Kirk.kok. kptk-k. 1974,73 \$.

171 Kirk.kok. ptk-k. 1974, 73 \$.

172 Kirk.kok. kptk-k. 1974,73\$.

173 Antila 2013, 250.

174 Kirk.kok. ptk-k. 1974, 73 \$.

175 Esim. Kirk.kok. kptk-k. 1981,52\$. 
176 Kortekangas 1974, 36-37; Kmaa 5.7.1974 Keskustelua: Kirkolliskokouksen vallankäytöstä (Erkki Pennanen); Kansan Lehti 15.5.1974 Kirkolliskokouksen valinta (pääk.); Antila 2010, 274.

177 Kirk.kok. kptk-s. 1977, 58 \$; Antila 2010, 352-353.

178 PTA KK Ce Ktr ptk. 10.2.1978 \$5.

179 Antila 2010,379.

180 Kirje oli kirkkopoliittisen työryhmän sihteerinä toimineen kokoomuksen järjestösihteerin, itse teologitaustaisen Hannu Salokorven valmistama, mutta se lähetettiin kahden kirkolliskokousedustajan, apulaisprofessori Seikko Eskolan ja diplomi-insinööri Heimo Malveen, nimissä. PTA KK Ce Ktr ptk. 16.3.1978 \$ 5, ptk. 6.4.1978 \$ 5, Seikko Eskola ja Heimo Malve kokoomuslaisille kirkolliskokousedustajille 21.4.1978.

181 Seikko Eskolan kirjallinen tiedonanto 28.4.2013. Sittemmin kokoomuksen kirkkopoliittinen työryhmä tosin valmisteli ainakin insinööri Rafael Nyqvistin puheenvuoroa syksyn 1978 talousarviokäsittelyssä. PTA KK Ce Ktr ptk. 27.10.1978 \$5.

182 Kmaa 5.5.1978 Puoluepeliä kirkolliskokoukseen?; Kansan Lehti 12.5.1978 Kirkonkukko: Pelin henki, ja helluntain; Sd 18.5.1978 Kirkolliskokous (Maunu Sinnemäki). Keskustan kirkkopoliittisen toimikunnan nimimerkki ihmetteli "kirkon sisäpiirien" säikähdystä, kun "Turussa pidettiin pieniä aattoseuroja”. Antila 2010, 383-384.

183 Antila 2010, 381

184 Kirk.kok. kptk-k. 1978, 6 \$.

185 Kirk.kok. kptk-k. 1978, 6 \$; Antila 2010, 381

186 Kirk.kok. kptk-k. 1978, 6 \$.

187 Ks. Kirk.kok. kptk-k. 1975, 71 \$; Kirk.kok. kptk-s. 1976, 44 \$.

188 Kirk.kok. kptk-k. 1978, 6-7\$.

189 Kirk.kok. kptk-k. 1978, 30 \$, $59 \$$.

190 Kirk.kok. kptk-k. 1978,59 \$.

191 Kirk.kok. kptk-k. 1978,30 \$.

192 Kirk.kok. kptk-s. 1974, 68 \$; Kirk.kok. kptk-y. 1974, 9 \$; Kirk.kok. ptk-y. 1974, $9 \$$.

193 Kirk.kok. kptk-s. 1977, $13 \$$.

194 Kirk.kok. kptk-k. 1975,76\$.

195 Kirk.kok. kptk-s. 1978, 9 \$, 44\$.

196 KMA KPA Ja SV 1974- "Uusi kirkolliskokous 1978-1981"; PTA KK Ce Ktr ptk. 17.5.1978 \$ 6, ptk. 27.10.1978 \$5; Kirk.kok. kptk-s. 1978, 9 \$, 44 \$; Antila $2010,395$.

197 Kirk.kok. kptk-s. 1978, 58 \$; Kirk.kok. ptk-s. 1978, 50 \$, liite VI 11; KL 33:533 (13.7.1973/6o7)

198 Kirk.kok. kptk-k. 1978, 30 \$, 52 \$.

199 Kirk.kok. kptk-s. 1976,54\$.

200 Kirk.kok. ptk-k. 1977, 60 \$, liite X-A 3.

201 Ossi Haaramäen haastattelu 28.10.2010; Alma Saaren sähköpostihaastattelu 9.2.2012.

202 Kirk.kok. kptk-k. 1974, 11 \$; Kirk.kok. kptk-k. 1978, 14 \$.

203 Kirk.kok. ptk-k. 1974,11\$, 14 \$.

204 Ossi Haaramäen haastattelu 28.10.2010.

205 Helander \& Pekonen 2007, 111.

206 Kirk.kok. kptk-s. 1974, 58 \$.

207 Esim. Kirk.kok. kptk-s. 1976, 61 §.

208 Murtorinne 1997, 81.

209 Alma Saaren sähköpostihaastattelu 9.2.2012.

210 Kirk.kok. kptk-s. 1978, 6 §.

211 Kirk.kok. ptk-s. 1974, 58 \$, liite III 19.

212 Kirkon toimikunnat 1974 \& 1976; Kirk.kok. ptk-s. 1975, 45 \$; Kirk.kok. ptks. 1976, 50 \$; Kirk.kok. ptk-s. 1977, 52 \$.

213 Kirk.kok. kptk-s. 1980, $10 \$$.

214 Ainakin kokoomuksessa ja keskustassa laaditut suunnitelmat valiokuntien kokoonpanosta toteutuivat heikonlaisesti. KMA KPA Ce KTmk 197778 "Kirkolliskokouksen valmistelevat toimenpiteet"; PTA KK Ce Ktr ptk. $16.3 .1978 \$ 5$.

215 Kirk.kok. ptk-s. 1977, 52 \$; Ossi Haaramäen haastattelu 28.10.2010. Matti Sihvosella ei ole muistikuvia tapahtumista. Matti Sihvosen puhelinhaastattelu 16.12.2013.

216 Kirk.kok. ptk. 1971, 219-221; Kirk.kok. ptk-l. 1971, liite IV-A, 38, 42 \& VI-B 1, 2-3 \& 1 a, 33; Kirk.kok. kptk-k. 1974, 2 \$; Juva 1976, 218.

217 Kirk.kok. kptk-k. 1974, 2 \$.

218 Kirk.kok. ptk-k. 1974, 14 §.

219 Kirk.kok. ptk-k. 1974, liite III 2.
220 Kirk.kok. kptk-k. 1974, 85 \$.

221 Kirk.kok. kptk-s. 1974, 24 \$; Kirk.kok. ptk-s. 1974, liite VI-C 3.

222 Kirk.kok. kptk-s. 1974, 29 \$.

223 Kirk.kok. kptk-s. 1974, 24 \$.

224 Kirk.kok. ptk-s. 1975, liite III 1, 10-11.

225 Kirk.kok. ptk-s. 1975, liite III 1, 12.

226 Helander \& Pekonen 2007, 23.

227 Kirk.kok. kptk-s. 1975, 10 §.

228 Kirk.kok. kptk-s. 1975, $10 \$$.

229 KKHA KKA Cib 1 "Alustuspuheenvuoro lausuntoluonnokseksi" (Timo Rusama) [1976]; Kirk.kok. kptk-k. 1978, $17 \$$.

230 Numminen 1996, 651.

231 Savolainen 1996, 674-675.

232 Kirk.kok. ptk-k. 1975, $30 \$$, liite V-B 10.

233 Kirk.kok. kptk-k. 1976, 45 \$.

234 Kirk.kok. kptk-s. 1975, 20 \$; Kirk.kok. ptk-s. 1975, liite V-D 5.

235 Kirk.kok. ptk-k. 1976, liite X-D 1 \& X-D 1 a.

236 Kirk.kok. kptk-k. 1976,101\$.

237 KKHA KKA Hh 1 ptk. 26.5.1976 \$3, ptk. 7.6.1976 \$6.

238 Kirk.kok. ptk-s. 1977, liite V 1, 19-23.

239 KKHA KKA Hh 1 ptk. 12.6.1975 \$192, ptk. 23.7.1975\$212.

240 KKHA KKA Hh 1 Esa Siljamäki komitean jäsenille s.a.

241 KKHA KKA Hh 1 ptk. 3.6.1977 $\$ 80$.

242 Kirk.kok. kptk-s. 1977, 17 \$, 38 \$; Kirk.kok. ptk-s. 1977, liite VII-C 4.

243 Kirk.kok. kptk-s. 1978, $16 \$$.

244 Kirk.kok. kptk-s. 1978, $16 \$$.

245 Kirk.kok. kptk-s. 1980,17\$.

246 Kirk.kok. kptk-s. 1977,17 \$, 38 \$; Kirk.kok. ptk-s. 1977, liite VII-C 4; Kirk.kok. kptk-k. 1978, 24 \$; Kirk.kok. kptk-s. 1978, 16 \$.

247 Kirk.kok. ptk-s. 1979, liite IV 11; Juva 1994, 302-303; Murtorinne 1997, 102103; S. Eskola 2012b, 461.

248 Kirk.kok. kptk-s. 1979, 44 §, 46 \$; SEK 1976-79, 68; Jokinen 1990, 94-95; Murtorinne 1997, 104-106.

249 Kirk.kok. ptk-s. 1981,32 \$; SEK 1980-83, 56, 75; Juva 1994, 355-358,361; Kansanaho 2001, 167; H.-T. Nieminen 2011,35; SK 26.3.1982 Arkkipiispa Mikko Juva: "En pakene rintamasta" (Tapani Ruokanen); Jokinen 1990, 101-102, 112-113; S. Salmi 2012, 14.

250 Ossi Haaramäen haastattelu 28.10.2010.

251 SEK 1972-75, 96; Murtorinne 1995, 248.

252 SEK 1972-75, 96-97.

253 Kirk.kok. kptk-s. 1974, 19 \$; Kirk.kok. ptk-s. 1974, liite VI-D 6.

254 KKHA KKA Cie 1 ptk. 25.10.1974 \$ 2; Kirk.kok. ptk-s. 1974, liite VI-D 6

255 Kirk.kok. kptk-s. 1974, 19\$, $59 \$$.

256 Kirk.kok. ptk-s. 1974, 19 \$, 59 \$.

257 Ks. esim. Kirk.kok. kptk-s. 1976, 31 \$; Kirk.kok. kptk-s. 1977, 22 \$; Kirk.kok kptk-k. 1978, 68 §; Kirk.kok. kptk-s. 1978, 24 §.

258 Kirk.kok. ptk-s. 1974, liite III 10.

259 Kirk.kok. ptk-s. 1981, liite IX-E 6.

260 Kirk.kok. kptk-s. 1978, 24 \$.

261 SEK 1976-79, 88-89; SEK 1980-83, 97

262 Kirk.kok. kptk-s. 1976, 31 \$.

263 Kirk.kok. kptk-s. 1975, 10 \$, 17 \$; Kirk.kok. kptk-k. 1976, 110 \$.

264 Kirk.kok.ptk-s. 1976, 64 \$, liite IX-D 7 \& 7 a; Kirk.kok. ptk-k. 1976, 110 \$, liite X-E 7.

265 Kirk.kok. ptk-k. 1974, liite VI-E 2; Kirk.kok. ptk-k. 1978, liite XI-B 4; SEK $1976-79,66$.

266 Kirk.kok. kptk-k. 1978, 2-3.

267 KKHA KKA Cc 12 "Opetusministeri Itälän vastauspuheenvuoro arkkipiispa Simojoelle" 10.5.1978; Kukkonen 1999, 47.

268 Ksml 9.5.1978 Syvällinen sanoma (pääk.); SSS 9.5.1978 Kirkko ja raha; Vaasa 9.5.1978 Arkkipiispan sana; Al 10.5.1978 Outo hyvä (pääk.); SkK 10.5.1978 Kirkon solidaarisuus (pääk.); Kaleva 12.5.1978 Arkkipiispa Martti Simojoki: Pappi ei saa olla vain pientä ryhmää varten (Kaarina Oittinen); Kansan Tahto 13.5.1978 Mitä kirkko voisi tehdä (pääk.); HS 21.5.1978 Kirkon menot kuriin (pääk.).

269 Kirk.kok. kptk-s. 1975, 17 \$. Myös esim. Kirk.kok. kptk-k. 1974, 100 \$; Kirk. kok. kptk-s. 1974, $19 \$$.

270 Kirk.kok. kptk-s. 1974, 19 \$.

271 Kirk.kok. kptk-s. 1974, 19 \$.

272 Ks. Kirk.kok. kptk-s. 1976, 31 \$; Kirk.kok. kptk-s. 1977, 22 \$; Kirk.kok. ptk-k. 
1979, liite XI.

273 Kirk.kok. kptk-s. 1974, 19 \$; Kirk.kok. ptk-s. 1978, liite VII-E 5.

274 Esim. Kirk.kok. kptk-s. 1975, 17 §, 19 §.

275 Kirk.kok. kptk-s. 1976, 31 \$; Kirk.kok. kptk-s. 1974, 19 \$. Kirkon ja valtion ulkopoliittisesta liikkumavarasta Jalovaara 2011, 205, 256.

276 SEK 1972-75, 143; Juva 1976, 222-223; Autio 1994, 354-355; Leino 2002, 215.

277 Kirk.kok. ptk-s. 1989, liite VII 1, 4.

278 Kirk.kok. kptk-k. 1974, 100 \$; Kirk.kok. ptk-k. 1974, liite III 3 \& VI-E 3.

279 Kirk.kok. ptk-k. 1974, $100 \$$.

280 Kirk.kok. kptk-k. 1974, $100 \$$.

281 Kirk.kok. kptk-s. 1974, 51 \$.

282 SEK 1976-79, 128.

283 Kirk.kok. kptk-s. 1974, 68 \$; Laki evankelis-luterilaisen kirkon virkaehtosopimuksista (968/1974); Laki evankelis-luterilaisen kirkon sopimusvaltuuskunnasta (970/1974).

284 Kirk.kok. kptk-s. 1975, 17 \$, 25 \$; Kirk.kok. kptk-k. 1976, 16 \$; Kirk.kok. kptk-s. 1976, 38 \$; SEK 1972-75, 143-144.

285 Kirk.kok. ptk-k. 1976, 12-18 \$.

286 Kirk.kok. ptk-k. 1976, liite II 3.

287 Kirk.kok. ptk-k. 1976, $109 \$$.

288 Kirk.kok. kptk-k. 1977,64 §.

289 Kirk.kok. ptk-k. 1976, liite IV 10.

290 Kirk.kok. ptk-s. 1976, 37 \$.

291 Kirk.kok. ptk-k. 1976, 80 \$, liite X-E 3; Kirk.kok. ptk-s. 1977, liite V 2 \& VII$\mathrm{D} 13$.

292 Kirk.kok. kptk-s. 1977, 18 \$, 59 \$.

293 Kirk.kok.ptk-s. 1978, 41 \$; Kirk.kok. kptk-k. 1980, 25 \$; Kirk.kok. ptk-k. 1980, liite III 1.

294 Kirk.kok. kptk-k. 1981, 49 \$, 51 \$; Kirk.kok. ptk-k. 1981, liite IX-D 1.

295 Hämeen Sanomat 25.3.1981 Jo kirkon väkikin uhkaa lakolla (pääk.); $K U$ 25.3.1981 Kummaa on (Taavetti); SS 25.3.1981 Kirkko ja lakot (pääk.); Kmaa 2.4.1981 Lakolta säästyttiin (pääk.), Kirkon palkoista päästiin ratkaisuun (Hannu Kuosmanen); US 11.4.1981 Kuopion uusi piispa Malmivaara: Lakko ei sovi kirkkoon; ESS 17.4.1981 Lakkouhkailu oli murheellista.

296 Kirk.kok. kptk-k. 1981, 37 \$; Kirk.kok. ptk-k. 1981, liite IX-A 1, 6-7.

297 Kirk.kok. kptk-s. 1981, 67\$.

298 Kirk.kok. kptk-k. 1977,34\$.

299 Kirk.kok. ptk-k. 1979,76 \$.

300 SEK 1976-79, 119; Erkkilä 2003, 88-89.

301 Kirk.kok. kptk-k. 1979, 44 \$; Kirk.kok. ptk-k. 1979, 76 \$, liite X-C 1 \& 1 a \& $1 \mathrm{~b}$.

302 Laasonen 1998, 210-219.

303 Kirk.kok. ptk. 1968, 237-240; Juva 1976, 207; Haapanen 1978, 22; Alvunger 2006, 30-32, 35, 205-207; Sorsa 2010, 110-112.

304 Evans 1996, 1; Vischer 2004, 27.

305 SEK 1972-75, 225; Rusama 1999, 299-300.

306 Vischer 2004, 27.

307 Kirk.kok. ptk-k. 1975, liite III 2. Komitean varajäseninä olivat kirkkoherra Timo Holma, dosentti Lauri Koskenniemi ja lehtori Eila Kauppinen.

308 KKHA KKA Cc 3 Naisjärjestöjen Keskusliiton vetoomus huhtikuussa 1975. SEK 1972-75, 37; Hämeen Sanomat 11.4.1975 Naispappeus (pääk.); SS 11.4.1975 Naiset asialla (pääk.); HS 14.4.1975 Naiset liikkeellä (pääk.).

309 Molina 2010, 24.

310 KKHA KKA Cc 3 Naisjärjestöjen Keskusliiton vetoomus huhtikuussa 1975.

311 KKHA KKA Cc 2 opetusministeri Ulf Sundqvistin puhe 4.11.1974.

312 KKHA KKA Cc 3 Naisjärjestöjen Keskusliiton vetoomus huhtikuussa 1975; Lähteenmäki 2006, 182.

313 KKHA KKA Cc 4 Länsi-Suomen rukoilevaiskansan lausunto [30.4.1975], Cc 3 SEKL:n hallitus kirkolliskokousedustajille 2.5.1975, Cc 4 Lestadiolaisen Uudenheräyksen Saarnaajainkokouksen julkilausuma 9.8.1975. Myös SRK:n vuosikokous totesi vuonna 1975 liikkeen kielteisen kannan naispappeuteen. Leppänen 2011, 21

314 Kirk.kok. kptk-k. 1975, 3.

315 Huovinen 1979, 114, 125.

316 Kirk.kok. ptk-k. 1975, liite III 2, 12, 15-17.

317 Kirk.kok. kptk-k. 1975, 19 \$.

318 Kirk.kok. kptk-k. 1975, $96 \$$.

319 Kirk.kok. ptk-k. 1975, liite V-B 1 \& V-C 4.

320 Kirk.kok. kptk-k. 1975, 22 \$, 97\$.
321 Alma Saaren sähköpostihaastattelu 25.1.2012.

322 Kirk.kok. kptk-k. 1975, 19 \$.

323 Kirk.kok. ptk-k. 1975, liite IV 8.

324 Kirk.kok. kptk-k. 1975, 71 \$; Molina 2010, 68-69, 77.

325 Kirk.kok. ptk-k. 1975, liite III 2, 9.

326 Kirk.kok. kptk-k. 1975, 19 \$; Seppo 2013, 192.

327 Kirk.kok. ptk-k. 1975, liite III 2, 11-12.

328 KKHA KKA Cib 1 ptk:t 1975.

329 KKHA KKA Cib 1 ptk. 8.5.1975 klo $19.00 \$ 2$.

330 Kirk.kok. kptk-k. 1975, 96 \$.

331 Kirk.kok. kptk-k. 1975,71§.

332 Kirk.kok. kptk-k. 1975, 71 \$; R. A. Ahonen 1991, 122; Typpö 2005, 32.

333 Kirk.kok. kptk-k. 1975,71 §.

334 Kirk.kok. kptk-k. 1975, 19 \$.

335 KKHA KKA Cc 4 Seppo A. Teinonen Martti Simojoelle 26.5.1975; Huovinen 2012, 483.

336 Kirk.kok. ptk-s. 1975,34§.

337 Kirk.kok. ptk-k. 1976, liite VII 2, 7-8.

338 Kirk.kok.ptk-k. 1976, liite VII 2

339 Kirk.kok. ptk-k. 1976, liite VII 2.

340 SEK 1972-75, 37; Kmaa 27.1.1976 Mietitään siis edelleen (pääk.); Kpr 29.1.1976 Dött lopp? (ledare).

341 Kmaa 27.1.1976 Virkakomitean hämmentävä mietintö ei tuo selvyyttä naispappeuskysymykseen (Heikki Tervonen).

342 Huovinen 1979, 96, 103-104.

343 Kirk.kok. kptk-k. 1976, 32 \$.

344 Kirk.kok. ptk-k. 1976, liite VII 2, 14-15, 19-20; Huovinen 1979, 96, 103-104, 106-112, 115-120.

345 Kirk.kok. ptk-k. 1976, liite VII 2, 5.

346 Kiviranta 2009, 234-236.

347 Piisp.kok. ptk-y. 1976,7 §.

348 Kirk.kok. ptk-k. 1976, liite III

349 HS 22.4.1976 Mielialat kypsyvät (pääk.); Kaleva 22.4.1976 Piispainkokouksen kanta (pääk.); Knen 22.4.1976 Naispappeus myötätuulessa (pääk.); Länsi-Suomi 22.4.1976 Myönnytys naispappeudelle (pääk.); TS 22.4.1976 Askel kohti ratkaisua (pääk.); $A U$ 22.4.1976 För husfridens skull (Meta Torvalds, ledare); ES 23.4.1976 Kohti naispappeutta (pääk.); SS 23.4.1976 Piispainkokouksen sana (pääk.); US 25.4.1976 Kirkkotien varrelta: Arvoituksellinen kompromissi (Vaeltaja); Kmaa 30.4.1976 Mahdollisesti (pääk.).

350 Kirk.kok. kptk-k. 1976,32 §.

351 KKHA KKA Cib 1 Timo Holma piispainkokouksessa 20.4.1976.

352 KKHA KKA Cib 1 "Luonnos Perustevaliokunnan mietinnön alkuosaksi Virkakomitean loppumietinnöstä" (Aimo T. Nikolainen); Kirk.kok. ptk-s. 1976, liite IX- B 2.

353 Kirk.kok. kptk-s. 1976, 44 §.

354 KKHA KKA Cc 5 tasa-arvoasiain neuvottelukunta kirkolliskokoukselle 29.4.1976.

355 SEK 1976-79, 23.

356 TS 3.5.1976 Syrjitäänkö naisia (pääk.)

357 Kmaa 30.4.1976 Keskustelua: Muuttunut virkakäsitys. Mielipidekirjoituksen allekirjoittajina olivat Lauri Haikola, Ahti Hakamies, Tuomo Mannermaa, Seppo A. Teinonen ja Kalevi Toiviainen.

358 Oulun hpk.kok. ptk. 1976, 9-12.

359 Kirk.kok. kptk-k. 1976,32 \$.

360 OMA MSA1 Ab:1o/85 Mikko Juva Simojoelle 15.6.1976.

361 Kirk.kok. kptk-s. 1976, 44 §.

362 Kirk.kok. kptk-k. 1976, 32 \$.

363 Kirk.kok. kptk-s. 1976, $44 \$$.

364 Kirk.kok. ptk-s. 1976, liite IX-B 2, 3, 11

365 Kirk.kok. ptk-s. 1976, liite IX-B 2, 3, 11

366 Kirk.kok. kptk-k. 1976,32 \$; Kirk.kok. kptk-s. 1976, 44 \$; Konttinen 1975, 8589; Molina 2010, 72, 76, 80, 96-97, 106, 139, 141-142, 163.

367 Kirk.kok. ptk-k. 1976, liite VII 2, 83.

368 Kirk.kok. kptk-k. 1976, 32 §.

369 Kirk.kok. kptk-s. 1974, 22 \$.

370 Ks. Juva 1976, 88-90, 123.

371 Kirk.kok. kptk-s. 1976, 44\$.

372 Nikolaisen ja Juvan aktiivisuudesta ks. Heinonen 1990, 29-30.

373 Kirk.kok. kptk-k. 1975, 19 \$; Kirk.kok. kptk-k. 1976, 32 \$; Kirk.kok. kptk-s. 
$1976,44 \$$.

374 SEK 1976-79, 11-12, 39-40; Vischer 2004, 47.

375 Esim. Kirk.kok. kptk-k. 1974, 64 \$; Kirk.kok. kptk-s. 1974, 5 \$; Kirk.kok. kptk-k. 1977, 8 \$; Kirk.kok. kptk-s. 1977, 22 \$.

376 KKHA KKA Cc 3 Naisjärjestöjen Keskusliiton vetoomus huhtikuussa 1975, "Naisjärjestöjen keskusliiton audienssi torstaina 10.4.1975 klo 09.15"; Antila 2010, 327-328.

377 Marjatta Väänäsen puhelinhaastattelu 28.4.2005; Antila 2010, 327.

378 Kirk.kok. kptk-s. 1976, 44 §.

379 Kirk.kok. kptk-s. 1976, 219-220; Kmaa 16.11.1976 Naispappeus kaatui määrävähemmistöön (Matti Sippo); Jaakko Nummisen haastattelu 4.7.2012.

380 Kirk.kok. ptk-s. 1976, liite VI 3; Mäkeläinen 1976b, 12, 22.

381 Kirk.kok. ptk-s. 1976, 48 §.

382 Ks. myös Kmaa 8.2.1977 Kirkolliskokous menettelytapakriisissä.

383 Kmaa 16.11.1976 Naispappeus kaatui määrävähemmistöön (Matti Sippo)

384 Kirk.kok. ptk-k. 1976, liite VII 2 Hiippakuntakokousten lausunnot; Kirk. kok. ptk-s. 1976, liite VI 3; Kmaa 16.11.1976 Naispappeus kaatui määrävähemmistöön (Matti Sippo); Juva 1978, 184. Juva näki tuloksessa vanhan jaon vanhoillisen Länsi-Suomen ja edistyksellisen Itä-Suomen välillä. Juva 1978, 184.

385 Kirk.kok. kptk-s. 1976, $44 \$$.

386 ESS 13.11.1976 Naispappeus enää kymmenen äänen takana (pääk.); Kaleva 13.11.1976 Lykkääntyi (pääk.); $M T$ 13.11.1976 Ei vielä tällä kertaa (pääk.); Vaasa 13.11.1976 Viivyttäjien erävoitto (pääk.); Kmaa 16.11.1976 Näkökulma; $\AA$ U 16.11.1976 Lämna inte snart fullbordat verk! (Meta Torvalds, ledare); Kmaa 19.11.1976 Näkökulma.

387 Kirk.kok. ptk-k. 1976, liite III; H.-T. Nieminen 2008, 193; Niiranen 2008, 337

388 Kirk.kok. kptk-k. 1976, 32 \$, 97 \$; Kirk.kok. ptk-k. 1976, liite IX 9 \& X-B 1 \& $1 \mathrm{a}$.

389 Ks. Kirk.kok. kptk-s. $1977,50 \$$.

390 KKHA KKA Cib 1 ptk. 9.8.1976 \$2, "Luonnos perustevaliokunnan mietinnön loppuosaksi virkakomitean loppumietinnöstä".

391 KKHA KKA Cib 1 ptk. 31.8.1976 \$ 4; Kirk.kok. ptk-s. 1976, liite IX-B 2, 7-8, 12.

392 Kirk.kok. ptk-s. 1976, liite IX-B 2.

393 Kirk.kok. ptk-s. 1976, liite VI 3.

394 Kirk.kok. kptk-s. 1976, 44 \$; Kirk.kok. ptk-s. 1976, liite IX-B 2, 8; Konttinen 1976, 81-82; Heinonen 1990, 85.

395 Kirk.kok. kptk-k. 1976,1-2.

396 Kirk.kok. kptk-s. 1976, 44 \$; Kirk.kok. ptk-s. 1976, liite IX-B 2.

397 Kirk.kok. kptk-s. 1976, 44 §.

398 Kmaa 8.2.1977 Kirkolliskokous menettelytapakriisissä, 22.2.1977 Kysymyksiä kirkolliskokouksen menettelytavasta (Paavalin synodin keskustoimikunta / Sigtrygg Serenius), 25.2.1977 Kirkolliskokouksen äänestysmenettely 10. 11. 1976 (Martti Simojoki), 4.3.1977 Seitsemän vastausta kirkolliskokouksen menettelytapaa koskeviin kahteentoista kysymykseen (Johannes Leivonen), 3.5.1977 Kirkolliskokouksen menettelytapaongelma jäänyt selvittämättä (Paavalin synodin keskustoimikunta / Eino J. Honkanen). Esimerkkinä naispappeuden vastustajien myöhemmästä tulkinnasta Kiviranta 2009, 245.

399 Kirk.kok. kptk-s. 1976, 44 \$.

400 Kirk.kok. kptk-s. 1976, 48 \$.

401 Kmaa 25.2.1977 Kirkolliskokouksen äänestysmenettely 10.11. 1976 (Martti Simojoki).

402 Antila 2011, 351-353.

403 Kirk.kok. ptk-l. 1971, liite VI-B 1 a; Kmaa 8.2.1977 Kirkolliskokous menettelytapakriisissä.

404 Antila 2011, 351-352.

405 Kmaa 8.2.1977 Kirkolliskokous menettelytapakriisissä.

$406 A l$ 1.5.1976 Kirkko parka (Urpo Harva); Herättäjä 6.5.1976 Kaksi varoitusta (pääk.); Kmaa 7.5.1976 Omantunnon suoja (pääk.); TS 9.5.1976 Kirkko koossa vai koolla (pääk.); SK 19/1976 Naispappeus ei ole edistynyt (Risto Lindstedt); Kotiliesi 10/1976 Ei väenväkisin (Eila Jokela, pääk.).

407 HS 12.11.1976 Suolapatsas (pääk.); Sd 13.11.1976 Kirkon syrjityt työntekijät (pääk.); SkT 13.11.1976 Epädemokraattinen kirkko (pääk.); Turun Päivälehti 13.11.1976 Torjuttu naispappeus (pääk.).

408 Kirk.kok. kptk-s. 1976, 44 \$; Heinonen 1990, 77.

409 Kirk.kok. ptk-s. 1976, liite IX-B 3.

410 Kirk.kok. kptk-s. 1976, 49 \$, 51 §. Samoin Taskila 1998, 173.

411 Kirk.kok. ptk-k. 1988, liite VIII 1, 10.
412 Kirk.kok. kptk-s. 1976, $49 \$, 68 \S$.

413 Kirk.kok. ptk-s. 1976, liite IX-B 3 a.

414 Kirk.kok. kptk-s. 1976, 68 \$.

415 Kirk.kok. ptk-s. 1976,72 §.

416 Kirk.kok.ptk-k. 1988, liite VIII 1, 13-14, 21

417 YKV 1997, 38; R. A. Ahonen 1991, 123.

418 Kiviranta 1973,10-11.

419 Mannermaa 1978, 52-54; Meyer 2004, 114-117.

420 Kirk.kok. ptk-k. 1976, liite II 1, 1; Euroopan reformatoristen kirkkojen konkordia 1998, 214-220.

421 LKTP 1973, 29; Kirk.kok. ptk-k. 1976, liite II 1,3-4; Toiviainen 2004, 113-115; Malkavaara 2011, 399; Forsberg 2012, 541.

422 Kirk.kok. ptk-k. 1976, liite II 1, 4-5.

423 Kirk.kok. ptk-k. 1976, liite II 1, 6.

424 Niiranen 2008, 383; Tuomala 2013, 20.

425 Kirk.kok. kptk-k. 1976,31 \$; Niiranen 2008, 385.

426 Kirk.kok. kptk-k. 1976, 31 \$; Jokinen 1990, 18-19, 21; Toiviainen 2004, 114; Niiranen 2008, 382-385; Tuomala 2013, 24.

427 Kirk.kok. kptk-k. 1976, 31 §.

428 KKHA KKA Cib 1 ptk. 7.3.1977 $\$ 5$, "Havaintoja Leuenbergin konkordian ongelmista" (Eero Parvio), "Vaihtoehtoinen perustevaliokunnan mietintö n:o 4/1977 (Juva)"; Ratzeburger Thesen 1972.

429 Kiviranta 2009, 175-176; Tuomala 2013, 30.

430 Kirk.kok. ptk-k. 1977, liite X-B 3, 6.

431 Ks. Mannermaa 1978, 41.

432 Kirk.kok. ptk-k. 1977, liite X-B 3, 6. Teologisesti arvioituna valiokunta yritti tehdä samoin kuin oli tehty konkordian metodia muutettaessa: hylätä barthilaisesta sananteologiasta lähtevät mallit. Sen jälkeen perustevaliokunta hylkäsi kuitenkin myös konkordian myöhemmissä vaiheissa esiin työntyneen metodin, jonka mukaan tarvittavaan kvantitatiiviseen yksimielisyyteen riitti yhteisymmärrys tietyssä hyvin rajatussa oppikokonaisuudessa. Näiden hylättyjen käsitysten tilalle valiokunta ei kuitenkaan kyennyt esittämään selkeää yhteysmallia ja mietintö ajautui sisäiseen ristiriitaan.

433 Kirk.kok. ptk-k. 1977, liite X-B 3, 6-7.

434 Kirk.kok. kptk-k. 1976, 5.

435 KKHA KKA Cib 1 "Vaihtoehtoinen perustevaliokunnan mietintö n:o 4/1977 (Juva)"; Kirk.kok. kptk-k. 1976, 31 \$; Kirk.kok. ptk-k. 1976, liite II 1, 6; Kirk.kok. ptk-k. 1977, liite X-B 3, 9.

436 Kirk.kok. kptk-k. 1977, 27 \$.

437 Kirk.kok. kptk-k. 1977, 27 \$; Niiranen 2008, 382.

438 Kirk.kok. kptk-k. 1977, 27 \$.

439 Kirk.kok. ptk-k. 1977, liite X-B 3 a. Eriävän mielipiteen allekirjoittivat Juvan lisäksi Gunnar Träskman, Eeva Ojanen ja Esko Kilpeläinen.

440 Kirk.kok. ptk-k. 1977,74\$.

441 Tuomala 2013,37

442 Toiviainen 2004, 116

443 Kirk.kok. kptk-k. 1977, 61 \$.

444 Kirk.kok. kptk-k. 1977, 27 \$.

445 KKHA KKA Cib 1 "Havaintoja Leuenbergin konkordian ongelmista" (Eero Parvio); Kirk.kok. kptk-k. 1977, 61 \$; Kirk.kok. ptk-k. 1977, liite X-B 3, 7.

446 OMA MSA1 Ab:10/85 Mikko Juva Simojoelle 15.6.1976.

447 Туррӧ 2005, 57, 64-65.

448 Ripatti 2004, 204.

449 Nuorteva 1989, 146.

450 Kirk.kok. kptk-k. 1977, $27 \$, 61 \S$.

451 Kirk.kok. kptk-k. 1977, 61 \$.

452 Kirk.kok. kptk-s. 1976, 44 \$.

453 Ks. Pekka Lempiäinen 1982, 50.

454 Kirk.kok. kptk-k. 1977, 27 \$.

455 Kirk.kok. kptk-k. 1977, 61 \$.

456 Kirk.kok. ptk-k. 1976, liite II 1, 1.

457 Kirk.kok. kptk-k. 1977, 27 \$.

458 Kirk.kok. kptk-k. 1974, 7

459 Papiston ja esivallan suhteesta routavuosina Murtorinne 1964

460 SEK 1972-75, 256; Autio 1994, 77-78; Kuusela 2000, 18.

461 Alkoholijuomien kulutus; Peltonen 2006, 442-443, 445

462 Juva 1976, 205, 219-220.

463 Juva 1976, 228. 
464 SEK 1972-75, 29.

465 Kirk.kok. kptk-k. 1974, 7-8.

466 Kirk.kok. kptk-k. 1974,75 \$, 110 \$.

467 Kirk.kok. ptk-k. 1974, liite II 2.

468 Kirk.kok. kptk-k. 1974, 16 \$.

469 Kirk.kok. kptk-k. 1974, $16 \$$.

470 Kirk.kok. kptk-k. 1974, 42 \$.

471 Kirk.kok. kptk-s. 1974, 46 \$.

472 Oulun hpk.kok. ptk. 1974, 8-13, 18-19.

473 Kirk.kok. ptk-k. 1974, 96 §.

474 Kuusela 2000, 30-32.

475 Kirk.kok. ptk-k. 1974, 1.

476 Kirk.kok. kptk-k. 1974, 261-263; Kirk.kok. ptk-k. 1974, $108 \$$.

477 Kirk.kok. ptk-s. 1974, liite VI-B 4 \& 4 a.

478 KKHA KKA Cib 1 ptk. 11.5.1974 \$1, ptk. 26.10.1974 \$2.

479 Kirk.kok. ptk-s. 1974, liite V 1; Kirk.kok. kptk-s. 1977, 16 \$; Kirk.kok. kptk-k. 1978, 29 \$; Kirk.kok. ptk-k. 1981, liite VIII 5.

480 Kirk.kok. kptk-k. 1975, 38 \$; Kirk.kok. kptk-s. 1975, 52 \$.

481 Kirk.kok. kptk-k. 1975, 38 §.

482 Kirk.kok. ptk-s. 1975, liite V-B 4.

483 Kuusela 2000, 32.

484 Kirk.kok. kptk-s. 1975, 26 \$; T. Hämäläinen 2012, 76-77.

485 Kirk.kok. ptk-s. 1975, liite V-B 4.

486 Esim. Kirk.kok. kptk-k. 1975, 38 \$; Kirk.kok. kptk-k. 1978, 17 \$.

487 Kirk.kok. kptk-s. 1975,52 \$.

488 Kirk.kok. ptk-s. 1975, $26 \S, 48$ \$, liite V-F 7 a; T. Hämäläinen 2012, 78.

489 SEK 1976-79, 258; Kettunen \& Jalava \& Simola \& Varjo 2012, 43.

490 SEK 1976-79, 256-257; Kuusela 2000, 34.

491 SEK 1976-79, 36, 38; Autio 1994, 79, 144; Kuusela 2000, 38-39, 43; Jalovaara 2011, 200-202.

492 Kirk.kok. ptk-k. 1978, 63 \$; SEK 1976-79, 257-258.

493 SEK 1976-79, 38; SEK 1980-83, 20, 284.

494 KKHA KKA Cc 12 "Opetusministeri Jaakko Itälä kirkolliskokouksen yhteydessä järjestettävässä kahvitilaisuudessa 10.5.1978 Turussa”.

495 KKHA KKA Cc 12 "Arkkipiispa Simojoen vastauspuheenvuoro opetusministeri Itälälle" 10.5.1978. Kolme vuotta aiemmin käsiteltävänä oli ollut Oulun hiippakuntakokouksen aloite seurakunnan palveluksessa olevien pappien poliittisen toiminnan rajoittamisesta. Aloitteen huoli oli pitkälti päinvastainen kuin Simojoella. Aloite ei johtanut tulokseen, mutta kirkolliskokouksen keskustelussa oli huomattavissa, että vasemmiston vahvalla alueella toimineet olivat kaikkein myönteisimpiä aloitteelle. Kirk.kok. kptk-k. 1975, $39 \$$. Heidän asenteessaan oli samaa kuin piispa E. G. Gulinilla sodan jälkeen: pappien poliittinen toiminta suuntautui lähinnä ei-sosialistisiin puolueisiin, eikä se siksi ollut hyväksi pyrittäessä luomaan yhteyksiä työväestöön. Kortekangas 2005, 459.

496 KKHA KKA Cc 12 "Opetusministeri Itälän vastauspuheenvuoro arkkipiispa Simojoelle" 10.5.1978.

497 KKHA KKA Ciia 1 ptk. 10.5.1978 klo $9 \$ 2$.

498 Kirk.kok. ptk-k. 1978, liite XI-E 1.

499 KKHA KKA Cc 20 opetusministeri Stenbäck kirkolliskokouksessa 5.11.1979, Cc 24 "Opetusministeri Pär Stenbäckin puhe ev.lut. kirkon kirkolliskokouksen 3.11.1980 yhteydessä järjestetyssä kahvitilaisuudessa".

500 Esim. Kirk.kok. kptk-s. 1979, 11.

501 Jaakko Nummisen haastattelu 4.7.2012.

502 Kirk.kok. kptk-k. 1977, 1-3; Kirk.kok. kptk-s. 1977, 60 §; SEK 1976-79, 20.

503 Kirk.kok. kptk-s. 1980, 45 \$.

504 Kirk.kok. kptk-s. 1980, 52 \$; SEK 1980-83, 29-30.

505 Kirk.kok. kptk-k. 1980, 90 \$; Kirk.kok. ptk-k. 1980, liite XI-B 3.

$506 \AA ̊$ U 10.5.1980 Fars dag i kyrkomötet (Meta Torvalds, ledare).

507 Kirk.kok. kptk-s. 1980, $32 \S$.

508 Kmaa 3.11.1981 Kirkolliskokouksen kirjelmät on "annettu tiedoksi" (Kirsti Ritopeura).

509 Kirk.kok. kptk-s. 1979, 40 \$; Kirk.kok. ptk-s. 1979, liite VIII-E 4; Kirk.kok. ptk-k. 1980, 78 \$, 91 \$, liite XI-D 1 \& XI-D 1 a; Kirk.kok. kptk-s. 1980, 32 \$, 37 \$; Kirk.kok. ptk-s. 1980, liite VII-F 1 b.

510 Kirk.kok. kptk-k. 1980, $92 \$$.

$511 H S$ 5.11.1980 Avoliitto kaipaa laajaa selvitystä (pääk.); ESS 8.11.198o Epäonnistunut kokous (Eeva Rissanen); Kansan Lehti 8.11.1980 Kirkonkukko: Suo siellä - vetelä täällä; $S k K$ 8.11.198o Avioliitto tasa-arvoiseksi (pääk.); Sd 8.11.1980 Punahilkan päiväkirja (Suzy Hukkanen); SS 8.11.198o Per- heen puolesta (pääk.); Vaasa 8.11.1980 Avosuhteen ongelma (pääk.); $\AA U$ 8.11.1980 Den svåra aborten (Meta Torvalds, ledare); Hbl 9.11.198o Abortlagen (Catharina Spåre, ledare); HS 9.11.1980 Voi hyvä isä sentään; Ilkka 9.11.1980 Avosuhde vai avioliitto (pääk.); Hämeen Sanomat 10.11.198o Kirkko selvensi kantaansa (pääk.); IS 10.11.198o Avoliitosta avosuhde (pääk.); Länsi-Suomi 10.11.198o Perhesuhdetta lujitettava (pääk.); Hbl 11.11.1980 Kyrka, äktenskap och samboende (Jan-Magnus Jansson); Kmaa 11.11.1980 Aikapula kirkolliskokouksessa (pääk.); KU 11.11.198o Reunahuomautuksia; Sana 11.11.198o Ehtiikö kirkko keskustella (pääk.); IS 13.11.1980 Avo vai avio? (Matti Almila); Ksml 13.11.1980 Kirkolla oikeus ottaa kanta (pääk.); Al 6.12.198o Hengellistä ja maallista (Urpo Harva); Uusi Tie 10.12.1980 Kirkolliskokous vetoaa valtiovaltaan (pääk.); Kpr 11.12.198o Nationens livsfrågor (Håkan Hellberg).

512 Kirk.kok. kptk-s. 1981, 74 \$.

513 Kirk.kok. kptk-s. 1980,34\$, 36 \$; 52 §.

514 Kirk.kok. kptk-s. 1975, 26 §.

515 Esim. Kirk.kok. kptk-s. 1980, 17 \$.

516 Kirk.kok. kptk-k. 1981, 25\$, $68 \$$.

517 KKHA KKA Ha 1 ptk. 3.6.1974 \$3, rkkptk. 26.2.1975 \$2; Kirk.kok. kptk-k. 1975, 22 \$; Kirk.kok. ptk-k. 1975, liite III 3, 7-8.

518 Kirk.kok. kptk-s. 1975,17 \$; Kirk.kok. kptk-k. 1976, 61 \$; Kirk.kok. kptk-s. 1976, $31 \S, 36 \S$.

519 Kirk.kok. kptk-k. 1977, 8 \$, 21-22 \$; Kirk.kok. kptk-s. 1980, 20 \$.

520 SEK 1976-79, 20.

521 S. Häkkinen 2010, 110-112; Sorsa 2010, 129, 133-134.

522 SEK 1972-75, 41-42; Vikström 2004, 107; Sorsa 2010, 135-138.

523 Sorsa 2010, 139-141.

524 Kirk.kok. ptk-k. 1974, 31 \$; Pentikäinen 2009, 70-71.

525 OMA MSA1 Ab:10/84 Mikko Juva Simojoelle 26.9.1971; SEK 1972-75, 42; Sorsa 2010, 141

526 Kirk.kok. kptk-s. 1974, 23 \$; Kirk.kok. ptk-s. 1974, liite VI-B 6.

527 Kirk.kok. ptk-s. 1974, 23 \$; Kirk.kok. ptk-s. 1974, liite VI-B 6 a; Kirk.kok. kptky. 1974, 3 \$.

528 Varapuheenjohtajana oli oikeusneuvos, sittemmin hovioikeuden presidentti Heimo Lampi ja muina jäseninä professori, sittemmin piispa Paavo Kortekangas, professori Eino Murtorinne sekä professori, sittemmin piispa Kalevi Toiviainen. Varajäseninä olivat asessori Ossi Haaramäki ja apulaisprofessori Ari Haavio. Sittemmin Murtorinteen ja Haavion pyydettyä eroa Murtorinteen tilalle valittiin vuonna 1976 professori Kauko Pirinen ja Haavion tilalle vuonna 1977 dosentti Voitto Huotari. Ensimmäisen vuoden aikana sihteerinä toimi päätoimisesti pastori Raimo Karvonen, minkä jälkeen tehtävää hoiti virkansa ohella Ossi Haaramäki. Kirk. kok. ptk-k. 1980, liite V 1, 9-10.

529 Kirk.kok. kptk-s. 1974, 23 \$; Sorsa 2010, 141

530 Seppo 1999, 42-43.

531 Kirk.kok. ptk-k. 1974, liite V 8. Ks. Juva 1976, 50-51, 65, 69-72, 79-80, 86-87; Nokkala 1986, 269-383.

532 Kirk.kok. kptk-s. 1974, 22 \$.

533 Kirk.kok. kptk-s. 1974, 22 \$.

534 Kirk.kok. ptk-k. 1978, liite X 4

535 SEK 1976-79, 22; Al 28.2.1979 Turvan hakua (pääk.); Hämeen Sanomat 28.2.1979 Uskonnollisuus (pääk.); Vaasa 28.2.1979 Uskonnollisuus ja kirkko (pääk.); Kouvolan Sanomat 1.3.1979 Uskonnollisuus tutkittu (pääk.); US 5.3.1979 Kirkkotien varrelta (Vaeltaja); KJK 7.3.1979 Yllättävä ristiriita (pääk.).

536 SEK 1976-79, 22

537 Kirk.kok. kptk-k. 1979, 54 \$; Kirk.kok. ptk-k. 1979, liite X-B 2.

538 SEK 1976-79, 27-28; Autio 1994, 342, 348; Murtorinne 1995, 390.

539 SEK 1976-79, 23, 28.

540 SEK 1976-79, 61-62.

541 Niiranen 2008, 294

542 SEK 1972-75, 53; Kirk.kok. kptk-k. 1977, 2.

543 Kirk.kok. kptk-k. 1979, 3-4.

544 SEK 1980-83, 288; Ksml 9.5.1979 Television hartausohjelmat (pääk.); Länsi-Suomi 9.5.1979 Kirkko kansan omanatuntona (pääk.); TS 10.5.1979 Kirkko ja kuvaruutu (pääk.); US 11.5.1979 Katseet kirkkoon (pääk.); Ilkka 13.5.1979 Kirkkopihasta (Apupappi); US 13.5.1979 Monenlaisia mietteitä (Pentti Pirhonen).

545 Kirk.kok. kptk-s. 1979, 24 \$; Kirk.kok. ptk-s. 1979, liite VIII-A 4, 39; S. Eskola 2012a, 90-92. 
546 Kirk.kok. kptk-k. 1979, 25 \$; Kirk.kok. kptk-s. 1979, 20 \$; Sorsa 2010, 169-173. 547 Kirk.kok. kptk-s. 1979, 20 \$; Stenbäck 1991, 144-145; Sorsa 2010, 167; Mustakallio 2012a, 521. Taxell ei tosin nähnyt tuomiokapitulien aseman valtion virastoina heikentävän kirkon itsenäisyyttä. Kirk.kok. kptk-s. 1979, 22.

548 Kirk.kok. ptk-k. 1980, liite V 1, 42.

549 Kirk.kok. kptk-k. 1979, 2.

550 Kirk.kok. kptk-k. 1979, 25 \$; Sorsa 2010, 172-175.

551 Kirk.kok. kptk-k. 1979, $25 \$$.

552 Kirk.kok. kptk-s. 1979, 20 \$, 22 \$; Sorsa 2010, 171-173.

553 Kirk.kok. kptk-s. 1979, 22 \$.

554 Kirk.kok. kptk-k. 1979, 25 \$; Kirk.kok. ptk-k. 1979, liite IV, 16-17; Sorsa 2010, 168-17o.

555 Kirk.kok. ptk-s. 1979, 22 \$; Sorsa 2010, 173-175.

556 Sorsa 2010, 181

557 Kirk.kok. ptk-k. 1980, liite V 1, 11, 24; SEK 1976-79, 32; Vikström 2004, 108; Ossi Haaramäen haastattelu 28.10.2010; Murtorinne 1995, 404; S. Häkkinen 2010, 114; Sorsa 2010, 177-178, 180; Eriksson 2013, 25.

558 Kirk.kok. kptk-k. 1980, 39 \$; Vikström 2004, 109.

559 Kirk.kok. kptk-s. 1980, 21 \$ Kirk.kok. ptk-s. 1980, liite VII-B 4; Vikström 2004, 110.

560 Kirk.kok. ptk-s. 1980, 39 \$; Sorsa 2010, 181. Komitean puheenjohtajaksi valittiin oikeusneuvos Johannes Leivonen ja varapuheenjohtajaksi piispa Erkki Kansanaho. Jäseninä olivat asessori Ossi Haaramäki, teologian tohtori Olli Heilimo, profesori Toivo Holopainen, valtiotieteiden maisteri Sinikka Isotalo, kirkkoneuvos Heikki Kokko, piispa Paavo Kortekangas, ye.everstiluutnantti Erkki Reinikainen, hallintoneuvos Olli Sakki, asessori Gunnar Träskman, lehtori Raili Turtola, professori Jaakko Voipio ja teologian tohtori Tapani Vuorela. Päätoimisena sihteerinä toimi ensin varatuomari Risto Voipio ja sitten varatuomari Ilkka Holopainen.

561 Kirk.kok. kptk-k. 1980, $39 \$$.

562 Kirk.kok. ptk-k. 1976, liite II 2 \& V 3.

563 Kirk.kok. kptk-s. 1977, 50 \$; Kirk.kok. ptk-s. 1977, liite VII-B 6

564 SEK 1980-83, 51-52; Jokinen 1990, 59-62.

565 Kirk.kok. kptk-k. 1981, 2-4.

$566 \AA$ 5 5.5.1981 Risk för trängre kyrka (Meta Torvalds, ledare); Hbl 6.5.1981 Mikko Juvas linjedragning (Jan-Magnus Jansson, ledare); Länsi-Savo 6.5.1981 Kansan kirkko (pääk.); SkK 6.5.1981 Kirkko ja uskovaiset (pääk.); Al 7.5.1981 Suvaitaan yhä (pääk.); Kmaa 7.5.1981 Arkkipiispan puhe (pääk.); SS 7.5.1981 Kansankirkko esillä (pääk.); WL 7.5.1981 Kalamies: Kirkon ääni; Hämeen Sanomat 8.5.1981 Suvaitsevainen kansankirkko (pääk.); Vaasa 8.5.1981 Tietoiseen toimintaan (Matti Kupari); Al 9.5.1981 Kevättä kirkossa (Vähtäri); HS 10.5.1981 Puheenvuoro joka oli tarpeen (pääk.); US 10.5.1981 Ymmärtävä kirkko (pääk.); Uusi Tie 13.5.1981 Kirkolliskokouksen jälkikaikua (pääk.); Sja 14.5.1981 Arkkipiispan kannanotto (Lauri Koskenniemi, pääk.); Jokinen 1990, 64-68.

567 Juva 1976, 168.

568 Kirk.kok. kptk-s. 1977, 21 §.

569 SEK 1972-75, 72; SEK 1976-79, 59.

570 SEK 1976-79, 62.

571 Kirk.kok. kptk-s. 1975, 53 \$; Kirk.kok. ptk-s. 1975, liite V-F 12.

572 Kirk.kok. kptk-s. 1977, 33 \$, 40 \$; Kirk.kok. ptk-s. 1977, liite VII-B 5.

573 Kirk.kok. kptk-s. 1975, 19 \$.

574 Jaakko Nummisen haastattelu 4.7.2012.

575 Kirk.kok. kptk-k. 1980, 44\$.

576 Mäkeläinen 1976a, 3, 10.

577 Heikkilä 1992, 7-8.

578 Kirk.kok. kptk-k. 1974, 5.

579 Kirk.kok. kptk-k. 1975, 92 \$, $102 \S$.

580 Kirk.kok. kptk-k. 1977, 82 §.

581 Kirk.kok. kptk-k. 1976, 111 §.

582 SEK 1976-79, 64, 68

583 SEK 1976-79, 64

584 Kirk.kok. kptk-s. 1977, 22 \$.

585 Kirk.kok. kptk-k. 1979, $54 \$$

586 Murtorinne 1995, 318-322.

587 Helander \& Pekonen 2007, 12, 15.

588 Kirk.kok. ptk-k. 1979, liite X-A 4.

589 SEK 1976-79, 62

590 Kirk.kok. kptk-k. 1974, 100 \$; Kirk.kok. kptk-k. 1975, 95 \$; Kirk.kok. kptk-k. 1976, 117 \$; Kirk.kok. kptk-s. 1977, 22 \$; Kirk.kok. kptk-s. 1979, 47 \$.
591 Kirk.kok. ptk-k. 1979, $20 \$$, liite X-A 4

592 Esim. Kirk.kok. kptk-s. 1975, 25 \$; Kirk.kok. ptk-s. 1976, 38 \$; Kirk.kok. kptkk. 1977,80 \$, 82 \$; Kirk.kok. kptk-k. 1980, 35 \$.

593 Kirk.kok. kptk-s. 1975, $26 \$$.

594 Kirk.kok. kptk-k. 1979, 47 \$.

595 Kirk.kok. kptk-s. 1980, 37 \$.

596 Esim. Kirk.kok. kptk-k. 1980, 44 §.

597 Kirk.kok. kptk-s. 1981, 74 §.

598 Kirk.kok. kptk-k. 1978, 63 \$.

599 Kirk.kok. kptk-k. 1978, 52 \$.

600 Kirk.kok. kptk-k.1980,39§.

601 S. Eskola 2012a, 71; Lohi 2012, 465.

602 Seppo 2013, 436.

603 S. Eskola 2004, 138; S. Eskola 2012a, 13.

604 Esim. Kirk.kok. kptk-s. 1975, 19 \$, 26 \$; Niiranen 2008, 297-298.

605 Kirk.kok. kptk-k. 1980, 83 \$; S. Eskola 2004, 138.

606 Kirk.kok. kptk-k. 1980, $20 \$$.

607 Kirk.kok. kptk-k. 1981,54\$.

608 Ollila 2007, 109-111.

609 S. Eskola 2004, 139-140.

610 Kirk.kok. kptk-k. 1976, $45 \$$.

611 Kirk.kok. kptk-s. 1981, 50 \$.

612 Ollila 2007, 60-61.

613 S. Eskola 2004, 140

614 Kirk.kok. kptk-s. 1975, 53 §.

615 S. Eskola 2012a, 82.

616 Toiviainen 2000, 76; S. Eskola 2005, 57; S. Eskola 2012a, 82.

617 Esim. Kirk.kok. kptk-s. 1976, 36 \$; Kirk.kok. kptk-k. 1977, 91 \$; Kirk.kok. kptk-s. $1977,29 \S$.

618 Kirk.kok. ptk-k. 1975, liite IV 1.

619 Kirk.kok. kptk-k. 1975, 56 \$.

620 Kirk.kok. kptk-s. 1975, 30 \$.

621 Kirk.kok. kptk-s. 1974, 22 \$; Typpö 2005, 15-16.

622 Kirk.kok. ptk-k. 1974, 110 \$; Kirk.kok. kptk-s. 1977, 40 \$.

623 Kirk.kok. kptk-k. 1976, 32 \$; Kirk.kok. kptk-k. 1980, 39 \$; Kirk.kok. kptk-s. $1980,21 \S$.

624 Kirk.kok. ptk-k. 1980, liite V 1, 15, 29, 39.

625 KKHA KKA Cig 1 ptk. 6.5.1981 \$3, 7.5.1981 klo 11.0o § 2; Kmaa 25.10.1984 Norjan kirkko sai Kirkolliskokouksen.

626 Bexell 1990, 159-160; Ekström 2003, 146-147; Lundstedt 2006, 142-145.

627 Numminen 1991, 140.

628 Kirk.kok. kptk-k. 1980,39 \$; Kirk.kok. kptk-s. 1980, 21 \$; Kirk.kok. ptk-s. 1980, liite VII-B 4.

629 KKHA KKA Cig 1 ptk. 11.4.1975 \$2; Kirk.kok. kptk-k. 1975, 10 \$; Sinikka Pylkkäsen haastattelu 7.1.2014.

630 Kirk.kok. kptk-k. 1974, $112 \$$.

631 Sinikka Pylkkäsen haastattelu 7.1.2014.

632 Kirk.kok. kptk-s. 1977, 60 \$; Kirk.kok. kptk-s. 1981, 74 \$. 


\section{NAISPAPPEUS, VIRSIKIRJA}

\section{JA RAAMATUNK ̈̈̈̈NNÖS 1982-1992}

1 KKHA KKA Cc 39 päätös yhteistyöelimen asettamisesta 17.11.1983; Autio $1997,197$.

2 Autio 1997, 196-197.

3 SEK 1984-87, 32-33.

4 Tiihonen 1996, 576; Autio 1997, 15-16; Meinander 1999, 448; Vainio 2007, 210.

$5 \quad$ Kallenautio 2005, 321.

6 SEK $1980-83,41,46$

7 SEK 1980-83, 43-45, 58; Murtorinne 1995, 392.

8 Meinander 1999, 449-450; Kallenautio 2005, 400-405; Visuri 2006, 244245 .

9 Visuri 2006, 262-264.

10 LTA Eca tuomiokapituli kirkolliskokouksen valitsijamiehille ja lääninrovasteille 5.1.1982.

11 HTA Eec 3 tuomiokapituli kirkolliskokouksen maallikkoedustajien valitsijamiehille 16.1.1982; LTA Eca tuomiokapituli kirkolliskokouksen maallikkoedustajien valitsijamiehille 18.1.1982.

$12 S d$ 3.2.1982 Kirkolliskokouksen ehostusta (pääk.); Eteenpäin 14.2.1982 Kansan ääni ei kuulu kirkolliskokoukseen (pääk.).

13 PTyö 11.2.1982 Kansanliike tarpeen: Kirkolliskokous olisi valittava oikealla vaalilla (Marjatta Valli).

14 US 5.2.1982 "Häpiä ja kunnia" (Eila Jokela).

15 Kmaa 29.1.1982 Vastuu valitsijoilla (pääk.); US 2.2.1982 Kaukainen kirkolliskokous (pääk.); SS 7.2.1982 Toisen kerroksen väkeä (Pentti Hakala); Sana 9.2.1982 Miten valita kirkolliskokous; Kmaa 4.5.1982 Uusi kirkolliskokous (pääk.).

16 Kirk.kok.ptk-k. 1982, liite XI Helsinki 4 \& XII 1; S. Eskola 2012a, 16-17.

17 Kirk.kok. ptk-k. 1983, liite VIII, 11-13.

18 Kirk.kok. kptk-s. 1983, 21 \$; Kirk.kok. ptk-k. 1983, liite VIII, 13, 18-19.

19 Kirk.kok. ptk-s. 1983, liite VIII-A 7.

20 Kirk.kok. ptk-k. 1983, liite VIII, 13, 17.

21 Kirk.kok. kptk-s. 1983, 25 \$.

22 Kirk.kok. kptk-s. 1983, $23 \$, 45$ \$.

23 Kirk.kok. kptk-s. 1983, $23 \$$.

24 Kirk.kok. kptk-s. 1983, 45 \$.

25 Kirk.kok. kptk-s. 1983, 25 \$; Kirk.kok. ptk-s. 1983, liite VIII-A 7 a.

26 Kirk.kok. ptk-s. 1983, $46 \$$.

27 Ilkka 3.3.1986 Kirkolliskokouksen voisi valita suorallakin vaalilla (pääk.); SS 11.3.1986 Naispappeus toteutuu (pääk.).

28 Eteenpäin 20.10.1985 Unilukkari: Hitsipilli takataskussa kirkolliskokoukseen; $S d$ 12.3.1986 Kirkko avoimeksi korjausta varten (pääk.). Otsikko viittasi vuonna 1967 julkaistuun, huomiota herättäneeseen pamflettiin. Ks. $M$. Ketola 2011.

29 US 28.2.1986 Kilpajuoksu kohtalon kanssa (Mikko Heikka); Sd 12.3.1986 Kirkko avoimeksi korjausta varten (pääk.); Knen 21.3.1986 Kirkon hallinto kansanvaltaisemmaksi (pääk.).

30 US 1.3.1986 Kirkolliskokouksen valintatapaa ei pidä muuttaa (Seikko Eskola); Sd 25.3.1986 Kirkolliskokous ja demokratia (Seikko Eskola).

31 US 18.6.1985 Naispappeudesta kova junttaus; Kaleva 25.6.1985 Kiskolliskokousvaalit lämmittävät jo mieliä (Pekka Koivisto).

32 Sd 25.10.1985 SDP haluaa kirkolliskokoukseen naispappeuden kannattajia, 29.10.1985 Kaikuja kirkosta (pääk.); Mäkinen 2008, 65.

33 HTA Eec 4 ehdokaslistojen yhdistelmä kirkolliskokouksen maallikkoedustajien vaalissa Helsingin hiippakunnassa 3 päivänä maaliskuuta 1986.

34 LTA Eca valitsijayhdistysten asiamiesten hakemukset kirkolliskokouksen maallikkoedustajien vaalissa 1986, Lapuan hiippakunnan ehdokaslistojen yhdistelmä kirkolliskokouksen maallikkoedustajain vaalissa 3.3.1986; SS 3.1.1986 Maallikkojen vaalit (pääk.); Ilkka 5.1.1986 Naispappeuskysymys ja politiikka värittävät kirkolliskokousvaaleja (pääk.); Pnen 5.1.1986 Kirkolliskokousvaalit (pääk.).

35 Kp 11.3.1986 Lähempään käsittelyyn: Uusi kirkolliskokous (Pentti Pulak$\mathrm{ka})$.

36 HTA Eec 3 pappisedustajien vaalin tulokset rovastikunnittain 1982.

37 LTA Ca ptk. 2.4.1986 \$50, liite 1.
38 HS 4.3.1986 Naispappeuden puoltajat lisäsivät kannatustaan.

39 Hbl 2.3.1986 Folkopinionens kyrkomötesval? (Catharina Spåre, ledare), 12.3.1986 'Kvinnoval' för kyrkan (Catharina Spåre, ledare), 3.1.1988 Nytt kyrkomöte ska väljas (Catharina Spåre).

40 SEK 1980-83, 54; Hbl 10.11.1983 Tigande kvinnan en talande bild (ledare).

41 Lähteenmäki 2006, 159.

42 SEK 1984-87, 174.

43 Murtorinne 1995, 393

44 Järvinen 2012, 10, liite 1

45 Kp 11.3.1986 Lähempään käsittelyyn: Uusi kirkolliskokous (Pentti Pulakka).

46 Pms 12.3.1986 pääk. (Voitto Savela).

47 Kirk.kok. ptk-s. 1986, liite VIII-F 2.

48 Kirk.kok. kptk-k. 1986, 30 \$; Kirk.kok. kptk-s. 1986, 24 \$.

49 Kirkkolain uudistamiskomitean mietintö 1988, 281; Kirk.kok. kptk-k. 1991, $44 \S$.

50 Al 8.3.1986 Liian kauan (pääk.); Kp 11.3.1986 Lähempään käsittelyyn: Uusi kirkolliskokous (Pentti Pulakka); SS 11.3.1986 Naispappeus toteutuu (pääk.); $S d$ 12.3.1986 Kirkko avoimeksi korjausta varten (pääk.).

51 Kirk.kok. kptk-k. 1986, 51 \$.

52 Kmaa 17.3.1988 Kirkko ei luota jäseniinsä (Heikki Tervonen, pääk.), 15.3.1988 Kirkolliskokousvaalin tuloslaskenta venyi viime hetkiin; $\AA \circlearrowright$ 4.5.1988 Låt folket välja kyrkomötet (Sonja Hellsten, ledare); Kmaa 12.5.1988 Näkökulma: Kirkkokansa pienoiskoossa? (Ritva Rasila).

53 Kirk.kok.ptk-s. 1986,37 §.

54 LTA Eca valitsijayhdistysten perustamisasiakirjat kirkolliskokouksen maallikkoedustajien vaalissa 1988; Kmaa 7.1.1988 Kirkolliskokoukseen yrittää yli 500 maallikkoa.

$55 A l$ 15.3.1988 Naiset rynnivät kirkolliskokoukseen (Unto Lahtonen); Kmaa 17.3.1988 Kirkolliskokoukseen uusia voimia.

56 HTA Eec 4 ehdokaslistojen yhdistelmä kirkolliskokouksen maallikkoedustajien vaalissa Helsingin hiippakunnassa 7 päivänä maaliskuuta 1988; Kmaa 7.1.1988 Kirkolliskokoukseen yrittää yli 500 maallikkoa; Leena Huiman kirjallinen tiedonanto 21.3.2014.

$57 \mathrm{Hbl}_{3}$ 3.1.1988 Nytt kyrkomöte ska väljas (Catharina Spåre); Kmaa 1.3.1988 Keskustelua: Lakimiehiä kirkolliskokoukseen (Jaakko Voipio), 3.3.1988 Kirkolliskokouksen edustajat valitaan maanantaina.

58 Kmaa 7.1.1988 Kirkolliskokoukseen yrittää yli 500 maallikkoa.

59 Gustafsson 1987, 12.

6o Smaa 25.3.1988 Uutta ilmettä kirkolliskokoukseen (Kellonsoittaja [Tapani Heinämäki]); Iisalmen Sanomat 27.3.1988 Pitkospuilta: Akateemisten kirkko (Risto Kormilainen); $H b l$ 1.5.1988 Kyrkomöte fyra år framåt (Catharina Spåre, ledare); Kmaa 12.5.1988 Näkökulma: Kirkkokansa pienoiskoossa? (Ritva Rasila).

61 HTA Eec 4 vaalilautakunnan ptk. 14.3.1988.

62 HTA Eec 4 vaalilautakunnan ptk. 21.3.1988 \$2.

63 Kirk.kok. kptk-s. 1988, 18 §.

64 Kyllikki Tiensuun suullinen tiedonanto 23.5.2011.

65 Leena Huiman kirjallinen tiedonanto 21.3.2014

66 Kmaa 17.3.1988 Kirkolliskokoukseen uusia voimia.

67 Kirk.kok. kptk-k. 1982, 5\$; Kirk.kok. kptk-k. 1986, 5 \$.

68 Kirk.kok. kptk-k. 1987, 3 \$.

69 Kmaa 22.4.1982 Vikströmin aikaan? (pääk.); M. Salmi 200o, 34-37; Kurkela 2012, 26.

70 Kirk.kok. kptk-k. 1982,5-6§.

71 Kirk.kok. kptk-k. 1988,5\$,7\$.

72 Sinikka Pylkkäsen haastattelu 7.1.2014.

73 Kirk.kok.kptk-k. 1982,7 \$; Kirk.kok. kptk-k. 1986,7 \$; Kirk.kok. kptk-k. 1988, $8 \S$.

74 Kirk.kok. kptk-k. $1982,8 \S$.

75 Kirk.kok. kptk-k. 1982, 12 \$.

76 Kirk.kok. kptk-k. 1986, 54 \$.

77 Kirk.kok. kptk-k. 1982, 53 \$, 55 \$; Kirk.kok. ptk-k. 1982, 45 \$, 53 \$, 55 \$; Kirk. kok. kptk-k. 1986, 25 \$, 69 \$, 71 \$; Kirk.kok. ptk-k. 1986, liite VI 2; Kirk.kok. kptk-k. 1988, 68 \$, 90 \$; Kirk.kok. ptk-k. 1988, liite IX 2.

78 Kirk.kok. kptk-s. 1983, 8 \$; Kirk.kok. kptk-s. 1987, 10 \$, 45 \$; Kmaa 8.11.1983 Keskusten johtokuntiin toivotaan asiantuntijoita (Kirsti Ritopeura).

79 Kirk.kok. kptk-s. 1989, 51 §.

8o Kirk.kok. ptk-k. 1985, 61 §; Smaa 18.5.1985 Kirkonmäeltä kuultua: Kirkol- 
liskokous jämäkkänä (Kellonsoittaja [Tapani Heinämäki]); Alma Saaren sähköpostihaastattelu 9.2.2012.

81 Kirk.kok. ptk-k. 1990, 49 \$

82 Kirk.kok. ptk-s. 1977,1 \$; Kirk.kok. ptk-k. 1979, 1 \$; Kirk.kok. ptk-s. 1981, 1 \$.

83 Kirk.kok. kptk-k. 1978, 41 \$; Kirk.kok. kptk-s. 1978, 25 \$; Juva 1976, 215-216; Kansanaho 1991, 522-524; Seppänen 1998, 66-67, 69-70.

84 SEK 1980-83, 50-51; SEK 1984-87, 32; Iisalmen Sanomat 17.1.1981 Pyhittämisestä (Ilmari); Kaleva 17.1.1981 Ongelmalliset arkipyhät (pääk.); Kp 17.1.1981 Arkipyhien palauttaminen (pääk.); TS 17.1.1981 Arkipyhiä kaivataan (pääk.); ES 11.2.1981 Arki ja pyhä (pääk.); Vaasa 12.2.1981 Arkipyhäongelmaan sovitteluratkaisu (pääk.); IS 18.2.1981 Arkipyhät paikoilleen (pääk.); KS 22.7.1981 Arkipyhien siirto ei saa kannatusta (pääk.); TS 22.7.1981 Arkipyhät (pääk.); Uusimaa 22.7.1981 Arkipyhät (pääk.); $A l$ 23.7.1981 Pyhien paikat (pääk.); Knen 23.7.1981 Arkipyhät (pääk.); US 23.7.1981 Pyhät ja epäpyhät (Seija-Riitta Laakso); Vaasa 23.7.1981 Arkipyhäkysymys yhä uudelleen (pääk.); Kouvolan Sanomat 24.7.1981 Arkipyhät (pääk.); $K U$ 24.7.1981 Arkipyhät ja viikonloput (pääk.); $\AA U$ 24.7.1981 Sök kompromiss om skuffade helgtrion (Meta Torvalds, ledare); Ksml 26.7.1981 Arkipyhien siirrossa tarvitaan myös työehtosopimuskeskusteluja (pääk.); $L K$ 26.7.1981 Arkipyhät esillä (pääk.); HS 27.2.1981 Arkipyhäkiistan ratkaisumallia haettava muualta (pääk.); Kansanaho 1991, 525; Seppänen 1998, 69 .

85 Autio 1994, 354.

86 Kirk.kok. ptk-k. 1982, liite II 1.

87 Kirk.kok. kptk-k. 1982, 68 \$; Kirk.kok. ptk-k. 1982, liite XIII-B 1.

88 Kirk.kok. ptk-k. 1982,75\$.

89 SEK $1980-83,15,17-18$

90 SEK 1980-83, 41, 46; Sorsa 2010, 191.

91 M. Salmi 2000, 52-53.

92 Kirk.kok. ptk-k. 1982, liite XIII-B 1.

93 Kirk.kok. kptk-k. 1982, 42 §, 68 §.

94 Myllymäki 1979, 5, 71, 89, 94, 219; Sipponen 1982, 550-551; Jyränki 2006, 65; Nousiainen 2006, 268.

95 Myllymäki 1979, 138; Myllymäki 1982, 6-7, 42-43; Björkstrand 1992, 4; Seppänen 1998, 70; Meinander 1999, 448; Antila 2008, 154-155, 158-160.

96 Nevakivi 2000, 315 .

97 KKHA KKA Cc ${ }_{31}$ Opetusministeriön Kirkko ja valtio -työryhmän muistio (Kirkolle tulevien lisäverotulojen käyttö); Kirk.kok. ptk-s. 1982, liite II 12; SEK 1980-83, 39; Autio 1997, 199.

98 Kirk.kok. kptk-s. 1982, 17 §. Nummisen mukaan seikkaperäinen puheenvuoro oli mitä ilmeisimmin hänen alaistensa valmistelema. Jaakko Nummisen haastattelu 4.7.2012.

99 Kirk.kok. kptk-s. 1982,17\$.

100 Kirk.kok. kptk-s. 1982, 48 \$; Kirk.kok. ptk-s. 1982, liite V-E 9.

101 Kirk.kok. kptk-k. 1982, 5.

102 TTA MJA Haa1 kirkolliskokouksen avauspuhe 3.5.1982.

103 Jaakko Nummisen haastattelu 4.7.2012.

104 Kirk.kok. kptk-k. 1982, 5.

105 Kirk.kok. kptk-s. 1982, 53 \$.

106 Kirk.kok. kptk-s. 1982, 53 \$; Sorsa 2010, 194.

107 SS 7.5.1982 Arkea vai pyhiä (pääk.); SSS 7.5.1982 Arkiset arkipyhät; Sd 8.5.1982 Liikkuvat kirkkopyhät (pääk.); Al 9.5.1982 Pyhäsiirrot (pääk.); Ksml 9.5.1982 Arkipyhät paikoilleen (pääk.); $S k K$ 9.5.1982 Kirkkokin odottaa joustamista (pääk.); ESS 15.5.1982 Arkipyhien paluu (pääk.); $\AA U$ 15.5.1982 Svårt med Himmelsfärd (Meta Torvalds); TS 13.11.1982 Kirkolliskokous taipumattomana (pääk.); KS 14.11.1982 Kirkko pitää sove-tulot (pääk.); SSS 3.6.1983 Arkipyhät tuskin takaisin (pääk.); TS 3.6.1983 Arkipyhien arvo (pääk.); Smaa 10.6.1983 Kirkonmäeltä kuultua: Arkipyhäkysymys (Kellonsoittaja [Jouko Talonen]); $S d$ 7.11.1984 Arkipyhät paikallaan (pääk.); TS 7.11.1984 Arkipyhät (pääk.); Hbl 8.11.1984 Facket såsar i helgdagsfrågan (ledare); HS 10.11.1984 Taas arkipyhät (pääk.); $L K$ 11.11.1984 Arkipyhät paikoilleen (pääk.); TS 13.11.1984 Muutokset paluuta vanhaan (pääk.); M. Salmi 2000, 62-63.

108 SEK 1980-83, 39; Sorsa 2010, 198

109 Kirk.kok. kptk-s. 1983, 12 \$; UT 1990, 7; US 25.3.1984 Björkstrand tiukkana: Myös kirkon kannettava vastuuta työttömistä (Hannu Kuosmanen).

110 Kirk.kok. ptk-k. 1985, 55 \$, liite XI-C 7.

111 Liitto 13.4.1985 Pyhät paikoilleen (pääk.); $S d$ 13.4.1985 Sapattiajattelua (pääk.); Smaa 13.4.1985 Kirkkopyhien palauttaminen paikoilleen oikea päätös (pääk.); SS 13.4.1985 Arkipyhien opetus (pääk.); HS 14.4.1985 Arkipyhät (pääk.); KU 15.4.1985 Entiselleen (pääk.); Hbl 16.4.1985 Söckenhelger och tandkräm (ledare); $K p$ 10.5.1985 Yhteisöveron poistolle ei ole kestäviä perusteita (pääk.); Ksml 12.5.1985 Kirkolla säilytettävä yhtiöiden verotusoikeus (pääk.); $S d$ 18.5.1985 Kirkko ei tarvitse yhtiöiden verotusta (pääk.); Knen 15.7.1985 Kirkkopyhät entiselleen (pääk.); Ksml 12.9.1985 Arkipyhät entisille paikoilleen (pääk.); HS 13.9.1985 Arat arkipyhät (pääk.); $S d$ 13.9.1985 Seuraukset selvittämättä (pääk.); Kaleva 16.9.1985 Arkipyhät ennalleen (pääk.).

112 Antila 2008, 159-160.

113 Bexell 1990, 161; Ekström 2003, 148-152, 156-157; Pahlmblad 2005, 403, 406-410.

$114 D N$ 10.5.1982 Kyrkomötet är en fars (Carin Stenström).

$115 S D$ 1.3.1983 Kyrkomötet (ledare).

116 Gustafsson 1987, 6; Brohed 2005, 277.

117 KMA KPA Ce KTmk 1979-84 toimikunnan työryhmän ptk. 3.5.1983 \$4; Kauppinen 2004, 144-145.

118 Sd 7.11.1984 Arkipyhät paikallaan (pääk.); TS 7.11.1984 Arkipyhät (pääk.); $\mathrm{Hbl} \mathrm{8.11.1984} \mathrm{Facket} \mathrm{såsar} \mathrm{i} \mathrm{helgdagsfrågan} \mathrm{(ledare);} \mathrm{Kmaa} \mathrm{8.11.1984} \mathrm{Ar-}$ kipyhien siirto esille lähiaikoina (Kirsti Ritopeura \& Riitta Ketola); HS 10.11.1984 Taas arkipyhät (pääk.); $L K$ 11.11.1984 Arkipyhät paikoilleen (pääk.); TS 13.11.1984 Muutokset paluuta vanhaan (pääk.).

119 SS 4.1.1986 Pyhien palautukselle kansalaisten kannatus; Björkstrand 1993, 98-99; Seppo 1999, 43-44; Sorsa 2010, 193.

120 Knen 12.9.1985 Eduskunta ja kirkon asiat (pääk.); KS 12.9.1985 Arkipyhien päättäjät (pääk.); $S d$ 13.9.1985 Seuraukset selvittämättä (pääk.); Kansanaho $1986,366$.

$121 K U$ 15.4.1985 Entiselleen (pääk.).

122 SEK 1984-87, 32; Kmaa 28.1.1986 Kirkollinen ensireaktio: pettymys, 30.1.1986 Oikeus ja kohtuus (päk.); US 6.2.1986 "Kukaan tuskin ajatteli tätä”; Holopainen 1986, 372; Hidén 1989, 149-154; Kansanaho 1991, 526; Björkstrand 1992, 4; Björkstrand 1993, 99; Haapakoski 2002, 44-49; Ekstrand 2012, 549 .

123 Nieminen 2011, 192

124 Haapakoski 2002, 6-7, 51; Sorsa 2010, 193.

125 US 4.5.1985 Millainen kirkon painoarvo (Hannu Kuosmanen); Holopainen 1986, 373; Haapakoski 2002, 49; Sorsa 2010, 185.

126 Tuomiokapitulitoimikunnan mietintö 1986, 88-91.

127 Kirk.kok. ptk-s. 1986, liite VIII-B 2; Sorsa 2010, 198-199, 201.

128 Kirk.kok. kptk-s. 1986, 23 \$, 49 \$; Kirk.kok. ptk-s. 1986, liite VIII 2 a; Sorsa 2010, 202-203.

129 Sorsa 2010, 202-204.

130 JNA puhe kirkolliskokoukselle marraskuussa 1986; Kirk.kok. kptk-s. 1986, 19 \$; Kmaa 6.11.1986 Kansliapäällikön patistus (pääk.).

131 Kirk.kok. kptk-s. 1986, $12 \S, 19 \S, 49 \S$.

132 Seppo 1989, 130; Autio 1997, 196; Sorsa 2010, 198

133 Ruotsissa toteutetuista osauudistuksista Ekström 2003, 169-181.

134 Kirk.kok.ptk-s. 1989,15\$.

135 Kirk.kok. kptk-k. 1988, 62 §; Kirk.kok. ptk-k. 1988, liite XI-B 1, liite 1.

136 Kirk.kok.ptk-s. 1988, liite VII-E 7 \& 7 a; Kirk.kok. kptk-s. 1988, 19 \&, 21 §, 42 \$; $A l$ 5.2.1987 Kirkon sove-ratkaisu ärsyttää yhä valtiota (Unto Lahtonen). 137 TTA AKA Fa22 Vikström Christoffer Taxellille 29.11.1988.

138 Kirk.kok. ptk-s. 1988, 19 \$, 42 \$, liite VII-E 7 \& 7 a; Kirk.kok. ptk-k. 1989, 40 \$, liite III 2 \& VII-B 5; Kirk.kok. ptk-s. 1989, liite IV 9, 13, 45, 67, 97 \& VIIIE 9.

139 ST 1982.

140 SEK 1980-83, 11, 33-34, 224-225; U. Hämäläinen 2011, 99; M. Salmi 200o, $76-85$.

141 Juva 1994, 330; Jalovaara 2011, 240-241.

142 Kirk.kok. kptk-s. 1980, 33 \$.

143 Kirk.kok. kptk-s. 1980, $33 \S, 36 \S$.

144 Kirk.kok. kptk-s. 1980, 36 \$.

145 SEK 1980-83, 34; Juva 1994, 331, 337-340; Malkavaara 2000, 261; Jalovaara 2011, 241-243; S. Salmi 2012, 27-28.

146 Meinander 1999, 402, 405.

147 Juva 1994, 340-342; M. Salmi 2000, 67-68, 74.

148 Kallenautio 2005, 401; Visuri 2006, 245, 252-254, 257-260.

149 Kirk.kok. ptk-k. 1983, 30 \$; Ryman 2004, 105-126; Brohed 2005, 287.

150 Kirk.kok. kptk-s. 1981, 31 \$; Kinnamon 2004, 65; McCullum 2004, 358. 
151 Vischer 2004, 40; McCullum 2004, 358; Mudge 2004, 286, 313.

152 Kirk.kok. kptk-k. 1983, 30 \$.

153 Kirk.kok. ptk-k. 1983, liite IX Porvoo 1.

154 Kirk.kok. kptk-k. 1983, $26 \$$.

155 Ilkka 5.5.1983 Vain kaksi piispaa (Jukka Lehtinen); US 6.5.1983 Eila Jokela.

156 KS 6.5.1983 Siviilipalvelijat (Veikko Valento); Kmaa 10.5.1983 Siviilipalvelus kirkon ongelmana (pääk.); Hämeen Sanomat 14.5.1983 'Kasapanoksia' kirkolliskokoukseen (pääk.); Länsi-Suomi 17.5.1983 Siviilipalvelus puhuttaa (pääk.); HS 21.5.1983 Kieltääkö kirkko aseista kieltäytyjät? (Jorma Korhonen); Smaa 21.5.1983 Kirkonmäeltä kuultua: Luther ja siviilipalvelus (Kellonsoittaja [Jaakko Elenius]).

157 Kirk.kok. kptk-s. 1983, 47 \$; Kirk.kok. ptk-s. 1983, liite VIII-B 5.

158 Kirk.kok. ptk-s. 1990, liite V 1.

159 Kirk.kok.ptk-s. 1990, liite IX-A 2.

160 Kirk.kok. kptk-s. 1990, $42 \$, 44 \$$.

161 Kirk.kok. kptk-s. 1987,13 \$, 15 \$; Kirk.kok. ptk-s. 1987, liite IV 7, 41 \& VI 1 \& VII-E 10.

162 SEK 1980-83, 35-36; Kirk.kok. kptk-s. 1984, 21 \$, 48 \$; SEK 1984-87, 133, 147; Murtorinne 1995, 426.

163 Kirk.kok. ptk-k. 1988, liite X 7.

164 Kirk.kok. kptk-k. 1988, 48 §.

165 Kirk.kok. ptk-k. 1988, liite XI-E 4

166 Kirk.kok. kptk-k. 1988,82 \$.

167 Kirk.kok. ptk-s. 1988, liite VII-F 4 a.

168 Kirk.kok. kptk-s. 1988, 34 \$; Kirk.kok. ptk-s. 1988, 47 \$, liite VII-F 4 b.

169 SEK 1988-91, 20.

170 Kirk.kok. ptk-s. 1986, liite IV 7; Kirk.kok.ptk-k. 1987,34 \&, liite VII-C 1; SEK $1984-87,147$.

171 Kirk.kok. kptk-s. 1988, $19 \$, 42 \S$.

172 Kirk.kok. ptk-k. 1979, lite II 3; Kirk.kok. ptk-k. 1983, liite III 3.

173 Kirk.kok. ptk-k. 1983, liite XI-E 5; Kirk.kok. kptk-k. 1983, 61 \$; Kirk.kok. kptk-k. 1984, 66 \$; Kirk.kok. ptk-k. 1984, liite XII-D 6; Kirk.kok. kptk-k. 1987, $72 \S$.

174 Kirk.kok. kptk-k. 1995, 9 \$.

175 Kirk.kok.ptk-k. 1983, liite XI-E 5; Kirk.kok. kptk-k. 1985, 66 \$; Kirk.kok. kptk-k. 1986, 20 \$, 80 \$; Kirk.kok. ptk-k. 1986, liite VIII-C 4; Kirk.kok. kptk-s. $1987,13 \$$.

176 Kirk.kok. kptk-k. 1986, 80 §.

177 Kirk.kok. kptk-k. 1989, 63 §.

178 Kirk.kok. kptk-k. 1984, 42 \$; Kirk.kok. kptk-k. 1986, 78 \$; Kirk.kok. kptk-s. 1988, 8 \$; Kirk.kok. ptk-s. 1986, liite VIII-E 6.

179 Kirk.kok. ptk-s. 1985, liite VI-D 6; Kirk.kok. kptk-s. 1986, 15 \$; Kirk.kok. kptk-s. $1987,13 \S$.

180 Kirk.kok. kptk-k. 1983, 61 \$; Kirk.kok. kptk-s. 1984, 21 §.

181 Kirk.kok. kptk-s. 1984, 21 §.

182 Kirk.kok. ptk-k. 1985, liite IV 5; Kirk.kok. kptk-s. 1985, 24 \$; Kirk.kok. ptk-s. 1985, $24 \S, 50 \$, 57 \S$, liite VI-D 10 \& 10 a; Autio 1997, 207; Rantanen 2004, 134-135.

183 Kirk.kok. kptk-k. 2009, $15 \$$.

184 Kirk.kok. kptk-s. 1989, 7\$, $18 \$, 47 \$, 54 \$, 59 \$$.

185 Kirk.kok. kptk-s. 1984, 21 \$; Kirk.kok. ptk-s. 1984, liite VI-E 7; Kirk.kok. kptk-s. 1986, 15 \$; Kirk.kok. ptk-s. 1986, liite VIII-E 5.

186 Kirk.kok. kptk-s. 1986, 15 \$, 33 \$; Kirk.kok. kptk-k. 1988, 54 \$; Kirk.kok. ptkk. 1988, liite X 9.

187 Honka-Hallila 2006, 282; Paloheimo 2007, 267.

188 Kirk.kok. kptk-s. 1983, 12 \$; Kirk.kok. ptk-s. 1983, liite VII 1; SEK 1980-83, 181-184, 293; SEK 1984-87, 139-140.

189 SEK 1984-87, 150.

190 Kirk.kok. kptk-s. 1984, 21 §.

191 Kirk.kok. kptk-k. 1987, 50 \$; Kirk.kok. ptk-k. 1987, liite V 4 \& VI 6 \& VI 8; Kirk.kok. ptk-s. 1987,32 \$, liite VII-F 6; Kirk.kok. ptk-k. 1991, 49 \$, liite IX-E

192 Kirk.kok. ptk-s. 1987, liite IV 7 \& VI 2

193 Kettunen 1993, 407-408; K. Ketola 2003, 74-75; Kinnamon 2004, 74

194 SEK 1984-87, 68; Kirkko 2000 1986, 50; Seurakunta 2000 1987, 16-17.

195 Kirk.kok. kptk-s. 1987, 15 \$; Kirk.kok. ptk-s. 1987, liite VI 2; Kirk.kok. kptk-s. 1988, 19 \$; Kirk.kok. ptk-k. 1990, liite VII-5; Kirk.kok. kptk-s. 1990, 14 \$, 27

196 Kirk.kok. kptk-s. 1987, 15 \$.

197 Kirk.kok. kptk-s. 1988, $19 \$$.
198 SEK 1984-87, 40, 58-59; Al 13.1.1988 Kuva kirkosta ristiriitainen.

199 Kirk.kok. kptk-s. 1988, 19 \$.

200 Kirk.kok. kptk-s. 1989, $18 \$, 20 \$$.

201 Kirk.kok. kptk-k. 1990, 52 \$; Kirk.kok. ptk-k. 1990, liite VIII-C 6.

202 Kirk.kok. kptk-s. 1990, 14 \$; Kirk.kok. kptk-s. 1991, 23 \$.

203 Kirk.kok. kptk-s. 1990, 14 §.

204 Kirk.kok. ptk-s. 1991, 23 \$, liite VI-E 7.

205 Kirk.kok. ptk-k. 1980, 45 \$, liite XI-A 2.

206 Kirk.kok.ptk-k. 1983, liite IX Tampere \& Mikkeli; Kirk.kok. ptk-k. 1984, liite IV 3.

207 Kirk.kok. ptk-s. 1984, liite VI-A 4.

208 Kirk.kok. kptk-s. 1984, 39 \$.

209 Kirk.kok. ptk-s. 1984, 46 \$.

$210 S d$ 13.8.1986 Karu totuus (pääk.); Ksml 15.8.1986 Seurakuntavaaleihin selvät tunnukset (pääk.); Ilkka 31.8.1986 Seurakunnat valmistautuvat vaaleihin (pääk.); KS 19.9.1986 Naispappeus ja seurakuntavaalit (pääk.); SS 26.2.1987 Politiikka ja kirkon vaalit (pääk.); Eteenpäin 2.3.1987 Politiikka menestyi seurakunnissa (VOX); TS 2.3.1987 Kirkollisvaalien tunnukset (pääk.).

211 Kirk.kok. kptk-k. 1987,64§.

212 Kaleva 8.5.1987 Kirkon politisoitumista pelätään, mutta sokkovaaleista halutaan päästä; US 8.5.1987 Arkkipiispa varoitteli Ruotsin mallista: Puoluetunnukset vaarantavat kirkon riippumattomuuden; Al 9.5.1987 Tunnukset (pääk.); ESS 9.5.1987 Tunnukset tulossa (pääk.); Pnen 9.5.1987 Tunnusten aika seurakuntavaaleissa (pääk.); TS 9.5.1987 Tunnukset tulossa (pääk.); Eteenpäin 10.5.1987 Turha huoli (pääk.); Sd 11.5.1987 Kirkon hitaat kiireet (pääk.); Knen 12.5.1987 Pimeät lyhdyt pois seurakuntavaaleista (pääk.); US 12.5.1987 Tunnus esiin (pääk.).

$213 S k K$ 7.11.1987 Kaksinaismoraaliako? (pääk.); Ilkka 10.11.1987 Kirkossa pelätään yhä politiikkaa (pääk.).

214 Kirk.kok. kptk-k. 1987, 64 \$.

215 Ks. Martikainen 1984, 182-183.

216 Kirk.kok. kptk-s. 1987,37 \$.

217 Kirk.kok. kptk-k. 1984, 14 \$; Kirk.kok. kptk-k. 1987, 64 \$; Savioja 1984, 92.

218 Johansson 1990, 167.

219 Kirk.kok. kptk-k. 1984, $14 \$$.

220 Kirk.kok. ptk-k. 1984, liite IV 3; $\AA U$ 10.9.1986 Partier i kyrkoval (Bo Stenström, ledare).

221 KKHA KKA Cc 58 "Opetusministeri Christoffer Taxell kirkolliskokouksessa Turussa 2.11.1987 klo 14".

222 Kirk.kok. kptk-s. 1987, 37 \$; Kpr 12.11.1987 Politiceringsspöket och kyrkan (Olav S. Melin, ledare).

223 Kmaa 5.11.1987 Puolueet ja kirkko (Tapani Ruokanen, pääk.).

224 Kirk.kok. ptk-k. 1988, liite IX 1.

225 Kirk.kok. kptk-s. 1988, 38 §.

226 Kirk.kok. kptk-s. 1988, 51 §.

227 Kmaa 15.11.1988 Kirkolliskokous hylkäsi tunnukset täpärästi.

228 Kirk.kok. ptk-k. 1991, liite IX-F 1, 98; Kirk.kok. ptk-s. 1991, liite VI-G 1 a, 15.

229 Kirk.kok. kptk-k. 1991, 44 \$; Kirk.kok. kptk-s. 1991, 22 \$.

230 Kirk.kok. kptk-s. 1988, 38 §.

231 Kirk.kok. kptk-k. 1980, $39 \$$.

232 Heikkilä 1992, 7; Heikkilä 1991, 107.

233 Kirkkolain uudistamiskomitean mietintö 1988, "Kirkolliskokoukselle".

234 Kirk.kok. kptk-k. 1988, 3.

235 TTA AKA Fa2 Ossi Haaramäki Vikströmille 31.10.1982, Vikström Haaramäelle 18.11.1982, Fa8 Ossi Haaramäki Vikströmille 23.10.1984; Ossi Haaramäen haastattelu 28.10.2010.

236 Kirk.kok. kptk-s. 1988, 18 \$; Heikkilä 1991, 104; Ripatti 1999, 108.

237 Leivonen 1989, 100; Autio 1997, 202.

238 Kirkkolain uudistamiskomitean mietintö 1988, 41, 106-107, 311; Kirk.kok. kptk-s. 1988,18 §.

239 Kirk.kok. kptk-s. 1988, 18 \$; Toiviainen 1989, 116.

240 KKHA KKA Hg 7 ptk. 22.3.1988 \$3.

241 KKHA KKA Hg 1 ptk. 22.5.1981 \$2; Kirkkolain uudistamiskomitean mietintö 1988, 11-12; Voipio 1989, 132-133; Kansanaho 1986, 365; Pirinen 1989, 110; Seppo 1989, 128.

242 Seppo 1989, 130.

243 Kirk.kok. ptk-k. 1991, liite IX-F 1, 2, 24; Kirk.kok. kptk-k. 1991, 26 \$.

244 Kirk.kok. kptk-s. 1988, 18 \$; Haaramäki 1988, 45-47.

245 Kirk.kok. kptk-s. 1988, 18 §. 
246 Kirk.kok. ptk-k. 1991, liite IX-F 1, 1-2.

247 Kirk.kok. ptk-k. 1991, liite V 1, 1

248 Kirk.kok. kptk-k. 1991, 26 \$; Kirk.kok. ptk-k. 1991, liite III 2.

249 Kirkkolain uudistamiskomitean mietintö 1988, 41.

250 Kirk.kok. kptk-s. 1988, 18 §.

251 Kirk.kok. ptk-k. 1991, liite III 2; Huovinen 1991, 483-484.

252 Kirk.kok. kptk-k. 1991, 28 \$; Kirk.kok. ptk-k. 1991, liite IX-F 1, 13, 31.

253 Kirk.kok. ptk-k. 1980, liite V 1, 24-25; SEK 1984-87, 68; Kirk.kok. kptk-k. 1991, $26 \$, 28$ \$; Huovinen 1991, 484-486.

254 SEK $1984-87,78$.

255 Huovinen 1991, 487-488.

256 Kirk.kok. kptk-s. 1991, 29 \$; TS 9.11.1991 Uusi kirkkolaki kasvattaa kirkon itsenäisyyttä. Matti Sihvonen ei muista oman äänestysratkaisunsa syitä. Matti Sihvosen puhelinhaastattelu 16.12.2013.

257 Kirkkolain uudistamiskomitean mietintö 1988, 176, 233.

258 Kirkkolain uudistamiskomitean mietintö 1988, 234.

259 Kirk.kok. kptk-k. 1991, $26 \$, 42$ \$; Kirk.kok. ptk-k. 1991, liite IX-F 1, 52, 65.

260 Juva 1976, 81.

261 S. Häkkinen 2010, 124.

$262 L K$ 13.8.1989 Saamen kieli ja kirkko (pääk.).

263 Kmaa 1.8.1989 Saamen kielen asema kirkossa (pääk.); LK 24.9.1989 Kirkkolaki huomioi saksankielisetkin saamelaisia paremmin (Veikko Väänänen).

264 KKHA KKA Cc 64 Saamen kieli viralliseksi kirkkolakiin -adressi.

265 Niittyvuopio 2011, 71.

266 Kirk.kok. kptk-k. 1991, 26 \$.

267 Kirk.kok. kptk-s. 1991, 22 \$; Kirk.kok. ptk-s. 1991, liite VI-G 1 a, 2-3.

268 Ahvenanmaan itsehallintolaki 6:36 (16.8.1991/1144).

269 Kirkkolain uudistamiskomitean mietintö 1988, 18, 136.

270 Kirk.kok. ptk-k. 1991, liite IX-F 1, 2.

271 Kirk.kok. kptk-k. 1991, 26 \$.

272 Kirk.kok. kptk-k. 1991, 26 \$; Kmaa 8.11.1991 Ahvenanmaalle voidaan perustaa myös suomenkielinen seurakunta (Risto Krogerus).

273 "finnar är vi inte, svenskar fick vi inte bli, låt oss alltså vara ålänningar". Kirk.kok. kptk-k. 1991, $26 \$$.

274 Kirk.kok. kptk-k. 1991, $26 \$$.

275 Kirk.kok. ptk-k. 1991, 26 \$.

276 Kirk.kok.ptk-s. 1991, liite VI-G 1 a, 2, 10.

277 Kirk.kok. kptk-s. 1991, 22 \$.

278 Kirk.kok. kptk-s. 1991, 22 \$; Kmaa 12.11.1991 Valmistunut kirkkolaki herätti heti periaatteellisen keskustelun.

279 Vp.ptk. 1993, 129/2.11.1993, 3790.

280 Autio 1997, 88-89.

281 Vp. ptk. 1993, 129/2.11.1993, 3798-380o.

282 Kirk.kok. kptk-k. 1982,3-6.

283 SEK 1980-83, 56; Al 5.5.1982 Juvan malli (pääk.); HS 5.5.1982 Hajautettu valta vaaraksi kirkolle (pääk.); Iisalmen Sanomat 5.5.1982 Arkkipiispan testamentti (pääk.); TS 5.5.1982 Kirkon hallinto kaipaa remonttia (pääk.); ESS 6.5.1982 Arkkipiispan testamentti (Eeva Rissanen, pääk.); Ksml 6.5.1982 Moniäänisyys voi olla kirkon voima (pääk.); Ilkka 7.5.1982 Kenellä kirkon ääni (pääk.); Kp 8.5.1982 Kirkon hallinto hakusalla (pääk.); US 12.5.1982 Kirkon hallinnon uudistus ei ole polkenut paikallaan (Erkki Kansanaho); Jokinen 1990, 109-111; M. Salmi 2000, 28-29; Heininen 2008, 200.

284 Eteenpäin 9.5.1982 Kirkon keskushallinto - tehoton ja sekava (pääk.).

285 Kirk.kok. kptk-k. 1982, 24 \$; M. Salmi 2000, 25-26.

286 KKHA KKA Cid 1 ptk. 10.5.1984 §2, ptk. 7.5.1986 §3, ptk. 8.5.1986 klo $13 \S$ 2; Kirk.kok. kptk-s. 1982, 8 \$; Kirk.kok. ptk-s. 1982, liite V-D 1; Kirk.kok. kptk-k. 1983, 38 \&; Kirk.kok. ptk-k. 1983, liite XI-A 1; SEK 1980-83, 78; Murtorinne 1997, 81; Eriksson 2013, 44-45.

287 Kirk.kok. kptk-k. 1982, 32 \$; Kirk.kok. kptk-k. 1984, 28 \$; Kirk.kok. kptk-s. 1985, 51 §; Kirk.kok. kptk-k. 1988, $26 \S$.

288 Kirk.kok. ptk-k. 1983, liite X 2.

289 Kirk.kok. ptk-k. 1984, 38 \$; Kirk.kok. ptk-s. 1986, liite VII 1, 32-50; Murtorinne 1997, 108-109.

290 Kirk.kok. kptk-k. 1987,33 §. Elementtien tasapainon välttämättömyyden on kyseenalaistanut historiantutkimuksen näkökulmasta myös Kauko Pirinen $(1985,246,258)$.

291 Kirk.kok. ptk-s. 1987, liite VII-G 1.

292 Kirk.kok. ptk-s. 1987, liite VII-G 1.
293 Kirk.kok. ptk-s. 1987, liite III 1.

294 Kirk.kok. kptk-s. 1987, 18 \$, 21 \$.

295 Tiihonen 1996, 576; Autio 1997, 204.

296 KKHA KKA Cc 57 ptk. 7.5.1987 \$ 2

297 Kirk.kok. ptk-s. 1987, liite VII-G 1.

298 Kirk.kok. ptk-s. 1989, liite VII 1, 6; Murtorinne 1997, 112-113.

299 Murtorinne 1997, 113

300 Kirk.kok. ptk-s. 1989, liite VII 1, 7-9; Murtorinne 1997, 114.

301 Kirk.kok. kptk-s. 1989, 27 \$; Murtorinne 1997, 115.

302 Kirk.kok. ptk-s. 1989, liite II 2; Murtorinne 1997, 115.

303 Kirk.kok. kptk-k. 1990, 29 \$; Kirk.kok. ptk-k. 1990, liite VIII-A 1 \& 1 a; Murtorinne 1997, 116-117.

304 Kirk.kok. kptk-k. 1990, 23 \$, $29 \$$.

305 Kirk.kok. kptk-k. 1991, $26 \$, 28 \$, 40$ \$; Murtorinne 1997, 117.

306 Kirk.kok. ptk-s. 1983, liite III.

307 Kirk.kok. kptk-s. 1981,39 §.

308 Kirk.kok. ptk-s. 1983, liite III.

309 Kirk.kok. kptk-s. 1983, 22 \$.

310 Kirk.kok. ptk-k. 1983, liite X 6

311 US 16.9.1983 Miehisyys kadoksissa (Markku Laitinen).

312 Kirk.kok. ptk-s. 1983, liite III.

313 Kirk.kok. ptk-k. 1984, liite XII-B 1.

314 SEK 1980-83, 54; Hbl 10.11.1983 Tigande kvinnan en talande bild (ledare); Vasabladet 10.11.1983 Den svåra kvinnoprästfrågan (ledare).

315 Kirk.kok. kptk-s. 1983, 22 \$.

$316 S K$ 4.11.1983 Vaikea ratkaisu (pääk.); Kaleva 8.11.1983 Kirkon valinta (pääk.); ESS 10.11.1983 Kirkon jakolinja (pääk.); KS 10.11.1983 Valta seurakunnille (Hermanni).

317 SEK 1980-83, 54; SK 4.11.1983 Vaikea ratkaisu (pääk.); Kp 9.11.1983 Keskustelua kirkon virasta (pääk.); ESS 12.11.1983 Naiset kohti pappeutta (KM).

318 A. Simojoki 1984b, 112-113; ESS 10.11.1983 Kirkon jakolinja (pääk.); Eteenpäin 10.11.1983 Pehmeä lasku naispappeuteen (pääk.); HS 10.11.1983 Pehmeä ratkaisu ei tyydytä naispappeuden vastustajia; Hämeen Sanomat 10.11.1983 Naispappeudesta sopii päättää seurakunnissa (pääk.); Ilkka 10.11.1983 Ei naispappeuskiistaa seurakuntiin (pääk.); KS 10.11.1983 Valta seurakunnille (Hermanni); TS 10.11.1983 Naispappeudessa pehmeään laskuun (pääk.); $A l$ 12.11.1983 Aika päättää (Vähtäri); ESS 12.11.1983 Naiset kohti pappeutta (KM).

319 KKHA KKA Cib 1 ptk. 8.2.1984 \$2; Kirk.kok. ptk-k. 1984, liite XII-B 1.

320 Kirk.kok. ptk-k. 1984, liite III 1.

321 Kirk.kok. kptk-k. 1984, 37 §.

322 Kirk.kok. ptk-k. 1984, liite XII-B 1

323 Kirk.kok. ptk-k. 1984, liite III 1.

324 US 5.5.1984 Ministeri Gustav Björkstrandin toiveet: Oopperatalo Helsinkiin, naispappeus kirkkoon (Hannu Kuosmanen); Ksml 8.5.1984 Kirkollisministeri puhui ajattelemattomia (pääk.); US 8.5.1984 Mielipiteet: "Ateistiministeritkään eivät puhu tuolla tavoin" (metropoliitta Johannes).

325 Kirk.kok. kptk-k. 1984, 34 \$; Keitanen 2012, 11-12.

326 SEK 1984-87, 43; SS 6.5.1984 Paavali torjuu naispappeuden; US 8.5.1984 Mielipiteet: "Ateistiministeritkään eivät puhu tuolla tavoin" (metropoliitta Johannes).

327 Kirk.kok. kptk-k. 1984, 34 \$; Kirk.kok. ptk-k. 1984, liite XII-B 1, eriävä mielipide 2.

328 Kirk.kok. kptk-k. 1984,34 \$, 37 \$; Vaasa 7.2.1984 Merkintöjä: Naiset asialla (Jussi Ranta); HS 12.5.1984 Perjantainen välipäätös (Paavo Tukkimäki).

329 US 9.5.1984 Valtio ei puutu naispappeuteen (Gustav Björkstrand).

330 Al 15.4.1984 Naisaskel (pääk.); TS 15.4.1984 Aika ratkaista naispappeus (pääk.); Iisalmen Sanomat 17.4.1984 Nainen alttarille (pääk.); KJK 18.4.1984 Ratkaisu vai lykkäys (pääk.); Vaasa 18.4.1984 Kirkon astuttava eteenpäin (pääk.); Knen 20.4.1984 Katse tulevaan (pääk.).

331 KKHA KKA Cc 39 vetoomus kirkolliskokoukselle 31.1.1984; Vaasa 7.2.1984 Merkintöjä: Naiset asialla (Jussi Ranta).

332 Veikkola 2006, 16-18.

333 A. Simojoki 1984a, 9; Brohed 2005, 289.

334 Kirk.kok. kptk-k. 1984, 34 §.

335 HS 12.5.1984 Perjantainen välipäätös (Paavo Tukkimäki); SK 20/1984 Kun toivo sammui (Tapani Ruokanen).

336 Kirk.kok. kptk-k. 1984, 37 \$; Eriksson 2013, 70.

337 Kirk.kok. kptk-k. 1984, 2-3.

338 Eriksson $2013,70$. 
339 Molina 2010,37.

340 Kirk.kok. ptk-k. 1984, 61 \$.

341 Kmaa 15.5.1984 Äänestyksen tulos.

342 SEK 1980-83, 53 .

343 KS 10.1.1984 Naispappeus lähestyy (pääk.); Kaleva 15.7.1984 Naispappeusratkaisulle kansalta vähän ymmärtämystä (Pekka Koivisto)

$344 A l$ 12.5.1984 Kiista pysyy (pääk.); $\mathrm{Hbl}_{12}$ 12.5.1984 Ett problem att leva med (Catharina Spåre); HS 12.5.1984 Vanhoillisten voitto kirkon tappioksi (pääk.); Ilkka 12.5.1984 Naisen pääsy papin virkaan siirtyi vieläkin (pääk.); Kaleva 12.5.1984 Kirkon koettelemus (pääk.); KM 12.5.1984 Niukka tappio naispappeudelle (pääk.); Knen 12.5.1984 Kehitys hidastui - ei pysähtynyt (pääk.); Kp 12.5.1984 Naispappeus tarvitsee vaalit (pääk.); $K S$ 12.5.1984 Taistelu jatkuu naispappeudesta (pääk.); Ksml 12.5.1984 Naispappeustaistelu vahingoittaa kirkkoa (pääk.); Länsi-Suomi 12.5.1984 Naiset vaikenevat edelleen (pääk.); Riihimäen Sanomat 12.5.1984 Ei naispappeja (pääk.); Sd 12.5.1984 Kirkon tappio (pääk.); SS 12.5.1984 Kaatui eteenpäin (pääk.); US 12.5.1984 Kirkko on hajalla (pääk.); Vaasa 12.5.1984 Kertaaminen jatkuu (pääk.); $\AA$ U 12.5.1984 En bedrövelsens dag (Meta Torvalds); PS 13.5.1984 Seurakuntavaalit tulevat vilkastumaan (pääk.); IS 16.5.1984 Naispappeus toteutuu aikanaan (pääk.); Kpr 17.5.1984 Spekulationer och förhoppningar (ledare).

345 Kirk.kok. ptk-k. 1984, liite XI 4.

346 Kirk.kok. ptk-k. 1985, 47 \$, liite XI-B 1.

347 Kirk.kok. ptk-s. 1985, 29 \$.

348 SEK 1984-87, 43, 57.

349 Kirk.kok. ptk-k. 1985, liite X 2.

350 Kirk.kok. kptk-k. 1985, $45 \$$.

351 Kirk.kok. kptk-k. 1985, 45 §.

352 Kirk.kok. ptk-k. 1985, 45 §.

353 IS 10.5.1985 Naispappeutta ajettiin harkitsemattomasti (pääk.).

354 SS 11.3.1986 Naispappeus toteutuu (pääk.); Ksml 12.3.1986 Naispappeus menee nyt läpi (pääk.); TS 13.3.1986 Liisalle vihdoin liperit (pääk.); US 20.3.1986 Naispappeus tulee (pääk.).

355 Heinonen 1990, 44; Molina 2010, 100

356 Kirk.kok. ptk-k. 1986, liite VII 10.

357 Kirk.kok. kptk-k. 1986,59\$.

358 Kirk.kok. ptk-k. 1986, liite VI 1:12 \& VII 6.

359 Kirk.kok. ptk-k. 1986, liite VII 6; TS 7.5.1986 Määräenemmistö jo allekirjoittanut naispappeusaloitteen.

360 Kirk.kok. ptk-k. 1986, liite VII 6.

361 Kirk.kok. kptk-k. 1986, 54 §.

362 Kirk.kok. ptk-s. 1986, liite VIII-B 1.

363 Kirk.kok. ptk-s. 1986, liite VIII-B 1.

364 Kirk.kok. ptk-s. 1986, liite III 1.

365 Kirk.kok. kptk-s. 1986, $22 \S$.

366 Kirk.kok. kptk-s. 1986, 54 \$; Heinonen 1990, 86; Veikkola 2006, 41-42.

367 Kirk.kok. ptk-s. 1986, liite III 1.

368 SS 25.9.1986 Piispan ratkaisu (pääk.); Al 26.9.1986 Rauhallisesti (pääk.); PS 26.9.1986 Piispainkokous avasi tietä kirkon yhtenäiselle toiminnalle (pääk.); SkK 26.9.1986 Naispappeuden kynnyksellä (pääk.); US 26.9.1986 Sovinto (pääk.), Odotusten mukaan (Eila Jokela); LK 27.9.1986 Tärkeä sovinto (pääk.); Pnen 27.9.1986 Kirkko valmistautuu uudistukseen sovitellen (pääk.); Kaleva 28.9.1986 Mies väistäköön (Tuulikki Ukkola, pääk.).

369 TS 20.4.1986 Ajan riento: Mitä kirkolliskokouksen jälkeen? (Mikko Juva).

370 US 24.10.1986 Naispappia ei haluta alttarille; Hämeen Sanomat 25.10.1986 Viime hetken yritys estää naispappeuden toteutuminen (pääk.); SS 25.10.1986 Harkinta tarpeen (pääk.); US 25.10.1986 Jälkipeliä (pääk.); Hbl 1.11.1986 Blir det äntligen 'ja'? (Catharina Spåre).

371 KKHA KKA Cc 55 "Piispoillemme".

372 Kirk.kok. ptk-s. 1986, liite VIII-B 1, eriävä mielipide.

373 Kirk.kok. kptk-s. 1986, 22 §.

374 Kirk.kok. ptk-s. 1986, 22 §.

375 Kirkkolain uudistamiskomitean mietintö 1988, 242.

376 Kirk.kok. kptk-k. 1986, 54 \$; Kirk.kok. kptk-s. 1986, 20 \$; US 9.5.1986 Huoli jälkihoidosta (Eila Jokela).

377 Kirk.kok. ptk-s. 1986,34 \$.

378 Alma Saaren sähköpostihaastattelu 9.2.2012; Molina 2010, 27.

$379 \AA$ A 8.11.1986 ÖMSESIDIG tolerans! (Meta Torvalds, ledare).

380 HS 12.3.1986 Naispappeus häämöttää (pääk.).

381 SEK 1984-87, 44
382 Liljeström 2008, 234.

383 H.-T. Nieminen 2011, 131.

384 Turun Päivälehti 7.11.1986 Hävinnyt piispa: "Kestävyyteni on vain fasadi" (Leena Pitkänen \& Toivo Köpilä); Eteenpäin 8.11.1986 Maallista (pääk.).

385 Kirk.kok. kptk-s. 1986, 22 §.

386 Kirk.kok. kptk-s. 1986, 34 §.

387 Kirk.kok. kptk-s. 1986, 22 \$.

388 Kirk.kok. kptk-s. 1986, 22 \$, 34§.

389 Kirk.kok. kptk-s. 1986,34 \$.

390 Kirk.kok. kptk-s. 1986, 34 §.

391 Kirk.kok. kptk-s. 1986, 34 §.

392 Kirk.kok. ptk.k. 1982, liite X, 6.

393 Kirk.kok. ptk-k. 1982, liite III 1, 3.

394 Kirk.kok. ptk-k. 1982, liite III 1,3.

395 Kirk.kok. ptk-s. 1984, liite VI-C 1.

396 KKHA KKA Cic 6 diakonian virkaan opiskelevat käsikirjavaliokunnalle 1.2.1984.

397 Kirk.kok. kptk-s. 1984, $20 \$, 42 \$$.

398 Kirk.kok. kptk-s. 1984, 20 \$.

399 Kirk.kok. kptk-s. 1984, 20 \$.

400 Kirk.kok. ptk-s. 1984, liite VI-C 1 a.

401 Tuomiokapitulikomitean mietintö 1994, liite 2, 9.

402 Kirk.kok. kptk-s. 1984, 20 \$.

403 Kirk.kok. kptk-s. 1984, 20 \$.

404 Kirk.kok. ptk-s. 1984, $20 \$$.

405 Kirk.kok. kptk-s. 1984, 20 \$.

406 Kirk.kok. ptk-k. 1988, liite VIII 1, 11-13.

407 Kirk.kok. ptk-k. 1988, liite VIII 1, 15.

408 Kirk.kok. kptk-s. 1984, 20 \$.

409 Kirk.kok. ptk-s. 1984, $20 \$$.

410 Cantell 1985, 49-50, 52-53.

411 Kirk.kok. ptk-s. 1985, liite VI-A 4.

412 Kirk.kok. kptk-s. 1985, 29 \$; Kirk.kok. ptk-k. 1988, liite VIII 1, 6.

413 Kirk.kok. ptk-k. 1988, liite VIII 2.

414 Kirk.kok. ptk-s. 1988, 15 \$; Kirk.kok. ptk-s. 1988, liite VII-B 4.

415 Kirk.kok. kptk-s. 1986, 12 \$; SEK 1984-87, 205.

416 Kirk.kok. kptk-k. 1987, 2-3.

417 Kirk.kok. kptk-k. 1987, 26 \$; Kirk.kok. kptk-s. 1987, 25 \$; Kirk.kok.ptk-s. 1987, liite VII-F 7

418 Kirk.kok. ptk-k. 1988, liite IX 9.

419 Näin Pohjalainen otsikoi pääkirjoituksensa. Pnen 14.9.1989 Piispojen herraseura sulkee yhä naiset ulos (pääk.). Lisäksi päätöstä arvostelivat esimerkiksi $A l$ 14.9.1989 Paimentytöt (pääk.); Knen 14.9.1989 Miehinen päätös loukkaa kaikkia (pääk.), 16.2.199o Kirkolliskokouksen hyväksyttävä naiset (pääk.); TS 18.2.199o Papiksi vaan ei piispaksi (pääk.); Kmaa 20.2.1990 Turha viivytys naispiispuuteen (pääk.).

420 Kirk.kok. kptk-k. 1990, 38 \$; Kirk.kok. ptk-k. 1990, liite II 1.

421 Kirk.kok. ptk-k. 1990, liite VIII-B 1.

422 Kirk.kok. kptk-k. 1990, 38 \$; Kirk.kok. ptk-k. 1990, liite VIII-B 1.

423 Kirk.kok. ptk-k. 1990, $41 \S$.

424 Ilkka 12.5.1990 Kivulias piispansynnytys (Marja-Liisa Kriikku).

425 Kirk.kok. ptk-k. 1990, 41 §.

426 SEK 1976-79, 149; SEK 1980-83, 164; Heino 1988, 26-27.

427 Kirk.kok. kptk-k. 1983, 1-4; SEK 1980-83, 43-45; SEK 1984-87, 16, 35; S. Häkkinen 2010, 215.

428 Kirk.kok. ptk-k. 1982, liite X; SEK 1980-83, 167-168.

429 Lisäksi jäseninä olivat asessori, teologian tohtori Sigtrygg Serenius ja suomen kielen asiantuntija, professori Matti Sadeniemi. Sihteerinä toimi ensin Olavi Rimpiläinen ja hänen jälkeensä teologian tohtori Risto Cantell.

430 Parvio 1977, 123-128; Koivula 2002, 31-40, 147; Ryökäs 2002, 22-23; Pajunen 2008, 184, 256-257, 270, 319, 323

431 Talonen 2012, 534-536.

432 Kirk.kok. ptk-k. 1982, liite X, 6.

433 Kakkuri 1995, 60-62; Koivula 2002, 37-39; Ryökäs 2002, 21-23; Pajunen 2008, 256-264.

434 Kirk.kok. kptk-k. 1982, 44 §.

435 Kirk.kok. ptk-k. 1982, liite III 1, 1 \& X, 6.

436 Kirk.kok. ptk-k. 1982, liite III 1, 12.

437 Kirk.kok. kptk-k. 1982, 44\$, 62 \$.

438 Kirk.kok. kptk-k. 1982, $44 \S$. 
439 Kirk.kok. kptk-k. 1982, 44 \$.

440 Kirk.kok. ptk-k. 1982, liite XIII-C 2.

441 Kirk.kok. kptk-k. 1982, 62 §.

442 Kirk.kok. kptk-k. 1983, 7 \$; Kirk.kok. ptk-k. 1983, liite II 1; Murtorinne 1995, $365-366,414$.

443 Kirk.kok. kptk-k. 1983,51 §.

444 Kirk.kok. kptk-k. 1983,7\$.

445 Kirk.kok. kptk-k. 1983,59\$.

446 Kirk.kok. kptk-k. 1984, $12 \$$.

447 KKHA KKA Cic 1 ptk. 6.5.1982 klo 15.30 \$ 3.

448 Kirk.kok. ptk-s. 1984, liite VI-C 1.

449 Kirk.kok. kptk-s. 1984, 14 \$, 20 \$.

450 Kirk.kok. kptk-s. 1984, 14 §.

451 Kirk.kok. ptk-k. 1986, liite VI 1:1 \& 1:14 \& 1:15.

452 Kirk.kok. kptk-k. 1986, 28 §.

453 Kirk.kok. ptk-s. 1986, 28 §.

454 Knuutila 2005, 76, 87.

455 Kirk.kok. kptk-s. 1984, $14 \$$.

456 Kirk.kok. kptk-k. 1982, $44 \S$.

457 Kirk.kok. kptk-s. 1984, 17 §.

458 Vanhoillislestadiolaisuutta koskeneesta julkisuudesta ks. Alatalo 2007, 78, 81-86, 93-109, 148

459 Kirk.kok. kptk-k. 1982, 44 \$; Kirk.kok. kptk-s. 1984, 14 \$, 17 \$; Kirk.kok. ptks. 1984, liite VI-C 1 .

460 Kirk.kok. kptk-s. 1984, 17 \$.

461 Yli-Opas 2010, 79, 228-229.

462 Kirk.kok. kptk-s. 1984, 20 \$, 42 \$; Kirk.kok. ptk-s. 1984, liite VI-C 1 \& 1 a.

463 Yli-Opas 2010, 80, 235.

$464 K p$ 23.10.1984 Kirkko keskellä elämää: Suuria asioita Turussa (Juhonpoika). Myös ESS 9.11.1984 Esalainen: Kirkolliset kierrokset (KM [Kauko Mäenpää]).

465 Kirk.kok. ptk-k. 1982, liite III 1, 6.

466 KKHA KKA Cic 6 Seppo Häyrynen käsikirjavaliokunnalle 6.4.1983 \& 23.10.1984; Kirk.kok. ptk-s. 1984, liite VI-C 1.

467 Kirk.kok. kptk-s. 1984, 14 \$, 20 \$; Kirk.kok. ptk-s. 1984, 20 \$, 42 \$, liite VI-C $1 \mathrm{a}$.

468 Kirk.kok. kptk-s. 1984, 20 \$.

469 Kirk.kok. ptk-s. 1984, $20 \$$, liite VI-C 1 a.

470 Kirk.kok. kptk-s. 1984, $14 \$, 42 \$$.

471 Kirk.kok. kptk-s. 1984, 45 \$.

472 Kirk.kok. ptk-l. 1973, liite VI-E 9; Kurki-Suonio 1985, 11.

473 Sarelin 1998, 16-19; Pajamo \& Tuppurainen 2004, 472-473.

474 Virsikirjaehdotus 1984a, 12. Kirkolliskokous valitsi vuonna 1973 komiteaan puheenjohtaja Lempiäisen ohella teologian maisteri Markku Kilpiön, kirjailija Anna-Maija Niemisen (Raittila), kanttoriurkuri, filosofian lisensiaatti Reijo Pajamon, kirjailija, pastori Niilo Rauhalan, kirkkoherra Esa Santakarin ja lääninrovasti Jukka Malmivaaran, jonka tilalle valittiin vuonna 1977 kirkkoherra Heikki Vaahtoniemi. Komitea kutsui sihteerikseen pastori Seppo Suokunnaan.

475 Kirk.kok. kptk-s. 1976, 63 \$; Kirk.kok. ptk-s. 1976, liite IX-C 3; Virsikirjaehdotus 1984a, 15, 17-18; Miettinen 1979, 50-51, 58-59, 109-111; Pajamo 2001, 120; Pajamo \& Tuppurainen 2004, 475-477.

476 Förslag till Svensk psalmbok 1983, 6. Kirkolliskokous valitsi vuonna 1975 muiksi jäseniksi director cantus Gunnar Ahlskogin, teologian lisensiaatti Gustav Björkstrandin, filosofian maisteri Ull-Britt Gustafssonin, pastori Henrik Perret'n, kirjailija Ole Torvaldsin ja diplomiurkuri Gunvor Helanderin, jonka tilalle valittiin 1980 toinen kirkkomuusikko Helge Degerman. Komitea kutsui sihteerikseen filosofian ja teologian lisensiaatti Karl-Johan Hanssonin, ja tehtävässä toimi osa-aikaisesti myös filosofian ylioppilas Catharina Östman.

477 Förslag till Svensk psalmbok 1983, 7; Virsikirjaehdotus 1984a, 13; Sarelin 1998, 178-180, 254-255.

478 Heino 1988, 41-42; Helander 1999, 56-57, 64-66.

479 KKHA KKA Hb 12 ptk. 16.2.1984, liite: Rauhala Suokunnaalle 27.1.1984; Virsikirjaehdotus 1984a, virsi 635. Rauhalan arvostelemassa muodossa sanat päätyivät myös lopulliseen virsikirjaan (virsi 598).

480 Virsikirjaehdotus 1984b; US 18.10 .1984 Seurakunnat veisaavat virsiä nyt hiki hatussa (Hannu Kuosmanen); $A l$ 3.11.1984 Turha virsikiire (pääk.); Pnen 3.11.1984 Tapulista: Virsikirjasta kertakäyttötavaraa? (Väkkäri); K. Häkkinen 1987, 107.
481 SkK 15.12.1984 Virsien kimpussa (pääk.).

482 Sarelin 1998, 262.

483 Kirk.kok. kptk-s. 1984, 43 \$; Pajamo 2001, 93, 210.

484 Kirk.kok. kptk-s. 1984, 43 \$, 47 \$; Kirk.kok. ptk-s. 1985, liite VI-G 1 I; Heino 1985, 19, 36; K. Häkkinen 1987, 106.

485 Kirk.kok. kptk-s. 1984, 47 \$; Kirk.kok. ptk-k. 1985, liite III 1, 8; Ruonakoski 2012, 35-38.

486 Virsikirjaehdotus 1984a, 19; Hansson 1977, 80; Sarelin 1998, 392.

487 Kirk.kok. kptk-s. 1984, 43\$, 47 \$; Kirk.kok. ptk-k. 1985, liite III 2; Kirk.kok. ptk-s. 1985, liite VI-G 1 I; Heino 1985, 10; K. Häkkinen 1987, 106; Ruonakoski 2012,34-35.

488 Kirk.kok. ptk-k. 1977, 92 \$, liite X-C 2; Förslag till Svensk psalmbok 1983, 6; Virsikirjaehdotus 1984a, 19.

489 Kirk.kok. kptk-s. 1984, 47 \$; Sarelin 1998, 311-312. Runebergin virsien muokkauksista Östman 1985.

490 Kirk.kok. kptk-s. 1984, 43 \$; Kirk.kok. ptk-s. 1985, liite VI-G 1 I; Heino 1985, 24, 29; K. Häkkinen 1987, 106; Ruonakoski 2012, 29-32, 42-43.

491 Kirk.kok. ptk-k. 1985, liite III 1, 2-3; Ruonakoski 2012, 44-45.

492 Kirk.kok. kptk-s. 1984, 43 \$.

493 Kirk.kok. ptk-k. 1985, liite III 1, 4.

494 KKHA KKA Hba 12 Aarre Huhtalan palaute 31.12.1984.

495 Parvio 1985, 21; Teinilä 2001, 87, 89; Suokunnas 2012, 226-228; US 31.3 .1985 Uusi virsikirja herätti kiivaan keskustelun (Hannu Kuosmanen); Pehkonen-Suoranta \& Mustakallio 2012, 502.

496 Kirk.kok. kptk-s. 1984, 47 \$; Kirk.kok. ptk-k. 1985, liite III 2; Sarelin 1998, 312-314.

497 Förslag till Svensk psalmbok 1983, 7; Virsikirjaehdotus 1984a, 13, 22.

498 Kirk.kok. ptk-k. 1985, liite III 1, 4, 7.

$499 A l$ 3.11.1984 Turha virsikiire (pääk.); US 13.11.1984 "Tehokas seurakunta?" (Jyrki Vesikansa); Länsi-Suomi 27.11.1984 Tyylitön virsikirjauudistus (pääk.); SkK 15.12.1984 Virsien kimpussa (pääk.); US 23.3.1985 Kirkossa kuohuu (pääk.); TS 29.3.1985 Oi, muistatko vielä sen virren (pääk.); HS 31.3.1985 Virsikirjaa kypsyteltävä (pääk.); ESS 1.4.1985 Virret valinkauhassa (pääk.).

500 Kirk.kok. kptk-s. 1984, 43 \$; Kirk.kok. kptk-k. 1985, 32 \$.

501 Ruonakoski 2012, 33.

502 KKHA KKA Hba 3 Eurajoen, Turun Henrikin ja Yläneen seurakuntien palautteet.

503 Heino 1985, 25.

504 KKHA KKA Hba 1 ptk. 21.8.1984 \$6, ptk. 3.-4.12.1984\$2.

505 KKHA KKA Hba 1 ptk. 10.1.1985 \$2.

506 KKHA KKA Hba 1 ptk. 21.8.1984 §6, ptk. 3.-4.12.1984 § 2; Kirk.kok. ptk-k. 1985, liite III 2.

507 KKHA KKA Hba 1 ptk. 21.8.1984 \$ 6; Kirk. kok. kptk-k. 1985, 32 §. Virsikirjakomitea ja -valiokunta saattoivat sekoittua pääkirjoitustasollakin: Hämeen Sanomat 9.5.1985 Virsikirjauudistuskin alkaa jo tyydyttää? (pääk.).

508 KKHA KKA Hba 14 Avoin kirje kirkkohallitukselle, kirkolliskokoukselle ja virsikirjavaliokunnalle.

509 KKHA KKA Hba 14 Vapaussoturien Huoltosäätiö, Suomen Sotaveteraaniliitto, Rintamamiesveteraanien Liitto ja Rintamanaisten Liitto arkkipiispalle ja piispainkokoukselle 11.2.1985

510 Kirk.kok. kptk-s. 1985, $20 \$$.

511 K. Häkkinen 1987, 30-33, 105.

512 KKHA KKA Hba 1 ptk. 18.-19.2.1985 \$2; Kirk. kok. kptk-k. 1985, $32 \S$.

513 Kirk.kok. kptk-k. 1985, 32-33 \$; Kyrkomötets protokoll höstsession 1985, bihang VI-G 1 II; Pajamo 2002, 92-93.

514 Kirk.kok. kptk-s. 1985, 20 \$.

515 Seppo Suokunnaan sähköpostihaastattelu 17.5.2012; Sarelin 1998, 320-322.

516 Kirk.kok. kptk-s. 1985, 45 \$; Kirk.kok. ptk-s. 1985, liite VI-G 1 I; Kyrkomötets protokoll höstsession 1985, bihang VI-G 1 II; Sarelin 1998, 319-320. Jaostojen sihteereinä toimivat kanttori, teologian maisteri Birgitta Sarelin sekä pastori, kanttoriurkuri Hannu Vapaavuori.

517 Sarelin 1998, 320, 366-368.

518 Sovijärvi 2008,78 .

519 Ruonakoski 2012, 55-57.

520 Kirk.kok. ptk-s. 1985, liite VI-G 1 I.

521 Kyrkomötets protokoll höstsession 1985, bihang VI-G 1 II; Sarelin 1998, 378380 .

522 Kirk.kok. kptk-k. 1985, 33 \$.

523 Kirk.kok. ktpk-s. 1985, 20 \$. 
524 Kirk.kok. ptk-s. 1985, liite VI-G 1 I; Ruonakoski 2012, 49, 52-54.

525 Kyrkomötets protokoll höstsession 1985, bihang VI-G 1 II.

526 Kirk.kok. kptk-s. $1985,20 \$$.

$527 H S$ 12.10.1985 Kiistellyt virret takaisin; $A l$ 13.10.1985 Vanha virsi (pääk.); SS 13.10.1985 Tutut virret entiseen asuunsa (pääk.); SkK 20.10.1985 Virsityövoitto (pääk.); Pajamo 2001, 240

528 Kirk.kok. ptk-s. 1985, liite VI-G 1 I.

$529 A l$ 13.10.1985 Vanha virsi (pääk.); SS 13.10 .1985 Tutut virret entiseen asuunsa (pääk.); SkK 20.10.1985 Virsityövoitto (pääk.); KS 24.10.1985 Virsiuudistus herkkää työtä (pääk.); $L K$ 7.11.1985 Virsikirja uusiutuu (pääk.); US 9.11.1985 Virsirunouden voitto (pääk.); IS 11.11 .1985 (pääk.).

530 Kmaa 22.10.1985 Virsikirjauudistus loppusuoralla (pääk.)

531 Seppo Suokunnaan sähköpostihaastattelu 17.5.2012; Sarelin 1998, 322-323; Ruonakoski 2012, 48.

532 Kirk.kok. kptk-s. 1985, $20 \$$.

533 Kirk.kok. kptk-s. 1985, 34 \$; Pajamo 2002, 95-96; Ruonakoski 2012, 59, 6566, 68-69.

534 Kirk.kok. kptk-s. 1985,34 \$; Ruonakoski 2012, 67-68.

535 Kirk.kok. kptk-y. 1986, 5 \$; Ruonakoski 2012, 79-80.

536 Kirk.kok. ptk-s. 1985, liite VI-G 1 a I.

537 Kirk.kok. kptk-y. 1986, 5 \$; Ruonakoski 2012, 79-80.

538 Ruonakoski 2012, 58.

539 Kirk.kok. kptk-s. 1985, 34 \$, 44 \$; Ruonakoski 2012, 70-72, 89, 92.

540 Kirk.kok. kptk-s. 1985, 22 \$.

541 Kirk.kok. ptk-k. 1985, liite III 1, 2.

542 P. Simojoki 1985, 23-24.

543 KKHA KKA Hba 1 ptk. 18.-19.2.1985\$2; Kirk.kok. kptk-k. 1985, 32 \$; Kirk. kok. ptk-s. 1985, liite VI-G 1 I; Ruonakoski 2012, 10.

544 Kirk.kok. kptk-s. 1985,32 \$.

545 Kirk.kok. kptk-s. 1985, 22 §.

546 HS 2.11.1985 Naiset eivät enää halua olla veljiä (Irja Askola, Raili Heikinheimo, Ursula Kontio, Pirkko Lehtiö, Sirkku Nyström, Anja Porio ja Arja Repo); Raiser 2004, 255, 260

547 Kirk.kok. kptk-s. 1985, 32 \$.

548 Kirk.kok. kptk-s. 1985, $32 \S$.

549 Kirk.kok. kptk-s. 1985,34§.

550 Kirk.kok. kptk-s. 1985, 20 \$.

551 Kirk.kok. kptk-s. 1985, 37 \$.

552 Ruonakoski 2012, 75.

553 Kaleva 9.11.1985 Virrentekijä Markku Kilpiö: Virsikirjakomitean uudistuslinja nurin (Pekka Koivisto).

554 Kirk.kok. kptk-s. 1985,34 \$.

555 Sittemmin kirkon jumalanpalvelus- ja musiikkitoiminnan keskus.

556 Kirk.kok. kptk-s. 1985, 20 \$; Seppo Suokunnaan sähköpostihaastattelu 17.5 .2012 .

557 Kirk.kok. kptk-s. 1984, 43 \$; Kirk.kok. kptk-s. 1985, 44 \$.

558 Papeista innokkaimpia sanankäyttäjiä olivat Lauri Koskenniemi, joka ylitti sadan puheenvuoron rajan, Timo Holma, Timo Kökkö, Heikki Vaahtoniemi, Reijo Mattila, Henrik Perret ja Tapani Vuorela. Vaahtoniemi ja Perret olivat olleet kumpikin sekä virsikirjakomiteassa että -valiokunnassa.

559 Yli 20 kertaa puhuivat koulunjohtaja Antti Lehtinen, diplomi-insinööri Juhani Kärkkäinen Raahesta ja vanhoillislestadiolainen Erkki Reinikainen. Rukoilevaisuuteen kuulunut Irja Vuorenpää oli naisedustajista aktiivisin keskustelija 16 puheenvuorollaan.

560 Suokunnas 2012, 235.

561 Kirk.kok. kptk-s. 1985, 45 §.

562 Kirk.kok. kptk-s. 1985, 45 \$; Sarelin 1998, 361-362.

563 Kirk.kok. kptk-s. 1985, $45 \$$.

564 Kirk.kok. kptk-s. 1985, $45 \$$.

565 KKHA KKA Hca 2 protokoll 10.1.1986 \$ 2, bihang: ”Jag ska gråtande kasta mig ner".

566 Kirk.kok. kptk-y. 1986, 6 \$.

567 Kirk.kok. kptk-y. 1986,7§.

568 Kaleva 9.11.1985 Virrentekijä Markku Kilpiö: Virsikirjakomitean uudistuslinja nurin (Pekka Koivisto). Myös Kmaa 24.1.1986 Puheenvuoro: Jäähyväiset virsikirjauudistukselle (Markku Kilpiö).

569 Teinilä 2001, 92, 94-96; Seppo Suokunnaan sähköpostihaastattelu 17.5.2012.

570 Kirk.kok. kptk-s. 1985, 20 \$. Ks. Pajamo 2001, 254.

571 KKHA KKA Ha 22 ptk. 21.12.1990 \$ 6-7.
572 Kmaa 15.3.1983 Murtunut ruoko, kestävä pilari (Lassi Nummi).

573 UT 1990, 6-7. Sihteerinä toimivat eri vaiheissa myös pastori Esko Rintala, TM Jorma Salminen ja TT Pauli Huuhtanen.

574 KKHA KKA Ha 1 ptk. 30.10.1974, liite; Kirk.kok. ptk-k. 1975, liite III 3, 1718.

575 Kirk.kok. kptk-k. 1982, 43 \$, 50 \$; Kirk.kok. ptk-k. 1988, liite X 12; Kirk.kok. ptk-s. 1989, liite VIII-C 3 .

576 Kirk.kok. ptk-k. 1975, liite III 3, 21-22 \& V-C 4; Harviainen 1990, 177; UT 1990, 7, 13-14.

577 Kirk.kok. ptk-k. 1975, liite V-C 4.

578 Kirk.kok. ptk-k. 1975, $97 \$$.

579 KKHA KKA Ha 1 ptk. 26.2.1974 \$3

580 Hyvönen 1990, 183.

581 Liljeqvist 1990, 206

582 Johannes 1986, 17-19; Hyvönen 1990, 184; Knen 21.9.1989 Ortodoksit hylkäämässä raamatunkäännöksen.

583 Aarne Toivanen 1990, 100-101; Aarne Toivasen haastattelu 20.1.2012.

584 Murtorinne 1995, 433

585 Kirk.kok. kptk-k. 1984, 66 \$; Kirk.kok. ptk-k. 1984, liite XII-D 6.

586 HS 19.5.1985 Raamatunkääntäjiä muistettu ehdotuksin, kiitoksin ja kirouksin.

587 Harviainen 2012, 582.

588 UT 1990, 20.

589 Aarne Toivasen haastattelu 20.1.2012.

590 UT 1990, 521-527; Harviainen 2012, 581; Aarne Toivasen haastattelu 20.1.2012; Raija Sollamon sähköpostihaastattelu 18.9.2013; Räisänen 2012a, 439.

591 Kiviranta 1990; E. Koskenniemi 1990; Mannermaa 1990; Annasara Toivanen 2012, 19, 31.

592 Aarne Toivanen 1989, 74; H. Koskenniemi 1992, 170-173; Thurén 1992, 176179; Aarne Toivanen 2012, 547.

593 UT 1990, 11.

594 UT 1990, 6, 19; Mannermaa 1990, 211

595 Aarne Toivanen 1989, 74-75; UT 1990, 521, 523.

596 Peura 1989, 488; Mannermaa 1990, 213-214; Räisänen 1990, 223-228.

597 Kirk.kok. ptk-s. 1991, liite VI-H 1.

598 Kirk.kok. kptk-s. 1989, 36 \$.

599 KKHA KKA Haa 2 ptk. 7.11.1990 \$2.

600 Kirk.kok. kptk-k. 1990, $26 \$$.

601 Kirk.kok. kptk-k. 1990, $26 \$, 28 \$$.

602 Kirk.kok. kptk-k. 1990, 28 \$; Kirk.kok. kptk-s. 1990, 19 \$; Kirk.kok. kptk-k. 1991, $22 \$$.

603 KKHA KKA Haa 1 Aarne Toivanen raamatunkäännösvaliokunnalle 26.1.1990, Aarne Toivanen Kalevi Toiviaiselle 8.2.199o, ptk. 22.2.1990 $§$ 3, "Piispainkokouksen lausunto kirkolliskokoukselle. Luonnos"; Kirk.kok. ptk-s. 1990, liite III 2.

604 KKHA KKA Haa 3 esityslista 6.3.1991; Piisp.kok. ptk-k. 1991, 5 \$, 31 §; Piisp. kok. ptk-y. 1991, 5 \$; Malkavaara \& Mustakallio 2012b, 571.

605 Kmaa 12.3.1991 Raamatunkäännöksen hankala aikataulu (pääk.), 19.3.1991 Ajan merkkejä: Piispa Kalevi Toiviainen on huolestunut ennenaikaisen tarkistuskomitean kaavailuista, 22.3.1991 Ajan merkkejä: Raamatunkäännös tarvitsee aikalisän (Eero Huovinen), 5.4.1991 Keskustelua: Käännösehdotuksen käsittelyaika kohtuullinen (Harri Raitis), Piispat tarvitsevat aikalisän (Ossi Haaramäki), Merkillinen tarkistuskomitea (Olavi Koivukangas), 9.4.1991 Keskustelua: Raamatunkäännös ei vielä tarvitse tarkistuskomiteaa (Heikki Mäkeläinen), 16.4.1991 Keskustelua: Onnistuisikohan tuo näin? (Aarre Huuskonen), Aikalisä Vt:n käännökselle (Antti Laato), 23.4.1991 Keskustelua: Valiokunta ei pohjusta komiteatyötä (Aarne Toivanen), 26.4.1991 Puheenvuoro: Raamatunkäännöksellä nyt liian kuristava aikataulu (Simo Peura \& Heikki Sariola), Raamattu ei hyödy tarkistuskomiteasta (Tapani Harviainen), 30.4.1991 Keskustelua: Raamatunkäännös tarvitsee lisäaikaa (Nakkilan seurakunnan lausuntoa valmisteleva työryhmä), Tarkistamiseen tarvitaan aikaa (Antti Laato), 3.5.1991 Raamatunkäännöksestä rohjettava tehdä päätös (pääk.).

606 Kirk.kok. kptk-k. 1991, 22 §.

607 Kirk.kok. kptk-k. 1991, $22 \$$.

608 Kirk.kok. kptk-k. 1991, 31-32 \$, 50 \$.

609 KKHA KKA Haa 4 "Huomioita piispainkokouksen lausunnosta, joka koskee Vanhan testamentin käännösehdotusta" (Ilmari Soisalon-Soininen); Kirk.kok. ptk-k. 1991, liite III 1; Piisp.kok. ptk-s. 1990, 7 \$. 
610 KKHA KKA Haa 1 Aarne Toivanen raamatunkäännösvaliokunnalle 26.1.1990; Kauppinen 1990, 31-32.

611 Kauppinen 1990, 8 \& 1991, 7.

612 Kirk.kok. kptk-s. 1991, 19 \$; Kirk.kok. ptk-s. 1991, liite VI-H 1, 2-3, 5.

613 Kauppinen 1990, 14, 19 \& 1991, 13-14.

614 Kauppinen 1990, 18 \& 1991, 16.

615 Kauppinen 1990, 26 \& 1991, 18, 22-23.

616 Aarne Toivasen haastattelu 20.1.2012.

$617 V T$ 1990, 6-8.

618 Räisänen 2012b, 56o-561.

619 Kirk.kok. ptk-s. 1991, liite VI-H 1, 7.

620 KKHA KKA Haa 4 ptk. 6.5.1991 \$3.

621 Kirk.kok. ptk-s. 1991, liite VI-H 1, 4-7; Raija Sollamon sähköpostihaastattelu 18.9.2013.

622 Hyvönen 1990, 185-186; Kauppinen 1990, 21.

623 KKHA KKA Haa 1 "En Khristō ja eis Khristō -ilmausten kääntäminen" (Timo Komulainen 17.8.1990).

624 Kirk.kok. ptk-s. 1991, liite VI-H 1, 6, 39.

625 T. Eskola 2002, 211; Kuula 2002, 205.

626 Kirk.kok. kptk-s. 1991, 49\$, $52 \$$.

627 Kirk.kok. kptk-s. 1991, $20 \$$.

628 Kirk.kok. kptk-s. 1991, $20 \$$.

629 Kirk.kok. kptk-s. 1991, $46 \$$.

630 Kirk.kok. kptk-s. 1991, 19-20 \$.

631 Kirk.kok. kptk-s. 1991, 19-20 \$, 40 \$; Kmaa 22.10.1991 Puheenvuoro: Raamatunkäännös ei ole vielä valmis (Timo Veijola).

632 Kirk.kok. kptk-s. 1991, 19 \$.

633 Kirk.kok. kptk-s. 1991, $49 \$$.

634 PS 10.10.1991 "Perkele" poistuu Raamatun sivuilta; Itä-Häme 12.10.1991 Sensuroitu perkele? (Seppo Häkkinen); IS 12.11.1991 Veikko Sinisalo ei luovu Perkeleestä äänestyspäätöksillä; Länsi-Savo 12.11.1991 Paholainen voitti äänestyksen (pääk.); TS 12.11.1991 Perkeleen tilalle paholainen; $A l$ 13.11.1991 Perkele vai paholainen; IS 13.11.1991 Perkeleestä (pääk.).

635 Harviainen 2012, 581; Lehtipuu \& Laine 2012, 590-593.

636 Kirk.kok. kptk-k. 1991, 50 \$.

637 Kirk.kok. kptk-s. 1991, 40 \$.

638 VT 1991,11-12; Aarne Toivanen 1991, 110.

639 Kirk.kok. ptk-k. 1991, liite III 1, 3.

640 Kirk.kok. kptk-k. 1991, 22 \$.

641 Kirk.kok. ptk-k. 1991, liite VI-H 1, 6.

642 Harviainen 2012, 581; Aarne Toivasen haastattelu 20.1.2012.

643 Kirk.kok. kptk-k. 1991, $50 \$$.

644 Kirk.kok. kptk-s. 1991, 40 \$.

645 Kirk.kok. kptk-y. 1992, $10 \$$.

646 Aarne Toivasen haastattelu 20.1.2012.

647 Kirk.kok. kptk-s. 1991, 27 \$; Kirk.kok. ptk-s. 1991, liite VI-H 1 \& 1 b.

648 Kauppinen 1991, 25.

649 Kirk.kok. kptk-s. 1989, 36 \$.

650 Kauppinen 1990, 29.

651 KKHA KKA Haa 4 ptk. 29.11.1991 \$3.

652 Kirk.kok. kptk-s. 1991, $49 \$$.

653 Aarne Toivanen 1989, 81

654 Kirk.kok. kptk-s. 1989, 36 \$.

655 Kirk.kok. kptk-s. 1991, 49 §.

656 Kirk.kok. ptk-y. 1991, $10 \$$, liite VI-H 1 b.

657 Kirk.kok. kptk-y. 1992,13\$.

658 Kmaa 5.11.1991 Vaalit ongelmana Ruotsinkin kirkossa (pääk.); HS 8.11.1991 Miksi? Onko kirkolliskokous oikea paikka raamatunkäännökselle? (Anneli Tukia); SS 10.11.1991 Oikea paikka raamatunkäännöksellä (Pauli Juusela).

659 HS 1.7.1985 Puheenjohtaja Reinikainen suviseuroissa: Raamatun uusi käännös ei kelvanne lestadiolaisille.

660 Kirk.kok. ptk-y. 1992, liite VI-H 1 b.

661 Kirk.kok. kptk-y. 1992, 10 \$.

662 Kirk.kok. kptk-y. 1992,15 \$; Kmaa 14.1.1992 Uusi raamatunkäännös hyväksyttiin 93-5 (Ritva Rasila). Vastaan äänestivät Fredric Cleve, Leena Huima, Liisi Jokiranta, Hannu Kippo ja Eeva Laato. Äänestyksestä pidättyivät Timo Holma, Pekka Leino, Henrik Perret, Göran Stenlund ja Mauno Vuollo. Kmaa 14.1.1992 Uusi raamatunkäännös hyväksyttiin 93-5 (Ritva Rasila).
663 Kirk.kok. kptk-y. 1992, 13 \$.

664 Kirk.kok. kptk-y. 1992, $13 \$$.

665 Raija Sollamon sähköpostihaastattelu 18.9.2013.

666 Kirk.kok. ptk-k. 1984, liite II 1; Kirk.kok. ptk-s. 1984, 28 \&, liite VI-B 7.

667 Kirk.kok. kptk-k. 1987,39 \$; Kirk.kok. ptk-k. 1987, liite VII-B 1; Kirk.kok. ptks. 1989, 20 \$, liite VI 3 \& VIII-E 9.

668 SEK 1984-87, 46; US 6.12.1986 Naispappeus oli tärkeintä.

669 SEK 1984-87, 160-161.

670 Autio 1997, 16; Vahtola 2003, 474.

671 TTA AKA Fa3 Vikström piispoille 21.2.1983; Mustakallio 2012a, 522.

672 Esim. Kirk.kok. kptk-s. 1983, 40 \$; Kirk.kok. kptk-s. 1985, 16 \$.

673 Kirk.kok. kptk-s. 1985, 22 \$.

674 Kirk.kok. kptk-s. 1985, 32 §. 


\section{KIRKON HALLINTO \\ ITSEN ÄISTYY 1992-2000}

Meinander 1999, 486; Vahtola 2003, 415

Turun hpk.kok. ptk. 1992, liite 1.

Vahtola 2003, 475.

SEK 1988-91, 40.

Kirk.kok. ptk-k. 1992, liite VII 3 \& 4.

Kirk.kok. kptk-k. 1992, 65 \$.

Kirk.kok. ptk-k. 1992, liite III 1 \& 2.

Kirk.kok. ptk-k. 1992, liite VII 2.

Kirk.kok. ptk-k. 1992, liite V 4.

Kirk.kok. ptk-k. 1980, liite V 1, 24.

Kirk.kok. ptk-k. 1980, liite V 1, 24.

Kirk.kok. ptk-k. 1980, liite V 1, 24-25.

13 Kmaa 6.3.1992 Kirkolliskokouksen edustajista vaihtuu lähes puolet.

14 LTA Eca rovastikuntien pappien kokousten ptk:t 2.3.1992.

15 Kmaa 6.3.1992 Kirkolliskokouksen edustajista vaihtuu lähes puolet.

16 HTA Eec 5 Helsingin hiippakunnan ehdokaslistojen yhdistelmä kirkolliskokouksen maallikkoedustajien vaalissa 2.3.1992, vaalilautakunnan ptk. 9.3.1992, liite 1; Kmaa 10.1.1992 Ehdokasmäärä väheni, hajautui, naisistui, 17.1.1992 Poliitikkoja ehdolla entistä enemmän, 11.2.1992 Kirkolliskokoukseen pyritään alueiden ja puolueiden pohjalta, Seitsemän pyrkii yksin.

17 Kmaa 10.1.1992 Kirkolliskokouksen 64 maallikkopaikkaa tavoittelee yli 500 ehdokasta.

18 Kmaa 10.1.1992 Ehdokasmäärä väheni, hajautui, naisistui, 6.3.1992 Kirkolliskokouksen edustajista vaihtuu lähes puolet.

19 Lähteenmäki 2006, 200.

20 Lähteenmäki 2006, 183.

21 Kmaa 27.12.1991 Miksi kirkolliskokous ei innosta maallikoita? (pääk.), Pääkaupunkiseudun nuoret pyrkivät kirkolliskokoukseen.

22 KJK 18.3.1992 Suhmurointia (Seppo Simola, pääk.)

23 HTA Eec 5 vaalilautakunnan ptk. 9.3.1992 $\$ 4$.

24 Kirk.kok. ptk-s. 1993,1§.

25 HTA Eec 5 Helsingin hiippakunnan ehdokaslistojen yhdistelmä kirkolliskokouksen maallikkoedustajien vaalissa 2.3.1992, vaalilautakunnan ptk. 9.3.1992, liite 1 .

26 LTA Eca Lapuan hiippakunnan ehdokaslistojen yhdistelmä kirkolliskokouksen maallikkoedustajien vaalissa 2.3.1992, vaalilautakunnan ptk. 9.3.1992 § 5; Kmaa 6.3.1992 Kirkolliskokouksen edustajista vaihtuu lähes puolet.

27 Kmaa 11.2.1992 Kirkolliskokoukseen pyritään alueiden ja puolueiden pohjalta.

28 Kmaa 28.2.1992 Uusi kirkolliskokous valitaan maanantaina (pääk.), Kirkolliskokouksen vaalityö jäi laimeaksi.

29 Kmaa 6.3.1992 Kirkolliskokouksen edustajista vaihtuu lähes puolet.

30 Kmaa 10.3.1992 Nuorisotyöntekijä Risto Rasimus odottaa jumalanpalvelusuudistuksen käsittelyä: Nuoret ja lapset esiin lepopäivän ohjelmassa.

31 Kmaa 17.1.1992 Poliitikkoja ehdolla entistä enemmän.

32 Kmaa 6.3.1992 Vaihtuvuus kiinnostava, osanotto huolestuttaa (pääk.), Kirkolliskokouksen edustajista vaihtuu lähes puolet.

33 Kirk.kok. ptk-k. 1995, 1\$; Kirk.kok. ptk-s. 1995, 1 \$.

34 Kmaa 22.12.1995 Kirkolliskokoukseen pyrkii 507 maallikkoa ja 218 pappia. 35 Kmaa 22.12.1995 Kirkolliskokous uudistuu huomattavasti (Ritva Rasila).

36 LTA Eca Lapuan hiippakunnan ehdokaslistojen yhdistelmä kirkolliskokouksen maallikkoedustajien vaalissa 12.2.1996; HTA Eec 6 valitsijayhdistysten perustamisasiakirjat maallikkoedustajien vaalissa; Kmaa 22.12.1995 Kirkolliskokous uudistuu huomattavasti (Ritva Rasila).

37 LTA Eca Lapuan hiippakunnan ehdokaslistojen yhdistelmä kirkolliskokouksen maallikkoedustajien vaalissa 12.2.1996.

38 LTA Eca vaalilautakunnan ptk. 19.2.1996\$5.

39 HTA Eec 6 valitsijayhdistysten perustamisasiakirjat maallikkoedustajien vaalissa.

40 LTA Eca vaalilautakunnan ptk. 19.2.1996 \$ 6; HTA Eec 7 lopulliset tulokset, pappisedustajat.

41 Sana 21.2.1996 Maailman menossa: Päävartion edessä pimeässä (Leena Huima); Kmaa 23.2.1996 Juristeista pula, järjestöt vyöryttävät (Ritva Rasila).

\section{vaalissa.}

49 LTA Eca valitsijayhdistysten perustamisasiakirjat kirkolliskokouksen maallikkoedustajien vaalissa 1996.

50 LTA Eca Jussi Lilja Aulis Ala-Kasarille 18.12.1995.

51 Kirk.kok. kptk-k. 1997, 76 \$; Kirk.kok. ptk-k. 1997, liite V 6 \& VI-E 7.

52 Länsi-Suomi 1.3.1992 Kirkon parlamenttivaalit (pääk.); Kmaa 9.2.1996 Hämärää vallankäyttöä (Tapani Ruokanen, pääk.); TS 11.5.1996 Kirkolliskokouksen valintatapa ei vastaa nykyajan vaatimuksia (pääk.).

53 Kirk.kok. ptk-k. 1992, liite VII 1; Kirk.kok. kptk-s. 1992, 38 \$, 62 \$; Kirk.kok. kptk-k. 1996, 31 \$; Kirk.kok. ptk-k. 1996, liite VIII 3.

54 Kirk.kok. ptk-s. 1993, liite IV 12; Kirk.kok. ptk-k. 1994, 54 §; Kirk.kok. ptk-k. 1994, liite IX-A 1; Kirk.kok. ptk-k. 1996, liite XI-E 1.

55 KKHA KKH täysistunnon ptk. 8.10.1992 \$167, liitteet $\$ 167$; Kirk.kok. $k p$ tk-k. 1993, 5 \$; Kirk.kok. ptk-k. 1993, liite IV 1.

56 KKHA KKH täysistunnon ptk. 8.10.1992 $\$ 167$, liitteet $\$ 167$ : korkeimman oikeuden esitys kirkkohallitukselle kirkkolain muuttamiseksi \& korkeimman hallinto-oikeuden esitys kirkkohallitukselle kirkkolain muuttamiseksi \& hallintoneuvos Olli Rikkosen äänestyslausunto; Kirk.kok. ptk-k. 1993, liite IV 1; Kirk.kok. kptk-s. 1993, 27 \$; Kirk.kok. ptk-s. 1993, liite VII-A 2. 57 Kirk.kok. ptk-k. 1993, 1 \$; Kirk.kok. kptk-k. 1994, 4.

58 Kirk.kok. kptk-k. 1993, 5 \$; Kirk.kok. kptk-s. 1993, 27 \$; Kirk.kok. kptk-s. 1994, $19 \$$.

59 Kirk.kok. kptk-s. 1993, 27§.

6 Kirk.kok. ptk-k. 1994, liite IX-A 2.

61 Kirk.kok. kptk-s. 1994, 19 \$.

62 Kirk.kok. kptk-s. 1994, 19 \$.

63 TTA AKA Dab Vikström Olli Rikkoselle 30.3.1993.

64 Kirk.kok. kptk-s. 1994, 19 \$.

65 Kirk.kok. ptk-k. 1994, liite IX-A 2. Muut allekirjoittajat olivat rehtori Kyllikki Tiensuu, pastori Hillevi Seppä ja pääsihteeri Ossi Haaramäki.

66 Marjatta Lehtisen suullinen tiedonanto 30.9.2012.

67 S. Eskola 2012a, 81; Keitanen 2012, 37-38.

68 Kirk.kok. kptk-s. 1994, 19 \$.

69 Sorsa 2010, 237.

$70 \quad$ Kirk.kok. kptk-s. 1993, 27 \$; Kirk.kok. kptk-s. 1994, 19 \$, 21 \$.

71 Kirk.kok. ptk-s. 1994, $29 \$$.

72 KKHA KKA Cc syksy $1994 \$ 29$.

73 Kirk.kok. kptk-s. 1995, 47 §.

74 Kirk.kok. ptk-k. 1993, liite VII 2, 26.

75 Tuomiokapitulikomitean mietintö 1994, 256-257.

76 Kirk.kok. kptk-k. 1999, $33 \$$.

77 Kirk.kok. ptk-s. 1995, 5\$, 45 \$, liite III 6 \& VI-B 4.

78 Kirk.kok. ptk-k. 1996, liite III 2.

79 Kirk.kok. ptk-s. 1996, liite VI-D 9.

80 Kirk.kok. kptk-k. 1996, 46 \$; Kirk.kok. ptk-k. 1996, liite X 5; S. Eskola 2012a, 85.

81 Laki saamelaiskäräjistä (17.7.1995/974).

82 Kirk.kok. ptk-s. 1996, liite VI-D 9.

83 Kirk.kok. kptk-s. 1996,19\$.

84 Kirk.kok. ptk-s. 1998, liite IV 9.

85 Kirk.kok. ptk-k. 1999, liite VIII-A 1.

86 Kirk.kok. kptk-k. 1999, 40 \$, 62 \$.

87 Kirk.kok. kptk-k. 1999, 40 \$.

88 Kirk.kok. kptk-k. 1999, 62 §.

89 Kirk.kok. ptk-k. 1999, liite VIII-A 1.

90 Kirk.kok. ptk-k. 1995, liite VIII 6.

91 Kirk.kok. kptk-s. 1995, 16 \$.

92 Kirk.kok. ptk-s. 1993, liite IV 8 \& VII-A 5.

93 Hidén 2006, 94

94 Kirk.kok. kptk-s. 1993, 137; Kirk.kok. ptk-s. 1993, liite IV 8. Ks. Hidén 2006, 98.

95 Kirk.kok. kptk-s. 1993,7\$.

96 Kirk.kok. ptk-s. 1993, liite IV 8. 
97 Kirk.kok. kptk-k. 1992,5-6 §.

98 Kirk.kok. kptk-k. 1996, 5-6\$.

99 Kirk.kok. kptk-k. 1992, 42 \$; Kmaa 8.5.1992 Ensimmäinen sd-edustaja kirkkohallitukseen (Tuomo Korteniemi).

100 Rainerma 2010, 46

101 Raija Sollamon sähköpostihaastattelu 18.9.2013.

102 S. Eskola 2012a, 143-144.

103 S. Eskola 2012a, 144; Raija Sollamon sähköpostihaastattelu 18.9.2013. Kaisu Rantala on myös muistellut äänestyksen tasaisuutta. Kaisu Rantalan puhelinhaastattelu 16.9.2013. Valitsijamiesten pöytäkirjassa todetaan sen sijaan vain lakonisesti, että Kortekangas valittiin puheenjohtajaksi. KKHA KKA Valiokuntien ptk:t 1996-99 Valitsijamiehet ptk. 6.5.1996 klo 16.30 § 2. 104 Raija Sollamon sähköpostihaastattelu 18.9.2013.

105 Ollila 2007, 55; Helander \& Pekonen 2007, 107-110.

106 Kirk.kok. kptk-k. 1996, 72 \$.

107 Kirk.kok. ptk-k. 1996,72 \$, 74\$.

108 Kirk.kok. kptk-k. 1996,72\$,74\$.

109 Kirk.kok. kptk-s. 1997, 43 \$.

110 S. Eskola 2012a, 97.

111 Kirk.kok. kptk-s. 1997, 43 \$.

112 Kirk.kok. ptk-s. 1993, liite IV 8.

113 SEK 1992-95, 228; Kangas 2003, 13.

114 Kirk.kok. kptk-k. 1992, 51 \$.

115 Kirk.kok. ptk-s. 1992, liite X-E 8.

116 Kirk.kok. kptk-s. 1993, 21 \$.

117 Kirk.kok. kptk-k. 1993, $45 \$$.

118 Kirk.kok. kptk-s. 1992,19\$.

119 Pernaa 2007, 100; Karisto \& Takala \& Haapola 2009, 330.

120 Kirk.kok. kptk-k. 1993, 3; Meinander 1999, 491-492.

121 Kirk.kok. kptk-k. 1993, 6 \$.

122 Kirk.kok. kptk-k. 1993, 66 \$; Kirk.kok. ptk-k. 1993, liite X-D 7.

123 Kirk.kok. kptk-k. 1993, 66 \$.

124 Kirk.kok. kptk-s. 1993, 21 \$; Kirk.kok. kptk-s. 1994, 38 \$; Kirk.kok. kptk-s. 1995, $21 \S$.

125 Kirk.kok. ptk-s. 1994, liite X-D 10.

126 Kirk.kok. kptk-k. 1993, $6 \$, 66 \S$.

127 SEK 1992-95, 245.

128 Kirk.kok. ptk-k. 1993, 67 \$, liite VIII 1 \& X-D 8.

129 Kirk.kok. ptk-s. 1993, liite VII-D 9.

130 SEK 1992-95, 246; J. Lampinen 2008, 19.

131 Länsi-Suomi 30.5.1993 Iskuja kirkon taloudelle (pääk.); Demari 31.5.1993 Kirkko, verot ja valtio (pääk.).

132 Kirk.kok. kptk-s. 1996, 17 §.

133 Kirkkohallitus 1993, 17; SEK 1992-95, 246; J. Lampinen 2008, 19-20.

134 Autio 1997, 199.

135 J. Lampinen 2008, 20.

136 SEK 1992-95, 35.

137 SEK 1992-95, 228

138 SEK 1992-95, 227-228, 249.

139 SEK 1992-95, 231, 237, 239.

140 SEK 1992-95, 229.

141 Kirk.kok. kptk-k. 1995, 55 \$; Kirk.kok. ptk-k. 1995, liite IX-C 5

142 Kirk.kok. kptk-s. 1997, 41 §.

143 Kirk.kok. kptk-k. 1995, 55 \$.

144 Kirk.kok. ptk-k. 1999, liite IV 2.

145 Kirk.kok. kptk-s. 1999, 35 \$.

146 Valtion ja kirkon taloudelliset suhteet 1997, 96; SEK 1996-99, 220-221.

147 Kirk.kok. kptk-s. 1997, 22 \$, $64 \$$.

148 Kirk.kok. ptk-s. 1997, liite X-C 9.

149 Kirk.kok. ptk-s. 1998, liite X-C 10; SEK 1996-99, 222; J. Lampinen 2008, 2930, 36-37, 41-45.

150 Kirk.kok. ptk-s. 1999, liite VIII-E 7.

151 SEK 1996-99, 225.

152 Kirk.kok. ptk-s. 1992, liite X-E 8.

153 Kirk.kok. kptk-s. 1992, $31 \S$. Rajaseututyön alkuvaiheen yhteydestä maanpuolustukseen Mustakallio 2010, 226, 236-240.

154 Kirk.kok. ptk-k. 1993, liite VIII 2 \& 3 \& IX 6; Kirk.kok. ptk-k. 1994, liite VII 2; Kirk.kok. ptk-k. 1996, liite VIII 6; Kirk.kok. ptk-k. 1997, liite IV 3.

155 Kirk.kok. ptk-k. 1993, 65\$, liite X-D 6.
156 Kirk.kok. ptk-k. 1995, 55 \$, liite IX-C 5; Mustakallio 2010, 246.

157 Kirk.kok. kptk-k. 1997, 18 \$; Kirk.kok. ptk-k. 1997, liite VI-E 5.

158 Kirk.kok. kptk-s. 1997, 41 \$.

159 Kirk.kok. kptk-s. 1992, $40 \$$.

160 Nousiainen 2006, 300.

161 Kirk.kok. kptk-s. 1992, 47 \$; Kirk.kok. ptk-s. 1992, liite X-E 10.

162 Kirk.kok. ptk-s. 1997, 82 \$, liite X-C 10.

163 SEK 1992-95, 249, 258.

164 Kirk.kok. ptk-k. 1993, liite VIII 7 .

165 Kirk.kok. ptk-k. 1993, liite IX 12; Kirk.kok. ptk-k. 1994, liite VIII 8.

166 Kirk.kok. kptk-k. 1993, 21 §.

167 Kirk.kok. kptk-k. 1993, 55 \$; Kirk.kok. ptk-k. 1993, liite IX 8.

168 Kirk.kok. kptk-s. 1994, 18 \$.

169 SEK 1992-95, 77.

170 Kirk.kok. ptk-s. 1994, liite X-D 10 a.

171 Kirk.kok. kptk-s. 1994, 38 \$.

172 Kirk.kok. ptk-s. 1997, liite X-C 7; SEK 1992-95, 242-243.

173 Kirk.kok. ptk-k. 1993, liite VII 2, 31.

174 Kirk.kok. ptk-s. 1992, liite X-E 4.

175 SEK 1992-95, 59.

176 Kirk.kok. ptk-k. 1996, 60 \$, liite XI-D 2; Kirk.kok. ptk-s. 1997, liite III 11

177 Kirk.kok. ptk-k. 1998, liite VII-B 1.

178 SEK 1996-99, 219-220.

179 Nousiainen 2006, 305; Tiitinen 2008, 69.

180 Kirk.kok. kptk-s. 1996, 21 \$.

181 Kirk.kok. kptk-k. 1992,34§.

182 SEK 1992-95, 152-154.

183 Kirk.kok. kptk-s. 1994, 18 \&; Kirk.kok. ptk-s. 1997, liite X-C 7; SEK 1988-91, 116-117; SEK 1996-99, 234-235.

184 SEK 1992-95, 52, 59, 67, 70; Niemelä 2003b, 140-143.

185 Kirk.kok. kptk-k. 1997, 1 \$, 44 §.

186 Kirk.kok. kptk-s. 1993, 48 \$; Kirk.kok. ptk-s. 1993, liite VII-E 7; Kirk.kok. kptk-k. 1994, 18 \$; Kirk.kok. ptk-k. 1994, liite VII 4 \& IX-D 3.

187 Kirk.kok. kptk-k. 1997, 44 §.

188 Kirk.kok. kptk-k. 1994, 12 \$, 49\$.

189 Kirk.kok. ptk-s. 1993, liite VII-C 1; Kirk.kok. ptk-s. 1995, liite VI-E 10.

190 Kirk.kok. kptk-s. 1993, 23 \$.

191 SEK 1992-95, 191.

192 Kirk.kok. kptk-s. 1993, 21 \$; Kirk.kok. kptk-s. 1994, 18 \$; Kirk.kok. ptk-s. 1994, liite VII 2.

193 Kirk.kok. ptk-s. 1999, 35 \$, liite VIII-E 7.

194 Kirk.kok. ptk-s. 1999, 35 \$, liite VIII-E 7; SEK 1996-99, 18-19; Lampela-Kivistö 2003, 135 .

195 Kirk.kok. ptk-s. 1992, liite X-D 1; Kirk.kok. ptk-s. 1997, liite X-E 9.

196 Kirk.kok. ptk-s. 1993, liite VII-C 1; Kirk.kok. ptk-s. 1998, liite X-E 11; Kirk.kok. ptk-s. 1997, liite X-E 19.

197 Kirk.kok. ptk-s. 1996, liite VI-D 7.

198 Kirk.kok. ptk-s. 1994, liite X-E 5; Kirk.kok. kptk-s. 1995, 14 \$; Kirk.kok. ptk-s. 1995, liite VI-E 10.

199 Kirk.kok. kptk-s. 1996, 16 \$.

200 Kirk.kok. kptk-s. 1992, 19 \$; Kirk.kok. ptk-s. 1992, liite X-E 4.

201 Kirk.kok. ptk-s. 1992, liite X-E 8.

202 Kirk.kok. kptk-s. 1992, 31 §.

203 Kirk.kok. kptk-s. 1994, 18 \$.

204 Kirk.kok. ptk-s. 1995, liite VI-D 6; Kaleva 10.11.1995 Suomen kirkoille Internet-palvelu (Pekka Koivisto).

205 Meinander 1999, 495.

206 Kirk.kok. kptk-s. 1995, 21 \$.

207 SEK 1996-99, 163.

208 Kirk.kok. kptk-s. 1997, 41 \$; Kirk.kok. kptk-s. 1998, 38 \$; Kirk.kok. ptk-s. 1998, liite X-C 10; Kirk.kok. ptk-s. 1999, liite VIII-E 7.

209 Kirk.kok. kptk-k. 1992, 3.

210 Kmaa 31.5.1991 Presidentti Mauno Koivisto epäilee kirkon mielivän valtiosuhteesta itselleen etuja (Ritva Rasila); $A l$ 1.6.1991 Koivisto haluaa kirkon etääntyvän valtiosta; Kmaa 4.6.1991 Arkkipiispa ymmällään presidentin mielipiteistä: Kirkolla velvollisuus seisoa ihmisten rinnalla; Haapakoski 2002, 74-82.

211 Kirk.kok. ptk-s. 1995, liite VI-E 10; Brohed 2005, 279.

212 HS 31.8.1995 Kompromissi "Ruotsin kirkosta" (pääk.). 
213 HS 30.8.1995 Voiko Suomessa eduskunta erottaa kirkon valtiosta? (Irma Stenbäck).

214 SEK 1992-95, 40; Knen 30.8.1995 Ruotsin kirkko "suomalaisaikaan" (pääk.); Leino 2002, 54

215 Huovinen 1999, 37; Ripatti 1999, 109-110; Sorsa 2010, 238.

216 Kirk.kok. kptk-s. 1994, 6 \$; Kirk.kok. kptk-k. 1995, 33 \$; Kirk.kok. kptk-s. 1995, $8 \S$.

217 Valtion ja kirkon taloudelliset suhteet 1997, 72.

218 Tuomiokapitulikomitean mietintö 1994, 255; Ossi Haaramäen haastattelu 28.10.2010; Matti Sihvosen puhelinhaastattelu 16.12.2013.

219 Kirk.kok. kptk-k. 1994, 41 \$; Kirk.kok. kptk-s. 1994, 6 \$; Elonheimo 2006, 151

220 Tuomiokapitulikomitean mietintö 1994, 46, 206.

221 Kirk.kok. kptk-k. 1994, 41 \$; Kirk.kok. kptk-s. 1994, 6 \$; Kirk.kok. ptk-k. 1995, liite IX-B 1, 8-9; Huovinen 1999, 40; Ripatti 1999, 109-110; Sorsa 2010, 237, 241.

222 Kirk.kok. kptk-k. 1994, 41 §.

223 Kirk.kok. kptk-k. 1994, 41 \$; Kirk.kok. kptk-s. 1994, 6 \$; Huovinen 1999, 40; Sorsa 2010, 258-259.

224 Kirk.kok. kptk-k. 1994, 41 \$; Kirk.kok. kptk-s. 1994, 6 \$.

225 HS 18.7.1994 Valtiokirkollisuus nousee Suomessa (Paavo Tukkimäki).

226 Tuomiokapitulikomitean mietintö 1994, 135; Kirk.kok. ptk-k. 1995, liite IX-B 1,5 .

227 Kirk.kok. ptk-s. 1994, liite X-C 1.

228 Kirk.kok. kptk-k. 1995, 33 \$.

229 Tuomiokapitulikomitean mietintö 1994, 136; Kirk.kok. ptk-k. 1995, liite IX-B 1,6 .

230 Kirk.kok. kptk-k. 1995, 33 \$.

231 Kirk.kok. kptk-k. 1994, 41 \$; Kirk.kok. kptk-k. 1995, 33 \$; Kirk.kok. kptk-s. 1995, liite, 3; Kmaa 18.11.1994 Kirkolliskokous: Kapitulien asemasta käynnistetään neuvottelut valtion kanssa (Ritva Rasila).

232 Seppo 1995, 445-446; Elonheimo 2006, 153.

233 Kirk.kok. ptk-s. 1994, liite II 2 \& IV 2.

234 Sorsa 2010, 241.

235 Kirk.kok. kptk-k. 1994, 41 \$; Kirk.kok. kptk-s. 1994, 6 \$; Kirk.kok. kptk-k. 1995, 33 \$; S. Eskola 2012a, 40.

236 Kirk.kok. kptk-s. 1994, 6 \$; Ripatti 1999, 110-111.

237 KKHA KKA Cib 2 ptk. 5.5.1994 klo 10.10 \$ 3, 12.9.1994 \$2, 11.11.1994 \$3, 30.11.1994§1-4.

238 Asiantuntijasihteerinä toimi ensin apulaisprofessori Eeva-Kaarina Nurmiranta ja sitten Turun arkkihiippakunnan lakimiesasessori Matti Mäkinen. KKHA KKA Cij 1 ptk. 7.11.1994 $\$ 13$. Valiokunta hankki asiantuntijalausunnot esimerkiksi professori Juha Sepolta, professori Markku Temmekseltä ja alivaltiosihteeri Juhani Kivelältä. KKHA KKA Cij 1 ptk. 8.11.1994\$17, ptk. 9.11.1994\$22.

239 Kirk.kok. ptk-k. 1995, liite IX-B 1, 11-12, 17

240 Ripatti 1999, 112.

241 Kirk.kok. ptk-s. 1994, liite II 2; Kirk.kok. ptk-k. 1995, liite IX-B 1, 11, 17, 29-30.

242 Tuomiokapitulikomitean mietintö 1994, 46; Kirk.kok. kptk-k. 1995, $33 \$$.

243 Kirk.kok. ptk-k. 1995, liite IX-B 1, 6-7, 10-11, 17.

244 Sorsa 2010, 239.

245 Kirk.kok. kptk-k. 1995, 33 \$.

246 Kirk.kok. ptk-k. 1995, liite IX-B 1, 7-8; Ripatti 1999, 111.

247 Kirk.kok. kptk-k. 1995, 33 \$; Kirk.kok. ptk-k. 1995, liite IX-B 1, 7-8; Sipponen 1996, 773; Ripatti 1999, 114.

248 Ripatti 1999, 113.

249 Kirk.kok. kptk-k. 1995, $33 \$$.

250 Kirk.kok. ptk-s. 1994, liite II 2; Kirk.kok. kptk-k. 1995, 33 §.

251 Kirk.kok. kptk-k. 1995, 33 \$.

252 Kirk.kok. kptk-k. 1995, $33 \$$.

253 Kirk.kok. kptk-s. 1995, 19 \$.

254 Kirk.kok. kptk-s. 1995, 19 \$; Tiihonen 1996, 584-585.

255 Kirk.kok. kptk-s. 1995, 19 \$.

256 Kirk.kok. kptk-s. 1994, 6 \$; Kirk.kok. ptk-s. 1994, liite II 2; Kirk.kok. kptk-k. $1995,33 \$$.

257 Kirk.kok. kptk-s. 1995, 8 \$; Kirk.kok. ptk-s. 1995, liite VI-C 2, 6-7.

258 Kirk.kok. kptk-s. 1995, 19 \$.

259 Kirk.kok. kptk-s. 1995, 8 \$, 33\$, $46 \S$.

260 Kirk.kok. kptk-s. 1995, 46 \$.

261 Kirk.kok. kptk-k. 1998, 56 \$; Kirk.kok. ptk-k. 1998, liite V 3.

262 Kirk.kok. ptk-s. 1998, liite IV 12; Kirk.kok. ptk-k. 1999, VIII-E 2.
263 Kirk.kok. kptk-k. 1999, 41 \$; Sorsa 2010, 260.

264 Kirk.kok. kptk-k. 1999, 43 \$; Sorsa 2010, 260.

265 SEK 1992-95, 19; Helander 2002, 130-131; Ripatti 2004, 172; Mustakallio 2012b, 557-558; Malkavaara \& Mustakallio 2012b, 572.

266 Al 9.3.1999 Piispojen talousteeseissä puurot ja vellit sekaisin (Pirjo Silveri \& Sami Suojanen); Il 9.3.1999 Piispat yhteiskuntapoliitikkoina (Jarmo Tarkki); Kauppalehti 11.3.1999 Kolumni: Piispatkin heräsivät (Juha Ruonala); SK 12.3.1999 Pääkirjoitus; Talouselämä 12.3.1999 Kolumni: Piispat vaalityössä (Eero Tuomainen); ESS 13.3.1999 Esalainen: Piispojen tilkkutäkki (Heikki Hakala); Il 13.3.1999 Piispat ja politiikka (pääk.); TS 24.3.1999 Piispoilla vasemmistoliiton talousohjelma (Matti Virén); Kaleva 27.3.1999 Pulssi: Kaipaako kirkko uskonpuhdistusta (Tuulikki Ukkola); HS 1.4.1999 Kohti yhteistä hyvää, piispat (Ahti Hirvonen); Kmaa 16.4.1999 Piispojen paperille pyyhkeitä (Olli Seppälä), Suomen Yrittäjien toimitusjohtaja Risto Suominen:"Piispojen kannanotto on asenteellisesti kirjoitettu" (Olli Seppälä); SK 30.7.1999 Piispat unohtivat ja erehtyivät (Risto Harisalo \& Ensio Miettinen).

267 SEK 1980-83, 40.

268 Kirk.kok. ptk-s. 1994, liite III 10.

269 Kirk.kok. kptk-s. 1994, 22 \$.

270 KKHA KKA Cc syksy 1994 kulttuuriministeri Tytti Isohookana-Asunmaan puheenvuoro kirkolliskokouksessa 9.11.1994; SS 11.11.1994 Arkkipiispa Vikström: Väestökirjanpito ei ole kirkolle periaatekysymys.

271 Kirk.kok. kptk-s. 1994, 22 \$.

272 Kirk.kok. kptk-s. 1994, 22 §.

273 Kirk.kok. ptk-s. 1994, liite X-B 3

274 Kirk.kok. ptk-s. 1994, liite X-B 3, liite 1.

275 Kmaa 18.11.1994 Kirkolliskokous: Kapitulien asemasta käynnistetään neuvottelut valtion kanssa (Ritva Rasila).

276 Kirk.kok. ptk-k. 1997, liite II 3 \& III 4 \& VI-C 2; SEK 1996-99, 188.

277 Sorsa 2010, 257.

278 Kirk.kok. ptk-k. 1992, liite III 2; Kuusela 2000, 61; Jalava \& Simola \& Varjo 2012, 88-90; S. Ahonen 2012, 164-167; Klemelä \& Vanttaja 2012, 191.

279 Länsi-Savo 23.1.1992 Uskonnonopetus arvoonsa (Kalevi Toiviainen); Hämeen Sanomat 1.2.1992 Paavo Kortekangas Tammelassa: Uskonnonopetuksen valinnaisuus on epäviisasta; HS 7.2.1992 Piispa Huovinen säilyttäisi uskonnon kouluopetuksessa; Kaleva 17.2.1992 Piispa Eero Huovinen: Koulujen uskonnon opetuksen kuuluu olla tunnustuksellista; Ksml 10.3.1992 Piispa Yrjö Sariola: Toisten armoilla vai omilla arvoilla; HS 18.3.1992 Arkkipiispan mielestä uskontotunteja pitäisi päinvastoin lisätä.

280 IS 10.2.1992 Yleissivistystä (pääk.); Ilkka 11.3.1992 Koulun arvomaailma heilahtamassa kauas oikealle (pääk.); Al 20.3.1992 Uskontoja lyhyesti (pääk.); SkK 1.4.1992 Uskonnonopetuksen merkitys (pääk.); Liitto 7.5.1992 Uskonnonopetusta ei pidä supistaa (pääk.).

281 Kirk.kok. kptk-k. 1992, 4.

282 Kirk.kok. kptk-k. 1992, 18 \&; Kuusela 2000, 63-64; Sorsa 2010, 225-226; HS 1.3.1992 Uskonto ja katsomustieto - tulevaisuuden oppiaine (Gustav Björkstrand), 11.3.1992 Etiikka osa koulun uskontoa (Olavi Aula), 22.3.1992 Eettinen kasvatus yhtenäiseksi (Jukka O. Mattila); Hbl 19.7.1992 Debatt i Hbl: Etikundervisningen (Gustav Björkstrand).

283 Kirk.kok. kptk-k. 1992, 18 §.

284 SS 7.5.1992 Isohookana-Asunmaa ehdottaa ekumeenista uskonnonopetusta (Pauli Juusela); Kaleva 8.5.1992 Kirkko jatkaa kamppailua lukion uskontotuntien puolesta (Pekka Koivisto); Kmaa 8.5.1992 Uskontoa opetettava vähintään kolme kurssia (Tuomo Korteniemi); Keitanen 2012, 28.

285 Kuusela 2000, 68.

286 Kirk.kok. kptk-k. 1992, 44 \$; Kirk.kok. ptk-k. 1992, liite VIII-A 1 a; Kuusela 2000, 65, 67; Sorsa 2010, 224.

287 SEK 1992-95, 297; Kunsela 2000, 69-70.

288 Kirk.kok. ptk-k. 1992, liite VII 5.

289 Kirk.kok. kptk-s. 1992, 25 \$; Kirk.kok. ptk-s. 1992, liite X-F 8.

290 Kirk.kok. kptk-s. 1992, 25 \$; Kirk.kok. ptk-s. 1992, liite X-F 8 a.

291 SEK 1992-95, 299-300.

292 Jalava \& Simola \& Varjo 2012, 92.

293 Kirk.kok. kptk-s. 1992, 19 \$; Kirk.kok. ptk-s. 1992, liite VIII 1.

294 Reijonen 1992, 73; Sorsa 2010, 227.

295 Kirk.kok. ptk-s. 1992, liite VI 3; Sorsa 2010, 228

296 Seppo 2003a, 469-470; Seppo 2003b, 53-54; Sorsa 2010, 229-230.

297 Kirk.kok.ptk-s. 1992,43\$, liiteX-B 2; Seppo 1993,199-205; Sorsa 2010, 232-233. 298 Kunttu 2007,302. 
299 Kirk.kok. kptk-s. 1992, 12 \$.

300 Kirk.kok. ptk-s. 1992, $43 \$$, liite X-B 2.

301 Kirk.kok. ptk-k. 1996, 65 \$, liite XI-B 1; Kirk.kok. ptk-s. 1997, liite X-D 3

302 Kunttu 2007,302.

303 Seppo 2003b, 55; Sorsa 2010, 235-236.

304 Kirk.kok. ptk-k. 1996, 65 \$, liite XI-B 1; Seppo 2002, 101; Seppo 2003b, 56-57; Sorsa 2010, 251-252.

305 KKHA KKA Cc kevät 1996 kansliapäällikkö Vilho Hirven juhlapuhe kirkolliskokouksen kevätistunnossa 1996; Kirk.kok. kptk-k. 1996, liite.

306 Kirk.kok. kptk-s. 1997, 21 \$, 59 \$; Kirk.kok. ptk-s. 1997, liite X-D 3; Seppo 2003b, 57; Sorsa 2010, 253-254.

307 Seppo 2003b, 57; Sorsa 2010, 254-255.

308 SEK 1988-91, 17.

309 Kirk.kok. kptk-k. 1994, 2-3.

310 Ilkka 3.5.1994 Arkkipiispa tukisti kirkon punaisia lehtiä (pääk.); $\mathrm{Hbl}$ 4.5.1994 Celibat utan snedsprång (ledare); HS 4.5.1994 Näkökulma: Kirkon poliittinen neitseys (Martti Lindqvist); Iisalmen Sanomat 4.5.1994 Puoluepolitiikka ei kirkon rooliin sovi (pääk.); Ksml 4.5.1994 Kirkko ja politiikka pidettävä erillään (pääk.); Kymen Sanomat 4.5.1994 (pääk.); LK 4.5.1994 Uskonto politiikan välineenä (pääk.); TS 4.5.1994 Arkkipiispan rajanveto (pääk.); Hbl 8.5.1994 Följa John - men hur? (ledare); HS 8.5.1994 Kolumni: Hermoherkkyyttä keskustassa (Janne Virkkunen).

311 KJK 20.4.1994 Kaikkien iltalypsyjen äiti (Seppo Simola, pääk.), 27.4.1994 Pääkirjoituksen maaseutukannanotto kimmastutti; Ksml 27.4.1994 Pääministeri ripittää Kotimaa-lehteä (Lasse Kangas); Il 28.4.1994 Kirkko etääntynyt porvareista (pääk.); Ksml 30.4.1994 Kirkon julkaisu ei voi olla puoluelehti (pääk.); KJK 11.5.1994 Journalistin selibaatti (Seppo Simola, pääk.).

312 Kirk.kok. ptk-s. 1999, 62 \$; SEK 1996-99, 202.

313 Kirk.kok. ptk-k. 1993, liite X-B 1.

314 Kirk.kok. ptk-k. 1993, 69\$, 71 \$.

315 Kirk.kok. kptk-k. 1993, 71 \$.

316 Vp.ptk. 1998, 79/8.6.1998, 2950.

$317 A l$ 11.6.1998 Miten ihminen voisi pilkata Jumalaa? (pääk.); ESS 11.6.1998 Yhden jumalan erityisasema (pääk.); Hämeen Sanomat 11.6.1998 Jumalanpilkka esillä toistuvasti (pääk.); SS 11.6.1998 Kiistelty pykälä elää sitkeästi (pääk.); TS 11.6.1998 Vanhoillisuutta moraaliasenteissa (pääk.); Vasabladet 13.6.1998 Behöver Gud skydd av lagen? (Birger Enges, ledare); LänsiSavo 14.6.1998 Eduskunta jumalisempi kuin kirkko (pääk.).

318 Kirk.kok. ptk-k. 1991, liite VIII 9; Kmaa 14.5.1991 Kirkkolaki uudistuu aloitteita jo uudesta (pääk.).

319 Kirk.kok. ptk-k. 1992, liite VII 7.

320 Kirk.kok. ptk-k. 1992, liite VII 7.

321 Savolainen 1996, 694; Sipponen 1996, 747, 787-788; Autio 1997, 23; Haveri 2008, 125, 128-129.

322 Sipponen 1996, 793-794, 796.

323 Kirkon suunta 2000 1992, 18-19.

324 Kettunen \& Jalava \& Simola \& Varjo 2012, 54-55.

325 Kirk.kok. kptk-k. 1992, 45 \$; Kirk.kok. ptk-k. 1992, liite VIII-C 5

326 Kirk.kok. kptk-k. 1992, $60 \$$.

327 Kirk.kok. ptk-k. 1992, 60 §, 63 §. Komitea kutsui sivutoimiseksi sihteerikseen hallintojohtaja Ilkka Holopaisen. Kirk.kok. ptk-k. 1993, liite VII 2, 2.

328 Kirkko 2000 1986, 7-8, 67-68; Seurakunta 2000 1987, 25-28; Kirkon suunta 2000 1992, 8-15, 18-19; Kirk.kok. ptk-k. 1993, liite VII 2, 4, 10, 22; SEK 1988 $91,63$.

329 Kirk.kok. ptk-s. 1993, liite VII-F 3.

330 Kirk.kok. kptk-s. 1993, 53 \$.

331 Kirk.kok. ptk-s. 1994, liite VIII, 1. Komitean muut varsinaiset jäsenet olivat sosiaalikeskuksen johtaja Ulla-Stina Henricson, talousjohtaja Marjatta Hirvonen, TT Juha Kauppinen, rehtori Raili Kemppainen ja toimitusjohtaja Reijo Telaranta. Sihteeriksi kutsuttiin TT Harri Palmu.

332 Kirk.kok. ptk-s. 1994, liite VIII, 19.

333 Kirkko 2000 1986, 68.

334 Seurakunta $20001987,28$.

335 Kirk.kok. ptk-s. 1994, liite VIII, 27.

336 Kirk.kok. kptk-s. 1994, 13\$, 17\$.

337 Kirk.kok. ptk-k. 1993, liite VII 2, 18-19.

338 Kirk.kok. ptk-s. 1994, liite VIII, 18.

339 Kirk.kok. kptk-k. 1993, 9 \$; Kirk.kok. kptk-s. 1994, 13 \$; Kirk.kok. ptk-s. 1994, liite II 1; Kirk.kok. ptk-k. 1995, liite III 1 \& V 1.
340 Kirk.kok. kptk-s. 1995, 43 \$.

341 Kirk.kok. ptk-k. 1993, liite VII 2, 4, 24.

342 Kirk.kok. kptk-k. 1993, $9 \$$.

343 Kirk.kok. ptk-s. 1994, liite II 1.

344 Kirk.kok. kptk-s. 1994, 13 \$.

345 Kirk.kok. kptk-s. 1993, 24 \$; Kirk.kok. kptk-s. 1994, 13 \$, 17 \$; Kirk.kok. ptk-s. 1994, liite VIII, 6.

346 Petri Karttusen kirjoitus 7.3.2012. - Mikko Heikka Rovastikuntamallin uusi tuleminen. $<$ http://www.kotimaa24.fi/blogit/article/?bid=62o\&id=31558>. Katsottu 29.6.2012.

347 Kirk.kok. kptk-s. 1992, 19 \$, 31 \$.

348 Kirk.kok. ptk-k. 1993, liite VII 2, 31.

349 Kirk.kok. ptk-s. 1993, liite V 2; Kirk.kok. ptk-s. 1994, liite II 1.

350 Kirk.kok. kptk-s. 1993, 24 \$.

351 Kirk.kok. kptk-s. 1993, 23 \$, 41 \$; Kirk.kok. ptk-s. 1993, liite VII-F 2 a \& VIIF 3 .

352 Kirk.kok. ptk-k. 1993, liite VII 2, 4.

353 Kirk.kok. kptk-k. 1993, 9\$; Kirk.kok. kptk-k. 1996, 14 \$.

354 Kirk.kok. kptk-k. 1993, $9 \$$.

355 Kirk.kok. ptk-k. 1993, liite IX 3 \& X-E 1.

356 Kirk.kok. kptk-k. 1993, 68 \$; Kirk.kok. ptk-k. 1997,78 \$, liite VI-A 1 \& 1 a \& 1 b.

357 Kirk.kok. ptk-s. 1999, liite VIII-D 5, 9.

358 Kirk.kok. kptk-s. 1994, 13\$, 17\$.

359 Kirk.kok. kptk-s. 1999, 8 \$; Kirk.kok. ptk-s. 1999, liite IV 11, 86-87.

360 Kirk.kok. kptk-k. 1996, 14 \$; Kirk.kok. kptk-k. 1997, 64 §.

361 Kirk.kok. kptk-k. 1996, $14 \$$.

362 Kirk.kok. kptk-k. 1993, 41 §.

363 Kirk.kok. ptk-k. 1993, liite VII 1, 16, 41, 78, 81; Pirinen 1990, 59, 62-63.

364 Kirk.kok. kptk-k. 1993, 41 §.

365 Kirk.kok. kptk-k. 1993, $41 \S$.

366 Kirk.kok. kptk-k. 1993, $41 \S$.

367 Kirk.kok. ptk-k. 1993, liite II 1.

368 Kirk.kok. kptk-k. 1993, $41 \S$.

369 Kirk.kok. ptk-s. 1994, 24 \$, 30 \$, liite X-A 7.

370 Kirk.kok. ptk-k. 1993, liite II 1 \& IV 2.

371 Kirk.kok. ptk-k. 1993, liite VII 1, 41.

372 Kirk.kok. ptk-s. 1994, $24 \$, 30$ \$, liite X-A 7.

373 Kirk.kok. ptk-s. 1994, liite VIII, 18-19.

374 Kirk.kok. kptk-s. 1994, 13\$, 17 §.

375 Kirk.kok. kptk-k. 1997, 20 \$; Kirk.kok. ptk-k. 1997, liite IV 5.

376 Kirk.kok. kptk-k. 1997, 20 \$.

377 Kirk.kok. kptk-s. 1997, 45 \$; Kirk.kok. ptk-s. 1997, liite X-E 17.

378 Kirk.kok. ptk-s. 1999, liite IV 11, 31.

379 Kirk.kok. ptk-s. 1999, liite VIII-D 5, 4.

380 Kirk.kok. kptk-y. 2000, 8 \$.

381 Kirk.kok. kptk-y. 2000, 11 §.

382 KKHA KKA Cc ylimääräinen istunto $2000 \$ 11$.

383 Kirk.kok. ptk-k. 1992, liite VII 7.

384 Kirk.kok. kptk-k. 1995, 36 \$.

385 Kirk.kok. ptk-k. 1992, liite V 1.

386 Esim. Kirk.kok. kptk-k. 1995, 36 \$.

387 Kirk.kok. ptk-k. 1995, liite V 5.

388 Kirk.kok. kptk-k. 1995, 36 \$.

389 Kirk.kok. kptk-k. 1995, 36 \$.

390 Kirk.kok. kptk-k. 1995, 36 \$; Paarma 2001, 12; Kansanaho 2002, 34; Mustakallio 2012b, 556 .

391 Kirk.kok. kptk-k. 1995, 36 \$.

392 Piisp.kok. ptk-s. 1995, 6 \$, 33 §; S. Eskola 2012a, 64.

393 Kirk.kok. kptk-k. 1995, 36 \$; Piisp.kok. ptk-s. 1995, 6 §.

394 Kirk.kok. ptk-s. 1995, liite II 2.

395 Kirk.kok. ptk-k. 1980, liite V 2

396 Kirk.kok. kptk-s. 1995, 35 §.

397 Kirk.kok. kptk-k. 1995, 36 \$.

398 Kirk.kok. kptk-s. 1995, 35 \$; Kirk.kok. ptk-s. 1995, liite VI-C 3; S. Eskola 2012a, 63-65.

399 Kirk.kok. ptk-s. 1995, 32 §.

400 Kirk.kok. ptk-s. 1995, $36 \$$.

401 Kirk.kok. ptk-k. 1996, liite VIII 10.

402 Kirk.kok. kptk-s. 1995, 35 §. 
403 KKHA KKA Cc syksy $1995 \$ 35$.

404 Kirk.kok. kptk-k. 1996,11\$, $19 \$$.

405 Kirk.kok. ptk-s. 1996, $25 \$$.

406 Kirk.kok. kptk-k.1996,19 \$; Kirk.kok. kptk-s. 1996,12 \$; Kirk.kok. ptk-s. 1996, liite VI-B 1.

407 Hiippakuntahallintokomitean mietintö 1998, 3-4, 63, 80, 126, 130, 132, 159; SEK 1996-99, 192.

408 Kirk.kok. kptk-k. 1998, 37 \$.

409 Kirk.kok. kptk-s. 1998, 24 §.

410 Kirk.kok. ptk-k. 1999, 33 \$, liite VIII-E 1; Kirk.kok. ptk-s. 1999, liite VIII-D 4; Kirk.kok. ptk-y. 2000,7\$.

$411 H S$ 15.5.1995 Ekumenia etenee (pääk.).

412 Kirk.kok. ptk-s. 1992, 40 \$, liite X-F 11.

413 Kirk.kok. kptk-k. 1994, 32 \$; Kirk.kok. ptk-k. 1994, liite VIII 6; Kirk.kok. ptkk. 1996, liite X 4; Kirk.kok. kptk-s. 1996,33 \$; Kirk.kok. ptk-s. 1996, liite VI-D 14; Kirk.kok. kptk-y. 2000, 11 §.

414 Kirk.kok. ptk-k. 1995, liite II 1; Grönvik 1994, 230-232, 235-236; Toiviainen 2004, 120.

415 Tiilikainen 2007,166

416 Kirk.kok. kptk-k. 1995, 31 §.

417 Ylioppilaslehti 13.4.1995 Iso gee: Ari Tammi ja kirkkojen kiista (Jarno Forssell); Tuomala 2013, 57.

418 Kirk.kok. kptk-k. 1995, 28 \$, 31 \$; Toiviainen 2004, 121; Tuomala 2013, 55-56, 58.

419 Kirk.kok. kptk-k. 1995, 31 §.

420 Kirk.kok. kptk-k. 1995, 28 \$.

421 Kirk.kok. kptk-k. 1995, 31 §.

422 Kmaa 12.5.1995 Porvoon julkilausuma ja kirkon rehellisyys (Jaakko Voipio).

423 Kirk.kok. ptk-k. 1995, liite V 2; Toiviainen 2004, 121.

424 Kirk.kok. ptk-s. 1999, 62 \$, liite VIII-B 7, 15-16; Sorsa 2010, 271.

425 Kirk.kok. kptk-k. 1995, 31 \$.

426 Kirk.kok. kptk-k. 1995, 31 \$; Tuomala 2013, 59-60.

427 Kirk.kok. kptk-k. 1995, 98-99.

428 Kirk.kok. kptk-s. 1992, 40 \$.

429 Kirk.kok. ptk-s. 1995, liite VI-A 1, 11-13.

430 Kirk.kok. ptk-s. 1995, liite VI-A 1, 14-15; Junttila-Rantanen 2003, 29-30.

431 Kirk.kok. ptk-s. 1995, liite VI-A 1, 15.

432 Kirk.kok. ptk-s. 1995, liite VI-A 1, 20.

433 KKHA KKA Cib 2 ptk. $30.11 .1994 \$ 6$.

434 Kirk.kok. ptk-s. 1995, 10 \$, 26 \$, 31 \$, liite VI-A 1 a.

435 Heimo Karhapää, Yrjö Koskimäki, Eeva Laato, Keijo Nissilä ja Risto Rasimus. KKHA KKA Cc syksy 1995, $31 \S$.

436 KKHA KKA Cc syksy 1995, 31 \$.

437 Leena Huiman kirjallinen tiedonanto 21.3.2014.

438 Tuomala 2013, 64-65, 69-70.

439 Junttila-Rantanen 2003, 71-72.

440 Kirk.kok. ptk-s. 1996, liite VI-C 4.

441 Kirk.kok. kptk-s. 1996, 17 \$.

442 Kirk.kok. ptk-s. 1999, liite VIII-F 1; Kirk.kok. kptk-y. 2000, 12 \$.

443 Kirk.kok. ptk-s. 1997, liite II 1, 1.

444 Kirk.kok. kptk-s. 1997, liite II 1, 6.

445 SEK 1992-95, 184-185; Kirk.kok. kptk-s. 1997, liite II 1, 1-2; Kvist 1996, 547548, 555; Sagulin 2005, 24-32; Tuomala 2013, 71

446 Kirk.kok. kptk-s. 1997, liite II 1, 16-17.

447 Kirk.kok. kptk-s. 1997, 32 \$; Tuomala 2013, 71.

448 Kirk.kok. kptk-s. 1997, 32 \$, 34 \$; Tuomala 2013, 72-74.

449 SEK 1996-99, 280.

450 Kirk.kok. kptk-s. 1997, 32 \$, 34 §; Sagulin 2005, 41-46.

451 Hentilä 2008, 151.

452 Kirk.kok. kptk-k. 1998,39 \$.

453 Kirk.kok. kptk-s. 1997, 34 \$; Sagulin 2005, 48-50, 55-56.

454 Kirk.kok. kptk-s. 1997, 32 \$.

455 Kirk.kok. kptk-s. 1997, 34 \$; Sagulin 2005, 57-77; Tuomala 2013, 77.

456 Kirk.kok. kptk-s. 1997, 34\$.

457 KKHA KKA Pvk Antti Saarelma vanhurskauttamisoppijaoston jäsenille 9.2.1998 \& 17.2.1998; Kirk.kok. ptk-k. 1998, liite VII-D 1, 6-7, 27-28.

458 Kirk.kok. ptk-k. 1998, liite VII-D 1, 28, 30.

459 Kirk.kok. ptk-k. 1998, liite VII-D 1, 37-43; Tuomala 2013, 82. 460 Kirk.kok. kptk-k. 1998,39\$.
461 Kirk.kok. kptk-k. 1998,39 \$. Mietintöä valmistelleessa jaostossa olivat piispa Juha Pihkala (puheenjohtajana), rovasti Riitta Aaltonen, professori Seikko Eskola, kirkkoherra Heikki Hurskainen ja kirkkoherra Tapani Nuutinen. Sihteerinä oli valiokunnan sihteeri Antti Saarelma. KKHA KKA Pvk. ptk. 4.11.1997\$2.

462 Kirk.kok. kptk-k. 1998, 39 \$; Tuomala 2013, 86.

463 Kirk.kok. kptk-k. 1998,39 \$.

464 Kirk.kok. kptk-k. 1998, 1 §.

465 Kirk.kok. kptk-k. 1998, 39 \$; Tuomala 2013, 87-88.

466 Kirk.kok. kptk-s. 1997, $32 \$$.

467 Kirk.kok. kptk-s. 1997, 32 \$, 34 \$.

468 Kirk.kok. kptk-k. 1998,39 \$.

469 Kirk.kok. kptk-k. 1998,39\$.

470 Kirk.kok. ptk-k. 1998, 41 §.

471 Kmaa 15.5.1998 Kirkolliskokous hyväksyi historiallisen sovintoasiakirjan (Juliska Lehtinen).

472 Tuomala 2013, 85-86.

473 Kmaa 15.5.1998 Kirkolliskokous hyväksyi historiallisen sovintoasiakirjan (Juliska Lehtinen); Toiviainen 2004, 123-124.

474 Kirk.kok. kptk-k. 1998,39\$.

475 Tuomala $2013,89$.

476 Kirk.kok. ptk-k. 1998, liite VII-D 1,38-39; Perusta 1/1998 Saksan evankeliset yliopistoteologit torjuvat Yhteisen julistuksen vanhurskauttamisesta.

477 Viidesläisyyden määrittelystä ja ylirajaisesta luonteesta ks. Meriläinen 2013.

478 Laasonen 1998, 240.

479 Kirk.kok. kptk-k. 1998, 39 §.

480 Malkavaara 2011,399.

481 SEK 1992-95, 250; SEK 1996-99, 224.

482 YKV 1997, 64-65; R. A. Ahonen 1991, 8-14; 96-98, 103-110; Kopperi 1994, 263.

483 Kirk.kok. ptk-k. 1994, liite II 1; Minkkinen 2006, 78.

484 Kirkko 2000 1986, 71; Seurakunta 2000 1987, 23.

485 Kirk.kok. ptk-k. 1994, liite II 1; Minkkinen 2006, 78-79.

486 Minkkinen 2006, 83-85, 99; Saraja 2009, 46-48.

487 Kirk.kok. ptk-k. 1994, liite II 1.

488 Kirk.kok. ptk-s. 1994, liite X-B 1; Minkkinen 2006, 92.

489 Kirk.kok. ptk-s. 1994, liite X-B 1; Saraja 2009, 49.

490 Kirk.kok. kptk-s. 1994, 34 §.

491 Kirk.kok. ptk-s. 1994, 44 \$; Minkkinen 2006, 94. Komitean muut jäsenet olivat diakonissa Karin Degerman, lehtori Kerttu Inkala, tuomiorovasti Matti Järveläinen (varapuheenjohtaja), dosentti Simo Peura, hiippakuntasihteeri Reijo Takamaa ja diakoniaopiston rehtori Maija Vehviläinen. Komitea kutsui sihteerikseen kirkkoherra Timo Komulaisen.

492 Kirk.kok. kptk-s. 1994, 34 §.

493 YKV 1997, 39-42, 53-55, 96, 112.

494 KKHA KKA Ho 1 muistio 14.12.1994\$5.

495 KKHA KKA Ho 1 muistio 12.1.1995 \$ 4, muistio 23.2.1995 \$3-4.

496 KKHA KKA Ho 1 muistio 28.1.1997 §5; YKV 1997, 67-74, 91, 133; Saraja 2009, 57-59.

497 Kirk.kok. kptk-s. 1997, $38 \$, 56$ \$.

498 KKHA KKA Ho 1 muistio 29.4.1997 \$ 7; YKV 1997, 132-133.

499 YKV 1997, 77-78; SEK 1996-99, 237.

500 Kirk.kok. kptk-y. 2000, $13 \$$.

501 Kirk.kok. kptk-s. 1997, $38 \$, 56 \$$.

502 Kirk.kok. kptk-s. 1997, 38 \$; Mustakallio 2012c, 564.

503 Kirk.kok. kptk-s. 1997, 56 §.

504 Kirk.kok. ptk-k. 1999, liite III 1; Saraja 2009, 61-63.

505 Kirk.kok. ptk-k. 1999, liite III 1.

506 Kirk.kok. kptk-y. 2000, $13 \$$.

507 Kirk.kok. ptk-s. 1999, liite VIII-B 6; Saraja 2009, 56.

508 Kirk.kok. ptk-s. 1999, liite VIII-B 6; Saraja 2009, 64-65.

509 Kirk.kok. ptk-y. 2000, $22 \S$.

510 Kmaa 21.1.200o Loputonta vetkuttelua diakonian viran kehittämisessä (Jaakko Elenius, pääk.).

511 Kirk.kok. ptk-s. 1988,14\$.

512 SEK 1984-87, 71; JKJ 1992, 12; Sariola 1992, 324 \& 2000, 398-399.

513 SEK 1984-87,72, 74; Kirk.kok. ptk-s. 1988, liite VII-C 1; Sariola 1992, 324-325.

514 SEK 1980-83, 158; JKJ 1992, 14-15, 17-21; Kotila 2000, 131-132; Vasiljev 2004, 37; Brohed 2005, 292-295. 
515 SEK 1980-83, 158; Kinnamon 2004, 56.

516 Kirk.kok. ptk-s. 1988, liite VII-C 1; JKJ 1992, 13; Sariola 1992, 324 \& 1994, 128 \& 2000, 400; Kotila 2000, 131.

$517 J K J$ 1992, 13, 28, 60; Sariola 1993, 137-139.

518 Kirk.kok. kptk-s. 1988, 14 §.

519 Kirk.kok. kptk-s. 1988, 14 §.

520 Kirk.kok. ptk-s. 1988, 14 \$, liite VII-C 1.

521 Valjus 1992, 331.

522 Kirk.kok. ptk-s. 1988, 14 §, liite VII-C 1.

523 Muut jäsenet olivat FM Rakel Liehu, dosentti Aila Mielikäinen, lehtori Juhani Haapasalo, director musices Kaj-Erik Gustafsson, kirkkoherra Jukka Lehtinen, diplomiurkuri, pastori Osmo Vatanen ja kirkkoherra Henrik Perret. Sihteerinä toimi aluksi dosentti Seppo Suokunnas, sitten pastori Kai Vahtola.

524 KKHA KKA Hdb 2 ptk. 24.-25.1.1991 \$13.

525 Kirk.kok. kptk-s. 1992, 16 \$, 23 §.

526 JKJ 1992, 28; T. Lampinen 1992, 295-296.

527 Kirk.kok. ptk-s. 1992, liite III 1, 6.

$528 J K J 1992,57$.

$529 J K J$ 1992, 62-63.

$530 J K J$ 1992, 125

531 Kirk.kok. kptk-s. 1992, $16 \$, 23 \$$.

532 Kirk.kok. kptk-s. 1992, $16 \$, 23 \$$. Teologisen Aikakauskirjan teemanumero oli $4 / 1992$.

533 Kirk.kok. kptk-s. 1992, 16 \$; Kirk.kok. ptk-s. 1992, liite III 1,3-4.

534 Haikarainen 1992, 281; Kirk.kok. kptk-s. 1992, 16 \$; Kirk.kok. ptk-s. 1992, liite III $1,2$.

535 Kirk.kok. ptk-s. 1992, liite III 1, 7.

536 Kirk.kok. kptk-s. 1992,16 \$; Kirk.kok. ptk-s. 1992, liite III 1, 9.

537 Kirk.kok. ptk-s. 1992, liite III 1, 9.

538 Kirk.kok. kptk-s. 1992, 16 \$; Koskenvesa 1992, 287-288.

539 Kirk.kok. kptk-s. 1992, 16 \$.

540 Kirk.kok. kptk-s. 1992, $16 \S$.

541 Kirk.kok. kptk-s. 1992,16\$, 23 \$.

542 Kirk.kok. kptk-s. 1992, 23 \$.

543 Kirk.kok. kptk-s. 1992, $16 \$$.

544 Kirk.kok. kptk-s. 1992, $23 \$$.

545 Kirk.kok. kptk-s. 1992, 16 \$; Kirk.kok. kptk-k. 1993, 36 §.

$546 J K J 1992,67,69-70$.

547 HS 25.1.1992 Palaavatko pyhimykset luterilaiseen kirkkoon? (Pekka Hakala); Kp 25.1.1992 Jumalanpalveluksesta tehdään koko kansan messu; Viikkolehti 31.1.1992 Toisaalta: Arkipyhimyksiä (Eero Matero); Kmaa 7.2.1992 Kirkko ei ole saamassa pyhimyskalenteria (Heikki Tervonen).

548 Kirk.kok. kptk-s. 1992, 23 \$.

549 Kirk.kok. ptk-s. 1992, liite III 1, 10

550 Kirk.kok. ptk-k. 1993, liite X-C 1.

551 Kirk.kok. ptk-k. 1993, liite X-C 1.

552 JKJ 1992, 202; Kirk.kok. kptk-s. 1992, 16 §.

553 Kirk.kok. kptk-s. 1992, 16 §.

554 Kirk.kok. ptk-s. 1992, liite III 1, 11 \& V 1.

555 JKJ 1992, 198; Kirk.kok. ptk-s. 1992, liite III 1, 12.

556 Kirk.kok. ptk-k. 1993, liite X-C 1; Sariola 1994, 118 \& 2000, 400.

557 Kirk.kok. kptk-k. 1993, $36 \$$.

558 Vasiljev 2004, 78-79

559 Käsikirjakomitean ehdotus 1997c, 23-38.

560 Vasiljev 2004, 96, 99.

561 Handbokskommitténs förslag 1997a \& 1997b; Käsikirjakomitean ehdotus 1997a \& 1997b. Rakel Liehu ja Henrik Perret pyysivät eroa vuonna 1993. Heidän tilalleen kirkolliskokous valitsi runoilija, sairaalapastori Niilo Rauhalan ja kirkkoherra Olav Johanssonin. Joulukuusta 1992 lähtien ruotsinkielisenä sihteerinä toimi dosentti Yngvill Martola. Syksystä 1996 lähtien osa-aikaisena sihteerinä oli lisäksi teologian tohtori Johanna Räsänen. Jaostojen kautta komiteatyössä oli mukana suuri joukko asiantuntijoita. Käsikirjakomitean ehdotus 1997c, 11-14.

562 Kirk.kok. kptk-s. 1997, 18 \$; Kirk.kok. kptk-k. 1998, 44 \$; Kirk.kok. kptk-s. 1998, 22 \$.

563 Kirk.kok. kptk-s. 1997, 18 \$; Kirk.kok. kptk-k. 1998, 44 §.

564 Kirk.kok. kptk-s. 1997, 18 \$; Kirk.kok. kptk-s. 1999, 25 \$.

565 Kirk.kok. kptk-s. 1997, 18 \$; Kirk.kok. kptk-k. 1998, 44 \$.

566 Käsikirjakomitean ehdotus 1997c, 23-25; Räsänen 1996, 184, 187.
567 Käsikirjakomitean ehdotus 1997c, 29; SEK 1996-99, 48.

568 Kirk.kok. kptk-s. 1997, 18 \$; Kirk.kok. kptk-k. 1998, 44\$.

569 KKHA KKA Kkvk ptk. 12.9.1997\$4.

570 JKJ 1992, 30; Käsikirjakomitean ehdotus 1997c, 31; SEK 1996-99, 52; T. Lampinen 1992, 298; Räsänen 1995, 190.

571 Kirk.kok. kptk-s. 1997, 18 \$.

572 Kirk.kok. ptk-s. 1998, liite III 1, 7, 24.

573 Kirk.kok. ptk-s. 1998, liite III 1, 6-7, 23

574 KKHA KKA Kkvk ptk. 27.2.1998 \$ 4.

575 Kirk.kok. ptk-k. 1999, liite VIII-C perustelut

576 Käsikirjakomitean ehdotus 1997c, 21; Kirk.kok. kptk-s. 1997, 18 \$.

577 Kirk.kok. kptk-s. 1997, 18 \$; Kirk.kok. ptk-s. 1998, liite III 1, 22; Kirk.kok. ptkk. 1999, liite VIII-C perustelut; Sariola 2000, 416-417.

578 Käsikirjakomitean ehdotus 1997b, 9; Käsikirjakomitean ehdotus 1997c, 131132.

579 Käsikirjakomitean ehdotus 1997c, 132; Kirk.kok. kptk-s. 1997, 18 §; Kirk.kok. ptk-s. 1998, liite III 1, 21; Kirk.kok. ptk-k. 1999, liite VIII-C perustelut.

580 Kirk.kok. kptk-k. 1998, 44 \$; Kirk.kok. ptk-k. 1999, liite VIII-C perustelut; SEK 1996-99, 52.

581 Pentti Lempiäinen 2003, 265.

582 Kirk.kok. kptk-k. 1999, $63 \$$.

583 Kirk.kok. ptk-k. 1999, liite VIII-C 1 a \& 2 a.

584 Kirk.kok. kptk-k. 1999, 63 \$.

585 Räsänen 1996, 176-178, 185, 188.

586 Käsikirjakomitean ehdotus 1997a, 371-458; Käsikirjakomitean ehdotus 1997c, 80,157 .

587 Kirk.kok. kptk-k. 1998, 44 \$; Kirk.kok. ptk-s. 1998, liite III 1,10-11; SEK 1996 $99,67$.

588 Kirk.kok. kptk-k. 1998, 44 §.

589 Kirk.kok. kptk-s. 1997, 18 §.

590 Kirk.kok. kptk-k. 1998, $44 \S$.

591 KKHA KKA Kkvk ptk. 7.5.1998 \$ 5, ptk. 2.-3.6.1999 \$ 6; Kirk.kok. ptk-s. 1999, liite VIII-C perustelut mietintöön 5, motiveringar till handboksutskottets betänkande 6 .

592 Kirk.kok. kptk-s. 1999, 25 \$; Kirk.kok. ptk-s. 1999, liite VIII-C perustelut mietintöön 5.

593 Kirk.kok. kptk-s. 1999, 61 §.

594 Kirk.kok. ptk-s. 1999, liite VIII-C perustelut mietintöön 5.

595 Kirk.kok. kptk-s. 1999, 25 \$, 37 \$, 59 \$; Kirk.kok. ptk-s. 1999, liite VIII-C perustelut mietintöön 5 .

596 Kirk.kok. kptk-s. 1999, 37 \$.

597 Kirk.kok. kptk-k. 1998, 44 §.

598 Kirk.kok. kptk-s. 1999, 37 §.

599 Kirk.kok. ptk-s. 1997, liite VIII-A 4-6; Kirk.kok. ptk-s. 1999, liite II 2 \& VIIIB 9.

600 Kirk.kok. kptk-s. 1999, 27 §.

601 Kirk.kok. kptk-s. 1999, 37 \$; Kirk.kok. ptk-s. 1999, liite VIII-C perustelut mietintöön 5; Sariola 2000, 406-407.

602 Kirk.kok. kptk-s. 1999, 37 §.

603 Kirk.kok. kptk-s. 1999, 37 \$.

604 Kirk.kok. kptk-s. 1999, 37 \$.

605 Kirk.kok. kptk-k. 1999, 35-36\$; $54 \$$.

606 Kirk.kok. kptk-k. 1999, $54 \$$.

607 Kirk.kok. kptk-k. 1998, 44 §.

608 Kirk.kok. kptk-s. 1999, 59 \$.

609 Kirk.kok. kptk-s. 1999, 37 \$, 48 \$.

610 Kirk.kok. kptk-s. 1999, 37 \$.

611 SEK 1996-99, 25-26; Niemelä 2003a, 146; Niemelä 2003b, 142.

612 Kirk.kok. kptk-s. 1999, $48 \$$.

613 Kirk.kok. kptk-s. 1999, $66 \$$.

614 KKHA KKA Cc syksy $1999 \$ 66$.

615 Kirk.kok. kptk-s. 1999, 67 \$, 77\$.

616 Kirk.kok. ptk-k. 1999, 80-81 \$; Kirk.kok. ptk-y. 2000, 19-20 §.

617 SEK 1988-91, 17, 30-33

618 SEK 1996-99, 24-25, 32-33.

619 Kotila 2000, 132; Knuutila 2005, 88.

620 Kirk.kok. kptk-s. 1997, 18 §.

621 Vasiljev 2004, 103-104.

622 Kirk.kok. kptk-s. 1999, 66 \$.

623 Sanoilla "kristinoppi" ja "katekismus" on monia merkityksiä, mutta täs- 
sä molemmilla viitataan teokseen, joka pyrkii esittämään kristillisen opin kirjallisessa muodossa. Ks. Poutiainen 1994, 7, 11. Erisnimenä Katekismus viittaa 1990-luvulla valmisteltuun ja hyväksyttyyn kristinoppiin.

624 Pulkkinen 2005, 9-10.

625 Pulkkinen 2005, 10-11.

626 Pulkkinen 2005, 12

627 Seurakunta 2000 1987,34-35; Pulkkinen 2005, 12, 15.

628 Kirk.kok. ptk-k. 1993, liite VIII 5; Pulkkinen 2005, 12-14.

629 Kirk.kok. ptk-k. 1993, 77 \$, liite X-E 6.

630 Kirk.kok. ptk-k. 1993, liite X-E 6.

631 Kirk.kok. kptk-k. 1997, 31 \$; Kirk.kok. ptk-k. 1997, liite V 1.

632 Poutiainen 1998, 10; Pulkkinen 2005, 16, 20-21.

633 Poutiainen 1998, 10; Pulkkinen 2005, 21-23, 25.

634 Pulkkinen 2005, 28, 33-34, 40-43, 47-48.

635 Kirk.kok. ptk-s. 1998, liite II 2; Pulkkinen 2005, 53, 56-6o.

636 Pulkkinen 2005, 49-52.

637 Kirk.kok. ptk-k. 1998, liite III 1; Pulkkinen 2005, 54-55.

638 Kirk.kok. kptk-k. 1998, 8 \$; Kirk.kok. ptk-k. 1998, 67 \$, liite VII-B 7; Pulkkinen 2005, 55-56.

639 Kirk.kok. ptk-s. 1998, liite II 2.

640 Kirk.kok. kptk-s. 1998, 16 \$; Pulkkinen 2005, 60-62.

641 Kirk.kok. kptk-s. 1998, 16 §.

642 Kirk.kok.ptk-k. 1999, liite VIII-B 3, 32, 39-40. Kristinoppijaoston muina jäseninä olivat Riitta Aaltonen, Tapani Nuutinen ja Voitto Savela sekä sihteereinä Matti Poutiainen ja Antti Saarelma.

643 Kirk.kok. ptk-k. 1999, liite VIII-B 3, 38; Pulkkinen 2005, 63-64.

644 Kirk.kok. kptk-s. 1998, 16 \$; Pulkkinen 2005, 61.

645 Kirk.kok. ptk-k. 1999, liite VIII-B 3, 41; Pulkkinen 2005, 64

646 Kirk.kok. kptk-k. 1999, 37 \$.

647 Kirk.kok. kptk-k. 1999, 37 \$; Luukkonen 2005, 69.

648 Kirk.kok. kptk-k. 1999, 37 \$.

649 Kirk.kok. kptk-k. 1999, 37 \$.

650 Kirk.kok. ptk-k. 1999, $69 \$$, liite VIII-B 3 a.

651 Kirk.kok. ptk-k. 1999, liite VIII-B 3; Pulkkinen 2005, 68.

652 SEK 1996-99, 76, 135.

653 Kirk.kok. kptk-k. 1999, 39 \$; Pulkkinen 2005, 68

654 Pulkkinen 2005, 67.

655 Pulkkinen 2005, 69.

656 Kirk.kok. ptk-s. 1999, liite VIII-B 8.

657 Kirk.kok. kptk-s. 1999, 40 \$.

658 Kirk.kok. kptk-y. 200o, 1 §.

659 Knen 10.9.200o Pieni sininen kirja täyttää uskon tyhjiöitä (pääk.); Smaa 18.9.200o Kirkkoon kohdistuu nyt mielenkiintoa (pääk.); $A l$ 20.9.200o Arvopostia (pääk.); ESS 23.9.200o Esalainen: Mitä se on? (Heikki Hakala); SS 29.9.200o Vanhaa ja uutta viiniä uudessa leilissä (pääk.).

660 Kirk.kok. ptk-s. 1999, liite VIII-E 7.

661 Kirk.kok. kptk-s. 1999, 35 §.

662 Kirk.kok. kptk-s. 1995, $14 \S$.

663 Kirk.kok. ptk-k. 1994, liite VIII 5 \& 6 \& 8.

664 Kirk.kok. kptk-k. 1994, 28 \$, 29\$, 31 §.

665 Kirk.kok. kptk-k. 1994, 28 \$, $29 \$$.

666 Kirk.kok. kptk-k. 1994, $28 \$, 29 \$, 31$ \$.

667 Kirk.kok. ptk-k. 1994, 60 \$, liite III 4 \& IX-B 5.

668 Kirk.kok. kptk-s. 1994, 35 \$.

669 Kirk.kok. ptk-s. 1995, liite VI-B 4 \& VI-C 2 a

670 Hiippakuntahallintokomitean mietintö 1998, 104

671 Kirk.kok. kptk-k. 1997,39 \$.

672 Kirk.kok. ptk-s. 1999, liite VIII-F 11.

673 SEK 1992-95, 59

674 Esim. Kirk.kok. kptk-s. 1993, 7\$.

675 Kirk.kok. kptk-k. 1993, 21 \$; Kirk.kok. kptk-k. 1994, 18 §.

676 SEK 1988-91, 65-66; SEK 1992-95, 86, 279.

677 Kirk.kok. ptk-k. 1996, liite XI-B 1.

678 Kirk.kok. kptk-k. 1996, liite.

679 Kirk.kok. kptk-s. 1994, 19 \$.

680 Kirk.kok. kptk-s. 1996, 17 \$.

681 Kirk.kok. kptk-s. 1996, 17 \$

682 Kirk.kok. kptk-s. 1995, 8 §.

683 Kirk.kok. kptk-s. 1995, $17 \S$.

\section{KIRKOLLISKOKOUS}

\section{POLARISOITUU 2000-2011}

1 SEK 2000-03, 110-111, 114 \& 2004-07, 73, 81; Niemelä 2003c, 167, 170-171.

$2 \quad$ Kirk.kok. kptk-k. 2009, $32 \$$.

3 SEK 1996-99, 9, 32; Kirk.kok. ptk-s. 200o, liite VII-F 4; Changing Values 2008, 173; Helander 2002, 127.

4 Kauppalehti 3.5.200o Kolumni: Kirkko muodissa (Kustaa Hulkko); Hbl 26.11.200o Kyrkan blir mera pop (Ann-Gerd Steinby, ledare).

5 SEK 2004-07, 45-47 \& 2008-11, 44, 54.

6 SEK 2008-11, 42, 85.

7 SEK 1996-99, 38 \& 2008-11, 74, 83-84.

SEK 2004-07, 53, 59, 90-93.

Kirk.kok. kptk-k. 2009, 18 \$, 21 \$, 25 \$.

10 SEK 2000-03, 177 \& 2004-07, 64-67.

11 SEK $2008-11,76$.

12 SEK 2000-03, 19

13 Turun kaupungin tilastollinen vuosikirja 2011, 19.

14 SEK 2000-03, 96 \& 2004-07, 13 \& 2008-11, 16-17.

15 Kirk.kok. kptk-k. 2001, 1 \$.

16 Kirk.kok. kptk-k. 2003, 1 §.

17 SEK 2004-07, 309; SEK 2008-11, 18-21.

18 Kirk.kok. kptk-k. 2009, 1 §.

19 Kirk.kok. kptk-k. 2009, 1 \$.

20 Kirk.kok. kptk-k. 2000, 5.

21 Kurkela 2012, 97-99, 104-107; Mustakallio 2012e, 601.

22 Kirk.kok. kptk-s. 2010, 1 §.

23 SEK 2008-11, 12, 84, 267-268, 271.

24 Kmaa 21.1.200o Saisiko kunnallisvaltuutettu äänestää puolestasi eduskuntavaaleissa? (Anna Tuliharju), 28.1.200o Rajoitettu kirkollinen äänioikeus (Mikko-Matti Rinta-Harri \& Seppo Kotilainen), 4.2.20oo Millaiset kirkolliskokousvaalit? (Seikko Eskola), Kirkolliskokousvaaleista on syytä keskustella (Marko Pasma), 11.2.200o Kirkolliskokousedustajien vaalit (Jussi Lilja), 24.3.200o Kansanvaali heikentäisi kirkolliskokousta (Seikko Eskola).

25 Kmaa 17.11.2000 Ei äänioikeutta kirkon rivijäsenille (Jaakko Elenius, pääk.).

26 Kirk.kok. kptk-s. 2000, 28 \$; Kirk.kok. kptk-k. 2004, 50 \$; Kirk.kok. ptkk. 2004, liite IX 12; Kmaa 13.2.2004 Kirkossa valittiin keskeiset päättäjät (Olli Seppälä), 7.2.2008 Netti tuo avoimuutta vaaleihin (Johannes Ijäs), 21.2.2008 Vaalitapa remonttiin (Olav S. Melin, pääk.), Kirkolliskokousvaalit 2008 (Meri Toivanen); Pnen 2.3.2008 Kirkolliskokousvaalissa voisi käyttää uusia järjestelmiä (pääk.).

27 Kirk.kok. ptk-s. 2004, 20 \$; Kmaa 1.11.2007 Ehdokkaat salaavat tavoitteensa (Ulla Lötjönen), 13.12.2007 Kirkkopuolueet esiin kulisseista (Ulla Lötjönen \& Taneli Kylätasku \& Gun Helminen), 7.2.2008 Netti tuo avoimuutta vaaleihin (Johannes Ijäs).

28 Kmaa 7.1.2000 Kirkolliskokouksen väki vaihtuu.

29 HTA Eec 8 valitsijayhdistysten perustamisasiakirjat kirkolliskokouksen maallikkoedustajien vaalissa 2000 , vaalilautakunnan ptk. 21.2.2000 $\$ 4$.

30 Länsi-Savo 19.2.20oo Kirkolliskokoukselta voi odottaa räväkkää keskustelua.

31 HTA Eec 8 valitsijayhdistysten perustamisasiakirjat kirkolliskokouksen maallikkoedustajien ja pappisedustajien vaalissa 2000, vaalilautakunnan ptk. 21.2.2000 \$ 4-5.

32 LTA Eca valitsijayhdistysten perustamisasiakirjat kirkolliskokouksen maallikkoedustajien vaalissa 2000, ehdokaslistojen yhdistelmä kirkolliskokouksen maallikkoedustajien vaalissa 14.2.2000.

33 LTA Eca ehdokaslistojen yhdistelmä kirkolliskokouksen pappisedustajien vaalissa 14.2.2000, kuulutus 21.2.2000; Kmaa 11.2.2000 Uutta asiantuntemusta kirkolliskokoukseen (17 allekirjoittajaa).

34 LTA Eca valitsijayhdistysten perustamisasiakirjat kirkolliskokouksen pappisedustajien vaalissa 2000 , ehdokaslistojen yhdistelmä kirkolliskokouksen pappisedustajien vaalissa 14.2.200o. Ensin mainitulta listalta valittiin kaksi kirkkoherraa, Eino Perälä Vaasasta ja Olavi Vuori Saarijärveltä, jälkimmäiseltä taas seurakuntapastori, rovasti Arvi Tuomi Jyväskylästä. LTA Eca kuulutus 21.2.2000.

35 Kmaa 11.2.200o Kirkolliskokousvaaleissa murroksen aika (Autuaan Hemmingin apupapit, 45 allekirjoittajaa). 
36 Länsi-Savo 19.2.200o Kirkolliskokoukselta voi odottaa räväkkää keskustelua; Kmaa 25.2.200o Edustajista vaihtui yli puolet.

37 Länsi-Savo 19.2.200o Kirkolliskokoukselta voi odottaa räväkkää keskustelua.

38 Piisp.kok. ptk-k. 2002, 1 §; Ilkka 5.9.2002 Kirkon marraskuiset vaalit kiinnostavat entistä enemmän (Marja-Liisa Kriikku); $A l$ 13.11.2002 Nuoret avasivat kirkon ovet (pääk.); HS 14.2.2004 Kirkolliskokouksen jäsenistä vaihtui yli puolet (Paavo Tukkimäki).

39 ESS 8.2.2004 Alle 30-vuotiaat haluavat äänensä kuuluviin kirkolliskokouksessa (Kaarina Palletvuori); Kmaa 13.2.2004 Kirkossa valittiin keskeiset päättäjät (Olli Seppälä).

$40 \quad$ Kmaa 19.12.2003 Hiippakuntavaltuusto kiinnostaa kirkolliskokousta enemmän.

41 HTA 3.8.1 kansio 4 valitsijayhdistysten perustamisasiakirjat kirkolliskokouksen pappisedustajien vaalissa 2004.

42 Kmaa 19.12.2003 Hiippakuntavaltuusto kiinnostaa kirkolliskokousta enemmän; ESS 8.2.2004 Alle 30-vuotiaat haluavat äänensä kuuluviin kirkolliskokouksessa (Kaarina Palletvuori).

43 HS 14.2.2004 Kirkolliskokouksen jäsenistä vaihtui yli puolet (Paavo Tukkimäki).

44 HTA 3.8.1 kansio 4 valitsijayhdistysten perustamisasiakirjat kirkolliskokouksen maallikkoedustajien vaalissa 2004.

45 Kmaa 19.12.2003 Hiippakuntavaltuusto kiinnostaa kirkolliskokousta enemmän.

46 Kmaa 19.12.2003 Hiippakuntavaltuusto kiinnostaa kirkolliskokousta enemmän.

47 Saarinen $2005,11,122$.

48 HS 14.2.2004 Kirkolliskokouksen jäsenistä vaihtui yli puolet (Paavo Tukkimäki).

49 Kmaa 20.2.2004 Eivätkö naiset äänestä naisia? (Raili Kettunen, pääk.) 20.2.2004 Kirkolliskokouksessa naisia yhä vähemmän (Taneli Kylätasku).

50 Kmaa 20.2.2004 Kirkolliskokouksessa naisia yhä vähemmän (Taneli Kylätasku); Yhteys-liikkeen kevätkokous 5.2.2004.

51 Torkkeli 2011, 10-11.

52 SK 17.3.2006 Tulkoot kaikki (Kaisa Raittila); Tulkaa kaikki -liike Liikkeen ohjelma. <http://www.tulkaakaikki.net/ohjelma.html>. Katsottu 28.2.2013.

53 Kansan Tahto 21.11.2006 Kirkon uudistusliike vasta matkalla pohjoiseen (Maija Aalto); Kmaa 23.11.2006 Tulkaa kaikki -liike ryminällä läpi (Anna-Kaisa Pitkänen); Torkkeli 2011, 10.

54 Kmaa 1.11.2007 Ehdokkaat salaavat tavoitteensa (Ulla Lötjönen); Tulkae kaikki-liike 25.1.2008 Tulkaa kaikki -liike haastaa kirkolliskokousvaaleissa. <http://www.tulkaakaikki.net/tiedote25012008.html>. Katsottu 28.2.2013; Vesa Hirvosen puhelinhaastattelu 25.2.2013.

55 Tulkaa kaikki -liike Etsi ehdokkaasi / valitut. <http://www.tulkaakaikki. net/kirkehd.html>. Katsottu 28.2.2013.

56 Strandberg 2012, 82.

57 Kmaa 24.1.2008 Huotari: Ketä kirkolliskokoukseen? (Voitto Huotari).

58 Kmaa 7.2.2008 Netti tuo avoimuutta vaaleihin (Johannes Ijäs).

59 Tulkaa kaikki -liike Etsi ehdokkaasi / valitut. <http://www.tulkaakaikki. net/kirkehd.html>. Katsottu 28.2.2013.

60 Suomen ev.lut. kirkko: Uutiset 18.12.2007 Kirkolliskokous- ja hiippakuntavaltuustojen vaaleissa ehdokkaita entistä enemmän. <http://evl.fi/EVLUutiset.nsf/Documents/o7F2447A17548AD1C22573B5004ABo14?Open Document\&lang=FI $>$. Katsottu 27.2.2013.

61 HTA Kirkolliskokousvaalit 2008 valitsijayhdistysten perustamisasiakirjat kirkolliskokouksen pappisedustajien vaalissa 2008 , vaalilautakunnan ptk. 18.2.2008\$4.

62 Lapuan hiippakunta 19.12.2007 Tiedote: Lapuan hiippakunnan maallikko- ja pappisjäsenten vaali 2008. <http://web.archive.org/ web/20080121232707/http://www.lapuanhiippakunta.fi/fi/kirkolliset vaalit_2008_/>. Katsottu 1.3.2013

63 Kmaa 1.11.2007 Ehdokkaat salaavat tavoitteensa (Ulla Lötjönen); Kaleva 18.12.2007 Nuoret eivät halua enää vaieta seurakunnassa (Kati Luoma); Suomen ev.lut. kirkko: Uutiset 18.12.2007 Kirkolliskokous- ja hiippakun tavaltuustojen vaaleissa ehdokkaita entistä enemmän. <http://evl.fi/EVLUutiset.nsf/Documents/o7F2447A17548AD1C22573B5004ABo14?Open Document\&lang=FI $>$. Katsottu 27.2.2013

64 Suomen ev.lut. kirkko: Uutiset 18.12.2007 Kirkolliskokous- ja hiippakuntavaltuustojen vaaleissa ehdokkaita entistä enemmän. <http://evl.fi/EV-
LUutiset.nsf/Documents/o7F2447A17548AD1C22573B5004ABo14?Open Document\&lang=FI $>$. Katsottu 27.2.2013.

65 HTA Kirkolliskokousvaalit 2008 valitsijayhdistysten perustamisasiakirjat kirkolliskokouksen pappisedustajien vaalissa 2008.

66 HTA Kirkolliskokousvaalit 2008 valitsijayhdistysten perustamisasiakirjat kirkolliskokouksen maallikko- ja pappisedustajien vaalissa 2008, vaalilautakunnan ptk. 18.2.2008 \$3-4

67 Suomen ev.lut. kirkko: Uutiset 18.12.2007 Kirkolliskokous- ja hiippakuntavaltuustojen vaaleissa ehdokkaita entistä enemmän. <http://evl.fi/EVLUutiset.nsf/Documents/o7F2447A17548AD1C22573B5004ABo14?Open Document\&lang=FI $>$. Katsottu 27.2.2013.

68 HTA 3.8.1 kansio 4 valitsijayhdistysten perustamisasiakirjat kirkolliskokouksen pappisedustajien vaalissa 2004.

69 HTA Kirkolliskokousvaalit 2008 valitsijayhdistysten perustamisasiakirjat kirkolliskokouksen maallikkoedustajien vaalissa 2008.

70 KJK-verkkosivut 28.11.2011 Miksi papit eivät äänestä kirkolliskokousvaaleissa? (Ulla Lötjönen). <http://www.kirkkojakaupunki.fi/uutiset/miksipapit-eivat-aanesta-kirkolliskokousvaaleissa >. Katsottu 1.12.2011.

71 SEK 2008-11, 302; Kmaa 21.2.2008 Kirkon päättäjistä vaihtui joka toinen, Kirkolliskokousvaalit 2008 (Meri Toivanen).

72 HTA Kirkolliskokousvaalit 2008 valitsijayhdistysten perustamisasiakirjat kirkolliskokouksen maallikkoedustajien vaalissa 2008 , vaalilautakunnan ptk. 18.2.2008\$3.

73 HTA Kirkolliskokousvaalit 2008 valitsijayhdistysten perustamisasiakirjat kirkolliskokouksen pappisedustajien vaalissa 2008, vaalilautakunnan ptk 18.2.2008\$4.

74 Juva 1976, 230

75 Väestön koulutusrakenne 2011, liitekuvio 1.

76 Paloheimo 2007, 324, 337.

77 Juva 1976, 230.

78 Juva 1976, 230

79 Kmaa 7.1.2011 Lestadiolaiset pyysivät anteeksi äänestämistään (Johannes Ijäs).

8o Linjaristiriidoista ks. Veikkola 2006, 84-86, 94-95, 99-103.

81 Juva 1976, 231.

82 Järvinen 2012, liite 1.

83 SEK 1972-75, 264 \& 2008-11, 397-400.

84 Ks. SEK 2008-11, 382 .

85 Suomen ev.lut. kirkko: Uutiset 13.2.2008 Kolmannes kirkolliskokousedustajista kuuluu myös hiippakuntavaltuustoon. <http://evl.fi/EVLUutiset.nsf/ Documents/50CBD96ED3F812F9C22573EEoo4F4188?OpenDocument\& lang=FI $>$. Katsottu 28.2.2013.

86 Juva 1976, 230

87 S. Häkkinen 2010, 155; Mykkänen 2012, 294.

88 Kotimaa24 9.11.2012, Kirkolliskokouksen antijytky - yksikään ei äänestänyt perussuomalaisia (Simo Alastalo \& Ville Talola \& Heli Yli-Räisänen). <http://www.kotimaa24.fi/uutiset/kotimaa/9649-kirkolliskokouksen-antijytky-yksikaan-ei-aanestanyt-perussuomalaisia >. Katsottu 18.2.2013. Kyselyn toteuttivat Kotimaa24 ja Yle Radio 1:n Horisontti-ohjelma.

89 Borg 2012b, 194

90 Juva 1976, 231.

91 Grönlund \& Westinen 2012, 169, 176; Mykkänen 2012, 306.

92 Borg 2012a, 131

93 Borg 2012a, 135.

94 Tiitinen 2008, 63

95 Kirk.kok. ptk-s. 2001, liite III 9, 1-2.

96 Kirk.kok. ptk-s. 2001, liite III 9, 2-3; Kirk.kok. ptk-k. 2002, 47 \$, liite XI-A 1.

97 Kirk.kok. ptk-s. 2001, liite III 9, 9-10; Kirk.kok. ptk-k. 2002, 47 \$, liite XI-A 1

98 Kirk.kok. ptk-s. 2001, liite III 9, 3-4.

99 Kirk.kok. kptk-s. 2005, 28 \$; S. Eskola 2012a, 139-141.

100 Tiitinen 2008, 72

101 Kirk.kok. kptk-s. 2001,14 \$; Kirk.kok. ptk-s. 2001, liite III 9, 7, 33, 35-36; Kirk. kok. ptk-k. 2002, liite XI-A 1; Kirk.kok. ptk-k. 2004, liite IX 2; Kirk.kok. ptks. 2005 , liite III 8 \& VII-A 7 .

102 Kirk.kok. kptk-k. 2000, 5-6\$.

103 Kirk.kok. kptk-k. 2004, 9-10 \$; Kirk.kok. kptk-k. 2008, 9-10 \$; Kmaa 21.5.2004 Työtapaturma kirkolliskokouksessa? (Kyllikki Tiensuu).

104 Kirk.kok. ptk-s. 2001, liite III 9, 5.

105 KKHA KKA Valitsijamiesten ptk:t 2004-08 ptk. 8.11.2005 klo 12.30 \$2, 8.11.2005 klo $14.15 \$ 2$; Kirk.kok. kptk-s. 2009, 38 \&, 
106 Kirk.kok. kptk-k. 2000, 29 \$, 61 \$; Kirk.kok. kptk-k. 2004, 48 \$, 59 \$; Kmaa 5.5.200o Kirkkohallitukseen parhaat maallikot (Mikael Krogerus).

107 Kirk.kok. ptk-k. 2000, 61 \$, liite VII; Kirk.kok. kptk-k. 2004, 59 \$; Kirk.kok. ptk-k. 2004, liite VIII \& XI 2; Kirk.kok. ptk-k. 2008, liite VII 3 \& XI 3.

108 Tulkaa kaikki-liike 13.2.2008 Kirkolliskokoukseen uudistusmielisten edustajien ryhmä. <http://www.tulkaakaikki.net/tiedote13022008.html>. Katsottu 28.2.2013; Vesa Hirvosen puhelinhaastattelu 25.2.2013.

109 Kirk.kok. kptk-k. 2009,55\$.

110 KKHA KKA Valiokuntien ptk:t 1996-99 Valitsijamiehet ptk. 22.10.1997 \$ 4, 5.11.1997\$2; Huovinen 2011, 184.

111 KKHA KKA Valitsijamiesten ptk:t 2000-03 ptk. 10.5.200o klo 9.50 §5; Kirk.kok. kptk-k. 2000, 62 \$.

112 KKHA KKA Valitsijamiesten ptk:t 2000-03 ptk. 18.10.2001 \$3; Kirk.kok. kptk-s. 2001, $25 \$$.

113 Kirk.kok. ptk-s. 2001, $25 \$$.

114 Kirk.kok. kptk-s. 2007, 22 \$.

115 Kirk.kok. kptk-k. 2009, $34 \$$.

116 Kirk.kok. kptk-k. 2010, 34-35\$.

117 Kirk.kok. kptk-k. 2002, 13 \$; Kirk.kok. kptk-s. 2002, 26 \$; Kirk.kok. ptk-s. 2002, liite IV 2, 1

118 Kirk.kok. kptk-s. 2002, $26 \$$.

119 Kirk.kok. kptk-s. 2002, 26 \$; Kirk.kok. ptk-s. 2002, liite IV 2, 4.

120 Seppo 2003b, 82.

121 Seppo 2003b, 90

122 Kirk.kok. kptk-k. 2004, 42 \$; SEK 2000-03, 29, 89, 97 \& 2004-07, 62-65; $K s m l$ 1.3.2004 Yliö: Kirkon jäsenyys - euroja vai jotakin syvempää? (Jukka Keskitalo); Länsi-Savo 12.3.2004 Protestipapit tulkitsevat kirkosta eroamista tiukasti (Hannu Jukarainen); TS 5.2.2004 Pappien typerä protesti (pääk.), 9.4.2004 Kirkollisvero muutakin kuin oman hautapaikan etumaksu (Ilkka Kantola); HS 10.4.2004 Vieraskynä: Hyötyajattelu ei sovi kirkkoon (Seppo Häkkinen).

123 Kirk.kok. ptk-k. 2004, liite IX 10.

124 Kirk.kok. ptk-s. 2004, 22 \$, liite V-E 9; Kirk.kok. ptk-s. 2005, liite IV 1.

125 Kirk.kok. ptk-k. 2004, liite IX 9.

126 Kirk.kok. ptk-s. 2004, 19 \$, liite V-E 6

127 Kirk.kok. kptk-s. 2004, $15 \$$.

128 Kirk.kok. kptk-s. 2004, 52 \$.

129 Kirk.kok. ptk-s. 2005, liite IV 1.

130 Kirk.kok. ptk-k. 2007, liite III 2.

131 Kirk.kok. kptk-k. 2007,16\$.

132 SEK 2004-07, 343 \& 2008-11,59-61; Meidän kirkko 2008.

133 SEK 2008-11, 61-62.

134 Kirk.kok. kptk-k. 2008,30\$.

135 Kirk.kok. ptk-k. 2008, liite IX-D 2.

136 Kirk.kok. ptk-s. 2008, liite VI-D 3; Kirk.kok. ptk-k. 2009, liite VII-E 5.

137 Kirk.kok. kptk-s. 2008, 10 \$; Kirk.kok. kptk-s. 2011, 21 \$; SEK 2008-11, 269.

138 Kirk.kok. ptk-k. 2008, liite VIII 7.

139 Vainio 2007, 255.

140 Kirk.kok. kptk-s. 2004, 15 §.

141 KKHA KKA Valiokuntien ptk:t 2004- Yleisvaliokunta II osasto ptk. 9.11.2005\$3.

142 Helander \& Pekonen 2007, 49.

143 Kirk.kok. ptk-s. 2008,37\$, liite VI-C 1; Kirk.kok. ptk-s. 2009, 23\$, liite VI-A 3.

144 Kirkko 2020 2010, 7; Kirk.kok. ptk-s. 2010, liite II 11; SEK 2008-11, 63.

145 Kirk.kok. ptk-s. 2011, liite V-E 4.

146 Kirk.kok. kptk-s. 2011, 17 \$, 21 \$.

147 Kirk.kok. kptk-s. 2011, 21 §.

148 Kirk.kok. kptk-s. 2011, 21 \$.

149 Kirk.kok. kptk-k. 2008, 1 §.

150 SEK 1996-99, 75-76; Kirk.kok. kptk-s. 2000, 12 §.

151 Kirk.kok. ptk-k. 2001, liite IV 1.

152 Kirk.kok. ptk-k. 2004, liite II 1; Kirk.kok. ptk-s. 2004, liite V-B 1.

153 Kirk.kok. kptk-s. 2004, 44 \$; Kirk.kok. ptk-s. 2004, liite V-B 1; Kmaa 19.11.2004 Lisäkummeille on kasvava tilaus (Johannes Ijäs).

154 Kirk.kok. kptk-s. 2004, 44 §.

155 Kirk.kok. kptk-s. 2004, 44 \$; Kmaa 19.11.2004 Lisäkummeille on kasvava tilaus (Johannes Ijäs).

156 Hämeen Sanomat 9.11.2004 Kirkolliskokous laajentamassa oikeutta päästä kummiksi; Al 10.11.2004 Ylänurkka: Myönteinen merkki, kummius kiinnostaa (Matti Mörttönen); Ilkka 13.11.2004 Piispainkokous jatkaa kum- miuden selvittämistä; Itä-Savo 14.11.2004 Kummi on aikuinen ystävä (Minna-Liisa Riestola); Knen 14.11.2004 Kummius ei saa vesittyä (pääk.). 157 Kmaa 19.11.2004 Lisäkummeille on kasvava tilaus (Johannes Ijäs).

158 Kirk.kok. kptk-s. 2004, 44\$.

159 Kirk.kok. kptk-s. 2005, 5 \$; Kirk.kok. ptk-s. 2005, liite II 1 \& VII-B 2.

160 Kirk.kok. ptk-k. 2009, liite V 3 \& VI 7.

161 Kirk.kok. kptk-k. 2009, 20 \$, 37\$.

162 Kirk.kok. ptk-k. 2009, liite V 3.

163 Kirk.kok. kptk-k. 2009, $20 \$$.

164 Kirk.kok. kptk-k. 2009, 37 \$.

165 Kirk.kok. ptk-s. 2009, 30 \$, liite VI-B 2; Kirk.kok. ptk-k. 2010, 61\$, liite VIII$\mathrm{C}_{3}$.

166 Kirk.kok. ptk-k. 2003, liite VIII-A 4.

167 Kirk.kok. ptk-k. 2003, liite VIII-A 4; Seppo 2003b, 161-163.

168 Vp. ak. C 2003, hallintovaliokunnan mietintö 14.

169 Kirk.kok. ptk-s. 2004, liite II 14; Kirk.kok. ptk-k. 2005,32 \$, liite VI-A 2; SEK 2000-03, 70-71.

170 Kirk.kok. kptk-s. 2011, 9 \$; Kirk.kok. ptk-s. 2011,31 \$, 37 \$, liite III 14 \& V-B 7.

171 Ks. Pernaa 2012, 31-32.

172 Kirk.kok. ptk-k. 2005, liite VI-A 2.

173 Kirk.kok. ptk-k. 1991, liite VIII 5.

174 Kirk.kok. kptk-k. 1991, 28 \$; Kirk.kok. ptk-s. 1991, 18 \$, liite VI-F 6.

175 Kirk.kok. ptk-k. 1996, liite X 1.

176 Kirk.kok. ptk-k. 1996, liite XI-E 5.

177 Ekström 2003, 270-271; Raiser 2004, 274.

178 Kirk.kok. kptk-s. 2000, 12 \$; Kirk.kok. ptk-k. 2003, liite VII 2.

179 Knen 1.9.2002 Kysymysmerkki on oikeassa paikassa (pääk.); Länsi-Savo 10.9.2002 Äänioikeus voisi alkaa rippikouluiässä (pääk.).

180 SEK 2004-07, 153; Niemelä 2003d, 195-201.

181 Kirk.kok. ptk-k. 2003, liite VII 2.

182 Kirk.kok. kptk-s. 2003, 36 \$, 61 \$; Kirk.kok. ptk-s. 2003, liite VII-E 11.

183 Kirk.kok. ptk-k. 2004, liite IX 7; Kirk.kok. ptk-k. 2006, liite VI 8

184 Kohti aktiivista kansalaisuutta 2005, 57,61.

185 Ilkka 29.5.2005 Arkkipiispa Paarma alentaisi kirkollista äänioikeusikärajaa.

186 Kirk.kok. ptk-k. 2006, liite VI 7.

187 Kirk.kok. ptk-s. 2006, liite IX-A 2.

188 Kirk.kok. ptk-s. 1991, liite VI-F 6; Kirk.kok. kptk-k. 1996, 81 §; Kirk.kok. ptkk. 1996, liite XI-E 5; Kirk.kok. kptk-s. 2006, 15 \$; Kirk.kok. kptk-s. 2007, 13 \$.

189 Kirk.kok. kptk-k. 2006, 24 \$; Kirk.kok. kptk-s. 2006, 15 \$; Kirk.kok. kptk-s. $2007,13 \S$.

190 Kirk.kok. kptk-s. 2006, 15 \$; Kirk.kok. kptk-s. 2007, 13 \$.

191 Kirk.kok. kptk-k. 2006, 24 \$; Kirk.kok. kptk-s. 2006, 15 \$; Kirk.kok. kptk-s. $2007,13 \$$.

192 Kirk.kok. kptk-s. 2007, 13 \$.

193 Kirk.kok. kptk-s. 2006, 15 \$; Kirk.kok. kptk-k. 2007, 19 \$.

194 Kirk.kok. kptk-s. 2006,15\$.

195 KKHA KKA Cc syksy $2006 \$ 15$.

$196 K S$ 12.11.2006 Kirkko voisi alentaa myös vaalikelpoisuusikää (pääk.).

197 Kaleva 10.11.2006 Harva 16-vuotias äänestää (pääk.); HS 13.11.2006 Kirkko osaa päättää myös ripeästi (pääk.).

198 HS 13.11.2006 Kirkko osaa päättää myös ripeästi (pääk.).

199 Kirk.kok. kptk-k. 2007,10 \$.

200 Kirk.kok. kptk-k. 2007,10 \$; Kirk.kok. kptk-k. 2007, $19 \$$.

201 Kirk.kok. kptk-k. 2007,19 \$; Kirk.kok. ptk-s. 2007, liite II 9.

202 Kirk.kok. ptk-s. 2007, liite II 9.

203 Kirk.kok. kptk-s. 2007, $19 \$$.

204 Kirk.kok. ptk-s. 2007, $26 \$$.

205 KKHA KKA Cc syksy $2007 \$ 26$.

206 Pnen 5.11.2007 Nuorten päätösvaltaa kirkossa syytä kasvattaa (pääk.); Knen 11.11.2007 Pitkä kypsyttely toi oikean päätöksen (pääk.); ESS 12.11.2007 Nuorille ääni seurakunnissa (pääk.).

207 SEK 2008-11,300-301.

208 Kirk.kok. ptk-k. 2009, liite VI 6.

209 Kirk.kok. ptk-k. 2009, liite V 1.

210 Kirk.kok. ptk-k. 2009, liite VI 5; Kurttila 2011, 6-9.

211 Kirk.kok. ptk-s. 2009, $24 \$, 32 \S, 47 \S$.

212 Kirk.kok. ptk-s. 2001, liite VIII-D 9.

213 Kirk.kok. kptk-s. 2002, $20 \$$.

214 Kirk.kok. kptk-k. 2006, 7 \$; Kirk.kok. kptk-s. 2006, 22 \$; Kirk.kok. ptk-k. 
2008, liite V 1; SEK 2004-07, 305, 322.

215 Kirk.kok. kptk-k. 2008, 24 \$; Kirk.kok. ptk-k. 2008, liite V 1.

216 Kirk.kok. kptk-s. 2008, 6 \$.

217 Kirk.kok. kptk-s. 2008, 6 \$.

218 Kirk.kok. kptk-s. 2008, 27 \$; Kirk.kok. ptk-s. 2008, liite VI-D 3.

219 Kirk.kok. kptk-s. 2011, 19 \$; SEK 2008-11, 67.

220 Kirk.kok. ptk-s. 2011, liite III 11 \& V-D 4.

221 SEK 1996-99, 206 \& 2000-03, 278.

222 SEK 2000-03, 277, 286; R. T. Nieminen 2005a, 11.

223 Kirk.kok. ptk-k. 2001, liite IV 1.

224 Kirk.kok. kptk-s. 2000, 24 \$; SEK 2000-03, 293.

225 Kirk.kok. kptk-s. 2000, $12 \$$.

226 Kirk.kok. kptk-s. 2000, 24 \$.

227 Kirk.kok. kptk-k. 2001, 9 \$; Kirk.kok. ptk-k. 2001, 58 \$, liite X-E 2.

228 SEK 2000-03, 286.

229 Kirk.kok. ptk-s. 2002, liite VIII-C 6.

230 Kirk.kok. kptk-s. 2002, 39 \$; Kirk.kok. ptk-s. 2002, liite VIII-C 8; SEK 200003, 31 .

231 Kirk.kok. ptk-k. 2004, liite III 7.

232 Kirk.kok. kptk-k. 2004, 27 \$.

233 Kirk.kok. ptk-k. 2005, liite VI-D 1.

234 Kirk.kok. kptk-k. 2004, 27 \$.

235 Kirk.kok. ptk-k. 2005, liite VI-D 1.

236 Kirk.kok. kptk-k. 2005, 41 \$.

237 Kirk.kok. kptk-k. 2005, $49 \$$.

238 Kirk.kok. ptk-s. 2001, 54 \$, liite III 14 \& VIII-D 11; SEK 2000-03, 72.

239 SEK 2000-03, 294.

240 Kirk.kok. kptk-s. 2004, 27 \$.

241 R. T. Nieminen 2005a, 11-12.

242 R. T. Nieminen 2005b, 42-44.

243 R. T. Nieminen 2005b, 45.

244 SEK 2004-07, 14-15.

245 Kmaa 11.11.2005 "Seurakuntarakennetta on hyvä pohtia jo nyt" (Johannes Ijäs).

246 Kirk.kok. ptk-s. 2005, liite IV 1.

247 Kirk.kok. kptk-s. 2005, $20 \$$.

248 Kirk.kok. ptk-k. 2006, liite VII-F 1; SEK 2004-07, 328-329; Mustakallio 2012c, 564 .

249 Kirk.kok. kptk-s. 2005, 20 \$; Mustakallio 2012C, 564.

250 Kirk.kok. ptk-s. 2005, liite VII-D 9.

251 Kirk.kok. kptk-s. 2005, 18 \$.

252 Pnen 5.11.2005 Kuntien rakennemuutos pakottaa kirkonkin pohtimaan rakennettaan (pääk.); Kaleva 13.11.2005 Tunneherkät seurakuntaliitokset (pääk.); TS 14.11.2005 Kirkko heräsi muutospaineisiin (pääk.).

253 Kirk.kok. kptk-s. 2006,9\$.

254 Kirk.kok. kptk-s. 2006, 21 \$.

255 SEK 2004-07,329.

256 Kirk.kok. kptk-s. 2006, 21 \$.

257 SEK 2008-11, 293.

258 Kirk.kok. ptk-s. 2008, liite V 3.

259 Kirk.kok. kptk-s. 2008, $14 \$$.

260 Kirk.kok. kptk-k. 2009, 48 \$; Kirk.kok. ptk-k. 2009, liite VII-C 1.

261 Kirk.kok. ptk-k. 2010, liite VII 1; Kirk.kok. ptk-s. 2010, 30 §.

262 Kirk.kok. ptk-k. 2008, liite VIII 8

263 Kirk.kok. kptk-k. 2008, 42 \$; Kirk.kok. kptk-k. 2011, 6 \$.

264 SEK 2008-11, 379-380.

265 Kirk.kok. kptk-k. 2010, 39 \$; Kirk.kok. ptk-k. 2010, liite VIII-D 1; Kirk.kok. kptk-k. 2011, 6 \$, 44 \$; Kirk.kok. ptk-k. 2011, liite III 1 \& VIII-C 2.

266 Kirk.kok. kptk-k. 2011, $6 \$$.

267 Kirk.kok. kptk-k. 2011, 6 \$, 44 \$; Keso \& Vakkuri 2011, 115-118.

268 Kirkko 2020 2010, 15, 62; Kirk.kok. ptk-s. 2011, liite V-E 4, 13.

269 Kirk.kok. ptk-s. 2011, liite V-E 4, 19.

270 Kirk.kok. ptk-s. 2011, liite III 11 \& V-D 4.

271 Kirk.kok. kptk-s. 2000, 24 \$; Ripatti 2012, 604.

272 Tiitinen 2008, 69.

273 Kirk.kok. ptk-s. 2009, liite VI-D 4.

274 Kirk.kok. kptk-s. 2005, 18 \$; Kirk.kok. ptk-k. 2006, liite VII-F 1.

275 Kirk.kok. kptk-s. 2007, 18 \$; Kirk.kok. ptk-s. 2007, liite VI-C 5.

276 Kirk.kok. kptk-k. 2012, 50 \$; Kirk.kok. ptk-k. 2012, liite IX-B 1.

277 Kirk.kok. kptk-s. 2004, 27 \$.
278 Kirk.kok. kptk-s. 2003, 28 \$.

279 Kirk.kok. kptk-s. 2004, 27 \$.

280 Kirk.kok. kptk-s. 2005, 26 \$; Kirk.kok. ptk-s. 2005, liite VII-C 6.

281 Kirk.kok. ptk-s. 2006, liite IX-B 3.

282 SEK 2008-11, 62

283 Kirk.kok. ptk-k. 2008, liite V 1; Kirk.kok. kptk-s. 2008, 6 \$; Kirk.kok. ptk-s. 2008, liite VI-D 3.

284 Kirk.kok. kptk-s. 2008, 6 \$; Kirk.kok. ptk-s. 2008, liite VI-D 3.

285 KKHA KKA Valiokuntien ptk:t 2008-12 Talousvaliokunta ptk. 27.3.2009 $\$ 3$, ptk. 25.9.2009 \$2, ptk. 23.10.2009\$2.

286 Kirk.kok. kptk-k. 2010, 15 \$, 42 \$.

287 Kirk.kok. kptk-k. 2010, $42 \$$.

288 Kirk.kok. kptk-k. 2010, $44 \S$.

289 KKHA KKA Cc kevät $2010 \$ 44$.

290 Kirk.kok. ptk-k. 2008, liite IX-C 2; Kirk.kok. ptk-k. 2009, liite VII-D 2

291 Kirk.kok. kptk-k. 2009, 15 \$; Kirk.kok. ptk-s. 2010, liite VI-E 5; Kirk.kok. ptks. 2011, liite V-D 4.

292 Kirk.kok. ptk-s. 2011, liite V-D 4.

293 Kirk.kok. kptk-s. 2008, $27 \$$.

294 Jyränki 2006, 82.

295 Kirk.kok. kptk-s. 2009, 8 \$.

296 Kmaa 19.5.200o Leena Rantanen kirkon keskusrahaston johtoon (Juliska Lehtinen).

297 Kirk.kok. ptk-s. 2000, liite VII-E 4.

298 Kirk.kok. kptk-s. 2000, 24 \$.

299 SEK 2000-03, 290.

300 Kirk.kok. kptk-k. 2001,39\$.

301 Kirk.kok. ptk-k. 2002, liite IV 7 \& XI-C 4; SEK 2004-07, 362.

302 Kirk.kok. ptk-k. 2003, liite III 9; Kirk.kok. ptk-s. 2003, 52 \$, liite VII-D 5; SEK 2000-03, $291 \&$ 2004-07, 362-363.

303 Kirk.kok. kptk-s. 2002, 32 \$.

304 Kirk.kok. ptk-s. 2011, liite V-D 4

305 SEK 2008-11, 337-338.

306 Kirk.kok. ptk-s. 2011, liite III 11 \& V-D 4.

307 Kirk.kok. kptk-s. 2011, 30 §.

308 Kirk.kok. kptk-s. 2010, $9 \$$.

309 Kirk.kok. ptk-k. 2011, liite III 10.

310 Kirk.kok. kptk-s. 2011, 30 \$, 36 \$; Kirk.kok. ptk-s. 2011, liite V-D 5.

311 Kirk.kok. ptk-s. 2011, liite III 11.

312 Kirk.kok. ptk-k. 2001, liite IV 1.

313 Kirk.kok. kptk-k. 2006, 7 \$; Kirk.kok. ptk-k. 2006, liite VII-E 1.

314 SEK 2004-07, 48-49.

315 Kirk.kok. kptk-k. 2006, 7 \$; Kirk.kok. ptk-k. 2007, liite III 3.

316 Kirk.kok. ptk-k. 2007, liite III 3, 3, 10; SEK 2004-07, 365.

317 Kirk.kok. kptk-k. 2007,17 \$.

318 Kirk.kok. kptk-k. 2007, 17 \$; Kirk.kok. ptk-s. 2007, 18 \$, liite II 8, 5 \& VI-C 5.

319 Kirk.kok. ptk-k. 2011, liite VIII-D 1.

320 SEK 2004-07,11.

321 Kirk.kok. kptk-k. 2007, 123; Kirk.kok. ptk-k. 2007, liite VI 1.

322 Kirk.kok. kptk-k. 2007, 26 \$; Kirk.kok. ptk-k. 2007, liite VI 1.

323 Kirk.kok. kptk-k. 2007, $26 \$$.

324 Kirk.kok. kptk-k. 2005, 29\$.

325 Kirk.kok. kptk-s. 2004, 15\$, 18 \$; Kirk.kok. kptk-k. 2005, 29 \$; Kirk.kok. kptkk. $2007,26 \$$.

326 Kirk.kok. ptk-k. 2007, 45 \$, liite VII-B 1.

327 Kirk.kok. kptk-s. 2008, 24 \$; Kiitollisuus, kunnioitus, kohtuus 2008.

328 Kirk.kok. kptk-s. 2010, 12 \$.

329 Kirk.kok. kptk-k. 2001, $41 \S$.

330 Kirk.kok. ptk-s. 2002, liite VIII-D 5.

331 Kirk.kok. ptk-k. 2001, liite IX 2.

332 Kirk.kok. kptk-k. 2001,31§.

333 Kirk.kok. kptk-k. 2001, 31 §.

334 Kirk.kok. ptk-k. 2001, liite X-F 2.

335 Kirk.kok. kptk-k. 2001, 31 \$.

336 Kirk.kok. kptk-k. 2002, $10 \$$.

337 Kirk.kok. ptk-k. 2002, liite IV 2; Kirk.kok. ptk-s. 2008, liite II 9, 15.

338 Kirk.kok. kptk-k. 2002, 11 \$; Kirk.kok. kptk-s. 2002, 30 \$; Kirk.kok. ptk-s. 2002, liite VIII-D 3.

339 Kirk.kok. kptk-k. 2002, 10 \$.

340 Kirk.kok. ptk-k. 2002, liite IV 1, 28-29. 
341 Kirk.kok. kptk-k. 2002,10 \$.

342 Kirk.kok. ptk-s. 2002, liite VIII-D 5; Kirk.kok. kptk-s. 2002, $24 \$$.

343 Kirk.kok. kptk-k. 2001, 7 \$; Kirk.kok. kptk-k. 2002, 10 \$.

344 Kirk.kok. kptk-k. 2002,10\$.

345 Kirk.kok. kptk-k. 2002, $10 \$$.

346 Kirk.kok. ptk-s. 2002, liite VIII-D 5.

347 Kirk.kok. kptk-s. 2002, $24 \$$.

348 Kirk.kok. ptk-s. 2002, liite VIII-D 5.

349 Kirk.kok. kptk-k. 2002, 10 \$; Kirk.kok. ptk-k. 2002, liite IV 1,33-34, 43 d; Kirk. kok. kptk-s. 2002, 24 \$; Kirk.kok. ptk-s. 2002, liite VIII-D 5.

350 Kirk.kok. kptk-k. 2002, 10 \$; Kirk.kok. ptk-k. 2002, liite IV 1,33-34; Kirk.kok. kptk-s. 2002, 24 \$; Kirk.kok. ptk-s. 2002, liite VIII-D 5.

351 Kirk.kok. kptk-s. 2002, $24 \$$.

352 Kirk.kok. kptk-s. 2002, 24 \$.

353 Kirk.kok. kptk-s. 2002, $24 \$$.

354 KKHA KKA Cc syksy $2002 \$ 24$.

355 Länsi-Uusimaa 8.11.2002 Pari sanaa: Kirkko hylkäsi maaseudun (Erja Hinkkanen).

356 Kirk.kok. ptk-k. 2001, liite III 1, 1, 6-7.

357 Kirk.kok. kptk-k. 2001,7 \$; Kirk.kok. ptk-k. 2001, liite III 1, 1, 6-7.

358 Kirk.kok. ptk-k. 2001, liite III 1, 1, 22.

359 Kirk.kok. ptk-k. 2001, liite III 1, 1,10, 12.

360 Kirk.kok. ptk-k. 2001, liite III 1, 2, 22.

361 Kirk.kok. kptk-k. 2001,7\$.

362 Kirk.kok. ptk-s. 2002, liite VIII-D 1, 4.

363 Kirk.kok. ptk-s. 2002, liite VIII-D 1, 4-5; Elonheimo 2006, 158.

364 Kirk.kok. kptk-s. 2002, 21 \$; Elonheimo 2006, 159-160.

365 Kirk.kok. ptk-k. 2002, liite III 2, 6; Kirk.kok. ptk-s. 2002, liite VIII-D 1, 7.

366 KKHA KKA Valiokuntien ptk:t 200o-03 Hallintovaliokunta ptk. 7.11.2001 klo $19.15 \S 2$; Kirk.kok. ptk-s. 2002, liite VIII-D 1, 5, 7-8; Elonheimo 2006, 158.

367 Kirk.kok. kptk-s. 2002, 21 \$.

368 Kirk.kok. kptk-s. 2002, $21 \S$.

369 Kirk.kok. kptk-s. 2002, 21 \$.

370 Kirk.kok. kptk-s. 2002, $21 \S$.

371 Kirk.kok. kptk-s. 2002, $23 \$$.

372 Kirk.kok. kptk-s. 2002, $21 \$, 23 \$$.

373 Kirk.kok. kptk-s. 2002, 23 \$.

374 Kirk.kok. kptk-s. 2002, 23 \$.

375 Kirk.kok. kptk-s. 2002, $23 \$$.

376 KKHA KKA Cc syksy $2002 \$ 23$.

377 Kirk.kok. ptk-k. 2002, liite III 2, 1.

378 Kirk.kok. kptk-s. 2002, $21 \S$.

379 Kirk.kok. kptk-k. 2006, 31 \$; Kirk.kok. kptk-k. 2009, 32 \$; Kirk.kok. kptk-k. 2010, 49 \$; Kmaa 12.10.2006 Hiippakuntavaltuustoille ei löydy yhtenäistä roolia (Juliska Lehtinen), 7.2.2008 Hiippakuntavaltuuston rooli epäselvä (Juliska Lehtinen); Elonheimo 2006, 163.

380 Kirk.kok. kptk-s. 2005, 26 \$; Kirk.kok. ptk-s. 2005, liite VII-C 6; Kirk.kok. kptk-s. 2006, $24 \S$.

381 Kirk.kok. ptk-s. 2010, 14-15 §.

382 Lalli 5.2.1998 Arkkipiispasta postiäänestys! (pääk.); Ksml 10.4.1998 Arkkipiispa koko kirkon valinnaksi (pääk.); Il 2.6.1998 Arkkipiispan vaalitapa muutettava (pääk.); Knen 8.8.1998 Arkkipiispan vaalitapa antaa aihetta ajatuksiin (pääk.); Länsi-Savo 15.8.1998 Arkkipiispa kuuluu koko kirkolle (pääk.); TS 19.8.1998 Kansankirkon arkkipiispan valinta liian harvain vallassa (pääk.); Hämeen Sanomat 20.8.1998 Arkkipiispan vaalia tulisi nopeasti uudistaa (pääk.); Ilkka 21.8.1998 Arkkipiispan valinta pitäisi siirtää kirkolliskokoukselle (pääk.); Kymen Sanomat 23.8.1998 Arkkipiispan vaalitapa ajan tasalle (pääk.); Ksml 18.9.1998 Arkkipiispuus on uudistettava (pääk.).

383 Kirk.kok. ptk-k. 1999, liite VI 9.

384 Kirk.kok. ptk-s. 2003, $38 \$, 49 \$$, liite VII-A 6; SEK 2000-03, 75.

385 Kirk.kok. ptk-s. 2001, liite III 7,5.

386 Kirk.kok. ptk-s. 2001, liite III 7, 32; SEK 2000-03, 69

387 Kirk.kok. ptk-s. 2001, liite III 7, 1, 32; SEK 2000-03, 69-70.

388 Kirk.kok. ptk-s. 2002, liite VIII-D 2, 7-8.

389 Kirk.kok. ptk-s. 2002, liite VIII-D 2, 8-9.

390 Kirk.kok. kptk-s. 2002, 40 \$.

391 Kirk.kok. ptk-s. 2002, $40 \$$.

392 KKHA KKA Cc syksy $2002 \$ 40$.
393 Kirk.kok. ptk-k. 2007, 39 \$, liite VII-F 3; Kirk.kok. ptk-k. 2008, 59 \$, liite IX-D 1.

394 Kirk.kok. ptk-s. 2003, liite IV 1; Kirk.kok. ptk-s. 2003, liite VII-A 7; Kirk.kok. ptk-k. 2004, liite IV 1.

395 Kirk.kok. kptk-k. 2001,33\$.

396 Kirk.kok. ptk-k. 2000, liite VIII 4 \& 9.

397 Kirk.kok. kptk-k. 2000, 45 \$; Kirk.kok. ptk-s. 2000, liite VII-D 2.

398 Kirk.kok. kptk-k. 2000, 55 \$; Kirk.kok. kptk-s. 2000, 33 \$.

399 Kirk.kok. ptk-k. 2002, liite IV 4; Kirk.kok. ptk-s. 2002, liite VIII-D 6.

400 Kirk.kok. kptk-s. 2002,34\$.

401 Kirk.kok. ptk-s. 2002, $46 \$$.

402 Kirk.kok. ptk-k. 2006, liite V 2.

403 Kirk.kok. ptk-k. 2006, liite VII-D 1.

404 Kirk.kok. ptk-k. 2006, 40 \$.

405 Kirk.kok. ptk-k. 2006, liite VI 2.

406 Kirk.kok. ptk-k. 2006, liite VI 3.

407 Kirk.kok. kptk-k. 2006, 17-18 \$; Kirk.kok. kptk-s. 2006, 19 \$.

408 Kirk.kok. kptk-s. 2006, 19 \$; Kirk.kok. ptk-s. 2006, liite IX-C 5.

409 Kirk.kok. kptk-k. 2006, 17\$.

410 Kirk.kok. ptk-k. 2007, liite VII-F 1.

411 Kirk.kok. kptk-k. 2007, 29 \$.

412 Kirk.kok. kptk-k. 2006, 17 \$; Kirk.kok. kptk-k. 2007, 29 \$.

413 Kirk.kok. kptk-k. 2007, 29\$.

414 Kirk.kok. kptk-k. 2009, 6 \$; Kirk.kok. ptk-k. 2009, liite II 1, 1, 17.

415 Kmaa 21.2.2008 Kotimaa tavoitti kaikki uudet kirkolliskokousedustajat: Homopareille ei siunaamiskaavaa (Johannes Ijäs).

416 Kirk.kok. kptk-k. 2009, 6 \$.

417 Kirk.kok. kptk-k. 2010, 40 \$; Kirk.kok. ptk-k. 2010, liite VIII-C 1.

418 Kirk.kok. ptk-k. 2011, liite III 6, 1, 11-12.

419 Kirk.kok. kptk-k. 2011,13\$.

420 Kirk.kok. ptk-s. 2011, liite V-B 5.

421 Kirk.kok. kptk-s. 2011, 15 \$.

422 Kirk.kok. ptk-s. 2011, liite V-B 5.

423 Kirk.kok. kptk-s. 2011, $15 \$$.

424 Kirk.kok. kptk-s. 2011, 22 \$.

425 Kirk.kok. kptk-k. 2000, 18 \$; Kirk.kok. kptk-k. 2001, 60 \$; Kirk.kok. ptk-k. 2001, liite X-A 1.

426 Hentilä 2008, 152, 167.

427 Kirk.kok. kptk-k. 2001, 60-61 \$; Junttila-Rantanen 2003, 146.

428 KKHA KKA Cc kevät $2001 \$ 60$; Tuomala 2013, 80, 85.

429 Kirk.kok. ptk-k. 2001, liite IV 1.

430 Kirk.kok. ptk-k. 2001, liite IX 8.

431 Kirk.kok. kptk-k. 2001,37\$.

432 Kirk.kok. ptk-s. 2001, 41 \$, liite VIII-E 15.

433 Ripatin ohella komiteaan kuuluivat dosentti Risto A. Ahonen, diplomiurkuri, musiikin maisteri Marjukka Andersson, diakoni, yhteiskuntatieteiden maisteri Jukka-Pekka Fabrin, pastori, diakonissa Raija Ikonen, dosentti Yngvill Martola, pääsihteeri Ouri Mattila, nuorisotyönohjaaja Risto Rasimus, uskonnon lehtori Salme Savo ja dosentti Seppo Suokunnas. Komitea kutsui sihteerikseen teologian tohtori Matti Revon.

434 Kirk.kok. ptk-y. 2000, 22 \$.

435 PV 2002, 19-20.

436 KKHA KKA Vrk muistio 27.4.2000, muistio 10.10.2000.

437 KKHA KKA Vrk muistio 10.10.2000 $\$ 4$.

438 Kirk.kok. kptk-s. 2001, 21 \$; Kirk.kok. ptk-k. 2002, liite III 3, 19.

$439 P V$ 2002, 137, 140, 145.

440 KKHA KKA Vrk Marjukka Andersson Ouri Mattilalle 29.4.2002.

441 KKHA KKA Vrk Simo Peura Jaakko Ripatille ja Matti Revolle 6.6.2002.

442 PV 2002, 4, 110-118, 145.

443 PV 2002, 161, 163-164.

444 PV 2002, 169, 177

445 Kirk.kok. kptk-k. 2003, 47 \$.

446 Kirk.kok. kptk-s. 2002, 37 \$.

447 Kirk.kok. ptk-k. 2003, liite VIII-B 1.

448 Piisp.kok. ptk-y. 2003, 5 \$; Kirk.kok. ptk-k. 2003, liite II 1, 4-5.

449 Kirk.kok. kptk-s. 2002,37\$.

450 Kirk.kok. kptk-k. 2003, 47 \$

451 Kirk.kok. ptk-k. 2003, liite II 1, 4-5, 9 \& VIII-B 1; Kirk.kok. ptk-s. 2003, liite VII-B 3,7 .

452 Kirk.kok. kptk-s. 2002,37\$. 
453 Kirk.kok. kptk-k. 2003, 47 \$; Kirk.kok. ptk-k. 2003, liite VIII-B 1.

454 PV 2002, 138; Kirk.kok. ptk-k. 2003, liite II 1, 8-9.

455 Kirk.kok. kptk-s. 2002, 37 \$; Kirk.kok. kptk-s. 2003,14\$.

456 HS 20.11.2002 Kanttorit pysykööt kanttoreina (Heikki Poutanen), 24.11.2002 Kanttorit tietenkin pysyvät kanttoreina (Hannu Vapaavuori), 29.11.2002 Kanttori pysyköön maallikkona (Matti Vainio).

457 Kirk.kok. kptk-s. 2002,37\$.

458 Kirk.kok. ptk-k. 2003, liite II 1, 8.

459 Kirk.kok. kptk-k. 2003, $47 \$$.

460 Kirk.kok. kptk-s. 2002,37\$.

461 Kirk.kok. ptk-k. 2003, liite II 1, 11.

462 Kirk.kok. kptk-s. 2003, 14 \$.

463 Kirk.kok. kptk-k. 2003, 47 \$.

464 Kirk.kok. ptk-s. 2003, liite VII-B 3, 8-9, 11-15.

465 Kirk.kok. ptk-s. 2003, liite VII-B 3, 7, 17-18; Saraja 2009, 88.

$466 \mathrm{Kmaa}$ 7.11.2003 Kirkon viran uudistaminen palasi lähtökuoppiin (Juliska Lehtinen).

467 Kirk.kok. kptk-s. 2003, 15\$, 47\$.

468 KKHA KKA Vrk muistio 8.2.2002 \$ 6; Kirk.kok. kptk-k. 2003, 47 \$; Kirk. kok. kptk-s. 2003, 14 \$; Kirk.kok. ptk-s. 2003, liite VII-B 3, 7.

469 Kirk.kok. kptk-s. 2003,14\$.

470 Kirk.kok. ptk-k. 2005, liite V 3.

471 Kirk.kok. kptk-k. 2005, 23\$,53\$.

472 Kirk.kok. kptk-k. 2007,19 \$; Saraja 2009, 97-98.

473 Kirk.kok. ptk-k. 2011, liite III 2; Rusama 2012, 610.

474 KKHA KKA Valiokuntien ptk:t 2008-12 Perustevaliokunta ptk. 5.9.2011 2; Kirk.kok. kptk-k. 2011, 8 \$; Kirk.kok. ptk-k. 2011, liite III 2; Kirk.kok. ptk-s. 2011, $32 \S$, liite V-B 6.

475 Kirk.kok. kptk-s. 2002,37\$.

476 Komitean muut jäsenet olivat professori Fredric Cleve, teologian tohtori Suvi-Päivi Koski, kirkkoherra Jukka Lehtinen, kirkkoherra Tapio Leinonen, rovasti Niilo Rauhala, teologian tohtori Riitta Särkiö, kanttori Teija Tuukkanen ja diplomiurkuri, pastori Osmo Vatanen. Komitean jaostoissa oli mukana lisäksi lukuisia muita henkilöitä. Sihteerinä toimivat vuorollaan pastori, sittemmin kirkkoherra Pentti Miettinen, teologian tohtori Johanna Räsänen ja lääninrovasti Timo Komulainen. Käsikirjakomitean ehdotus 2001b, 1-2.

477 Kirk.kok. ptk-k. 2001, liite IV 1; SEK 2000-03, 103, 123; Niemelä 2003C, 179184.

478 Kirk.kok. ptk-k. 2001, liite VI 1; Käsikirjakomitean ehdotus 2001b, 2-3.

479 Kirk.kok. kptk-s. 2000, 12 \$.

480 SEK 2000-03,107.

481 Handbokskommitténs förslag 2001a \& 2001b; Käsikirjakomitean ehdotus 2001a \& 2001b.

$482 J K J$ 1992, 124.

483 Käsikirjakomitean ehdotus 2001b, 8-9; SEK 2000-03, 106.

484 Kirk.kok. kptk-s. 2001, 21 \$.

485 Kirk.kok. ptk-k. 2002, liite III 3, 4 \& V 1.

486 Kirk.kok. ptk-k. 2003, liite VIII-C 1.1, 4 .

487 KKHA KKA Kkvk ptk. 13.5.2002 \$2, raamattujaoston kokousmuistio 25.10.2002; Kirk.kok. kptk-k. 2003, 39 \$; Kirk.kok. ptk-k. 2003, liite VIII-C $1.1,7$.

488 KKHA KKA Kkvk ptk. 23.8.2002 $\$ 60$, ptk. 24.-25.9.2002 $\$ 68$, ptk. 17.10.2002 $\$ 77$, ptk. 13.6.2003 $\$ 74$, ptk. 25.-26.9.2003 \$109, $\$ 111$.

489 Kirk.kok. kptk-k. 2003,39 \$.

490 Kirk.kok. kptk-s. 2001, 21 \$; Kirk.kok. kptk-k. 2003, 41 \$.

491 Kirk.kok. kptk-s. 2001, 21 \$.

492 Kirk.kok. kptk-s. 2001, 21 \$; Hytönen 2005, 84.

493 Käsikirjakomitean ehdotus 2001b, 21.

494 Yli-Opas 2010, 235.

495 Changing Values 2008, 238.

496 KKHA KKA Kkvk ptk. 11.-12.3.2003 $\$ 36$, ptk. 3.4.2003 $\$ 46$, rakennejaoston kokousmuistio 3.4.2003\$4; Kirk.kok. ptk-k. 2003, liite VIII-C 1.1, 7-8; Kirk.kok. kptk-s. 2003, $15 \$$.

497 KKHA KKA Kkvk ptk. 13.5.2002 \$2; Kirk.kok. ptk-k. 2003, liite VIII-C 1.1, 4; Hytönen 2005, 114, 255-256.

498 Kirk.kok. ptk-k. 2002, liite III 3, 9; Kirk.kok. ptk-k. 2003, liite VIII-C 1.1, 5.

499 Kirk.kok. kptk-k. 2003,39 \$, 41 \$.

500 Kirk.kok. kptk-k. 2003, 39\$, $41 \S$.

501 KKHA KKA Kkvk ptk. 11.-12.3.2003 \$34; Kirk.kok. kptk-k. 2003,39 \$; Kirk. kok. ptk-k. 2003, liite VIII-C 1.1, 10.

502 Kirk.kok. ptk-k. 2003, liite VIII-C 1.1, liite: eriävä mielipide.

503 Kirk.kok. kptk-k. 2003, 39\$, 41\$.

504 Kirk.kok. kptk-s. 2001, 21 \$.

505 KKHA KKA Kkvk rakennejaoston puhelinkokouksen muistio 10.5.2002 $\$ 7$; Kirk.kok. ptk-k. 2003, liite VIII-C 1.1, 9.

506 Kirk.kok. kptk-k. 2003,39\$.

507 Käsikirjakomitean ehdotus 2001b, 11.

508 Kirk.kok. ptk-k. 2002, liite III 3, 7.

509 Kirk.kok. kptk-s. 2001, 21 §.

510 Kirk.kok. ptk-k. 2003, liite VIII-C 1.1, 6; Kirk.kok. kptk-s. 2003, $15 \$$.

511 Kirk.kok. kptk-k. 2003, 41 \$, 65\$; Kirk.kok. ptk-k. 2003, liite VIII-C 1.1. a.

512 Kirk.kok. kptk-s. 2004, 15 \$; Kirk.kok. ptk-k. 2005, liite VI-E 1.

513 Kirk.kok. ptk-k. 2008, liite VIII 9; Kirk.kok. ptk-k. 2008, 42 \$, liite VII-B 1.

514 Kirk.kok. ptk-s. 2002, liite VIII-F 1; Esim. Nya testamentet 1981, Matteusevangeliet 28:19, Andra Korinthierbrevet 13:13.

515 Käsikirjakomitean perustelut 1997, 155-156.

516 Kirk.kok. kptk-s. 1998, 29 \$; Kirk.kok. ptk-s. 1998, liite X-D 3.

517 Kirk.kok. ptk-k. 1999, liite VIII-C perustelut.

518 Kirk.kok. kptk-s. 1999, 27 \$; Kirk.kok. ptk-s. 1999, liite II 2.

$519 \mathrm{Hbl}_{30.1 .2001}$ Den helige Ande eller den heliga Anden? (Birgitta Jernvall Ingman).

520 Kirk.kok. ptk-s. 2000, liite II 1.

521 Kirk.kok. kptk-s. 2000, $6 \$, 46 \$$.

522 Kirk.kok. kptk-s. 2000, 46 \$; Kirk.kok. ptk-s. 2000, liite VII-C 3.

523 Kirk.kok. ptk-s. 200o, $46 \$$.

524 KKHA KKA Cc syksy $2000 \$ 46$.

525 Kirk.kok. kptk-s. 2000, $49 \$$.

526 KKHA KKA Cc syksy $2000 \$ 49$.

527 Kirk.kok. ptk-k. 2001, liite VIII 5; ; Hbl 30.1.2001 Den helige Ande eller den heliga Anden? (Birgitta Jernvall Ingman).

528 Kirk.kok. ptk-s. 2002, liite VIII-F 1.

529 Hbl 23.3.2001 Biskopens oförstånd (Johanna Westman, ledare).

$530 \mathrm{Hbl}$ 24.3.2001 Biskop Erik Vikström: Jag skäms för mitt stift (Lena Skogberg).

531 Kirk.kok. ptk-k. 2001, liite VIII 5.

532 Handbokskommitténs förslag $2001 \mathrm{~b}$.

533 Kirk.kok. kptk-k. 2001, 21 \$.

534 Kirk.kok. kptk-k. 2002,37\$.

535 Kirk.kok. kptk-k. 2001, 21 \$; Kirk.kok. kptk-k. 2002,37\$.

536 "Ledamot Kippos exempel från Nedervetil är ett bra exempel på hur långt Henrik Perret's propaganda har nått." Kirk.kok. kptk-k. 2002, 37 §.

537 Kirk.kok. kptk-k. 2001, 21 \$; Kirk.kok. kptk-k. 2002,37\$.

538 Kirk.kok. ptk-s. 2002, liite VIII-F 1.

539 Kirk.kok. kptk-s. 2002, 41 \$; SEK 2000-03, 108-109.

540 Kirk.kok. kptk-s. 2002, 41 §.

541 KKHA KKA Cc kevät 2000 opetusministeriön tervehdys kirkolliskokouksessa 8.5.2000.

542 Kirk.kok. ptk-k. 2005, liite VI-E 1, liite: hallintovaliokunnan lausunto; Kirk. kok. kptk-k. 2006, 28 \$.

543 Kirk.kok. ptk-s. 2010, liite VI-F 5.

544 Esim. Kirk.kok. kptk-k. 2005, 37 \$.

545 Leino 2002, 17-18, 164, 324; Heikkilä 2003, 201.

546 Leino 2002, 196-197.

547 Kirk.kok. ptk-s. 2003, liite III 13.

548 Kirk.kok. ptk-s. 2004, liite V-A 4, 6, 8-9.

549 Kirk.kok. ptk-s. 2003, liite VII-A 10,3-5.

550 Kirk.kok. ptk-s. 2003, liite VII-A 10, 7-8.

551 Kirk.kok. kptk-s. 2003, $57 \$$.

552 Kirk.kok. kptk-s. 2003, 57 \$; Björkstrand 2012, 18-19.

553 Kirk.kok. kptk-s. 2003, 57 \$.

554 Kirk.kok. kptk-s. 2003, $57 \S$.

555 Kirk.kok. kptk-s. 2003, $60 \$$.

556 KKHA KKA Cc syksy $2003 \$ 60$.

557 Kirk.kok. ptk-k. 2004, liite III 1.

558 Kirk.kok. kptk-k. 2004, 21 \$; Kirk.kok. kptk-s. 2004, 31 §.

559 KKHA KKA Valiokuntien ptk:t 2004- Lakivaliokunta ptk. 13.9.2004 $\$$; Kirk.kok. ptk-s. 2004, liite V-A 4, 1.

560 Kirk.kok. kptk-s. 2004, 31 \$; Kirk.kok. ptk-s. 2004, liite V-A 4, 6, 8-9.

561 Kirk.kok. kptk-s. 2004, $31 \S$. 
562 Kirk.kok. kptk-s. 2004, 31 §.

563 Kirk.kok. kptk-s. 2004, 38 \$.

564 Kirk.kok. ptk-k. 2008, liite III 1.

565 Kirk.kok. ptk-k. 2008, liite VI-A 1; Kirk.kok. ptk-k. 2009, liite VII-A 1.

566 Kirk.kok. ptk-k. 2009, liite VII-A 1.

567 Kirk.kok. kptk-k. 2009,39\$.

568 Kirk.kok. kptk-k. 2009,39\$, 57\$; Keitanen 2012, 17.

569 Leino 2002, 275; Ekström 2003, 252-255.

570 Kirk.kok. kptk-k. 1990,1-4; Kettunen 2006, 526.

571 Kirk.kok. ptk-s. 1991, 23 \$, liite II 10, 93 \& VI-E 7; Kettunen 2006, 526.

572 Kirk.kok. ptk-k. 2000, 71 \$, liite VIII 10 \& IX-E 1; Kirk.kok. ptk-s. 2000, 24 $\S$, liite III 9, 100 \& VII-E 4; Kettunen 2006, 527, 529.

573 Kirk.kok. kptk-s. 1993, 21 \$; Kirk.kok. ptk-s. 1993, liite VII-D 9.

574 Kirk.kok. kptk-k. 2009, $59 \$$.

575 Kirk.kok. ptk-k. 2012, liite II 4; Kirk.kok. ptk-s. 2012, $28 \$, 38 \$$, liite VI-B 1.

576 Leino 2002, 200-201.

577 Kirk.kok. ptk-k. 2001, liite IX 3 \& 5 .

578 Kirk.kok. kptk-k. 2001,34\$.

579 Kirk.kok. ptk-k. 2001,70 \$, liite X-F 4.

580 Kirk.kok. ptk-s. 2002, liite III 8; Kirk.kok. ptk-k. 2003, 59 \$.

581 Kirk.kok. kptk-k. 2001,32 \$.

582 Kirk.kok. kptk-k. 2001, 7 \$; Kirk.kok. ptk-k. 2001, liite III 1, 1, 12.

583 Kirk.kok. kptk-k. 2001,7\$.

584 Kirk.kok. ptk-s. 2002, liite VIII-D 1, 11-12.

585 Kirk.kok. kptk-s. 2002, 21 \$.

586 Raiser 2004, 268.

587 Kirk.kok. ptk-k. 2010, liite II 2, 44-45; Koivisto 2011, 41.

588 Penttinen 2009, 78-79.

589 Kirk.kok. ptk-s. 2003, liite VII-B 2, 2-3.

590 SEK 2000-03, 37.

591 Kirk.kok. ptk-s. 2003, liite VII-B 2,3-4.

$592 K M$ 15.2.2002 Kirkko kieli keskellä suuta (pääk.); Länsi-Savo 15.2.2002 Kirkko kiemurtelee kuin mato koukussa; Pnen 20.2.2002 Parisuhdelaista kirkon ongelma, jos joku haluaa järjestää testin (Matti Kupari, pääk.); SK 22.2.2002 Pääkirjoitus.

593 Kirk.kok. ptk-k. 2002, liite $\mathrm{X}_{3}$ \& 4.

594 Kirk.kok. ptk-k. 2002, liite $\mathrm{X}_{3}$.

595 Ventä 2009, 113.

596 Hämeen Sanomat 9.4.2002 Kirkolliskokous ja perustuslaki (pääk.); HS 15.4.2002 Koskinen: Kirkonkin pitää noudattaa parisuhdelakia.

597 Kirk.kok. ptk-k. 2002, liite X 4.

598 Kirk.kok. kptk-k. 2002, 27 \$.

599 SEK 2000-03, 38-39; Kmaa 10.5.2002 Parisuhteen siunaamiseen suhtaudutaan penseästi (Juliska Lehtinen); Järvi 2007, 43.

600 SkK 14.5.2002 Kirkkoa uhkaa kahtiajako (pääk.); Smaa 14.5.2002 Kirkolla on pohdittavaa (pääk.); ES 15.5.2002 Homoliittoko kirkon tärkeimpiä arvokysymyksiä? (Esa Vilenius, pääk.); Ksml 15.5.2002 Kirkolta kaivataan avarakatseisuutta (pääk.); Pnen 17.5.2002 Kirkon pitkä mukautuminen parisuhdelakiin (Matti Kupari); TS 17.5.2002 Kirkko katsoo nyt omaan peiliinsä (Heikki Kauhanen); Hbl 18.5.2002 Kyrkan och de homosexuella (Ulrica Lövdahl).

601 Kirk.kok. kptk-k. 2002, $23 \$$.

602 Kirk.kok. kptk-k. 2002, 27 \$.

603 Kirk.kok. kptk-k. 2002, 27 \$.

604 Kirk.kok. kptk-k. 2002, 27\$, $29 \$$.

605 Kirk.kok. kptk-k. 2002, 27 \$.

606 Kirk.kok. kptk-k. 2002,27\$, $29 \$$.

607 Kirk.kok. kptk-k. 2002, $27 \S$.

608 Kirk.kok. kptk-k. 2002, $29 \$$.

609 Kirk.kok. kptk-k. 2002, 27\$, $29 \$$.

610 Kirk.kok. kptk-k. 2002, $29 \$$.

611 Kirk.kok. kptk-k. 2002, $29 \$$.

612 Kirk.kok. kptk-k. 2002, 27 \$.

613 Kejonen \& Hintsala 2013, 149-150.

614 KKHA KKA Valiokuntien ptk:t 2000-03 Perustevaliokunta ptk. 27.9.2002 $\$ 3$; Kirk.kok. ptk-s. 2003, liite VII-B 2, 1.

615 KKHA KKA Valiokuntien ptk:t 2000-03 Perustevaliokunta ptk. 28.2.2003 $\$ 6$.

616 Kirk.kok. ptk-s. 2003, liite VII-B 2, 5-9.

617 Kirk.kok. ptk-s. 2003, liite VII-B 2, 9, 12.
618 Kirk.kok. ptk-s. 2003, liite VII-B 2, eriävä mielipide.

619 Kmaa 10.10.2003 Kirkossa vallitsee erilaisia käsityksiä homoseksuaalisuudesta (Johannes Ijäs).

620 Kirk.kok. ptk-s. 2003, liite VII-B 2, 12.

621 Kirk.kok. ptk-s. 2003, liite VII-B 2, 11.

622 Kirk.kok. kptk-s. 2003, $21 \$, 26 \$$.

623 Kirk.kok. kptk-s. 2003, 26 \$.

624 Kirk.kok. kptk-s. 2003, $26 \$$.

625 Kirk.kok. kptk-s. 2003, $26 \$$.

626 HS 9.10.2003 Homoliitoista eripuraa kirkon sisällä (pääk.); Pnen 3.11.2003 Kansankirkko kulkee keskitietä (pääk.); Hämeen Sanomat 7.11.2003 Homoseksuaalisuus kirkolle vaikea pala (pääk.); Itä-Savo 9.11.2003 Kirkko pistää päänsä pensaaseen (Pauli Potinkara, pääk.).

627 Tuomiokapitulin perusteluista ks. Hirvonen 2004b, 470-476.

628 Saarinen 2005, 11, 112, 116.

629 Kirk.kok. ptk-s. 2003, liite VII-B 4, 4-5; SEK 200o-03, 65, 260-261.

630 Kmaa 21.9.2001 Valkealan kirkkoherraksi valittiin "vanhauskoinen" (Juliska Lehtinen), 5.10.2001 Keskustelun paikka: Esimieheni aikoo väistellä minua! (Minna Tanska), 12.10.2001 Keskustelun paikka: Valkealan vaalista (Petri Hiltunen); Kymen Sanomat 1.7.2002 Pappisnaiset jättävät Valkealan seurakunnan (Laila Sairo); ESS 6.7.2002 Naispappeudesta lihava riita Valkealassa (Mikko Knuuttila); Kouvolan Sanomat 6.7.2002 Kirkolliskokouksen nahkapäätös mahdollistaa erilaiset tulkinnat (pääk.); Kymen Sanomat 6.7.2002 Ylänurkka: Kirkkoherran paikka (Rain Kooli); SS 12.7.2002 Nainen joutuu yhä väistymään (pääk.); $A l$ 16.7.2002 Kirkkoministeri panisi seurakunnan paimeneksi pyrkivät tasa-arvotestiin (Riitta Järventie); HS 16.7.2002 Ryhdikäs kirkko panisi pisteen naisten sorrolle (pääk.); Hämeen Sanomat 17.7.2002 Tasa-arvo ei toteudu vieläkään seurakunnissa (pääk.); TS 17.7.2002 Naispapeilta puuttuu yhä todellinen tasa-arvo kirkossa (pääk.); PS 19.7.2002 Pimeyttä Valkealassa (pääk.); Ilkka 20.7.2002 Kanta naispappeuteen tiedoksi etukäteen (pääk.); Hbl 22.7.2002 Kvinnliga präster är skyddslösa (Ann-Gerd Steinby); ESS 28.7.2002 Naispapit hyväksytään (pääk.); $S k K$ 28.7.2002 Kirkkoherraehdokkaan kerrottava periaatteensa (pääk.); Kouvolan Sanomat 30.7.2002 Valkealan seurakunnasta on eronnut jo 53 henkilöä (Katri Kupari); KS 25.8.2002 Kirkkoherran asema puntariin (pääk.); KS 3.9.2002 Naispappeusponnesta kiistellään jälleen; Ksml 26.9.2002 Kirkkoherralta odotetaan yhteistyökykyä (pääk.); Kouvolan Sanomat 21.3.2003 Tuomiokapitulin nahkapäätös jätti ongelmapesän ennalleen (pääk.); SS 23.3.2003 Tuomiokapituli teki merkittävän ratkaisun (pääk.); TS 23.3.2003 Naiset pappeina Suomessa jo 15 vuotta, mutta vastustus kytee yhä (pääk.); Iisalmen Sanomat 25.3.2003 Epätasa-arvon rippeet pois kirkosta (pääk.).

$631 A l$ 16.7.2002 Kirkkoministeri panisi seurakunnan paimeneksi pyrkivät tasa-arvotestiin (Riitta Järventie); Ilkka 7.11.2002 Dromberg: Kirkolla suuri merkitys arvoyhteisönä; Kmaa 8.11.2002 Uskonnonvapauslaki tulee voimaan ensi elokuussa (Juliska Lehtinen).

632 Kirk.kok. ptk-k. 2003, liite V 2 \& VII 6; SEK 2000-03, 80.

633 Kirk.kok. kptk-k. 2003, $22 \$$.

634 Kirk.kok. kptk-k. 2003, $22 \S$.

635 Kirk.kok. ptk-s. 2003, 44 \$, liite VII-B 4, 7-8.

636 Työn johtaminen 2006, 51-55, liite 1; H.-T. Nieminen 2008, 268-269.

637 SEK 2004-07, 308.

638 Kirk.kok. kptk-k. 2006, 1 \$.

639 Kirk.kok. kptk-k. 2006, 20 \$; Kirk.kok. ptk-k. 2006, liite VI 5.

640 Kirk.kok. kptk-k. 2006, 20\$, $22 \$$.

641 Kirk.kok. kptk-k. 2006, 45 \$.

642 Kirk.kok. kptk-k. 2006, $22 \$$.

643 Kirk.kok. ptk-s. 2006, liite VII 1; H.-T. Nieminen 2008, 270.

644 Kirk.kok. kptk-k. 2006, $22 \$$.

645 Kirk.kok. ptk-s. 2006, liite II 2, osa A; Leino 2002, 300-301.

646 Kirk.kok. ptk-s. 2007, liite VI-A 4, 6; Kirk.kok. ptk-s. 2008, liite II 5, 15.

647 Kirk.kok. ptk-s. 2006, liite II 2, osa A.

648 Kirk.kok. kptk-s. 2006, 9 \$; Kirk.kok. kptk-k. 2007, 8 \$; Kirk.kok. kptk-s. 2007, $16 \$$.

649 HS 17.1.2007 Naispappien syrjintää ei saa sietää (pääk.); Il 17.1.2007 Kirkossa lisää jännitteitä (pääk.); HS 20.1.2007 Naispappien syrjintää kirkossa ei saa sietää (Jukka Paarma); Il 26.3.2007 Kiista naispapeista kärjistyi yhä (pääk.); SS 26.3.2007 Pieni äänekäs joukko (pääk.); HS 27.3.2007 Älkää vaietko seurakunnissa (pääk.); Uusimaa 28.3.2007 Naispappien syrjinnälle on saatava loppu (pääk.); SK 30.3.2007 Jälkiruokanen (Tapa- 
ni Ruokanen); HS 6.4.2007 Kiista naispappeudesta koettelee kirkon ykseyttä (Eero Huovinen); Uusimaa 6.4.2007 Arkkipiispa otti tiukan kannan (pääk.); Ksml 10.4.2007 Kansanliike syntyy, jos kirkko ei ryhdistäydy (pääk.); Kouvolan Sanomat 26.11.2007 (pääk.).

650 Kirk.kok. kptk-s. 2006, 9 \$; Kirk.kok. kptk-k. 2007, 8 \$.

651 Kirk.kok. kptk-s. 2006, 9 \$; Kirk.kok. kptk-k. 2007, 8 \$; Kirk.kok. kptk-s. 2007, $16 \$$.

652 Kirk.kok. ptk-s. 2007, liite VI-A 4, 34.

653 Kirk.kok. ptk-s. 2007, liite VI-A 4, 3.

654 Kirk.kok. kptk-s. 2007, 16 \$; Kirk.kok. ptk-s. 2007, liite VI-A 4, 9.

655 Kirk.kok. kptk-s. 2007, 16 \$; Kirk.kok. ptk-s. 2007, liite VI-A 4, liite: eriävä mielipide lakivaliokunnan mietintöön.

656 Kirk.kok. ptk-s. 2007, liite VI-A 4, 5, 7 .

657 Kirk.kok. kptk-s. 2007, $16 \$$.

658 KKHA KKA Cc syksy 2007 \$16; Kirk.kok. ptk-s. 2007, liite VI-A 4 a.

659 Kirk.kok. kptk-s. 2007, $25 \$$.

660 KKHA KKA Cc syksy $2007 \$ 25$.

661 Kirk.kok. kptk-s. 2006, $9 \$$.

$662 K m a a$ 15.11.2007 Kirkon työlainsäädäntö jäi rempalleen (Ulla Lötjönen).

663 Kirk.kok. ptk-s. 2008, liite II 5, 19.

664 Kirk.kok. kptk-s. 2008, 22 §.

665 Kirk.kok. ptk-s. 2009, liite VI-A 2, 3, 7-8, eriävä mielipide lakivaliokunnan mietintöön 2/2009.

666 Kirk.kok. ptk-s. 2009, liite VI-A 2, 9-10.

667 Kirk.kok. kptk-s. 2008, 22 \$; Kirk.kok. kptk-s. 2009, 20 \$.

668 Kirk.kok. kptk-s. 2009, $20 \$, 22 \S, 42 \S$.

669 Vp. ak. E 2009, lakialoite 31.

670 SEK 2008-11, 24-25; HS 30.10.2010 Kirkkokansa ojentaisi käden vähemmistöille (pääk.), Yli puolet sallisi homoparien avioliittoon vihkimisen (Piia Elonen), Kirkon nykylinja ei tyydytä (Piia Elonen \& Marja Hannula).

671 SEK 2008-11, 27, 381; HS 30.10.2010 Kirkkokansa ojentaisi käden vähemmistöille (pääk.), Yli puolet sallisi homoparien avioliittoon vihkimisen (Piia Elonen), Kirkon nykylinja ei tyydytä (Piia Elonen \& Marja Hannula).

672 Kirk.kok. ptk-k. 2010, liite II 2, 46-47; Koivisto 2011, 39, 45, 48-49.

673 Kirk.kok. ptk-k. 2010, liite II 2, 46-47.

674 Homoseksuaalisuus Raamatussa ja kirkon opetuksessa 2007; Homoseksuaalisuus kristillisessä ihmiskuvassa ja lainsäädännössä 2009; Kirkko ja rekisteröidyt parisuhteet 2009.

675 Hämeen Sanomat 7.2.2007 Alanurkka: Kirkko nosti päänsä puskasta (Riikka Happonen); Kaleva 10.2.2007 Kirkko väisti vielä miinan (pääk.); Pnen 1.9.2008 Kipeä parisuhde kirkolle (pääk.); Hbl 30.9.2008 Präst fick välsigna kvinnopar (Julia Wiræus); HS 30.9.2008 Kirkko hyväksyi rukoushetken naisparin puolesta (Markus Myllyoja); Hämeen Sanomat 30.9.2008 Homoparin siunanneesta papista tehdyt kantelut kaatuivat; Ilkka 30.9.2008 Papista tehdyt kantelut kaatuivat; Knen 30.9.2008 Kantelut homoparin siunauksesta kaatuivat; $L K$ 30.9.2008 Homoparin siunanneesta papista tehdyt kantelut nurin; Ksml 30.9.2008 Homoparin siunaamisesta tehdyt kantelut kaatuivat; Metro 30.9.2008 Homoparin siunannut pappi välttyi moitteilta; TS 30.9.2008 Homoparin siunanneesta papista tehdyt kantelut kaatuivat; Pnen 1.10.2008 Tuomiokapituli ei hirttäytynyt (pääk.).

676 Ventä 2009, 119.

677 TS 9.10.2008 Evankelisluterilaisen kirkon piispojen rivit rakoilevat (Anne Savolainen), 2.11.2008 Yhteiskunnan vaatimukset syövät ihmisten voimavarat (Anne Savolainen); Mustakallio 2012d, 583-584.

678 Kirk.kok. ptk-k. 2010, liite II 2, 76.

679 Kirk.kok. ptk-k. 2010, liite II 2,70.

680 Kirk.kok. ptk-k. 2010, liite II 2, 70, 76.

681 Kirk.kok. kptk-k. 2010,17\$, 27\$, 32 \$.

682 Ks. Kirk.kok. ptk-k. 2010, liite II 2, 44-45; Koivisto 2011, 40-41.

683 Kirk.kok. kptk-k. 2010,17 \$. Kursivointi tekijän.

684 Kirk.kok. kptk-k. 2010, $32 \S$.

685 KKHA KKA Valiokuntien ptk:t 2008-12 Perustevaliokunta ptk. 23.8.2010 $\$ 2$.

686 HS 17.10.2010 Arkkipiispa: Tv-ohjelman kuva kirkosta ei todellinen (Marjukka Liiten).

687 Kmaa 28.10.2010 Rukouksen toteutumiselle tukea (Taneli Kylätasku); HS 31.10.2010 Kirkon homolinja on horjuva (Katja Kuokkanen), 6.11.2010 Kirkon kanta homopareihin ratkeaa pian (Katja Kuokkanen).

688 Näin esimerkiksi Helsingin Sanomat. HS 9.11.2010 Arkkipiispa haluaa selvän homokannan (Mikko Välimaa), 11.11.2010 Kanta homopareihin vielä avoin (Janne Toivonen), 12.11.2010 Puhetulva masensi Turussa (Janne Toivonen), 13.11.2010 Kirkko tunnusti homoparien olemassaolon (Janne Toivonen), 14.11.2010 Kirkolliskokous löysi keskitien ratkaisun (pääk.), Maan pinnalta: Terveisiä kirkolliskokouksesta (Janne Toivonen).

689 Kirk.kok. kptk-s. 2010,1 \$.

690 Suomen ev.lut. kirkko: Uutiset 8.11.2010 Kulttuuri- ja urheiluministeri Stefan Wallinin puhe kirkolliskokouksessa. <http://evl.fi/EVLUu-

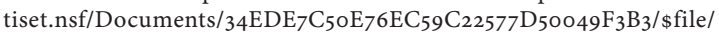
kirkolliskokouso81110\%5B1\%5D.doc >. Katsottu 8.11.2010.

691 Kirk.kok. ptk-s. 2010, liite VI-D 4, 5-6, 8.

692 Kirk.kok. ptk-s. 2010, liite VI-D 4, 9.

693 Kirk.kok. ptk-s. 2010, liite VI-D 4, 11

694 Kirk.kok. ptk-s. 2010, liite VI-D 4, 12-13.

695 KKHA KKA Valiokuntien ptk:t 2008-12 Perustevaliokunta ptk. 9.11.2010 klo $13.14 \$ 2$.

696 Kirk.kok. ptk-s. 2010, liite VI-D 4, 6.

697 Kirk.kok. kptk-s. 2010, 32 \$; Kmaa 19.11.2010 Parisuhderukous tuli kirkkoon (Jussi Rytkönen), Kolumni: Luottamusta tarjolla (Simo Peura).

698 Kirk.kok. ptk-s. 2010, liite VI-D 4, eriävä mielipide perustevaliokunnan mietintöön.

699 Kirk.kok. kptk-s. 2010, 32 \$.

700 Kirk.kok. ptk-s. 2010, 34 \$.

701 Kirk.kok. kptk-s. 2010, 32 \$.

$702 H S$ 14.11.2010 Kirkolliskokous löysi keskitien ratkaisun (pääk.).

703 KKHA KKA Valiokuntien ptk:t 2008-12 Perustevaliokunta ptk. 9.11.2010 klo $9.18 \$ 2$; Kirk.kok. ptk-s. 2010, liite VI-D 4, 12.

704 Kirk.kok. ptk-k. 2010, liite II 2,78.

705 Antila 2011, 350-357.

706 Kirk.kok. ptk-s. 2010, liite VI-D 4, 13.

707 Kirk.kok. kptk-s. 2010,32 \$.

708 KKHA KKA Cc syksy $2010 \$ 34$; Kotimaa24 16.11.2010 Vanhoillislestadiolaiset äänestivät rukouksen puolesta (Johannes Ijäs). <http://www.kotimaa24.fi/uutiset/841-vanhoillislestadiolaiset-aanestivat-rukouksenpuolesta $>$. Katsottu 17.11.2010.

709 Kirk.kok. kptk-s. 2010, 32 §.

710 Kmaa 7.1.2011 Lestadiolaiset pyysivät anteeksi äänestämistään (Johannes Ijäs); Kotimaa24 30.12.2010 Vanhoillislestadiolaisia edustajia pyytänyt anteeksi kirkolliskokousäänestystään (Johannes Ijäs). < http://www.kotimaa24.fi/uutiset/119o-vanhoillislestadiolaisia-edustajia-pyytanyt-anteeksi-kirkolliskokousaanestystaan>. Katsottu 30.12.2010; Kotimaa24 26.1.2011 Vanhoillislestadiolaiset puivat kirkolliskokousäänestystä (Johannes Ijäs) $<$ http://www.kotimaa24.fi/uutiset/kotimaa/1369-vanhoillislestadiolaisetpuivat-kirkolliskokousaanestysta $>$. Katsottu 26.1.2011.

711 Kirk.kok. ptk-s. 2001, liite III 9, 4.

712 Kirk.kok. ptk-s. 2001, liite VIII-E 15.

713 Kirk.kok. kptk-s. 2001, 41 \$.

714 Kirk.kok. kptk-s. 2001, 52 \$; Kirk.kok. kptk-k. 2005, 43 \$; Kirk.kok. kptk-k. 2006, 30 \$; Kirk.kok. kptk-s. 2006, 18-19\$.

715 Kirk.kok. kptk-k. 2006,30\$.

716 Kirk.kok. kptk-s. 2001, 41 \$; Kirk.kok. ptk-s. 2001, liite III 9, 5; Kirk.kok. kptk-k. 2005, $43 \$$.

717 Tiitinen 2008, 66

718 Kirk.kok. ptk-k. 2007, liite III.

719 Kirk.kok. kptk-k. 2010,30\$.

720 Kirk.kok. kptk-s. 2011, $19 \$$.

721 Kirk.kok. kptk-s. 2009, $26 \$$.

722 Kirk.kok. kptk-s. 2010, 23 \$; Kirk.kok. kptk-k. 2011,31 \$; SEK 2008-11, 312.

723 Kirk.kok. kptk-k. 2006,7\$.

724 Kirk.kok. kptk-k. 2004, 1 \$; Kmaa 4.11.2005 "Asiat jäävät usein pyörimään kirkon Bermudan kolmioon" (Johannes Ijäs).

725 Kmaa 14.5.2004 Kirkolliskokous koolle kolmesti vuodessa? (Johannes Ijäs).

726 Kirk.kok. ptk-s. 2002, liite IV 2,11.

727 Kirk.kok. ptk-s. 2002, liite IV 2, 14; Kirk.kok. ptk-k. 2005, liite VI-E 1, liite: hallintovaliokunnan lausunto.

728 Kirk.kok. ptk-k. 1980, liite V 1, 16, 44; Kirk.kok. ptk-s. 2008, liite II 9, 1, 2526; H.-T. Nieminen 2008, 248-251; S. Häkkinen 2013, 293-294.

729 Kirk.kok. kptk-s. 2009, 43 \$; Kirk.kok. ptk-s. 2009, liite VI-C 2, 7-9, 10, 13.

730 Kirk.kok. ptk-k. 2000, liite VIII 5; Kirk.kok. ptk-s. 2001, liite VIII-E 18; Kirk. kok. kptk-k. 2010, 24 \$; Kirk.kok. ptk-k. 2010, liite VII 3; Kirk.kok. ptk-s. 2011, 
$21 \S$, liite VI-F 5 .

731 Grönlund \& Westinen 2012, 184.

732 Kirk.kok. kptk-k. 2011, $1 \$$.

733 Huovinen 2011, 26, 89.

734 Pihkala 2007, 97-98.

735 Pihkala 2007, 94-95.

736 Kirk.kok. ptk-k. 2011, liite VII 2; Kakkuri 2012, 607-608.

737 Vischer 2004, 48.

738 Kirk.kok. kptk-k. 2001, 41 \$; Kirk.kok. ptk-k. 2001, liite IV 1 \& X-F 1; Kirk.kok. kptk-s. 2001, 23 \$; Kirk.kok. ptk-s. 2001, liite VI 2 \& VIII-D 9; SEK 2008-11, 240, $246,249$.

739 Kirk.kok. ptk-k. 2000, liite VIII 2; Kirk.kok. kptk-s. 2000,35 \$; Kirk.kok. ptks. 2000, liite VII-F 11; Kirk.kok. ptk-s. 2003, liite VI 1.

740 Helander \& Pekonen 2007, 19, 66.

741 Kirk.kok. kptk-s. 2008, 22 \$.

742 Kauppinen 2004, 144.

743 Kirk.kok. kptk-k. 2009, $32 \S$.

744 Helander \& Pekonen 2007, 132.

745 S. Eskola 2004, 139; S. Eskola 2012a, 82-83.

746 Kirk.kok. kptk-k. 2001,31 \$.

747 Kirk.kok. kptk-k. 2001,34 \$; Kirk.kok. kptk-s. 2003, 57 \$.

748 Kirk.kok. kptk-s. 2003, 11 \$; Kirk.kok. kptk-s. 2006, 6 \$, 24 \$.

749 Ks. esim. Kmaa 8.5.2005 Maallikot on valittu tasavertaisiksi päättäjiksi (Juliska Lehtinen).

750 SEK 2000-03, 47-48 \& 2004-07, 23; Kirk.kok. kptk-s. 2008, 24 \$; K. Ketola 2003, 53, 85; Kääriäinen \& Niemelä \& Ketola 2003, 261; Mikkola 2003, 80; S. Häkkinen 2010, 202-203.

751 Kirk.kok. kptk-k. 2005, $29 \$$.

752 Uusi Tie 23/10.6.2010 Mitä tehdä, kun kirkon johtajat luopuvat uskosta? (Leif Nummela, pääk.).

753 Kmaa 30.9.2010 Kirkollinen keskustelu kärjistyi (pääk.), Myös vapaat suunnat virittävät piispaboikottia (Jussi Rytkönen), Ekumeeninen viima kiusaa Askolan alkukautta (Johannes Ijäs).

754 Kirk.kok. kptk-s. 2010, 32 \$.

755 Kirk.kok. kptk-k. 2005, 29 \$; Kirk.kok. ptk-k. 2006, liite VI 5.

756 Kirk.kok. kptk-k. 2011,31 \$.

757 Kirk.kok. kptk-s. 2010, $32 \$$.

758 US 7.11.1978 Ahti Auranen: Kirkolliskokous olisi valittava kansanvaaleilla. 
LIITE:

\section{KIRKOLLISKOKOUSEDUSTAJAT 1974-2011}

Sarakkeeseen Arvo/ammatti on merkitty se oppiarvo, arvonimi tai ammattinimike, jonka edustaja ilmoitti, kun hänet valittiin tutkimuskaudella viimeistä kertaa kirkolliskokoukseen. Kunkin kirkolliskokousedustajan tehtävät kirkolliskokouksessa on merkitty kirjainlyhenteillä. Iso kirjain tarkoittaa varsinaista jäsenyyttä kirkolliskokouksen elimessä (valitsijamiehet tai jokin valiokunta), pieni kirjain taas varajäsenyyttä. Lihavoitu kirjain tarkoittaa, että henkilö on ollut kyseisen elimen (valitsijamiehet/valiokunta/valiokunnan osasto) puheenjohtaja. Mikäli kirjain/kirjaimet on kursivoitu, kyseessä on vain osan vaalikaudesta istunut varaedustaja.

Kirjainlyhenteiden selitykset:

$\mathrm{X}$

kirkolliskokouksen jäsen ilman jäsenyyksiä valiokunnissa tai valitsijamiehissä

Pj kirkolliskokouksen puheenjohtaja tai varapuheenjohtaja Pö pöytäkirjan tarkastaja

pö pöytäkirjan tarkastajan varamies

V valitsijamies

v valitsijamiesten varamies

$\mathrm{H}$ hallintovaliokunnan jäsen

K käsikirjavaliokunnan jäsen

k käsikirjavaliokunnan varajäsen

Ka kansliavaliokunnan jäsen

ka kansliavaliokunnan varajäsen

Ks kasvatusasiain valiokunnan jäsen

ks kasvatusasiain valiokunnan varajäsen

$\mathrm{Ku} \quad$ kirkkolain uudistamisvaliokunnan jäsen

L lakivaliokunnan jäsen

1 lakivaliokunnan varajäsen

P peruste(/siviili)valiokunnan jäsen

$\mathrm{p} \quad$ peruste(/siviili)valiokunnan varajäsen

$\mathrm{R}$ raamatunkäännösvaliokunnan jäsen

$\mathrm{T}$ talousvaliokunnan jäsen

t talousvaliokunnan varajäsen

Tm

tm

To

to
Valitsijamiesten ja valiokuntien kokoonpanot vaihtuivat jonkin verran kunkin vaalikauden kuluessa, joten yhdelle nelivuotiskaudelle merkityt kirkolliskokoustehtävät voivat olla yksittäisen edustajan osalta joko yhtäaikaisia tai peräkkäisiä. Esimerkiksi kirjainyhdistelmä vLToV tarkoittaa kirkolliskokouksen varsinaista jäsentä, joka toimi valitsijamiesten varamiehenä, lakivaliokunnan puheenjohtajana ja toimitusvaliokunnan jäsenenä. Myöhemmin vaalikauden aikana hänet valittiin varsinaiseksi valitsijamieheksi. 


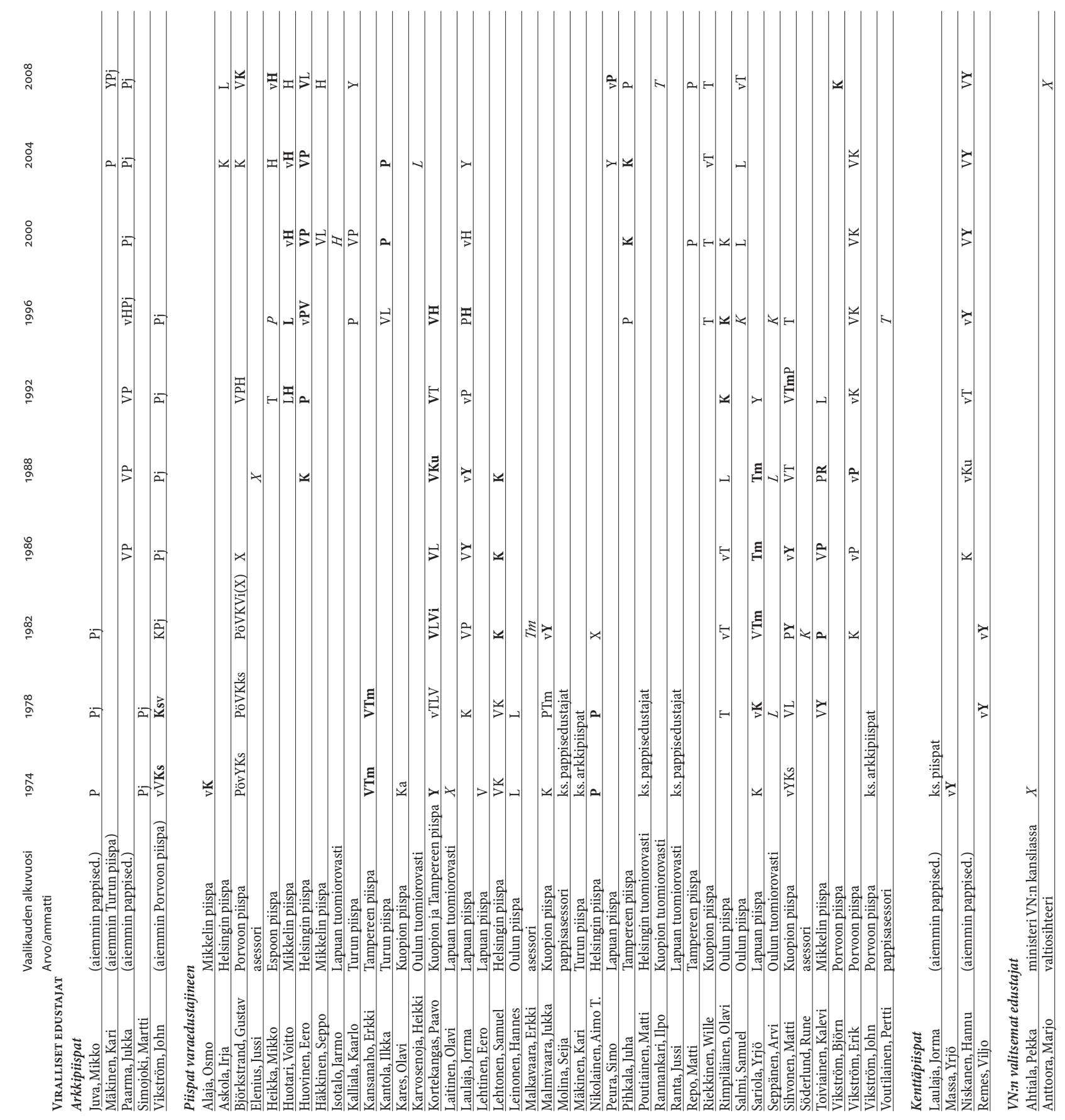



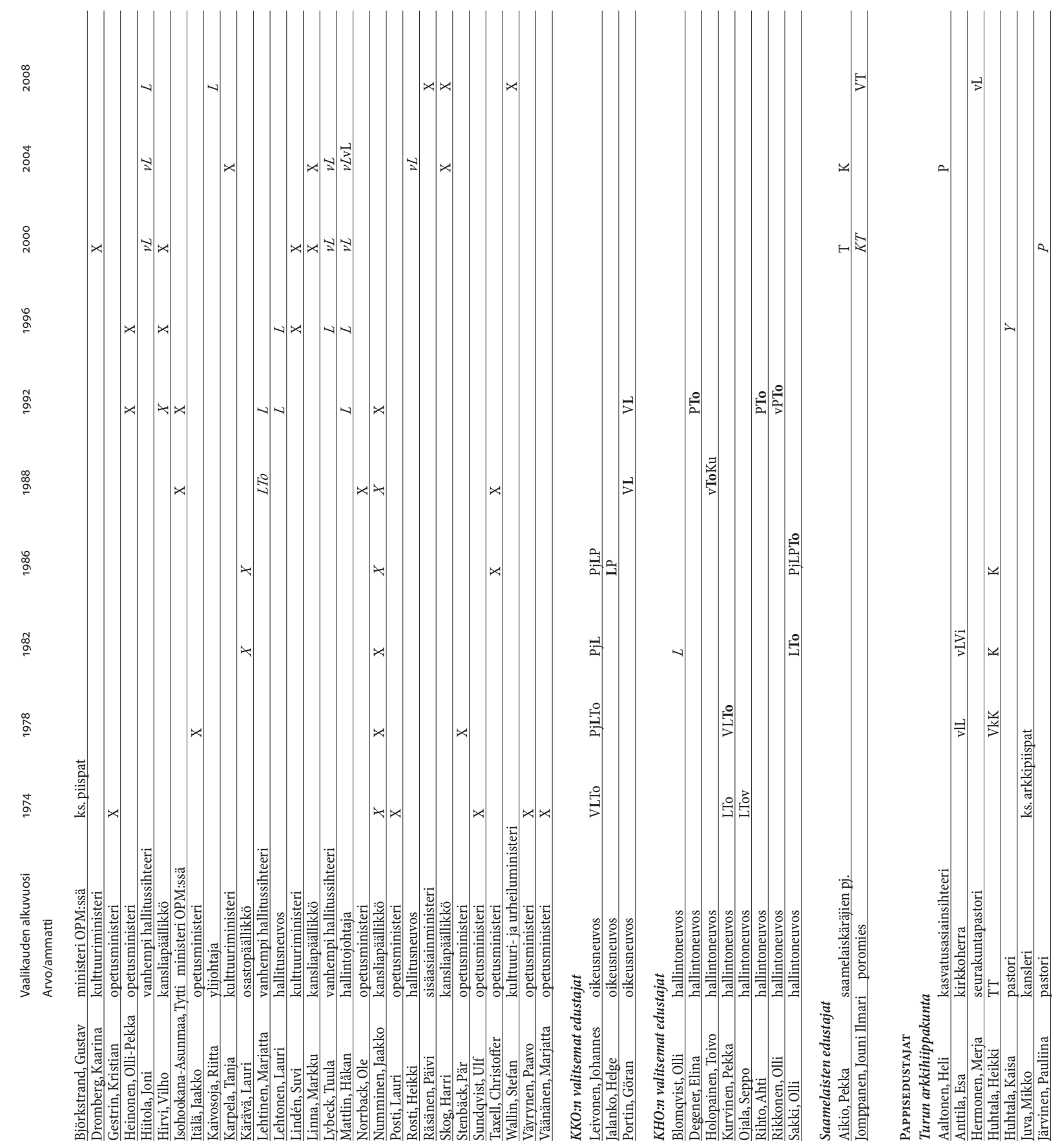


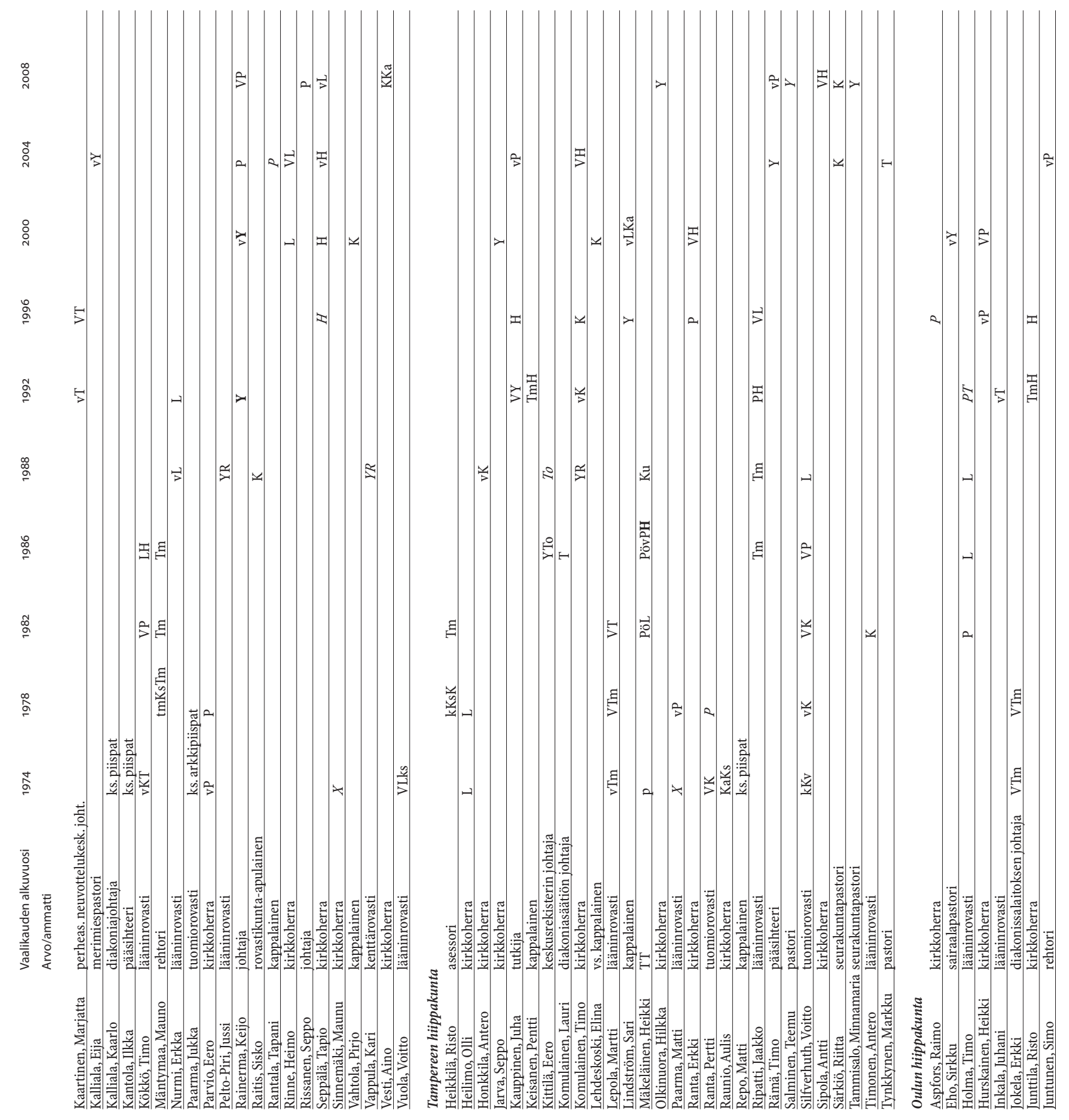

382 Li ite: Kirkoliskokousedustajat $1974-2011$ 


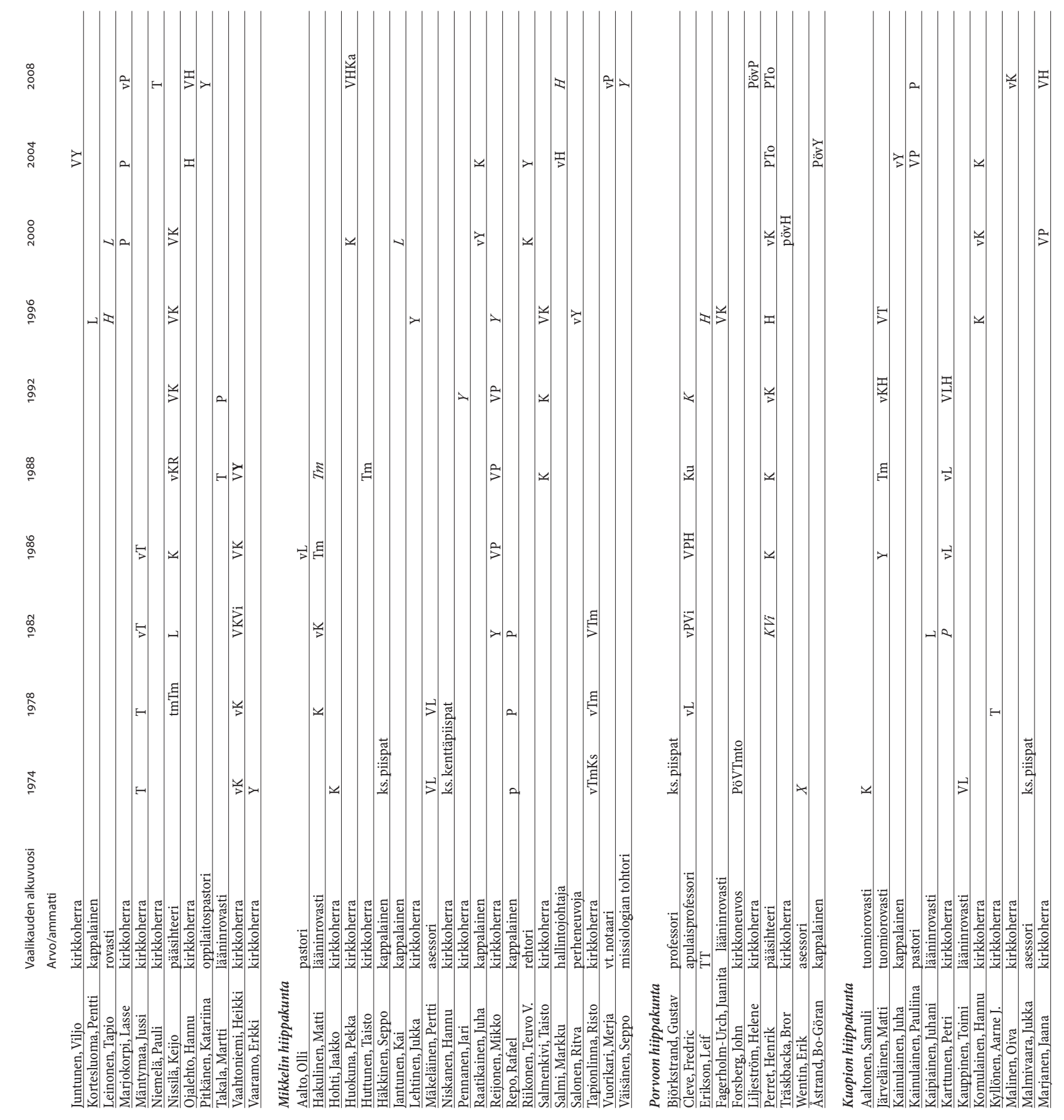




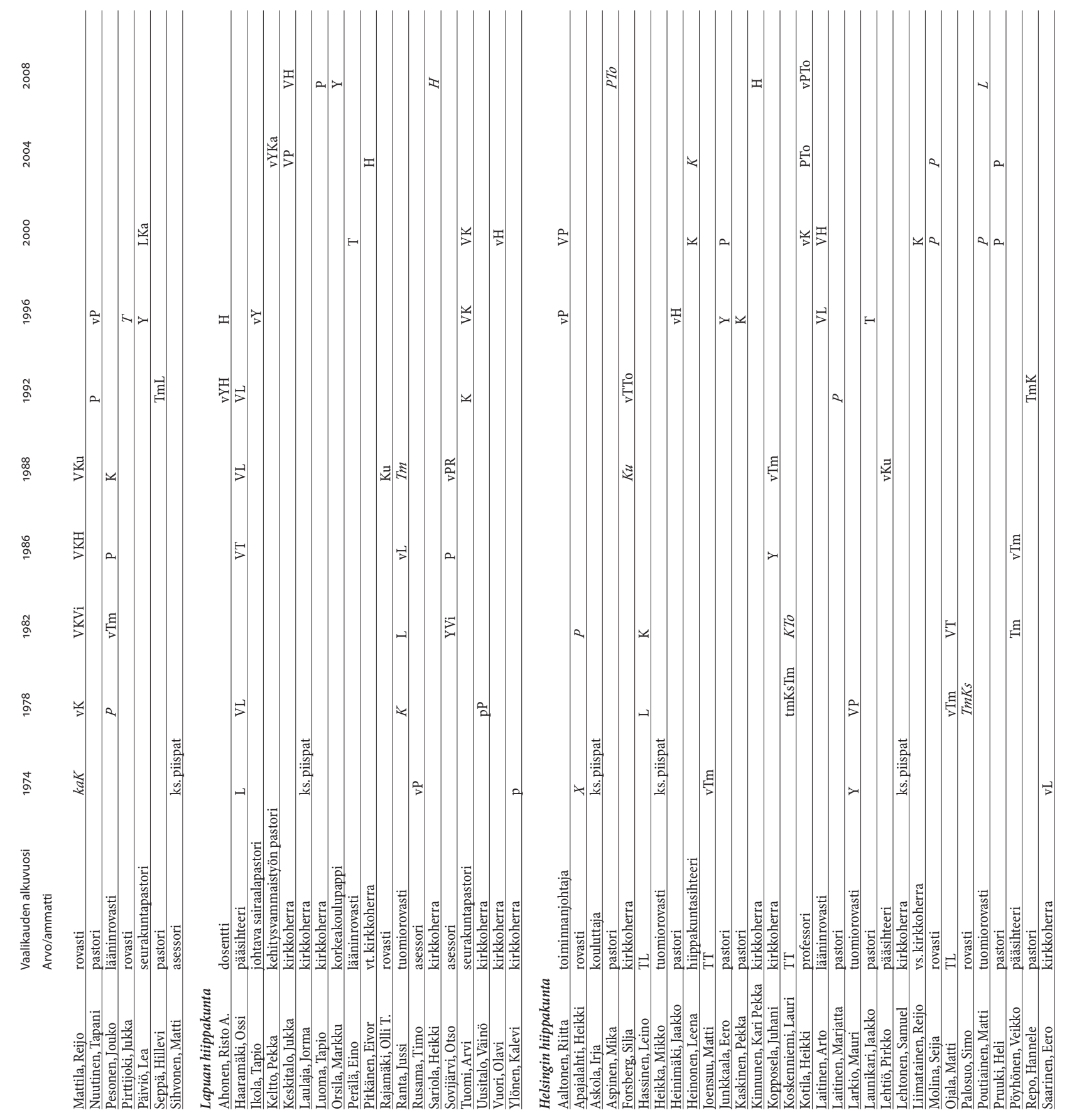



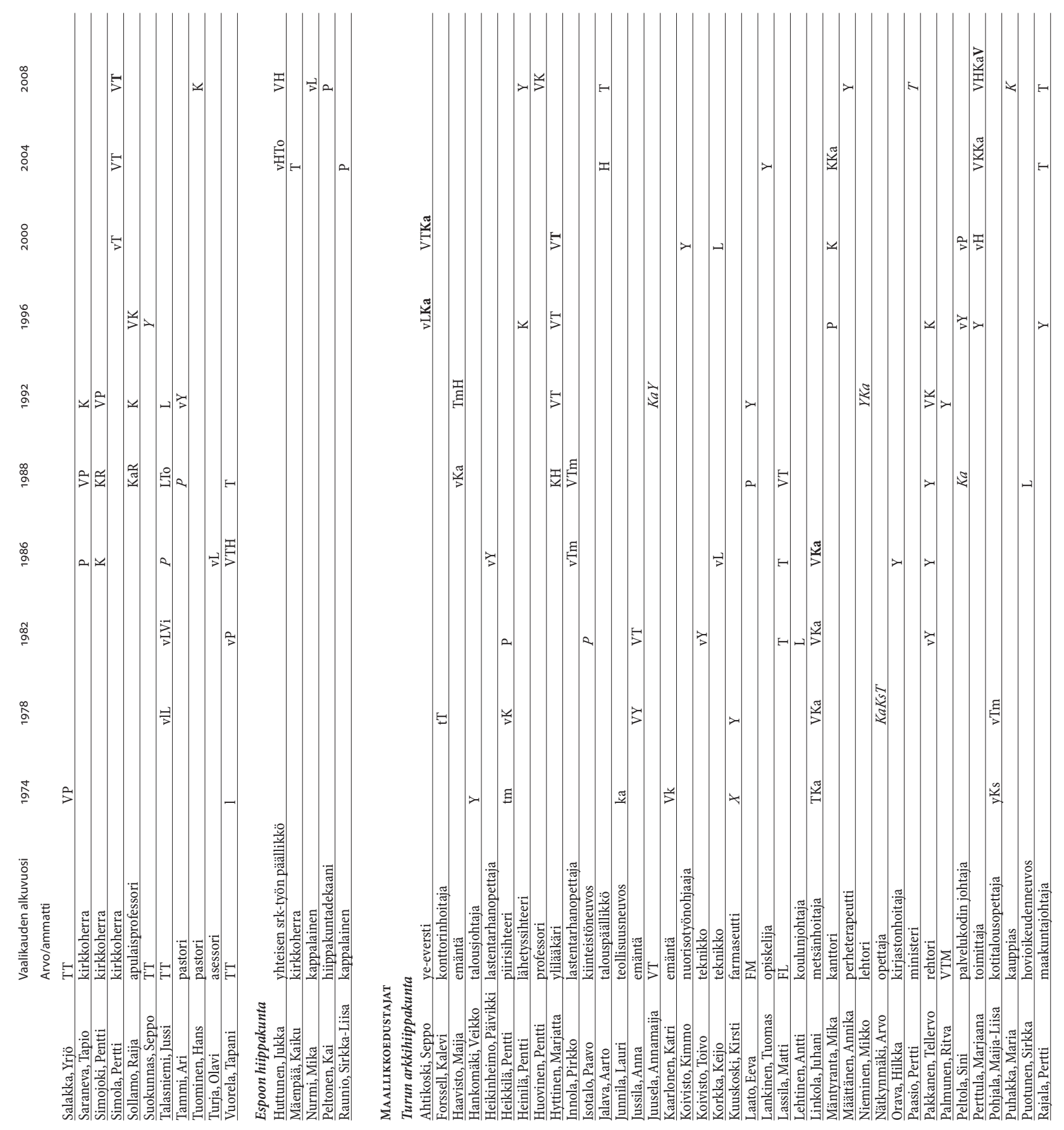


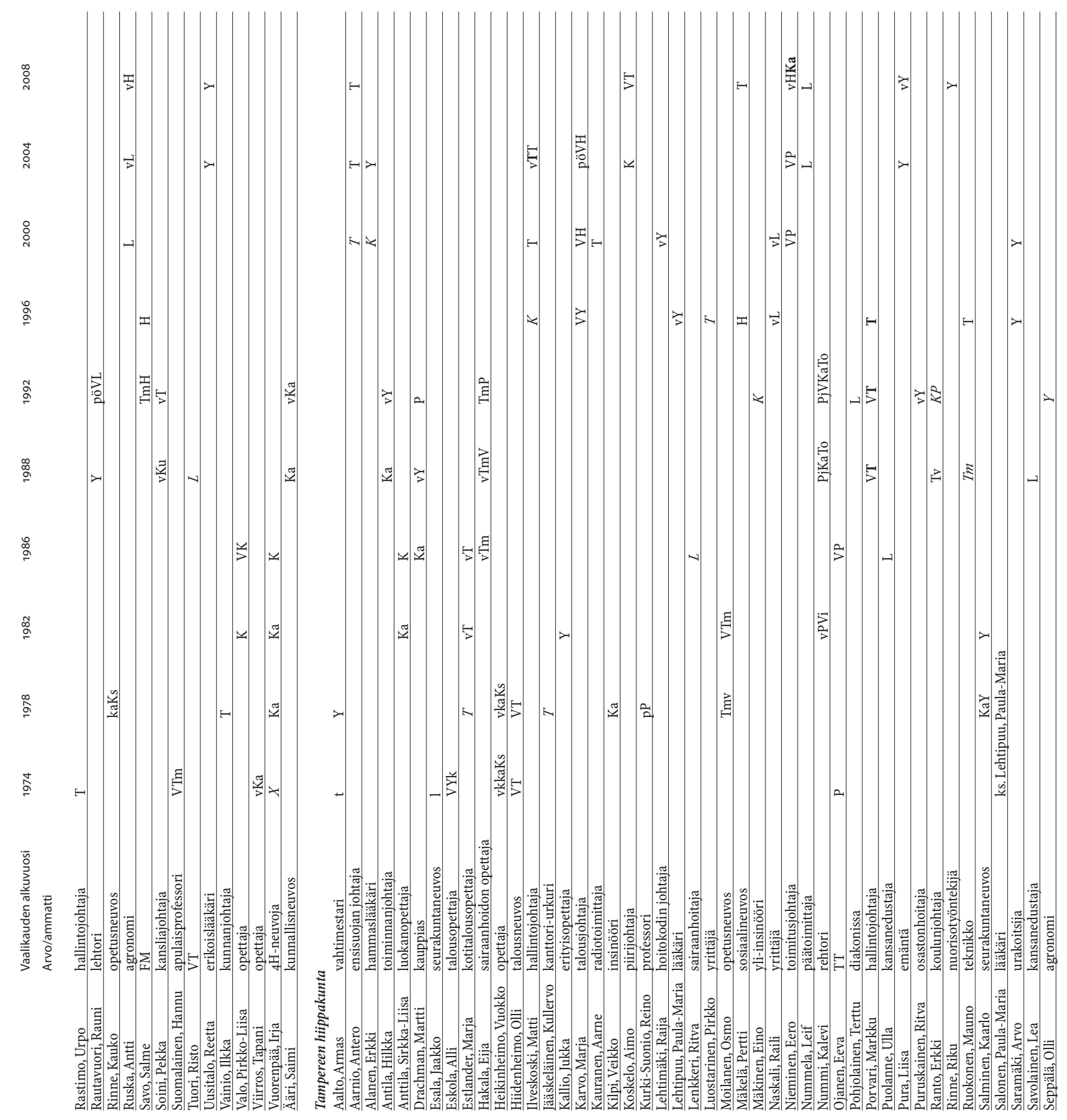

386 LIITE: KIRKOLLISKOKOUSEDUSAJAT $1974-2011$ 


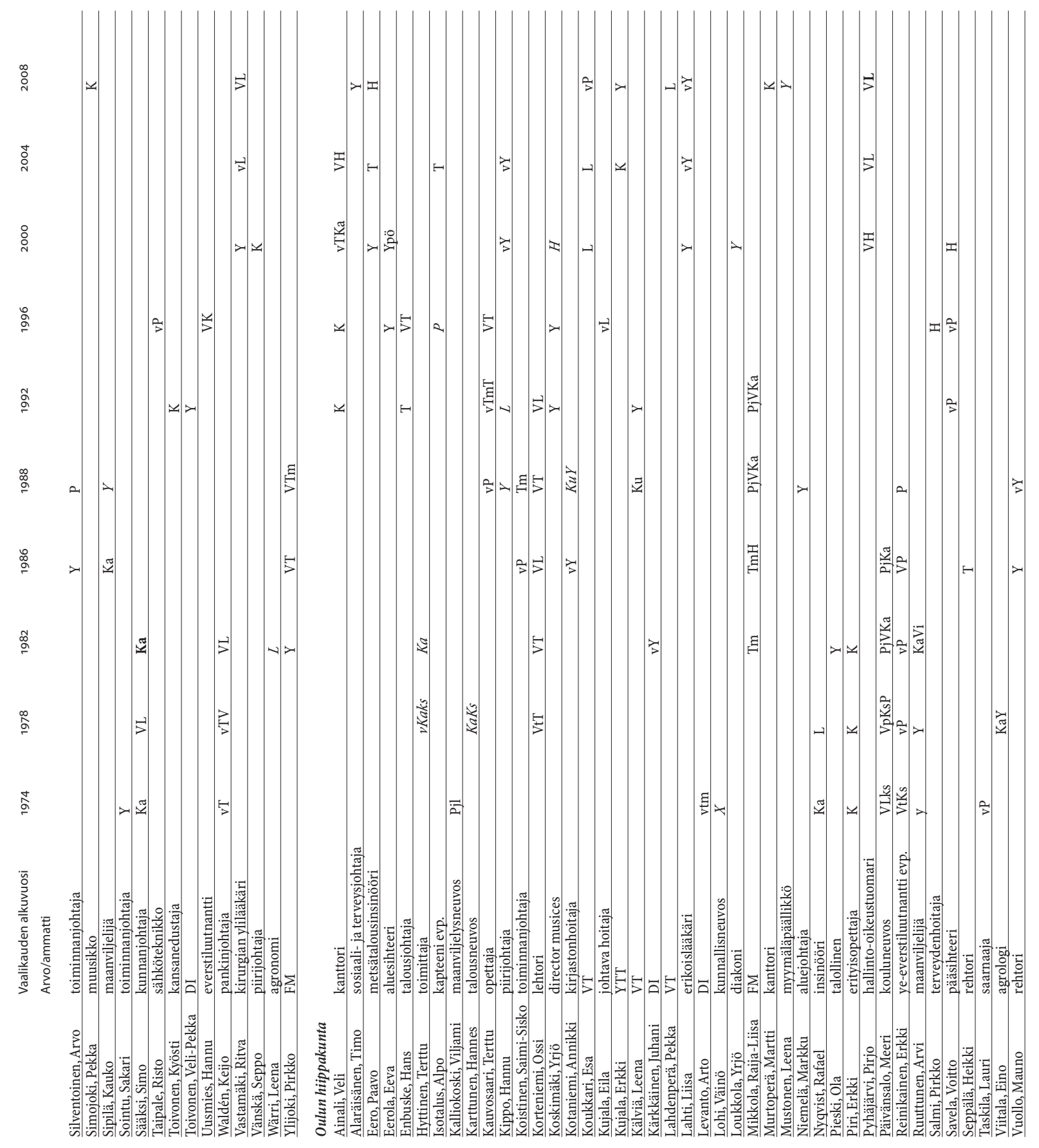




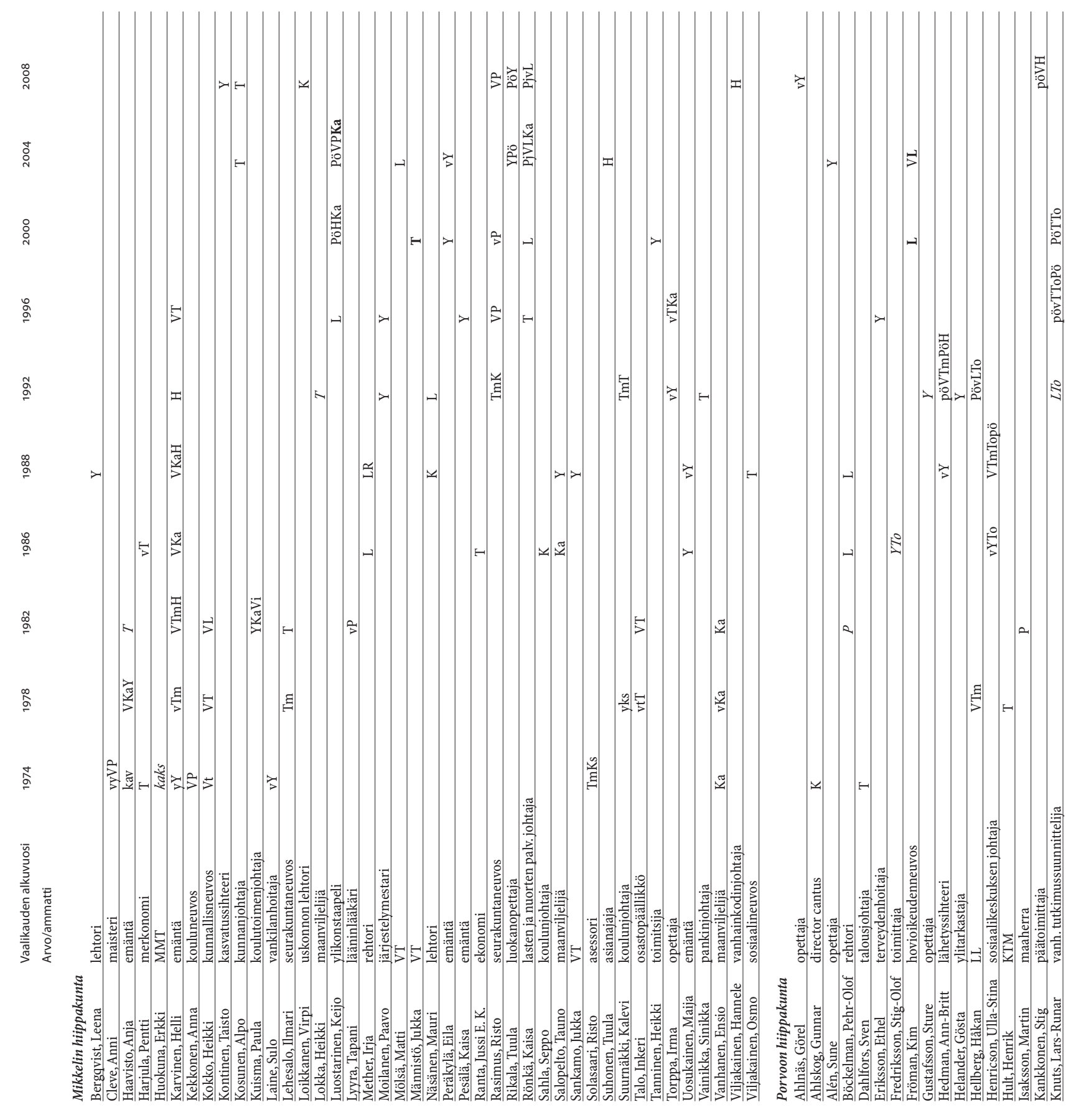

388 LIITE: KIRKOLLISKOKOUSEDUtajat $1974-2011$ 


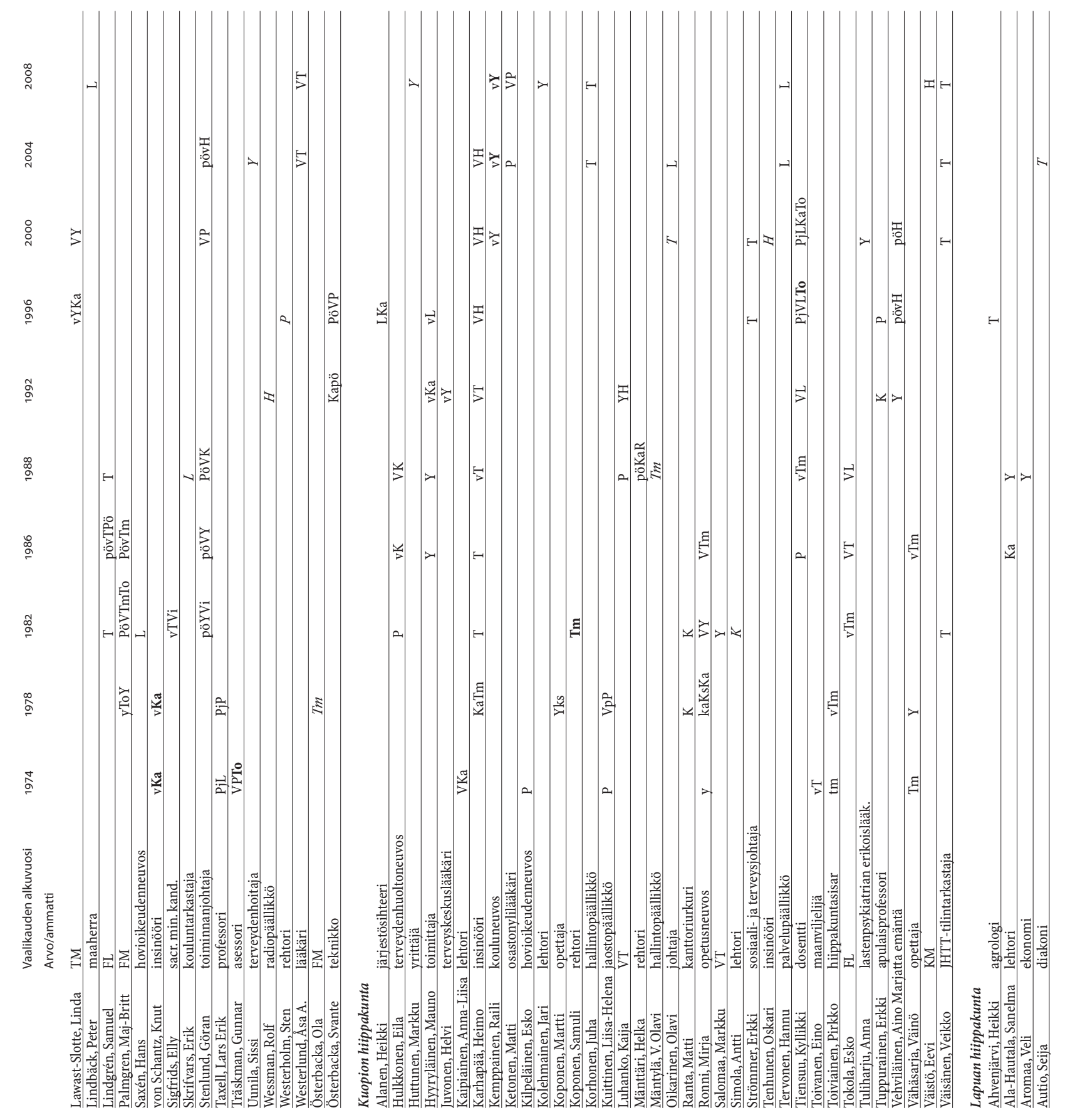




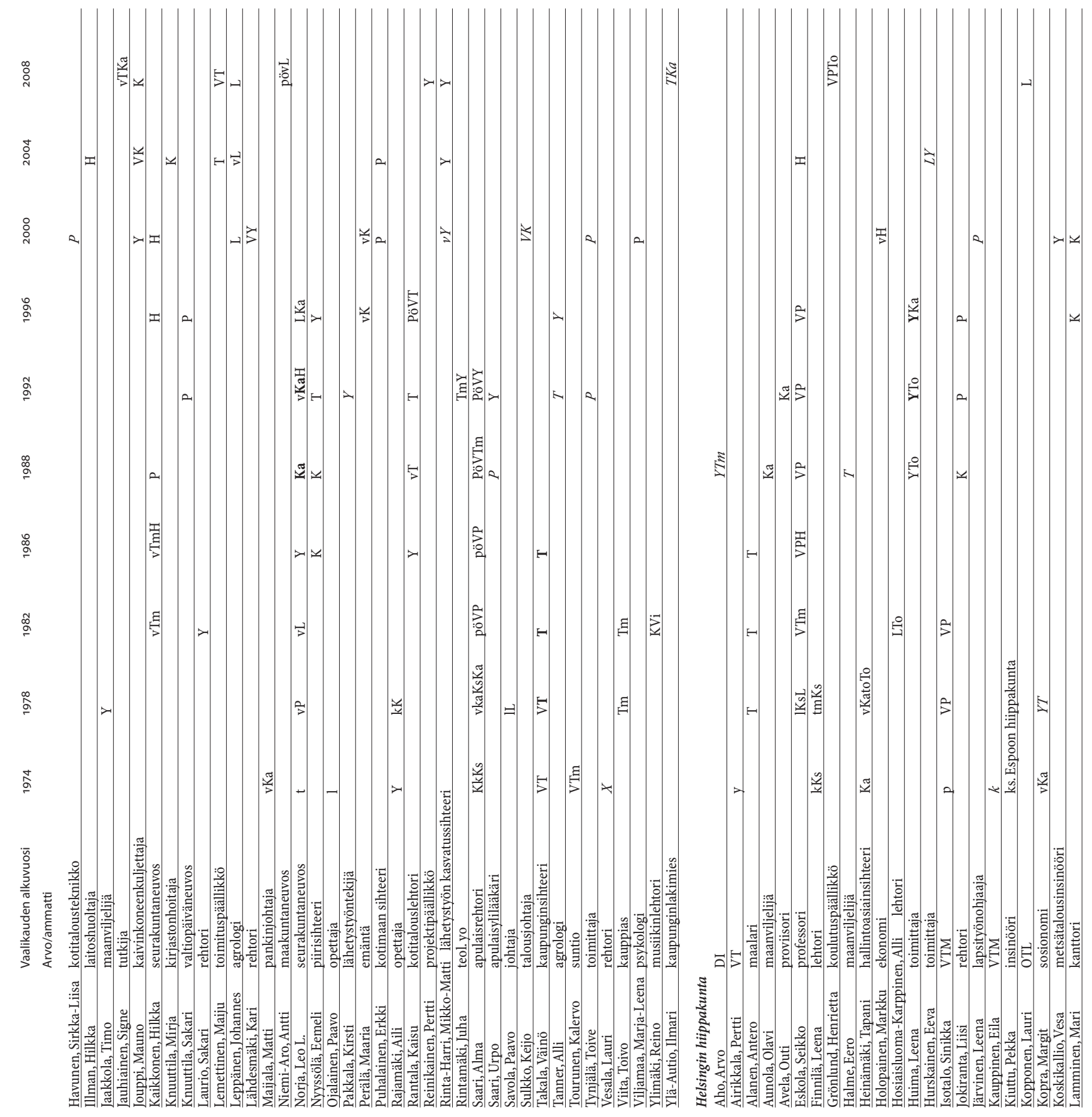



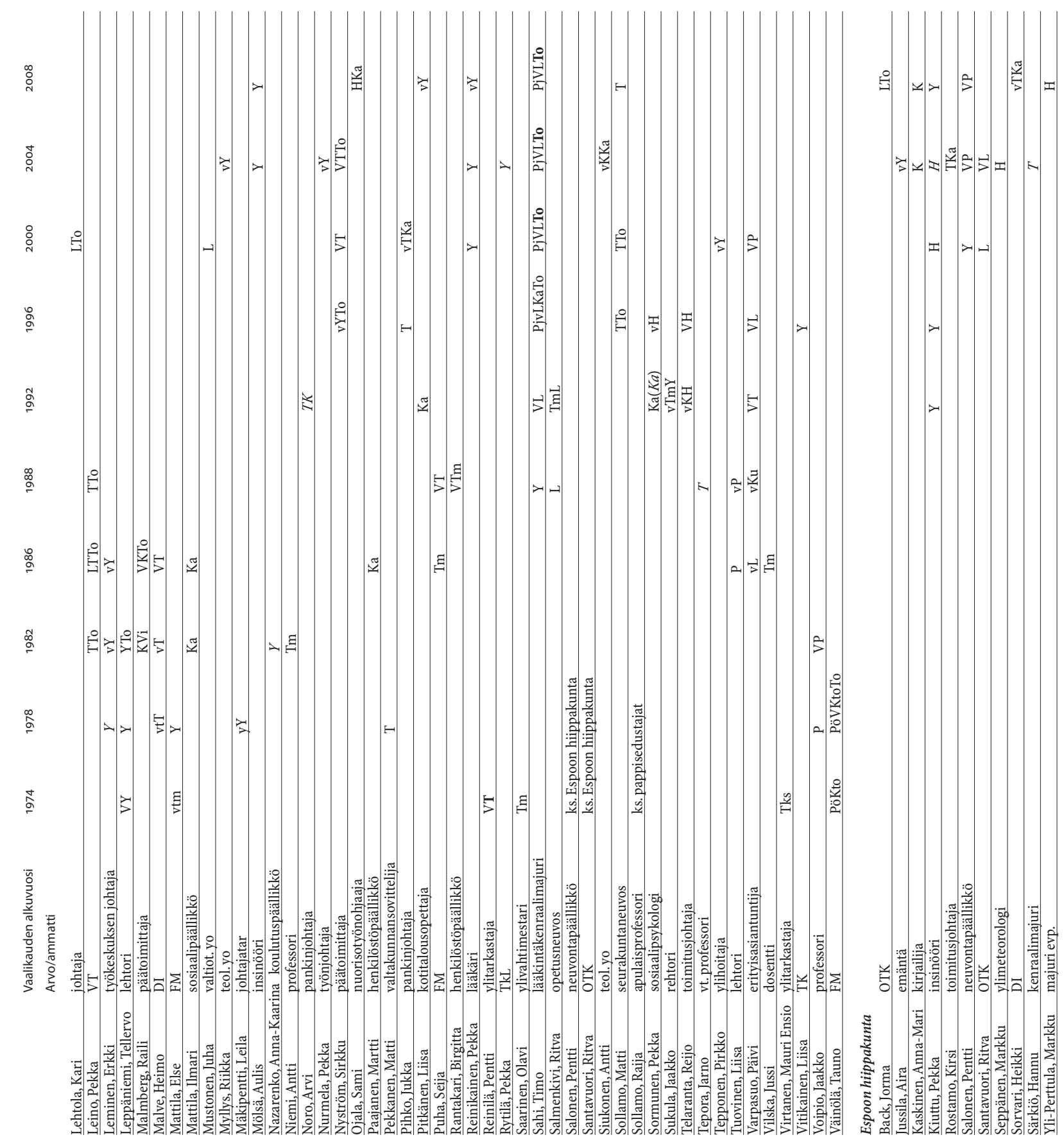
LYHENTEET

$\begin{array}{ll}\text { ak. } & \text { asiakirjat } \\ \text { atk. } & \text { automaattinen tietojenkäsittely } \\ \text { diss. } & \text { akateeminen väitöskirja } \\ \text { EU } & \text { Euroopan unioni } \\ \text { EY } & \text { Euroopan yhteisö } \\ \text { FSSM } & \text { Finlands evangelisk-lutherska Student- } \\ & \text { och Skolungdomsmission } \\ \text { hpk.kok. } & \text { hiippakuntakokous } \\ \text { k. } & \text { kevätistuntokausi } \\ \text { KHO } & \text { korkein hallinto-oikeus } \\ \text { kirk.kok. } & \text { kirkolliskokous } \\ \text { KKK } & \text { kirkon kasvatusasiain keskus } \\ \text { KKO } & \text { korkein oikeus } \\ \text { KL } & \text { kirkkolaki } \\ \text { kptk-k. } & \text { keskustelupöytäkirja, kevätistuntokausi } \\ \text { kptk-s. } & \text { keskustelupöytäkirja, syysistuntokausi } \\ \text { OPM } & \text { opetusministeriö } \\ \text { p. } & \text { painos } \\ \text { piisp.kok. } & \text { piispainkokous } \\ \text { pj. } & \text { puheenjohtaja } \\ \text { ptk. } & \text { pöytäkirja } \\ \text { ptk-k. } & \text { pöytäkirja, kevätistuntokausi } \\ \text { ptk-l. } & \text { pöytäkirjojen liitteet } \\ \text { ptk-s. } & \text { pöytäkirja, syysistuntokausi } \\ \text { pääk. } & \text { päkirjoitus } \\ \text { RKP } & \text { Ruotsalainen kansanpuolue } \\ & \text { [vuodesta 2o1o: Suomen ruotsalainen kansanpuolue] } \\ \text { SAK } & \text { Suomen Ammattiliittojen Keskusjärjestö } \\ \text { SDP } & \text { Suomen Sosialidemokraattinen Puolue } \\ \text { SKHS } & \text { Suomen kirkkohistoriallinen seura } \\ \text { SKHST } & \text { Suomen kirkkohistoriallisen seuran toimituksia } \\ \text { SKHSV } & \text { Suomen kirkkohistoriallisen seuran vuosikirja } \\ \text { SKS } & \text { Suomalaisen Kirjallisuuden Seura } \\ \text { SKST } & \text { Suomalaisen Kirjallisuuden Seuran Toimituksia } \\ \text { s.l. } & \text { ilman paikkaa (sine loco) } \\ \text { SLEF } & \text { Svenska Lutherska Evangeliföreningen i Finland } \\ \text { SLEY } & \text { Suomen Luterilainen Evankeliumiyhdistys } \\ \text { SMP } & \text { Suomen Maaseudun Puolue } \\ \text { SRK } & \text { Suomen Rauhanyhdistysten Keskusyhdistys } \\ \text { STKS } & \text { Suomalainen Teologinen Kirjallisuusseura } \\ \text { STKSJ } & \text { Suomalaisen Teologisen Kirjallisuusseuran julkaisuja } \\ \text { VJ } & \text { valtiopäiväjärjestys } \\ \text { VN } & \text { valtioneuvosto } \\ \text { vp. } & \text { valtiopäivät } \\ \text { WSOY } & \text { Werner Söderström Osakeyhtiö } \\ \text { y. } & \text { ylimääräinen istuntokausi } \\ & \end{array}$

\section{LÄHTEET JA KIRJALLISUUS}

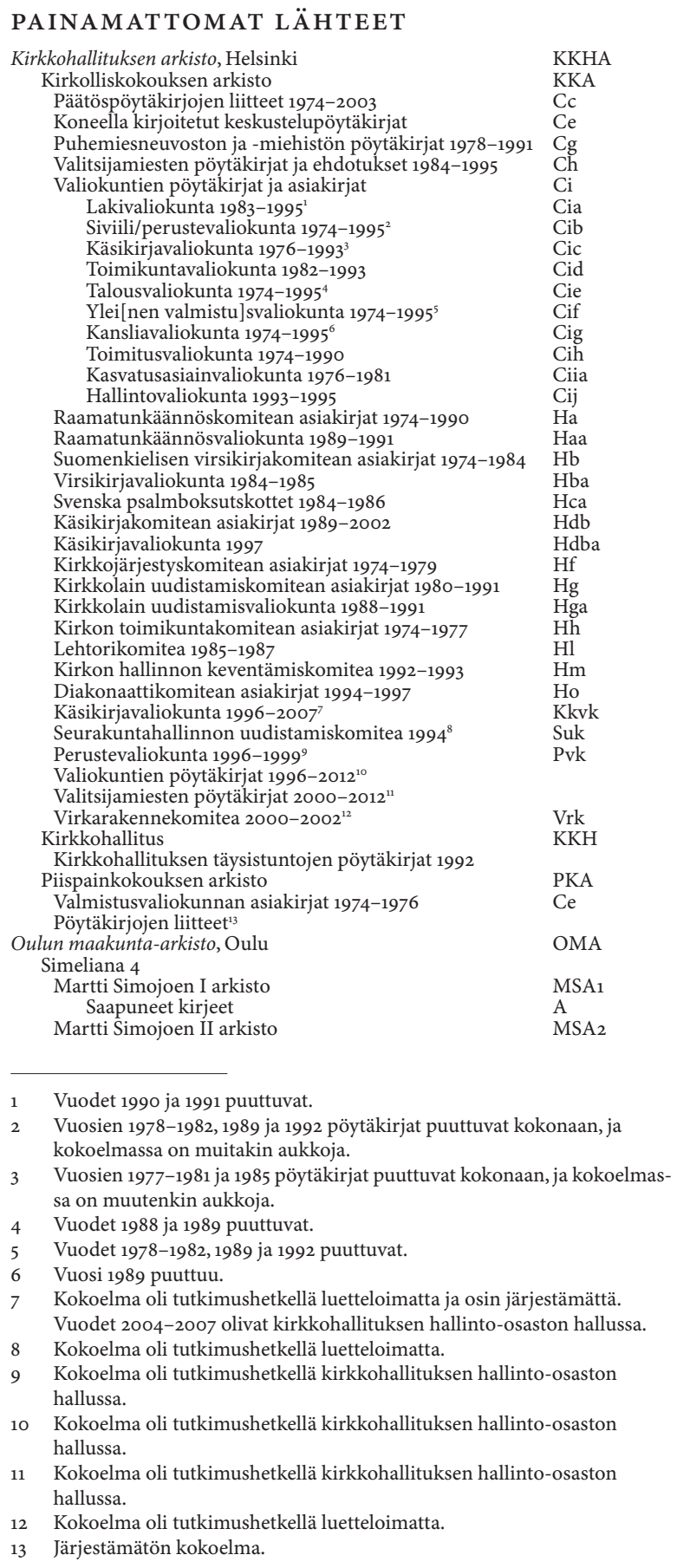


Yksityisiltä saapuneet kirjeet

Turun tuomiokapitulin arkisto, Turku

Martti Simojoen arkisto

Kirjeitä 1964-1978

Saapuneet kirjeet 1961-1978

Mikko Juvan arkisto

Kirjeenvaihtoa 1978-1982

Puheita

Arkkipiispan kanslian arkisto

Lähetetyt kirjeet 1992-2010

Arkkipiispan kotimainen kirjeenvaihto 1982-1990

Lapuan tuomiokapitulin arkisto, Lapua

Tuomiokapitulin pöytäkirjat

Saapuneet asiakirjat, kirkolliskokous 1974-2002

Hiippakuntahallinto

Kirkolliskokousedustajien vaalit 2004, 2008

Helsingin tuomiokapitulin arkisto, Helsinki

Kirkollis- ja hiippakuntakokousvaalit 1974-2000

Kirkolliskokousvaali 2004, vaaliasiakirjat

Kirkolliskokousvaalit $2008^{14}$

Keskustan ja maaseudun arkisto, Helsinki

Keskustapuolueen puoluetoimiston arkisto

Toimikunnat Vaalit Kirkkopoliittinen toimikunta 1974-1988

$$
\text { Seurakuntavaalit 1974- }
$$

Porvarillisen työn arkisto, Helsinki

Kansallinen Kokoomus

Toimi- ja valiokunnat

Kirkkopoliittinen työryhmä 1977-1978

Työväen Arkisto, Helsinki

Kristillisten sosialidemokraattien liitto

Liittotoimikunnan ja työvaliokunnan pöytäkirjat 1970-1977 C 1

Liittokokouspöytäkirjat 1970-1977

Jaakko Nummisen arkisto, Sipoo

\section{KIRKOLLISKOKOUKSEN PÖYTÄKIRJAT \\ JA KÄSITELLYT MIETINNÖT}

Apokryfikirjat 2003: Kuusi apokryfikirjaa. Tobitin kirja, Juditin kirja, Kreikkalainen Esterin kirja, Barukin kirja, Jeremian kirje, Danielin kirjan lisäyk set. Käännösehdotus. Apokryfikirjojen käännöskomitea. [Kirkkohallitus, Helsinki].

Apokryfikirjat 2004: Kaksi apokryfikirjaa. Viisauden kirja, Ensimmänen makkabilaiskirja. Käännösehdotus. Apokryfikirjojen käännöskomitea. [Kirkkohallitus, Helsinki].

Apokryfikirjat 2005: Sirakin kirja heprealaisen ja kreikkalaisen tekstin mukaan. Käännösehdotus. Apokryfikirjojen käännöskomitea. [Kirkkohallitus, Helsinki].

Apokryfikirjat 2006: Apokryfikirjat - käännösehdotuksen 4. osa. Toinen makkabilaiskirja, Kolmas makkabilaiskirja, Neljäs makkabilaiskirja, Manassen rukous, Psalmi 151. Liite Suomen evankelis-luterilaisen kirkon kirkolliskokouksen syysistuntokauden 2006 pöytäkirjaan. [Kirkkohallitus, Helsinki].

Avioliittotoimikunnan mietintö 1983: Avioliiton solmiminen ja purkaminen. Avioliittotoimikunnan mietintö. Komiteanmietintö 1983:20. [Oikeusministeriö], Helsinki.

Evankeliumikirja 2009a: Evankeliumikirja: viittomakielinen käännösehdotus DVD1. Kirkkohallitus / jumalanpalvelus ja musiikki \& kirkon tiedotuskeskus.

Evankeliumikirja 2009b: Evankeliumikirja: viittomakielinen käännösehdotus DVD2. Kirkkohallitus / jumalanpalvelus ja musiikki \& kirkon tiedotuskeskus.

Förslag till Svensk psalmbok 1983: Förslag till Svensk psalmbok för den evangelisklutherska kyrkan i Finland. Svenska psalmbokskommittén, Vasa.

Girkolaš doaimmahusaid girji 2004: Girkolaš doaimmahusaid girji. Suoma evangelalaš-luteralaš girku girkogiehtagirji III. Suoma evangelalaš-luteralaš girku guovddášhálddahus Ráidu A 2004:1. Helsset.

Handbokskommitténs förslag 1997a: Den evangelisk-lutherska kyrkans i Finland kyrkohandbok I. Gudstjänstbok. Förslag utarbetat av den kyrkomötet år 1988 tillsatta handbokskommittén. Centralstyrelsen i den evangelisk-lutherska kyrkan i Finland Serie A 1997:3. Kyrkostyrelsen, Helsingfors.

Handbokskommitténs förslag 1997b: Kyrkohandbok för den evangelisk-lutherska kyrkan i Finland II. Evangeliebok. Förslag utarbetat av den kyrkomötet år 1988 tillsatta handbokskommittén. Den evangelisk-lutherska kyrkans i Finland centralförvaltning Serie A 1997:4. Kyrkostyrelsen, Helsingfors.

Handbokskommitténs förslag 2001a: Förslag till Handbok för kyrkliga förrättningar utarbetat av den av kyrkomötet år 1988 tillsatta handbokskommittén.

14 Järjestämätön kokoelma, katsottu tammikuussa 2011

Motiveringar. Den evangelisk-lutherska kyrkans i Finland centralförvaltning Serie A 2001:3. Kyrkostyrelsen, Helsingfors.

Handbokskommitténs förslag 2001b: Kyrkohandbok för den evangelisk-lutherska kyrkan i Finland III. Kyrkliga förrättningar. Förslag utarbetat av den av kyrkomötet år 1988 tillsatta handbokskommittén. Den evangelisk-lutherska kyrkans i Finland centralförvaltning Serie A 2001:4. Kyrkostyrelsen, Helsingfors.

Handboksutskottets betänkande 1999: Kyrkohandbok II för evangelisk-lutherska kyrkan i Finland. Evangeliebok. Handboksutskottets betänkande nr 2/1999 som gäller förslaget utarbetat av handbokskommittén tillsatt av kyrkomötet 1988. Finlands evangelisk-lutherska kyrkas kyrkomötes vårsession 1999, bilaga till protokoll VIII.C.2. Kyrkostyrelsen, Helsingfors.

Hiippakuntahallintokomitean mietintö 1998: Suomen evankelis-luterilaisen kirkon kirkolliskokouksen 8.11.1995 asettaman hiippakuntahallintokomitean mietintö. Suomen ev.-lut. kirkon keskushallinto Sarja A 1998:1. Kirkkohallitus, Helsinki.

JKJ 1992: Jumalan kansan juhla. Suomen evankelis-luterilaisen kirkon kirkolliskokouksen vuonna 1988 asettaman käsikirjakomitean välimietintö. Suomen ev.lut. kirkon keskushallinto Sarja A 1992:1. Kirkkohallitus, Helsinki.

Kirholij toimâttâsâi kirje 2004: Kirholij toimâttâsâi kirje anarâškielân (väljejum uásih). Suomâ evangelâš-luteerlâš kirho kirkkokietâkirje III. Suomâ evangelâš-luteerlâš kirho kuávdášhaldâttâs Sarja A 2004:2. Helsig.

Kirkko 2020 2010: Kirkko 2020. Suomen evankelis-luterilaisen kirkon tulevaisuusselonteko. Suomen ev.lut. kirkon kirkkohallituksen julkaisuja 2010:7. Kirkkohallitus, Helsinki.

Kirkkohallitus 1993: Kirkkohallituksen ja Kirkon keskusrahaston toimintakertomus vuodelta 1993. [Kirkkohallitus, Helsinki].

Kirk.kok. kptk-k. 1974-2012: Suomen evankelis-luterilaisen kirkon kirkolliskokous. Keskustelupöytäkirja. Kevätistunto[kausi]. Kirkkohallitus, Helsinki.

Kirk.kok. kptk-s. 1974-2011: Suomen evankelis-luterilaisen kirkon kirkolliskokous. Keskustelupöytäkirja. Syysistunto[kausi]. Kirkkohallitus, Helsinki.

Kirk.kok. kptk-y. 1974: Ylimääräinen kirkolliskokous 30.12.1974. Teoksessa Suomen evankelis-luterilaisen kirkon kirkolliskokous. Keskustelupöytäkirja. Syysistunto 1974. Ylimääräinen kirkolliskokous 30.12.1986. Kirkkohallitus, Helsinki.

Kirk.kok. kptk-y. 1986: Ylimääräinen istuntokausi 13.2.1986. Teoksessa Suomen evankelis-luterilaisen kirkon kirkolliskokous. Keskustelupöytäkirja. Syysistuntokausi 1985. Ylimääräinen istuntokausi 13.2.1986. Kirkkohallitus, Helsinki.

Kirk.kok. kptk-y. 1992: Ylimääräinen istunto 10-11.1.1992. Teoksessa Suomen evankelis-luterilaisen kirkon kirkolliskokous. Keskustelupöytäkirja. Syysistuntokausi 1991. Ylimääräinen istunto 10-11.1.1992. Kirkkohallitus, Helsinki.

Kirk.kok. kptk-y. 2000: Ylimääräinen istunto 10.-12.1.2000. Teoksessa Suomen evankelis-luterilaisen kirkon kirkolliskokous. Keskustelupöytäkirja. Syysistuntokausi 1999. Ylimääräinen istunto 10-12.1.2000. Kirkkohallitus, Helsinki.

Kirk.kok. ptk. 1963: Suomen evankelisluterilaisen kirkon yhdeksännentoista varsinaisen kirkolliskokouksen pöytäkirjat 1963. Kirkkohallitus, Helsinki 1964.

Kirk.kok. ptk. 1968: Suomen evankelisluterilaisen kirkon kahdennenkymmenennen varsinaisen kirkolliskokouksen pöytäkirjat 1968. Kirkkohallitus, Helsinki 1969.

Kirk.kok. ptk. 1971: Suomen evankelis-luterilaisen kirkon ylimääräisen kirkolliskokouksen pöytäkirjat 1971. Kirkkohallitus, Helsinki 1972.

Kirk.kok. ptk. 1973: Suomen evankelis-luterilaisen kirkon kahdennenkymmenennenensimmäisen varsinaisen kirkolliskokouksen pöytäkirjat 1973. Kirkkohallitus, Helsinki 1974.

Kirk.kok. ptk-k. 1974-2012: Suomen evankelis-luterilaisen kirkon kirkolliskokous. Pöytäkirja. Kevätistunto[kausi]. Kirkkohallitus, Helsinki.

Kirk.kok. ptk-l. 1963: Suomen evankelisluterilaisen kirkon yhdeksännentoista varsinaisen kirkolliskokouksen pöytäkirjain liitteet 1963. Kirkkohallitus, Helsinki.

Kirk.kok. ptk-1. 1968: Suomen evankelis-luterilaisen kirkon kahdennenkymmenennen varsinaisen kirkolliskokouksen pöytäkirjain liitteet 1968. Kirkkohallitus, Helsinki.

Kirk.kok. ptk-l. 1971: Suomen evankelis-luterilaisen kirkon ylimääräisen kirkolliskokouksen pöytäkirjain liitteet 1971. Kirkkohallitus, Helsinki.

Kirk.kok. ptk-l. 1973: Suomen evankelis-luterilaisen kirkon kahdennenkymmenennenensimmäisen varsinaisen kirkolliskokouksen pöytäkirjain liitteet 1973. Kirkkohallitus, Helsinki.

Kirk.kok. ptk-s. 1974-2012: Suomen evankelis-luterilaisen kirkon kirkolliskokous. Pöytäkirja. Syysistunto[kausi]. Kirkkohallitus, Helsinki.

Kirk.kok. ptk-y. 1974: Ylimääräinen kirkolliskokous 30.12.1974. Teoksessa Suomen evankelis-luterilaisen kirkon kirkolliskokous. Pöytäkirja. Syysistunto 1974. Ylimääräinen kirkolliskokous 30.12.1974. Kirkkohallitus, Helsinki.

Kirk.kok. ptk-y. 1986: Ylimääräinen istuntokausi 13.2.1986. Teoksessa Suomen evankelis-luterilaisen kirkon kirkolliskokous. Pöytäkirja. Syysistuntokausi 1985. Ylimääräinen istuntokausi 13.2.1986. Kirkkohallitus, Helsinki.

Kirk.kok. ptk-y. 1992: Ylimääräinen istunto 10.-11.1.1992. Teoksessa Suomen evankelis-luterilaisen kirkon kirkolliskokous. Pöytäkirja. Syysistuntokausi 1991. Ylimääräinen istunto 10.-11.1.1992. Kirkkohallitus, Helsinki.

Kirk.kok. ptk-y. 2000: Ylimääräinen istunto 10.-12.1.2000. Teoksessa Suomen evankelis-luterilaisen kirkon kirkolliskokous. Pöytäkirja. Syysistuntokausi 1999. Ylimääräinen istunto 10.1.-12.1.2000. Kirkkohallitus, Helsinki.

Kirkkolain uudistamiskomitean mietintö 1988: Kirkkolain uudistamiskomitean mietintö. I ja II kirja. Liite Suomen evankelis-luterilaisen kirkon kirkollis- 
kokouksen syysistuntokauden 2006 pöytäkirjaan. Suomen ev.-lut. kirkon keskushallinto Sarja A 1988:2. Kirkkohallitus, Helsinki.

Kirkon toimikunnat 1974: Kirkon toimikuntien toimintakertomukset vuodelta 1974. [Kirkkohallitus], Helsinki 1975

Kirkon toimikunnat 1976: Kirkon toimikuntien toimintakertomukset vuodelta 1976. [Kirkkohallitus], Helsinki 1977.

Kyrkomötets protokoll höstsession 1985: Den evangelisk-lutherska kyrkan i Finland. Kyrkomötet. Protokoll. Höstsession 1985. Kyrkostyrelsen, Helsingfors.

Käsikirjakomitean ehdotus 1997a: Suomen evankelis-luterilaisen kirkon kirkkokäsikirja I. Jumalanpalvelusten kirja. Suomen evankelis-luterilaisen kirkon kirkolliskokouksen vuonna 1988 asettaman käsikirjakomitean ehdotus. Suomen ev.-lut. kirkon keskushallinto Sarja A 1997:2. Kirkkohallitus, Helsinki.

Käsikirjakomitean ehdotus 1997b: Suomen evankelis-luterilaisen kirkon kirkkokäsikirja II. Evankeliumikirja. Suomen evankelis-luterilaisen kirkon kirkolliskokouksen vuonna 1988 asettaman käsikirjakomitean ehdotus. Suomen ev. lut. kirkon keskushallinto Sarja A 1997:2. Kirkkohallitus, Helsinki.

Käsikirjakomitean ehdotus 1997c: Kirkolliskokouksen vuonna 1988 asettaman käsikirjakomitean mietinnön perustelut. Suomen ev.-lut. kirkon keskushallinto Sarja A 1997:5. Kirkkohallitus, Helsinki.

Käsikirjakomitean ehdotus 2001a: Suomen evankelis-luterilaisen kirkon kirkkokäsikirja III. Kirkollisten toimitusten kirja. Suomen evankelis-luterilaisen kirkon kirkolliskokouksen vuonna 1988 asettaman käsikirjakomitean ehdotus. Suomen ev.-lut. kirkon keskushallinto Sarja A 2001:1. Kirkkohallitus, Helsinki.

Käsikirjakomitean ehdotus 2001b: Kirkolliskokouksen vuonna 1988 asettaman käsikirjakomitean ehdotus Kirkollisten toimitusten kirjaksi. Perustelut. Suomen ev.-lut. kirkon keskushallinto Sarja A 2001:2. Kirkkohallitus, Helsin$\mathrm{ki}$.

PV 2002: Palvelijoiksi vihityt. Suomen evankelis-luterilaisen kirkon vuonna 2000 asettaman virkarakennekomitean mietintö. Suomen ev.-lut. kirkon keskushallinto Sarja A 2002:1. Kirkkohallitus, Helsinki.

Sálbmagirji 1993: Sálbmagirji 1993. Korálagirji. Pohjoissaamenkielinen virsikir ja. Suomen ev.-lut. kirkon keskushallinto Sarja A 1993:1. Kirkkohallitus, Helsinki.

Salmâkirje 1993: Salmâkirje 1993. Koraalkirje. Inarinsaamenkielinen virsikirja. Suomen ev.-lut. kirkon keskushallinto Sarja A 1993:2. Kirkkohallitus, Helsinki.

SEK 1972-75: Suomen evankelis-luterilainen kirkko vuosina 1972-1975. Martti Lindqvist \& Jouko Sihvo \& Markku Isotalo \& Heikki Mäkeläinen. Kirkon tutkimuslaitos, Tampere 1977

SEK 1976-79: Suomen evankelis-luterilainen kirkko vuosina 1976-1979. Heikki Mäkeläinen \& Harri Heino \& Eero Bäckman. Kirkon tutkimuslaitos, Tampere 1981.

SEK 1980-83: Suomen evankelis-luterilainen kirkko vuosina 1980-1983. Harri Heino \& Tage Kurtén \& Juha Kauppinen. Kirkon tutkimuskeskus, Tampere 1985 .

SEK 1984-87: Suomen evankelisluterilainen kirkko vuosina 1984-1987. Harri Hei no \& Juha Kauppinen \& Risto Ahonen. Kirkon tutkimuskeskus, Tampere 1989 .

SEK 1988-91: Suomen evankelis-luterilainen kirkko vuosina 1988-1991. Harr Heino \& Juha Kauppinen \& Risto A. Ahonen. Kirkon tutkimuskeskus Tampere 1993.

SEK 1992-95: Suomen evankelis-luterilainen kirkko vuosina 1992-1995. Harri Heino \& Kari Salonen \& Jaakko Rusama \& Risto Ahonen. Kirkon tutkimuskeskus, Tampere 1997.

SEK 1996-99: Kirkko uudelle vuosituhannelle. Suomen evankelis-luterilainen kirkko vuosina 1996-1999. Kari Salonen \& Kimmo Kääriäinen \& Kati Niemelä. Kirkon tutkimuskeskus, Tampere 2000.

SEK 2000-03: Kirkko muutosten keskellä. Suomen evankelis-luterilainen kirkko vuosina 200o-2003. Kimmo Kääriäinen \& Maarit Hytönen \& Kati Niemelä \& Kari Salonen. Kirkon tutkimuskeskuksen julkaisuja 89. 2. korjattu. p. Kirkon tutkimuskeskus, Tampere 2004.

SEK 2004-07: Monikasvoinen kirkko. Suomen evankelis-luterilainen kirkko vuosina 2004-2007. Kimmo Kääriäinen \& Kimmo Ketola \& Kati Niemelä \& Harri Palmu \& Hanna Salomäki. Kirkon tutkimuskeskuksen julkaisuja 103. Kirkon tutkimuskeskus, Tampere 2008

SEK 2008-11: Haastettu kirkko. Suomen evankelis-luterilainen kirkko vuosina 2008-2011. Harri Palmu \& Hanna Salomäki \& Kimmo Ketola \& Kati Niemelä. Kirkon tutkimuskeskuksen julkaisuja 115. Kirkon tutkimuskeskus, Tampere 2012.

Tuomiokapitulikomitean mietintö 1994: Suomen evankelis-luterilaisen kirkon kirkolliskokouksen 6.11 .1989 asettaman tuomiokapitulikomitean mietintö. Suomen ev.-lut. kirkon keskushallinto Sarja A 1994:1. Kirkkohallitus, Helsinki.

Tuomiokapitulitoimikunnan mietintö 1986: Tuomiokapitulitoimikunnan mietintö. Osamietintö 2. Komiteanmietintö 1985:65. [Opetusministeriö], Helsinki.

UT 1990: Uusi testamentti. Raamatunkäännöskomitean ehdotus. Suomen evankelis-luterilaisen kirkon kirkolliskokouksen syysistuntokauden 1989 pöytäkirjan liite. Suomen ev.-lut. kirkon keskushallinto Sarja A 1989:2. Kirkkohallitus, Helsinki.

Valtion ja kirkon taloudelliset suhteet 1997: Valtion ja kirkon taloudelliset suh- teet. De ekonomiska relationerna mellan staten och kyrkan. Komiteanmietintö 1997:7. Opetusministeriö, [Helsinki].

Virsikirjaehdotus 1984a: Suomen evankelis-luterilaisen kirkon virsikirja. 21. varsinaisen kirkolliskokouksen asettaman virsikirjakomitean ehdotus. Virsikirjakomitea, Helsinki.

Virsikirjaehdotus 1984b: Suomen evankelis-luterilaisen kirkon virsikirja. 21. varsinaisen kirkolliskokouksen asettaman virsikirjakomitean ehdotus. Suomen Kirkon Sisälähetysseura, [Helsinki].

VT 1990: Vanha testamentti I. Raamatunkäännöskomitean ehdotus. Suomen evankelis-luterilaisen kirkon kirkolliskokouksen kevätistuntokauden 1990 pöytäkirjan liite. Suomen ev.-lut. kirkon keskushallinto Sarja A 1990:1. Kirkkohallitus, Helsinki.

VT 1991: Vanha testamentti II. Raamatunkäännöskomitean ehdotus. Suomen evankelis-luterilaisen kirkon kirkolliskokouksen kevätistuntokauden 1991 pöytäkirjan liite. Suomen ev.-lut. kirkon keskushallinto Sarja A 1991:1. Kirkkohallitus, Helsinki.

YKV 1997: Yhdessä kirkon virassa. Suomen evankelis-luterilaisen kirkon vuonn 1994 asettaman diakonaattikomitean mietintö. Kirkolliskokouksen syysistuntokauden 1997 pöytäkirjan liite VIII.B. Suomen ev.-lut. kirkon keskus hallinto Sarja A 1997:9. Kirkkohallitus, Helsinki.

\section{MUUT PAINETUT L ÄHTEET}

Cantell, Risto 1985: Yksi virka ja viran kolmijako. Teologinen Aikakauskirja.

Changing Values 2008: Changing Values and Beliefs in 85 Countries. Trends from the Values Surveys from 1981 to 2004. Loek Halman \& Ronald Inglehart \& Jaime Diez-Medrano \& Ruud Luijkx \& Alejandro Moreno \& Miguel Basáñez. Brill, Leiden \& Boston.

Eskola, Seikko 2004: Kirkolliskokous parlamenttina. Teologinen Aikakauskirja.

Eskola, Seikko 2012a: Ristivetoa kirkon parlamentissa. Maallikkona kirkolliskoko$u$ ksessa. Kleio. Edita, Helsinki.

Eskola, Timo 2002: Paavali. Kärsimyksen ja lohdutuksen apostoli. Johdatus Paavalin opetuksiin. Iustitia. SLEY-Kirjat \& Suomen teologinen instituutti, Helsinki.

Euroopan reformatoristen kirkkojen konkordia 1998: Euroopan reformatoristen kirkkojen konkordia (Leuenbergin konkordia). Teoksessa Ekumeeninen työkirja. Kirkkojen tekstejä 1973-1997. Studia missiologica et oecumenica fennica 59. Luther-Agricola-Seura, Helsinki.

Haaramäki, Ossi 1988: Kansankirkon tehtävänjaolla. Kirkon tehtävän kirkko-oikeudellista pohdintaa. Kirjaneliö, Helsinki.

Haikarainen, Raine 1992: Kosmista iloa ja inhimillistä rosoa. Käsikirjakomite an välimietinnön musiikinteologista pohdintaa. Teologinen Aikakauskirjo.

Harviainen, Tapani 1990: Vanha testamentti uutena käännöksenä. Teologinen Aikakauskirja.

Harviainen, Tapani 2012: Vuoden 1992 raamatunkäännöksen syntytilanne ja tausta. Teologinen Aikakauskirja.

Heikkilä, Markku 1992: Mitä todelliselta kirkkolainuudistukselta voidaan odottaa? Teologinen Aikakauskirja.

Homoseksuaalisuus kristillisessä ihmiskuvassa ja lainsäädännössä 2009: Homoseksuaalisuus kristillisessä ihmiskuvassa ja lainsäädännössä. Toim. Antti Saarelma. Kirkon tutkimuskeskuksen julkaisuja 105. Kirkon tutkimuskeskus, Tampere.

Homoseksuaalisuus Raamatussa ja kirkon opetuksessa 2007: Homoseksuaalisuus Raamatussa ja kirkon opetuksessa. Toim. Antti Saarelma. Kirkon tutkimuskeskuksen julkaisuja 101. Kirkon tutkimuskeskus, Tampere.

Huovinen, Eero 1991: Konfirmaatio ja kirkollinen äänioikeus. Teologinen Aikakauskirja.

Huovinen, Eero 1999: Kokonaisuus on osiensa summa. Kirkon ja valtion suhteiden tarkastelua. Teologinen Aikakauskirja.

Huovinen, Eero 2011: Lähdön aika. WSOY, Helsinki.

Hyvönen, Väinö A. 1990: Yhteinen raamatunkäännös. Teologinen Aikakauskirja. Hämäläinen, Unto 2011: Suomi Orwellin vuonna 1984. HS kirjat, [Helsinki]

Johannes, metropoliitta 1986: Raamatunsuomennos ja ortodoksinen kirkko. Teoksessa Kohti uutta Kirkkoraamattua. Näkökulmia Raamatun kääntämiseen. Toim. Jorma Salminen \& Aarne Toivanen. Suomen Eksegeettisen Seuran julkaisuja 43. Suomen Eksegeettinen Seura, Helsinki.

Juva, Mikko 1994: Seurasin nuoruuteni näkyä. Muistettavaa vuosilta 1939-82. 2. p. Otava, Helsinki.

Kansanaho, Erkki 2001: Elämän matkakirja. Itinerarium vitae. Kirjapaja, Helsinki.

Kansanaho, Erkki 2002: Jukka Paarman tie arkkipiispaksi. Teoksessa Arkki ja arki. Arkkipiispa Jukka Paarman juhlakirja. Toim. Marketta Ruoppila-Martinsen. Pyhän Henrikin säätiön julkaisuja 3. Kirjapaja, Helsinki.

Kasvamaan yhdessä 2004: Kasvamaan yhdessä. Piispojen puheenvuoro perhe- ja seksuaalietiikan kysymyksistä. Kirjaneliö, Helsinki.

Kauppinen, Juha 2004: Kirkolliskokouksen ryhmittymät ja niiden vaikutus. Teologinen Aikakauskirja.

Kejonen, Eetu \& Hintsala, Meri-Anna 2013: Torjuttuna vai ymmärrettynä? Homoseksuaalisuuden kohtaaminen. Teoksessa Tuoreet oksat viinipuus sa. Vanhoillislestadiolaisuus peilissä. Toim. Meri-Anna Hintsala \& Mauri Kinnunen. Kirjapaja, Helsinki. 
Kiitollisuus, kunnioitus, kohtuus 2008: Kiitollisuus, kunnioitus, kohtuus. Suomen evankelis-luterilaisen kirkon ilmasto-ohjelma. Suomen ev.lut. kirkon kirkkohallituksen julkaisuja 2008:1. Kirkkohallitus, Helsinki.

Kirkko 2000 1986: Kirkko 200o. Kirkon toiminnan pitkän aikavälin kehittämissuunnitelma. Suomen ev.-lut. kirkon keskushallinto Sarja B 1986:1. [Kirkkohallitus, Helsinki].

Kirkko ja rekisteröidyt parisuhteet 2009: Kirkko ja rekisteröidyt parisuhteet. Suomen evankelis-luterilaisen kirkon piispainkokouksen 14.9.2005 asettaman työryhmän mietintö. Suomen ev.-lut. kirkon keskushallinto Sarja B 2009:1. [Kirkkohallitus, Helsinki].

Kirkon kalenteri 1975: Kirkon kalenteri 1975. Suomen Kirkon Sisälähetysseura, Helsinki.

Kirkon päättäjät 1996: Kirkon päättäjät. Suomen ev.lut. kirkko. Matrikkeli 1996. Kotimaa, Helsinki.

Kirkon suunta 2000 1992: Kirkon suunta 200o. Alhaalta kasvava kirkko. Suomen evankelis-luterilaisen kirkon piispainkokouksen 14.9.1988 asettama Kirkko 2000 -prosessin seurantatyöryhmä. Suomen ev.-lut. kirkon keskushallinto Sarja B 1992:2. [Kirkkohallitus, Helsinki].

Kiviranta, Simo 1973: Luterilaisten ja reformoitujen yhteyspyrkimykset. Teoksessa LKTP 1973.

Kiviranta, Simo 1990: Kriittisiä havaintoja Uuden testamentin käännösehdotuksen kristologiasta. Teologinen Aikakauskirja.

Kiviranta, Simo 2009: Katkelmia. Haastatteluista koonnut Helena Simons. Suomen Luther-säätiö, [Helsinki]

Kohti aktiivista kansalaisuutta 2005: Kohti aktiivista kansalaisuutta. Kansalaisyhteiskunta 2006 -toimikunnan raportti. Oikeusministeriön julkaisu 2005:14. Oikeusministeriö, Helsinki.

Kortekangas, Paavo 1974: Suomen kirkon elämää. Teoksessa Kirkon kalenteri 1975. Suomen Kirkon Sisälähetysseura, Helsinki.

Koskenniemi, Erkki 1990: Sujuva suomenkieli vai asiallinen tarkkuus? Paavalin kirjeiden käännösehdotuksen kritiikkiä. Teologinen Aikakauskirja.

Koskenniemi, Heikki 1992: Raamattua nykysuomeksi kääntämässä. Teoksessa Kotimatkalla 1992. Suomen Luterilaisen Evankeliumiyhdistyksen vuosikirja. SLEY-Kirjat, [Helsinki].

Koskenniemi, Lauri 200o: Unohtumattomia aikoja ja ihmisiä. SLEY-Kirjat, Helsinki.

Koskenvesa, Esko 1992: Kansanjuhla hoviväelle. Teologinen Aikakauskirja.

Kurki-Suonio, Erkki 1985: Virsikirjaehdotuksesta. Teologinen Aikakauskirja.

Kuula, Kari 2002: Paavali. Kristinuskon ensimmäinen teologi. 2. p. Edita, Helsinki.

Lapuan hpk.kok. ptk. 1976: Pöytäkirja Lapuan hiippakunnan hiippakuntakokouksesta Lapualla maaliskuun 9 ja 10 päivinä 1976. Lapua.

Lapuan hpk.kok. ptk. 1978: Pöytäkirja Lapuan hiippakunnan hiippakuntakokouksesta Lapualla 15.-16.3.1978, s.l.

Lehtipuu, Outi \& Laine, Esko M. 2012: Mitä runomuoto merkitsee psalmien kääntämiselle? Runoilija Kirsi Kunnas raamatunkäännöstyössä. Teologinen Aikakauskirja.

Leivonen, Johannes 1989: Kirkkolakiesityksen yleisesittelyä. Teologinen Aikakauskirja.

Lempiäinen, Pentti 2003: Jumalanpalvelus - ketä varten? Teoksessa Muutoksen tulkkina. Kirkot ja uskonnollinen elämä osana yhteiskuntaa. Toim. Eila Helander. Käytännöllisen teologian laitoksen julkaisuja 106. Helsingin yliopiston käytännöllisen teologian laitos \& Kirjapaja, Helsinki.

Liljeqvist, Matti 1990: Vaihtoehtoisen raamatunkäännöksen arviointia. Teologinen Aikakauskirja.

LKTP 1973: Leuenbergin konkordialuonnoksen teologisia perusongelmia: Suomen evankelis-luterilaisen kirkon työryhmän muistio. Toim. Simo Kiviranta. Missiologian ja ekumeniikan seuran julkaisuja 22. Missiologian ja ekumeniikan seura, Helsinki.

Mannermaa, Tuomo 1990: Paavalin kirjeiden suomennoksen filosofis-teologinen lähtökohta. Teologinen Aikakauskirja.

Nieminen, Heikki-Tapio 2011: Piispainkronikka. Sodanjälkeiset arkkipiispat, piispat ja kenttäpiispat lähikuvassa. Edico, Helsinki.

Numminen, Jaakko 1991: Suomen ja Ruotsin kirkolliskokouksista ja kirkoista. Teoksessa Purjeena perinne. Juhlakirja Arkkipiispa John Vikströmin täyttäessä 60 vuotta 1. lokakuuta 1991. Turun arkkihiippakunnan vuosikirja XLI. Turun arkkihiippakunta, Turku.

Nya testamentet 1981: Nya testamentet. Bibelkommissionens utgåva 1981. Första upplagan. Svenska Bibelsällskapet, [Stockholm].

Oulun hpk.kok. ptk. 1974: Vuonna 1974 pidetyn Oulun hiippakuntakokouksen päätökset. Oulu.

Oulun hpk.kok. ptk. 1976: Vuonna 1976 pidetyn Oulun hiippakuntakokouksen päätökset. Oulu.

Paarma, Jukka 2001: Arvot ja armo. Paimenkirja. Pyhän Henrikin säätiön julkaisuja 2. Kirjapaja, Helsinki.

Parvio, Martti 1985: Luterilaisen kirkon virsikirjaehdotus. Teologinen Aikakauskirja.

Penttinen, Arja 2009: Sateenkaarikansan elämän valintoja. Arcus-verkoston puheenvuoro. Teoksessa Homoseksuaalisuus kristillisessä ihmiskuvassa ja lainsäädännössä. Toim. Antti Saarelma. Kirkon tutkimuskeskuksen julkaisuja 105. Kirkon tutkimuskeskus, Tampere.

Peura, Simo 1989: Olla Kristuksessa. Näkökohtia Raamatun kääntämisestä, ekumeenisesta metodologiasta ja etiikasta. Teologinen Aikakauskirja.

Pihkala, Juha 2007: Piispa. Tampereen hiippakunnan vuosikirja 2008. Minerva, Helsinki \& Jyväskylä.

Piisp.kok. ptk-k. 1991: Piispainkokouksen pöytäkirja 5.-6.3.1991. [Kirkkohallitus, Helsinki].

Piisp.kok. ptk-k. 2002: Piispainkokouksen pöytäkirja 12.-13.2.2002. Kirkkohallitus, [Helsinki].

Piisp.kok. ptk-s. 1990: Piispainkokouksen pöytäkirja 11.-12.9.199o. [Kirkkohallitus, Helsinki]

Piisp.kok. ptk-s. 1995: Piispainkokouksen pöytäkirja 12.-13.9.1995. [Kirkkohallitus, Helsinki].

Piisp.kok. ptk-y. 1976: Piispainkokouksen pöytäkirja 20.4.1976. [Kirkkohallitus, Helsinki].

Piisp.kok. ptk-y. 1991: Piispainkokouksen pöytäkirja 29.4.1991. [Kirkkohallitus, Helsinki].

Piisp.kok. ptk-y. 2003: Piispainkokouksen pöytäkirja 31.3.2003. Kirkkohallitus, [Helsinki].

Rainerma, Keijo 2010: Ahtaalla ja avaralla. 6o. Perussanoma, Kauniainen

Ratzeburger Thesen 1972: Ratzeburger Thesen zur „Leuenberger Konkordie“. Bundesvorstand der „Kirchlichen Sammlung um Bibel und Bekenntnis“. Ratzeburg.

Räisänen, Heikki 1990: "Kristuksessa" raamatunkäännöksen ongelmana. Teologinen Aikakauskirja.

Sariola, Yrjö 1992: Käsikirjakomitean välimietintö. Liikkeellelähtö kohti uudistuvaa jumalanpalvelusta. Teologinen Aikakauskirja.

Sariola, Yrjö 1993: Seurakunta jumalanpalveluksen liturgisena subjektina? Teologiset periaatteet. Teologinen Aikakauskirja.

Sariola, Yrjö 1994: Uudistuva jumalanpalvelus. Tutkielmia jumalanpalveluksen teologiasta. STKSJ 191. STKS, Helsinki.

Sariola, Yrjö 200o: Uuden kirkkokäsikirjan syntyprosessin tarkastelua. Teologinen Aikakauskirja.

Seurakunta 2000 1987: Seurakunta 200o. Suomen evankelis-luterilaisen kirkon piispainkokouksen 11.2.1987 Helsingissä asettaman Kirkko 2000 -jatkotyöryhmän mietintö. Suomen ev.-lut. kirkon keskushallinto Sarja B 1987:5. [Kirkkohallitus, Helsinki].

Simojoki, Anssi 1984a: Miksi tämä kirja? Teoksessa Herran käsky. Asiatietoa naispappeuskysymyksestä. Toim. Anssi Simojoki. SLEY-Kirjat, Helsinki.

Simojoki, Anssi 1984b: Havaintoja naispappeuden teologisista perusteluyrityksistä Suomen kirkossa. Teoksessa Herran käsky. Asiatietoa naispappeuskysymyksestä. Toim. Anssi Simojoki. SLEY-Kirjat, Helsinki.

Simojoki, Pentti 1985: Eräitä havaintoja virsikirjaehdotuksesta. Teologinen Aikakauskirja.

Sollamo, Raija 2006: Vanhan testamentin apokryfikirjojen uusi suomennos. Teoksessa Signum unitatis - Ykseyden merkki. Piispa Juha Pihkalan juhlakirja. Tampereen hiippakunnan vuosikirja 2007. Toim. Ari Hukari. Kirjapaja, Helsinki.

Sovijärvi, Otso 2008: Pappilaelämää. Kirkosta, ihmisistä ja vallasta. Sartia, Helsinki.

ST 1982: Suomen teologit 1982. Suomen kirkon pappisliitto, [Helsinki].

Stenbäck, Pär 1991: Sillä me emme voi mitään totuutta vastaan. Teoksessa Purjeena perinne. Juhlakirja Arkkipiispa John Vikströmin täyttäessä 60 vuotta 1. lokakuuta 1991. Turun arkkihiippakunnan vuosikirja XLI. Turun arkkihiippakunta, Turku.

Suokunnas, Seppo 2012: Herätysliikkeiden vaikutus vuoden 1986 virsikirjaan. Teoksessa Crux spes unica. Risti, ainoa toivo. Piispa Olavi Rimpiläinen 75 vuotta. Toim. Jouko M.V. Heikkinen \& Veijo Koivula. Aurinko, [Helsinki].

Taskila, Lauri 1998: Työ on Herran. Tuokiokuvia sanankylväjän matkoilta. SRK, Oulu.

Teinilä, Mari 2001: Anna-Maija Raittila. Luottamuksen pyhiinvaeltaja. Kirjapaja, Helsinki.

Thurén, Jukka 1992: Yrittänyttä ei laiteta. Teoksessa Kotimatkalla 1992. Suomen Luterilaisen Evankeliumiyhdistyksen vuosikirja. SLEY-Kirjat, [Helsinki].

Toivanen, Aarne 1989: Sanotaan se suomeksi. Uudistuva raamatunkäännös UT. Kirjapaja, Helsinki.

Toivanen, Aarne 1990: Sanotaan se suomeksi. Uudistuva Raamatun käännös VT 1. Kirjapaja, Helsinki.

Toivanen, Aarne 1991: Sanotaan se suomeksi. Uudistuva Raamatun käännös VT 2. Kirjapaja, Helsinki.

Toiviainen, Kalevi 1989: Ekklesiologisia kysymyksiä kirkkolain äärellä. Teologinen Aikakauskirja.

Toiviainen, Kalevi 2000: Kirkon kaapin päällä. Sata vuotta - 50 vaikuttajaa. Kirjapaja, Helsinki.

Turun hpk.kok. ptk. 1992: Turun arkkihiippakunnan 17.3.1992 pidetyn lakimääräisen hiippakuntakokouksen pöytäkirja. s.l.

Turun kaupungin tilastollinen vuosikirja 2011: Turun kaupungin tilastollinen vuosikirja 2011. Statistisk årsbok för Åbo stad 2011. Turun kaupungin keskushallinto, Turku.

Työn johtaminen 2006: Työn johtaminen, työyhteisöjen kehittäminen ja työturvallisuus. Piispainkokouksen 10.-11.2.2004 asettaman työryhmän mietintö. Suomen ev.-lut. kirkon keskushallinto Sarja B 2006:2. [Kirkkohallitus, Helsinki].

Ventä, Kari 2009: Rekisteröidyn parisuhteen siunaamisen juridiikka. Teokses- 
sa Homoseksuaalisuus kristillisessä ihmiskuvassa ja lainsäädännössä. Toim. Antti Saarelma. Kirkon tutkimuskeskuksen julkaisuja 105. Kirkon tutkimuskeskus, Tampere.

Vikström, John 2004: Kirkolliskokouksen vaikutus ja merkitys kirkon hallinnossa. Teologinen Aikakauskirja.

Voipio, Jaakko 1989: Kirkkoa koskevat oikeusnormit ja säädösten hierarkia. Teologinen Aikakauskirja.

Vp. ak. C 2003: Vuoden 2003 valtiopäivät. Asiakirjat C. Valiokuntien mietinnöt ja lausunnot. Eduskunta, Helsinki 2004

Vp. ak. E 2009: Vuoden 2009 valtiopäivät. Asiakirjat E. Aloitteet. Eduskunta, Helsinki 2010.

Vp. ptk. 1993: Vuoden 1993 valtiopäivät. Pöytäkirjat. Eduskunta, Helsinki 1994.

Vp. ptk. 1998: Vuoden 1998 valtiopäivät. Pöytäkirjat. Eduskunta, Helsinki 2000.

\section{SANOMA- JA AIKAKAUSLEHDET}

Al Aamulehti

Demari

DN Dagens Nyheter

ES Etelä-Saimaa

ESS Etelä-Suomen Sanomat

Eteenpäin

$\mathrm{Hbl}$ Hufvudstadsbladet

Herättäjä

HS Helsingin Sanomat

Hämeen Sanomat

Iisalmen Sanomat

Il

Iltalehti

Ilkka

IS Ilta-Sanomat

Itä-Häme

Itä-Savo

Jäsenlehti-

Kaleva

Kansan Lehti

Kansan Tahto

Kauppalehti

Keski-Uusimaa

KJK Kirkkoja kaupunki

KM Karjalan Maa

Kmaa Kotimaa

Knen Karjalainen

Kotiliesi

Kouvolan Sanomat

Kp Keskipohjanmaa

Kpr Kyrkpressen

KS Kainuun Sanomat

Ksml Keskisuomalainen

Kristityn Vastuu

Kymen Sanomat

Lalli

LK Lapin Kansa

Länsi-Savo

Länsi-Suomi

Länsi-Uusimaa

Metro

MT Maaseudun Tulevaisuus

Perusta

Pms Päivämies

Pnen Pohjalainen

PS Pohjolan Sanomat

Sana

Sd Suomen Sosialidemokraatti

SD Svenska Dagbladet

Sisarenpoika

Sanansaattaja
KU Kansan Uutiset

PTyö Pohjolan Työ

Riihimäen Sanomat
1976,1978-1989, 1991-1992, 1998-2000, 2002, 2004

1993

$1976,1978,1981,2002$

1976, 1980-1985, 1987, 1998-1999, 2000, 2002, 2004, 2007

1982-1983, 1985-1987

1980-1981, 1983-1986, 1988, 1992-1994, 2000-2002, 2008

1976

1975-1976, 1978, 1980-1986, 1991-1995, 1999, 2002-2004, 2006-2008, 2010

1975, 1979-1981, 1983, 1985-1986, 1992, 1998, 2002-2004, 2007-2008 1981-1982, 1984, 1988, 1994, 2003 1994, 1998-1999, 2004, 2006-2007 1979-1980, 1982-1984, 1986-1987, 1990 1992, 1994, 1998, 2002, 2004-2005, 2008 1977,1980-1981,1984-1985,1991-1993, 1995 1991 2003-2004

ppisliitto 1986

1976, 1978, 1981, 1983-1987, 1992, 1995, 1999, 2005-2007

$1974,1978,1980$

1978,2006

1999-2000

1995

$1979,1984,1992,1994$

1984, 2002

1974-2011

1976, 1978, 1981, 1984-1987, 1989-1990, 1995, 1998, 2000, 2002, 2004, 2007-2008 1976

$1979,1981,2002-2003,2007$

1981-1986, 1992, 2004

$1976,1980,1984,1987$

1978, 1981-1986, 1993, 2002, 2006

1974, 1978-1982,1984-1986, 1992,1994.

1998, 2002, 2004, 2007-2008

2002

1980-1981, 1985

1994, 1998, 2002, 2004-2005

1998

1985,1992

1980-1981, 1984-1986, 1989, 1994, 2008

1981, 1991-1992, 1998, 2000, 2002, 2004

1976, 1979-1980, 1983-1984, 1992-1993, 1998

2002

2008

1976

1998

1986

1984, 1986-1987, 1989, 2002-2003, 2005, 2007-2008

1984, 1986, 1991, 2002

1982

1984

1980, 1982, 1996

$1976,1978,1980,1982,1984-1987$

1983

1993

1981
SK

Suomen Kuvalehti

SkK

Satakunnan Kansa

SkT Satakunnan Työ

Smaa Suomenmaa

SS Savon Sanomat

SSS Salon Seudun Sanomat

Talouselämä

Turun Sanomat

US Turun Päiväleht

Uusi Suomi

Uusimaa

Uusi Tie

Vaasa

Vasabladet

Viikkolehti

WL Warkauden Leht

Yliopppilaslehti

ÅU Åbo Underrättelser
1976, 1982-1984, 1999, 2002, 2004, 2006-2007

1978, 1980-1982, 1984-1987, 1992, 2002, 2004

1976

$1983,1985,1988,2000,2002$

1975-1976, 1978, 1980-1982, 1984-1987

1991-1994, 1998, 2000, 2002-2003, 2007

$1978,1982-1983$

1999

1976, 1978-1979, 1981-1987, 1990-1991,

1993-1994, 1996, 1998-1999, 2002-

2005, 2008

1976,1986

1974, 1976, 1978-1979, 1981-1987

1981, 2007

$1980-1981,1995,2010$

$1974,1976,1978-1981,1984$

1983,1998

1992

1981

1995

1976, 1980-1982, 1984, 1986, 1988, 2004

\section{VERKKOPÄIVÄKIRJAT}

Heikka, Mikko (Kotimaa24). <http://www.kotimaa24.fi/omasivuni?view $=$ profile $\&$ uid $=4694>$

Kemppinen, Jukka. <http://kemppinen.blogspot.com>.

Siukonen, Antti (2004-07). <http://www.nuorikirkko.net>.

\section{MUUT INTERNET-LÄHTEET}

Alkoholijuomien kulutus: Suomen virallinen tilasto (SVT): Alkoholijuomien kulutus. Terveyden ja hyvinvoinnin laitos, Helsinki. < http://www.tilastokeskus.fi/til/ajkul/index.html>. Katsottu 4.8.2013.

Kansantalouden tilinpito 2006: Suomen virallinen tilasto (SVT): Kansantalouden tilinpito 2006*. Bruttokansantuote (BKT) markkinahintaan 19752006. Tilastokeskus, Helsinki. <http://tilastokeskus.fi/til/vtp/2006/ vtp_2006_2008-01-31_tau_001.html >. Katsottu 18.3.2011.

Kansantalouden tilinpito 2012: Suomen virallinen tilasto (SVT): Kansantalouden tilinpito 2012. Liitetaulukko 1. Bruttokansantuote (BKT) markkinahintaan 1975-2012*. Tilastokeskus, Helsinki. <http://www.tilastokeskus.fi/til/ vtp/2012/vtp_2012_2013-03-01_tau_001_fi.html>. Katsottu 22.3.2013.

KJK-verkkosivut: Kirkko ja kaupunki. <http://www.kirkkojakaupunki.fi>. Katsottu 2011.

Kotimaa24: Kotimaa24. <http://www.kotimaa24.fi>. Katsottu 2010-2013.

Kuluttajahintaindeksi: Suomen virallinen tilasto (SVT): Kuluttajahintaindeksi. Tilastokeskus, Helsinki. < http://tilastokeskus.fi/til/khi/tau.html >. Katsottu 22.3.2013.

Lapuan hiippakunta: Lapuan hiippakunta. <http://www.lapuanhiippakunta.fi>. Katsottu 2013.

Meidän kirkko 2008: Meidän kirkko - osallisuuden yhteisö. <https://evl.fi/EVLfi. nsf/Documents/49BEA3A9834046A9C225749Coo290C4F/\$file/Meidan kirkko_strategia2015.pdf >. Katsottu 12.3.2013.

Seurakuntalainen: Seurakuntalainen. Kristillinen uutismedia. <http://www.seurakuntalainen.fi/>. Katsottu 2011-2013.

Suomen ev.lut. kirkko: Uutiset: Suomen ev.lut. kirkko: Uutiset. $<$ http://evl.fi/EVLUutiset.nsf/Perushaku?ReadForm \&Start $=1 \&$ Count $=10$ \&lang $=$ FI $>$. Katsottu 2013.

Tulkaa kaikki -liike: Tulkaa kaikki -liike. <http://www.tulkaakaikki.net/index. html>. Katsottu 2013.

Väestön koulutusrakenne 2011: Suomen virallinen tilasto (SVT): Väestön koulutusrakenne 2011. Tilastokeskus, Helsinki 2012. <http://www.stat.fi/til/ vkour/2011/vkour_2011_2012-12-04_fi.pdf >. Katsottu 4.3.2013.

Yhteys-liikkeen kevätkokous 5.2.2004: Muistio Yhteys-liikkeen kevätkokouksesta 5.2.2004. <http://www.yhteys.org/poytakirjat/kevatkokous2004.pdf >. Katsottu 4.11.2010.

\section{HAASTAT TELUT JA TIEDONANNOT}

Professori Seikko Eskolan kirjallinen tiedonanto 28.4.2013.

Asessori Ossi Haaramäen haastattelu 28.10.2010.

Dosentti Vesa Hirvosen puhelinhaastattelu 25.2.2013.

Filosofian maisteri Leena Huiman kirjallinen tiedonanto 21.3.2014.

Vanhemman hallitussihteerin Marjatta Lehtisen suullinen tiedonanto 30.9.2012.

Ministeri Jaakko Nummisen haastattelu 4.7.2012.

Varatuomari Sinikka Pylkkäsen haastattelu 7.1.2014. 
Seurakuntaneuvos Kaisu Rantalan puhelinhaastattelu 16.9.2013. Seurakuntaneuvos Alma Saaren sähköpostihaastattelut 25.1.2012 ja 9.2.2012. Piispa Matti Sihvosen puhelinhaastattelu 16.12.2013.

Professori Raija Sollamon sähköpostihaastattelu 18.9.2013.

Dosentti Seppo Suokunnaan sähköpostihaastattelu 17.5.2012.

Professori Kyllikki Tiensuun suullinen tiedonanto 23.5.2011.

Dosentti Aarne Toivasen haastattelu 20.1.2012.

Ministeri Marjatta Väänäsen puhelinhaastattelu 28.4.2005.

\section{KIRJALLISUUS}

Ahlgren, Kirsi 2001: Naiset kirkolliskokousedustajina vuosina 1938-1973. Suomen ja Skandinavian kirkkohistorian julkaisematon pro gradu -tutkielma. Helsingin yliopisto, kirkkohistorian laitos.

Ahonen, Risto A.1991: Diakonaatin uudistus. Diakonian viran kehittäminen Suomen evankelis-luterilaisessa kirkossa ja muissa luterilaisissa kirkoissa. Kirkon tutkimuskeskus Sarja A 56. Kirkon tutkimuskeskus, Tampere.

Ahonen, Sirkka 2012: Yleissivistävä koulutus hyvinvointiyhteiskunnassa. Teoksessa Tiedon ja osaamisen Suomi. Kasvatus ja koulutus Suomessa 196o-luvulta 200o-luvulle. Toim. Pauli Kettunen \& Hannu Simola. Suomen kasvatuksen ja koulutuksen historia 3. SKST 1266:3, Tiede. SKS, Helsinki.

Alatalo, Jani 2007: Kohti avoimuutta. Vanhoillislestadiolaisuuden käsittely julkisuudessa ja vanhoillislestadiolaisten suhtautuminen julkisuuteen Suomessa vuosina 1976-1984. Jani Alatalo, Jyväskylä.

Alestalo, Matti 1980: Yhteiskuntaluokat ja sosiaaliset kerrostumat toisen maailmansodan jälkeen. Teoksessa Suomalaiset. Yhteiskunnan rakenne teollistumisen aikana. WSOY, Porvoo \& Helsinki \& Juva.

Alvunger, Daniel 2006: Nytt vin i gamla läglar. Socialdemokratisk kyrkopolitik under perioden 1944-1973. Diss. Lund. Församlingsförlaget, Göteborg.

Antila, Jaakko Olavi 2008: Arkipyhät - osoitus kirkolliskokouksen asemasta ja toiminnasta Suomen poliittisessa järjestelmässä 1971-1982?. Teoksessa SKHSV 98. SKHS, Helsinki.

Antila, Jaakko Olavi 2010: "Politiikka on kirkossa". Keskustapuolueen kirkkopoliittisten tavoitteiden muotoutuminen vuosina 1966-1978. SKHST 213. Diss. Helsinki. SKHS, Helsinki.

Antila, Jaakko Olavi 2011: Usko, oppi ja määräenemmistö kirkolliskokouksessa. Neljän vuosikymmenen tulkintavaikeudet. Teologinen Aikakauskirja.

Antila, Jaakko Olavi 2013: Kirkollinen hallintohistoria tutkimusalana. Teoksessa Kristinuskon historian tutkimusalat ja metodit. Toim. Jaakko Olavi Antila \& Esko M. Laine \& Juha Meriläinen. SKHST 226. SKHS, Helsinki.

Autio, Veli-Matti 1994: Suurjärjestelmien aika koittaa 1966-1980. Hyvinvointivaltion koulutus- ja kulttuuripolitttiset visiot haasteeksi uudistuneelle opetusministeriölle. Opetusministeriön historia 6. Opetusministeriö, Helsinki.

Autio, Veli-Matti 1997: Vakiintuneisuudesta uusien muotojen etsimiseen 19811995. Opetusministeriön historia 7. Opetusministeriö, Helsinki.

Bexell, Oloph 1990: Präster och lekmän i kyrkomötet. Några linjer i allmänna kyrkomötets diskussion om sin egen sammansättning. Teoksessa $\mathrm{Med}$ engagemang och medansvar. En bok om lekmannaskapet i Svenska kyrkan. Festskrift till Carl Henrik Martling. Redaktion Oloph Bexell \& Sven-Erik Brodd \& Gunnar Edqvist \& Sören Ekström \& Gunnar Weman. Verbum, Stockholm.

Björkstrand, Gustav 1980: Barnens nattvardsgång. Församlingsförbundet, [Helsingfors].

Björkstrand, Gustav 1992: Onko ero kirkon ja valtion välillä mahdollinen? Teologinen Aikakauskirja.

Björkstrand, Gustav 1993: Striden om söckenhelgerna. Teoksessa Vägar och vyer. Föredrag och artiklar i praktisk teologi. Skrifter i praktisk teologi vid Åbo Akademi 37. [Åbo Akademi], Åbo.

Björkstrand, Gustav 2012: Enligt lika grunder. Språkkonsekvensbedömning av de föreslagna strukturmodellerna för den evangelisk-lutherska kyrkan i Finland. Magma-studie 4/2012. Finlands svenska tankesmedja Magma, [Helsingfors].

Borg, Sami 2012a: Valitsijoiden liikkuvuus eduskuntavaaleissa 2007-2011. Teoksessa Muutosvaalit 2011. Selvityksiä ja ohjeita 16/2012. Oikeusministeriö, Helsinki. <http://urn.fi/URN:ISBN:978-952-259-172-2>. Katsottu 18.2.2013.

Borg, Sami 2012b: Perussuomalaiset. Teoksessa Muutosvaalit 2011. Selvityksiä ja ohjeita 16/2012. Oikeusministeriö, Helsinki. <http://urn.fi/ URN:ISBN:978-952-259-172-2>. Katsottu 18.2.2013.

Brohed, Ingmar 2005: Sveriges kyrkohistoria 8. Religionsfrihetens och ekumenikens tid. Verbum, Stockholm.

Ekstrand, Sixten 2012: Gustav Björkstrand (1941-) Porvoon piispa, käytännöllisen teologian professori, Åbo Akademin rehtori, opetusministeri. Teoksessa Kirkollisia vaikuttajia Pyhästä Henrikistä nykypäivään. Toim. Hannu Mustakallio. Studia Biographica 10. SKS, Helsinki.

Ekström, Sören 2003: Makten över kyrkan. Om Svenska kyrkan, folket och staten. Verbum, Stockholm.

Elonheimo, Markku 2006: Piispa, hiippakunta ja tuomiokapituli - pysyvyyttä ja muutoksia kirkon alkuajoilta aina nykyiseen hiippakuntahallintoon. Teoksessa Viisi leipää ja kaksi kalaa - savolaispojan eväät. Piispa Wille Riekkinen 60 vuotta 2006. Toim. Sakari Häkkinen. Kirjapaja, Helsinki.
Eriksson, Jyrki 2013: Arkkipiispa John Vikström Suomen kirkolliskokouksen puheenjohtajana 1982-1998. Suomen ja Skandinavian kirkkohistorian julkaisematon pro gradu -tutkielma. Helsingin yliopisto, teologinen tiedekunta.

Erkkilä, Lasse 2003: Kanttorin virka. Teoksessa Kirkkomusiikin käsikirja. Toim. Lasse Erkkilä \& Ulla Tuovinen \& Erkki Tuppurainen. Kirjapaja, Helsinki.

Eskola, Seikko 2005: Leivonen, Johannes (1917-1995). Teoksessa Suomen kansallisbiografia 6. Studia Biographica 3:6. SKS, Helsinki.

Eskola, Seikko 2012b: Mikko Juva (1918-2004) arkkipiispa, Helsingin yliopiston kansleri, historian ja kirkkohistorian professori, Liberaalisen Kansanpuolueen puheenjohtaja. Teoksessa Kirkollisia vaikuttajia Pyhästä Henrikistä nykypäivään. Toim. Hannu Mustakallio. Studia Biographica 10. SKS, Helsinki.

Evans, G. R. 1996: Method in Ecumenical Theology. The lessons so far. Cambridge University Press, Cambridge.

Forsberg, Juhani 2012: Tuomo Mannermaa (1937-) ekumeniikan professori, Luther-tutkija. Teoksessa Kirkollisia vaikuttajia Pyhästä Henrikistä nykypäivään. Toim. Hannu Mustakallio. Studia Biographica 10. SKS, Helsinki.

Grönlund, Kimmo \& Westinen, Jussi 2012: Puoluevalinta. Teoksessa Muutosvaalit 2011. Selvityksiä ja ohjeita 16/2012. Oikeusministeriö, [Helsinki]. $<$ http://urn.fi/URN:ISBN:978-952-259-172-2>. Katsottu 18.2.2013.

Grönvik, Lorenz 1994: Porvoon yhteinen julkilausuma ja kirkollinen virka. Teologinen Aikakauskirja.

Gustafsson, Göran 1987: Kyrkomötet 1983-1985. Ledamöterna och deras aktivitet. Religion och samhälle 1987:11 $\mathrm{nr} 25$. Religionssociologiska institutet, Stockholm.

Haapakoski, Petri 2002: Tasavallan presidentti Mauno Koiviston näkemys kirkon roolista ja tehtävästä suomalaisessa yhteiskunnassa. Suomen ja Skandinavian kirkkohistorian julkaisematon pro gradu -tutkielma. Helsingin yliopisto, kirkkohistorian laitos.

Haapanen, Pirkko 1978: Kirkko ottaa kantaa. Kirkon tutkimuslaitos Sarja A 33. Kirkon tutkimuslaitos, Tampere.

Hansson, Karl-Johan 1977: Tradition och förnyelse. Fakta och synpunkter inför den finlandssvenska psalmboksrevisionen. Kyrkans forskningsinstitut Serie B 28. Kyrkans forskningsinstitut, Tammerfors.

Harakas, Stanley Samuel 2004: Science, Technology, Ecology. Teoksessa A History of the Ecumenical Movement. Volume 3. 1968-20oo. Ed. by John Briggs \& Mercy Amba Oduyoye \& Georges Tsetsis. World Council of Churches, Geneva.

Haveri, Arto 2008: Suomalainen paikallinen itsehallinto - demokratian ja tehokkuuden perusta. Teoksessa Suomen ja kansanvallan haasteet. Suomen eduskunta 100 vuotta 12. Edita, Helsinki.

Heikkilä, Markku 1991: Uudistuva kirkkolaki. Teoksessa Kirkon uudistusten teologia. Suomalaisen Teologisen Kirjallisuusseuran vuosikirja 1991. Toim. Kari Kopperi. STKSJ 174. STKS, Helsinki.

Heikkilä, Markku 2003: Kirkko-oikeus, kirkko ja yhteiskunta. Teoksessa Muutoksen tulkkina. Kirkot ja uskonnollinen elämä osana yhteiskuntaa. Toim. Eila Helander. Käytännöllisen teologian laitoksen julkaisuja 106. Helsingin yliopiston käytännöllisen teologian laitos \& Kirjapaja, Helsinki.

Heininen, Simo 2008: Turun piispat Pyhästä Henrikistä Mikko Juvaan. Pyhän Henrikin säätiön julkaisuja 6. Edita, [Helsinki]

Heino, Harri 1985: Seurakuntien lausunnot suomenkielisestä virsikirjaehdotuksesta. Vuonna 1984 annettujen lausuntojen erittely ja tulostus. Kirkon tutkimuskeskus Sarja B 49. Kirkon tutkimuskeskus, Tampere.

Heino, Harri 1988: Uskonnollisuuden ja kirkollisuuden muutoksia toisen maailmansodan jälkeisessä Suomessa. Kirkon tutkimuskeskus Sarja B 56. Kirkon tutkimuskeskus, Tampere.

Heinonen, Martti 1990: Kirkolliskokousedustajien puheenvuorot naispappeudesta vuoden 1976 ja 1986 kirkolliskokouksissa. Käytännöllisen teologian julkaisematon pro gradu -tutkielma. Helsingin yliopisto, käytännöllisen teologian laitos.

Helander, Eila 1999: Uskonto ja arvojen murros. Teoksessa Uskonto ja nykyaika. Yksilö ja eurooppalaisen yhteiskunnan murros. Toim. Markku Heikkilä. Atena Kustannus, Jyväskylä.

Helander, Eila 2002: Kirkon julkisuuskuvat. Teoksessa Arkki ja arki. Arkkipiispa Jukka Paarman juhlakirja. Toim. Marketta Ruoppila-Martinsen. Pyhän Henrikin säätiön julkaisuja 3. Kirjapaja, Helsinki.

Helander, Voitto \& Pekonen, Kyösti 2007: Eduskunnan vahvistuva valiokuntalaitos. Teoksessa Valiokunnat lähikuvassa. Suomen eduskunta 100 vuotta 7 . Edita, Helsinki.

Hentilä, Seppo 2008: Euroopan unionin luottamuspula - suomalaisen kansanvallan haaste. Teoksessa Suomen ja kansanvallan haasteet. Suomen eduskunta 100 vuotta 12. Edita, Helsinki.

Hidén, Mikael 1989: Lakien voimaantulo ja toimivallanjako. Tasavallan presidentin ns. arkipyhien siirrosta 24.1.1986 tekemän päätöksen esiin nostamia näkökohtia. Teoksessa Juhlajulkaisu - Festskrift Curt Olsson 1919.28/9.1989. Juridiska föreningens i Finland publikationsserie 54. Lakimiesliiton kustannus, Helsinki.

Hidén, Mikael 2006: Juridiikkaa ja muotoja eduskuntatyössä. Teoksessa Miten eduskunta toimii. Suomen eduskunta 100 vuotta 6. Edita, Helsinki.

Hiltunen, Petri 1998: Aikuisten ateria? Keskustelu lasten ehtoollisesta Suomessa vuosina 1950-1980. STKSJ 214. Diss. Helsinki. STKS, Helsinki. 
Hirvonen, Vesa 2004a: Kirkolliskokouksen juutalaiskeskustelu keväällä ja syksyllä 200o. Teologinen Aikakauskirja.

Hirvonen, Vesa 2004b: Onko homoseksuaalisessa parisuhteessa elävä kelpoinen papinvirkaan? Teologinen Aikakauskirja.

Holopainen, Toivo 1986: Kirkkolaki valtion lakina. Teologinen Aikakauskirja.

Honka-Hallila, Helena 2003: Veljeysliike. Kristillisten Sosialidemokraattien Liitto 1946-. SDP \& Kristillisten Sosialidemokraattien Liitto, [Helsinki].

Honka-Hallila, Helena 2006: Eduskunta sosiaalisena työyhteisönä. Teoksessa Miten eduskunta toimii. Suomen eduskunta 100 vuotta 6. Edita, Helsinki.

Huovinen, Eero 1979: Nainen ja pappisvirka. Argumentaatioanalyysi Suomen evankelis-luterilaisessa kirkossa käydystä naispappeuskeskustelusta. STKSJ 116. STKS, Helsinki.

Huovinen, Eero 2012: Seppo Antero Teinonen (1924-1995) dogmatiikan professori, ekumeeninen vaikuttaja. Teoksessa Kirkollisia vaikuttajia Pyhästä Henrikistä nykypäivään. Toim. Hannu Mustakallio. Studia Biographica 10. SKS, Helsinki.

Hytönen, Maarit 2005: Kirkollisten toimitusten teologia. Kirkon tutkimuskeskuksen julkaisuja 91. Kirkon tutkimuskeskus, Tampere.

Häkkinen, Kati 1987: Virsikirjauudistuskeskustelu maakuntien ykköslehdissä ja Kotimaassa vuosina 1984-1985. Käytännöllisen teologian julkaisematon laudaturtutkielma. Helsingin yliopisto, käytännöllisen teologian laitos.

Häkkinen, Seppo 2010: Ihanne ja todellisuus: jäsenyyteen sitoutuminen Suomen evankelis-luterilaisessa kirkossa 196o-luvulta 20oo-luvulle. Kirkon tutkimuskeskuksen julkaisuja 108. Diss. Helsinki. Kirkon tutkimuskeskus, Tampere.

Häkkinen, Seppo 2013: Piispainkokouksen tehtävän määrittely vuosina 19972012. Teoksessa Olavin ja Mikaelin jalanjäljissä. Hymnologian ja liturgiikan seuran vuosikirja Hymnos 2013. Toim. Tapani Innanen \& Teija Pitkänen \& Timo Åvist. Hymnologian ja liturgiikan seura, Helsinki.

Hämäläinen, Tiina 2012: "Kirkon piirissä tätä kysymystä kierrellään kuin kissa kuumaa puuroa": keskiolutlaki kristillisenä haasteena vuosina 1968 1977. Suomen ja Skandinavian kirkkohistorian pro gradu -tutkielma. Helsingin yliopisto, teologinen tiedekunta. <http://urn.fi/URN:NBN:fife201205255612>. Katsottu 24.4.2013.

Ikola, Kaisa 2004: Puoli vuosituhatta Laihian seurakunnassa. Kappeliseurakunto 1508-1576. Itsenäinen seurakunta 1576-200o. Laihian seurakunta, [Laihia].

Isohookana-Asunmaa, Tytti 2008: Verkkaisesta luottamushenkilöstä kiireiseksi ammattilaiseksi. Teoksessa Suomen ja kansanvallan haasteet. Suomen eduskunta 100 vuotta 12. Edita, Helsinki.

Jalava, Marja \& Simola, Hannu \& Varjo, Janne 2012: Hallinnosta hallintaan. Koulutuksen hallinnon muutos 1960-luvulta 2000-luvulle. Teoksessa Tiedon ja osaamisen Suomi. Kasvatus ja koulutus Suomessa 196o-luvulta 200o-luvulle. Toim. Pauli Kettunen \& Hannu Simola. Suomen kasvatuksen ja koulutuksen historia 3. SKST 1266:3, Tiede. SKS, Helsinki.

Jalovaara, Ville 2011: Kirkko, Kekkonen ja politiikka 1962-1982. SKHST 219 SKHS, Helsinki.

Jalovaara, Ville 2013: Kirkko, valtio ja SDP. Teologinen Aikakauskirja.

Johansson, Sture 1990: Lekmannaskapet och politiken i kyrkan. Kyrkomöte och centralstyrelse under 1980-talet. Teoksessa Med engagemang och medansvar. En bok om lekmannaskapet i Svenska kyrkan. Festskrift till Carl Henrik Martling. Redaktion Oloph Bexell \& Sven-Erik Brodd \& Gunnar Edqvist \& Sören Ekström \& Gunnar Weman. Verbum, Stockholm.

Jokinen, Erkki 1990: Kansankirkon rajat ja rakenteet. Arkkipiispa Mikko Juvan kansankirkko-ohjelma ja sen vastaanotto vuosina 1978-1982. Suomen ja Skandinavian kirkkohistorian julkaisematon pro gradu -tutkielma. Helsingin yliopisto, kirkkohistorian laitos.

Junttila-Rantanen, Riikka 2003: Porvoon julistus kirkko-oikeudellisena ongelmana. Ekumenian uudet haasteet. Käytännöllisen teologian julkaisematon pro gradu -tutkielma. Helsingin yliopisto, käytännöllisen teologian laitos.

Juva, Mikko 1976: Kirkon parlamentti. Suomen kirkolliskokousten historia $1876-$ 1976. Otava, Helsinki.

Juva, Mikko 1978: Perinne ja uudistus Suomen kirkolliskokouksissa. Teoksessa Nova et vetera. Studia in honorem Martti Parvio. Editor Olavi Rimpiläinen. SKHST 105. Societas Historiae Ecclesiasticae Fennica, Helsinki.

Jyränki, Antero 2006: Kansanedustuslaitos ja valtiosääntö 1906-2005. Teoksessa Eduskunnan muuttuva asema. Suomen eduskunta 100 vuotta 2. Edita, Helsinki

Järvi, Mia 2007: Homoseksuaaleista käyty keskustelu Suomen evankelis-luterilaisessa kirkossa ihmisoikeuksien näkökulmasta 2000-luvulla. Teologisen etiikan ja sosiaalietiikan julkaisematon pro gradu -tutkielma. Helsingin yliopisto, systemaattisen teologian laitos.

Järvinen, Laura 2012: Kansanlähetysläiset kirkolliskokousedustajat 1974-2012. Kirkkohistorian pro gradu -tutkielman keskeneräinen käsikirjoitus. Helsingin yliopisto, teologinen tiedekunta. Tekijän hallussa.

Kakkuri, Teemu 1995: Mustakaavusta messupapiksi. Liturgiset veljet ja evankelisuuden panos kirkolliseen uudistukseen. Teoksessa Kotimatkalla 1995. Suomen Luterilaisen Evankeliumiyhdistyksen vuosikirja. SLEY-Kirjat, [Helsinki].

Kakkuri, Teemu 2012: Anna-Mari Kaskinen (1958-) kirjailija, Vivamon toimintakeskuksen johtaja. Teoksessa Kirkollisia vaikuttajia Pyhästä Henrikistä nykypäivään. Toim. Hannu Mustakallio. Studia Biographica 10. SKS,
Helsinki.

Kallenautio, Jorma 2005: Suomi kylmän rauhan maailmassa. Suomen ulkopolitiikka Porkkalan palautuksesta 1955 Euroopan unionin jäsenyyteen 1995. SKST 1042. SKS, Helsinki.

Kangas, Olli 2003: Laman varjo ja nousun huuma. Suomalainen yhteiskunta 1990-luvun lopulla. Teoksessa Laman varjo ja nousun huuma. Sosiaali- ja terveysturvan tutkimuksia 72. Kansaneläkelaitos, Helsinki.

Kansanaho, Erkki 1976: Suomen kirkon hallinto. Gaudeamus, Helsinki.

Kansanaho, Erkki 1986: Kirkkolain nykyiset uudistuspyrkimykset. Teologinen Aikakauskirja.

Kansanaho, Erkki 1991: Arkipyhien siirrot. Miten kaikki oikein tapahtui? Teologinen Aikakauskirja.

Karisto, Antti \& Takala, Pentti \& Haapola, Ilkka 2009: Matkalla nykyaikaan. Elintason, elämäntavan ja sosiaalipolitiikan muutos Suomessa. 5. p. WSOY, Helsinki.

Kauppinen, Juha 1990: Seurakuntien lausunnot Uuden testamentin käännösehdotuksesta. Kirkon tutkimuskeskus Sarja B 63. Kirkon tutkimuskeskus, Tampere.

Kauppinen, Juha 1991: Seurakuntien lausunnot Vanhan testamentin käännösehdotuksesta. Kirkon tutkimuskeskus Sarja C 43. Kirkon tutkimuskeskus, [Tampere].

Keitanen, Maarit 2012: Valtioneuvoston edustajan toiminta Suomen evankelisluterilaisen kirkon uusimuotoisessa kirkolliskokouksessa vuosina 19742011. Kirkkohistorian julkaisematon kandidaatintutkielma. Helsingin yliopisto, teologinen tiedekunta. Tekijän hallussa.

Keso, Vesa \& Vakkuri, Jarmo 2011: Rakennemuutosten yhteys seurakuntien talouskehitykseen. Kirkon tutkimuskeskuksen www-julkaisuja 25. Kirkon tutkimuskeskus, Tampere. <http://sakasti.evl.fi/julkaisut.nsf/8C2FCE9 B2926C267C22578B7002490D8/\$FILE/www25.pdf >. Katsottu 21.3.2013.

Ketola Kimmo 2003: Uusi kansanomainen uskonnollisuus. Teoksessa Moderni kirkkokansa. Suomalaisten uskonnollisuus uudella vuosituhannella. Kimmo Kääriäinen \& Kati Niemelä \& Kimmo Ketola. Kirkon tutkimuskeskuksen julkaisuja 82. Kirkon tutkimuskeskus, Tampere.

Ketola, Mikko 2011: Kirkko avoinna korjauksia varten -teos ja sen vastaanotto vuonna 1967. Teoksessa Yliopisto, kirkko ja yhteiskunta. Aila Lauhan juhlakirja. Toim. Antti Laine ja Aappo Laitinen. SKHST 218. SKHS, Helsinki.

Kettunen, Paavo 1993: Hiljaisuuden retriitit ja meditaatio pastoraalipsykologisena kysymyksenä. Teologinen Aikakauskirja.

Kettunen, Paavo 2006: Joensuun teologisen tiedekunnan synty - sadan vuoden prosessi. Teologinen Aikakauskirja.

Kettunen, Pauli \& Jalava, Marja \& Simola, Hannu \& Varjo, Janne 2012: Tasa-arvon ihanteesta erinomaisuuden eetokseen. Koulutuspolitiikka hyvinvointivaltiosta kilpailuvaltioon. Teoksessa Tiedon ja osaamisen Suomi. Kasvatus ja koulutus Suomessa 196o-luvulta 200o-luvulle. Toim. Pauli Kettunen \& Hannu Simola. Suomen kasvatuksen ja koulutuksen historia 3. SKST 1266:3, Tiede. SKS, Helsinki.

Kinnamon, Michael 2004: Assessing the Ecumenical Movement. Teoksessa A History of the Ecumenical Movement. Volume 3. 1968-2000. Ed. by John Briggs \& Mercy Amba Oduyoye \& Georges Tsetsis. World Council of Churches, Geneva.

Klemelä, Kirsi \& Vanttaja, Markku 2012: Ammatillinen koulutus. Teoksessa Tiedon ja osaamisen Suomi. Kasvatus ja koulutus Suomessa 1960-luvulta 200o-luvulle. Toim. Pauli Kettunen \& Hannu Simola. Suomen kasvatuksen ja koulutuksen historia 3. SKST 1266:3, Tiede. SKS, Helsinki.

Knuutila, Jyrki 2005: Kirkkokäsikirjojen ja kirkko-oikeuden välinen suhde Suomessa 1400-luvun lopulta 200o-luvun alkuun. Teoksessa Kirkko Taide - Viestintä. Markku Heikkilän juhlakirja. Toim. Sari Dhima. SKHST 197. SKHS, Helsinki.

Koivisto, Jussi 2011: Ruotsin kirkon kehitys samaa sukupuolta olevien parien rukoushetkestä sukupuolineutraaliin avioliittoon vihkimiseen (19942009). Teologinen Aikakauskirja.

Koivula, Veijo 2002: Professori Martti Parvion näkemys messusta ja sen uudistamisesta. Käytännöllisen teologian julkaisematon lisensiaatintutkimus. Helsingin yliopisto, käytännöllisen teologian laitos.

Konttinen, Esa 1975: Naispappeuden puoltamisen argumentaatio Ruotsissa. Metacentrum. Helsingin yliopiston systemaattisen teologian laitoksen julkaisuja 2. Dogmatiikan laudatur-tutkielma. Helsingin yliopiston systemaattisen teologian laitos, Helsinki.

Konttinen, Esa 1976: Keskustelu naispappeudesta Ruotsissa vuoden 1958 jälkeen. Kirkon tutkimuslaitos Sarja B 25. Kirkon tutkimuslaitos, Tampere.

Kopperi, Kari 1994: Kolmisäikeinen virka ja luterilainen teologia. Teologinen Aikakauskirja.

Kortekangas, Paavo 2005: Tampereen hiippakunta 1923-1959. Teoksessa Viipurin - Porvoon - Tampereen hiippakunnan historia 1554-2004. Edita, Helsinki.

Kortekangas, Paavo \& Huotari, Voitto 1974: Seurakunta vaaliuurnilla. Tutkimus vuoden 1970 seurakuntavaaleista. Kirkon tutkimuslaitos Sarja A 24. Kirkon tutkimuslaitos, Tampere.

Kotila, Heikki 200o: Liturgian lähteillä. Johdatus jumalanpalveluksen historiaan ja teologiaan. Käytännöllisen teologian laitoksen julkaisuja 97. Helsingin yliopiston käytännöllisen teologian laitos, Helsinki.

Kukkonen, Mia 1999: Kirkon muutos 1978. Ohitetun vaaran vuosi? Suomen ja 
Skandinavian kirkkohistorian julkaisematon pro gradu -tutkielma. Helsingin yliopisto, kirkkohistorian laitos.

Kunttu, Tapani 2007: Valiokuntapersoonia viideltä vuosikymmeneltä. Teoksessa Valiokunnat lähikuvassa. Suomen eduskunta 100 vuotta 7 . Edita, Helsinki.

Kurkela, Kari 2012: Kirkollista vaalijournalismia mediassa: Suomen evankelis-luterilaisen kirkon arkkipiispanvaalien yhteydessä vuosina 1982-2010. Suomen ja Skandinavian kirkkohistorian julkaisematon pro gradu -tutkielma. Helsingin yliopisto, teologinen tiedekunta.

Kurttila, Tuomas 2011: Vuoden 2009 kirkolliskokouksen päätös lapsivaikutusten arvioinnista. Käytännöllisen teologian julkaisematon pro gradu -tutkielma. Helsingin yliopisto, teologinen tiedekunta.

Kuusela, Mirka 200o: Kirkko uskonnonopetuksen puolustajana 1970-1993. Suomen ja Skandinavian kirkkohistorian julkaisematon pro gradu -tutkielma. Helsingin yliopisto, kirkkohistorian laitos.

Kvist, Hans-Olof 1996: Yhteinen julistus vanhurskauttamisopista. Taustaa ja arviointia. Teologinen Aikakauskirja.

Kääriäinen, Kimmo \& Niemelä, Kati \& Ketola, Kimmo 2003: Maallistuuko Suomi? Teoksessa Moderni kirkkokansa. Suomalaisten uskonnollisuus uudella vuosituhannella. Kimmo Kääriäinen \& Kati Niemelä \& Kimmo Ketola. Kirkon tutkimuskeskuksen julkaisuja 82. Kirkon tutkimuskeskus, Tampere.

Laaksovirta, Tuula H. 2007: Eduskunnan virallinen tiedonvälitys. Teoksessa Ensimmäinen ja neljäs valtiomahti. Suomen eduskunta 100 vuotta 10. Edita, Helsinki.

Laasonen, Pentti 1998: Luterilaisuus Rooman ja Geneven välissä. Luterilaisuuden identiteettitaistelu 1577-noin 1590 [po.1690]. SKHST 171. SKHS, Helsinki.

Lampela-Kivistö, Liisa 2003: 1990-luvun talouskriisi ja kirkko. Teoksessa Muutoksen tulkkina. Kirkot ja uskonnollinen elämä osana yhteiskuntaa. Toim. Eila Helander. Käytännöllisen teologian laitoksen julkaisuja 106. Helsingin yliopiston käytännöllisen teologian laitos \& Kirjapaja, Helsinki.

Lampinen, Jari 2008: Valtion käsi kirkon kukkarossa. Verotuksen muutoksien vaikutus kirkon talouteen 1990-2005. Julkaisematon käsikirjoitus. Tekijän hallussa.

Lampinen, Tapio 1992: Käsikirjakomitean ehdotukset ja seurakunnan työntekijöiden odotukset ja käytännöt. Teologinen Aikakauskirja.

Laurinkari, Juhani 1976: Über die Beschlussfassung in einer normativen Organisation. Die Auswahl der Synodenvertreter der evangelisch-lutherischen Kirche Finnlands und ihr Einfluss auf die Beschlussfassung im Jahre 1973. Universität Helsinki. Institut für Sozialpolitik. 4/1976. Diss. Helsinki. Universität Helsinki, Institut für Sozialpolitik, Helsinki.

Leino, Pekka 2002: Kirkkolaki vai Laki kirkosta. Hallinto-oikeudellinen tutkimus kirkon oikeudellisista normeista ja niiden synnystä. Suomalaisen Lakimiesyhdistyksen julkaisuja A-sarja 231. Diss. Helsinki. Suomalainen Lakimiesyhdistys, Helsinki.

Lempiäinen, Pekka 1982: Teologisen tiedekunnan edustajat kirkolliskokouksessa 1876-1973. Käytännöllisen teologian julkaisuja C 3. Helsingin yliopiston käytännöllisen teologian laitos, Helsinki.

Leppänen, Mari 2011: Naispappeuspuhe vanhoillislestadiolaisessa herätysliikkeessä vuosina 1975-2010. Suomen ja Skandinavian kirkkohistorian pro gradu -tutkielma. <http://urn.fi/URN:NBN:fi-fe201106091716>. Katsottu 24.4.2013.

Liljeström, Marianne 2008: Pohjoismainen tasa-arvo ja Suomi. Teoksessa Suomen ja kansanvallan haasteet. Suomen eduskunta 100 vuotta 12. Edita, Helsinki.

Lindegård, Sven 1957: Consistorium regni och frågan om kyrklig överstyrelse. En studie i den svenska kyrkoförfattningens teori och praxis, 1571-1686. Bibliotheca theologiae practicae 5. Diss. Lund. Gleerup, [Lund].

Lohi, Seppo 2012: Erkki Reinikainen (1919-2006) lestadiolaisvaikuttaja, everstiluutnantti. Teoksessa Kirkollisia vaikuttajia Pyhästä Henrikistä nykypäivään. Toim. Hannu Mustakallio. Studia Biographica 10. SKS, Helsinki.

Lundstedt, Göran 2006: Biskopsämbetet och demokratin. Biskopsrollens förändring i Svenska kyrkan under 19oo-talets senare del. En kyrkorättslig undersökning. Bibliotheca theologiae practicae 82. Diss. Uppsala. Artos \& Norma, Skellefteå.

Luukkonen, Sampo 2005: Avioliitto muuttuvan ajan haastamana - avioliittoasiat kirkolliskokouskeskusteluissa vuosina 1993-2004. Käytännöllisen teologian julkaisematon pro gradu -tutkielma. Helsingin yliopisto, käytännöllisen teologian laitos.

Lähteenmäki, Maria 2006: Naiset tasa-arvoisemman yhteiskunnan puolesta 1907-2003. Teoksessa Naiset eduskunnassa. Suomen eduskunta 100 vuotta 4. Edita, Helsinki.

Malkavaara, Mikko 200o: Kirkko muuttuvassa yhteiskunnassa. Kirkko toisen maailmansodan jälkeen, 1944-2000. Teoksessa Kirkon historia 200o. Kristinusko Suomessa. Weilin+Göös, [Espoo].

Malkavaara, Mikko 2011: Kirkon ekumeenisten suhteiden ja kansainvälisen vastuun murros 1960-luvulla. Teoksessa Kirkkohistorian alueilla. Juhlakir ja professori Hannu Mustakallion täyttäessä 6 o vuotta. Toim. Ilkka Huhta \& Juha Meriläinen. SKHST 217. Karjalan teologisen seuran julkaisuja 2. SKHS \& Karjalan teologinen seura, Helsinki.

Malkavaara, Mikko \& Mustakallio, Hannu 2012a: Paavo Kortekangas (1930) Tampereen piispa, Kuopion piispa, kirkkososiologian professori. Teoksessa Kirkollisia vaikuttajia Pyhästä Henrikistä nykypäivään. Toim. Hannu
Mustakallio. Studia Biographica 10. SKS, Helsinki.

Malkavaara, Mikko \& Mustakallio, Hannu 2012b: Eero Huovinen (1944-) Helsingin piispa, dogmatiikan professori. Teoksessa Kirkollisia vaikuttajia Pyhästä Henrikistä nykypäivään. Toim. Hannu Mustakallio. Studia Biographica 10. SKS, Helsinki.

Mannermaa, Tuomo 1978: Preussista Leuenbergiin. Leuenbergin konkordian teologinen metodi. Missiologian ja ekumeniikan seuran julkaisuja 29. Missiologian ja ekumeniikan seura, Helsinki.

Martikainen, Eeva 1984: Regimenttioppi Lutherin ajattelussa ja sen myöhempi tulkinta. Teologinen Aikakauskirja.

Martola, Yngvill 1982: Evangeliska vigningshandlingar? Granskning av formulären 11-26 i förslaget till ny handbok för den evangelisk-lutherska kyrkan i Finland. Laudaturuppsats i dogmatik. Åbo Akademi, Institutionen för praktisk teologi.

McCullum, Hugh 2004: Racism and Ethnicity. Teoksessa A History of the Ecumenical Movement. Volume 3. 1968-20oo. Ed. by John Briggs \& Mercy Amba Oduyoye \& Georges Tsetsis. World Council of Churches, Geneva.

Meinander, Henrik 1999: Tasavallan tiellä. Suomi Kansalaissodasta 20oo-luvulle. Suomennos Paula Autio. Schildts, Espoo.

Meriläinen, Juha 2013: Viides herätysliike. Teoksessa Kristinuskon historian tutkimusalat ja metodit. Toim. Jaakko Olavi Antila \& Esko M. Laine \& Juha Meriläinen. SKHST 226. SKHS, Helsinki.

Meyer, Harding 2004: Christian World Communions. Teoksessa A History of the Ecumenical Movement. Volume 3. 1968-200o. Ed. by John Briggs \& Mercy Amba Oduyoye \& Georges Tsetsis. World Council of Churches, Geneva.

Miettinen, Pentti 1979: Virsikirjauudistuskeskustelu lehdistössä vuonna 1976. Käytännöllisen teologian julkaisematon pro gradu -tutkielma. Helsingin yliopisto, käytännöllisen teologian laitos.

Mikkola, Teija 2003: Muuttuvat arvot ja uusi keskiluokka. Tutkimus arvojen mittaamisesta ja monitasoisuudesta. Helsingin yliopiston sosiologian laitoksen tutkimuksia 241. Diss. Helsinki. Helsingin yliopisto, sosiologian laitos, Helsinki.

Minkkinen, Antti 2006: Maallikkotyöntekijöitä vai osallisia yhdestä kirkon virasta? Suomen evankelis-luterilaisen kirkon diakonaatin uudistuspyrkimykset 1988-1994. Suomen ja Skandinavian kirkkohistorian julkaisematon pro gradu -tutkielma. Helsingin yliopisto, kirkkohistorian laitos.

Molina, Seija 2010: Naiset ja naisten puheet kirkolliskokouksen naispappeuskeskusteluissa vuosina 1974-1987. Diss. Helsinki. Helsingin yliopisto, Helsinki. E-thesis. <http://urn.fi/URN:ISBN:978-952-10-6169-1>. Katsottu 15.9.2010.

Mudge, Lewis S. 2004: Ecumenical Social Thought. Teoksessa A History of the Ecumenical Movement. Volume 3. 1968-200o. Ed. by John Briggs \& Mercy Amba Oduyoye \& Georges Tsetsis. World Council of Churches, Geneva.

Murtorinne, Eino 1964: Papisto ja esivalta routavuosina 1899-1906. SKHST 68. Diss. Helsinki. SKHS, Helsinki.

Murtorinne, Eino 1995: Suomen kirkon historia 4. Sortovuosista nykypäiviin 1900-1990. WSOY, Porvoo \& Helsinki \& Juva.

Murtorinne, Eino 1997: Viisi vuosikymmentä kirkon keskushallintoa. Kirkon keskushallinnon synty ja kehitys vuoteen 1994. Kirkkohallitus, [Helsinki]

Mustakallio, Hannu 2010: Die kirchliche Arbeit in der finnischen Grenzregion in den 1920er- und 1930er-Jahren. Teoksessa Kirchliche Zeitgeschichte. Internationale Halbjahreszeitschrift für Theologie und Geschichtswissenschaft. Heft 1. Vandenhoeck \& Ruprecht, Göttingen.

Mustakallio, Hannu 2012a: John Vikström (1931-) arkkipiispa, Porvoon piispa, systemaattisen teologian apulaisprofessori. Teoksessa Kirkollisia vaikuttajia Pyhästä Henrikistä nykypäivään. Toim. Hannu Mustakallio. Studia Biographica 10. SKS, Helsinki.

Mustakallio, Hannu 2012b: Jukka Paarma (1941-) arkkipiispa. Teoksessa Kirkollisia vaikuttajia Pyhästä Henrikistä nykypäivään. Toim. Hannu Mustakallio. Studia Biographica 10. SKS, Helsinki.

Mustakallio, Hannu 2012c: Voitto Huotari (1943-) Mikkelin piispa, dosentti. Teoksessa Kirkollisia vaikuttajia Pyhästä Henrikistä nykypäivään. Toim. Hannu Mustakallio. Studia Biographica 10. SKS, Helsinki.

Mustakallio, Hannu 2012d: Wille Riekkinen (1946-) Kuopion piispa, dosentti. Teoksessa Kirkollisia vaikuttajia Pyhästä Henrikistä nykypäivään. Toim. Hannu Mustakallio. Studia Biographica 10. SKS, Helsinki.

Mustakallio, Hannu 2012e: Kari Mäkinen (1955-) arkkipiispa, Turun piispa. Teoksessa Kirkollisia vaikuttajia Pyhästä Henrikistä nykypäivään. Toim. Hannu Mustakallio. Studia Biographica 10. SKS, Helsinki.

Mykkänen, Juri 2012: Uskonto ja äänestäminen. Teoksessa Muutosvaalit 2011. Selvityksiä ja ohjeita 16/2012. Oikeusministeriö, [Helsinki]. <http://urn.fi/ URN:ISBN:978-952-259-172-2>. Katsottu 18.2.2013.

Mylly, Juhani 2006: Edustuksellisen kansanvallan läpimurto. Suomen eduskunta 100 vuotta 1. Edita, Helsinki.

Myllymäki, Arvo 1979: Etujärjestöt, tulopolitiikka ja ylimmät valtioelimet. Julkisoikeudellinen tutkimus etujärjestöjen solmimien vakauttamis- ja tulopoliittisten sopimusten vaikutuksesta eduskunnan, tasavallan presidentin ja valtioneuvoston toimintaan ja asemaan vuosina 1968-1975. Diss. Tampere. Finnpublishers, [Tampere].

Myllymäki, Arvo 1982: Elvytys, etujärjestöt ja valtion rooli. Julkisoikeudellinen tutkimus vuosien 1977-1979 elvytyspolitiikasta ja sen vaikutuksesta talous- 
järjestelmämme toimintakykyyn sekä valtion rooliin. Julkisoikeuden julkaisusarja A 1. Tampereen yliopisto, [Tampere].

Mäkeläinen, Heikki 1976a: Oivalluksen vaellus kirkossa. Hiippakunta- ja pappeinkokousten aloitteet vuosina 1967-1974 ja niiden kohtalo. Kirkon tutkimuslaitos Sarja B 26. Kirkon tutkimuslaitos, Tampere.

Mäkeläinen, Heikki 1976b: Seurakunnat ja naispappeus. Raportti kirkkoneuvostojen kannanotoista syksyn 1976 kirkolliskokoukselle. Kirkon tutkimuslaitos Sarja B 27. Kirkon tutkimuslaitos, Tampere.

Mäkinen, Joonas 2008: Sivustaseuraajasta kansankirkon toimijaksi. SDP:n kirkkopolitiikka vuosina 1977-1987. Suomen ja Skandinavian kirkkohistorian julkaisematon pro gradu -tutkielma. Helsingin yliopisto, kirkkohistorian laitos.

Nevakivi, Jukka 200o: Jatkosodasta nykypäivään 1944-1999. Teoksessa Suomen polittinen historia 1809-1999. WSOY, Porvoo \& Helsinki \& Juva.

Niemelä, Kati 2003a: Suomalaisten uskonnollisuus uuden vuosituhannen alussa. Teoksessa Muutoksen tulkkina. Kirkot ja uskonnollinen elämä osana yhteiskuntaa. Toim. Eila Helander. Käytännöllisen teologian laitoksen julkaisuja 106. Helsingin yliopiston käytännöllisen teologian laitos \& Kirjapaja, Helsinki.

Niemelä, Kati 2003b: Suomalaisten sitoutuminen uskonnollisiin yhdyskuntiin. Teoksessa Moderni kirkkokansa. Suomalaisten uskonnollisuus uudella vuosituhannella. Kimmo Kääriäinen \& Kati Niemelä \& Kimmo Ketola. Kirkon tutkimuskeskuksen julkaisuja 82. Kirkon tutkimuskeskus, Tampere.

Niemelä, Kati 2003c: Uskonnonharjoitus. Teoksessa Moderni kirkkokansa. Suomalaisten uskonnollisuus uudella vuosituhannella. Kimmo Kääriäinen \& Kati Niemelä \& Kimmo Ketola. Kirkon tutkimuskeskuksen julkaisuja 82. Kirkon tutkimuskeskus, Tampere.

Niemelä, Kati 2003d: Uskonnollisuus eri väestöryhmissä. Teoksessa Moderni kirkkokansa. Suomalaisten uskonnollisuus uudella vuosituhannella. Kimmo Kääriäinen \& Kati Niemelä \& Kimmo Ketola. Kirkon tutkimuskeskuksen julkaisuja 82. Kirkon tutkimuskeskus, Tampere.

Nieminen, Heikki-Tapio 2008: Piispainkokous. Piispainkokouksen synty, tehtävät ja toiminta 1908-2008. Kirkkohallitus, Helsinki.

Nieminen, Risto T. 2003: Kirkko 2000 -prosessi ja kansalaisten seurakunta. Teoksessa Muutoksen tulkkina. Kirkot ja uskonnollinen elämä osana yhteiskuntaa. Toim. Eila Helander. Käytännöllisen teologian laitoksen julkaisuja 106. Helsingin yliopiston käytännöllisen teologian laitos \& Kirjapaja, Helsinki.

Nieminen, Risto T. 2005a: Seurakunta yhteiskuntarakenteen murroksessa. Teoksessa Seurakuntarakenne murroksessa. Yhdistyvien seurakuntien organisaation ja toimintayhteisön muutosprosessi. Risto T. Nieminen \& Leena Vallenius \& Mikko Tähkänen. Kirkon tutkimuskeskuksen julkaisuja 92. Kirkon tutkimuskeskus, Tampere.

Nieminen, Risto T. 2005b: Seurakuntajaon muutokset Suomen ev.-lut. kirkossa. Teoksessa Seurakuntarakenne murroksessa. Yhdistyvien seurakuntien organisaation ja toimintayhteisön muutosprosessi. Risto T. Nieminen \& Leena Vallenius \& Mikko Tähkänen. Kirkon tutkimuskeskuksen julkaisuja 92. Kirkon tutkimuskeskus, Tampere.

Niiranen, Pekka 2008: Martti Simojoki - kirkon ääni. Kirjapaja, Helsinki.

Niittyvuopio, Erva 2011: Saamelaisidentiteetti Suomen kirkossa. Teoksessa Sa muel Salmi. Pohjoisen piispa. Toim. Niilo Pesonen \& Kari Tiirola. Edita, [Helsinki].

Nokkala, Immo 1986: Ehtoollispakkokysymys Suomessa 1818-1910. SKHST 137 Diss. Helsinki. SKHS, Helsinki.

Nousiainen, Jaakko 2006: Suomalainen parlamentarismi. Teoksessa Eduskunnan muuttuva asema. Suomen eduskunta 100 vuotta 2. Edita, Helsinki.

Numminen, Jaakko 1996: Valtioneuvosto. Teoksessa Suomen keskushallinnon historia 1809-1996. Hallintohistoriakomitea \& Edita, Helsinki.

Nuorteva, Jussi 1989: Suomen vankeinhoidon historiaa osa 2. Suomen vankeinhoidon matrikkeli 1881-1988. Oikeusministeriön vankeinhoito-osasto \& Valtion painatuskeskus, Helsinki.

Ollila, Anne 2007: Ammattina kansan edustaminen. Teoksessa Kansanedustajan työ ja arki. Suomen eduskunta 100 vuotta 5 . Edita, Helsinki.

Paavonen, Tapani 2006: Talouden kehitys ja talouspolitiikka hyvinvointivaltion kaudella. Teoksessa Eduskunta hyvinvointivaltion rakentajana. Suomen eduskunta 100 vuotta 8. Edita, Helsinki.

Pahlmblad, Christer 2005: Kyrkomöte, läroämbete, demokrati: kyrkomötets sammansättning i Evangelisk-lutherska kyrkan i Finland och i Svenska kyrkan. Teoksessa Svenskt $i$ Finland - finskt $i$ Sverige 1. Dialog och särart. Människor, samhällen och idéer från Gustav Vasa till nutid. Redaktörer Gabriel Bladh \& Christer Kuvaja. Skrifter utgivna av Svenska litteratursällskapet i Finland 682:1. Svenska litteratursällskapet i Finland, Helsingfors.

Pajamo, Reijo 2001: Virsikirjan sävelmistöuudistus 1973-1986. Kirkkomusiikin osaston julkaisuja 25. Sibelius-Akatemia, Helsinki.

Pajamo, Reijo 2002: Virsikirjaehdotuksen sävelmistön käsittely kirkolliskokouksessa. Teoksessa Uskonto ja viestintä. Käytännöllisen teologian laitoksen Vuosikirja 2002. Toim. Liisa Lampela-Kivistö. Käytännöllisen teologian laitoksen julkaisuja 104. Helsingin yliopisto, käytännöllisen teologian laitos, Helsinki.

Pajamo, Reijo \& Tuppurainen, Erkki 2004: Suomen musiikin historia. Kirkkomusiikki. WSOY, Helsinki.
Pajunen, Mika K. T. 2008: “Towards 'a real reunion'?” Archbishop Aleksi Lehtonen's efforts for closer relations with the Church of England 1945-1951. Schriften der Luther-Agricola-Gesellschaft 62. Diss. Helsinki. Luther-Agricola-Society, Helsinki.

Paloheimo, Heikki 2007: Eduskuntavaalit 1907-2003. Teoksessa Kansanedustajan työ ja arki. Suomen eduskunta 100 vuotta 5 . Edita, Helsinki.

Parvio, Martti 1977: The Liturgical Brethren. A Page in History on the Postwar Liturgical Movement in Finland. Teoksessa Ecclesia leiturgia ministerium. Studia in honorem Toivo Harjunpää. Publications of the Luther-AgricolaSociety B 9. [Luther-Agricola-Society], Helsinki.

Pehkonen-Suoranta, Kaisa-Liisa \& Mustakallio, Hannu 2012: Anna-Maija Raittila (1928-) runoilija, Taizé-liikkeen tunnetuksi tekijä. Teoksessa Kirkollisia vaikuttajia Pyhästä Henrikistä nykypäivään. Toim. Hannu Mustakallio. Studia Biographica 10. SKS, Helsinki.

Peltonen, Matti 2006: Keskioluen vapautus 1969. Teoksessa Alkoholin vuosisata. Suomalaisten alkoholiolojen vaiheita 19oo-luvulla. Toim. Matti Peltonen \& Hanna Kuusi \& Kaarina Kilpiö. Historiallinen Arkisto 122. SKS, Helsinki.

Pentikäinen, Ismo 2009: Arkkipiispa Martti Simojoki kirkkolain ja kirkon järjestysmuodon uudistajana 1964-1978. Kirkkohistorian pro gradu -tutkielma. JoyPub. <http://urn.fi/ URN:NBN:fi:joy-20090028>. Katsottu 14.9.2010.

Pernaa, Ville 2007: Neljäs valtiomahti haastaa ensimmäisen. Teoksessa Ensimmäinen ja neljäs valtiomahti. Suomen eduskunta 100 vuotta 10. Edita, Helsinki.

Pernaa, Ville 2012: Vaalikamppailu mediassa. Teoksessa Muutosvaalit 2011. Selvityksiä ja ohjeita 16/2012. Oikeusministeriö, [Helsinki]. <http://urn.fi/ URN:ISBN:978-952-259-172-2>. Katsottu 18.2.2013.

Pirinen, Kauko 1979: Puolueiden kirkkopoliittiset ohjelmat 1969-1973. Teoksessa SKHSV 68-69. SKHS, Helsinki.

Pirinen, Kauko 1985: Schaumanin kirkkolain synty. SKHST 132. SKHS, Helsinki.

Pirinen, Kauko 1989: Kirkkolain kokonaisuudistuksen vaikea tie. Teologinen Aikakauskirja.

Pirinen, Kauko 1990: Papinvaalilainsäädännön kehitys Suomessa vuoteen 1964. Teoksessa SKHSV 79. SKHS, Helsinki.

Poutiainen, Matti 1994: Uudistuva kristinoppi. Suomalaisen katekismusreformin teologianhistoriallinen tausta. Kirkon tutkimuskeskus Sarja B 75. Kirkon tutkimuskeskus, Tampere.

Poutiainen, Matti 1998: Katekismuksen sisältö. Kirkon tutkimuskeskus Sarja A 72. Kirkon tutkimuskeskus, Tampere.

Pulkkinen, Jari 2005: Huovisen kristinopista kirkon katekismukseksi. Katekismusuudistus Suomen evankelis-luterilaisessa kirkossa 1993-1999. Suomen ja Skandinavian kirkkohistorian julkaisematon pro gradu -tutkielma. Helsingin yliopisto, kirkkohistorian laitos.

Raiser, Elisabeth 2004: Inclusive Community. Teoksessa A History of the Ecumenical Movement. Volume 3. 1968-20oo. Ed. by John Briggs \& Mercy Amba Oduyoye \& Georges Tsetsis. World Council of Churches, Geneva.

Rantala, Liisa 2010: Sielunhoitajat sillanrakentajina. Kirkon kuurojentyö 18961982. Deaf Studies in Finland 3. Diss. Joensuu. Kuurojen liitto. <http://urn. fi/URN:ISBN:978-952-5396-58-4>. Katsottu 23.5.2014.

Rantanen, Leena 2004: Kirkolliskokous ja kirkon talous. Teologinen Aikakauskirja.

Reijonen, Mikko 1992: Uskonnonvapaus yhdentyvässä Euroopassa. Kirkon tutkimuskeskus Sarja A 59. Kirkon tutkimuskeskus, Tampere.

Ripatti, Jaakko 1999: Erillään mutta yhdessä. Kirkko ja valtio viime vuosien kirkolliskokouskeskusteluissa. Teologinen Aikakauskirja.

Ripatti, Jaakko 2004: Mikkelin hiippakunta jälleenrakennusvaiheesta nykypäivään. Teoksessa Kaakonkulman kapituli. Savonlinnan, Viipurin ja Mikkelin hiippakunta 1897-2004. Toim. Ouri Mattila \& Tuula Mäkitalo \& Esa-Matti Peura. Paavali Juustenin säätiö \& Kirjapaja, Helsinki.

Ripatti, Jaakko 2012: Leena Rantanen (1956-) kirkon keskusrahaston johtaja, kirkkoneuvos. Teoksessa Kirkollisia vaikuttajia Pyhästä Henrikistä nykypäivään. Toim. Hannu Mustakallio. Studia Biographica 10. SKS, Helsinki.

Rissanen, Antero 1989: Kirkon kasvatustoiminnan kokonaisohjelman käyttö seurakuntien kasvatustoiminnassa. K-ohjelman seurantatutkimus. Kirkon kasvatusasiain keskuksen johtokunnalle laadittu selvitys. Kirkon tutkimuskeskus Sarja B 58. Kirkon tutkimuskeskus, Tampere.

Ruonakoski, Leevi 2012: Virsitekstien muotoutuminen virsikirjaehdotuksesta vuoden 1986 virsikirjaan. Kirkon tutkimuskeskuksen www-julkaisuja 3o. Kirkon tutkimuskeskus, Tampere. <http://sakasti.evl.fi/julkaisut.nsf/ o7D747ADAoAoo913C2257A980023A46F/\$FILE/www3o.pdf > . Katsottu 17.4.2013.

Rusama, Jaakko 1999: Kohti ykseyttä. Suomen ekumeenisen neuvoston synty ja toiminta 1917-1997. Kirkon tutkimuskeskus Sarja A 75. Suomen ekumeenisen neuvoston julkaisuja LXI. Kirkon tutkimuskeskus, Tampere.

Rusama, Jaakko 2012: Heikki Kotila (1960-2010) käytännöllisen teologian professori, päätoimittaja. Teoksessa Kirkollisia vaikuttajia Pyhästä Henrikistä nykypäivään. Toim. Hannu Mustakallio. Studia Biographica 10. SKS, Helsinki.

Ryman, Björn 2004: Ärkebiskop Olof Sundbys sista initiativ: Liv och Fredkonferensen i Uppsala 1983. Teoksessa Kyrkohistorisk årsskrift 2004. Skrifter utgivna av Svenska Kyrkohistoriska Föreningen 1:104. Svenska Kyrkohistoriska Föreningen, Uppsala. 
Ryökäs, Riikka 2002: Maiestas Domini. Dora Jungin liturgisten tekstiilien viesti. Joensuun yliopiston teologisia julkaisuja 4. Diss. Joensuu. Joensuun yliopisto, Joensuu.

Räisänen, Heikki 2012a: Aimo Tauno Nikolainen (1912-1995) Helsingin piispa eksegetiikan professori. Teoksessa Kirkollisia vaikuttajia Pyhästä Henrikistä nykypäivään. Toim. Hannu Mustakallio. Studia Biographica 10. SKS Helsinki.

Räisänen, Heikki 2012b: Raija Sollamo (1942-) Raamatun alkukielten professori, Helsingin yliopiston vararehtori. Teoksessa Kirkollisia vaikuttajia Pyhästä Henrikistä nykypäivään. Toim. Hannu Mustakallio. Studia Biographica 10. SKS, Helsinki.

Räsänen, Johanna 1995: Seurakuntalaisten jumalanpalveluskokemukset ja uudistusodotukset vuonna 1992. Kirkon tutkimuskeskus Sarja A 66. Diss. Helsinki. Kirkon tutkimuskeskus, Tampere.

Räsänen, Johanna 1996: Jumalanpalvelus minun makuuni. Kirkossa harvoin käyvien näkemyksiä. Kirkon tutkimuskeskus Sarja B 77. Kirkon tutkimuskeskus, Tampere.

Saarinen, Satu 2005: "On sovelias ikeeni ja keveä on kuormani". Naispastoreiden kokemuksia pappeudestaan Oulun hiippakunnassa 1980-luvulta 20oo-luvun alkuun. Acta Universitatis Lapponiensis 85. Diss. Rovaniemi. KustannusPuntsi, Inari.

Sagulin, Marko 2005: Keskustelu Yhteisestä julistuksesta. YJV-asiakirjan hyväksyminen Suomen evankelis-luterilaisessa kirkossa. Ekumeniikan julkaisematon pro gradu -tutkielma. Helsingin yliopisto, systemaattisen teologian laitos.

Salmi, Mikko 200o: Kirkon muutos 1982. Sivustaseuraajan roolista aktiiviseksi vaikuttajaksi. Suomen ja Skandinavian kirkkohistorian julkaisematon pro gradu -tutkielma. Helsingin yliopisto, kirkkohistorian laitos.

Salmi, Sari 2012: Arkkipiispa Mikko Juvan kirjeenvaihto kirkolliskokousvuosina 1978-1982. Kirkkohistorian julkaisematon kandidaatintutkielma. Helsingin yliopisto, teologinen tiedekunta. Tekijän hallussa.

Saraja, Anja 2009: Sanan vai rakkauden palveluksessa? Diakonian viralle esitetyt teologiset perusteet Suomen evankelis-luterilaisessa kirkossa vuosina 1997-2006. Käytännöllisen teologian pro gradu -tutkielma. Helsingin yliopisto, käytännöllisen teologian laitos. <http://urn.fi/URN:NBN:fife201008262362>. Katsottu 24.4.2013.

Sarelin, Birgitta 1998: Behålla och förnya. Den finlandssvenska psalmboksrevisionen 1975-1986. Diss. Åbo. Åbo Akademis förlag, Åbo.

Savioja, Anita 1984: Ehdokkaiden vaalikelpoisuusehtojen ja tunnusten käyttökiellon tulkinnasta ja merkityksestä seurakuntavaaleissa. Kirkon tutkimuslaitos Sarja C 16. Kirkon tutkimuslaitos, Tampere.

Savolainen, Raimo 1996: Keskusvirastot, virastot ja laitokset 1917-1996. Teoksessa Suomen keskushallinnon historia 1809-1996. Hallintohistoriakomitea \& Edita, Helsinki.

Seppo, Juha 1989: Mitä kirkkolakiuudistus merkitsee luterilaisen kirkon ja valtion välisissä suhteissa? Teologinen Aikakauskirja.

Seppo, Juha 1993: Luterilainen kirkko ja uskonnonvapaus perusoikeutena. Teologinen Aikakauskirja.

Seppo, Juha 1995: Tuomiokapitulien asema osana kirkon ja valtion välisiä suhteita. Teologinen Aikakauskirja.

Seppo, Juha 1999: Kirkko ja itsenäinen Suomi 1917-1998. Teoksessa Uskonto ja nykyaika. Yksilö ja eurooppalaisen yhteiskunnan murros. Toim. Markku Heikkilä. Atena Kustannus, Jyväskylä.

Seppo, Juha 2002: Kirkko, valtio ja uskonnonvapaus. Teoksessa Arkki ja arki. Arkkipiispa Jukka Paarman juhlakirja. Toim. Marketta Ruoppila-Martinsen. Pyhän Henrikin säätiön julkaisuja 3. Kirjapaja, Helsinki.

Seppo, Juha 2003a: Sekularisaatio ja uskonnonvapaus: Suomen tapaus (19922002). Teoksessa Vanha ja nuori. Juhlakirja Simo Heinisen täyttäessä 60 vuotta. Toim. Kaisamari Hintikka \& Hanna-Maija Ketola \& Päivi Salmesvuori. Luther-Agricola-Seura, Helsinki.

Seppo, Juha 2003b: Uskonnonvapaus 20oo-luvun Suomessa. Logos. Edita, Helsinki.

Seppo, Juha 2013: Kirkonmies ja muuttuva maailma. Martti Simojoki I. WSOY, Helsinki.

Seppänen, Johanna 1998: Keskustelu arkipyhistä kirkon ja yhteiskunnan suhteiden näkökulmasta vuodesta 1965 vuoteen 1986. Suomen ja Skandinavian kirkkohistorian julkaisematon pro gradu -tutkielma. Helsingin yliopisto, kirkkohistorian laitos.

Sipponen, Kauko 1982: Etujärjestöt ja eduskuntatyö. Teoksessa Suomen kansanedustuslaitoksen historia XII. Eduskunnan historiakomitea, Helsinki.

Sipponen, Kauko 1996: Julkinen valta ja yksilö. Teoksessa Suomen keskushallinnon historia 1809-1996. Hallintohistoriakomitea \& Edita, Helsinki.

Sorsa, Leena 2010: Kansankirkko, uskonnonvapaus ja valtio. Suomen evankelisluterilaisen kirkon kirkolliskokouksen tulkinta uskonnonvapaudesta 19632003. Kirkon tutkimuskeskuksen julkaisuja 109. Diss. Helsinki. Kirkon tutkimuskeskus, Tampere.

Strandberg, Kim 2012: Sosiaalisen median vallankumous? Ehdokkaat, valitsijat ja sosiaalinen media vuoden 2011 eduskuntavaaleissa. Teoksessa $\mathrm{Muu}$ tosvaalit 2011. Selvityksiä ja ohjeita 16/2012. Oikeusministeriö, [Helsinki] <http://urn.fi/URN:ISBN:978-952-259-172-2>. Katsottu 18.2.2013.

Strömsholm, Gustav 1997: De homosexuella som kyrklig spelbricka. En analys av aktörerna, aktionerna och debatten i Finland år 1993. Diss. Åbo. Åbo Aka- demis förlag, Åbo.

Talonen, Jouko 2001: Lestadiolaisuuden hajaannukset. Teoksessa Lestadiolaisuuden monet kasvot. Toim. Jouko Talonen \& Ilpo Harjutsalo. Iustitia 14. Suomen teologinen instituutti, Helsinki.

Talonen, Jouko 2012: Olavi Rimpiläinen (1937-) Oulun piispa, kirkon koulutuskeskuksen johtaja. Teoksessa Kirkollisia vaikuttajia Pyhästä Henrikistä nykypäivään. Toim. Hannu Mustakallio. Studia Biographica 10. SKS, Helsinki.

Talonen, Jouko 2014: Lestadiolaisuuden synty, leviäminen ja hajaannukset. Teologinen Aikakauskirja.

Tiihonen, Seppo 1996: Presidentti. Teoksessa Suomen keskushallinnon historia 1809-1996. Hallintohistoriakomitea \& Edita, Helsinki.

Tiilikainen, Teija 2007: Suomen ulkopolitiikka ja EU-politiikka 1995-2005. Teoksessa Kansainvälinen eduskunta. Suomen eduskunta 10o vuotta 11. Edita, Helsinki.

Tiitinen, Seppo 2008: Eduskuntatyön uudistuminen. Teoksessa Suomen ja kansanvallan haasteet. Suomen eduskunta 100 vuotta 12. Edita, Helsinki.

Toivanen, Aarne 2012: Lassi Nummi arvioi Uuden testamentin suomennosta. Teologinen Aikakauskirja.

Toivanen, Annasara 2012: Kirkolliskokous Uusi Tie -lehdessä vuosina 19742011. Kirkkohistorian julkaisematon kandidaatintutkielma. Helsingin yliopisto, teologinen tiedekunta. Tekijän hallussa.

Toiviainen, Kalevi 2004: Ekumeeniset kysymykset kirkolliskokouksessa 19762002. Teologinen Aikakauskirja.

Torkkeli, Susanna 2011: Rakennetaan suvaitsevainen ja moniarvoinen, ihmisten näköinen kirkko: Tutkimus Tulkaa kaikki -liikkeen aktiivijäsenten osallistumisesta ja vaikuttamisesta uudistusliikkeessä. Kirkkososiologian julkaisematon pro gradu -tutkielma. Helsingin yliopisto, teologinen tiedekunta.

Tuomala, Essi 2013: Ekumeeniset sopimukset Suomen evankelis-luterilaisen kirkon kirkolliskokouksen käsittelyssä 1976-1998. Suomen ja Skandinavian kirkkohistorian julkaisematon pro gradu -tutkielma. Helsingin yliopisto, teologinen tiedekunta.

Typpö, Sakari 2005: "Suola sentään on". Oulun hiippakunnan vanhoillislestadiolaiset kirkolliskokousedustajat ensimmäisessä uusimuotoisessa kirkolliskokouksessa 1974-1977. Suomen ja Skandinavian kirkkohistorian julkaisematon pro gradu -tutkielma. Helsingin yliopisto, kirkkohistorian laitos.

Vahtola, Jouko 2003: Suomen historia. Jääkaudesta Euroopan unioniin. Otava, Helsinki.

Vainio, Jouni 2007: "Varsinainen työhän tehdään valiokunnissa". Teoksessa Valiokunnat lähikuvassa. Suomen eduskunta 100 vuotta 7 . Edita, Helsinki.

Valjus, Tuomo 1992: Ruotsin kirkon jumalanpalveluskirjojen uudistaminen. Teologinen Aikakauskirja.

Vasiljev, Hanna 2004: Seurakunta liturgian subjektina -periaate jumalanpalvelusuudistuksessa 1988-2000. Ekumeniikan julkaisematon pro gradu -tutkielma. Helsingin yliopisto, systemaattisen teologian laitos.

Veikkola, Marketta 2006: Suomen Luterilainen Evankeliumiyhdistys ja naispappeuskysymys 1984-2000. Kirkkohistorian pro gradu -tutkielma. UEF Electronic Publications. <http://epublications.uef.fi/pub/URN_NBN_fi_ joy-20070161/>. Katsottu 5.8.2011.

Vischer, Lukas 2004: Major Trends in the Life of the Churches. Teoksessa A History of the Ecumenical Movement. Volume 3. 1968-200o. Ed. by John Briggs \& Mercy Amba Oduyoye \& Georges Tsetsis. World Council of Churches, Geneva.

Visuri, Pekka 2006: Suomi kylmässä sodassa. 2. p. Otava, Helsinki.

Vuorinen, Susanne 2008: Sana tulee näkyväksi. Viittomakielinen kirkkokäsikirja Suomen evankelis-luterilaiselle kirkolle 1997-2001. Suomen ja Skandinavian kirkkohistorian julkaisematon pro gradu -tutkielma. Helsingin yliopisto, kirkkohistorian laitos.

Välimäki, Hannu 2006: Lapuan hiippakunnan synty ja toiminta 1956-2006. Teoksessa Haasteena yhteys. Lapuan hiippakunnan viisi vuosikymmentä 1956-2006. Toim. Eija Harmanen. Kirjapaja, Helsinki.

Yli-Opas, Antti 2010: Avioliiton teologia Englannin kirkossa ja Suomen evankelisluterilaisessa kirkossa vuosina 1963-2006. Kirkon tutkimuskeskuksen julkaisuja 112. Diss. Helsinki. Kirkon tutkimuskeskus, Tampere.

Östman, Catharina 1985: Psalm och språk. Finlandssvenska revisioner av Runebergspsalmer 1865-1983. Kyrkohistoriska arkivet vid Åbo Akademi Meddelanden 20. Åbo Akademi, Åbo. 


\section{SAMMANFAT TNING:}

\section{KYRKOMÖTET I DEN EVANGELISK-LUTHERSKA KYRKAN I FINLAND 1974-2011}

Kyrkomötet, det högsta beslutande organet i den evangelisk-lutherska kyrkan i Finland, samlades från och med år 1876 i Åbo först med tio års och sedan med fem års mellanrum. Kyrkomötet beslöt självständigt om de kyrkliga böckerna och hade ensamrätt att ge förslag rörande kyrkolagen. Statsmakten kunde enbart godkänna eller förkasta dessa förslag, och de statliga organen hade ingen initiativrätt i kyrkomötet. År 1944 förstärktes kyrkans egen centralförvaltning avsevärt när kyrkostyrelsen och det förstärkta biskopsmöte som bildades kring biskoparna inledde sin verksamhet. Det förstärkta biskopsmötet skötte vissa av kyrkomötets uppgifter mellan kyrkomötena. Trots det var man tvungen att sammankalla extraordinarie kyrkomöten med jämna mellanrum vid sidan av de ordinarie kyrkomötena.

Beslutssystemet enligt den dåvarande modellen var inte längre tillfredsställande i 1960-talets Finland. De flesta ansåg att besluten om kyrkan fattades för långsamt när det statliga beslutsfattandet samtidigt blev allt snabbare. I slutet av 1960-talet och i början av det följande årtiondet hade kyrkomötet redan omkring 140 medlemmar. Mötet hade vuxit sig för stort, och valet av lekmannaombud som förrättades genom majoritetsval i varje prosteri motsvarade inte principen om representativitet tillräckligt väl. Kyrkomötet 1968, som sammanträdde i en omvälvande, världsomspännande brytningstid, var förutseende och inledde bland annat ett omfattande projekt för att reformera kyrkans centralförvaltning.

År 1974 inledde det förnyade kyrkomötet, som sammanträdde två gånger om året, sin verksamhet. Organet var mindre än tidigare med 108 lekmannaombud, präster och biskopar som medlemmar. Avhandlingen Kansankirkko ristipaineessa (Folkkyrkan i korsdrag) sätter ombuden åren 1974-2011 under lupp och utreder vilka kyrkomötets medlemmar var, hur de valdes och vad de gjorde. Vilka av dem hade mest makt och hurudana grupperingar har kunnat skönjas i kyrkomötets arbete? När dessa frågor utretts har de viktigaste källorna varit kyrko- mötenas tryckta protokoll med bilagor och i viss mån även kommittéernas och utskottens otryckta handlingar. Avhandlingen betraktar också helheten - kyrkomötet i relation till kyrkan, affärsvärlden, lagstiftningen som helhet, den teologiska diskussionen och massmedierna. Den ser också på hur förhoppningarna på kyrkomötesreformen uppfylldes. Framskred kyrkomötet så långsamt eller så raskt som olika iakttagare ansett?

\section{MERA DEMOKRATI}

I samband med kyrkomötesreformen 1974 försökte man i enlighet med den tidens allmänna ideal stärka både effektiviteten och demokratin i kyrkans förvaltning. Förstärkta biskopsmötet där biskoparna hade en central maktposition avskaffades, och en del av dess uppgifter överfördes till det lekmannadominerade kyrkomötet. Det förnyade kyrkomötet var otvetydigt kyrkans högsta beslutande organ som skulle ha förmågan att fatta snabba beslut och ta ställning i aktuella frågor. Centralförvaltningens övriga viktigaste organ var den utvidgade kyrkostyrelsen och biskopsmötet som bestod av biskoparna, fältbiskopen och en assessor från varje domkapitel.

Det förnyade kyrkomötet beslutade liksom tidigare om de kyrkliga böckerna och hade ensamrätt att lägga fram förslag till ändringar i kyrkolagen. En ny uppgift var att besluta om hela kyrkans ekonomi och styra dess verksamhet. Dessutom fick kyrkomötet en allmän behörighet att behandla frågor som gällde tro och lära. Godkännandet av förslag till kyrkolag och ärenden som rörde kyrkliga böcker, tro och lära förutsatte liksom tidigare tre fjärdedelars kvalificerad majoritet. Kyrkomötet fick fler uppgifter, men samtidigt blev organet genom den tätare mötestakten en del av kyrkans vardag. Kyrkostyrelsen, biskopsmötet, kommittéer som tillsatts av kyrkomötet, stiftens stiftsmöten och kyrkomötets ombud hade initiativrätt i kyrkomötet.

Med fyra års mellanrum valdes 32 prästombud och 64 lekmanna- 
ombud i stiften. I demokratisk anda infördes ett proportionellt valsätt som alternativ till majoritetsval i valet av lekmannaombud - dock utan kandidatuppställning. I praktiken skedde valförberedelserna alltmer bakom kulisserna och valet kritiserades för hemlighetsmakeri. Lekmannaombuden var fortsättningsvis till största delen högt utbildade tjänstemän, varav en mycket stor andel inom undervisningssektorn. Prästombuden hörde till prästerskapets ledande skikt. Närmare hälften av alla kyrkomötesombud hade en bakgrund inom någon väckelserörelse.

Efterhand blev yrkesfördelningen bland ombuden mångsidigare. Särskilt den ekonomiska recessionen i början av 1990-talet ledde till mera dynamiska val av ombud. I valet av lekmannaombud klarade sig den privata sektorns representanter bättre än tidigare, och i valet av prästombud blev kyrkoherdarna tvungna att ge vika för präster med särskilda uppgifter. Fram till slutet av den undersökta perioden var ändå det typiska lekmannaombudet en person i ledande ställning inom den offentliga sektorn.

Diskussionen om att öppna upp prästämbetet för kvinnor var livlig på 1970- och 1980-talen, vilket också avspeglades i kyrkomötesvalen. Andelen kvinnliga ombud steg kraftigt men deras auktoritet var till en början svag. Från och med år 1982 valdes regelbundet en kvinna till vice ordförande för kyrkomötet. Också i övrigt fick kvinnorna efterhand synligare uppgifter än tidigare i kyrkans centralförvaltning, bland annat genom könskvotering. Däremot började kvinnornas andel av kyrkomötets ombud minska på 1990-talet, då valen inte längre förknippades med något principiellt mål som gällde kvinnornas ställning. Dessutom blev det svårare att koncentrera rösterna när antalet kvinnliga kandidater ökade.

På samma sätt gick det också när det gällde unga vuxna. Under 200o-talet gjordes mycket för att få dem invalda samtidigt som undersökningar och kyrkans medlemsstatistik visade att under 30-åringarnas band till kyrkan påtagligt försvagats. Det ökande antalet unga kandidater gjorde det ändå i praktiken svårare för dem att bli invalda i kyrkomötet. I stället steg lekmannaombudens genomsnittsålder klart under 200o-talet, vilket speglade kyrkans åldrande medlemskår. På församlingsnivå lyckades kyrkomötet öka de ungas möjligheter att delta i beslutsfattandet genom att år 2007 godkänna en sänkning av rösträttsåldern i församlingsval till 16 år. Kyrkomötet följde internationella förebilder såsom Svenska kyrkans beslut från 1999. I det finländska samhället, där man samtidigt diskuterade en sänkning av rösträttsåldern i kommunalval till 16 år, var kyrkomötet däremot en föregångare.

I valet av lekmannaombud övergick man helt och hållet till ett proportionellt valsätt år 1986, och i valet av prästombud tio år senare. Valbestämmelserna utgick inte längre från att man regionalt med så brett samförstånd som möjligt valde betrodda representanter för kyrkan. Det väsentliga blev i stället att trygga ett rättvist antal platser för olika åsiktsgrupperingar. Valbestämmelserna förändrades snabbare än attityderna. Kandidatlistorna som sammanställts på regional eller partipolitisk grund var lösa och upprätthöll traditionen av personval trots att den inte passade ihop med det proportionella valsättet. Kandidatlistornas svaga ideologiska bindning var också en viktig orsak till att inga fasta ombudsgrupper bildades inom kyrkomötet. Ombuden samarbetade och deltog i förhandlingar främst med andra ombud som valts från samma stift.

Situationen började långsamt förändras under 1990-talet och 2000-talet, då klart kyrkopolitiska kandidatlistor blev vanligare. Listorna hade detaljerade målsättningar som ombuden tillsammans försökte genomföra också i kyrkomötet. Valmansföreningar med entydiga program fick mest synlighet i valen. Förändringen avspeglade sig i kyrkomötets diskussionsklimat. I denna värderingarnas brytningstid började kyrkomötet, som tidigare varit rätt enhetligt och kompromissökande, polariseras. Idealbilden av det oberoende ombudet började samtidigt ge vika, en idealbild som i kyrkomötet till skillnad från riksdagen överlevt länge också i praktiken. Allt oftare räknade man med att ett kyrkomötesombud representerade sin stödgrupp.

Även om valet av kyrkomötets lekmannaombud i grunden inte var partipolitiskt till sin natur etablerade sig Samlingspartiet, Centern och efterhand också Socialdemokraterna i kandidatuppställningen. Av den orsaken avspeglades det politiska fältets förändringar långsamt $\mathrm{i}$ kyrkomötet. Genom hela den undersökta perioden fanns nationellt betydande partier utan anhängare i kyrkomötet: Folkdemokraterna i början och Sannfinländarna i slutet av perioden. Partifördelningen bland lekmannaombuden var utpräglat borgerlig. Utgående från en enkät bland ombuden år 2011 motsvarade prästombudens partipreferenser befolkningens genomsnitt betydligt bättre än lekmannaombudens partipreferenser. Prästkvoten, som tidvis ansetts vara en "odemokratisk" komponent i kyrkomötet, säkerställde att de församlingsmedlemmar som röstat på vissa partier i valen var representerade.

År 2011 meddelade cirka hälften av ombuden att de åtminstone löst tillhörde någon väckelserörelse. Andelen var mycket lik den år 1974, men de ombud som tillhörde väckelserörelser var inte längre lika tydligt koncentrerade till vissa traditionella geografiska områden. I början höll sig väckelserörelsernas lekmannaombud från norr framme såväl med initiativ till kyrkomötet som i debatterna i plenum. Efterhand förflyttades tyngdpunkten i initiativ och debatter söderut. Bestämmelser i kyrkolagen som utgick från landsbygdens perspektiv orsakade problem framför allt i de stora städerna i söder, vilket ledde till ständiga initiativ. De kandidatlistor som sammanställts med utpräglat 
kyrkopolitiska målsättningar koncentrerades också till södra Finland, varför de kyrkliga frontlinjerna började ta form där.

Strävan efter att stärka demokratin kom till uttryck i kyrkomötesreformen 1974 också genom att antalet officiella ombud minskades. Särskilt de officiella juristmedlemmarna blev färre. Kvar blev ombuden valda av Högsta domstolen och Högsta förvaltningsdomstolen, som förblev mycket inflytelserika ända in på 1980-talet. Därmed påverkades kyrkolagens innehåll synligast av personer som inte hade rätt att verka som riksdagsledamöter. Efterhand fick kyrkans förvaltning ändå fler drag av Montesquieus maktdelningsprinciper. Ett steg i förändringsprocessen var att de ombud som valdes av de högsta domstolarna år 1996 försvann ur sammansättningen på domstolarnas eget initiativ. I kyrkomötets prioritetsordning fick strävan efter en tydlig maktdelning ändå ge vika för minoriteternas rättigheter. Sammansättningen utökades med ett sameombud som från och med år 2000 valdes av sametinget till medlem av kyrkomötet.

Biskoparna, fältbiskopen och en representant vald av statsrådet förblev officiella ombud under hela den undersökta perioden. Den sistnämndas betydelse växte från och med 1980-talet samtidigt som flera andra band mellan kyrkan och statsmakten brast. Biskoparna å sin sida var under åren efter kyrkomötesreformen betydande maktutövare på mötet, så att kyrkomötet till sitt arbetssätt fortsättningsvis påminde om ett "utvidgat biskopsmöte". Ärkebiskopen var kyrkomötets ordförande och de övriga biskoparna ledde de flesta av utskotten. Andelen ombud valda genom val ökade sedermera långsamt i utskottens ledning. Trots att också utskottens sammansättning efterhand blev mångsidigare utgjorde prästerna majoriteten i de utskott som beredde de mest betydelsefulla kyrkliga reformerna under hela den undersökta perioden.

Varken biskoparnas självskrivna medlemskap eller prästkvoten på 32 medlemmar ifrågasattes någonsin särskilt kraftigt. Tvärtom konstaterade den kyrkoordningskommitté som arbetade i slutet av 1970-talet att såväl församlingsmedlemmarnas representation som tjänsteinnehavarnas närvaro skulle tryggas på alla förvaltningsnivåer. Uppmärksamheten fokuserades under 1970-talet alltmer på kyrkans mest grundläggande väsen och uppgift. En atmosfär som var alltmer positiv till kyrka och religiositet möjliggjorde perspektivförändringen. Utvecklingen gick i motsatt riktning jämfört med Sverige, där kyrkomötet samtidigt knöt mycket närmare band med det politiska fältet än i Finland. Å andra sidan tjänade det lutherska kyrkomötet i Finland som förebild vid utformningen av det norska kyrkomötet som inledde sin verksamhet år 1984 .

Under åren efter kyrkomötesreformen lade de officiella ombuden överlägset oftast fram ändringsförslag i plenum. Endast i snitt vart sjunde av dessa förkastades, vilket vittnar om de officiella ombu- dens auktoritet. Plenums betydelse i kyrkomötets beslutsfattande återspeglas i sin tur av att också cirka hälften av lekmannaombudens ändringsförslag godkändes. Även om biskoparna hade en ansenlig makt i plenum släpade utvecklingen av stiftens verksamhet efter och biskopsmötets auktoritet vacklade. Situationen i stiften förbättrades när kyrkomötet inrättade nya tjänster. Däremot började biskopsmötet efterhand framträda som stiftsnivåns intressebevakare, vilket ledde till att kyrkomötet förhöll sig tvivlande till de teologiska motiveringar som biskopsmötet framförde.

Under den undersökta periodens sista år förbättrades biskopsmötets resurser och kyrkomötet följde biskopsmötets linje i de väsentligaste frågorna. Däremot ledde den stiftsöverskridande nya gruppverksamheten och de nya värderingarna som ifrågasatte auktoriteter till att de enskilda biskoparna förlorade en del av den makt de haft i början. Det var paradoxalt att den konstitutiva ämbetssynen samtidigt etablerades i den kyrkliga diskussionen och att man teologiskt började framhäva kyrkans särskilda ämbete.

Kyrkomötets arbetssätt etablerades särskilt från och med 1980-talet. Liksom allmänt i de europeiska parlamenten fick utskotten mera makt. Ombudens iver och behov av att föreslå ändringar minskade tydligt. I och med grundlagsreformen i början av 200o-talet övergick Finlands statliga beslutsfattande på ett avgörande sätt till parlamentarismen. Också inom kyrkan märktes en förändring: Kyrkostyrelsens ställning framhävdes på samma sätt som statsrådets roll för staten, men samtidigt skärptes den parlamentariska kontrollen över båda organen. Med riksdagen som förebild infördes verktyg i kyrkomötets arbetsordning som förbättrade ombudens informationstillgång och påverkningsmöjligheter redan under beredningsskedet.

Också kyrkomötets makt förstärktes indirekt genom att kyrkostyrelsen fick bättre möjligheter att bereda och verkställa, även om man i kyrkomötet tidvis kritiserade kyrkostyrelsen för alltför självständig maktutövning. Också i kyrkomötets arbete fick ecklesiastikråden en mer framträdande roll än tidigare. Trots att de endast hade närvarooch yttranderätt i kyrkomötet övertog de åtminstone i någon mån biskoparnas roll som kyrkans främsta tjänsteinnehavare. Så skedde efter att ecklesiastikråden i kyrkostyrelsens plenum gjorts till föredragande i stället för beslutsfattare och beslutanderätten koncentrerats till de förtroendevalda.

Särskilt under recessionsåren i början av 1990-talet växte viljan inom kyrkomötet att effektivera kyrkans förvaltning med stats- och kommunalförvaltningen som förebild. Lekmannaombuden gick inte med på att minska representativiteten och kyrkomötet gick därmed miste om ett sätt att effektivera förvaltningen. Däremot var lekmännen i allmänhet mycket villiga att effektivera förvaltningen genom att avskaffa bestämmelser om underställning och genom att överföra be- 
slutanderätt till de lokala församlingarna. Kyrkans arbetstagare understödde ändå inte denna åtgärd. De olika parterna var bara beredda att effektivera förvaltningen genom åtgärder som hade ökat den egna makten eller åtminstone upprätthållit den. När recessionen dessutom var över visade sig förändringarna svåra att genomföra. Så småningom lyckades kyrkomötet överföra beslutanderätt till den lokala nivån. Samtidigt ändrades bestämmelser som ursprungligen planerats för församlingsförvaltningen i landsbygdssamhället långsamt och mödosamt för att passa stora stadsförsamlingar.

Fram till tidigt 200o-tal kunde man säga att kyrkomötet i sin verksamhet utgjorde en miniatyr av folket. I många uppmärksammade avgöranden skiljde sig mötets åsiktsfördelning inte väsentligt från hela befolkningens. I den meningen fungerade den representativitet som eftersträvades i kyrkomötesreformen. Under det nya årtusendets första årtionde började situationen ändå förändras: åsikterna bland majoriteten av befolkningen gled snabbt isär från de aktiva församlingsmedlemmarnas ståndpunkter särskilt på temat sexualetik. Den centrala frågan var hur kyrkomötet skulle lyckas reagera på ett alltmer pluralistiskt samhälle.

\section{KYRKOMÖTET I ETT PLURALISTISKT SAMHÄLLE}

När kyrkomötesreformen planerades i slutet av 1960-talet och början av 1970-talet höll samhällsstrukturerna och värderingarna på att förändras snabbt. Genom att öka kyrkomötets sammanträdestakt hoppades kyrkans beslutsfattare kunna anpassa sig till förändringarna. På den tiden antingen genomförde eller påbörjade de sista kyrkomötena av gammal modell flera omfattande reformprojekt, men i och med kyrkomötesreformen övergick man till kontinuerligt reformarbete i små steg. Det innebar att kyrkomötets förslag till ändringar i kyrkolagen belastade den statliga lagstiftningsapparaten och stötte på hinder. Å andra sidan visade sig också kyrkomötets nya sammanträdestakt vara för långsam för statsmaktens behov av utlåtanden. Uppgiften att ge utlåtanden överfördes efterhand till kyrkostyrelsen. Den kunde reagera snabbt, men kyrkomötet blev utanför många statliga lagstiftningsprojekt som var viktiga för kyrkan.

Också när kyrkomötets arbete snabbades upp fördröjdes förändringstakten av kravet på tre fjärdedels kvalificerad majoritet. Särskilt åren 1976 och 1984 när framställningarna om att öppna prästämbetet för kvinnor föll anklagades kyrkomötet i pressen för konservatism. Det faktum att kyrkomötesombudens röstningsbeteende i stor utsträckning påminde om hela befolkningens åsiktsfördelning hamnade i skymundan. Längre in i den undersökta perioden gjorde övergången till proportionellt valsätt i kyrkomötesvalen beslutsfattandet långsammare. Till exempel var det positiva beslutet om kvinnliga präster år 1986 i mångt och mycket möjligt till följd av att majoritetsval fortfarande tillämpades i valet av prästombud. I de flesta stiften intogs prästombudsplatserna av den majoritet som understödde att prästämbetet öppnades för kvinnor.

Med det proportionella valsättet började olika åsiktsgrupperingar som ofta stod rätt långt ifrån varandra göra sina röster hörda. Det blev svårare att uppnå tillräcklig enighet. Under den undersökta periodens sista år påverkades kyrkan också av polariseringsutvecklingen i de västerländska kyrkorna, det finländska samhället och det politiska landskapet som delvis var en följd av den ekonomiska krisen år 2008. I många beslut om att låta ett ärende förfalla syns det också att lagstiftningsprocessen blivit alltmer komplicerad. Det utvidgade området för statlig lagstiftning och kyrkomötets egna avgöranden begränsade kyrkomötets svängrum trots att banden mellan kyrkan och staten formellt blev lösare. Under 200o-talet kunde kyrkomötet inte bearbeta lagförslagen lika fritt som på 1970-talet, då det i många avseenden var både beredningsorganisation och beslutsorgan. Under 200o-talet låg beredningen i kyrkostyrelsens händer, och missnöje med någon del av förslaget kunde leda till att hela förslaget förkastades i stället för att bearbetas.

Åren när kyrkomötesreformen planerades i slutet av 1960-talet och början av 1970-talet var en tid av vänsterradikalism. Kyrkomötet fick anpassa sig till många förändringar som var otrevliga för kyrkan, och ännu när det förnyade kyrkomötet inledde sitt arbete våren 1974 såg framtiden mycket osäker ut. Vid den tiden visade kyrkomötets diskussioner och ställningstaganden ändå att ett nytt skede hade börjat. Kyrkomötet var inte längre berett att ge upp på samma sätt som några år tidigare. Kyrkomötet uppnådde också resultat till exempel när det gällde försvaret av religionsundervisningens ställning i skolorna. När det allmänna attitydklimatet förändrades i slutet av 1970-talet minskade efterhand behovet av strikt gränsdragning gentemot det övriga samhället, och samtidigt fick kyrkan utrymme att framhäva sin autonomi. I slutet av 1970-talet och i början av 1980-talet fungerade kyrkomötet aktivt och utifrån kyrkans egna utgångspunkter som ett slags folkets samvete.

I folkkyrkan försökte kyrkomötet kombinera bredd med konfessionalitet. På denna grund byggdes det folkkyrkliga program som kyrkoordningskommittén utarbetade i slutet av 1970-talet. Samma sätt att tänka präglade också beslutet om kvinnliga präster år 1986. Som viljeyttring inkluderade kyrkomötet en kläm som skulle trygga handlingsfriheten inom kyrkan för dem som motsatte sig beslutet. Trots att klämmen inte var juridisk till sin natur fick den tyngd och blev svårare att tolka på grund av de förbehåll som dess motståndare framförde under diskussionens gång. På samma sätt hamnade kyrkomötet senare i paradoxala situationer då det framhävde betydelsen av medlem- 
skapet i kyrkan och samtidigt minskade medlemmarnas skyldigheter. Det visade sig vara svårt att höja tröskeln för utträde ur kyrkan och samtidigt underlätta inträdet.

Redan i samband med att kyrkomötet grundades på 180o-talet hade målet varit att minska kyrkans beroende av statsmakten. Vid samma tid som kyrkomötesreformen planerades i slutet av 1960-talet och början av 1970-talet förekom åter högljudda krav på att minska banden mellan kyrkan och staten. När förändringstrycket steg utredde Finlands lutherska kyrka mångsidigt sitt förhållande till staten. I Sverige ledde förslagen till förändringar i förhållandet mellan kyrka och stat inte till några snabba åtgärder, och så gick det också sedermera i Finland. Även om staten också i Finland inledde en utredning om saken dämpades diskussionen efterhand under 1970-talet när den politiska radikalismen minskade och den allmänna stämningen blev mera positiv gentemot kyrkan.

I den nya situationen hade kyrkomötesombuden ännu mindre lust än tidigare att avstå från banden mellan kyrka och stat. För kyrkomötets praktiska beslut innebar den nya tiden ändå inte någon minskad självständighet. Tvärtom bedömde kyrkomötet sin ställning som så stark att man år 1982 vågade fatta beslut i strid med finansministeriets och arbetsmarknadsorganisationernas vilja. Kyrkomötet föreslog till exempel att trettondagen och Kristi himmelsfärdsdag, som det extraordinarie kyrkomötet år 1971 gått med på att flytta till lördagen, åter skulle firas på samma dagar som tidigare. Stödet från det parlamentariska systemet och de nya personliga kontakterna till rikets regering - särskilt Svenska folkpartiets ministrars verksamhet i undervisningsministeriet under 1980-talet - var viktiga stöttepelare för kyrkomötet. På så sätt kunde den nära relationen mellan kyrkan och staten i vissa situationer stärka kyrkans oavhängighet.

Den ekonomiska recessionen påskyndade upplösningen av banden mellan kyrkan och staten i början av 1990-talet. År 1994 trädde totalreformen av kyrkolagen i kraft. Kyrkoordningen och valordningen för kyrkan skiljdes åt från kyrkolagen, och kyrkomötet fick rätt att självständigt besluta om dem. Samtidigt öppnade reformen för genomförandet av många förändringskrav som sjudit under ytan. Det svenska principbeslutet år 1995 om att skilja kyrkan från staten från och med början av år 2000 satte också fart på debatten. Även i Finland godkände kyrkomötet slutligen i snabb takt de förändringar som överförde underhållet av domkapitlen, som varit statens uppgift sedan reformationstiden, till kyrkan år 1997 och utnämningen av biskopar år 2000. Kyrkomötet följde det program som kyrkoordningskommittén utarbetat. Enligt programmet skulle kyrkan eftersträva en så omfattande oavhängighet från staten som möjligt och starkare än tidigare identifiera sig med den världsvida kyrkan.

Från 1970-talet till 1990-talet behandlade kyrkomötet betydelseful- la ekumeniska dokument. När besluten bereddes var målet inom kyrkans centralförvaltning teologisk precision. Kyrkomötet följde upp beredningen och lyssnade särskilt på ärkebiskoparna. År 1977 beslutade kyrkomötet under ledning av ärkebiskop Martti Simojoki att inte underteckna Leuenbergdeklarationen. Bakgrunden var en oro över kyrkans lutherska identitet och en vilja att följa samma linje som de närmaste nordiska systerkyrkorna. I kyrkomötets diskussioner förekom också nationell oro över kyrkans finländska identitet.

Vid sidan av ekumeniken var fredsfrågan och rasförtrycket i Sydafrika aktuella internationella teman på 1980-talet. Sovjetunionens begynnande öppning utåt och slutligen det socialistiska systemets sönderfall gav kyrkomötet utrymme att fritt behandla hjälpbehovet bland de kristna i Östeuropa. Det ökande svängrummet ledde till att kyrkomötet diskuterade internationellt ansvar särskilt mycket under den mandatperiod som började år 1988, alltså internationellt sett relativt sent. Majoritetskyrkans beslutsfattare ville inte testa gränserna i Finlands officiella, försiktiga utrikespolitik, utan levde med den internationella situationen och det förändrade svängrummet.

Under det följande årtiondet hade Borgådeklarationen som mål att skapa en djupare kontakt mellan de anglikanska kyrkorna i Storbritannien och Irland samt de lutherska kyrkorna i Norden och de baltiska staterna. Deklarationen kom upp till behandling i kyrkomötet i maj 1995, då Finland varit EU-medlem i bara några månader. Av den orsaken avspeglade sig misstänksamheten mot Europeiska unionen i kyrkomötets behandling av dokumentet. I huvudsak diskuterades ändå teologiska och juridiska tolkningsproblem. Vissa ansåg att dokumentet alltför mycket framhävde kyrkans ämbete eller förde den lutherska kyrkan närmare Rom. Ärkebiskop John Vikström däremot förespråkade aktivt att deklarationen skulle godkännas. I november 1995 godkände kyrkomötet Borgådeklarationen med klar marginal. För att försäkra skeptikerna och särskilt offentligheten om att det inte var fråga om att ändra bekännelsen nämnde kyrkomötet separat att deklarationen godkändes utifrån kyrkans bekännelse.

Samtidigt kom Gemensamma deklarationen om rättfärdiggörelseläran upp till behandling i Evangelisk-lutherska kyrkan i Finland. Med det luthersk-katolska dokumentet skulle de ömsesidiga fördömandena av varandras rättfärdiggörelseläror under reformationen konstateras vara missriktade. I den finländska beredningen föreslogs flera korrigeringar i dokumentet - ett tecken på den kritiska attityd mot dokumentet som rådde i landet jämfört med läget i många andra lutherska kyrkor. Efter ändringarna ställde sig biskopsmötet enhälligt bakom dokumentet som kyrkomötet tog upp till behandling hösten 1997.

I diskussionen upprepades flera av de teman som kommit upp när Borgådeklarationen diskuterades. Asymmetrin mellan kyrkosamfundens doktriner fick stor uppmärksamhet. För lutheranerna var rätt- 
färdiggörelseläran ett kriterium för kyrkans enhet som man inte kunde avstå från, men för den katolska kyrkan bara ett av många kriterier. Man frågade sig om det fanns andra läroskillnader som skulle ha undergrävt den gemensamma deklarationen. Kritikerna hänvisade till att människan också efter rättfärdiggörelsen var både fullständigt rättfärdig och fullständigt syndig. Med stöd av den nya finländska lutherforskningen framhävde deklarationens förespråkare rättfärdiggörelsen inte bara som förlåtelse utan också som Kristi helgande närvaro. Efter en grundlig behandling godkändes dokumentet i den avgörande omröstningen år 1998 med rösterna 88-17, vilket innebar kvalificerad majoritet.

Genom hela den undersökta perioden var lekmannaombuden med väckelsebakgrund mest kritiska mot ekumeniken. Tyngdpunkten skiftade ändå från en allmän, principiell ekumenikritik till specificerad kritik mot innehållet i ekumeniska dokument. Den nationellt färgade oron över den finländska kristendomen gav utrymme för kritik mot läran, där frontlinjerna gick genom olika länder och kyrkor. Genom hela den undersökta perioden behöll den evangelisk-lutherska kyrkan i Finland liksom Svenska kyrkan ett visst avstånd till de reformerta, men skapade kontakter med katolikerna och anglikanerna.

Enligt målet för kyrkoordningskommittén såg kyrkomötet sig självt under 1990-talet som en del av en familj av kyrkor. I behandlingen av olika reformer relaterade den sina egna beslut till de europeiska utvecklingsriktningarna och den världsvida kyrkan. En viss motreaktion följde under 200o-talet, då kyrkomötet - precis som hela det finländska samhället och många andra västerländska kyrkor - började vända sig inåt och fokusera på sina egna problem. Dessutom började man på allvar tolka de praktiska åtgärder som Borgådeklarationen föranledde först efter att den godkänts. I praktiken var man tvungen att i stor utsträckning tackla problemen i efterhand. Dessa problem dök upp särskilt när kyrkans ämbete och dess natur diskuterades. Särskilt från och med 1990-talet behandlades kyrkans ämbetsstruktur aktivt, men framstegen försvårades av att tolkningarna av den lutherska teologin, de ekumeniska utvecklingslinjerna och de olika tjänsteinnehavargruppernas förväntningar sinsemellan var så olika. Slutligen började uppmärksamheten på 200o-talet riktas mot andra frågor än ämbetsstrukturen, till exempel hur uppgifterna ska kunna skötas med en minskande personal och med stöd av frivilliga.

I slutet av 1990-talet och i början av 200o-talet började kyrkan på nytt hitta sig själv i en missionssituation. Allt fler uppgav att deras tro var annorlunda än den som kyrkan undervisade. Kyrkomötet försökte bemöta situationen genom att förnya de kyrkliga böckerna. De kyrkliga förrättningarna, som var särskilt viktiga för att nå medlemmarna, förnyades med bara två årtiondens mellanrum: kyrkomötet godkände nya handböcker för kyrkliga förrättningar åren 1984 och 2003. De liturgiska reformkommittéerna sökte influenser i den internationella liturgiska rörelsen och stödde sig på forskning på hög nivå och gammalkyrkliga förebilder. Kyrkomötet diskuterade ofta mycket praktiska frågor och försökte göra böckerna mer användarvänliga. I behandlingen av psalmboksreformen, bibelöversättningen och gudstjänstreformen försökte kyrkomötet bevara de mest välbekanta delarna i samma form som förr. Beroende på perspektivet antingen berikade eller bröt kyrkomötet stilen i böckerna.

Särskilt innehållet i de finsk- och svenskspråkiga psalmboksförslagen orsakade livlig offentlig debatt i mitten av 1980-talet. Det accepterades allmänt att nya psalmer infördes och psalmsamlingen gjordes mångsidigare, men slopandet och bearbetningen av psalmer kritiserades. Särskilt bearbetningen av psalmer som fått ett stort nationellt och kulturellt symbolvärde blev föremål för kraftig kritik bland såväl finsksom svenskspråkiga. Kyrkomötet fick backa inför responsen och ta ett steg tillbaka mot melodierna och formuleringarna i de gällande psalmböckerna. Å andra sidan fortsatte kyrkomötet på psalmbokskommittéernas linje till exempel genom att försöka införa samma melodier på finska och på svenska för många psalmer.

Kyrkomötet godkände de nya psalmböckerna år 1986. Organet hade aldrig tidigare på samma sätt stått i fokus för samhällsdebatten som vid den tiden, då den nya psalmboken och prästämbetet för kvinnor diskuterades. Ett breddat och tekniskt utvecklat mediefält såg till att det blev så. Under 1970-talet hade kyrkomötet ofta diskuterat samhället, men under det följande årtiondet var det samhället som diskuterade kyrkomötet.

Samtidigt med psalmboksreformen pågick det finskspråkiga bibelöversättningsarbetet. För första gången i de finska bibelöversättningarnas historia var en grundläggande utgångspunkt att översättningen så väl som möjligt skulle betjäna landets alla kristna samfund. Den bibelöversättningskommitté som tillsatts år 1973 sökte liksom psalmbokskommittéerna paralleller särskilt i Sverige, där de kyrkliga böckerna också förnyades.

Bibelöversättningskommitténs översättningsförslag orsakade ingen motsvarande offentlig debatt eller responsvåg som psalmboksförslaget. Psalmerna berörde finländarnas inre på ett annat sätt än Bibeln. Av samma orsak var argumentationen i kyrkomötets diskussion om bibelöversättningen mera präglad av kristendoms- och språkfrågor än inför beslutet om psalmboken, då flera personliga och känslosamma inlägg framfördes. Kyrkomötet kände heller ingen press att avvika från kommittéberedningens linje i samma mån som när psalmböckerna förnyades. Bevarandet av kopplingarna mellan Gamla och Nya testamentet och särskilt Paulusbrevens teologi fick mest uppmärksamhet.

Lekmannaombuden var påfallande aktiva när bibelöversättningen diskuterades. Deras tröskel att ingripa i Bibelns formuleringar var inte 
lika hög som när det gällde psalmpoesins detaljer eller de kyrkliga förrättningarnas former, där det närmast var prästombuden som stod för diskussionen. Den nya finskspråkiga bibelöversättningen godkändes 1992 och togs i bruk samma år. Kyrkomötets beslut om kyrkliga böcker under 1980-talet och början av 1990-talet visade att det förnyade kyrkomötet klarade av att snabbt slutföra stora projekt.

År 1988 inledde kyrkomötet en gudstjänstreform. I bakgrunden fanns problemen i församlingarna, där antalet gudstjänstdeltagare sjönk allt snabbare. Nya alternativa gudstjänster och ökningen av liturgiska textilier och nattvardsgudstjänster påskyndade också reformen. Samtidigt handlade det om att gå med i den ekumeniska reformrörelsen. Teologiskt sett var bakgrunden den liturgiska församlingsuppfattningen vars representanter ansåg att gudstjänsterna skulle bli församlingslivets medelpunkt. Man var på väg att inleda en reform som inte bara skulle vara en handboksreform, utan liksom namnet antydde en gudstjänstreform som berörde hela församlingslivet.

I början av 1990-talet verkade kyrkans framtid mycket osäker. Undersökningar visade att allt färre ställde sig bakom den kristna läran, och i och med recessionen blev de ekonomiska utsikterna allt dystrare. I kyrkomötet avspeglade sig samhällsproblemen tydligt också i diskussionen om gudstjänstreformen. Många liturgiska detaljer verkade ovidkommande inför människornas nöd. Dessutom fick kyrkomötet sedan slutet av det föregående årtiondet bemöta allt starkare krav på neutralitet, med utgångspunkt i det alltmer individualistiska samhället. Kyrkomötet behandlade flera statliga reformprojekt som präglades av en negativ uppfattning av religionsfriheten. Medborgarna skulle snarare skyddas från religionsutövning än garanteras möjligheter till sådan. Så var det trots att en positiv betoning av religionsfriheten samtidigt var på väg att förstärkas i den internationella diskussionen.

Kyrkans ståndpunkter i lagfrågor åsidosattes ofta i beredningen, men började efterhand beaktas i slutskedet av lagstiftningsarbetet. Samtidigt blev finländarnas band till kyrkan starkare igen. I början av årtiondet uppgav endast en tredjedel av finländarna att de trodde på Gud enligt den kristna läran, men i slutet av årtiondet uppgav hälften av medborgarna att de gjorde det. När också den ekonomiska recessionen var över kunde kyrkomötet åter koncentrera sig på kyrkans interna projekt. I början av 1990-talet hade kyrkomötet förberett sig på en överlevnadskamp, men några år senare kunde man koncentrera sig på frågor kring liturgi och lära i ett kyrkovänligt klimat. Den nya katekesen, gudstjänstboken och evangelieboken godkändes vid övergången till det nya årtusendet. Mötet uppmärksammade också betjäningen av minoriteter genom att effektivisera arbetet med kyrkliga texter på samiska och teckenspråk.

Kyrkomötet kunde i lugn och ro förnya de kyrkliga böckerna under 1990-talet, men i början av det nya årtusendet hamnade organet åter i den offentliga diskussionens brännpunkt. I de svenskspråkiga medierna uppstod en häftig diskussion om stavningen av den heliga Andens namn. I de kyrkliga böckerna hade den personlighetsbetonande maskulina formen den helige Ande efterhand och inte alltid helt öppet bytts ut till formen den heliga Anden. Tvisten avgjordes till slut när kyrkomötet beslöt att tillåta också den traditionella formen.

Tvistens uppkomst avslöjade faktorer som också i övrigt märktes i behandlingen av de svenskspråkiga kyrkliga böckerna. För det första hade enstaka personval en mycket stor betydelse när de svenskspråkiga kyrkliga böckerna förnyades: kyrkomötet gav i praktiken beslutanderätten till sina medlemmar från det svenskspråkiga Borgå stift. Deras sammanlagda antal kunde vara bara en bråkdel av de personer som deltagit i kommittéarbetet. För de svenskspråkiga böckerna betydde övergången från en expertkommitté till ett demokratiskt beslutsorgan att antalet beslutsfattare minskade. Samtidigt ökade slumpmässigheten.

För det andra visade tvisten att kyrkomötet inte i praktiken kunde påverka innehållet i den svenskspråkiga bibelöversättningen Bibel 2000 som mötet hade godkänt. Den diskussion som för den finskspråkiga bibelöversättningens del förts i berednings- och beslutsskedena fick föras i efterhand. Sveriges avgöranden påverkade också i övrigt kyrkomötets arbete - till exempel när kyrkomötet godkände den finskspråkiga översättningen av apokryferna år 2007. Kyrkomötet var tvunget att begränsa boksamlingen jämfört med översättningskommitténs förslag för att de finsk- och svenskspråkiga samlingarna inte skulle skilja sig från varandra.

Finländarnas förändrade värderingar och kyrkomötets svar på utvecklingen blev särskilt tydliga i diskussionen om äktenskapet. Ännu i slutet av 1970-talet diskuterade kyrkomötet seriöst prästens rätt att vägra viga frånskilda till ett nytt äktenskap. Under 1980-talet när förrättningshandboken förnyades inkluderade kyrkomötet fortsättningsvis ett avskalat vigselformulär. Det kopplades ändå inte längre direkt till vigsel av frånskilda, och utökades med fler kristna inslag än tidigare. När kyrkomötet i slutet av 1990-talet fattade beslut om katekesen införde plenum stycken om möjligheten till omgifte i det sjätte budordets förklaringstext. I början av 200o-talet krävde kyrkomötet slutligen inte längre något avskalat vigselformulär i den nya handboken för kyrkliga förrättningar. Utvecklingen avspeglade en attitydförändring. I början av det nya årtusendet förnekade bara några procent av finländarna kategoriskt att en skilsmässa kunde vara berättigad. Också kyrkomötet flyttade sin uppmärksamhet från skilsmässa till andra relationsfrågor.

Under 200o-talets första årtionde befann sig kyrkomötet i fråga om värderingar i en liknande allmän brytningstid som när kyrkomötesreformen förbereddes i övergången mellan 1960- och 1970-talen. Bryt- 
ningen gällde särskilt sexualetiken, och framskred mycket snabbt efter att lagen om registrerat partnerskap mellan personer av samma kön trätt i kraft år 2002. Under dessa år diskuterade kyrkomötet kyrkans ställning i frågan och fick balansera mellan åsiktsriktningar som låg allt längre från varandra. Korstrycket mot kyrkomötet var som störst när en våg av utträden ur kyrkan uppstod inför den avgörande omröstningen i oktober 2010. Kyrkomötet stannade för en känslig kompromisslösning. Det gav biskopsmötet i uppgift att utarbeta anvisningar för pastorala möten med personer som registrerat sitt partnerskap. Beslutet påminde i stor utsträckning om Svenska kyrkans handlande år 1994.

Beslutet fattades med enkel röstmajoritet. Läget påminde mycket om år 1976, då kyrkomötet konstaterat att det enligt kyrkans lära var möjligt att öppna prästämbetet för kvinnor. I båda fallen saknades en kvalificerad majoritet, men trycket att prestera någon typ av budskap var så starkt att kyrkomötets ledning tolkade tillämpningsområdet för kravet på kvalificerad majoritet snävt.

Målet med kyrkomötesreformen hade varit ett beslutssystem som snabbt kunde reagera på samhällsförändringar, men de förändrade värderingarna innebar samtidigt en polarisering. Kyrkomötet fick fokusera på att söka kompromisser och förhindra intern söndring. På 200o-talet fanns inte längre tid eller tillräcklig enighet för samma slags ställningstagande verksamhet som i slutet av 1970-talet och början av 1980-talet.

\section{FRÅN LAGSTIFTNING TILL EKONOMI OCH VERKSAMHETSSTRATEGIER}

Kyrkans omvärld förändrades snabbt i slutet av 190o-talet och början av 2000-talet också i andra avseenden än i fråga om värderingar. Kyrkomötet måste ständigt fästa mer uppmärksamhet vid såväl kyrkans egen ekonomi som den globala ekonomins svängningar. Flyttningsrörelsen ökade den ekonomiska ojämlikheten mellan församlingarna, vilket kyrkomötet måste ta itu med i form av utjämningsåtgärder. För att nå en alltmer rörlig medlemskår måste man fundera på funktionella lösningar. Problemet var att dessa visioner inte var särskilt enkla att omsätta i praktiken.

Budgeterna för kyrkans centralfond ökade kraftigt under 1970- och 1980-talen. Kyrkomötet inrättade tiotals gemensamma kyrkliga tjänster. Mötets ekonomiutskott försökte begränsa de svällande utgifterna och efterlyste en långsiktigare verksamhets- och ekonomiplanering. Den fyraåriga verksamhets- och ekonomiplanen infördes på 1980-talet, men dess ramar förhindrade inte att budgeterna svällde. Under åren av snabb ekonomisk tillväxt i slutet av årtiondet lyckades kyrkan slutligen dämpa ökningen i sin egen totalbudget. Avigsidan var att kyrkomötet vid den tiden ännu inte gick med på att börja med pensions- fondering, vilket skulle ha ökat församlingarnas utgifter men minskat det senare trycket på pensionsavgifterna.

Kyrkomötets linje var konsekvent. Enligt den skulle såväl församlingarna som hela kyrkan ta ut skatt enbart för det aktuella årets behov. På dessa grunder vägrade kyrkomötet att betala tillbaka extrainkomster från beskattningen av sociala förmåner till staten, men på samma grunder avvisade mötet sin egen möjlighet att börja bygga upp fonder. Fonderingstänkandet fick fotfäste först när de ekonomiska utsikterna blev dystrare. Åren av ekonomisk recession avslöjade i början av 1990-talet hur bräcklig församlingarnas skattebas var. I synnerhet församlingarnas samfundsskatteinkomster visade sig vara nyckfulla. När antalet arbetslösa fyrdubblades fruktade man att inte bara samfundsskatteinkomsterna, utan också den kyrkoskatt som uppbars från församlingsmedlemmarna skulle rasa och orsaka ekonomiska problem för både församlingarna och kyrkans centralfond. Efter upplevelserna under recessionen gick de tidigare årens hushållning ur hand i mun inte längre för sig, och den kraftiga fonderingens inledningsskede sammanföll med nedskärningarna. Trots den stora oron klarade sig kyrkans ekonomi ändå genom 1990-talet relativt oskadd.

Också pensionsfonderingen tog fart mitt i recessionen år 1991. Hela kyrkans ekonomi, som också sedan tidigare påverkades av den konjunkturkänsliga samfundsskatteandelen, blev genom placeringarna ännu mer beroende av företagens framgång. I den situationen blev etisk placeringsverksamhet ett viktigt samtalsämne. År 1999 färdigställdes anvisningarna om etisk placeringsverksamhet, och åtta år senare de nya anvisningarna för ansvarsfull placeringsverksamhet som delvis utformats tillsammans med Svenska kyrkan. Vid sidan av valet av placeringsobjekt var syftet att påverka företagens verksamhet. Också oron över klimatförändringen ökade och under 20oo-talet inledde kyrkomötet beredningen av kyrkans klimatprogram.

Från och med år 2008 försköt de ekonomiska kriserna allmänt uppmärksamheten från globala problem till den egna nationalstaten och den personliga utkomsten. I någon mån kunde samma förändring också noteras i kyrkomötets diskussioner. I stället för de många samhälleliga verksamhetsformerna var det individuella frälsningsbudskapet på väg tillbaka upp på agendan. Ombuden började kräva en ny missionsinriktning av kyrkan i det finländska samhället. Däremot förblev den yttre missionen genom hela den undersökta perioden ett rätt avlägset ämnesområde ur kyrkomötets synvinkel. Inom kyrkan fanns flera officiella, självständiga missionsorganisationer. Således utformades också de praktiska riktlinjerna för missionsarbetet på annat håll än i kyrkomötet.

Under den undersökta periodens gång kom en ständigt ökande andel av hela kyrkans ekonomi att flytta utom räckhåll för kyrkomötets direkta beslutanderätt. Samma förändring skedde för Finlands riksdag 
när det gällde statsfinanserna. I utvecklingen av pensionssystemet var kyrkomötets uppgift framför allt att följa läget och stödja det reformarbete som kyrkostyrelsen genomförde. Dessutom fattade kyrkomötet viktiga och svåra beslut vid vissa vändpunkter. Kyrkans och statens ekonomiska relationer där kyrkomötet varit avgörande under 1980-talet överfördes likaså till kyrkostyrelsen.

Under 1990- och 2000-talen övergick kyrkomötet efterhand till ramlagstiftning i vissa administrativa avgöranden, och samma tänkesätt påverkade också kyrkomötets övriga uppgiftsområden. I sina beslut om kyrkans ekonomi ingrep kyrkomötet inte längre i detaljer såsom enstaka tjänster, men samtidigt utökades ombudens möjligheter att få information och föra principdiskussioner om hela kyrkans ekonomi genom ändringar i arbetsordningen. Tanken om ramlagstiftning präglade också gudstjänstreformen. Beslutanderätt om gudstjänsten överfördes från kyrkomötet till den lokala församlingen. Förändringen var knuten till kyrkomötets självförståelse. På 1980-talet, vid tiden för totalreformen av kyrkolagen, såg kyrkomötet sig självt som ett lagstiftningsorgan som också hade behandlat gudstjänstordningen som ett regelverk på förordningsnivå. På 1990-talet förstärktes däremot betoningen av verksamheten och det praktiska kyrkolivet.

Kyrkomötets intresse för verksamheten ökade överraskande samtidigt som ansvaret för styrningen av hela kyrkans verksamhet överfördes från kyrkomötet till kyrkostyrelsen år 1994. Recessionen tvingade kyrkan att ifrågasätta tidigare verksamhetssätt och fundera på verksamhetsformernas prioritetsordning. Omformningen av kyrkans kommittéer och centraler till enheter under kyrkostyrelsen förde dess- utom dessa organ betydligt närmare kyrkomötet än tidigare. Kyrkomötet flyttade sin uppmärksamhet alltmer från verksamhetsstyrningen till verksamhetens innehåll. Strategiarbetet och framtidsvisionerna ökade kraftigt i början av 2000-talet.

Samtidigt nådde flyttningsrörelsen sin kulmen och den ekonomiska ojämlikheten mellan församlingarna växte. Fram till år 2005 fattade kyrkomötet betydande ekonomiska utjämningsbeslut, och det gick inte att uppfatta samma motsättningar mellan norr och söder som under tidigare årtionden. Den gemensamma oron över församlingarnas ekonomi fick ombuden att ge avkall på den egna församlingens intressen. Å andra sidan fick samma oro kyrkomötet och kyrkostyrelsen att se på församlingsstrukturen närmast ur en ekonomisk och administrativ synvinkel. Målet blev församlingssammanslagningar. Först i mitten av årtiondet började man diskutera sammanslagningarnas effekter på det andliga livet och församlingsidentiteten.

Under 2000-talet talade kyrkomötet mer än någonsin tidigare om visioner och skissade upp framtidsbilder om den människonära församlingen. De praktiska resultaten var ändå ekonomiska effektiviseringsåtgärder som var lärdomar från recessionen. De många initiativen och betänkandena om verksamheten samt strategidiskussionerna i plenum ledde bara till ett fătal egentliga förändringar i strukturerna. Det var inte lätt att förvandla visioner till bestämmelser. Ändå visade visionerna att det förnyade kyrkomötet blivit en del av kyrkans vardag där församlingarnas dagliga verksamhet och möten med församlingsmedlemmarna diskuterades. Trots alla meningsskiljaktigheter var kyrkomötet ett möte som bad och sjöng tillsammans. 


\section{HENKILÖHAKEMISTO}

Aalto, Arvo 51

Aaltonen, Samuli 23

Aarnio-Jääskeläinen, Liisa 11

Agricola, Mikael 345

Aho, Arvo 166

Aho, Esko 218, 219

Ahonen, Risto A. 185, 222, 233

Ahtikoski, Seppo 195, 298

Ahtisaari, Martti 187, 207, 211, 212

Aikio, Pekka 246,336, 337

Ainali, Veli 236, 307, 308

Airola, Eeva 250

Alaja, Osmo 28, 30, 32, 33, 36, 58, 84, 86, 93, 148

Alanen, Antero 107

Alanen, Heikki 255

Andersson, Jonas 158

Andersson, Marjukka 306

Aro, Jussi 164

Arwidsson, A. I. 131

Askola, Irja 261

Aunola, Olavi 171

Auranen, Ahti 17, 39, 40, 47, 72, 339

Avela, Outi 187, 196

Bergholm, Kari 111

Björkstrand, Gustav 11, 23, 26, 57, 100, 108, 115, 136, 213, 215

Blix, Elias 160

Böckelman, Pehr-Olof 131, 132

Cantell, Risto 159,230

Cleve, Fredric 26, 124, 125, 131, 133, 135, 143, 144, 153, 156, 174, 238, 313

Drachman, Martti 105, 172, 231

Dromberg, Kaarina 324

Eerola, Eeva 233

Eho, Sirkku 262, 311

Elenius, Jaakko 237, 262

Elsilä, Jari 202

Endén, Rauno 12

Eriksson, Thure 56,60

Eskola, Seikko 11, 23, 90, 92, 101, 108, 133, 177, 193, 197, 211, 223, 224, 272, 297

Fagerholm-Urch, Juanita 241, 242, 313

Forsberg, John 38, 39, 72

Fröman, Kim 263, 273, 317

Gandhi, Indira 119

Gerhardt, Paul 160

Haapa, Esko 56, 6o, 164

Haaramäki, Ossi 12, 44, 59, 127, 191, 192, 206, 227
Haavio, Jaakko 154, 160

Hallamaa, Olli 322

Hallberg, Pekka 317

Halonen, Tarja 212

Halttunen, Matti 40, 41, 102, 192, 214, 231, 274, 282, 297, 317, 326, 333

Hammarskjöld, Dag 240

Hassinen, Leino 79, 80, 119, 126, 147, 148, 177, 247

Heikka, Mikko 185, 198, 204, 214, 220, 221, 224, 247, 278, 283, 288, 294, 324, 325, 327

Heikkilä, Markku 11, 219-222

Heikkilä, Pentti 145

Heikkilä, Risto 159

Heilimo, Olli 24,67

Heinimäki, Jaakko 206, 225, 241, 242, 248, 250

Heininen, Simo 11

Heinonen, Eero 38,39

Heinonen, Leena 302

Heinämäki, Tapani 38

Hellberg, Håkan 198

Hidén, Mikael 186

Hieronymus 230

Hiitola, Joni 318

Hiller, Philipp Friedrich 159

Hirvi, Vilho 217, 255, 316

Hirvola, Pirkko 94, 95

Holkeri, Harri 175

Holma, Timo 6o, 61, 110, 138, 140, 149, 166, 168, 170, 178

Holopainen, Pirkko 94, 95

Huhta, Erkki 214

Huhtala, Aarre 153, 167

Huhtala, Heikki 149

Huima, Leena 11, 107, 131, 195, 196, 229, 231-233, 235, 247, 253, 312

Huokuna, Pekka 275, 312

Huotari, Voitto 210, 227, 228, 235, 236, 242, 254, 265, 287, 299, 300, 309, 310

Huovinen, Eero 57, 128, 129, 166, 167, 169, 170, 173, 182, 183, 191, 192, 210, 212, 219, $225,226,227,230,232,245,247,250,289,298,301,309-311,320,321,323,334$

Huttunen, Jukka 285, 286, 304, 335

Huuskonen, Aarre 39

Hyttinen, Marjatta 273, 285, 290

Hyyryläinen, Mauno 106, 179, 202, 214, 241, 280, 282

Hyöky, Ritva 56,60

Häkkinen, Seppo 274, 275, 279, 295, 308, 323

Ignatius, Pirkko 193, 319

Ikola, Osmo 164

Innanen, Jouko 208

Isohookana-Asunmaa, Tytti 132, 212, 215

Isotalo, Sinikka 55

Itälä, Jaakko 51, 75

Jansson, Gunnar 132

Jantunen, Kai 311

Jauhiainen, Signe 265, 290 
Joensuu, Matti 52

Johannes, metropoliitta 136

Jokela, Eila 101

Jokela, Erkki 34, 90

Jokiranta, Liisi 107, 168, 230, 231, 233, 234

Jomppanen, Jouni 337

Junkkaala, Eero 233, 234, 250, 322

Junttila, Risto $186,197,286,289$

Jussila, Aira 303

Juva, Mikko 11, 12, 15, 25, 37, 40, 45, 48, 52, 60, 62-64, 66, 68-71, 76, 78, 80, 81, $83,85,89,92,93,95-97,113,114,116,117,132-134,139,152,179,180,192,197$ $227,266,271$

Järveläinen, Matti 122, 133, 208, 229, 230, 237

Kaarlonen, Katri 63,87

Kaartinen, Marjatta 188, 197, 243

Kaikkonen, Hilkka 147, 148, 150, 309

Kailas, Uuno 156

Kainulainen, Pauliina 277, 281, 294

Kalliala, Kaarlo 233, 248-250

Kallio, Kyösti 87

Kalliokoski, Viljami 23, 26, 33, 36-39, 109, 195

Kamppuri, Hannu 187

Kansanaho, Erkki 31, 37, 38, 40, 42-44, 46-48, 52, 65, 68, 71, 79-81, 90, 92, 93, 97,119

Kantola, Ilkka 247, 299-301, 308, 322

Kares, Olavi 16, 28, 32, 37, 147, 148

Karhapää, Heimo 12, 230

Karjalainen, Sakari 22

Karjalainen, Sanni 38

Karlsson, Henrik 168

Karpela, Tanja 276, 286, 327, 337

Karppinen, Matti 12

Karttunen, Petri 158, 212, 219

Karvinen, Helli 142, 160

Karvo, Marja 301

Kaskinen, Anna-Mari 158, 277, 334

Kauppinen, Juha 208, 281

Kauvosaari, Terttu 130, 193, 215, 222, 228

Kekkonen, Anna 73

Kekkonen, Urho 21, 100, 101

Kemppainen, Raili 287

Keskitalo, Jukka 275, 326, 338

Ketonen, Matti 334

Kilpiö, Markku 162,163

Kinnunen, Kari Pekka 274, 338

Kippo, Hannu 169, 295, 315, 321

Kiuttu, Pekka 203, 206, 289

Kivi, Aleksis 89

Kiviranta, Simo 57, 60, 61, 68, 165

Klemola, Jyri 197

Knuuttila, Sakari 195, 216, 217, 226, 256

Koivisto, Kimmo 296, 297

Koivisto, Mauno 100, 112, 115, 207

Kokko, Heikki 39, 108

Komulainen, Timo 168

Korhonen, Keijo 202

Korpela, Simo 159

Kortekangas, Paavo 44, 56, 63, 73, 92, 116, 126, 127, 129, 130, 143, 144, 153-158, 160-162, 178, 179, 196, 219, 222, 227, 229

Koskenniemi, Erkki 165

Koskenniemi, Heikki 164, 165

Koskenniemi, Lauri 158-160, 177

Koskimäki, Yrjö 234, 239, 244, 305, 321, 330

Koskinen, Johannes 320

Kotila, Heikki 11, 264, 302, 306-309, 315

Koukkari, Esa 329

Krankka, Pekka 12

Krogerus, Mikael 297,319, 336

Kuha, Heimo 263
Kujala, Erkki 286, 324, 325, 338

Kumpusalo, Marjatta 250

Kunnas, Kirsi 169

Kurtén, Alvar 152

Kurvinen, Pekka 24, 56, 65, 190

Kustaa Vaasa 208, 210

Kuusisto, Taneli 156

Kuuskoski, Katri 11

Kylliäinen, Antti 233

Kääriäinen, Kimmo 275

Kökkö, Timo 40, 47, 149, 159, 178

Laasonen, Pentti 55, 234

Laato, Antti 167

Laato, Eeva 107, 168, 239

Lahtinen, Marja 250

Lahtinen, Veikko 250

Laine, Sulo 70

Laitinen, Arto 193, 225, 228, 285, 319

Laitinen, Marjatta 204, 297

Laitinen, Markku 135

Lamminen, Mari 189, 307, 311

Lampinen, Pekka 20

Lankinen, Tuomas 291

Larkio, Mauri 45, 74, 85, 133

Lauha, Aarre 164

Laulaja, Jorma 12, 105, 136, 192, 210, 243, 244, 285, 302, 321, 322, 324

Launikari, Jaakko 225, 228

Lawast-Slotte, Linda 275, 298

Lehtinen, Eero 28, 32, 39

Lehtinen, Marjatta 110, 192

Lehtinen, Reijo 88, 111, 122, 123, 177

Lehtipuu, Paula-Maria 248-250, 281

Lehtiö, Pirkko 56, 60, 107

Lehtola, Kari 297

Lehtonen, Lauri 211, 212

Lehtonen, Samuel 136, 147, 148, 178

Leino, Pekka 102,103

Leinonen, Hannes 39, 42, 62, 64, 67

Leinonen, Tapio 246

Leivonen, Johannes 15, 23, 37, 39, 42, 56, 58, 65, 66, 84, 90, 92, 93, 102, 103, 109, $126,127,138,139,149,150,180,190,193,219,252$

Lemmetyinen, Eeva-Kaija 12

Lempiäinen, Pentti 151, 157, 242

Lepola, Martti 61

Leppänen, Johannes 323

Lindén, Suvi 213

Lindgrén, Samuel 215

Linkola, Juhani $27,33,39,40,81,177$

Linna, Juha 41

Linna, Väinö 41

Lipponen, Paavo 202, 213, 332

Luoma, Tapio 277, 334

Luther, Martin 57, 62, 235, 247

Löytty, Jaakko 158

Löytty, Seppo 78

Maijala, Matti 26

Malmberg, Raili 148, 158

Malmivaara, Jukka 40, 111, 116, 117, 136

Mannermaa, Tuomo 62, 68, 70, 165

Marjanen, Jaana 311

Marjokorpi, Lasse 286, 287, 291, 311, 315, 320, 322, 323

Martikainen, Jouko 36, 139

Martola, Yngvill 313, 315

Massa, Yrjö 16, 56

Mattila, Reijo 136, 158

Mattlin, Håkan 276,326

Miettunen, Martti 75

Mikkola, Raija-Liisa 109, 185, 195, 237, 238 
Murtoperä, Martti 329, 330

Mustakallio, Hannu 12

Myllys, Riikka 263, 281, 283

Mäkeläinen, Heikki 62, 68, 111, 119, 133, 139, 197, 206, 219, 251, 330

Mäkeläinen, Pertti 83,111, 120, 197

Mäkinen, Kari 116, 261, 327, 328, 334, 336, 338

Männistö, Jukka 299

Mäntymaa, Eeva 94, 95

Mäntymaa, Jussi 12, 49, 54

Mäntymaa, Mauno 151

Mäntyranta, Mika 307

Määttänen, Annika 334

Niemelä, Pentti 39

Nikolainen, Aimo T. 44, 47, 58, 59, 61-64, 66-69, 71, 73, 77, 78, 80-82, 86, 87, 90, $92,93,97,135,148,149,163-165,170,171,174$

Nikula, Paavo 320

Niskanen, Hannu 126, 195, 237, 243

Nissilä, Keijo 168, 173, 223, 231

Norja, Leo L. 12, 197

Nummela, Leif $315,325,337$

Nummi, Kalevi 109, 185, 195

Nummi, Lassi 164

Numminen, Jaakko 12, 56, 63, 75, 84, 100, 112-116, 192, 201, 212

Nurmisto, Aulis 33

Nuutinen, Tapani 231

Nyqvist, Rafael 39, 63, 68, 205

Nyström, Berit 94, 95

Nyström, Sirkku 87, 189, 244

Obare, Walter 323

Ojala, Matti 119

Ojala, Sami 284

Ojala, Seppo 24, 42

Ojalainen, Paavo 83

Ojanen, Eeva 58,73

Olkinuora, Hilkka 260

Olsson, Arne 323

Orsila, Markku 284

\section{Paajanen, Martti 122}

Paarma, Jukka 182, 183, 195, 213, 223, 226, 227, 239, 245, 260, 261, 263, 274, $276-279,281,298,311,312,323-325,327$

Paavali, apostoli $166-169$

Paavali, arkkipiispa 136

Paavilainen, Maija 209

Palva, Heikki 164

Parvio, Eero 23, 27, 59, 62, 63, 66, 68-70

Parvio, Martti 143,147

Pekkanen, Matti 26, 111, 112

Pellinen, Markku 193

Peltonen, Kai 278

Pennanen, Jari 274

Pennanen, Kirsti 94, 95

Perret, Henrik 100, 140, 156, 159, 162, 174, 232, 244, 311, 314, 315, 324

Perttula, Marjaana 233, 248, 334

Perälä, Maaria 300, 321

Pesonen, Jouko 138

Pesonen, Tuomo 284

Peura, Simo 277, 282, 306, 327

Pieski, Ola 102, 130

Pihkala, Juha 119, 164, 194, 233, 236, 248, 306, 309, 316, 321, 334

Pihlaja, Pirjo 12, 274, 275

Pimen, Moskovan patriarkka 16

Piri, Erkki 23, 89, 90

Pirttijoki, Jukka 202, 255

Pohjala, Maija-Liisa 27

Pohjolainen, Terttu 185

Popiełuszko, Jerzy 119

Portin, Göran 190-193, 197, 227, 252, 255, 273
Porvari, Markku 120, 123, 172, 198, 200, 220, 221

Poutiainen, Matti 247

Pruuki, Heli 281, 282, 305, 321, 322

Puha, Seija 122, 172

Puolanne, Ulla 108, 122

Puotunen, Sirkka 177

Puruskainen, Ritva 187

Pyhäjärvi, Pirjo 262, 273, 304, 317, 319

Pylkkänen, Sinikka 36, 40, 95, 96, 109

Päivänsalo, Meeri 38, 39, 42, 58, 73, 109, 135, 138

Pöyhönen, Veikko 121,132

Rainerma, Keijo 196, 239, 274, 325

Raitis, Sisko 107

Raittila, Anna-Maija 153, 161

Rajala, Pertti 225

Rajamäki, Aili 25

Rajamäki, Olli T. 247

Ranta, Erkki 233, 236

Ranta, Jussi 139, 177

Ranta, Matti 148, 154

Ranta, Pertti 40, 89, 92

Rantala, Jaana 121

Rantala, Kaisu 196

Rantanen, Leena 121, 274, 285-289, 292-294

Rasimus, Risto 275,306

Rastimo,Urpo 27

Rauhala, Niilo 152, 153

Raunio, Aulis 92

Rautavuori, Rauni 118, 194, 196, 205

Reagan, Ronald 117

Rehn, Olli 218

Reijonen, Mikko 191, 228

Reinikainen, Erkki 68, 90, 93, 117, 118, 120, 145, 149, 162, 172, 173, 179

Reinilä, Pentti 49, 88, 92

Remes, Viljo 42

Repo, Hannele 196, 205, 239, 249

Repo, Matti 306

Repo, Rafael 136

Riekkinen, Wille 236, 245, 283, 300, 321, 323, 324, 326, 327

Riikonen, Teuvo V. 274, 282, 337

Rikkonen, Olli 190, 191

Rimpiläinen, Olavi 6o, 99, 107, 117, 129, 130, 135, 136, 141, 147, 162, 166, 167, 172, 173, 180, 192, 227, 231, 235, 241, 244, 245, 247, 262, 309, 314, 337

Rinta-Harri, Mikko-Matti 308,337

Rintamäki, Juha 187

Ripatti, Jaakko 11, 237, 305, 308

Rissanen, Seppo 267

Ronni, Mirja 73, 97

Rostamo, Kirsi 277,284

Runeberg, Johan Ludvig 153,161

Ruokanen, Tapani 125

Rusama, Timo 47, 79, 111

Ruuttunen, Arvi 156,158

Ryömä, Kaija 94, 95

Räisänen, Heikki 108, 165, 168

Rämä, Timo 267, 282

Rönkä, Kaisa 272

Saari, Alma 12, 25, 58, 151

Saari, Urpo 173

Saarilahti, Toivo 46

Saarinen, Eero 45

Sahi, Timo 172, 173, 195, 213, 223, 225, 255, 272, 273, 301

Sakki, Olli 109, 113, 142, 190

Salakka, Yrjö 69

Salmenkivi, Ritva 107

Salmenkivi, Taisto 244

Salmi, Samuel 263, 299, 306, 317

Salminen, Kaarlo 162 
Saloheimo, Mauno 17,39

Salonen, Paula-Maria ks. Lehtipuu, Paula-Maria

Salonen, Pentti 329

Santavuori, Ritva 274, 276, 322, 326

Saraneva, Tapio 58, 93, 118, 205, 228

Sariola, Yrjö 55, 56, 63-65, 139, 141, 142, 147, 149, 158, 161, 162, 166, 167, 173, 178 , $185,196,211,238$

Sarsa, Kai 17, 39, 50, 55, 111

Savela, Voitto 231, 233

Savolainen, Lea 108,125

Schantz, Knut von 88

Schauman, F. L. 207

Schütt, Tamara 94, 95

Seppälä, Tapio 303, 329

Setälä, Osmo 202

Sihvo, Jouko 100, 106

Sihvonen, Matti 44, 128, 129, 136, 140, 144, 173, 184, 185, 201, 208, 212

Siljamäki, Esa 47

Silvola, Anna Maija 38-40

Simojoki, Anssi 61

Simojoki, Martti 10, 16, 21, 25, 27, 30-32, 36, 39, 45, 48, 51, 57, 58, 62-66, 68-72, $75,77,78,80,81,84,85,87,90,91,93,95,119,137,145,179,230,261$

Simojoki, Pekka 158

Simojoki, Pentti 159, 231

Simola, Pertti 273, 285, 290, 292, 302, 303

Siukonen, Antti 263, 281, 283

Soini, Pekka 227

Soisalon-Soininen, Ilmari 164, 167

Sollamo, Matti 189,320

Sollamo, Raija 122, 167, 168, 170, 171, 188, 189, 196, 197, 209, 216, 264, 315

Sontonga, Enoch 158

Sormunen, Eino 94, 247

Sormunen, Pekka 187, 189, 207, 233

Sovijärvi, Otso $145,153,156,158,177$

Spong, John Shelby 323

Stenbäck, Pär 75, 77, 111, 114

Stenlund, Göran 158, 162, 174, 314

Sundqvist, Ulf $16,24,57,73,77,78$

Suomalainen, Hannu 27,72

Taipale, Risto 233

Takala, Martti 169, 170, 240

Takala, Väinö 50, 88, 106, 120, 179, 239

Talasniemi, Jussi 77, 104, 166, 170

Tammi, Ari 196, 210, 228, 229, 231, 235, 249, 25

Tamminen, Jukka 195

Tarvainen, Olavi 66

Taskila, Lauri 59, 90, 93

Taxell, Christoffer 76, 116, 125, 127

Taxell, Lars Erik 15, 24, 37, 39, 42, 64-66, 70, 71, 76, 79, 81, 82, 109, 128, 180

Teinonen, Seppo A. 56-62, 66, 71, 234, 296

Telaranta, Reijo 189

Temmes, Markku 211

Terserus, Johannes 249
Thurén, Jukka 164, 165, 167

Tiensuu, Kyllikki 11, 12, 139, 195, 213, 233, 273

Tiililä, Osmo 57,71

Toivanen, Aarne 164-166,171

Toiviainen, Kalevi 26, 42, 88, 93, 127, 134, 138, 146, 164, 166, 169, 170, 172, 178, 238

Toivonen, Kyösti 187,188

Tokola, Esko 12, 139

Träskbacka, Bror 314, 316

Träskman, Gunnar 24, 36, 64, 116, 127

Tuohimäki, Juha 274

Tuomas, piispa 340

Tuomi, Arvi 296, 306, 307

Tuovinen, Liisa 122

Tuppurainen, Erkki 223, 242-244

Tynkkynen, Markku 279

Tynkkynen, Oras 283

Typpö, Leonard 158

Uosukainen, Riitta 215

Vaahtoniemi, Heikki 33, 118, 156, 158-16o, 180

Vahtola, Pirjo 309, 324

Wallasvuo, Tellervo 94, 95

Wallin, Stefan 328,338

Vanhanen, Ensio 29

Varpasuo, Päivi 107, 128, 187, 193, 219, 297

Vastamäki, Ritva 284

Veijola, Timo 164, 169

Veinio, Jouni 22, 54

Ventä, Kari 187, 257

Vikström, Björn 288, 291

Vikström, Erik 131, 133, 143, 144, 146, 204, 205, 225, 229, 235, 241, 245, 248, 283 , $289,298,299,306,313-315,319,324$

Vikström, John 39, 45, 46, 48, 59, 62-64, 69, 72, 74, 78, 81, 82, 89, 93, 100, 114 $116,119,124-128,131,132,134-137,144,146,158,172,176,179,180,182,183$, $184,185,187,192,195,196,198,206,207,209,215,218,226,227,229-231,233$, $249,256,257,278,318$

Virolainen, Jyrki 93

Virtanen, Terttu 94, 95

Voipio, Aarni 147

Voipio, Jaakko 23, 24, 41, 76, 102, 112, 116, 125, 127, 135, 138, 147-151, 180, 229

Voipio, Risto 322

Vuollo, Mauno 105

Vuorela, Olavi $17,39,45$

Vuorela, Tapani $138,139,159$

Vuorenpää, Irja 157, 159

Vähäsarja, Väinö 38, 68, 92, 179

Väinölä, Tauno 73, 96,154

Väkevä, Sointu 94, 95

Väänänen, Marjatta $63,74,75,77,78,136$

Ylimäki, Reino 158

Österbacka, Svante 203, 233, 250 
KESKEISI Ä VUOSILUKUJA 1974-2011

uusimuotoinen kirkolliskokous aloittaa toimintansa arkkipiispa Martti Simojoen johdolla

sopimusjärjestelmä tulee voimaan kirkossa

naispappeusesitys kaatuu, lehtorin tehtäviä lisätään

kirkolliskokous hyväksyy jättäytymisen Leuenbergin konkordian ulkopuolelle

Mikko Juva nimitetään arkkipiispaksi

John Vikström nimitetään arkkipiispaksi

kirkolliskokous esittää loppiaisen ja helatorstain palauttamista entisille paikoilleen, siirto toteutuu 1992 uusi kirkollisten toimitusten kirja hyväksytään naispappeusesitys kaatuu virsikirja hyväksytään ylimääräisessä istunnossa maallikkoedustajien vaalissa on ensi kertaa täysin suhteellinen vaalitapa ja ehdokasasettelu naispappeusesitys hyväksytään, asia siirtyy eduskunnalle ensimmäiset naiset saavat pappisvihkimyksen ja pääsevät pappisedustajiksi

eläkerahastointi alkaa

uusi raamatunkäännös hyväksytään ylimääräisessä istunnossa

uusi kirkkolainsäädäntö (kirkkolaki, kirkkojärjestys ja kirkon vaalijärjestys) tulee voimaan

kirkon keskushallinnon uudistus astuu voimaan, kirkkohallituksen asema vahvistuu

kirkolliskokous hyväksyy Porvoon julistuksen

pappisedustajien vaalissa on ensi kertaa suhteellinen vaalitapa ja ehdokasasettelu

tuomiokapitulit siirtyvät kokonaan kirkolle

kirkolliskokous hyväksyy Yhteisen julistuksen vanhurskauttamisopista

Jukka Paarma nimitetään arkkipiispaksi

kristinoppi hyväksytään ja jaetaan riemuvuonna 2000 kaikkien seurakuntalaisten koteihin

jumalanpalvelusten kirja ja evankeliumikirja hyväksytään ylimääräisessä istunnossa

piispojen nimittäminen siirtyy tasavallan presidentiltä kirkolle

laki samaa sukupuolta olevien rekisteröidystä parisuhteesta tulee voimaan, kirkolliskokous saa kaksi asiaa koskevaa edustaja-aloitetta

kirkollisten toimitusten kirja hyväksytään

uusi Espoon hiippakunta aloittaa toimintansa

uudistettu hiippakuntahallinto hiippakuntavaltuustoineen astuu voimaan

Vanhan testamentin apokryfikirjojen suomenkielinen käännös hyväksytään

seurakuntavaalien äänioikeusikärajan alentaminen 16 vuoteen hyväksytään

Kari Mäkinen valitaan arkkipiispaksi

kirkolliskokous antaa piispainkokoukselle tehtäväksi laatia ohjeet parisuhteensa rekisteröineiden pastoraalista kohtaamista varten 